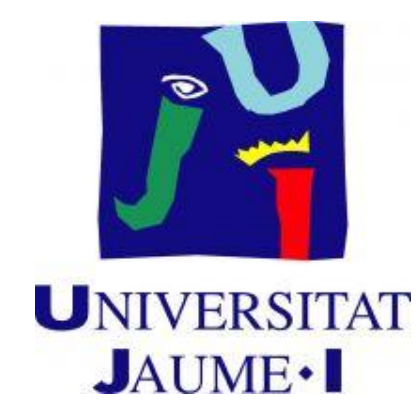

\author{
FACULTAD DE CIENCIAS JURÍDICAS Y ECONÓMICAS \\ DEPARTAMENTO DE DERECHO PÚBLICO \\ PROGRAMA DE DOCTORADO INTERUNIVERSITARIO \\ SISTEMA DE JUSTICIA PENAL
}

\title{
TESIS DOCTORAL \\ LA LIBERTAD VIGILADA EN LA LEY ORGÁNICA 5/2010, DE REFORMA DEL CÓDIGO PENAL DE 1995
}

Presentada por:

David Eleuterio Balbuena Pérez

Dirigida por:

Prof. Dr. José Luis González Cussac

Catedrático de Derecho penal

Profa. Dra. Cristina Guisasola Lerma

Profesora Titular de Derecho penal

Castellón, junio de 2014 
A mi madre, in memoriam. 
A mi maestro, el profesor José Luis González Cussac, por haberme dado la oportunidad de aprender de él tantas cosas, por las inestimables orientaciones, observaciones y correcciones sin las que no habría sido posible alcanzar este objetivo. Por ser un claro ejemplo de lo que debe ser un gran jurista en este siglo y por irradiar, con su sencillez y honestidad, esa fuerte vocación universitaria que - sin darse cuenta- a todos nos contagia. Por demostrar su firme compromiso con el avance del conocimiento para la correcta evolución del Derecho penal de nuestro tiempo, y por haberme transmitido tantas cosas que sería imposible enumerar en estas líneas.

A mi tutora académica, la profesora Cristina Guisasola Lerma, por haber codirigido esta tesis, por el interés mostrado en mi trabajo desde el primer momento, por la ayuda, las indicaciones, los consejos, por llevarme a sus clases y por darme la oportunidad de que comparta mis inquietudes con sus alumnos.

A mi alma mater, la Universitat Jaume I de Castellón, por proporcionarme los medios necesarios para llevar a cabo esta investigación. En especial al departamento de Derecho público, por haberme concedido la beca de colaboración entre los cursos académicos 2009-2010 y 2010-2011, que me permitió realizar algunas colaboraciones docentes en el área de Derecho penal y concluir un importante ciclo del programa de doctorado interuniversitario en el que estaba inmerso: el trabajo de investigación y el Diploma de Estudios Avanzados para la obtención de la suficiencia investigadora.

A la Agencia Española de Cooperación Internacional para el Desarrollo (AECID), por haberme concedido la beca de investigación predoctoral del Ministerio de Asuntos Exteriores y de Cooperación (becas MAEC-AECID), para llevar a cabo una estancia de investigación y docencia en Paraguay durante los años 2012 y 2013, que supuso un paso importante en mi formación por haberme dado la oportunidad de conocer otra realidad jurídica en materia de medidas de seguridad, que, sin duda, fue esencial para madurar la posición crítica que sobre esta delicada materia siempre he tratado de mantener.

Al director del centro de documentación de la Universitat Jaume I, Vicent Falomir, que en todo momento y siempre que estuvo en sus manos, se mostró dispuesto a ayudarme en todo lo necesario para que pudiera avanzar en mi trabajo, porque esas actitudes con los doctorandos de la casa, son las que marcan la diferencia. Al personal de la biblioteca, por la paciencia que siempre tuvieron conmigo. 
A Concha, del Departamento de Derecho público, que siempre está de buen humor, por su ayuda con los trámites administrativos universitarios durante todos estos años.

A mi profesora de Derecho constitucional, Cristina Pauner Chulví, a quien siempre tuve en muy alta estima, por gestionar $-y$ conseguirme- la reserva permanente de la cabina de estudio en la segunda planta de la biblioteca, porque ahí fue donde pasé la mayor parte del tiempo para la elaboración de este trabajo.

A mi profesora de Derecho penal, María Luisa Cuerda Arnau, sin cuyas primeras enseñanzas —que fueron las que me marcaron- mi trayectoria como jurista no habría sido la misma. Por haberme cedido un espacio en sus clases en las que tuve la magnífica oportunidad de compatir mis experiencias con sus alumnos, en unas -siempre emocionantes- colaboraciones docentes que tuvieron lugar en las mismas aulas de la Facultad en las que, tiempo atrás, yo también fui su alumno.

A todos los profesores de los que he tenido el placer de aprender Derecho en este apasionante programa de doctorado interuniversitario, tanto en la Universitat de Lleida (Carolina Villacampa Estiarte, Nuria Torres Rosell, Bernardo Feijoo Sánchez, Gonzalo Quintero Olivares, Ramón García Albero y, en especial, Josep Maria Tamarit Sumalla), como en la Universitat Jaume I de Castellón (Andrea Planchadell Gargallo, Caty Vidales Rodríguez, Tomás Vives Antón y, por supuesto, Pepe), porque - de una forma o de otratodos ellos han dejado en mí su impronta.

A mis compañeros de doctorado y, en especial, a mis amigos Nicolás Oxman, Sabina Cervera y Christa Madrid.

A mis amigos paraguayos que se doctoraron en España: Manuel Guanes, Lorena Balbuena y Pablo Rojas, porque siempre me dieron palabras de ánimo, consejos útiles y momentos de amistad sincera.

A los profesores Lina Díaz Cortés y Fernando Pérez Álvarez, por dejarme formar parte de la familia que compone la organización del Congreso Internacional de Jóvenes Investigadores en Ciencias Penales de la Universidad de Salamanca.

A mis compañeros de profesión, los abogados que me ayudaron con mis asuntos judiciales de los que no me pude ocupar en los momentos más difíciles: mi hermano Fabio y mis amigos Ximo Maiques, Raquel Huguet, Izaskun Elesgaray y Javier Martínez.

A mis amigos, por el apoyo y la compresión constante.

A mis hermanos, tíos, primos y sobrinos y, en general, a toda mi familia, por hacerme creer que este maravilloso sueño era posible. 
A mi esposa, Gigí, por su inestimable ayuda, su cariño, su amor incondicional y porque sin su paciencia, sin su apoyo y sin su comprensión, nada de esto habría sido posible.

A mi padre, a quien debo la pasión que siento por el Derecho.

A mi madre, que siempre supo transmitirme e inculcarme su profundo amor por la docencia y que falleció repentinamente poco antes de que esta tesis estuviera terminada, pero que, antes de irse, todavía tuvo tiempo de ayudarme con la traducción y comprensión de los textos en francés que aparecen citados en las referencias bibliográficas, aspecto que, para mí, siempre tendrá un valor especial en este trabajo. Gracias mamá. 
ÍNDICE SISTEMÁTICO

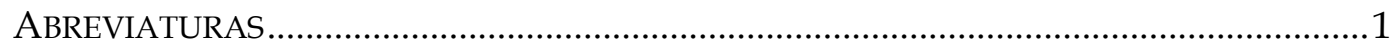

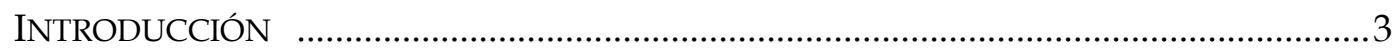

CAPÍTULO PRIMERO. LAS MEDIDAS DE SEGURIDAD.............................................................

I. ANTECEDENTES HISTÓRICOS .......................................................................................11

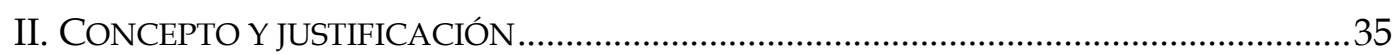

III. MONISMO, DUALISMO Y SISTEMA VICARIAL ............................................................ 45

IV. EJEMPLOS DE MEDIDAS DE SEGURIDAD EN DERECHO COMPARADO .........................59

V. PRINCIPIOS RECTORES .................................................................................... 72

VI. CLASES DE MEDIDAS DE SEGURIDAD................................................................. 82

VII. MEDIDAS DE SEGURIDAD Y PELIGROSIDAD CRIMINAL ..............................................84

1. Imputabilidad, inimputabilidad y semiimputabilidad ................................................. 84

2. La peligrosidad criminal.................................................................................. 112

2.1. Métodos de determinación de la peligrosidad............................................... 117

3. El tratamiento del delincuente habitual peligroso .................................................132

4. El tratamiento del delincuente sexual peligroso ………………………...............147

5. El control estatal sobre la delincuencia peligrosa ……………………………....156

CAPÍTULO SEGUNDO. LA LIBERTAD VIGILADA. ANTECEDENTES...................................161

I. REFERENCIAS AL DERECHO COMPARADO ............................................................. 161

II. ANTECEDENTES EN DERECHO ESPAÑOL.............................................................. 177

1. En la legislación penal de menores ........................................................................177

a) Naturaleza jurídica de las medidas en el Derecho penal de menores .............. 178

b) Principios informadores................................................................................... 180

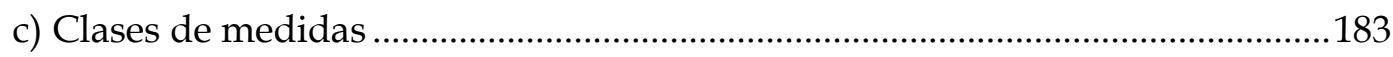

d) La medida de libertad vigilada ............................................................................ 185

2. Antecedentes en el Derecho penal de adultos......................................................198

a) Primeras formulaciones en España..................................................................... 198

b) El Anteproyecto de reforma del CP, de 14 de julio de 2006 .................................202

c) El Proyecto de reforma del CP, de 15 de enero de 2007 ………………………......204

d) El Anteproyecto de reforma del CP, de 14 de noviembre de 2008 ....................206 
e) El informe del Consejo Fiscal, de 4 de febrero de 2009.

f) El informe del Consejo General del Poder Judicial, de 26 de febrero de $2009 . . . . .$.

g) El Dictamen del Consejo de Estado, de 29 de octubre de 2009 ......................... 217

h) El Anteproyecto de reforma del CP, de 23 de julio de 2009 .............................. 218

i) El Proyecto de Ley 121/52, de 27 de noviembre de 2009 ................................... 219

1. La tramitación en el Congreso de los Diputados ............................................. 219

a) La publicación del proyecto ……................................................................. 220

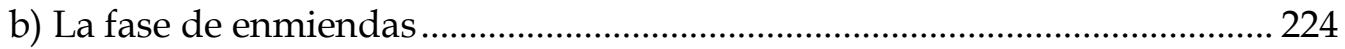

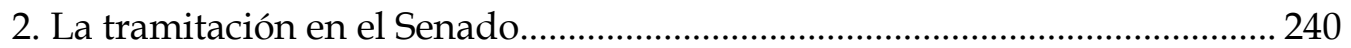

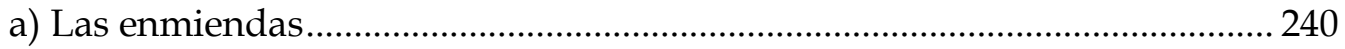

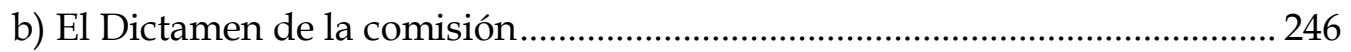

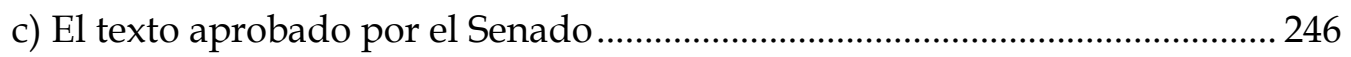

III. LA DECISIÓN MARCO 2008/947/JAI, DEL CONSEJO DE LA UE, DE 27 DE NOVIEMBRE DE 2008

CAPÍTULO TERCERO. LA LIBERTAD VIGILADA EN LA REFORMA DEL CÓDIGO PENAL DE 2010. 261

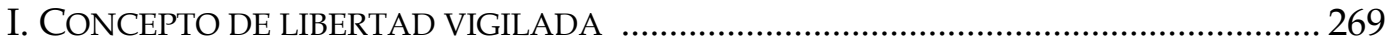

1. Previsión general. Libertad vigilada para inimputables y semiimputables .... 271

2. Previsión especial. Libertad vigilada para imputables 277

2.1. Libertad vigilada para supuestos de delitos contra la libertad e

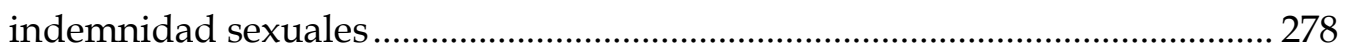

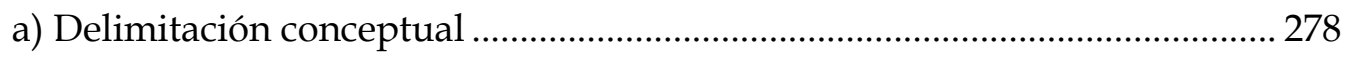

b) El tratamiento penológico de los delitos contra la libertad e indemnidad

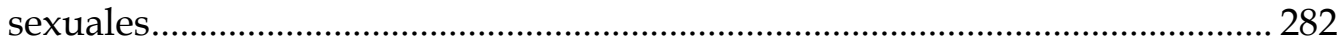

2.2. Libertad vigilada para supuestos de delitos de terrorismo ........................ 286

a) Delimitación conceptual .................................................................................. 290

b) El tratamiento penológico de los delitos de terrorismo ................................. 294

II. LIBERTAD VIGILADA. CONTENIDO Y ALCANCE........................................................... 304

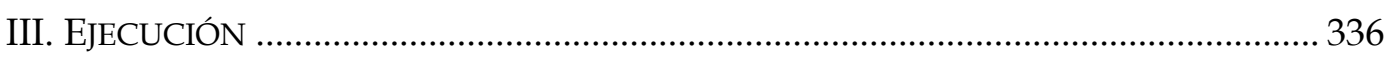

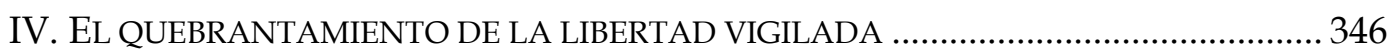

V. EL REAL DECRETO 840/2011, DE 17 DE JUNIO ....................................................... 352

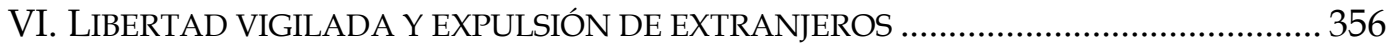




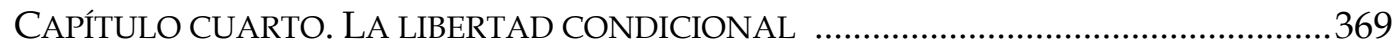

I. ASPECTOS GENERALES DE LA LIBERTAD CONDICIONAL _............................................369

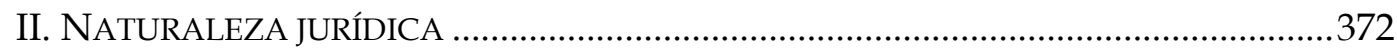

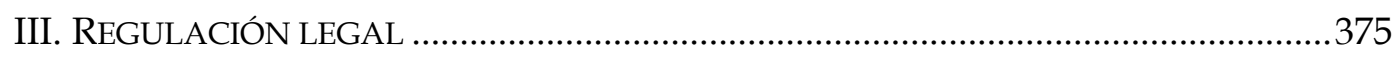

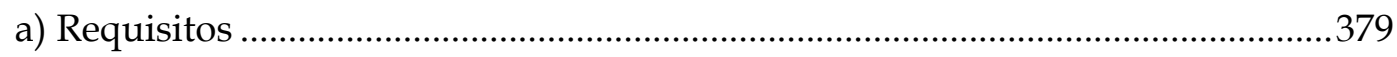

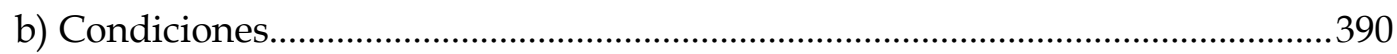

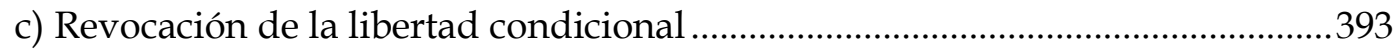

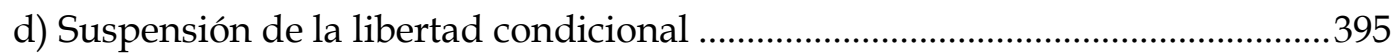

e) Adelantamiento de la libertad condicional.............................................................396

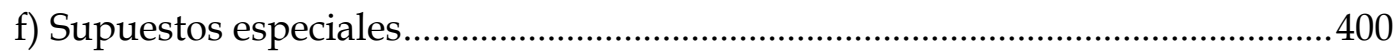

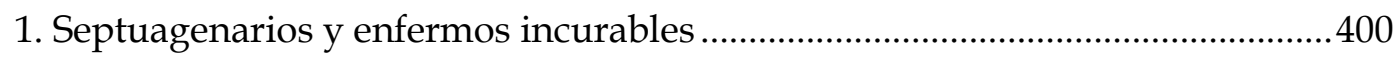

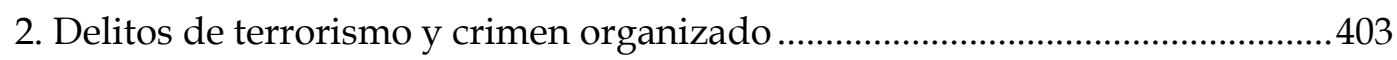

g) Extranjeros no residentes en España .................................................................408

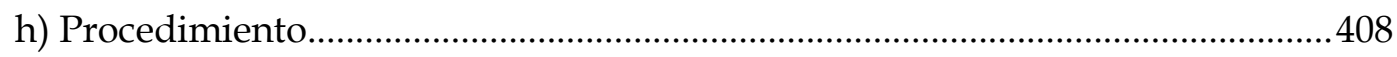

i) La libertad condicional en el Proyecto de reforma del Código penal, de 20 de

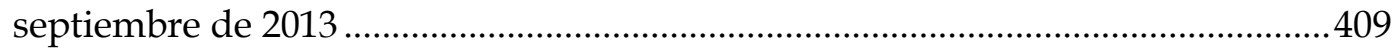

IV. LIBERTAD CONDICIONAL Y LIBERTAD VIGILADA ....................................................410

CAPÍtUlo Quinto. LA LiberTAd VIGILADA EN EL PROYECTO DE REFORMA DEL CÓDIGO PENAL, DE 20 DE SEPTIEMBRE DE 2013 .............................................................419

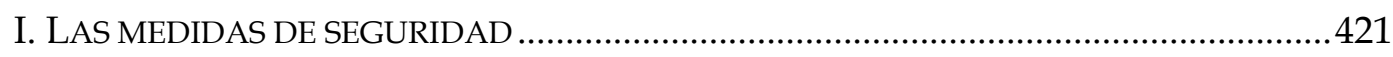

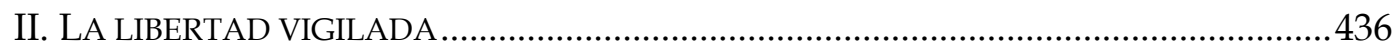

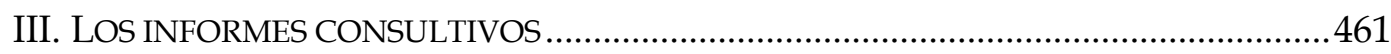

a) El informe del Consejo General del Poder Judicial, de 16 de enero de 2013 .......... . .461

b) El informe del Consejo Fiscal, de 20 de diciembre de 2012 .................................466

c) El Dictamen del Consejo de Estado, de 27 de junio de 2013 ..............................469

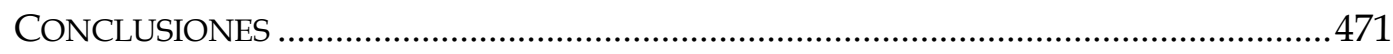

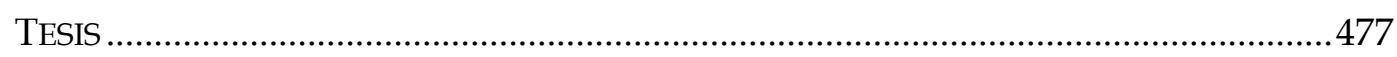

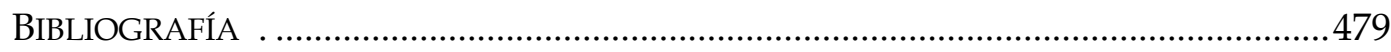





\begin{tabular}{|c|c|}
\hline AN & Audiencia Nacional \\
\hline $\mathrm{AP}$ & Audiencia Provincial \\
\hline ATC & Auto del Tribunal Constitucional \\
\hline BOCG & Boletín oficial de las Cortes General \\
\hline BOE & Boletín oficial del Estado \\
\hline BVerfG & Bundesverfassungsgericht, (Tribunal Federal Constitucional alemán). \\
\hline $\mathrm{CC}$ & Código civil \\
\hline CCAA & Comunidades Autonómas \\
\hline CE & Constitución española \\
\hline $\mathrm{CEDH}$ & Convenio Europeo de Derechos Humanos \\
\hline CIE & Centro de Internamiento de Extranjeros \\
\hline $\mathrm{CP}$ & Código penal \\
\hline DOUE & Diario Oficial de la Unión Europea \\
\hline DUDH & Declaración Universal de los Derechos Humanos \\
\hline JCVP & Juez central de Vigilancia Penitenciaria \\
\hline JVP & Juez de Vigilancia Penitenciaria \\
\hline LEC & Ley Orgánica 1/2000, de Enjuiciamiento Civil \\
\hline LECrim & Ley de Enjuiciamiento Criminal \\
\hline LO & Ley Orgánica \\
\hline LOGP & Ley Orgánica 1/1979, General Penitenciaria \\
\hline LOPJ & Ley Orgánica 6/1985, del Poder Judicial \\
\hline LORPM & $\begin{array}{l}\text { Ley Orgánica 5/2000, reguladora de la Responsabilidad Penal de los } \\
\text { Menores }\end{array}$ \\
\hline $\mathrm{RD}$ & Real Decreto \\
\hline $\mathrm{RM}$ & $\begin{array}{l}\text { Reglamento de Menores, aprobado por Real Decreto 1774/2004, de } 30 \text { de } \\
\text { julio }\end{array}$ \\
\hline SAN & Sentencia de la Audiencia Nacional \\
\hline SAP & Sentencia de la Audiencia Provincial \\
\hline STC & Sentencia del Tribunal Constitucional \\
\hline STS & Sentencia del Tribunal Supremo \\
\hline StGB & Strafgesetzbuch (Código penal alemán) \\
\hline TEDH & Tribunal Europeo de Derechos Humanos \\
\hline TS & Tribunal Supremo \\
\hline $\mathrm{TC}$ & Tribunal Constitucional \\
\hline
\end{tabular}




\section{LA LIBERTAD VIGILADA EN LA LEY ORGÁNICA 5/2010, DE REFORMA DEL CÓDIGO}

PENAL DE 1995

\section{INTRODUCCIÓN}

La presente tesis doctoral versa sobre la libertad vigilada en la LO 5/2010, de 22 de junio, por la que se reforma el Código penal de 1995. La justificación de la elección del tema es múltiple, por cuanto que se trata de una figura nueva en el sistema español de consecuencias jurídicas del delito que, si bien cuenta con antecedentes legislativos en nuestro Derecho histórico y también con precedentes en el ámbito de los menores, no es hasta 2010 cuando se traspasa la barrera del dualismo con tendencia monista que imperó desde la promulgación del Código penal de 1995, por el que las medidas de seguridad no encontraban acomodo sistemático para ser aplicadas a personas imputables.

La novedad es, pues, el factor determinante que impulsa este estudio y lo dota de especial interés académico, sobre todo porque la tendencia reformista que en el ámbito jurídico-penal se está llevando a cabo en los últimos tiempos, parece que pretende desembocar en un retorno al dualismo rígido de corte clásico en el que penas y medidas de seguridad coexistirán como medios de reacción frente al delito y se aplicaran de forma conjunta para servir a los fines preventivo-generales y especiales de forma simbiótica.

La reforma pasó por varias formulaciones previas en distintos anteproyectos que la concibieron con naturalezas jurídicas también distintas, aunque finalmente prosperó la idea de concebirla como medida de seguridad y no como pena. La voluntad del legislador fue, por una parte, proporcionar una válvula de escape para solucionar el problema de aquellos presos que por su mal pronóstico de reinserción no tienen acceso a la libertad condicional y pasan a la libertad plena de forma abrupta cuando la pena se extingue por cumplimiento, con los perjudiciales efectos que tal práctica puede conllevar para la reinserción del sujeto y para la sociedad en su conjunto. Y, por otra, ofrecer una respuesta para la pregunta -que sigue sin respuesta- de qué hacer con los delincuentes imputables peligrosos en los que la peligrosidad subsiste tras el cumplimiento de la pena de prisión.

La tendencia de los últimos diez años, consistió en otorgar un tratamiento jurídico a esta clase de sujetos exclusivamente en la pena, esto es, en la culpabilidad, mediante técnicas de exasperación de penas, cumplimiento íntegro, especialidades en materia de 
concursos, libertad condicional, etc., pero siempre desde la óptica de la pena como única respuesta frente a la peligrosidad que se presenta en diversas clases de delitos que cometen personas imputables. El cambio es de notable relevancia porque a ello se suma la novedad de que, a los delincuentes sexuales y terroristas, además de la pena de prisión -que puede haber experimentado exasperaciones, límites temporales elevados, imposibilidades de acceso a beneficios penitenciarios, etc.-, se les impone la libertad vigilada de cumplimiento sucesivo y sin solución de continuidad. Sobre estas categorías de delincuentes, la persistencia de la peligrosidad criminal tras la pena de prisión se presume, partiendo, en esencia, del fracaso de la pena de prisión para reinsertar a los terroristas o a los delincuentes sexuales, por lo que, desde ese prisma, la opción legislativa que ofrece un tratamiento diferenciado a determinados tipos de delincuentes nos puede abocar a un Derecho penal de autor contrario a la concepción del Derecho penal que gravita sobre el principio del hecho.

Por todo ello, los objetivos del presente estudio son analizar los antecedentes de la figura de la libertad vigilada, su evolución legislativa hasta su promulgación, el análisis de su contenido y alcance, y su interrelación sistemática en el ordenamiento jurídico, para terminar ofreciendo algunas conclusiones sobre su conveniencia, legitimidad y sobre su contenido, aportando algunas propuestas para su mejor regulación.

Realizadas estas consideraciones introductorias del interés que, a mi juicio, presenta el tema que es objeto del presente estudio, conviene exponer brevemente su contenido sistemático en el que se indican los principales puntos tratados en la estructura de la tesis, que analiza de forma pormenorizada la medida de seguridad de libertad vigilada en la reforma del Código penal de 2010.

En el Capítulo Primero, dedicado a las medidas de seguridad, se hace una aproximación a la teoría general de las mismas, desde sus antecedentes históricos, para trazar su concepto y la necesaria distinción previa entre el monismo y el dualismo o la conjunción de ambos en el sistema vicarial. Se traen a colación algunos ejemplos de medidas de seguridad en el Derecho comparado, se enumeran los principios rectores y sus clases, y finalmente se dedica un apartado a la peligrosidad criminal y a las medidas de seguridad que necesariamente parten de la previa distinción entre imputabilidad e inimputabilidad y de las distintas clases de peligrosidad existentes. También se realiza un 
estudio sobre los métodos de determinación de la peligrosidad y finalmente se habla del tratamiento del delincuente habitual peligroso, con especial mención al delincuente sexual y al control estatal sobre la delincuencia peligrosa.

El Capítulo Segundo está dedicado a los antecedentes de la libertad vigilada, con un apartado de referencias al Derecho comparado y otro para el Derecho español, en el que se analiza el precedente legislativo en el ámbito de los menores y finalmente se centra la atención en el Derecho penal de adultos. Se realiza un estudio de las primeras formulaciones en España de la libertad vigilada y se analiza toda la tramitación parlamentaria hasta llegar a la LO 5/2010, para lo cual se estudian en profundidad todos los anteproyectos de reforma presentados desde 2006 hasta el proyecto de 2009 que finalmente se aprobó para dar paso a la reforma, sobre el que se realiza un análisis detallado de la tramitación parlamentaria, con sus correspondientes fases de enmiendas tanto en el Congreso de los Diputados como en el Senado. Finalmente en este capítulo, se analiza la Decisión Marco 2008/947/JAI, del Consejo de la UE, de 27 de noviembre de 2008, relativa a la aplicación del principio de reconocimiento mutuo de sentencias y resoluciones de libertad vigilada con miras a la vigilancia de las medidas de libertad vigilada y las penas sustitutivas.

En el Capítulo Tercero, se aborda la regulación de la libertad vigilada en la reforma del Código penal, operada mediante la LO 5/2010, para lo cual se establece primeramente una delimitación conceptual, separando su previsión general para supuestos de inimputabilidad y semiimputabilidad, y su previsión especial para delincuentes sexuales y terroristas. En la previsión especial se realiza también una delimitación de las figuras delictivas a las que va dirigida y sus respectivos tratamientos penológicos. Posteriormente se analiza el contenido de la libertad vigilada, su régimen de ejecución, las especialidades en materia de quebrantamiento de la medida de seguridad, la relación existente entre libertad vigilada y la expulsión de los extranjeros, y finalmente se añade un apartado en el que se tratan otros aspectos relevantes que resultan de especial interés para el resultado final del presente estudio.

El Capítulo Cuarto está dedicado a la relación existente entre libertad condicional y libertad vigilada, para lo cual se efectúa un previo análisis de la libertad condicional, desde sus aspectos más generales, naturaleza jurídica y su regulación legal, hasta los 
supuestos especiales y el procedimiento para su aplicación. Finalmente se dedica un apartado a la libertad vigilada y libertad condicional, tratando de delimitar claramente los problemas existentes para que ambas figuras coexistan en relación armónica dentro del sistema.

El Capítulo quinto está dedicado a la libertad vigilada en el Proyecto de reforma del Código penal, de 20 de septiembre de 2013, impulsado por el actual Gobierno del Partido Popular y que es muy probable que se convierta en ley en un horizonte no muy lejano. En dicho Capítulo se hace un análisis de la regulación proyectada de la libertad vigilada, haciendo también un resumen de las modificaciones más importantes que, en materia de medidas de seguridad, se pretende introducir en el ordenamiento español.

Seguidamente se dedica un apartado a las conclusiones que, de forma sintética, se resumen como culminación del trabajo de investigación realizado en los capítulos precedentes.Y, por último, se añade un apartado de bibliografía ordenado alfabéticamente con indicación de los autores, edición, lugar de publicación, editorial y año, para facilitar al lector su fácil localización. 
“La libertad es 'casi un milagro', un equilibrio delicado y apenas creíble que no soporta convicciones demasiado entusiastas ni tutelas demasiado enérgicas, de modo que, muchas veces, quienes intentan defenderla con mayor vigor la ponen involuntariamente en peligro".

-Tomás Salvador Vives Antón—1.

\section{CAPÍTULO PRIMERO. LAS MEDIDAS DE SEGURIDAD}

Las medidas de seguridad son mecanismos de reacción penal distintos de las penas, pues se basan en la peligrosidad futura y no en la culpabilidad por los hechos cometidos en el pasado. Las medidas de seguridad gravitan sobre la prevención especial que parte de formulaciones de las llamadas teorías relativas ${ }^{2}$ (o de la prevención) ${ }^{3}$ de las

1 VIVES ANTÓN, T.S., “La libertad como pretexto”. Valencia: Tirant lo Blanch. 1995, p. 388.

2 Las teorías relativistas fueron impulsadas por los juristas de la Ilustración, entre los que destacan Beccaria, Lardizábal, Bentham, Romagnosi, Filangieri o Feuerbach, por el especial hincapié en la prevención general; y Lombroso, Ferri, Garófalo o Karl Grolman, por sus enfoques de la pena en íntima relación con la peligrosidad del delincuente y encaminada a la prevención especial. En el moderno Derecho penal, autores como Silva Sánchez, Gimbernat Ordeig o Luzón Peña, mantienen una visión relativista de la pena.

${ }^{3}$ Abandonadas las teorías absolutas o de la retribución (vid. ROXIN, C., "Fin y justificación de la pena y de las medidas de seguridad". En ROXIN, C. / BELOFF, M. / MAGARIÑOS, M. / ZIFFER, P.S. / BERTONI, E.A. / RÍOS, R.T., Determinación judicial de la pena. Buenos Aires: Editores del Puerto. 1993, p. 16), que se basaban en el aforismo inspirado en la fórmula de Séneca punitur quia peccatum est (vid. MAGGIORE, G., Derecho penal. Vol. II. El delito. La pena. Medidas de seguridad y sanciones civiles. Traducción de la $5^{\text {a }}$ Ed. italiana por José J. Ortega Torres. Bogotá: Temis. 1954, p. 248), que implica que la pena es retribución o la compensación por el mal causado y por el que debe responder el autor. Según esta concepción, la violación del Derecho debe ser retribuida con un castigo y la pena es una necesidad ética y una venganza o solidaridad (Ibidem, pp. 256 y 257). La conocida como "Ley del Talión" (ojo por ojo, diente por diente, sangre por sangre) tiene su fundamento en las teorías absolutas, que arrancan en la Antigüedad clásica y se encuentran sobre todo en los textos bíblicos y en los griegos. Pitágoras, decía que la pena era un talión moral y Platón en Gorgias decía que la pena es la medicina de la perversidad y un medio de purificar el alma del mal en justicia (vid. PLATÓN, "Gorgias". En PLATÓN, Obras completas. Traducción de Patricio de Azcárate. Tomo 5. Madrid: Medina y Navarro. 1871, pp. 189 a 199). También en el Derecho romano y en el germánico se usó la venganza de sangre y, posteriormente, refirieron a ella filósofos y teólogos cristianos como Tomás de Aquino o Alfonso de Castro (vid. POLAINO NAVARRETE, M., Derecho penal. Parte general. Tomo I. Fundamentos científicos del Derecho penal. $6^{\mathrm{a}}$ Ed. Barcelona: Bosch. 2008, p. 66). Los representantes más destacados de esta corriente surgen con el Idealismo alemán, para Kant la pena es un "imperativo categórico", una exigencia incondicionada de la justicia, libre de toda consideración utilitaria esto es, que no desempeña ninguna función social, sino que simplemente retribuye el comportamiento delictivo en la justa medida y proporción retribuyendo en el plano de igualdad el mal ocasionado. Es significativo el ejemplo de la isla de Kant, en el que afirma que una sociedad que viviera en una isla si decidiera disolverse, disgregarse y dispersarse por todo el mundo, "antes tendría que ser ejecutado hasta el último asesino que se encuentre en la cárcel, para que cada cual reciba lo que merecen sus actos y el homicidio no recaiga sobre el pueblo que no ha exigido este castigo: porque puede considerársele como cómplice de esta violación pública de la justicia", (vid. KANT, I., La metafísica de las costumbres. 1797. Traducción y notas de Adela Cortina Orts y Jesús Conill Sancho. Barcelona: Atalaya. 1993, pp. 166 a 169). 
${ }^{4}$ Hay dos clases de prevención general: la negativa, basada en las teorías de Feuerbach, para quien la pena ejerce una coacción psicológica (vid. NAUCKE, W., "Prevención general y derechos fundamentales de la persona". En NAUCKE, W. / HASSEMER, W. / LÜDERSSEN, K., Principales problemas de la prevención general. Traducción de Traducción de Gustavo Eduardo Aboso y Tea Löw, Buenos Aires-Montevideo: Bdef. 2004, pp. 24 y 25), que supone una amenaza que afecta a la generalidad de las personas en su fuero interno (vid. FEUERBACH, P.J.A., Lehrbuch des gemeinen in Deutchsland gültigen. Peinlichen Retchs. Giefsen. $14^{\mathrm{a}}$ Ed. München. 1847, p. 38), produciendo un efecto disuasorio que implica que los individuos se abstienen de delinquir para evitar que les sea aplicada la pena (vid. ALCÁCER GUIRAO, R., Los fines del Derecho penal. Liberalismo y comunitarismo en la justificación de la pena. Buenos Aires: Ad-hoc. 2001, p. 125), cuya ejecución en un caso concreto actúa advirtiendo e intimidando, tanto sobre la totalidad de los sujetos como sobre el lesionado, a quien se le proporciona la satisfacción de que no quede impune la acción antijurídica que se perpetró contra él (vid. LISZT, F., Tratado de Derecho Penal, $4^{\mathrm{a}}$ Ed. 1926. Traducido de la 20ª Edición Alemana por Luis Jiménez de Asúa. Madrid: Reus. 1999. Tomo II, p. 9). Y la prevención general positiva, que se traduce en que la pena persigue, mediante su imposición, una finalidad de confirmación de la vigencia de la norma, esto es "finalidad de reforzar los valores de la norma fomentando su cumplimiento por la sociedad", (vid. ORTS BERENGUER, E. / GONZÁLEZ CUSSAC, J.L., Compendio de Derecho Penal. Parte General. $3^{\mathrm{a}}$ Ed. Valencia: Tirant lo Blanch. 2011, p. 393). La prevención general positiva está esencialmente dirigida al pasado en busca de restablecer, reforzar o reafirmar la vigencia del ordenamiento jurídico en el estado anterior a la alteración de la estabilidad psíquica producida por el delito, (vid. MILTON PERALTA, J., “Prevención general positiva como respeto por el orden jurídico. A su vez, una distinción analítica entre distintos conceptos de "prevención general positiva"." En InDret. Revista para el análisis del Derecho. 2/2008. Barcelona: 2008, p. 6), adquiriendo así todo el protagonismo la imposición de la sanción que pretende que los ciudadanos consideren justo el contenido de la norma y se sientan motivados valorativamente para actuar conforme a ella respetándola (vid. ALCÁCER GUIRAO, R., Los fines del Derecho penal..., cit. p. 25), sin embargo algunos autores defienden que la prevención general positiva necesita ser complementada con la teoría de la prevención general negativa (vid. MILTON PERALTA, J., "Prevención general positiva...", cit. p. 26); de esa forma el Derecho penal actúa como un engranaje que genera y estabiliza las expectativas de conducta; y la imposición de la sanción penal es el elemento esencial del que se sirve el Estado para reafirmar la vigencia del ordenamiento jurídico (vid. PÉREZ MANZANO, M., “Fundamento y fines de Derecho penal. Una revisión a la luz de las aportaciones de la Neurociencia". En InDret. Revista para el análisis del Derecho. 2/2011. Barcelona: 2011, p. 13). La prevención general positiva parte de la formulación de la teoría dialéctica de la pena de Hegel (vid. JESCHECK, H.H., Tratado de Derecho Penal. Parte General. $4^{\mathrm{a}}$ Ed. Traducción de José Luis Manzanares Samaniego. Granada. 1993, p. 61), que concibe el delito como negación y la pena como la negación de la negación, esto es, una doble negación que produce la reafirmación de la norma jurídica y el restablecimiento del ordenamiento jurídico quebrantado Con esta formulación, lo que pretende proteger el Derecho es el propio ordenamiento jurídico mediante la reafirmación de la vigencia de la norma, (vid. HEGEL, W.F., Fundamentos de la Filosofía del Derecho. 1820. Traducción de C. Díaz, Madrid: Libertarias/Prodhufi. 1993, p. 334). El delincuente, al quebrantar la norma, expresa su voluntad contraria a la misma cuestionando la validez misma del ordenamiento jurídico, (vid. POLAINO NAVARRETE, M., Derecho penal Parte general..., cit. Tomo I, p. 72). Posteriormente, esta concepción de Hegel ha sido seguida por Jakobs para la formulación de la teoría funcional de la pena, (vid. JAKOBS, G., Sociedad, norma y persona en una teoría del Derecho penal funcional. Traducción de Manuel Cancio Meliá y Bernardo Feijoo Sánchez. Madrid: Civitas. 1996, pp. 15 y ss.; JAKOBS, G., La pena estatal: significado y finalidad. Traducción y estudio preliminar de Manuel Cancio Meliá y Bernardo Feijoo Sánchez. Madrid: Thomson-Civitas. 2006, pp. 83 y ss); no obstante, conviene tener presente que las leyes penales con finalidades de prevención general positiva, en la actualidad son calificadas por algunos autores como neoretribucionismo (vid. GARCÍA ALBERO, R., “Acumulación jurídica de penas y cumplimiento íntegro: La reforma de los artículos 76 y 78 CP”. En TAMARIT SUMALLA, J.M. / GARCÍA ALBERO, R., La reforma de la ejecución penal. Valencia: Tirant lo Blanch. 2004. [www.tirantonline.com]. TOL 519.287, p. 5).

${ }^{5}$ La prevención especial, es la que tiende a prevenir los delitos que pueda cometer un delincuente concreto en el futuro, siendo la finalidad de la pena la evitación de que el penado vuelva a delinquir, puesto que sirve de escarmiento al sujeto propiciando su resocialización (vid. LANDECHO VELASCO C.M. / MOLINA BLÁZQUEZ, C., Derecho Penal Español. Parte General. Madrid: Tecnos. 2010, p. 519). El origen de la discusión en torno a los fines de la pena, nace en un fragmento de los Diálogos de PLATÓN (vid. ROXIN, C., "Fin y justificación de la pena...", cit. p. 20), donde Protágoras contrapone la idea de penar porque se ha delinquido a la idea de penar para que no se delinca: punitur quia pecatum est vs. punitur ut ne peccetur, lo que se traduce en la contraposición entre teorías absolutas y relativas, (vid. SANZ MORÁN, A.J., "Las teorías penales hoy". En DÍAZ Y GARCÍA CONLLEDO, M. / GARCÍA AMADO, J.A., (Edits.), Estudios de filosofía del Derecho penal. Bogotá: Universidad Externado de Colombia. 2006, p. 139). La prevención especial históricamente ha 
pensamiento penal ha desembocado en las llamadas teorías mixtas (de la unión o la unidad) o también denominadas eclécticas, que conjugan retribución y prevención poniendo de relieve que la finalidad de la sanción penal no puede ser otra que el castigo retribucionista, pero que necesariamente deberá ir acompañado de las finalidades preventivas, tanto especiales como generales ${ }^{6}$. Es mayoritaria la posición que entiende que, fundamentalmente, las medidas de seguridad sirven a la prevención especial7,

gravitado sobre el fundamento de que la comisión de un hecho punible contiene la amenaza de futuras lesiones del orden jurídico y, por tanto, la pena sirve para evitar futuros delitos, no para reparar los delitos pasados que ya no se pueden cambiar porque no es posible volver atrás en el tiempo. De ese modo, la prevención especial negativa, responde a la idea de inocuización o neutralización del delincuente, mientras que la prevención especial positiva es la que descansa sobre el tratamiento rehabilitador del condenado y se basa en la resocialización o readaptación del infractor para que no vuelva a delinquir cuando se produzca el retorno a su vida en libertad (vid. BARATTA, A., "Viejas y nuevas tendencias del Derecho penal". En BUSTOS RAMÍREZ, J., Prevención y teoría de la pena. Santiago de Chile: Editorial Jurídica ConoSur Ltda. 1995, p. 83).

${ }^{6}$ Estas teorías unitarias comienzan a formularse con Aristóteles y Tomás de Aquino y fueron seguidas por Pacheco, Silvela, Concepción Arenal y Dorado Montero. Según JAKOBS, G., Sobre la teoría de la pena. Traducción de Manuel Cancio Meliá. Cuadernos de conferencias y artículos, núm. 16. Bogotá: Universidad Externado de Colombia. Centro de Investigaciones de Derecho Penal y Filosofía del Derecho. 1998, p. 9, las teorías de la unión cumplen una función de mediación entre las teorías absolutas y las relativas, de forma que combinan la retribución de culpabilidad mediante la pena influyendo en la rehabilitación, en la intimidación o en el aseguramiento, tanto en el autor concreto como en los potenciales autores, consiguiendo así el equilibrio entre todos los fines de la pena que se integran en una relación armónica. Básicamente existen cuatro grandes teorías mixtas, a saber: la teoría retributivo-preventiva, basada en la doble función que debe cumplir la pena: castigar (retribuir) y prevenir (evitar nuevos delitos). Sus principales impulsores son Novakovsky, quien afirma que la retribución es el medio para alcanzar la prevención general que, a su vez, se consigue mediante el poder de la confirmación del Derecho (vid. POLAINO NAVARRETE, M., Derecho penal Parte general..., cit. Tomo I, p. 79, con cita de NOVAKOVSKY, F., "Freiheit, Schuld, vergeltung”, Festschrift für Thodor Rittler, 1957, pp. 55 y ss., 86 y ss.), Welzel, que mantiene que "la pena está justificada como retribución, de acuerdo con la medida de la culpabilidad" (WELZEL, H., Derecho penal. Parte General. Traducción de Carlos Fontán Balestra, Buenos Aires: Depalma. 1956, p. 234), y Kaufmann incide en el carácter legitimador de la pena que es ejercida por la propia retribución, rechazando también una retribución pura, carente de prevención (vid. KAUFMANN, A., "Die Aufgabe des Strafrechs", Stafrechtsdogmatik zwischen Sein und Wert. Gesammelte Aufsätze und Vorträge. Köln: Carl Heymanns Verlag KG. 1982, pp. 269 y ss.). La teoría diferenciadora de la unión, impulsada principalmente por Schmidhäuser, se basa en que la pena cumple al mismo tiempo funciones preventivo-generales y preventivo-especiales, y distingue un sentido objetivo-general que se refleja en la sociedad en su conjunto, siendo la pena la confirmación de la vigencia de la norma, generando un efecto preventivo sociopedagógico y de lucha contra el crimen; y un sentido subjetivo-individual de la pena, que variará según su destinatario, esto es, v.g., si la norma se dirige al legislador, a las fuerzas y cuerpos de seguridad del Estado, a los órganos jurisdiccionales, al penado o, en última instancia, a la sociedad en su conjunto. La teoría unificadora o dialéctica, que rechaza la retribución como fin de la pena y se centra en su vertiente preventiva (general y especial conjuntamente), teoría que desde mediados de los años sesenta ha venido siendo propugnada por ROXIN, C., Derecho penal..., cit. pp. 99 y ss., quien fija el límite de la pena en la culpabilidad, de forma que no podrá rebasarse nunca la medida culpabilística, pero sí podrá reducirse la misma con base en criterios de prevención especial, como la resocialización, reinserción social, etc. La teoría modificada de la unión, impulsada principalmente por Gössel, para quien la retribución es un elemento innegable de las sanciones penales por cuanto que va siempre conectada a la comisión de un hecho punible, pero no es su fin, puesto que el fundamento de la pena se sitúa en la culpabilidad del autor que opera como límite de su gravedad y extensión; y en casos de ausencia de culpabilidad, el fundamento (que dará lugar a la aplicación de medidas de seguridad) es la peligrosidad criminal que opera igualmente como criterio limitador de la gravedad y extensión de las medidas de seguridad que puedan imponerse.

7 GRACIA MARTÍN, L., "Las medidas de seguridad y reinserción social”. En GRACIA MARTÍN, L (Coord.), Tratado de consecuencias jurídicas del delito. Valencia: Tirant lo Blanch. 2006, p. 436. Este autor manifiesta que "las medidas de seguridad y reinserción social deben orientarse exclusivamente a los fines de la prevención especial, es decir: a la advertencia individual, a la corrección o enmienda y a la inocuización del delincuente". En ese sentido también se pronuncia LANDROVE DÍAZ, G., Las consecuencias jurídicas del delito. $6^{\mathrm{a}}$ Ed. Madrid: 
porque carecen del carácter retributivo propio de las penas y no se basan en la culpabilidad y en el pasado, sino que responden al ideal de prevención sobre la base de la peligrosidad con miras al futuro. Prevención especial que se concreta en una actuación de corrección, socialización, tratamiento y educación sobre la persona peligrosa para evitar que delinca en el futuro, incidiendo en el control del peligro que procede del mismo y evitando que la comunidad vuelva a sufrir sus efectos (prevención especial positiva), pero también tienen finalidad incuiozadora basada en métodos de profilaxis que aseguran la no presencia del delincuente peligroso en la sociedad (prevención especial negativa), que queda así protegida del peligro que representan. Sin embargo, algunos autores mantienen que las medidas de seguridad, a pesar de que cumplen una finalidad predominantemente preventivo-especial, también pueden servir a la prevención general ${ }^{8}$ pero solo fácticamente y de forma colateral ${ }^{9}$. Otros autores como JAKOBS afirman que las medidas de seguridad tienen también un efecto de prevención general positiva debido a que, con su aplicación, sirven al mantenimiento de la autoridad de la norma y a la vigencia del Derecho, restablecen el orden jurídico quebrantado por el delito y con ello se crea la suficiente seguridad cognitiva para el apoyo de una garantía normativa, y que, principalmente, se trata de mantener la confianza en la generalidad de la norma ${ }^{10}$.

Las medidas de seguridad no han generado precisamente pocos enfrentamientos a

Tecnos. 2005, pp. 116 y 117; SANZ MORÁN, A.J., Las medidas de corrección y de seguridad en el Derecho Penal. Madrid: Lex Nova. 2003, pp. 135 y 135; CHOCLÁN MONTALVO, J.A., Individualización de la pena. Función de la culpabilidad y la prevención en al determinación de la sanción. Madrid: Colex. 1997, p. 29; SIERRA LÓPEZ, M.V., Las medidas de seguridad en el nuevo Código Penal. Valencia: Tirant lo Blanch. 1997, pp. 94 y 95; ZUGALDÍA ESPINAR, J.M., Fundamentos de Derecho penal. $3^{\text {a }}$ Ed. Valencia: Tirant lo Blanch. 1993, pp. 138 y 139; ANTÓN ONECA, J., La prevención general y la prevención especial en la teoría de la pena. Discurso leído en la apertura del curso académico de 1944 a 1945. Universidad de Salamanca, imprenta Cervantes. 1944, pp. 105 y ss.; ANTÓN ONECA, J., Derecho penal. $2^{a}$ Ed., anotada y corregida por José Julián Hernández Guijarro y Luis Beneytez Merino. Madrid: Akal. 1986, p. 620; BERDUGO GÓMEZ DE LA TORRE, I. / ARROYO ZAPATERO, L. / FERRÉ OLIVÉ, J.C. / GARCÍA RIVAS, N. / SERRANO PIEDECASAS, J.R., / TERRADILLOS BASOCO, J.M., Curso de Derecho Penal. Parte General. Barcelona: Ediciones Experiencia. 2004, p. 511; LUZÓN CUESTA, J.M., Compendio de Derecho Penal. Parte General. $18^{\text {a }}$ Ed. Madrid: Dykinson. 2010, p. 251; CEREZO MIR, J., Curso de Derecho penal español. Parte general. (I) Introducción. 6a ED. Madrid: Technos. 2004; Pág. 33.

8 RUBIO LARA, P.A., “Las medidas de seguridad tras la reforma de la LO 5/2010 de 22 de Junio del Código Penal: Perspectivas Doctrinales y Jurisprudenciales. Problemas y Soluciones". En Revista de Derecho Penal y Procesal, núm. 25. Navarra: Aranzadi. 2011, pp. 34 y 35. Este autor mantiene que las medidas de seguridad tienen finalidad preventiva, tanto especial como general, porque producen en la comunidad un efecto intimidatorio y un efecto de reforzamiento de la confianza en la política criminal del Estado (y en la propia norma) en la aplicación y ejecución de las medidas de seguridad para los delincuentes peligrosos.

9 JORGE BARREIRO, A., "Reflexiones sobre la problemática actual y el futuro de las medidas de seguridad criminales: su regulación en el Derecho penal español y en el Derecho comparado". En LUZÓN PEÑA, D.M., (Dir.), Derecho penal del Estado social y democrático de Derecho. Libro homenaje a Santiago Mir Puig. Madrid: La Ley. 2010, p. 610.

10 JAKOBS, G., Derecho penal. Parte General. Fundamentos y teoría de la imputación. $2^{\text {a }}$ Ed. Traducida por Joaquín Cuello Contreras y José Luis Serrano González de Murillo. Madrid: Marcial Pons. 1997, pp. 41 y 42. 
nivel doctrinal a lo largo de la historia y su actual configuración es fruto de un largo proceso histórico en el que siempre han estado presentes, de lo que me ocupo en profundidad a continuación.

\section{ANTECEDENTES HISTÓRICOS DE LAS MEDIDAS DE SEGURIDAD}

Las medidas de seguridad son producto de los postulados del moderno Derecho penal y sus orígenes más recientes y ciertos se identifican con la aparición en el siglo XIX de la Escuela Postiva Italiana11, aunque en algunos trabajos de FEUERBACH y KLEIN ${ }^{12}$ ya aparecen referencias a esta categoría de sanciones si bien de forma embrionaria ${ }^{13}$. No obstante, su aparición fáctica se remonta a los orígenes mismos de la civilización y del Derecho, ya que las figuras de carácter penal con contenido profiláctico, asegurativo o corrector han estado siempre presentes a lo largo de la historia ${ }^{14}$, aunque hasta el siglo XIX no existen como tales las medidas de corrección y de seguridad.

$1^{\circ}$. En las primeras civilizaciones, los primitivos ordenamientos jurídicos tuvieron siempre respuestas criminales frente a sujetos considerados especialmente peligrosos, frente a los que el sistema establecido, por precario que fuera, tendía a articular medidas de protección frente a los que pretendían erradicar el sistema o subvertir el orden establecido y asumido por los distintos integrantes de la civilización ${ }^{15}$.

11 BLANCO LOZANO, C., Tratado de Derecho penal español. Tomo I. El sistema de la parte general. Vol. 1. Fundamentos del Derecho penal español. Las consecuencias jurídico-penales. Barcelona: Bosch. 2004, p. 483.

12 A Klein se le considera el fundador del sistema de doble vía o dualista, debido a que desarrolló la idea de implementar junto con las penas, medidas de carácter asegurativo con orientación preventivo-especial, idea que pasó posteriormente, en fecha 5 de febrero de 1794, al Derecho Territorial Prusiano. Vid. SANZ MORÁN, A.J., Las medidas de corrección y de seguridad..., cit. p. 22.

${ }^{13}$ MAPELLI CAFFARENA, B., Las consecuencias jurídicas del delito. $5^{\text {a }}$ Ed. Navarra: Civitas. 2011, p. 353.

14 LANDROVE DÍAZ, G., Las consecuencias..., cit. p. 115. Este autor explica que la afirmación de que las medidas son creación del moderno Derecho penal de finales del siglo XIX solo es atendible desde el punto de vista terminológico y en sentido estrictamente técnico, ya que desde tiempos inmemoriales se combatió la criminalidad con mecanismos represivos y preventivos que, en ocasiones, sobrepasaban los parámetros estrictamente penales.

15 Se trata de una necesidad biológica de defensa y aseguramiento social que, por voluntad del poder instaurado, se trasforma en principios que sirven a la idea de garantizar la seguridad y vigencia del propio sistema frente a los ataques de los sujetos considerados peligrosos, lo cual se traduce en la instrumentalización de dichos principios a través de normas y leyes. Vid. LEAL MEDINA, J., La historia de las medidas de seguridad. De las instituciones preventivas más remotas a los criterios científicos penales modernos. Navarra: Thomson Aranzadi. 2006, p. 31. 
a) El Derecho Sumerio ${ }^{16}$, o Derecho propio de la civilización de Sumer (ubicada en la antigua Mesopotamia, junto a los ríos Tigris y Éufrates, años 5500 a.C. a 2004 a. C.) ${ }^{17}$, es en esta civilización donde se promulga la primera medida de seguridad que se conoce en la historia de las medidas, consistente en la expulsión de la ciudad de usureros, ladrones y toda suerte de criminales con el objetivo ulterior y prioritario de proteger a sus ciudadanos ${ }^{18}$.

b) En el Derecho babilónico-mesopotámico ${ }^{19}$, de donde se extraen indicios y signos manifiestos de medidas de seguridad, puesto que se advierte una notable presencia de los fines de prevención, profilaxis y aseguramiento, con cuya aplicación y ejecución se trataba de evitar la comisión de nuevos y futuros delitos ${ }^{20}$. Las concretas consecuencias penales contenidas en el Código Hammurabi de las que se deduce su carácter de medidas de

\footnotetext{
16 Esta civilización constituye el origen de la Historia de la Humanidad, según los expertos. Ibidem, p. 32.

17 Es en esta civilización, en la ciudad de Lagash, donde se produjo el nacimiento de la primera medida de seguridad escrita cuando, a través de un golpe de Estado, el trono fue ocupado por el dictador Uruinimgina (años 2352 a.C. a 2342 a.C.). Debido a la crítica situación económica que atravesaba el país, el Rey Lugallanda (que por lo demás era legítimo) introdujo una serie de normas fiscales y de control monetario que le condujeron al golpe de Estado, puesto que tales abusos tributarios y de control del comercio, provocaron un irrespirable clima de irritación en los campesinos y sacerdotes. El nuevo príncipe tenía la urgente misión de restablecer el orden, derogar las leyes impuestas anteriormente por su antecesor y devolver las tierras a los sacerdotes que habían sido despojados arbitrariamente de ellas. Los abusos fiscales consistieron básicamente en que los campesinos y los sacerdotes se vieron obligados a pagar mayores impuestos con las consecuentes amenazas, por parte del poder, de que si no obedecían iban a ser expropiados. Todo ello propició que los grupos sociales afectados se sintieran maltratados y oprimidos, y ese clima de malestar había que corregirlo de alguna forma. Ibidem, p. 33.
}

18 Ibidem, pp. 33 y 34. Este autor señala que "tanto el lugar donde se declara, la ciudad, por ser éste el sitio donde se establecía el vínculo de pertenencia del hombre al grupo, como por el objetivo inicial de la expulsión de los criminales más peligrosos, para entrar en otro mayor; evitar que con su permanencia y estancia en la metrópoli puedan seguir conspirando y cometiendo crímenes, poniendo en peligro el orden y la convivencia ciudadana". [...] Sigue diciendo este autor que "la medida de expulsión de la población a los indeseables no trata de castigar y retribuir un acto o comportamiento antijurídico por haber conculcado el orden social establecido, más bien busca alejar, mantener distante e inocuizar de la manera más rápida, un mal; el peligro que representan para la comunidad un determinado tipo de personas que, lejos de cometer actos concretos y determinados, más bien por el contrario, la perpetración de conductas antisociales, continuas y constantes, unidas a actuaciones criminales diversas que causan una gran alarma social por su peligrosidad en el entorno físico donde gravitan, lleva a la máxima autoridad civil y religiosa a dictar su expulsión definitiva de la ciudad, como medida profiláctica que intercede en la salvaguarda del lugar y centro de reunión donde mejor se protegen las relaciones humanas de todo tipo en paz y tranquilidad".

${ }^{19}$ Cuyo máximo esplendor fue durante la I Dinastía de Babilonia, de donde surge el primer documento escrito que se conserva, considerado uno de los más valiosos textos legales de la Historia de todos cuantos han sido hallados como legado de estas culturas. Se trata del Código Hammurabi (Rey de Babilonia durante los años 1792 a. C. a 1750 a.C.) publicado alrededor del año 1753 a.C., al que el propio Rey Hammurabi denominó "dinat msharim" que significa "sentencias justas". Ibidem, p. 35 y 36.

20 "Hammurabi, al que los dioses designan como el príncipe piadoso, temeroso de dios, es el elegido para proclamar en el imperio, un orden justo, que destruya al perverso y al malvado, así como para evitar que el fuerte oprima al débil, para fomentar el bienestar de las gentes". Ibidem, p. 37. 
seguridad son las siguientes: la expulsión de la ciudad21; la amputación de la mano al médico 22 , y la mutilación de la nodriza ${ }^{23}$.

$2^{\circ}$. En el mundo griego, durante los siglos IV y $\mathrm{V}$ a. C., nace uno de los principios de las medidas de seguridad: la prevención especial. En efecto, PLATón, (427 a 347 a.C.) refiere en sus Diálogos a figuras jurídicas preventivas o profilácticas, fundadas en la reeducación social, como la expulsión del territorio ateniense o el alejamiento24. También encontramos la figura del ostracismo25, a la refiere PLATÓN en sus Diálogos²6 y también

${ }^{21}$ Ley 54 del Texto Babilónico: "Si un señor cohabita con su hija, se le hará salir a ese señor de la ciudad". Se trata de una medida de seguridad porque su objetivo y finalidad no es otra que evitar que el sujeto vuelva al lugar del crimen o, dicho de otro modo: se trata de evitar el riesgo de reincidencia, alejándole del lugar donde el crimen fue perpetrado. Por su parte, la Ley 157 del Código Hammurabi dice: "si un señor, después de su padre, yace en el seno de su madre, se les quemará a ambos". En este caso no se trata de una medida de seguridad sino de una pena, pues la finalidad ya no es evitar la reincidencia, o evitar que el sujeto vuelva al lugar del crimen, sino que aquí la finalidad es puramente retributiva. Además, se observa claramente que la medida resulta mucho más benigna que la pena. Ibidem, pp. 37 y 38.

22 Ley 218 del Código Hammurabi “se le amputará la mano al médico que ha llevado a cabo una operación de importancia en un señor con una lanceta de bronce y le ha causado la muerte, o bien ha abierto la cuenca del ojo a un señor con dicha lanceta y le ha destruido el ojo". Ibidem, p. 38. Este autor expresa que "la intención que se deduce con el castigo no es reprimir una conducta ni punir la acción que se entiende negligente por parte del médico, sino que lo que se pretende es incapacitarle, dejarle impedido selectivamente con el claro propósito de hacer que no vuelva a practicar otra operación a ningún señor".

${ }^{23}$ Ley 194 del texto Babilónico: “Si un señor que ha entregado a su hijo a una nodriza para amamantarlo, muere entre sus manos y la nodriza sin el conocimiento del padre o de la madre del niño muerto, liga y une a su seno otro niño con el mismo fin, la convencerán de ello, en caso contrario, y puesto que lo hace sin el consentimiento de los padres del niño muerto, se le amputarán los pechos". Se trata de una medida de seguridad de tipo asegurativa, creada con el único propósito de evitar que en el futuro se cometa el mismo delito. Ibidem, pp. 39 y 40. Según este autor, en este supuesto, el delito “no es otro que intentar obtener más recursos económicos aceptando lactancias, cobrándolas, volviendo de nuevo a pactar con otros padres nuevas crianzas, sin llegar a poner en conocimiento de los padres del niño muerto la circunstancia de su fallecimiento para así no tener que devolver y reembolsarles las cantidades cobradas por realizar su yermo servicio". Se pretende también corregir la perversidad y peligrosidad de la nodriza, que se desprende de la mera intención de ocultar el cadáver del niño.

24 PLATÓN, “Las leyes. Libro noveno". En PLATÓN, Obras completas. Tomo 10. Madrid: Ed. Patricio de Azcárate. 1872, p. 109. Para este autor, "todo hombre, sea extranjero o esclavo, a quien se sorprenda robando una cosa sagrada, será expulsado, desnudo, del territorio del Estado, después de haberle grabado en la frente y en las manos el sello de su crimen y de haber recibido los azotes que los jueces hubieren decretado. Este castigo podrá quizá corregirle y hacerle mejor, porque ninguna pena, impuesta conforme al espíritu de la ley, tiene por fin el mal del que la sufre, sino que su efecto es hacerle mejor o menos malo". Este derecho al castigo de la antigua Grecia, que se concibe como un bien que purifica y cura el alma corrompida por el mal, es una fase embrionaria de lo que hoy conocemos como los internamientos terapéuticos obligatorios para los inimputables que deliquen a causa de su enfermedad mental, (vid. LEAL MEDINA, J., La historia de las medidas..., cit. p. 46 y 47).

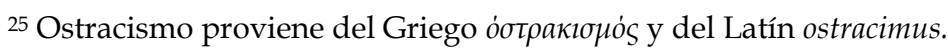

${ }^{26}$ El ostracismo quedó debidamente reflejado en la obra de PLATÓN, fruto de que era una medida de muy frecuente y común utilización; así, en sus Diálogos, Sócrates le pregunta interrogando a Gorgias: “¿Recuerdas haber dicho antes, que no debía tropezarse con los maestros de gimnasia, ni arrojarlos de las ciudades, porque un atleta haya abusado del pugilato y cometido alguna acción injusta, y que, en igual forma, si algún orador hace un uso indebido de la Retórica, no debe hacerse recaer la falta sobre su maestro, ni desterrarle el Estado, sino sobre el autor mismo de la injusticia, que no ha usado de la Retórica como debía? ¿Has dicho esto o no?”, 
ARISTÓTELES en la Política ${ }^{27}$, que era una orden de expulsión de la ciudad, dirigida a gobernantes, filósofos, militares poderosos, o personas de reconocido poder en la sociedad. La expulsión comprendía también la prohibición de entrar en la polis o de volver a su lugar de residencia, durante un período de tiempo que venía determinado en la resolución que la imponía, que provenía siempre de un Magistrado ${ }^{28}$. Era, por tanto, una medida que se adoptaba para determinadas personas que se temía que abusaban de su poder y se beneficiaban de su autoridad, y así se convirtió en un arma política al servicio de la eliminación civil de los adversarios políticos de turno.

Otro elemento básico y fundamental de las medidas de seguridad surge en esta época helenística: la noción de enfermedad mental. En efecto, la medicina griega pondrá fin a una concepción de la locura como algo sobrenatural que solo hallaba cura en la magia o en la espiritualidad, para pasar a concebirse como unos trastornos mentales o males del espíritu ${ }^{29}$. Una sociedad en la que el estado mental ideal era el equilibrio del cuerpo y la mente ${ }^{30}$, donde sin embargo la situación concluía compleja si sobrevenía la enfermedad.

$3^{\circ}$. En el Derecho romano, con la Ley de las XII Tablas, fechada entre los años 451 a 449 a. C., aparecen signos ocultos de medidas de seguridad en las distintas consecuencias jurídicas del crimen existentes. Aparte de las penas que en ella se catalogaban, existían otras consecuencias sancionadoras que, más que imponer un daño al culpable, pretendían asegurar la vigencia y el control del poder político, a través de neutralizar a un determinado grupo de personas del que podía preverse que se desprendía un cierto nivel de peligrosidad para el grupo ${ }^{31}$. Ejemplos de ello son el destierro ${ }^{32}$ y la deportación, que

\footnotetext{
y Gorgias le responde: "lo he dicho". Vid. PLATÓN, “Gorgias". En PLATÓN, Obras completas. Tomo 5. Madrid: Ed. Patricio de Azcárate. 1871, p. 153.

27 ARISTÓTELES, "Política”. En ARISTÓTELES, Obras filosóficas. Barcelona: Océano. 2000, pp. 319 y 320. Según este autor, "por eso se instituyó el ostracismo en los Estados democráticos; porque tienden a la igualdad ante todo, y por ello desterraron de la ciudad durante cierto tiempo a los que parecía que predominaban en demasía a causa de sus tesoros, o el número de sus partidarios, o cualquier otra influencia política. [...] El ostracismo es medida de la misma naturaleza, que obra alejando y eliminando a los ciudadanos más encumbrados".

28 LEAL MEDINA, J., La historia de las medidas..., cit. p. 48.

${ }^{29}$ Que como dijo HIPÓCRATES, la relación causal entre el organismo físico y la mente produce determinados tipos de temperamentos o personalidades anómalas. Ibidem, p. 50.

30 Kalos Kai Aräos.

31 LEAL MEDINA, J., La historia de las medidas..., cit. Pág. 59.
} 
iba acompaña de la pérdida de la ciudadanía romana ${ }^{33}$. Y también en el Derecho romano se puede observar el tratamiento jurídico que se le daba al furiosi, (loco o furioso) que era irresponsable penalmente y por ello conformaba una categoría jurídica que requería protección y vigilancia ${ }^{34}$.

$4^{\circ}$. En el Cristianismo aparece el ideal asistencial basado en la caridad y en la misericordia, dignificando la persona humana y dulcificando la ejecución de penas y castigos en una humanización del Derecho penal por la que se prohíbe la crucifixión y comienza a mejorarse el trato que se da a los enfermos, mendigos y pequeños delincuentes comunes. La terapia se basa en el amor y en ese sentido se instrumenta al servicio de la rehabilitación ${ }^{35}$, donde adquiere protagonismo el monasterio como institución benéfica y como centro de reclusión para la gente improductiva y marginal. Su tratamiento se basa en la oración, en el estricto orden interno y en la disciplina en el trabajo en el interior de monasterio, que se concibe como eje fundamental sobre el que gira el tratamiento que pretende la trasformación de las conductas desviadas de los que allí son recluidos.

5. En la Edad Media. En la Alta (siglos VI al XI d. C.) predomina la ignorancia, la superstición y la pobreza, surgiendo el vasallaje como única forma de garantizar la seguridad y la supervivencia debido a la crisis del Imperio Romano por las interminables guerras e invasiones bárbaras, que provoca las migraciones en masa al campo, abandonando todos los campos del conocimiento de la ciencia y del Derecho, que a partir de ese momento serán únicamente materias asiladas en los monasterios que no son más

32 Que a pesar de su extendida utilización en el Imperio Romano, no venía descrito en el catálogo de penas de la Ley de las XII Tablas, por lo que se deduce que se trataba de algo distinto no considerado como una sanción de tipo retributivo y represivo (como sucede en el resto de penas de la época) sino como algo más benigno, y que por no revestir ni siquiera carácter de pena, se imponía con enorme arbitrariedad e injusticia, lo cual refuerza la idea de que se trataba de una figura diferente, que puede asociarse a una medida de seguridad. Ibidem, pp. 59 y 60.

33 Y que consistía en la obligación de residir en una de las islas ubicadas dentro del Imperio designada por el magistrado, con la prohibición expresa de salir de la misma. O la relegación, que consistía en relegarse a un monasterio por tiempo de tres años, donde tenía que residir observando las más estrictas normas de convivencia religiosa; y cuando se trataba de encubridores de cuatreros, eran relegados por diez años fuera del territorio de Italia. Ibidem, p. 62.

34 Ibidem, p. 65.

35 Ibidem, p. 73. Como explica este autor, "la virtud está en el bien, y se vincula con la afectividad y hermandad; instrumentos que se constituirán, junto con el amor al prójimo y la ayuda a todo necesitado, en el tratamiento institucional que va a presidir los primeros centros de internamiento y de atención de los asociales, que aislados y separados de la ciudad, comenzarán a fundarse en todo el continente occidental". 
que centros de conocimiento, de disciplina y de internamiento de los inadaptados sociales. El ciudadano manifiesta un claro desinterés por lo público que aparece fuertemente desprestigiado y se instaura con fuerza la hegemonía de la Iglesia, que imparte una doctrina intransigente con el hombre y exigente con su contenido, ensalzando la condena del ser humano - que debe pagar su tributo por haber crucificado a Jesús- al sufrimiento y al dolor terapéutico acrecentado por la intolerancia y la rigidez del poder religioso imperante, que exhibe el poder de Dios extremadamente severo y cruel bajo la idea de la culpa y del pecado que mantiene a la transformada población atemorizada e inmovilizada.

En ese orden de cosas, el Derecho vigente en esta época regula medidas de seguridad de tipo asegurativo con exclusión absoluta del enfermo mental, y con el único fin de garantizar el orden y el mantenimiento de la seguridad ${ }^{36}$. El Derecho visigodo contempla en el Fuero Juzgo la medida de echar para siempre fuera de la tierra, el destierro por tres años de la tierra, cortar el dedo pulgar de la mano derecha al escribano, la castración, la excomunión, la prohibición de habitar durante dos años continuos en aquella provincia donde el infractor haya cometido la usurpación o la deportación ${ }^{37}$.

En la Baja Edad Media (siglos XII al XV d. C.), se desarrolla el comercio en las ciudades, se produce una unificación militar y religiosa, y la organización política y jurídica se basa en la voluntad del Monarca de proteger a la sociedad y asegurar su territorio frente a peligros externos y frente a conflictos en el orden interno, debido a las pugnas en el campo y la ciudad por parte de campesinos, mercaderes y nobles. Alfonso X, antes de las Partidas, redactó el Fuero Real (año 1255) que contenía las medidas de "echar por Jamás de la Tierra", para el que se casare con una mujer religiosa o monja, sanción que conllevaba la devolución de ésta al monasterio del que salió (Fuero Real, Libro IV. Ley II) y la de "echarlos de la Tierra por siempre", para supuestos del hombre que yaciere con la mujer de su padre, de su hermano, de su hijo, etc. (Fuero Real Libro IV. Ley III) ${ }^{38}$.

Ya en las Partidas, aparece la ausencia de toda capacidad de culpa del inimputable al que se exime de responsabilidad cuando se trate del loco, furioso o desmemoriado, con

\footnotetext{
36 Ibidem, pp. 79 a 83.

37 Ibidem, pp. 87 a 96.

38 Ibidem, pp. 119 a 121.
} 
la obligación legal que se impone a la familia de ejercitar la guardia y custodia mientras persista la causa de inimputabilidad, configurado así como una medida de custodia familiar (Partida VII, Título I, Leyes I a IX), aunque era frecuente que si la custodia no surtía efecto, se hiciera cargo de ellos la autoridad religiosa que les recluía en monasterios, en castillos fortificados habitados por monjes u otras autoridades eclesiásticas o en las mazmorras del rey ${ }^{39}$.

Surge una idea de peligrosidad en las personas consideradas pobres, como los vagos, lisiados, mutilados, indeseables y enfermos mentales, que socialmente serán catalogados como gente peligrosa, a los que hay que sumar los apestados (víctimas de la peste negra que asoló Europa a partir de 1348). La exclusión social de enfermo mental es absoluta, de forma que el loco o furioso es considerado hereje o endemoniado y la religión católica se convierte en la única terapia posible, que se traduce en exorcismos, torturas y todo tipo de castigos ${ }^{40}$, que revisten severidad draconiana con la llegada de la Inquisición. La aplicación de penas retributivas en exceso basadas en castigos físicos y mutilaciones, genera la aparición de una numerosísima clase social de vagabundos, mutilados y asociales que frecuentan las ciudades de forma sospechosa conformando un grupo social que se presume de elevada peligrosidad, que va a ser objeto de expulsiones y alejamientos como medidas de protección frente a los futuros delitos que se espera que cometerán, adquiriendo gran relevancia la idea de profilaxis que busca la seguridad de la comunidad. En ese sentido las Partidas contienen las siguientes figuras preventivas:

a) El destierro, que revestía varias modalidades: con pérdida de todos los bienes (Partida VII, Título XXXI, Ley IV), en una Isla para siempre o en un lugar de encierro por tiempo determinado - hasta cinco años (Partida VII, Título VIII, Ley V) o por no más de diez años (Partida VII, Título XIV, Ley XIX)—. La otra modalidad es el destierro sin pérdida de los bienes. La consideración del destierro como medida asegurativa alejada del carácter retributivo de la pena resulta clara y solo pretende evitar que el sometido a la

\footnotetext{
39 Ibidem. Págs 124 a 129.

40 Ibidem, p. 131. Como expresa este auror, "nos encontramos con la actitud intolerante y sectaria de la Iglesia que entorpece con trabas constantes y obstáculos doctrinarios, el estudio de las facultades cerebrales y sus posibles repercusiones, impidiendo configurar tratamientos solventes para estos males, lo que habilita a que sean los propios familiares de los enfermos o ellos mismos, quienes acudan a buscar alguna solución para su anomalía en la astrología, incluso en la magia. Así, el enfermo mental puede ser quemado, atormentado o recibir fuertes sufrimientos, cuando en la mayoría de los casos lo que pretende es encontrar una salida racional al dolor y al malestar psíquico del que se desconocen sus causas".
} 
medida pueda poner el peligro los bienes jurídicos protegidos y los derechos individuales, lo que se desprende de la temibilidad constatada por las acciones pasadas cometidas. Y también se desprende de la distinción de la propia Ley para imponer penas o medidas según las clases de personas ${ }^{41}$. El carácter de medida de seguridad se desprende también de la menor relevancia de los hechos cometidos como manifestación externa del sujeto, que ponen de manifiesto la improcedencia de la ejemplaridad de la pena como manifestación más clara de la retribución, y se opta por la imposición del destierro como medida debido, por ejemplo, a la menor intensidad del dolo o a supuestos imprudentes o culposos ${ }^{42}$. Y también se desprende ese carácter por su utilización en la persecución de figuras penales de difícil acreditación como los delitos familiares, que revisten una enorme dificultad para el Juez, de tal forma que la imposición de la medida -que implica alejamiento inmediato del entorno familiar- resulta más eficaz que la imposición de penas ${ }^{43}$.

b) Otras medidas como la expulsión de los leprosos de la ciudad, basada únicamente en la enfermedad y que se adoptaba como aseguramiento fundado en la sanidad y la salud del grupo, evitando así el contagio (Partida VII, Título II, Preámbulo); la marca, que se

\footnotetext{
41 Ibidem, p. 140, y notas al pie 116 a 118. “Destierro para siempre en una Isla si quien mata a otro es caballero o fijodalgo. Los constituidos en dignidad sufren el destierro como medida de seguridad. Los más humildes, para el mismo crimen son entregados a las bestias. Incluso otras interpretaciones hablan que entre ambas categorías hay una tercera. Los de clase media que serán decapitados (Partida VII, Título VIII, Ley XV). Destierro para siempre para aquellos fijodalgos $u$ hombres honrados que incendiasen casas, mieses $u$ otros edificios, a la fuerza y con armas, tanto si ordenasen la quema como si ayudasen a poner fuego. Mientras que si quien ha cometido semejante acción es un hombre de menor entidad o guisa, más bien vil, debe ser echado en el fuego para que se queme (Partida VII, Título X, Ley XI). Destierro para siempre en alguna Isla para aquellos hombres libres que, mudando o faltando a la verdad cometieren algunas de las falsedades descritas en la Ley. Tanto en las escrituras verdaderas, como en los testamentos, sellos y cartas. O en las palabras, en pleito o similares. Si fuere siervo debe morir por ello (Partida, VII, Título VIII, Leyes I a IV)".
}

42 Ibidem, p. 140 y notas al pie 119 y 120. “Destierro en alguna Isla por cinco años, para los médicos y cirujanos que sin conocimientos suficientes, teniendo enfermos a su cuidado, practican cualquier tipo de intervención quirúrgica y a causa de ellos y de su impericia, los pacientes mueren. Igual medida penal para la mujer que diese hierbas y otros brebajes a otra con el fin de que aborte o impida la formación de la futura persona y por tal circunstancia le llegase la muerte (Partida VII, Título VIII, Ley VI). Destierro en alguna Isla por cinco años, para el padre que sobre el hijo, o el señor sobre su siervo, o el maestro sobre su discípulo, en el ejercicio legítimo y mesurado del castigo o de la enseñanza de la disciplina, se excedieran cruelmente en el derecho y en su práctica y a causa del abuso en su ejecución le hubiera ocasionado heridas tan graves que le hubiesen producido la muerte, siempre que se obrara sin intención ni maldad alguna o sin ánimo de perseguir la muerte sobre los que se impone el correctivo (Partida VII, Título VIII, Ley IX)".

43 Ibidem, p. 141 y notas al pie 122 y 123.Este autor explica lo siguiente: “Destierro para siempre en alguna Isla para, siendo todos sus bienes confiscados pasando a disposición del Rey, para e guardador que tuviera a su cargo una hija huérfana y la diera como mujer a su hijo o nieto, tanto en vida como en testamento. Igualmente si al final el tutor o guardador tuviera trato con ella sin que mediara casamiento de por medio (Partida VII, Título XVII, Ley VI). Destierro por tiempo de cinco años o pérdida de cuantos bienes tuviera en aquel lugar donde formalizó su matrimonio, para aquellos que se casan dos veces, sabiendo viven sus mujeres (Partida VII, Título XVII, Ley XVI)". 
aplica a los judíos para identificarles y poder mantenerles controlados y fiscalizados cuando deambulan mezclados entre los cristianos (Partida VII, Título XXIV, Ley XI); o la medida de echar de la Tierra, como una modalidad de destierro para los blasfemos que insulten a Dios o a la Virgen Santa (Partida VII, Título XXVIII, Ley IV) ${ }^{44}$.

$6^{\circ}$. En el moderno Derecho penal, las medidas de seguridad han sido una constante, desde el absolutismo hasta la actualidad encontramos medidas de seguridad en multitud de textos legales cuya evolución es el resultado de la proliferación de la idea de profilaxis y peligrosidad.

a) En las Monarquías Absolutas (siglos XVI a XVIII), las normas jurídicas emanadas del poder político sirven de sustento legitimador para el uso de la fuerza y la imposición de penas de gran dureza, ya que el dolor físico y el escarmiento propio de las penas persiste en esta época para el mantenimiento del sistema, acentuado con la llegada de los Tribunales de la Inquisición que se nutre de las penas para la intimidación y para la purificación y limpieza de las almas corrompidas por el crimen. Sin embargo en ese contexto surgen una serie de normas eminentemente profilácticas y preventivas basadas en el seguimiento y la expulsión de los asociales, que generan un Derecho penal de autor donde la importancia no reside en el delito sino la personalidad de los sujetos y su carácter peligroso, considerados enemigos del Estado. Se producen castigos de gran severidad, expulsiones masivas y encierros ilimitados que pretenden anticiparse al delito y a los estados antisociales, que se identifican con toda clase de marginales o personas contrarias al orden religioso instaurado (herejes), judíos, moros y un amplio elenco de personas que simplemente están disgregados por la península y se les considera peligrosos por improductivos y catalogados bajo el estado de vagancia y mendicidad -y en menor medida las situaciones de necesidad o enfermedad- serán objeto de duros castigos por ser calificados como peligrosos y temibles debido a las manifestaciones externas de sus peculiares formas de vida, lo que les conducirá a ser declarados personas non gratas para el Estado 45 .

Pero sin duda la vagancia es el estado de peligrosidad más acusado en la etapa absolutista, y se recurre a las pragmáticas, cédulas reales u ordenanzas y a leyes especiales

\footnotetext{
44 Ibidem, pp. 141 a 143.

45 Ibidem, pp. 169 a 170.
} 
por las que se regulan los estados peligrosos, como las promulgadas por los Reyes Católicos: la pragmática de Granada de 30 de marzo de 1492, por la que se decretó la expulsión de todos los judíos con prohibición de regreso; la pragmática de Zaragoza de 2 de agosto de 1948 por la que se decreta la prohibición de regresar al reino a los herejes que se encuentren ausentes del mismo; la pragmática de Granada de 5 de septiembre de 1499, que decretó la expulsión también a los que vinieren de reinos extraños; la pragmática de Granada de 20 de julio de 1501 y la de Sevilla de 12 de febrero de 1502, por las que se decretó la expulsión de los mudéjares o moros. Don Carlos y Doña Juana, en 1528 dictaron la prohibición a los vagabundos de merodear por la Corte sin autorización. Las Cortes de Madrid de 1540, promulgaron una disposición por la que se prohibía mendigar y pedir limosna en el pueblo sin autorización.

Felipe II en Madrid, por pragmática de mayo de 1566, elevó las penas para los vagos (vagantes) y extendió las medidas asegurativas aplicables a ellos, a los egipcios, a los caldereros extranjeros, mendigos y vendedores de frutas en las calles ${ }^{46}$; en Aranjuez en 1568 prohibió el paso a las Indias de los gitanos por su elevada peligrosidad. Felipe III, por pragmática de Segovia de 9 de diciembre de 1609 decretó la expulsión de los moriscos con prohibición expresa de regreso bajo pena de muerte ${ }^{47}$, y por Cédula de 28 de junio de 1619 dictada en Belén de Portugal, decretó la expulsión de los gitanos que no se avecinaren o hermanaren en los pueblos de más de mil habitantes en un plazo de seis meses.

Felipe IV, por pragmática de 8 de mayo de 1633, impuso la obligación a los gitanos de integrarse, les obligó a vivir en comunidad, a hablar como las demás gentes y a profesar los mismos oficios, intentando alejarles de la marginación y de sus costumbres

\footnotetext{
46 PÉREZ Y LÓPEZ, A.J., Teatro de la legislación universal de España é Indias. Por orden cronológico de sus cuerpos y decisiones no recopiladas; y alfabético de sus títulos y principales materias. Madrid: Imprenta de Don Antonio Espinosa. 1797. Tomo XVI, pp. 161 y 162. “Don Felipe II. Pragmática de mayo de 1566. [...] Ley II. Los vagantes, los egipcios y los caldereros extrangeros, que según las leyes deben salir del Reyno, y los mendigantes sanos y los que venden frutas por las calles, y tienen tiendas de comer. En quanto á la edad, se observe lo dispuesto contra los ladrones y rufianes, y dichos vagantes se castiguen, aunque aleguen no haber sido amonestados por pregón público ni particular".

47 SYLVESTRE MARTíNEZ, M., Librería de Jueces, utilísima y universal. Madrid: Imprenta de Blas Román. 1772. Tomo octavo, p. 155. “Artículo II. De los Judíos y Moros y Rescatados, Gazis, Mudexares y Christianos Nuevos", p. 158. "S.I. De las leyes recopiladas. 24. [...] Por Real Resolución del Monarca Phelipe III de 9 de diciembre de 1609 se expelieron absolutamente de estos Reynos todos los Moriscos, à excepción de los Esclavos, y se executó su expulsión en el termino de treinta dias despues que fue publicada, permitiendoles se llevasen en Mercaderias no prohibidas todo quanto importasen sus bienes muebles, y el dinero necesario para su viaje por Mar ò por tierra como les conviniera".
} 
que se consideraban peligrosas, y prohibió la utilización del término gitano en el lenguaje común48; y la pragmática de 1643 reprimió duramente a los bandoleros. Carlos II, por pragmática de Madrid de 20 de noviembre de 1692, continuó con las represiones a los gitanos, reiterado en la pragmática de Madrid de 20 de julio de $1695^{49}$.

Felipe V, en el palacio de Buen Retiro, el 20 de septiembre de 1712, decretó la expulsión de los moros llamados cortados o libres a los que mandó con sus familias y bienes a África50; y por cédula de 20 de septiembre de 1726, dispuso que no se pueda oír a los gitanos en recursos de queja ante Tribunales superiores, reforzando además el contenido de la anterior pragmática de 1712. Fernando VI dictó en Madrid su Real Ordenanza de 13 de octubre de 1749 , por la que dispuso que no se consintiera a los vagabundos ni gente sin trabajo, que deambulare libre y ocioso para evitar caer en la perversión, delegando en los Corregidores el cuidado de los vagos, ociosos y mal entretenidos ${ }^{51}$.

48 Vid. Novisima Recopilación de las Leyes de España. Mandada formar por el Señor Carlos IV. Dividida en XII libros en que se reforma la Recopilación publicada por el Señor Don Felipe II en el año de 1567, reimpresa últimamente en el de 1775. Y se incorporan las pragmáticas, cédulas, decretos, órdenes y resoluciones Reales, y otras providencias no recopiladas, y expedidas hasta el de 1804. Madrid: 1805. Libro XII, Título XVI, De los Gitanos, su vagancia y otros excesos. Ley V, p. 359. “Que de aquí adelante ellos ni otros algunos, así hombre como mugeres, de cualquier edad que sean, no vistan ni anden con traje de gitanos, no usen la lengua ni se ocupen en los oficios que les estan prohibidos y suelen usar, no vistan ni anden con trage de gitanos, ni anden en ferias, sino que anden y vistan como los demas vecinos de estos reynos, y se ocupen en los mismo oficios y ministerios, de modo que no haya diferencias de unos á otros; pena de dos cientos y seis años de galeras á los que contravinieren en cualquiera de los casos referidos, y la pena de galeras se conmute en la de destierro a las mujeres. 1. Que so las mismas penas dentro de dos meses salgan los suso dichos de los barrios en que viven con nombre de gitanos, y que se dividan y mezclen entre los demás vecinos, y no hagan juntas en público ni en secreto; y las Justicias esten con particular atencion á ver como los cumplen, y si se comunican ó casan entre si mismos, y como cumplen con la obligacion de cristianos asistiendo á las Iglesias [...]. 2. Y para extirpar de todo punto el nombre de gitanos, mandamos, que no se lo llamen, ni se atreva ninguno á llamárselo, y que se tenga por injuria grave, y como tal sea castigada con demostración; y que ni en danzas ni en otro acto alguno se permita accion ni representacion, trage ni nombre de gitanos; pena de dos años de destierro y de cincuenta mil maravedís para la nuestra Cámara, Juez y denunciador por iguales partes, contra cualquiera que contraviniere por la primera vez, y la segunda sea la pena doblada".

${ }^{49}$ LEAL MEDINA, J., La historia de las medidas..., cit. p. 173.

50 Novisima Recopilación de las Leyes de España..., cit. Libro XII, Título II, Ley V, p. 313. “En Buen Retiro à 20 de septiembre de 1712. Expulsion general de los moros llamados cortados ó libres. Habiendo considerado los graves inconvenientes que se siguen, tanto en lo político como en lo espiritual, de la persistencia en España de los moros que llaman cortados ó libres, las utilidades que trae consigo expelerlos de ella, y las precauciones que, para evitar que en adelante los haya en mis reynos, deben ponerse; he resuelto se haga una expulsion genera de estos moros cortados, obligandoseles á salir fuera de mis dominios sin que se interponga mas dilacion que la de aquel tiempo limitado, que por las Justicias de ellos se les diere, para recoger sus familias y caudales, y conducirse con ellos al Africa".

51 Ordenanza de 13 de octubre de 1749 para el restablecimiento e instrucción de intendentes de provincias y exercitos, por orden de Su Magestad Don Felipe VI. Madrid: Imprenta Manuel Fernandez. 1749, p. 9. “XXI. Tendràn todo el cuidado, que corresponde à mi confianza, en solicitar por sì, y por medio de sus subdelegados, saber la calidad, vida y costumbre de sus Vecinos, y Moradores, para corregir y castigar los ociosos, y mal entretenidos, que lexos de servir à lo que pide cualquiera Republica bien ordenada, para 
Carlos III, por pragmática de 12 de mayo de 1771, dispuso la llamada "cláusula de retención" 52 , consistente en que a los delincuentes considerados muy peligrosos -declarados rebeldes o incorregibles condenados por delitos graves- se les podía prolongar la pena incluso indefinidamente ${ }^{53}$ para salvaguardar a la sociedad en su conjunto del peligro que suponían ${ }^{54}$; en Aranjuez por Real Decreto y Cédula de 7 de mayo de 1775, definió como vagos a quienes abandonaren el trabajo o andaren en juegos y tabernas, los que carecieren de rentas y no se dedicaren a las labores del campo, y declaró prohibida la tolerancia a la ociosidad, concepto que se verá reforzado por la Real Orden de 18 de noviembre de 1777, con una posterior extensión mediante Real Cédula de 25 de mayo de 1783 también a los buhoneros, saludadores y personas que llevaren animales domesticados como marmotas, caballos o perros, con quienes demostraren habilidades, siendo recogidas las normas para castigar a la vagancia y otros excesos en la pragmática de 19 de septiembre de ese mismo año 178955. Por último, Carlos IV, por Real Resolución y orden de 27 de marzo y de 8 de junio de 1802, reafirmó la prohibición de entrada y residencia en el reino a los judíos ${ }^{56}$.

b) En el Siglo XIX, período caracterizado por la contraposición de dos grandes corrientes doctrinales -y por la aparición de otras nuevas de carácter ecléctico- se resume, a grandes rasgos en las formulaciones teorías de la Escuela Clásica, con PESSINA, ROSSI, CARMIGNANI ${ }^{57}$ y sobre todo con CARRARA, que partiendo del liberalismo individualista de principios del S. XIX profesaba la absoluta vigencia del libre albedrío que gravitaba sobre un concepto esencial de delito, abstracto, racional y despegado de la realidad empírica, por lo que todo el fundamento de la responsabilidad del delincuente se

mantenerse en quietud, y policìa, y sin escandalos, que causen lunar al christiano règimen de ellas, desfiguran todo este semblante por su ociosidad, dando ocasión a pervertir a los bien entretenidos".

52 LANDECHO VELASCO, C.M., en COBO DEL ROSAL, M., (Dir.), Comentarios al Código penal. Tomo IV. Madrid: Edersa. 1999, p. 30.

53 SANZ MORÁN, A.J., Las medidas de corrección y de seguridad..., cit. p. 23.

54 LEAL MEDINA, J., La historia de las medidas..., cit. pp. 187 y 188.

55 Y también dicta, en esa misma línea de contenidos la Real Orden de 17 de marzo de 1784, la Real Resolución de 4 de septiembre de 1785, y la cédula de Aranjuez de 13 de abril de 1788. Ibidem, pp. 174 y 175.

56 Ibidem, pp. 174 y 175.

${ }^{57}$ LANDECHO VELASCO, C.M., en COBO DEL ROSAL, M., (Dir.), Comentarios..., cit. Tomo IV, pp. 32 y 33. 
construía sobre su culpabilidad. Por ese motivo, proclamaba que la pena retributiva debía ser la única respuesta proveniente del Estado para satisfacer los ideales de justicia ${ }^{58}$.

Por su parte, la Escuela Positiva Italiana se funda en 1876 por obra de FERRI ${ }^{59}$, LOMBROSO $^{60}$ y GARÓFALO ${ }^{61}$, cuyas teorías —de preeminente carácter criminológico—62 principalmente se basan en la utilización del método inductivo (frente al método deductivo de la Escuela Clásica), en el delincuente como centro de atención (pasando el delito a ocupar un segundo plano), en la exigencia de responsabilidad basada en la peligrosidad (y no en la culpabilidad), e imponiendo medidas de seguridad o de resocialización (en lugar de penas) ${ }^{63}$. La configuración de las medidas de corrección y de seguridad como mecanismos jurídicos autónomos para ofrecer respuestas ante el delito

58 CARRARA, F., Programa de Derecho Criminal. Parte General. Dictado en la Universidad de Pisa. Vol. II. Traducido de la $11^{\text {a }}$ edición italiana por Sebastián Soler. Buenos Aires: Depalma. 1944, pp. 1 y ss.

59 JIMÉNEZ DE ASÚA, L., Principios de Derecho penal. La ley y el delito. $3^{\text {a }}$ Ed. 1958. Buenos Aires: AbeledoPerrot. Reimpresión de 1997, p. 51. Explica este autor que "el propio Ferri, en su Sociología criminal, clasifica la explicación del delito conforme a las teorías de los que de él se ocuparon, y frente a las tesis de Albrecht y Durkheim, que creyeron en la normalidad del delincuente, figuran las muy numerosas explicaciones de la anormalidad como causa del delito, que forma tres series: la de la anormalidad biológica, la de la anormalidad social y la de la biológico-social, de la que Ferri se atribuye el invento. [...] Ferri dedicó su tesis doctoral a la negación del libre albedrío, y como determinista, tuvo que basar la responsabilidad en un hecho meramente objetivo: vivir en sociedad".

60 Ibidem, pp. 48 y 49. Este autor expresa que “César Lombroso, médico hebreo de origen español, quiso aplicar el método experimental al estudio de la demencia y trató de encontrar las notas diferenciales, para que fuese más fácil el peritaje médico, entre el delincuente y el loco. Mas, a medida que el genial israelita avanzaba en sus estudios y observaciones, los resultados eran contrarios a los que él esperó: lo que parecía dibujarse indeleblemente no era la distinción entre el loco y el criminal, sino su parecido, a virtud de la semejanza que ambos tenían con un tercer término que Prichard bautizó con la denominación de moral insanity. [...] Había recogido datos sobre los cráneos y mandíbulas, arcos cigomáticos y fosas oculares, medidas de la braza y de la altura, sinostosis prematuras, etc., etc., sin saber por qué eran esos estigmas más frecuentes en el hombre delincuente que en el honrado. Pero un día, hacia el año 1870, haciendo la autopsia del bandido Vilella, encuentra en su cráneo la que él denominó "foseta occipital media" y que es rarísimo encontrar en el hombre, siendo, en cambio, frecuente en los animales inferiores como los peces. No volvió a hallar Lombroso la dicha foseta, o, al menos, no la encontró en tal medida, a lo largo de sus geniales experiencias; pero entonces le bastó para ver, como en un chispazo súbito, la interpretación de todas aquellas anomalías somáticas halladas en los criminales. En realidad, el hombre delincuente reproducía al salvaje, en verdadero atavismo que a veces se remontaba, en la escala zoológica, a los seres prehumanos".

61 Ibidem, pp. 49, 50 y 51. Como señala este autor, “Rafael Garófalo era juez y barón; es decir, pertenecía a la clase atacada por el positivismo criminológico: ejercía la justicia que Lombroso y Ferri criticaban y ello fue muy significativo para una posible síntesis que no se realizó Garófalo pudo haber logrado la síntesis con su concepción del delito natural y con la temibilidad, que pudo y debió ser, como él dijo, un criterio positivo del Derecho penal. A la postre, y al cabo de los años, Garófalo volvió, en la senectud, a las concepciones de que saliera y se hizo fascista y reaccionario".

62 LOMBROSO publica ese mismo año su obra "L'uomo delinquente in rapporto all'antropologia, giurisprudenza e disciplina carceraria"; FERRI con su tesis doctoral sobre "la teorica dell'imputabilità e a negazione del libero arbitrio", de la que se editó en 1978 la obra "los nuevos horizontes del derecho y del procedimiento penal", y GARÓFALO con sus obras "un criterio positivo della penalità" (1800) y "Criminologia" (1885). Vid. los comentarios de GÓMEZ, E., Tratado de Derecho Penal. Tomo I. Buenos Aires: Compañía Argentina de Editores. 1939, pp. 67 y 68.

63 LANDECHO VELASCO C.M. / MOLINA BLÁZQUEZ, C., Derecho Penal..., cit. p. 91. 
con instrumentos distintos a la pena, se debe a la formulación de la Escuela Positiva ${ }^{64}$, que concebía el Derecho penal en la negación misma del libre albedrío y en la reafirmación de lo que se conoce como determinismo y, en consecuencia, se exigiría la reestructuración de la sanción que no hallase su fundamento en la culpabilidad65. La Escuela Positiva Italiana perfiló las bases orientativas o los trazos esenciales para la sistematización de las medidas en el sistema de sanciones penales, de los que arrancan las subsiguientes formulaciones en varios textos legales de gran relevancia para el devenir posterior del Derecho penal. Los integrantes de la Escuela Positiva se preguntaban si se podría intervenir cuando ya se sabe que un sujeto es peligroso a través de la aplicación de las ciencias de la conducta, al igual que cuestionaban la suficiencia de la pena frente a quienes son declarados culpables de haber cometido algún delito y además son peligrosos para el futuro, de ahí que terminasen por proponer un código sin penas que estuviera basado en un elenco de tratamientos posibles que se aplicarían a cada sujeto atendiendo a su peligrosidad derivada de la etiología apreciada en ellos. De hecho, FERRI elaboró un proyecto en 1921 basándose en estas teorías cuyo art. $2^{\circ}$ decía: “dentro de los límites fijados por la ley, la sanción será aplicada al delincuente según su estado peligroso", aunque este tipo de propuestas no terminaro por cuajar del todo ${ }^{66}$.

Al margen de esto, la conocida como Lucha de Escuelas ${ }^{67}$, deriva del propio nacimiento de la Escuela Positiva, que precisamente se origina en una clara contraposición, no solo jurídica sino también política y religiosa de sus integrantes, que

\footnotetext{
64 LEAL MEDINA, J., La historia de las medidas..., cit. p. 328. Como indica este autor, “la formación de las medidas penales, ocultas en el pasado como consecuencias jurídicas diferentes a las penas, descubiertas tras la eclosión oficial a finales del siglo XIX de la mano de la Escuela Positiva italiana, alimentan y se alinean a favor de la seguridad, promoviendo la defensa social más que la libertad individual. Es debido a la forma y al mecanismo embrionario de su configuración. Su reconocimiento en las diferentes legislaciones preventivas europeas será consecuencia de la necesidad legislativa, al apreciar sensiblemente la impunidad en que se había constituido el derecho penal, gracias a la formulación dogmática de considerar a todos los hombres libres y por tanto con capacidad de culpa. Así las medidas penales cobrarían carta de naturaleza, siendo aceptadas legal e institucionalmente tras la alarma social provocada por la ausencia y falta de reacción penal, frente a las conductas y comportamiento de determinados inimputables y reincidentes, que quedaban sin respuesta en el marco organizativo racional que había puesto de moda la Escuela Clásica del derecho, a cuyos postulados jurídicos se plegaron todas las leyes haciendo realidad la codificación del derecho penal".
}

65 URRUELA MORA, A., Las medidas de seguridad y reinserción social en la actualidad. Especial consideración de las consecuencias jurídico-penales aplicables a sujetos afectos de anomalía o alteración psíquica. Granada: Comares. 2009, p. 7. Sigue diciendo este autor que "frente a la pena y con caracteres totalmente opuestos a la misma venían a exigir los seguidores de la Escuela Positiva Italiana una reacción penal basada en criterios de defensa social y cuyo eje consistía en la evitación de delitos cara a futuro, y por lo tanto, fundada en la temibilidad puesta de manifiesto por el delincuente".

66 MAPELLI CAFFARENA, B., Las consecuencias..., cit. pp. 351 y 352.

${ }^{67}$ LANDECHO VELASCO, C.M., en COBO DEL ROSAL, M., (Dir.), Comentarios..., cit. Tomo IV, pp. 37 y 38. 
pretende "monopolizar el Derecho penal y hasta producir en él una "revolución copernicana" en frase del mismo LOMBROSO"68; y pretende construir un Derecho penal para defender a la sociedad, esencialmente basado en las medidas (reeducativas, resocializadoras o de seguridad) ${ }^{69}$.

La Escuela Positiva rechaza el método deductivo y apriorístico de la Escuela Clásica, adoptando un método empírico basado en la observación del delincuente en la experiencia, porque considera que el delito es un hecho humano y social, compuesto de una multiplicidad de factores externos e internos de orden antropológico y social, y no admite la concepción del delito como un mero ente jurídico producto de la voluntad inteligente y libre del delincuente, como propugna la Escuela Clásica. De hecho, el libre albedrío que según esta Escuela fundamenta el delito, no es admitido por los positivistas que, contrariamente a los pensamientos clásicos por los que no pueden castigados los delitos perpetrados por quienes carecen de entendimiento y voluntad, la Escuela Positiva propugna un concepto de responsabilidad que se extiende a todos los autores - sin excepción- de hechos previstos en la ley penal como delitos, de tal forma que la sanción penal es de todo punto ineludible, para lo que se adaptan las sanciones a las condiciones del sujeto atendiendo fundamentalmente a las circunstancias que influyen en su personalidad. Además, la Escuela Positiva rechaza la idea de proporcionalidad de la pena a la que refiere contumazmente la Escuela Clásica, ya que para esta corriente, no hay forma humana de establecer una proporción acertada entre el mal causado por el delito y el mal que la propia pena representa, por lo que reafirma la idea de que la sanción penal deberá imponerse atendiendo únicamente a la peligrosidad del delincuente ${ }^{70}$.

Consecuentemente, la polémica entre las Escuelas, dará lugar a las conocidas como Teorías intermedias, de la que destaca la Terza Scuola con autores como AlimENA,

68 LANDECHO VELASCO C.M. / MOLINA BLÁZQUEZ, C., Derecho Penal..., cit. p. 92. “Porque, según este autor, había que pasar a hacer centro del Derecho penal al delincuente en vez del delito, de modo semejante a lo que hizo COPÉRNICO a poner como centro de nuestro sistema planetario al Sol en vez de a la Tierra".

${ }^{69}$ GÓMEZ, E., Tratado de Derecho Penal..., cit. Tomo I Págs. 70 y 71. Este autor expresa que "por ello el tecnicismo de los positivistas ha reemplazado la palabra "pena" por la palabra "sanción". Exige, además, el principio de la responsabilidad legal, que la sanción cambie de calidad y de grado, según las circunstancias especiales del individuo agente, las del acto realizado y las de la sociedad en que aquél vive. La peligrosidad del delincuente debe ser el criterio invariable para la imposición de las sanciones. Surge de ahí, como consecuencia lógica, la necesidad de abandonar el sistema de las penas de duración determinadas. No armoniza, éste, con la finalidad de readaptación social del delincuente que el positivismo penal asigna a las sanciones".

70 GÓMEZ, E., Tratado de Derecho Penal..., cit. Tomo I, pp. 71 y 72. 
CARNEVALE, SABATINI, LONGHI, IMPALLOMENI, etc., que pretenden la conciliación de las teorías de ambas Escuelas anulando los métodos de una y otra al poner como límite de la pena la minimización del sufrimiento y la maximización de la defensa de la sociedad en su conjunto, propugnando un sistema dualista de penas y medidas ${ }^{71 / 72}$. Aunque aceptaba la inexistencia del libre albedrío como los positivistas, reconocía - por otra parte- que el hombre puede dirigir conforme a su voluntad sus acciones, mezclando elementos de naturaleza contradictoria. La Terza Escuola sostenía que la pena no era un castigo retributivo - mal por mal- sino una sanción que provenía directamente de la defensa social que contenía conjuntamente una vertiente sancionadora y otra de coacción psicológica, ya que no negaba que la pena actuara tanto sobre el sujeto que la sufre como sobre los demás que observan cómo se aplica. También rechazaba la idea de los delincuentes natos, y afirmaba que la criminalidad se adquiere por factores educacionales o ambientales que les desvían y les convierten al sujeto en criminales habituales ${ }^{73}$.

Sin embargo y, como ya se ha visto, la concepción del Derecho penal retribucionista y los postulados de la Escuela Clásica que se mostraban ya inoperantes e ineficaces frente a determinados sujetos, así como su insuficiencia frente a comportamientos asociales que requerían reacción penal urgente, se vio hartamente superada por la creciente importancia de una categoría de privación o restricción de derechos - medidas de seguridad-, promovida por la Escuela Positiva que pretendía agrupar bajo una misma sanción penal todas las conductas criminalmente relevantes ${ }^{74}$, en

71 GARCÍA-PABLOS DE MOLINA, A., Criminología. Una introducción a sus fundamentos teóricos. $6^{\mathrm{a}}$ Ed. Valencia: Tirant lo Blanch. 2007, p. 273. Este autor explica que "la Terza Scuola [...] cuya actitud de síntesis o compromiso se refleja en los siguientes postulados: nítida distinción entre disciplinas empíricas (método experimental) y disciplinas normativas (que requerirían un método abstracto y deductivo); contemplación del delito como producto de una pluralidad de factores, endógenos y exógenos, muy compleja; sustitución de la tipología positivista por otra más simplificada, que distingue entre delincuentes "ocasionales", "habituales" y "anormales"; dualismo penal o uso complementario de penas y medidas, frente al monismo clásico (monopolio de la pena retributiva) o al positivismo (exclusividad de las medidas); actitud ecléctica respecto al problema del libre albedrío, conservando la idea de la responsabilidad moral como fundamento de la pena, y la de temibilidad, del de la medida; actitud de compromiso, también, en cuanto a los fines de la pena, aunando las exigencias de retribución y las de corrección del delincuente".

72 JIMÉNEZ DE ASÚA, L., Principios de Derecho penal..., cit. p. 61. Como indica este autor “en Alemania podemos hablar de una escuela tercera, constituida por Merkel, Liepmann, Oetker, etc. Conciliar la justicia y el finalismo fue el afán de estos escritores, que continúan la tradición de las escuelas mixtas, en que la justicia y la utilidad se amalgaman".

73 RAMOS, J.P., Curso de Derecho penal. Tomo I. Fundamentos y teorías generales. Buenos Aires: Ariel. 1927, pp. 271 y 272.

74 MAPELLI CAFFARENA, B., Las consecuencias..., cit. pp. 351. Este autor explica que "los postitivistas, con una fuerte implantación en la ciencia jurídica europea en el ambiento poco democrático de la década de los 
orden a preservar el orden social75. Se configuró así una nueva finalidad del Derecho penal que se alejaba de la idea primordial de castigar el mal causado y retribuir el crimen perpetrado, dando paso a la finalidad de evitación de la comisión de posibles delitos futuros.

c) El Anteproyecto del CP Suizo de Carl STOOSS de 189376, que adopó una solución de compromiso en la lucha de Escuelas ${ }^{77}$, introdujo un sistema de medidas de seguridad en la parte general para superar las deficiencias con que se encontraba la pena y el principio de culpabilidad en relación a determinados grupos de criminales peligrosos ${ }^{78}$. Precisamente a STOOSS se le atribuye la conceptualización e implementación legislativa ${ }^{79}$ de las medidas de corrección y seguridad ${ }^{80}$ al haber plasmado por primera vez un sistema dualista $^{81}$ o binarista $^{82}$ de consecuencias del delito ${ }^{83}$ que asociaba penas a la culpabilidad y

años viente y treinta del siglo pasado, denunciaban las deficiencias de un sistema penal concebido de forma retributiva".

75 LEAL MEDINA, J., “Un estudio de las actuales medidas de seguridad y los interrogantes que plantean en la moderna dogmática del Derecho penal". En Revista Aranzadi de Derecho y Proceso Penal, núm. 20. Navarra: Thomson Aranzadi. 2008, p. 22, nota al pie 2. Este autor expresa que "la moderna sanción que se promovía se debía condicionar a las circunstancias particulares y singulares de cada persona. De esta forma, se formulan una serie de consecuencias criminales que tienen como requisito previo la peligrosidad del individuo, dejando a un lado su culpabilidad".

76 STOOSS, C., Strafe und sicherden Massanahmen, ZStrR, 1905, pp. 1 y ss; STOOSS, C., Zur natur der sicherden Massanahmen, ZStrR, 1930, pp. 18 y ss., citas extraídas de URRUELA MORA, A., Las medidas de seguridad..., cit. p. 7, nota el pie 16 .

77 JORGE BARREIRO, A., “Reflexiones sobre la problemática...", cit. p. 600.

78 WELZEL, H., Derecho penal..., cit. p. 258. Explica este autor que la pena es la retribución por el injusto cometido por el sujeto, mientras que las medidas de seguridad conforman una suerte de protección del conjunto de la comunidad frente a los hechos delictivos que en el futuro puedan cometer los individuos peligrosos, y especifica que "este sistema fue desarrollado en 1893 por CARLOS STOOSS. Se obtiene la protección de la comunidad impidiendo una actividad delictual futura de personas peligrosas (medidas de seguridad en el sentido más estricto), o reeducando al autor para una vida ordenada (medidas de corrección)".

79 MAPELLI CAFFARENA, B., Las consecuencias..., cit. p. 354.

80 Con el matiz de que el primer CP prusiano, obra de KLEIN, elaboró una teoría de las medidas de seguridad y corrección en la que remarcaba su carácter autónomo respecto de las penas, que atendían más a la peligrosidad que a la culpabilidad con el prioritario objetivo de extraer el contenido aflictivo propio de las penas. Vid. LEAL MEDINA, J., La historia de las medidas..., cit. p. 263. Este autor señala que "las medidas que este Código penal prusiano establecía eran de duración indeterminada y su control y vigilancia le correspondían al Tribunal penal que las hubiera dictaminado. En tal sentido este penalista dictaminó que los mendigos vagabundos y holgazanes no pueden ser puestos en libertad tras ver cumplida su pena, hasta que no demostrasen que se encuentran en condiciones de vivir de manera honorable, justificando legalmente la retención o la falta de excarcelación, en sus perversas inclinaciones y tendencias lo que obliga a la comunidad a considerarlos y conceptuarlos de sujetos peligrosos".

81 CHOCLÁN MONTALVO, J.A., "La medida de seguridad”. En CALDERÓN CEREZO, A. / CHOCLÁN MONTALVO, J.A., Derecho penal. Tomo I. Parte general. ${ }^{\text {a }}$ Ed. Barcelona: Bosch. 2001, p. 496.

82 LANDROVE DÍAZ, G., Las consecuencias..., cit. p. 116. 
medidas a la peligrosidad ${ }^{84}$, aunque finalmente el texto no fue aprobado pero dejó su impronta que fue de vital importancia para los posteriores códigos penales como el austríaco de 190985, ya que trató de armonizar y coordinar el ideal de justicia retributiva con factores biológicos, sociológicos y psicológicos etc., para lo que se sirve de las medidas de seguridad y corrección como complemento o como sustitutivo aplicable en supuestos donde sea imprescindible, reforzando la lucha contra el delito mediante técnicas retributivas y preventivas conjugadas de forma dual. El citado proyecto suizo definía como inimputables a los que presentan predisposición espiritual o corporal para delinquir y, en concreto, a los bebedores habituales, a los reincidentes y delincuentes profesionales, los corrompidos, los perezosos, los delincuentes juveniles, los incapaces y los inimputables en sentido estricto que carecen de capacidad de comprender las penas que les puedan ser impuestas. Para todo este elenco de delincuentes peligrosos, el proyecto de STOOSS presentaba la pena como insuficiente o ineficaz, por lo que optó por sustituirla por medidas como, v.g., el internamiento en una casa de trabajo o en un asilo de bebedores con prohibición de acceso de locales donde se dispense alcohol ${ }^{86}$. Con esta formulación de STOOSS y los postulados de la Escuela Positiva Italiana, las medidas de seguridad adquieren verdadera relevancia en el sistema penal y reciben el mayor impulso alcanzado hasta el momento, a través de que se fortalece de forma clara el carácter profiláctico y preventivo de las sanciones penales.

d) En Argentina, el CP de 1886, eximía de pena al que hubiera cometido el hecho en estado de locura, sonambulismo, imbecilidad absoluta o beodez completa o involuntaria, o con perturbación de los sentidos o de la inteligencia, pero no decía nada sobre qué hacer con los absueltos por dichas causas, lo que generó críticas para la posterior reforma. El Proyecto de 1891 planteó que en estos casos de enajenación mental, se debía recluir al agente en un establecimiento de alienados criminales, o en un departamento especial de

\footnotetext{
83 SÁNCHEZ YLLERA, I., en VIVES ANTÓN, T.S., (Coord.), Comentarios al Código Penal de 1995. Vol. I. Valencia: Tirant lo Blanch. 1996, p. 529

84 URRUELA MORA, A., Las medidas de seguridad..., cit. p. 7. Este autor indica que "la citada solución normativa articulada por STOOSS constituía una posición ecléctica frente a las posiciones monistas más exacerbadas, en unos casos partidarias de continuar con la pena como única consecuencia frente al delito, y en otros de articular una nueva fórmula de reacción frente a la delincuencia, fundada en la peligrosidad e independiente de la culpabilidad (Escuela Positiva Italiana)".

85 LEAL MEDINA, J., La historia de las medidas..., cit. p. 262, nota al pie 84.

86 Ibidem, p. 264. Este autor asevera que "el delito-pena y el estado peligroso-medida de seguridad se convocan y van a permanecer organizadas bajo un mismo frente legislativo común. La finalidad de aseguramiento se proyecta contra todo tipo de impunidad y frente a cualquier desprotección social".
} 
los manicomios comunes ${ }^{87}$, al igual que en el Proyecto de 1906; y posteriormente el CP de 1921, en su art. 34, dispuso la reclusión en un manicomio del enajenado, cuando hubiera peligro de que se dañare a sí mismo o a los demás ${ }^{88}$.

e) La ley alemana contra delincuentes habituales y peligrosos y sobre medidas de seguridad y de corrección, de 24 de noviembre de 1933, del régimen nacionalsocialista, que incluía en su catálogo de medidas la castración de delincuentes sexuales, concibiendo las medidas de seguridad desde una perspectiva utilitarista que las convertía en un instrumento de un política criminal basada en la eficacia, renunciando a las ya alcanzadas garantías individuales ${ }^{89}$, aunque el Proyecto de 1930 seguía el modelo dualista que conjugaba penas y medidas de seguridad como mecanismos de lucha contra el delito y preveía medidas como el establecimiento de curación y cuidado para inimputables y sujetos de imputabilidad disminuida, el asilo de bebedores para los alcohólicos, la custodia de seguridad para los delincuentes habituales peligrosos y la vigilancia de protección, entre otras $^{90}$.

f) El Código penal español de 1928. Al margen de las referencias a los Códigos penales españoles de 1848 y 1870, en los que se establecía una previsión especial de internamiento en hospitales a los locos o dementes que hubieran sido declarados exentos de responsabilidad penal ${ }^{91}$; el CP de 1928 -durante la dictadura de Primo de Ribera- es

87 MORENO, R., El Código Penal y sus antecedentes. Buenos Aires: Tommasi Editor. 1922, pp. 226, 227 y 238.

88 MANIGOT, M.A., Código Penal de la Nación Argentina. Anotado y comentado. Buenos Aires: Abeledo-Perrot. 1969 , pp. 52 у 60.

89 SANZ MORÁN, A.J., "Sobre la justificación de las medidas de corrección y de seguridad". En Homenaje al profesor Dr. Gonzalo Rodríguez Mourullo. Navarra: Thomson Civitas. 2005, p. 970.

90 MEZGER, E., Tratado de Derecho penal. Traducción de la $2^{\mathrm{a}}$ Ed. Alemana (1933) y notas de Derecho español por J.A. Rodríguez Muñoz, Madrid: Revista de Derecho privado. 1935. Tomo II, pp. 395 y 396.

91 CASTELLÓ NICÁS, N., “Causas de inimputabilidad: drogadicción”. En Estudios de Derecho judicial, núm. 110. Actual doctrina de la imputabilidad. Madrid: Consejo General del Poder Judicial. 2007, pp. 377 y 378 . Este autor expresa que "el Código Penal de 1848 y subsiguiente reforma de 1850 atiende al "loco o demente, a no ser que haya obrado en un intervalo de razón" (art. $8^{\circ}-1^{\circ}$ ). En párrafos aparte del mismo precepto precisa que "Cuando el loco o demente hubiere ejecutado un hecho que la ley califique de delito grave, el Tribunal decretará su reclusión en uno de los hospitales destinados a los enfermos de aquella clase, del cual no podrá salir sin previa autorización del mismo Tribunal". Y continúa: "En otro caso será entregado a su familia bajo fianza de custodia; y no presentándola, se observará lo dispuesto en el párrafo anterior". Entre las causas de atenuación contempla exclusivamente la de "ejecutar el hecho en estado de embriaguez, cuando ésta no fuere habitual o posterior al proyecto de cometer el delito" (art. $9^{\circ} .6^{\mathrm{a}}$ ). El texto de 1870 dice que "no delinquen" el imbécil y el loco, a no ser que éste haya obrado en un intervalo de razón (art. $8^{\circ} .1^{\circ}$ ). En línea con el precedente inmediato de este precepto señala que en el caso de haber cometido un hecho que la ley califica de delito grave, "el Tribunal decretará su reclusión en uno de los hospitales destinados a los enfermos de aquella clase, del cual no podrá salir sin previa autorización del mismo Tribunal”. En párrafo aparte establece, siguiendo igualmente a su antecesor que "si la ley calificare de delito menos grave el hecho ejecutado por el imbécil o el 
el texto positivo en el que aparecen por primera vez las medidas de seguridad en el Derecho español 92 (arts. 90 y ss.) ${ }^{93}$. La España proletaria del S. XIX vive la revolución industrial y, con ella, una suerte de revueltas sociales, huelgas, incremento de delitos violentos, atentados, etc., que colocan a la Monarquía en una especial situación de fragilidad ante la incapacidad de sus gobiernos para mantener el control del imparable aumento de la delincuencia, lo que desemboca en un nuevo Código penal absolutista y totalitario con el objetivo de proteger el régimen dictatorial establecido por el General Primo de Rivera. Sin embargo, el Código incorpora el sistema dual y viene a describir por primera vez las medidas de seguridad postdelictuales - con exclusión expresa de las predelictuales- basadas en el presupuesto de la peligrosidad delictiva, de tal forma que las medidas actúan como complemento de las penas y que también pueden imponerse de forma acumulativa bajo los principios de subordinación de la medida y de aplicación preferente de la pena (art. 200 CP de 1928) ${ }^{94}$.

El Código dirigía la aplicación de las medidas a los inimputables, a los sujetos especialmente peligrosos cuando la peligrosidad viniera impuesta por la ley, y a los vagos, y contenía cuatro clases de medidas: 1) privativas de libertad, entre las que se encontraba la retención en un establecimiento para delincuentes incorregibles o habituales, el internamiento en un manicomio judicial para sujetos penalmente irreprochables, el asilo de bebedores y el internamiento en casas de trabajo para vagos; 2) restrictivas de libertad, que son, la expulsión de los extranjeros del territorio nacional, la prohibición de regreso al lugar de comisión del delito o a donde resida la víctima o sus familiares, y la sumisión a vigilancia de la autoridad; 3) privativas de derechos, entre las que se encuentra la privación de la patria potestad, tutela o curatela; y la suspensión de empleo, cargo, arte u oficio; 4) patrimoniales, que son la caución de conducta, el comiso, la publicación de la sentencia a costa del penado, y el cierre del local en caso que hubiera sido utilizado para la comisión del delito ${ }^{95}$.

loco, el Tribunal, según las circunstancias del hecho, practicará lo dispuesto en el párrafo anterior, o entregará al imbécil o loco a su familia, si ésta diese suficiente fianza de custodia".

92 CUEllo CONTRERAS, J., El Derecho penal español. Parte general. Notas introductorias. Teoría del delito. Madrid: Dykinson. 2002, p. 147.

93 LANDECHO VELASCO, C.M., en COBO DEL ROSAL, M., (Dir.), Comentarios..., cit. Tomo IV, pp. 42 y 43.

94 LEAL MEDINA, J., La historia de las medidas..., cit. pp. 265 a 267.

95 Ibidem, pp. 267 y 268. 
Como novedades destacables en este texto legal, encontramos además la eximente de debilidad mental como una forma de exclusión de la culpabilidad, y la posibilidad de imposición de medidas de seguridad a personas jurídicas como la disolución o la suspensión, aunque lo realmente relevante es que fue el primer Código con un sistema dualista de reacción frente al crimen que, a su vez, buscaba el aseguramiento y mantenimiento de la defensa social y de la seguridad pública por encima de todo, incluso de los propios derechos individuales ${ }^{96}$.

g) La Ley de Vagos y Maleantes de 4 de agosto de 193397, que vino precedida por la derogación del CP de 1928 -por Decreto de 14 de abril de 1931-y la promulgación del CP de 1932, estableció un amplio elenco de medidas de seguridad de entre las que se distinguía entre predelictuales ${ }^{98}$ y postdelictuales, y es la primera norma especial que se dedica con carácter exclusivo al ámbito de la prevención. Esta ley estuvo vigente hasta 1970, pero desde su promulgación hasta su sustitución en ese año por la Ley de Peligrosidad y Rehabilitación Social, a consecuencia del golpe militar de Franco el 18 de julio de 1936, el sistema soportó una serie de transformaciones extremadamente profundas ${ }^{99}$. La finalidad de esta Ley eminentemente práctica -de orientación positivista-100 era la reducción o eliminación de la criminalidad, y frente a las medidas postedelictuales que se aplicaban con carácter facultativo a sujetos que la ley consideraba peligrosos, las medidas por lo general estaban destinadas a evitar la futura comisión de hechos delictivos cuando se pronosticaban como altamente probables, para lo que la ley definía la categoría de sujetos temibles aun antes de que delinquieran, a los que llamó vagos habituales, categoría que comprendía a los proxenetas, rufianes, mendigos, ebrios y

\footnotetext{
96 Ibidem. Pág. 270.

${ }^{77}$ LANDECHO VELASCO, C.M., en COBO DEL ROSAL, M., (Dir.), Comentarios..., cit. Tomo IV, p. 44.

98 CUELLO CONTRERAS, J., El Derecho penal español..., cit. p. 127. Según este autor, la denominación de esta ley así como la técnica utilizada que preveía estados peligrosos sin relación alguna con el delito y medidas de seguridad predelictuales, son aspectos que evidencian la "defectuosa y desafortunada regulación de esta materia en nuestro país".
}

99 MAPELLI CAFFARENA, B. / TERRADILLOS BASOCO J.M., Las consecuencias jurídicas del delito. Madrid: Civitas. 1996, p. 201. Estos autores expresan que antes de la promulgación del CP de 1944, hubo un Anteproyecto elaborado por la Delegación Nacional de Falange y Derecho, que se inspiraba en el pensamiento de Castejón y que contenía veintiuna medidas de seguridad a las que se adicionaba una más que disponía que "cualquier otra prevención de igual entidad o análoga a las anteriores que el tribunal considere útil para el fin de precaver de reincidencia". También explican que, del mismo modo que sucedió en Italia, el progresismo humanitario que proclamaba la Ley de Vagos y Maleantes fue asimilada por el fascismo, que la convirtió en un sistema penal sin vinculación con el principio de legalidad y de ninguna otra garantía.

100 COBO DEL ROSAL, M. / QUINTANAR DÍEZ, M., en COBO DEL ROSAL, M., (Dir.), Comentarios al Código penal. Tomo IV. Madrid: Edersa. 1999, pp. 77 y 78. 
toxicómanos habituales, profesionales, personas que no pudieran justificar la procedencia de su dinero, quienes explotaran juegos prohibidos, quienes suministraran alcohol a menores de catorce años, los que ocultaren su verdadero nombre a la autoridad, los extranjeros que quebrantaren una orden de expulsión, etc.101; y también a los que manifestaren actitud reveladora de inclinación al delito por frecuentar casas de juegos prohibidos o se advirtiera en ellos un trato frecuente con delincuentes, o los que ejecutaren actos de brutalidad, insolencia o cinismo, tales como el maltrato a animales, cosas o plantas ${ }^{102}$. Esta ley distinguía, pues, entre medidas aplicables a sujetos que no habían cometido delito alguno —que se traduce en la llamada peligrosidad social- y medidas aplicables a sujetos que han demostrado su peligrosidad o su "tendencia criminal" a través de la comisión de un delito —-peligrosidad criminal—103.

Esta ley se mantuvo vigente a pesar de la promulgación del CP de 1944, en el que no se introdujeron medidas de seguridad, sino que, por una parte, se mantuvo su vigencia y, por otra, regía el $\mathrm{CP}^{104}$. Fue modificada con posterioridad por la ley de 15 de julio de 1965, por la que se estableció la medida de prohibición del ejercicio de comercio o industria y se introdujo la homosexualidad como una nueva categoría de estado peligroso; y las medidas podían ser aplicadas tanto de forma simultánea como sucesiva.

h) La Ley 16/1970, de 4 de agosto, de Peligrosidad y Rehabilitación Social105, reformada por Ley de 28 de noviembre de 1974 y desarrollada por su Reglamento, aprobado por RD 1144/197106, vino a sustituir a la anterior Ley de Vagos y Maleantes ${ }^{107}$ y constituye un icono en nuestro ordenamiento penal preventivo porque contempla el elenco de estados

\footnotetext{
101 LEAL MEDINA, J., La historia de las medidas..., cit. p. 23, nota al pie 3. Como indica este autor "para su tiempo, esta ley supone un avance jurídico-penal notable al seguir los postulados científicos modernos; antropológicos y sociológicos en boga por aquel entonces del derecho penal. La naturaleza de ley especial que es, le confiere un carácter universal y vis atractiva respecto a la materia que regulaba. Y por tanto hace que se dedique por completo a recoger los presupuestos y las medidas penales, en su mayoría predelictuales, que son de aplicación a los índices de peligrosidad contemplados previamente en la norma".

102 Ibidem, p. 297.

103 ANTÓN ONECA, J., Derecho penal..., cit. p. 620.

104 Ibidem, pp. 625 a 643.

105 LANDECHO VELASCO, C.M., en COBO DEL ROSAL, M., (Dir.), Comentarios..., cit. Tomo IV, pp. 44 y 45.

106 LUZÓN CUESTA, J.M., Compendio..., cit. p. 251.

107 Aunque la previsión de las medidas de seguridad siguió en la misma línea que en la anterior ley, contemplando estados de peligrosidad social, peligrosidad criminal y medidas que podían aplicarse antes de haber cometido ningún delito.
} 
peligrosos ${ }^{108} \mathrm{y}$ medidas de seguridad adjetivado por un procedimiento específico para la declaración de dichos estados, aunque su verdadero afán represivo acabaría por desnaturalizar y volatilizar su aplicación al servicio de la prevención ${ }^{109}$. El art. 2 b) de esta ley contemplaba un catálogo de sujetos a quienes se consideraba peligrosos sociales110, como los vagos, los mendigos, los ebrios habituales, los toxicómanos, los que se comportaran de forma insolente menospreciando las normas de convivencia social y los homosexuales'111, que fueron excluidos del listado mediante la Ley 77/1978, de 28 de diciembre ${ }^{112}$.

A todo este elenco de sujetos se les aplicaban las medidas que estaban previstas en el art. 5 de la Ley 16/1970, y que eran indeterminadas con una enorme dosis de relatividad en cuanto plazos mínimos y máximos, pudiendo incluso extenderse hasta la curación o corrección del individuo. Se distinguen las siguientes: a) medidas privativas de libertad: que son el internamiento del sujeto peligroso en un centro de trabajo o de custodia, y el arresto de cuatro a doce fines de semana; b) medidas restrictivas de libertad: son el aislamiento en casas de templanza hasta alcanzar la curación, la obligación y prohibición de residir en determinados lugares, la expulsión del territorio nacional, el sometimiento a la vigilancia de la autoridad, el tratamiento ambulatorio hasta la total curación, la privación del permiso de conducir vehículos a motor o la prohibición para obtenerlo, la prohibición de visitar locales de bebidas alcohólicas o frecuentar lugares donde se realicen actividades peligrosas; c) medidas pecuniarias, que son la multa, incautación de dinero o efectos a favor del Estado, la clausura del local, y la caución de conducta que puede sustituirse por la sumisión a la vigilancia de las autoridades ${ }^{113}$.

i) La Constitución Española de 1978 supuso un fuerte cuestionamiento de la Ley de 1970 que, de forma coetánea, en 1978 sufrió una modificación por la que se eliminaron

\footnotetext{
108 MIR PUIG, S., Derecho penal. Parte general. $8^{\text {a }}$ Ed. Barcelona: Reppertor. 2008, p. 768.

109 LEAL MEDINA, J., La historia de las medidas..., cit. p. 24, nota al pie 5.

110 ZUGALDÍA ESPINAR, J.M., Fundamentos de Derecho penal..., cit. p. 144.

111 RODRÍGUEZ DEVESA, J.M. / SERRANO GÓMEZ, A., Derecho penal español. Parte general. 18a Ed. Madrid: Dykinson. 1995, pp. 1000 a 1020.

112 REBOLLO VARGAS, R., “De las medidas de seguridad”. En CÓRDOBA RODA, J. / GARCÍA ARÁN, M., (Dirs.), Comentarios al Código Penal. Parte General. Madrid: Marcial Pons. 2011.

113 LEAL MEDINA, J., La historia de las medidas..., cit. pp. 304 y 305.
} 
multitud de estados peligrosos como el de los homosexuales ${ }^{114}$, que dejaron de ser una categoría de peligrosidad o de perturbación de la personalidad. La Ley de Peligrosidad y Rehabilitación Social fue analizada por el Tribunal Constitucional en las STC 23/1986, de 14 de febrero, STC 159/1985, de 27 de noviembre115, STC 112/1988, de 8 de junio y STC 24/1993, de 21 de enero'116, que fueron decisivas para la nueva concepción de las medidas de seguridad117, cuya esencia se plasmaría en la LO 10/1995, de 23 de noviembre, del nuevo $\mathrm{CP}$, que incorporó en su articulado las medidas de seguridad y de reinserción social (arts. 95 y ss.), y con ella se derogó expresamente la Ley de Peligrosidad y Rehabilitación Social (disposición derogatoria única de la LO 10/1995). La nueva formulación de las medidas de seguridad se basaría en la postdelictualidad y la necesaria acreditación de la peligrosidad mediante la concurrencia de causas de inimputabilidad, mejorada con una regla vicarial para los supuestos de semiimputabilidad, y en ningún caso estaban previstas medidas de seguridad para imputables. De esa forma, desaparece la peligrosidad social que regía en la Ley de Peligrosidad y Rehabilitación social, para dar paso a un concepto mucho más claro y preciso acorde con la nueva realidad constitucional, el de peligrosidad criminal que pasa a ser el fundamento de las medidas de seguridad y también uno de sus presupuestos ${ }^{118}$.

Sin duda con la llegada del constitucionalismo y los derechos fundamentales, la idea de seguridad va cediendo importancia a la libertad individual, de ahí que las medidas asegurativas con escaso contenido educativo o terapéutico pasen a un segundo plano, creándose una suerte de medidas de segundo rango al servicio de la inocuización que revisten carácter eminentemente sancionador y operan de forma subordinada a las medidas principales, ya que el aseguramiento contiene en su esencia una realidad asegurativa que se concibe como necesaria. La seguridad como derecho se ve sometida a un fuerte retroceso y las medidas que conllevan privaciones de libertad, únicamente

\footnotetext{
114 MIR PUIG, S., Derecho penal. Parte general..., cit. p. 768.

115 VIVES ANTÓN, T.S., “Constitución y medidas de seguridad”. En VIVES ANTÓN, T.S., La libertad como pretexto. Valencia: Tirant lo Blanch. 1995, pp. 245 a 251. Edición original en Poder Judicial, núm. 3, 1986.

116 DE LAMO RUBIO, J., Penas y medidas de seguridad en el nuevo Código. Barcelona: Bosch. 1997, pp. 530 a 537.

117 ZUGALDÍA ESPINAR, J.M., Fundamentos de Derecho penal..., cit. pp. 147 a 150.

118 JORGE BARREIRO, A., en COBO DEL ROSAL, M., (Dir.), Comentarios al Código penal. Tomo IV. Madrid: Edersa. 1999, pp. 71 y 72.
} 
pueden ser impuestas cuando es estrictamente necesario y cuando no hay otra medida menos gravosa que pueda eliminar la alta peligrosidad criminal119.

\section{CONCEPTO Y JUSTIFICACIÓN}

Como se ha visto, tras las formulaciones de la Escuela Positiva Italiana que supusieron el abandono del afán retribucionista clásico, cobraron importancia las medidas de seguridad ${ }^{120}$, cuya finalidad era exclusivamente la evitación de futuros delitos debiendo aplicarse allá donde se constante la existencia o persistencia de peligrosidad criminal, siendo que en la actualidad están previstas en la mayoría de ordenamientos y aparecen reguladas con esa misma denominación en el vigente CP español de 1995. Se las denomina medidas con la finalidad de diferenciarlas de las penas, y de seguridad por la relevancia que adquiere el mantenimiento del orden y paz ante cualquier clase de personas ${ }^{121}$; pero conceptualmente, podemos definir las medidas de seguridad como las “consecuencias jurídicas del delito, de naturaleza penal, fundadas en la peligrosidad criminal del sujeto y dirigidas a la realización de fines preventivo-especiales"122. Son "los métodos que se utilizan respecto a sujetos que han cometido al menos un hecho punible, para obtener su resocialización o, en último extremo, para mantenerlos aislados, a fin de que no causen perjuicio a la convivencia ciudadana"123. Son, pues, "todos aquellos medios por los cuales se trata de obtener la adaptación del individuo a la sociedad (medidas educadoras o correccionales), o la eliminación de los inadaptables a la sociedad (medidas de protección o de seguridad, en sentido estricto)"124.

Las medidas de seguridad pretenden ser aplicadas a determinados delincuentes que sobrepasan la culpabilidad individual, con fundamento únicamente en su

119 LEAL MEDINA, J., La historia de las medidas..., cit. pp. 329 y 330.

${ }^{120}$ LANDECHO VELASCO, C.M., en COBO DEL ROSAL, M., (Dir.), Comentarios..., cit. Tomo IV, p. 47. Este autor explica que el nombre originario fue el de medidas de seguridad, pero suele objetarse que el nomen iuris no es comprensivo de la finalidad correctiva sino solo de la asegurativa, por lo que se viene también utilizando un segundo nombre, medidas de corrección y de seguridad que abarca ambas finalidades. Un tercer nombre es simplemente el de medidas, que tiene la ventaja de ser más breve y ambas connotaciones quedan sobreentendidas.

${ }^{121}$ LEAL MEDINA, J., La historia de las medidas..., cit. Pág. 328.

122 URRUELA MORA, A., Las medidas de seguridad..., cit. p. 4.

${ }^{123}$ LANDECHO VELASCO, C.M., en COBO DEL ROSAL, M., (Dir.), Comentarios..., cit. Tomo IV, p. 48.

${ }^{124}$ LISZT, F., Tratado de Derecho Penal, $4^{\mathrm{a}}$ Ed. 1926. Traducido de la 20a Edición Alemana por Luis Jiménez de Asúa. Madrid: Reus. 1999, Tomo III, p. 197. 
peligrosidad ${ }^{125}$, por lo que su existencia no se vincula al binomio culpabilidad-pasado sino al de peligrosidad-futuro, y su aplicación vendrá determinada por la concurrencia de determinados presupuestos, derivados de conjugar varios preceptos del CP: en primer lugar, el art. $1.2 \mathrm{CP}$, a cuyo tenor: "las medidas de seguridad solo podrán aplicarse cuando concurran los presupuestos establecidos previamente por la Ley"; el art. 6.1 CP, que dispone que: "las medidas de seguridad se fundamentan en la peligrosidad criminal del sujeto al que se impongan, exteriorizada en la comisión de un hecho previsto como delito"; el art. 95.1 CP dice que "las medidas de seguridad se aplicarán por el Juez o Tribunal, previos los informes que estime convenientes, a las personas que se encuentren en los supuestos previstos en el Capítulo siguiente de este Código, siempre que concurran estas circunstancias: $1^{\mathrm{a}}$ ) Que el sujeto haya cometido un hecho previsto como delito. $2^{\mathrm{a}}$ ) Que del hecho y de las circunstancias personales del sujeto pueda deducirse un pronóstico de comportamiento futuro que revele la probabilidad de comisión de nuevos delitos"; y los arts. 101 a 103 y 104 CP, en relación con los arts. 105 a 107 CP contemplan la aplicación de las medidas a quienes hayan sido declarados exentos de responsabilidad criminal por aplicación de los arts. $20.1^{\circ}, 2^{\circ}$ y $3^{\circ} \mathrm{CP}$, o se les aplique la eximente incompleta en virtud del art. 21.1 ${ }^{\text {a }}$ CP. La aplicación de las medidas de seguridad -en consecuencia- exige la concurrencia de determinados presupuestos:

$\left.1^{\circ}\right)$ La previa comisión de un delito ${ }^{126}$, presupuesto que deriva del propio art. 6.1 $\mathrm{CP}$ in fine, viene a trasponer el aforismo nulla periculositas sine crimen, que se traduce en la exigencia de haber cometido un hecho previsto en el CP como delito ${ }^{127}$. La previa comisión de un delito (o postdelictualidad) ${ }^{128}$ según expresa LANDROVE DíAZ, cumple una triple función de garantía que se traduce, en primer lugar, en que refuerza el pronóstico

\footnotetext{
125 LANDROVE DÍAZ, G., Las consecuencias..., cit. p. 116. Como afirma este autor "estas medidas no son dictadas con el fin de compensación retribuidora por un hecho injusto, sino para la seguridad futura de la comunidad frente a violaciones ulteriores del Derecho a esperarse de parte de ese autor. El hecho cometido tiene así valor de conocimiento y síntoma de peligrosidad".

126 CHOCLÁN MONTALVO, J.A., “La medida de seguridad...”, cit. pp. 499 y 500.

127 CARBONELL MATEU, J.C., Derecho penal. Concepto y principios constitucionales. $2^{\mathrm{a}}$ Ed. Valencia: Tirant lo Blanch. 1996, p. 40. Este autor explica que "no es posible la aplicación de una medida sobre la base exclusiva de un juicio de probabilidad de actuaciones futuras que no se haya traducido en una acción anterior; en otras palabras, no son posibles las medidas de seguridad pre-delictuales. La aplicación exige la declaración judicial de que el sujeto ha cometido una conducta antijurídica y de que puede volver a cometerla".
}

128 JORGE BARREIRO, A., en RODRÍGuEZ MOURUllO, G. (Dir.) / JORGE BARREIRO, A. (Coord.), Comentarios al Código Penal. Madrid: Civitas. 1997, pp. 299 y 300. 
de peligrosidad; en segundo lugar, fortalece la vigencia del principio de legalidad; y en tercer lugar, reduce a límites tolerables la función preventiva ${ }^{129}$.

La cuestión que se plantea por la doctrina es si el hecho previsto como delito es extensible también a las faltas. Favorable a este criterio se muestra URRUELA MORA, para quien la dicción literal del precepto ("delito") debe comprender también a las faltas, toda vez que, excluirlas, supone confundir los fundamentos de las penas con los de las medidas de seguridad y un desconocimiento sobre el extremo de que la peligrosidad criminal carece de vinculación condicionante con la gravedad del delito que haya podido cometer, porque incluso tratándose de una falta, su peligrosidad puede ser considerable ${ }^{130}$. A ese respecto manifiesta GRACIA MARTín que el término delito puede ser interpretado en sentido amplio o estricto, puesto que existen preceptos en el Código que usan la expresión "delito" para referirse indistintamente a delitos y faltas ${ }^{131}$. Acorde con esta interpretación es la previsión del art. $130.6 \mathrm{CP}$, relativa a la prescripción del delito, que se extiende también a las faltas ${ }^{132}$. Además, manifiesta este autor el presupuesto de delito previo es extensible a las faltas a través de una interpretación teleológica material, que incida en los fundamentos y fines de las medidas de seguridad. A tal efecto las medidas únicamente deben fijarse atendiendo a la probabilidad de comisión de hechos futuros, por lo que la comisión de una simple falta puede poner de manifiesto esa probabilidad futura de comisión delictiva, precisamente porque sale a relucir la peligrosidad del autor ${ }^{133}$.

Contrario a este argumento se muestra LLORCA ORTEGA, que manifiesta que no procede la extensión de la interpretación literal del término delito del art. 6.1 CP a las faltas, puesto que, el propio art. 6 CP impone el límite de que la medida no puede ser más gravosa ni de mayor duración que la pena abstractamente aplicable al hecho cometido, y

\footnotetext{
${ }^{129}$ LANDROVE DÍAZ, G., Las consecuencias..., cit. p. 118.

130 URRUELA MORA, A., Las medidas de seguridad..., cit. pp. 42 y 43.

131 GRACIA MARTÍN, L., “Las medidas de seguridad y reinserción...”, cit. p. 453.

132 CEREZO MIR, J., Curso de Derecho penal. (I)..., cit. p. 17.

133 GRACIA MARTÍN, L., “Las medidas de seguridad y reinserción...”, cit. p. 454. Este autor indica que "las medidas de seguridad no encuentran su fundamento en el hecho punible realizado ni, por lo tanto, en la gravedad del mismo, sino únicamente en la peligrosidad del sujeto y en la gravedad de los delitos que aparezcan de probable comisión en el futuro por aquél. Puesto que la comisión de una falta puede constituir ya un relevante y decisivo indicio de la peligrosidad del sujeto, y puede aparecer además como probable la comisión por él de delitos de suma gravedad en el futuro".
} 
eso provocaría la inoperancia de la medida que se impusiese ${ }^{134}$. Y también mantiene una posición similar JORGE BARREIRO, cuando afirma que el término "delito", en sentido estricto, solo comprende las infracciones graves y menos graves, no las faltas ${ }^{135}$. Pero en los últimos años se ha venido admitiendo por la jurisprudencia menor, la aplicación de medidas de seguridad a las faltas y, a título de ejemplo, podemos citar la SAP de la de Las Palmas de Gran Canaria, 422/2005, de 7 de septiembre de 2005, que impone las medidas de tratamiento externo en centro médico y prohibición de acudir al centro de trabajo de los denunciantes, así como de aproximarse a ellos por un tiempo de seis meses. Ciertamente, en este supuesto se aplicó la eximente completa del art. $20.1^{\circ} \mathrm{CP}$ para la falta, pero se impusieron las medidas de seguridad referidas. También la SAP de Murcia 26/2002, de 8 de febrero de 2002, aplicó la medida de seguridad de seis meses de tratamiento médico externo por la comisión de una falta de amenazas y otra de lesiones con la eximente completa de alteración psíquica. Y la SAP de Bizkaia, 724/2003, de 19 de diciembre de 2003, en un supuesto de eximente completa del art. $20.2^{\circ} \mathrm{CP}$, aplicó una medida de seguridad de doce días de tratamiento médico por haber cometido varias faltas de lesiones ${ }^{136}$.

La interpretación sin duda que me parece más apropiada dentro de la sistemática del Código, es la que propone RUBIO LARA, que parte de la distinción entre medidas privativas de libertad y no privativas de libertad, ya que, como se verá, las medidas privativas de libertad solo pueden imponerse cuando la infracción cometida lleve aparejada pena privativa de libertad, por lo que esta clase de medidas únicamente serían aplicables a los delitos graves y menos graves, no así a las faltas; por el contrario, nada obstaría a que las medidas de seguridad no privativas de libertad pudieran ser impuestas por la comisión de faltas ${ }^{137}$, con la única excepción de la libertad vigilada a imputables, que solo cabe en supuestos de delitos en sentido estricto, y que además deben ser de terrorismo o contra la libertad e indemnidad sexual138. Además, el término "delito" no

\footnotetext{
134 LLORCA ORTEGA, J., Manual de determinación de la pena. $6^{a}$ Ed. Valencia: Tirant lo Blanch. 2005, p. 316 y nota al pie 361.

135 JORGE BARREIRO, A., en COBO DEL ROSAL, M., (Dir.), Comentarios..., cit. Tomo IV, pp. 70.

136 Resoluciones citadas por URRUELA MORA, A., Las medidas de seguridad..., cit. p. 43, nota al pie 69.

137 En el mismo sentido REBOLLO VARGAS, R., La llibertat vigilada: pena accessòria o mesura de seguretat contra els condemnats per delictes sexuals $i$ delictes de terrorisme. Barcelona: Centre d'Estudis Jurídics i Formació Especialitzada. 2010, p. 41.

138 RUBIO LARA, P.A., “Las medidas de seguridad...", cit. p. 124.
} 
exige que esté consumado, sino que cabe la aplicación de medidas de seguridad ante formas imperfectas de ejecución y ante formas de participación distintas de la autoría ${ }^{139}$.

$\left.2^{\circ}\right)$ La peligrosidad criminal del sujeto ${ }^{140}$, que deriva del art. $95.1 \mathrm{CP}$, y que se define como la probabilidad de que el sujeto realice en el futuro hechos delictivos ${ }^{141}$. Como ya hemos venido diciendo, las medidas de seguridad tienen su fundamento en la peligrosidad criminal — de la que me ocuparé más adelante- aunque adelanto algunas consideraciones, puesto que la cuestión central no reside en el concepto mismo de peligrosidad, sino en el juicio de pronóstico sobre la misma, pues la forma de determinar el pronóstico se fundamenta en técnicas muy alejadas de la certeza jurídica. Al respecto manifiesta la doctrina que cuando se utilizan métodos psicológicos y criminológicos para realizar el pronóstico, éste termina por alejarse cada vez más de la legalidad y de la seguridad que se precisa en el ámbito jurídico-penal142. Por ello, junto con el presupuesto de la previa comisión de un delito, que será el síntoma, se exige la constatación de la peligrosidad criminal, para lo que el $\mathrm{CP}$ dispone dos criterios distintos que actúan como elementos constitutivos del presupuesto de la peligrosidad:

a) La apreciación de una causa de exención o disminución de la responsabilidad penal que elimine o reduzca la imputabilidad del sujeto, esto es, la necesaria concurrencia de una eximente, que se traduce en que debe declararse previamente su inimputabilidad o semiinputabilidad para lo que que deberán concurrir las características típicas de alguna de las categorías de estados peligrosos ${ }^{143}$, que son: los inimputables, sujetos exentos de responsabilidad criminal por aplicación de las eximentes del art. $20.1^{\circ}, 2^{\circ}$ y $3^{\circ} \mathrm{CP}$, anomalía o alteración psíquica, intoxicación plena o síndrome de abstinencia, y alteraciones de la percepción, de nacimiento o de la infancia, que impidan al sujeto percibir la conciencia de la realidad ${ }^{144}$; y los semiimputables, que son los supuestos

\footnotetext{
139 REBOLLO VARGAS, R., La llibertat vigilada..., cit. p. 42.

140 CHOCLÁN MONTALVO, J.A., “La medida de seguridad...”, cit. pp. 501 y 502.

141 JORGE BARREIRO, A., en RODRÍGueZ MOURUllO, G. (Dir.) / JORGE BARREIRO, A. (Coord.), Comentarios..., cit. p. 300.

142 SIERRA LÓPEZ, M.V., Las medidas de seguridad..., cit. p. 93

143 GRACIA MARTÍN, L., “Las medidas de seguridad y reinserción...”, cit. pp. 455 a 457.

144 JORGE BARREIRO, A., en RODRÍGUEZ MOURUllO, G. (Dir.) / JORGE BARREIRO, A. (Coord.), Comentarios..., cit. pp. 298 y 299.
} 
anteriores con la salvedad de que la exención de la responsabilidad no es completa sino incompleta por aplicación del art. 21.1 ${ }^{\mathrm{a}} \mathrm{CP}$.

b) Excepcionalmente las medidas de seguridad pueden imponerse también junto con la pena a sujetos imputables y culpables, cuando sean considerados peligrosos en aquellos casos que requieran el tratamiento de una medida a causa de su propia personalidad ${ }^{145}$, ya que es perfectamente factible que un imputable se encuentre fuertemente caracterizado por su peligrosidad criminal, por lo que, atendiendo a la justificación de las medidas de seguridad con base exclusivamente en la peligrosidad, pueden ser añadidas a la pena ${ }^{146}$. Por ese motivo, el CP dispone unas reglas por las que, en dos supuestos distintos, constata en el sujeto que la peligrosidad concurre y le confiere el carácter de peligroso:

$1^{\circ}$. Cuando se trata de delitos contra la libertad e indemnidad sexuales y delitos de terrorismo. A pesar de que desde la entrada en vigor del CP de 1995 se ha venido manteniendo que la peligrosidad no puede ser presumida sino que ha de estar probada ${ }^{147}$, desde la reforma operada mediante LO 5/2010, los delincuentes sexuales y terroristas conforman una categoría de personas con unos rasgos específicos que determinan ipso iure la concurrencia de la peligrosidad. Es más, la naturaleza de los delitos cometidos pone en funcionamiento un mecanismo por el que se va a presumir que la peligrosidad perdurará incluso después del tratamiento recibido en prisión mediante la pena de cumplimiento previo a la medida de seguridad, por lo que la peligrosidad no parece que se constate en términos factibles, sino que se presume con una clara tendencia a la volatilización de la constatación de su realidad ${ }^{148}$.

145 POLAINO NAVARRETE, M., Derecho penal. Parte general...., cit. Tomo I, p. 86.

146 ALONSO RIMO, A., “Medidas de seguridad y proporcionalidad con el hecho cometido (a propósito de la peligrosa expansión del Derecho penal de la peligrosidad)". En Estudios Penales y Criminológicos. Vol. XXIX. 2009, pp. 124 y 125. Como indica este autor, "ello resulta acorde con la concepción general que tales autores postulan sobre las medidas de seguridad, que parecen concebir como una suerte de refuerzo de las penas, como instrumento para luchar contra la criminalidad (y en concreto, contra la peligrosidad del autor) allí donde la pena ajustada a la culpabilidad resulta insuficiente".

147 GRACIA MARTÍN, L., “Las medidas de seguridad y reinserción...”, cit. p. 457.

148 MAPELLI CAFFARENA, B., Las consecuencias..., cit. p. 360. Este autor incide en la debilidad del fundamento para la imposición de la libertad vigilada en estos dos grupos de delincuentes -los sexuales y los terroristas- sobre la idea de la persistencia de la peligrosidad tras el cumplimiento de la pena, ya que no parece que sea coherente no imponerla también al asesino o al secuestrador si persiste en él la misma idea de peligrosidad que justifica la medida. 
La libertad vigilada para imputables pretende, por un lado, tutelar los intereses de las víctimas y otras personas que el propio código enumera (familiares y personas cercanas a la víctima), entendiendo por intereses no solo su integridad física sino también la moral, donde debe incluirse la tranquilidad y estabilidad emocional, y el aseguramiento de un espacio mínimo de libertad donde puedan desarrollar su vida con garantías mínimas de dignidad y de paz (al menos por lo que respecta al eventual contacto con el agresor). Y también se persigue una finalidad inocuizadora (prevención especial negativa) para lograr reducir los riesgos de victimización, evitar la reiteración delictiva, sin castigar al agresor de acuerdo a su grado de culpabilidad, sino por la peligrosidad que el hecho cometido indica con miras hacia la comisión de hechos futuros. Se pretende, pues, el control de un grupo de riesgo, frente al que predomina una certeza de alta peligrosidad, y de muy difícil recuperación o resocialización ${ }^{149}$. Sin embargo, no faltan autores que afirman que aunque el legislador ha preferido llamar a la libertad vigilada "medida de seguridad", en realidad se trata de una auténtica pena que se inserta dentro de unas figuras penales que siguen siendo "un campo de cultivo óptimo para introducir sistema de control estatal de dudosa constitucionalidad"150.

$2^{\circ}$. El otro supuesto es la medida de seguridad sustitutiva del art. $89 \mathrm{CP}$ consistente en la expulsión del territorio nacional de extranjeros ${ }^{151}$. Se trata de un supuesto en el que se aplica una medida eminentemente asegurativa y profiláctica que en el CP español fue introducida por la LO 11/2003152, con carácter general en el art. 96.3 CP, reformando el art. $89 \mathrm{CP}$ para sustituir las penas privativas de libertad inferiores a seis años a los extranjeros no residentes legalmente en España153 o las penas superiores a seis años una vez hayan cumplido las tres cuartas partes de la condena o alcancen el tercer grado de

\footnotetext{
149 RUBIO LARA, P.A., “Las medidas de seguridad...", cit. p. 37. Este autor señala que "esto significa un paso adelante en la tradicional concepción del sistema penal fundamentado en la "post-rehabilitación" y dirigido ahora a lo que podemos denominar "custodial continuum", creando mecanismos de control continuo sobre el sujeto sin necesidad de que se encuentre en prisión".

150 MAPELLI CAFFARENA, B., Las consecuencias..., cit. p. 360.

151 LEGANÉS GÓMEZ, S., “La expulsión de los penados extranjeros”. En La Ley Penal, núm. 91, 2012, pp. 74 a 86.

152 LO 11/2003, de 29 de septiembre, de medidas concretas en materia de seguridad ciudadana, violencia doméstica e integración social de los extranjeros.

153 GUISASOLA LERMA, C., "Reformas penales y tendencias político-criminales en materia de inmigración”. En La Ley Penal, núm. 67, 2010, pp. 37 a 54.
} 
tratamiento penitenciario ${ }^{154}$ y paralelamente con la reforma del art. $108 \mathrm{CP}$ para establecer con carácter general y en los mismos supuestos de extranjeros no residentes legalmente, la expulsión como medida sustitutiva de otras medidas de seguridad impuestas por la comisión de un delito cuando hayan sido declarados inimputables ${ }^{155}$. Tras la reforma de la LO 5/2010156, está prevista con carácter general en el art. 96.3 CP como medida de seguridad no privativa de libertad ${ }^{157}$ que en su modalidad del art. $89 \mathrm{CP}^{158}$ sustituye siempre a penas privativas de libertad inferiores a seis años ${ }^{159}$. La sustitución será, por lo general, acordada en la propia sentencia (art. 89.1 CP) sin necesidad de aguardar al proceso de ejecución ${ }^{160}$, pero también se podrá acordar en un momento posterior (art. 89.1, $2^{\circ}$ párrafo CP). Por otra parte, la nueva redacción implica la imposibilidad del expulsado de regresar a España durante un plazo de diez a cinco años (art. 89.2 CP) frente a los diez años de la anterior redacción, y el archivo de cualquier procedimiento de autorización de residencia o trabajo (art. $89.3 \mathrm{CP})^{161}$. Del mismo modo, se prevé la

\footnotetext{
154 La Exposición de Motivos de la LO 11/2003, decía en este punto que "de esta forma se logra una mayor eficacia en la medida de expulsión, medida que, no podemos olvidar, se alcanzaría de todas maneras por la vía administrativa al tratarse de personas que no residen legalmente en España y que han delinquido. En definitiva, se trata de evitar que la pena y su cumplimiento se conviertan en formas de permanencia en España quebrantando así de manera radical el sentido del ordenamiento jurídico".
}

155 PORTILLA CONTRERAS, G., “La exclusión de la inmigración ilegal del espacio físico y moral: un nuevo Narrenschiff Europeo". En ÁLVAREZ GARCÍA, F.J. (Dir.), La adecuación del Derecho penal español al ordenamiento de la Unión Europea. La política criminal europea. Valencia: Tirant lo Blanch. 2009, p. 537. Este autor expresa que "no es que sustituya la pena por la expulsión, sino que al cumplimiento casi efectivo de la pena privativa de libertad seguiría la expulsión, alcanzando niveles insospechados de retribucionismo".

156 GUISASOLA LERMA, C., “Consideraciones político-legales para una reformulación de la expulsión legal de condenados extranjeros sin residencia legal. (Art. 89 del CP)". En Estudios penales y criminológicos, núm. 30, 2010, pp. 206 a 218.

157 LANDECHO VELASCO C.M. / MOLINA BLÁZQUEZ, C., Derecho Penal..., cit. p. 613.

158 GUISASOLA LERMA, C., “La reforma del Código penal en materia de expulsión judicial de extranjeros como medida sustitutiva de penas privativas de libertad (art. 89)". En ÁLVAREZ GARCÍA, F.J. / GONZÁLEZ CUSSAC, J.L., (Dirs.), Comentarios a la reforma penal de 2010. Valencia: Tirant lo Blanch. 2010, pp. 131 a 136.

${ }^{159}$ Lo que genera la duda de si pueden ser sustituidas todas las penas de esa naturaleza -la pena de prisión, la responsabilidad personal subsidiaria por impago de multas y la localización permanente- aunque no parece que esta interpretación tan extensiva sea acorde con el espíritu de la norma. Vid. CUGAT MAURI, M, "La desaprovechada reforma de la expulsión de extranjeros, art. 89 CP”. En QUINTERO OLIVARES, G., (Dir.), La Reforma Penal de 2010: Análisis y Comentarios. Navarra: Thomson Aranzadi. 2010, p. 103.

160 Aunque podrá acordarse de forma motivada, dando en todo caso audiencia al propio penado, al Ministerio Fiscal y a las demás partes personadas el cumplimiento de la pena en un centro penitenciario en España, lo que supone que la decisión es discrecional y debe ser sometida a debate procesal informado por el principio de contradicción. Ibidem, p. 101.

161 Y si el extranjero regresa a España antes del tiempo fijado en la sentencia, cumplirá la pena que le fue sustituida, y si fuera sorprendido en la frontera, será nuevamente expulsado con pérdida del tiempo transcurrido fuera del país, reiniciándose nuevamente el cómputo del plazo de prohibición de entrada (art. 89.4 CP). Para asegurar la efectividad de la expulsión, el extranjero podrá ser internado en un centro de extranjeros con el límite de sesenta días previsto para la expulsión administrativa, y si la expulsión no pudiera llevarse a efecto, se cumplirá la pena privativa de libertad inicialmente sustituida (art. 89.6 CP). 
expulsión en supuestos de penas privativas de libertad que el penado ya esté cumpliendo cuando alcance el tercer grado de tratamiento penitenciario y siempre que haya cumplido las tres cuartas partes de la condena -salvo que existan razones que aconsejen la permanencia en el centro penitenciario hasta el cumplimiento íntegro, art. $89.5 \mathrm{CP}$-, siendo esta modalidad de la expulsión una medida de seguridad a posterior. Y por último, el art. 89.7 CP contiene un listado de delitos a los que no será aplicable la expulsión, que son los relacionados con la inmigración ilegal de los arts. 312, 313 y $318 \mathrm{CP}$, con la finalidad de que los autores no puedan seguir realizando dichas actividades cuando regresen a sus respectivos países ${ }^{162}$.

Las medidas de seguridad son, pues, formas de reacción jurídica frente al delito, que se conciben como mecanismos de respuesta alternativos a la pena. Se trata de medios penales, vinculados al delito pero con diferente naturaleza y fines, por lo que algunos autores afirman que, aunque gozan de las mismas garantías que las penas, no deben tener la consideración de sanciones ${ }^{163}$. Sin embargo la STC 159/1985, de 27 de noviembre, la STC 23/1986, de 14 de febrero y la STC 21/1987, de 19 de febrero, vinieron a poner de manifiesto tanto la pena como la medida de seguridad tienen un innegable carácter aflictivo por cuanto que constituyen privaciones o restricciones de derechos, lo que ha llevado a un sector de la doctrina a considerarlas auténticas sanciones penales ${ }^{164}$. Suponen una restricción de bienes jurídicos, tienen una finalidad pedagógica y asistencial que responde a la concreción de la idea de prevención ${ }^{165}$, encaminada al control de la peligrosidad del sujeto y la evitación que cometa nuevos delitos, que se consigue a través de medios correctores o de aseguramiento, y deben ser aplicadas única y exclusivamente por los órganos jurisdiccionales ante la existencia de una peligrosidad criminal que vendrá determinada por los supuestos tasados en la ley, que son: inimputables y semiimputables, imputables condenados por delitos sexuales o de terrorismo, y extranjeros no residentes legalmente condenados a penas inferiores a seis años.

162 CUGAT MAURI, M., “La desaprovechada reforma de la expulsión...”, cit. p. 105.

163 RUBIO LARA, P.A., “Las medidas de seguridad...”, cit. p. 33.

164 REBOLLO VARGAS, R., La llibertat vigilada..., cit. p. 16; GARCÍA RIVAS, N., “La libertad vigilada y el Derecho penal de la peligrosidad". En Revista General de Derecho Penal, núm. 16. 2011, p. 23.

165 COBO DEL ROSAL, M. / VIVES ANTÓN, T.S., Derecho penal, Parte General. 5a Ed. Valencia: Tirant lo Blanch. 1999, p. 994. 
Conviene tener presente que el art. $6.2 \mathrm{CP}^{166}$, ha generado multitud de críticas doctrinales, en el sentido de que condicionar la extensión de la medida de seguridad al límite temporal de la pena que correspondería en caso de aplicarse la pena por el delito concreto, desnaturaliza la esencia de las medidas de seguridad, por lo que un sector de la doctrina calificaba de sui generis esta configuración de las medidas, por cuanto que prescindía del criterio de la peligrosidad de comisión de hechos futuros que es consustancial a esta clase de sanciones penales ${ }^{167}$. Otros autores interpretan esta norma en sentido garantista, en la medida en que pretende preservar la seguridad jurídica y no la proporcionalidad ${ }^{168}$.

Según SIERRA LÓPEZ, las principales objeciones que se hacen a este precepto son, por un lado, que el obstáculo para que la medida de seguridad no sea más grave que la pena supone una "perturbación entre sanciones claramente diferentes", porque la pena se basa en la culpabilidad y la medida en la peligrosidad criminal; y por otro, que la pena prevista en abstracto adquiere protagonismo para la aplicación de la medida, lo que implica que se tenga en cuenta el hecho cometido - el pasado- y no la peligrosidad del autor - el futuro- impidiendo un clara distinción entre ambas categorías de sanciones y configurando el Derecho penal sobre el principio del hecho.

Esta autora explica que SILVA SÁNCHEZ169 propone, para evitar estas objeciones que transforman las medidas en "pseudopenas" al trasladar las garantías de las penas a las medidas, dotar a las medidas de un sistema de garantías propio, de tal forma que "los principios de necesidad, adecuación y subsidiariedad, se pondrían en relación con la concreta peligrosidad del autor, y el principio de proporcionalidad tanto de la duración

\footnotetext{
166 Que dispone que "las medidas de seguridad no pueden resultar ni más gravosas ni de mayor duración que la pena abstractamente aplicable al hecho cometido, ni exceder el límite de lo necesario para prevenir la peligrosidad del autor".

167 SIERRA LÓPEZ, M.V., La medida de libertad vigilada. Valencia: Tirant lo Blanch. 2013, pp. 61 y 62, y nota al pie 74, con cita de JORGE BARREIRO, A., "Reflexiones sobre la compatibilidad de las medidas de seguridad en el CP de 1995 con las exigencias del Estado de derecho". En Homenaje al Prof. Rodríguez Mourullo. Madrid: Civitas. 2005, p. 577.

168 SIERRA LÓPEZ, M.V., La medida de libertad vigilada..., cit. p. 62, con cita de LASCURAÍN SÁNCHEZ, J.A., "Por un Derecho Penal solo penal: Derecho Penal, Derecho de medidas y Derecho Administrativo sancionador". En Homenaje al Prof. Rodríguez Mourullo. Madrid: Civitas. 2005, p. 599.

169 SILVA SÁNCHEZ, J.M., “Consideraciones sobre las medidas de seguridad para inimputables y semiimputables”. En Homenaje al Prof. Rodríguez Mourullo. Madrid: Civitas. 2005, p. 795.
} 
como del contenido de la intervención tomarían como base la probabilidad de comisión de futuros delitos y no solamente el hecho ya cometido"170.

\section{MONISMO, DUALISMO Y SISTEMA VICARIAL}

El sistema de sanciones penales puede orientarse de diversas formas en función de la conjunción de sanciones penales por la que se opte al conformar el entramado de consecuencias jurídicas que coexistan en el sistema. En ese sentido, surgen históricamente varias teorías que proponen varias soluciones, que son, en esencia, el sistema monista o de vía única que contempla únicamente una de las dos alternativas - pena o medida- y el sistema dualista o de doble vía que conjuga ambas aunque de distintas formas - pena y medida-. En las siguientes líneas me ocupo de cada una de ellas.

a) Las teorías monistas ${ }^{171}$, mantienen el establecimiento de una única respuesta punitiva por parte del Estado contra el delito, o bien penas o bien medidas, pero no aceptan la combinación de ambas reacciones penales como mecanismos que puedan coexistir en un mismo sistema penal, sino que más bien se trata de una fusión de las penas y las medidas de seguridad en una sola forma de sanción ${ }^{172}$. El monismo encuentra, pues, su fundamento en que penas y medidas de seguridad son materialmente lo mismo, diferenciándose únicamente su ejecución.

Las teorías monistas se desdoblan, a su vez, en dos variantes ${ }^{173}$ : el monismo de medidas de seguridad, desarrollado por los positivistas italianos, que parte de que la peligrosidad del sujeto ha de ser combatida por medio de mecanismos orientados a la prevención especial, dotados de carácter asegurativo y resocializador, y proclama la validez de un sistema que utilice la sustitución de penas por medidas de seguridad. Esta teoría monista fue objeto de abundantes críticas por su falta de concreción y por el riesgo que comportaba para la seguridad jurídica ${ }^{174}$. Por su parte, la otra vertiente de las teorías

\footnotetext{
170 SIERRA LÓPEZ, M.V., La medida de libertad vigilada..., cit. pp. 62 y 63.

171 SIERRA LÓPEZ, M.V., Las medidas de seguridad..., cit. pp. 118 a 120.

172 MAPELLI CAFFARENA, B., Las consecuencias..., cit. p. 360.

173 CUELLO CONTRERAS, J., El Derecho penal español..., cit. p. 151.

174 SANZ MORÁN, A.J., "De nuevo sobre el tratamiento del delincuente habitual peligroso". En BUENO ARÚS, F. / HELMUT KURY / RODRÍGUEZ RAMOS, L. / ZAFFARONI, E.R., (Dirs.), Derecho penal y
} 
monistas, el monismo de penas, incide en la suficiencia de las penas orientadas preventivamente, sin que sea necesario acudir a técnicas represivas distintas, por lo que bastará con readaptar la orientación de las mismas en orden a la desaparición de la peligrosidad. En el programa de Marburgo de Von LISZT, la misión del Derecho penal no es retributiva sino preventiva ${ }^{175}$, para lo que la pena puede utilizarse como medio de intimidación, como medio de corrección de los delincuentes que no son susceptibles de ser intimidados con la pena pero pueden ser corregidos, y como medio de aseguramiento de la sociedad frente a los incorregibles; pero esta concepción no terminó de imponerse a las teorías a las que se aferraba la Escuela Clásica, que asociaban la pena a la retribución y a la culpabilidad ${ }^{176}$.

La concepción más retributiva y tradicional de esta clase de monismo está hoy abandonada, pero ha surgido también el denominado "nuevo monismo"177 que, en su vertiente más acentuada, busca extraer del Derecho penal las medidas de seguridad para trasladarlas al ámbito de Derecho administrativo o del Derecho privado. Otra vertiente neomonista más moderada, proponía la aplicación de las medidas de seguridad únicamente a casos de inimputabilidad pero sometiéndola al mismo régimen y limitaciones propias de las penas ${ }^{178}$. Este denominado "nuevo monismo" propugna también, por una parte, una opción que extrae las medidas de seguridad del Derecho penal, de forma que éste queda reservado al ámbito del injusto culpable con la única aplicación de la pena proporcionada al injusto y la culpabilidad, y el Derecho de medidas de seguridad se convierte en Derecho meramente asistencial. Y, por otra parte, las medidas de seguridad reducen notablemente sus ámbitos de aplicación a los delincuentes inimputables peligrosos, de forma que se genera una única respuesta ante el delito.

Criminología como fundamento de la política criminal. Estudios en homenaje al profesor Alfonso Serrano Gómez. Madrid: Dykinson. 2006, p. 1087.

175 Vid. LISZT, F., La idea del fin en Derecho penal 1882. Traducción de Carlos Pérez del Valle. Granada: Comares. 1995, pp. 43 a 96.

176 FRISCH, W., “Las medidas de corrección y seguridad en el sistema de consecuencias jurídicas del Derecho penal. Clasificación en las teorías de la pena, configuración material y exigencias en el Estado de Derecho". En InDret. Revista para el análisis del Derecho. 3/2007. Barcelona: 2007, p. 4.

177 URRUELA MORA, A., Las medidas de seguridad..., cit. pp. 14 y 15.

178 SANZ MORÁN, A.J., “De nuevo sobre el tratamiento...”, cit. p. 1087. 
No obstante, la doctrina española ha venido diciendo que la confusión entre pena y medidas de seguridad, en una única sanción es contraproducente ${ }^{179}$, y JORGE BARREIRO aduce que los principales inconvenientes del monismo son la falta de precisión de sus formulaciones, la confusión que se produce entre las dos categorías de sanciones y las dificultades con que los operadores jurídicos se encuentran para ponerlas en práctica ${ }^{180}$.

b) Las teorías dualistas, defienden -frente a las teorías de los positivistas italianosel carácter retributivo de la pena, completada, allí donde se muestre insuficiente o de imposible aplicación ${ }^{181}$, con medidas de seguridad o de corrección ${ }^{182}$, lo que implica que parten de la afirmación de que penas y medidas son medios distintos de reacción penal estatal frente al delito, cada uno dotado de contenido propio y con finalidades distintas ${ }^{183 / 184}$. El sistema dualista o de doble vía es la contraposición al sistema monista que pretende resaltar las diferencias entre penas y medidas de seguridad, negando que sean lo mismo y, por tanto, trata de establecer un "un orden de cumplimiento impermeable entre ambas"185. Como afirma SÁNCHEZ YLLERA, "los defensores del sistema dualista, o binarista, entienden, sin embargo, que es debida la coexistencia de penas y medidas de seguridad, y que éstas se acumulan a las primeras ejecutándose, normalmente, a continuación de ellas. Se mantiene una doble vía en la lucha contra el delito: la pena atiende a la culpabilidad, la medida se basa en la peligrosidad futura del

179 JORGE BARREIRO, A., en RODRÍGUEZ MOURUllO, G. (Dir.) / JORGE BARREIRO, A. (Coord.), Comentarios..., cit. p. 311; COBO DEL ROSAL, M. / VIVES ANTÓN, T.S., Derecho Penal..., cit. p. 986. Según estos autores "el monismo en Derecho penal introduce más que una fusión entre penas y medidas, una confusión de dichas instituciones que no puede ser aceptada ni conceptualmente, ni tampoco con fundamento en consideraciones políticocriminales. La pena debe mantener su primordial función de prevención general y su noción retributiva, como hemos expuesto. Y la medida de seguridad, por el contrario, su eminente proyección de prevención especial".

180 JORGE BARREIRO, A., en LASCURAÍN SÁNCHEZ, J.A., Introducción al Derecho penal. Navarra: Civitas. 2011, p. 335.

181 SIERRA LÓPEZ, M.V., Las medidas de seguridad..., cit. pp. 115 a 118.

182 SANZ MORÁN, A.J., Las medidas de corrección y de seguridad..., cit. p. 28.

${ }^{183}$ Las penas son consecuencias del delito que se imponen atendiendo al valor del bien jurídico atacado, a la culpabilidad del sujeto y a la gravedad del hecho cometido, mientras que las medidas de seguridad se construyen sobre la consideración de la peligrosidad del sujeto, que no tienden a imponer un sufrimiento penal o un castigo al culpable, sino que consisten en un medio asegurativo o educativo para proteger a la sociedad de daños y peligros que provengan de personas que hayan cometido algún delito. Vid. CUELLO CALÓN, E., La moderna penología..., cit. pp. 95 y 96; y SANZ MORÁN, A.J., Las medidas de corrección y de seguridad..., op. cit. p. 31.

184 FRISCH, W., “Las medidas de corrección...”, cit. p. 5.

185 MAPELLI CAFFARENA, B., Las consecuencias..., cit. p. 361. Este autor señala que “las propuestas dualistas están motivadas por el ambiente favorable a las tesis monistas que se vivió en la Europa de los años treinta. Los peligros del monismo se conjuraron huyendo a un dualismo radical que exige el cumplimiento de la pena y después el de la medida". 
delincuente. Su fundamento y su finalidad son distintos y por ello ambas deben cumplirse acumulativa y sucesivamente"186.

El sistema de doble vía propuesto por STOOSS pretendía combatir el delito mediante la pena que se basaba en criterios retributivos y la medida de seguridad que descansaba sobre aspectos preventivos en función de la peligrosidad del individuo, de forma que la duración de la medida de seguridad no estaba definida estrictamente por la ley, sino que únicamente se fijaban unos límites basados en criterios de la experiencia, por lo que, los tratamientos no podían sobrepasar un determinado tiempo de duración que aparecía como el límite. Este sistema se caracterizaba por estar sujeto al principio de legalidad y al de jurisdiccionalidad -imposición exclusivamente a través de los jueces- y eran medidas de seguridad relativamente indeterminadas, porque su duración dependía de la persistencia o desaparición de la peligrosidad, aunque con sujeción a ciertos límites temporales. El objeto de estas medidas de seguridad era complementar a las penas y servir eficazmente a funciones preventivas que la pena es incapaz de cumplir, de forma que se permitía tanto la acumulación de ambas sanciones - pena más medida- como la sustitución de la medida por la pena si las necesidades político-criminales lo permitían187. El modelo de doble vía que integra el dualismo rígido ${ }^{188}$, consiste en que la medida de seguridad comienza a cumplirse una vez extinguida la pena por cumplimiento efectivo, de forma que existe entre ambas sanciones una secuencia lógica y ordenada que produce un efecto marcadamente disfuncional en cuanto su rigidez, puesto que no permite ofrecer ninguna solución a los casos en los que desaparece la peligrosidad solo con el cumplimiento de la pena, por cuanto que, en esos casos, la medida de seguridad debe cumplirse igualmente ${ }^{189}$.

Este modelo dualista o de doble vía se acabará aceptado incluso por Von LISZT ${ }^{190}$, y de hecho, con motivo del intento por reconciliar la Escuela Clásica y la Moderna, se

\footnotetext{
186 SÁNCHEZ YLLERA, I., en VIVES ANTÓN, T.S., (Coord.), Comentarios..., cit. p. 529.

187 REBOLLO VARGAS, R., “De las medidas de seguridad...”, cit. p. 790.

188 JORGE BARREIRO, A., en LASCURAÍN SÁNCHEZ, J.A., Introducción..., cit. p. 335.

189 MAPELLI CAFFARENA, B., Las consecuencias..., cit. p. 361.

190 LISZT, F., Tratado de Derecho Penal..., cit. Tomo III, pp. 198 y 199. Como indica este autor, “en realidad es cierto que las medidas de seguridad no precisan, necesariamente, estar asociadas a la comisión de un acto punible en sí mismo, y, por consiguiente, que escapan al concepto de pena; así ocurre cuando se impone asistencia educativa frente a niños y adolescentes abandonados, pero que no son aún delincuentes, o cuando es internado un enfermo mental de peligro general antes de que haya cometido un delito. Pero si la medida de
} 
preparó un anteproyecto de CP alemán en 1909 que, junto con las penas, admitía la custodia para dementes, la internación de desintoxicación y la pena de seguridad, y un contraproyecto en 1911 que fue elaborado con representantes de ambas escuelas, KAHL por la Clásica, Von LISZT y Von LILIENTHAL por la Moderna, y con la mediación neutral de GOLSDSCHMIDT, trabajo que introdujo la doble vía distinguiendo entre penas y medidas, y que fue la base para otro Proyecto, el de 1913 elaborado por KAHL, FRANK y Von HIPPEL, que también adoptó el sistema de doble vía pero que no se llegó a publicar y únicamente tuvo repercusión en la adaptación que se produjo en el Proyecto de 1919 que igualmente quedó sin ser un Proyecto oficial del Gobierno alemán debido al comienzo de la Primera Guerra Mundial191. BIRKMEYER, a propósito de la preparación del Proyecto del CP de Suecia en 1913, impulsó la idea de la conveniencia de elaborar dos códigos, uno retributivo para las penas y otro preventivo para las medidas de seguridad, idea también plasmada en 1922 por autores alemanes como BELING, en su obra "Metódica de la Legislación", y también autores italianos como LONGHI en su obra "Per un Códice della Prevenzione criminale", que propugnaron que debía existir un $\mathrm{CP}$ en el que se definieran los delitos y se establecieran las penas asociadas a ellos, y otro código llamado de prevención o de seguridad, en el que se describieran los estados peligrosos y se definieran las medidas de seguridad que les serían aplicables ${ }^{192}$.

No obstante, aunque la propuesta inicial de STOOSS permitía la sustitución recíproca de ambas categorías de sanciones, su implementación en los distintos ordenamientos jurídicos a través de leyes positivas, evidenciaron una tendencia a acumular penas y medidas de seguridad, con un incremento de la punitividad, resultando ser doblemente aflictiva la solución implantada ${ }^{193}$. Pero el carácter aflictivo de las medidas

seguridad está asociada a la comisión de un hecho punible, puede muy bien asumir en sí misma la esencia de la pena (un mal ligado a la reprobación), e indudablemente también desde el punto de vista de la teoría retributiva. Y en cuanto que ésta admita, además, la pena, aun cuando solo accesoriamente, la prosecución del fin correccional y asegurador, en tanto entrara la pena en la esfera de la medida de seguridad. Ambas instituciones jurídicas son como dos círculos secantes: la pena puramente retributiva y la pura medida de seguridad están en oposición, pero, dentro de la esfera que le es común, puede entrar la medida de seguridad en lugar de la pena (con ella "reemplazada" [virkariieren]) y viceversa".

191 Vid. ROXIN, C., Derecho penal. Parte General. Tomo I. Fundamentos. La estructura de la teoría del delito. Traducción de la $2^{\text {a }}$ Ed. alemana por Diego Manuel Luzón Peña, Manuel Díaz y García Conlledo, y Javier de Vicente Remesal. Madrid: Civitas. 1997, pp. 115 y 116.

192 Vid. JIMÉNEZ DE ASÚA, L., Principios de Derecho penal. La ley y el delito. $3^{\text {a }}$ Ed. 1958. Buenos Aires: AbeledoPerrot. Reimpresión de 1997, pp. 64 y 65.

193 REBOLLO VARGAS, R., "De las medidas de seguridad...", cit. pp. 790 y 791 . Este autor relata que precisamente ésta fue la opción vigente en España hasta la reforma de 1983, momento en el que dejó de regir el sistema dualista puro que aplicaba penas y medidas sucesivamente, de forma que si ambas concurrían, se 
de seguridad pronto fue tachado por KOHLRAUSCH de "fraude de etiquetas"194, de ahí que se buscara paliar sus carencias mediante el sistema vicarial. ROXIN llega incluso a afirmar que "la denominación generalmente acuñada de "Derecho penal" realmente es incorrecta. Más exactamente debería llamarse: “Derecho penal y de medidas"; y que aunque la pena descansa sobre el presupuesto de la culpabilidad y sobre el hecho pasado cometido, la medida de seguridad lo hace sobre el repsupuesto de la peligrosidad persistente para el comportamiento futuro del sujeto, por lo que "la culpabilidad no es condición de una medida, pero tampoco la impide. Más bien sucede que la culpabilidad como presupuesto de la pena y la peligrosidad como presupuesto de la medida se encuentran entre sí en relación de dos círculos secantes" 195 .

Según explica Jorge BARREIRO, el dualismo rígido o clásico "es critiable y difícilmente sostenible en la actualidad", porque resulta irracional por cuanto que propicia el cumplimiento sucesivo de pena y medida de seguridad "con resultados funestos" para la pretendida reinserción social del delincuente peligroso; y porque resulta injusto aplicar un doble tratamiento "como si existieran dos personalidades" cuando solo hay una, y aunque el delincuente sea trasladado de un centro de cumplimiento de penas a otro de cumplimiento de medidas de seguridad, solo hay una sanción. De ese modo, el dualismo solo puede tener favorable acogida si el sistema de medidas de seguridad se ajusta a los principios limitadores del ius puniendi estatal y si el dualismo gravita sobre la clara distinción entre penas para el reproche culpabilístico orientadas a la prevención general y especial, y medidas de seguridad para la peligrosidad orientadas a la prevención especial sin carácer retributivo, de forma que se complementen en su ejecución a través del sistema vicarial que sustituye pena por medida. En defintiva, se puede admitir un dualismo flexible que evite la doble privación de libertad y los efectos nocivos que genera el dualismo rígido ${ }^{196}$.

c) El sistema vicarial, surge como respuesta al debate acerca de si penas y medidas son sanciones penales equivales o distintas, y como un mecanismo de articular ambas

\footnotetext{
daba prioridad a la pena y la medida de seguridad "prolongaba la privación de libertad impuesta con la pena a modo de "criminalización subterránea" de comportamientos que no eran constitutivos de delito, pero que podían resultar socialmente incómodos".

194 SANZ MORÁN, A.J., Las medidas de corrección y de seguridad..., cit. p. 32.

195 ROXIN, C., Derecho penal..., cit. pp. 42 y 43.

196 JORGE BARREIRO, A., en LASCURAÍN SÁNCHEZ, J.A., Introducción..., cit. p. 336.
} 
instituciones de forma compatible con el principio de ne bis in idem. Se torna necesario encontrar una forma de armonizar y paliar los defectos o carencias del dualismo, ya que las formas acumulativas de penas y medidas implican una duplicidad sancionadora más que cuestionable, por lo que el sistema vicarial implementa la posibilidad de sustitución recíproca de penas y medidas de seguridad ${ }^{197}$, con base en el principio de oportunidad que posibilitará la imposición de la sanción — pena o medida de seguridad-que más convenga al sujeto y que sea jurídicamente sea más aceptable ${ }^{198}$.

En 1914, el jurista alemán EXNER ${ }^{199}$ describió el núcleo esencial del sistema vicarial a través de la formulación de tres características: $1^{\mathrm{a}}$ ) determinación del orden de cumplimiento sucesivo de los dos tipos de sanciones, de la forma que resulte más favorable a la reeducación o resocialización; $2^{\mathrm{a}}$ ) extensión de todos los efectos beneficiosos alcanzados con la primera sanción (medida de seguridad) a la sanción que deba cumplirse en segundo lugar (pena); y $3^{\mathrm{a}}$ ) aplicación de los mecanismos de sustitución y demás previsiones legales en torno a la ejecución íntegramente a ambas sanciones, de forma que se favorezca su resocialización ${ }^{200}$.

Como afirma ReBOllo VARGAS, el sistema vicarial fue una solución de compromiso entre las opciones monista y dualista, de forma que el Juez, antes de tomar una decisión acerca de la imposición de una medida de seguridad, tendrá que tener en cuenta una serie de factores que se presentaban como irrelevantes hasta ese momento, como la situación personal, social, ambiental, o cualquier otra que tuviera relevancia para atender a las necesidades de defensa social. De esa forma, la decisión del Juez llegaba hasta el punto de poder optar por la pena o por la medida de seguridad en función de dichos criterios. Es, por tanto, una opción mixta con elementos dualistas, que permite imponer una pena basada en la culpabilidad o una medida basada en la peligrosidad, o ambas con una regla distinta a la de la acumulación, esto es, primero aplicar la medida de seguridad y después la pena, computando el tiempo cumplido de la medida de seguridad

\footnotetext{
197 SIERRA LÓPEZ, M.V., Las medidas de seguridad..., cit. pp. 120 a 128 y 397 a 432.

198 POLAINO NAVARRETE, M., Derecho penal Parte general..., cit. Tomo I, p. 97. Este autor explica que "la aplicación de sanciones penales a tenor de este sistema punitivo se hace de una manera no acumulativa (pena más medida), lo que puede resultar incompatible con el principio de ne bis in idem, sino precisamente de forma vicarial: esto es, la medida de seguridad se computa en la penalidad total prevista por la ley y excluye el tanto correspondiente de pena a que se ha hecho acreedor el autor de la acción delictiva".
}

199 EXNER, F., Die theorie der Scherungsmittel. Berlin: 1914, pp. 197 a 225.

200 SANZ MORÁN, A.J., Las medidas de corrección y de seguridad..., cit. p. 33. 
a la pena posterior de forma que solo se cumple el tiempo restante con la posibilidad de suspender la ejecución de la pena. Este sistema, aunque es una solución que puede suponer una respuesta efectiva para determinados sujetos a los que no es fácil proporcionar un tratamiento adecuado en el sistema dualista rígido, lo cierto es que recibe también algunas críticas que se basan en que se genera incerteza en el penado y quiebra el principio de seguridad jurídica, porque el Juez cuenta con un amplio margen de discrecionalidad para decidir, lo que puede afectar de forma incisiva en dicho principio ${ }^{201}$.

El sistema vicarial es, pues, "una síntesis entre monismo y dualismo que permite la fungibilidad entre pena y medidas para asegurar los fines preventivos; de ahí que se conozca también como neomonismo y que, incluso, en algunos países como Suecia o Inglaterra, haya dado lugar a la práctica confusión de ambas" 202 . En ese orden de cosas, la configuración en el CP de 1995 fue la siguiente: para el delincuente imputable peligroso, la solución fue totalmente monista, aplicando únicamente penas ${ }^{203}$, exasperándolas en caso de reincidencia y sin posibilidad de aplicarles además medidas de seguridad, pero con un elenco de penas accesorias con contenidos muy próximos - cuando no idénticosa las medidas de seguridad. Para los inimputables, la opción también fue monista, aplicándoles exclusivamente medidas de seguridad en lugar de penas. Y para los semiimputables la solución fue dualista, mediante la introducción ${ }^{204}$ de las reglas del sistema vicarial ${ }^{205}$, que consiste, según el art. $99 \mathrm{CP}^{206}$, en que, en caso de concurrencia de penas y medidas de seguridad privativas de libertad, el Juez o Tribunal ordenará primero el cumplimiento de la medida, que se abonará posteriormente a la pena ${ }^{207}$ tal y como dispone el art. 104.1 CP, en los supuestos de eximente incompleta del art. 21.1 ${ }^{\mathrm{a}} \mathrm{CP}$ en

\footnotetext{
201 REBOLLO VARGAS, R., “De las medidas de seguridad...”, cit. pp. 791 y 792.

202 MAPELLI CAFFARENA, B., Las consecuencias..., cit. p. 360.

203 SIERRA LÓPEZ, M.V., La medida de libertad vigilada..., cit. p. 64.

204 No obstante, en España la vicarialidad tuvo su primera aparición en la reforma de 1983, pero su entrada fue parcial, únicamente aplicable a los internamientos de semiimputables enajenados mentales o con alteraciones de la percepción. Vid. MAPELLI CAFFARENA, B., Las consecuencias..., cit. p. 360.

205 SÁNCHEZ YLLERA, I., en VIVES ANTÓN, T.S., (Coord.), Comentarios..., cit. p. 529.

$206 \mathrm{El}$ art. 99 CP, tras la reforma operada mediante LO 15/2003, de 25 de noviembre, quedó como sigue: “En el caso de concurrencia de penas y medidas de seguridad privativas de libertad, el Juez o Tribunal ordenará el cumplimiento de la medida, que se abonará para el de la pena. Una vez alzada la medida de seguridad, el Juez o Tribunal podrá, si con la ejecución de la pena se pusieran en peligro los efectos conseguidos a través de aquélla, suspender el cumplimiento del resto de la pena por un plazo no superior a la duración de la misma, o aplicar alguna de las medidas previstas en el artículo 96.3”.
}

207 LUZÓN CUESTA, J.M., Compendio..., cit. p. 260. 
relación con los apartados $1^{\circ}, 2^{\circ}$ y $3^{\circ}$ del art. 20 CP208. En esos casos, se deberá cumplir primero la medida de seguridad y después, una vez alzada, se cumplirá la pena, con la posibilidad de suspender el cumplimeinto del resto de la medida por un plazo no superior al que le restaría por cumplir de pena ${ }^{209}$, o aplicar una medida de seguridad no privativa de libertad de las pervistas en el art. $96.3 \mathrm{CP}^{210}$. Conviene tener presente que este sistema únicamente es aplicable a las penas y medidas de seguridad privativas de libertad, ya que solo las sanciones penales de esa naturaleza tienen imposibilitado materialmente el cumplimiento simultáneo ${ }^{211}$. Se trata, pues, de un "dualismo flexible" que intercambia o sustituye la pena privativa de libertad por la medida de seguridad privativa de libertad en la fase de ejecución ${ }^{212}$.

La LO 5/2010, ha introducido un cambio sustancial calificado por un sector de la doctrina como "neodualismo" 213 puesto que conjuga penas y medidas de seguridad sin sujeción al sistema vicarial ${ }^{214}$, esto es, un régimen sumatorio ${ }^{215}$ que rompe con el monismo para los imputables peligrosos, de forma que, en la libertad vigilada aplicable a

\footnotetext{
208 Conviene tener presente que, en el caso de la drogodependencia, de la redacción del texto se desprende que solo se permite aplicar la vicarialidad cuando concurre la eximente incompleta, no cuando concurre la atenuante de drogadicción o la eximente analógica por la misma causa, lo que se achaca a un error del legislador, pero que en cualquier caso ha sido salvado mediante creación jurisprudencial que viene a admitir que las medidas de seguridad para casos de eximente incompleta, también son aplicables en casos de aplicación de la atenuante de drogadicción del art. 21.2 CP (STS de 11 de abril de 2002, STS de 18 de septiembre de 2000, y STS de 26 de octubre de 2001, entre otras). Vid. MAPELLI CAFFARENA, B., Las consecuencias..., cit. pp. 362 y 363.
}

209 CHOCLÁN MONTALVO, J.A., "La medida de seguridad...", cit. p. 512. Este autor afirma que esta posibilidad "supone abandonar una especie de perdón judicial que autorizaba la regulación precedente al facultar al Tribunal a dar por extinguida la pena o reducir su duración en atención al buen éxito del tratamiento".

210 DEMETRIO CRESPO, E., en ARROYO ZAPATERO, L. / BERDUGO GÓMEZ DE LA TORRE, I. / FERRÉ OLIVÉ, J.C. / GARCÍA RIVAS, N. / SERRANO PIEDECASAS, J.R. / TERRADILLOS BASOCO, J.M. (Dirs.), Comentarios al Código penal. Madrid: Iustel. 2007. Pags. 285 y 286.

211 MAPELLI CAFFARENA, B., Las consecuencias..., cit. p. 362

212 JORGE BARREIRO, A., “Reflexiones sobre la problemática...”, cit. pp. 624 y 625. Este autor explica que en el sistema español se pasó de un "criticable dualismo rígido clásico" que acumulaba penas y medidas de seguridad privativas de libertad con preferencia por la pena, a un "discutible dualismo de tendencia monista en el CP de 1995".

213 CUELlO CONTRERAS, J. / MAPELli CAFFARENA, B., Curso de Derecho penal. Parte General. Madrid: Tecnos. 2011, p. 356. Se trata de una recuperación de la relación dualista entre penas y medidas de seguridad, "entendiéndolas como dos realidades impermeables unidas secuencialmente y precedidas por la ejecución de la medida".

214 ETXEBARRÍA ZARRABEITIA, X., “Las medidas de seguridad como instrumentos de reinserción”. En Revista Sepín práctica penal, núm. 60. 2010, p. 19.

215 ACALE SÁNCHEZ, M., “Nuevos presupuestos para la imposición de penas y medidas de seguridad”. En PÉREZ CEPEDA, I. (Dir.) / GORJÓN BARRANCO, M.C., (Coord.), El proyecto de reforma del Código Penal de 2013 a debate. Salamanca: Ratio Legis. 2014, p. 26. 
delincuentes sexuales (art. 192.2 CP) y terroristas (art. 579.3 CP), la medida de seguridad puede cumplirse de forma sucesiva a la pena, cuya ejecución se lleva a cabo sin solución de continuidad tras extinguirse la pena de prisión ${ }^{216}$ sumándose a la misma, con el objetivo de someter a esta clase de delincuentes a una suerte de control de baja intensidad encaminado a la neutralización de la peligrosidad ${ }^{217}$. Este sistema de doble vía que se aleja de la -para algunos autores errónea-218 concepción del CP de 1995 fundada en que el sistema dualista necesariamente debe asociar medidas de seguridad con ausencia total o parcial de imputabilidad, supone un "criticable retorno al dualismo rígido" 219, al modelo de medidas de seguridad complementarias a las penas, acercándose a lo previsto en otros ordenamientos que parecían haberse descartado con la promulgación del CP en 1995.

La discusión dogmática sobre la justificación de las medidas de seguridad que se aplican con posterioridad a la pena para imputables centra sus principales objeciones en que no es posible presumir la peligrosidad cuando no se constata a través de métodos científicos o médicos, que se sobrepasa el límite de la proporcionalidad y que se trata de un fraude de etiquetas 220 . Según la explicación de WELZEL, "pena y medida de seguridad pueden concurrir en un mismo caso y, por cierto, sucede esto en todos aquellos supuestos en que un autor capaz de culpabilidad es peligroso por encima del hecho individual culpable. Como la pena y la medida de seguridad son distintas en su naturaleza -aquélla la retribución justa por el hecho cometido, ésta la protección de la comunidad ante la peligrosidad del autor-, se colocan independientemente una al lado de la otra (el llamado

216 GARCÍA ALBERO, R., “La nueva medida de seguridad de libertad vigilada”. En Revista Aranzadi doctrinal, núm. 6, 2010, p. 185. Este autor señala que "la postulada pena de libertad vigilada no es sino la constatación de que el Código penal de 1995 cerró en falso el debate entre monismo y dualismo, trasunto éste de un problema de más calado: la crisis del principio según el cual el criterio de distribución de riegos entre sociedad y delincuente debe ser solo y exclusivamente la culpabilidad por el hecho previo, y la pena proporcional a la entidad del injusto culpable".

217 MAPELLI CAFFARENA, B., Las consecuencias..., cit. p. 365.

218 ETXEBARRÍA ZARRABEITIA, X., “Las medidas de seguridad...”, cit. p. 19, nota al pie 4, con cita de ZUGALDÍA ESPINAR, J.M., "Medidas de seguridad complementarias y acumulativas para autores peligrosos tras el cumplimiento de la pena". En Revista de Derecho penal y Criminología. núm. 1, 2009, pp. 199 a 212.

219 JORGE BARREIRO, A., en LASCURAÍN SÁNCHEZ, J.A., Introducción..., cit. p. 337.

220 ZAFFARONI, E.R., “Teoría de las Consecuencias Jurídicas del Hecho Punible”. En Nuevo Código Penal. Opiniones y comentarios. Asunción: Colegio de Abogados del Paraguay. 1999, pp. 103 y 104. Este autor expresa, invocando el "embuste de etiquetas" al que refería Kohlrausch, que las medidas de seguridad no son más que penas con otra denominación, y pone el ejemplo del Código penal brasileño de 1940 que para salvar la prohibición constitucional de penas superiores a treinta años de privación de libertad, en su Exposición de Motivos argumentó que dicho límite solo es predicable respecto de las penas pero no respecto de las medidas de seguridad. También aduce este autor el ejemplo de Stalin, que proclamaba que la pena capital no era tal, sino la "máxima medida de defensa social", por lo que, siguiendo la misma lógica, podríamos decir que la pena capital no infringe la proscripción constitucional siempre que su aplicación se haga como medida de seguridad y no como pena. 
sistema dualista o paralelo). El autor es penado y sometido a la medida de seguridad hasta la eliminación de su peligrosidad. Así, el delincuente toxicómano es remitido a un establecimiento especializado, antes o después de la punición de su hecho para eliminar su manía"221. También MEZGER afirma que, frente a estas objeciones, "en el ámbito de la lucha contra el delito sigue en pie una duplicidad de la misión que ha de resolverse: la misión de la prevención general que tiende de modo más enérgico hacia el "principio del acto", y la misión de prevención especial que se orienta de modo más decidido hacia el "principio del autor", aparecen una al lado de la otra. Ahora bien, si a esta duplicidad de las misiones debe también corresponder la duplicidad de los medios (pena y medida), no es ciertamente una cuestión de principio, sino de índole práctica. No puede negarse que una cierta sustitución y reemplazamiento recíprocos de ambas medidas (pena y medida de seguridad en los casos en que su contenido se corresponda esencialmente, es ya hoy posible y adecuado. Pero, en conjunto [...], corresponderá mejor a la consciencia jurídica del presente el sistema dualista, es decir, la separación estructural entre pena y medida asegurativa" 222 .

JESCHECK afirma que las objeciones constitucionales a las medidas de seguridad posteriores a la pena, no son importantes: “Quien abusa repetidamente de la libertad para cometer delitos graves, y representa también un considerable peligro para el futuro, puede, en interés de la justificada demanda de seguridad por parte de la sociedad, ser sometido a la necesaria restricción de sus movimientos" 223 . Por su parte, JAKOBS la justifica afirmando que la ausencia de seguridad cognitiva en el comportamiento personal ${ }^{224}$, no permite que el delincuente sea tratado como persona y es posible coaccionarle para

\footnotetext{
221 WELZEL, H., Derecho penal..., cit. pp. 240 a 242. Este autor afirma que “la función de protección jurídica de la pena está limitada, tanto material como personalmente, a la retribución justa por el quebrantamiento del derecho de parte del autor que actúa culpablemente. Esta función la cumple plenamente frente a los autores de oportunidad y conflicto, de la clase de población socialmente capaz de convivencia; pero no contempla la peligrosidad de ciertos delincuentes, que sobrepasan la culpabilidad individual. En ellos, la pena debe ser completada con medidas de seguridad, cuya base no es la culpabilidad, sino la peligrosidad. Estas medidas no son dictadas con el fin de compensación retribuidora por un hecho injusto, sino para la seguridad futura de la comunidad frente a las violaciones ulteriores del derecho a esperarse de parte de ese autor. El hecho cometido tiene aquí solamente valor de conocimiento y de síntoma de la peligrosidad común del autor, a establecerse también por otros medios".

222 MEZGER, E., Tratado de Derecho penal..., cit. pp. 396 y 397.

223 JESCHECK, H.H., Tratado de Derecho Penal..., cit. pp. 739 y 740.

224 JAKOBS, G., El Derecho penal como disciplina científica. Traducción de A. Van Weezel. Navarra: Civitas. 2008, pp. 104 y 105.
} 
apartarle de la sociedad o para que recupere la seguridad cognitiva de la que carece ${ }^{225}$. Y dice que "cuando falta esta seguridad cognitiva, no se puede esperar al próximo uso incorrecto de la libertad, sino que hay que procurar ya antes una mejora de la situación de seguridad"226. De ahí que ante las personas que suponen una amenaza de causar algún daño, se pueda reaccionar con mecanismos como la custodia de seguridad que no privan de ningún derecho a quienes no son realmente una amenaza ${ }^{227}$.

La doctrina española ha venido manteniendo opiniones muy dispares, URRUELA MORA mantiene que en el sistema español, las medidas como la custodia de seguridad alemana $^{228}$ serían contrarias al mandato constitucional del art. 25.2 CE229; ALONSO RIMO, afirma que la lógica de la peligrosidad está dotada de cierto peligro, porque la posibilidad de imponer medidas de seguridad que complementen a la pena para su cumplimiento sucesivo, nos conduciría a admitir también las medidas de seguridad indefinidas e incluso las predelictuales230; ROBLES PLANAS mantiene que sería posible la implementación de un Derecho de medidas desvinculado del de la pena, porque podría ofrecer soluciones a supuestos de excepcional peligrosidad que supusieran "una amenaza inminente, grave y

225 JAKOBS, G., “Coacción y personalidad. Reflexiones sobre una teoría de las medidas de seguridad complementarias a la pena”. En InDret. Revista para el análisis del Derecho. 1/2009. Barcelona: 2009, p. 11.

226 Ibidem, pp. 13 y 14. Según explica este autor, "quien quiere "participar" como persona en Derecho, como ciudadano, tiene una prestación debida que ha de cumplir permanentemente: tiene que generar fiabilidad cognitiva. Si esta obligación no se cumple de modo imputable y de una manera cualificada, en cuyos detalles no hay que entrar aquí, la sociedad civil tiene que conseguir coactivamente la fiabilidad cognitiva, precisamente mediante medidas de seguridad complementarias a la pena que excluyen de determinadas actividades sociales. La legitimación de las medidas de seguridad complementarias a la pena proviene de un defecto personal, causado de manera responsable, de aquél a quien hay que aplicar la medida: éste no ha cumplido la "prestación debida" consistente en velar por su fiabilidad cognitiva".

227 Ibidem, p. 10. Este autor ejemplifica diciendo que las personas cierran la puerta de sus casas durante la noche, protegen sus pertenencias, y que nadie dejará que un niño quede a cargo de un pederasta conocido o que un defraudador notorio administre la caja en un negocio.

228 Esta medida de seguridad (Sicherungsverwahrung) también está prevista en el Código penal paraguayo, texto punitivo basado en el modelo alemán que, tras su promulgación en 1997, generó un intenso debate sobre la llamada "reclusión de seguridad" (art. $75 \mathrm{CP}$ ). En ese sentido SCHÖNE, W., Contribuciones al orden jurídicopenal paraguayo. Asunción: Intercontinental. 2000, pp. 114 y 115, mantiene que esta medida de seguridad es válida ya que no toda privación de libertad tiene el carácter de pena, de ahí que la medida pueda (y en algunos casos deba) ser revisada y pueda ponérsele fin acreditando la desaparición de la peligrosidad en que se basa, aspectos que no son predicables en el ámbito de las penas, con la ventaja de que la medida de seguridad es aplicable de forma excepcional bajo la concurrencia de determinados supuestos. Especialmente crítico es FERNÁNDEZ ARÉVALOS, E., "Medidas de Vigilancia, de Mejoramiento y de Seguridad en el Nuevo Código Penal". En Nuevo Código Penal. Opiniones y comentarios. Asunción: Colegio de Abogados del Paraguay. 1999, pp. 156 y 157, que habla de "embuste de etiquetas" porque se transgrede el principio de ne bis in idem. Y CASAÑAS LEVI, J.F., Manual de Derecho penal. Parte General. 6 ${ }^{a}$ Ed. Asunción: La Ley Paraguaya. 2012, p. 177 y 179, afirma que esta reclusión de seguridad no sirve a la prevención especial, y a pesar de que reviste forma de medida de seguridad, es pura y simplemente una pena privativa de libertad.

229 URRUELA MORA, A., Las medidas de seguridad..., cit. p. 21,

230 ALONSO RIMO, A., “Medidas de seguridad...”, cit. pp. 135 y 136, 
suficientemente concreta y probable (no siendo posible la mera posibilidad)", que quedaría condicionada a la necesidad de su utilización y a la persistencia de la gravedad y probabilidad del peligro, por lo que las posibilidades de proporcionar seguridad a través del Derecho de la peligrosidad son muy limitadas231. GRACIA MARTín refiere a que el tratamiento para el delincuente peligroso puede tener solución en el campo de la culpabilidad, a través de agravaciones penológicas como la reincidencia o la multirreincidencia ${ }^{232}$.

Para VIVES ANTÓN, la concurrencia de penas y medidas de seguridad puede ser válida y sin que quepa oponer obstáculos de constitucionalidad cuando, como sucede en supuestos de acumulación de varias penas en el castigo de un hecho, el legislador decide sancionar en parte con una pena y en parte con una medida, siempre que se respeten los límites de proporcionalidad233. SANZ MORÁN se muestra partidario de otorgar una respuesta dualista para imputables peligrosos de criminalidad media o grave, "dando preferencia al carácter correctivo de la intervención frente al meramente asegurativo" 234 . CEREzO MIR, refiere a la conveniencia de tratar al delincuente habitual peligroso reincidente mediante medidas de seguridad complementarias a la pena, puesto que la habitualidad delictiva implica la concurrencia del presupuesto de la peligrosidad que justifica y legitima la aplicación de esta clase de medidas de seguridad235, y también SILVA SÁNCHEZ que considera conveniente la previsión de algún género de medidas de control de la vida en libertad tras el cumplimiento de la pena, así como la implementación de medidas de seguridad para los habituales o peligrosos aunque sin sujeción absoluta a un criterio de proporcionalidad con el hecho cometido que las anule antes de comenzar, pero que tampoco sean totalmente indeterminadas o condicionadas a esa discutible

\footnotetext{
231 ROBLES PLANAS, R., ““Sexual Predators”. Estrategias del Derecho Penal de la peligrosidad”. En InDret. Revista para el análisis del Derecho. 4/2007. Barcelona, 2007, p. 20,

232 GRACIA MARTÍN, L., "Sobre la legitimidad de medidas de seguridad contra delincuentes imputables peligrosos en el Estado de Derecho". En GARCÍA VALDÉS, C. / CUERDA RIEZU, A. / MARTÍNEZ ESCAMILLA, M. / ALCÁCER GUIRAO, R. / VALLE MARISCAL DE GANTE, M., Estudios penales en homenaje a Enrique Gimbernat. Vol. I. Madrid: Edisofer. 2008, p. 1000.

233 VIVES ANTÓN, T.S., “Constitución y medidas...", cit. p. 251. Este autor expresa que "no siempre será constitucionalmente ilegítima la concurrencia sobre un mismo hecho de pena y medida de seguridad. Lo será, desde luego, cuando la pena exprese por sí sola la total reprobación que el ordenamiento jurídico proyecta sobre el hecho y la medida suponga, por consiguiente, solo una ilegítima desaprobación de la personalidad del autor".

234 SANZ MORÁN, A.J., “De nuevo sobre el tratamiento...", cit. pp. 1098 a 1101, con cita de SÁNCHEZ LÁZARO Y JORGE BARREIRO, entre otros.

235 CEREZO MIR, J., Curso de Derecho penal. (I)..., cit. pp. 249 a 255.
} 
desaparición de la peligrosidad que fundamenta su imposición, sino que tendrían que ser medidas de seguridad que se aplicasen sobre "un criterio de proporcionalidad que determine -valorativamente- el momento en que el riesgo de reincidencia pasa a ser asumido por el conjunto de la sociedad, como parece razonable que tenga lugar en el marco de un Estado de derecho que disponga una distribución equilibrada entre individuo y sociedad" 236 .

Por su parte, GUISASOLA LERMA como respuesta legal para los delincuentes habituales peligrosos imputables, se muestra partidaria del sistema dualista, pero sin una rígida acumulación de penas y medidas para un mismo hecho, sino con una adecuada articulación del sistema vicarial que permita aplicar medidas de seguridad también a imputables cuando se aprecie peligrosidad criminal o pronóstico de comisión de futuros delitos que en ningún caso puede presumirse iuris et de iure, sino que deberá ser constatado en cada caso por el órgano judicial atendiendo a criterios fiables, de forma que no se vulneren los principios de ne bis idem y de proporcionalidad ${ }^{237}$. Ahora bien, según esta autora las medidas aplicables a imputables tendrían que ser no privativas de libertad como la libertad vigilada238, y afirma que la custodia de seguridad debe rechazarse en nuestro ordenamiento por su finalidad eminentemente asegurativa o de simple reclusión, ya que "la medida de seguridad ha de estar orientada prioritariamente a la corrección y no al mero aseguramiento" 239 .

GARCíA RIVAS señala que “a poco que se analice el grado de fiabilidad de los sistemas de detección de la misma, nos percatamos de que dicha detección dista mucho de estar asegurada con el rigor que exige la imposición de medidas de seguridad capaces

\footnotetext{
236 SILVA SÁNCHEZ, J.M., “El retorno de la inocuización...”, cit. p. 709.

237 GUISASOLA LERMA, C., Reincidencia y delincuencia habitual. Valencia: Tirant lo Blanch. 2008. Págs. 151 a 155.

238 Y en ese mismo sentido se pronunció también la Comisión para el Estudio de las Medidas de Prevención de la Reincidencia, que en su dictamen no hizo referencia alguna a la custodia de seguridad, sino que su propuesta era "añadir la vigilancia de conducta o libertad vigilada". Vid. Comisión para el Estudio de las Medidas de Prevención de la Reincidencia, creada mediante Resolución JUS/2362/2007, DOGC núm. 4937, de 24 de julio. Informe publicado por el Centre d'Estudis Jurídics i Formació Especialitzada i la Generalitat de Catalunya. 2008, p. 9.

239 GUISASOLA LERMA, C., Reincidencia..., cit. pp. 159 y 160. La autora cita un estudio de la Central de Observación de la Dirección de Instituciones Penitenciarias de 2001, que refleja que los internos que han permanecido en régimen cerrado y en aislamiento, revelan un elevado porcentaje de reincidencia al cabo de los tres años siguientes a su salida, por lo que tanto la indeterminación temporal del aislamiento como la no participación en actividades programadas y el cumplimiento más rígido, son causas que determinan una mayor reincidencia.
} 
de privar de libertad a una persona, o de restringírsela, durante mucho tiempo" 240 . AGUADO LÓPEZ explica que sería válida tanto la opción que apuesta por otorgar un tratamiento al delincuente habitual peligroso y reincidente mediante medidas de seguridad complementarias a la pena ${ }^{241}$, como a través de un tratamiento específico en la ejecución de la pena privativa de libertad, puntualizando que, en cualquier caso, la segunda de las propuestas sería más respetuosa con el marco constitucional español ${ }^{242}$.

\section{EJEMPLOS DE MEDIDAS DE SEGURIDAD EN DERECHO COMPARADO}

En el presente apartado se expondrán brevemente y a título meramente ejemplificativo, algunos ejemplos de medidas de seguridad en distintos ordenamientos jurídicos. El caso de Italia fue de notable importancia por el proyecto del jurista FERRI en 1921, que apostaba por una concepción monista de las medidas ${ }^{243}$. No obstante, en el CP de 1930 todavía vigente, las medidas aparecen reguladas en el Título VIII, del Libro I, bajo la rúbrica "De las medidas administrativas de seguridad", donde se ofrece un catálogo de medidas que pasan por la previa y básica distinción de medidas personales y patrimoniales. Las personales se desdoblan, a su vez, en privativas de libertad y no privativas de libertad; las privativas de libertad son la colonia agrícola, casa de trabajo, casa de cura y custodia, manicomio judicial y reformatorio judicial; y las no privativas de libertad son las prohibiciones de estancia, prohibiciones de frecuentar determinados locales, expulsión de extranjeros y libertad vigilada. Por su parte, las medidas patrimoniales son la caución de buena conducta y la confiscación ${ }^{244}$. Es de resaltar la

240 GARCÍA RIVAS, N., “La libertad vigilada...”, cit. p. 16. Este autor expresa que "habrá que saber cómo puede realizarse dicho pronóstico, rechazando de plano el denominado "intuitivo", que no es otra cosa que el realizado por el juez sin base científica y fiándolo todo a su "ojo clínico"“.

241 AGUADO LÓPEZ, S., La multirreincidencia y la conversión de faltas en delito: Problemas constitucionales y alternativas político-criminales. Madrid: Iustel. 2008, pp. 123 a 129.

242 AGUADO LÓPEZ, S., “Tratamiento penal del delincuente reincidente peligroso: ¿con medidas de seguridad o en la ejecución de la pena?". En La Ley Penal, núm. 102, 2013, pp. 56 a 64.

243 SANZ MORÁN, A.J., Las medidas de corrección y de seguridad..., cit. p. 47.

244 PIGHI, G., “Sistemas penales comparados. Las medidas de seguridad. Italia”. En Revista Penal, núm. 23, 2008, pp. 240 y 241. Este autor explica que el código penal italiano prevé dos medidas de seguridad patrimoniales: la primera es la caución de buena conducta (art. $237 \mathrm{CP}$ ) que es un depósito dinerario al que vienen obligados los sometidos a libertad vigilada o a la prohibición de acudir a establecimientos de bebidas alcohólicas que infrinjan las imposiciones o de los que son liberados de la medida de seguridad de la casa de trabajo. Si hay buena conducta, el depósito se devuelve, pero si no, pasa al patrimonio del Estado. La segunda es la confiscación, que es una expropiación de los instrumentos de delitos (instrumenta scaeleris) o los productos del mismo (producta scaeleris), o sus beneficios y ganancias (art. $240 \mathrm{CP}$ ). Solo tiene por objeto cosas muebles o inmuebles que estén en conexión con el delito cometido. En relación a esta confiscación, este autor señala que un sector de la doctrina pone en duda su carácter de medida de seguridad porque el requisito de la 
existencia de numerosas leyes especiales que contemplan medidas predelictuales, de carácter meramente administrativo y no penal, que reciben el nombre de "medidas de prevención", y que vienen siendo objeto de un fuerte debate doctrinal acerca de la posible incompatibilidad con las exigencias que impone el juego democrático y el Estado de Derecho 245 .

En Alemania la incorporación de medidas de seguridad no se produjo hasta los inicios del período nacionalsocialista, mediante la Ley contra delincuentes habituales y peligrosos y sobre medidas de seguridad y de corrección, de 24 de noviembre de 1933246, caracterizada por una rígida acumulación de penas y medidas donde el papel central lo jugaba la denominada custodia de seguridad, aunque bajo el nomen iuris de medidas se escondían auténticas penas corporales como la castración de los delincuentes sexuales ${ }^{247}$. El StGB de 1871, tras las profunda reforma de 1969 que entró en vigor el 1 de enero de 1975248, combina penas y medidas de seguridad ${ }^{249}$, optando por un modelo muy elástico de aplicación de las medidas, basado en la primacía de la corrección (Besserung), sobre la seguridad (Sicherung) que pasó a un segundo plano ${ }^{250}$.

Las medidas de seguridad en Alemania251 están reguladas en el Título VI de la tercera de las cinco partes en que se divide la parte general del StGB, y comprende los $§ 61$

peligrosidad no está presente; es por eso que algunos autores lo otorgan naturaleza de pena accesoria, pero la es mayoritaria la posición doctrinal que afirma que, tal y como ha venido reiterando la jurisprudencia existente en la materia, su naturaleza es de medida de seguridad, porque está destinada a prevenir nuevos delitos interrumpiendo la relación entre los objetos, las personas y los beneficios y ganancias.

245 SANZ MORÁN, A.J., Las medidas de corrección y de seguridad..., cit. p. 48.

246 Ibidem, p. 52.

247 GRACIA MARTÍN, L., “Las medidas de seguridad...”, cit. p. 433.

248 ROXIN, C., Derecho penal..., cit. p. 125.

249 STRATENWERTH, G., Derecho penal..., cit. pp. 24 a 45.

250 ROXIN, C., Derecho penal..., cit. p. 54.

251 HERNÁNDEZ BASUALTO, H., "Sistemas penales comparados. Las medidas de seguridad. Alemania". En Revista Penal, núm. 23, 2008, p. 218. Este autor expresa que "el derecho penal alemán consagra explícitamente un sistema dual o de doble vía en materia de reacciones al delito: por una parte la pena y por la otra las medidas de corrección y seguridad. Mientras la pena ve limitados sus fines preventivos por el principio de culpabilidad (cfr. § 46 I StGB), las medidas en cambio persiguen fundamentalmente la protección de la comunidad frente al peligro que representa el autor del delito, en base a un diagnóstico de peligrosidad que prescinde de las exigencias de culpabilidad. [...] En la actualidad las dudas fundamentales que plantea el modelo se refieren a su compatibilidad con el ordenamiento constitucional, a las posibilidades reales del tratamiento de autores con marcada inclinación criminal y a la credibilidad de los métodos de diagnóstico. Respecto de lo primero el aspecto problemático es la legitimación de intromisiones muy relevantes en la esfera de derechos de las personas, altamente coincidentes con las penas y que, no obstante, no se encuentran sometidas a los límites que impone el principio de culpabilidad, de reconocido rango constitucional. Asumido 
a 72. No obstante, esta regulación debe ser completada con el Título V (igualmente de la tercera parte de la parte general), que regula la confiscación y el comiso, que a pesar de que no pueden ser consideradas medidas de seguridad en sentido estricto, se incluyen junto a la "inutilización" en la amplia definición de medidas de seguridad que otorga el § 11 StGB ${ }^{252}$. Por tanto, las medidas contenidas en los parágrafos 61 y siguientes del StGB pueden ser privativas de libertad, entre las que encontramos el internamiento en un hospital psiquiátrico, el internamiento en un centro de deshabituación y la custodia seguridad; y también pueden ser no privativas de libertad, que son: la vigilancia de conducta $^{253}$, la privación del permiso de conducir y la inhabilitación profesional254.

Nos detendremos, por su importancia, en el análisis de la custodia de seguridad 255 (Sicherungsverwahrung), que es una medida de seguridad orientada básicamente a la inocuización del delincuente peligroso y resocialización de delincuentes habituales256, por eso se dice que es "una medida pura de defensa social" 257. Se trata de la medida más grave del Derecho alemán, cuya finalidad es la protección de la sociedad frente al peligroso

mayoritariamente, sin embargo, que la pena por sí sola no está en condiciones de satisfacer las necesidades preventivas a que debe atender el sistema penal, se tiende a admitir que las medidas están justificadas constitucionalmente en virtud de una ponderación que tiene en cuenta la existencia de intereses preponderantes y los deberes de protección que pesan sobre el Estado. Esta justificación explica también los presupuestos materiales fundamentales comunes a todas las medidas, a saber la peligrosidad del autor, establecida a partir de un diagnóstico que considera como requisito mínimo la existencia de un hecho previo que reúna las características de delito o al menos de un hecho típico y antijurídico y que arroje como conclusión no la simple posibilidad de comisión de un nuevo hecho de esas características, sino la probabilidad de dicha comisión, en el sentido de un alto grado de posibilidad. Por último se requiere que la medida sea proporcional, exigencia esta última que, sin perjuicio de su rango directamente constitucional, se encuentra explícitamente recogida en materia de medidas, en términos de prohibirse medidas que no guarden proporción con los hechos cometidos por el autor, con los hechos que se pueden esperar de él y con el grado de peligro que emana de él (§ 62)".

252 SANZ MORÁN, A.J., Las medidas de corrección y de seguridad..., cit. p. 55.

253 HERNÁNDEZ BASUALTO, H., “Sistemas penales comparados...”, cit. p. 220 y 221.

254 JESCHECK, H.H., Tratado de Derecho Penal..., cit. pp. 731 a 756.

255 BORJA JIMÉNEZ, E., “Custodia de seguridad, peligrosidad postcondena y libertad en un Estado democrático de la era de la globalización: una cuestión de límites”. En Revista General de Derecho penal, núm. 18, 2012, pp. 1 a 57.

256 SILVA SÁNCHEZ, J.M., “El retorno de la inocuización. El caso de las reacciones jurídico-penales frente a los delincuentes sexuales violentos". En ARROYO ZAPATERO, L. / BERDUGO GÓMEZ DE LA TORRE, I., (Dirs.), Homenaje al Dr. Marino Barbero Santos in memoriam. Vol. I. Castilla-La Mancha: Ediciones Universidad de Castilla-La Mancha, Salamanca: Ediciones Universidad de Salamanca. 2001, pp. 699 y 700. Este autor manifiesta que "esta idea rectora conduce a reducir los requisitos de la "custodia de seguridad" (sicherheistenvarhung) consecuencia jurídica (medida posterior a la pena) no limitada por el principio de culpabilidad, sino por consideraciones de eliminación de la peligrosidad, aun cuando no se excluya el tratamiento". (La cursiva es mía).

257 GRACIA MARTÍN, L., “Sobre la legitimidad de medidas...”, cit. Pag. 996. 
delincuente por tendencia258, respecto del que se ha revelado ineficaz incluso la larga ejecución penitenciaria ${ }^{259}$ y está contemplada en el § 66 StGB, y comporta la privación de libertad impuesta tras la pena y de forma acumulada a ella. El origen de la justificación de la custodia de seguridad se encuentra en los fundamentos contenidos en el proyecto de RADBRUCH de 1922260, pero no entró en vigor hasta 1933, no se convirtió en Derecho vigente hasta la aprobación de la ley de 24 de noviembre de 1933, inicialmente prevista para reincidentes y delincuentes de especial peligrosidad. En los primeros años tuvo una frecuente aplicación ${ }^{261}$ para combatir la reincidencia y la habitualidad delictiva, aunque el fue en la reincidencia por delitos patrimoniales donde más su utilizó ${ }^{262}$. Sufrió una reforma en 1949 y en 1969 —en vigor desde 1975-263 por la que se intensificaron los requisitos para su aplicación en aras a excluir de su aplicación a los delincuentes patrimoniales de menor gravedad y a los menores de treinta años ${ }^{264}$. Hubo también una modificación introducida por la ley de 26 de enero de 1998, de lucha contra los delitos sexuales $^{265}$ y otros delitos peligrosos 266 , que se traduce en la extensión del ámbito de aplicación de la medida de custodia de seguridad y de la vigilancia de conducta, y también se traduce en una mayor incidencia en el tratamiento penitenciario a través de la terapia social para los autores de delitos contra la libertad e indemnidad sexuales, lo cual supone un fuerte endurecimiento del sistema que no tuvo precisamente buena acogida entre la doctrina científica ${ }^{267}$. A través de la ley de 21 de agosto de 2002, se introdujo una

\footnotetext{
258 JAKOBS, G., La pena estatal..., cit. pp. 160 y 161.

259 JESCHECK, H.H., Tratado de Derecho Penal..., cit. p. 739 y 740.

260 MUÑOZ CONDE, F., Edmund Mezger y el Derecho penal de su tiempo. Estudios sobre el Derecho penal en el Nacionalsocialismo. Valencia: Tirant lo Blanch. 2002, pp. 40 y 41.

261 Ibidem, p. 42. Este autor incide en que esta medida de seguridad fue introducida en el régimen nacionalsocialista y además fue muy utilizada por el mismo.
}

262 GUISASOLA LERMA, C., Reincidencia..., cit. pp. 49 y 50.

263 ZACHARIAS, S., "La medida de custodia de seguridad a posteriori. ¿Pena o medida de seguridad?”. En DÍAZ CORTÉS, L.M., (Coord.), Delito, pena, política criminal y tecnologías de la información y la comunicación en las modernas ciencias penales. Memorias del II Congreso Internacional de Jóvenes Investigadores en Ciencias penales. Salamanca: Aquilafuente. 2012, pp. 189 y 190.

264 GUISASOLA LERMA, C., Reincidencia..., cit. p. 50.

265 ROCA POVEDA, M., “La libertad vigilada. Notas desde una visión penitenciaria”. En La Ley Penal, núm. 96-97, 2012, p. 39. Este autor señala que la custodia de seguridad se aplica desde 1998 "guiada por el leit motiv de la lucha contra los delitos sexuales".

266 ARMAZA ARMAZA, E.J., El tratamiento penal del delincuente imputable peligroso. Tesis doctoral. Universidad del País Vasco. 2011, p. 284. Indica este autor que si bien esta medida de seguridad gozó de gran aplicación en sus inicios, a finales de los noventa del siglo pasado cayó en desuso, y fue a través de esta reforma cuando volvió a adquirir protagonismo para dar respuesta al componente mediático que vino acompañando a ciertos delitos contra la vida y la integridad sexual.

267 SILVA SÁNCHEZ, J.M., “El retorno de la inocuización...”, cit. pp. 705 a 707. 
nueva previsión para la custodia de seguridad, de tal modo que se permitía acordarla a reserva (vorbehaltenen sicherungsverwahrug), para los supuestos en que no fuera posible determinar en la sentencia si el sujeto es efectivamente peligroso, en cuyo caso se deja la medida en reserva con la posibilidad de aplicarla una vez cumplida la pena por la que fue condenado en la sentencia268. Además, mediante la ley de 23 de julio de 2004 se introdujo otra ampliación, consistente en la imposición de la custodia de seguridad con posterioridad a la sentencia (nachträliche sicherungsverswahrung), si durante la privación de libertad por un delito ocasional contra la vida, la integridad física o la libertad e indemnidad sexuales, se desprendía la existencia de peligrosidad ${ }^{269}$.

La custodia de seguridad es una medida basada en una finalidad asegurativa y de reclusión del autor ${ }^{270}$, que experimentó en los últimos años importantes modficaciones en su regulación 271 , demostrando una clara tendencia a ampliar su proyección y sus límites ${ }^{272}$. Podemos distinguir dos clases de custodia de seguridad:

a) Custodia de seguridad de imposición preceptiva para los delincuentes con varios antecedentes penales, que precisa de la concurrencia de varios requisitos 273 , previstos en el $\S 66, \mathrm{n}^{\mathrm{o}} 1$, a saber: $1^{\circ}$ ) Debe haber dos condenas anteriores firmes por delitos dolosos a pena privativa de libertad de al menos un año ${ }^{274}$. Se incluye también la pena juvenil, y es relevante destacar que en aras de la lucha contra la delincuencia internacional, se toman

268 GARCÍA ALBERO, R., “Ejecución de penas en el proyecto de reforma. Estudio de un problema concreto: ¿qué hacer con los reos habituales o reincidentes en los que subsiste la peligrosidad criminal tras el licenciamiento definitivo?". En ÁLVAREZ GARCÍA. F., (Dir.), La adecuación del Derecho penal español al ordenamiento de la Unión Europea. La política criminal europea. Valencia: Tirant Lo Blanch. 2009, p. 132.

269 ZACHARIAS, S., “La medida de custodia..., cit. pp. 191 y 192.

270 MEDINA SCHULZ, G., "Sistemas penales comparados. Principales reformas en la legislación penal y procesal (2003-2006). Alemania”. En Revista penal, núm. 18. 2006, p. 250.

271 Vid. MERKEL, G., “Incompatible Contrasts? - Preventive Detention in Germany and the European Convention on Human Rights". En German Law Journal, Vol. 11, núm. 09, 2010, pp. 1046 y ss.

272 GUISASOLA LERMA, C., Reincidencia..., cit. p. 50. La autora indica que "tras la reforma penal de 1998 en la lucha contra la delincuencia sexual (Gesetz zür bekampfung von Sexualdelikten und anderen gefährlichen Straftaten de 26 de enero de 1998), así como en el año 2002 (Ley de 7 de junio de 2002) que permite la imposición de la custodia de seguridad junto a la prisión perpetua y no sólo junto a la temporal (como sucedía hasta entonces)".

273 CANO PAÑOS, M.A., "El marco jurídico y criminológico de la custodia de seguridad (Sicherungsverwahrung) en el Derecho penal alemán". En Cuadernos de Doctrina y Jurisprudencia Penal, núm. 20-21, 2006, pp. 647 a 717.

274 JESCHECK, H.H., Tratado de Derecho Penal..., cit. p. 741. Como apunta este autor, "puesto que se pretende combatir la criminalidad grave, ha de exigirse que en la pena global se incluyese como mínimo una pena individualizada de un año o más". 
también en cuenta las sentencias dictadas en el extranjero ${ }^{275}$. Por lo que respecta a la sucesión temporal, el segundo delito debe haber sido cometido después de la firmeza de la segunda sentencia ${ }^{276} .2^{\circ}$ ) Antes del nuevo hecho delictivo cometido, es necesario el cumplimiento previo de dos años de pena privativa de libertad como mínimo, o el sometimiento por igual período de dos años a la ejecución de una medida de seguridad privativa de libertad 277 . Ese cumplimiento previo puede responder a la ejecución de una pluralidad de condenas siempre que cada una de ellas refiera a una pena privativa de libertad no inferior a un año ${ }^{278} .3^{\circ}$ ) Tras las dos condenas anteriores ya firmes y el mencionado cumplimiento previo, el reo ha de haber cometido el delito determinante de la custodia de seguridad, que deberá ser doloso y por el que se haya impuesto una pena privativa de libertad de al menos dos años $279.4^{\circ}$ ) Junto a estos tres requisitos formales se exige un requisito material cuya finalidad consiste en aplicar la medida de seguridad únicamente a los delincuentes importantes y peligrosos ${ }^{280}$, lo que se traduce en que, de la valoración conjunta del delincuente y de sus delitos, debe derivarse un pronóstico de que cometerá delitos adicionales graves. Esos delitos deben ser sintomáticos o que permitan conocer la clase y dirección de la criminalidad del sujeto, concepto ambiguo que intenta ser aclarado por el propio código mediante ejemplos (que no son los únicos a los que se aplica) como aquéllos en los que la víctima sufre graves daños psíquicos o corporales, o que producen un daño económico de gran importancia. El Tribunal solo disfruta de cierto margen de discrecionalidad en la apreciación o constatación de dichos elementos que conforman el requisito material de pronóstico de comisión de nuevos delitos graves ${ }^{281}$.

\footnotetext{
275 GUISASOLA LERMA, C., Reincidencia..., cit. p. 53.

276 JESCHECK, H.H., Tratado de Derecho Penal..., cit. p. 741.

277 GUISASOLA LERMA, C., Reincidencia..., cit. p. 53.
}

278 JESCHECK, H.H., Tratado de Derecho Penal..., cit. p. 741. Este autor señala que "con este requisito se pretende subrayar especialmente el carácter de la custodia de seguridad como último medio de la Política criminal".

279 ARMAZA ARMAZA, E.J., El tratamiento penal del delincuente..., cit. p. 283 y 284, nota al pie 477.

280 JESCHECK, H.H., Tratado de Derecho Penal..., cit. p. 742. Incide este autor en que "la valoración conjunta del delincuente y de sus delitos ha de ser que aquél, debido a su tendencia a la comisión de delitos graves, resulta peligroso para la colectividad. El precepto debe interpretarse restrictivamente, ya que la custodia de seguridad se contrae a la grave criminalidad. La imagen del delincuente por tendencia viene determinada por una procedencia vinculada a circunstancias sociales y educacionales notablemente deficitarias, por la actividad criminal llevada a cabo hasta el momento (particularmente la criminalidad precoz y gran rapidez en la reincidencia), por la clase de los delitos (particularmente la especialización y la comisión profesional), por la falta de vinculación (v.g. la carencia de domicilio fijo y de relaciones familiares), por las deficiencias intelectivas y por las faltas graves de carácter (sobre todo el temor al trabajo)".

281 GUISASOLA LERMA, C., Reincidencia..., cit. p. 53. 
b) Custodia de seguridad de imposición facultativa para quienes hayan cometido previamente varios delitos aunque no haya condena por ellos 282 . Con esta previsión se deja abierta la posibilidad de aplicarla al peligroso delincuente en serie, incluso si hubiese logrado sustraerse hasta el momento a una condena o al cumplimiento de una pena. Según dispone el $\S 66 \mathrm{II}$, los requisitos son: $1^{\circ}$ ) El reo debe haber merecido una pena de al menos un año en cada uno de los tres delitos dolosos anteriores. $2^{\circ}$ ) Debe haber sido condenado por uno o varios delitos (pena global) a una pena privativa de libertad no inferior a tres años; sin embargo, los hechos que no fueron todavía objeto de sentencia solo pueden tomarse en consideración si hubiera condena simultánea ${ }^{283}$. Al igual que en el supuesto anterior de imposición preceptiva, se exige idéntico requisito material de prognosis de peligrosidad, sin que sea decisivo que por estos hechos haya condena anterior 284 .

Para ambas modalidades de custodia de seguridad, está prevista la denominada prescripción de reincidencia ( $(66$ IV), que se traduce en que para la comprobación de los requisitos formales del § 66 I y II no se tendrá en cuenta el delito anterior si entre el mismo y el nuevo delito cometido, han trascurrido más de cinco años, exceptuando de dicho cómputo el tiempo que el penado haya permanecido internado en cualquier clase de custodia 285 .

En cuanto a la duración del internamiento en custodia de seguridad, en la reforma de 1998 se eliminó el límite de diez años para la primera vez que se imponía la medida, por lo que quedó sin límite máximo de cumplimiento286, aunque transcurridos diez años, por regla general, se producía la remisión de la medida, salvo que se acredite que el sujeto

\footnotetext{
282 ARMAZA ARMAZA, E.J., El tratamiento penal del delincuente..., cit. pp. 287 y 288.

283 JESCHECK, H.H., Tratado de Derecho Penal..., cit. p. 743. Como apunta este autor, "puesto que en dicho planteamiento pueden faltar por completo las penas anteriores y los cumplimientos previos, trata de colocarse particularmente alto el listón de la condena desencadenante".

284 GUISASOLA LERMA, C., Reincidencia..., cit. p. 54. La autora señala que "el requisito material es el mismo que en el caso de la custodia a los delincuentes con varios antecedentes penales, esto es, una valoración del hecho, de la personalidad del autor y una prognosis de peligrosidad, según esa valoración. Sin embargo el legislador, prevé a continuación expresamente que no resulta decisivo que estos hechos hayan sido objeto de condena anterior. Por consiguiente los hechos punibles cometidos pueden haber dado lugar a condena, pero no es necesario que haya sido objeto de ella, pudiendo constituir, por ejemplo, la materia de una acusación o de una resolución de apertura de un procedimiento pendiente".
}

285 JESCHECK, H.H., Tratado de Derecho Penal..., cit. p. 743.

286 GARCÍA RIVAS, N., “La libertad vigilada...”, cit. p. 18. 
continúa siendo peligroso, y en ese caso se podría prolongar incluso de forma perpetua ${ }^{287}$. La reforma de 2002 introdujo una especie de reserva de imposición de la custodia de seguridad por la que podía no imponerse en la sentencia pero sí en una nueva vista oral que tendría lugar antes de que terminara de cumplirse la pena y en la que habría que decidir sobre el pronóstico de peligrosidad. También en 2004 hubo una reforma por la que se permitía la imposición de la custodia aún sin haber hecho la reserva antes aludida, sino decretarse en cualquier momento del cumplimiento de la pena. $Y$ en 2008, a través de la Gesetz zur Einführung der nachträgliche Schirungsverwahrung bie Verurteilungen nach Jugenstrafechtm, se amplió su apliación extendiéndola hasta la justicia penal juvenil288.

Todos estos aspectos fueron sometidos al Tribunal Federal Constitucional alemán (BVerfG) que en un primer momento, en su Sentencia de 10 de febrero de 2004, declaró que era constitucional la supresión del límite máximo de cumplimiento de la custodia de seguridad ${ }^{289}$ y en su sentencia de 23 de agosto de 2006 (en la que fue ponente Hassemer) volvió a pronunciarse el alto tribunal para declarar la constitucionalidad ${ }^{290}$ de la imposición de la custodia de seguridad con posterioridad a la pena ${ }^{291}$. No obstante, el TEDH en su Sentencia de 17 de diciembre de 2009, declaró que la regulación de la custodia de seguridad en Alemania tras las sucesivas reformas era contraria al CEDH ${ }^{292}$, lo que generó que el BVerfG, en su Sentencia de 4 de mayo de 2011, declarase inconstitucional esta posibilidad ilimitada de prolongación de la restricción a la libertad aun si persiste la peligrosidad ${ }^{293}$, declarando que la custodia de seguridad implica igualmente una restricción grave en la libertad del penado, a quien se le deberá garantizar siempre una perspectiva de liberación, para lo cual será necesario articular un programa

\footnotetext{
287 MERKEL, G., “Incompatible Contrasts...”, cit. pp. 1047 y 1048.

288 ACALE SÁNCHEZ, M., “Medición de la respuesta punitiva y Estado de Derecho. Especial referencia al tratamiento penológico del delincuente imputable peligroso". En Revista Aranzadi de Derecho y Proceso Penal, núm. 24. 2010, p. 79.

289 REQUEJO RODRÍGUEZ, P., “Peligrosidad criminal y Constitución”. En Indret. Revista para el Análisis del Derecho, 3/2008. Barcelona: 2008, p. 5.

290 GARCÍA ALBERO, R., “Ejecución de penas en el proyecto...”, cit. p. 132.

291 REBOLLO VARGAS, R., “De las medidas de seguridad”. En CÓRDOBA RODA, J. / GARCÍA ARÁN, M., (Dirs.), Comentarios al Código Penal. Parte General. Madrid: Marcial Pons. 2011, p. 800.

292 GARCÍA RIVAS, N., “La libertad vigilada...”, cit. pp. 18 a 22.

293 BORJA JIMÉNEZ, E., “Custodia de seguridad, peligrosidad postcondena y libertad en el estado democrático de la era de la globalización. una cuestión de límites". En Revista General de Derecho Penal, núm. 18, 2012, pp. 5 y ss.
} 
de ejecución distinto al de la pena que justifique la custodia, impidiendo con ello que la privación de libertad se perpetúe 294 .

También se planteó en Alemania la delimitación de la custodia de seguridad como pena o como medida, aspecto que fue inicialmente resuelto por el BverfG en su Sentencia de 5 de diciembre de 2004, aduciendo que se trata de una medida de seguridad, pero por otra parte, el TEDH en su Sentencia de 17 de diciembre de 2009, consideró que es una pena por carecer en su aplicación de diferencias significativas con la pena privativa de libertad ${ }^{295}$, siendo que incluso la ejecución tiene el mismo fin de reinserción social que cohabita con el efecto intimidatorio 296 , de ahí que algunos autores alemanes propongan su derogación 297 . De hecho, el BverfG en Sentencia de 4 de mayo de 2011, se retractó de su anterior doctrina sentada en 2004, declarando inconstitucional la actual regulación de la custodia por carecer de distinción efectiva con la pena de prisión y fijando un periodo transitorio para los casos en que se hubiera aplicado la medida con anterioridad a la aparición de esa Sentencia, con fecha límite hasta el 31 de mayo de 2013298.

En ese orden de cosas, la doctrina expresa que de los recientes pronunciamiento del $\mathrm{TEDH}$ se desprende que nos encontramos ante figuras con naturaleza ambigua que conforman un tertium genus de sanciones entre las penas y las medidas de seguridad, por cuanto que se trata de privaciones o limitaciones de la libertad impuestas al sujeto que ya ha cumplido la pena de prisión, porque gravitan sobre el presupuesto de la peligrosidad

294 ZACHARIAS, S., “La medida de custodia...”, cit. pp. 204 y 205.

295 BORJA JIMÉNEZ, E., “Apuntes de urgencia sobre la legitimidad y los límites de la custodia de seguridad en el Anteproyecto de Reforma del Código Penal de 2012". En Revista General de Derecho Penal, núm. 19, 2013, pp. 9 a 13 .

296 ZACHARIAS, S., "La medida de custodia...", cit. pp. 197 y 198. Como indica esta autora, "no se reconoce una diferencia cualitativa entre las sanciones en el juicio de imposición y la ejecución, o sea, ambas sanciones están impuestas por parte de la justicia criminal. Como consecuencia el TEDH concluye que la medida de custodia de seguridad se califica como pena, de modo que los principios del art. 7 CEDH deberán ser aplicados. Así que la limitación infringe el principio nulla poena sine lege como parte del principio de irretroactividad. Por eso, dicho principio también se encuentra violado. Aparte de dicha sentencia otro juicio se dedica a la clasificación de la medida de seguridad pero en la forma a posteriori. El Tribunal analiza y afirma en la sentencia $n^{\circ} 6587 / 04 \mathrm{H}$./ Deutschland la infracción del art. 5 CEDH. Además, consta y cita la sentencia ${ }^{\circ}$ 19359/04M./ Deutschland refiriéndose a los resultados allá mencionados".

297 ULLENBRUCH, T., Nachträgliche Schierungsverwahrung - ein legislativer "Spuk" im judikativen "fegefeuer"? En NStZ, 2007, p. 62.

298 SIERRA LÓPEZ, M.V., La medida de libertad vigilada..., cit. pp. 82 y 83. 
criminal, pero también sobre el de la comisión de determinados delitos en cuya comisión concurre también la culpabilidad 299 .

El caso de Paraguay —que debido a la influencia de los códigos penales europeos en Iberoamérica, promulgó en 1997 un Código penal basado en el modelo alemán bajo el asesoramiento técnico de SCHÖNE- contempla la reclusión en un establecimiento de seguridad con posterioridad a la pena privativa de libertad para reincidentes ${ }^{300}$ (art. 75 $\mathrm{CP})$, que tendrá una duración máxima de diez años por encima de la pena privativa de libertad (de la que el penado deberá haber cumplido al menos dos años) y se aplicará en supuestos en los que el sujeto haya sido condenado al menos dos veces por infracciones penales dolosas, y siempre que se constate que existe una tendencia a cometer delitos graves $^{301}$ que conlleven para la víctima graves daños psíquicos, físicos o económicos, lo cual deberá deducirse de la propia personalidad del sujeto ${ }^{302}$ y de las circunstancias del hecho. No obstante, en la ejecución de dicha medida de seguridad, se podrá conceder un permiso a prueba de entre dos y cinco años (art. $79 \mathrm{CP}$ ), en los que el sujeto podrá permanecer en libertad bajo la sujeción de un asesor a prueba y con las reglas de conducta que se le impongan ${ }^{303}$-previstas en los arts. 46 a 48 del CP y que son las genéricas para el caso de suspensión condicional de la pena privativa de libertad-, que pueden ser, entre otras, acatar órdenes relativas al domicilio, trabajo, tiempo libre, o administración de sus recursos económicos; obligación de presentación periódica ante el juzgado u otra entidad o persona que se determine; prohibición de poseer determinados objetos que pudiesen estimularle a delinquir; o el sometimiento a tratamiento médico o de desintoxicación siempre que el penado preste su consentimiento ${ }^{304}$.

\footnotetext{
299 GARCÍA RIVAS, N., “La libertad vigilada...”, cit. p. 23.

300 LÓPEZ CABRAL, M.O., Código Penal paraguayo. $2^{\text {a }}$ Ed. Asunción: Intercontinental. 2009, p. 309. Este autor expresa que "esta medida es impuesta al autor del hecho punible reincidente conjuntamente con la condena privativa de libertad, ordenándose su reclusión en un establecimiento de seguridad a los efectos de preservar a la sociedad en contra de la predisposición del autor tendiente a ejecutar más hechos punibles de importancia; predisposición entendida ya sea como propensión caracterológica o adquirida por la práctica, para la comisión repetida de hechos punibles".
}

301 CASAÑAS LEVI, J.F., Manual de Derecho penal..., cit. p. 177.

302 LÓPEZ CABRAL, M.O., Código Penal paraguayo..., cit. p. 309. Este autor expresa que “queremos resaltar la importancia del pleno estudio de la exteriorización de la personalidad, que debe ser efectuada por personales médicos idóneos en el ramo o campo específico, porque esa circunstancia de mayor incidencia para la aplicación de la medida de reclusión y que permitirá la certeza de la medida a ser adoptada y que indudablemente implica".

303 MORA RODAS, N.A., Código Penal paraguayo comentado. $4^{a}$ Ed. Asunción: Intercontinental. 2009, p. 243.

304 CENTURIÓN ORTIZ, R.F., Derecho penal. Parte General. Asunción: La Ley Paraguaya. 2010, p. 607. 
En Suiza, el Anteproyecto de Carl STOOSs de 1893 al que ya hemos referido antes, aunque no fue hasta 1937 cuando se promulgó un código penal unitario siguiendo las líneas trazadas por STOOSS, basado en la vicariedad, y que sufrió una importante modificación en virtud de la ley de 18 de marzo de 1971. Las medidas que contiene dicho texto legal pueden ser de dos clases: privativas de libertad, que son el internamiento en centro psiquiátrico (art. 43), el internamiento en centro de deshabituación (art. 44), custodia de delincuentes habituales (art. 42), envío a un centro de trabajo educativo cuando se trate de jóvenes adultos cuyas edades estén comprendidas entre los 18 y 25 años (art. 100 bis). La medida privativa de libertad es siempre alternativa a la pena ${ }^{305}$. Y también existen medidas no privativas de libertad, que son: la privación de la patria potestad, la inhabilitación profesional, la expulsión del territorio nacional, la prohibición de acudir a determinados establecimientos de bebidas alcohólicas, la caución y el comiso.

El ordenamiento de Portugal opta por un sistema distinto al que se denomina "pena relativamente indeterminada", aplicable a supuestos de alcoholismo (entre otros) donde la adicción incide directamente en la perpetración del delito306; y ello obedece a una tendencia neomonista que se traduce en la existencia de penas para imputables y medidas para inimputables, separando claramente presupuestos de aplicación en uno y otro supuesto $^{307}$. Su regulación se encuentra en el Capítulo VI, del Título III del Libro Primero $\mathrm{CP}$, ubicado sistemáticamente después de la regulación de la referida pena relativamente indeterminada. Solo hay una medida privativa de libertad, prevista en los arts. 91 y ss. $\mathrm{CP}$, que consiste en el internamiento de inimputables, sometidos a una gran flexibilidad en cuanto a suspensión condicional, revisión, libertad a prueba en fase final, y se admiten

\footnotetext{
305 SANZ MORÁN, A.J., Las medidas de corrección y de seguridad..., cit. pp. 60 y 61.

306 DE LACERDA DA COSTA PINTO, F., “Sistemas penales comparados. Las medidas de seguridad. Portugal". En Revista Penal, núm. 23, 2008, p. 253. Este autor expressa que "As medidas de segurança, mesmo aquelas privativas da liberdade, aplicam-se não só a inimputáveis (art. $91^{\circ}$ e ss do Código Penal), como, em casos muito específicos, também a imputáveis (art. $104^{\circ}$ e ss do Código Penal). Finalmente, a pena de prisão sendo em regra determinada na decisão judicial condenatória, pode ser "relativamente indeterminada" no caso dos delinquentes por tendência (imputáveis perigosos) que sejam condenados em prisão efetiva superior a dois anos de prisão por crime doloso, tendo anteriormente sofrido duas ou mais condenações desta natureza e gravidade. Em tais casos, se o agente, numa avaliação conjunta de todos os factos, revelar a persistência de "uma acentuada inclinação para o crime" a pena será relativamente indeterminada, o que significa um agravamento de dois terços na pena mínima e um acréscimo de seis anos à pena máxima, sem que se ultrapasse, de qualquer modo, o limite máximo da pena de prisão (art. $83^{\circ}$ do Código Penal), que é em Portugal de vinte e cinco anos".
}

307 FIGUEIREDO DIAS, J., Direito penal português. Parte General II. As consequências jurídicas do crime. $2^{\mathrm{a}}$ Reimpressão. Coimbra: Coimbra Editora. 2009, pp. 555 a 592. 
prórrogas sucesivas del internamiento originario (art. 92 CP). También existen medidas no privativas de libertad, que son: la prohibición de actividades (art. $100 \mathrm{CP}$ ), la privación de licencia de conducción (art. 101 CP), la prohibición de acceder a la concesión de la licencia de conducción (art. $102 \mathrm{CP}$ ), la pérdida de los instrumentos, objetos productos o ventajas del delito (arts. 109 a 112 CP), y también se regulan supuestos de inimputabilidad sobrevenida (arts. 104 a $108 \mathrm{CP})^{308}$.

En Argentina, el CP de 1921 que tras varias reformas sigue vigente, incluyó únicamente tres medidas de corrección y seguridad en la parte general, dos de carácter curativo y preventivo referidas a sujetos inimputables por ausencia de culpabilidad, que son la reclusión en manicomio para enajenados mentales (art. $34 \mathrm{CP})^{309}$ y la reclusión en establecimiento adecuado para el caso de cualquier otra causa de inimputabilidad distinta a la enajenación mental; y otra de carácter eliminatorio, consistente en la reclusión por tiempo indeterminado para supuestos de reincidencia. Posteriormente, a través de la promulgación de leyes especiales, se amplió el elenco de medidas y, en concreto, la ley 23737, de 1989, sobre la represión de la tenencia y tráfico de estupefacientes y psicotrópicos, prevé en sus arts. 16 a 18 y 21, medidas de seguridad curativas y educativas para sujetos con adicciones a drogas tóxicas, estupefacientes o sustancias psicotrópicas o a los que experimentan con ellas 310 .

En Uruguay, las medidas de seguridad son clasificadas en el art. $92 \mathrm{CP}$ en cuatro categorías: las medidas curativas aplicables a enfermos, bebedores, consumidores de

\footnotetext{
308 SANZ MORÁN, A.J., Las medidas de corrección y de seguridad..., cit. p. 64.

309 ZAFFARONI, E.R. / ALAGIA, A. / SLOKAR, A., Derecho Penal. Parte General. $2^{\mathrm{a}}$ Ed. Buenos Aires: Adiar. 2002 , p. 928. Como indican estos autores "el enajenado es sometido a reclusión, pues no saldrá del manicomio es decir que permanecerá encerrado- hasta decisión judicial, o sea, por tiempo indeterminado, que puede ser el resto de su vida. En rigor es la única pena realmente perpetua que existe en el código, pues su término no depende de nada que pueda hacer la persona para ponerle fin. La idea rectora es que el enfermo mental requiere internación manicomial mientras sea peligroso $\mathrm{y}$, siendo peligroso porque es enfermo, deberá permanecer en reclusión mientras continúe la enfermedad. Por cierto, todo esto corresponde a una psiquiatría de siglos pasados (propia de las camisas de fuerza, celdas acolchadas, duchas frías, etc.), siendo absurdo sostener que el enfermo mental debe permanecer recluido para su seguridad después de décadas de uso de psicofármacos y cuando nadie discute que la reclusión manicomial es el último recurso que emplea la psiquiatría actual, incluso desde sus perspectivas más tradicionales y conservadoras. Por lo demás, existen enfermos mentales (como los oligofrénicos) que por definición nunca pueden ser curados con los medios disponibles, dada la base neurológica del padecimiento; luego, pensar en su internación perpetua sólo es concebible dentro del programa de eliminación masiva y de prevención mediante la evitación de la reproducción, que proyectaba la psiquiatría de la época, pero que constituye una aberración que nadie sostendría con seriedad en la actualidad".
}

310 NIÑO, L.F., “Sistemas penales comparados. Las medidas de seguridad. Argentina”. En Revista Penal, núm. 23, 2008, p. 222. 
drogas tóxicas declarados irreprochables y a los ebrios habituales; las medidas de seguridad educativas en relación a los menores infractores; las eliminativas que implican la aplicación adicional de la medida de seguridad, que actúa como un complemento a la privación de libertad, y preventivas que se aplican respecto de sujetos que han pretendido delinquir pero que por diversas causas no han quebrantando la norma penal ${ }^{311}$.

En Guatemala, tuvieron vigencia este tipo de leyes para el control de la peligrosidad social desde la reforma liberal de 1871. Actualmente en el art. 88 del CP guatemalteco están previstas como medidas de seguridad el internamiento en establecimiento siquiátrico, el internamiento en granja agrícola, centro industrial u otro análogo, el internamiento en establecimiento educativo o de tratamiento especial, la libertad vigilada, la prohibición de residir en lugar determinado, la prohibición de concurrir a determinados lugares y la caución de buena conducta ${ }^{312}$.

En Brasil, las medidas de seguridad se aplican en casos de sentencia absolutoria impropia, sentencia condenatoria del semiimputable y en casos de enfermedad mental que sobrevenga durante el cumplimiento de la pena. El CP brasileño contiene dos clases de medidas (art. $96 \mathrm{CP}$ ), la primera es la medida de seguridad detentiva, que se traduce en la internación en hospital de custodia y tratamiento psiquiátrico, o en otro establecimiento adecuado 313 ; y la segunda es la medida de seguridad no detentiva, que implica la sujeción del individuo a tratamiento ambulatorio ${ }^{314}$.

311 GALAIN PALERMO, P., “Sistemas penales comparados. Las medidas de seguridad. Uruguay”. En Revista Penal, núm. 23, 2008, p. 258. Según este autor "el sistema de duración de las medidas de seguridad tiene una doble característica: de indeterminación absoluta e indeterminación relativa. Las medidas de seguridad curativas tienen una indeterminación absoluta; sin un mínimo ni máximo. Las restantes medidas son de indeterminación relativa. Las medidas de seguridad educativas no contienen un mínimo pero sí un máximo fijado en 10 años; las medidas de seguridad eliminativas y las preventivas tienen fijado un mínimo de 1 año y un máximo de 15 años. Los lugares destinados para el cumplimiento de tales medidas son seleccionados de acuerdo al fin que es buscado por el tipo de medida a imponer".

312 DE LEÓN VELASCO, H.A. / DE MATA VELA, J.F., Derecho penal guatemalteco. $12^{\text {a }}$ Ed. Guatemala: Editorial Lerena. 2000, pp. 294 y ss.; LAYLLE CONTRERAS, L.B., "Análisis jurídico de la aplicación de medidas de seguridad en el Hospital Nacional de salud mental de Guatemala". Tesis doctoral. Guatemala: Universidad de San Carlos de Guatemala. 2007, pp. 10 y ss.

313 CURIA, L.R. / CÉSPEDES, L. / NICOLETTI, J., (Edit.), Vade Mecum. 14ª Ed. São Paulo: Saraiva. 2012, pp. 518 y 519.

314 COUTO DE BRITO, A., "Sistemas penales comparados. Las medidas de seguridad. Brasil”. En Revista Penal, núm. 23, 2008, p. 226. Este autor señala que "las Medidas de Seguridad están previstas para aplicación a los inimputables. Sin embargo, en ciertos casos, se aconseja la aplicación a los semi-imputables, que aunque tengan la capacidad de comprender el carácter preventivo de la pena, no la tiene en su plenitud. A estos, el juez impondrá una sentencia condenatoria, pero podrá optar por reducir su pena o sustituirla por una Medida de Seguridad. No sólo por las condiciones físicas y psicológicas limítrofes impuestas por cualquier régimen de 


\section{PRINCIPIOS RECTORES}

El derecho de medidas se construye en torno a unos principios que conforman lo que URRUELA MORA denomina "principios informadores del derecho de medidas" 315. Para este autor los principios que informan el derecho de medidas son el de legalidad, irretroactividad y proporcionalidad, aunque otros autores incluyen también el principio de igualdad, última ratio, postdelictualidad y pronóstico de peligrosidad 316.

a) Principio de legalidad ${ }^{317}$. Quizás sea éste el principio más relevante en esta materia. Se desdobla, a su vez, en seis exigencias derivadas del propio principio: taxatividad, reserva de ley, irretroactividad, garantía jurisdiccional, legalidad de ejecución y prohibición de analogía318. Nadie discute en la doctrina que el aforismo nullum crimen, nulla poena sin lege praevia, scripta et stricta, en el que se condensa el contenido del principio de legalidad, sea aplicable también a las medidas de seguridad ${ }^{319}$. La denominada garantía criminal (nullum crimen sine lege), exige la comisión de un hecho tipificado como delito, con independencia de las consecuencias que de él se deriven (penas o medidas) ${ }^{320}$. Por su parte, la exigencia de nullum poena sine lege praevia, implica que no cabe imponer ninguna medida que no haya sido previamente establecida por la ley, a lo que hay que añadir que dicha ley no podrá ser otra norma distinta de una LO, salvo supuestos de ley penal en blanco. Es decir, que se trata de una reserva de LO, que deriva de la propia

prisión, pero hasta mismo por circunstancias intrínsecas al condenado, eventualmente podrá sobrevenirle una enfermedad mental durante el cumplimiento de la pena, lo que demandará su transferencia al establecimiento adecuado como el Hospital de Guardia y Tratamiento Psiquiátrico (art. 108) u otro instituto similar. Esta es la exacta orientación del art. 183 de la Ley de Ejecuciones Penales (L. 7.210/1984). [...] Por no haber previsión legal, hay duda sobre por cuánto tiempo el condenado deberá permanecer internado, en estos casos en los que la enfermedad mental surge durante la ejecución de la pena".

315 URRUELA MORA, A., “Los principios informadores del derecho de medidas en el Código Penal de 1995”. En Revista de Derecho Penal y Criminología de la UNED, núm. 8. Madrid. 2001, pp. 167 y ss.

316 GARCÍA ARAN, M., Fundamentos y Aplicación de Penas y Medidas de Seguridad en el Código Penal de 1995. Navarra: Aranzadi. 1997, pp. 130 a 134.

317 Sobre el principio de legalidad en general, vid. DE VICENTE MARTÍNEZ, R., El principio de legalidad penal. Valencia: Tirant lo Blanch. 2004, pp. 13 y ss.

318 SANZ MORÁN, A.J., Las medidas de corrección y de seguridad..., cit. p. 110.

319 SÁNCHEZ YLLERA, I., en VIVES ANTÓN, T.S., (Coord.), Comentarios..., cit. p. 532.

320 A este respecto manifiesta SANZ MORÁN, A.J., Las medidas de corrección y de seguridad..., cit. p. 111 y 112, que "no es infrecuente encontrar la sustitución, en relación a las medidas, del nullum crimen sine lege por el nulla periculositas sine lege, a nuestro juicio sin razón; pues este último criterio tendría, más bien, su correlato en un nulla culpa sine lege, que nadie exige". 
dicción del art. 1.2 CP, a cuyo tenor: "las medidas de seguridad solo podrán aplicarse cuando concurran los presupuestos establecidos previamente por la Ley" ${ }^{321 .}$

Especial mención requiriere la prohibición de analogía, pues no es pacífica la cuestión de la posible la aplicación analógica de normas penales que favorezcan al reo, esto es: analogía in bonam partem. En principio, la analogía no está permitida en el ámbito del Derecho penal, pero lo cierto es que el TS (Sala Segunda) ha venido admitiendo la posibilidad de extender analógicamente alguna medida de seguridad a supuestos no previstos penalmente, basándose en la calificación más favorable de una medida curativa que algunas penas ${ }^{322}$.

La garantía jurisdiccional del principio de legalidad tiene, a su vez, dos vertientes: una referida a la imposición de la medida, y otra a su ejecución ${ }^{323}$. La primera de ellas viene a garantizar que las medidas de seguridad únicamente podrán ser impuestas a través del oportuno (y necesario) proceso judicial, pues una consecuencia jurídica del delito (ya sea una pena o una medida) solo puede ser impuesta por los Jueces y Tribunales, por medio del proceso ${ }^{324}$. Y más aún: la medida se seguridad, según se desprende del art. 3.1 CP, solo puede imponerse mediante Sentencia firme ${ }^{325}$. Por su parte, la garantía jurisdiccional en su vertiente de ejecución, deriva del art. 3.2 CP326, e implica la eliminación de toda posibilidad de que la ejecución de la medida se lleve a efecto de forma distinta a las previsiones legales y reglamentarias existentes, al tiempo que impone a los Jueces y Tribunales la tarea de llevar a cabo el control de su ejecución ${ }^{327}$.

321 SÁNCHEZ MELGAR, J., en SÁNCHEZ MELGAR, J. (Coord.), Código penal. Comentarios y jurisprudencia.

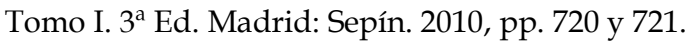

322 SANZ MORÁN, A.J., Las medidas de corrección y de seguridad..., cit. p. 113.

${ }^{323}$ LANDECHO VELASCO, C.M., en COBO DEL ROSAL, M., (Dir.), Comentarios..., cit. Tomo IV, pp. 63 y 64.

324 Es lo que MONTERO AROCA denomina los monopolios en la aplicación del Derecho Penal: exclusividad estatal, exclusividad por los Jueces y Tribunales y exclusividad procesal. MONTERO AROCA, J., Proceso Penal y Libertad..., cit. pp. 25 a 36; y MONTERO AROCA, J., Principios del proceso penal. Una explicación basada en la razón. Valencia: Tirant Lo Blanch. 1997, pp. 15 a 24.

325 Art. 3.1. “No podrá ejecutarse pena ni medida de seguridad sino en virtud de sentencia firme dictada por el Juez o Tribunal competente, de acuerdo con las leyes procesales".

326 3.2. "Tampoco podrá ejecutarse pena ni medida de seguridad en otra forma que la prescrita por la Ley y reglamentos que la desarrollan, ni con otras circunstancias o accidentes que los expresados en su texto. La ejecución de la pena o de la medida de seguridad se realizará bajo el control de los Jueces y Tribunales competentes".

327 URRUELA MORA, A., Las medidas de seguridad..., cit. pp. 26 y 27. 
Por último, la exigencia de taxatividad encuentra un problema fundamental en su formulación respecto de las medidas, toda vez que en la declaración de peligrosidad siempre hay un alto grado de incertidumbre inherente al juicio de pronóstico ${ }^{328}$, y como indica URRUELA MORA “en el decretamiento de la medida, al encontrarse las mismas fundadas en la peligrosidad criminal del sujeto, entran a jugar factores de predicción tales como el pronóstico de la peligrosidad criminal, que no puede ser objeto de tasación por vía legal"329. El legislador deberá apoyarse en indicadores de la peligrosidad subjetiva según la experiencia, y además deberá basarse en los indicios concurrentes en el caso concreto. Realmente, es tarea del legislador fijar los presupuestos de aplicación de las medidas y fijar el contenido de la peligrosidad que fundamente la imposición de las medidas, pero, por el contrario, se verá imposibilitado para establecer las bases del pronóstico concreto e individualizado de peligrosidad. Por ello, no le quedará más opción que fijar el criterio de la peligrosidad en relación con la gravedad del hecho y con la probabilidad con que cabe esperar hechos futuros de idéntica o similar naturaleza delictual ${ }^{330}$.

El problema de la taxatividad reside también en el carácter indeterminado de la temporalidad de la medida, pues su duración depende de la persistencia o desaparición de la peligrosidad del sujeto, aspecto que no casa bien con la exigencia de certeza, taxatividad, concisión y claridad de las leyes penales por las que se articulan las sanciones, por lo que se hará necesario el establecimiento de límites máximos de cumplimiento de la medida, y como indica SANZ MORÁN, quien suministra las pautas para subsanar las carencias del principio de legalidad en cuanto a la fijación de la peligrosidad criminal del sujeto y en cuanto a la determinación de los límites de cumplimiento de las medidas, es el principio de proporcionalidad 331 , que será tratado más adelante.

\footnotetext{
328 SANZ MORÁN, A.J., Las medidas de corrección y de seguridad..., cit. p. 114.

329 URRUELA MORA, A., Las medidas de seguridad..., cit. p. 27.

330 SANZ MORÁN, A.J., Las medidas de corrección y de seguridad..., cit. p. 114.

331 Ibidem, p. 115.
} 
b) Principio de Irretroactividad. Se desprende del propio tenor literal del art. 2.1 $\mathrm{CP} 332$, y que denota una clara voluntad del legislador de mantener la vigencia del principio de irretroactividad en la aplicación de las medidas de seguridad ${ }^{333}$, cuyo alcance se concreta en el art. 2.2 CP334 al nominar que las que serán retroactivas las leyes penales que favorezcan al reo aun cuando ya hubiese recaído sentencia y la condena estuviese cumpliéndose ${ }^{335}$. No obstante, existe un debate doctrinal acerca de la posibilidad de aplicación retroactiva de las medidas, que deriva de la formulación alemana del principio en el $\S 2$, apartado 6 del StGB, mediante la que se permite aplicar la medida de seguridad vigente en el momento de celebración del juicio ${ }^{336}$. Pues bien, seguidamente analizamos, de forma breve, las dos posiciones doctrinales enfrentadas que existen en España: la primera plantea la posibilidad de que se apliquen medidas de seguridad y reinserción social introducidas en el Código mediante una ley posterior al hecho delictivo, posición mantenida por autores como CUELlO CALÓN337, RODRÍGUEZ MOURULLO338, ANTÓN ONECA ${ }^{339}$ y JIMÉNEZ DE AsÚA ${ }^{340}$, y más recientemente, SILVA SÁNCHEZ ${ }^{341}$. Otros autores como GRACIA MARTÍN ${ }^{342}$ y URRUELA MORA ${ }^{343}$, sostienen que si una ley introduce nuevos

332 Art. 2.1. "No será castigado ningún delito ni falta con pena que no se halle prevista por Ley anterior a su perpetración. Carecerán, igualmente, de efecto retroactivo las Leyes que establezcan medidas de seguridad".

333 BERDUGO GÓMEZ DE LA TORRE, I. / ARROYO ZAPATERO, L. / GARCÍA RIVAS, N. / FERRÉ OLIVÉ, J.C. / SERRANO PIEDECASAS, J.R., Lecciones de Derecho penal. Parte general. $2^{\text {a }}$ Ed. Barcelona: Praxis. 1999, p. 392.

334 “Art. 2.2. No obstante, tendrán efecto retroactivo aquellas leyes penales que favorezcan al reo, aunque al entrar en vigor hubiera recaído sentencia firme y el sujeto estuviese cumpliendo condena. En caso de duda sobre la determinación de la Ley más favorable, será oído el reo. Los hechos cometidos bajo la vigencia de una Ley temporal serán juzgados, sin embargo, conforme a ella, salvo que se disponga expresamente lo contrario".

335 COBO DEL ROSAL, M. / QUINTANAR DÍEZ, M., Instituciones de Derecho penal español. Parte general. Madrid: CESEJ. 2004, p. 392. Estos autores expresan que se permite una retroactividad de las medidas de seguridad en cuanto a su duración y cumplimiento.

336 URRUELA MORA, A., Las medidas de seguridad..., cit. p. 28.

337 CUELlO CALÓN, E., Derecho Penal. Tomo I. Parte General. Vol I. Barcelona: Bosch. 1960, p. 209.

338 RODRÍGueZ MOURUlLO, G., Derecho Penal. Parte General. Madrid: Civitas. 1978, p. 132. Expresa este autor que "el fundamento de la pena es siempre un acto asilado. El de la medida un estado (estado peligroso del sujeto) que, como tal, se prolonga en el tiempo. Un mismo estado peligroso puede subsistir durante una sucesión de leyes y aparecer, por tanto, como presupuesto fáctico actual respecto de cada una de ellas".

339 ANTÓN ONECA, J., Derecho penal..., cit. pp. 633 a 635.

340 Vid. URRUELA MORA, A., Las medidas de seguridad..., cit. p. 29; y CEREZO MIR, J., Curso de Derecho penal. (I)..., cit. p. 222 y ss.

341 SILVA SÁNCHEZ, El nuevo Código Penal: cinco cuestiones fundamentales. Barcelona: Bosch. 1997, pp. 15 y ss.

342 GRACIA MARTÍN, L., "Las medidas de seguridad y reinserción...”, cit. p. 448. Este autor señalaexplica que "cuando se niega, pues, la posibilidad de una "supuesta" retroactividad de las leyes que establecen medidas de seguridad, no se tiene en cuenta que si el estado de peligrosidad del sujeto permanece en el momento del juicio, entonces la medida está vigente y puede ser aplicada, y esto no es ya aplicación retroactiva de la ley penal". 
estados de peligrosidad o nuevas medidas y entra en vigor antes de la celebración del juicio, pueden ser perfectamente aplicadas sin que dicha aplicación deba interpretarse como retroactiva, pues la peligrosidad debe valorarse a lo largo de todo el proceso. Postura contraria es la que mantienen LANDECHO VELASCO ${ }^{344}$, BENEYTEZ MERINO345 y JIMÉNEZ VILLAREJO ${ }^{346}$ que inciden en que la aplicación retroactiva de las medidas carece de cobertura legal por imperativos del art. 2.1 CP, siendo relevante la opinión de MAPELLI CAFFARENA que, al margen de invocar ese mismo fundamento, también aduce que "con el argumento de la bondad acrítica de los fines resocializadores corremos el riesgo de volver de nuevo a los abusos preconstitucionales que permitían actuar predelictualmente", ya que si tuviéramos un sistema en el que solo tuviéramos medidas terapéuticas que se aplicasen exclusivamente a los inimputables —que no pueden comprender ni las normas que infringen ni las consecuencias de sus infracciones- podríamos admitir la irretroactividad, en tanto que no podría afirmarse que añadiese ninguna garantía para el destinatario de las medidas. Pero si las medidas de seguridad actuales no son ni todas terapéuticas ni tampoco las que revisten ese carácter están dotadas de cierto grado de represión que prima sobre la prevención, y si, por otra parte, tampoco son destinatarios de las medidas los inimputables en exclusiva, parece lógico que la garantía de la irretroactividad deba extenderse también a las medidas de seguridad que actualmente tenemos 347 .

JORGE BARREIRO indica que la garantía penal del art. 2.1 CP comporta que las medidas de seguridad carezcan de efecto retroactivo, lo cual comulga una perspectiva garantista, pero ello implica prescindir de la diversidad de la naturaleza y fundamentos de las medidas de seguridad, que no son castigos sino consecuencias jurídicas del delito que se basan en el estado de peligrosidad individual del sujeto ${ }^{348}$.

\footnotetext{
343 URRUELA MORA, A., Las medidas de seguridad..., cit. p. 30.

${ }^{344}$ LANDECHO VELASCO, C.M., en COBO DEL ROSAL, M., (Dir.), Comentarios..., cit. Tomo IV, pp. 64 y 65.

345 BENEYTEZ MERINO, L., en CONDE-PUMPIDO FERREIRO, C., (Dir.), Código penal comentado. Tomo I. Barcelona: Bosch. 2004, p. 332.

346 JIMÉNEZ VILLAREJO, J., en CONDE-PUMPIDO FERREIRO, C., (Dir.), Código penal. Doctrina y jurisprudencia. Tomo I. Madrid: Trivium. 1997, p. 1314.

347 MAPELLI CAFFARENA, B., Las consecuencias..., cit. p. 368.

348 JORGE BARREIRO, A., “Reflexiones sobre la problemática...”, cit. p. 605.
} 
c) Principio de proporcionalidad. En el derecho de medidas, se configura como un principio de carácter limitador ${ }^{349}$ que viene a hacer las veces del principio de culpabilidad en relación a la pena ${ }^{350}$, y opera como límite a la finalidad de prevención especial de las medidas de seguridad ${ }^{351}$. Es el principio más cuestionable y cuestionado de todos los que rigen las medidas de seguridad ${ }^{352}$ y tiene dos vertientes: una relacionada con el hecho delictivo cometido 353 , que servirá para la fijación de los límites máximos de cumplimiento ${ }^{354}$; y otra relacionada con la peligrosidad, en el sentido de adecuar la medida al estado de peligrosidad en que se basa su imposición 355 .

Este principio, también denominado principio de prohibición de exceso, se desdobla en tres principios más. El primero de ellos es el de adecuación a fin o idoneidad, que implica la existencia de una aptitud de la medida para alcanzar los fines que la justifican y la conformidad con los mismos ${ }^{356}$. Es decir, que la medida debe ser apta para salvaguardar a la colectividad del sujeto peligroso y para intervenir en la peligrosidad del mismo 357 .

El segundo es el principio de necesidad de la medida ${ }^{358}$ o intervención mínima359 en el momento de la conminación penal abstracta, que se vincula al carácter fragmentario y subsidiario del Derecho penal 360 e implica que una medida no resultará necesaria cuando otras formas de intervención estatal —que no necesariamente deberán ser penales-

\footnotetext{
349 AGUADO LÓPEZ, S., “Tratamiento penal del delincuente...”, cit. pp. 58 y 59.

350 SANZ MORÁN, A.J., Las medidas de corrección y de seguridad..., cit. p. 125.

351 AGUADO LÓPEZ, S., La multirreincidencia y la conversión..., cit. pp. 129 a 132.

352 MAPELLI CAFFARENA, B., Las consecuencias..., cit. p. 369.

353 Aunque este elemento, afirma JORGE BARREIRO, A., en COBO DEL ROSAL, M., (Dir.), Comentario..., cit. p. 73, ocupará un papel secundario en la formulación del principio de proporcionalidad, nunca será determinante, porque no es un presupuesto garantista de las medidas de seguridad.
}

354 SÁNCHEZ YLLERA, I., en VIVES ANTÓN, T.S., (Coord.), Comentarios..., cit. p. 532.

355 SANZ MORÁN, A.J., Las medidas de corrección y de seguridad..., cit. p. 126 y 129.

356 CUERDA ARNAU, M.L., “Aproximación al principio de proporcionalidad en Derecho Penal”. En Estudios en Memoria del profesor Dr. D. José Ramón Casabó Ruiz. Universidad de Valencia. Instituto de Criminología. 1997. Vol. I, p. 469.

357 URRUELA MORA, A., Las medidas de seguridad..., cit. p. 30. Este autor indica que "el criterio de la adecuación implica la necesaria idoneidad de la medida adoptada, con su arsenal terapéutico disponible para hacer frente a la específica peligrosidad criminal revelada por el autor".

358 MAPELLI CAFFARENA, B., Las consecuencias..., cit. pp. 368 y 369.

359 JORGE BARREIRO, A., “Reflexiones sobre la problemática...”, cit. p. 606.

360 CUERDA ARNAU, M.L., “Aproximación al principio...”, cit. p. 470. 
puedan ser igualmente aptas o idóneas para la consecución de los fines preventivo-especiales perseguidos ${ }^{361}$. Este principio se relaciona directamente con la fundamentación material de las medidas de seguridad, pues el art. 6.2 CP dispone que “las medidas de seguridad no pueden resultar ni más gravosas ni de mayor duración que la pena abstractamente aplicable al hecho cometido, ni exceder el límite de lo necesario para prevenir la peligrosidad del autor" 362 , de modo que se configura la regulación de las medidas de seguridad gravitando sobre el estricto marco de la proporcionalidad que en esta materia cumple la misma función que el principio de culpabilidad en las penas ${ }^{363}$. En ese sentido, una medida de seguridad satisfará las exigencias del principio de necesidad cuando no se consideren adecuadas para combatir la peligrosidad criminal del sujeto cualesquiera otras respuestas menos gravosas o invasivas en la esfera personal del mismo, con lo que la medida de seguridad impuesta resultará ser la más idónea para la correcta consecución de los fines referidos ${ }^{364}$.

En ese orden de cosas, el apartado 1, in fine, de los arts. 101, 102 y 103 CP respectivamente, dispone una previsión de idéntica redacción, en relación a las medidas privativas de libertad para el caso de inimputables peligrosos, a cuyo tenor: "el internamiento no podrá exceder del tiempo que habría durado la pena privativa de libertad, si hubiera sido declarado responsable el sujeto, y a tal efecto el Juez o Tribunal fijará en la sentencia ese límite máximo". Y en el caso de semiimputables, el art. 104.1 CP, dispone que "el internamiento no podrá exceder de la pena prevista por el Código para el delito"365. Además, si un delito concreto no lleva aparejada pena privativa de libertad, la medida de seguridad que cabrá imponer en caso de que esa infracción la haya cometido un inimputable, deberá ser también no privativa de libertad ${ }^{366}$, aspecto que quedó plasmado en la redacción que al art. 95.2 CP confirió la LO 15/2003, de 25 de octubre,

\footnotetext{
361 URRUELA MORA, A., Las medidas de seguridad..., cit. p. 35.

362 BERDUGO GÓMEZ DE LA TORRE, I. / ARROYO ZAPATERO, L. / GARCÍA RIVAS, N. / FERRÉ OLIVÉ, J.C. / SERRANO PIEDECASAS, J.R., Lecciones..., cit. pp. 393 y 394.

363 JORGE BARREIRO, A., “Reflexiones sobre la problemática...”, cit. p. 607.

364 URRUELA MORA, A., Las medidas de seguridad..., cit. p. 36.

365 Aspecto que, debido a la diferencia de redacción para los supuestos de inimputabilidad y semiimputabilidad, algunos autores hablan de que la regulación es desconcertante. Vid. JORGE BARREIRO, A., “Reflexiones sobre la problemática...", cit. pp. 607 y 608.

366 JORGE BARREIRO, A., en COBO DEL ROSAL, M., (Dir.), Comentarios..., cit. Tomo IV Pág. 73.
} 
estableciendo que, en esos casos, las medidas aplicables serían las del art. $96.3 \mathrm{CP}$, con la consecuente exclusión de las medidas de internamiento ${ }^{367}$.

Y dando un paso más, las medidas de seguridad privativas de libertad tampoco se podrán imponer en casos de responsabilidad personal subsidiaria por impago de multas, esto es, en supuestos en los que el sujeto pudiera haber sido condenado a multa que, a su vez, se sustituyera por esta otra pena privativa de libertad subsidiaria por el impago. Lo que no quedó claro en la regulación es si la gravedad a la que refiere el Código debe relejar también la fase de ejecución, v.g., si la LOGP contiene disposiciones que restan gravedad a la pena durante su ejecución, eso debe trasladarse también a las medidas de seguridad a la hora de atender a la exigencia de que las medidas no pueden ser más gravosas que las penas que corresponderían imponer en su caso a los culpables ${ }^{368}$.

Y el tercero es el principio de proporcionalidad stricto sensu, que refiere a la mesura, a la extensión, a la determinación de la medida de seguridad, e implica la exigencia de que las medidas mantengan una razonable relación valorativa con el hecho, lo que supone una carga coactiva entre la medida de seguridad y el fin perseguido ${ }^{369}$.

En relación a la duración de la medida, como se ha visto, el art. 6.2 CP toma como referencia la pena en abstracto que correspondería al imputable en su caso y, como indica MAPELLI, es conveniente conferir una interpretación garantista de esta previsión y alejarse de las interpretaciones que vienen presididas por un "desproporcionado e infundado afecto a la defensa social y a la prevención general". De ese modo, si admitimos que las medidas solo sirven para prevenir delitos en el futuro, su duración tendría el único límite en la necesidad y, en consecuencia, tendrían que ser indeterminadas o limitarse solo por la gravedad de los delitos que se teme que se produzcan en el futuro; pero - sigue diciendo este autor- que esa interpretación está copada de riesgos que convertirían las enfermedades en cargas y, en consecuencia, en causas de discriminación frente a los que se encuentran bien de salud.

\footnotetext{
367 CALDERÓn CEREZO, A. / CHOCLÁN MONTAlVO, J.A., Código penal comentado. Barcelona: Deusto. 2005, p. 184.

368 MAPELLI CAFFARENA, B., Las consecuencias..., cit. p. 369.

369 CUERDA ARNAU, M.L., “Aproximación al principio...”, cit. p. 474.
} 
Aparte, algunas enfermedades mentales que no tienen cura, posibilitarían que la privación de libertad mediante la medida de seguridad se perpetuase en el tiempo. Por eso mismo, este autor explica que la técnica utilizada por el legislador es imprecisa y la regla insuficiente, toda vez que no se termina de comprender por qué debe tomarse como referencia el marco legal abstracto de la pena que cabría imponer y no la pena en concreto, al igual que carece de adecuada respuesta normativa el supuesto en que se comete un delito que lleva aparejada una pena de distinta naturaleza a la de la medida que se pretende aplicar; o el supuesto de concurrencia de distintas penas de distinta naturaleza, incluida la posibilidad de considerar las penas accesorias como referente para calibrar la gravosidad y atender a las exigencias de proporcionalidad. Tampoco se precisa el supuesto del cómplice, v.g., en el sentido de si el marco legal abstracto aplicable al inimputable cómplice que debe operar como límite para la proporcionalidad de la medida, debe ser igual que el aplicable al autor ${ }^{370}$.

Por otra parte, nótese que cuando se trata de infracción consumada o intentada, el art. $61 \mathrm{CP}$ dispone que, cuando la ley establece una pena, se entiende que es por la infracción consumada, lo que no termina de parecer correcto es que ese marco legal abstracto por la infracción consumada sea también el mismo para la infracción intentada cuando lo que tratamos de aplicar es una medida de seguridad y no una pena. En ese orden de cosas, este autor incide en la insostenibilidad de la afirmación de que, en general, la pena reducida que corresponde a la tentativa no pueda aplicarse en la imposición de las medidas de seguridad, por lo que, el error reside en tomar como referencia la pena que habría correspondido al culpable, siendo que la mejor interpretación sería la que permitiese que, a partir de esa referencia, la pena se concrete lo máximo posible evitar la desigualdad de trato entre el imputable y el inimputable. Por eso sigue diciendo que el criterio que contiene el CP es muy deficiente, porque omite establecer una diferenciación clara según la distinta naturaleza de las medidas de seguridad y porque el punto de partida es la pena que le hubiera correspondido al culpable, aspecto que supone, en sí mismo, una suerte de ficción por cuanto que "la realidad es que esa pena no existe $y$, lo que es peor, no se puede llegar a saber, porque

370 MAPELLI CAFFARENA, B., Las consecuencias..., cit. pp. 370 y 371. 
para conocer la gravedad de la culpabilidad de una persona es preciso conocer, precisamente, la capacidad que le faltó" 371 .

Especial mención merece la proyección del principio de proporcionalidad en la duración de la libertad vigilada para imputables tras la pena de prisión, pues el legislador optó por una solución que atiende a dos criterios distintos dependiendo de la gravedad del delito cometido, esto es, si el delito es menos grave, la libertad vigilada durará entre uno y cinco años por encima de la pena; y si es grave, tendrá una duración de entre cinco y diez años, por lo que el criterio es, nuevamente, el que apuesta por tomar como referencia los márgenes más amplios posibles, cuando habría sido preferente tomar como referencia la pena efectivamente impuesta y concretada en la sentencia condenatoria ${ }^{372}$.

No obstante, conviene que hagamos referencia a las principales objeciones que se vienen oponiendo a la formulación de este principio en el CP de 1995 en relación a las medidas de seguridad. Según JORGE BARREIRO, son dos: la primera la confusión y solapamiento entre medidas de seguridad y penas que implica que se produzca una asimilación que desconoce las esenciales diferencias entre unas y otras, esto es, en los fundamentos, las medidas se basan en la peligrosidad y las penas en la culpabilidad; en el contenido, las medidas de seguridad contienen tratamiento terapéutico, aseguramiento y corrección; mientras que las penas contienen castigo por el injusto típico cometido de forma culpable; y en la finalidad, ya que las medidas de seguridad tienen finalidades preventivo-especiales y las penas tiene efectos preventivo-generales y preventivo-especiales. La segunda objeción, según este autor, es el “olvido imperdonable del CP de 1995 de la referencia obligada en el principio de proporcionalidad, en el ámbito de las medidas de seguridad, a la comparación de la entidad de la medida aplicable con la gravedad de los delitos que pueda cometer el sujeto peligroso en el futuro y el grado de peligrosidad criminal del autor" 373 .

d) El principio de subsidiariedad. Este principio opera tanto en la imposición como en la ejecución de la medida. En la imposición, como ya se ha dicho, rige el principio de

\footnotetext{
371 Ibidem, p. 371. Indica también este autor que la deficiencia del criterio ha sido también reconocido por la jurisprudencia (STS de 19 de enero de 1995).

372 Ibidem, pp. 371 y 372.

373 JORGE BARREIRO, A., “Reflexiones sobre la problemática...”, cit. pp. 609 y 610.
} 
necesidad, que se traduce en que la medida debe ser idónea, pero además la idoneidad tiene que estar íntimamente relacionada con la subsidiariedad, que implica que las medidas de seguridad se impondrán cuando no sea posible imponer otros mecanismos jurídicos para controlar la peligrosidad del sujeto. No obstante, la subsidiariedad va más allá, al proyectarse sobre la exigencia de que la medida en concreto debe resultar el medio más benigno (idóneo) dentro de las clases de medidas en su totalidad ${ }^{374}$, de forma que, por ejemplo, no se acudirá a una medida privativa de libertad cuando pueda servir a sus fines plenamente una medida no privativa de libertad.

e) El principio de igualdad. Este principio adquiere protagonismo en el derecho de medidas en su tradicional vinculación con la proporcionalidad, que se manifiesta en que el tratamiento desigual de un supuesto solo puede mantenerse si es proporcionado y razonable375. En ese sentido, la doctrina afirma que lo anterior "llevado al terreno de inimputables y las medidas de seguridad, podría cuestionar la aplicación de una privación de derechos desigual respecto del imputable que hubiera cometido el mismo hecho" 376 .

\section{CLASES DE MEDIDAS DE SEGURIDAD}

Según la distinción tradicional las medidas de seguridad se distinguen entre predelictuales y postdelictuales. Las primeras son aquellas que se imponen a un sujeto antes de que haya cometido algún delito, puesto que su imposición se basa en su peligrosidad. Las segundas son las que se imponen con esa misma base pero siempre tras la comisión de un hecho delictivo ${ }^{377}$. En nuestro actual sistema penal la postdelictualidad un presupuesto esencial para que entren en juego las medidas de seguridad.

Otras clasificaciones refieren a medidas originarias o reemplazantes, porque se imponen a inimputables o semiimputables como única sanción posible a esta categoría de sujetos y porque reemplazan o sustituyen a la pena que correspondería a esa infracción delictiva en caso de tratarse de sujetos plenamente culpables; medidas de seguridad

\footnotetext{
374 SANZ MORÁN, A.J., Las medidas de corrección y de seguridad..., cit. p. 124.

375 STC de 10 de noviembre de 1988.

376 GARCÍA ARAN, M., Fundamentos y aplicación de penas..., cit. pp. 131 y 132.

377 LANDROVE DÍAZ, G., Las consecuencias..., cit. p. 117.
} 
complementarias o suplementarias de la pena, que se imponen como complemento a la pena allá donde ésta resulta insuficiente para combatir la peligrosidad del sujeto; y medidas de seguridad sustitutivas o vicariales, que se aplican según las reglas del sistema vicarial ${ }^{378}$.

No obstante, la clasificación más relevante es la que se basa en la incidencia de las medidas de seguridad en la esfera de la libertad individual. Son las siguientes: el art. 96 CP clasifica las medidas de seguridad en dos grandes bloques ${ }^{379}$ : privativas de libertad y no privativas de libertad 380 . Las medidas privativas de libertad381, pueden ser de tres tipos, dependiendo de cuál sea su naturaleza, que puede ser correctiva, asegurativa o curativa, y son: el internamiento en un centro de psiquiátrico; el internamiento en un centro de deshabituación; y el internamiento en un centro educativo especial ${ }^{382}$. Medidas no privativas de libertad ${ }^{383}$, que son: la inhabilitación profesional ${ }^{384}$; la expulsión del territorio nacional de extranjeros no residentes legalmente en España; la obligación de residir en un lugar determinado; la prohibición de residir en el lugar o territorio que se designe, con la consecuente obligación de comunicar su domicilio, así como los cambios que se produzcan en el mismo; la prohibición de acudir a determinados lugares, territorios, espectáculos deportivos o culturales, o de visitar establecimientos de bebidas alcohólicas o de juego; la custodia familiar; la privación del derecho a conducir vehículos a motor y ciclomotores; la privación del derecho a la tenencia y porte de armas; la prohibición de aproximarse a la víctima, o a aquellos de sus familiares $\mathrm{u}$ otras personas que determine el Juez o Tribunal; la prohibición de comunicarse con la víctima o con aquellos de sus familiares $\mathrm{u}$ otras personas que determine el Juez o Tribunal; la sumisión a tratamiento externo en centros médicos o establecimientos de carácter socio-sanitario; y el sometimiento a programas de tipo formativo, cultural, educativo, profesional, de educación sexual y otros similares ${ }^{385}$, y la libertad vigilada.

\footnotetext{
378 POLAINO NAVARRETE, M., Derecho penal Parte general..., cit. Tomo I, pp. 88 a 91.

379 SÁNCHEZ MELGAR, J., en SÁNCHEZ MELGAR, J. (Coord.), Código penal..., cit. Tomo I, pp. 730 a 739.

380 JORGE BARREIRO, A., en COBO DEL ROSAL, M., (Dir.), Comentarios..., cit. Tomo IV, pp. 92 a 99.

381 CHOCLÁN MONTALVO, J.A., “La medida de seguridad...”, cit. pp. 505 a 507.

382 Sobre estas medidas vid. SIERRA LÓPEZ, M., Las medidas de seguridad..., cit. pp. 98 a 107; JORGE BARREIRO, A., “Reflexiones sobre la problemática...", cit. pp. 616 a 619.

383 Sobre esta clasificación vid. LANDROVE DÍAZ, G., Las consecuencias..., cit. pp. 123 y 24; y GARCÍA ARÁN, M., Fundamentos y aplicación de penas..., cit. pp. 140 y 131.

384 Sobre esta medida vid. ORTS BERENGUER, E. / GONZÁLEZ CUSSAC, J.L., Compendio..., cit. p. 505.

385 Sobre todas estas medidas vid. GRACIA MARTÍN, L., “Las medidas de seguridad y reinserción...”, cit. pp. 470 a 477; JORGE BARREIRO, A., “Reflexiones sobre la problemática...”, cit. pp. 619 a 622.
} 


\section{MEDIDAS DE SEGURIDAD Y PELIGROSIDAD CRIMINAL}

Las medidas de seguridad tienen su fundamento en la peligrosidad, y definir los estados peligrosos para integrar en ellos categorías de sujetos que serán destinatarios finales de las medidas de seguridad, es el aspecto donde las teorías tienden a volatilizarse por la extrema dificultad que plantea emitir un pronóstico certero de la peligrosidad criminal. Por ello, en el presente apartado se analizan los distintos estados peligrosos, los métodos de determinación de la peligrosidad y la respuesta positiva que ofrece nuestro legislador a la luz de la última reforma y, en especial, sobre la libertad vigilada. Con carácter general, las medidas de seguridad están destinadas a los inimputables y a los semiimputables, pero también a ciertos sujetos peligrosos imputables, por lo que se torna necesario perfilar los conceptos de imputabilidad, inimputabilidad y semiimputabilidad, de lo que me ocupo a continuación.

\section{Imputabilidad, inimputabilidad y semiimputabilidad}

A) La imputabilidad se integra en la culpabilidad 386 , de modo que configura la legitimidad del juicio personal de reproche ${ }^{387}$, y abarca la capacidad de acción, de culpabilidad y de pena ${ }^{388}$; es, pues, un presupuesto de la culpabilidad ${ }^{389}$. El contenido del llamado juicio de culpabilidad, se compone de dos vertientes fundamentales: la primera es la imputabilidad o capacidad de entender y comprender la ilicitud del hecho; y la

386 SAINZ CANTERO, J.A., Lecciones de Derecho penal. Parte general. $3^{\text {a }}$ Ed. Barcelona: Bosch. 1990, pp. 645 a 647.

387 DÍEZ RIPOLLÉS, J.L., “Aspectos generales de la imputabilidad”. En Estudios de Derecho judicial, núm. 110. Actual doctrina de la imputabilidad. Madrid: Consejo General del Poder Judicial. 2007, pp. 18 y 19. Este autor señala que "la concepción de la culpabilidad como un juicio de reprochabilidad contiene un presupuesto que debe ser debidamente atendido: el reproche supone que el sujeto que estamos enjuiciando hubiera podido omitir su resolución de voluntad antijurídica y adoptar una resolución de voluntad conforme con las exigencias del ordenamiento jurídico. Esto es, el juicio de reproche implica que aquel a quien se lo dirigimos tenía la capacidad para obrar de un modo distinto a como lo ha hecho".

388 BUENO ARÚS, F., “Menor de edad: imputabilidad o inimputabilidad sui generis. Influencia en este punto de la Ley Orgánica Reguladora de la Responsabilidad penal del menor". En Estudios de Derecho judicial, núm. 110. Actual doctrina de la imputabilidad. Madrid: Consejo General del Poder Judicial. 2007, p. 330. Según este autor "se dice que la imputabilidad es capacidad de acción, capacidad de culpabilidad y capacidad de pena... Por supuesto que esas tres acepciones no son equivalentes, pero deseo hacer al respecto dos observaciones. $L a$ primera es que todos esos conceptos enunciados, aunque no iguales, están íntimamente relacionados entre sí, al hacer referencia a la aptitud para realizar acciones, es decir, movimientos voluntarios; a la aptitud para realizar voluntaria y libremente acciones prohibidas, a sabiendas de la ilegalidad de las mismas, por lo cual se merece un reproche, que es el fundamento de la responsabilidad penal, y finalmente la aptitud para cumplir una condena representa la aptitud para aceptar y asumir la decisión judicial y el cumplimiento de las obligaciones en que la condena consiste, aceptando asimismo el régimen jurídico y el tratamiento correspondiente con ánimo de rehabilitación, es decir, con voluntad de enmienda, o con voluntad de respeto de la ley, a mayor abundamiento si el condenado valora como justa la pena impuesta".

389 COBO DEL ROSAL, M. / QUINTANAR DÍEZ, M., Instituciones..., cit. p. 167. 
segunda es la conciencia de esa ilicitud, que se traduce en si el agente sabía o pudo saber que su conducta era contraria a la norma penal ${ }^{390}$. Como afirma MEZGER, para la fundamentación del reproche culpabilístico es necesaria la imputabilidad potencial del autor, y la necesidad de imputación a consecuencia del actuar doloso o con enemistad hacia el Derecho, o del actuar imprudente cuando esté especialmente previsto por la ley penal ${ }^{391}$, y en ese sentido manifiesta que "la imputabilidad no es incapacidad de acción, o incapacidad del injusto, o incapacidad de pena, sino incapacidad de culpabilidad. Al inimputable le falta una característica de la culpabilidad penal, as saber: su acto puede ser acción y puede ser acción injusta, pero nunca una acción injusta “culpable”392“.

Partiendo de que etimológicamente el término imputar proviene del latín imputare y significa atribuir, la imputabilidad no puede ser otra cosa que la necesaria concurrencia de un conjunto de características que hacen posible la atribución de un hecho delictivo (típico y antijurídico) a una persona. En ese sentido, ORTS BERENGUER y GONZÁLEZ CUSSAC, definen la imputabilidad como "la capacidad de entender, valorar y actuar consecuentemente. Por tanto, en primer lugar requiere la capacidad de entender y valorar la naturaleza e ilicitud del hecho realizado. En segundo término precisa también la capacidad de poder actuar según esa apreciación, valoración o comprensión. Así pues, hace referencia a las capacidades físicas, biológicas, psíquicas y psicosociales de una persona en el momento de cometer el hecho"393. Y COBO DEL ROSAL y VIVES ANTÓN señalan que "el concepto de capacidad jurídico-penal es un concepto genérico, omnicomprensivo, frente al cual la imputabilidad reviste un carácter específico y concreto. La imputabilidad puede ser entendida como una parte o elemento de la capacidad jurídico-penal; pero en ningún caso puede ser confundida con ella". La imputabilidad es, pues, "el conjunto de requisitos psicobiológicos, exigidos por la legislación

\footnotetext{
390 ORTS BERENGUER, E. / GONZÁLEZ CUSSAC. J.L., Compendio..., cit. p. 185. Expresan estos autores que "esta conciencia no existirá cuando se aprecie un error sobre la prohibición, es decir, en los casos en que el sujeto pensara equivocadamente que su acción era conforme a Derecho".

391 MEZGER, E., Modernas orientaciones de la dogmática jurídico-penal. Traducción de Francisco Muñoz Conde. Valencia: Tirant lo Blanch. 2000, p. 56.

392 MEZGER, E., Tratado de Derecho penal..., cit. p. 83.

393 ORTS BERENGUER, E. / GONZÁLEZ CUSSAC. J.L., Compendio..., cit. pp. 186 y 187. Según explican estos autores, "la imputabilidad no es pues equivalente a la capacidad de acción, sino a la capacidad de comprender lo que se está haciendo, a la capacidad de entender que la conducta es contraria a Derecho, y finalmente, de poder dominar o controlar su conducta".
} 
penal vigente, que expresan que la persona tenía la capacidad de valorar y comprender la ilicitud del hecho realizado por ella y de actuar en los términos requeridos por el ordenamiento jurídico"394.

Como ya dijera Von LISZT, "la imputabilidad es la capacidad de conducirse socialmente, es decir, de observar una conducta que responda a las exigencias de la vida política común de los hombres. Sólo en cuanto esta capacidad existe o se supone, puede ser imputada, como culpable, la conducta antisocial". En ese sentido, dice este autor que "la imputabilidad supone, pues, que la psiquis del autor disponga de la riqueza necesaria de representaciones para la completa valoración social". Así, LISZT define la imputabilidad como "la facultad de determinación normal. Por consiguiente, es susceptible de imputabilidad todo hombre con desarrollo mental y mentalmente sano, cuya conciencia no se halle perturbada. El contenido normal y la fuerza motivadora normal de las representaciones constituyen la esencia de la imputabilidad". Y también dice este autor, que en un sentido puramente formal "también puede ser definida la imputabilidad como la capacidad de obrar en Derecho penal, es decir, la capacidad de realizar actos referentes al Derecho penal, que traigan consigo las consecuencias penales de la infracción"395.

El CP no define expresamente la imputabilidad, sino que se limita a enumerar las causas de inimputabilidad, por lo que el concepto se obtiene a la inversa ${ }^{396}$. El motivo por el que no encontramos una definición positiva de imputabilidad en el $\mathrm{CP}$, reside en que “la misión del legislador no consiste en la definición positiva de la imputabilidad, sino en la descripción de aquellos estados que excepcionalmente hacen parecer como imposible la imputabilidad"397. Para MARTín HERNÁNDEZ, "la imputabilidad es un concepto jurídico de base psicológica. De él dependen los de responsabilidad y culpabilidad". Sigue diciendo este autor que el fundamento de la imputabilidad reside en "la afirmación de la voluntad humana como criterio informante de la capacidad para responder de las

\footnotetext{
394 COBO DEL ROSAL, M. / VIVES ANTÓN, T.S., Derecho penal. Parte General..., cit. pp. 576 y 577.

395 LISZT, F., Tratado de Derecho Penal..., cit. Tomo II, pp. 396 a 398.

396 ORTS BERENGUER, E. / GONZÁLEZ CUSSAC. J.L., Compendio..., cit. p. 186. Según estos autores “si una persona no puede incluirse en uno de los supuestos descritos en el art. $20 \mathrm{CP}$, entonces legalmente se le considera capaz de entender y valorar el significado jurídico de su conducta y de poder actuar en consecuencia; es decir, será imputable, y podrá responder penalmente de su conducta ilícita".

397 LISZT, F., Tratado de Derecho Penal..., cit. Tomo II, p. 397 a 399. Este autor señala que "debe considerarse, además, la relatividad del concepto expuesto. Numerosos grados de transición conducen a la reacción anormal. Por consiguiente, es esencialmente falsa y peligrosa la separación de los delincuentes en responsables y no responsables, y, por consiguiente, la brusca oposición entre penas y medidas de seguridad. De aquí resulta la importancia del concepto de la imputabilidad disminuida".
} 
acciones, libertad que puede perderse, o no haber existido nunca, si en el sujeto no se reúnen las circunstancias que lo condicionan. En la imputabilidad se da, pues, la coincidencia de un concepto jurídico y de uno psicológico"398.

La imputabilidad, por tanto, hace referencia a un modo de ser del sujeto, a un cúmulo de factores internos que le revisten de la necesaria capacidad para ser objetivamente responsable de sus actos antijurídicos. Dichos factores o elementos son, según la mayor parte de la doctrina, los siguientes: un estado de madurez mínimo, entendido tanto desde un punto de vista fisiológico como psíquico, y ambas vertientes se presentan como necesarias para la conformación del estado de madurez; una conciencia plena sobre los actos que el sujeto realiza, estado que debe abarcar la vigilia y el entendimiento; por último, capacidad de administrar tanto su propia voluntariedad como su libertad ${ }^{399}$. La imputabilidad penal se basa en dos aspectos esenciales: la inteligencia y la voluntad, de modo que, cuando hayan desaparecido o estén gravemente alteradas, la imputabilidad desaparece o puede que ni siquiera exista ${ }^{400}$. En conclusión: "sin imputabilidad la culpabilidad y, por consiguiente, el delito, son imposibles" ${ }^{401}$.

B) La inimputabilidad debe definirse en contraposición con la imputabilidad ${ }^{402}$, por cuanto que constituye su reverso ${ }^{403}$, por ese motivo, está contemplado en el CP dentro de

\footnotetext{
398 MARTÍN HERNÁNDEZ, M.A., “¿Cabe la sustitución de la pena de privación de libertad por una medida de seguridad en el caso de concurrencia de la atenuante de grave drogadicción?". En GUZMÁN DÁLBORA, J.L. / SERRANO MAÍlLO, A., (Coords.), Derecho penal y Criminología como fundamento de la política criminal. Estudios en homenaje al Profesor Alfonso Serrano Gómez. Madrid: Dykinson. 2006, p. 884.
}

399 BUENO ARÚS, F., “Menor de edad: imputabilidad...", cit. p. 241. Este autor expresa que "las bases de la imputabilidad, de la culpabilidad, del merecimiento de pena y de la responsabilidad correspondiente, consisten en que el desarrollo de la personalidad haya conducido a que el sujeto al actuar obre con conciencia y con voluntad, es decir, sabiendo lo que se hace (el conocimiento debe abarcar: acción, causalidad, resultado, preterintencionalidad) y sabiendo lo que significa (conciencia de antijuridicidad) y, no obstante, queriendo hacerlo (decisión personal, carencia de presiones ajenas, comisión del delito por medio de otro, frialdad de ánimo, pasión que no produzca trastorno mental, falta de coacción o amenaza). En consecuencia, la ley presume el desarrollo de la personalidad con las características indicadas a efectos penales con la mayor amplitud, porque existe la convicción de que el adulto sin trastornos mentales comprende perfectamente la razón de ser de que haya conductas socialmente prohibidas y la razón de ser del correspondiente castigo, sin el cual la sociedad correría el riesgo de desaparecer".

400 MARTÍN HERNÁNDEZ, M.A., “Cabe la sustitución de la pena...”, cit. p. 885. Indica este autor que “en ello coincide la mayoría de la doctrina española, que estima imputable a quien tiene capacidad de comprender lo ilícito del hecho o de obrar conforme a tal entendimiento. En consecuencia, toda alteración mental que afecte estas funciones psicológicas es causa de no imputabilidad".

401 LISZT, F., Tratado de Derecho Penal..., cit. Tomo II, p. 401.

402 WELZEL, H., El nuevo Sistema de Derecho penal. Una introducción a la doctrinal de la acción finalista. Reimpresión de la $1^{\mathrm{a}}$ Ed. en Castellano. Traducida por Cerezo Mir. Montevideo: Bdef Montevideo-Buenos Aires. 2001, p. 147. Para este autor "es más fácil, por ello, formular este juicio de modo negativo que de modo 
las causas de exención de la responsabilidad penal o eximentes ${ }^{404}$. "La inimputabilidad no es más que el reverso de la imputabilidad, es decir, su aspecto negativo, consistente en la ausencia de imputabilidad. Causas de inimputabilidad son, por tanto, aquellos supuestos en los que no puede afirmarse que la persona sea imputable en el momento de la realización del delito" 405 .

Tradicionalmente se ha venido considerando que la inimputabilidad concurre cuando falta el desarrollo mental y cuando falta la salud mental ${ }^{406}$. El primero de ellos, es el referente a la minoría de edad, cuyo reflejo en el CP lo encontramos en el art. 19, que dispone que los menores de dieciocho años de edad carecen de responsabilidad criminal, pero cuando un menor de esa edad comete un hecho previsto en el CP como delito, se le podrá exgir responsabilidad conforme a lo previsto en las disposiciones de la LORPM. Como ya hemos dicho, la imputabilidad es el resultado de un proceso de socialización en el que el individuo va desarrollando una serie de facultades que le permiten conocer las normas que rigen la convivencia en el grupo al que pertenece y regir sus actos de conformidad con ellas, pero en el caso de los menores cobra especial relevancia, por cuanto que hay una innegable etapa evolutiva en la madurez del ser humano en la que los rasgos de la personalidad no están ni pueden estar plenamente definidos 407 , por lo que la imputabilidad en esta fase cronológica todavía puede sufrir algún tipo de modificación de forma coetánea con el proceso de formación física y psíquica del individuo, por lo que se hace necesario acudir a medidas educativas y correctoras de su proceso de

positivo: excluye entonces a todos aquellos hombres que no son todavía, o no son ya, capaces de la misma autodeterminación plena de sentido; estos son los que pos su juventud (y sordomudez), o por su anormalidad mental, no son capaces de culpabilidad".

403 COBO DEL ROSAL, M. / QUINTANAR DÍEZ, M., Instituciones..., cit. p. 173.

404 FOUCAULT, M., Surveiller et punir. París. 1975. Traducción de A. Garzón del Camino, Vigilar y castigar. Ed. Siglo XXI de España editores S.A. 1990, p. 25. Este autor explica que “bajo el nombre de crímenes y de delitos, se siguen juzgando efectivamente objetos jurídicos definidos por el Código, pero se juzga a la vez pasiones, instintos, anomalías, achaques, inadaptaciones, efectos de medio o de herencia; se castigan las agresiones, pero a través de ellas las agresividades; las violaciones, pero a la vez perversiones; los asesinatos son también pulsiones o deseos. Se dirá: no son ellos los juzgados; si los invocamos, es para explicar los hechos que hay que juzgar, y para determinar hasta qué punto se hallaba implicada en el delito la voluntad del sujeto. Respuesta insuficiente. Porque son ellas, esas sombras detrás de los elementos de la causa, las efectivamente juzgadas y castigadas".

405 COBO DEL ROSAL, M. / VIVES ANTÓN, T.S., Derecho penal. Parte General..., cit. p. 583.

406 LISZT, F., Tratado de Derecho Penal..., cit. Tomo II, pp. 405 a 407.

407 BUENO ARÚS, F., "Menor de edad: imputabilidad...", cit. p. 347. Este autor afirma que "si no hay responsabilidad penal es porque, sustantivamente, la menor edad significa la carencia de la madurez necesaria para responder porque el sujeto ha cometido el hecho prohibido consciente y libremente. En el menor falta la capacidad de juicio o libertad de decisión (autodeterminación) en el grado necesario para que el Derecho intervenga con su sistema penal". 
socialización ${ }^{408}$. Aun así, todavía hay que establecer un criterio cronológico para excluir la responsabilidad penal de los menores de poca edad, a los que no pueden considerarse imputables por no haber alcanzado aún la capacidad suficiente para que la sociedad en su conjunto pueda hacerles responsables. Por tanto, se hace necesario, por razones también de seguridad jurídica, fijar un límite de edad penal exacto, por debajo del que no será posible exigir responsabilidad penal, que se ha establecido en catorce años ${ }^{409}$. La inimputabilidad penal se establece, pues, hasta los catorce años ${ }^{410}$.

El segundo, cuando falta la salud mental411, es a lo que Von LISZT refirió como comprensivo "no sólo de las enfermedades mentales propiamente dichas, sino también de los retrasos en el desarrollo (idiotismo e imbecilidad) y los estados de degeneración mental (debilidad senil), así como las enfermedades corporales, en sentido propio, que van acompañadas de perturbaciones mentales (delirio febril, enfermedades nerviosas), y, finalmente las perturbaciones morbosas y transitorias de la actividad mental (estados de

408 MUÑOZ CONDE, F. / GARCÍA ARÁN, M., Derecho Penal, Parte General. $8^{\text {a }}$ Ed. Valencia Tirant lo Blanch. 2010 , p. 364. Estos autores señalan que "por eso, en esta etapa es más importante influir en la socialización del menor que ha cometido el delito, y en el respeto a las normas por parte de éste, a través de medidas educativas y correctoras de sus defectos de socialización, que con una pena que, por más que se oriente a la reinserción social del condenado, tiene un componente aflictivo que puede incidir negativamente en las posibilidades de socialización del menor."

409 BUENO ARÚS, F., "Menor de edad: imputabilidad...", cit. pp. 346 y 347. Para este autor "la fijación de la mayoría de edad en el CP significa el límite de la imputabilidad y por lo tanto el límite de la responsabilidad penal. Formalmente, significa el punto de arranque de la responsabilidad penal por haber cometido actos delictivos (típicos), de manera que sólo puede incurrir en pena por la comisión de un delito quien tenga ya cumplida la edad prevista en el CP vigente; antes de esa edad se puede incurrir en responsabilidad civil, ya que la indemnización a la víctima se vincula directamente al patrimonio del autor y no requiere culpabilidad en el mismo, y también el sujeto puede ser objeto de medidas de seguridad decretadas por un Juez, cuyo fundamento sería la defensa de la sociedad contra una persona peligrosa, pero repito que no se puede imponer una pena al menor de edad porque, al faltar el requisito de la imputabilidad, falta la culpabilidad y no hay propiamente delito, sino la comisión de un hecho prohibido por las leyes que, si fuera cometido por un adulto, sería constitutivo de delito, como dicen los documentos de las Naciones Unidas".

${ }^{410}$ MUÑOZ CONDE, F. / GARCÍA ARÁN, M., Derecho Penal..., cit. p. 365.

411 FOUCAULT, M., Maladie mentale et personnalité. París.1954. Traducción de E. Kestelboim, Enfermedad mental y personalidad. $2^{\mathrm{a}}$ Ed. Buenos Aires: Paidos. 1979, p. 116. Explica este autor que "la revolución burguesa ha definido la humanidad del hombre por una libertad teórica y una igualdad abstracta. Y el enfermo mental se erige en sujeto de escándalo: es la demostración de que el hombre concreto no es enteramente definido por el sistema de derechos abstractos que le son reconocidos teóricamente, puesto que ese sistema no da cabida a esta eventualidad humana que es la enfermedad, y que para los enfermos mentales la libertad es vana y la igualdad no tiene significado; por otra parte, es la prueba de que su vida real de hombre libre, de ciudadano igual a todo los otros, el hombre puede encontrar condiciones que supriman efectivamente esta libertad y esta igualdad; que puede encontrarse en situaciones que aten su libertad y que lo aíslen para siempre de la comunidad. Demuestra que la sociedad burguesa, por los mismo conflictos que han hecho posible su enfermedad, no está hecha a la medida del hombre real; que es abstracta en relación al hombre concreto y a sus condiciones de existencia; que continuamente pone en conflicto la idea unitaria que se hace del hombre y el status contradictorio que le otorga que le otorga. El enfermo mental es la apoteosis de este conflicto. Y si por el mito de la alienación mental, se lo expulsa de los límites exteriores de la ciudad, es para no ver en él la escandalosa expresión de sus contradicciones que hecho posible sui enfermedad, y que constituyen la realidad misma de la alienación social". 
intoxicación, etc.). Pero, así como no todas las perturbaciones de la salud corporal perfecta pueden ser consideradas como enfermedades, tampoco se excluye la imputabilidad por todo trastorno de la actividad mental; el mínimum con que el Derecho debe generalmente contentarse, constituye, como en todos los casos, el límite inferior"112. Esta segunda categoría está contemplada dentro del art. $20 \mathrm{CP}^{413}$, apartados $1^{\circ}, 2^{\circ}$ y $3^{\circ}$, que son las denominadas eximentes. Veamos con detenimiento cada una de ellas:

$1^{\circ}$. Anomalía o alteración psíquica. La fórmula por la que opta el CP de 1995 es el denominado "sistema mixto o biológico psicológico", que requiere la concurrencia de la alteración psíquica o anomalía, y que el sujeto no pueda ser capaz de comprender la ilicitud del hecho precisamente a causa de la referida alteración y, por ese motivo, no pueda actuar conforme a esa compresión ${ }^{414}$. La perturbación de las facultades volitivas o cognoscitivas puede afectar tanto a la capacidad de conocer la ilicitud del hecho como a la voluntad de actuar conforme a dicha comprensión, pero no conviene perder de vista que si dicha perturbación es parcial, concurrirá una circunstancia atenuante, que será de mayor o menor alcance, dependiendo de su intensidad, y que el efecto psicológico

412 LISZT, F., Tratado de Derecho Penal..., cit. Tomo II, pp. 405 a 407. Este autor expresa: “pero la vida espiritual del hombre maduro mentalmente y mentalmente sano, está sujeta también a vacilaciones, que aunque descansen en base fisiológica, pueden sin embargo, excluir la imputabilidad, $\mathrm{y}$, además, entrar por transiciones imperceptibles, en el terreno patológico. [...] Más concretamente diremos que, en caso de trastorno profundo, (hocgradig) de la conciencia, a causa del cual la asociación de los sucesos exteriores con la conciencia propia sólo se realiza imperfectamente, se perturba la capacidad de determinarse regularmente por representaciones, y, por consiguiente, queda excluida la imputabilidad. A esta categoría pertenecen el desmayo, el sueño y el amodorramiento (Schlaftrunkenheit), la sugestión hipnótica y la embriaguez. El Contraproyecto alemán, por el contrario, castiga, como los demás proyectos, el hecho de ponerse por sí mismo (Schiversetzen) en estado de embriaguez".

413 Art. 20. “Están exentos de responsabilidad criminal: $1^{\circ}$. El que al tiempo de cometer la infracción penal, a causa de cualquier anomalía o alteración psíquica, no pueda comprender la ilicitud del hecho o actuar conforme a esa comprensión. El trastorno mental transitorio no eximirá de pena cuando hubiese sido provocado por el sujeto con el propósito de cometer el delito o hubiera previsto o debido prever su comisión. $2^{\circ}$. El que al tiempo de cometer la infracción penal se halle en estado de intoxicación plena por el consumo de bebidas alcohólicas, drogas tóxicas, estupefacientes, sustancias psicotrópicas u otras que produzcan efectos análogos, siempre que no haya sido buscado con el propósito de cometerla o no se hubiese previsto o debido prever su comisión, o se halle bajo la influencia de un síndrome de abstinencia, a causa de su dependencia de tales sustancias, que le impida comprender la ilicitud del hecho o actuar conforme a esa comprensión. $3^{\circ}$. El que, por sufrir alteraciones en la percepción desde el nacimiento o desde la infancia, tenga alterada gravemente la conciencia de la realidad".

414 CÓRDOBA RODA, J., “De la infracción penal”. En CÓRDOBA RODA, J. / GARCÍA ARÁN, M., (Dirs.), Comentarios al Código Penal. Parte General. Madrid: Marcial Pons. 2011, p. 149. Este autor indica que "tal formulación del efecto psicológico propio de estas causas de inimputabilidad proviene de la dogmática penal elaborada con anterioridad a la promulgación del CP de 1995, que con buen criterio ha asumido dicho texto legal". 
descrito debe concurrir al tempo de cometer la infracción ${ }^{415}$. Las anomalías más frecuentes son las que se describen a continuación.

a) Psicosis, o enfermedades mentales propias que viene motivando la aplicación de la eximente ${ }^{416}$. Se caracterizan porque confluye en el sujeto una patología hasta ese momento inexistente o inapreciable, que transforma profundamente su personalidad y suele acarrear la pérdida de aptitudes y disposiciones psíquicas que implican que el sujeto ya no vuelve a ser el mismo, quedando afectada la totalidad de su esfera psicosomática417. Las alteraciones psicóticas pueden ser exógenas, esto es, toxifrenias, psicosis traumáticas y también las seniles; o endógenas que pueden presentarse en forma de esquizofrenias, paranoias o psicosis maniaco-depresivas ${ }^{418}$.

b) Esquizofrenia: es la enfermedad mental por excelencia, se trata de un grupo de trastornos mentales crónicos y graves, caracterizados por alteraciones en la percepción o la expresión de la realidad, que causa además una mutación sostenida de varios aspectos del funcionamiento psíquico del individuo, principalmente de la conciencia de la realidad, y una desorganización neuropsicológica más o menos compleja, en especial de las funciones ejecutivas ${ }^{419}$. El brote de esta enfermedad implica la pérdida del contacto con la realidad y una interrupción en la continuidad de la vida del que la sufre, difuminándose su propia identidad que le convierte en una persona totalmente diferente y queda impedido para establecer un juicio correcto de la realidad que percibe, ya que implica un abanico de disfunciones cognoscitivas y emocionales en la percepción, el pensamiento el lenguaje y la capacidad comunicación, que causan una total desorganización del comportamiento con especial incidencia en la afectividad, la fluidez del pensamiento y del habla, la formación de la voluntad, y sobre todo un grave deterioro de su actividad en el

\footnotetext{
415 CÓRDOBA RODA, J., “De la infracción penal...”, cit. pp. 150 y 151.

416 Sentencias del TS de 15 de abril de 1948, de 1 de junio de 1962, de 26 de diciembre de 2000, de 21 de febrero de 2002, de 26 de septiembre de 2005, entre otras muchas. Y de no producir el efecto psicológico necesario para eximir de responsabilidad, pueden dar lugar a la eximente incompleta, así por todas, las Sentencias del TS de 8 de mayo de 1944 y de 4 de febrero de 1964.

417 PUERTA LUIS, L.R., “Causas de inimputabilidad: anomalías y alteraciones psíquicas. Trastorno mental transitorio". En Estudios de Derecho judicial, núm. 110. Actual doctrina de la imputabilidad. Madrid: Consejo General del Poder Judicial. 2007, p. 51.
}

418 MUÑOZ CONDE, F. / GARCÍA ARÁN, M., Derecho Penal..., cit. p. 370.

419 PUERTA LUIS, L.R., “Causas de inimputabilidad..., cit. pp. 52 a 54. 
ámbito laboral y en el social ${ }^{420}$. La constatación de la esquizofrenia en el sujeto, da lugar a la apreciación de la eximente ${ }^{421}$, y en ese sentido se pronuncia la Sentencia del TS de 16 de noviembre de 2004.

c) El trastorno delirante o paranoia, es una enfermedad mental que se define como psicosis endógena, que nace y proviene de causas íntimas relacionadas con el propio sujeto que la padece aunque, al igual que en la generalidad de enfermedades mentales, se encuentra sujeta a una amplia variedad de hipótesis y criterios que en ocasiones se contraponen, pero es un rasgo definitorio de la paranoia el hecho de que su aparición es consecuencia de una predisposición del sujeto derivada de causas internas o externas como vivencias o delirios ajenos que desencadenan la detonación mental del sujeto ${ }^{422}$. Consiste en que el enfermo presenta un delirio crónico, irrebatible con argumentos lógicos y fuertemente sistematizados, cuyas ideas pueden incluso contagiarse a terceros por su elevada dosis de convicción y de compresibilidad siendo la proyección de su trastorno uno de sus rasgos más característicos ${ }^{423}$.

Las temáticas del paranoico suelen manifestarse de varias formas o categorías de delirios. Los más frecuentes suelen ser los delirios persecutorios, donde el enfermo se siente perseguidor y perseguido, pudiendo reaccionar desproporcionadamente ante cualquier situación, lo que le hace extremamente peligroso ya que nunca admite otra verdad que no sea la suya y suele cometer injurias, desobediencias a la autoridad o sus agentes, y toda clase de delitos contra la vida y la integridad física; los delirios de grandeza, de erotismo o los mesiánicos, donde el enfermo cree estar elegido por la

420 GARCÍA-PABLOS DE MOLINA, A., Criminología..., cit. p. 370. Explica este autor que “el esquizofrénico siente como su Yo pierde unidad, se escinde, se resquebraja; siente como las ideas, los sentimientos y el pensamiento no le pertenecen, dejan de ser propios, porque alguien les gobierna y manda. Tal fragmentación disociativa le ocasiona una singular angustia. Pensamientos e ideas delirantes, percepciones alucinatorias, pérdida del sentido del Yo, de la propia identidad, disminución o pérdida de la capacidad volitiva, alteraciones de la afectividad (desapego, ambivalencia, embotamiento, indiferencia y frialdad, etc.), trastornos del sistema lógico (pensamiento paralógico, simbólico y sincrético, rigidez y perseveración del pensamiento) y del sistema verbal, retraimiento y ruptura con la realidad, el mundo externo (autismo) e incluso actitudes y gestos extravagantes (manierismo) forman parte del mundo del esquizofrénico quien vive en soledad una existencia torturada, sin conciencia de su enfermedad, y sin obtener ventaja secundaria alguna de la misma".

421 ORTS BERENGUER, E. / GONZÁLEZ CUSSAC. J.L., Compendio..., cit. p. 367.

422 SÁNCHEZ MELGAR, J., en SÁNCHEZ MELGAR, J. (Coord.), Código penal..., cit. Tomo I, p. 181.

${ }^{423}$ GARCÍA-PABLOS DE MOLINA, A., Criminología..., cit. p. 373. Como indica este autor "la hipertrofia del Yo [...] a la que se une su suspicacia y desconfianza, su recelo hacia los demás, su falta de sentido del humor, y su hostilidad determinada por la autorreferencia en la interpretación de cuanto sucede - por más que se trate de hechos nimios o producto del azar-y por el pensamiento proyectivo característico de su trastorno". 
divinidad y delinque por el bien de la humanidad creyendo estar realizando hazañas heroicas que le colocan en una situación muy difícil para mostrar arrepentimiento, ya que él siempre está en posesión de la única verdad absoluta; o de injusticia ${ }^{424}$, siendo frecuente la comisión de delitos de acusación y denuncia falsa. El paranoico celotípico se comporta de una manera muy similar al persecutorio, y sus celos patológicos - que en ocasiones son fruto de varios años de formación lenta y silenciosa de sentimientos de odio y venganzasuelen desembocar en la realización de crímenes fríos, premeditados y reflexivos que son entendidos por él como una suerte de castigo ejemplar necesario, del que son acreedores quienes le provocan, siendo una forma de impartir justicia que es comprendida por el enfermo como la única solución, ya que su inteligencia, la verosimilitud de sus planteamientos y su facilidad para crear falsas apariencias, suelen acarrear que la víctima incurra en un fatal exceso de confianza ${ }^{425}$.

La jurisprudencia distingue la paranoia propiamente dicha de la simple personalidad paranoide, siendo que ésta última es una suerte de predisposición a la paranoia, especialmente si va asociada a otras alteraciones internas o externas que en mayor o menor medida, puden estar presentes en la mente humana. (STS de 12 de marzo de 1996, con cita de las STS de 26 de mayo de 1995, de 26 de octubre de 1989, de 16 de diciembre de 1988, y de 22 de enero de 1986) ${ }^{426}$.

d) Psicosis maníaco-depresivas, también denominados trastornos bipolares, alternan fases de exaltación del ánimo - manías- con períodos depresivos normalmente separados por lapsos de tiempo muy prolongados de lucidez y normalidad, que se repiten de forma cíclica. En la fase depresiva el enfermo experimenta sentimientos de tristeza, autoinculpación, deterioro físico, alteraciones del sueño o del apetito, pérdida de energía, falta de interés, desesperanza, preocupaciones hipocondríacas, autoacusaciones, ansiedad,

424 PUERTA LUIS, L.R., Causas de inimputabilidad...", cit. p. 55.

425 GARCÍA-PABLOS DE MOLINA, A., Criminología..., cit. p. 374. Este autor explica que “el paranoico no se siente enfermo, ni lo parece. Su capacidad de juicio y raciocinio, sus sentimientos, su obrar, permanecen intactos, ya que el trastorno sólo afecta a una parcela de su psiquismo (aquella a la que se refiere su delirio). El resto de la personalidad del paranoico se conserva sin alteraciones sensibles. Fuera de la temática delirante, el paranoico se adapta razonablemente al medio. Su inteligencia puede ser superior a la media, aunque se ponga al servicio del delirio. Suele ser buen trabajador, aunque frío y distante. Amante padre de sus hijos, aunque rígido y autoritario. Fiel esposo o esposa, aunque celoso y desconfiado. Ahora bien posee un colosal potencial de agresividad, latente pero siempre dispuesto, que tiene su origen en la sólida implantación y convencimiento de su propio delirio, y en rasgos determinados de la personalidad del paranoico".

426 PUERTA LUIS, L.R., “Causas de inimputabilidad...”, cit. p. 57. 
etc., que pueden ir acompañadas de ideas delirantes ${ }^{427}$. En esta fase, existe un gran riesgo de suicidio, que puede ir precedido de homicidios o asesinatos a sus seres queridos a quien -normalmente por amor o para salvarles de un mal que según él experimentan-y acto seguido pone fin a su vida. En la fase maníaca (o eufórica), el sujeto experimenta todo lo contrario, euforia, irritabilidad, exaltación, incremento de la actividad social o laboral, sentimientos de grandeza, incremento desmesurado de la actividad sexual, verborrea y locuacidad, hiperactividad psicomotriz, insomnio, energía desproporcionada, tendencia a emprender grandes negocios con elevado riesgo y a dilapidar su patrimonio gastando sin control. En esta fase hay una mayor tendencia a delinquir, siendo comunes las estafas, falsedades, exhibicionismo, delitos sexuales, usurpación de títulos y honores, allanamiento de morada, etc., usurpaciones del estado civil, duplicidades de matrimonios, etc. ${ }^{428}$ Desde el punto de vista de la imputabilidad, ambos extremos colocan al sujeto en situación de inimputabilidad, porque en ambos casos carece de capacidad para darse cuenta de lo que hace ${ }^{429}$.

e) Oligofrenias: que aunque no se consideran enfermedades mentales, pueden afectar a la imputabilidad del sujeto, en la medida en que un retraso mental disminuye la capacidad intelectual para comprender la ilicitud del hecho. Son los supuestos de debilidad mental, idiocia o imbecilidad ${ }^{430}$. Las formas más graves de oligofrenias dan lugar a la causa de exención, pero otras formas de aparición dan lugar a la aplicación de la circunstancia atenuante ${ }^{431}$. La STS de 25 de abril de $2002^{432}$ vino a decir que partiendo de las pautas psicométricas que ofrecen los resultados de test de personalidad e inteligencia, se considera que cuando el sujeto presenta un coeficiente inferior al 25 por 100 de lo normal, la carencia intelectiva es severa y la oligofrenia es profunda, por lo que su consecuencia jurídico-penal debe ser la aplicación de la eximente completa; si el coeficiente oscila entre el 25 y el 50 por 100 la oligofrenia es de mediana intensidad, y corresponde la aplicación de la eximente incompleta; y si el sujeto sufre un déficit en su

\footnotetext{
427 Ibidem, p. 60.

428 GARCÍA-PABLOS DE MOLINA, A., Criminología..., cit. pp. 379 y 380.

429 PUERTA LUIS, L.R., “Causas de inimputabilidad...”, cit. p. 62.

430 MUÑOZ CONDE, F. / GARCÍA ARÁN, M., Derecho Penal..., cit. p. 370.

431 CÓRDOBA RODA, J., “De la infracción penal...”, cit. p. 153.

432 En el mismo sentido se pronuncian, entre otras, las STS de 23 de marzo y 24 de julio de 2001; de 11 de julio y 21 de octubre de 1988; de 26 de febrero, 15 de julio, 8 de septiembre, 14 de octubre y 13 de diciembre de 1994; de 30 de noviembre de 1996 y de 31 de julio de 1998.
} 
coeficiente intelectual entre el 50 y el 70 por 100, se califica de oligofrenia ligera o de mera debilidad equiparable a un simple retraso mental cuyo tratamiento jurídico sería el de una atenuante analógica. Cuando el coeficiente intelectual se sitúa por encima del 70 por 100, por lo general se considera al sujeto plenamente imputable, pues no sería más que una simple torpeza mental ${ }^{433}$.

d) Psicopatías: entendidas como meros trastornos de la personalidad, no se consideran verdaderas enfermedades mentales, aunque vinculadas a otro tipo de alteraciones psíquicas pueden tener algún efecto atenuante o incluso eximente, aunque esta última posibilidad es de muy difícil concurrencia ${ }^{434}$. El psicópata se distingue por dos rasgos: la actuación mediante impulsos incontrolados acompañados de la incapacidad de respuestas emocionales ante situaciones en que normalmente el sujeto responde manifestando empatía; y por otra parte, agresividad y ausencia de sentimientos de culpa o arrepentimiento que hacen inviable la finalidad del castigo ${ }^{435}$. Como es sabido, la psicopatía puede resumirse en una sintomatología - para la que no existe tratamientoque desencadena una falta total de empatía que le impide experimentar los sentimientos de los demás, a modo de "daltonismo moral", que significa que esta clase de individuos carecen de límites a sus deseos de ejecutar actos perniciosos o simples comportamientos conflictivos, de los que son incapaces de inhibirse, en la medida en que son personas

433 SÁNCHEZ MELGAR, J., en SÁNCHEZ MELGAR, J. (Coord.), Código penal..., cit. Tomo I, p. 181.

434 MUÑOZ CONDE, F. / GARCÍA ARÁN, M., Derecho Penal..., cit. p. 371.

435 GARCÍA-PABLOS DE MOLINA, A., Criminología..., cit. p. 395. Este autor indica que "en el área emocional interpersonal destacan la locuacidad y encanto superficial del psicópata. Su egocentrismo y grandioso sentido de la propia valía, narcisismo y elevada autoestima son, también, rasgos característicos del mismo. Así como su total ausencia de remordimiento y sentimiento de culpa, y su falta de empatía o capacidad de ponerse en lugar de los demás y apreciar los sentimientos de éstos. El psicópata es un manipulador nato, miente y engaña por convicción, e incluso sin necesidad. Y padece un déficit muy relevante de afectividad que le incapacita para sentir de modo profundo y sincero las emociones humanas: ni siquiera muestra su organismo respuestas psicofisiológicas asociadas al miedo o la ansiedad. En cuanto a los aspectos más característicos del estilo de vida del psicópata, llama la atención la particular impulsividad de éste, consecuencia más de su deseo permanente de alcanzar la satisfacción inmediata que del carácter o temperamento del psicópata. El psicópata exhibe un deficiente control de la conducta, actúa, sin más, pasa a la acción sin que funcionen los mecanismos inhibitorios que permiten a los demás humanos frenar sus tendencias agresivas. Necesita por otra parte, una excitación continuada e increscendo, mostrando un hambre desmesurada por vivir nuevas sensaciones, incompatible con una vida normal y rutinaria. No asume sus responsabilidades (vg. las familiares) ni le preocupa la repercusión negativa de su comportamiento en terceras personas de su entorno. La carrera del psicópata se inicia en la infancia, manifestando signos muy precoces de destrucción y violencia de modo persistente, sorprendiendo su percepción positiva de actos crueles hacia los demás. Estos y otros rasgos hacen del psicópata un individuo especialmente preparado para acometer las empresas criminales más absurdas y para ejecutar delitos con una violencia desproporcionada y gratuita". 
hipoactivas que necesitan un plus de estimulación para realizarse. Desde ese punto de vista, la actividad delictiva de estos sujetos es realmente elevada ${ }^{436}$.

La doctrina señala que los rasgos esenciales que definen a la psicopatía (como por ejemplo, el egocentrismo, la grandilocuencia, el narcisismo, la autojustificación, la impulsividad, la falta general de inhibiciones en su comportamiento y la necesidad controlar y de tener poder) son una combinación óptima para los hechos delictivos o meramente asociales. Los rasgos comunes a todos los psicópatas consisten en que se encuentran condicionados por un trastorno primario de la vida afectiva, que genera que sean incapaces de mantener un comportamiento social adecuado en las relaciones interpersonales, de tal forma que las relaciones sociales les incomodan porque aparecen para ellos distorsionadas. Suele ser frecuente que carezcan de cualquier relación social, lo que genera, a su vez, un marcado egocentrismo, debido también a que el psicópata siente la necesidad de atender a sus propias necesidades sin preocuparle en absoluto nadie más. Los tres rasgos definitorios de las personalidades psicopáticas son la asocialidad, la falta de fijación afectiva y la incapacidad de control de una predominante actitud de satisfacción de necesidades egoístas. En ese orden de cosas, el psicópata no suele presentar ningún impedimento intelectual para estar en conocimiento de las normas sociales, y suele ser frecuente que, desde ese conocimiento, adapte su conducta a ellas para conseguir sus objetivos, pero carece de toda capacidad para asumir en su fuero interno el orden social establecido y los principios por los que se rige ${ }^{437}$.

La inimputabilidad del psicópata es uno de los aspectos más discutidos en la dogmática penal, lo que vino generando que se plantearan serias dudas en la doctrina y hubo una corriente de pensamiento que lo consideraba inimputable ${ }^{438}$. No obstante, todo ello paulatinamente ha ido cediendo terreno a la consideración de que no puede

436 CANCIO MELIÁ, M., “Psicopatía y Derecho penal: algunas consideraciones introductorias”. En FERNÁNDEZ TERUELO, J.G. / GONZÁLEZ TASCÓN, M.M. / VILLA SIEIRO, S.V., (Coords.), Estudios penales en homenaje al profesor Rodrigo Fabio Suárez Montes. Oviedo: Constitutio Criminalis Carolina, D.L. 2013. Pág. 117. Este autor señala que la psicopatía es una constante antropológica que siempre ha estado presente en todas las civilizaciones, que además suele ser casi exclusivo del género masculino, y que entre el 15\% y el 25\% de la población carcelaria está compuestas por psicópatas.

437 POZUECO ROMERO, J.M. / ROMERO GUILLENA, S.L. / CASAS BARQUERO, N., “Psicopatía, violencia y criminalidad: un análisis psicológico-forense, psiquiátrico-legal y criminológico (Parte II)". En Cuadernos de Medicina Forense, Vol. 17, núm. 4. 2011, pp. 176 y 177.

438 ZAFFARONI, E.R. / ALAGIA, A. / SLOKAR, A., Derecho Penal..., cit. p. 710 y 711. 
encuadrarse dentro de esa categoría ${ }^{439}$ y excluirse totalmente la imputabilidad, aunque sí se ha venido reconociendo que, con carácter general, la psicopatía debe producir una atenuación de la pena ${ }^{440}$ y suele dar lugar a la aplicación de la eximente incompleta ${ }^{441}$, y algunos autores afirman que el criterio que debe seguirse deberá atender a la sintomatología del sujeto en cada caso, lo que permitirá conocer si se le podía exigir la comprensión de la ilicitud de su conducta y que adaptara su comportamiento a la norma $^{442}$. Un sector de la doctrina viene aceptando que la psicopatía puede dar lugar a la consideración jurídica de inimputable, en la medida en que el psicópata experimenta una anomalía o alteración psíquica que implicaría la reducción o desaparición del libre albedrío que acompaña a una imposibilidad material de motivarse conforme a la norma, por lo que sería necesario dar lugar a que la intervención penal se llevase a cabo mediante medidas de seguridad 443 .

No obstante, los estudios sobre las psicopatías que hasta ahora se conocían, no venían permitiendo la plena exención de responsabilidad penal culpabilística a los psicópatas, debido a que son personas que entienden perfectamente las normas de conducta, incluso las normas penales, con todo su contenido y alcance ${ }^{444}$, pero las perciben como simples obstáculos que les impiden conseguir aquello que ansían, por lo que pueden responder ante esos impedimentos de muy diversas formas. Son personas que asimilan todo lo que hacen como correcto, según la valoración de las normas que llevan a cabo conforme a un código particular de conducta que ellos mismos construyen. En consecuencia, si algo que entienden como correcto según sus normas y sus códigos, a pesar de ello, no sale bien o el resultado es inesperado, la culpa no será de los demás, en

439 POZUECO ROMERO, J.M. / ROMERO GUILLENA, S.L. / CASAS BARQUERO, N., “Psicopatía, violencia y criminalidad...", cit. p. 183 y 184. Estos autores ponen de manifiesto, desde la definición doctrinal de la inimputabilidad, que si se acude a los rasgos psicopáticos científicamente constatados, en ninguno de ellos se expresa que este tipo de individuos padezcan trastornos mentales transitorios, anomalías psíquicas ni alteraciones de la percepción, por lo que quedarían excluidos de la categoría de inimputables.

440 TAMARIT SUMALLA, J.M., “Culpabilidad, maldad e imputabilidad: aportaciones de la dogmática penal a la cultura jurídica europea”. En Revista de Derecho penal y Criminología, 2a Época, núm. 17. 2006, p. 211.

441 SÁNCHEZ MELGAR, J., en SÁNCHEZ MELGAR, J. (Coord.), Código penal..., cit. Tomo I, p. 182.

442 ZAFFARONI, E.R. / ALAGIA, A. / SLOKAR, A., Derecho Penal..., cit. p. 711

443 LEAL MEDINA, J., “La psicopatía y su incidencia como anomalía psíquica en la doctrina del Tribunal Supremo. La interacción de los factores biológicos, genéticos y ambientales en el juicio de imputabilidad. Un nuevo enfoque hacia la prevención del delito, el derecho a la seguridad y la reeducación del sujeto". En Revista de Derecho y Proceso Penal, núm. 10. 2003, pp. 157 y ss.

444 IGLESIAS RÍO, M.A., “La eximente de "anomalía o alteración psíquica”. (Art. 20.1 CP). Una problemática abierta hacia el futuro científico". En Anuario de Derecho Penal y Ciencias Penales. Tomo 56, núm. 1. 2003, pp. 166 a 173. 
quienes descargarán de forma cínica toda la responsabilidad, por eso sus relaciones sociales son una fuente de conflictos segura y en potencia, que en cualquier momento puede desencadenarse. Todo ello, junto con la interacción de circunstancias ambientales, puede generar actividad delictiva en los psicópatas, sin olvidar que otro rasgo que les caracteriza es la agresividad y la violencia que suelen utilizar cuando el encanto, la manipulación, las amenazas o la intimidación no les dan resultado. Según explican los expertos, los psicópatas son magníficos manipuladores de las personas, a las que utilizan como si fuera objetos para la consecución de sus objetivos, con la especialidad de que saben captar las necesidades ajenas mediante técnicas depuradas de seducción, previa identificación de los puntos débiles de las demás personas. El psicópata suele despertar las ambiciones de los demás para después engañarles. "Todo este ciclo de manipulación psicopática está repleto de una retahíla de mentiras que utiliza como herramienta de trabajo y que le llevan a desvirtuar la verdad con el objetivo de conseguir algo para él/ella" 445 .

Sin embargo, respecto a las psicopatías hay que distinguir antes de la promulgación del CP de 1995, ya que el anterior texto utilizaba el término "enajenado" que vino siendo interpretado por la jurisprudencia en el sentido de no atribuir relevancia a la psicopatía como circunstancia excluyente o minoradora de la imputabilidad 446 . Después de la promulgación del CP de 1995, se sustituye aquel término por el de anomalía o alteración psíquica y es bajo el umbral de la anomalía donde se permite incluir la psicopatía. En ese sentido la STS de 18 de octubre de 2002, apreció la eximente ya que el sujeto "fue víctima de un delirio y no se halló en situación de comprender que su conducta era realmente intolerable". Y la STS de 18 de marzo de 2003 vino a decir que "la gravedad inferior de las psicopatías y trastornos de la personalidad en comparación con las psicosis graves y los niveles más profundos de la oligofrenia, impedirán prácticamente siempre su acogida como circunstancias eximentes, teniendo su normal comparo de efectividad en las incompletas con valor atenuante" 447 .

\footnotetext{
445 POZUECO ROMERO, J.M. / ROMERO GUILLENA, S.L. / CASAS BARQUERO, N., “Psicopatía, violencia y criminalidad...", cit. p. 177.

446 A título de ejemplo podemos citar las STS de 4 de febrero de 1956, de 23 de mayo de 1957, de 25 de mayo y 30 de junio de 1970.

447 Resoluciones citadas por CÓRDOBA RODA, J., “De la infracción penal...”, cit. p. 154.
} 
e) Neurosis: puede considerarse como enfermedades mentales 448 , con diversas manifestaciones, como simples reacciones vivenciales anómalas, y podrán dar lugar a la eximente completa o incompleta según el grado de intensidad que presenten, así como la relación o incidencia de la forma de aparición del brote neurótico con el hecho concreto antijurídico cometido449. Se definen como el "conjunto de síntomas psíquicos y emocionales producidos por un conflicto psicológico que con el tiempo se han hecho crónicos. En la neurosis están presentes las afecciones emotivas molestas, penosas o entorpecedoras de la actividad normal del sujeto, sin que existan alteraciones importantes del pensamiento, de la percepción o del sentido de la realidad" 450 . Por lo general comporta ansiedad, infelicidad e incertidumbre con la consecuente ineficacia para la vida social y las actividades laborales, y suele traducirse en fobias, angustia y pánico, reacciones obsesivo-compulsivas, histerias nerviosas, hipocondrías, o arrebatos explosivos; y aunque por lo general dará lugar a la atenuante analógica del art. $21.6 \mathrm{CP}$, puede apreciarse la eximente incompleta ${ }^{451}$; y en casos muy extremos puede apreciarse también la eximente completa (STS de 13 de octubre de 2001).

f) Epilepsia: se trata de una enfermedad que puede tener consecuencias sobre las facultades mentales y volitivas del sujeto, por lo que habrá que estudiar detenidamente caso por caso, ya que, como indica la STS de 18 de noviembre de 2005 "puede hacerle

448 COBO DEL ROSAL, M. / VIVES ANTÓN, T.S., Derecho penal. Parte General..., cit. pp. 587 y 588 . Estos autores explican que "la oposición tradicional entre psicosis, como enfermedades de índole orgánica, y neurosis, como trastornos puramente vivenciales que no serían estados patológicos propiamente dichos, resulta hoy inaceptable. El fundamento teórico de la distinción entre psicosis y neurosis es impreciso, pues no se puede utilizar como criterio ni la gravedad de la dolencia, ni siquiera el grado de conciencia que el sujeto es capaz de alcanzar respecto de la existencia de su trastorno, proponiéndose por algunos, como diferencia última entre ambas, la pérdida del acceso a los niveles más elevados de la vida psíquica, comprobable en las psicosis y que no se produce en las neurosis. El desarrollo, relativamente tardío, de la investigación psiquiátrica en torno a las neurosis, la multitud de formas en que aparece, el alcance tan diverso que cabe otorgarles, tanto respecto del psiquismo general del sujeto afectado, cuanto en orden a la influencia sobre el hecho particular, la discusión en torno a su carácter patológico, etc., son circunstancias que han influido en el hecho de que la jurisprudencia haya mostrado cierta renuencia a tomar en consideración las alteraciones de la imputabilidad por ellas provocadas. En la actualidad, y sobre la base de que el neurótico tiene efectivamente alterada la capacidad de entender y de querer, deberían incardinarse bajo la eximente primera del art. 20 del Código penal muchos supuestos concretos de hechos realizados bajo la influencia de un trastorno neurótico".

449 MUÑOZ CONDE, F. / GARCÍA ARÁN, M., Derecho Penal..., cit. p. 371.

${ }^{450}$ LEAL MEDINA, J., “Un estudio de las actuales medidas...”, cit. pp. 333 y 334. Este autor explica que "en general al neurótico se le ha tenido por imputable, ya que parece conservar un conjunto de salud mental que le permite apreciar el valor de los actos que ejecuta, conservando la facultad de deliberación y de resolución. Una simple neurosis de carácter no supone más que el individuo padece trastornos de temperamento, que reacciona ante los acontecimientos de la vida de modo diferente a como lo haría la generalidad de las personas, conservando intactas, el conocimiento, la voluntad y el discernimiento para distinguir el bien y el mal, lo lícito de lo ilícito".

451 COBO DEL ROSAL., M. / QUINTANAR DÍEZ, M., Instituciones..., cit. p, pp. 178. 
traspasar también los confines de la locura hasta convertirlo en irresponsable permanente de cualquiera de sus actos, dentro de cuyos extremos, claro está, caben asimismo estados intermedios, que cuentan hoy con soluciones jurídicas adecuadas a cada uno de los posibles grados con los que se manifiesta la responsabilidad penal disminuida". Es una enfermedad multiforme con trastornos mentales eléctricos del cerebro, afectando al sistema nervioso central. El epiléptico experimenta tres fases importantes, que son: la fase comicial, inmediatamente anterior a la segunda fase, de ataque pleno, donde el enfermo convulsiona y pierde el control sobre su actividad psicomotriz; y la tercera fase es la crepuscular, que es la posterior al ataque o a la crisis central. En cada una de esas fases, el nivel de imputabilidad es diferente, por lo que habrá que atender a cada caso, pero suele ponerse de manifiesto por la doctrina, que en la fase aguda o de ataque, el sujeto queda exento de responsabilidad penal - piénsese en los hechos punibles que se cometen por omisión-y en las otras dos fases la pena suele atenuarse ${ }^{452}$, ya que en las auras epilépticas o estados crepusculares, el individuo experimenta una perturbación de sus facultades cognoscitivas y volitivas pero no las tiene totalmente abolidas, por lo que solo contará con una imputabilidad reducida o parcial, al igual que la epilepsia sintomática o residual que genera ataques comiciales o equivalentes. No obstante, la epilepsia larvada suele interesar al Derecho penal, que se centra en los ataques epilépticos que producen una anulación de la imputabilidad, siempre que la acción u omisión se realice en ese estado crítico o postcrítico. El estado intercrítico solo la disminuye, no la anula453.

g) Ludopatía: también conocida como adicción al juego, es una patología que se traduce en una absoluta dependencia al juego de combinaciones aleatorias, suerte, envite o azar, y que puede conducir al sujeto a cometer delitos, sobre todo cuando el ludópata se ve en imperiosa necesidad de obtener dinero para satisfacer su necesidad compulsiva de jugar ${ }^{44}$. Obviamente, en función del grado de afectación que produzca en el sujeto en relación al efecto psicológico, será de aplicación la eximente o la atenuante, y ese sentido se pronuncia la STS de 9 de mayo de 2003, que dispone que "la ludopatía o adicción al juego puede considerarse una dependencia psíquica que, cuando es grave y determina de modo directo e inmediato la comisión de hechos delictivos funcionalmente dirigidos a la obtención de fondos para satisfacer la compulsión al juego, permite ordinariamente la

\footnotetext{
452 SÁNCHEZ MELGAR, J., en SÁNCHEZ MELGAR, J. (Coord.), Código penal..., cit. Tomo I, p. 179.

453 COBO DEL ROSAL., M. / QUINTANAR DÍEZ, M., Instituciones..., cit. p.

454 CÓRDOBA RODA, J., “De la infracción penal...”, cit. p. 155.
} 
apreciación de una atenuante analógica del art. $21.6^{\circ}$ en relación al $21.2^{\circ}$, por tener análoga significación que otras adicciones graves [...]. Solo en supuestos de excepcional gravedad puede llegar a plantearse la eventual apreciación de una eximente, completa o incompleta, cuando pericialmente se acredite fuera de toda duda una anulación absoluta o cuasi absoluta de la capacidad de raciocinio o voluntad del acusado".

$2^{\circ}$. El trastorno mental transitorio. El segundo párrafo del art. $20.1^{\circ} \mathrm{CP}$, contempla esta posibilidad como eximente, siempre dicho trastorno no haya sido expresamente provocado por el sujeto para colocarse a sí mismo en situación de inimputabilidad. En efecto, para la concurrencia del trastorno mental transitorio el sujeto, al igual que en la previsión del primer párrafo del art. $20.1^{\circ} \mathrm{CP}$, no ha de poder comprender la ilicitud del hecho o actuar conforme a dicha comprensión, por lo que es preciso acudir a todo lo anteriormente dicho sobre anomalía o alteración psíquica, en el sentido de que, quien sufre un trastorno mental transitorio al tiempo de cometer el delito, estará exento de responsabilidad criminal ${ }^{455}$, siempre que dicho trastorno le ocasione el efecto psicológico idéntico al descrito en el párrafo primero del art. $20.1^{\circ} \mathrm{CP}$, y que dicho trastorno no haya sido ocasionado por una intoxicación plena a causa de bebidas alcohólicas o cualesquiera otras sustancias que produzcan efectos análogos. Por otra parte, el trastorno debe de ser transitorio, esto es, temporal, ocasional y no definitivo, por lo que debe aparecer en el sujeto sin encontrar su causa en una anomalía o alteración psíquica existente de modo duradero en él 456 .

Especial detenimiento merece la segunda parte del precepto, que refiere a que el trastorno mental transitorio no eximirá de pena cuando hubiese sido provocado por el sujeto con el propósito de cometer el delito o hubiese previsto o debido prever su comisión. Lo primero que hemos de manifestar es que se trata de una manifestación de la denominada actio libera in causa, en la que el sujeto se coloca previamente en una situación

455 COBO DEL ROSAL., M. / QUINTANAR DÍEZ, M., Instituciones..., cit. p. 175. Estos autores relacionan algunos ejemplos en que puede producirse este trastorno mental transitorio: la enajenación con carácter transitorio, brotes esquizofrénicos catatónicos, estados episódicos maníacodepresivos, estado crepuscular epiléctico, estados iniciales de parálisis general progresiva en las remisiones, trastornos producidos por traumas craneales o ciertas enfermedades mentales como la encefalitis, síndrome manésico y estados de debilidad hipersetésico emocional, algunas reacción psicógneas como las depreseiones activas, delirios, histerias, fobias, etc.

456 CÓRDOBA RODA, J., “De la infracción penal...”, cit. p. 157. 
de inimputabilidad en la que comete el ilícito penal mediante acción u omisión ${ }^{457}$. Dicha colocación puede ser dolosa, en cuyo caso el sujeto "se utiliza a sí mismo como un mero instrumento material en la comisión del delito. Por tanto, y de modo semejante a lo que ocurre en la autoría mediata, ha de entenderse ejecutado el delito justo en el momento en que se adquiere el trastorno mental preordenado a su comisión" ${ }^{\prime 48}$. Y también puede presentarse de forma imprudente, que deriva de la propia redacción del precepto que refiere a que " $o$ hubiese previsto o debido prever su comisión" $" 459$.

Como hemos dicho, el trastorno mental transitorio es una situación que produce idéntico efecto psicológico que el previsto en el párrafo $1^{\circ}$ del art. $20.1^{\circ} \mathrm{CP}$, y que no debe ser causado por la ingesta de bebidas o sustancias, lo cual deriva de una mera interpretación sistemática del art. $20.1^{\circ}$ y $2^{\circ} \mathrm{CP}$. Por ello, realmente la única posibilidad en que puede plantearse tal situación no puede ser otra que en supuestos de sometimiento voluntario del sujeto a sesiones de profunda hipnosis, o a cualquier otro método psíquico de alteración de la capacidad sensorial. Como indica CóRDOBA RODA, “la inclusión de este requisito tiene un claro sentido en relación a la eximente segunda del art. 20, pues el consumo de bebidas alcohólicas o de sustancias estupefacientes puede haber se producido o con el propósito de cometer un delito o con la previsión o previsibilidad de su comisión. Por el contrario, no parece que dicho requisito tenga ningún sentido respecto a la

\footnotetext{
457 MEZGER, E., Tratado de Derecho penal..., cit. pp. 55 y 56. Como expresa este autor, "en lo que respecta al problema de la imputabilidad es relevante en todo caso el tiempo de la ejecución de la acción. [...] Por tiempo de la acción ha de entenderse el tiempo en que el sujeto despliega su actividad. Pero esto no impide el castigo de las llamadas actiones liberae in causa. Por tales ha de entenderse aquellas acciones en las que el sujeto establece la causa decisiva en un momento en que es imputable, mientras que, en cambio, su conducta corporal sólo se desenvuelve en un tiempo en que su imputabilidad está ausente. Puede decirse que en estos casos se utiliza a sí mismo como instrumento".
}

458 COBO DEL ROSAL, M. / VIVES ANTÓN, T.S., Derecho penal. Parte General..., cit. pp. 609. Según estos autores, "parece lo más correcto sostener que quien se coloca a sí mismo en situación de inimputabilidad para llevar a cabo el delito, está ya iniciando su ejecución. Y si ello es así, en el supuestos de la actio libera in causa dolosa, no existe una disociación entre el momento de la acción y momento de la imputabilidad"; también MEZGER, E., Tratado de Derecho penal..., cit. p. 56, asevera que "la actio libera in causa puede, según las circunstancias concretas, ser una acción positiva o una omisión, una conducta dolosa o culposa. [...] Supóngase que el guardagujas, dolosamente y con la intención de que el tren descarrile, se embriaga hasta perder el sentido (al objeto de cortase a sí mismo la retirada de un posible y eficaz arrepentimiento), es decir, produce dolosamente una omisión; o piénsese en el sujeto que, sabiendo cómo reacciona su naturaleza al estímulo de una bebida alcohólica, se embriaga (hacer efectivo) precisamente para matar durante la borrachera a un hombre, muerte para la que le falta, como él sabe, el valor en estado normal. De todas estas consideraciones resulta, pues, la posibilidad de las actiones liberae in causa".

459 COBO DEL ROSAL, M. / VIVES ANTÓN, T.S., Derecho penal. Parte General..., cit. p. 610. Estos autores indica que "si la actio libera puede ser contemplada ya como inicio de la realización del correspondiente tipo de injusto y, al llevarla a cabo, concurren en el autor los presupuestos de la reprochabilidad imprudente respecto al resultado concreto, no existe ningún obstáculo para exigirle responsabilidad a título de imprudencia". 
eximente de trastorno mental transitorio del párrafo segundo de la circunstancia primera, pues en tal supuesto la aparición del trastorno no ha sido creada por el agente, a diferencia de lo que ocurre con quien decide tomar una bebida alcohólica o consumir una droga" 460 .

$3^{\circ}$. Intoxicación. La circunstancia $2^{\circ}$ del art. $20 \mathrm{CP}$, proclama la inimputabilidad del que al tiempo de cometer la infracción penal se halle en estado de intoxicación plena por el consumo de bebidas alcohólicas, drogas tóxicas, estupefacientes, sustancias psicotrópicas u otras que produzcan efectos análogos, siempre que no haya sido buscado con el propósito de cometerla o no se hubiese previsto o debido prever su comisión, o se halle bajo la influencia de un síndrome de abstinencia, a causa de su dependencia de tales sustancias, que le impida comprender la ilicitud del hecho o actuar conforme a esa comprensión ${ }^{461}$. Se requiere, pues, un estado de toxicomanía o alcoholismo, y que como consecuencia del mismo quede anulada o afectada gravemente su capacidad de compresión y motivación del autor ${ }^{462}$. La intoxicación puede ser valorada según el CP en tres niveles distintos: el primer nivel es el de la exclusión total de la imputabilidad, que concurre cuando el sujeto se encuentra en un estado de intoxicación plena o cuando se halla bajo el síndrome de abstinencia, aunque la apreciación práctica de la eximente en estos casos es prácticamente inexistente ${ }^{463}$. El segundo nivel daría lugar a la apreciación de la eximente incompleta, cuando la alteración de las capacidades intelectivas y volitivas no es plena sino parcial ${ }^{464}$. El tercer nivel es el previsto en la atenuante del art. $21.2^{\mathrm{a}} \mathrm{CP}$, donde concurre una grave adicción a las sustancias, que debe tener también un efecto psicológico en la imputabilidad del sujeto, aunque de menor entidad que la eximente incompleta 465 .

${ }^{460}$ CÓRDOBA RODA, J., “De la infracción penal...”, cit. p. 159.

${ }^{461}$ OBREGÓN GARCÍA, A., “La eximente del art. 20.2, inciso $1^{\circ} \mathrm{CP}$ : estado de intoxicación plena por consumo de alcohol u otras drogas". En Estudios de Derecho judicial, núm. 110. Actual doctrina de la imputabilidad. Madrid: Consejo General del Poder Judicial. 2007, pp. 171 y ss.

462 ORTS BERENGUER, E. / GONZÁLEZ CUSSAC. J.L., Compendio..., cit. p. 369.

${ }^{463}$ CASTELLÓ NICÁS, N., "Causas de inimputabilidad: drogadicción...", cit. p. 416. Según este autor, "en cuanto a la eximente completa, sin embargo, su aplicación está práctica está casi invalidada, -como también sucedió bajo la vigencia del anterior texto punitivo-, salvo supuestos muy excepcionales y grave deterioro psíquico".

${ }^{464}$ MUÑOZ CONDE, F. / GARCÍA ARÁN, M., Derecho Penal..., cit. pp. 372 y 373. Estos autores señalan que, "dado el beneficioso régimen de atenuación de la pena que la misma provoca, la alteración, aunque no plena, debe ser bastante relevante, no bastando con que sea ligera y poco importante.

465 Ibidem, p. 373. 
La jurisprudencia ha venido exigiendo la concurrencia de varios requisitos para la apreciación de la eximente. Así, para los casos de toxicomanías, se precisa, por una parte, que el drogadicto se encuentre en un estado de intoxicación derivado del previo consumo de drogas, y actúe bajo su influencia; y por otra, que como consecuencia de este consumo quede anulada por completo la voluntad e inteligencia del sujeto. En cuanto a la referencia del precepto al síndrome de abstinencia, las STS de 24 de noviembre de 1997, de 4 de marzo de 2002, de 20 de junio de 2002, de 3 de octubre de 2010 y de 22 de marzo de 2005, inciden en que debe tratarse de algo distinto a la simple crisis de ansiedad, por cuanto que, en uno y otro caso, las capacidades intelectivas y volitivas quedan afectadas aunque de forma muy distinta, y ello repercute en el tratamiento penal que a una y otra deba dárseles. Por su parte, para la embriaguez (tal y como rezan la STS de 10 de mayo de 1999 y de 27 de abril de 2000, entre muchas otras), se requiere que el consumo de cualquier bebida alcohólica determine una anulación de la voluntad e inteligencia del sujeto, ya que el simple alcoholismo crónico no causa ninguna alteración de la capacidad de comprender y actuar ${ }^{466}$.

$4^{\circ}$. Alteraciones en la percepción de la realidad. Esta causa de inimputabilidad contiene dos presupuestos, uno biológico-psicológico de carácter temporal, derivado de la exigencia de que las alteraciones sean desde el nacimiento o la infancia, lo que impone la necesidad de excluir del ámbito de aplicación de la eximente los supuestos en que dicha alteración se aprecie en el sujeto una vez trascurrido el período de infancia; y otro normativo-valorativo consistente en que dicha alteración le produzca una grave alteración de la conciencia de la realidad ${ }^{467}$, lo que se traduce en que para su apreciación deben concurrir los dos, puesto que el presupuesto biológico no es en sí mismo suficiente para apreciar la inimputabilidad, ya que lo realmente relevante es el efecto psicológico que produce al alterar gravemente la conciencia de la realidad, de forma que, lo que el

\footnotetext{
466 ORTS BERENGUER, E. / GONZÁLEZ CUSSAC, J.L., Compendio..., cit. p. 369.

467 CARMONA SALGADO, C., "Causas de inimputabilidad: alteración de la percepción”. En Estudios de Derecho judicial, núm. 110. Actual doctrina de la imputabilidad. Madrid: Consejo General del Poder Judicial. 2007, p. 464. Esta autora indica que "en la regulación vigente del art. $20.3^{\circ} \mathrm{CP}$ sigue siendo, al igual que su antecesora (art. $8.3^{\circ}$ ), una fórmula de inimputabilidad de naturaleza esencialmente normativo-valorativa que se compone de un presupuesto biológico-psicológico temporal, reflejado en la exigencia legal de sufrir "desde el nacimiento o la infancia alteración en la percepción", estado psicológico éste en el que puede encontrarse inmerso quien la padezca por haber carecido de la suficiente instrucción en esa su primera fase de la vida, debiendo materializarse dicha deficiente percepción en una "grave alteración de la conciencia de la realidad", que constituye la consecuencia jurídica de dicho padecimiento con eventual repercusión en la imputabilidad penal".
} 
sujeto debe tener alteradas, son las facultades para conocer las pautas de comportamiento y los valores imperantes en la sociedad en su conjunto. En ese sentido, esta eximente requiere la constatación de una falta de comunicación con el mundo externo, que determina graves carencias para desenvolverse $\mathrm{u}$ orientarse moralmente en la convivencia con los demás ciudadanos, que debe tener su origen en el nacimiento o la infancia468, y que suponga una alteración de la percepción a causa de un defecto sensorial que impida o limite en gran medida el proceso de socialización de la persona ${ }^{469}$, lo que se da normalmente en supuestos de sordomudez, ceguera y anomalías cerebrales o disminuciones psíquicas ${ }^{470}$, o en el supuesto de los llamados "niños-lobo" en los que se da una situación de aislamiento no voluntario que les puede afectar gravemente al desarrollo, o a los autistas, cuyas anomalías sensoriales les producen dificultades de comunicación, confusión y aislamiento.

El fundamento de esta eximente estriba en la existencia de una situación de incomunicación con el entorno social que le impide conocer la realidad que le rodea y, por tanto, motivarse por la norma. Por eso la alteración de la percepción puede consistir en la aparición de ilusiones o alucinaciones, ya sean auditivas (en las que el sujeto cree estar escuchando frases amenazantes), visuales, gustativas $u$ olfativas, en supuestos en que el sujeto cree que las personas más próximas a él le envenenan la comida o el aire que respira, etc. ${ }^{471}$ No osbtante, CEREZO MIR afirma que la eximente de alteraciones en la percepción debería suprimirse por tratarse de una medida superflua que además tiene escasa importancia político—criminal, porque apenas cuenta con apliación práctica ${ }^{472}$.

C) La semiimputabilidad, por su parte, es un concepto de construcción doctrinal creado para catalogar a aquellos sujetos en los que concurren las eximentes antes descritas como causas de inimputabilidad, pero de forma incompleta. La previsión en el Código

\footnotetext{
${ }^{468}$ MUÑOZ CONDE, F. / GARCÍA ARÁN, M., Derecho Penal..., cit. p. 366 y 367. Estos autores manifiestan que "si por el contrario el sujeto ha adquirido conocimientos y experiencia suficiente para saber que sus acciones contradicen o no las normas y después sufre la alteración en la percepción, no será aplicable la eximente, por lo menos en su forma completa".

469 MORALES PRATS, F., La alteración en la percepción (art. 8.2 CP): contenido y límites, en Jornadas sobre psiquiatría forense. Madrid: Centro de Estudios Judiciales. 1990, pp. 80 y ss.

470 ORTS BERENGUER, E. / GONZÁLEZ CUSSAC, J.L., Compendio..., cit. p. 370.

471 CÓRDOBA RODA, J., “De la infracción penal...”, cit. p. 166.

472 CEREZO MIR, J., “Alteraciones en la percepción”. En QUINTERO OLIVARES, G. / MORALES PRATS, F. (Coords.), El nuevo Derecho penal español. Estudios penales en memoria del Profesor José Manuel Valle Muñiz. Navarra: Aranzadi. 2001, p. 146.
} 
deriva del art. 21.1 $\mathrm{CP}^{473}$, y se trata de supuestos en que el sujeto presenta una culpabilidad disminuida ${ }^{474}$. Sobre este particular, damos aquí por reproducidas todas las referencias a las eximentes de los arts. $20.1^{\circ}, 2^{\circ}$ y $3^{\circ} \mathrm{CP}$, cuando su concurrencia no dé lugar a una inimputabilidad plena, sino parcial475. En estos casos de eximente incompleta, el efecto penológico previsto es el de rebajar uno o dos grados la pena atendiendo al grado y a la intensidad de la causa que concurra (art. $68 \mathrm{CP}$ ), pero en caso de que además exista peligrosidad, se podrán imponer medidas de seguridad ${ }^{476}$ con sujeción a las reglas del sistema vicarial.

D) La reimputabilidad, es un concepto al que refiere MARTín HERNÁNDEZ, cuando afirma que debido a los avances en el tratamiento de de los trastornos mentales y en especial la psicosis, que cuenta con imporantes avances en el ámbito farmacéutico, puede ocurrir que cometa un delito un sujeto inimputable por una alteración psíquica alienante, pero posteriormente, debido a los tratamientos, consiga una mejoría siginificativa que le coloque en situación de imputabilidad. De forma que, si posteriormente, cuando ya se encuentra curado de su patología psíquica, comete otro delito, será plenamente imputable. Sigue diciendo este autor que se trata de una posibilidad que deberá estar presente en la elaboración de los informes periciales psiquiátricos, que tendrán que tener en cuenta los documentos médicos de fechas anteriores. También explica este autor que, debido a las importantes consecuencias legales que puede proyectar esta circunstancia en el ámbito del proceso, deberá ser objeto de prueba por parte de la acusación pero también de la defensa, cuando se mantengan posiciones contrapuestas sobre su concurrencia ${ }^{477}$.

\footnotetext{
$473 \mathrm{El}$ art. 21.1 ${ }^{\mathrm{a}} \mathrm{CP}$ dispone: “Son circunstancias atenuantes: $1^{\circ}$. Las causas expresadas en el Capítulo anterior, cuando no concurrieren todos los requisitos necesarios para eximir de responsabilidad en sus respectivos casos".

${ }^{474}$ MAPELLI CAFFARENA, B., Las consecuencias..., cit. p. 362.

475 COBO DEL ROSAL., M. / QUINTANAR DÍEZ, M., Instituciones..., cit. p. 176. Estos autores hablan de que puede darse la imputabilidad disminuida en supuestos de fiebre, dolor, mutilaciones y traumatismos, ceguera, estados críticos de la mujer y del hombre, personas de reacciones primitivas, personas de reacciones explosivas, actos de corto circuito, sugestión, pasiones y obsesiones, angustias y fobias, estados afectivos intelectuales mórbidos, estados histéricos y neuróticos, comportamientos delirantes, alucinaciones e impulsiones, psicosis intermitentes y disociaciones éticas y esquizofrénicas del comportamiento humano.

476 ORTS BERENGUER, E. / GONZÁLEZ CUSSAC, J.L., Compendio..., cit. p. 367. Een relación a las anomalías o alteraciones psíquicas, estos autores expresan que "la apreciación de la eximente completa podrá comportar la imposición de medidas de seguridad, siempre que además se declare la existencia de peligrosidad criminal", p. 369 en relación a la intoxicación, y pág. 370 en relación a las alteraciones en la percepción de la realidad: "así mismo, permite la imposición de medidas de seguridad cuando exista, además, peligrosidad criminal".
}

477 MARTÍN HERNÁNDEZ, M.A., “¿Cabe la sustitución de la pena...”, cit. p. 887. 
E) El trastorno mental inhabilitante para conocer el sentido de la pena, previsto en el art. $60 \mathrm{CP}$ que contempla un supuesto específico de sustitución de la pena privativa de libertad por medidas de seguridad para el caso en el que penado se encuentre incapacitado para comprender el sentido de la pena, una vez pronunciada la sentencia ${ }^{478}$. A ello refiere también la LECrim en sus arts. 991 a 994, que regulan el procedimiento ${ }^{479}$ que - a modo de incidente-480 debe seguirse a efectos de la suspensión de la ejecución de la pena por trastorno mental ${ }^{481}$, y que consta de una primera fase administrativa-penitenciaria que consiste en la iniciación del expediente por parte del Director del centro penitenciario a efectos de constatar la demencia, y una segunda fase judicial, donde, una vez recibido el expediente administrativo por el Tribunal sentenciador, se dará audiencia al Miniterio Fiscal, a las acusaciones y a la defensa como paso previo a acordar lo que proceda sobre la demencia sobrevenida, pero solo si hay oposición se celebrará una vista contradictoria por los trámites del juicio oral482 regulado en los arts. 680 a 743 LECrim ${ }^{483}$.

\footnotetext{
478 Art. 60.1. "Cuando, después de pronunciada sentencia firme, se aprecie en el penado una situación duradera de trastorno mental grave que le impida conocer el sentido de la pena, el Juez de Vigilancia Penitenciaria suspenderá la ejecución de la pena privativa de libertad que se le hubiera impuesto, garantizando que reciba la asistencia médica precisa, para lo cual podrá decretar la imposición de una medida de seguridad privativa de libertad de las previstas en este Código que no podrá ser, en ningún caso, más gravosa que la pena sustituida. Si se tratase de una pena de distinta naturaleza, el Juez de Vigilancia Penitenciaria apreciará si la situación del penado le permite conocer el sentido de la pena y, en su caso, suspenderá la ejecución imponiendo las medidas de seguridad que estime necesarias. El Juez de Vigilancia comunicará al ministerio fiscal, con suficiente antelación, la próxima extinción de la pena o medida de seguridad impuesta, a efectos de lo previsto por la disposición adicional primera de este Código.

2. Restablecida la salud mental del penado, éste cumplirá la sentencia si la pena no hubiere prescrito, sin perjuicio de que el Juez o Tribunal, por razones de equidad, pueda dar por extinguida la condena o reducir su duración, en la medida en que el cumplimiento de la pena resulte innecesario o contraproducente".
}

${ }^{479}$ MORENO CATENA, V. (Dir.) / COQUILLAT VICENTE, A. / DE DIEGO DÍEZ, A. / JUANES PECES, A. / DE LLERA SUÁREZ BÁRCENA, E., El Proceso penal. Doctrina, jurisprudencia y formularios. Vol. V. Valencia: Tirant lo Blanch. 2000, pp. 3746 a 3748; DE LA ROSA CORTINA, J.M., en SÁNCHEZ MELGAR, Julián (coord.), Ley de Enjuiciamiento Criminal. Comentarios y jurisprudencia. Tomo II. Madrid: Sepín. 2010, pp. 3484 a 3494 .

480 RIFA SOLER, J.M. / VALLS GOMBAU, J.F. / RICHARD GONZÁLEZ, M., El proceso penal práctivo. $6^{a}$ Ed. Madrid: La Ley. 2009, pp. 1962 y 1963.

${ }^{481}$ GÓMEZ COLOMER, J.L., “El proceso de ejecución”. En MONTERO AROCA, J. / GÓMEZ COLOMER, J.L. / MONTÓN REDONDO, A. / BARONA VILAR, S., Derecho Jurisdiccional III. Proceso Penal. 21 ${ }^{\mathrm{a}}$ Ed. Valencia: Tirant lo Blanch. 2013, pp. 460 a 462.

482 SEOANE SPIEGELBERG, J.L., en PÉREZ-CRUZ MARTÍN, A.J. / FERREIRO BAAMONTE, X.X. / PIÑOL RODRÍGUEZ, J.R. / SEOANE SPIEGELBERG, J.L., Derecho Procesal penal. $2^{\mathrm{a}}$ Ed. Navarra: Civitas. 2010, p. 1012.

${ }^{483}$ Sobre la regulación del juicio oral, vid. los comentarios de LÓPEZ LÓPEZ, A. / DE URBANO CASTRILLO, E., en SÁNCHEZ MELGAR, Julián (coord.), Ley de Enjuiciamiento Criminal. Comentarios y jurisprudencia. Tomo II. Madrid: Sepín. 2010, pp. 2271 a 2490; RIFA SOLER, J.M. / VALLS GOMBAU, J.F. / RICHARD GONZÁLEZ, M., El proceso penal práctivo..., cit. pp. 1131 a 1167. 
Sobre el contenido del art. $60 \mathrm{CP}$ hemos de resaltar que difiere en algunos aspectos del contenido del art. $20 \mathrm{CP}$, ya que el precepto refiere a "situación de trastorno mental grave", frente a las causas de inimputabilidad -ya vistas- del art. 20 CP que refieren a "anomalía o alteración psíquica". Dicha diferenciación nos obliga, por fuerza, a conferirle un significado diferente, en el sentido en que pueden concurrir otras alteraciones de la normalidad distintas a las del art. $20 \mathrm{CP}$. En cualquier caso, tanto las anomalías o alteraciones del art. 20 CP como cualesquiera otras, cuando aparezcan de forma sobrevenida, podrán únicamente ser apreciadas para aplicar la sustitución de la pena impuesta por medidas de seguridad, cuando revistan entidad suficiente para incapacitar al sujeto para la compresión del sentido de la pena -nótese igualmente la diferencia con el art. $20 \mathrm{CP}$ que predica la incapacidad del sujeto para "comprender la ilicitud del hecho o actuar conforme a esa comprensión"-, ya que se exige que el trastorno sea duradero y grave ${ }^{484}$.

Sin duda la cuestión más compleja es qué debe entenderse por "sentido de la pena" a efectos de la sustitución en estos supuestos, porque la pena cuenta con finalidad retribucionista y reeducadora (art. 25.2 CE y art. 1 LOGP), y adentrándonos en contenidos más dogmáticos, podríamos incluso hablar de fortalecimiento de la vigencia de la norma y reafirmación del ordenamiento jurídico, prevención general positiva y negativa, prevención especial, etc. En ese sentido, no es exigible a quien es perfectamente imputable que conozca todos estos fines de la pena, sino que, a estos efectos, únicamente debe entenderse como la mera retribución y reeducación. Pero respecto al art. $60 \mathrm{CP}$, no parece tan claro que la incapacidad de comprensión incluya tanto el fin reeducador como el retribucionista, puesto que la sustitución de una pena privativa de libertad por una medida de seguridad también privativa de libertad como exige el precepto, estará

\footnotetext{
484 Aunque hay autores que esta formulación tan imprecisa no genera pocos problemas. DE LLERA SUÁREZBÁRCENA, E., “Imputabilidad y fines de la pena. La relación de los efectos psicológicos previstos en el art. 20 y en el art. 60 CP". En Estudios de Derecho judicial, núm. 110. Actual doctrina de la imputabilidad. Madrid: Consejo General del Poder Judicial. 2007, p. 275. Este autor explica que "el art. 60 exige por otro lado características del trastorno mental que éste sea grave y duradero, pero no establece cuánto de grave ni cuánta duración. En realidad el adjetivo "grave" sin más constituye un concepto jurídico indeterminado que genera campos de inseguridad jurídica y que sugiere al juez la conveniencia de apoyarse exclusivamente en los dictámenes psiquiátricos con todas sus ventajas y también sus inconvenientes. Tampoco resuelve la norma los supuestos de enfermedades metales intermitentes. Otro tanto sucede con el carácter duradero de la situación de trastorno mental, que implica una cierta duración temporal y que tampoco delimita el precepto, de modo que únicamente sirve para eliminar del ámbito de aplicación del art. 60 las situaciones de trastorno mental transitorio aludidas por el art. $20.1^{\circ}$, párrafo $2^{\circ} \mathrm{CP}$, aproximándose así al viejo concepto de enajenación, tendiendo a considerar tales trastornos como duraderos cuando el pronóstico de los peritos no pueda establecer su duración".
} 
igualmente orientada a la reeducación y reinserción social (art. 25.2 CE), por lo que extender el fin reeducador al parámetro de la incapacidad de comprensión de la pena, no parece tener mucho sentido, con la añadidura de que el tratamiento reeducador que pueda proporcionarse al penado en prisión no es ni siquiera una actividad fundamental del actividad penitenciaria —que se centra en la custodia de los internos (art. 1 LOGP)—, sino que lo que existe es un derecho fundamental del interno el que las penas se orienten hacia ese fin ${ }^{485}$, pero no está obligado a recibir dicho tratamiento de reiserción ni a someterse al mismo ${ }^{486}$.

No obstante, conviene que nos detengamos en algunos aspectos que comenta la doctrina. El primero es la cuestionable opción legislativa que acude a las medidas de seguridad en caso de inimputabilidad sobrevenida, ya que, en estos casos no puede hablarse - en rigor en cuanto a los principios- de peligrosidad criminal que fundamenta las medidas de seguridad porque no deriva de la comisión de un delito, sino de un estado incidental que sobreviene durante la ejecución de la pena y que coloca al sujeto en situación de inimputabilidad. Además, la solución elegida se aparta del principio de jurisdiccionalidad al permitir que sea el JVP mediante auto en un incidente en la ejecutoria quien acuerde la imposición de una medida de seguridad, cuando tendría que ser el Juez o Tribunal encargado del plenario quien lo acuerde en la sentencia. Por eso, hay autores que señalan que la opción no es del todo satisfactoria y que lo procedente sería acudir al proceso del art. 763 LEC para el internamiento involuntario 487.

\footnotetext{
485 Derecho fundamental que, como ha venido declarando el TC, no es susceptible de ser invocado en amparo ya que, pese a su ubicación sistemática, no es más que un mandato constitucional dirigido al legislador, STC 28/1998 y 88/1998; y ATC 15/1984 y 219/1988, entre otras muchos resoluciones en ese sentido.

486 ZÚÑIGA RODRÍGUEZ, L., "El tratamiento penitenciario". En BERDUGO GÓMEZ DE LA TORRE, I. (Coord.), Lecciones y materiales para el estudio del Derecho penal. Tomo VI. Derecho penitenciario. Madrid: Iustel. 2010, p. 151. Según esta autora "en el ámbito penitenciario, el vocablo tratamiento se une con diversos significados. Primero, sirve para delimitar las actividades que se desarrollan en el régimen penitenciario encaminadas a la resocialización. Segundo, constituye el núcleo argumental de las decisiones que se toman sobre los penados. Y, tercero, sirve para denominar al personal responsable de las actividades resocializadoras".

487 Sobre este proceso vid. CHIMENO CANO, M., Incapacitación, tutela e internamiento del enfermo mental. Navarra: Thomson Aranzadi. 2003, pp. 19 y ss.; GÓMEZ COLOMER, J.L., "Procesos civiles no dispositivos". En MONTERO AROCA, J. / GÓMEZ COLOMER, J.L. / BARONA VILAR, S. / CALDERÓN CUADRADO, M.P., Derecho jurisdiccional II. Proceso Civil. 21 ${ }^{\text {a }}$ Ed. Valencia: Tirant lo Blanch. 2013, pp. 762 a 769; BANACLOCHE PALAO, J. “Los procesos especiales”. En BANACLOCHE PALAO, J. / CUBILLO LÓPEZ, I.J., Aspectos fundamentales de Derecho procesal civil. Madrid: La Ley. 2012, pp. 448 a 452; ASENCIO MELLADO, J.M., en ASENCIO MELLADO, J.M. (Coord.), Ley de Enjuiciamiento Civil comentada y con jurisprudencia. Madrid: La Ley. 2013, pp. 2166 a 2170; LOZANO BLANCO, J., en TORIBIOS FUENTES, F. (Dir.), Comentarios a la Ley de Enjuiciamiento Civil. Valldolid: Lex Nova. 2012, pp. 1424 a 1426; ORTELLS RAMOS, M. / CUCARELLA GALIANA, L.A., en GIMENO SENDRA, V. (Dir.), Proceso civil práctivo. Tomo X. 4 a Ed. Madrid: La Ley. 2010, pp. 231 a 251; GONZÁLEZ POVEDA, P., en XIOL RÍOS, J.A., (Coord.) Enjuiciamiento civil. Comentarios y
} 
El segundo aspecto es el concerniente a cuando se trate de penas no privativas de libertad que el reo se halle cumpliendo, que se sustituirán por las medidas de seguridad que el JVP considere necesarias según dispone el propio art. $60 \mathrm{CP}$, que no termina de aclarar si la medida a imponer podrá o no ser privativa de libertad, esto es, si solo es posible imponer tratamiento ambulatorio o si, por el contrario, puede imponerse cualquier medida atendiendo a las necesidades y a la salud mental del sujeto. Esta segunda opción no parece que pueda descartarse, por lo que la doctrina expresa que igualmente la opción es insatisfactoria, ya que, para estos casos, habría sido preferible remitir en bloque al internamiento involuntario en el ámbito del proceso civil. Por todo ello, se afirma que la opción de acudir a la imposición de medidas de seguridad en estos casos del art. $60 \mathrm{CP}$, no responde a una precisión conceptual técnica, sino que a lo que se remite es al contenido material de las medidas de seguridad, no a ellas en sentido técnico ${ }^{488}$.

F) Por último, conviene hacer referencia al supuesto en el que el imputado carece de capacidad procesal, que se define como la aptitud mental y corporal necesaria para seguir el proceso, para percibirlo con naturalidad y poder materializar la contradicción. No obstante, en estos casos no se trata de una cuestión jurídica como sucede en el ámbito civil, donde la ausencia de capacidad procesal debe acreditarse mediante una sentencia de incapacitación, sino que en el fuero penal se trata de una apreciación fáctica que puede desprenderse durante la tramitación de la causa, en cuyo caso el Juez ordenará la exploración médico-forense del imputado (art. 381 LECrim) y, si le falta la capacidad procesal por enajenación o alteración grave de la percepción, puede sobreseer la causa (art. 637.3 ${ }^{\circ}$ LECrim) y acordar el internamiento o alguna de las medidas de seguridad del

jurisprudencia. Tomo III. Madrid: Sepín. 2008, pp. 4345 a 4352; GARBERÍ LLOBREGAT, J. Derecho procesal civil. Procesos declarativos y proceso de ejecución. ${ }^{2}$ Ed. Barcelona: Bosch. 2012, pp. 599 a 612; GARCÍA Y GARCÍASOTUGA, F.J., en CORDÓN MORENO, F. / ARMENTA DEU, T. / MUERZA ESPARZA, J.J. / TAPIA FERNÁNDEZ, I., (Coords.), Comentarios a la Ley de Enjuiciamiento Civil. Vol. II. Navarra: Aranzadi. 2001, pp. 774 a 778; VÁZQUEZ IRUZUBIETA, C., Comentario a la Ley de Enjuiciamiento Civil. ${ }^{\mathrm{a}}$ Ed. Madrid: Economist \& Jurist. 2012, pp. 1104 a 1106; GARBERÍ LLOBREGAT, J. (Dir.) / TORRES FERNÁNDEZ DE SEVILLA, J.M. / CASERO LINARES, L., Los procesos civiles. Comentarios a la Ley de Enjuiciamiento Civil, con formularios y jurisprudencia. Vol. 4. $2^{\text {a }}$ Ed. Barcelona: Bosch. 2010, pp. 3210 a 3223. APARICIO AUÑÓN, E., en LORCA NAVARRETE, A.M. (Dir.) / GUILARTE GUTIÉRREZ, V. (Coord.), Comentarios a la nueva Ley de Enjuiciamiento Civil. Tomo IV. Valladolid: Lex Nova. 2000, pp. 4033 a 4043; SANCHO GARGALLO, I., en FERNÁNDEZBALLESTEROS, M.A. / RIFÁ SOLER, J.M. / VALLS GOMBAU, J.F., (Coords.), Comentarios a la Nueva Ley de Enjuiciamiento Civil. Tomo III. Barcelona: Atelier. 2000, pp. 3464 a 3476.

488 ACALE SÁNCHEZ, M., “Medición de la respuesta punitiva..., cit. pp. 172 a 177. Esta autora afirma que por estos motivos, la referencia que la LO 5/2010 hace a que el art. $60 \mathrm{CP}$ es un antecedente de imposición conjunta de penas y medidas de seguridad para el imputable, en realidad no es cierta. 
art. 96.2 CP. Sin embargo, esto no siempre sucede de esa forma, ya que este procedimiento solo resulta de aplicación cuando de las diligencias sumariales resulta patente la falta de capacidad procesal del imputado, por lo que, con frecuencia, se tramita todo el proceso y en la sentencia es donde se declara la inimputabilidad y la consecuente absolución que va acompañada de la imposición de medidas de seguridad ${ }^{489}$.

Por otra parte, puede producirse la demencia sobrevenida con archivo de la causa, prevista en el art. 383 LECrim $^{490}$, demencia que incapacita al procesado para someterse al juicio oral y para ejercitar su defensa en condiciones normales, en cuyo caso "si aquélla hubiera sobrevenido tras la comisión de los hechos dará lugar, concluida la instrucción, al archivo de la causa hasta que, en su caso, se recobrara la sanidad quedando el afectado internado en lugar adecuado (art. 383 LECrim y 101 CP)"491. El fundamento estriba en el núcleo fundamental del derecho de autodefensa y de asistencia letrada, ambas vertientes del derecho de defensa, que se ven menoscabadas en el caso de que el sujeto no esté capacitado para ejercitarlo, en el sentido de la "posibilidad de seguir todas las vicisitudes del proceso, afrontar su interrogatorio y hacer a su abogado y al Tribunal todas las observaciones que fuesen pertinentes sobre el desarrollo de las pruebas o sobre cualquier otra incidencia o circunstancia que pueda surgir en el desarrollo del juicio"492. En estos casos, como la demencia sobreviene después de haberse cometido el delito, el Juez puede ordenar el reconocimiento forense del imputado y archivar la causa en lo concerniente a él, adoptando alguna de las medidas de seguridad del art. 96.2 CP y pudiendo proseguir el juicio si hay otros imputados. Si el enajedo recupera la salud mental, el proceso se reabrirá para continuarlo ${ }^{493}$.

\footnotetext{
${ }^{489}$ FERREIRO BAAMONTE, X.X., en PÉREZ-CRUZ MARTÍN, A.J. / FERREIRO BAAMONTE, X.X. / PIÑOL RODRÍGUEZ, J.R. / SEOANE SPIEGELBERG, J.L., Derecho Procesal penal. $2^{\mathrm{a}}$ Ed. Navarra: Civitas. 2010, p.143.

490 "Art. 383. Si la demencia sobreviniera después de cometido el delito, concluso que sea el sumario, se mandará archivar la causa por el Tribunal competente hasta que el procesado recobre la salud, disponiéndose, además, respecto de éste, lo que el Código Penal, prescribe para los que ejecutan el hecho en estado de demencia. / Si hubiese algún otro procesado por razón del mismo delito que no se encontrase en el caso del anterior, continuará la causa solamente en cuanto al mismo".

491 MONTÓN REDONDO, A., “Los actos de investigación”. En MONTERO AROCA, J. / GÓMEZ COLOMER, J.L. / MONTÓN REDONDO, A. / BARONA VILAR, S., Derecho Jurisdiccional III. Proceso Penal. $21^{\text {a }}$ Ed. Valencia: Tirant lo Blanch. 2013, p. 212.

${ }^{492}$ DE LLERA SUÁREZ-BÁRCENA, E., "Imputabilidad y fines de la pena...", cit. p. 276, con cita de la STS de 2 de abril de 1993.

${ }^{493}$ FERREIRO BAAMONTE, X.X., en PÉREZ-CRUZ MARTÍN, A.J. / FERREIRO BAAMONTE, X.X. / PIÑOL RODRÍGUEZ, J.R. / SEOANE SPIEGELBERG, J.L., Derecho Procesal..., cit. p. 144.
} 


\section{La peligrosidad criminal}

Como hemos venido diciendo, las medidas de seguridad se aplican con fundamento en la peligrosidad, de tal forma que nos resta por examinar cuál es el significado de la misma, en qué supuestos se constata, cuáles son los métodos por los que se determina y en qué casos persiste en el sujeto por encima de todas las cosas. El peligro se define por la doctrina como el "riesgo o contingencia inminente de que suceda algún mal" ${ }^{494}$, de cuya literalidad se extraen dos elementos: la posibilidad o probabilidad de que se produzca un resultado; y el carácter dañoso o lesivo de dicho resultado. La peligrosidad, es la capacidad criminal, que constituye el núcleo central del estado peligroso ${ }^{495}$.

Por otra parte, la peligrosidad abarca tanto el aspecto innato del sujeto como el ambiente en el que vive o desarrolla su vida social, por lo que, en principio, podemos distinguir entre peligrosidad como inadaptación social, que suele darse en personas que padecen alteraciones o trastornos psíquicos o enfermedades infectocontagiosas, circunstancia que les coloca en una situación de inadaptabilidad social por la que la percepción del resto de la gente es que esas personas representan un peligro real, aunque no suelen cometer delitos sino meras conductas antisociales derivadas de sus patologías 496; o peligrosidad como condición interna del sujeto, en los términos en los que se refirió GAROFALO a la temibilitá como perversidad ${ }^{497}$ que persiste en el delincuente y la magnitud del mal que puede temerse de él ${ }^{498}$.

\footnotetext{
494 SIERRA LÓPEZ, M.V., Las medidas de seguridad..., cit. p. 83.

495 LANDECHO VELASCO, C.M., en COBO DEL ROSAL, M., (Dir.), Comentarios..., cit. Tomo IV, p. 49.

496 LEAL MEDINA, J., “Un estudio de las actuales medidas...”, cit. p. 202.

497 LANDECHO VELASCO, C.M., en COBO DEL ROSAL, M., (Dir.), Comentarios..., cit. Tomo IV, p. 49. En 1880, Garófalo publica su obra "Di un criterio positivo della penalità", donde introduce el término "temibilità" del que deriva el actual de peligrosidad.

498 Como indica RAMOS, J.P., Curso de Derecho penal..., cit. Tomo I, pp. 266 y 267, “existe una clase de criminales que tienen anomalías psíquicas y muy frecuentemente anomalías anatómicas, no patológicas, sino con un carácter degenerativo o regresivo, y a veces atípico; muchos de cuyos rasgos prueban la suspensión de desarrollo moral, aún cuando la facultad de ideación sea normal; criminales que tienen ciertos instintos y ciertos arranques que pueden compararse a los de los salvajes y a los de los niños; que están, por último, desprovistos de todo sentimiento altruista, y, por tanto, obran exclusivamente bajo el impulso de sus deseos. Estos son lo que cometen los asesinatos por motivos exclusivamente egoístas, sin influjo alguno de prejuicios, sin complicidad indirecta del medio social. Como la anomalía es absolutamente congénita, la sociedad no tiene deber alguno para con ellos; y respecto de sí misma, no tiene más que el de suprimir a aquellos seres con los que no puede hallarse ligada por vínculo alguno de simpatía, los cuales, obrando tan sólo por egoísmo, son incapaces de adaptación y representan un continuo peligro para todos los miembros de la asociación".
} 
Por el contrario, la peligrosidad puede ser entendida como un conjunto de condicionantes externos que influyen en el sujeto y lo convierten en peligroso ${ }^{499}$. Pero lo realmente relevante es establecer una norma jurídica por la que encuadrar en el sistema penal la peligrosidad, que normalmente se traduce en la previsión de la reincidencia, o la descripción de estados peligrosos que serán el presupuesto de la peligrosidad, como la previa comisión de un delito y la concurrencia de causas de inimputabilidad ${ }^{500}$.

El concepto de peligrosidad está dotado de una enorme ambigüedad ${ }^{501}$, y con frecuencia suele ser utilizado como instrumento para la materialización de políticas criminales en orden a la represión de determinadas conductas a las que únicamente cabría circunscribir en el ámbito de las penas, por lo que no es extraño encontrar que la peligrosidad es invocada como fundamento para el endurecimiento de la represión penal $\mathrm{y}$, en concreto, como justificación para la imposición de penas o el incremento de la duración de las mismas. Es más, en el ordenamiento español existen referencias directas a la peligrosidad en la normativa penitenciaria, como en el art. 10 LOGP, que dispone que los establecimientos de régimen cerrado o departamentos especiales estarán destinados a los "penados de peligrosidad extrema" o para casos de indapatados; y en los mismos términos está redactado el art. 102.5, apartado 2, letra c) del Reglamento Penitenciario, que además dispone que para la clasificación en primer grado de los internos de peligrosidad extrema, se ponderará "la pertenencia a organizaciones delictivas o bandas armadas mientras no muestren signos de haber abandonado la disciplina interna de

\footnotetext{
499 Feuerbach concebía la peligrosidad como la cualidad de la persona que hace presumir fundadamente que violará la ley; para Rocco era la potencia, aptitud, idoneidad o capacidad personal para ser autor de actos nocivos o peligrosos; y para Grispigni, consistía en la capacidad personal de ser con probabilidad el autor. Vid. GONZÁleZ ROURA, O., Derecho Penal. Parte General. Tomo II. $2^{\mathrm{a}}$ Ed. Buenos Aires: Valerio Abeledo Editor. 1925, p. 177.
}

500 LEAL MEDINA, J., “Un estudio de las actuales medidas...”, cit. p. 214. Como señala este autor: "si la integración de todas las tendencias que se conocen acerca de la idea de peligrosidad como norma jurídica, y tomando como faceta de examen cualquiera de los elementos que la componen, pueden dar como resultado una definición que haga referencia al estado de inadaptación social de un individuo, a las circunstancias internas que le condicionan, o a los aspectos ambientales que le influyen poderosamente, lo cierto es que si una ley que determine y establezca las conductas exteriorizadas, que además de resultar contrarias y dañosas a la ordenada convivencia, resulten tipificadas como delictivas o antisociales, no podríamos hablar de la peligrosidad como el presupuesto que les da vida. Aunque el concepto de peligrosidad no sólo resulta predicable de los aspectos sustantivos del derecho penal y por tanto referido al ámbito de la inimputabilidad, a los delitos ya cometidos y los que se presume que el sujeto cometerá en el futuro, sino que conjurar el peligro de determinados individuos ha sido entendido y relacionado con el proceso penal, que aparece para la moderna dogmática criminal como instrumento firme de protección social".

501 GUDÍN RODRÍGUEZ-MAGARIÑOS, F., La nueva medida de seguridad postdelictual de libertad vigilada. Especial referencia a los sistemas de control telemáticos. Valencia: Tirant lo Blanch. 2011, p. 94. Expresa este autor que "el concepto de peligrosidad más que un concepto jurídico indeterminado puede ser reputado como un potencial jurídico tan etéreo como difuso". 
dichas organizaciones", por lo que, en el caso de los terroristas, se les entenderá extremadamente peligrosos mientras no renuncien a su pertenencia a la organización, sin tener en cuenta otros aspectos derivados de su peligrosidad subjetiva ${ }^{502}$.

En principio no hay una sola clase de peligrosidad503, y su existencia misma ha estado siempre presente en la evolución histórica del Derecho penal como ya se ha visto anteriormente, pero se trata de un concepto ampliamente difuso cuya concreción no resulta tan sencilla como la determinación de la culpabilidad o de una mera causa de inimputabilidad, sino que implica una prognosis que se anticipa a los ulteriores actos que pudiere cometer, lo cual no resulta en absoluto tarea fácil. LANDECHO VELASCO habla de que existe, junto con la distinción de peligrosidad social y peligrosidad criminal, otra distinción basada en si la peligrosidad es predelictual o postdelictual. La primera concurre cuando el sujeto todavía no ha sido condenado por delito alguno o cuando todavía no lo ha cometido, pero puede que sí los haya cometido y que, simplemente, no se haya podido demostrar o no haya sido objeto de fijación por parte de las autoridades de persecución de los delitos, ya que, con frecuencia, la habitualidad delictiva comienza a manifestarse a edades cortas y suele tardar en detectarse. La segunda, la peligrosidad postdelictual se desprende de la previa condena por un delito. Lo imporantante de esta distinción, como señala este autor, es que permite la fijación de los límites de la intervención estatal en materia de tratamiento penal de los estados peligrosos en consonancia con los principios de presunción de inocencia y de mínima intervención penal504.

Como indica VIVES ANTÓN, la peligrosidad únicamente es capaz de observar el daño presente como un mero indicio del posible daño que puede producirse en el futuro, por lo que "la categoría del daño se reconduce a la del riesgo". De ahí que las dos categorías que resultan sean la peligrosidad criminal que se traduce en la probabilidad de

\footnotetext{
502 CÁMARA ARROYO, S., “La libertad vigilada en adultos: naturaleza jurídica, modos de aplicación y cuestiones penitenciarias". En La Ley Penal, núm. 96-97, 2012, p. 12.

503 GONZÁleZ ROURA, O., Derecho Penal. Parte General..., cit. Tomo II, p. 181. Este autor señala que "si bien los términos "peligrosidad" y "estado peligroso" son usados como equivalentes, convendría dar al primero un sentido genérico y uno específico al segundo, en el sentido de excluir del último la peligrosidad congénita, permanente o en estado latente, como serían entre otros, los autores de crímenes atroces, los anormales o defectuosos, los habitantes, etc., y para los peligrosos aún no delincuentes".
}

504 LANDECHO VELASCO, C.M., en COBO DEL ROSAL, M., (Dir.), Comentarios..., cit. Tomo IV, pp. 56 y 57. 
delinquir, y peligrosidad social que se traduce en un riesgo para la comunidad ${ }^{505}$. En ambas categorías de peligrosidad, tanto la reacción como la forma de combatirlas deben ser distintas 506 .

La peligrosidad social es "el estado de inadaptación social de un individuo, exteriorizado por conductas contrarias a la ordenada convivencia, tipificadas como delictivas o antisociales, del que se deriva la relevante probabilidad de que continuará realizando acciones dañosas para la sociedad"507. La doctrina señala que se puede definir la peligrosidad social como una alta probabilidad de que una persona cause un mal jurídico a la comunidad por medio de sus acciones futuras ${ }^{508}$. Esta clase de peligrosidad es la propia del individuo asocial, que está inadaptado o marginado en la vida social, pero no suele ser frecuente que delinca o, en cualquier caso, no suele cometer delitos de especial gravedad, sino que sus transgresiones a la ley penal se indetifican con pequeños hurtos o delitos leves contra el patrimonio, en la mayoría de ocasiones constitutivas de faltas. Pero lo relevante es que esta clase de sujetos no consigue llevar una vida con el valor de la regularidad en el trabajo, ni puede adaptar su comportamiento a la regularidad que marca la vida en sociedad, de forma que se va quedando al margen de ella, cual si fuese un parásito que se traduce en la mendicidad como forma de vida, pero no puede afirmarse que sea un delincuente peligroso ${ }^{509}$, aunque moleste en la convivencia en sociedad y sea un asocial.

La peligrosidad criminal es "la cualidad de la persona en la que se aprecia, demuestra o revela, una alta probabilidad para cometer futuros hechos previstos en la ley como delitos. Lo decisivo es que la elevada probabilidad vaya referida a la perpetración de posteriores y previsibles ilícitos penales"510. Se presenta así esta clase de peligrosidad

505 VIVES ANTÓN, T.S., “Métodos de determinación de la Peligrosidad”. En VIVES ANTÓN, T.S., La libertad como pretexto. Valencia: Tirant lo Blanch. 1995, p. 18. Edición original en Peligrosidad social y medidas de seguridad, Colección de Estudios del Instituto de Criminología y Departamento de Derecho Penal de la Universidad de Valencia. 1974.

506 REBOLLO VARGAS, R., “De las medidas de seguridad...”, cit. p. 792.

507 MORENILLA RODRÍGUEZ, J.M., "Peligrosidad social y la tipología del sujeto peligroso". En Documentación Jurídica núm. 20. Madrid: Ministerio de Justicia, Secretaría General Técnica. 1978, p. 1178.

508 VIVES ANTÓN, T.S., “Métodos de determinación de la Peligrosidad...”, cit. p. 19.

${ }^{509}$ LANDECHO VELASCO, C.M., en COBO DEL ROSAL, M., (Dir.), Comentarios..., cit. Tomo IV, p. 57.

510 LEAL MEDINA, J., “Un estudio de las actuales medidas...”, cit. pp. 216 a 226. Este autor distingue entre peligrosidad criminal propiamente y peligrosidad social, entendida como una probabilidad de realizar una conducta socialmente nociva que no llega a ser delictiva. 
como la posibilidad de que una persona delinca o de que siga una "vida delincuencial", lo que se traduce en una conducta antisocial que coloca al individuo como una verdadera amenaza para la sociedad en su conjunto, porque se autocoloca en contra de la estructura de la legalidad y convive transgrediéndola511. Como afirman COBO DE ROSAL y VIVES ANTÓN, "la peligrosidad es básicamente una situación o status de la persona que ha de ser formulado judicialmente. Así, pues, se trata de un juicio, y más precisamente, de un juicio de futuro, en la medida que supone la afirmación de una probabilidad de delinquir. En ese sentido, la peligrosidad no es más que un pronóstico" 512.

La peligrosidad criminal se determina a través del método intuitivo, con una predicción de futuro, que requiere una primera fase de investigación de la personalidad peligrosa, en la que el Juez debe, junto con el enjuiciamiento de los hechos, valorar a la persona indagando en su posible peligrosidad criminal, que no es otra cosa que el conjunto de cualidades y rasgos que le distinguen de los demás, que le definen y que proyectan sobre el sujeto la forma de representar la realidad y de formarse una explicación de lo que sucede a su alrededor. La personalidad es la forma en que cada individuo piensa, siente y se comporta, que deriva de un proceso de formación de la misma que se fragua durante toda su vida. Es "el conjunto de cualidades propias que condensan elementos biológicos, psicológicos, socioculturales que conforman un todo propio e individual que aparece y se manifiesta ante los demás y modula el comportamiento. [...] Representa la estructura psicológica total del individuo, tal y como se revela en la forma de pensar y expresarse, en sus actitudes e intereses, en sus acciones y en su visión de la vida" ${ }^{513}$. La personalidad se compone de una serie de rasgos adquiridos y de otros innatos o genéticos que afectan de modo directo a la predisposición delictiva, para lo cual será necesario llevar a cabo tanto un análisis antropológico, como somático y psíquico que permita la predicción del comportamiento en el futuro, siendo la pieza esencial el informe médico, psicológico o psiquiátrico, elaborado por expertos, aunque la predicción certera no es algo que pueda afirmarse como plenamente posible o fiable 514.

\footnotetext{
511 LANDECHO VELASCO, C.M., en COBO DEL ROSAL, M., (Dir.), Comentarios..., cit. Tomo IV, p. 57.

512 COBO DEL ROSAL, M. / VIVES ANTÓN, T.S., Derecho penal. Parte General..., cit. p. 991.

513 LEAL MEDINA, J., “Un estudio de las actuales medidas...”, cit. p. 255.

514 Ibidem, pp. 258 y 259. Expresa este autor que “aunque el alto número de variables que inciden en el análisis de la personalidad hacen que se difumine el objeto del proceso preventivo que no es otro que deducir la peligrosidad criminal del individuo, por lo que la meta final se torna resbaladiza y difícil de acotar, poniendo en riesgo la finalidad terapéutica de la medida, no es menos cierto que la imprecisión que contiene su estudio,
} 
Una segunda fase de deducción de la peligrosidad, que no plantea pocos problemas, es la que requiere un juicio de pronóstico, para el que existen varios métodos de los que podemos destacar, en esencia, el método científico y el método intuitivo, de los que me ocuparé seguidamente; pero, en cualquier caso, conviene tener en cuenta que la peligrosidad puede extraerse de factores únicamente relacionados con el propio sujeto, pero también derivados de su entorno o de la naturaleza de delito cometido, por lo que no es infrecuente la combinación de métodos o la conjugación de criterios legales que hagan referencia a tales extremos como requisitos para la imposición de medidas de seguridad basadas en la peligrosidad criminal ${ }^{515}$.

\subsection{Métodos de determinación de la peligrosidad}

Sin duda la cuestión más compleja en relación a la peligrosidad es su determinación, su constatación y su efectiva predicción. El art. $95 \mathrm{CP} \multimap$ como ya se ha visto supra- dispone que la peligrosidad se desprende de una suerte de pronóstico de comportamiento futuro que será revelador de probabilidades de comisión de nuevos delitos, pero, como viene afirmando la doctrina, "habrá que saber cómo puede realizarse dicho pronóstico, rechazando de plano el denominado "intuitivo", que no es otra cosa que el realizado por el juez sin base científica y fiándolo todo a su "ojo clínico"516. No obstante, existen varios métodos para llevar a cabo dicho proceso en el que se determine la pretendida peligrosidad, de lo que me ocupo en el presente apartado que seguidamente paso a desarrollar.

1. Los métodos científicos. También llamado método "empírico-discursivo"517, consiste en que la ciencia basa sus teorías científicas en el sometimiento a una

se puede ver atenuada por el soporte técnico pericial de los informes de conducta y de las opiniones científicas que se viertan al tribunal acerca de la personalidad del sujeto".

515 GUDÍN RODRÍGUEZ-MAGARIÑOS, F., La nueva medida de seguridad..., cit. p. 97. Este autor expresa que “la peligrosidad, como requisito que recoge el Código penal para aplicar una medida de seguridad en el art. 95.1, se puede entender desde un punto de vista subjetivo u objetivo. El primero se halla relacionado con el individuo y los factores internos de capacidad criminal; de personalidad, carácter estado sensitivo-emocional que predisponen al sujeto a delinquir. El segundo, guarda relación con el delito cometido y los factores externos del sujeto; con el ambiente y entorno o como recoge la STS de 2 de octubre de 1999, con la proximidad entre el delincuente y su víctima o su familia, y la consiguiente posibilidad de enfrentamientos mutuos".

516 GARCÍA RIVAS, N., “La libertad vigilada...”, cit. p. 16.

517 VIVES ANTÓN, T.S., “Métodos de determinación de la Peligrosidad...”, cit. p. 19. 
multiplicidad de experimentos de ataque a la hipótesis para conseguir refutarla y, si no se consigue, la teoría se convierte en válida. Ahora bien, si uno de esos experimentos falla, no puede hablarse con plena certeza de que la teoría sea cierta científicamente, por lo que queda frustrada o "falsada" 518. Sin embargo, cuando se trata de ofrecer un pronóstico de peligrosidad criminal, lo cierto es que cualquier técnica utilizada que haya arrojado algún resultado constatado, no puede ser completamente fiable, y únicamente si se apoya en una teoría de ciencia pura de la que se deduzca un pronóstico fiable podrá ser considerado un verdadero método científico de prognosis criminal, lo cual se busca en diversos ámbitos de la ciencia como la biología, la psicología o la neurociencia.

a) La fundamentación biológica. Para esta fundamentación fue crucial la obra de LOMBROSO519, por la que se proclama una concepción del delincuente nato, con características anatómicas y fisiológicas distintas que se manifiestan incluso a través de rasgos físicos que le identificaban claramente como una especie de hombre destinado al delito que, para la teoría lombrosiana, no tenía cabida en la sociedad ${ }^{520}$. En consonancia con las tesis positivistas que negaban la existencia del libre albedrío, un sujeto con unas características biológicas diferenciables y determinadas, vendría a ser un delincuente efectivo o en potencia. LOMBROSO publicó en 1876 su obra “Tratado antropológico experimental del hombre delincuente", basada en la utilización del método empírico a través del análisis de más de cuatrocientas autopsias de delincuentes, seis mil estudios sobre delincuentes vivos fuera de prisión, y de otros veinticinco mil reclusos en prisiones de toda Europa; distinguiendo seis categorías de delincuentes: el nato o atávico, el loco moral, el epiléptico, el loco ocasional y el pasional; la delincuencia femenina 521, y el

\footnotetext{
518 Ibidem, p. 21. Este autor indica que, no obstante, "siempre es posible encontrar una vía de escape de la falsación, por ejemplo, mediante la introducción ad hoc de una hipótesis auxiliar o por cambio de ad hoc de una definición: se puede, incluso, sin caer en incoherencia lógica, adoptar la posición de negarse a admitir cualquier experiencia falsadora". Cuando los defensores de una hipótesis cualquiera, ante los resultados negativos de su confrontación con los hechos emprenden, cosa nada infrecuente, el camino de rehuir la falsación recurriendo a cualquiera de los expedientes citados, dan a su teoría un "sesgo convencional": ya no podrá ser refutada, pero por eso mismo habrá dejado de pertenecer a la ciencia”. (La cursiva es mía).

519 LOMBROSO, C., L'uomo delinquente.Torino: Fratelli Bocca Editori. 1889.

520 VIVES ANTÓN, T.S., "Métodos de determinación de la Peligrosidad...", cit. p. 22. Este autor indica que "en la flamante era burguesa, el delincuente no tenía sitio adecuado. Era preciso presentarlo como un residuo de épocas pretéritas y salvajes, como un despojo evolutivo. De acuerdo con los principios positivistas, Lombroso concibió a ese ser como fatalmente destinado al delito por sus deficiencias orgánicas".
}

${ }^{521}$ LOMBROSO, C. / FERRERO, G., La donna delinquente, la prostitutita en la donna normale. Torino: Frateli Bocca Editore. 1903. 
delincuente político ${ }^{522}$, y en su teoría de la criminalidad relaciona el atavismo con la epilepsia y la locura moral, de forma que el criminal nato es un ser inferior atávico, que no ha sido capaz de evolucionar ${ }^{523}$.

Posteriormente, aparecen una serie de modelos científico-positivistas y neopositivistas, que orientan sus teorías biológicas en varias direcciones, como la Antropometría en la que destacan autores como BERTILLON, que rechaza la teoría lombrosiana pero propone un complejo entramado de once medidas corporales que, junto con un sistema de fotografías comparativas de otros delincuentes, hallaba el canon perfecto para identificar al delincuente524; o la Antropología, con autores como GORING, que era un médico de prisiones que en su obra "The English Convict", refutó la tesis lombrosiana y aunque admitía la inferioridad heredada del criminal, no admitía la existencia de características físicas del delincuente ${ }^{525}$. Y también la teoría del antropólogo HOOTON, que en 1939 publicó su obra "The American criminal. An Anthropological Study", en la que rebate a GORING mostrándose a favor de la teoría de que el delincuente es un ser inferior biológicamente y que el crimen solo se combate extirpando el sustrato físico y psíquico de

522 GARCÍA-PABLOS DE MOLINA, A., Criminología..., cit. pp. 259 y 256. Como explica este autor, “en cuanto a la teoría lombrosiana de la criminalidad, ocupa un lugar destacado la categoría del delincuente "nato", esto es, una subespecie o subtipo humano (entre los seres vivos superiores pero sin alcanzar el nivel superior del "homo sapiens"), degenerado, atávico (producto de la regresión y no de la evolución de las especies), marcado por una serie de "estigmas" que le delatan e identifican y se transmiten por vía hereditaria. LOMBROSO inició sus investigaciones antropológicas a raíz de los hallazgos que creyó encontrar al examinar el cráneo de un conocido delincuente ("una larga serie de anomalías atávicas, sobre todo una enorme foseta occipital media y una hipertrofia del verme, análoga a la que se encuentra en los vertebrados inferiores"). Y basó el "atavismo" o carácter regresivo del tipo criminal en el examen del comportamiento de ciertos animales y plantas, en el de tribus primitivas y salvajes de civilizaciones aborígenes e, incluso, en ciertas actitudes de la psicología infantil profunda".

523 LOMBROSO, C., Los criminales. Barcelona: Centro editorial Presa. 1876, pp. 7 a 55.

524 BERTILLON, A., “La identificación antropométrica”. En Revista Mexicana de Criminología, núm. 1, 1976. Citado por GARCÍA-PABLOS DE MOLINA, A., Criminología..., cit. p. 309, nota al pie 99.

525 GARCÍA-PABLOS DE MOLINA, A., Criminología..., cit. pp. 310 y 311. Este autor explica que la obra “The English Convict" es un estudio biométrico, con sólido respaldo estadístico, con el que GoRING respondía a un célebre reto de LOMBROSO. Para el autor, LOMBROSO se sirvió de un método anatómico patológico, basado en la observación directa, pero sin instrumentos de medición objetivos, infiriendo, en consecuencia, la supuesta normalidad o anormalidad del individuo de los estigmas así detectados. En su lugar, GoRING se mostró partidario de un método estadístico, que podría ofrecer mediciones precisas y fiables, con independencia de posibles prejuicios del investigador. Sus conclusiones fueron dos: en primer lugar, que carecía de fundamento científico la tesis lombrosiana del delincuente como tipo físico, sui generis, en sentido antropológico. GoRING no encontró estigmas degenerativos ni diferencias sensibles entre el grupo criminal y el no criminal. En segundo lugar, que sí había base empírica para mantener la inferioridad del criminal y el carácter hereditario de ésta. Ahora bien, según GoRING dicha inferioridad -y el déficit psíquico de inteligencia en que se concretaba- no debía de interpretarse en sentido patológico, como expresión de anormalidad en el delincuente". (La cursiva es mía). 
tal inferioridad, ya que aparece normalmente como inferioridad mental de forma hereditaria 526 .

Por su parte, la biotipología, establece una correlación entre las características físicas del sujeto y sus rasgos psicológicos, de tal forma que establece una suerte de silogismo formado por caracteres somáticos o corporales y mentales, y por carácter y temperamento. Con KERTSCHMER como máximo exponente, en 1921 formuló su obra "Constitución y carácter" (Körperbau und Charakter)527, en la que elaboró una doble tipología que ha venido a llamarse constitucional y caracterológica, por la que distinguió claramente entre los tipos constitucionales ${ }^{528}$ y los tipos caracterológicos ${ }^{529}$, a los que les otorgó una predicción criminal, de forma que los pícnicos rara vez delinquen, los leptosomáticos suelen cometer robos y estafas y presentan alto índice de reincidencia, y los atléticos presentan altas tasas de criminalidad y suelen ser violentos ${ }^{530}$.

Para las concepciones biologicistas, su desarrollo supondría una necesaria reconfiguración dogmática de la culpabilidad, en el sentido de que el determinismo biológico del individuo que le empujase a actuar de una forma concreta, impediría

526 Ibidem, p. 311. Este autor señala que "los delincuentes, según la investigación de НоOTON, serían inferiores a los no delincuentes en casi todas las medidas corporales. $\mathrm{Y}$ algunos rasgos físicos reflejarían fielmente la inferioridad constitucional de éstos: poca frente e inclinada, cuello largo y delgado, hombros caídos; labios finos, breves ángulos mandibulares, maxilares poco ajustados, muy perceptible punto de DARWIN, orejas pequeñas con los bordes del pabellón auditivo ligeramente enroscado, rostros tensos, mandíbulas pequeñas, secreción nasal abundante, predominio de ojos azul-grisáceos, escaseando los ojos azules y oscuros, con pliegues pronunciados y cejas poco pobladas. El tatuaje, por último, sería más frecuente entre los delincuentes. НоотоN, además, creyó poder constatar una clara correlación entre determinadas características físicas y las diferentes clases de delincuentes: así los individuos altos y delgados serían proclives a la comisión de asesinatos y atracos; los altos y corpulentos, homicidios, falsificaciones y estafas; los bajos, hurtos y desvalijamientos; los bajos y gruesos, violaciones y abusos sexuales, etc."

527 KERTSCHMER, E., Constitución y carácter. Traducción de J. Solé Segarra de la edición alemana, (Körperbau und Charakter, Berlin: Springer. 1921), Barcelona: Labor. 1947, p. 415. Este autor explica que "de los tipos criminales interesan, principalmente en biotipología, los delincuentes habituales, porque los fundamentos de su fracaso social están sobre todo en la predisposición hereditaria o en sus desviaciones prodisclínicas, y sólo de modo accesorio en la situación exterior".

528 Que son, leptosomáticos (cuerpo alargado y delgado, cabeza pequeña y nariz puntiaguda), atléticos (desarrollo de la musculatura, tórax, cabeza, etc.), pícnicos (desarrollo de las cavidades viscerales, gran abdomen, cabeza redonda y ancha, piernas cortas, obeso, etc.) y displásticos (gigantismo, obesidad mórbida e infantilismo eunocoide), y el tipo mixto (combinación de las anteriores).

529 Que son los esquizotímicos, que pertenecen a la clase leptosomática, compuesta por los hipertésicos (personas nerviosas e irritables), intermedios (personas frías, enérgicas, serenas), y anestésicos (personas apáticas y solitarias), cuando sufren agravaciones se convierten en una modalidad esquizoide; ciclotímicos, que son personas extrovertidas o pícnicas y pueden ser hipomaníacos (que presentan continuamente alegría y movimiento), sintónicos (que suelen ser realistas, prácticos o humoristas), y flemáticos (tranquilos y tristes); y viscosos que son personas atléticas entre el leptosomático y el pícnico, y suelen ser pasivos y tranquilos normalmente.

530 GARCÍA-PABLOS DE MOLINA, A., Criminología..., cit. pp. 314 y 315. 
ejercitar sobre él un juicio personal de reproche por sus actos debido a que podría acreditarse que no pudo actuar de otra forma, "bastando la comprobación cuasinaturalística de que la acción fue llevada a cabo por una determinada persona". Además, en el ámbito de las sanciones penales, también habría que reconfigurar el sistema, de forma que en esta clase de sujetos habría que idear una serie de medidas de corrección y de seguridad con la finalidad de eliminar la peligrosidad criminal, como intervenciones quirúrgicas impuestas coactivamente al delincuente cuando presente alguna alteración cromosomática. Aspectos que, como afirma la doctrina, resultarían contrarios a los derechos fundamentales a la integridad física y a la dignidad de la persona 531 .

En ese orden de cosas, como apunta VIVES ANTÓN, "todo biologicismo, en el terreno del pronóstico criminal, comporta un grave error metodológico, consistente en el mismo intento de establecer una correlación lineal entre dos fenómenos -el cuerpo y el acto delictivo-, pertenecientes a dos sistemas diferentes - la naturaleza y la Cultura-" 532 . La ciencia penal actual se basa en que la voluntad del ser humano no está determinada por factores genéticos o biológicos, sino al contrario: lo que se afirma que existe es cierta libertad de voluntad o indeterminismo relativo que sirve de sustento a la idea de culpabilidad que descansa sobre la premisa de que el hecho es ilícito en la medida en que se pudo comprender su ilicitud y actuar conforme a dicha comprensión. La comprobación de que el comportamiento humano está determinado por factores genéticos, "supondría un total resquebrajamiento de los pilares sobre los que se asienta el edificio de la ciencia del Derecho penal", aunque esa posibilidad viene siendo descartada por la doctrina porque en el ser humano no puede afirmarse que el factor genético sea el único determinante, sino que influyen también otros factores como los ambientales y ninguno de ellos permite ofrecer un fundamento exclusivo sobre la conducta de la persona ${ }^{533}$.

b) La fundamentación sociológica. La sociología ha tratado de fundamentar el pronóstico de peligrosidad con resultados muy alejados de alcanzar el nivel de certeza

\footnotetext{
531 URRUELA MORA, A., “Culpabilidad y herencia genética”. En Bioética y Derecho. Studia iuridica 20. CGPJ CEJFE. 2004, p. 106.

532 VIVES ANTÓN, T.S., “Métodos de determinación de la Peligrosidad...", cit. pp. 24 y 25. Este autor manifiesta que "el mito criminal nato no acaba de morir. Parece como si se pretendiera convertir al criminal en miembro de una raza maldita por la naturaleza. Y tal vez, inconscientemente, se busca con ello descargar en la naturaleza las culpas de la sociedad".

533 URRUELA MORA, A., “Culpabilidad y herencia genética...”, cit. pp. 109 y 110.
} 
que exige toda fundamentación científica, que estaban basados en mecanismos naturalistas534, o económicos, siendo en éste último donde ENGELS afirmaba que en un momento y un lugar determinados, la clase más oprimida, la proletaria, era la que estaba predeterminada para delinquir, por cuanto que el delito era un mecanismo de reacción frente a las situaciones de miseria. Ambos métodos, terminaron por abandonar el esquema de causación simple en los que la relación causal es unitaria, para dar cabida a la causación múltiple, en donde hay una pluralidad de causas y efectos que conducen necesariamente a la utilización de estadísticas, con el consecuente fracaso de sus planteamientos, por cuanto que dichos métodos no permiten realizar predicciones fiables sobre individuos o sobre aspectos particulares ${ }^{535}$.

Para FERRI la delincuencia no deriva de las patologías de los individuos, sino que es el resultado de combinar factores antropológicos, psíquicos y sociales, tales como la densidad de población, la opinión pública, la familia, la moral, religión, educación, etc. ${ }^{536}$ y propugnaba un sistema basado no en el Derecho penal, sino en la Sociología criminal537, integrada por la psicología positiva, la antropología criminal y la estadística social ${ }^{538}$.

c) La fundamentación psicológica. Los modelos psicologicistas se centran en la psiquiatría, la psicología y el psicoanálisis. La teoría psicoanalista representada por FREUD, busca desvelar las intenciones que yacen ocultas en el fuero interno del delincuente y parte de la contraposición entre el instinto de la vida (o Eros, con fuerte matiz en el aspecto de la sexualidad) y el de la muerte (o destrucción) que es el que

\footnotetext{
534 VIVES ANTÓN, T.S., “Métodos de determinación de la Peligrosidad...”, cit. pp. 25 y 26. Este autor expresa que "“Por un procedimiento matemático muy sencillo", decía el príncipe KROPOTKIN, "se puede hallar la fórmula que permite predecir el número de crímenes, sin más que consultar el termómetro y el higrómetro. Tomad la temperatura media del mes, multiplicadla por siete, añadid la humedad media, volved a multiplicarla por siete, añadid la humedad media, volved a multiplicarla por dos, y tendréis el número de homicidios que se han de cometer en el mes". "Pero yo", añade BERNALDO DE QUIRÓs, "he realizado esta operación en Madrid y me ha dado resultados absurdos".

535 VIVES ANTÓN, T.S., “Métodos de determinación de la Peligrosidad...”, cit. p. 27. Este autor manifiesta que "no es, pues, de extrañar, que en el ámbito de la sociología criminal se hable de "el círculo vicioso del concepto de causación": círculo vicioso, que, innecesario es decirlo, hace enormemente problemático todo pronóstico".

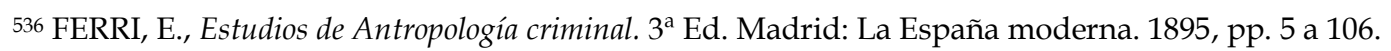

537 FERRI, E., Sociología criminal. Tomo II. Madrid: Centro editorial del Góngora. 1907, pp. 3 y ss.

538 GARCÍA-PABLOS DE MOLINA, A., Criminología..., cit. pp. 263 y 264.
} 
permite asociar el comportamiento delictivo al ansia destructora innata ${ }^{539}$. En los delincuentes neuróticos, se plantea si ante un diagnóstico de neurosis criminal o antisocial, es posible extraer una deducción de hechos futuros. En ese sentido REIK en su obra "El psicoanálisis del crimen", plantea el valor de las pruebas indiciarias, concluyendo que no es posible utilizar un método psicológico para predecir si un sujeto realizará hechos delictivos en el futuro, porque tampoco puede asegurarse a través de este método si cometió hechos pasados, ya que el psicoanálisis es una teoría que estudia personalidades y no hechos, por lo que, el hecho concreto - pasado o futuro-, no puede tener cabida en sus predicciones ${ }^{540}$.

La psicopatología criminal analiza los síntomas de las enfermedades mentales que se manifiestan en las personalidades de los delincuentes, siendo que aprecia manifestaciones patológicas en la inteligencia, en el pensamiento y el lenguaje, en la memoria, en la voluntad, la atención, la conciencia, la percepción, la afectividad y en los instintos, de forma que otorga relevancia criminógena a estos factores dejando de lado las afecciones a la imputabilidad ${ }^{541}$. Sin embargo la criminología psicológica, impulsada por PINATEL, se basaba en que el delito deriva de una actividad psíquica anormal caracterizada por el egocentrismo, labilidad, agresividad e indiferencia afectiva ${ }^{542}$, de las que derivan las dos características fundamentales del delincuente peligroso: la inadaptación y la temibilidad. Si después cometen el acto, es lo único que les va a diferenciar como criminales y, a partir de ahí, se podrá elaborar el juicio de pronóstico analizando en qué medida ha intervenido la personalidad criminal en la realización del hecho. Ese paso al acto es lo que sirve de

\footnotetext{
539 Ibidem, p. 346. Según indica este autor "el complejo de Edipo tiene particular interés en la teoría freudiana, pues muchos criminales, según el autor, tienen su explicación en aquel complejo, que lejos de suceder, precede e impulsa la comisión del delito y tendría su origen en una vivencia inconsciente de niño. FREUD conecta la evolución del instinto sexual con otras tantas etapas de la evolución de la personalidad y, a su vez, éstas y las diversas manifestaciones delictivas, de suerte que el sujeto que ha padecido el trauma (éste detiene su normal evolución personal) acusa los estigmas propios de las fases en la que aquél se ha fijado siendo, en consecuencia, proclive a la comisión, en cada caso, de determinados hechos criminales (los individuos "fijados" en la fase "oral" cometerían delitos de expresión verbal y serían propensos a hábitos como el alcoholismo); por último, la potenciación del mundo inconsciente y la división dinámica de la personalidad en tres esferas (Yo, Ello y Super-Yo) subrayan uno de los postulados del psicoanálisis ortodoxo: todos los actos del hombre tienen una explicación oculta que solo la introspección puede revelar y, en concreto, el delito hunde sus raíces en desequilibrios y conflictos íntimos en la estructura de la personalidad (a menudo, ausencia o debilidad del Super-Yo, instancia que vela por la correcta interiorización de normas y valores).
}

540 VIVES ANTÓN, T.S., "Métodos de determinación de la Peligrosidad...", cit. p. 30. Este autor señala que "cuando el sicoanálisis habla de personalidad delincuente, lo hace en el más estricto sentido: no por referencia a hechos delictivos presentes o futuros, sino por un juicio sobre la personalidad misma".

541 GARCÍA-PABLOS DE MOLINA, A., Criminología..., cit. p. 356.

542 LANDECHO VELASCO, C.M., en COBO DEL ROSAL, M., (Dir.), Comentarios..., cit. Tomo IV, pp. 53 y 54. 
base para considerar al individuo anormal como delincuente, pero "el paso al acto no puede servir, en Criminología, para trazar una línea divisoria entre los individuos normales de los que no lo son, porque ni sociológica ni sicológicamente, pueden equipararse delito y anormalidad. Pero es que, además, el utilizarlo como tal línea divisoria podría conducirnos al absurdo" 543 .

d) Las técnicas de pronóstico. Tras lo visto hasta aquí, nos queda por analizar si las técnicas de pronóstico que puedan ser aplicadas al delincuente, pueden arrojar resultados fiables o no. $\mathrm{Y}$ en ese sentido, el método matemático de predicción basado en la utilización de tablas, no es posible aplicarlo a ninguna ciencia social porque cuando se trata de fenómenos sociales sería imposible la obtención de suficientes estadísticas ${ }^{544}$ dada la diversidad y el cambio constante de la sociedad que provocaría que el éxito del pronóstico dependiera finalmente de factores como el azar545; y además, "con las tablas de pronóstico no se predice la peligrosidad individual. Las tablas, a lo sumo, determinarán el porcentaje de futuros delincuentes que existiera en un determinado grupo de personas. Pero la peligrosidad es la probabilidad que cada una de esas personas tiene de delinquir en el futuro" 546. GARCÍA RIVAS señala que el método estadístico fue enormemente utilizado en EEUU, sobre la base de la construcción de un conjunto de características definitorias y siempre presentes en los reincidentes, de forma que sería suficiente con la detección de ese elenco de caracteres para formular un juicio meramente estadístico cuyo resultado sería la probabilidad de reincidencia, pero en cualquier caso, ese método recibió serias y fundadas críticas doctrinales que entendían que si se prescinde del análisis individualizado del sujeto, lo único que se consigue es colocarle una etiqueta que le

\footnotetext{
543 VIVES ANTÓN, T.S., “Métodos de determinación de la Peligrosidad...”, cit. p. 35.

544 ALONSO RIMO, A., "Medidas de seguridad...", cit. pp. 114 y 115. Este autor afirma que "las nuevas tendencias en las técnicas de predicción de la peligrosidad -que proceden de EEUU si bien se van extendiendo "lenta pero inexorablemente" por el continente europeo- prescinden del análisis psicológico del sujeto concreto y se basan más en métodos estadísticos a partir de determinados indicadores genéricos".

545 SILVA SÁNCHEZ, J.M., “El retorno de la inocuización...”, cit. p. 701, nota al pie 5. Como dice este autor “los métodos predictivos basados en el análisis psicológico individual de responsabilidad o peligrosidad han sido sustituidos por otros de naturaleza actuaria (actuarial justice), de modo que el delito pasa a ser abordado con las mismas técnicas probabilísticas y cuantitativas que, en el ámbito de los seguros, por ejemplo, se utilizan para la gestión de riesgos. Ello supone recurrir al método estadístico, tomando como base determinados indicadores, cuya cuantificación es el punto de partida para emitir pronósticos de peligrosidad sobre grupos o clases de sujetos, sin necesidad de entrar en estudios de la psicología de individuo concreto". (La cursiva es mía).

546 VIVES ANTÓN, T.S., “Métodos de determinación de la Peligrosidad...”, cit. p. 38. Sigue diciendo este autor: "hay una sutil ignoratio sive mutatio elenchi, cuando lo que realmente predicen las tablas se toma por un auténtico pronóstico de peligrosidad".
} 
identificará como integrante de un grupo de riesgo, pero no se podrá, en modo alguno, formular una prognosis individualizada con pretensiones de fiabilidad, con la consecuente imposibilidad de anclaje dentro de las garantías propias del Derecho penal ${ }^{547}$.

En definitiva, ninguna fundamentación científica es suficientemente segura como para otorgar un pronóstico certero de peligrosidad en todos los casos.

2. El método intuitivo, por su parte, basado en la intuición que es un proceso intelectual racional y legítimo, puede emplearse en materias donde es posible llegar a esa formación lógica científicamente, esto es, por ejemplo, el peligro concreto al que refiere el $\mathrm{CP}$ en las figuras delictivas de esta clase que, además, en la práctica, el Juez determina la existencia de peligro basándose en la experiencia común, apreciando su concurrencia en los casos en que la misma se evidencia. Pero no puede aplicarse este método para la predicción de la peligrosidad del individuo, puesto que quedaría sujeto únicamente a la mera intuición del Juez, que no encontraría apoyo en ningún otro elemento más que en sí mismo, con lo que no es admisible tampoco este método porque es manifiestamente irracional548. Además, como indica la doctrina "el cerebro individual humano, dada su plasticidad, va evolucionando de modo que una persona transcurrido un cierto periodo de tiempo es sustancialmente distinto de quien era en el pasado por eso predecir la peligrosidad en el futuro en largos periodos de tiempo se nos antoja una tarea tan vana como hercúlea y es un desideratum exigir de los órganos judiciales predicciones de este tipo" 549 .

La del enfermo mental es, pues, la única peligrosidad que racional y empíricamente puede constatarse, aunque sería erróneo afirmar generalizando que toda enfermedad mental conlleva necesariamente la actividad delictiva o que conduce a ella, pues se ha constatado, por ejemplo, que los psicóticos presentan un porcentaje de infracciones penales muy inferior a los delincuentes que no padecen ninguna enfermedad,

547 GARCÍA RIVAS, N., “La libertad vigilada...”, cit. p. 16.

548 VIVES ANTÓN, T.S., "Métodos de determinación de la Peligrosidad...", cit. p. 39. Este autor expresa que "si, como sostenemos, es imposible, al menos por ahora, un pronóstico científico de delincuencia futura, queda dicho que la intuición del juez no abrevia el camino del proceso discursivo, sino que campea a sus anchas, sin más apoyo que sí misma. Con lo cual el método carece de racionalidad, y es inadmisible desde cualquier punto de vista. Y no deja de ser curioso que la peligrosidad, introducida en Derecho Penal bajo la capa cientifista de la Escuela Positiva, se determine generalmente en las legislaciones recurriendo a la intuición del juez, es decir, con métodos de un irracionalismo palmario".

${ }^{549}$ GUDÍN RODRÍGUEZ-MAGARIÑOS, F., La nueva medida de seguridad..., cit. p. 106. 
por lo que la cuestión no está absolutamente descrita en la enfermedad sino en las personalidades adaptadas a la vida y a los valores delincuenciales. Ahora bien, en los trastornos mentales severos se ha experimentado un elevado riesgo de comisión de delitos violentos y en serie, que aparecen asociados a las patologías, por lo que "la correlación, pues, no se establece genéricamente entre enfermedad mental y crimen, sino de forma más matizada: entre las patologías psíquicas más severas, de un lado, y las manifestaciones violentas y más graves de la delincuencia, de otro" ${ }^{550}$. Los métodos de pronóstico de la peligrosidad criminal, en cuanto a las medidas de seguridad, afirma ROBLES PLANAS, contienen enormes limitaciones que generan "importantes márgenes de incertidumbre frente a los que la lógica de la seguridad responde con el "principio de precaución"“ 551.

En conclusión, todos los métodos de determinación de la peligrosidad han presentado dificultades que ya fueron expuestas magistralmente por VIVES ANTÓN en la década de los $70^{552}$ y más recientemente por MARTíNEZ GARAY, en varias publicaciones sucesivas, en las que ofrece nuevos datos que evidencian la escasa fiabilidad de los métodos de pronóstico. 553

3. La neurociencia. Los avances tecnológicos en investigaciones biológicas y la llamada neurociencia, se adentran en el estudio del cerebro humano y por ahí se pretende encontrar una respuesta neurocientífica para la predicción de la peligrosidad ${ }^{554}$, basada en

550 GARCÍA-PABLOS DE MOLINA, A., Criminología..., cit. p. 413. Este autor afirma que "rigurosas investigaciones longitudinales han podido establecer y constatar de modo empírico que individuos con trastornos mentales severos exhiben un riesgo estadísticamente significativo de implicarse en la comisión de delitos violentos. Esto es, delitos de particular gravedad (vg. homicidio múltiple, homicidio por móviles sexuales, etc.) o modalidades agravadas de aquellos por la concurrencia del ensañamiento, la alevosía, etc. suelen aparecer asociados a relevantes patologías psíquicas del autor".

551 ROBLES PLANAS, R., ““Sexual Predators...”, cit. p. 16.

552 VIVES ANTÓN, T.S., VIVES ANTÓN, T.S., “Métodos de determinación de la Peligrosidad...”, cit. Pág. 18.

553 MARTÍNEZ GARAY, L., “La incertidumbre de los pronósticos de seguridad: consecuencias para la dogmática de las medidas de seguridad". En InDret. Revista para el análisis del Derecho. 2/2014. Barcelona, 2014, Págs. 3 a 68; MARTÍNEZ GARAY, L., "Minority Report: pre-crimen y pre-castigo. Prevención y predicción". En VIVES ANTÓN, T.S. / CARBONELL MATEU, J.C. / GONZÁLEZ CUSSAC, J.L. / ALONSO RIMO, A. / ROIG TORRES, M., (Dirs.), Crímenes y castigos. Miradas al Derecho penal a través del arte y la cultura. Valencia: Tirant lo Blanch. 2014, pp. 579 a 606.

554 GUDÍN RODRÍGUEZ-MAGARIÑOS, F., La nueva medida de seguridad..., cit. p. 104. Según este autor “la moderna neurología y la neurociencia van orientadas hacia un funcionamiento orgánico físico del cerebro, sin embargo, los niveles de comprensión del complejo engranaje del funcionamiento cerebral se muestran hoy por hoy absolutamente inalcanzables, siendo meros mitos populares las ideas como el brain washing donde se pudiera condicionar por factores exógenos el funcionamiento mental a modo de una vulgar máquina. Sin 
el conocimiento de lo que un sujeto pueda sentir o pensar a través de la lectura de su actividad cerebral555, utilizando técnicas de neuroimagen y, en concreto, el escáner de resonancia magnética nuclear funcional (Functional Magnetic Resonance Imaging, fRMI), que consiste en la obtención de imágenes que detectan las variaciones que experimenta el flujo sanguíneo en distintas áreas o regiones del cerebro, de forma que la visión que se logra es anatómico-funcional, que se traduce en que la información obtenida es "de lo que ocurre mientras está ocurriendo. Tener este tipo de conocimiento es fundamental para quien asimila "ver el cerebro" con "ver lo que hacemos"“556. Más específicamente relata CANCIO MELIÁ que la técnica de resonancia magnética nuclear funcional, consigue representar las imágenes cerebrales y medir la actividad hemodinámica cerebral, obteniendo una especie de fotografía de la actividad neuronal y de sus consecuencias. De todo ello se puede apreciar el flujo de riego sanguíneo en las distintas regiones del cerebro que deja al descubierto la actividad neuronal. Esto se consigue mediante una previa subdivisión de cerebro en aproximadamente ciento treinta mil cubos de tres milímetros cada uno y la prueba a través de esta técnica se basa en una medición doble de la señal del nivel de oxígeno en la sangre (Blood Oxygen Level Determination), la primera en condiciones normales y la segunda cuando se le ordena realizar alguna actividad como un

embargo, ello no equivale a sostener que el sistema de pensamiento computacional algorítmico sea trasladable al mundo de las ideas".

555 Vid. RUBIA, F.J., “Neurociencia y libertad”. En DEMETRIO CRESPO, E., (Dir.) / MAROTO CALATAYUD, M., (Coord.), Neurociencias y Derecho penal. Nuevas perspectivas en el ámbito de la culpabilidad y tratamiento jurídico-penal de la peligrosidad. Madrid: Edisofer. 2013, pp. 185 a 190; DEMETRIO CRESPO, E., "Libertad de voluntad, investigación sobre el cerebro y responsabilidad penal. Aproximación a los fundamentos del moderno debate sobre Neurociencias y Derecho penal". En InDret. Revista para el análisis del Derecho. 2/2011. Barcelona: 2011, pp. 2 a 31; RAMOS VÁZQUEZ, J.A., Ciencia, libertad y Derecho penal. (Aporías del determinismo y defensa de la libertad de acción como base del sistema penal). Valencia: Tirant lo Blanch. 2013, pp. 29 a 253; FEIJOO SÁNCHEZ, B., “Culpabilidad jurídico-penal y Neurociencias”. En DEMETRIO CRESPO, E., (Dir.) / MAROTO CALATAYUD, M., (Coord.), Neurociencias y Derecho penal. Nuevas perspectivas en el ámbito de la culpabilidad y tratamiento jurídico-penal de la peligrosidad. Madrid: Edisofer. 2013, pp. 269 a 298; PÉREZ MANZANO, M., "Fundamento y fines de Derecho...", cit. pp. 2 a 32; FEIJOO SÁNCHEZ, B., “Derecho Penal y Neurociencias. ¿Una relación tormentosa?". En InDret. Revista para el análisis del Derecho. 2/2011. Barcelona: 2011, pp. 2 a 50; PÉREZ MANZANO, M., "El tiempo de la conciencia y la libertad de decisión: bases para una reflexión sobre Neurociencia y responsabilidad penal". En DEMETRIO CRESPO, E., (Dir.) / MAROTO CALATAYUD, M., (Coord.), Neurociencias y Derecho penal. Nuevas perspectivas en el ámbito de la culpabilidad y tratamiento jurídico-penal de la peligrosidad. Madrid: Edisofer. 2013, pp. 105 a 136; ROTH, G., “Delincuentes violentos: ¿seres malvados o enfermos mentales?" En DEMETRIO CRESPO, E., (Dir.) / MAROTO CALATAYUD, M., (Coord.), Neurociencias y Derecho penal. Nuevas perspectivas en el ámbito de la culpabilidad y tratamiento jurídico-penal de la peligrosidad. Madrid: Edisofer. 2013, pp. 669 y ss; PARDO, M.S., / PATERSON, D., "Fundamentos filosóficos del Derecho y la neurociencia". En InDret. Revista para el análisis del Derecho. 2/2011. Barcelona: 2011, pp. 2 a 45; VIVES ANTÓN, T.S., "Neurociencia y determinismo reduccionista: una aproximación crítica”. En DEMETRIO CRESPO, E., (Dir.) / MAROTO CALATAYUD, M., (Coord.), Neurociencias y Derecho penal. Nuevas perspectivas en el ámbito de la culpabilidad y tratamiento jurídico-penal de la peligrosidad. Madrid: Edisofer. 2013, pp. 219 a 233.

556 NARVÁEZ MORA, M., “El impacto de la neurociencia sobre el derecho: el caso de la responsabilidad subjetiva". En Revista Telemática de Filosofía del Derecho, núm. 15. 2012, p. 203. 
movimiento. Con ello se consigue identificar la intensidad de la señal que es mayor cuanto más alta es la actividad neuronal, debido a que el nivel de oxígeno detectado es también mayor. Todo ello es procesado por un ordenador que proporciona una imagen neuronal en tres dimensiones, de la que se desprende una clara identificación de cómo es la morfología funcional del cerebro 557.

Recientes descubrimientos en estudios realizados sobre el cerebro, evidencian que la neurociencia es capaz de predecir la reincidencia en personas de alto riesgo, de forma que, de la actividad cerebral estudiada en delincuentes adultos, se consiguió predecir que iban a volver a delinquir. Por ello, los neurocientíficos aseveran que estos descubrimientos permitirían desarrollar un "biomarcador neurocognitivo" para identificar el comportamiento antisocial persistente e intervenir en consecuencia558.

Si bien el sistema de justicia penal ha venido realizando predicciones sobre el comportamiento futuro de los individuos en varias fases del proceso penal, como la sentencia o en la fase de ejecución de las penas privativas de libertad en orden a la adopción de resoluciones sobre la concesión o no de la libertad condicional, etc., la tendencia en los últimos años ha tratado de limitar la discrecionalidad de los órganos jurisdiccionales y demás operadores jurídicos en relación a dichas predicciones y sus efectos en la adopción de resoluciones en el proceso. Limitaciones que persiguen, sobre todo, establecer criterios más restrictivos sobre los que basar ese tipo de decisiones. En consecuencia, algunos autores plantean si la neurociencia sería capaz de aportar elementos válidos para establecer con precisión la peligrosidad futura de las personas, de forma que los resultados pudieran utilizarse tanto para incrementar la discrecionalidad de los juzgadores a la hora de dictar sentencia, como para limitar considerablemente ese margen de discrecionalidad 559 .

557 CANCIO MELIÁ, M., “Psicopatía y Derecho penal...”, cit. p. 118.

558 Vid. AHARONI, E. / VINCENT, G.M. / HARENSKI, C.L. / CALHOUN, V.D. / SINNOTT-ARMSTRONG, W. / GAZZANIGA, M.S. / KIEHL, K.A., "Neuroprediction of future rearrest". En PNAS, vol. 110, núm. 15, abril 2013, pp. 6223 a 6228. También puede accederse en [www.pnas.org/cgi/doi/10.1073/pnas.1219302110], págs. 1 a 6. (Consultado el 10/3/2014).

559 Vid. GREELY, H.T., "Neuroethics: The Neuroscience Revolution, Ethics, and the Law. Prediction, Litigation, Privacy, and Property: Some Possible Legal and Social Implications of Advances in Neuroscience". Santa Clara University. 2004. Puede consultarse accederse al texto completo de este trabajo en el siguiente enlace: [http://www.scu.edu/ethics/publications/submitted/greely/neuroscience_ethics_law.html\#starback]. (Consultado el $10 / 3 / 2014)$. 
Desde el punto de vista de la imputabilidad y la inimputabilidad, a través de técnicas neurocientíficas se plantea la posibilidad de adentrarnos en el funcionamiento de la mente humana y ampliar el espectro de causas de inimputabilidad, al atribuir el comportamiento humano a condicionantes subyacentes en la mente -enfermedades mentales- que hasta ahora no podían considerarse como tales, no podían detectarse con claridad y no forman parte de las comúnmente aceptadas causas de inimputabilidad ${ }^{560}$. En ese sentido, la neurociencia puede proporcionar imágenes que detecten ciertas anormalidades o anomalías que podrían excluir la punibilidad convirtiendo al sujeto en inimputable, reducir la punibilidad mediante atenuaciones penológicas por eximentes incompletas (semiimputabilidad) o simplemente atenuar la pena por circunstancias personales descubiertas a través de neuroimágenes. En síntesis, se trataría de redefinir el concepto de inimputabilidad por trastorno mental y extenderlo a otras posibles causas subyacentes que pudieran ser identificadas a través de esta clase de métodos científicos.

Sobre este aspecto, podemos resaltar algunos casos que comenta la doctrina ${ }^{561}$, con especial detenimiento en las psicopatías, que presentan especiales consideraciones desde

560 Vid. NARVÁEZ MORA, M., “El impacto de la neurociencia sobre el derecho...”, cit. pp. 208. Esta autora manifiesta que la revisión del sistema de responsabilidad penal que la neurociencia propone se basaría en dos aspectos, a saber: la capacidad del individuo, donde el impacto de la neurociencia no residiría tanto en la descripción de nuevas categorías o grupos de personas inimputables sino en demostrar que en los grupos que ya están previstos en las legislaciones penales deben adicionarse muchos más casos de los que ahora se consideran; y causalidad, donde el impacto de la neurociencia consistiría en demostrar que lo que ahora consideramos acciones no son tales, sino sucesos que simplemente ocurren.

561 El primero es el que comenta FEIJOO SÁNCHEZ, (previamente expuesto por BURNS y SWERDLOW BURNS / RUSSELL SWERDLOW, "Right Orbitofrontal Tumor with Pedophilia Symptom and Constructional Apraxia Sign". En Archiv Neurology, núm. 60, 2003, pp. 437 a 440. Vid. FEIJOO SÁNCHEZ, B., “Derecho Penal y Neurociencias...", cit. p. 2, nota al pie 3, y pág. 3), sobre el profesor de cuarenta años y padre de familia, que comienza a consumir y coleccionar pornografía infantil y paulatinamente va aumentando su conducta delictiva hasta que llega a acosar sexualmente a su hijastra en edad preadolescente y también a sus alumnas. Consecuentemente, le fue impuesto un tratamiento hormonal antiandrógneo para neutralizar su peligrosidad y evitar la recaída en los delitos sexuales por los que fue condenado, pero el tratamiento resultó ser infructuoso y tuvo que ingresar en prisión. A los pocos meses de cumplimiento de la condena, debido a que el penado estaba aquejado de fuerte dolores de cabeza, se le detectó un tumor cerebral del que fue intervenido y la tendencia sexual desviada desapareció por completo, posibilitando su puesta en libertad por haber desaparecido la peligrosidad criminal. Pero los dolores de cabeza se repitieron varios meses después y, con ellos, volvió la tendencia sexual desviada, emprendiendo una nueva colección masiva de pornografía infantil. Un nuevo examen médico acreditó la aparición de un nuevo tumor en la misma zona del cerebro, que generó una nueva intervención que erradicó automáticamente su inclinación delictiva. Lo que este autor destaca es que esta persona en todo momento comprendía la ilicitud de su conducta, pero actuaba convencido de que él tomaba las decisiones libremente. En este supuesto, la neurociencia convirtió en innecesaria la pena en ambos casos, especialmente en el segundo. Cuarenta años atrás esta persona habría sido considerada como un ser malvado y culpable, pero los avances científicos en la neuroimagen, permitieron transformar esa maldad en una enfermedad mental por la que no es posible exigir responsabilidad. El segundo supuesto es el caso de Herbert Weinstein, que simuló un suicidio tras estrangular a su esposa mediante y resultó que tenía un quiste cerebral en la membrana arácnida. La defensa intentó introducir en el proceso una prueba de escáner cerebral para demostrar la inimputabilidad, lo cual generó muchas dudas sobre si el jurado terminaría absolviendo al 
la óptica de los avances de la neurociencia. Lo que la doctrina plantea, es si la técnica de resonancia magnética nuclear funcional, es capaz de abrir una puerta para el estudio de la psicopatía observando no su conducta sino el funcionamiento de su cerebro, sus diferencias morfológicas, anatómicas y funcionales y, desde ahí, arrojar resultados en el terreno de inimputabilidad ${ }^{562}$. Como primer paso, la neurociencia refutó la hipótesis de que los psicópatas son personas que presentan lesiones en la corteza prefontral563, ya que la neuroimagen ha comprobado que algunos psicópatas presentan anomalías o lesiones en dicha región cerebral, pero no es un rasgo común a todos ellos. En ese sentido, CANCIO MELIÁ habla de que si a través de esos medios - teniendo en cuenta las reservas sobre el actual el nivel de desarrollo de esas técnicas para la certeza del diagnóstico- podemos identificar con precisión cuál es la base neuro-fisiológica que integra las psicopatías y, por tanto, si podemos dar con la explicación del origen de la conducta psicopático-desviada, podríamos reconsiderar la inclusión de esta categoría de sujetos en la esfera de la inimputabilidad, dando la lugar al exclusión del reproche culpabilístico por los crímenes cometidos, y aplicárles medidas de corrección y de seguridad postdelictuales en lugar de penas. Además, este autor parte de que es indispensable reconocer que la sociedad no puede permanecer indiferente ante los nuevos descubrimientos sobre cómo funciona el cerebro humano, ya que lo contrario sería como no reconocer un nuevo conocimiento en las leyes de la física o de la naturaleza. Y en ese sentido, propone que debe avanzarse en la definición de las categorías de culpabilidad, de forma que se clarifique la combinación de su carácter normativo con el factor biológico, hacia un concepto funcional de culpabilidad 564 .

acusado, lo que generó que el Ministerio Público ofreciera un trato al acusado cambiando la calificación a homicidio imprudente y el juicio no se llegó a celebrar ni a introducirse esa prueba en el proceso (Vid. SYMINGTON, G., "Neurolaw: de la defensa judicial hacia un Derecho Penal del enemigo". En Revista de la Universidad de Estudios de Bogotá. núm. 9. Colombia, 2012, p. 85).

562 Vid. CANCIO MELIÁ, M., “Psicopatía y Derecho penal...”, cit. pp. 118 y ss. Este autor relata el experimento que se está llevando a cabo en las penitenciarías de Nuevo México por el neurocientífico KIEHL, consistente en someter a este tipo de exámenes a los reclusos considerados psicópatas, para obtener resultados más precisos en cuanto a su diagnóstico. Dicho experimento se relata detalladamente en AHARONI, E. / VINCENT, G.M. / HARENSKI, C.L. / CALHOUN, V.D. / SINNOTT-ARMSTRONG, W. / GAZZANIGA, M.S. / KIEHL, K.A., “Neuroprediction of future rearrest...”, cit. pp. 6223 a 6228.

563 La corteza prefrontal ventromedial es una región del cerebro que tiene implicaciones en la toma de decisiones emocionales porque participa en el aprendizaje de inversión afectivo o la impulsividad; se trata de una región que está íntimamente relacionada con otras áreas de la corteza y con la amígdala, que es una estructura cortical que participa en el control y modulación de los procesos de aprendizaje y en las emociones, como la ansiedad, el miedo, la euforia, etc. En profundidad vid. CONTRERAS, D. / CATENA, A. / CÁNDIDO, A. / PERALES, J.C. / MALDONADO, A., "Funciones de la corteza prefrontal ventromedial en la toma de decisiones emocionales". En International Journal of clinical and health Psychology, vol. 8, núm. 1, 2008, pp. 285 a 310.

564 CANCIO MELIÁ, M., “Psicopatía y Derecho penal...”, cit. pp. 119 a 124. 
No obstante, algunos autores señalan que los estudios realizados sobre este tema evidencian que el mero hecho de poder describir la conducta de una persona desde el punto de vista neurocientífico no arroja resultados exculpatorios más allá de los que ya se tienen, porque el hecho de decir que la causa del hecho punible fue la reducción de niveles de dopamina en lugar de decir que la causa fue su estado de alteración nerviosa o de agitación, es un aspecto que no cambia nada en cuanto a si esa persona debe ser condenada o absuelta en el proceso, porque realmente en nada va a variar para considerarle libre, incapaz, irresponsable, irreprochable, etc. De ahí que se afirme que el impacto que la Neurociencia tendrá en el Derecho será el que las personas le permitan ya que su incursión efectiva en el campo ámbito jurídico será mayor cuanto menos objeciones se le opongan; y que el límite reside en nuestras concepciones axiomáticas, en los significados y conceptos científicos de los que disponemos en cada momento, que serán útiles en la medida en que sean capaces de generar juicios verdaderos; pero cuando hablamos de conceptos normativos - y no científicos- se produce un cambio sustancial, porque dichos conceptos tienen otro funcionamiento al tratarse de reglas que rigen la forma de interrelacionarnos los unos con los otros 565 .

En definitiva, predecir la peligrosidad mediante esta técnica “se nos antoja hoy en día una tarea prácticamente imposible pues el funcionamiento de las redes neuronales cada información que se almacena en el cerebro mediante neuronas entra en conexión con otras formando una especie de mallas. Cada neurona participa en varias redes con lo que tan pronto como una red es excitada en cualquier punto, la información que representa es reclamada" 566 . La neurociencia constituye uno de los grandes avances que ha conocido la historia en materia de ciencias normativas, pero se encuentra, hoy por hoy, en una fase muy experimental que todavía no ofrece resultados concluyentes ${ }^{567}$ que permitan su

\footnotetext{
565 Vid. NARVÁEZ MORA, M., “El impacto de la neurociencia sobre el derecho...”, cit. pp. 219 y 220.

566 GUDÍN RODRÍGUEZ MAGARIÑOS, F., La nueva medida de seguridad..., cit. p. 105. Como indica este autor, “dado que actúan como una red, participan muchas neuronas, ninguna relevancia tiene la pérdida de algunas de ellas, el debilitamiento de algunas sinapsis, ya que la información permanecerá".

567 HASSEMER, W., “Neurociencias y culpabilidad en Derecho penal”. En InDret. Revista para el análisis del Derecho. 2/2011. Barcelona: 2011, p. 4. Este autor expresa que "los neurocientíficos han alcanzado con su trabajo conocimientos que, en caso de que sean correctos e idóneos, sustraen la base a buena parte de nuestros puntos de partida sobre el Derecho penal y su mundo; esto explica las características de las reacciones desde la ciencia del Derecho penal. No es posible ver una línea en ellas. Llegan desde un distanciamiento lúdico en el plano de la teoría de la ciencia, pasando por profundos programas alternativos, que quieren establecer un cortafuegos salvador entre los cantos de sirena y la dogmática jurídico-penal de la culpabilidad, mostrando un desesperado empeño en mantener con vida el Derecho penal de la culpabilidad aun bajo los golpes de la
} 
implementación como método fiable de predicción de la peligrosidad 568 , aunque no se descarta su posible aplicación en un ulterior estado de avance y desarrollo tecnológico.

\section{El tratamiento del delincuente habitual peligroso}

Nos queda por analizar la cuestión referente al tratamiento del delincuente habitual peligroso, que supone una de las preocupaciones más acentuadas del legislador, aunque es un problema que ha existido siempre y se remonta al mundo antiguo ${ }^{569}$, las últimas tendencias legislativas del Derecho penal en relación a este aspecto concreto, vienen experimentando una dirección inocuizadora que ha sido denominada por SILVA SÁNCHEZ “el retorno de la inocuización”570, y que en ordenamientos como el alemán (al margen de la custodia de seguridad a la que ya hemos referido anteriormente), el suizo, el austríaco, etc., se proyectan sobre figuras como la prisión perpetua (que a pesar de su nomenclatura permiten el acceso a la libertad condicional bajo determinados presupuestos); el de Reino Unido con la "Criminal Justice Act" de 2003, que en su art. 225 regula las "sentence of imprisonment for life" que permiten igualmente la reclusión perpetua,

biología humana, hasta llegar a la candorosa exhortación a la ciencia del Derecho penal de "no hacerse artificialmente la ciega y sorda", sino de "aprovechar la oportunidad de repensar la atribución jurídico-penal de culpabilidad y responsabilidad".

568 DEMETRIO CRESPO, E., “Libertad de voluntad, investigación...”, cit. p. 24. Según este autor, “los defensores de este modo de ver las cosas imaginan un escenario apocalíptico en el que la medidas curativas socio-terapéuticas se aplicarían con fines puramente preventivos dando lugar, por ejemplo, a esterilizaciones y castraciones en los delitos contra la libertad sexual, intervenciones en el cerebro, medicación generadora de estados de debilidad en los delincuentes violentos, etc. Por el contrario, apenas cabría pensar en una resocialización en un sentido humano y comunicativo, pues esta última precisa que se despierte en los delincuentes el sentimiento de responsabilidad por su propio hecho".

569 GRACIA MARTÍN, L., “Sobre la legitimidad de medidas...", cit. p. 2008. Este autor manifiesta que "el problema social y político del delincuente habitual no es una cuestión de nuestro tiempo, sino que es tan antigua como la historia misma de la sociedad política. Y, aunque pueda parecer lo contrario, las respuestas y las fórmulas vigentes en la teoría y en la práctica del mundo moderno respecto del tratamiento de este tipo de delincuente son asimismo coincidentes en sus rasgos esenciales con las ya ideadas a tal efecto por el mundo antiguo, las cuales han estado presentes en todo el curso histórico de las ideas penales con variaciones sólo en las formas. Recordaré sólo algunos ejemplos para ilustrar esta afirmación. Como es sabido, el sofista Protágoras rechazó todo sentido retributivo del castigo, ya que, por el contrario le asignó únicamente finalidades disuasorias y pedagógicas; sin embargo, Protágoras planteó claramente una excepción precisamente en el caso de los delincuentes habituales, para los cuales la reacción de la comunidad tenía que orientarse a la eliminación de tales sujetos. [...] El estado de ilegalidad [...] es uno en que reinan la desconfianza y el riesgo permanente, y en el cual, por ello mismo, los hombres experimentan el temor y el miedo que son originados por la inseguridad. [...] Para Tomás de Aquino, el "pecador" carece de dignidad y, por ello, "puede ser muerto [por el Estado] como un animal (velut bestia)". [...] A mi juicio, no parece estar muy alejada de la idea de exclusión del sujeto especialmente peligroso para la seguridad general, la justificación excepcional de la pena de muerte que propone Beccaria contra el ciudadano que "tenga tales relaciones y tal poder que interese a la seguridad de la nación; cuando su existencia pueda producir una revolución peligrosa en la forma de gobierno establecida". También en Kant se encuentra más o menos explícita la idea de la exclusión de los individuos peligrosos en razón de la amenaza que representan para la seguridad".

570 SILVA SÁNCHEZ, J.M., “El retorno de la inocuización...”, cit. pp. 701 a 710. 
y el "imprisonment for public protection", que conlleva una pena indeterminada cuya extensión no puede ser inferior a diez años de internamiento, sin olvidar que también existen las llamadas "extended sentences" aplicables a delincuentes violentos y sexuales, con un periodo de internamiento que va de los cinco a los ocho años y opera a modo de periodo de seguridad que se computa como si se fuera una pena ${ }^{571}$; o el ordenamiento estadounidense donde se prevén leyes como la de "Three strikes you are out"572 -que por otra parte descansa en la función inocuizadora derivada de la regla en su día propuesta por Von LISZT-573, la “selective incapacitation"574, etc.

En España el tratamiento del delincuente habitual peligroso, se lleva a cabo en la imposición y determinación de la pena o en su ejecución, mediante la agravante de reincidencia ${ }^{575}$ del art. $22.8 \mathrm{CP}^{576}$ y de la multirreincidencia ${ }^{577}$ del art. $66.5^{\mathrm{a}} \mathrm{CP}^{578}$, o

571 REBOLLO VARGAS, R., “De las medidas de seguridad...”, cit. p. 801.

572 JAKOBS, G., La pena estatal..., cit. pp. 161 y 162. Este autor explica que “abiertamente se persigue el aseguramiento en leyes recientes de algunos Estados de EEUU relativas a reincidentes, cuya regulación más conocida -pero no la única- se refiere a la segunda reincidencia, es decir, al tercer hecho, ordenando, en función del paso del hecho y de los hechos previos, 25 años de privación de libertad, o incluso de libertad de por vida, en algunos casos, incluso excluyendo la posibilidad de una puesta en libertad anticipada. Partiendo de una regla de béisbol, el lenguaje popular dice: "three strikes and you are out".

573 LISZT, F., Der Zweekgedanke im Strafrecht. 1882. Traducción de C. Pérez del Valle. La idea del fin en Derecho penal. Granada: Comares. 1995, p. 87. Este autor opina que "la "inocuización" de los delincuentes incorregibles sería posible si el Código penal estableciese -en fórmula análoga a la de los parágrafos 244 y 245 del Código vigente- que en el caso de una tercera condena por uno de los delitos mencionados antes se impusiera la pena de reclusión por tiempo indeterminado. La pena se cumpliría e régimen de comunidad y en establecimientos especiales (presidios de carácter disciplinario o de trabajos forzados)".

574 SANZ MORÁN, A.J., “De nuevo sobre el tratamiento...”, cit. p. 1092.

575 Aunque autores como GUISASOLA LERMA, C., Reincidencia..., cit. p. 71, afirman que la agravante de reincidencia no supone que el sujeto sea más peligroso que otros. "En contra de fundamentar la agravación de la reincidencia en la mayor peligrosidad criminal se ha argumentado que el reincidente no es más peligroso que el resto de los delincuentes; puede serlo o no, pero la peligrosidad no puede presumirse iuris et de iure como hace el Código vigente. En definitiva, si ese hubiese sido el fundamento de la agravación de la pena del reincidente, tendría que haber previsto la aplicación de una medida de seguridad, que es la reacción adecuada para combatir el "estado de peligrosidad criminal"“".

576 Art. 22. "Son circunstancias agravantes. 8. Ser reincidente. Hay reincidencia cuando, al delinquir, el culpable haya sido condenado ejecutoriamente por un delito comprendido en el mismo Título de este Código, siempre que sea de la misma naturaleza. A los efectos de este número no se computarán los antecedentes penales cancelados o que debieran serlo".

577 GONZÁLEZ CUSSAC, J.L., “La Contrarreforma Penal de 2003: nueva y vieja política criminal”. En Revista Xurídica Galega, núm. 38. 2003, p. 25. Expresa este autor que la conversión de la agravante de reincidencia en cualificada por el número de delitos cometidos implica que el renacimineto de la agravante de "multirreincidencia", que quedó derogada en la Reforma Parcial y Urgente del 15 de junio de 1983. "La condena anterior por tres o más delitos comprendidos en el mismo Título de este Código, obliga a apreciar esta agravante cualificada legalmente y aplicar la pena superior en grado en toda su extensión”. En profundidad sobre la multirreincidencia, vid. AGUADO LÓPEZ, S., La multirreincidencia y la conversión..., cit. pp. 11 a 116.

578 Art. 66.5 a "Cuando concurra la circunstancia agravante de reincidencia con la cualificación de que el culpable al delinquir hubiera sido condenado ejecutoriamente, al menos, por tres delitos comprendidos en el 
mediante las reglas del art. $78 \mathrm{CP}$ para el cumplimiento íntegro de las penas en casos de concurso de delitos. Además, la concurrencia de la agravante de reincidencia, impide el acceso al derecho de gracia ventando así el indulto; impide la suspensión condicional de la pena del art. 81.1 CP y en el caso de que el autor haya cometido el delito a causa de adicción grave a bebidas alcohólicas, drogas tóxicas, estupefacientes, psicotrópicos u otras sustancias de efectos análogos, el art. 87 CP contiene una regla especial de suspensión condicional de la pena, que puede comportar en el caso de reincidentes, el sometimiento del penado a una serie de obligaciones y reglas de conducta579.

Y dejando al margen el tratamiento de los inimputables, el delincuente habitual y peligroso tiene también una respuesta a través de la nueva formulación de la doble vía - pena más medida de seguridad- en determinados supuestos en los que la peligrosidad se constata por la naturaleza de los delitos cometidos. Así, la libertad vigilada para delincuentes sexuales y terroristas que se impone en sentencia ${ }^{580}$ para cumplirla tras la pena privativa de libertad, también conforma una verdadera respuesta para el problema de la reiteración o habitualidad delictiva, ya que su regulación contiene una facultad de no imposición a los delincuentes primarios atendiendo a la menor peligrosidad (art. 192.1 $\mathrm{CP}$ in fine y art. 573.3 CP in fine), lo que se traduce, aunque regulado a la inversa, en que la libertad vigilada procederá en casos en que no se trate de delincuente primario. Ahora bien, se trata de una facultad y no de un mandato directo al Juez o Tribunal para que su imposición se lleve a cabo solo en casos de habitualidad, por lo que su aplicación no queda únicamente circunscrita a ella. Aunque por delincuente primario habría que entender el que no es reincidente -que no haya cometido delitos previos de la misma naturaleza- puesto que no tiene mucho sentido considerar como delincuente primario a efectos de la libertad vigilada a quien pueda haber cometido previamente alguna infracción penal que no guarde ninguna relación con el delito por el que posteriormente es condenado, por cuanto que aquella infracción anterior no sería sintomática de la

mismo título de este Código, siempre que sean de la misma naturaleza, podrán aplicar la pena superior en grado a la prevista por la Ley para el delito de que se trate, teniendo en cuenta las condenas precedentes, así como la gravedad del nuevo delito cometido. / A los efectos de esta regla no se computarán los antecedentes penales cancelados o que debieran serlo".

579 GUISASOLA LERMA, C., Reincidencia..., cit. pp. 86 a 89.

580 Como indica GARCíA ALBERO, R., en QUINTERO OLIVARES, G., Comentarios al Código penal. Tomo I. Navarra: Aranzadi. 2011, p. 685, la posibilidad de imponer la medida de seguridad tras el cumplimiento de la pena sin que se haya impuesto previamente en la sentencia, debe descartarse aunque nos encontremos ante supuestos de peligrosidad sobrevenida o simplemente de constatación sobrevenida de la peligrosidad, porque ello iría en contra del principio de ne bis in idem, con cita de la STC 23/1986, de 14 de febrero. 
peligrosidad de la que se pretende proteger a la sociedad mediante la medida de seguridad, que tiene como presupuesto de aplicación la comisión de unos delitos de naturaleza específica581, aunque dicha interpretación puede que no sea del todo convincente ateniendo al tenor literal del precepto y a las exigencias que impone el principio de taxatividad, por lo que no sería tampoco extraño considerar como primario únicamente a quien cuente con un impecable e inexistente historial delictivo ${ }^{582}$.

Además, conviene tener presente que, en estos casos, con mucha frecuencia se va a aplicar también la agravante de reincidencia, con sus correspondientes efectos de exasperación en la pena ${ }^{583}$, lo que denota una más que dudosa afectación al principio de ne bis in idem, ya que, de entrada, se está aplicando, por un lado, una agravación en la pena basada en la reiteración delictiva y, por otro, una medida de seguridad que se impone además de la pena. Si ambas instituciones (la agravante y la medida de seguridad) tienen el fundamento en la reiteración delictiva (ya que hay una facultad de no imposición de la libertad vigilada a los delincuentes primarios) cuesta mantener una fundamentación precisa que justifique la concurrencia de ambas sanciones. La agravante de reincidencia se basa en la reiteración delictiva, en el mayor reproche que merece el acto por ser reiterado y porque denota peligrosidad criminal del autor, un riesgo patente de que puede volver a reincidir, de ahí que se incremente la extensión de la pena mediante la aplicación de la agavante ${ }^{584}$. Pero, al mismo tiempo, se mantiene que la medida de

581 CID MOLINÉ, J., “La medida de seguridad de libertad vigilada (art. 106 CP y concordantes)”. En SILVA SÁNCHEZ, J.M., (Dir.) / PASTOR MUÑOZ, N., (Coord.) El nuevo Código penal: comentarios a la reforma. Las Rozas: La Ley. 2012, p. 195. Este autor indica que "un primer problema que se plantea en referencia a esta cuestión es la relativa a la interpretación del concepto de "delincuente primario", pues los artículos que regulan la imposición de la libertad vigilada en supuestos de condena a pena privativa de libertad por delito contra la libertad sexual (art. $192 \mathrm{CP}$ ) y terrorismo (art. $579.3 \mathrm{CP}$ ) establecen la condición de que la persona no sea delincuente primario llevará a que la medida de libertad vigilada sea obligatoria. Sobre la base de la excepcionalidad con la que debe aplicarse la libertad vigilada, resulta razonable interpretar "delincuente primario" como sinónimo de no reincidente, pues carece de sentido que el haber cometido con anterioridad un delito distinto a aquéllos para los que se prevé la libertad vigilada, deba llevar a hacer obligatoria la libertad vigilada".

582 Por eso, autores como, por ejemplo, ACALE SÁNCHEZ, M., "Medición de la respuesta punitiva...", cit. p. 190, aduce que delincuente primario es quien carece de condena anterior, pero parace que puede entenderse que esa condena anterior debe ser por hechos similares.

583 En general sobre las circusntancias modificativas vid. GONZÁLEZ CUSSAC, J.L., Teoría general de las circunstancias modificativas de la responsabilidad criminal. Valencia: Universidad de Valencia. 1988, pp. 53 y ss; y sobre la agravante de reincidencia vid. CÓRDOBA RODA, J., "De la infracción penal..." cit. pp. 302 a 308; CORCOY BIDASOLO, M. / MIR PUIG, S., Comentarios al Código Penal: Reforma 5/2010. Valencia. Tirant lo Blanch. 2011, p. 111; COBO DEL ROSAL, M. / VIVES ANTÓN, T.S., Derecho Penal. Parte General..., cit. pp. 899 a 903.

584 MONGE FERNÁNDEZ, A., La circunstancia agravante de reincidencia desde los fundamentos y fines de la pena. Barcelona: Bosch. 2009, pp. 99 a 127. Esta autora explica que los fundamentos de la agravación, desde las 
seguridad subsiguiente también se basa en la peligrosidad, lo que conduce a algunos autores a afirmar que estamos ante otra clase de peligrosidad: la social, que además se articula a través de una nueva y moderna conceptualización que descansa sobre finalidades meramente inocuizadoras y de satisfacción de las demandas punitivas de la sociedad 585 .

También está previsto el caso de la medida de seguridad sustitutiva de expulsión del delincuente peligroso extranjero, donde no se requiere ni siquiera ese mínimo de reiteración para que entre en escena la neutralización operada mediante la doble vía sin la necesaria sujeción a causas de inimputabilidad.

Con anterioridad a la formulación de este nuevo sistema de doble vía en el Código penal, un importante sector de la doctrina ya se mostraba conforme con esta opción como respuesta al interrogante de qué hacer con el delincuente habitual peligroso en el que persiste la peligrosidad tras el cumplimiento de la pena de prisión. Así por ejemplo,

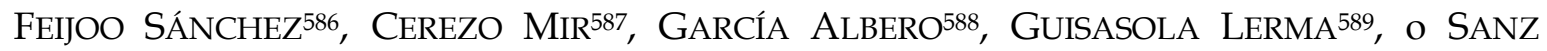

diversas teorías que se han ido formulando, en la insuficiencia relativa de la pena (formulada por CARRARA), en la repetición de las infracciones (formulada por MANZINI), en la mayor culpablidad del sujeto, en su mayor peligrosidad, en la personalidad del reo, en la mayor posibilidad de delinquir en el futuro a la que refería ANTOLISEI, a la mayor inclinación a delinquir (referida por BETTIOL), a la mayor gravedad del injusto y a la mayor agravación de la culpabilidad.

585 ACALE SÁNCHEZ, M., “Medición de la respuesta punitiva...”, cit. p. 190.

586 FEIJOO SÁNCHEZ, B., “La libertad vigilada en el Derecho penal de adultos”. En DÍAZ-MAROTO y VILLAREJO, J. (Dir.), Estudios sobre las reformas del Código Penal: (operadas por las LO 5/2010, de 22 de junio, y 3/2011, de 28 de enero). Navarra: Civitas. 2011, pp. 232 y 233.

587 CEREZO MIR, J., Curso de derecho penal Español. Parte General. (III) Teoría del delito/2. $6^{\text {a }}$ Ed. Madrid: Tecnos. 2004, pp. 173 y ss.

588 GARCÍA ALBERO, R., “Ejecución de penas en el proyecto...", cit. p. 135. Según este autor "España no puede seguir siendo un istmo en lo que a protección de determinados delincuentes especialmente peligrosos se refiere. Como se dijo, más allá de ciertas restricciones al acceso al tercer grado, libertad condicional, acumulación jurídica de penas, así como a la inveterada agravante de reincidencia, no existe en nuestro país instrumento legal alguno que permita neutralizar o minimizar una peligrosidad criminal grave, que subsiste al cumplimiento de la pena de prisión".

589 GUISASOLA LERMA, C., Reincidencia..., cit. p. 100. La autora expresa que "compartimos las críticas dirigidas a la falta de respuesta legal específica frente al problema del delincuente habitual peligroso, concretamente la ausencia de previsión de medidas de seguridad o de corrección". Sigue diciendo (pág. 105) que "a nuestro juicio [...] resulta más razonable acudir a la vía de medidas de corrección y de seguridad, antes que al incremento de penas". Y sigue diciendo (pág. 160) que la libertad vigilada para delitos graves contra la integridad física o contra la libertad sexual "podría ser impuesta en sentencia en los citados casos, si bien su contenido se concretaría en el momento de su licenciamiento definitivo, incorporando una serie de medidas u obligaciones conectadas con los factores de riesgo de reincidencia. Así, entre otras, junto a la obligación de notificación de domicilio, traslados de éste, también la vigilancia electrónica en casos muy graves -control telemático y el control por GPRS- podría rebajar el riesgo de la reincidencia. Sin embargo, deben primar aquellas que estén imbuidas de componentes asistenciales o curativos. Así el sometimiento a programas de tratamiento de tipo terapéutico o educativo otros similares, después de cumplida la condena, resulta acorde con las 
MORÁn que al respecto vino a decir que "no tenemos inconveniente en mostrarnos partidarios de una respuesta dualista al problema del delincuente habitual peligroso de criminalidad media o grave. Opción que fundamenta Frisch [...] en el dato de que la pena no está en condiciones de asumir con carácter exclusivo las distintas exigencias derivadas de la prevención especial que, en muchos casos, se satisfacen mejor con una adecuada combinación de penas y medidas" 590 . Y también la Comisión para el Estudio de las Medidas de Prevención de la Reincidencia (conocida como comisión MENA), en su informe manifestó que "por otro lado, hoy en día no se dispone, a nivel legislativo, de instrumentos de control posteriores a la liberación definitiva del penado. La Comisión propone la reforma del Código penal en el sentido de añadir la vigilancia de conducta entre las medidas que puede acordar el juez o tribunal a la hora de dictar sentencia condenatoria. La vigilancia de conducta o libertad vigilada, dada su naturaleza material más próxima a las medidas de seguridad, podría ser, en su caso, adoptada bajo la fórmula de las penas accesorias, ya existente en el Código penal. Dicha medida, que se impondría junto con la pena correspondiente al tipo de delito cometido, debería estar prevista legalmente de forma limitada en una lista determinada de delitos y sometida a límites precisos de duración en función de la gravedad del delito. La concreción de las obligaciones que se impondrían al condenado debería dejarse en manos del órgano judicial competente" 591.

Parece, pues, que se han venido resolviendo los interrogantes que planteaba la posibilidad de la utilización de la doble vía para supuestos de sujetos imputables peligrosos, en el sentido de aplicar una pena en proporción a la culpabilidad y una medida de seguridad acorde también con la proporcionalidad para hacer frente a su

líneas básicas de nuestra propuesta, enmarcada en una política criminal justa a la par que eficaz. Cobran pues especial interés medidas como la sujeción a tratamiento externo en centros médicos o establecimientos de carácter socio-sanitario, previstas en los arts. $96.2 .11^{\circ}$ y 105.1 a) $\mathrm{CP}$, o el sometimiento a programas de tipo formativo, cultural, educativo, profesional, de educación sexual u otros similares, como los previstos en los arts. $96.2 .12^{\circ}$ y 105.1 f) CP. De suerte que, el contenido concreto de libertad vigilada debiera incluirse expresamente en el Código penal, o efectuarse una remisión en estos casos a las medidas de seguridad no privativas de libertad o a las obligaciones en materia de suspensión, incorporando las nuevas aquí apuntadas".

590 SANZ MORÁN, A.J., “De nuevo sobre el tratamiento...”, cit. p. 1100. Este autor señala que “habrá que dar preferencia, en la articulación de estos dos mecanismos de respuesta al delito, al carácter correctivo de la intervención, frente al meramente asegurativo; fundamento de la medida a imponer lo será siempre el pronóstico de individualizado de peligrosidad criminal y no una mera verificación general o pertenencia del sujeto a una categoría configurada de manera más o menos apriorística".

591 Comisión para el Estudio de las Medidas de Prevención de la Reincidencia, creada mediante Resolución JUS/2362/2007, DOGC núm. 4937, de 24 de julio. Informe publicado por el Centre d’Estudis Jurídics i Formació Especialitzada i la Generalitat de Catalunya. 2008, p. 9. 
peligrosidad, aunque, a mi juicio, el verdadero inconveniente a nivel dogmático reside en la afirmación de si es posible, mediante la constatación de la habitualidad o de la reincidencia como único elemento de juicio, efectuar un pronóstico de peligrosidad fiable que garantice que ese sujeto en cuestión no será acreedor de los efectos reeducadores que se supone que la pena privativa de libertad cumplida en prisión le habrá debido proporcionar, en lógica consonancia con la regulación del sistema. La cuestión reside en determinar si podemos, por el mero hecho de constatar la habitualidad, presumir que la peligrosidad perdurará incluso después de cumplida la pena $\mathrm{y}$, por ende, podemos legitimar la prolongación de las libertades mediante medidas de seguridad que, téngase en cuenta, igualmente comportan un importante contenido restrictivo para el sujeto. En ese orden de cosas, debemos efectuar una previa clasificación de delincuentes en los que podríamos encontrarnos con este problema apriorísticamente planteado, que serían, los delincuentes habituales, los profesionales y los que delinquen por convicción; en cada una de estas categorías o tipos de autor, en la medida en que no son idénticas aunque puedan presentar rasgos coincidentes significativos, puede apreciarse un tratamiento penal distinto, tanto en la tipificación de normas penales (parte especial) como en la previsión de consecuencias penológicas (parte general) ${ }^{592}$.

Conviene tener presente que fue a partir de 1930 cuando la teoría criminológica de los tipos penales adquirió una enorme virtualidad debido a las formulaciones de MEZGER que vino a distinguir entre delincuentes por la situación y delincuentes por el carácter. En el primer grupo se encontraban los delincuentes de conflicto (Konfliktverbrecher), que se sirven del delito como mecanismo de superación de un conflicto personal con la situación en la que se encuentran, que personalmente la resuelven inclinándose por la utilación del delito en lugar de acudir a una forma de solución fuera de él; los delincuentes de desarrollo (Entwicklungsverbrecher), en los que el estado de desarrollo del delincuente tiene una conexión directa con el ilícito penal que cometen; y por último el delincuente

\footnotetext{
592 GÓMEZ MARTÍN, V., El Derecho penal de autor. Valencia: Tirant lo Blanch. 2007. TOL 1.108.725, p. 13. Este autor manifiesta que "el Código penal español y el StGB alemán, por ejemplo, no son una excepción a ese planteamiento. Ambos textos legales toman en consideración para la determinación de la pena ciertos elementos referidos al autor del hecho típico -no, por tanto, del hecho típico mismo-, esto es, determinados elementos personales del sujeto activo. Esta toma en consideración se produce tanto en la Parte General como en la Parte Especial de los respectivos textos. Algunos de estos elementos personales son la condición de delincuente "reincidente", "habitual" o "profesional" del autor u otras "circunstancias personales del sujeto". Se trata de elementos que describen ciertas cualidades del autor que lo convierten en un sujeto especialmente peligroso. [...] En su condición de datos de la realidad empírica, todos estos elementos típicos de naturaleza criminológica constituyen, al mismo tiempo, el objeto de análisis de una de las teorías más representativas de la Criminología clásica: la "teoría de la formación de tipos de autor"“.
} 
ocasional (Gelegenheitsver-brecher) en el que el delito se presenta como un incidente aislado y puntual en su vida sin mayor repercusión. El segundo grupo comprende el delincuente por tendencia (Neigungsverbrecher), y el delincuente por afición (Hangverbrecher), en el que la tendencia delictiva se presenta como una afición o hobbie; y el delincuente de estado (Zustandsverbrecher), categoría donde la conducta delictiva se eleva a la categoría de estado personal como si se tratara de un estado civil, que se instaura en el sujeto de forma permanente 593 .

Al margen de esto, la clasificación criminológica de la teoría de los tipos de autor determina el grado de peligrosidad de cada una de las clases, de modo que el delincuente profesional, el reincidente y el habitual manifiestan una peligrosidad superior al resto de autores, lo que permite otorgarles un tratamiento positivo diferente ${ }^{594}$, por lo que se hace necesario analizar previamente cada una de ellas. En el caso del delincuente habitual, el art. $94 \mathrm{CP}$ lo describe como el que haya realizado tres delitos del mismo capítulo en un plazo no superior a cinco años y haya sido condenado por todos ellos ${ }^{595}$. Von LISZT estableció en su Programa de Marburgo dos clases de delincuentes habituales: los incorregibles596, a quienes dirigía su idea de inocuización, y los necesitados de corrección, a quienes destinaba la finalidad correctora mediante la aplicación de varias clases de penas, de

593 Ibidem, p. 21.

594 Ibidem, p. 13. Este autor manifiesta que "un Derecho penal orientado a las consecuencias y que pretenda luchar eficazmente contra el delito no puede contentarse con la mera constatación empírica de la mayor peligrosidad abstracta de estos dos tipos de autor como hecho perteneciente a la realidad fenomenológica. Es preciso que esta mayor peligrosidad de algunos sujetos se materialice en derecho positivo. Esta materialización se produce en la forma de tipos penales que disponen para el delincuente reincidente, habitual o profesional una pena superior a la prevista para el delincuente ocasional, aunque el hecho concreto cometido sea exactamente el mismo. Convertida en derecho positivo, la especial peligrosidad de los tipos criminológicos de autor de referencia pasará a constituir, además, la ratio legis de los tipos penales en que se encuentran recogidos. Ésta será la guía que servirá para orientar su interpretación teleológico-objetiva. En conclusión: de acuerdo con este planteamiento, parece que una correcta interpretación teleológica de los tipos penales cuyos respectivos sujetos activos responden a una determinada tipología criminológica de autor (como, por ejemplo, la del delincuente reincidente, habitual o profesional) obliga al dogmático a tener un mínimo conocimiento de dichos tipos criminológicos de autor".

595 GUISASOLA LERMA, C., Reincidencia ..., cit. p. 140.

596 LISZT, F., Der Zweekgedanke im Strafrecht..., cit. pp. 83 y 84. Este autor expresa que "la lucha contra la delincuencia habitual es una de las tareas más urgentes de la actualidad. Del mismo modo que un miembro enfermo contagia a todo el organismo, la célula cancerosa del delincuente habitual, en rápido crecimiento, se extiende cada vez más intensamente en nuestra vida social". Sigue diciendo este autor (pág. 86) que "es sencillamente absurda la pretensión de corregir a estas personas en celdas de prisión con unos costes elevadísimos. Es algo más que absurdo que al cabo de algunos años se les deje en libertad como animales de rapiña hasta que, después de cometer tres o cuatro nuevos delitos, tengan que volver a ser "corregidos". Sin embargo, nuestro sistema de previsión de marcos penales no sólo permite estas consecuencias, sino que las exige. [...] La sociedad ha de protegerse frente a los sujetos incorregibles. Sin embargo, si nosotros no queremos decapitar ni ahorcar, y no podemos deportar, únicamente nos queda la cadena perpetua (o, en su caso, por un tiempo indeterminado)". 
forma que gradualmente se preparase al delincuente para su puesta en libertad que quedaría sometida, posteriormente, a vigilancia policial durante un máximo de cinco años 597 .

El delincuente profesional, aunque no cuenta con una regulación específica en nuestro $\mathrm{CP}$, es una subespecie del habitual ${ }^{598}$ con la salvedad de que el profesional vive de su actividad delictiva y de las ganancias obtenidas mediante el crimen, siendo que la pena es un mero riesgo que asume a modo de riesgo laboral derivado de su profesión. Sus características definitorias son: adaptación social, organización más o menos estable, planificación cuidadosa de cada una de sus acciones con empleo de los medios técnicos adecuados, reparto de tareas, no suelen relacionarse con delincuentes de inferior categoría y el fin perseguido no suele ser la mera supervivencia, sino la riqueza y acumulación de bienes materiales 599 .

El delincuente habitual asocial, caracterizado por su inadaptación social por sus carencias culturales, económicas y de conocimientos técnicos, suelen actuar individualmente o en grupos reducidos con planificaciones nulas o muy rudimentarias que hacen que nunca sean capaces de reportar grandes beneficios de sus crímenes. Suelen presentar adicciones a sustancias tóxicas o estupefacientes y la actividad delictiva únicamente está destinada a la supervivencia a su autosuministro de las sustancias a las

\footnotetext{
597 Ibidem, pp. 88 y 89. Este autor dice que "la delincuencia habitual procede también de individuos necesitados de corrección, que, aunque propensos por una predisposición hereditaria o adquirida, todavía no están perdidos sin salvación posible. [...] El tribunal, ante el primero y el segundo delito, tendría que pronunciarse por el traslado en un establecimiento de corrección. La duración de la pena (no expresada en la condena) alcanzaría un mínimo de un año y un máximo de cinco. La pena comenzaría con el aislamiento celular. En caso de que se observara buena conducta, el Consejo de Vigilancia podría acordar, aunque de modo revocable, el paso progresivo a la vida en régimen de comunidad. El trabajo y la enseñanza elemental serían los medios para remover la fuerza de resistencia a su aplicación. Los castigos corporales y las penas disciplinarias estarían absolutamente excluidas. Cada año, el Consejo de Vigilancia podría dirigir al tribunal superior la propuesta de excarcelación del recluso que, al parecer, se haya corregido. El excarcelado quedará bajo vigilancia policial por el mismo tiempo que hubiera permanecido en prisión. En cualquier caso, después de cinco años desde su ingreso, tendría que llevarse a cabo la excarcelación, y el excarcelado quedaría otros cinco años bajo vigilancia policial".
}

598 GUISASOLA LERMA, C., Reincidencia..., cit. p. 142. La autora señala que "por lo que se refiere a la profesionalidad en el delito, considero que esta figura debe contemplarse expresamente en nuestro Código penal, como respuesta jurídica a un realidad presente en nuestro actual escenario criminal".

599 NICOLÁS GUARDIOLA, J.J., “El delincuente”. En NICOLÁS GUARDIOLA J.J. (Dir.) / GINER ALEGRÍA, C.A., (Coord.), Prevención, predicción y tratamiento. Condenados a penas privativas de libertad. Murcia: DM. 2011, p. 31. Este autor incide en que los delitos más frecuentes cometidos por este tipo de delincuentes son el tráfico de estupefacientes a gran escala, los secuestros, las extorsiones, la falsificación de moneda, el tráfico de vehículos, los atracos de furgones blindados, los robos en cámaras acorazadas y bancos, así como las falsedades documentales. 
que son adictos ${ }^{600}$. El delincuente por convicción se mueve por motivaciones personales como si se tratase de una religión, de tal forma que el delincuente no se considera como tal ni tampoco se siente culpable, sino que experimenta una suerte de justificación por sus crímenes basada en sus creencias ${ }^{601}$. Es el caso de los terroristas, a los que, por razones sistemáticas, referiré más adelante. (Vid. infra, Capítulo Tercero, apartado 2.2).

Sin olvidar esta clasificación, aunque dejándola momentáneamente de lado, la habitualidad delictiva tiene en nuestro ordenamiento un tratamiento especial que se proyecta sobre varios frentes. Como se ha dicho, mediante la agravante de reincidencia (art. $22.8 \mathrm{CP})^{602}$ y la discutida multirreincidencia; mediante reglas que impiden la sustitución (art. $88 \mathrm{CP})^{603}$ y la suspensión de la pena (art. $81 \mathrm{CP}$ ) 604 ; mediante la regulación de la figura del delito continuado del art. $74 \mathrm{CP}^{605}$, y mediante la conversión de faltas en

600 Ibidem, pp. 31 y 32. Según este autor, "las actividades delictivas habituales se refieren a: robos con violencia e intimidación, robos con fuerza en establecimientos comerciales y domicilios, robos en el interior de vehículos, tráfico de estupefacientes a pequeña escala y agresiones sexuales".

601 HERRERO-TEJEDOR ALGAR, F., “Terrorismo y tribunales militares”. En GONZÁLEZ CUSSAC, J.L. (Dir.) / FERNÁNDEZ HERNÁNDEZ, A., Fuerzas armadas y seguridad pública. Consideraciones en torno al terrorismo y la inmigración. Col lecció “Estudis jurídics”, núm. 14. Castellón: Universitat Jaume I. 2007, pp. 40 y 41.

602 GUISASOLA LERMA, C., Reincidencia..., cit. pp. 74 y 75. La autora incide en que "para poder apreciar la agravante de reincidencia, en primer lugar, el culpable, al delinquir, debe haber sido con anterioridad condenado ejecutoriamente por otro delito. La expresión "al delinquir" supone la exigencia de la comisión de un nuevo delito, y no de una falta, interpretación que viene corroborada por el hecho de que la infracción anterior y posterior han de ser "delitos" comprendidos en el mismo Título, y de la misma naturaleza [...]. A su vez, el momento de delinquir ha de ser posterior a una condena, esto es, a una sentencia ejecutoria firme. La sentencia firme, como es sabido, no se alcanzará hasta que no se agoten todos los recursos, según lo establecido en el art. 141 párrafo $5^{\circ}$ de la LECrim". Sigue diciendo (pág. 85) que "si se dan los requisitos legales de la circunstancia agravante de reincidencia, contenidos en el art. 22.8, el juez o tribunal, necesariamente, aplicará la pena en la mitad superior de la que fije la ley para el delito. No hay duda pues de que en el texto penal vigente la agravante de reincidencia se configura como circunstancia agravante de aplicación obligatoria".

603 ORTS BERENGUER, E. / GONZÁLEZ CUSSAC, J.L., Compendio..., cit. pp. 470 y 471 . Según estos autores "sólo puede operar la sustitución cuando se trate de penas inferiores a un año de privación de libertad. El criterio orientador de la sustitución es que lo aconsejen las circunstancias personales del reo, la naturaleza del hecho, su conducta y en particular su esfuerzo para reparar el daño causado. Excepcionalmente, el Código permite que se puedan sustituir penas de prisión hasta dos años, "cuando de las circunstancias del hecho y del culpable se infiera que el cumplimiento de (las penas) habría de frustrar los fines de prevención y reinserción social". En cualquier caso, en estos dos supuestos se exige para que opere la sustitución que el reo no sea habitual".

604 Ibidem, pp. 466 y 467. Estos autores aseveran que "el condenado ha de haber delinquido por primera vez, es decir, no puede ser reincidente (delincuente primario). De todos modos el Código precisa que a estos efectos no se tienen en cuenta las condenas por delitos imprudentes ni los antecedentes penales que hayan sido cancelados o que debieran serlo con arreglo a las normas de cancelación contenidas en el propio texto penal. Sobre este punto, la doctrina mayoritaria sostiene que tampoco se computan a efectos de reincidencia la previa comisión de faltas, de acuerdo a una interpretación gramatical, en la medida en que se entiende el término delinquir en el sentido estricto de cometer delitos y no faltas. Igualmente se considera que sólo ha delinquido en el sentido del precepto, quien ya ha sido condenado por sentencia firme".

605 CUELLO CONTRERAS, J. / MAPELLI CAFFARENA, B., Curso de Derecho penal..., cit. pp. 226 y 227. Estos autores señalan que "varias acciones en sentido natural cada una de las cuales realiza por sí misma el tipo 
delitos por la mera reiteración delictiva: es el caso de la transformación en delito de la conducta consistente en realizar, en el plazo de un año, tres faltas de hurto cuando el montante total sustraído exceda de $400 €^{606}$, previsto en el inciso final del art. 234 CP607; o la reiteración en el plazo de un año de cuatro faltas de lesiones del art. $617 \mathrm{CP}$, que también se trasforma en delito (art. $147.1 \mathrm{CP})^{608}$. Y por último, mediante la creación de delitos habituales o figuras delictivas donde la habitualidad es un elemento del tipo, pudiendo distinguir entre delitos habituales propios e impropios, dependiendo de si cada acción aislada constituye en sí misma un delito, o si separadamente no son delito y solo se convierten en delictivas por la presencia de habitualidad, como el caso del art. $173.1 \mathrm{CP}$ que tipifica —desde la reforma de 2010- el delito de acoso laboral e inmobiliario ${ }^{609}$, figuras en las que se requiere la reiteración 610 , el art. 173.2 CP que contempla el delito de violencia doméstica habitual611 o la receptación de faltas del art. 299 CP612.

delictivo pueden convertirse en un delito continuado bajo los siguientes presupuestos: a) Pluralidad de acciones [...] b) Continuidad espacial y temporal [...] c) Misma forma comisiva [...] d) Mismo bien jurídico [...] e) Dolo continuado [...]. La pena a aplicar será la correspondiente a la infracción más grave en la mitad superior (art. $74.1)^{\prime \prime}$.

606 TORRES ROSELL, N., “El delito de hurto”. En QUINTERO OLIVARES, G., (Dir.) La Reforma Penal de 2010: Análisis y Comentarios. Navarra. Thomson Aranzadi. 2010, p. 196. Según esta autora "el objetivo del apartado segundo del art. 234.1 es el de posibilitar la aplicación de la pena de hurto, esto es, una pena de prisión de entre seis y dieciocho meses, a conductas que debido a lo escaso de la cuantía sustraída no pasan de ser meras faltas de hurto del art. $623.1 \mathrm{CP}$. Son requisitos para la aplicación del precepto la concurrencia de tres acciones constitutivas de falta de hurto, la realización de tales acciones en el plazo de un año y, en tercer lugar, la superación, en el montante acumulado, de los cuatrocientos euros que constituyen el mínimo exigido para apreciar el delito de hurto. La reforma a la que se somete el precepto constituye una modificación a la versión resultante de la LO 11/2003 mediante la cual se elevó ya a la categoría de delito la comisión de cuatro faltas de hurto -y no tres, como en el texto que viene a aprobarse-".

607 GUISASOLA LERMA, C., Reincidencia..., cit. p. 104. Expresa la autora que "en nuestro derecho interno, la reforma de 1983 acabó con la tradición agravatoria del "tertium furtus", no habiendo necesidad políticacriminal que justifique su recuperación, máxime cuando contamos con la virtualidad agravatoria del delito continuado. Su pretendida reintroducción parece pues un intento por parte del legislador de plasmar una política criminal que evoca el pensamiento de "a la tercera va la vencida" (three strikes you are out) de reciente incorporación en los EE.UU."

608 CARBONELL MATEU, J.C. / GONZÁLEZ CUSSAC, J.L., con la colaboración de GUARDIOLA GARCÍA, J., "Lesiones". En VIVES ANTÓN, T.S. / ORTS BERENGUER, E. / CARBONELL MATEU, J.C. / GONZÁLEZ CUSSAC, J.L. / MARTÍNEZ-BUJÁN PÉREZ, C.M., Derecho Penal. Parte Especial. $3^{\text {a }}$ Ed. Valencia: Tirant lo Blanch. 2010, p. 139. Estos autores explican que "la LO 11/2003 ha introducido en el art. 147.1 un segundo párrafo que castiga con la misma pena de las lesiones básicas al que en el plazo de un año, haya realizado cuatro veces la acción descrita en el art. 617 del Código. Se construye así un delito de lesiones sobre la base de repetición de lesiones no constitutivas de delitos, en las que además no se requiere identidad de sujeto pasivo: salto cualitativo en virtud de la mera reiteración cuantitativa cuya explicación habrá que entroncar con la potenciación de los efectos penales de la reincidencia llevada a cabo por la misma LO 11/2003. La valoración que ha de merecer esta previsión ha de ser sumamente negativa".

609 CORCOY BIDASOlO, M. / MIR PUIG, S., Comentarios..., cit. p. 408 a 410. Afirman estos autores que, en ambas modalidades de acoso, la reiteración de la conducta es lo que dota de relevancia penal a cada uno de los actos de acoso, que valorados de forma separada, no podrían ser constitutivos de trato degradante porque en ese caso ya se encuadrarían en el tipo básico del art. 173.1 CP.

610 FERNÁNDEZ PALMA, R., “Acoso laboral e inmobiliario (arts. 172.1, párrafo tercero y 173.1, párrafos segundo y tercero CP)". En QUINTERO OLIVARES, G., (Dir.), La Reforma Penal de 2010: Análisis y Comentarios. 
La pregunta que surge después de todo lo anterior es si, además, podemos imponer medidas de seguridad complementarias a la pena para el tratamiento del delincuente habitual que, por su reiteración delictiva, se considera peligroso y que el tratamiento en el ámbito estrictamente de la pena no satisface plenamente a los propósitos de garantizar la seguridad de la sociedad, por lo que se plantea el interrogante de si es posible ofrecer mediante esta técnica, una respuesta válida al servicio de la inocuización. En principio, las medidas de seguridad de cumplimiento consecutivo y complementario a la pena como la custodia de seguridad alemana, tienen vigencia en muchos ordenamientos jurídicos, en España se ha venido debatiendo su legitimidad y se argumenta que una medida de seguridad como esa puede ir en contra de la dignidad de la persona ${ }^{613}$. A mi juicio, sobre la legitimidad de las medidas de seguridad complementarias a la pena en estos casos de habitualidad delictiva, no se ve afectada la dignidad, porque como indica GRACIA MARTíN, "la custodia de seguridad no priva al individuo de su autonomía o, si se quiere decir de otro modo, de su condición de persona responsable, y por ello no puede rechazarse con el argumento de que sea contraria al principio del respeto debido a la dignidad humana"614. Sin embargo, este mismo autor

Navarra. Thomson Aranzadi. 2010, p. 155. Este autor aduce que "las conductas, además, deben ser reiteradas de actos hostiles o humillaciones. Con esta redacción se reconoce la escasa entidad aislada de las agresiones que conforman el acoso y la necesaria reiteración, como núcleo definitorio del delito".

611 CORCOY BIDASOLO, M. / MIR PUIG, S., Comentarios..., cit. pp. 410 y 411. Como afirman estos autores, “en la LO 14/1999, el legislador se pronuncia sobre uno de los temas que más controversia había suscitado en la práctica de los tribunales: el concepto de habitualidad. Desde entonces, para apreciarla se debe atender al número de actos de violencia que resulten acreditados, así como la proximidad temporal de los mismo, con independencia de que dicha violencia se haya ejercido sobre diferentes víctimas, y de que los actos violentos hayan sido o no objeto de enjuiciamiento en procesos anteriores. [...] En relación con el número de actos de violencia, la jur. may. inicialmente exigía tres actos probados. En la actualidad doc. y jur. may. se inclinan por prescindir del número concreto de actos probados, poniendo el acento en la necesidad de constatar un estado de violencia permanente".

612 GUISASOLA LERMA, C., Reincidencia..., cit. p. 108. La autora asevera que "para que pueda hablarse de delito habitual es preciso que el hecho típico pueda o deba ser realizado mediante la ejecución de varias conductas idénticas. Tales delitos pueden clasificarse como en delitos habituales propios, cuando las conductas aisladamente no constituyen delito, y delitos habituales impropios, cuando cada una de las conductas, aisladamente, constituye delito, sin que la realización de varias de ellas implique más que un solo delito. En los delitos habituales propios la realización del tipo exige una repetición de actos sin que, normalmente, la figura legal precise el número exacto de ellos que hay que realizar para entender cometido el delito. Por consiguiente, entendemos que el delito de malos tratos habituales previsto en el art. 173 puede ser considerado realmente un delito habitual propio. A este modelo parece responder también el delito de receptación de faltas (art. 299 CP). Para que la receptación de las faltas pueda considerarse delictiva, se exige como elemento típico que se trate de un comportamiento habitual".

613 SIERRA LÓPEZ, M.V., La medida de libertad vigilada..., cit. p. 75.

614 GRACIA MARTÍN, L., “Sobre la legitimidad de medidas de seguridad...”, cit. pp. 990 y 991 . Según este autor, "cuando el sistema ético individual de acción no concuerda con el orden social de protección por el Derecho, y el individuo pone en práctica su particular sistema de acción contrario a dicho orden social, entonces el Derecho tiene que poder imponerlo a dicho individuo, pues de otro modo no le sería posible 
incide en que, a pesar de que dichas medidas no afectan de forma directa e ilegítima en la dignidad de las personas, no es menos cierto que su utilización no deja de ser un instrumento que afecta a los derechos fundamentales, por lo que habrá que sopesar si el mal que se trata de evitar mediante su utilización, es mayor o menor de la afección o lesión a otros derechos que se ven afectados por su utilización concreta615. Es decir: por una parte está la defensa social y la prevención de peligros para los bienes jurídicos más relevantes incluidas las posibles víctimas; y por otra, el derecho a la libertad, a la igualdad, a la seguridad, a la legalidad, a la humanidad de las penas, a no ser objeto de tratos inhumanos o degradantes, etc., todos ellos derechos fundamentales. Una colisión de tal calado no puede resolverse de otra forma que no sea haciendo primar todos estos derechos del penado sobre la defensa social y la prevención de peligros, porque la prognosis, como se ha visto, no es ni siquiera un aspecto que pueda asegurarse, esto es: “el carácter pseudoempírico de toda prognosis de peligrosidad en el caso de sujetos imputables hace que la misma prognosis de peligrosidad para largos periodos temporales sea insostenible en el plano científico de la experiencia". Y sigue diciendo este autor que, "ha de tenerse en cuenta además que la peligrosidad de un sujeto no debe bastar para llevar a cabo una injerencia en sus derechos fundamentales una vez que el mismo ya ha saldado sus cuentas mediante el cumplimiento de una pena privativa de libertad proporcionada al injusto del hecho cometido y a su culpabilidad por este hecho" 616 .

cumplir su tarea fundamental de superar la guerra de todos contra todos". Sigue diciendo este autor (págs. 995 y 996) que "todo el que lleva a cabo de un modo reiterado hechos delictivos abandona de hecho el estado de sociabilidad y se traslada de un modo éticamente libre al estado de imbecilidad definido por Pufendorf. En ese sentido, pues en la custodia de seguridad o en cualquier medida de carácter exclusivamente inocuizador no cabe ver nada más que la efectiva realización de la decisión de voluntad éticamente libre de quien de hecho quiere permanecer en estado de imbecilidad. Como incluso en ese estado continúa siendo una persona responsable, éticamente libre y capaz de reincorporarse al estado de socialidad mediante una decisión asimismo autónoma, es decir, éticamente libre, el Derecho tiene que establecer vías que hagan posible dicha reinserción".

615 Ibidem, pp. 996 y 997. Este autor explica que “la funcionalidad o adecuación prácticas de un instrumento para la realización de su fin, sin embargo, son necesarias pero no suficientes para la justificación del instrumento mismo. No es legítimo el recurso a cualquier instrumento adecuado a su fin "a toda costa", sino que han de tenerse en cuenta los efectos colaterales reales que pueda tener su aplicación para otros valores y principios que se ven afectados inexorablemente con el uso de aquél. [...] La ponderación de los intereses en juego [...] tiene que llevar a la conclusión, a mi juicio, de que [...] representa un mal considerablemente mayor que el que se trata de evitar, con lo cual la medida deber ser rechazada en aras del principio de proporcionalidad inherente al Estado de Derecho".

616 Ibidem, pp. 997 y 998. Para este autor, "la indeterminación o incertidumbre respecto del mal que se trata de evitar, y en definitiva, la inseguridad del pronóstico de peligrosidad, contrasta con la actualidad y efectividad del grave menoscabo que experimenta ante todo el derecho fundamental a la libertad del sometido a custodia de seguridad, y con la de otros efectos negativos asociados a aquel menoscabo, lo cual tiene que verse como un claro indicativo de que el mal que se causa es mucho mayor que el que se trata de evitar". 
En definitiva, las medidas de seguridad privativas de libertad de cumplimiento posterior a la pena, es dudoso que puedan tener cabida en nuestro ordenamiento porque podrían ir en contra de la proporcionalidad, y el pronóstico de peligrosidad es tan incierto y ofrece tan escasa fiabilidad que no está justificada ni siquiera su necesidad. Atendiendo además a que ya se cuenta con agravaciones específicas muy serias en el ámbito de la pena - como ya se ha visto- no parece que la prolongación de las privaciones en la esfera de la libertad sea del todo armónica con la máxima in dubio pro libertate, non pro securitate, siendo pues, innecesaria; pero sí puede ser posible ante el innegable riesgo que presenta la habitualidad delictiva -como antes decíamos- acudir a medidas de seguridad no privativas de libertad, entre las que está la libertad vigilada que es objeto del presente estudio 617 .

La tesis contraria es la que defiende JAKOBS, cuando afirma que el delincuente habitual peligroso que no presenta suficiente seguridad cognitiva en su comportamiento personal, puede ser objeto de medidas de aseguramiento posteriores a la pena en cuanto que es tratado como enemigo ${ }^{618}$. El Estado está legitimado, cuando un autor revela por su comportamiento que no se puede confiar en que adaptará su comportamiento a la norma, a no tratarle como una persona en Derecho "sino que el aseguramiento se dirige contra él en cuanto individuo peligroso; por lo tanto, en esa medida se le despersonaliza jurídicamente"619. La aplicación de medidas de seguridad de cumplimiento posterior y complementario a la pena de prisión, como la custodia de seguridad, para JAKOBS no supone una privación de libertad a causa de la realidad personal del delincuente, sino por la elevada dosis de presunción de delitos futuros manifestada en su comportamiento anterior, y "con una reciente exclusión, los hechos ulteriores del enemigo se convierten en perturbaciones de un orden - en lo que a él se refiere- ya no sólo cognitivo; la

617 GRACIA MARTÍN, L., “Sobre la legitimidad de medidas...”, cit. p. 999. Sigue diciendo este autor que "para hacer frente a ese riesgo, cabe recurrir a otros medios proporcionados, como la restricción de posibilidades de obtención de la libertad condicional y de beneficios penitenciarios por motivos de peligrosidad, un mayor control de excarcelado con posterioridad mediante su sometimiento a vigilancia o a reglas de conducta, etc."

618 JAKOBS, G., La pena estatal..., cit. p. 168. Explica este autor que “quien continuamente se comporta como Satán, al menos no podrá ser tratado como persona en Derecho en lo que se refiere a la confianza de que cumplirá con sus deberes; pues falta el apoyo cognitivo para ello".

${ }^{619}$ Ibidem, p. 172. Este autor expresa que "puede mantenerse la pretensión abstracta de que el afectado debe regirse por las normas jurídicas, es decir, que en el plano abstracto, conceptual, es posible que el delincuente a asegurar se mantenga como persona; sin embargo en el trato real que se le dispensa se convierte en el trato a un enemigo". 
confirmación de la norma cede ante la administración de seguridad"620. Algunos autores mantienen que "la peligrosidad tiene una relación de especie a género con el Derecho penal de autor y ambos encuentran su referencia en el denominado Derecho penal del enemigo"621, formulado en la construcción teórica de JAKOBS que, por otra parte, ha sido objeto de numerosas críticas doctrinales ${ }^{622}$.

Por último, si admitimos la aplicación de medidas de seguridad a posteriori a sujetos imputables peligrosos, $\mathrm{y}$, en concreto la libertad vigilada, conviene hacer

620 Ibidem, p. 173. "Esta despersonalización -esto debe destacarse- se produce de modo puntual, exclusivamente en lo que se refiere al posible uso defectuoso de la libertad. Por lo demás, la personalidad jurídica queda incólume; en un ejemplo, el delincuente a asegurar mantiene su derecho y debe pagar impuestos".

${ }^{621}$ GUDÍN RODRÍGUEZ-MAGARIÑOS, F., La nueva medida de seguridad..., cit. p. 96. En opinión de este autor, "si el presupuesto de la responsabilidad criminal se traslada a la situación de riesgo, a la pertenencia a un grupo u organización, a la peligrosidad ex ante, la redacción se traslada también desde la pena hasta la medida de seguridad predelictiva, que de esta forma se convierte en pieza esencial del sistema punitivo. La anticipación al ataque, la necesidad de prevención, son consecuencia lógica de este pensamiento. Pero con el redescubrimiento del binomio peligrosidad social ex ante y su consecuencia lógica, la medida de seguridad predelictual también nace el fantasma de la "pena absolutamente indeterminada": mientras subsista la peligrosidad y no preste una mínima "seguridad cognitiva", existirá la necesidad de prevenir la seguridad (el sistema), y entonces, sin contrapesos ni límites, habrá de mantenerse el régimen restrictivo o privado de derechos del enemigo".

622 Por ejemplo de autores como GONZÁLEZ CUSSAC, J.L., El derecho penal frente al terrorismo. Cuestiones y perspectivas. Lección inaugural del curso 2005/2006. Castellón. Universitat Jaume I. 2005, p. 34; GONZÁLEZ CUSSAC, J.L., "El renacimiento del pensamiento totalitario en el seno de Estado de Derecho: la doctrina del derecho penal del enemigo". En Revista Penal. La Ley, núm. 19, enero de 2007, pp. 60 y 61 . Este autor afirma que "el punto de partida del derecho penal del enemigo, diferenciando entre personas y no-personas, entre personas e individuos, entre ciudadanos y enemigos, es antes que nada un regreso a la tribu, a la caverna y por tanto el fin del progreso de la humanidad. Supone un retroceso milenario en el mundo de las ideas, para llevarnos a la recuperación de las nociones de las culturas antiguas acerca de "los otros", los que no pertenecen a nuestra tribu, a los que están fuera de la caverna. Nos propone un regreso a la noche de los tiempos, a construir dos sistemas: uno de reglas para los ciudadanos y otro precisamente para los diferentes, para los que no son como nosotros". También MUÑOZ CONDE, F., "Las reformas de la Parte Especial del Código Penal español de 2003, de la tolerancia cero al derecho penal del enemigo". En Revista de Derecho penal, núm. 2. Buenos Aires. 2005; MUÑOZ CONDE, F., De nuevo sobre el "Derecho penal del enemigo". En PÉREZ ÁlVAREZ, F., (Editor.), Vniversitas Vitae, homenaje a Ruperto Núñez Barbero. Salamanca: Aquílafuente. Ediciones Universidad de Salamanca. 2007, p. 525. Este autor expresa que "la primera observación que puede hacerse a JAKOBS es que su "Derecho penal del enemigo" recuerda mucho al "Derecho penal de autor" que propugnaron los penalistas nazis, según el cual lo relevante no era el hecho delictivo cometido, sino la "perversión", "inclinación o tendencia al delito" o "peligrosidad criminal" que pudiera tener su autor". Y también muchos otros autores de los que podemos nombrar, por todos, a los siguientes: MANTOVANI, F., “El Derecho penal del enemigo, el Derecho penal del amigo, el enemigo del Derecho Penal, y el amigo del Derecho penal". En GARCÍA VALDÉS, C. / CUERDA RIEZU, A. / MARTÍNEZ ESCAMILLA, M. / ALCÁCER GUIRAO, R. / VALLE MARISCAL DE GANTE, M., (Coords.), Estudios penales en homenaje a Enrique Gimbernat. Madrid: Edisofer. 2008, pp. 423 a 448; POLAINO NAVARRETE, M., "Entre el Derecho penal simbólico y el Derecho penal del enemigo: la represión punitiva de la llamada "violencia de género"." En DÍAZ-MAROTO VILLAREJO (Coord.), Derecho y Justicia penal en el S XXI. Liber amicorum. Homenaje al profesor Antonio González-Cuellar García. Madrid: Colex. 2006, pp. 673 a 612; GRACIA MARTÍN, L., El horizonte del finalismo y el "derecho penal del enemigo". Valencia: Tirant Lo Blanch. 2005; NIÑO, L.F., "Derecho penal del enemigo: nuevos argumentos para el viejo discurso del poder punitivo". En PÉREZ ÁLVAREZ, F., (Editor.), Vniversitas Vitae, homenaje a Ruperto Núñez Barbero. Salamanca: Aquílafuente. Ediciones Universidad de Salamanca. 2007, pp. 553 a 566. 
referencia a la necesidad de protocolos de actuación, ya que, necesariamente hemos de partir de la imposibilidad ya referida de establecer cánones de peligrosidad fiables sobre los que construir la aplicación automática de la medida de seguridad derivada de la constatación de la peligrosidad criminal, por lo que, como indica GUDÍN RODRÍGUEZ-MAGARIÑOs "es preciso plantear al menos un protocolo de actuación o unos cánones o criterios para perfilar el volátil e implacable concepto de la peligrosidad, que permitan convertir la actuación judicial en intuiciones que pudieran degenerar en la más pura arbitrariedad. Parece necesario instaurar un protocolo de actuación donde partiendo de los informes pormenorizados de los oficiales de la libertad vigilada se pueda constatar la evolución individualizada del convicto sujeto a la medida" ${ }^{623}$.

\section{El tratamiento del delincuente sexual peligroso}

En cuanto al delincuente sexual peligroso que presenta elevadas tasas de reincidencia y en el que se constata que la peligrosidad subsiste tras el tratamiento recibido en prisión, la sensación de inseguridad que estos individuos producen en la colectividad ciudadana ha venido generando una serie de reacciones estratégicas en todos los países de nuestro entorno, que se traducen, como ya se ha visto, en el aumento de la duración de las penas encaminadas a la inocuización, en programas de tratamiento, en la aplicación de medidas de seguridad de cumplimiento posterior a la pena privativa de libertad, en la creación de registros públicos y en la castración química. En esta materia se ha venido produciendo en los últimos años un notable incremento de las penas y demás mecanismos en el ámbito estrictamente de las consecuencias jurídicas del delito y en su aplicación, así como la creación de nuevos tipos penales en esa materia. Pero, por razones sistemáticas, de estos aspectos nos referiremos en otro lugar de este trabajo al que nos remitimos, [vid. infra, Capítulo Tercero, apartado 2.1].

En relación a los programas de tratamiento, en España comienzan con el Programa de Control de la Agresión Sexual (SAC), que provenía de su previa aplicación en Cataluña

\footnotetext{
${ }^{623}$ GUDÍN RODRÍGUEZ-MAGARIÑOS, F., La nueva medida de seguridad..., cit. p. 108. Como indica este autor, "la calidad de los informes dependerá, y mucho, de la formación de estos funcionarios cuanto más pluridisciplinar sea (criminología, psicología, asistencia social, etc.) complementado con la experiencia en el tratamiento con personas conflictivas. Cuanto más detallados y precisos sean los informes éstos contarán con mayores potencialidades de adaptación a las necesidades reales del sujeto".
} 
en 1996624. Actualmente, de conformidad con la previsión constitucional de que toda persona condenada tiene derecho a que la pena se oriente hacia la reinserción mediante un plan individualizado, en el caso específico de la delincuencia sexual "el sistema penitenciario español dispone de programas de orientación cognitivo-conductual dirigidos a educar a la persona en la capacidad de resolución de problemas, al fomento de la empatía, a la capacidad de control de sus impulsos y en la confrontación de las cogniciones que neutralizan la conducta delictiva"625, y que son programas que han demostrado ser eficaces y que en multitud de ocasiones arrojan pronósticos favorables de reinserción en los penados.

La creación de registros públicos para mantener la publicidad sobre la existencia de delincuentes sexuales que, a pesar de que están en libertad, son considerados peligrosos, consiste en una suerte de lista negra que necesariamente les va colocar en una situación de marginalidad. En España no existe este tipo de registros, sino que únicamente existe el Registro Central de Penados donde se inscriben las condenas y a través del que se certifica la existencia de antecedentes penales; aunque hay un primer paso en la ley penal que podría aventurar la futura implantación de este tipo de sistemas en nuestro país, que está previsto en la Disposición adicional segunda de la LO 5/2010, que insta al Gobierno, en conjunción con las Comunidades Autónomas, a crear, en el plazo de un año, un registro electrónico para la inscripción de las faltas ${ }^{626}$, sobre todo a los efectos de constatar la reiteración en la comisión de este tipo de infracciones y que podría extenderse en futuras reformas hacia la creación de registros de delincuencia sexual o de otra índole.

Por otra parte, en EE.UU., este sistema de registros públicos de delincuentes sexuales está debidamente implantado y conlleva la obligación de que el penado, una vez excarcelado, se inscriba en el registro, para lo que deberá personarse en la Comisaría de Policía más próxima al lugar donde pretenda ubicar su residencia. En caso de no

${ }^{624}$ FERNÁNDEZ VILLAZALA, T., “La medición de los delitos sexuales como base empírica de la expansión del derecho penal”. En PÉREZ ÁLVAREZ, (Editor) / DÍAZ CORTÉS, L.M., (Coord.) Temas actuales de investigación en Ciencias penales. Memorias del I Congreso Internacional de Jóvenes Investigadores en Ciencias penales. Salamanca: Aquilafuente. 2011, p. 274.

${ }^{625}$ CID MOLINÉ, J., “La medida de seguridad de libertad vigilada...”, cit. p. 196.

626 “Disposición adicional segunda. Sistema electrónico de registro de faltas. El Gobierno, en colaboración con las Comunidades Autónomas con competencia en la materia, establecerá en el plazo de un año un sistema electrónico de registro para las faltas". 
presentarse, la Policía puede proceder a la detención para llevar a efecto la inscripción ${ }^{627}$; de esa forma, quien asume la carga de su seguridad es el propio sujeto628. Una vez inscrito, la publicidad de las inscripciones se hace a través de Internet, mediante la venta de la información en soportes informáticos (cds), publicaciones en periódicos, en ordenadores situados en la ferias de las localidades, y se publican fotografías, el nombre, la dirección, etc. Sin embargo, lo que algunos autores ponen de manifiesto es que, por su propia existencia, dichos registros "producen una mayor inseguridad ciudadana entre las personas que localizan a un individuo que ha sido condenado por algún delito sexual y que vive en su zona. Por lo que en algunas situaciones los vecinos buscan forzar la situación para que esta persona emigre del barrio incluso llegando, para ello, a utilizar la fuerza" 629 .

El criterio seguido en EE.UU. para estos registros es el que establece tres niveles de peligrosidad, de forma que el acceso a la información registral se va volviendo más accesible y más publica cuanto más peligroso es el delincuente registrado. Así, el nivel I es para delincuentes sexuales de riesgo moderado, que implica que únicamente las autoridades tendrán acceso a la información registrada; el nivel II es de riesgo medio, que conlleva que pueda tener acceso a la información, además de las autoridades, cualquier organización de interés general; y por último el nivel III es de alto riesgo, en cuyo caso todos los ciudadanos tienen derecho a acceder y conocer la información registral sobre la peligrosidad sexual inscrita ${ }^{630}$. El riesgo que este mecanismo comporta es que se deja en manos de los particulares el tratamiento de dichos datos que pueden ser procesados con incontrolado alcance y con incognoscible significación a largo plazo. Todo ello, unido al “alarmismo inherente de la lógica de la seguridad lleva necesariamente a la estigmatización y exclusión permanente de la visa social de quienes ya hayan cumplido su condena. Toda una invitación a las llamadas "reacciones informales" que están muy

\footnotetext{
627 FERNÁNDEZ VILLAZALA, T., “La medición de los delitos sexuales...", cit. p. 277. Señala este autor que "nos encontramos ante otro tipo de condena, justificada por la prevención de la delincuencia sexual, pudiendo incluso la policía realizar una detención preventiva en ese sentido".

628 SIERRA LÓPEZ, M.V., La medida de libertad vigilada..., cit. p. 96.

${ }^{629}$ FERNÁNDEZ VILLAZALA, T., “La medición de los delitos sexuales...”, cit. p. 277. Este autor indica que "por estos motivos, estos "ex convictos sexuales" intentan no registrarse, pese a las graves penas que ello conlleva, o se trasladan a otros países, donde no le consta ningún tipo de antecedente en estos delitos, y no existe ningún tipo de control".
}

630 ROBLES PLANAS, R., ““Sexual Predators...”, cit. p. 12. 
lejos del pretendido ideal de seguridad"631. Por otra parte, se objeta a esta medida que produce una vulneración del derecho a la intimidad personal y a la dignidad, debido a que su objetivo es la degradación de la persona, provocar sentimiento de vergüenza y humillación, que le conduce al aislamiento, debido al inevitable efecto estigmatizador que, a su vez, dificulta enormemente la reinserción ${ }^{632}$.

La castración química o tratamiento hormonal reversible, está regulada en algunos Estados de EE.UU.633 y en Europa, sobre todo por las concepciones Francesa y Británica del tratamiento del delincuente sexual reincidente; así como también en Alemania donde, a pesar de que la castración química no se maneja como una opción político-criminal, existe una ley de castración voluntaria que está vigente desde 1969 (aunque su escasa aplicación oscila entre diez o doce castraciones al año). Consiste en la administración de una medicación antiandrógena basada en compuestos químicos de acetato de medroxiprogesterona (MPA) comercializado bajo el nombre de "Depro-Provera", y acetato de cyproterona (CPA), con la finalidad de suprimir en el sujeto la producción de testosterona e impedir con ello la aparición de impulsos sexuales ${ }^{634}$. Se administra periódicamente y es de efectos reversibles, de forma que la mera interrupción de la dosificación periódica implica que vuelva a desencadenarse el comportamiento anterior. Esta reversibilidad es una las causas que justifican su utilización frente a la castración médico-quirúrgica, que no es reversible y además es notablemente más cara que la química.

631 Ibidem, p. 17.

632 SIERRA LÓPEZ, M.V., La medida de libertad vigilada..., cit. pp. 97 y 98. Esta autora afirma que lo más llamativo de esta medida es que se produce un enaltecimiento del reproche moral debido al alto nivel de estigmatización que produce la publicación de ciertos datos del sujeto, aumentando y fomentando la desaprobación moral.

633 ROBLES PLANAS, R., ““Sexual Predators...”, cit. pp. 9 y 10. Este autor explica que “en la actualidad aproximadamente un tercio de los estados que forman los Estados Unidos de América tienen en vigor leyes de castración. De nuevo fue durante la década de los 90 cuando apareció por primera vez en tiempos recientes la posibilidad de usar medicamentos para luchar contra el peligro que representan los delincuentes sexuales. En esta ocasión fue California el primer Estado en dotarse de una ley de castración química en el año 1996. En términos generales la castración química de los Estados Unidos constituye una medida de tratamiento que posibilita que no se ejecute la totalidad de la privación de libertad del condenado, esto es, opera como una condición para obtener la libertad condicional (parole). Así sucede en California, Florida, Colorado, Georgia, Louisiana, Montana, Texas, Oregon y Wisconsin. Más allá de ello, las regulaciones cada Estado divergen considerablemente. Así, en Florida la ley autoriza al juez a imponerla incluso ya en el primer delito sexual, siendo obligatoria a partir del segundo delito sexual. En otros estados, en cambio, el juez goza de mayor discrecionalidad. En cuanto a su duración ésta también varía en función del estado. En Florida, por ejemplo, es el Juez quien debe determinarla y puede llegar a ser de por vida. En otros estados (California, Oregon) la duración de la medida queda en manos del correspondiente Departamento de Corrección. Sólo en California está previsto un procedimiento de consentimiento informado para el sujeto que recibe el tratamiento".

634 Ibidem, p. 9. Este autor explica que "operan enviando al cerebro la falsa señal de que el organismo dispone de suficiente testosterona, de manera que aquel deja inmediatamente de producirla". 
El sometimiento suele ser voluntario - aunque no siempre- por lo que se ha venido sosteniendo por la doctrina que únicamente cuando sea voluntario será conforme con el derecho a la autonomía personal y a la autodeterminación sobre el propio cuerpo. Se ha venido argumentando también, que incluso el consentimiento prestado vulnera el derecho a la libertad porque se presta bajo la amenaza del cumplimiento de la pena privativa de libertad y se usa como moneda de cambio para eludir aquélla, por lo que el penado tiene que elegir; pero aun así, sigue siendo una ampliación de su esfera de libertad porque de no existir la posibilidad de la castración química, únicamente podría existir la prisión ineludible ${ }^{635}$. También se objeta que en casos en que el sujeto es además violento, solo se consigue neutralizar parcialmente la peligrosidad, ya que únicamente queda afectada la inhibición sexual que no se extiende a los impulsos violentos y tampoco en aquellos casos en los que el instinto sexual no sea "anormal", por lo que su efectividad quedaría reducida a los instintos sexuales desviados (pedofilia) ${ }^{636}$.

Por otra parte, también se ha venido afirmando que esta técnica de la castración química atenta contra el derecho a la procreación, afirmación que carece de sentido porque, al ser reversible, este derecho no queda erradicado sino solo suspendido mientras dure el tratamiento. En cualquier caso la castración química puede tener efectos positivos en supuestos de parafilias, pedofilias, aunque en criminalidad derivada de inclinaciones sexuales desviadas de predisposición violenta, su utilización puede tener efectos contrarios a los perseguidos porque no suele resultar modificada la conducta mediante tratamientos hormonales 637 . No obstante, todavía no se conocen a ciencia cierta los efectos secundarios que tales tratamientos pueden producir a largo plazo, siendo que, en principio, a corto plazo se han descrito el aumento de peso, insomnio, disfunciones de la vesícula biliar y atrofia testicular, sudores fríos, pesadillas, debilidad muscular y fatiga, nauseas, dipnea, caída del pelo, dolor de cabeza, calambres en las extremidades, dolor de articulaciones y flebitis, entre otras. Por todo ello, entendemos que su utilización, al margen de los pretendidos efectos beneficiosos para la sociedad, conlleva un importante

635 Ibidem, p. 11. "Se advierte un mínimo de consenso en EE.UU. relativo a que la castración química es preferible a la pena de prisión de larga duración y que es admisible siempre y cuando se sepa que va a ser efectiva para tratar el concreto desorden sexual del sujeto y que éste muestre la suficiente disposición para tratar de corregir su comportamiento sexual, vinculándose, además, a una terapia psiquiátrica convencional".

636 SIERRA LÓPEZ, M.V., La medida de libertad vigilada..., cit. pp. 93 a 95.

637 ROBLES PLANAS, R., ““Sexual Predators...”, cit. p. 11. 
riesgo para la integridad física del sujeto cuyo alcance todavía no se conoce con exactitud 638 .

En EE.UU. todavía no está zanjado el debate acerca de la legitimidad de la utilización de la castración química, de forma que los defensores afirman que se trata de un tratamiento (no un castigo) que se aplica por necesidades médicas; y los detractores afirman que se trata de un castigo cruel e inusual contrario al texto constitucional estadounidense (y en concreto a la octava enmienda). Sobre este particular, indica ROBLES PlANAS que "la Corte Suprema de los Estados Unidos tiene establecida una doctrina desde 1972 con una serie de características para calificar un castigo como contrario a la octava enmienda, características que parecen no concurrir en el caso de la castración química: un castigo es cruel y excepcional si su aplicación es arbitraria, desaprobada por la comunidad y desproporcionado respecto de los fines que persigue el legislador" 639 .

En España, la libertad vigilada parece que deja abierta la posibilidad de aplicación de este tratamiento, de forma voluntaria, bajo la previsión del art. 106.1 k) CP que contempla "la obligación de seguir tratamiento médico externo o de someterse a un control periódico", en relación con el art. 192.1 CP (que dispone la aplicación de la libertad vigilada para delincuentes sexuales) y con el art. 100.3 CP, que refiere, de una forma un tanto peculiar, a la voluntariedad de dicho tratamiento al disponer que la negativa del sujeto a someterse al tratamiento o a continuar con él, no será considerado quebrantamiento de condena, debido a que el sometimiento al tratamiento debe poder interrumpirse cuando el sujeto quiera, por la primacía del derecho a la autodeterminación, ya que, como indica SIERRA LÓPEZ, lo contrario podría suponer un delito contra la libertad. No obstante, esta misma autora afirma que el consentimiento no sería necesario en supuestos de inimputabilidad o semiimputabilidad, lo que nos conduciría a considerar esta medida como una pena corporal y, por ende, inconstitucional ${ }^{640}$.

Sobre la reincidencia y la predicción en los delincuentes sexuales, los recientes estudios sobre la materia, han venido arrojando una serie de resultados empíricos que trataré de exponer en las líneas que siguen, haciendo referencia, sobre todo, a un

\footnotetext{
638 FERNÁNDEZ VILLAZALA, T., “La medición de los delitos sexuales...”, cit. pp. 276 y 277.

639 ROBLES PLANAS, R., ““Sexual Predators...”, cit. p. 10.

640 SIERRA LÓPEZ, M.V., La medida de libertad vigilada..., cit. pp. 95 y 96.
} 
procedimiento de evaluación específico, el Sexual Violence Risk-20, que consiste en que la evaluación del riesgo la realiza un experto forense a través de una lista estandarizada de factores de riesgo, y se llega a un juicio de riesgo final mediante una toma de decisión estructurada. Se trata de un proceso continuo de evaluación, de revisión y de reevaluación del riesgo ${ }^{641}$, que permite la toma de decisiones sobre la gestión institucional y comunitaria de los delincuentes sexuales, y refleja los cambios que se producen en los distintos factores de riesgo dinámicos, ya sean individuales o sociales, susceptibles de ser modificados mediante las intervenciones técnicas oportunas; o estáticos, individuales o sociales, de imposible corrección o modificación como el historial delictivo, nivel social, intelectual o económico, etc.

Actualmente, en ninguno de los centros penitenciarios españoles está totalmente implantado este mecanismo, dado que todavía no hay una validación oficial del procedimiento para España, y su uso es únicamente puntual y ha sido utilizado para llevar a cabo una investigación en las prisiones de Cataluña, mediante una traducción y adaptación dirigida por ANDRÉS PUEYO, en el marco del Grupo de Estudios Avanzados en Violencia (GEAV) de la Universidad de Barcelona. El estudio se basó en la utilización de fuentes como entrevistas de clasificación inicial a los internos ${ }^{642}$, protocolos de clasificación y expedientes penitenciarios ${ }^{643}$, y el análisis de las fichas penitenciarias. La

641 PÉREZ RAMÍREZ, M. / MARTÍNEZ GARCÍA, M. / REDONDO ILLESCAS, S., “Evaluación y predicción del riesgo de reincidencia en agresores sexuales". En Documentos de Trabajo. Investigación: Delitos sexuales y reincidencia. Barcelona: Centre d'Estudis Jurídics i Formació Especialitzada. 2009, p. 192. Estos autores explican que "la predicción efectuada se circunscribe al momento temporal en el que se realiza. Esta perspectiva reconoce que el riesgo de violencia no es estático, sino que es dinámico y fluctúa con el cambio de las circunstancias (Douglas et al., 1999). Por este motivo, una predicción de riesgo de un individuo concreto tiene una vigencia temporal y, por tanto, una fecha de caducidad. Desde este enfoque, es de vital importancia que se lleven a cabo evaluaciones periódicas del riesgo de violencia, ya que se entiende la predicción de violencia como un elemento integrado en un proceso más amplio que incluye también la gestión del riesgo. La gestión del riesgo de violencia implica sugerir o implementar intervenciones o estrategias para reducir la probabilidad de violencia o de reincidencia. Los profesionales forenses que trabajan con delincuentes sexuales se enfrentan a una presión creciente por parte de la población para que evalúen con precisión los niveles y muestren un proceso de toma de decisión lo más transparente posible (Craig et al., 2006). Un delincuente sexual que se etiquete como sujeto de alto riesgo requerirá una supervisión comunitaria mucho más estricta que un sujeto que se considere de bajo riesgo de reincidencia sexual. Por este motivo, es necesaria una buena predicción de la reincidencia sexual tanto para evitar víctimas futuras como para reducir el coste institucional de estos sujetos y maximizar los recursos disponibles en la atención a los sujetos que realmente lo necesitan".

642 Ibidem, pp. 198 y 200. Estos autores indican que "la información que recoge la entrevista de clasificación inicial hace referencia a la historia de vida del individuo, desde su infancia hasta el momento actual. Ésta incluye la conducta escolar, el ambiente familiar, la relación con el grupo de iguales, la vida laboral, la familia adquirida, los problemas de salud, el consumo de sustancias tóxicas, el inicio de conductas delictivas, la adaptación al sistema penitenciario y los planes a corto y a largo plazo".

643 Ibidem, p. 200. Siguen diciendo estos autores que "en los protocolos y en los expedientes penitenciarios se puede encontrar toda la información existente sobre el individuo durante su estancia en prisión. Incluye 
investigación agrupa varios ítems relacionados con la violencia sexual previa, que son: la frecuencia de delitos sexuales graves, con incidencia tanto en el tiempo que trascurre entre los delitos como el riesgo de los delitos cometidos; las tipologías sexuales diversas, que hacen referencia a la variedad de víctimas y a la diversidad de conductas sexuales delictivas cometidas; la gravedad del daño físico o psicológico producido en la víctima; el uso de armas o amenazas de muerte; la progresión en la frecuencia o en la gravedad de los delitos, que incide directamente en la trayectoria delictiva; y dos factores más: por una parte la minimización extrema o la negación de las agresiones sexuales y, por otra, las actitudes que demuestran tolerancia o apoyo a las agresiones sexuales ${ }^{644}$.

El estudio también realiza un análisis de factores psicosociales, de los que destacamos, en resumen (y porque muchos de esos factores exceden del contenido del presente estudio) la desviación sexual, que implica la presencia de una parafilia o de un patrón de excitación sexual anormal y disfuncional) y el haber sido víctima de abusos en la infancia ${ }^{645}$. Las conclusiones de dicho estudio se pueden agrupar sintéticamente en las siguientes: 1) Se comprueba que el procedimiento de pronóstico utilizado, obtiene una tasa elevada de aciertos, en concreto el 78,5\% de clasificaciones correctas para la predicción de la reincidencia sexual. 2) Se comprueba que la influencia de otras variables relevantes en la investigación como el tratamiento psicológico o el número de delitos condenados, son significativas en la mejora de la predicción de la violencia sexual. 3) La frecuencia de la reincidencia sexual es muy baja, pero se advierte que la utilización de variables específicas así como de instrumentos adecuados, la predicción de la violencia sexual puede llegar a ser muy elevada. 4) Se trata de un estudio piloto retrospectivo, pero los primeros resultados obtenidos avalan una buena validez predictiva del método empleado (Sexual Violence Risk-20), aunque en el estudio se advierte de la carencia experimentada al haber realizado la investigación con ausencia de algunos datos que podrían ser relevantes a efectos de la predicción de la violencia sexual, y que han sido

\footnotetext{
información judicial (testimonio de sentencia, resoluciones por parte de los jueces correspondientes, etc.), las entrevistas con los diferentes profesionales (psicólogos, educadores sociales, pedagogos, maestros, etc.), los informes del equipo técnico de tratamiento del centro, los expedientes disciplinarios cuando se ha impuesto una sanción al interno, la ficha penitenciaria, el conjunto de actividades realizadas en el centro, etc.".

644 Ibidem, p. 198. También afirma estos que “estos dos últimos ítems se relacionan con un patrón más extenso de desviación de la responsabilidad personal del comportamiento criminal e incluyen un amplio abanico de creencias o de valores que fomentan el patriarcado, la misoginia o el contacto entre adultos y menores".
}

645 Ibidem. Pág. 198. 
rellenados mediante la modalidad actuarial que, sin embargo, arroja mejores resultados que el método actuarial646.

Por todo ello, concluyo que realmente la prognosis criminal en materia de delitos sexuales merece una implementación en esta línea de investigación, más que en el incremento de la represión penal y de la creación de medidas de seguridad y de corrección. Y sobre todo, para la efectiva materialización de las medidas de seguridad postpenitenciarias como la libertad vigilada, habría que basar la decisión de la imposición o de su concreción en fase de ejecución, en previos estudios metodológicos que permitan acercarnos a un pronóstico que se aproxime más a lo que podría entenderse por fiable, teniendo en cuenta las propias limitaciones del sistema, evitando el exceso de automaticidad en la aplicación de la medida que no se basa, hoy en día, en una constatación verídica de la persistencia de la peligrosidad y del riesgo de reincidencia en materia de delitos sexuales ${ }^{647}$.

Por último, conviene mencionar un aspecto al que refiere TORRES ROSELL, que señala que el problema de la delincuencia sexual viene siendo abordado de una forma simplista porque se cataloga a los delincuentes como un grupo homogéneo, "pretendiendo diseñar y adoptar idénticas medidas de intervención y de supervisión intensiva para todos ellos", cuando en realidad cada tipología de delincuentes sexuales reviste características singulares que los diferencian, como por ejemplo los agresores sexuales violentos, los oportunistas, los de conducta sádica, los psicopáticos, los pedófilos, o los que actúan de forma que no llegan a mantener contacto sexual directo con sus víctimas. Y en ese sentido esta autora señala que las políticas criminales en esta materia se toman al unísono sin atender a estas especialidades tipológicas y tratando a todo el fenómeno de la delincuencia sexual como si fueran depredadores sexuales o pederastas, "construyendo entorno a éstos la imagen arquetípica del delincuente sexual y descuidando las particularidades de otros individuos o concretas modalidades en la comisión del delito que deberían ser tomadas en consideración en la decisión sobre la

646 Ibidem, pp. 213 y 214.

647 ANDRÉS PUEYO, A., El control $i$ el tractament dels delinqüents d'alt risc: la "gestió dels casos". I Jornada de Criminologia "Control penal i prevenció del delicte en la societat de la informació". Barcelona: Universitat Oberta de Catalunya i Centre d'Estudis Jurídics i Formació Especialitzada, 2011, p. 5. Este autor asevera lo siguiente: "La llibertat vigilada: una nova mesura per gestionar el risc de reincidència. Probablement mes eficaç si es fa en un context de "gestió del risc"“. 
adopción de medidas de supervisión intensiva y, en particular, sistemas de seguimiento continuado del penado" 648 .

Del mismo modo FEIJOO SÁNCHEZ afirma que los delitos sexuales no presentan, por lo general, índices de reincidencia mayores que otros ámbitos delictivos, sino que solo se aprecia un pequeño número de delincuentes que han cometido delitos de esta naturaleza, que posteriormente reinciden. En ese sentido, este autor explica que quizás la libertad vigilada debería estar destinada exclusivamente a este reducido número de delincuentes de elevado riesgo de reincidencia de acuerdo con los índices y los estudios previos, de forma que la libertad vigilada no sea una medida de seguridad de aplicación estandarizada 649 .

En ese mismo sentido se pronuncia GARCÍA ALBERO, cuando afirma que el pronóstico de reinserción del que supuestamente carecen los delincuentes sexuales no encuentra sustento empírico ni científico en la actualidad, por lo que concluye que la libertad vigilada aplicable a delincuentes sexuales según la regulación conferida mediante la reforma del CP a través de la LO 5/2010, incorpora el "mito de la incorregibilidad del delincuente sexual" 650 .

\section{El control estatal sobre la delincuencia peligrosa}

La delincuencia peligrosa y la sensibilidad social experimentada hacia ella, vienen generando una serie de estrategias de control estatal de las que la libertad vigilada forma parte y que descansan sobre la idea del panoptismo formulada por FOUCAULT, que parte de la construcción teórica inicial del Panóptico de BENTHAM ${ }^{651}$ que concibió una figura arquitectónica circular en cuyo centro hay ubicada una torre de vigilancia y en la parte exterior están las celdas separadas que tienen dos ventanas: una exterior que permite la entrada de la luz y otra interior que permite la vigilancia desde la torre ${ }^{652}$, de forma que

\footnotetext{
648 TORRES ROSELL, N., “Libertad vigilada y seguimiento continuado de penados. Contenido e implicaciones político criminales". En Revista Electrónica de Ciencia Penal y Criminología (en línea). núm. 14, 2012.Pág. 35.

649 FEIJOO SÁNCHEZ, B., “La libertad vigilada...”, cit. pp. 229 y 230.

650 GARCÍA ALBERO, R., en QUINTERO OLIVARES, G., Comentarios..., cit. Tomo I, p. 692.

651 BENTHAM, J., Panopticon. 1791. Traducción de E. Mira, El panòptic. Barcelona: Edicions 62.1985.

652 Pueden verse gráficamente en FOUCAULT, M., Surveiller et punir..., cit. Lámina 17, plano del Panóptico de Bentham; láminas 18 y 19, proyecto de penitenciaría de Harou-Romain, 1840; lámina 20, proyecto de
} 
cualquier movimiento del interno es observado por el vigilante653. De esa forma, se induce en el vigilado un estado permanente y consciente de sometimiento a la visibilidad del vigilante, lo que provoca que, aunque la vigilancia sea intermitente, el efecto de vigilancia sea permanente654; y se consigue una situación real mediante una situación ficticia, toda vez que quien sabe que está siendo observado -o que puede con toda probabilidad estarlo- "reproduce por su cuenta las coacciones del poder; las hace jugar espontáneamente sobre sí mismo; inscribe en sí mismo la relación de poder en la cual juega simultáneamente los dos papeles, se convierte en el principio de su propio sometimiento"655. FOUCAULT habla de que BENTHAM se inspiró en la casa de fieras de Versalles, diciendo que "el Panóptico es una colección zoológica real; el animal está reemplazado por el hombre, por la agrupación específica la distribución individual, y el rey por la maquinaria de un poder furtivo" 656 , pero la formulación teórica va mucho más allá de reducción de su utilización penitenciaria, ya que la idea de BENTHAM desarrollada por FOUCAULT, concibe el Panoptismo como una figura de tecnología política alejada de un uso específico y que en cada una de sus aplicaciones puede perfeccionar el ejercicio del poder al que sirve, de forma que un número reducido de personas puede vigilar o controlar a un número muy elevado de miembros de la colectividad y porque la presión constante que ejerce, actúa ex ante, de forma que se anticipa a las faltas, errores o hechos delictivos que los sometidos a control pudieran ejecutar. "El Panoptismo es un intensificador de cualquier aparato de poder"657, que se concibe como una nueva

penitenciaría de Harou-Romain, 1840, que plasma el plano y el corte de las celdas donde se observa que cada una tiene un aposento, un taller y un pasillo, "durante la oración, la puerta de la entrada está abierta y el preso arrodillado (dibujo central)"; y la lámina 21, proyecto de penitenciaría de Harou-Romain, 1840, en la que se observa un recluso en su celda durante su oración ante la torre central.

653 Ibidem, p. 204. Este autor señala que "la plena luz y la mirada de un vigilante captan mejor que la sombra, que en último término protegía. La visibilidad es un trampa".

654 Ibidem, p. 205. Como afirma este autor, “Bentham ha sentado el principio de que el poder debía ser visible e inverificable. Visible: el detenido tendrá sin cesar ante los ojos la elevada silueta de la torre central de donde es espiado. Inverificable: el detenido no debe saber jamás si en aquel momento se le mira; pero debe estar seguro de que siempre puede ser mirado. [...] El Panóptico es una máquina de disociar la pareja ver-ser visto: en el anillo periférico es totalmente visto, sin ver jamás; en la torre central, se ve todo. Sin ser jamás visto".

655 Ibidem, p. 206. Sigue diciendo este autor que "por ello, el poder externo puede aligerar su peso físico, tiende a lo incorpóreo; y cuanto más se acerca a ese límite, más constantes, profundos, adquiridos de una vez para siempre e incesantemente prolongados serán sus efectos: perpetua victoria que evita todo enfrentamiento físico y que siempre se juega de antemano".

656 Ibidem, pp. 206 y 207. Y puede verse gráficamente la lámina XIV, donde se observa en grabado de Aveline de la colección zoológica de Versalles en la época de Luis XIV, con esta misma estructura del ideado Panóptico de Bentham.

657 Ibidem, pp. 209 y 210. Expresa este autor que "hace de modo que el ejercicio del poder no se agregue del exterior, como una coacción rígida o como un peso, sobre las funciones en las que influye, sino que esté en ellas lo bastante sutilmente presente para aumentar su eficacia aumentando él mismo sus propias presas. El dispositivo panóptico no es simplemente un punto de unión, un cambiador entre mecanismo de poder y una 
"anatomía política" que fija su fin último en la disciplina y no en la relación de soberanía, de forma que mediante un mecanismo elemental y de fácil transmisión, funciona la sociedad "atravesada y penetrada por mecanismos disciplinarios" 658.

En ese orden de cosas, la sociedad actual busca mecanismos para articular ese concepto amplio de control que abarca el poder, el conocimiento, la normalización y la disciplina, como afirma GUDÍN RODRÍGUEZ-MAGARIÑOS, “como remoto antecedente de la libertad vigilada bajo control telemático la famosa "jaula transparente y circular" que simbolizaba a la vigilancia de la prisión panóptica, se ha dispersado por toda la geografía de las ciudades generando subculturas — suburbios, lugares públicos calificados de "alto riesgo"- Estos espacios prohibidos demandan una acción de control por las autoridades más lejos de adoptar medidas constructivas de integración suelen optar por criterios represivos en donde el Estado, a través de las prácticas de cero tolerancia, focaliza la vigilancia y el control de grupos etiquetados como "potencialmente peligrosos", ciñendo el sentimiento de peligrosidad el nuevo concepto arquetípico sobre el que se atiende a configurar el nuevo Derecho penal del siglo XXI, que se desentiende de otros fines como los puramente retribucionistas o los resocializadores"659. De tal modo que se crean auténticas "cárceles sociales" mediante la vigilancia de espacios y el etiquetamiento de colectivos de personas bajo el prisma de perfiles de peligrosidad que nos conduce a lo que él llama "industria para el control del delito" encaminada hacia la creación de un modelo de Estado controlador cuyo interés es vigilar y observar a sus integrantes a través de multitud de mecanismos. Por ese motivo, la actual tendencia legislativa busca suplir la falta de control sobre esos espacios que el Estado no controla, mediante la creación de mecanismos punitivos como la implementación de medios telemáticos, como en el caso de la implantación de la vídeo vigilancia que fue operada mediante la LO 4/1997, de 4 de agosto; el control y seguimiento de los internos, el control telemático en casos de violencia de género o en casos de delincuencia sexual -sobre todo para la pederastia- y en supuestos de terrorismo, o el registro electrónico para la inscripción de las faltas al que refiere la Disposición adicional segunda de la LO 5/2010. También lo es la pena de

\footnotetext{
función; es una manera de hacer funcionar unas relaciones de poder en una función, y una función por esas relaciones de poder".

658 Ibidem, p. 212. Sigue diciendo este autor que "en la famosa jaula trasparente y circular, con su elevada torre, poderosa y sabia, se trata quizá para Bentham de proyectar una institución disciplinaria perfecta; pero se trata también de demostrar cómo se puede "desencerrar" las disciplinas y hacerlas funcionar de manera difusa, múltiple, polivalente en el cuerpo social entero".
}

659 GUDÍN RODRÍGUEZ-MAGARIÑOS, F., La nueva medida de seguridad...., cit. p. 129. 
localización permanente que implica la obligación de permanecer en un lugar concreto y que suele ser en realidad un arresto domiciliario, y cuya ejecución se lleva a cabo mediante un sistema de verificación de la voz telefónica que se comprueba en las cinco o diez llamadas aleatorias diarias que el penado recibe en el lugar en que deba encontrase, pudiendo serle instalado por parte de Instituciones penitenciarias un teléfono fijo en ese domicilio en caso de que el penado no tenga línea telefónica (art. 14.1 del Real Decreto 840/2011, de 17 de junio); llamadas que se le hacen de forma intermitente y sin horario predeterminado, por las que se comprueba electrónicamente si la voz es efectivamente la del penado al tiempo que se le hace repetir una frase que es analizada mediante métodos biométricos.

La LO 5/2010 ha tratado de abordar el problema de los delincuentes de tendencia interna irresistible, que son personas que se muestran incapaces de inhibir sus tendencias o instintos pero que no llegan a sobrepasar por defecto la franja de la culpabilidad individual, por lo que no se les puede considerar inimputables ${ }^{660}$. El legislador ha tratado, pues, de ofrecer una respuesta para los dos supuestos que -según un sector de la doctrina-661 no plantean problemas de legitimidad cuando se acude a recursos neutralizadores de la peligrosidad como las medidas de seguridad postdelictivas.

La libertad vigilada es una nueva manifestación de esta política criminal de control ${ }^{662}$, que encuentra una plasmación idónea mediante la previsión de la utilización de medios electrónicos o telemáticos de seguimiento del sometido a la medida y "la libertad vigilada no es más que un hito concreto de una tendencia global para mantener el volumen del crímenes (o incluso cualquier fenómeno paralegal oculto a los ojos del Estado) bajo unos niveles de control"663.

${ }^{660}$ FEIJOO SÁNCHEZ, B., “La libertad vigilada...”, cit. p. 229.

661 FRISCH, W., “Las medidas de corrección...”, cit. pp. 26 a 36.

662 ACALE SÁNCHEZ, M. “Medidas de seguridad”. En ÁLVAREZ GARCÍA, F.J., (Dir.) / DOPICO GÓMEZALLER, J., (Coord.), Estudio crítico sobre el Anteproyecto de Reforma penal de 2012. Valencia: Tirant lo Blanch. 2013, pp. 434 y 435. Esta autora explica que "si las penúltimas reformas practicadas en materia penal penitenciaria han consistido en vaciar de contenido resocializador a la pena privativa de libertad, ahora que se ha debatido una nueva reforma del Código penal, defender la inclusión de otra consecuencia -la libertad vigilada- para alcanzar el difícil fin de la reinserción social, es decir, a lo que expresamente ha renunciado aquélla, no es honesto y está reflejando que el padre de esta disposición no es otro que un legislador pantocrático sentado en el centro un panóptico, desde donde lo controla todo pero desde donde también se deja ver -paradójicamente- por todos".

663 GUDÍN RODRÍGUEZ-MAGARIÑOS, F., La nueva medida de seguridad..., cit. p. 189. Como expresa este autor "los límites del conocimiento del Estado sobre la vida de sus ciudadanos, en la ya denominada "sociedad 
Como indica CID MOLINÉ, "la libertad vigilada no es propiamente una nueva medida de seguridad, sino más bien un nuevo nombre que reciben las medidas de seguridad no privativas de libertad y que agrupa a un conjunto de medidas que ya existían anteriormente en la legislación, junto con otras no previstas. De esta manera, si distinguimos [...] las medidas de seguridad por el objeto que persiguen —control de la persona, protección de la víctima o rehabilitación- observamos que la novedad principal consiste en que se introducen adicionales instrumentos de control de la persona, resultando en particular relevante la localización permanente, que permite reforzar el contenido incapacitador de la libertad vigilada" 664 .

Hay una tendencia en nuestro sistema a proyectar respuestas jurídico-penales asegurativas con base en diagnósticos de propensión a la peligrosidad de sujetos determinados, y que suelen ser objeto de señalamiento previo por sectores mediáticos que generan "pánicos morales", de forma que, si el diagnóstico es incierto, la opción es decantarse por la peligrosidad del individuo cuya peligrosidad no es posible constatar, pero hay cierto grado de probabilidad de que lo sea, construyendo así un nuevo principio que desplaza al clásico in dubio pro reo y da paso a al in dubio pro securitate, lo que para un sector de la doctrina supone asumir la peligrosidad que encierra el propio Derecho penal de la peligrosidad 665 .

de la información", aparece como el tema crucial a debatir en el siglo XXI. Y es que, el gran argumento que posee el Estado para controlar inmensas masas de informaciones de sus ciudadanos, es precisamente la seguridad colectiva".

664 CID MOLINÉ, J., La medida de seguridad de libertad vigilada..., cit. p. 186, y vid. la tabla que aparece en las págs. 186 a 188 .

665 REBOLLO VARGAS, R., “De las medidas de seguridad...”, cit. p. 802. 


\section{CAPÍTULO SEGUNDO. LA LIBERTAD VIGILADA. ANTECEDENTES}

En el presente Capítulo se analizan los antecendentes de la libertad vigilada, para lo que se invocan algunas referencias relevantes de Derecho comparado, las primeras formulaciones en España y el supuesto de la libertad vigilada en el ámbito de la responsabilidad penal de los menores infractores, vigente desde la promulgación de la LORPM, en 2000. Posteriormente se centra la atención en la reciente actividad legislativa que ha llevado a la introducción en el CP de la libertad vigilada, en concreto en los distintos Anteproyectos y Proyectos de reforma presentados en sede parlamentaria, que culminaron con la promulgación de la LO 5/2010. De todas estas cuestiones y de algunas más, me ocupo a continuación.

\section{REFERENCIAS Al DERECHO COMPARADO}

Podemos encontrar formulaciones de la libertad vigilada en varios ordenamientos de todo el mundo, aunque con regulaciones sensiblemente distintas. Su origen está en el Código francés y posteriormente se fue extendiendo a otros países como Bélgica o Italia ${ }^{666}$. En el presente apartado se analizarán, a título de ejemplo, algunas de las regulaciones existentes de la libertad vigilada en Derecho comparado, para lo que se citarán algunos países del continente europeo y otros concernientes al Derecho anglosajón.

En el Derecho continental, Alemania ha venido contemplando tradicionalmente en sus regulaciones, distintas formulaciones de la libertad vigilada, ya que el StGB de 15 de mayo de 1870, contenía una categoría de penas accesorias que recaían sobre la libertad, y se distribuían en tres tipos: sometimiento a la vigilancia policial, la entrega a la autoridad policial del Estado y la expulsión del territorio Federal667. En dicha formulación, el Tribunal decidía si, una vez cumplida la condena, según su arbitrio y en los casos tasados en la ley, facultaba a la autoridad superior de la policía del Estado, para que pudiera tener al condenado bajo su vigilancia durante un plazo máximo de cinco años, contados a partir de que la pena de prisión hubiese sido cumplida, prescrita o remitida (§ 38). Además, según lo previsto en el $\S 39$ de dicho texto legal, los efectos de la vigilancia de la policía

\footnotetext{
666 CUELLO CONTRERAS, J. / MAPELLI CAFFARENA, B., Curso de Derecho penal..., cit. pp. 359 y 360.

667 LISZT, F., Tratado de Derecho Penal..., cit. Tomo III, pp. 262 a 266.
} 
eran: a) la prohibición de permanencia en determinados lugares como locales, establecimientos de bebidas, teatros, estaciones, etc.; b) expulsión del territorio federal durante cinco años como máximo; c) registros domiciliarios sin ninguna restricción, durante el tiempo de vigencia de la vigilancia policial.

Actualmente en el vigente StGB existen básicamente dos medidas de seguridad que guardan similitud con libertad vigilada, que son: la vigilancia de conducta y la custodia de seguridad, aunque la segunda - a la que ya hemos referido- es una medida de seguridad privativa de libertad, por lo que su contenido es sensiblemente distinto. La vigilancia de conducta ("führungsauftsicht") ${ }^{668}$ que es una medida de seguridad no privativa de libertad que permite la imposición de varias reglas de conducta "weisungen"669. Su misión es proporcionar a los criminales de alto riesgo y con un desfavorable pronóstico social, la ayuda necesaria para pasar de la privación de libertad a la libertad, así como asegurar al mismo tiempo la protección de la comunidad frente a esa persona peligrosa, evitando así su internamiento ${ }^{670}$. En ese sentido afirma STRATENWERTH que "se trata de meras limitaciones a la libertad de carácter predominantemente asegurador -aunque igualmente de utilidad para evitar la reincidencia-"671. Está prevista en el $\S 68$ StGB y ss., y se aplica en los casos de penas privativas de libertad de al menos seis meses por razón de un delito para el que la ley prevé específicamente la medida de vigilancia conducta. Es por tanto una facultad que tiene el propio Tribunal, que puede imponer esta medida junto con la pena privativa de libertad, si existe el peligro de que pueda cometer nuevos delitos tras el cumplimiento de la misma672. Se necesita del seguimiento de un profesional encargado de llevar a efecto la vigilancia (ayudante de prueba), y de la supervisión por un establecimiento de vigilancia673.

\footnotetext{
668 TAMARIT SUMALLA, J.M., “La integración jurídica en la Unión Europea y la reforma de 2006. Las penas y la reforma". En ÁLVAREZ GARCÍA, F.J. (Dir.), La adecuación del Derecho penal español al ordenamiento de la Unión Europea. La política criminal europea. Valencia: Tirant lo Blanch. 2009, p. 83.

669 MANZANARES SAMANIEGO, J.L., "La libertad vigilada”. En Diario La Ley, n 7534 . Especial Reforma del Código Penal, 2010, p. 55.

670 JESCHECK, H.H., Tratado de Derecho Penal..., cit. p. 748.

671 STRATENWERTH, G., Derecho Penal. Parte General I. El hecho punible. Traducción de Manuel Canci Meliá y Marcelo A. Sancinetti. Navarra: Thomson Civitas. 2005, p. 42.

672 JAKOBS, G., Derecho penal. Parte General..., cit. p. 41.

673 JESCHECK, H.H., Tratado de Derecho Penal..., cit. p. 749.
} 
Se prevé que el Tribunal pueda, facultativamente, imponer al condenado determinadas obligaciones o reglas de conducta ( $\$ 68 \mathrm{~b} \mathrm{I})^{674}$ que se pueden prolongar durante el tiempo que dure la vigilancia, o por un intervalo de tiempo más breve, y son: la fijación de un lugar determinado en el que el sujeto que deberá residir, la obligación de solicitar autorización del centro de vigilancia para desplazarse a determinados lugares, la prohibición de acudir a emplazamientos donde existan alicientes que puedan incitarle a cometer nuevos delitos, la prohibición de tenencia de determinados objetos, o de llevar a cabo actividades de las que pueda abusar para delinquir nuevamente, la privación del derecho de conducir, la obligación de presentación en el establecimiento de vigilancia, obligación de comunicar cualquier cambio de domicilio o empleo, etc. Esta vigilancia, tiene como máximo una duración de cinco años y un mínimo de dos, aunque puede alzarse cuando desaparezca la peligrosidad criminal que motivó su imposición ${ }^{675}$; y en esta regulación también se prevé que la vigilancia orientadora pueda imponerse para supuestos de remisión condicional de la pena privativa de libertad, que sea superior a los nueve meses, con el límite subjetivo de que el penado sea menor de 27 años.

En los presupuestos de vigilancia de conducta pueden distinguirse dos grupos de casos: $1^{\circ}$. Vigilancia de conducta tras el cumplimiento de la pena. La medida puede acordarse en caso de peligro de que ese mismo sujeto cometa nuevos delitos respecto a los que la ley prevé especialmente la vigilancia de conducta por la frecuencia de la reincidencia, siempre que se hubiera impuesto una pena privativa de libertad de al menos seis meses, y se aplica, por propia disposición legal, y el penado haya cumplido totalmente una pena privativa de libertad de al menos dos años, cuando no haya podido acceder a la libertad condicional debido a la ausencia de pronóstico favorable de reinserción que se exige para la misma ${ }^{676} .2^{\circ}$. Vigilancia de conducta en conexión con una medida privativa de libertad. En este caso la medida se aplica siempre por disposición legal, y más en concreto por la

674 EIRANOVA ENCINAS, E., (Coord.), Código Penal alemán StGB. Código Procesal Penal alemán StPO. Madrid: Marcial Pons. 2000, pp. 49 y 50.

675 JESCHECK, H.H., Tratado de Derecho Penal..., cit. pp. 749 y 750.

676 HERNÁNDEZ BASUALTO, H., “Sistemas penales comparados...”, cit. p. 220 y 221. Según este autor, "la vigilancia de conducta ( $\$ \S 68$ y ss.) presupone que el sujeto haya sido condenado a una pena privativa de libertad de al menos seis meses por el delito para el cual la ley prevé especialmente la medida, cuando exista el peligro de que cometa nuevos delitos. Adicionalmente está prevista como alternativa para medidas con privación de libertad ( $\$ 68$ II, con expresa referencia a los $\S \S 67$ b, 67 c, 67 d II, III y V y 68 f). La medida consiste en la sujeción a la vigilancia de una agencia estatal, complementada con la designación de un oficial de vigilancia ("ayudante de libertad a prueba", Bewährungshelfer) que debe servir de apoyo para el condenado ( 68 a), pudiendo impartirse además instrucciones obligatorias de conducta, tales como la de residir en $u$ determinado lugar, abstenerse de acercarse a ciertos lugares o personas, etc. (§ $68 \mathrm{~b})$ ". 
suspensión condicional de una medida privativa de libertad, y por el transcurso del plazo completo de diez años en el caso del primer internamiento en custodia de seguridad ${ }^{677}$.

En Italia las medidas de seguridad -entre las que se encuentra la libertad vigilada- se imponen, por una parte, a sujetos peligrosos que hayan delinquido y no sean imputables (arts. 203 CP); pero también se imponen a personas imputables, junto con la pena privativa de libertad (para su cumplimiento una vez haya remitido ésta), siempre y cuando en la sentencia haya un pronunciamiento de "la declaración de tendencia a delinquir", declaración que se extingue cuando se produce la rehabilitación del reo (art. $109 \mathrm{CP})$. En estos casos, la medida será revocada cuando el sujeto deje de ser socialmente peligroso, lo cual no se podrá producir hasta pasado el período mínimo que se fijará según los casos, y que para los delincuentes por tendencia será de 4 años (art. $217 \mathrm{CP}$ ) 678 . La libertad vigilada (libertà vigilata) ${ }^{679}$ está contemplada en los arts. 228 y ss. CP, y consiste en una limitación de la libertad personal del sujeto mediante un conjunto de prescripciones de contenido positivo o negativo, encaminado a evitar la comisión de nuevos delitos y facilitar la reinserción social ${ }^{680}$. El estado de libertad de la persona se confía a la autoridad de seguridad pública que deberá supervisarla ${ }^{681}$. Tendrá una duración mínima de un año y el Juez ordenará el cumplimiento de una serie de requisitos que podrán ser modificados a lo largo de la vigencia de la medida. Se trata de evitar que el sujeto cometa nuevos delitos y de facilitar mediante el trabajo su readaptación y rehabilitación en la vida social ${ }^{682}$. Esas prescripciones deberán constar en un documento denominado "carta precettiva", que el sometido a la libertad vigilada deberá llevar siempre consigo 683 .

677 JESCHECK, H.H., Tratado de Derecho Penal..., cit. p. 749.

678 BELZUNEGUI, B., “La libertad vigilada en la última reforma de Código penal español”. En Derecho penal online, [http://www.derechopenalonline.com/derecho.php?id=16,691,0,0,1,0.]; (consultado el 20/5/2014).

679 Se trata de un medida de seguridad que cuenta con gran tradición en el ordenamiento italiano y ya se referían a ella autores como BELLAVISTA, La libertà vigilata. Palermo: Circolo giuridico. 1934.

680 FIANDACA, G. / MUSCO, E., Diritto penale. Parte generale. Quinta Edizione. Bologna: Zanichelli Editore. 2007 , p. 828 .

681 PADOVANI, T., Dirito penale. Seconda edizione. Milano: Giuffrè Editore. 1993, p. 437.

682 ALEO, S., Il Sistema penale. I. La parte generale del diritto penale. II. Altri profili normativi e istituzionali. Milano. Giuffrè Editore. 2004, p. 246.

683 ANTOLISEI, F., Manuale di Diritto penale. Parte generale. Sedicesima edizione. Milano: Dott. A. Giuffrè Editore. 2003. Pág 828. 
La libertad vigilada puede ser impuesta de forma facultativa ${ }^{684}$ en los siguientes casos, previo dictamen de peligrosidad685: a) a la persona que esté condenada a una pena de prisión por tiempo igual o superior a un año ${ }^{686}$; b) en aquellos casos en que el propio CP permite la aplicación de medidas de seguridad a hechos no previstos como delito en el código (art. $229 \mathrm{CP}$ ) que son: el delito imposible; la incitación para cometer un delito que no es aceptada; y el acuerdo entre varias personas que no va seguido de la comisión del delito ${ }^{687}$. El sometimiento a la libertad vigilada será obligatorio688 siempre que exista peligrosidad social en el sujeto ${ }^{689}$, en los siguientes casos: a) cuando vaya acompañada de una pena de prisión de no menos de diez años, y no podrá en este caso ser inferior a tres; b) cuando el delincuente acceda a la libertad condicional; c) cuando se trate de delincuente profesional o habitual, que no estando sometido a medida de seguridad, cometa un nuevo delito, que revele una nueva manifestación de su profesionalidad o habitualidad; d) en los demás casos determinados por la Ley.

El CP italiano no contiene una lista exhaustiva de requisitos que deben se impuestos al vigilado para la individualización de la medida tanto en términos personales y del entorno familiar, salvo la obligación del vigilado de no trasladar su domicilio o de no permanecer en un municipio distinto del que se le asignó, y la obligación de informar a los órganos de control de cualquier cambio de domicilio en el marco de dicho municipio. No obstante, la praxis judicial ha ido perfilando los requisitos en que se debe concretar la individualización de la medida ${ }^{690}$.

684 FIANDACA, G. / MUSCO, E., Diritto penale..., cit. p. 828.

685 ANTOLISEI, F., Manuale di Diritto penale..., cit. p. 829.

686 PAGLIARDO, A., Principi de Dirito penale. Parte generale. Quarta edizione. Milano: Dott. A. Giuffrè Editore. 1993. Pág 695.

687 ALEO, S., Il Sistema penale..., cit. p. 247.

688 ROLAND RIZ, Lineamenti di Dirito penal. Parte generale. Padova: CEDAM. 2000, pp. 488 y 489.

689 FIANDACA, G. / MUSCO, E., Diritto penale..., cit. p. 828.

690 Ibidem, p. 828. Como indican estos autores, "en la práctica casi se ha codificado un conjunto de requisitos que han compensado la falta de carácter obligatorio y la limitación de la discrecionalidad del juez de vigilancia. Estos requisitos son los siguientes: la obligación de encontrar un trabajo estable, la obligación de no retirarse en la noche después de cierto tiempo, la obligación de no salir en la mañana antes de un cierto tiempo, la obligación de no menoscabar o acompañarse de personas que puedan ser peligrosos para la seguridad pública, obligación de no portar o tener armas o, en general, herramientas para agresión, la obligación de no participar en actos públicos, reuniones sin la autorización de la autoridad a PS, la obligación de presentarse ante el juez de vigilancia cuando se le requiera". 
La duración mínima de la libertad vigilada será de un año y, como ya hemos visto, no podrá ser inferior a tres años si se impone junto a una pena de prisión de diez años o más (art. 230, ap. 1, 1 CP) y tampoco podrá rebasar este límite mínimo de tres años cuando al penado se le haya concedido la amnistía o el indulto, o cuando no se haya ejecutado la condena de cadena perpetua (art. 210, párrafo $3 \mathrm{CP})^{691}$.

El incumplimiento de la medida el Juez puede exigir la "caución de buena conducta", que es una medida de seguridad patrimonial (arts. 237-239 CP) que consiste en que el condenado deberá prestar una caución de entre $103 €$ y $2.036 €$, o en la constitución de un derecho real de garantía. Se trata de una medida que pretende evitar durante su cumplimiento cometa nuevos delitos por temor a una pérdida patrimonial 692 . En el caso de que dicha caución no sea prestada, o en casos de trasgresión particularmente grave de la libertad vigilada, puede ser sustituida por la asignación en una colonia agrícola, o en una casa de trabajo; y en caso de menores, el ingreso en un centro reformatorio judicial ${ }^{693}$.

En Francia encontramos la vigilancia o seguimiento socio-judicial (suivi socio-judiciare) ${ }^{694}$, introducida como una nueva pena mediante una ley de 1998695, (Loi du 17 juin 1998 relative à la prévention et à la répression des infractions sexuelles), debido al aumento de casos de pedofilia y de homicidios acompañados de violaciones de niños, cometidos por sujetos reincidentes ${ }^{696}$. Está regulada en los arts. 131-36-1 a 131-36-8 del CP, y precisado por los artículos 36-1 al 131-6-8 del Código procesal penal y por los arts. L. 355-33 a L. 355-3 del Código de la salud pública, y se presenta en forma de pena, aunque debido a la discusión de la doctrina francesa acerca de su naturaleza sancionadora entre pena o medida de seguridad, mayoritariamente se ha venido admitiendo que, a pesar de su ubicación y denominación como pena, en realidad se trata de una medida de seguridad ${ }^{67}$. El seguimiento socio-judicial presenta un carácter sui generis, intermedio

\footnotetext{
${ }^{691}$ FIANDACA, G. / MUSCO, E., Diritto penale..., cit. p. 828.

692 ANTOLISEI, F., Manuale di Diritto penale..., cit. p. 831.

693 Ibidem, p. 830.

${ }^{694}$ LEROY, J., Droit pénal général. $3^{\text {a }}$ Ed. Paris: L.G.D.J. Lextenso Editions. 2010, pp. 361 y 362.

695 ROCA POVEDA, M., “La libertad vigilada...”, cit. p. 39.

696 BOULOC, B., Droit pénal général. 20ª Ed. Paris: Dalloz. 2007, p. 457.

697 ARÁNGUEZ SÁNCHEZ, C. / ALARCÓN NAVÍO, E., El Código Penal francés. Traducido y anotado. $2^{\mathrm{a}}$ Ed. Granada. Comares. 2003, p. 58, nota al pie 82.
} 
entre la pena complementaria y la medida de seguridad, a la que el legislador francés no ha querido incluir en el catálogo de penas al sustraerla en su ubicación de la subsección del CP titulada "del contenido y de las modalidades de aplicación de ciertas penas", sino que la ubica en una subsección autónoma, aunque integrada en el título y en el capítulo del Código dedicado a las penas.

Se trata de una medida que puede ser aplicada a personas declaradas culpables por infracciones penales de naturaleza sexual698, y su objeto es asegurar el control postcarcelario del condenado, control que puede traer consigo, si llega el caso, un aspecto médico ${ }^{699}$. Está definida en el art. 131-36-1 CP como la obligación para el condenado de someterse bajo el control del Juez de la aplicación de las penas, durante una duración determinada por el Tribunal encargado del enjuiciamiento, a medidas de vigilancia y de asistencia destinadas a prevenir la reincidencia ${ }^{700 .}$

La suivi socio-judiciare puede acompañar a una pena privativa de libertad y también puede aparecer como pena principal. Su duración depende de si acompaña a un delito o a un crimen 701 , pudiendo durar hasta veinte años si se trata de un crimen y hasta diez años si se trata de un delito; y también podrá llegar a los treinta años si se trata de un crimen castigado con treinta años de reclusión criminal. Por último, se prevé la duración ilimitada para supuestos de reclusión a perpetuidad, que fue introducida mediante una ley de 2004 (Loi du 9 mars 2004)702. Y en el caso de que la suivi socio-judiciare acompañe a una pena privativa de libertad, aquélla empezará a cumplirse a partir de la puesta en libertad del penado (arts. 131-361 a 3 CP) ${ }^{703}$. El pronunciamiento sobre su imposición parte de que el tribunal en la Sentencia fija el tiempo de cumplimiento, en los casos en que

\footnotetext{
698 DREYER, E., Droit pénal général. Paris. Flammarion. 2006, pp. 173 y 174.

${ }^{699}$ MOLFESSIS, N. (Dir.) / DESPORTES, F. / LE GUNEHEC, F., Droit pénal général. 9a Ed. Paris: Economica. 2002, p. 752. Con cita de J. CASTAGNÈDE, Le suivi-sociojudiciaire applicable aux délinquants sexuels ou la dialectique sanction-traitement. D., 1999 chr. 23; B LAVIELLE, Surveiller et soigner les agresseurs sexuels, un des défis posés par la loi du 17 de juin 1999. RSC. 1999, p. 35.

700 LARGUIER, J., Droit pénal général. $19^{a}$ Ed. Paris. Dalloz. 2003; MOLFESSIS, N. (Dir.) / DESPORTES, F. / LE GUNEHEC, F., Droit pénal général..., cit. p. 753.

701 El Código penal francés distingue entre crímenes, delitos y contravenciones en su art. 111-1, (crimes, délits e contraventions), los crímenes son infracciones penal graves, los delitos vendrían a ser infracciones penales menos graves, y las contravenciones serían infracciones leves o faltas. Vid. MOLFESSIS, N. (Dir.) / DESPORTES, F. / LE GUNEHEC, F., Droit pénal général..., cit. p. 69.

702 BOULOC, B., Droit pénal général..., cit. p. 457.

703 MOLFESSIS, N. (Dir.) / DESPORTES, F. / LE GUNEHEC, F., Droit pénal général..., cit. p. 753.
} 
se permite su imposición al tribunal sentenciador (arts. 136-36-1) y también tras el cumplimiento de la pena de prisión por el Juez de aplicación de penas ${ }^{704}$.

La Loi du 12 décembre 2005, dispuso que la suivi socio-judiciaire pudiera comprender, a título de medida de seguridad, la colocación de medios de vigilancia electrónica móvil, pero solo podrá imponerse a los condenados a al menos siete años de privación de libertad, y cuando a través de informes médicos se haya constatado su peligrosidad y cuando esta medida sea indispensable para prevenir la reincidencia a partir del día en que termine de cumplirse la pena privativa de libertad ${ }^{705}$.

Según el art. 36-5 CP, la inobservancia por parte del condenado de las obligaciones resultantes del seguimiento es sancionada con privación de libertad, cuya duración máxima —que no puede exceder de dos años en caso de delito y de cinco años en caso de crimen- deberá venir inicialmente fijada en la sentencia, siendo al Juez encargado de la ejecución de las penas a quien le compete la decisión, en su caso, sobre esta privación de libertad706.

Consiste, pues, en el sometimiento del penado a ciertas obligaciones impuestas por el Juez, con el objetivo principal de combatir la reincidencia mediante una adecuada orientación para la reinserción ${ }^{707}$. Dichas medidas son, con carácter general, las previstas para la ejecución del régimen a prueba (art. 132-44 CP) ya que el propio art. 131-36-2 $\mathrm{CP}$ remite a dicho precepto expresamente, y son: la obligación de responder a las citaciones del Juez encargado de aplicar la pena; recibir las visitas del trabajador social y comunicarle la información o los documentos que faciliten el control de sus medios y de la ejecución de sus obligaciones; comunicarle al trabajador social sus cambios de empleo, residencia o desplazamiento cuya duración exceda de quince días, así como comunicar cualquier cambio de domicilio o empleo; y por último: obtener la autorización previa del

\footnotetext{
704 TAMARIT SUMALLA, J.M., “La integración jurídica...”, cit. p. 83.

705 BOULOC, B., Droit pénal général..., cit. p. 457 y 458.

706 MOLFESSIS, N. (Dir.) / DESPORTES, F. / LE GUNEHEC, F., Droit pénal général..., cit. p. 753. Como afirman estos autores, "el condenado es advertido por el presidente de la jurisdicción, después del pronunciamiento de la condena, de las consecuencias que entrañaría la inobservancia de sus obligaciones (arts. 131-3-1 a 3)".

707 PRADEL, J., Droit pénal général. 16ª Ed. Paris: Éditions Cujas. 2006, p. 553.
} 
Juez encargado de aplicar las penas para cualquier desplazamiento al extranjero cuando obstaculice la ejecución de sus obligaciones ${ }^{708}$.

Con carácter especial, el sujeto puede quedar también sometido a las reglas de conducta del art. 132-45 CP, al que remite el propio art. 131-36-2, $2^{\circ}$ párrafo $\mathrm{CP}$, que son: ejercer una actividad profesional, o bien asistir a unas clases o a una formación profesional; fijar su residencia en un lugar determinado; someterse a medidas de examen médico, de tratamiento o de atención, incluso en régimen de hospitalización; justificar que contribuye a las cargas familiares o que paga con regularidad las pensiones alimenticias a las que está obligado; reparar total o parcialmente, en función de su capacidad contributiva, los daños causados por la infracción, incluso en ausencia de decisión acerca de la acción civil; justificar que satisface, en función de su capacidad contributiva, las cantidades debidas a la Hacienda Pública como consecuencia de la condena; abstenerse de conducir algunos vehículos determinados por las categorías de permisos previstos en el Código de la circulación; no dedicarse a la actividad profesional durante cuyo ejercicio o con ocasión de cuyo ejercicio se haya cometido la infracción; abstenerse de visitar cualquier lugar especialmente determinado; no hacer apuestas, en especial en los organismos de apuestas mutuas; no frecuentar locales en los que se despachen bebidas alcohólicas; no frecuentar a algunos condenados, particularmente a los autores o a los cómplices de la infracción; abstenerse de entablar relación con ciertas personas, particularmente con la víctima de la infracción; y por último, no tener o portar armas 709 .

Y también con carácter especial, dispone el art. 131-36-2, $2^{\circ}$ párrafo $\mathrm{CP}$ que el sujeto podrá además someterse a las siguientes medidas: abstenerse de visitar cualquier lugar o categoría de lugares especialmente señalados y, principalmente, en los lugares a los que acuden habitualmente menores; abstenerse de frecuentar o relacionarse con ciertas personas o categorías de personas y, principalmente, con menores, exceptuando, en su caso, aquellos designados por el Juez o Tribunal; y no ejercer actividad profesional o de voluntariado que implique un contacto habitual con menores ${ }^{710}$.

\footnotetext{
708 MOLFESSIS, N. (Dir.) / DESPORTES, F. / LE GUNEHEC, F., Droit pénal général..., cit. p. 753 y 754; ARÁNGUEZ SÁNCHEZ, C. / ALARCÓN NAVÍO, E., El Código Penal francés..., cit. pp. 78 y 79.

709 ARÁNGUEZ SÁNCHEZ, C. / ALARCÓN NAVÍO, E., El Código Penal francés..., cit. pp. 79 y 80. ${ }^{710}$ MOLFESSIS, N. (Dir.) / DESPORTES, F. / LE GUNEHEC, F., Droit pénal général..., cit. p. 753; ARÁNGUEZ SÁNCHEZ, C. / ALARCÓN NAVÍO, E., El Código Penal francés..., cit. p. 59.
} 
El seguimiento socio-judicial, que no puede acordarse más que en los casos previstos por la ley, se impone en caso de homicidio o asesinato acompañado de violación, torturas o actos de barbarie, así como en caso de agresiones sexuales (incluidos los actos de exhibicionismo), corrupción de menores, grabación de la imagen pornográfica de un menor, difusión de mensajes violentos o pornográficos y agresiones sexuales a un menor (arts. 221-9-1, 22-48-1 y 227-31 CP). En materia correccional 711 puede imponerse como pena principal (art. 131-36-1 CP) 712 .

Puede ir acompañada o no de la injonction des soins (orden terminante de cuidados) que es una imposición de tratamiento médico, bajo el control de un médico coordinador, y puede dar lugar a la recuperación (sanación) del sujeto. Está prevista en el art. 131-36-4 $\mathrm{CP}$, que consiste en someterse a un tratamiento dispensado por un médico coordinador y otro médico terapeuta, con una remisión al Código de la Salud pública para la delimitación de sus funciones ${ }^{713}$. El contenido del tratamiento puede ser muy variado, y cabe la administración de medicamentos antiandrógenos (castración química). No obstante, será necesario el previo consentimiento expreso e indubitado del propio penado, y su negativa no genera en este caso la aplicación sustitutiva de la privación de libertad a la que antes he referido, aunque si no se somete al tratamiento voluntariamente y rechaza tal posibilidad, no podrá disfrutar de una hipotética y posible reducción de condena a la que eventualmente pudiera tener derecho ${ }^{714}$.

\footnotetext{
711 En el Derecho francés se distingue entre sanciones criminales, correccionales y de policía. Las penas criminales son la reclusión criminal y la detención, así como en algunos casos la multa. En materia correccional son privación de libertad por un máximo de diez años. La pena privativa de libertad será criminal si consiste en una reclusión y será correccional si consiste en un encarcelamiento (emprisonment). Las otras penas correccionales son: la multa, los días-multa, el stage de citoyenneté, destinado a integrar en el condenado los valores republicanos de tolerancia y respeto de la dignidad humana; el trabajo de interés general (travail d'intérêt général), las penas privativas o restrictivas de derechos y las penas complementarias. Vid. PRADEL, J., Droit Pénal général..., cit. p. 245.
}

712 MOLFESSIS, N. (Dir.) / DESPORTES, F. / LE GUNEHEC, F., Droit pénal général..., cit. p. 754. Estos autores señalan que "entre el autor de una exhibición sexual condenado, a título principal a dos años de seguimiento socio-judicial (y posible de seis meses de cárcel en caso de violación de esta medida), y el auto de una violación seguida de homicidio condenado a treinta años de seguimiento socio-judicial (cuya violación sería sancionada con cinco años de encarcelamiento), vemos que las hipótesis de aplicación podrían ser muy variadas. Las reglas sobre la rehabilitación y el registro judicial de antecedentes penales han sido adaptadas a la especificidad del seguimiento socio-judicial, con el fin de evitar una rehabilitación de la medida, o su eliminación en el registro judicial de antecedentes penales antes de que haya alcanzado el término fijado para su ejecución (arts. 133-16 C. pén.; arts. 736, 746 y 777 C. pr. Pén.)".

713 Ibidem. cit. p. 754 y 755.

714 ARÁNGUEZ SÁNCHEZ, C. / ALARCÓN NAVÍO, E., El Código Penal francés. Traducido y anotado..., cit. p. 59. Véase la nota el pie 83. 
La injonction des soins solo puede ser acordada por el Tribunal sentenciador si cuenta con un informe pericial médico que certifique que el sujeto es susceptible de ser sometido a tratamiento médico. En caso de homicidio o asesinato de un menor precedido o acompañado de una violación, de tortura o de actos de barbarie, el dictamen pericial deberá ser emitido por al menos dos expertos ${ }^{715}$.

La injonction des soins podrá igualmente ser acordada por el Juez de aplicación de las penas con posterioridad a una condena a un seguimiento socio-judicial no comportando la orden de cuidados médicos, con la condición -igualmente- de que una comisión de expertos ordenada por dicho Magistrado, estime que un tratamiento puede ser considerado como posible y conveniente (art. 763-3 del Código procesal penal). El legislador francés también ha contemplado la hipótesis de que el autor de un delito sexual, niegue los hechos durante el proceso y, en consecuencia, se emita informe por parte del experto que concluya que el tratamiento es inviable y, sin embargo, después de varios años de cumplimiento de su condena en prisión, reconozca su culpabilidad convirtiéndose así en susceptible de ser sometido al tratamiento médico (injonction des soins). En estos casos, a la vista de un nuevo informe pericial, el Juez de aplicación de las penas podrá entonces añadir al seguimiento socio-judicial, la orden formal de cuidados médicos que el Tribunal encargado del enjuiciamiento no pudo acordar ${ }^{716}$.

El seguimiento socio-judicial no se ejerce más que en un medio abierto, y normalmente no comporta ninguna obligación mientras perdura la privación de libertad del condenado. No obstante, hay excepciones cuando el seguimiento socio-judicial comporta un aspecto médico, en cuyo caso, el condenado tendrá la posibilidad de comenzar un tratamiento durante la ejecución de su pena privativa de libertad. Además, el Juez encargado de la aplicación de las penas, debe informar al penado cada seis meses de la posibilidad de emprender un tratamiento. Finalmente, salvo decisión contraria de dicho Juez, los condenados que no hayan empezado con un tratamiento estando privados

\footnotetext{
715 MOLFESSIS, N. (Dir.) / DESPORTES, F. / LE GUNEHEC, F., Droit pénal général..., cit. p. 754.

716 Ibidem, p. 755. Estos autores indican que "por lo general, los informes periciales de expertos permitiendo apreciar la evolución de la personalidad del condenado podrán siempre ser ordenados por el Juez de aplicación de las penas durante la privación de libertad del penado, especialmente antes de su liberación. Un informe pericial de expertos será incluso obligatorio si la condena ha sido impuesta más de dos años antes (art. 763-4 C. pén.)".
} 
de libertad, no tendrán derecho a las reducciones de pena suplementarias por no haber realizado esfuerzos serios de reinserción social117.

En cuanto la injonction des soins después de la liberación, será necesario siempre el consentimiento del penado. Por otra parte, la función de Juez de aplicación de las penas $^{718}$, que constituye el eje principal de la medida de seguimiento socio-judicial, está dotada de ciertas prerrogativas relevantes: 1) Es quien controla -directamente o a través de los agentes de control (agent de probation) - el respeto de las medidas del seguimiento, comprendiendo la injonction des soins (debiendo el condenado remitirle a intervalos regulares los informes del médico que le trata). 2) Puede modificar o completar las obligaciones del seguimiento socio-judicial, y debe resolver las solicitudes de levantamiento del conjunto de la medida que el condenado puede formular una vez al año. 3) Puede ejecutar el encarcelamiento por inobservancia de las obligaciones resultantes del seguimiento, comprendiendo la injonction des soins si ya ha sido dictada.

Por último, el seguimiento socio-judicial, también está previsto para ser aplicado en el ámbito de los menores y las funciones serán entonces ejercidas por el Juez de Menores, que puede - sin embargo- a partir de la mayoría de edad del condenado, inhibirse en favor del aludido Juez de aplicación de las penas ${ }^{719}$.

Por su parte, el Derecho anglosajón cuenta con gran arraigo en figuras penales de este tipo y, en Reino Unido, por ejemplo, están las penas que pertenecen al catálogo de cumplimiento en comunidad, dentro del marco de las denominadas "Comunity punishment"720. En este sistema, estas penas están previstas para delitos de menor gravedad y en los que el sujeto presente características que aconsejen que esta pena sea ya suficiente para cumplir su objetivo resocializador ${ }^{721}$. Estas penas están coordinadas con programas de reinserción y necesitan la ayuda de instituciones locales y demás entes que cuenten con una estructura organizativa que permita su materialización y, sobre todo, de

\footnotetext{
717 Ibidem, p. 755.

718 Para todas estas funciones en profundidad, vid. ibidem, pp. 756 a 759.

719 Ibidem, p. 758.

720 WORRALL, A. / HOY, C., Punishment in the Community. $2^{\mathrm{a}}$ Ed., Cullompton. 2005, pp. 17 y ss.

721 GRUPO DE ESTUDIOS DE POLÍTICA CRIMINAL, Una propuesta alternativa al sistema de penas y su ejecución, y a las medidas cautelares personales. GEPC. 2005, p. 43.
} 
estas instituciones y de la coordinación de ellos y sus programas, depende en buena medida la efectividad de estas penas.

Actualmente en el Reino Unido existe la Criminal Justice Act 2003722, que contiene un período de seguridad para ser aplicado tras el cumplimiento de la pena, en determinados delincuentes sexuales contumaces ${ }^{723}$. La Criminal Justice Act 2003, prevé una extended sentence o una indeterminate sentence por la contumacia en delitos sexuales. La primera consiste en un período de seguridad tras el cumplimiento de la pena de prisión, que se computa temporalmente como si de una condena se tratase ${ }^{724}$. Con ello se consigue, además, alterar el cómputo del tiempo para el acceso a la libertad condicional, de forma que, la mitad del cumplimiento de la pena para acceder a la libertad condicional, coincide con el cumplimiento íntegro de la pena de prisión ${ }^{725}$. Está prevista también para los delincuentes violentos, donde el referido período de extensión no podrá exceder de cinco años. Dicho período de extensión tampoco podrá exceder de ocho años para los delitos sexuales. La segunda, reservada a los supuestos más graves, puede desembocar o bien en una sentence for public protection de una duración mínima de diez años de prisión ${ }^{726}$, o bien en una live sentence ${ }^{727}$ o prisión perpetua ${ }^{728}$.

Las medidas de vigilancia en el Reino Unido, descansan sobre dos pilares: la obligación de notificación, introducida por la Sex offenders Act de 1997, que impone la obligación a ciertos delincuentes de notificar a la policía su nombre, alias o mote, domicilio, etc.; y la imposición de determinadas obligaciones que minimicen el riesgo de reincidencia. Se trata, pues, de someter al liberado definitivo a determinadas obligaciones de control similares a las que se usan para dotar de contenido a la libertad condicional, aunque con distintas variantes. $\mathrm{Y}$ en ese orden de cosas, junto a las extended sentences antes

\footnotetext{
722 ROCA POVEDA, M., “La libertad vigilada...”, cit. p. 39.

723 MANZANARES SAMANIEGO, J.L., “La libertad vigilada...”, cit. pp. 58 y 59.

724 SIERRA LÓPEZ, M.V., La medida de libertad vigilada..., cit. pp. 54 y 55.

725 GARCÍA ALBERO, R., “Ejecución de penas en el proyecto...”, cit. p. 131.

726 ROBLES PLANAS, R., ““Sexual Predators”. Estrategias del Derecho Penal de la peligrosidad”. En InDret. Revista para el análisis del Derecho. 4/2007. Barcelona, 2007, p. 5.

727 MANZANARES SAMANIEGO, J.L., “La libertad vigilada...”, cit. p. 5.

728 SILVA SÁNCHEZ, J.M., Tiempos de Derecho penal. Madrid: Edisofer. 2009, p. 39. Este autor señala que “en el Reino Unido desde 2003 existen las denominadas IPP (Indeterminate Public Protection Sentences), sentencias indeterminadas con fines de protección pública en cuya virtud ya cumplen condena de privación de libertad (potencialmente) perpetua más de un centenar de personas".
} 
vistas, coexisten las medidas acordadas ex novo cuando se produce la extinción de la responsabilidad penal del condenado. En efecto, las "restraining orders" introducidas en 1997, y las "sex offender orders" de 1998, fueron reformadas y sustituidas por las "sexual offences prevention orders" contenidas en la Sexual offences Act 2003. Dichas medidas deben ser acordadas por la Magistrate Court a petición de la Jefatura de Policía, y se podrán imponer a los sujetos que hayan sido condenados por determinados delitos, tanto en el Reino Unido como en el extranjero, cuando se advierta que esas personas, por su comportamiento desde que fueron condenadas, necesitan la imposición de dicha orden para proteger al conjunto de la sociedad por la presencia de un riesgo que se califica como grave $^{729}$.

Para su imposición existe un procedimiento previsto en los arts. 51 a 57 de la Magistrate's Court Act de 1980, y en esencia, se deberá hacer constar los motivos razonables que justifican la orden, así como las obligaciones concretas en que debe materializarse ${ }^{730}$, salvo las referentes a las antes mencionadas obligaciones de notificación (notification orders) cuya aplicación en estos casos será automática y ex lege. En cuanto a la duración, es de resaltar el hecho de que pueden ser indeterminadas, con una duración mínima de cinco años y, una vez trascurridos, deberá existir un nuevo pronunciamiento judicial sobre las circunstancias concurrentes en el sujeto a efectos de prorrogar o revocar la orden. Y, por último, caben también órdenes interinas, que se aplican mientras se tramita y se decide la imposición de una orden definitiva, y para lo que se tendrá en cuenta, entre otros aspectos, la necesidad de un período de control posterior a la liberación del penado, la necesidad de proteger al público de daños graves del delincuente, y la necesidad de prevenir la comisión de nuevos delitos por parte del delincuente, así como la necesidad, en mayor o menor medida, de rehabilitar al sujeto ${ }^{731}$.

En el caso de los Estados Unidos de Norteamérica, encontramos la "life time supervision"732, cuyo cumplimiento comienza tras la pena de prisión en determinados

\footnotetext{
729 GARCÍA ALBERO, R., “Ejecución de penas en el proyecto...”, cit. p. 133.

730 Ibidem, p. 133. Este autor señala que "dichas obligaciones han de ser congruentes y deberán limitarse a lo necesario para prevenir el riesgo".

731 Ibidem, p. 133, y nota al pie 12.

732 ROCA POVEDA, M., “La libertad vigilada...”, cit. pp. 39.
} 
delitos, y se halla sujeta a la supervisión de un agente denominado "parole officer"733. El reo ha de comunicar los cambios de profesión y domicilio para facilitar el control y éste puede completarse, además, mediante una serie de prohibiciones u órdenes que van en la línea de las reglas de conducta del Derecho europeo. Junto a la medida de libertad vigilada existen también las denominadas civil commitment or involuntary commitment ${ }^{734}$, que consisten en un internamiento por la persistencia de la peligrosidad del sujeto una vez extinguida la pena. Su frecuente aplicación a los delincuentes sexuales se refleja en las llamadas Sexual Violent Predators-Laws735, modelo que en la actualidad se ha generalizado en los Estados Unidos ${ }^{736}$. Y no se olvide que la reclusión perpetua es de aceptación general en ese país, sin mencionar que hay varios Estados que mantienen vigente la pena capital737.

Las posibilidades de aplicación de la libertad vigilada presentan algunas particularidades como la posibilidad de revestir forma de medida cautelar, siendo la función de los agentes de libertad vigilada informar al Juez acerca de la personalidad del delincuente y de la necesidad de aplicación de la medida en la ulterior sentencia que se dicte $^{738}$. Además, con ello se persigue que el acusado sepa que desde el inicio del proceso existe un control sobre él, aunque sea un control meramente asistencial en aras a evitar la reincidencia y potenciar la reinserción ${ }^{739}$, al tiempo que permite garantizar que la sociedad se sienta más protegida al saber que los acusados que están en libertad, se encuentran de alguna forma controlados.

\footnotetext{
733 MANZANARES SAMANIEGO, J.L., “La libertad vigilada...”, cit. p. 56.
}

734 ROBLES PLANAS, R., “"Sexual Predators"...", cit. p. 5. Este autor pone afirma que "pionero en este sentido fue el Estado de Washington, que en el año 1990 aprobó la "Community Protection Act" [...] y estableció, junto a la creación de los registros para delincuentes sexuales, la medida denominada "civil commitment" o "involuntary commitment". Con este nuevo instrumento, aunque el delincuente sexual hubiera cumplido su condena, éste debía permanecer privado de libertad por su peligrosidad para la comunidad por tiempo indeterminado hasta que dejara de representar un peligro para aquélla".

735 Ibidem, p. 5. Según este autor, "particularmente, en el ámbito de la delincuencia sexual se van aprobando progresivamente en casi todos los Estados de los Estados Unidos las denominadas "Sexual Violent PredatorsLaws" -repárese en la denominación de la ley, literalmente "predator" significa "depredador"-".

736 ROCA POVEDA, M., “La libertad vigilada...", cit. p. 39.

737 MANZANARES SAMANIEGO, J.L., “La libertad vigilada...”, cit. p. 4.

738 MAGRO SERVET V. / SOLAZ SOLAZ, E., Manual Práctico sobre Ejecución Penal. Las medidas alternativas a la prisión: suspensión, sustitución y expulsión. $2^{\text {a }}$ Ed. Madrid: La Ley. 2010, p. 225. Expresan estos autores que "los agentes de la libertad vigilada no intervienen tras la sentencia, sino que lo hacen antes, es decir, durante la instrucción cuando el Juez ha acordado la medida cautelar que puede ser de alejamiento con la adición de la libertad vigilada, con lo que no se trata de una medida post sentencia y en la fase de ejecución, sino que se gesta ya cuando se ha iniciado el procedimiento penal".

739 Ibidem, pp. 225 y 226. 
Posteriormente, la libertad vigilada también podrá ser impuesta en la sentencia, y para ello el Juez se basará en los informes previos que haya elaborado el agente de libertad condicional en la fase sumarial durante la vigencia de la libertad vigilada como medida cautelar, y su control podrá ser encargado a criminólogos, psicólogos, trabajadores sociales, educadores, etc., que necesariamente deberán estar adscritos al órgano jurisdiccional ${ }^{740}$.

La libertad vigilada también se puede aplicar como sustitutivo del ingreso en prisión, condicionado al abono de la responsabilidad civil derivada del delito, siendo el agente de libertad vigilada quien deberá controlar el pago o formular al penado los recordatorios que sean necesarios ${ }^{741}$.

Por último, podemos destacar el modelo de intervención del agente de libertad vigilada en el Estado de New Jersey, a través del denominado Programa de Intervención Preventiva (PTI), que se aplica a los acusados que son delincuentes primarios, para conseguir una rehabilitación temprana y disuadirles para futuros comportamientos delictivos $^{742}$. Los encargados de ejecutar este programa son los agentes de libertad vigilada, y para su aplicación debe ser el propio acusado quien lo solicite antes de que el Fiscal formule su acusación, y se fija como plazo máximo veintiocho días después de

\footnotetext{
740 HENDLER, E.S., Derecho Penal y Procesal de los Estados Unidos. Buenos Aires: Ad-Hoc. 1996, p. 129. Este autor señala que "es característico del sistema de enjuiciamiento que rige en muchos de los Estados la división del proceso en una fase de la determinación de la culpabilidad y otra de fijación de la sentencia. El primero concluye con el veredicto del jurado y el segundo se desenvuelve, ya sin jurado, sobre la base de un informe preparado, usualmente, por un funcionario de probation, es decir, una suerte de inspector o supervisor de cumplimiento de condenas condicionales. Según las leyes de los distintos Estados este informe puede ser requerido optativamente por el Juez o bien puede resultar legalmente obligatorio".
}

741 MAGRO SERVET V. / SOLAZ SOLAZ, E., Manual Práctico sobre Ejecución Penal..., cit. pp. 228 y 229. Estos autores relatan que "esta medida está contemplada en el Estado de California bajo la figura de "las responsabilidades de la sustitución", introducida por el conocido ex actor de cine, Arnold Swarzenegger, Gobernador del Estado de California (www.victimcompensation.ca.gov). En esta medida se trata de conseguir del penado la restitución como pago del dinero a una víctima que sufrió las pérdidas debido a su conducta criminal. Así, en este Estado se incluye como medida complementaria a la de libertad vigilada, pero para autores de delitos mayores de edad y menores, la de restitución a la víctima del crimen de todas las pérdidas monetarias que le ocasionó al cometer ese crimen".

742 Ibidem, pp. 229 y 230. Según estos autores "en el modelo de rehabilitación se hace hincapié en que las circunstancias sociales, culturales, o las condiciones económicas a menudo son causa del resultado de una decisión del acusado de cometer el delito. En pocas palabras, PTI se esfuerza por resolver problemas personales que tienden a consecuencia de las condiciones que aparecen a causa del delitos, y el última instancia, para prevenir futuras conductas delictivas por el autor de un delito". 
formulada aquélla ${ }^{743}$. Básicamente, la concesión al penado de la libertad vigilada implica una serie de exigencias de cumplimiento, como la de obedecer las leyes federales y estatales, notificar al agente de libertad vigilada dentro de veinticuatro horas si está detenido o citado para comparecer ante cualquier órgano jurisdiccional, informar a su agente de cualquier cambio de domicilio, permitir que le visite en su residencia, responder a todas las investigaciones que le realice, solicitarle autorización para ausentarse fuera del Estado, comunicarle cualquier cambio de trabajo y cooperar con el agente en todo aquello que sea necesario para el buen fin de la ejecución de la medida. Obviamente, el incumplimiento podrá dar lugar a que el agente emita un informe del que se servirá el Tribunal para modificar las condiciones de supervisión PTI, o revocarla y proceder al internamiento en prisión ${ }^{744}$.

\section{ANTECEDENTES EN DERECHO ESPAÑOL}

\section{En la legislación penal de menores}

La libertad vigilada como medida encaminada a la reeducación en el ámbito de los menores, cuenta con constantes referencias legislativas en España durante el Siglo XX, puesto que ya aparecía contemplada en la Ley de Bases sobre organización y atribuciones de los Tribunales para niños de 1918, en el Texto Refundido de los Tribunales Tutelares de Menores de 1948745 , y en la LO 4/1992746. En efecto, la libertad vigilada, fue una medida frecuentemente utilizada por los Juzgados de Menores bajo la vigencia de la LO 4/1992, de 5 de junio, Reguladora de la Competencia y el Procedimiento de los Juzgados de Menores (arts. 18 y 19)747, pero dada su insuficiente e imprecisa regulación, posteriomente,

743 Ibidem, p. 230. Estos autores explican que "el proceso de solicitud incluye una entrevista con el acusado por un miembro del personal de la Sala de lo Penal de la Corte Superior con un informe escrito detallando la decisión de admisión o rechazo en el programa PTI. Cuando un acusado es aceptado en el PTI en la recomendación de la Sala de lo Penal, con el consentimiento del Fiscal y el acusado, el Juez podrá aplazar todas las nuevas actuaciones contra el acusado por un período no superior a 36 meses. El solicitante puede apelar un rechazo a la Juez Presidente de la Sala Penal dentro de los 10 días del rechazo".

744 Ibidem, pp. 230 y 231.

745 HIGUERA GUIMERÁ, J.F., Derecho penal juvenil. Barcelona: Bosch. 2003, p. 168.

746 CEZÓN GONZÁLEZ, C., La nueva Ley Orgánica reguladora de la responsabilidad penal de los menores. Barcelona: Bosch. 2001, p. 51.

747 VARGAS CABRERA, B., en CONDE-PUMPIDO FERREIRO, C., Ley de la responsabilidad penal de los menores. Doctrina con jurisprudencia y normativa complementaria. Madrid: Trivium. 2001, p. 160. 
la LO 5/2000, de 12 de enero, Reguladora de la Responsabilidad Penal de los Menores748 (LORPM), vino a a actualizar la disciplina normativa, "concretando los contenidos y suprimiendo las caducas disposiciones sobre derechos de guarda y ecuación"749, de modo que contempla la libertad vigilada como una consecuencia jurídica del delito en su art. 7.1 h). Antes de pasar al análisis sobre la regulación de la libertad vigilada en la LORPM, conviene efectuar algunas consideraciones acerca de las medidas que son aplicables a los menores infractores, su naturaleza jurídica, principios informadores, clases de medidas, etc., que se desarrollan seguidamente.

\section{a) Naturaleza jurídica de las medidas en el Derecho penal de menores}

La LORPM al denominar medidas a las sanciones penales aplicables a los menores, persigue una finalidad suavizadora de la terminología que bajo el nomen iuris de "medidas", en realidad se trata de penas, lo que ha sido incluso calificado como "fraude de etiquetas" por un importante sector de la doctrina ${ }^{750}$. No obstante, la cuestión es mucho más compleja, ya que la LORPM usa la denominación de medidas de naturaleza sancionadora-educativa, de lo que se desprende que existen coincidencias con las penas en adultos y también diferencias. Las principales coincidencias son que el presupuesto necesario para su imposición es la comisión de un hecho delictivo previsto en el CP (ya sea delito o falta); y difieren de las penas en su finalidad educativa basada en el interés preferente del menor, así como en la gran flexibilidad en su aplicación que se traduce en un amplio margen de maniobra basado en la evolución en la intervención del menor ${ }^{751}$.

Igualmente debemos establecer diferencias entre las medidas de seguridad en adultos aplicables a sujetos que tengan mermada en mayor o menor medida su imputabilidad, y su equivalente en menores, esto es, medidas encaminadas a la prevención y no al reproche culpabilístico. Sobre este aspecto hemos de poner de manifiesto que las diferencias más destacables con las medidas de seguridad son: que se

\footnotetext{
748 Reformada por LO 8/2006, de 4 de diciembre.

749 VARGAS CABRERA, B., en CONDE-PUMPIDO FERREIRO, C., Ley de la responsabilidad..., cit. p. 160.

750 Sobre esta cuestión, vid. ORTS BERENGUER, E. / GONZÁLEZ CUSSAC, J.L., Compendio..., cit. p. 363; y LANDROVE DÍAZ, G., Las consecuencias..., cit. pp. 165 a 169, que expresa que "a pesar de los malabarismos terminológicos [...] en realidad nos encontramos ante consecuencias jurídicas de la infracción materialmente constitutivas de penas. Tal fraude de etiquetas no es ninguna novedad en la Justicia de menores española".

751 CERVELLÓ DONDERIS, V., La medida de internamiento en el Derecho penal del menor. Valencia: Tirant lo Blanch. 2009, p. 17.
} 
alude a la gravedad del hecho en la selección de la medida, y que se permite su imposición tanto a menores imputables como inimputables ${ }^{752}$, siendo las medidas más cercanas a las medidas de seguridad en adultos, el internamiento terapéutico y el tratamiento ambulatorio. Tal posibilidad aparece regulada en el art. 5.2 LORPM753.

En este sentido debemos resaltar que, tal y como se desprende del art. 9.5 LORPM, las medidas del art. $7.1 \mathrm{~d}$ ) y e) solo se podrán imponer a menores en los que concurra alguna de las causas de inimputabilidad de los apartados 20.1, 2 y 3 CP754, en cuyo caso se imponen como medidas de seguridad ${ }^{755}$. Y en cuanto a los menores en los que concurra alguna causa de semiimputabilidad, según la Circular de la Fiscalía 1/2000, las referidas medidas del art. 7.1 d) y f) se podrán imponer solas o como complemento de alguna otra medida 756 .

Por todo ello, podemos concluir que, como indica CERVELLó DONDERIS, "se trata de una especie de medidas sui generis, ya que comparten puntos comunes y diferencias tanto con las penas como con las medidas de seguridad, con una indiscutible naturaleza penal propia de una sanción, si bien con una finalidad educativa específica orientada a la

752 Ibidem, p. 18. Esta autora índica que "ante esta aparente contradicción hay que destacar las razones que apoyan su consideración de medidas: Formales: denominación legal. Contenido: intervención educativa. Procedimiento: flexibilización en la aplicación y ejecución. Finalidad: interés prioritario del menor".

753 A cuyo tenor: "Los menores en quienes concurran las circunstancias previstas en los números 1, 2, 3 del art. 20 del vigente Código Penal les serán aplicables, en caso necesario, las medidas terapéuticas a las que refiere el art. 7.1 letras d) y e) de la presente Ley". Y los apartados d) y e) del art. 7.1 LORPM disponen quelo siguiente: “art. $7.1 \mathrm{~d}$ ). Internamiento terapéutico en régimen cerrado, semiabierto o abierto. En los centros de esta naturaleza se realizará una atención educativa especializada o tratamiento específico dirigido a personas que padezcan anomalías o alteraciones psíquicas, un estado de dependencia de bebidas alcohólicas, drogas tóxicas o sustancias psicotrópicas, o alteraciones en la percepción que determinen una alteración grave de la conciencia de la realidad. Esta medida podrá aplicarse sola o como complemento de otra medida prevista en este artículo. Cuando el interesado rechace un tratamiento de deshabituación, el Juez habrá de aplicarle otra medida adecuada a sus circunstancias"; "art. 7.1 e). Tratamiento ambulatorio. Las personas sometidas a esta medida habrán de asistir al centro designado con la periodicidad requerida por los facultativos que las atiendan y seguir las pautas fijadas para el adecuado tratamiento de la anomalía o alteración psíquica, adicción al consumo de bebidas alcohólicas, drogas tóxicas o sustancias psicotrópicas, o alteraciones en la percepción que padezcan. Esta medida podrá aplicarse sola o como complemento de otra medida prevista en este artículo. Cuando el interesado rechace un tratamiento de deshabituación, el Juez habrá de aplicarle otra medida adecuada a sus circunstancias".

754 “Cuando en la postulación del Ministerio Fiscal o en la resolución dictada en el procedimiento se aprecien algunas de las circunstancias a las que se refiere el artículo 5.2 de esta Ley, sólo podrán aplicarse las medidas terapéuticas descritas en el artículo 7.1, letras d) y e) de la misma".

755 CARDENAL MONTRAVETA, S., “La reincidencia en el Derecho penal de menores. En LUZÓN PEÑA, D.M., Derecho penal del Estado social y democrático de Derecho. Libro Homenaje a Santiago Mir Puig. Madrid: La Ley. 2010, p. 667.

756 COLÁS TURÉGANO, A., “Aspectos penales característicos de la delincuencia juvenil”. En GONZÁLEZ CUSSAC, J.L. / CUERDA ARNAU, M.L., (Coords.) Estudios sobre la responsabilidad penal del menor. Col lecció “Estudis jurídics" núm. 9. Castellón: Universitat Jaume I. 2006, p. 103. 
recuperación individual y social del menor"757. Las características esenciales de las medidas en el ámbito de los menores son las siguientes: intervención mínima, finalidad educativa, interés prioritario del menor, flexibilidad judicial y duración en función de tramos de edad758.

\section{b) Principios informadores}

Como toda intervención punitiva estatal, el Derecho penal de menores y en concreto la aplicación de las medidas, debe estar informado por una serie de principios que garanticen la defensa de los derechos fundamentales que, en síntesis ${ }^{759}$, son los siguientes:

$1^{\circ}$. Principio de legalidad. La concreción penal de este principio en nuestro texto constitucional deriva del art. 25.1 CE, donde se contempla la garantía de que debe existir una ley previa que determine las diversas infracciones penales impidiendo el efecto retroactivo de la misma, con proscripción de la analogía. Sin embargo, dicho precepto no contiene referencia alguna a las medidas sancionadoras-aducativas para el ámbito de los menores, debido a que, en el momento de la promulgación del texto constitucional, la actual regulación para los menores estaba todavía muy lejos de aparecer en escena, y también por la estrechez del marco constitucional. No obstante, la aplicación del principio de legalidad en este ámbito se infiere de la propia remisión que efectúa la Disposición Final $1^{\text {a }}$ del CP, a la LORPM760. No obstante lo anterior, la LORPM proclama el principio de legalidad en su art. $43^{761}$.

\footnotetext{
757 CERVELLÓ DONDERIS, V., La medida de internamiento..., cit. p. 19.

758 Ibidem, pp. 20 a 27.

759 En profundidad sobre los principios rectores en la responsabilidad penal de los menores, vid. MARTÍNEZ SERRANO, A., "Principios sustantivos y procesales básicos de la responsabilidad penal de los menores establecidos en la LO 5/2000". En ORNOSA FERNÁNDEZ, M.R. (Dir.), La responsabilidad penal de los menores: aspectos sustantivos y procesales. Cuadernos de Derecho Judicial. Madrid: CGPJ. 2001, pp. 19 a 39.

760 AYO FERNÁNDEZ, M., “Las garantías del menor infractor. (Ley orgánica 5/2000, de 12 de enero, sobre Responsabilidad Penal de los Menores y sus modificaciones posteriores)". En Revista de Derecho y Proceso Penal. Monografía núm. 12. Navarra: Thomson Aranzadi. 2004. Págs. 163 y 164.

761 “Art. 43. Principio de legalidad. 1. No podrá ejecutarse ninguna de las medidas establecidas en esta Ley sino en virtud de sentencia firme dictada de acuerdo con el procedimiento regulado en la misma. 2. Tampoco podrán ejecutarse dichas medidas en otra forma que la prescrita en esta Ley y en los reglamentos que la desarrollen". Véase al respecto el comentario de LÓPEZ LÓPEZ, A.M., La Ley Penal del Menor y el Reglamento para su aplicación. Comentarios, concordancias y jurisprudencia. Granada: Comares. 2007, pp. 307 a 310.
} 
El marco legal de la aplicación del Derecho penal de menores como expresión del principio de legalidad es, pues, la LORPM 5/2000, y sus reformas incorporadas a través de la Ley 7/2000, 9/2000 y 8/2006, y su Reglamento de desarrollo (RM) aprobado por RD 1774/2004, de 30 de julio. El CP y las leyes penales especiales actúan como supletorias de la LORPM según se desprende de la Disposición Final $1^{\text {a }} \mathrm{CP}^{762}$. Sobre la competencia de las CCAA para legislar sobre esta materia, hemos de mencionar brevemente, que les Illes Balears aprobaron una Ley en su Parlamento, la Ley 6/1995, de 21 de marzo, de actuación de la Comunidad Autónoma en la aplicación de las medidas judiciales sobre menores infractores, que por la STC 243/2004, de 16 de diciembre, fue declarada parcialmente inconstitucional al entender que la creación de medidas diferentes a las previstas en la legislación estatal vigente, no es constitucionalmente posible 763 .

Además, existen varios Tratados Internacionales en la materia de entre los que podemos destacar la Convención sobre los Derechos del Niño de Naciones Unidas, de 20 de noviembre de 1989, ratificada por España el 30 de noviembre de 1990. Las Reglas Mínimas de las Naciones Unidas para la Administración de Justicia de Menores (Reglas de Beijing, de 29 de noviembre de 1985). Las Reglas de Naciones Unidas para la Protección de Menores Privados de Libertad, de 14 de diciembre de 1990. Y en el ámbito europeo, el Consejo de Europa se encuentra preparando unas Reglas Europeas sobre menores delincuentes en orden a recoger los principios básicos de las medidas aplicables a menores ${ }^{764}$.

En cuanto al contenido del principio de legalidad, se concreta en el necesario control judicial de la ejecución de las medidas por el Juez de Menores, que se traduce en el seguimiento de la evolución del menor con el fin de adaptar las resoluciones a la finalidad perseguida y a garantizar el cumplimiento de la legalidad por parte de las instituciones encargadas de la ejecución de las medidas, así como de ejercer un control efectivo sobre

\footnotetext{
762 CERVELLÓ DONDERIS, V., La medida de internamiento..., cit. pp. 28 y 29. Esta autora indica que "la ley no hace referencia alguna a la supletoriedad de la Ley Penitenciaria LOGP ni a su Reglamento (RP), pese a que la Circular 1/2000 FGE entendió que en lo que beneficiaría sí podría serlo. El Código Penal y la Ley de Enjuiciamiento Criminal, sin embargo, sí son leyes supletorias según dispone expresamente la Disposición Final Primera".

763 Ibidem, p. 29.

764 Ibidem, pp. 29 a 31.
} 
los derechos fundamentales del menor ${ }^{765}$. Dicho control judicial deberá llevarse a cabo mediante la resolución de los incidentes que se planteen, oído el Ministerio Fiscal y el Letrado del menor ${ }^{766}$.

$2^{\circ}$. Principio de proporcionalidad. La exigencia derivada de este principio pasa por la necesaria adecuación de la gravedad de las sanciones con el hecho cometido, actuando como límite para evitar la imposición de consecuencias más graves que el delito por el que se imponen ${ }^{767}$. Para ello se parte de la intervención mínima del Derecho penal y de que no deben imponerse sanciones más graves si pueden imponer otras menos gravosas, lo que se traduce en la denominada prohibición de exceso ${ }^{768}$.

En el Derecho penal de menores, la adecuada ponderación entre gravedad del hecho y de la pena, no tiene un reflejo real y efectivo, toda vez que la finalidad no es retributiva sino educadora, y está basada en el interés preferente del menor, por lo que, tanto la elección de la medida concreta que deba imponerse como su duración, deberán ser acordadas por el Juez atendiendo a una proporcionalidad que no presenta una manifestación pura769. Además, no conviene olvidar que en el Derecho penal de menores está vigente el principio de oportunidad 770 , que se traduce en que puede evitarse el inicio del proceso en atención a la innecesariedad de imposición de medidas educadoras ${ }^{771}, \mathrm{u}$ optar preferentemente por la imposición de medidas no privativas de libertad. En ese sentido, manifiesta AYO FERNÁNDEZ que “dada la naturaleza sancionadora de las medidas que son susceptibles de imposición a los menores, es exigible que exista proporcionalidad en la reacción sancionadora que prevé la Ley al comportamiento delictual del menor, sin

\footnotetext{
765 CADENA SERRANO, F.A., “Las medidas previstas en la LORRPM”. En SAMANES ARA, C., (Coord.), La responsabilidad penal de los menores. Zaragoza: El justicia de Aragón. 2003, p. 52.

766 AYO FERNÁNDEZ, M., Las garantías del menor infractor..., cit. p. 175.

767 CADENA SERRANO, F.A., “Las medidas previstas...”, cit. pp. 52 y 53.

768 AYO FERNÁNDEZ, M., Las garantías del menor infractor..., cit. p. 188.

769 CERVELLÓ DONDERIS, V., “Sistema de sanciones en el Derecho penal de menores”. En CERVELLÓ DONDERIS, V. / COLÁS TURÉGANO, A., La responsabilidad penal del menor de edad. Madrid: Tecnos. 2002, p. 119.

770 CERVELLÓ DONDERIS, V., “Las medidas en el Derecho penal de menores”. En GONZÁLEZ CUSSAC, J.L. / CUERDA ARNAU, M.L., (Coords.) Estudios sobre la responsabilidad penal del menor. Col lecció "Estudis jurídics", núm. 9. Castellón: Universitat Jaume I. 2006, p. 128.

771 Véase a este respecto la obra de ORNOSA FERNÁNDEZ, M.R., Derecho Penal de Menores. Comentarios a la Ley Orgánica 5/200, de 12 de enero, reguladora de la responsabilidad penal de los menores y a su Reglamento aprobado

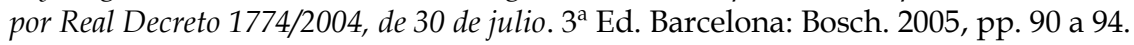


olvidar que los objetivos educativos que proclama dicha Ley pudieran modular la proporcionalidad de las medidas previstas"772.

$3^{\circ}$. Intervención educativa. El rechazo a la finalidad retributiva e intimidatoria de las medidas que proclama la Exposición de Motivos de la LORPM, viene a poner de manifiesto que la finalidad educativa preside todo el sistema del Derecho penal de menores, extendiéndose tanto a su regulación, como a su aplicación y ejecución, adquiriendo así un total protagonismo. El principio de resocialización proclamado en el art. 25.2 CE773, tiene un especial reflejo en el art. 55 LORPM en relación a la medida de internamiento, y también el art. $6 \mathrm{RM}$ recoge como criterio preferente el superior interés del menor, el respeto al libre desarrollo de la personalidad y la preferencia de su entorno familiar 774 .

\section{c) Clases de medidas}

Las medidas que pueden ser impuestas a los menores infractores están contempladas en el art. 7 LORPM 775 , sin que haya en la norma una sistematización legal del catálogo, por lo que, según manifiesta doctrina, la clasificación puede hacerse en función del bien jurídico al que afectan ${ }^{776}$. Partiendo de esta premisa podemos clasificarlas

772 AYO FERNÁNDEZ, M., Las garantías del menor infractor..., cit. p. 190.

773 Que dispone que “2. Las penas privativas de libertad y las medidas de seguridad estarán orientadas hacia la reeducación y reinserción social y no podrán consistir en trabajos forzados. El condenado a pena de prisión que estuviere cumpliendo la misma gozará de los derechos fundamentales de este Capítulo, a excepción de los que se vean expresamente limitados por el contenido del fallo condenatorio, el sentido de la pena y la Ley penitenciaria. En todo caso, tendrá derecho a un trabajo remunerado y a los beneficios correspondientes de la Seguridad Social, así como al acceso a la cultura y al desarrollo integral de su personalidad".

774 CERVELLÓ DONDERIS, V., La medida de internamiento..., cit. p. 35.

775 En general sobre las medidas, vid. MARTÍN SÁNCHEZ, A., “Las medidas en la Ley Orgánica 5/20010, de 12 de enero de responsabilidad penal de los menores". En ORNOSA FERNÁNDEZ, M.R. (Dir.), La responsabilidad penal de los menores: aspectos sustantivos y procesales. Cuadernos de Derecho Judicial. Madrid: CGPJ. 2001. Pags. 439 a 512; MARTÍNEZ GONZÁLEZ, I., “De las medidas”. En GÓMEZ RIVERO, M.C., Comentarios a la Ley Penal del Menor (Conforme a las reformas introducidas por la LO 8/2006). Madrid: Iustel. 2007, pp. 112 a 124; VARGAS CABRERA, B., en CONDE-PUMPIDO FERREIRO, C., Ley de la responsabilidad..., cit. pp. 129 a 185; DE LA ROSA CORTINA, J.M., “Las medidas y sus reglas de aplicación”. En DE URBANO CASTRILLO, E. / DE LA ROSA CORTINA, J.M., La responsabilidad penal de los menores. Adaptada a la LO 8/2006, de 4 de diciembre. Navarra: Thomson Aranzadi. 2007, pp. 53 a 111; CUELLO CONTRERAS, J., El nuevo Derecho penal de menores. Madrid: Civitas. 2000, pp. 55 a 64; CADENA SERRANO, F.A., "Las medidas previstas...", cit. pp. 70 a 96; CEZÓN GONZÁLEZ, C., La nueva Ley Orgánica..., cit. pp. 48 a 62; HAVA GARCÍA, E. / RÍOS CORBACHO, J.M., “Las medidas aplicables a menores en la ley 5/2000”. En RUIZ RODRÍGUEZ, L.R. / NAVARRO GUZMÁN, J.I. (Coords.), Menores. Responsabilidad pena y atención psicosocial. Valencia: Tirnat lo Blanch. 2004, pp. 143 a 179.

776 CERVELLÓ DONDERIS, V., “Las medidas en el Derecho penal...”, cit. p. 129. 
del siguiente modo: a) Medidas privativas de libertad, que incluyen el internamiento en régimen abierto, en régimen cerrado, y en régimen semiabierto. b) Medidas privativas de derechos, que son las prestaciones en beneficio de la comunidad, la privación del permiso de conducir o del derecho a obtenerlo o de las licencias de caza y de armas, la inhabilitación absoluta, y la prohibición de aproximarse a la víctima o con aquellos familiares o personas que el Juez determine. c) Medidas restrictivas de derechos, que son: la permanencia de fin de semana y la libertad vigilada (a la que me referiré en profundidad más adelante). d) A su vez, dentro de las medidas privativas o restrictivas de derechos, puede distinguirse entre las que son de inmediata ejecución, que son: las prestaciones en beneficio de la comunidad, la privación del permiso de conducir o del derecho a obtenerlo o de las licencias de caza y de armas; y las que implican un control prolongado que serían todas las demás antes mencionadas777. e) Medidas terapéuticas778, que son: el internamiento en centro terapéutico ${ }^{779}$ y tratamiento ambulatorio para la deshabituación y trastornos mentales ${ }^{780}$. Aunque algunos autores ubican el internamiento terapéutico en las medias privativas de libertad, y el tratamiento ambulatorio en las medidas restrictivas de derechos ${ }^{781}$. f) Medidas Educativas ${ }^{782}$, que son: la asistencia a un centro de día783, la convivencia con otra persona, familia o grupo educativo ${ }^{784}$, la realización de tareas socio-educativas ${ }^{785}$ y la amonestación ${ }^{786}$. Y un último criterio de clasificación de las medidas es el que propone ORNOSA FERNÁNDEZ, en función de la aceptación o no por parte del menor, de tal modo que podríamos distinguir entre medidas voluntarias (que serían las prestaciones en beneficio de la comunidad, el internamiento terapéutico y el tratamiento ambulatorio para tratamientos de deshabituación); y forzosas,

\footnotetext{
777 Sobre esta clasificación véase la obra de ORNOSA FERNÁNDEZ, M. R., Derecho Penal de Menores..., cit. p. 206.

778 CERVELLÓ DONDERIS, V., La medida de internamiento..., cit. p. 36.

779 Sobre esta medida vid. LÓPEZ LÓPEZ, A.M., La Ley Penal del Menor..., cit. pp. 63 a 67.

780 Sobre esta medida vid. Ibidem, pp. 67 a 69.

781 ORNOSA FERNÁNDEZ, M.R., Derecho Penal de Menores..., cit. p. 206.

782 CERVELLÓ DONDERIS, V., “Las medidas en el Derecho penal...”, cit. p. 130.

783 Sobre esta medida vid. CERVELLÓ DONDERIS, V., “Sistema de sanciones...”, cit. pp. 161 y 162.

784 Sobre esta medida vid. ibidem. cit. pp. 162 y 163.

785 Sobre esta medida vid. ibidem, p. 163, aunque otros autores clasifican esta medida bajo la categoría de medidas protectoras. En ese sentido ORNOSA FERNÁNDEZ, M.R., Derecho Penal de Menores. Comentarios..., cit. p. 206.

786 Sobre esta medida puede verse Sobre esta medida vid. CERVELLÓ DONDERIS, V., "Sistema de sanciones...", cit. p. 164. Aunque otros autores clasifican esta medida bajo la categoría de medidas admonitorias. En ese sentido ORNOSA FERNÁNDEZ, M.R., Derecho Penal de Menores..., cit. p. 206
} 
que serían todas las demás, salvo supuestos de conformidad del menor de los arts. 32 y 36 LORPM787.

\section{d) La medida de libertad vigilada}

Antes de entrar en el análisis de su regulación, conviene hacer una breve referencia a que se trata de una medida que reviste una importante versatilidad y la Exposición de Motivos de la LORPM vino a decir es "como una vigilancia o supervisión a cargo de personal especializado, con el fin de que el menor infractor adquiera las habilidades, capacidades y actitudes necesarias para un correcto desarrollo personal y social", todo ello en conjunción con la finalidad de la ley en su conjunto que busca el mejor interés del menor ${ }^{788}$.

En cuanto a la regulación legal, la LORPM contempla la medida de libertad vigilada en su artículo $7.1 \mathrm{~h})^{789}$ y habida cuenta de la amplitud con la que está redactado el art. $7.1 \mathrm{~h}$ ) regla $7^{\mathrm{a}} \mathrm{LORPM}$, el contenido de la medida siempre deberá quedar definido con los contornos más precisos posibles al dictar sentencia, lo cual no impide que se pueda producir una condena a libertad vigilada en la que únicamente se especifique en la

\footnotetext{
787 ORNOSA FERNÁNDEZ, M.R., Derecho Penal de Menores..., cit. pp. 206 y 207.
}

788 ACALE SÁNCHEZ, M., “Medición de la respuesta punitiva...”, cit. p. 167.

789 A cuyo tenor: “art. 7. Definición de las medidas susceptibles de ser impuestas a los menores y reglas generales de determinación de las mismas. 1. Las medidas que pueden imponer los Jueces de Menores, ordenadas según la restricción de derechos que suponen, son las siguientes: h) Libertad vigilada. En esta medida se ha de hacer un seguimiento de la actividad de la persona sometida a la misma y de su asistencia a la escuela, al centro de formación profesional o al lugar de trabajo, según los casos, procurando ayudar a aquélla a superar los factores que determinaron la infracción cometida. Asimismo, esta medida obliga, en su caso, a seguir las pautas socio-educativas que señale la entidad pública o el profesional encargado de su seguimiento, de acuerdo con el programa de intervención elaborado al efecto y aprobado por el Juez de Menores. La persona sometida a la medida también queda obligada a mantener con dicho profesional las entrevistas establecidas en el programa y a cumplir, en su caso, las reglas de conducta impuestas por el Juez, que podrán ser alguna o algunas de las siguientes: $1^{a}$. Obligación de asistir con regularidad al centro docente correspondiente, si el menor está en edad de escolarización obligatoria, y acreditar ante el Juez dicha asistencia regular o justificar en su caso las ausencias, cuantas veces fuere requerido para ello. $2^{\mathrm{a}}$. Obligación de someterse a programas de tipo formativo, cultural, educativo, profesional, laboral, de educación sexual, de educación vial $\mathrm{u}$ otros similares. $3^{\mathrm{a}}$. Prohibición de acudir a determinados lugares, establecimientos o espectáculos. $4^{\text {a }}$. Prohibición de ausentarse del lugar de residencia sin autorización judicial previa. $5^{\mathrm{a}}$. Obligación de residir en un lugar determinado. $6^{\text {a }}$. Obligación de comparecer personalmente ante el Juzgado de Menores o profesional que se designe, para informar de las actividades realizadas y justificarlas. $7^{\mathrm{a}}$. Cualesquiera otras obligaciones que el Juez, de oficio o a instancia del Ministerio Fiscal, estime convenientes para la reinserción social del sentenciado, siempre que no atenten contra su dignidad como persona. Si alguna de estas obligaciones implicase la imposibilidad del menor de continuar conviviendo con sus padres, tutores o guardadores, el Ministerio Fiscal deberá remitir testimonio de los particulares a la entidad pública de protección del menor, y dicha entidad deberá promover las medidas de protección adecuadas a las circunstancias de aquél, conforme a lo dispuesto en la LO 1/1996". 
sentencia el tiempo de la misma, posponiendo su concreción a la fase de ejecución de sentencia, al igual que debe permitirse al Juez el levantamiento de las reglas de conducta de acuerdo con la evolución del programa al que esté sometido el menor ${ }^{790}$.

Debido a la versatilidad de la medida y la referencias ya comentadas de la Exposición de Motivos de la LORPM, es por lo que la libertad vigilada aparece en el texto de la Ley como medida principal que se impone al menor por sentencia, derivada de la comisión de un hecho delictivo, según lo previsto en el artículo 7.1.h); o también puede venir impuesta como un segundo tramo de la medida de internamiento (ex art. 7.2 de LORPM), que operaría tras haber cumplido aquélla satisfactoriamente y existiera pronóstico favorable para el menor; aparece también como medida cautelar ${ }^{791}$, prevista en el art. 28.1 de la ley792; y finalmente, aparece en el art. 40.1 c) de la LORPM como modalidad en la ejecución del fallo ${ }^{793}$. No obstante, hay que tener en cuenta, que para su aplicación hay que acudir al reglamento que desarrolla la LORPM, aprobado por RD 1774/2004, en concreto en el art. 18, donde se contempla la regulación para la individualización del programa de ejecución de la medida794/795.

790 RODRÍGUEZ LÓPEZ, P., Ley orgánica de Responsabilidad Penal de los Menores. Especial análisis de la reparación del daño. Madrid: Dijusa. 2005, p. 91.

791 CEZÓN GONZÁLEZ, C., La nueva Ley Orgánica..., cit. p. 56.

792 MONTERO HERNÁNDEZ, T., La justicia juvenil en España. Comentarios y reflexiones. Madrid: La Ley. 2009, pp. 304 y 305.

793 En este sentido, LÓPEZ LÓPEZ, A.M., La Ley Penal del Menor..., cit. pp. 74 y 75, para este autor "en cualquiera de sus formas siempre cumplirá una doble funcionalidad, sancionadora y asistencial".

${ }^{794}$ DOLZ LAGO, M.J., Comentarios a la legislación penal de Menores. Valencia: Tirant lo Blanch. 2007, pp. 113 a 116.

795 El citado precepto del reglamento reza del siguiente tenor: “art. 18. Libertad vigilada. 1. Una vez designado el profesional encargado de la ejecución de la medida y notificada la designación al juzgado de menores, se entrevistará con el menor al efecto de elaborar el programa individualizado de ejecución de la medida. 2. En el programa individualizado de ejecución de la medida, el profesional expondrá la situación general detectada, los aspectos concretos referentes a los ámbitos personal, familiar, social, educativo, formativo o laboral en los que se considera necesario incidir, así como las pautas socioeducativas que el menor deberá seguir para superar los factores que determinaron la infracción cometida. También propondrá la frecuencia mínima de las entrevistas con el menor, que posibiliten el seguimiento y el control de la medida, sin perjuicio de otras que puedan mantener el profesional y el menor en el curso de la ejecución, cuando el primero las considere necesarias. 3. Si con la medida se hubiera impuesto al menor alguna regla de conducta que requiera para su cumplimiento un programa o recurso específico, este se elaborará o designará por la entidad pública y se adjuntará al programa individualizado de ejecución de la medida. 4. Lo dispuesto en este artículo será también de aplicación para la ejecución del período de libertad vigilada previsto en los artículos 7.2, 9.5, 40.2.c y apartado 2.c de la disposición adicional cuarta de la Ley Orgánica 5/2000, de 12 de enero, reguladora de la responsabilidad penal de los menores". Sobre la referencia a la Disposición Final Cuarta de la LORPM, hemos de manifestar que dicha disposición fue derogada por LO 8/2006, por la que se modifica la LO 4/2000 LORPM, por lo que la remisión que efectúa el reglamento ha quedado vacía de contenido. 
La libertad vigilada presenta, pues, un contenido que se estructura a partir de la combinación de tres actividades distintas: la vigilancia a cargo de personal especializado, la programación de actividades socio-educativas, y por último, cuando el Juez lo considere necesario, puede completar la medida con la imposición de las obligaciones o reglas de conducta a las que refiere, a título de ejemplo, el art. 7.1 h) ${ }^{796}$. Pretende ayudar al menor a superar los factores que causaron la comisión de los hechos delictivos por los que se le impone la sanción. No osbtante, la doctrina viene manifestando que para que la libertad vigilada sea eficaz, requiere la dotación de personal suficiente y especializado, por cuanto que la medida supone una intervención prolongada en el tiempo sobre el menor y, sin esos medios personales, la medida podría quedar vacía de contenido con la consecuente volatilización de la sanción impuesta al menor ${ }^{797}$.

En cuanto a sus distintas modalidades, la primera es como medida principal. Se trata de una medida que puede imponerse por cualquier delito o falta cometido por el menor, y podrá durar hasta seis meses para las faltas (art. 9.1 LORPM), y hasta dos años para los delitos (art. 9.3 LORPM), salvo supuesto de complemento de la medida de internamiento a la que después referiré, y se deberá abonar el período que hubiere cumplido si la libertad vigilada se acordó como medida cautelar. La segunda modalidad es como un segundo tramo de la medida de internamiento ${ }^{798}$, que necesariamente deberá llevar aparejado un período de libertad vigilada, y la duración en ambos períodos no podrá sobrepasar el límite establecido en los arts. 9 y 10 LORPM. Ello deriva de la previsión contenida en el art. 7.2 LORPM799, que dispone que las medidas de internamiento constarán de dos períodos, un primer período que se llevará a cabo en el centro correspondiente y el segundo en régimen de libertad vigilada, en la modalidad que elija por el Juez. Contiene también el precepto una referencia a que el equipo técnico deberá informar respecto del contenido de los dos períodos para que el Juez pueda expresar en la sentencia la duración que corresponde a cada uno de ellos. Sobre esto, la

\footnotetext{
796 MAPELLI CAFFARENA, B. / GONZÁLEZ CANO, M.I. / AGUADO CORREA, T., Comentarios a la Ley Orgánica 5/2000 Reguladora de la Responsabilidad Penal de los Menores. Sevilla: Junta de Andalucía. Consejería de Justicia y Administración Pública. Instituto Andaluz de Administración Pública. 2002, p. 87.

797 ACALE SÁNCHEZ, M., “Medición de la respuesta punitiva...”, cit. p. 168.

798 VARGAS CABRERA, B., en CONDE-PUMPIDO FERREIRO, C., Ley de la responsabilidad..., cit. p. 164.

799 Art. 7.2. "Las medidas de internamiento constarán de dos períodos: el primero se llevará a cabo en el centro correspondiente, conforme a la descripción efectuada en el apartado anterior de este artículo, el segundo se llevará a cabo en régimen de libertad vigilada, en la modalidad elegida por el Juez. La duración total no excederá del tiempo que se expresa en los artículos 9 y 10. El equipo técnico deberá informar respecto del contenido de ambos períodos, y el Juez expresará la duración de cada uno en la sentencia".
} 
doctrina resalta que, en esta modalidad, la libertad vigilada es una fase de cumplimiento de la medida de internamiento que se cumple, por ende, en medio abierto, de ahí que se aprecie una similitud más que evidente entre la libertad vigilada en menores y la libertad condicional en adultos, ya que la primera implica - al igual que la segunda en su ámbito de aplicación- la preparación del menor para que no vuelva a delinquir cuando acceda a la libertad plena ${ }^{800}$.

Los límites temporales - previstos en el art. 10 LORPM—801 refieren a los supuestos en que el menor haya cometido delitos de homicidio y asesinato (137 y $138 \mathrm{CP}$ ), agresiones sexuales (179 y $180 \mathrm{CP}$ ) o terrorismo (571 a $580 \mathrm{CP}$ ), o cualquier otro delito previsto en el $\mathrm{CP}$ con pena superior a quince años. En estos casos, si el menor al tiempo de cometer los hechos tuviere catorce o quince años de edad, se le impondrá una medida de internamiento en régimen cerrado de uno a cinco años que podrá ser complementada por libertad vigilada de hasta tres años (art. 10.2 a) LORPM). Y si el menor tuviere dieciséis o diecisiete años de edad, se le impondrá una medida de internamiento en régimen cerrado de uno a ocho años de duración, complementada en su caso por libertad vigilada con asistencia educativa de hasta cinco años (art. 10.2 b) LORPM) ${ }^{802}$. Como explican algunos autores, su aplicación no es más que un complemento de la medida de internamiento que la convierte en una especie de híbrido entre una medida autónoma y un segundo período de la medida de internamiento, con lo cual, "también puede verse como un híbrido entre

\footnotetext{
800 ACALE SÁNCHEZ, M., “Medición de la respuesta punitiva...”, cit. pp. 168 y 169.

801 Art. 10.2."Cuando el hecho sea constitutivo de alguno de los delitos tipificados en los artículos 138, 139, 179, 180 y 571 a 580 del Código Penal, o de cualquier otro delito que tenga señalada en dicho Código o en las leyes penales especiales pena de prisión igual o superior a quince años, el Juez deberá imponer las medidas siguientes: a) si al tiempo de cometer los hechos el menor tuviere catorce o quince años de edad, una medida de internamiento en régimen cerrado de uno a cinco años de duración, complementada en su caso por otra medida de libertad vigilada de hasta tres años. b) si al tiempo de cometer los hechos el menor tuviere dieciséis o diecisiete años de edad, una medida de internamiento en régimen cerrado de uno a ocho años de duración, complementada en su caso por otra de libertad vigilada con asistencia educativa de hasta cinco años. En este supuesto sólo podrá hacerse uso de las facultades de modificación, suspensión o sustitución de la medida impuesta a las que se refieren los artículos 13, 40 y 51.1 de esta Ley Orgánica, cuando haya transcurrido al menos, la mitad de la duración de la medida de internamiento impuesta. [...] 4. Las medidas de libertad vigilada previstas en este artículo deberán ser ratificadas mediante auto motivado, previa audiencia del Ministerio Fiscal, del letrado del menor y del representante de la entidad pública de protección o reforma de menores al finalizar el internamiento, y se llevará a cabo por las instituciones públicas encargadas del cumplimiento de las penas".
}

802 MAPELLI CAFFARENA, B. / GONZÁLEZ CANO, M.I. / AGUADO CORREA, T., Comentarios a la Ley Orgánica 5/2000..., cit. p. 86. 
la libertad vigilada en sentido estricto y la libertad asistida, cuyas virtudes superan en mucho a las de la libertad vigilada" 803 .

Un aspecto que conviene resaltar es el referente a la previsión del art. 10.4 LORPM $^{804}$ que dispone que el control de la libertad vigilada se hará por las instituciones públicas encargadas del cumplimiento de penas, cuando debería referir a "entidades públicas o profesionales encargados del seguimiento", lo que indica que el legislador opta por endurecer el trato a los menores infractores dejando de lado la consideración de que no se están aplicando penas sino medidas educativas. Por otra parte, cuando el menor pasa a cumplir su medida de internamiento en un centro penitenciario según dispone el art. 14.4 LORPM, la libertad vigilada posterior será controlada por los servicios postpenitenciarios que carecen de la debida preparación para ejecutar dicha medida, propiciando que la libertad vigilada se cumpla como una mera libertad condicional, no como una libertad vigilada en su verdadera concepción según la previsión normativa de la que deriva ${ }^{805}$.

La tercera modalidad es como medida cautelar, prevista en el art. 28 LORPM. Se trata de una situación nacida de una resolución judicial provisional y de duración limitada, por la que se restringe el derecho a la libertad del menor imputado por un delito, ante la existencia de indicios racionales sobre los que cabe presumir que el mantenimiento del menor en libertad plena, podría dificultar el desarrollo normal del proceso ${ }^{806}$. Para esta tercera modalidad, conviene que nos detengamos brevemente para analizar sus presupuestos procesales así como el procedimiento para su adopción, sin olvidar que las principales características de las medidas cautelares son la instrumentalidad, la

\footnotetext{
803 ORTS BERENGUER, E. / GONZÁLEZ CUSSAC, J.L., Compendio..., cit. pp. 365 y 366.
}

804 A cuyo tenor: "art. 104. Las medidas de libertad vigilada previstas en este artículo deberán ser ratificadas mediante auto motivado, previa audiencia del Ministerio Fiscal, del letrado del menor y del representante de la entidad pública de protección o reforma de menores al finalizar el internamiento, y se llevará a cabo por las instituciones públicas encargadas del cumplimiento de las penas".

805 ACALE SÁNCHEZ, M., "Medición de la respuesta punitiva...", cit. pp. 170 a 172. Esta autora explica que en estos supuestos el legislador se aparta del objetivo educativo y de salvaguardar el interés del menor, para centrarse en el aspecto sancionador pasando a cumplir finalidades de retribución y prevención general, olvidando que estas finalidades no encuentran cómodo anclaje en la LORPM.

806 DÍAZ MARTÍNEZ, M., La Instrucción en el Proceso Penal de Menores. Madrid: Colex. 2003, p. 147. 
jurisdiccionalidad, la provisionalidad, la homogeneidad ${ }^{807}$, la oficialidad, la contradicción y la revocabilidad 808 .

1. Presupuestos procesales: En la adopción de medidas cautelares en el proceso de menores, deben concurrir los presupuestos típicos de toda medida cautelar: fumus boni iuris y periculum in mora, que se desprenden de la pprevisión contenida en el art. 28.1 LORPM ${ }^{809} .1^{\circ}$. Fumus boni iuris, o apariencia de buen derecho, consistente en un juicio de imputación o sospecha fundada de que el menor ha participado en la comisión de un delito $^{810}$. Para la adopción de la medida cautelar de libertad vigilada es suficiente una sospecha motivada y objetiva sobre la autoría del menor en el hecho que se le imputa. $2^{\circ}$. Periculum in mora, que se traduce en el riesgo de fuga del presunto infractor ${ }^{811}$, que deberá ser igualmente fundado y necesariamente deberá ir conjugado con el anterior presupuesto (fumus iuris) $^{812}$. Para la adopción de la libertad vigilada en fase de instrucción no es necesaria la concurrencia de otros presupuestos extracautelares, como la repercusión y alarma social, o las circunstancias personales del menor, toda vez que el art. 28.2 LORPM solo los exige para la medida de internamiento.

2. Procedimiento: La medida cautelar se deberá adoptar por el procedimiento establecido en el art. 28.1, párrafo $3^{\circ}$ LORPM, que dispone que deberá adoptarse por el Juez (no por la Fiscalía de Menores ${ }^{813}$ ) y deberá darse audiencia a la defensa del menor y

\footnotetext{
807 MORA ALARCÓN, J.A., Derecho penal y procesal de menores. Valencia: Tirant lo Blanch. 2002, p. 137.

808 DE URBANO CASTRILLO, E., “Medidas cautelares”. En DE URBANO CASTRILLO, E. / DE LA ROSA CORTINA, J.M., La responsabilidad penal de los menores. Adaptada a la LO 8/2006, de 4 de diciembre. Navarra: Thomson Aranzadi. 2007, pp. 169 a 170.
}

809 “Artículo 28. Reglas generales. 1. El Ministerio Fiscal, de oficio o a instancia de quien haya ejercitado la acción penal, cuando existan indicios racionales de la comisión de un delito y el riesgo de eludir u obstruir la acción de la justicia por parte del menor o de atentar contra los bienes jurídicos de la víctima, podrá solicitar del Juez de Menores, en cualquier momento, la adopción de medidas cautelares para la custodia y defensa del menor expedientado o para la debida protección de la víctima. / Dichas medidas podrán consistir en internamiento en centro en el régimen adecuado, libertad vigilada, prohibición de aproximarse o comunicarse con la víctima o con aquellos de sus familiares u otras personas que determine el Juez, o convivencia con otra persona, familia o grupo educativo. / El Juez, oído el letrado del menor, así como el equipo técnico y la representación de la entidad pública de protección o reforma de menores, que informarán especialmente sobre la naturaleza de la medida cautelar, resolverá sobre lo propuesto tomando en especial consideración el interés del menor. La medida cautelar adoptada podrá mantenerse hasta que recaiga sentencia firme".

810 DE URBANO CASTRILLO, E., “Medidas cautelares...”, cit. pp. 170 y 171.

811 MORA ALARCÓN, J.A., Derecho penal y procesal de menores..., cit. p. 137.

812 DÍAZ MARTÍNEZ, M., La Instrucción en el Proceso Penal de Menores..., cit. pp. 148 y 149.

813 ARROM LOSCOS, R., El Proceso Penal con Implicación de Menores. (Ley Orgánica 5/2000 sobre Responsabilidad Penal de los Menores). Assaigs Jurídics 8. Palma de Mallorca: Universitat de les Illes Balears. 2002, p. 61. Este 
al equipo técnico. Se configura como una especie de fase de informe sobre la naturaleza de la medida que en su caso pudiere adoptar el Juez, quien resolverá basándose en dichos informes y teniendo en cuenta el interés del menor. Frente al Auto que resuelva sobre la adopción de la medida cautelar, solo cabrá recurso de apelación en el plazo de cinco días ante la Audiencia Provincial, a un solo efecto: el devolutivo, careciendo, pues, de efectos suspensivos (art. 41.3 LORPM) 814 .

En cuanto a su duración, tal y como expresa el art. 28.1, párrafo $3^{\circ}$ LORPM, in fine, la medida cautelar adoptada podrá mantenerse hasta que recaiga sentencia firme y, como expresa DÍAZ MARTíNEZ, "en relación con las medidas de libertad vigilada o convivencia con otra persona, familia o grupo, de ser estimadas, no tienen plazo límite de duración. La idea protectora que parece animar su adopción —custodia y defensa del menor- justifica la referencia más flexible a otros momentos procesales que actúan como límite, cuales son la celebración de audiencia o la substanciación de los eventuales recursos (art. 28.1)"815. En la Memoria de la Fiscalía General del Estado de 2010816, se pone de manifiesto que la Fiscalía de Algeciras ha venido aplicando en 2009 el criterio de que, en casos de homicidio y asesinato, se impone como medida cautelar la libertad vigilada (hasta que recaiga sentencia) una vez hayan trascurrido los nueve meses de internamiento cerrado. Y en la memoria de la Fiscalía de 2012, se menciona que el Auto núm. 432/2011, de 23 de junio, de la AP de Tenerife (Secc. $5^{a}$ ), estimó el recurso de apelación interpuesto por la Fiscalía de menores contra el Auto del juzgado que rechazó la adopción de la medida cautelar de tratamiento ambulatorio y vino a considerar que, aunque el art. 28 LORPM no hace expresa referencia a dicho tratamiento, el mismo se puede acordar como medida cautelar, incardinándolo como regla de conducta dentro de esta modalidad de libertad vigilada ${ }^{817}$.

autor expresa lo siguiente: “consecuencia de atribuir la instrucción a un órgano no jurisdiccional lo es el que dicho órgano no pueda acordar aquellas diligencias que tengan la consideración de actos jurisdiccionales, tal es el caso de la adopción de medidas cautelares restrictivas de derechos fundamentales".

814 DÍAZ MARTíNEZ, M., La Instrucción en el Proceso Penal de Menores..., cit. p. 154.

815 Ibidem, p. 155.

816 Puede consultarse en la siguiente dirección de la página web oficial del Ministerio Fiscal: [http://www.fiscal.es/cs/Satellite? $c=$ PageEcid=1247140094968Elanguage=esEpagename $=$ PFiscal/Page/FGE_contenido FinalEvest=1247140094968]; (consultado el 21/5/2014).

817 Vid. Memoria de la Fiscalía General del Estado de 2012. Vol. I, Cap. III, ap. 7, pág. 964. 
Por último, el art. 28.5 LORPM tiene previsto el abono de la medida cautelar cumplida818. El abono se produce tanto en la causa en la que se adoptó la medida como en causas distintas siempre que los hechos sean anteriores a la adopción de las medidas, admitiendo incluso la compensación de la medida cautelar sufrida cuando en el proceso en el que se ordenó, el menor hubiese salido absuelto o condenado a una medida de menor duración que la medida cautelar aplicada. Lo que no es admisible es el abono a hechos posteriores a la adopción de la medida cautelar, pues "podría equivaler a una compensación en "pena futura" como si de una invitación a delinquir se tratara"819.

La cuarta es como modalidad en la ejecución del fallo, que deriva de las reglas especiales contenidas en el art. 47 LORPM (que fue modificado mediante LO 8/2006, de 4 de diciembre) para la refundición de las medidas impuestas. En el caso de la libertad vigilada, el art. 47.5 d) dispone que en los casos en que deba imponerse la libertad vigilada, previstos en el art. 10 LORPM (vid supra), se ejecutarán una vez haya finalizado el periodo de internamiento previsto en dicho precepto ${ }^{820}$.

Otra modalidad es la relativa a la suspensión de la ejecución del fallo ${ }^{821}$, prevista en el art. 40.2 c) LORPM $^{822}$, del que se desprende que la libertad vigilada se configura como un mecanismo que dota de contenido a la suspensión condicional del fallo, quedando el menor sujeto al régimen de libertad vigilada que se le imponga junto con las condiciones previstas en las letras a) y b) del mismo precepto, esto es: no ser condenado

818 “Art. 28.5. El tiempo de cumplimiento de las medidas cautelares se abonará en su integridad para el cumplimiento de las medidas que se puedan imponer en la misma causa o, en su defecto, en otras causas que hayan tenido por objeto hechos anteriores a la adopción de aquéllas. El Juez, a propuesta del Ministerio Fiscal y oídos el letrado del menor y el equipo técnico que informó la medida cautelar, ordenará que se tenga por ejecutada la medida impuesta en aquella parte que estime razonablemente compensada por la medida cautelar".

819 DÍAZ MARTÍNEZ, M. / LUACES GUTIÉRREZ, A.I., “El proceso Penal de Menores (I)”, En VÁZQUEZ GONZÁlEZ, C. /SERRANO TÁRRAGA, M.D., (Editores), Derecho Penal Juvenil. Madrid: Dykinson. 2005, p. 284.

820 RODRÍGUEZ GÓMEZ, C., en GÓMEZ RIVERO, M., C., Comentarios a la Ley Penal del Menor..., cit. pp. 364 a 369.

821 VARGAS CABRERA, B., en CONDE-PUMPIDO FERREIRO, C., Ley de la responsabilidad..., cit. p. 165.

822 A cuyo tenor: “art. 40. Suspensión de la ejecución del fallo. 2. Las condiciones a las que estará sometida la suspensión de la ejecución del fallo contenido en la sentencia dictada por el Juez de Menores serán las siguientes: c) Además, el Juez puede establecer la aplicación de un régimen de libertad vigilada durante el plazo de suspensión o la obligación de realizar una actividad socio-educativa, recomendada por el equipo técnico o la entidad pública de protección o reforma de menores en el precedente trámite de audiencia, incluso con compromiso de participación de los padres, tutores o guardadores del menor, expresando la naturaleza y el plazo en que aquella actividad deberá llevarse a cabo". 
en sentencia firme por delito cometido durante el tiempo que dure la suspensión -si ha alcanzado la mayoría de edad- o no serle aplicada una nueva medida mediante sentencia firme en procedimiento de menores durante el tiempo que dure la suspensión y que el menor asuma el compromiso de mostrar una actitud y disposición de reintegrarse a la sociedad, no incurriendo principalmente en la comisión de nuevas infracciones ni en el incumplimiento de las pautas de comportamiento adicionales que le hayan podido ser impuestas $^{823}$. Esta modalidad es, para algunos autores, de enorme eficacia, pues los menores suelen percibir que el incumplimiento de la libertad vigilada dará lugar a la revocación de la suspensión de la ejecución del fallo que, a su vez, implica el ingreso en un centro de internamiento ${ }^{824}$.

En cuanto a la duración de la libertad vigilada y delitos a los que se aplica, la regla general es que todas las medidas pueden tener una duración máxima de dos años (art. 9.3 LORPM), las prestaciones en beneficio de la comunidad cien horas, y la permanencia en fines de semana ocho fines de semana como máximo. Ahora bien, la duración de la libertad vigilada se presenta como una de las excepciones a dicha regla y se clasifica mediante varios criterios: $1^{\circ}$ ) Por la levedad de los hechos (art. 9.1 LORPM), que se traduce en que si los hechos son reputados falta, la libertad vigilada no podrá exceder de seis meses ${ }^{825} .2^{\circ}$ ) Por la extrema gravedad de los hechos, entendiendo que concurre cuando se trata de delitos cometidos con violencia o intimidación en las personas o generando grave riesgo para la vida e integridad física de las mismas y delitos cometidos en grupo o que el menor perteneciere o actuare al servicio de bandas, organizaciones o asociaciones. En estos casos, la medida de libertad vigilada podrá durar cinco años por encima del tiempo cumplido en internamiento, que será de entre uno y seis años, siempre que se trate de menores que tengan dieciséis y diecisiete años. $3^{\circ}$ ) Por el tipo de delito cometido, esto es, homicidio, asesinato, agresión sexual, terrorismo y cualquier otro con pena de prisión en abstracto de quince años o más. En estos casos se impondrá la medida de internamiento de entre uno y cinco años y hasta tres años más de libertad vigilada cuando se trate de menores de catorce y quince años de edad; y entre uno y ocho años de internamiento y hasta cinco años de libertad vigilada con asistencia educativa cuando los menores tengan dieciséis y diecisiete años de edad. $4^{\circ}$. Por la concurrencia de varios

\footnotetext{
823 ACALE SÁNCHEZ, M., “Medición de la respuesta punitiva...”, cit. p. 169.

824 DE LA ROSA CORTINA, J.M., “Las medidas y sus reglas de aplicación...”, cit. p. 66.

825 CERVELLÓ DONDERIS, V., La medida de internamiento..., cit. p. 38.
} 
delitos, cuando alguno de ellos es de los previstos en el art. 10.2 LORPM, esto es, delitos graves y menos graves con violencia o intimidación. En estos casos se eleva de seis a diez años el internamiento cerrado, seguido de sus correspondientes períodos de libertad vigilada, que podrá durar hasta tres años si se trata de menores de catorce y quince años, y hasta cinco para el caso de menores de dieciséis y diecisiete años de edad ${ }^{826}$.

En cuanto a la ejecución de la libertad vigilada, las reglas generales para la ejecución de las medidas están en los Capítulos primero y segundo, del Título VII, LORPM, y en la Sección Primera, del Capítulo III, RM. Para proceder a la ejecución hay que remitir a la entidad pública la ejecutoria y el testimonio de particulares del Juzgado de menores, así como los informes técnicos que consten en la causa y la identificación del Letrado del menor ${ }^{827}$. La ejecución de las medidas en el proceso de menores está informada por el principio de legalidad, que se desprende del art. 43 LORPM ${ }^{828}$ y está dotada de la garantía de jurisdiccionalidad (art. 44 LORPM), en el sentido de que recae sobre el Juez de Menores el control de la ejecución ${ }^{829}$, y todas la resoluciones que se dicten por incidencias en la misma, revestirán forma de Auto y podrán ser revisables por el Juez mediante el oportuno recurso de reforma en el plazo de tres días. Contra el Auto que resuelva el recurso de reforma cabrá interponer recurso de apelación en el plazo cinco días ante la Audiencia Provincial ${ }^{830 .}$

La liquidación de la medida se encuentra en el art. 46 LORPM, y para poder ejecutarla es necesario que la Sentencia sea firme y que se haya aprobado el oportuno programa de ejecución, que se elabora por las instituciones públicas según el art. 10 RM, y se aprueba por el Juez de Menores competente para la ejecución, tal y como se desprende del art. 42.2 c) LORPM. Una vez aprobado el programa, el Secretario Judicial del Juzgado de Menores deberá dar cuenta y proceder a la liquidación de la medida, señalando fecha

\footnotetext{
826 Ibidem, p. 39.

827 SERRANO TÁRRAGA, M. D., “Medidas susceptibles de imposición a los menores”. En VÁZQUEZ GONZÁlEZ, C. /SERRANO TÁRRAGA, M.D., (Editores), Derecho Penal Juvenil. Madrid: Dykinson. 2005, p. 374.

828 Art. 43. "Principio de legalidad. 1. No podrá ejecutarse ninguna de las medidas establecidas en esta Ley sino en virtud de sentencia firme dictada de acuerdo con el procedimiento regulado en la misma. 2. Tampoco podrán ejecutarse dichas medidas en otra forma que la prescrita en la Ley y en reglamentos que al desarrollan".

829 LLORCA GARCÍA, P., “La ejecución de las medidas”. En GÓMEZ RIVERO, M., C., Comentarios a la Ley Penal del Menor (Conforme a las reformas introducidas por la LO 8/2006). Madrid: Iustel. 2007, p. 358.

830 ARROM LOSCOS, R., El Proceso Penal con Implicación de Menores..., cit. p. 94.
} 
de inicio y de conclusión de la misma, y abonando el período que en su caso haya podido cumplir el menor a través de medidas cautelares.

En el caso de la libertad vigilada, solo procederá su abono si le fue impuesta también como medida cautelar en fase de instrucción. Posteriormente se abrirá el denominado expediente personal, regulado en los arts. 46.1 y 48 LORPM, en el que deberán incluirse los informes relativos al menor, la resoluciones judiciales que lo afecten y se irán incluyendo paulatinamente todas las resoluciones que puedan dictarse durante la ejecución de la medida. Finalmente, se dará traslado de la liquidación y del testimonio de particulares e informes técnicos a la entidad pública encargada del cumplimiento de la medida, y se notificará al Ministerio Fiscal y al Letrado del menor el inicio de la ejecución ${ }^{831}$. La libertad vigilada del art. 10 LORPM, se ejecutará una vez finalizado el internamiento cerrado al que refiere dicho precepto ${ }^{832}$.

Sobre el quebrantamiento de la libertad vigilada, el art. 50 LORPM contempla los supuestos de quebrantamiento de las medidas impuestas al menor y, en concreto, el apartado 2 del precepto es el que regula las reglas para el caso de que la medida quebrantada sea no privativa de libertad, en cuyo caso el Juez de Menores podrá sustituir la medida por otra de la misma naturaleza, si el Ministerio Fiscal lo solicita. La segunda parte del precepto regula un supuesto excepcional de sustitución de la medida por otra de internamiento en centro semiabierto por el tiempo que le reste por cumplir, si lo solicita el Ministerio Fiscal, y siempre previa audiencia del Letrado del menor y del equipo técnico.

Además, el propio art. 50.3 LORPM prevé que en caso de quebrantamiento, el Juez de Menores deberá deducir testimonio y remitirlo a la Fiscalía de menores a efectos de que valoren la posibilidad de incoar diligencias si la conducta mereciera reproche sancionador 833 , dentro del amplio margen del que dispone la Fiscalía en virtud del principio de oportunidad, que a diferencia del proceso de adultos donde impera el principio de necesidad, pueden no incoar ni siquiera diligencias por no revestir excesiva gravedad el quebrantamiento, o por no ser necesario para el primordial interés del menor.

831 LLORCA GARCÍA, P., “La ejecución de las medidas...”, cit. p. 362.

832 Ibidem, p. 368.

833 ORNOSA FERNÁNDEZ, M. R., Derecho Penal de Menores..., cit. p. 477 a 481. 
Por otra parte, conviene hacer algunas consideraciones sobre la aplicación de la LORPM desde su entrada en vigor, puesto que la medida que en más ocasiones se ha impuesto a los menores infractores es la libertad vigilada, así lo ponen de manifiesto varios estudios realizados 834 , de los que se desprende que la libertad vigilada supone un $49,03 \%$ del total de las medidas que se impusieron solo en el primer año de vigencia de la LORPM por los Juzgados de Menores $835 / 836$.

Especial detenimiento merece el incidente de transformación de la medida de libertad vigilada en régimen semiabierto, previsto en el art. 50.2 LORPM ${ }^{837}$ como una consecuencia del quebrantamiento de la medida. Según las memorias de la Fiscalía General del Estado de 2010, la transformación de libertades vigiladas en internamientos en centro semiabierto supuso un incremento considerable durante el año 2010, debido a que, por un lado, es la medida que más se impone a los menores infractores y, por otro, es la medida que más se quebranta, lo que podría deberse al elevado número de menores que debe atender cada técnico y al dilatado período de tiempo que transcurre entre la sentencia y la primera cita con el mismo. En ese orden de cosas, la Fiscalía de Valencia, cuando solicita la imposición de la medida de libertad vigilada en el escrito de alegaciones, añade la expresión: "el menor será advertido del contenido del art. 50.2 LORPM", precisamente previendo la rápida transformación de la libertad vigilada en

834 GARCÍA PÉREZ, O., (Dir.) / DÍEZ RIPOLLÉS, J.L. / PÉREZ JIMÉNEZ, F. / GARCÍA RUIZ, S., La delincuencia juvenil ante los Juzgados de Menores. Valencia: Tirant lo Blanch. 2008, pp. 173 a 191.

835 En la Provincia de Valencia, en el año 2004, se impusieron 444 medidas de libertad vigilada, siendo ésta la medida de mayor aplicación en dicha circunscripción judicial, pero no sólo en ese año, sino que también en los años precedentes desde la entrada en vigor de la ley: en el año 2001 se impusieron 320 medidas de libertad vigilada; en 2002 la imposición de esta medida experimentó un ligero descenso hasta la cifra de 271; y en 2003 fueron 304 las que se impusieron. Cifras que van en aumento, siendo a día de hoy la medida que preferentemente se impone según el criterio de la Fiscalía de Menores y de los Juzgados de Menores de Valencia. En este sentido vid. GUISASOLA LERMA, C., "La delincuencia de menores en la provincia de Valencia: análisis de las estadísticas oficiales". En GONZÁLEZ CUSSAC, J.L. / CUERDA ARNAU, M.L., (Coords.), Estudios sobre la responsabilidad penal del menor. Col lecció “Estudis jurídics" núm. 9. Castellón: Universitat Jaume I. 2006, pp. 367 y 368.

836 Otra cuestión sería la relativa a su efectividad o a si esta medida cumple sus fines de reeducación. Lo cierto es que hay estudios que revelan que los menores a los que se les impone una medida de libertad vigilada presentan un alto índice de reincidencia, aunque no es la medida que presenta un mayor porcentaje de reincidentes, ya que ese puesto lo ocupa la medida de internamiento con un $62,8 \%$ de reincidentes, frente al 31,9\% cuando se impone la libertad vigilada. Vid. GARCÍA PÉREZ, O., (Dir.), La delincuencia juvenil..., cit. p. 181, vid., el gráfico que contempla los porcentajes de reincidencia en cada una de las medidas que se imponen a menores infractores.

837 “Art. 50. 2. Si la medida quebrantada no fuere privativa de libertad, el Ministerio Fiscal podrá instar del Juez de Menores la sustitución de aquélla por otra de la misma naturaleza. Excepcionalmente, y a propuesta del Ministerio Fiscal, oídos el letrado y el representante legal del menor, así como el equipo técnico, el Juez de Menores podrá sustituir la medida por otra de internamiento en centro semiabierto, por el tiempo que reste para su cumplimiento". 
internamiento en régimen abierto para el previsible caso de quebrantamiento. $\mathrm{Y}$ las Fiscalías de Sevilla y Lleida han optado por solicitar, si el tipo delictivo lo permite, una medida de internamiento en centro semiabierto que se deja en suspenso y su cumplimiento dependerá de que el menor cumpla satisfactoriamente una medida de libertad vigilada durante el período de ejecución, conforme al art. 40.2 c) LORPM, evitando así problemas que pudieren surgir posteriormente, ya que, en caso de que el menor incumpla la libertad vigilada, se alza la suspensión y comienza a cumplirse el internamiento en régimen abierto. Se trata de un criterio para supuestos en que previsiblemente el cumplimiento de la libertad vigilada no será satisfactorio, por lo que, los Juzgados de Menores de los partidos judiciales de Sevilla y Lleida, están imponiendo esta modalidad de medidas, accediendo a lo que solicita la Fiscalía838.

La memoria de la Fiscalía General del Estado de 2013, afirma que la libertad vigilada continúa siendo la medida más veces utilizada en toda España y narra un aumento paulatino en su aplicación, ya que en 2007 se utilizó en 8.218 ocasiones, en 2008 la cifra es de 9.382, en 2009 se utilizó en 10.346 ocasiones, en 2010, la cifra fue muy parecida, 10.527, en 2011 la libertad vigilada se utilizó en 10.920 ocasiones y en 2012 se aplicó 10.289 veces, al igual que en 2013, cuya cifra es prácticamente idéntica a la del año anterior839. En la Comunidad Valenciana, en 2012 se impusieron 1.017 medidas de libertad vigilada, de las cuales 304 fueron en Alicante, 142 en Castellón y 571 en Valencia ${ }^{840}$. Y en 2013 se impusieron 271 medidas de libertad vigilada en Alicante ${ }^{841}$, en Valencia 551842, y en Castellón $161^{843}$.

Según los datos del Instituto Nacional de Estadística, en 2009 se impusieron en total en toda España 4.657 setencias con condenas a medidas de libertad vigilada, de las que 754 se impusieron a menores con 14 años de edad, 1.128 a menores con 15 años, 1.368 a menores con 16 años, y 1.407 a menores con 17 años de edad. En 2012, 661 se impusieron

\footnotetext{
838 Vid. Memoria de la Fiscalía General del Estado de 2010. Vol. I, cap. III, ap. G), págs. 1005 y 1006.

839 Vid. Memoria de la Fiscalía de 2013. Vol. I, cap. III, ap. 6, pág. 423.

840 Vid. Memoria de la Fiscalía de 2013. Vol. II, cap. II, ap. 3, pág. 1144.

841 Vid. Memoria de la Fiscalía de 2013. Vol. II, cap. IV, ap. 2, (gráfico). [wwww.fiscal.es].

842 Vid. Memoria de la Fiscalía de 2013. Vol. II, cap. IV, ap. 2, (gráfico). [wwww.fiscal.es].

843 Vid. Memoria de la Fiscalía de 2013. Vol. II, cap. IV, ap. 2, (gráfico). [www.fiscal.es].
} 
a menores con 14 años de edad, 912 a menores con 15 años, 1.149 a menores con 16 años, y 1.210 a menores con 17 años de edad 844 .

\section{Antecedentes en el Derecho Penal de adultos}

Ciertamente, la importancia de este estudio reside en la figura de la libertad vigilada en el ámbito del Derecho penal de adultos, cuya reciente incorporación en el CP, a través de la LO 5/2010, ha venido generando que se cuestione su validez y sobre todo el contenido de su regulación. No obstante, la libertad vigilada en España cuenta con antecedentes en varios textos punitivos aunque su énfasis comienza con la elaboración y publicación de una serie de Anteproyectos y Proyectos de reforma del CP de 1995. De todo ello me ocupo en el presente apartado.

\section{a) Primeras formulaciones en España}

La libertad vigilada aparece por primera vez en España en el CP de 1822 y desapareció con la promulgación del CP de 1870845. El CP de 1822 recogía en su art. 28 lo que se denominaba la "sujeción a la vigilancia especial de las autoridades" y su contenido venía regulado en el art. $78 \mathrm{CP}$, a cuyo tenor:

"El reo á quien se imponga la sujecion á la vigilancia especial de las autoridades, tendrá obligacion de dar cuenta de su habitacion y modo de vivir á la autoridad local, y de presentársele personalmente en los períodos que esta le prevenga; la cual podrá exigirle fianza de buena conducta cuando esta se hiciere sospechosa; y si no la diere, confinarle en un pueblo ó parte de él donde pueda trabajar, y aun arrestarle por el tiempo que crea conveniente, si quebrantare este confinamiento; pero sin escederse nunca del término señalado á la sujecion del reo bajo la vigilancia de la misma autoridad"846.

\footnotetext{
${ }^{844}$ La Fuente de la que el INE extrae la información para la estadística es el Registro Central de Sentencias de Responsabilidad Penal de los Menores.

845 CUELLO CONTRERAS, J. / MAPELLI CAFFARENA, B., Curso de Derecho penal..., cit. pp. 359 y 360.

846 MANZANARES SAMANIEGO, J.L., “La libertad vigilada...", cit. p. 2. Este autor indica que "es precisamente la autoridad local la autorizada para exigir al reo, en su caso, una "fianza de buena conducta", que aparece como pena no corporal sétima (sic) del repetido art. 28, e incluso para acordar un arresto que parece conectar -hasta cierto punto, al menos- con el que se impone como castigo en la pena corporal quinta".
} 
El CP de 1848 incluía la "sujecion á la vigilancia de la autoridad" entre las penas correccionales $^{847}$ del art. 24, y su duración oscilaba entre siete meses y tres años (art. 24 $\mathrm{CP}$ ). La aplicación de la pena debía ser comunicada al Gobierno para su conocimiento antes del comienzo de su ejecución y su contenido constaba de tres obligaciones concretas previstas en el art. $42 \mathrm{CP}$, a cuyo tenor:

"La sujecion á la vigilancia de la Autoridad produce en el penado las obligaciones siguientes:

$1^{a}$. Fijar su domicilio y dar cuenta de él a la Autoridad inmediatamente encargado de su vigilancia, no pudiendo cambiarlo sin conocimiento y permiso de la misma Autoridad dado por escrito.

$2^{a}$. Observar las reglas de inspeccion que aquella prefije.

3a. Adoptar oficio, arte, industria ó profesión, si no tuviere medios propios y conocidos de subsistencia. Siempre que un penado quede bajo la vigilancia de la Autoridad, se dará conocimiento de ello al Gobierno"848.

Esta pena correccional se convertía en acumulativa cuando se tratase de penados reincidentes por haber cometido el delito de vagancia (art. $252 \mathrm{CP}$ ), y el vigilado contraía la obligación de comunicar su lugar de residencia y de solicitar autorización judicial para cambiar de domicilio. Además, debía cumplir las obligaciones que le impusiera la autoridad, entre las que estaba, como más importante, la de tener un oficio ${ }^{849}$. La regulación de esta pena en el CP de 1848 fue reproducida de forma idéntica en el CP de 1850, sin que variase ni siquiera la numeración de los artículos, por lo que no será necesaria ninguna precisión adicional al respecto. Esta pena estuvo vigente hasta 1870, momento en el que se promulgó un nuevo $\mathrm{CP}$ y desapareció la sujeción a la vigilancia de la autoridad, únicamente se mantuvo la caución, el extrañamiento y el confinamiento 850 .

${ }^{847}$ GARCÍA RIVAS, N., “La libertad vigilada...”, cit. p. 5.

848 MANZANARES SAMANIEGO, J.L., "La libertad vigilada...", cit. pp. 2 y 3. Como señala este autor, “aunque el Código Penal de 1848 recoge la caución entre sus penas comunes a las aflictivas, correccionales y leves, prescinde de la misma en relación con la sujeción a la vigilancia de la autoridad".

849 GARCÍA RIVAS, N., “La libertad vigilada...”, cit. p. 5.

850 MANZANARES SAMANIEGO, J.L., “La libertad vigilada...”, cit. p. 3. 
El CP de 1928 reunió por primera vez en España las penas y las medidas de seguridad en un mismo texto legislativo ${ }^{851}$. El art. 90 apartado $12^{\circ}$, contemplaba la medida de "prohibición de que el reo, al extinguir la condena, vuelva a residir en el lugar en que cometió el delito, o en que residían la víctima o su familia". Su contenido venía desarrollado en el art. 106 $\mathrm{CP}$, que disponía que:

"Los Tribunales, en los delitos contra las personas, atendiendo a la gravedad de los hechos, y al peligro que el delincuente represente, podrán acordar en sus sentencias la prohibición de que el reo vuelva al lugar en que hubiere cometido el delito, o en que resida la víctima o su familia, si fueren distintos, después de extinguida la pena, dentro del período de tiempo que en el mismo Tribunal señale según las circunstancias del caso".

Por su parte, el sometimiento del delincuente a la vigilancia de la Autoridad, tal y como venía denominándose en los códigos anteriores, resurge en este $\mathrm{CP}$, al venir prevista en el art. 90, apartado $13^{\circ}$, y desarrollada en el art. $107 \mathrm{CP}$, con el siguiente tenor literal:

"Los Tribunales, en los casos en que por la gravedad del delito o condición del delincuente lo consideren oportuno, podrán acordar en las sentencias que, por los encargados de su ejecución, cuando aquél haya cumplido la pena, se advierta a las Autoridades gubernativas el peligro social que represente, por si éstas entendieren que, dentro de sus facultades, deben adoptar medidas de vigilancia especial" ${ }^{\prime \prime 252}$.

En 1932 y 1933 se produce una separación total entre penas y medidas de seguridad, quedando las penas reguladas en el CP de 1932 y las medidas de seguridad en la Ley de Vagos y Maleantes, de 4 de agosto de 1933, que vino a regular en su art. 4 la

\footnotetext{
851 El CP de 1928 era de corte clásico aunque se notaba la inclusión destacada de algunos rasgos de las teorías modernas que conferían especial importancia a la personalidad del delincuente y dotaban al carácter represivo del sistema penal, de un componente de defensa social contra las infracciones penales, (CUELLO CALÓN, E., El nuevo Código penal español. Tomo I. Barcelona, 1929, p. 9). Esa defensa social, no obstante, era entendida incorrectamente, pues muchas veces se transformaba en defensa política, (ANTÓN ONECA, J., Los antecedentes del nuevo Código penal. Madrid, 1929, pp. 26 a 30). El CP de 1928, pues, contenía lo que algunos autores llamaron un "nuevo eclecticismo" que gravitaba sobre la perversidad del delincuente y el peligro social, (JIMÉNEZ DE ASÚA, L., Al servicio del Derecho penal. Madrid, 1930, p. 63).

852 MANZANARES SAMANIEGO, J.L., “La libertad vigilada...”, cit. p. 3. Este autor explica que “el Código Penal de 1928 distinguía así claramente entre dos medidas de seguridad que no debieran mezclarse o confundirse. La vigilancia propiamente dicha no tiene que presuponer una prohibición de regreso a determinado lugar o de residir en el mismo".
} 
"sumisión a la vigilancia de la autoridad"853, que pretendía cumplir la doble finalidad de tutelar y proteger al sujeto, con una duración de entre uno y cinco años ${ }^{854}$, y que rezaba así:

"Séptima. Sumisión a la vigilancia de la autoridad. La vigilancia será ejercida por delegados especiales y tendrá carácter tutelar y de protección. Los Delegados cuidarán de proporcionar trabajo, según su aptitud y conducta, a los sujetos a su custodia. La duración de esta medida será de uno a cinco años, y podrá ser reemplazada por caución de conducta".

El art. 7 vino a regular los supuestos en que dicha medida debía ser impuesta, mediante la siguiente formulación:

"Los reiterantes, reincidentes y delincuentes peligrosos, serán internados en un Establecimiento de custodia después de cumplir la pena que les fuere impuesta por sentencia judicial. Las medidas de seguridad que los Tribunales impongan a tenor de lo prevenido en este artículo y el $3^{\circ}$ de la presente Ley, habrán de cumplirse por el reo inmediatamente después de extinguir las Penas aplicadas por el delito o delitos sancionados. Por ningún motivo se concederán los beneficios de la condena condicional y de la libertad provisional cuando se hubiere declarado el estado peligroso del culpable y en tanto no se revoque totalmente la medida de seguridad impuesta, cualquiera que sea su naturaleza"855.

El CP de 1944 coincide casi por completo con el de 1932 en la marginación de las medidas de seguridad ${ }^{856}$, y se mantuvo la vigencia de la citada Ley de Vagos y Maleantes hasta su sustitución mediante la promulgación de la Ley de Peligrosidad y Rehabilitación

853 SIERRA LÓPEZ, M.V., La medida de libertad vigilada..., cit. pp. 19 y 20.

854 GARCÍA RIVAS, N., “La libertad vigilada...", cit. p. 5.

855 MANZANARES SAMANIEGO, J.L., “La libertad vigilada...”, cit. p. 3. Sigue diciendo este autor que "aparte, como medidas de seguridad quinta y sexta del art. 4, figuran la obligación de declarar el domicilio o residir en un lugar determinado, así como la de residir en el lugar o territorio que el Tribunal designe".

856 QUINTANO RIPOLLÉS, A., Curso de Derecho Penal. Tomo I. Madrid: Editorial Revista de Derecho Privado. 1963, p. 521. Este autor explica que "el servicio de Libertad Vigilada tuvo su origen, como la redención de penas por el trabajo, con el limitado propósito de liquidar la situación de la población penal a raíz de la guerra civil, y controlar las actividades de las que continuamente se iba liberando. Por O. de 24 de enero de 1946 se extendió al cuidado de los beneficiados en libertad condicional, constituyéndose el organismo mediante una Subdirección General en la Dirección de Prisiones, una Comisión central y las provinciales y locales. Transformando su originario carácter policíaco en tutelar, gran parte de los servicios están encomendados a funcionarios judiciales o fiscales, figurando el servicio entre los de los patronatos postcarcelarios de la Merced y de San Pablo en el Reglamento de Servicio de Prisiones". 
Social, de 4 de agosto de 1970, cuyo art. 5 recogía en su apartado 14º la sumisión a la vigilancia de la autoridad, al disponer que:

“Esta vigilancia será ejercida por delegados especiales y tendrá el carácter tutelar y de protección. Los delegados cuidarán de proporcionar trabajo, según su aptitud y conducta, a los sujetos a su vigilancia. La duración de esta medida será de uno a cinco años y podrá ser reemplazada por caución de conducta".

Y en los apartados $9^{\circ}$ y $10^{\circ}$ del propio art. 5 de la referida Ley, se contemplaba la obligación de residir en un lugar determinado y la prohibición de residir en el lugar o territorio que se designe. El penado tenía la obligación de declarar el lugar en que estuviera radicado su domicilio, así como los cambios que pudieran producirse en el mismo 857 . Por otra parte, el art. 25 disponía que "si concurriere con las medidas de seguridad impuestas alguna pena total o parcialmente pendiente de ejecutar, y aquéllas y ésta no fueren susceptibles de cumplimiento simultáneo, se ejecutará preferentemente la pena", y como comenta la doctrina, se trata de "un precedente digno de destacar no sólo porque hunde sus raíces en la dictadura franquista sino porque en esa Ley se establecían medidas de seguridad pre-delictuales" 858 .

Con la llegada de la Constitución de 1978 y la promulgación del CP de 1995, figuras como la libertad vigilada dejan de estar presentes en la regulación vigente y no es hasta 2006, momento en que se publica un Antreproyecto para reformar el CP, cuando se produce un resurgimiento de esta figura que culmina con su introducción en el texto punitivo en 2010. De todos estos aspectos y de algunos más, me ocupo a continuación.

\section{b) El Anteproyecto de Reforma del CP, de 14 de julio de 2006}

El texto del Anteproyecto de Reforma del CP, de 14 de julio de 2006, pretendió conferir un tratamiento penológico reforzado para los delincuentes habituales y reincidentes, añadiendo consecuencias jurídicas que les serían aplicables. El art. $94 \mathrm{CP}$ establecía la posibilidad de imponerles alguna de las siguientes medidas: el período de seguridad para acceder a la clasificación en tercer grado, que se traduce en haber

\footnotetext{
857 MANZANARES SAMANIEGO, J.L., “La libertad vigilada...”, cit. p. 3.

858 GARCÍA RIVAS, N., “La libertad vigilada...”, cit. p. 5.
} 
cumplido la mitad de la pena impuesta, el sometimiento del penado a programas de tratamiento educativo o terapéutico con una duración de hasta dos años ${ }^{859}$, y la libertad vigilada que podría decretarse una vez cumplida la pena de prisión impuesta por tiempo de hasta dos años ${ }^{860}$. También contemplaba el mismo precepto la posibilidad de la expulsión de los extranjeros del art. $89 \mathrm{CP}$, una vez cumplida la pena de prisión.

Es en este contexto en el que aparece en escena la libertad vigilada como pena restrictiva de derechos menos grave ${ }^{861}$, según las previsiones de los proyectados arts. $39 \mathrm{y}$ 33.3 n) $\mathrm{CP}$, aunque el concepto de esta pena venía en el art. 48.4, al nominar que "la libertad vigilada obliga al penado a facilitar de manera constante y efectiva su localización", siendo, por tanto, una figura que contenía una única obligación consistente en estar siempre localizable, facilitando a tal efecto y de forma continuada, los datos necesarios para ello. Esta pena podía ser aplicada según el art. 88.1 CP como sustitutiva de la pena de prisión ${ }^{862}$ no superior a dos años 863 , con una duración temporal de entre seis meses y un año, por aplicación del límite previsto en el art. 33.3 CP, dado que el propio art. 88.1 CP no contenía indicación alguna sobre este aspecto, contrariamente a lo que sucedía con el resto de penas sustitutivas. Como ya se ha dicho, también podía imponerse como pena complementaria para reincidentes y habituales, con una duración máxima de dos años, en virtud del art. $94 \mathrm{CP}$.

La imposición de esta pena debía hacerse mediante resolución motivada previa audiencia de las partes y la ejecución se difería al momento en que terminase de cumplirse la condena, de tal forma que no podía revisarse su conveniencia ni extinguirla de forma anticipada en caso de que las circunstancias que hicieron posible su ejecución hubieran

\footnotetext{
859 SIERRA LÓPEZ, M.V., La medida de libertad vigilada..., cit. p. 26. Esta autora indica que la libertad vigilada no aparecía en el catálogo de penas, sino únicamente dentro del de medidas de seguridad no privativas de libertad, por lo que su naturaleza debía ser de medida, no de pena, por lo que concluye que en este texto proyectado se abría la posibilidad de imposición conjunta de pena y medida de seguridad para reincidentes o habituales, de manera acumulativa o complementaria.

860 No obstante, ninguna referencia se hacía a la libertad vigilada en la Exposición de Motivos del Anteproyecto, sino que directamente y de forma sorpresiva, se encontraban referencias a esta figura en el articulado. Vid. BOLDOVA PASAMAR, M.A., "Consideraciones político-criminales sobre la introducción de la libertad vigilada". En ReCrim. Revista del Instituto Universitario de investigación en Criminología y Ciencias Penales de la UV. 2009, p. 302.

861 Algunos autores hablan de que esta formulación conformaba una "heterogénea figura penal”, que generó fuertes críticas por parte del CGPJ. Vid. CÁMARA ARROYO, S., “La libertad vigilada...”, cit. p. 7.

862 GUDÍN RODRÍGUEZ-MAGARIÑOS, F., La nueva medida de seguridad..., cit. pp. 202 y 203.

863 BOLDOVA PASAMAR, M.A., “Consideraciones político-criminales...”, cit. p. 303.
} 
variado y ya no fuera necesario su cumplimiento, posibilidad que quedaba vedada por la propia naturaleza de pena de esta figura ${ }^{864}$.

\section{c) El Proyecto de reforma del CP, de 15 de enero de 2007}

El Proyecto de reforma del CP, de 15 de enero de 2007865, incluyó la libertad vigilada de una forma que por un sector de la doctrina se calificó de "confusa"866 con naturaleza híbrida ${ }^{867}$, atribuyéndole un triple carácter: como pena privativa de derechos, como sustitutivo de las penas de prisión que no excedieran de dos años, y como medida que podía imponerse a los reincidentes y habituales ${ }^{868}$. En cuanto a la primera variante, siguiendo la formulación proyectada en 2006, venía prevista en la letra j) del art. 39 CP, incluyéndola en el listado de las penas privativas de derechos. La libertad vigilada obligaba al penado a facilitar de manera efectiva y constante su localización, con una duración de seis meses a un año según disponía el art. 33, n) CP, y con posibilidad de control por el Tribunal a través de medios electrónicos. Según la doctrina, esta previsión no era más que una especie de localización permanente atenuada, que se limitaba a que el órgano jurisdiccional tuviese conocimiento en todo momento del paradero del penado, aspecto que implicaba que su carácter aflictivo pasara a ser "testimonial" 869.

La segunda variante de la libertad vigilada consistía en que se podía imponer como sustitutivo de la prisión en los casos en que la pena privativa de libertad no fuera superior a dos años conforme a la redacción proyectada del art. 88.1 d) CP870. Sobre este particular el informe consultivo que elaboró el CGPJ, se mostraba absolutamente contrario a la inclusión de esta pena con esta regulación, poniendo de manifiesto que sería "desaconsejable" y que implicaría la "volatilización de la respuesta penal", ya que suponía un sustitutivo de la pena de prisión que colisionaba con la finalidad del beneficio

\footnotetext{
864 SIERRA LÓPEZ, M.V., La medida de libertad vigilada..., cit. p. 27.

865 Proyecto de Ley 121/119, BOCG, de 15 de enero de 2007, Congreso de los Diputados. Serie A-119.

866 REBOLLO VARGAS, R., “De las medidas de seguridad...”, cit. p. 803.

867 GUDÍN RODRÍGUEZ-MAGARIÑOS, F., La nueva medida de seguridad..., cit. p. 203.

868 CÁMARA ARROYO, S., “La libertad vigilada...”, cit. p. 7. Este autor habla de que la libertad vigilada pasó a ser "una medida comodín, utilizada en muy diversos ámbitos punitivos, sin que se estableciera una pormenorizada regulación para su efectiva ejecución".

869 REBOLLO VARGAS, R., “De las medidas de seguridad...”, cit. p. 804.

870 GUDÍN RODRÍGUEZ-MAGARIÑOS, F., La nueva medida de seguridad..., cit. p. 203.
} 
de la suspensión de la pena y las obligaciones que conlleva, porque encontrándose la pena en suspenso, el contenido de la suspensión podía llegar a ser más grave que si se ejecutaba la pena sustituida por la libertad vigilada, con lo que se producía un efecto contrario al que persiguen una y otra figura ${ }^{871}$. En cualquier caso, REBOLLO VARGAS afirma que en relación al "carácter simbólico de la pena (restrictiva de derechos) y su nulo carácter aflictivo", habría sido mejor proyectarla como un mecanismo para la suspensión de la pena y no para la sustitución, porque su utilización habría estado orientada al cumplimiento de ciertas reglas de conducta con miras a la prevención especial ${ }^{872}$.

Las obligaciones en que se concretaba el contenido de la libertad vigilada eran la prohibición de acudir a determinados lugares, de comunicar con la víctima o de aproximarse a ella, etc., que ya estaban previstas como penas autóctonas y con sustantividad propia, por lo que se podía producir una suerte de solapamiento entre las penas privativas de derechos y las obligaciones específicas en que concreta la libertad vigilada.

La tercera variante era la prevista para los reincidentes y habituales (art. $94 \mathrm{CP}$ ), previsión que se hacía eco de las voces doctrinales que venían poniendo de manifiesto la viabilidad de la formulación de la libertad vigilada para este tipo de delincuentes contumaces ${ }^{873}$. La libertad vigilada, no venía prevista en ningún tipo de la parte especial y su previsión posibilitaba que a los reos reincidentes y habituales les fuera impuesta esta sanción como un mecanismo para impedir que las penas privativas de libertad pudiesen ser suspendidas (art. 94.1 CP) o sustituidas en los reos habituales (art. 94.2 CP). Además, el art. 94.3.4 $\mathrm{CP}$ disponía que a los reincidentes o habituales se les impondría la libertad

\footnotetext{
871 El informe del CGPJ rezaba del siguiente tenor: “El Consejo considera que a la luz de los antecedentes de Derecho nacional y comparado, la posibilidad de que la libertad vigilada pueda jugar un papel relevante en el Derecho penal de adultos en España es bastante discutible, al menos en el formato que ofrece el Anteproyecto. Como pena sustitutiva de la prisión resulta sumamente desaconsejable pues implica la volatilización de la respuesta penal, con grave detrimento de las exigencias de afirmación del ordenamiento jurídico conculcado, y cabe anticipar que en su aplicación práctica generaría además el extraño fenómeno de que la imposición de esta pena sustitutiva de la prisión devendría menos gravosa e intervencionista que la concesión de un beneficio penal como es la suspensión condicional, el cual como es sabido -vid. art. $83.1 \mathrm{CP}$ - lleva aparejado cuando se aplica a la pena de prisión la posibilidad de que el Juez o Tribunal vincule su otorgamiento cuando lo estime necesario al cumplimiento de ciertas obligaciones y reglas de conducta de marcada orientación preventivo-especial muy semejantes a las descritas en el Derecho alemán o en el ámbito de la jurisdicción de menores".

872 REBOLLO VARGAS, R., “De las medidas de seguridad...”, cit. p. 805.

873 GUISASOLA LERMA, C., Reincidencia..., cit. p. 159; y también TAMARIT SUMALLA, J.M., “La integración jurídica en la Unión Europea...", cit. p. 84.
} 
vigilada por tiempo de hasta dos años después de haber cumplido la condena, superando la duración prevista en el art. 33, n) CP que era de seis meses a un año cuando se aplicaba a través del art. 39, j) CP874.

Algunos autores hablan de que la libertad vigilada en esta modalidad revestía naturaleza de medida de seguridad al estar prevista en un capítulo nuevo rubricado “De la reincidencia y de la habitualidad", que recogía una serie de obligaciones dirigidas al juzgador para que adoptase alguna de las medidas allí descritas cuando se tratase de reos reincidentes o habituales. Entre esas medidas estaba la libertad vigilada por tiempo máximo de dos años, que se aplicaría una vez cumplida la condena (art. 94) ${ }^{875}$.

\section{d) El Anteproyecto de reforma del CP, de 14 de noviembre de 2008}

Especial detenimiento merece el Anteproyecto de reforma del CP, de 14 de noviembre de 2008, que formuló la libertad vigilada como pena ${ }^{876}$, con una pretendida finalidad de reinserción en la sociedad del delincuente, a través de la desaparición de su peligrosidad criminal. Se concibió como una pena privativa de derechos accesoria877, de cumplimiento sucesivo a la pena de prisión consistente en el sometimiento del condenado al control judicial durante el tiempo que se señalase en la sentencia ${ }^{878}$ o hasta alcanzar la reinserción, a través del cumplimiento de alguna, algunas o todas las obligaciones concretas, tasadas legalmente, que el JVP tendría que determinar en la fase de ejecución ${ }^{879}$.

\footnotetext{
874 REBOLLO VARGAS, R., “De las medidas de seguridad...”, cit. p. 805.

875 GARCÍA RIVAS, N., “La libertad vigilada...”, cit. p. 7.

876 CÁMARA ARROYO, S., “La libertad vigilada...”, cit. p. 8.

877 GARCÍA RIVAS, N., “La libertad vigilada...”, cit. pp. 8 y 9.

878 DE MARCos MAdRUGA, F., en GÓMEZ TOMILLO, M., (Dir.), Comentarios al Código penal. $2^{\mathrm{a}}$ Ed. Valladollid: Lex Nova. 2011, p. 437.
}

879 El informe del Consejo de Ministros, de 14 de noviembre de 2007, vino a decir lo siguiente: "Libertad vigilada. Además de incidir en la protección de los menores, el Anteproyecto de Ley lo hace también frente a los terroristas y sus víctimas. Crea la figura penal denominada "libertad vigilada" para el control y seguimiento de terroristas y delincuentes sexuales. El inicio del cumplimiento de esta pena tendrá lugar, en su caso, a partir de la finalización de la privativa de libertad. El motivo de esta nueva pena es la incapacidad, en ocasiones, de que las condenas de prisión consigan el fin de la reinserción del delincuente a la sociedad, lo que hace necesario la adopción de medidas que permitan el tratamiento y control de estos individuos después de cumplida la pena privativa de libertad. La libertad vigilada consistirá en la imposición de una serie de obligaciones que deberá cumplir el condenado [...]". 
Se trataba de una pena accesoria ${ }^{880}$, a la que no podían serle de aplicación las normas generales de las penas accesorias, puesto que a pesar de la denominación, se trataba de una pena sui generis que comportaba normas propias de aplicación y su imposición nada tenía que ver con las restantes delimitaciones aplicables a las penas accesorias previstas en el CP. Tampoco se trataba de una consecuencia accesoria ${ }^{881}$ de las previstas en el título IV del Libro I CP, arts. 127 y ss., que son consecuecias jurídicas del delito de naturaleza discutible y discutida, puesto que no tienen fácil acomodo ni entre las penas ni entre las medidas de seguridad882, y que se reducen únicamente al comiso y las medidas en relación a las sociedades mercantiles, por lo que la libertad vigilada no podía ser una consecuencia accesoria puesto que no se encontraba incluida en su catálogo.

La consideración de pena "accesoria" únicamente implicaba que nunca y en ningún caso se podía imponer como pena principal, de forma única o alternativa a otra, puesto que el legislador no quiso preverla en ninguno de los delitos de la parte especial como pena principal, conjunta o alternativa a la de prisión, sino siempre acompañando a otra pena principal privativa de libertad, con lo cual, se trataba de una suerte pena accesoria sui generis, condicionando el inicio del cómputo de su cumplimiento al momento en que la pena principal (que debía ser siempre privativa de libertad), se hubiera cumplido. Abierto quedó el debate sobre si debía extenderse este inicio del cómputo a cuando el penado hubiera pasado al tercer grado de tratamiento penitenciario, o a cuando hubiera accedido a la libertad condicional, ya que el texto no lo terminaba de dejar claro.

Expresaba la Exposición de Motivos del Anteproyecto que la pena privativa de libertad no cumple plenamente con los fines de prevención especial a los que sirve, y ello es más palmario en supuestos de delincuentes sexuales y terroristas, donde existe una difícil reinserción por resultar de extrema dificultad que tras el cumplimiento de la pena privativa de libertad, exista un pronóstico favorable de reinserción que ponga de manifiesto la materialización de la prevención especial por la pena ya cumplida. Es por

\footnotetext{
880 Esta formulación guardaba una gran similitud con las formulaciones alemanas de las penas accesorias que recaen sobre la libertad, y en concreto sobre la sujeción a la vigilancia de la policía, como pena accesoria contemplada en el StGB de 1870. Vid. LISZT, F., Tratado de Derecho penal..., cit. Tomo III, pp. 262 a 266.

881 MUÑOZ CONDE, F. / GARCÍA ARÁN, M., Derecho Penal, Parte General. $8^{\text {a }}$ Ed. Valencia Tirant lo Blanch. 2010, p. 620. Como indican estos autores "no son penas porque no guardan relación ni con la gravedad del hecho ni con la culpabilidad del autor; tampoco pueden considerarse medidas de seguridad porque no se asientan en un juicio sobre la peligrosidad personal del responsable".
}

882 LANDROVE DÍAZ, G., Las consecuencias..., cit. p. 127. 
ese motivo por el que se justifica la necesidad de la creación de esta nueva pena, instrumentalizada a la consecución de un "fin principal": la reinserción del sujeto en la sociedad $^{883}$. De todo lo anterior se desprende que la libertad vigilada únicamente estaba justificada en aquellos sujetos que no fueran susceptibles de ser reinsertados en la sociedad mediante la imposición de penas privativas de libertad más o menos extensas.

La Exposición de Motivos del Anteproyecto distinguía dos momentos clave en la aplicación de la libertad vigilada: la imposición de la pena y su duración, que debería venir impuesta en sentencia por el Tribunal; y por otra parte el alcance y contenido de la pena, que podrá ser determinado conjuntamente por ese mismo Tribunal y el JVP884. Es importante señalar que la duración de la libertad vigilada siempre iba a estar condicionada al pronóstico favorable de reinserción, por lo que su duración final y la realidad de su alcance, a pesar de poder llegar hasta los veinte años en sentencia, podía verse notablemente reducida por la existencia de pronóstico favorable de reinserción, esto es, como decía el Anteproyecto, "una vez cumplido el fin de reinserción".

La libertad vigilada no vino prevista en ninguna de las figuras delictivas a las que se pretendía aplicar, sino que aparecía únicamente en la parte general (y no en la parte

883 La Exposición de Motivos del Anteproyecto vino a decir que "si bien es cierto que la pena privativa de libertad cuenta entre sus fines el de satisfacer las exigencias de la prevención especial, no lo es menos que en numerosas ocasiones no logra responder plenamente a este objetivo. Esta situación destaca por su gravedad en los casos de delincuentes sexuales y terroristas donde las características de los hechos revelan al mismo tiempo una especial peligrosidad por parte de los autores y una gran dificultad en su tratamiento. Esta circunstancia hace necesaria la creación de una nueva pena accesoria, denominada "libertad vigilada" cuya conformación estará adecuada a un fin principal, a saber: el de lograr la reinserción del sujeto a la sociedad. Esta pena deberá ser impuesta por el Juez o Tribunal en la Sentencia sólo en los casos expresamente previstos por la Ley. En dicha Sentencia constará necesariamente la imposición de la pena y su duración, mientras que el alcance y contenido podrá ser determinado tanto por el Juez Sentenciador como por el Juez de ejecución, quienes decidirán las obligaciones a cumplir por el condenado de entre una lista prevista ad hoc por la Ley. En lo que respecta al cumplimiento de la pena de libertad vigilada, el mismo será simultáneo y sucesivo a la pena de prisión. De esta forma, frente a delitos graves resultará aplicable, además de la pena privativa de libertad, una pena accesoria de libertad vigilada entre uno y vente años superior a la pena de prisión, y frente a delitos menos graves, una pena de libertad vigilada entre uno y diez años, también superior a la pena privativa de libertad. No obstante, en el supuesto de que exista un pronóstico positivo de reinserción, se prevé la posibilidad de reducir la duración de la pena o bien que la misma quede sin efecto. En la medida en que el fin prioritario que persigue la aplicación de la pena accesoria de libertad vigilada es la prevención especial, la aplicación de la misma durante un plazo prolongado no es susceptible de lesionar derechos fundamentales, puesto que se trata de una mínima restricción de las libertades que se mantendrá en tanto la pena aún no haya podido satisfacer el fin de rehabilitación que se propone. Además, y tal como se ha manifestado, una vez cumplido el fin de reinserción, el plazo establecido inicialmente en la sentencia no representará obstáculo alguno para la reducción temporal de la medida. De esta forma, se dará en la ejecución de esta pena preferencia al carácter correctivo de la intervención frente al meramente asegurativo, con lo que la contraposición entre los deberes de protección de la seguridad colectiva y de los derechos de los individuos que conciernen al Estado se resolverá con una adecuada distribución de cargas entre individuo y sociedad".

884 BOLDOVA PASAMAR, M.A., “Consideraciones político-criminales...”, cit. p. 305. 
especial para delitos en los que estuviera contemplada entre las penas previstas como principales, de cumplimiento simultáneo o alternativo). Por su parte, la Exposición de Motivos proclamaba un cumplimiento simultáneo y sucesivo dependiendo de la gravedad del delito que se cometiera. No obstante, no se termina de entender en qué consistía esta previsión de cumplimiento "simultáneo", puesto que en el articulado del mismo Anteproyecto no vino referencia alguna a esta forma de cumplimiento, sino que del texto legal se desprendía una única forma de cumplimiento: el sucesivo, que se traduce en que la libertad vigilada comenzaría a cumplirse cuando se hubiera cumplido la pena de prisión. Esta contradicción entre la Exposición de Motivos y el articulado vino motivada por el hecho de que, en un lapso temporal de tan solo dos semanas de diferencia, se publicaron dos Anteproyectos distintos, uno de 27 de octubre de 2008 y otro posterior de 14 de noviembre de 2008. En el primero de ellos, la referencia al cumplimiento simultáneo venía prevista tanto en la Exposición de Motivos como en el articulado; y por su parte, en el Anteproyecto de 14 de noviembre de 2008, las referencias a cumplimiento simultáneo únicamente aparecían en la Exposición de Motivos.

Por último, conviene resaltar en este punto, las referencias que hizo la Exposición de Motivos a la duración de la pena, en relación con la posible vulneración de derechos fundamentales. Expresaba el texto que ese plazo tan prolongado en que podía estar aplicándose la pena accesoria, no era susceptible de lesionar derechos fundamentales, puesto que "se trata de una mínima restricción de las libertades que se mantendrá en tanto la pena no haya podido satisfacer el fin que se propone" 885 . Se trataba, pues, de un incremento punitivo que la Exposición de Motivos entendía no solo justificado, sino también que la restricción era mínima886.

\footnotetext{
885 Con ello parecía olvidar, pues, el legislador que la pena es la manifestación más fuerte del poder, la ultima ratio, y siempre arranca desde la premisa de que la libertad debe ser restringida, sacrificada o mermada, en la menor medida posible, y ello como consecuencia lógica de las disposiciones de la DUDH de 1948 y la CE de 1978, disposiciones en las que se proclama que no se impondrán más penas que las estrictamente necesarias, y todo ello conforme a los postulados del principio de proporcionalidad. Sobre este principio vid. CUERDA ARNAU, M.L., "Aproximación al principio...", cit. pp. 447 a 491; y DE LA MATA BARRANCO, N.J., El principio de proporcionalidad penal. Valencia: Tirant lo Blanch. 2007, pp. 17 y ss.

886 Como vino a decir VIVES ANTÓN, “el endurecimiento de las penas no obedece, pues, a tratar de combatir un incremento de la delincuencia que no se ha producido". Para este autor, no existía un incremento de la delincuencia que justificara la agravación punitiva en el CP y la creación de esta nueva pena accesoria que se podía prolongar hasta veinte años por encima de la pena principal, porque sencillamente la delincuencia en el año inmediatamente anterior a la promulgación del citado Anteproyecto había descendido. En ese sentido manifestó acertadamente este autor que "la Exposición de Motivos del Anteproyecto trata de explicarlo en términos técnicos o de tutela de intereses generales; pero, aunque esos argumentos puedan justificar algunas previsiones del Anteproyecto, en modo alguno justifican ni excusan, en general, el incremento de la represión
} 
El apartado octavo del Anteproyecto añadía al CP un art. 49 bis con la siguiente redacción:

“1. La pena de libertad vigilada tendrá siempre carácter de pena accesoria. Esta pena consistirá en el sometimiento del condenado a control judicial durante el tiempo que se señale en la sentencia a través del cumplimiento por su parte de alguna o algunas de las obligaciones señaladas en el apartado siguiente, que el juez de vigilancia determinará en la fase de ejecución. El cómputo de esta pena comenzará a partir del cumplimiento de la pena privativa de libertad ${ }^{887}$.

2. La pena de libertad vigilada llevará consigo todas o alguna de las siguientes obligaciones:

a) la de estar siempre localizable

b) la presentación periódica en el lugar que se establezca.

c) la de comunicar inmediatamente cada cambio del lugar de residencia o del lugar o puesto de trabajo.

d) la prohibición de ausentarse sin autorización del juez o tribunal del lugar donde resida.

e) la de no aproximarse a la víctima, o a aquellos de sus familiares u otras personas que determine el Juez o Tribunal.

f) la de no comunicarse con las personas previstas en la letra anterior.

g) la de no acudir a determinados lugares o establecimientos.

h) la de no residir en determinados lugares.

i) la de no desempeñar determinadas actividades que pueda aprovechar para cometer hechos punibles de similar naturaleza.

j) la de participar en programas formativos, laborales, culturales, de educación sexual u otros similares.

k) la de seguir tratamiento médico externo.

3. Para garantizar el cumplimiento efectivo de esta pena, el Juez o Tribunal podrá acordar la utilización de medios electrónicos que permitan la localización y seguimiento permanente del reo.

que se propone". Vid. VIVES ANTÓN, T.S., Reflexiones jurídico-políticas a propósito de un Anteproyecto de Código Penal ¿Estado democrático o Estado autoritario? Valencia: www.tirantonline.com. TOL1.405.952. 2008, p. 5.

887 En la redacción que se le dio a este artículo en la versión inicial del Anteproyecto de 27 de octubre de 2008, se decía que el cumplimiento sería simultáneo y sucesivo al de la pena de prisión, y en su redacción final, en fecha 14 de noviembre de 2008, se suprimió la referencia al cumplimiento simultáneo, aunque sí que refería a ese extremo la Exposición de Motivos. El artículo se redactó inicialmente así: “1. La pena de libertad vigilada tendrá siempre carácter de pena accesoria. Esta pena consistirá en el sometimiento del condenado a control judicial durante el tiempo que se señale en la sentencia a través del cumplimiento por su parte de alguna o algunas de las obligaciones señaladas en el apartado siguiente, que los jueces o tribunales determinarán en la sentencia o con posterioridad en la fase de ejecución. El cumplimiento de esta pena será simultáneo y sucesivo al de la pena de prisión impuesta". 
4. Durante la fase de ejecución el Juez de Vigilancia, oído el Ministerio Fiscal, concretará las obligaciones del condenado, pudiendo modificarlas en lo sucesivo conforme a la evolución del reo, y controlará su cumplimiento, requiriendo periódicamente los informes que considere necesarios a las administraciones públicas correspondientes. Las demás circunstancias de ejecución de esta pena se establecerán reglamentariamente ${ }^{888}$.

5. El Juez de Vigilancia Penitenciaria, oídos el Ministerio Fiscal y el interesado, podrá en cualquier momento reducir la duración de la libertad vigilada o dejarla sin efecto siempre que en vista del pronóstico positivo de reinserción se considere innecesaria la continuidad de las obligaciones impuestas.

6. En caso de incumplimiento de una o varias obligaciones el Juez de Vigilancia Penitenciaria, a vista de las circunstancias concurrentes y oído el Ministerio Fiscal, podrá modificar las obligaciones, o bien deducir testimonio para proceder de conformidad con lo establecido en el artículo $468^{\prime \prime}$.

Por otra parte, el número Decimotercero del Anteproyecto añadía al Código un art. 57 bis), en virtud del cual la pena de libertad vigilada se impondría cuando el autor hubiera sido condenado por uno o más delitos contra la libertad o indemnidad sexuales o por delitos de terrorismo, que quedaba redactado así:

“1. Sin perjuicio de lo dispuesto en los artículos anteriores de este capítulo, la pena accesoria de libertad vigilada será impuesta por el Juez o Tribunal junto con la pena principal privativa de libertad en los siguientes casos:

a) cuando el autor haya sido condenado por uno o más delitos del Título VIII del Libro II de este Código.

b) cuando el autor haya sido condenado por un delito de terrorismo de la sección segunda del capítulo V del Título XXII de este Código, a una pena privativa de libertad igual o superior a diez años, o por dos o más delitos de terrorismo de la citada sección habiéndose apreciado la agravante de reincidencia en cualquiera de ellos.

2. En caso de que el delito fuera grave la libertad vigilada tendrá una duración de entre diez y veinte años, y si el delito fuera menos grave, entre uno y diez años. En los supuestos de reincidencia, habitualidad, pluralidad de delitos o extrema gravedad, el Juez o Tribunal impondrá la pena en su mitad superior. Cuando no concurran los anteriores supuestos impondrá la pena en

888 En la redacción del Anteproyecto de 27 de octubre de 2008, el artículo decía lo siguiente: “4. Durante la fase de ejecución el Juez sentenciador, a propuesta del Juez de vigilancia y oído el Ministerio Fiscal, concretará las obligaciones del condenado. La ejecución se desarrollará bajo el control del Juez de Vigilancia penitenciaria, quien requerirá periódicamente los informes sobre el cumplimiento de las obligaciones a la Administración. Las demás circunstancias de ejecución de esta pena se establecerán reglamentariamente". 
la extensión que estime adecuada en atención a las circunstancias personales del delincuente y a la naturaleza del hecho delictivo" 889 .

Por último, se modificaba el apartado 2 del art. $468 \mathrm{CP}$, que quedaba redactado como sigue:

“2. Se impondrá en todo caso la pena de prisión de seis meses a un año a los que quebrantaren una pena de las contempladas en el artículo 48 de este Código o una medida cautelar o de seguridad de la misma naturaleza impuestas en procesos criminales en los que el ofendido sea alguna de las personas a las que se refiere el artículo 173.2, así como a aquellos que quebrantaren la pena de libertad vigilada".

Los delitos sexuales iban a llevar aparejada la imposición de la pena accesoria de libertad vigilada y su duración dependería del delito o delitos por el que se hubiese condenado a los penalmente responsables: la libertad vigilada sería grave siempre que se impusiera como accesoria de una pena de prisión de más de cinco años; y sería menos grave cuando fuera impuesta como accesoria de una pena de prisión de entre uno y cinco años. Y lo mismo para los delitos de terrorismo pero con los siguientes criterios de aplicación: una regla general, que se traducía en que el reo debía haber sido condenado por dos o más delitos de terrorismo y que esa condena sumara diez años de prisión o más; y una regla especial, que disponía que se podría aplicar, cualquiera que fuera su duración, cuando el reo hubiera sido condenado por dos o más delitos de terrorismo y en alguno de ellos (como mínimo) se hubiera aplicado la agravante de reincidencia ${ }^{890}$. Es decir, un criterio dependía de la duración de las penas impuestas en dos o más delitos de terrorismo (diez años o más), y el otro criterio dependía de si concurría o no la agravante de reincidencia, independientemente de que esos dos o más delitos de terrorismo por los que necesariamente debía haber sido condenado el sujeto, tuvieran prevista una pena por tiempo inferior a diez años de prisión.

\footnotetext{
${ }^{889}$ En su redacción de 27 de octubre de 2008, este artículo quedaba así: “2. En caso de que el delito fuera grave la libertad vigilada tendrá una duración superior a la de la pena de prisión impuesta de entre uno y veinte años, y si el delito fuera menos grave, entre uno y diez años".

890 REBOLLO VARGAS, R., “De las medidas de seguridad...”, cit. p. 807.
} 
En cuanto a la duración de la libertad vigilada podía ser de entre uno y veinte años 891 , y contenía el Anteproyecto una cuádruple previsión: en primer lugar, la libertad vigilada tendría una duración de entre diez y veinte años si el delito fuera grave. En segundo lugar, si el delito fuera menos grave, tendría una duración de entre uno y diez años; en tercer lugar, se impondría la libertad vigilada en su mitad superior, siempre que concurriera alguna de estas circunstancias: reincidencia, habitualidad, pluralidad de delitos o que los mismos fueran de extrema gravedad. Y en cuarto y último lugar, cuando no concurriera ninguna de las anteriores previsiones la pena sería impuesta en la extensión que se estimara adecuada en atención a las circunstancias personales del delincuente y a la naturaleza del hecho delictivo ${ }^{892}$.

En el art. 49 bis, 3 CP se hizo referencia a unos medios electrónicos encaminados a la localización y seguimiento permanente del reo para garantizar el éxito de la libertad vigilada. También había una previsión específica para los casos en que el penado que se hallare en cumplimiento de la pena de libertad vigilada, incumpliera, quebrantara o no atendiera una o varias de las obligaciones que le fueren impuestas 893 , con dos consecuencias distintas derivadas del incumplimiento: una era la modificación de las obligaciones, y otra la incoación de un nuevo proceso penal con sustantividad propia, por un hecho previsto entre los delitos contra la Administración de Justicia, esto es: quebrantamiento de condena del art. $468 \mathrm{CP}$. El problema que a priori se planteaba era determinar en qué casos procedía una modificación de las obligaciones y en qué casos procedía incoar un nuevo proceso penal, puesto que las consecuencias a nivel penológico en uno y otro caso, eran muy diferentes: si se modificaban las obligaciones, el penado continuaba cumpliendo esa misma pena, aunque con distintas obligaciones añadidas, o con sustitución de unas por otras, lo que en ningún caso implicaba que el penado tuviera que someterse a un nuevo proceso, ni que se le pudiera imponer una nueva pena de prisión por incumplir dichas obligaciones. Si por el contrario, se deducía testimonio y se instruía una nueva causa penal, el sujeto podía verse afectado por una nueva condena con

\footnotetext{
$891 \mathrm{El}$ apartado Sexto del Anteproyecto, modificaba el art. $40 \mathrm{CP}$, desplazando el apartado 5, que pasaba a ser el 6; y el 5 preveía la duración de la libertad vigilada, al disponer que: “5. La pena de libertad vigilada tendrá una duración de uno a veinte años".

892 BOLDOVA PASAMAR, M.A., “Consideraciones político-criminales...”, cit. pp. 307 a 312.

893 Así el apartado 6 del art. 49 bis, disponía: “En caso de incumplimiento de una o varias obligaciones el Juez de Vigilancia Penitenciaria propondrá al Tribunal Sentenciador, a vista de las circunstancias concurrentes y oído el Ministerio Fiscal, la modificación de las obligaciones, o bien que se deduzca testimonio para proceder de conformidad con lo establecido en el artículo $468^{\prime \prime}$.
} 
pena de prisión con una posible agravante de reincidencia, y además se iba ver sensiblemente aumentada la población penitenciaria.

De todo lo anterior se desprende que esta formulación de la libertad vigilada no parecía muy acertada, ya que de la propia redacción y bajo la forma de pena, la realidad de la libertad vigilada parecía confundirse con caracteres propios de una medida de seguridad, toda vez que su duración, su alcance, su contenido y su efectividad dependían de que existiera o no un pronóstico favorable de reinserción ${ }^{894}$, con lo cual, nada tenía que ver para su efectiva materialización el hecho delictivo del que derivaba, no dependía en absoluto del hecho pasado cometido como en el resto de penas, sino que dependía del futuro pronóstico de reinserción ${ }^{895}$ como en las medidas de seguridad.

\section{e) El informe del Consejo Fiscal, de 4 de febrero de 2009}

Este informe 896 , a pesar de no mostrarse contrario a la implantación de la libertad vigilada, criticó fuertemente ciertos aspectos, de los que resaltaremos los más relevantes. Primeramente, criticó el carácter accesorio que se le pretendía dar a la pena, puesto que luego no se comportaba como una pena accesoria ${ }^{897}$. En efecto, la libertad vigilada

894 REBOLLO VARGAS, R., “De las medidas de seguridad...”, cit. p. 806.

895 VIVES ANTÓN, T.S., Reflexiones..., cit. p. 4. Este autor manifiesta que “esa dependencia de pronóstico, cuya falta de seguridad coloca al condenado (y también al Juez) en una situación inaceptable".

896 Puede consultarse el texto íntegro del informe en DIEGO DÍAZ SANTOS, M.R. / MATELLANES RODRÍGUEZ, N.P. / FABIÁN CAPARRÓS, E.A., (Comps.), Anteproyecto de Ley Orgánica de 14 de noviembre de 2008, de Reforma del Código Penal. Acompañado de los informes del Consejo General del Poder Judicial y del Consejo Fiscal. XXI Congreso Universitario de Alumnos de Derecho Penal. Universidad de Salamanca: Ratio legis. 2009, pp. 117 a 239.

897 El informe expresa en este punto lo siguiente: “El precepto comentado se abre con una declaración acerca de la naturaleza de la pena, que se califica categóricamente ("siempre") de accesoria. Tal declaración, no obstante, más allá de cuál haya sido la concreta voluntad del prelegislador al formularla, resulta técnicamente cuestionable. De hecho, más allá de ese aserto normativo, podría decirse que la nueva pena de libertad vigilada será precisamente porque lo dice la norma, una pena accesoria, y tal vez en algunos aspectos pueda parecerlo, pero desde luego no se comporta como tal. En efecto, es una pena "accesoria" cuya duración no tiene por qué coincidir con la de la principal y que cuenta, además, con sus propias reglas de aplicación independientes de aquélla (art. 57 bis). Estas quiebras de la regla de la accesoriedad propiamente entendida ya tenían precedentes en la regulación de la aplicación judicial del alejamiento (art. 57 CP). Pero al menos hay dos diferencias que alejan aún más a esta nueva pena de libertad vigilada de la idea de accesoriedad: 1) La ejecución del alejamiento sí se lleva a cabo, al menos en parte, accesoriamente, es decir, junto a la principal o con ella (aunque exceda de su duración), mientras que la libertad vigilada sólo comienza a ejecutarse una vez que se ha extinguido la pena principal (art. 49 bis 1, in fine), o sea, forzosamente separada de ella; 2) Por mucho que en el caso del alejamiento se prevean normas autónomas de determinación de su duración, distintas de las que rigen la pena principal, unas se vinculan accesoriamente a las otras, de modo que la duración de la accesoria depende de la duración de la principal. Sin embargo, basta revisar el tenor literal del propuesto art. 57 bis para comprobar que la duración máxima y mínima de tal pena "accesoria" no se vincula formalmente a la de la "principal" sino que se liga de manera directa a la calificación del delito como grave o 
guardaba enormes diferencias con lo que el CP contempla como penas accesorias, no solo por el inicio del cómputo de su ejecución, sino también su duración, que no dependía de la duración de la pena de prisión, sino también porque contaba con sus propias normas de aplicación. Acertadamente expresó el informe que el legislador se ha movido por un criterio pragmático, pretendiendo dotar a ciertos delitos de una nueva pena, sin modificarlos en su formulación contenida en la parte especial del $\mathrm{CP}$, sino acudiendo a las normas de la parte general.

También vino a criticar el informe la omisión del papel que puede desempeñar la víctima en cuanto a la determinación de la libertad vigilada, pues la ocasión era óptima para empezar a legislar en materia de intervención de la víctima a los solos efectos de la determinación del alcance de esta medida, máxime cuando su duración y el contenido de las obligaciones que podía comportar eran tan amplias y dispares 898 .

\section{f) El informe del Consejo General del Poder Judicial, de 26 de febrero de 2009}

El informe consultivo del CGPJ ${ }^{899}$ se mostró muy crítico con la formulación de la libertad vigilada en el Anteproyecto de 2008 como una nueva pena, y a este respecto resaltaremos únicamente dos cuestiones que merecen especial atención: por una parte, la inexistencia de reformas en relación al necesario desarrollo reglamentario que regule la ejecución de la libertad vigilada; y por otra, la prescripción de la pena. En cuanto al primero de los aspectos, critica el CGPJ que el Anteproyecto refería al necesario desarrollo reglamentario para la ejecución y que dicho desarrollo no acompañaba a la reforma,

menos grave; en realidad, observados esos matices y el conjunto de las modificaciones normativas propuestas en el Anteproyecto, podría aventurarse que el énfasis con el que el prelegislador subraya la calidad de pena accesoria de la libertad vigilada parece obedecer, más que a un criterio técnico-jurídico, a una finalidad pragmática, como es la de eludir la necesidad de una revisión pormenorizada de la parte especial del Código Penal para asignar la pena de libertad vigilada a cada uno de los delitos a los que entiende que ha de aparejarse. Pero hubiera bastado seguir la misma técnica del art. 57 -por más que su ubicación sistemática sea per se, y por los motivos expuestos, cuestionable-, sin necesidad tal vez de incidir de modo tan explícito en una afirmación de accesoriedad que no resiste fácilmente un análisis dogmático riguroso".

898 El informe rezaba así: "Merece una mención especial la absoluta omisión de cualquier referencia a la posible audiencia o participación de la víctima en relación con la determinación y ejecución de esta pena, que incluso puede ser pasivamente afectada por ella (en el caso de la obligación de alejamiento), lo que no parece cohonestarse con la política legislativa de reforzada atención a los afectados por los hechos criminales (delitos sexuales y de terrorismo) a los que pretende dar respuesta específica la libertad vigilada".

899 Puede consultarse el texto íntegro del informe en DIEGO DÍAZ SANTOS, M.R. / MATELLANES RODRÍGUEZ, N.P. /FABIÁN CAPARRÓS, E.A., (Comps.), Anteproyecto de Ley Orgánica de 14 de noviembre de $2008 \ldots$, cit. pp. 41 a 116. 
quedando por ello un tanto incompleta ${ }^{900}$. Además, manifiesta acertadamente el informe que la aplicación de la libertad vigilada después de que el penado haya superado la fase de libertad condicional, resulta claramente contraria al mandato constitucional del art. 25.1 en cuanto el sistema progresivo, porque la libertad vigilada puede suponer un régimen más gravoso que el de la libertad condicional o el tercer grado, cuando el penado se encuentra aún en fase de ejecución de la pena de prisión; con lo cual, tras su extinción, comenzaría el cumplimiento de la libertad vigilada con un régimen que podría suponer un retroceso en la progresión penitenciaria constitucionalmente diseñada901.

El Consejo estaba en lo cierto con estas observaciones, pero probablemente el legislador pretendía que la libertad vigilada comenzara a cumplirse en el mismo momento que la libertad condicional, de ahí la previsión de cumplimiento simultáneo, por lo que la pena de prisión cuando se accediera a la libertad condicional y la libertad vigilada, se cumplirían simultáneamente, dando lugar a un nuevo régimen de cumplimiento en libertad, que implicaría una adición la libertad vigilada al ya previsto para la libertad condicional, pues de otro modo no se comprende qué quiso decir el

\footnotetext{
900 Expresa el informe del CGPJ que: “Aunque el art. 49 bis) 4 según el Anteproyecto de 2008 prevé que las circunstancias sobre la ejecución de esta pena, más allá de las señaladas en el propio artículo, se desarrollarán reglamentariamente, el análisis técnico de la misma padece insuficiencias esenciales, si, como es el caso, la reforma penal no viene acompañada de las concretas y simultáneas reformas reglamentarias (o en el propio Código Penal) sobre el cumplimiento de esta pena. En consecuencia, el informe no puede prescindir de referirse a los requisitos básicos de la ejecución de esta pena, pese a la remisión contenida en el Anteproyecto de 2008 a una futura regulación reglamentaria. El art. 49 bis) 4 es, pues, el primer objeto de análisis crítico, precisamente por no ir acompañado de estas normas esenciales para el análisis de la pena de libertad vigilada y no prever, tampoco, aspectos esenciales de la ejecución de esta pena en el propio Anteproyecto. En efecto, en el Anteproyecto de 2008 la libertad vigilada se configura como una pena que se impone en la sentencia como accesoria de la privativa de libertad, cuya duración puede alcanzar veinte años, cuyo cumplimiento es posterior al de la pena de prisión, y cuyo contenido tiene que ser determinado por el Juez de Vigilancia Penitenciaria tras el cumplimiento de la pena de prisión".

901 Sigue diciendo el informe: “De acuerdo con nuestra legislación penitenciaria, la libertad vigilada está, pues, llamada a ejecutarse después de la fase de libertad condicional de cumplimiento de la pena de prisión, o bien después de una pena de prisión cumplida de modo excepcional sin acceso a la libertad condicional, pero sometida, en todo caso, al sistema de progresión en el grado en cuanto al régimen de cumplimiento. Progresión que, según la legislación penitenciaria, depende fundamentalmente de la evolución periódicamente revisada por la Administración penitenciaria de los efectos del tratamiento penitenciario individualizado. Teniendo esto en cuenta, sería incompatible con el régimen progresivo penitenciario, que se basa en el modelo constitucional diseñado en el art. 25.1 de la Constitución, que la libertad vigilada pudiese suponer una obligación legal para el Juez de Vigilancia Penitenciaria de imponer al penado un retroceso con respecto al régimen de cumplimiento de la pena de prisión en libertad condicional, en caso de que el condenado haya accedido al mismo, es decir, un viaje hacia un régimen más restrictivo que ésta o, incluso, más restrictivo que el tercer grado penitenciario. En suma, la libertad vigilada tiene que cumplirse de forma compatible en cuanto a las obligaciones que impone al condenado con el sistema progresivo de cumplimiento de las penas de prisión. Así pues, allí donde el progreso individual del sujeto le haya hecho merecedor de la libertad condicional o del tercer grado penitenciario, la libertad vigilada no debería poder ser más gravosa que éstos, si no concurren nuevos elementos de juicio que acrediten la necesidad de un régimen más restrictivo debido a un juicio de peligrosidad inexistente en las fases previas de cumplimiento de la pena de prisión."
} 
legislador en la Exposición de Motivos del Anteproyecto con eso de "cumplimiento sucesivo y simultáneo".

En cuanto a la segunda de las cuestiones que merecen especial atención sobre el informe, efectúa el Consejo un razonamiento interesante en relación a la prescripción de la pena de libertad vigilada. En efecto, el CGPJ manifiesta que el régimen de prescripción para las penas accesorias no contempla ninguna especialidad en materia de libertad vigilada, por lo que, atendiendo a la norma general, a los diez años prescriben las penas accesorias que acompañan a penas graves, y a los cinco años prescriben las accesorias que acompañan a delitos menos graves. Con esta observación, advierte el Consejo que en determinados delitos que lleven aparejada la pena accesoria de libertad vigilada, tal y como venía formulada en dicho Anteproyecto, dicha pena estaría prescrita en el momento en que tuviera que empezar a ejecutarse ${ }^{902}$, por lo que debería crearse una regulación específica que alterase la norma general de prescripción de las penas en relación a la libertad vigilada, precisamente para evitar que en el momento en que deba empezar a cumplirse, nos encontremos con la imposibilidad de ejecutarla por encontrarse ya prescrita.

\section{g) El Dictamen del Consejo de Estado, de 29 de octubre de 2009}

El Consejo de Estado, en su dictamen de 29 de octubre de 2009, vino a argumentar, en relación las dudas constitucionales que se planteaban en cuanto a la acumulación de penas y medidas de seguridad para los imputables peligrosos y sus posibles excesos de duración total resultantes de la acumulación de penas largas de prisión con libertad vigilada posterior, que el Tribunal Constitucional, en su STC 136/1999, ya señaló que la

\footnotetext{
902 El informe expresa lo siguiente: “Ha de observarse que el régimen general de prescripción de las penas accesorias puede ser inadecuado para la pena de libertad vigilada. La reforma no contempla ninguna previsión específica a este respecto, por lo que serán de aplicación los plazos de diez años previstos para las restantes penas graves y de cinco años para las penas menos graves. Consecuentemente, para un delito al que se impusiera una pena de 10 a 12 años de prisión, como por ejemplo de violación (art. 179), debido a que el inicio del cómputo del plazo de prescripción se produce desde la firmeza de la sentencia, la pena de libertad vigilada habría prescrito en el momento de comenzar su ejecución. Por tal motivo, habría que contemplar una excepción a la regla según la cual el cómputo de la prescripción de las penas accesorias se corresponde con el de la pena principal. Al ser el fundamento de esta nueva pena un juicio de peligrosidad más propio de una medida de seguridad que de una pena, puede adoptarse la fórmula prevista en el artículo 135.3, según el cual "si el cumplimiento de una medida de seguridad fuere posterior al de una pena, el plazo se computará desde la extinción de ésta", lo que incluye la extinción de la pena de prisión por prescripción, por lo que existiendo un pronóstico de peligrosidad del penado que determine la necesidad de la pena de libertad vigilada, el dies a quo del plazo de prescripción de esta pena sería la fecha de prescripción de la pena privativa de libertad".
} 
valoración de la proporcionalidad sobre la cantidad y calidad de la pena en relación con el tipo de conducta delictiva, debe partir de que es potestad exclusiva del legislador la configuración de cuáles son los bienes que son merecedores de tutela penal, y cuáles son los comportamientos que van a ser penalmente relevantes a efectos de su persecución, así como las clases de sanciones que se les asocia y su extensión, para evitar que esos comportamientos se produzcan. El legislador, por su parte, para ejercitar esa potestad en la configuración del ius puniendi, está dotado de amplios márgenes de libertad que derivan de su legitimidad democrática y de su posición constitucional. Esos márgenes de libertad, encuentran su único límite en el respeto al marco constitucional, por lo que "la relación de proporción que deba guardar un comportamiento penalmente típico con la sanción que se le asigna será el fruto de un complejo juicio de oportunidad", y para el que "ha de atender no solo al fin esencial y directo de protección al que responde la norma, sino también a otros fines legítimos que pueda perseguir con la pena"903.

\section{h) El Anteproyecto de reforma del CP, de 23 de julio de 2009}

En fecha 23 de julio de 2009, coincidiendo con el cambio de titularidad de Ministerio de Justicia ${ }^{904}$, se publicó un nuevo Anteproyecto en el que cambió radicalmente la regulación de la libertad vigilada. Se planteó esta vez como una medida de seguridad ${ }^{905}$ y no como una pena accesoria906, con lo que cambió por completo el concepto, la finalidad, la ubicación sistemática en el Código, su ejecución y, en definitiva, su íntegra formulación. No considero necesario analizar en profundidad este Anteproyecto porque en fecha 27 de noviembre de 2009 se publicó el Proyecto de Reforma del CP —del que me ocupo en el apartado siguiente- que en relación a la libertad vigilada vino a trasponer de forma prácticamente idéntica el texto del referido Anteproyecto.

No obstante, conviene que nos detengamos brevemente a analizar las razones del cambio que supuso este Anteproyecto, que fue decisivo para la reformulación de la

\footnotetext{
903 Las frases entre comillas son citas textuales que el Dictamen transcribe del fundamenteo jurídico 23 de la STC 136/1999.

904 Tras la dimisión del Ministro de Justicia Mariano Fernández Bermejo en febrero de 2009, ocupó el cargo Antonio Caamaño, que hasta entonces había sido Secretario de Asuntos Constitucionales y Parlamentarios del Gobierno de PSOE, quien mantuvo la titularidad del Ministerio hasta el final de la legislatura en noviembre de 2011.

905 GARCÍA RIVAS, N., “La libertad vigilada...”, cit. pp. 9 y 10.

906 CÁMARA ARROYO, S., “La libertad vigilada...”, cit. p. 9.
} 
libertad vigilada no como pena sino como medida de seguridad, que son las que enumera SIERRA LÓPEZ, diciendo que, en primer lugar, al tratarse de una pena accesoria que no se cumplía del mismo modo que el resto de penas accesorias (cumplimiento simultáneo a la pena principal) se tendría que haber ideado un régimen especial de cumplimiento; en segundo lugar, también en la determinación del tiempo de duración de la pena accesoria se debería haber establecido un régimen especial, debido a que su concreción no se basaba en la misma duración que la pena principal como sucede en las penas accesorias, sino que se basaba en la peligrosidad y no existía criterio alguno en ese sentido; en tercer lugar, se generaba una antinomia en el propio sistema penal, ya que era una pena que no descansaba sobre el presupuesto de la culpabilidad como en el resto de penas sino en el de la peligrosidad como en las medidas de seguridad; y en cuarto lugar, dicha formulación necesitaba también cambios en materia de prescripción de las penas, ya que al ser de cumplimiento posterior a la pena principal, llegado el momento de ejecutarse, la pena estaría ya prescrita y, para evitarlo, se tendría que haber aplicado el régimen de prescripción de las medidas de seguridad, aspecto que no se encontraba en sintonía con el resto del sistema907.

\section{i) El proyecto de Ley 121/52, de 27 de noviembre de 2009}

Como se ha dicho, la formulación de la libertad vigilada en este proyecto fue como medida de seguridad ${ }^{908}$, aplicable por un lado a sujetos que presenten -en mayor o menor medida - una merma en su imputabilidad, y también a terroristas y delincuentes sexuales. En el presente apartado se analiza la tramitación parlamentaria del Proyecto, analizando las enmiendas que se presentaron en el Congreso de los Diputados, así como en el Senado, hasta llegar al texto que finalmente se aprobó.

\section{La tramitación en el Congreso de los Diputados}

El Proyecto de Ley 121/52, fue presentado por el Gobierno, a través de la Comisión de Justicia, en fecha 19 de noviembre de 2009, y calificado en fecha 24 de noviembre de 2009, siendo la fecha de su publicación el 27 de noviembre de 2009. Fueron ponentes Rosa María Díez González, Jordi Jané i Guasch, Carmen Juanes Barciela, Dolors Montserrat

\footnotetext{
907 SIERRA LÓPEZ, M.V., La medida de libertad vigilada..., cit. pp. 108 y 109.

908 CÁMARA ARROYO, S., “La libertad vigilada...”, cit. pp. 9 y 10.
} 
Montserrat, Emilio Olabarría Muñoz, Joan Ridao i Martín, Àlex Sáez Jubero, Federico Trillo-Figueroa Martínez-Conde y Julio Villarrubia Mediavilla.

\section{a) La publicación del proyecto}

El texto se publicó en el Boletín Oficial de las Cortes Generales, Congreso de los Diputados, serie A, núm. 52-1, de 27/11/2009, y la Exposición de Motivos refería a la libertad vigilada manifestando que en el ordenamiento español la rehabilitación y la reinserción social constituyen el objetivo prioritario del sistema de penas y, sobre todo, de la pena privativa de libertad, pero que ante determinados perfiles criminológicos que se resisten a ese efecto rehabilitador, la pena resulta insuficiente para excluir el riesgo de reincidencia, que puede derivarse de trastornos de la personalidad o de la conducta que se aprecia con claridad en los delitos sexuales, o por ideología como en los terroristas. El texto hablaba que de que la inocuización consistente en la prolongación ilimitada de la privación de libertad sería contraria a los principios constitucionales que rigen nuestro sistema penal (proporcionalidad, reinserción, etc.), pero por otra parte, reconoce que el catálogo de sanciones penales que contiene el $\mathrm{CP}$, cuando se trata de conductas como las descritas, son marcadamente elevadas $\mathrm{y}$, en ocasiones, sujetas a supuestos de cumplimiento íntegro que, en consecuencia, se traducen en resultados prácticos muy próximos a la cadena perpetua. Por ese motivo, resulta necesario optar por otras soluciones para conciliar la rehabilitación del delincuente con otros valores como la seguridad y la libertad del resto de personas que se convierten en potenciales víctimas del condenado que retorna a la sociedad. El texto dice que "agotada, pues, en estos casos, la dimensión retributiva de la pena, la peligrosidad subsistente del sujeto halla su respuesta idónea en la medida de seguridad, institución que tiene por objeto en nuestro ordenamiento tradicional el tratamiento de las personas peligrosas, que han acreditado tal condición mediante la efectiva realización de un hecho delictivo".

Por ese motivo, se introduce una nueva medida bajo el nombre de libertad vigilada cuyo contenido aglutina otras medidas ya previstas en el $\mathrm{CP}$, que se integran y se refunden en ese concepto común ${ }^{909}$. De ese modo, la libertad vigilada se impone, de manera facultativa o preceptiva - según los casos- y cuyo contenido se concreta en una

\footnotetext{
909 Autores como MAPELLI CAFFARENA, B., Las consecuencias..., cit. p. 377, refieren por este motivo a la libertad vigilada como una "macromedida".
} 
serie de limitaciones, obligaciones, prohibiciones o reglas de conducta, aplicables separada o conjuntamente, y que puede modificarse atendiendo a la evolución del sujeto mediante un procedimiento en el que se refuerza la garantía de contradicción extendiéndola a las víctimas aunque no sean parte en el proceso. Lo novedoso de esta medida es que no solo se aplica a supuestos de inimputabilidad y semiimputabilidad, sino también cuando la peligrosidad deriva del perfil de personalidad del sujeto o de la naturaleza del hecho cometido, lo que deberá venir previsto en cada figura penal expresamente. En estos casos la medida se impone en sentencia junto a la pena privativa de libertad para su ejecución posterior a la pena en función del pronóstico de peligrosidad.

En la concreción del contenido de la libertad vigilada y en su ejecución a los efectos de acordar la sustitución, modificación, suspensión o cesación, intervienen el JVP, los servicios penitenciarios y el Juez o Tribunal sentenciador, debido a que este último conoce las circunstancias del caso y puede ser relevante para la elección de las medidas en que se concreta la libertad vigilada. Su duración, será de un máximo de cinco años pero en la modalidad postpenitenciara puede llegar a los diez años para los delitos sexuales y de terrorismo.

Ya en el desarrollo del articulado, el aparatado Decimonoveno del Proyecto, modificaba el art. 97 CP, que disponía que durante la ejecución de la sentencia, el Juez o Tribunal tendrá que adoptar a través del procedimiento previsto en el art. $98 \mathrm{CP}$, alguna de las decisiones posibles enumeradas en el propio precepto, consistentes en el mantenimiento de la medida de seguridad impuesta, en el cese de la misma por desaparición de la peligrosidad, en la sustitución de una medida de seguridad por otra que el Tribunal considere más adecuada para los fines pretendidos, siempre que esté prevista su aplicación al supuesto concreto de que se trate, con la salvedad de que esta sustitución podrá ser revocada y regresar a la aplicación de la medida sustituida si la evolución no fuera favorable. Y por último, el Tribunal podrá decidir si deja la medida en suspenso, esto es, si suspende su ejecución por un plazo no superior al que reste por cumplir según el contenido de la sentencia, con la condición de que no delinca durante el plazo de suspensión y con la salvedad de que podrá revertirse la suspensión si se dan las circunstancias del art. $95 \mathrm{CP}$ que son las que, con carácter general, describen la peligrosidad criminal. 
El apartado vigésimo del Proyecto, modificaba el art. $98 \mathrm{CP}$, imponía una obligación al JVP de elevar, con frecuencia anual como mínimo, una propuesta de mantenimiento, cese, sustitución o suspensión de la medida, basada en los informes emitidos por los facultativos y profesionales que asistan al sometido a la medida de seguridad o por las Administraciones Públicas competentes y, en su caso, en el resultado de las demás actuaciones que para ese cometido pudiese acordar el propio JVP. Con esa propuesta, el Juez o Tribunal sentenciador, emitiría su resolución, de forma motivada y previa audiencia del sometido a la medida y del Ministerio Fiscal, así como de las demás partes $\mathrm{y}$, en especial, de las víctimas que lo hubieran solicitado en cualquier momento de la ejecución de la sentencia, siempre que permanezcan localizables para evacuar dicho trámite.

El apartado vigésimo segundo del Proyecto, modificaba el art. $96 \mathrm{CP}$, de forma que la libertad vigilada quedaba dentro del catálogo de las medidas no privativas de libertad; y el apartado vigésimo tercero, modificaba el art. $105 \mathrm{CP}$, que disponía que en los casos previstos en los arts. 101 a $104 \mathrm{CP}$ (que son los que con carácter general regulan la imposición de medidas de seguridad privativas de libertad) cuando imponga la medida privativa de libertad o durante la ejecución de la misma, el Juez o Tribunal podrá imponer, de forma razonada, una o varias medidas de las que enumera el precepto $y$, además, necesariamente deberá imponer alguna de ellas en los casos expresamente previstos en el código. En ese orden de cosas, la previsión era que por un tiempo no superior a cinco años, se podría imponer libertad vigilada o custodia familiar, y por un tiempo de hasta diez años, libertad vigilada, cuando expresamente lo dispusiera el código, la privación del derecho a la tenencia y porte de armas, y la privación del derecho a conducir vehículos a motor y ciclomotores. El propio precepto aclaraba que para decretar estas medidas o para concretar dicha obligación cuando por ley viene obligado a imponerlas, el Juez o Tribunal sentenciador estaría obligado a basar su decisión en los informes de los facultativos y profesionales encargados de asistir al sometido a la medida, y tanto el JVP como los servicios de la Administración correspondiente, deberán informar al Tribunal en ese sentido. Por último, el precepto decía que para todos estos supuestos, el Tribunal dispondría la ayuda necesaria y atención al sometido a la medida de los servicios sociales competentes. 
El apartado vigésimo cuarto del Proyecto modificaba el art. 106 CP, cuya redacción venía a decir que la libertad vigilada consistirá en el sometimiento del condenado a control judicial a través del cumplimiento por su parte de alguna o algunas de las siguientes medidas: la obligación de estar siempre localizable mediante aparatos electrónicos que permitan su seguimiento permanente, la obligación de presentarse periódicamente en el lugar que el Juez o Tribunal establezca, la de comunicar inmediatamente, en el plazo máximo y por el medio que el Juez o Tribunal señale a tal efecto, cada cambio del lugar de residencia o del lugar o puesto de trabajo, la prohibición de ausentarse del lugar donde resida o de un determinado territorio sin autorización del Juez o Tribunal, la prohibición de aproximarse a la víctima, o a aquellos de sus familiares $\mathrm{u}$ otras personas que determine el Juez o Tribunal, la prohibición de comunicarse con la víctima, o con aquellos de sus familiares $u$ otras personas que determine el Juez o Tribunal, la prohibición de acudir a determinados territorios, lugares o establecimientos, la prohibición de residir en determinados lugares, la prohibición de desempeñar determinadas actividades que puedan ofrecerle o facilitarle la ocasión para cometer hechos delictivos de similar naturaleza, la obligación de participar en programas formativos, laborales, culturales, de educación sexual u otros similares, la obligación de seguir tratamiento médico externo, o de someterse a un control médico periódico ${ }^{910}$.

910 Los apartados 2, 3 y 4 del art. 106 CP quedaron redactados como sigue: “2. Sin perjuicio de lo dispuesto en el art. 105, el Juez o Tribunal deberá imponer en la sentencia la medida de libertad vigilada para su cumplimiento posterior a la pena privativa de libertad impuesta siempre que así lo disponga de manera expresa este Código. En estos casos, con anterioridad suficiente a la extinción de la pena privativa de libertad, de modo que la medida de libertad vigilada pueda iniciarse en ese mismo momento, el Juez de Vigilancia Penitenciaria, por el procedimiento previsto en el art. 98, elevará la oportuna propuesta al Juez o Tribunal sentenciador, que, con arreglo a dicho procedimiento, concretará, sin perjuicio de lo establecido en el art. 97, el contenido de la medida fijando las obligaciones o prohibiciones enumeradas en el apartado 1 de este artículo que habrá de observar el condenado. Si éste lo hubiera sido a varias penas privativas de libertad que deba cumplir sucesivamente, lo dispuesto en el párrafo anterior se entenderá referido al momento en que concluya el cumplimiento de todas ellas. Asimismo, el penado a quien se hubiere impuesto por diversos delitos otras tantas medidas de libertad vigilada que, dado el contenido de las obligaciones o prohibiciones establecidas, no pudieran ser ejecutadas simultáneamente, las cumplirá de manera sucesiva, sin perjuicio de que el Juez o Tribunal pueda ejercer las facultades que le atribuye el apartado siguiente. 3. Por el mismo procedimiento del art. 98, el Juez o Tribunal podrá: a) Modificar en lo sucesivo las obligaciones y prohibiciones impuestas. b) Reducir la duración de la libertad vigilada o incluso poner fin a la misma en vista del pronóstico positivo de reinserción que considere innecesaria o contraproducente la continuidad de las obligaciones o prohibiciones impuestas. c) Dejar sin efecto la medida cuando la circunstancia descrita en la letra anterior se dé en el momento de concreción de las medidas que se regula en el número 4 del presente artículo. 4 . En caso de incumplimiento de una o varias obligaciones el Juez o Tribunal, a vista de las circunstancias concurrentes y por el mismo procedimiento indicado en los números anteriores, podrá modificar las obligaciones o prohibiciones impuestas. Si el incumplimiento fuera reiterado o grave, revelador de la voluntad de no someterse a las obligaciones o prohibiciones impuestas, el Juez deducirá, además, testimonio por un presunto delito del art. 468 de este Código". 
El apartado vigésimo quinto del Proyecto modificaba el apartado 3 del art. 100 CP, y disponía que en los casos de incumplimiento, el Juez o Tribunal deberá deducir testimonio por quebrantamiento de condena, excluyendo expresamente la negativa del sujeto a someterse a tratamiento médico o a continuar el ya iniciado e inicialmente consentido, con la especialidad de que el Juez o Tribunal tendrá la facultad de sustituir el tratamiento inicial consentido o el posteriormente rechazado, por otra medida de entre las aplicables a ese supuesto concreto.

El apartado cuadragésimo quinto del Proyecto, modificaba los apartados 1 y 2 del art. 192, que pasaban a ser los apartados 2 y 3 del mismo artículo, y se modificaban los apartados 1 y 3, que disponían que a los condenados a pena de prisión por uno o más delitos comprendidos en el mismo título del código, se les impondrá además la medida de libertad vigilada, cuya ejecución se llevaría a cabo después de la pena privativa de libertad, con una duración de cinco a diez años si alguno de los delitos fuera grave, y de uno a cinco años si se trata de uno o más delitos menos graves. Si es un solo delito y además es delincuente primario, el Tribunal podrá imponer o no la medida de libertad vigilada en atención a la menor peligrosidad.

El apartado centésimo vigésimo noveno del Proyecto, modificaba el art. 579 CP, y en su apartado 3, refería a la libertad vigilada en el sentido de que a los condenados a pena grave privativa de libertad por uno o más delitos de los previstos en el mismo capítulo del código, se les impondrá además la medida de libertad vigilada de cinco a diez años, y de uno a cinco años si la pena privativa de libertad fuera menos grave, con la salvedad de que si se trata de un solo delito que no sea grave y además el delincuente es primario, el Tribunal podrá imponer o no la medida de libertad vigilada en atención a la menor peligrosidad del sujeto.

\section{b) La fase de enmiendas}

La fase de enmiendas ${ }^{911}$ se vio sometida a varias ampliaciones de plazo para su presentación por los distintos Grupos Parlamentarios, ante la multitud de enmiendas que

\footnotetext{
911 Comisión de Justicia, Enmiendas, desde el 27/11/2009 hasta el 10/03/2010.
} 
se estaban preparando para ser presentadas. Así, se hicieron siete ampliaciones de plazo $^{912}$. Finalmente se presentaron las enmiendas que se relacionan a continuación.

\author{
1) Enmiendas a la totalidad913.
}

\title{
1. Por el Grupo Parlamentario Mixto, se presentó una enmienda a la totalidad
} (enmienda núm. 2), en la que, en esencia, se decía que la actual reforma responde a convulsiones de la sociedad derivadas de los graves acontecimientos de los últimos tiempos que no reflejan la realidad de la criminalidad de España, y que se trata de una forma de legislar que imposibilita el fin constitucional de reinserción, al tiempo que recuerda que España tiene uno de los índices más altos de presos de toda Europa'14.

912 BOCG, Congreso de los Diputados, núm. A-52-2 de 16/12/2009, ampliación del plazo de enmiendas;
BOCG, Congreso de los Diputados, núm. A-52-3 de 23/12/2009, ampliación del plazo de enmiendas; BOCG,
Congreso de los Diputados, núm. A-52-4 de 03/02/2010, ampliación del plazo de enmiendas; BOCG,
Congreso de los Diputados, núm. A-52-5 de 10/02/2010, ampliación del plazo de enmiendas; BOCG,
Congreso de los Diputados, núm. A-52-6 de 17/02/2010 ampliación del plazo de enmiendas; BOCG,
Congreso de los Diputados, núm. A-52-7 de 24/02/2010, ampliación del plazo de enmiendas; BOCG,
Congreso de los Diputados, núm. A-52-8 de 03/03/2010, ampliación del plazo de enmiendas. 913 De las enmiendas a la totalidad presentadas, destacaremos únicamente el contenido que alude a la libertad vigilada, por lo que el texto íntegro de las enmiendas puede consultarse en el BOCG, Congreso de los Diputados, núm. A-52-9 de 18/03/2010. Enmiendas e índice de enmiendas al articulado.

914 El BNG no discute la necesidad de acometer modificaciones en el Código Penal derivadas de compromisos internacionales asumidos por el Estado Español -decisiones marco europeas, convenios internacionales- y que se hallaban pendientes de transposición al ordenamiento interno, como el decomiso de los productos, instrumentos y bienes relacionados con el delito, ataques a los sistemas de información, corrupción en el sector privado, corrupción en la que estén implicados funcionarios comunitarios o de Estados miembros, delitos cometidos en conflictos armados, piratería, ni tampoco la necesidad de introducir otras reformas relevantes y debatidas doctrinalmente, como el cómputo de la prescripción delictiva, responsabilidad penal de las personas jurídicas, pena de privación de la patria potestad. Lo que resulta cuestionable es que se aborde un conglomerado de reformas que, presentadas bajo el paraguas de la mutabilidad de la realidad social, responden en definitiva a graves y recientes acontecimientos que han producido una gran conmoción social, reformas, entre otras, como la nueva pena accesoria de libertad vigilada y el endurecimiento de la represión de ciertos delitos. Lo cierto es que resulta muy peligroso legislar según las convulsiones de la sociedad o la atención de los medios de comunicación y sin una reflexión suficiente. Una actitud que se erige abiertamente en motivación de partes fundamentales de la reforma tal y como se reconoce en la Exposición de Motivos del Proyecto, consolidando una preocupante tendencia al endurecimiento punitivo, por cuanto las penas privativas de libertad asignadas a muchas infracciones resultan ser, comparativamente, gravísimas. En este proyecto de ley volvemos a comprobar la pretensión, reiterada en los últimos años en las diversas reformas de la legislación penal, de resolver cualquier tipo de conflicto acudiendo al Código Penal, convirtiendo este instrumento que, por su especial naturaleza, debería ser el último recurso a emplear, en la regla, de manera que cualquier altercado o irregularidad que uno pueda imaginar -sea en el ámbito doméstico, escolar, laboral, periodístico, en Internet, etc.- tiene a la vista una imputación penal. El proyecto de reforma del Código Penal, especialmente con la regulación de la libertad vigilada y el endurecimiento de las penas, cuestiona abiertamente el artículo 25.2 de la Constitución, que establece la reinserción del penado como objetivo de la pena, y la doctrina del Tribunal Constitucional, que considera que la preparación para la libertad de un penado es un supuesto irrenunciable. Se ha abordado esta reforma aprovechando las presiones mediáticas que están conformando una opinión pública errónea en torno a la criminalidad y la seguridad ciudadana, que no se corresponde con la realidad de nuestra situación criminológica, así, debemos recordar que el Estado Español tiene el dudoso honor de tener uno de los porcentajes de presos más altos de Europa (164 presos por cada 100.000 habitantes, mientras que la media europea es de 63 por cada 100.000), sin embargo, en el Estado 
2. Por el Grupo Parlamentario Vasco (EAJ-PNV) se presentó una enmienda a la totalidad (enmienda núm. 3), basada en que la imposición de medidas de seguridad tras la pena privativa de libertad, consolidaba la prisión perpetua ${ }^{915}$.

\section{Por el Grupo Parlamentario de Esquerra Republicana-Izquierda} Unida-Iniciativa per Catalunya-Verds, se presentó la enmienda núm. 4, que está separada en dos motivaciones de distintos intervinientes: la de la componente de Esquerra Republicana de Catalunya del Grupo Parlamentario de ERC-IU-IC, por la que se justificaba la enmienda a la totalidad del proyecto basándose en el rechazo al incremento punitivo que suponía la reforma. Con datos de estadísticas de distintos países

Español la tasa de criminalidad es del 47,6 por 100.000 habitantes, muy lejos de la europea $(70,4)$ y mucho más lejos aún de otros Estados como Reino Unido $(101,6)$ o Alemania $(76,3)$ que pasan por ser más duros que el Estado Español en la represión de la delincuencia. Parece, delante de estos datos, que el endurecimiento de las penas, y el establecimiento de penas accesorias como la libertad vigilada no es la solución más idónea y urgente. Pues bien, la reforma que se nos propone lejos de corregir la evidente contradicción que supone que el porcentaje de población reclusa en el Estado Español sea de los más altos de Europa cuando su tasa de criminalidad es de las más bajas, se vuelve a olvidar de que las causas de la criminalidad no radican sólo en la voluntad del individuo aislado en cuanto delincuente, sino también en las condiciones y circunstancias que le rodean. El Derecho penal es necesario para la convivencia, pero para que no se convierta en un instrumento ilegítimo e ineficaz, requiere para su modificación no sólo que se abandonen las presiones mediáticas, sino que se piense en términos de eficacia preventiva compatible con el respeto a los derechos fundamentales de todos los seres humanos, víctimas y delincuentes. Por consiguiente, las reformas penales tendentes a un endurecimiento de las penas deben realizarse de forma sosegada y analizando desde una perspectiva criminológica todas las circunstancias que rodean el tipo delictivo, ya que en caso contrario estaríamos provocando situaciones que impedirían la reeducación y reinserción social a la que un gran número de condenados estarían en condiciones objetivas de acceder, además de vulnerar lo establecido en el artículo 25.2 de la Constitución, que declara que "las penas privativas de libertad y las medidas de seguridad estarán orientadas hacia la reeducación y reinserción social...". De lo que se trata, más que de defender un endurecimiento de las penas o de un cumplimiento íntegro de las mismas que no atienda a las circunstancias particulares del delincuente, es de conseguir que la Administración de Justicia actúe con diligencia en los trámites judiciales. Lo que se debe abordar es el establecimiento de medidas que solucionen la ineficacia de la Administración de Justicia que provoca, en no pocas ocasiones un incumplimiento de las sentencias, esa es la cuestión que debe tratarse y no la supresión de beneficios penitenciarios a los delincuentes, o el endurecimiento de las penas. El debate sobre el tratamiento penal de la delincuencia es otro, y debería abordarse teniendo en cuenta que cualquier solución que se proponga es absurda si el sistema judicial no es capaz de aplicarla. Numerosos expertos han abogado por la defensa de un modelo de derecho penal que se aparta radicalmente del modelo que defiende esta reforma, basada exclusivamente en aspectos punitivos y retributivos, ese otro derecho penal que el BNG también defiende es el que debería servir de inspiración a la reforma del Código Penal, un Derecho Penal basado en la satisfacción a las víctimas mediante una justicia restaurativa, la mejora de la eficacia real de la Administración de Justicia, la creación de una cultura de derecho penal mínimo, la Apuesta por el fin reeducativo y reinsertador de las penas privativas de libertad, la creación de instrumentos de justicia social, también para la prevención de los delitos y por la humanización de la vida en la cárcel; en definitiva, por lo que Filangieri definió, hace ya dos siglos, como objetivo irrenunciable para la mejora social: la superación de un sistema punitivo confesional en las prohibiciones, feroz en los castigos, vejatorio en las imputaciones, arbitrario en las decisiones. Por todas estas razones, el BNG defiende la devolución del presente proyecto de Ley al Gobierno".

915 Justificación: “El Proyecto de Ley Orgánica por la que se modifica la Ley Orgánica 10/1995, de 23 de noviembre, del Código Penal, se funda en el mito de un pretendido Sistema Penal español benevolente, cuando de hecho es el más represivo de Europa. La condena a prisión perpetua no existe en el Estado español, aunque existen de hecho condenas a prisión perpetua, en algunos casos, por la imposibilidad de su revisión, y en otros casos, porque la reforma introduce medidas de seguridad vigilada o medidas de libertad vigilada posterior a la pena que consolidan la prisión perpetua, soslayando de forma dudosamente constitucional, el dilema de si resulta legítimo imponer medidas a personas imputables que ya han liquidado su condena". 
de Europa, se ponía de manifiesto una de las realidades más contradictorias de la criminalidad en España, que con uno de los índices más altos de población penitenciaria, España tiene uno de los índices de criminalidad más bajos de Europa ${ }^{916}$. La segunda parte de la enmienda es la motivación de la componente de Izquierda Unida-Iniciativa per Catalunya Verds del Grupo Parlamentario de ERC-IU-ICV, que incide en la motivación efectuada por la anterior justificación de datos de criminalidad, incremento de población penitenciaria y recalca la idea de que no está justificado el incremento punitivo como solución a los conflictos sociales. También denuncia la perniciosa utilización del término "seguridad" creando una artificial sensación subjetiva de inseguridad en un país donde la violencia y la inseguridad son realmente bajas ${ }^{917}$.

916 “Contrariamente (a lo que se puede pensar) el Estado Español presenta una de las tasas más alta de población reclusa de Europa y unos de los índices de criminalidad más bajos. Según el Ministerio del Interior, la tasa de criminalidad en España entre julio de 2008 y junio de 2009 fue de 47 delitos por cada mil habitantes, muy inferior a la media europea $(70,4)$, sólo por encima de Grecia, Portugal e Irlanda, y lejos de Francia $(57,5)$, Alemania (76,3) o Gran Bretaña $(101,6)$. Además desde hace 20 años que la línea de criminalidad es descendente en el Estado Español. Estas cifras se compadecen poco con el hecho de que los 87 centros penitenciarios del Estado albergan hoy a 76.000 internos frente a los 33.000 de 1990: un incremento del 130 por ciento en los últimos veinte años, cuando el aumento de la población española ha sido del 20 por ciento, de los 38,8 millones de habitantes de 1991 a los 46,7 en 2009, según el instituto Nacional de Estadística. A pesar de estos datos tan significativos, el 90 por 100 de los ciudadanos creen que el Estado Español es cada vez más peligroso, debido entre otros motivos a la incertidumbre derivada de la crisis económica, por la alarma de determinados episodios criminales o por el fenómeno de la multirreincidencia. La comparación con Europa es igual de llamativa: según el Centro Internacional de Estudios Penitenciarios del King's College, si en España hay 160 presos por cada cien mil habitantes, en Italia -con más de 59 millones de habitantes- hay 92, en Francia -más de 62 millones de población- 96 y en Alemania -82 millones- sólo 89. Esta situación se explica porque el Código Penal de 1995 supuso un grave endurecimiento del sistema punitivo debido al el aumento de la duración de las condenas de prisión, consecuencia, entre otras razones, de la eliminación de la redención de penas por trabajo, sin que se hubiere procedido a una disminución equivalente de las penas. De tal manera que, como muestran las estadísticas del Consejo de Europa, el Estado español se sitúa entre los Estados de la Unión Europea en que el periodo medio de estancia en la cárcel es mayor (13 meses, frente a 8 en la Unión Europea.) Esta misma tendencia de endurecimiento de las penas se ha mantenido también en las posteriores reformas del Código Penal efectuadas en el año 2003, de tal forma que la libertad condicional es más difícil de obtener. En resumen, cada vez entran más presos y salen menos. Además todo ello tiene un elevado coste para la sociedad, pues con normas penales más duras no se resuelven los problemas y por contra se está dando una falsa imagen de seguridad".

917 “La evolución de la delincuencia común en España, analizada en la década de 1998 a 2008, muestra una tendencia cercana al estancamiento, con una ligera tasa descendente, simultánea a un incremento sustancial del grado de denuncias de los delitos perpetrados. La evolución de la población reclusa, también en este periodo, refleja un incremento constante, hasta el punto de situar a España entre los países europeos con una de las mayores tasas de población reclusa por habitante. En los últimos años se viene produciendo un incremento promedio de 3.000 reclusos anuales. Los anteriores datos muestran que España tiene una tasa de delincuencia comparativamente baja y, sin embargo, es uno de los países de Europa con mayor número de personas encarceladas, lo que debería llevar a una reflexión y revisión en profundidad sobre las últimas reformas del Código Penal, que ya desde su misma aprobación ha favorecido esta tendencia al incremento de las personas reclusas sin responder a un incremento de la delincuencia. Por ello puede afirmarse que se ha creado de forma irresponsable y artificial una sensación subjetiva de inseguridad ciudadana que en nada se corresponde con la realidad, pues España, en el marco de la Unión Europea, es un país de violencia e inseguridad ciudadana realmente baja. En virtud de esta situación, carece de justificación una reforma que mantiene, en términos generales, el agravamiento, provocado por las reformas anteriores, de determinadas penas y en la criminalización de conductas o comportamientos que deberían tener un tratamiento administrativo o civil. A ello se suma la constatación de la desproporción entre el tratamiento dado a delitos 
2) Enmiendas parciales.

De todas las de enmiendas parciales que se presentaron al Proyecto, por razones obvias, únicamente se relacionan las que afectan a la libertad vigilada, que son las siguientes:

$1^{\circ}$. Enmiendas al apartado vigésimo del artículo único del Proyecto, que modifica el art. 98 $C P$.

\section{Por el Grupo Parlamentario Esquerra Republicana-Izquierda Unida-Iniciativa}

per Catalunya-Verds, se presentó la enmienda núm. 16, por la que se proponía la eliminación del apartado vigésimo del art. único del Proyecto, que modificaba el art. 98918. Este Grupo parlamentario ponía de manifiesto que el CP de 1995 cerró el debate sobre monismo y dualismo, y optó por no imponer medidas de seguridad a imputables, por lo

comunes y menos graves, en comparación con los delitos de guante blanco, incidiendo así en los resultados injustos de la denunciada ausencia de una verdadera política criminal. Parece que, como consecuencia de la percepción social de la delincuencia y del irreal tratamiento benévolo de la misma, se produce una tendencia de los partidos mayoritarios a rentabilizar políticamente el derecho penal. Frente a ello, IU-ICV hacen suyas las afirmaciones de destacados penalistas agrupados en la Plataforma "otro derecho penal es posible" en el sentido de que "el continuo y desmesurado recurso al derecho penal no constituye el medio más eficaz ni más justo de abordar los problemas sociales y evitar y prevenir los delitos". Si se continúa promoviendo la idea individualista de la delincuencia, con menciones a "perfiles criminológicos", tal y como se hace en la Exposición de Motivos del Proyecto de Ley sometido a nuestra consideración, nunca se acabará con la percepción de que hay más conflictos sociales que deben ser incluidos en el Código Penal, de que las penas a imponer deben ser incrementadas y de que el tratamiento a los delincuentes debe ser más duro. Es decir, en la medida en la que el tratamiento de lo criminal se desarrolle en el marco de debates populistas y poco rigurosos, la atención a los conflictos sociales seguirá considerándose como un problema de personas inadaptadas frente a las que la única receta será su inclusión en el ámbito penal y su internamiento en prisión el máximo tiempo posible. En esta perniciosa tendencia incide la utilización del término "seguridad" únicamente vinculado al fenómeno de la delincuencia, sin considerar en toda su amplitud los aspectos sociales que influyen en la seguridad y en la percepción social de la misma, tales como la seguridad laboral, la seguridad relacionada con la vivienda o la seguridad relacionada con la protección social ante situaciones de necesidad. Parece que la huida hacia un endurecimiento y extensión del Código Penal pretende ocultar la dificultad $\mathrm{y}$, en ocasiones, retroceder en el tratamiento del resto de necesidades sociales que tienen una sustancial incidencia en la percepción ciudadana sobre la seguridad y en la misma persistencia de determinadas actividades delictivas. Una política criminal que busque la finalidad esencial de reducir la criminalidad no puede centrarse en una lógica de más cárceles, más policía, más procedimientos penales y mayor duración de las penas. Está demostrado que esta vía no reduce la criminalidad. Hay fenómenos sociales que están en la raíz de los delitos y que dificultan la reinserción y sobre éstos debe incidir tanto la caracterización de las penas como la forma de cumplimiento de las condenas, como la misma definición de los tipos delictivos".

918 La motivación fue la siguiente: “El CP 1995 decidió no imponer medidas de seguridad a imputables. El cambio de opinión que supone esta reforma debe ser discutido en un contexto más amplio, referido a si resulta legítimo imponer medidas a personas imputables que ya han liquidado su condena. El número de personas con gran peligrosidad tras la condena es muy reducido -hay datos sobre delitos sexuales-. La medida terminará aplicándose a muchos más supuestos de los previstos. Se desestiman las posibilidades de control policial habituales, factibles en colectivos reducidos. Se desestiman, indebidamente, otras opciones, como el recurso a inhibidores hormonales para los delincuentes sexuales, que pueden actuar como sustitutivos, y no como añadidos, a la pena privativa de libertad". 
que con la libertad vigilada se estaba dando marcha atrás en aquella decisión del legislador de 1995, con base en razones de dudosa legitimidad. También planteaba un problema de aplicación, ya que previsiblemente la libertad vigilada iba a ser aplicada a muchos más supuestos de los deseados por la norma, siendo el número de delincuentes peligrosos que necesitan medidas de control tras el cumplimiento de sus penas, muy reducido. Pero lo realmente relevante de esta enmienda es la propuesta de acudir a otros medios de control menos restrictivos de las libertades, como el control policial aplicable a colectivos reducidos, y en el caso de los delincuentes sexuales, utilizar inhibidores hormonales que podrían actuar como sustitutivos o como añadidos. Es decir, que se propone, antes de imponer una medida de seguridad, optar por técnicas médicas de tratamiento de los impulsos sexuales, tanto en formas sustitutivas de la privación de libertad, como en aplicaciones adicionales a la misma.

1. Por el Grupo Parlamentario Mixto se presentó la enmienda núm. 78, al art. único del proyecto, apartado vigésimo, y se proponía la supresión de la expresión “o de una medida de libertad vigilada que deba ejecutarse después del cumplimiento de una pena privativa de libertad". Sobre esta enmienda no consta en el diario de sesiones la justificación.

2. Por el Grupo Parlamentario Vasco (EAJ-PNV) se presentó la enmienda núm. 112, que proponía la supresión del apartado vigésimo, artículo único, que modificaba el artículo 98 CP919. Este Grupo Parlamentario también ponía en entredicho la introducción de este neodualismo, cuya discusión quedo zanjada en el CP de 1995, no habiendo razón para romper con aquel sistema y abrir la puerta a la imposición de medidas de seguridad a imputables.

3. Por el Grupo Parlamentario Esquerra Republicana-Izquierda Unida-Iniciativa per Catalunya Verds, se presentó la enmienda núm. 304 al artículo único, apartado vigésimo, proponiendo la modificación del apartado 1 del art. $98 \mathrm{CP}$ que queda redactado como sigue:

\footnotetext{
919 Bajo la siguiente justificación: “El Código Penal de 1995 decidió no imponer medidas de seguridad a imputables. Optó por la ilegitimidad de imponer medidas a personas imputables que ya han cumplido su condena y se eliminan las posibilidades de control policial habituales, factibles a colectivos reducidos de personas con características criminológicas de gran peligrosidad cuya condena ha sido ya cumplida".
} 
"1. A los efectos del artículo anterior, cuando se trate de una medida de seguridad privativa de libertad que deba ejecutarse después del cumplimiento..., (resto igual)".

La justificación que se dio fue la misma que para la enmienda núm. 16 (vid. supra), cuya transcripción y comentarios doy por reproducidos.

$2^{\circ}$. Enmiendas al apartado vigésimo segundo del artículo único del Proyeto, que modifica el art. $96.3 \mathrm{CP}$.

1. Por el Grupo Parlamentario Esquerra Republicana-Izquierda Unida-Iniciativa per Catalunya-Verds se presentó la enmienda núm. 17, por la que se proponía la modificación del apartado vigésimo segundo del art. único del Proyecto, que quedaba redactado como sigue:

“3. En ambos casos el Juez o Tribunal deducirá testimonio por el quebrantamiento. A estos efectos, no se considerará quebrantamiento de la medida la negativa a continuar un tratamiento médico inicialmente consentido".

Mediante esta enmienda se llamaba la atención sobre la colisión entre la obligación de sometimiento a tratamiento médico a una persona imputable a través de la libertad vigilada y la innegable autonomía de todo paciente (penado o no) para decidir libremente sobre su sometimiento al mismo. Este aspecto realmente ya presentaba una solución parecida en el texto proyectado, al decir que el incumplimiento de la obligación de sometimiento al tratamiento médico impuesto, no daría lugar al quebrantamiento de condena, pero con esta enmienda se quería ir más allá, prolongando el alcance de dicha dispensa de incumplimiento hasta el abandono del tratamiento, entendido éste como total e indubitado y puesto de manifiesto abiertamente por el penado 920.

\footnotetext{
920 La motivación fue la siguiente: "el texto del proyecto no tiene sentido: la negativa a someterse a tratamiento médico (que exige consentimiento para imponerse), nunca puede ser quebrantamiento de la medida, puesto que para quebrantarla es necesario que ya esté impuesta y, para imponerla, es necesario el consentimiento del sujeto. Si lo que se quiere decir es que la falta de consentimiento sobre el tratamiento médico no quebranta la medida (ya impuesta), hay que referirse, obviamente, a la falta de consentimiento posterior a la imposición de la medida. En este ámbito, para respetar la exigencia de consentimiento de los tratamientos médicos (exigencia del derecho fundamental a la dignidad y, además, de la Ley de Autonomía del Paciente), lo que debe decirse es que, si después de imponerse el tratamiento médico consentido, el afectado quiere abandonarlo (por ejemplo, por sus efectos secundarios), ese abandono es licito (porque el consentimiento debe exigirse durante todo el tratamiento) y, por tanto, no hay delito de quebrantamiento".
} 
$3^{\circ}$. Enmiendas al apartado vigésimo tercero del artículo único del Proyecto, que modifica el art. $105 \mathrm{CP}$.

1. Por el Grupo Parlamentario de Esquerra Republicana-Izquierda Unida-Iniciativa per Catalunya-Verds se presentó la enmienda núm. 18, que proponía la eliminación del apartado vigésimo tercero del art. único del Proyecto, que modificaba el art. $105 \mathrm{CP}$, bajo una motivación idéntica a las ya vistas en las enmiendas 16 y 304, que doy por reproducida.

2. Por el Grupo Parlamentario Mixto se presentó la enmienda núm. 79, al artículo único, apartado vigésimo tercero, que modificaba el art. 105 CP (vid. supra), y se proponía la supresión. No consta la justificación de esta enmienda en el Diario de Sesiones.

3. Por el Grupo Parlamentario Vasco (EAJ-PNV), se presentó la enmienda núm. 113 al art. único, apartado vigésimo tercero, que modificaba el art. 105, proponiendo la supresión del precepto, con base en la justificación idéntica a la presentada en la enmienda núm. 112 (en relación a al apartado vigésimo del proyecto, que modifica el art. $98 \mathrm{CP}$ ), por lo que doy por reproducida su justificación íntegramente, así como los comentarios que ya hemos hecho sobre este particular, (vid. supra).

4. Por el Grupo Parlamentario Esquerra Republicana-Izquierda Unida-Iniciativa per Catalunya Verds, se presentó la enmienda núm. 305, al art. único, apartado vigésimo tercero, que modificaba el art. $105 \mathrm{CP}$, proponiendo la supresión de la letra a) del apartado 2 del artículo $105 \mathrm{CP}$, con idéntica justificación que en la enmienda 304 (en relación a al apartado vigésimo del proyecto, que modifica el art. $98 \mathrm{CP}$ ), por lo que doy por reproducido íntegramente su contenido, (vid. supra).

4. Enmiendas al apartado vigésimo cuarto del artículo único del Proyecto, que modificaba el art. 106 CP.

1. Por el Grupo Parlamentario de Esquerra Republicana-Izquierda Unida-Iniciativa per Catalunya-Verds se presentó la enmienda núm. 19, por la que 
proponía la modificación del apartado vigésimo cuarto del art. único del Proyecto, en el siguiente sentido:

“Supresión del número 2 del artículo 106 del Proyecto y modificación del último inciso del número 4 del artículo 106 propuesto, que debe quedar como sigue: "Si el incumplimiento fuera reiterado o grave, revelador de no someterse a las obligaciones impuestas sustrayéndose así al cumplimiento de la condena, el juez deducirá además, testimonio a los efectos de la estimación, en su caso, del delito del artículo 468 de este Código"."

La primera parte de la enmienda proponía que para el quebrantamiento de condena existiera una voluntad de incumplir la medida, esto es, dolo directo, de forma que no todo incumplimiento - por reiterado o grave que pudiera ser- implicase la comisión del delito, ya que algunas veces el penado puede incumplir por motivos diversos que pueden guardar relación directa con su inadaptación a la sociedad por el transcurso de tantos años de prisión. La segunda parte de la enmienda, se ocupa de una cuestión técnica que únicamente pretende reforzar la presunción de inocencia ${ }^{921}$.

2. Por el Grupo Parlamentario Mixto se presentó la enmienda núm. 80, proponiendo la supresión del apartado vigésimo cuarto del art. único del Proyecto, que modificaba el art. 106 CP. Sobre su justificación, no hay constancia en el Diario de Sesiones.

3. Por el Grupo Parlamentario Vasco (EAJ-PNV), se presentó la enmienda núm. 114 al art. único, apartado vigésimo cuarto, que modificaba el art. 106, proponiendo la supresión del precepto, con idéntica justificación que la aducida en las enmiendas 112 (en relación al apartado vigésimo, art. 98 CP) y 113 (en relación al apartado vigésimo tercero, art. $105 \mathrm{CP}$ ), por lo que doy por reproducido su contenido, (vid. supra).

\footnotetext{
921 La motivación fue la siguiente: “deducir testimonio por quebrantamiento de condena (art. 468) en el incumplimiento de reglas de conducta acompañantes de la pena, requiere que exista voluntad de sustraerse al cumplimiento de la condena. Por otra parte, es aconsejable que el Código penal no incorpore la incorrecta utilización del término "presunto" que ha sido consagrada por los medios de comunicación y que ya se ha deslizado inexplicablemente, en algún texto legal como la reciente reforma de la LOGP. En efecto: si los ciudadanos tienen derecho a la "presunción de inocencia", cuando son acusados de delito son "presuntos inocentes", nunca "presuntos responsables" o "presuntos delincuentes", sino todo lo contrario. Por la misma razón, cuando se deduce testimonio por un delito, no se "presume" ningún delito, sino que se aprecian indicios de su comisión que deberán ser confirmados -o no-, en el proceso correspondiente".
} 
4. Por el Grupo Parlamentario Popular, se presentó la enmienda núm. 345, al apartado vigésimo cuarto del art. único del Proyecto, proponiendo su modificación en el siguiente sentido:

"Se propone modificar al apartado vigésimo cuarto del proyecto de ley que modifica al artículo 106 del Código Penal cambiando la redacción del apartado 1 y añadiendo un nuevo apartado 5 que tendrán el siguiente texto:

“1. La libertad vigilada consistirá en el sometimiento del condenado a control judicial a través del cumplimiento por su parte de alguna o algunas de las siguientes medidas: [...]

k) Prohibición de hacer declaraciones o manifestaciones a la prensa escrita, radiofónica, televisiva o de nuevas tecnologías que le den notoriedad al penado, o supongan aprovechamiento económico de éste, relativas al hecho por el cual fue condenado.

1) Prohibición, mientras dure la medida acordada, de publicar el mismo, o ceder los derechos a terceros -incluidos los de la propia imagen-, libros, artículos, ensayos o cualquier otro medio que supongan para el mismo relevancia personal o aprovechamiento económico como consecuencia del hecho delictivo por el que fue condenado.

$[\ldots]$

5. Para garantizar el efectivo cumplimiento de la medida, el Juez o Tribunal podrá acordar la utilización de medios electrónicos que permitan la localización permanente del reo.

En todo caso se designará en los términos que señale la Ley General Penitenciaria de un responsable que se haga cargo del control del cumplimiento de las medidas impuestas mientras dure la medida impuesta"."

La primera parte de la enmienda añadía dos nuevas medidas a la libertad vigilada, que implicaban la incomunicación del condenado, coartando su libertad de expresión al prohibirle hacer manifestaciones del tipo que sea en los medios de comunicación. Pero es que además la incomunicación se extendía a la propiedad intelectual, impidiendo que el sujeto publique libros, artículos o ensayos, o ceda derechos a terceros los derechos cuando salga de prisión y mientras esté cumpliendo la medida. La segunda parte de la enmienda proponía la introducción de un agente de seguimiento de la libertad vigilada, como de hecho existe en otros países, al que se le llamaría "responsable del seguimiento"922.

922 La justificación que se dio fue la siguiente: “No parece muy realista pretender controlar judicialmente al condenado sólo a través del cumplimiento de las obligaciones que se imponen en el apartado 1 del artículo que se enmienda. Por ello, se proponen dos soluciones: En primer lugar y conforme se recogió en el anteproyecto de 2008 se debe establecer con carácter general y no como medida que el juez o tribunal puede elegir entre las varias que aparecen contenidas en el catálogo descrito en el apartado 1 de este artículo la 
5. Por el Grupo Parlamentario Mixto se presentó la enmienda núm. 406, que proponía la modificación del artículo único, punto vigésimo cuarto del Proyecto, proponiendo el siguiente texto:

“2. [...]

En estos casos, al menos dos meses antes a la extinción de la pena privativa de libertad, de modo que la medida de libertad vigilada pueda iniciarse en ese mismo momento, el Juez de Vigilancia Penitenciaria [...]."

Texto que se sustituye:

“2. [...]

En estos casos, con anterioridad suficiente a la extinción de la pena privativa de libertad, de modo que la medida de libertad vigilada pueda iniciarse en ese mismo momento, el Juez de Vigilancia Penitenciaria [...]." 923

6. Por el Grupo Parlamentario Mixto se presentó la enmienda núm. 407, al art. único del Proyecto, punto vigésimo cuarto, proponiendo la modificación en el siguiente sentido:

Texto que se propone:

“3. [...]

b) Reducir la duración de la libertad vigilada o incluso poner fin a la misma en vista de los oportunos informes acerca de la situación y la evolución del condenado, su grado de rehabilitación, la probabilidad de reincidencia o reiteración delictiva, concretados todos ellos en un pronóstico positivo de reinserción que haga innecesaria o contraproducente la continuidad de las obligaciones o prohibiciones impuestas".

Texto que se sustituye:

“3. [...]

b) Reducir la duración de la libertad vigilada o incluso poner fin a la misma en vista del pronóstico positivo de reinserción que considere innecesaria o contraproducente la continuidad de las obligaciones o prohibiciones impuestas". 924

obligación de estar siempre localizable mediante aparatos electrónicos. Asimismo, en consonancia con las disposiciones de la LOGP, es necesario designar a un responsable que se haga cargo del seguimiento del sujeto a quien se le hubiera impuesto una medida de libertad vigilada. La solución propuesta es recogida en el derecho alemán a través de la figura allí denominada "ayudante de prueba", que se hace cargo del cumplimiento de las medidas que se hubieren impuesto al condenado. Se introducen dos letras al apartado 1 del artículo 106 mediante las cuales se recogen nuevas medidas dirigidas a impedir que el autor, condenado por el delito, pueda sacar provecho personal o económico de los hechos, agraviando todavía más a las víctimas del delito".

${ }^{923}$ La justificación fue únicamente mejora técnica. 
5. Enmiendas al apartado cuadragésimo quinto del artículo único del Proyecto, que modificaba el art. 192 CP.

1. Por el Grupo Parlamentario de Esquerra Republicana-Izquierda Unida-Iniciativa per Catalunya-Verds se presentó la enmienda núm. 28, por la que se proponía la modificación del apartado cuadragésimo quinto del art. único del Proyecto, en el siguiente sentido:

“Supresión del número 1 del artículo $192 \mathrm{CP}$, propuesto por el proyecto y supresión de la expresión "o bien la privación de la patria potestad" en el apartado número 3".

Este Grupo Parlamentario proponía la supresión de la libertad vigilada para delincuentes sexuales, porque su inclusión responde a las campañas mediáticas y no a un problema penal-penitenciario ${ }^{925}$.

924 La justificación fue únicamente mejora técnica.

925 Y la motivación fue la siguiente: "la libertad vigilada puede ser admitida como pena o medida de seguridad a imponer en los delitos en que resulte indicado, como pena o medida principal u originaria. Por ello, no se enmienda el apartado decimoctavo, en el que se incluye en el catálogo general de medidas de seguridad (y concordantes). En cambio, en el apartado ahora enmendado, se obliga a imponer la libertad vigilada en los delitos sexuales, para ser ejecutada después de cumplirse la pena impuesta. Es cierto que se permite no imponerla en casos de escasa peligrosidad, recurso frecuentemente utilizado por el legislador en este tipo de reformas inducidas por alarmas mediáticas: primero se endurece la ley y después, se deja una puerta abierta a que los jueces renuncien a ello, basándose, como en este caso, en pronósticos inciertos y conceptos abiertos como la "peligrosidad", lo que sólo provoca inseguridad. La libertad vigilada como medida de seguridad posterior al cumplimiento de la pena viene motivada por las campañas mediáticas sobre la excarcelación de determinados delincuentes sexuales. Como ha puesto de manifiesto el Grupo de Estudios de Política Criminal, (septiembre 2009) en relación a los delincuentes sexuales que tras cumplir condena presentan riesgo de reincidencia: “...el hecho de que se trate de casos que levantan una alarma social no significa que se trate cuantitativamente de un problema penal-penitenciario de grandes dimensiones, sobre todo cuando se constata que los índices de reincidencia en los delitos sexuales caen una vez que los condenados pasan por un programa de rehabilitación en prisión, convirtiendo con ello el problema "social" en un problema "penal-penitenciario" secundario que afecta a no más de una decena de casos en toda España, que no pueden convertirse en el centro de atención de las reformas penales, legitimando de paso toda una batería de medidas a aplicar a la generalidad de los condenados...". Lo anterior se basa en estudios que indican que, sobre un porcentaje general de reincidencia del 38 por 100, la reincidencia en delitos sexuales es del 18 por 100 y, en relación a éste, cae hasta el 5 por 100 si se aplican tratamientos integrales dirigidos a la reinserción. La libertad vigilada post-condena, es pues, un incremento del control penal posterior al cumplimiento de la pena, alentado mediáticamente, que renuncia a mejorar los genuinos instrumentos de intervención penitenciaria -como el tratamiento- y la asistencia social post-penitenciaria o bien, en algunos casos extraordinarios, la vigilancia policial no invasiva cuyos límites deberían igualmente establecerse. Por otra parte, la libertad condicional, como último período de la condena, es el ámbito en el que mejorar los instrumentos de control y vigilancia sobre el liberado condicionalmente, puesto que se trata de una institución de puesta a prueba y preparatoria para la libertad definitiva. En resumen: se trata de mejorar los instrumentos ya existentes para abordar los casos excepcionales minoritarios, en lugar de incrementar indiscriminadamente el control, para todos los delitos sexuales". 
$6^{\circ}$. Enmiendas que proponían la inclusión en el Proyecto de nuevos apartados.

1. Por el Grupo Parlamentario Esquerra Republicana-Izquierda Unida-Iniciativa per Catalunya-Verds, se presentó la enmienda núm. 45, que pretendía la adición de un nuevo apartado al art. único del Proyecto, por el que se añadía un nuevo apartado al art. $92 \mathrm{CP}$, que quedaría redactado como sigue:

“4. También podrán obtener la libertad condicional los condenados a penas de prisión, aunque no se hayan cumplido los requisitos establecidos en el artículo 90.1 de este Código, cuando, por aplicación de los límites establecidos en el artículo 76.1.a) y b) de este Código, el cumplimiento efectivo de la condena alcanzare los veinte años o cuando, al no resultar aplicable el apartado 2 de este último precepto, el cumplimiento sucesivo de las penas alcanzare también el mismo número de años. En estos supuestos la Administración penitenciaria elevará el expediente de libertad condicional al Juez de Vigilancia Penitenciaria que, a la hora de resolverlo, oídos el Ministerio Fiscal, Instituciones Penitenciarias y las demás partes, valorará la naturaleza, circunstancias y número de delitos cometidos, la personalidad del condenado, sus antecedentes, su evolución en el tratamiento reeducador, la dificultad para delinquir y la escasa peligrosidad, así como sus condiciones de vida. El Juez de Vigilancia Penitenciaria, al decretar la libertad condicional de estos penados, impondrá la medida de libertad vigilada hasta el total cumplimiento de la condena. En el caso de que sea denegada la libertad condicional y en tanto el reo no haya cumplido en su totalidad la condena, la Administración penitenciaria volverá a elevar anualmente el expediente de la libertad condicional al Juez de Vigilancia hasta alcanzar el cumplimiento efectivo de la pena los veinticinco años. En este último supuesto le será concedida al reo la libertad condicional con sujeción a la medida de libertad vigilada hasta llegar al cumplimiento total de la condena".

Este Grupo Parlamentario proponía que la libertad vigilada pudiese acordarse en supuestos en los que al sujeto le hubiera sido denegada la libertad condicional, suponiendo así una alternativa a la prisión con mayores restricciones que la libertad condicional, de forma que, si el sujeto no presenta suficiente pronóstico favorable de reinserción para acceder a la libertad condicional o no cumple los requisitos en su totalidad, pueda acordarse la libertad vigilada, posibilitando así su reinserción ${ }^{926}$.

\footnotetext{
926 La motivación fue la siguiente: "según datos de la Secretaría General de Instituciones Penitenciarias (SGIIPP) hay en la actualidad unas 345 personas presas, prácticamente todas hombres, sin contar las condenadas por terrorismo, con condenas no acumulables superiores a los 30 años; una de ellas tiene una condena de 38.585 días, esto es, casi 106 años. Las condenas que rebasan la cronología de una vida humana vulneran los principios constitucionales de reeducación y reinserción social -art. 25.2 CE-, la dignidad -art. 10 CE-, la promoción de la igualdad real y efectiva -art. 9.2- y la proscripción de tratos inhumanos y degradantes
} 


\section{Por el Grupo Parlamentario de Esquerra Republicana-Izquierda}

Unida-Iniciativa per Catalunya Verds se presentó la enmienda núm. 296, al artículo único, proponiendo la inclusión de un apartado nuevo en el siguiente sentido:

-art. 15 CE-. Si bien es cierto que la STC 81/1997, de 22 de abril, interpretó el art. 25.2 CE como un mandato al legislador que no contiene derechos subjetivos a favor de los condenados, no lo es menos que la localización sistemática de la norma en la Sección $1^{\text {a }}$, Capítulo II, Título I de la Constitución la sitúa entre los derechos fundamentales a los que el art. 53. 1 y 2 -por su especial categoría- prevé una protección legal y jurisdiccional también especial, frente al tratamiento y garantías que el propio art. 53 en su apdo. 3 establece para los derechos contenidos en el Capítulo II bajo la denominación -aquí sí- de principios rectores. Cierto es que, según el art. 25.2 CE, la orientación de las penas contenida en el mandato constitucional no se refiere a la expresión de las finalidades de la pena, retribución o prevención, sino que constituye un principio que se erige como límite último infranqueable proscriptor de cualquier posible situación penal que excluya materialmente a priori cualquier mínima posibilidad de reeducación y reinserción social. Y ello sucede, precisamente, en los casos de cadena perpetua encubierta que incluye nuestro Código Penal. La preparación para la vida en libertad a lo largo del cumplimiento de la condena como mínimum innegociable (STC 112/96) quedaría vaciado de contenido constituyendo una burla al mandato constitucional si por la excesiva duración de la condena la libertad resultase ilusoria o por producirse tan tarde y con consecuencias tan penosas para el sujeto llegara a constituir un trato inhumano degradante. En esta línea y con un desarrollo más detallado la STS de 27 de enero de 1999 explicita cómo lo que el legislador no ha querido regular, la cadena perpetua, no puede ser introducido por vía de acumulación aritmética de condenas. Pues "es indudable que una pena que segrega definitivamente al condenado de la sociedad no puede cumplir tales objetivos (los del art. 25.2 CE) y es, por tanto, incompatible con ellos". Por otra parte, los especialistas, y ahondando en el mismo fundamento, han comprobado empíricamente que una privación de libertad prolongada y continuada produce en no pocos casos graves perturbaciones de la personalidad. Por tales razones se considera en la actualidad que una configuración razonable de la ejecución de las penas privativas de larga duración requiere que el condenado pueda albergar la posibilidad de un reintegro a la sociedad libre, dado que lo contrario podría constituir, además de la vulneración del principio de humanidad y reinserción, anteriormente referidos, un "trato inhumano y degradante" al suponer el quantum de la pena a cumplir una humillación o una sensación de envilecimiento superior a la que acompaña a la simple imposición de la condena, proscrito en el art. 15 de la Constitución (STC 65/1986, de 22 de mayo). En este sentido, la Audiencia Nacional (Autos de 30 de enero y de 5 de marzo de 1992) señala en un caso de extradición que “en ningún caso el reclamado cumpliría de condena más de 30 años de prisión continuada efectiva, por así imponerlos principios constitucionales que vinculan directamente a este Tribunal en sus resoluciones, tales como los que se refieren a las funciones que cumplen las penas en nuestro ordenamiento jurídico (el art. $25 \mathrm{CE}$ habla de que las penas están orientadas hacia la reeducación y la reinserción social, y estos fines excluyen la pena de prisión a cadena perpetua). También otros principios como el respeto a la dignidad humana -principio de humanidad de las penas- a través del sometimiento a penas o tratos inhumanos o degradantes". Todo ser humano privado de libertad debe albergar la esperanza de que un día pueda salir en libertad. Si este horizonte penal queda cerrado por las condenas debido a que la suma de las mismas las haya convertido, de hecho, en una cadena perpetua, las consecuencias que esta situación genera son graves desde el punto de vista de la prevención de delitos y del mantenimiento del orden dentro del centro penitenciario. En este sentido, se puede generar la misma impunidad hacia la comisión de delitos futuros si se limita el tiempo máximo de condena a 20 años, que si el quantum de condena impide la salida de por vida. Las personas en esta situación "no tienen nada que perder" pues las condenas que sobrevengan no se cumplirán por la limitación temporal de la vida humana. Por ello, la comisión de nuevos delitos o faltas disciplinarias dentro de la cárcel se convierten en una posibilidad real y, por ende, más condenas, más víctimas y más gasto público. En esta misma línea, podríamos referirnos de forma expresa al principio de proporcionalidad, que no sólo ha de vincular al legislador en la fase de individualización legal de las penas y al Juzgador en la judicial, cuando debe imponer una pena concreta dentro de los marcos penales establecidos, atendiendo a las circunstancias personales del autor y a la gravedad del hecho, sino también en fase de ejecución efectiva de la pena privativa de libertad la proporcionalidad no debe ser meramente aritmética y puede seguir los mismos postulados que en fases anteriores del proceso penal. Este principio básico del derecho penal debe aunar tanto el reproche jurídico previsto por el legislador como la necesidad de preservar la dignidad de la persona sin comprometerla con un encarcelamiento tan prolongado que acabe destruyendo sus posibilidades de resocialización. El paso del tiempo va sin duda reduciendo la necesidad de pena y la proporción entre el quantum de pena y los fines que ha de cumplir aquella. Ello no obsta para que se prevean mecanismos eficaces que impidan que la eventual excarcelación de una persona en la que aún haya un peligro de nuevas conductas delictivas, genere más criminalidad o riesgo de impunidad hacia el futuro". 
“Se añade un nuevo apartado por el que se suprimen las letras $\mathrm{f}$, g y h, del artículo $39 \mathrm{CP}$. Prohibición de residencia, de aproximarse y de comunicarse".

Esta enmienda pretendía la supresión de ciertas penas privativas de derechos, porque ya están previstas como medidas de seguridad, y más coherente esa naturaleza ${ }^{927 .}$

3. Por el Grupo Parlamentario Esquerra Republicana-Izquierda Unida-Iniciativa per Catalunya Verds, se presentó la enmienda núm. 297 al art. único del Proyecto, proponiendo la adición de un apartado nuevo en los siguientes términos:

“Se añade un nuevo apartado por el que se suprime el artículo $48 \mathrm{CP}$, de aproximarse y de comunicarse.

1. Artículo 48 y correlativos CP.

De supresión.

[Se trataría de convertir "el alejamiento" en medida de seguridad en vez de pena. Como medidas de seguridad ya están previstas en el art. 96.3. ${ }^{\circ}$ Habría que modificar un número importante de artículos del CP $(33.2,33.3,33.4,39,40,48,57,96.3,105,153,173$ y 468) para dar a las medidas de seguridad de alejamiento el mismo tratamiento que a la nueva de libertad vigilada, esto es, que se pueda imponer a imputables, por ciertos delitos y que se pueda revisar durante la ejecución.

Configurada la libertad vigilada (nuevo art. 106) como medida de seguridad imponible en algunos delitos a personas imputables y dado que incluye en sí todas las obligaciones de residencia y prohibición de aproximación y comunicación, lo suyo sería eliminar todas las referencias al "alejamiento" como pena y prever la libertad vigilada para los autores de violencia de género. Así tendríamos una legislación más coherente, la imposición del "alejamiento" tendría que pasar por un juicio individualizado y se podrían modificar o cesar cuando las circunstancias variasen.

Se podría meter una disposición común a los Títulos I a VIII idéntica a la medida de libertad vigilada del nuevo 192 y 579.3 para los casos de violencia de género]".

Como se observa, esta enmienda pretendía la supresión de la orden de alejamiento y la aplicación de la libertad vigilada a supuestos de violencia de género ${ }^{928}$.

\footnotetext{
927 La justificación fue la siguiente: “Conversión de estas penas en medidas de seguridad, de modo análogo a la nueva medida de libertad vigilada, imponibles a personas imputables. Es más coherente esta naturaleza de medidas de seguridad con su contenido de medida de control y protección de la víctima".

928 La justificación que se dio fue la siguiente: "La coloquialmente denominada pena de alejamiento no debe tener naturaleza jurídica de pena, sino de medida de seguridad, del mismo modo que la nueva medida de
} 
4. Por el Grupo Parlamentario de Esquerra Republicana-Izquierda Unida-Iniciativa per Catalunya Verds se presentó la enmienda núm. 299, al art. único, que proponía la adición de un apartado nuevo por el que se añadía un nuevo apartado al art. 92 CP. Entendemos que se trata de un lapsus de este Grupo Parlamentario, ya que esta enmienda se presentó por duplicado y de forma idéntica a la enmienda 45 antes comentada, por lo que no nos detendremos en su análisis, (vid. supra).

\section{$7^{\circ}$. Enmiendas a la Exposición de Motivos del Proyecto.}

Por el Grupo Parlamentario Socialista se presentó la enmienda núm. 480, a la Exposición de Motivos del Proyecto, que proponía una redacción distinta, basada en algunas precisiones pero que no diferían demasiado del texto enmendado ${ }^{929}$. No se presentaron más enmiendas a la Exposición de Motivos.

3) Informe sobre la ponencia930.

Respecto de las enmiendas anteriormente relacionadas, el informe sobre la ponencia manifestó el rechazo de la totalidad de las enmiendas planteadas a excepción de la enmienda 480 (a la Exposición de Motivos) que fue aceptada con las modificaciones técnicas resultantes de la incorporación de enmiendas al texto del Proyecto. La Ponencia

libertad vigilada. No ostentan estas consecuencias jurídicas la naturaleza ni el contenido ni la finalidad de las sanciones penales, sino que son mecanismos para la protección de las víctimas. Por ello deben regirse por otras normas, las de las medidas de seguridad, dado que a partir de esta reforma es posible imponer medidas de seguridad a personas imputables".

929 Del texto propuesto en la enmienda, sólo nos interesa extraer lo concerniente a la libertad vigilada y la redacción que se propuso fue la siguiente: "Como es sabido, en el ordenamiento jurídico español la rehabilitación y la reinserción social del delincuente constituyen el objetivo prioritario del sistema de penas, y en particular de la pena privativa de libertad. Es notorio, sin embargo, que en determinados supuestos de especial gravedad ese efecto rehabilitador de la pena se ve dificultado, en la medida en que ésta no resulta suficiente o adecuada para excluir un elevado riesgo de reincidencia. La opción inocuizadora, que se traduciría en la prolongación ilimitada y/o indiscriminada de la privación de libertad, choca obviamente con principios elementales del Derecho Penal que la Constitución ampara, como la exigencia de proporcionalidad y la propia orientación rehabilitadora de la prisión, sin perjuicio, claro está, de su finalidad retributiva, que como ha señalado el Tribunal Constitucional- también es constitucionalmente legítima en la medida en que se mueva dentro de parámetros de proporcionalidad. Es necesario, por tanto, para los casos de especial gravedad expresamente previstos, contemplar otras soluciones que, sin cejar en el esfuerzo rehabilitador que debe seguir inspirando el tratamiento penitenciario, permitan conciliar las referidas exigencias constitucionales con otros valores no menos dignos de tutela, como son la seguridad y la libertad del resto de los ciudadanos, potenciales víctimas del delincuente no rehabilitado que el sistema penitenciario devuelve a la sociedad. Agotada, pues, la dimensión retributiva de la pena, la peligrosidad subsistente del sujeto halla su respuesta idónea en una medida de seguridad". El resto igual.

930 BOGC, Congreso de los Diputados, núm. A 52-10, de 21/04/2010. Comisión de Justicia. 
propuso la aceptación de la enmienda 406 (al art. 106 CP) con una corrección técnica consistente en la sustitución de la expresión "antes a" por "antes de". Y por último se aceptó una transacción a la enmienda 17 (relativa al art. 100.3 CP) ${ }^{931}$. La enmienda 407 al art. $106 \mathrm{CP}$, finalmente fue retirada.

4) Aprobación por el pleno y remisión al Senado.

El pleno del Congreso de los Diputados aprobó el texto para su remisión al Senado ${ }^{932}$ con el mantenimiento de la totalidad de las enmiendas anteriormente relacionadas, salvo la 407 que, como ya se ha dicho, fue retirada. No obstante, en el texto que se remitió al Senado ${ }^{933}$ se alteró el orden y la numeración de los apartados del artículo único, de tal forma que quedaron así: el apartado vigésimo segundo modificaba el art. 96 $\mathrm{CP}$; el vigésimo tercero modificaba el art. 97 CP; el vigésimo cuarto, el art. $98 \mathrm{CP}$; el vigésimo quinto modificaba el art. 100.3 CP; el vigésimo séptimo modificaba el art. 105 CP; el vigésimo octavo, el art. 106 CP; el quincuagésimo segundo, el art. 192 CP, y por último el centésimo quincuagésimo cuarto, modificaba el art. 579 CP. La relevancia de esta modificación reside en que este orden es el que posteriormente mantuvo la LO 5/2010, de 23 de junio, de reforma del CP.

\section{La tramitación en el senado}

\section{a) Las enmiendas}

Tras la remisión del texto por el Congreso, en el Senado igualmente se tuvo que ampliar el plazo para la presentación de enmiendas ${ }^{934}$, y finalmente las presentadas fueron las que se detallan a continuación935.

\footnotetext{
931 Por el Grupo Parlamentario Popular se propusieron transacciones en relación a las enmiendas a 384, 387, 388, 389, 390 y 392 (las tres últimas fueron propuestas in voce), consistentes el la sustitución del término "prisión perpetua revisable" por el de "prisión indefinida revisable". La ponencia rechazó igualmente todas ellas.

932 BOCG, Congreso de los Diputados, serie A, núm. 52-11, de 28/04/2010.

933 BOCG, Senado, serie II, núm. 48-a, de 06/05/2010.

934 BOCG, Senado, núm. II-48-b de 20/05/2010, p. 55

935 BOCG, Senado, núm. II-48-c de 27/05/2010, p. 57. Enmiendas (Senado).
} 
$1^{\circ}$. Enmiendas al (nuevo) apartado vigésimo segundo del artículo único del Proyecto (art. $96 \mathrm{CP})$.

1. Por el Grupo Parlamentario de Senadores Nacionalistas (GPSN) se presentó la enmienda núm. 24, al art. único del Proyecto, apartado vigésimo segundo, proponiendo la supresión del precepto con base en la siguiente justificación:

“El Código Penal de 1995 decidió no imponer medidas de seguridad a imputables. Optó por la ilegitimidad de imponer medidas a personas imputables que ya han cumplido su condena y se eliminan las posibilidades de control policial habituales, factibles a colectivos reducidos de personas con características criminológicas de gran peligrosidad cuya condena ha sido ya cumplida".

Este Grupo Parlamentario reitera en el Senado las críticas al neodualismo que se aleja del sistema de penas y medidas de seguridad del CP de 1995, cuyas consideraciones doy por reproducidas, (vid. supra).

2. Por el Grupo Parlamentario de Senadores Nacionalistas (GPSN) se presentó la enmienda núm. 25, al art. único del Proyecto, apartado vigésimo segundo, proponiendo la supresión del precepto. Esta enmienda refería a la libertad vigilada como pena accesoria, quizás en un intento por poner de manifiesto que bajo la forma de medida de seguridad, se esconde una verdadera pena, cuyos fundamentos para ser impuesta no parecen estar precisamente en armonía con el marco constitucional; o quizás se deba simplemente a un lapsus nomenclativo, trasladando los reproches que se le hicieron a la libertad vigilada como pena accesoria en el Anteproyecto de 2008. Lo relevante de esta enmienda, es que denuncia la prolongación de la restricción de las libertades en períodos post-carcelarios, que con esta nueva regulación alcanzan límites históricos ${ }^{936}$.

3. El Grupo Parlamentario Entesa Catalana de Progrés (GPECP), formuló la enmienda núm. 171 al art. único del Proyecto, apartado vigésimo segundo, proponiendo

\footnotetext{
936 Con base en la siguiente justificación: "Defendemos la supresión de la pena accesoria de libertad vigilada, que ofrece dudas de constitucionalidad al configurarse como un instrumento de control posterior a la excarcelación, con dificultades evidentes para que pueda ser conciliada con el régimen de tercer grado penitenciario o con la libertad condicional, y que, en los casos más graves, llega tras el cumplimiento de larguísimas penas privativas de libertad, pudiendo alcanzar el período total de restricción de libertad unos extremos insólitos en nuestra tradición jurídica".
} 
la supresión del precepto, donde se reproduce la justificación conferida en las enmiendas 16, 18 y 304 de las tramitadas en el Congreso de los Diputados, por lo que doy sus consideraciones por reproducidas.

$2^{\circ}$. Enmiendas al apartado vigésimo cuarto del artículo único del Proyecto (art. 106 CP).

1. El Grupo Parlamentario Entesa Catalana de Progrés (GPECP), formuló la enmienda núm. 173 al art. único del Proyecto, apartado vigésimo cuarto, que rezaba así:

"Se modifica el apartado 1 del artículo $98 \mathrm{CP}$ que queda redactado como sigue:

1. A los efectos del artículo anterior, cuando se trate de una medida de seguridad privativa de libertad que deba ejecutarse después del cumplimiento... (resto igual)".

La justificación es idéntica a la enmienda 171, por lo que no será necesario reproducir sus consideraciones, (vid. supra).

2. El Grupo Parlamentario Entesa Catalana de Progrés (GPECP), formuló la enmienda núm. 174 al art. único, apartado vigésimo cuarto del Proyecto, proponiendo la supresión del apartado, con base en justificación idéntica a la de las enmiendas 171 y 173, que doy por reproducida, (vid. supra).

3․ Enmiendas al apartado vigésimo séptimo del artículo único del proyecto (art. $105 \mathrm{CP}$ ).

1. Por el Grupo Parlamentario de Senadores Nacionalistas (GPSN) se presentó la enmienda núm. 28 al art. único del Proyecto, apartado vigésimo séptimo que modifica el artículo $105 \mathrm{CP}$, proponiendo la supresión de este precepto. La justificación fue la misma que en la enmiendas 24 , que doy por reproducida, (vid. supra).

2. El Grupo Parlamentario de Senadores Nacionalistas (GPSN), formuló la enmienda núm. 29 al art. único, apartado vigésimo séptimo del Proyecto, proponiendo la supresión de este apartado, con base en idéntica justificación que en la enmiendas 25, que doy por reproducida, (vid. supra). 
3. El Grupo Parlamentario Entesa Catalana de Progrés (GPECP), formuló la enmienda núm. 175 al art. único del Proyecto, apartado vigésimo séptimo, por la que se proponía la supresión de la letra a) del apartado 2 del art.105. La justificación fue la misma que la de la enmienda 173 (en relación al art. $106 \mathrm{CP}$ ) por lo que la doy por reproducida, (vid. supra).

$4^{\circ}$. Enmiendas al apartado vigésimo octavo del artículo único del Proyecto (art. 106 CP).

1. Por el Grupo Parlamentario de Senadores Nacionalistas (GPSN) se presentó la enmienda núm. 26, al art. único, apartado vigésimo cuarto del Proyecto, proponiendo la modificación del apartado 1 del art. 98 CP, suprimiendo la expresión "o de una medida de libertad vigilada que deba ejecutarse después del cumplimiento de una pena privativa de libertad". La justificación fue idéntica a la de la enmienda 25 (en relación al art. 100.3 CP), por lo que la doy por reproducida, (vid. supra).

2. Por el Grupo Parlamentario de Senadores Nacionalistas (GPSN) se presentó la enmienda núm. 27 al artículo único, apartado vigésimo cuarto, que modifica el artículo 98, proponiendo la supresión de este precepto. La justificación fue idéntica a la de la enmienda 24 (en relación al art. 100.3 CP), por lo que la doy por reproducida, (vid. supra).

3. El Grupo Parlamentario Popular en el Senado (GPP), formuló la enmienda núm. 104, al artículo único, apartado vigésimo octavo, que reproduce la enmienda 345 del Congreso de los Diputados, por lo que doy por íntegramente por reproducido su contenido y consideraciones, (vid. supra).

4. El Grupo Parlamentario Popular en el Senado (GPP), formuló la enmienda núm. 105 al art. único, apartado vigésimo octavo del Proyecto, proponiendo la siguiente modificación:

"Se modifica el apartado vigésimo octavo del artículo único del Proyecto de Ley Orgánica por la que se modifica la Ley Orgánica 10/1995, de 23 de noviembre, del Código Penal, modificando la redacción dada a la letra i) del apartado 1 del artículo 106 del Código Penal, con el siguiente tenor literal:

i) La prohibición de desempeñar, en cualquier Estado, determinadas actividades que puedan ofrecerle o facilitarle ocasión para cometer hechos delictivos de similar naturaleza". 
Mediante esta enmienda, se propone la introducción de una nueva medida del catálogo de las obligaciones en que se concreta la libertad vigilada, consistente en que el condenado no pueda realizar, en España ni en ningún otro Estado, determinadas actividades que puedan propiciar la comisión de nuevos delitos. Se trata de un aspecto que aparece de forma novedosa en la tramitación parlamentaria en la fase del Senado (desconociendo por qué no se adujo esta cuestión en el Congreso de los Diputados en la fase previa), e incide en la preocupación por la pederastia, basándose en propuestas que provienen de las instituciones de la Unión Europea ${ }^{937 .}$

5. El Grupo Parlamentario Entesa Catalana de Progrés (GPECP), formuló la enmienda núm. 172 al artículo único, apartado vigésimo octavo, que viene a reproducir la enmienda 19 del Congreso de los Diputados, por lo que no será necesario repetirla, (vid. supra).

6. Por el Grupo Parlamentario de Senadores Nacionalistas (GPSN), se formuló la enmienda núm. $30 \mathrm{al}$ art. único, apartado vigésimo octavo del Proyecto, proponiendo la supresión. La justificación fue la misma que la de las enmiendas 24, 27 y 28, por lo que la doy por reproducida, (vid. supra).

7. El Grupo Parlamentario de Senadores Nacionalistas (GPSN), se formuló la enmienda núm. 31 al art. único, apartado vigésimo octavo del Proyecto, proponiendo al supresión del apartado, con idéntica justificación a al de las enmiendas 25, 26 y 29, que doy por reproducida, (vid. supra).

$4^{\circ}$. Enmiendas al apartado vigésimo tercero del artículo único del Proyecto (art. $97 \mathrm{CP}$ ).

El Grupo Parlamentario Entesa Catalana de Progrés (GPECP), formuló la enmienda núm. 176 al art. único, apartado vigésimo tercero, proponiendo la supresión del apartado con base en la misma justificación que las enmiendas 173 y 174, en relación al art. $106 \mathrm{CP}$, que doy por reproducida, (vid. supra).

\footnotetext{
937 La justificación fue la siguiente: “de acuerdo con la propuesta presentada por la Comisaria Europea de Justicia, Cecilia Malmström, y para no facilitar a estos delincuentes la reanudación de sus actividades delictivas, especialmente los delitos sexuales contra menores, en países distintos de aquellos en los que fueron condenados".
} 
5. Enmiendas al apartado quincuagésimo segundo del artículo único del Proyecto (art. 192 $C P)$.

El Grupo Parlamentario Entesa Catalana de Progrés (GPECP), formuló la enmienda núm. 191 al art. único, apartado quincuagésimo segundo del Proyecto, que viene a trasponer de forma idéntica la enmienda 28 del Congreso de los Diputados, que doy íntegramente por reproducida, (vid. supra).

\section{$6^{\circ}$. Enmiendas que proponen la inclusión de apartado nuevo.}

1. El Grupo Parlamentario de Senadores Nacionalistas (GPSN), formuló la enmienda núm. 73, al art. único del Proyecto, proponiendo un apartado nuevo con la siguiente redacción:

“En el apartado 1 del artículo 104, se propone la siguiente modificación:

1. En los supuestos de eximente incompleta en relación con los números 1, 2 y 3 del artículo 20 o de concurrencia de las circunstancias atenuantes $2 .^{\circ}$ o $6 .^{\circ}$, el Juez o Tribunal podrá imponer, además de la pena correspondiente, las medidas previstas en los artículos 101, 102 y 103.

No obstante, la medida de internamiento solo será aplicable cuando la pena impuesta sea privativa de libertad y su duración no podrá exceder de la de la pena prevista por el Código para el delito. Para su aplicación se observará lo dispuesto en el artículo 99". 938

Esta enmienda proponía la extensión de las medidas de seguridad a supuestos de concurrencia de atenuantes, esto es, a sujetos imputables cuyas circunstancias modificativas de la responsabilidad criminal no llegan a eximirle ni total ni parcialmente, y que únicamente son atenuantes.

2. El Grupo Parlamentario Entesa Catalana de Progrés (GPECP), formuló la enmienda núm. 224 al artículo único del Proyecto, proponiendo un apartado nuevo, que reproduce las enmiendas 45 y 299 del Congreso de los Diputados (recordemos que ya aparecieron duplicadas allí, y ahora se presentan por duplicado otra vez, ya que en el

938 Con base en la siguiente justificación: “proponemos recoger la doctrina jurisprudencial que permite la aplicación de medidas de seguridad, como el internamiento, en el caso de atenuantes relativas a la imputabilidad (por ejemplo drogodependientes), por ser más acorde con los objetivos humanitarios de reinserción de la pena". 
Senado se presentó también con idéntico postulado la enmienda núm. 275). Doy por reproducido el contenido y las consideraciones de todas ellas, (vid. supra).

3. El Grupo Parlamentario Entesa Catalana de Progrés (GPECP), formuló la enmienda núm. 273 al artículo único, apartado nuevo, que reproduce la enmienda 297 del Congreso de los Diputados, por lo que no será necesario incidir más en ella.

\section{b) El Dictamen de la comisión}

La Comisión de Justicia, tras deliberar sobre el Proyecto acordó aceptar como dictamen el texto remitido por el Congreso de los Diputados, con varios votos particulares del Grupo Parlamentario Mixto (GPMX), del Grupo Parlamentario de Senadores Nacionalistas (GPSN), del Grupo Parlamentario Catalán en el Senado de Convergència i Unió (GPCIU), del Grupo Parlamentario Popular en el Senado (GPP), y del Grupo Parlamentario Entesa Catalana de Progrés (GPECP), con mantenimiento todos ellos de sus respectivas enmiendas para su debate en el Pleno ${ }^{939}$. Pero merece que hagamos mención a un aspecto que viene poniendo de manifiesto la doctrina, y es que el dictamen de la Comisión de Justicia del Senado emitió su dictamen en solo dos horas y media, tiempo en el que supuestamente se analizaron las doscientas ochenta enmiendas que se presentaron al Proyecto, lo que evidencia que el texto se aprobó sin apenas discusión en las Cortes Generales, lo que, según algunos autores, ha generado que la decisión tomada en relación a la libertad vigilada que finalmente se aprobó, haya sido una "decisión inmadura" 940 .

\section{c) El texto aprobado por el Senado}

El Senado finalmente aprobó el texto que le remitió el Congreso de los Diputados$^{941}$, y en consecuencia, vio luz el Proyecto de LO 621/000048, por la que se

\footnotetext{
939 BOCG, Senado, núm. II-48-d de 07/06/2010, p. 181. Dictamen de la Comisión y votos particulares (Senado).

940 REBOLLO VARGAS, R., “De las medidas de seguridad...”, cit. p. 797.

941 BOCG. Senado Núm. II-48-e de 11/06/2010 Pág. 183. Texto aprobado por el Senado. “El Pleno del Senado, en su sesión del día 9 de junio de 2010, ha aprobado el Proyecto de Ley Orgánica por la que se modifica la Ley Orgánica 10/1995, de 23 de noviembre, del Código Penal, sin introducir variaciones en el texto remitido por el Congreso de los Diputados, que aparece publicado en el Boletín Oficial de las Cortes Generales, Senado, Serie II, número 48 (a), de fecha 6 de mayo de 2010." Y Diario de Sesiones. Senado Núm. 83 de 09/06/2010 Pág. 4428 .
} 
modifica LO 10/1995, de 23 de noviembre, del CP942. El dato relevante sobre la aprobación, es que el Pleno del Senado aprobó el texto en su sesión de fecha 2 de junio de 2010, destinando al efecto tan solo una hora ${ }^{943}$. La doctrina afirma que la tramitación parlamentaria fue muy rápida y que vino marcada por el "inmovilismo", debido a que no se aceptó ninguna de las modificaciones propuestas por vía de enmniendas a la libertad vigilada ${ }^{944}$.

III. LA DECISIÓN MARCo 2008/947/JAI, DEL CONSEJO DE LA UNIÓN EUROPEA, DE 27 DE NOVIEMBRE DE 2008

El Diario Oficial de la Unión Europea de 16 de diciembre de 2008 (L 337/102 a 122) publicó, en aplicación del Título VI del Tratado de la Unión Europea, la Decisión Marco 2008/947/JAI, del Consejo de la UE, de 27 de noviembre de 2008, relativa a la aplicación del principio de reconocimiento mutuo de sentencias y resoluciones de libertad vigilada con miras a la vigilancia de las medidas de libertad vigilada y las penas sustitutivas ${ }^{945}$. Ya en el programa de medidas de 29 de noviembre de 2000, adoptado con el fin de poner en práctica el principio de reconocimiento mutuo de las resoluciones en materia penal, el Consejo se pronunció a favor de la cooperación en el ámbito de las condenas en suspenso y la libertad condicional. La Decisión Marco 2008/909/JAI del Consejo, se refiere especialmente al reconocimiento mutuo y a la ejecución de las penas privativas de libertad o medidas que conlleven una privación de libertad, a efectos de su ejecución en la Unión Europea ${ }^{946}$.

\footnotetext{
942 BOE Núm. 152 de 23/06/2010, Ley Orgánica 5/2010, de 22 de junio, por la que se modifica la Ley Orgánica 10/1995, de 23 de noviembre, del Código Penal.

943 REBOLLO VARGAS, R., “De las medidas de seguridad...”, cit. p. 797.

944 ACALE SÁNCHEZ, M., “Medición de la respuesta punitiva..., cit. p. 157.

$945 \mathrm{Y}$ en particular, su art. 31, apartado 1, letras a) y c), y su art. 34, apartado 2, letra b), basada en la iniciativa de la República Federal de Alemania y de la República Francesa de 30 de junio de 2007, y a la vista del Dictamen del Parlamento Europeo emitido el 25 de octubre de 2007, que consideró que, dentro del objetivo fijado de la Unión Europea de crear un espacio de libertad, seguridad y justicia, se hace necesaria la cooperación policial y judicial con objeto proporcionar un alto nivel de seguridad, y una de las piedras angulares de esta cooperación es el principio de reconocimiento mutuo de las resoluciones judiciales, establecido en las conclusiones del Consejo Europeo de Tampere de 15 y 16 de octubre de 1999 y confirmado en el Programa de La Haya de 4 y 5 de noviembre de 2004 sobre la consolidación de la libertad, la seguridad y la justicia en la Unión Europea (DOUE C 53, de 3 de marzo de 2005).

946 DOUE L 327 de 5 de diciembre de 2008.
} 
La inclusión de la libertad vigilada en nuestro sistema penal, vino apareciendo en los anteproyectos y proyectos que preceden a la LO 5/2010, precisamente por la necesaria armonización de las normas comunitarias y por la publicación de esta Decisión Marco de 27 de noviembre de 2008947, de ahí quizás la premura de la inclusión de la libertad vigilada en la reforma ${ }^{948}$ pese a las críticas recibidas y con los problemas -que más adelante se analizarán- que se advierten de su actual regulación ${ }^{949}$. Quizás donde más claramente pueda verse este aspecto es en el art. 25 de la Decisión Marco, que impone un mandato a los Estados miembros de tomar las medidas necesarias para dar cumplimiento a la misma antes del 6 de diciembre de 2011, de ahí que la reforma del CP, en cumplimiento de dicho mandato, haya dado entrada a la libertad vigilada el 23 de junio de 2010, con una vacatio legis de seis meses, entrando en vigor el 23 de diciembre de 2010, fecha muy cercana a la programada en la Decisión Marco (con el irrelevante transcurso de diecisiete días por encima de las indicaciones de la citada norma comunitaria).

Como indica SIERRA LÓPEZ, el primer problema que se advierte de esta Decisión Marco es la traducción de la rúbrica del texto que no coincide plenamente con otras traducciones que se han llevado a cabo en otros ordenamientos como el inglés, que refiere a "sentencia y decisiones de sometimiento a prueba, con miras a la supervisión de medidas probatorias y de las sanciones alternativas", o el alemán que refiere a "sentencias y resoluciones de puesta a prueba, con miras a la supervisión de medidas probatorias y sanciones alternativas", por lo que parece que realmente la Decisión Marco se refiere a

\footnotetext{
947 Precisamente la Disposición Final Segunda del Proyecto de reforma del CP de 27 de noviembre de 2009, enumeraba las normas de Derecho de la Unión Europea incorporadas al mismo y la doctrina afirma que "parecería adecuado, dada la incorporación de esta nueva medida de libertad vigilada, acomodar su regulación a lo previsto en la Decisión Marco 2008/947/JAI, del Consejo, de 27 de noviembre de 2008". Vid. SANZ MORÁN, A.J., "Libertad vigilada y quebrantamiento de condena. Arts. 106 y 468 CP”. En ALVAREZ GARCÍA, F.J. / GONZÁLEZ CUSSAC, J.L., (Dirs.), Consideraciones a propósito del Proyecto de Ley de 2009 de modificación del Código Penal. (Conclusiones del seminario interuniversitario sobre la reforma del Código Penal celebrado en la Universidad Carlos III de Madrid). Valencia: Tirant lo Blanch. 2010, p. 144.
}

948 REBOLLO VARGAS, R., La llibertat vigilada..., cit. p. 19. Este autor explica que “la Comissió de Justícia del Senat va dictaminar en només dues hores i mitja la reforma del Codi penal, ventilant (permeti'm l'expressió) les dues centes vuitanta emendes que l'acompanyaven en aquest espai de temps. Afegeix-li que el Ple del Senat, en la seva sessió del 2 de juny del 2010, ho va realitzar només en una hora. Evidentment no és una qüestió de temps, però del que no hi ha cap dubte és el desinterès de la Càmera Altra en la modificació d'un text al que s'incorporaven nous delictes, en el que es reformaven altres més enllà de les millores de caràcter tècnic o que s'incorporaven al text figures tan rellevants com la responsabilitat penal de les persones jurídiques o la llibertat vigilada".

949 Ibidem, p. 18. Como indica este autor, "sigui com sigui, sembla que els vaivens del legislador en quant a la forma que havia d'adoptar la llibertat vigilada responen inequívocament a una sola raó: que s'ha adoptat una decisió immadura, el que es constata amb les diverses formes en les que s'havia previst, però, més que adoptar un caràcter o un altre, és a dir, ja es tractés de pena restrictiva de drets, de pena accessòria o de mesura de seguretat, el determinant és el contingut que se li atribueix". 
figuras de suspensión condicional a prueba con sometimiento a medidas de control sobre el penado. En el caso español, se usa la expresión libertad vigilada que tras la reforma operada mediante la LO 5/2010 hace referencia a cuestiones totalmente distintas ${ }^{950}$. Sigue diciendo esta autora que la definición de la libertad vigilada que contiene el art. 2.7 de la Decisión Marco, refiere a "las obligaciones impuestas e instrucciones dictadas por una autoridad competente a una persona física de conformidad con el Derecho nacional del Estado de emisión en relación con una pena suspendida, una condena condicional o una libertad condicional", por lo que concluye que la Decisión Marco únicamente refiere a penas suspendidas, sustituidas o a la libertad condicional cuando conlleven un control sobre los sujetos sometidos a ellas y que, por tanto, la libertad vigilada como pena o medida de seguridad de cumplimiento posterior a la pena de prisión no está prevista en esta Decisión Marco951.

No obstante, siguiendo con el análisis de la Decisión Marco, el Considerando 8, dispone que:

“El reconocimiento mutuo y la vigilancia de las penas suspendidas, las penas condicionales, las penas sustitutivas y las resoluciones sobre libertad condicional tienen por objeto incrementar las posibilidades de reinserción social del condenado al permitirle mantener sus lazos familiares, lingüísticos, culturales y de otra índole. No obstante, también deben mejorar el control del cumplimiento de las medidas de libertad vigilada y de las penas sustitutivas con objeto de evitar la reincidencia y de este modo tener en cuenta el principio de la protección de las víctimas y del público en general”.

Y sigue diciendo en el Considerando 9, que existen diversos tipos de medidas de libertad vigilada y penas sustitutivas que son comunes en los Estados miembros que todos ellos están dispuestos a vigilar y, en consecuencia, la vigilancia de estos tipos de medidas y sanciones debe ser obligatoria, sin perjuicio de determinadas excepciones a las que luego referiré.

Las medidas de libertad vigilada, incluyen obligaciones de conducta, residencia, educación y formación, y las limitaciones o modalidades del ejercicio de una actividad

\footnotetext{
950 SIERRA LÓPEZ, M.V., La medida de libertad vigilada..., cit. p. 52 y nota al pie 68.

951 Ibidem, p. 53.
} 
profesional952, para cuyo control se podrá acudir a medios electrónicos con arreglo al Derecho y los procedimientos nacionales 953 . De tal forma que una resolución judicial en materia de libertad vigilada dictada por un Estado miembro, puede ser trasladada a otro Estado miembro donde el penado vaya a residir954. No obstante, considera la Decisión Marco, que un Estado miembro puede negarse al reconocimiento de una sentencia o una resolución de libertad vigilada si consiste en un tratamiento médico o terapéutico para el que el Estado de ejecución no esté facultado de conformidad con su ordenamiento interno 955 .

Los procedimientos para solicitar el reconocimiento de las sentencias o resoluciones en materia de libertad vigilada se harán mediante un certificado y un formulario que incorpora la propia Decisión Marco (Anexos I y II) ${ }^{956}$. La Decisión Marco

\begin{abstract}
952 Considerando 9. "Las medidas de libertad vigilada y las penas sustitutivas cuya vigilancia es, en principio, obligatoria incluyen, entre otras, las resoluciones relacionadas con la conducta (como la obligación de abandonar el consumo de alcohol), la residencia (como la obligación de cambiar de residencia por motivos de violencia doméstica), la educación y la formación (como la obligación de seguir un curso de conducción segura), las actividades de ocio (como la obligación de dejar de o ir a practicar un deporte determinado) y las limitaciones o modalidades del ejercicio de una actividad profesional (como la obligación de buscar una actividad profesional en un entorno de trabajo diferente; esta obligación no incluye la vigilancia del cumplimiento de las inhabilitaciones profesionales impuestas a la persona como parte de la pena)".
\end{abstract}

953 En su caso, para la vigilancia de las medidas de libertad vigilada o las penas sustitutivas se podría recurrir a medios electrónicos, con arreglo al Derecho y los procedimientos nacionales.

954 Considerando 12: “El Estado miembro en el que la persona de que se trate sea condenada puede transmitir una sentencia y, cuando corresponda, una resolución de libertad vigilada al Estado miembro en el que la persona condenada resida de forma legal y habitual con vistas a su reconocimiento y a efectos de la vigilancia de las medidas de libertad vigilada o de las penas sustitutivas contenidas en la misma". Se amplía el contenido en los considerandos 13, 14 y 15, (vid).

955 Considerando 16: “Un Estado miembro puede negarse a reconocer una sentencia y, si procede, una resolución de libertad vigilada si la sentencia en cuestión se ha dictado contra una persona que no ha sido declarada culpable, como en el caso de un enfermo mental, y la sentencia o, si procede, la resolución de libertad vigilada establece un tratamiento médico o terapéutico que el Estado de ejecución no esté facultado para vigilar respecto de tales personas con arreglo a su Derecho nacional." Considerando 17: "El motivo de denegación relacionado con la territorialidad solo debe aplicarse en casos excepcionales y con miras a establecer una cooperación lo más amplia posible en virtud de lo dispuesto en la presente Decisión marco, al tiempo que se toman en consideración sus objetivos. Toda decisión de aplicar este motivo de denegación debe apoyarse en un análisis de cada caso concreto y en consultas entre las autoridades competentes de los Estados de emisión y ejecución". Considerando 18: “En caso de que las medidas de libertad vigilada o las penas sustitutivas incluyan trabajos en beneficio de la comunidad, el Estado de ejecución debe estar facultado para denegar el reconocimiento de la sentencia y, si procede, de la resolución de libertad vigilada si los trabajos en beneficio de la comunidad deben, en principio, concluir en un plazo inferior a seis meses".

956 Considerando 19: “El formulario del certificado está redactado de forma que los elementos esenciales de la sentencia $\mathrm{y}$, cuando proceda, de la resolución de libertad vigilada figuren en el certificado, que debe traducirse a la lengua oficial o a una de las lenguas oficiales del Estado de ejecución. El certificado debe ayudar a las autoridades competentes del Estado de ejecución en la adopción de decisiones en el contexto de la presente Decisión Marco, incluidas las decisiones de reconocimiento y asunción de responsabilidades para la vigilancia de medidas de libertad vigilada y penas sustitutivas, las decisiones de adaptación de las medidas de libertad vigilada y penas sustitutivas y las decisiones ulteriores, en particular en caso de incumplimiento de una medida de libertad vigilada o de una pena sustitutiva". 
fija previamente el ámbito de aplicación y sus objetivos en la reinserción social de la persona condenada, en mejorar la protección de las víctimas y del público en general, y en facilitar la aplicación de medidas de libertad vigilada y penas sustitutivas adecuadas en el caso de las personas condenadas que no vivan en el Estado que dictó el pronunciamiento de condena957. Seguidamente, en su art. 2 se dedica a las definiciones ${ }^{958}$, de las que

957 “Art. 1. Objetivos y ámbito de aplicación. 1. La presente Decisión Marco tiene como objetivos facilitar la reinserción social de la persona condenada, mejorar la protección de las víctimas y del público en general y facilitar la aplicación de medidas de libertad vigilada y penas sustitutivas adecuadas en el caso de las personas condenadas que no vivan en el Estado de condena. Para alcanzar estos objetivos, la presente Decisión Marco establece normas con arreglo a las cuales un Estado miembro, distinto de aquel en el que la persona de que se trate haya sido condenada, reconocerá las sentencias y, si procede, las resoluciones de libertad vigilada y vigilará las medidas de libertad vigilada impuestas sobre la base de una sentencia o las penas sustitutivas contenidas en tal sentencia, y tomará todas las demás decisiones en relación con dicha sentencia, a menos que la presente Decisión Marco establezca otra cosa.

2. La presente Decisión Marco sólo se aplicará: a) al reconocimiento de sentencias y, si procede, de resoluciones de libertad vigilada; b) a la transferencia de la responsabilidad de la vigilancia de medidas de libertad vigilada y penas sustitutivas; c) a todas las demás decisiones relacionadas con las contempladas en las letras a) y b), con arreglo a las definiciones y disposiciones de la presente Decisión Marco.

3. La presente Decisión Marco no se aplicará: a) a la ejecución de sentencias en materia penal por las que se impongan penas privativas de libertad o medidas de privación de libertad que entren dentro del ámbito de aplicación de la Decisión Marco 2008/909/JAI; b) al reconocimiento y ejecución de sanciones pecuniarias y resoluciones de decomiso que entren dentro del ámbito de aplicación de la Decisión Marco 2005/214/JAI del Consejo, de 24 de febrero de 2005, relativa a la aplicación del principio de reconocimiento mutuo de sanciones pecuniarias, y de la Decisión Marco 2006/783/JAI del Consejo, de 6 de octubre de 2006, relativa a la aplicación del principio de reconocimiento mutuo de resoluciones de decomiso.

4. La presente Decisión Marco no podrá tener por efecto modificar la obligación de respetar los derechos fundamentales y los principios jurídicos fundamentales consagrados en el artículo 6 del Tratado de la Unión Europea".

958 “Art. 2. Definiciones. A efectos de la presente Decisión Marco, se entenderá por:

1) "sentencia", la resolución u orden firme de un órgano judicial del Estado de emisión por la que se establece que una persona física ha cometido una infracción penal y se le impone: a) una pena privativa de libertad o cualquier medida privativa

de libertad, si se ha concedido la puesta en libertad condicional sobre la base de dicha sentencia o mediante una resolución ulterior de libertad vigilada; b) una pena suspendida; c) una condena condicional, o d) una pena sustitutiva;

2) "pena suspendida", cualquier pena privativa de libertad o medida privativa de libertad cuya ejecución se suspende de forma condicional, en su totalidad o en parte, al dictarse sentencia, imponiendo una o más medidas de libertad vigilada que pueden incluirse en la propia sentencia o determinarse en una resolución de libertad vigilada aparte dictada por una autoridad competente;

3) "condena condicional", la sentencia en virtud de la cual se difiere de forma condicional la imposición de una pena imponiendo una o más medidas de libertad vigilada, o en la que se imponen medidas de libertad vigilada en lugar de una pena privativa de libertad o una medida privativa de libertad; tales medidas de libertad vigilada pueden incluirse en la propia sentencia o determinarse en una resolución de libertad vigilada aparte dictada por una autoridad competente;

4) "pena sustitutiva", la pena que no constituye ni una pena privativa de libertad, ni una medida privativa de libertad, ni una sanción pecuniaria, y que impone una obligación o instrucción;

5) "resolución de libertad vigilada", una sentencia firme de un órgano judicial o una resolución firme de una autoridad competente del Estado de emisión, adoptada sobre la base de tal sentencia, a) que conceda una libertad condicional, o b) que imponga medidas de libertad vigilada;

6) "libertad condicional", una resolución firme, dictada por una autoridad competente o basada en el Derecho nacional, sobre la liberación anticipada de una persona condenada tras el cumplimiento de parte de la pena privativa de libertad u otra cualquier medida privativa de libertad, en virtud de la imposición de una o más medidas de libertad vigilada;

7) "medidas de libertad vigilada", las obligaciones impuestas e instrucciones dictadas por una autoridad competente a una persona física de conformidad con el Derecho nacional del Estado de emisión en relación con una pena suspendida, una condena condicional o una libertad condicional; 
podemos extraer que la libertad vigilada, en los distintos Estados miembros, puede revestir formas de aplicación que se extienden tanto a penas suspendidas como a condenas condicionales en las que la pena privativa de libertad se difiera o se sustituya por libertad vigilada, o para supuestos de libertad condicional959.

Sin duda el precepto más relevante es el art. 4, que describe los tipos de medidas de libertad vigilada y de penas sustitutivas ${ }^{960}$. Explica ACALE SÁNCHEZ que de la lectura de este artículo se produce una suerte de confusión que deriva de que el precepto enuncia que se podrán imponer "medidas de libertad vigilada o penas sustitutivas" que después aparecen previstas en un mismo catálogo que enumera el propio artículo, dando a entender que se trata de lo mismo o que son conceptos más o menos sinónimos que refieren a un conjunto de obligaciones a las que puede ser sometido el penado con la finalidad de evitar la reincidencia. Son una serie de obligaciones como la de comunicar a la autoridad el cambio de domicilio o lugar de trabajo, la de no entrar en determinadas localidades, lugares, o zonas definidas del Estado de emisión o del Estado de ejecución, limitaciones para salir del Estado, requerimientos sobre su conducta, residencia, educación y formación o actividades de ocio, límites al ejercicio de una actividad profesional, obligación de presentarse ante una autoridad, obligación de evitar todo contacto con personas específicas o con objetos que haya utilizado para delinquir, la obligación de reparación del daño o de presentar pruebas del cumplimiento de esta obligación y la obligación de realizar trabajos en beneficio de la comunidad. También se contempla la obligación de cooperar con un agente de vigilancia o con un representante de servicios sociales y la obligación de someterse a tratamiento terapéutico o a tratamiento

8) "Estado de emisión", el Estado miembro en el que se ha dictado sentencia en el sentido de la letra a);

9) "Estado de ejecución", el Estado miembro en el que se procede a la vigilancia de las medidas de libertad vigilada y las penas sustitutivas a raíz de una decisión adoptada con arreglo al artículo 8".

959 ACALE SÁNCHEZ, M., “Medición de la respuesta punitiva...”, cit. pp. 71 a 74.

960 Art. 4. “Tipos de medidas de libertad vigilada y de penas sustitutivas. 1. La presente Decisión Marco se aplicará a las siguientes medidas de libertad vigilada o penas sustitutivas: a) obligación de la persona condenada de comunicar a una autoridad específica todo cambio de domicilio o lugar de trabajo; b) obligación de no entrar en determinadas localidades, lugares, o zonas definidas del Estado de emisión o del Estado de ejecución; c) imposición de limitaciones respecto a la salida del territorio del Estado de ejecución; d) requerimientos relativos a la conducta, la residencia, la educación y la formación o las actividades de ocio, o que establezcan límites al ejercicio de una actividad profesional o determinen modalidades de tal ejercicio; e) obligación de presentarse en determinadas fechas ante una autoridad específica; f) obligación de evitar todo el contacto con personas específicas; g) obligación de evitar todo el contacto con objetos específicos que la persona condenada ha utilizado o podría utilizar para cometer infracciones penales; h) obligación de reparar económicamente los daños causados por la infracción o de presentar pruebas del cumplimiento de esta obligación; i) obligación de realizar trabajos en beneficio de la comunidad; j) obligación de cooperar con un agente de vigilancia o con un representante de un servicio social que tenga responsabilidades con respecto a la persona condenada; k) obligación de someterse a tratamiento terapéutico o a tratamiento de deshabituación". 
de deshabituación. En cualquier caso, corresponde a los Estados cuando incorporen a sus ordenamientos internos la Decisión Marco, decidir cuáles de una y otra categoría están dispuestas a asumir además de las que expresamente se relacionan ${ }^{961}$.

En el art. 5 se fijan los criterios para la transmisión de una sentencia y, en su caso, la resolución de libertad vigilada, por lo que dispone que en los casos en que la persona condenada haya regresado o desee regresar al Estado en que tenga su residencia legal y habitual, el Estado de emisión podrá transmitir a dicho Estado miembro la sentencia y, en su caso, la resolución de libertad vigilada; o también podrá transmitirse a un Estado miembro distinto del de residencia del penado, siempre que dicho Estado preste el consentimiento.

El procedimiento para la transmisión de la sentencia y resolución de libertad vigilada, se hará a través de certificación conforme al Anexo I de la Decisión Marco y viene regulado en el art. 6962, con las consecuencias de que el Estado de emisión dejará de tener competencia para la vigilancia de las medidas de libertad vigilada (art. 7). El Estado de ejecución podrá reconocer la sentencia y la resolución de libertad vigilada, en cuyo

961 ACALE SÁNCHEZ, M., “Medición de la respuesta punitiva...”, cit. pp. 74 y 75.

962 Art. 6. "Procedimiento para la transmisión de la sentencia y, en su caso, de la resolución de libertad vigilada. 1. Cuando, en aplicación del artículo 5, apartados 1 o 2, la autoridad competente del Estado de emisión transmita una sentencia y, en su caso, una resolución de libertad vigilada a cualquier otro Estado miembro, se asegurará de que esta vaya acompañada de un certificado, cuyo formulario normalizado figura en el anexo I.

2. La autoridad competente del Estado de emisión transmitirá directamente la sentencia y, en su caso, la resolución de libertad vigilada, junto con el certificado a que se refiere el apartado 1, a la autoridad competente del Estado de ejecución por cualquier medio que deje constancia escrita y en condiciones que permitan al Estado de ejecución determinar su autenticidad. Si la autoridad competente del Estado de ejecución así lo solicita, se le transmitirá el original de la sentencia y, en su caso, de la resolución de libertad vigilada, o copias certificadas de las mismas, así como el original del certificado. Todas las comunicaciones oficiales entre las autoridades competentes mencionadas se harán también de forma directa.

3. El certificado mencionado en el apartado 1 deberá estar firmado por la autoridad competente del Estado de emisión, que deberá certificar la autenticidad de su contenido.

4. Además de las medidas y penas mencionadas en el artículo 4, apartado 1, el certificado mencionado en el apartado 1 incluirá solo las medidas o penas notificadas por el Estado de ejecución interesado de conformidad con lo dispuesto en el artículo 4, apartado 2.

5. La autoridad competente del Estado de emisión transmitirá la sentencia y, en su caso, la resolución de libertad vigilada, junto con el certificado a que se refiere el apartado 1, solo a un Estado de ejecución cada vez. 6. Si la autoridad competente del Estado de emisión desconoce cuál es la autoridad competente del Estado de ejecución, efectuará todas las consultas necesarias, inclusive a través de los puntos de contacto de la red judicial europea creada por la Acción Común 98/428/JAI del Consejo, a fin de obtener esa información del Estado de ejecución.

7. Cuando la autoridad del Estado de ejecución que reciba una sentencia y, en su caso, una resolución de libertad vigilada, junto con el certificado mencionado en el apartado 1, no sea competente para reconocerla ni para adoptar las correspondientes medidas de vigilancia de las medidas de libertad vigilada o la pena sustitutiva, los transmitirá de oficio a la autoridad competente e informará de ello sin demora a la autoridad competente del Estado de emisión por cualquier medio que deje constancia escrita". 
caso adoptará sin demora todas las medidas necesarias para la efectividad de la vigilancia; podrá denegar el reconocimiento por las causas que se contemplan en el art. 11 de la propia Decisión Marco, o aplazar la decisión, de forma motivada, por un plazo razonable 963 .

Para el caso de que las medidas de libertad vigilada o penas sustitutivas no sean compatibles con el Derecho del Estado de ejecución, habrá que adaptarlas al mismo y deberán corresponder tanto como sea posible a las dictadas en el Estado de emisión, de forma que no sean por tiempo inferior a la duración máxima establecida para infracciones equivalentes con arreglo al Derecho del Estado de ejecución ${ }^{964}$.

Se ocupa seguidamente el texto de la doble tipificación en su art. 10, que a tal efecto dispone lo siguiente:

“1. Darán lugar al reconocimiento de la sentencia y, en su caso, la resolución de libertad condicional, y a la vigilancia de las medidas de libertad vigilada y penas sustitutivas, en las condiciones que establece la presente Decisión Marco y sin control de la doble tipificación de los

\footnotetext{
963 Art. 8. “Decisión del Estado de ejecución. 1. La autoridad competente del Estado de ejecución reconocerá la sentencia y, en su caso, la resolución de libertad vigilada que se le hayan transmitido con arreglo al artículo 5 y siguiendo el procedimiento previsto en el artículo 6, y adoptará sin demora todas las medidas necesarias para la vigilancia de las medidas de libertad vigilada y penas sustitutivas, a no ser que decida acogerse a alguno de los motivos para denegar el reconocimiento y la vigilancia que se contemplan en el artículo 11.

2. La autoridad competente del Estado de ejecución podrá aplazar la decisión de reconocimiento de la sentencia y, en su caso, de la resolución de libertad vigilada si el certificado mencionado en el artículo 6, apartado 1, está incompleto o no corresponde manifiestamente a la sentencia o, en su caso, a la resolución de libertad vigilada, hasta que transcurra un plazo razonable fijado para completar o corregir el certificado".
}

964 Art. 9. “Adaptación de las medidas de libertad vigilada o de las penas sustitutivas. 1. En caso de que las medidas de libertad vigilada o las penas sustitutivas pertinentes sean, por su naturaleza o duración, o por la duración del período de libertad vigilada, incompatibles con el Derecho del Estado de ejecución, la autoridad competente de dicho Estado podrá adaptarlas a la naturaleza o duración de las medidas de libertad vigilada o penas sustitutivas, o a la duración del período de libertad vigilada, que se apliquen en su Derecho nacional a infracciones equivalentes. Las medidas de libertad vigilada o las penas sustitutivas o la duración del período de libertad vigilada, una vez adaptadas, deberán corresponder tanto como sea posible a las dictadas en el Estado de emisión.

2. Cuando se adapte la medida de libertad vigilada, la pena sustitutiva o el período de libertad vigilada porque su duración sea superior a la duración máxima prevista por el Derecho del Estado de ejecución, la duración de la medida de libertad vigilada, la pena sustitutiva o el período de libertad vigilada, una vez adaptadas, no será inferior a la duración máxima establecida para infracciones equivalentes con arreglo al Derecho del Estado de ejecución.

3. Las medidas de libertad vigilada, las penas sustitutivas o el período de libertad vigilada, una vez adaptadas, no deberán ser más severas ni más largas que las medidas de libertad vigilada, las penas sustitutivas o el período de libertad vigilada inicialmente impuestos.

4. Una vez recibida la información contemplada en los artículos 16, apartado 2, o 18, apartado 5, la autoridad competente del Estado de emisión podrá decidir retirar el certificado mencionado en el artículo 6, apartado 1, siempre y cuando no haya comenzado todavía la vigilancia en el Estado de ejecución. Tal decisión se tomará y comunicará lo antes posible, dentro de un plazo máximo de diez días tras la recepción de la información". 
hechos, las siguientes infracciones, siempre que estén castigadas en el Estado miembro de emisión con pena privativa de libertad o medida de privación de libertad de un máximo de al menos tres años, tal como se definen en el Derecho del Estado de emisión: pertenencia a una organización delictiva, terrorismo, trata de seres humanos, explotación sexual de niños y pornografía infantil, tráfico ilícito de estupefacientes y sustancias psicotrópicas, tráfico ilícito de armas, municiones y explosivos, corrupción, fraude, incluido el que afecte a los intereses financieros de las Comunidades Europeas con arreglo al Convenio de 26 de julio de 1995, relativo a la protección de los intereses financieros de las Comunidades Europeas, blanqueo del producto del delito, falsificación de moneda, incluida la falsificación del euro, delitos informáticos, delitos contra el medio ambiente, incluido el tráfico ilícito de especies animales protegidas y de especies y variedades vegetales protegidas, ayuda a la entrada y residencia en situación ilegal, homicidio voluntario, agresión con lesiones graves, tráfico ilícito de órganos y tejidos humanos, secuestro, detención ilegal y toma de rehenes, racismo y xenofobia, robo organizado o a mano armada, tráfico ilícito de bienes culturales, incluidas las antigüedades y las obras de arte, estafa, chantaje y extorsión, violación de derechos de propiedad intelectual o industrial y falsificación de mercancías, falsificación de documentos administrativos y tráfico de documentos administrativos falsos, falsificación de medios de pago, tráfico ilícito de sustancias hormonales y otros factores de crecimiento, tráfico ilícito de materiales radiactivos o sustancias nucleares, tráfico de vehículos robados, violación, incendio voluntario, delitos incluidos en la jurisdicción de la Corte Penal Internacional, secuestro de aeronaves y buques, sabotaje" 965 .

El art. 11, relaciona los motivos por los que el Estado de ejecución puede denegar el reconocimiento solicitado, que pueden ser tanto de forma como de fondo:

a) Los motivos de forma son: cuando el certificado que se remita en el formulario del Anexo I de la Decisión Marco, esté incompleto o no corresponda manifiestamente a la sentencia o a la resolución de libertad vigilada y no haya sido completado o corregido

965 Sigue diciendo el art. 10: “2. El Consejo podrá decidir en todo momento, por unanimidad y previa consulta al Parlamento Europeo, en las condiciones previstas en el artículo 39, apartado 1, del Tratado de la Unión Europea, añadir otras categorías de infracciones a la lista del apartado 1 del presente artículo. El Consejo estudiará, a la vista del informe que se le presente en virtud del artículo 26, apartado 1, de la presente Decisión Marco, si procede ampliar o modificar la lista.

3. Con respecto a las infracciones no contempladas en el apartado 1, el Estado de ejecución podrá supeditar el reconocimiento de la sentencia y la vigilancia de las medidas de libertad vigilada y de las penas sustitutivas a la condición de que la sentencia se refiera a hechos que sean también constitutivos de infracción según el Derecho del Estado de ejecución, sean cuales fueren sus elementos constitutivos o su calificación.

4. En el momento de la adopción de la Decisión Marco o ulteriormente, todo Estado miembro podrá notificar, mediante declaración notificada a la Secretaría General del Consejo, que no aplicará el apartado 1. Tal declaración podrá retirarse en cualquier momento. Tanto las declaraciones como su retirada se publicarán en el Diario Oficial de la Unión Europea". 
dentro de un plazo razonable fijado por la autoridad competente del Estado de ejecución; o cuando no se cumplan los criterios expuestos en los arts. 5 y 6 de la Decisión Marco.

b) Los motivos de fondo son: cuando la vigilancia de las medidas de libertad vigilada o las penas sustitutivas vulneren el principio ne bis in idem; si la sentencia se refiere a hechos no constitutivos de infracción según el Derecho del Estado de ejecución; cuando la ejecución de la pena haya prescrito según el Derecho del Estado de ejecución; cuando el Derecho del Estado de ejecución reconozca una inmunidad que impida la vigilancia de las medidas de libertad vigilada; cuando la pena se refiera a hechos que sean competencia del Estado de ejecución conforme a su Derecho nacional; cuando el condenado, debido a su edad, no pueda ser considerado penalmente responsable de los hechos en que se basa la sentencia según el Derecho del Estado de ejecución; si la sentencia se dictó en rebeldía, a no ser que en el certificado conste que la persona fue convocada personalmente o que se le notificó en legal forma constando la fecha y lugar del procedimiento que dio lugar a la sentencia dictada en rebeldía, o bien que el interesado haya indicado a una autoridad competente que no impugna la resolución; cuando la sentencia o, en su caso, la resolución de libertad vigilada, incluya medidas médicas o terapéuticas que el Estado ejecución no pueda vigilar debido a su sistema jurídico o sanitario; cuando la duración de la medida de libertad vigilada o de la pena sustitutiva sea inferior a seis meses; y si la sentencia se refiere a infracciones penales que, con arreglo a la legislación del Estado de ejecución, se consideran cometidas en su totalidad, en su mayor parte o esencialmente dentro de su territorio, o en un lugar considerado equivalente a su territorio ${ }^{966}$. Para la decisión sobre la denegación referida, el art. 12 confiere un plazo de sesenta días, que podrá, excepcionalmente, prorrogarse

\footnotetext{
966 Sigue diciendo el art. 11: “2. En lo que se refiere a las infracciones cometidas parcialmente dentro del territorio del Estado de ejecución o en un lugar considerado equivalente a su territorio, la autoridad competente del Estado de ejecución solo se acogerá al apartado 1, letra k), en circunstancias excepcionales y en casos concretos, atendiendo a las circunstancias específicas del caso y teniendo en cuenta, en particular, si la mayor parte o una parte esencial de los hechos ha tenido lugar en el Estado de emisión.

3. En los casos indicados en el apartado 1, letras a), b), c), h), i), j) y k), antes de tomar la decisión de denegar el reconocimiento de la sentencia o, en su caso, de la resolución de libertad vigilada, y la asunción de la vigilancia de las medidas de libertad vigilada y penas sustitutivas, la autoridad competente del Estado de ejecución consultará por cualquier medio adecuado a la autoridad competente del Estado de emisión y, cuando sea oportuno, le pedirá que facilite sin demora la información adicional necesaria.

4. Cuando la autoridad competente del Estado de ejecución haya decidido alegar un motivo de denegación contemplado en el apartado 1 del presente artículo, en particular los motivos a que se refieren las letras d) o k) de dicho apartado, podrá decidir, no obstante, de acuerdo con la autoridad competente del Estado de emisión, realizar la vigilancia de la(s) medida(s) de libertad vigilada o de la(s) pena(s) sustitutiva(s) impuestas por la sentencia y, en su caso, por la resolución de libertad vigilada que le hubieren sido presentadas, sin asumir la responsabilidad de adoptar ninguna de las decisiones contempladas en el artículo 14, apartado 1, letras a), b) y c)".
} 
siempre que se dé cuenta y explicación de las causas de la demora y comunique el plazo estimado para adoptar la decisión.

El Derecho aplicable para la ejecución de la libertad vigilada y penas sustitutivas será la del Estado de ejecución (art. 13) que podrá exigir al penado que presente pruebas del cumplimiento de la obligación de reparación del daño causado por la infracción. Se transfiere al Estado de ejecución la competencia para adoptar cualquier decisión ulterior acerca de la ejecución de la libertad vigilada o pena sustitutiva, pena suspendida o condena condicional y, en particular, para la modificación de las obligaciones o instrucciones contenidas en la medida de libertad vigilada o pena sustitutiva, la modificación de la duración del período de libertad vigilada, la revocación de la suspensión de la ejecución de la sentencia o de la resolución de la puesta en libertad condicional, y la imposición de una pena privativa de libertad o medidas de privación de

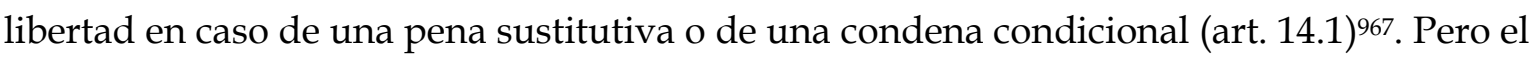
Estado emisor puede declararse único competente para adoptar algunas decisiones que puedan afectar a la ejecución (art. 14.3) ${ }^{968}$.

No obstante, cuando el Estado de ejecución pueda adoptar las modificaciones anteriormente expuestas, hay una obligación de las autoridades competentes del Estado de ejecución de informar al Estado emisor sobre cualquier decisión relativa a las referidas

\footnotetext{
967 Sigue diciendo el art. 14: “2. El Derecho del Estado de ejecución será aplicable a las decisiones adoptadas con arreglo al apartado 1 y a todas las consecuencias subsiguientes de la sentencia, incluida, si ha lugar, la ejecución de la pena privativa de libertad o la medida de privación de libertad y, en caso necesario, la adaptación de dicha pena o medida".

968 “3. Cada Estado miembro podrá declarar, en el momento de la adopción de la presente Decisión Marco o en una fecha posterior, que en su condición de Estado de ejecución se negará a asumir la responsabilidad indicada en el apartado 1, letras b) y c), en los casos o categorías de casos que especifique, en particular: a) con respecto a las penas sustitutivas, cuando la sentencia no imponga una pena privativa de libertad o medida de privación de libertad que deba aplicarse en caso de incumplimiento de las obligaciones o requerimientos de que se trate; b) con respecto a las condenas condicionales; c) en los casos en que la sentencia se refiera a hechos que no constituyan infracción según el Derecho del Estado de ejecución, sean cuales fueren sus elementos constitutivos o su calificación.

4. Cuando un Estado miembro se acoja a alguna de las posibilidades contempladas en el apartado 3, la autoridad competente del Estado de ejecución volverá a transferir la competencia a la autoridad competente del Estado de emisión en los casos de incumplimiento de una medida de libertad vigilada o pena sustitutiva si la autoridad competente del Estado de ejecución considera que debe adoptarse una decisión ulterior a tenor del apartado 1, letras b) o c).

5. En los casos a que se refiere el apartado 3 del presente artículo, no se verán afectadas ni la obligación de reconocer la sentencia y, en su caso, la resolución de libertad vigilada, ni la obligación de adoptar sin demora todas las medidas necesarias para la vigilancia de las medidas de libertad vigilada o las penas sustitutivas, como establece el artículo 8, apartado 1.

6. Las declaraciones contempladas en el apartado 3 se realizarán mediante notificación a la Secretaría General del Consejo. Estas declaraciones podrán retirarse en cualquier momento. Las declaraciones y retiradas de declaraciones mencionadas en el presente artículo se publicarán en el Diario Oficial de la Unión Europea".
} 
modificaciones (art. 16), al igual que existen una serie de obligaciones de las autoridades de ejecución cuando la competencia respecto a las resoluciones ulteriores corresponda al Estado de emisión conforme al art. 14.3, que se encuentran en el art. 17969. Tanto el Estado de emisión como el Estado de ejecución podrán conceder amnistía e indulto, pero únicamente el Estado emisor podrá resolver en materia de revisión de sentencia (art. 19).

Las competencias del Estado de ejecución cesarán en el momento en que el penado deje de tener su residencia en ese Estado o se fugue, transfiriéndolas nuevamente al Estado emisor (art. 20.1), o el propio Estado emisor podrá solicitar que vuelva a transferir la competencia en caso de que se estén llevando a cabo nuevos procesos penales contra el interesado en el Estado de emisión (art. 20.2), y cuando el Estado emisor reasuma las competencias, tendrá en cuenta el período y grado de cumplimiento de las medidas de libertad vigilada o de las penas sustitutivas en el Estado de ejecución, así como todas las decisiones que hayan sido adoptadas por el Estado de ejecución durante el tiempo que haya estado bajo sus competencias (art. 20.3).

Por último, merece que me detenga en la especial disposición acerca de que la Decisión Marco se aplicará también a Gibraltar (art. 24), imponiendo también un mandato

\footnotetext{
969 "Art. 17. Obligaciones de las autoridades afectadas cuando la competencia respecto de las resoluciones ulteriores corresponde al Estado de emisión. 1. En caso de que la autoridad competente del Estado de emisión sea competente para las resoluciones ulteriores mencionadas en el artículo 14, apartado 1, en virtud de la aplicación del artículo 14, apartado 3, la autoridad competente del Estado de ejecución le comunicará de inmediato: a) todo dato que pueda tener como efecto la revocación de la suspensión de la ejecución de la sentencia o revocación de la resolución de puesta en libertad condicional; b) todo dato que pueda suponer la imposición de una pena privativa de libertad o medida de privación de libertad; c) todos los hechos y circunstancias ulteriores cuya comunicación solicite la autoridad competente del Estado de emisión y que sean esenciales para que esta pueda adoptar las resoluciones subsiguientes de conformidad con su Derecho nacional.

2. Si un Estado miembro se ha acogido a la posibilidad contemplada en el artículo 11, apartado 4, la autoridad competente de dicho Estado informará a la autoridad competente del Estado miembro de emisión en caso de incumplimiento, por parte de la persona condenada, de la medida de libertad vigilada o de la pena sustitutiva.

3. La información sobre los datos mencionados en el apartado 1, letras a) y b), y en el apartado 2 se comunicará empleando el formulario normalizado que figura en el anexo II. La información sobre los hechos y circunstancias mencionados en el apartado 1, letra c), se comunicará empleando un medio que deje constancia escrita, incluido, a ser posible, el formulario normalizado que figura en el anexo II.

4. Si, el Derecho del Estado de emisión dispone que, el condenado ha de ser oído por la autoridad judicial antes de que se adopte una decisión sobre la imposición de una pena, este requisito podrá cumplirse, mutatis mutandis, de conformidad con los procedimientos establecidos en instrumentos de Derecho internacional o de la Unión Europea que contemplen la posibilidad de realizar audiencias mediante videoconexión".

5. La autoridad competente del Estado de emisión informará sin demora a la autoridad competente del Estado de ejecución de todas las decisiones sobre: a) la revocación de la suspensión de la ejecución de la sentencia o la revocación de la resolución de puesta en libertad condicional; b) la aplicación de la pena privativa de libertad o medida de privación de libertad cuando dicha medida esté incluida en la sentencia; c) la imposición de una pena privativa de libertad o medida de privación de libertad, cuando dicha medida no esté incluida en la sentencia; d) la extinción de las medidas de libertad vigilada o de las penas sustitutivas".
} 
a los Estados miembros de tomar las medidas necesarias para dar cumplimiento a la misma antes del 6 de diciembre de 2011 (art. 25); e igualmente impone a los Estados la obligación de remitir a la Comisión, información acerca del cumplimiento de la Decisión Marco a efectos de que se pueda elaborar un informe que permita a evaluar la medida en relación a que los Estados miembros hayan tomado las medidas necesarias para cumplir la Decisión Marco, y su margen de aplicación; informe que irá acompañado de propuestas legislativas y que se deberá elaborar, a más tardar, el 6 de diciembre de 2014 (art. 26). 


\section{CAPÍTULO TERCERO. LA LIBERTAD VIGILADA EN LA REFORMA DEL CÓDIGO PENAL DE} 2010

Mediante la LO 5/2010, de 22 de junio, por la que se modifica la LO 10/1995, de 23 de noviembre, del CP, alejándose definitivamente de la hipótesis de formular la libertad vigilada como pena, se introdujo en el texto punitivo español como medida de seguridad 970 , aproximándose a las regulaciones ya existentes de figuras similares en los vecinos ordenamientos de Italia, Francia y Alemania, afianzándose en la línea de la política criminal más conservadora de Europa ${ }^{971}$, aunque se trata de una medida de seguridad que no tiene mucho que ver con la libertad vigilada que ya existía en España en el ámbito de la responsabilidad penal de los menores, que se trata de una medida en la que fundamentalmente se asigna un educador al menor vigilado 972 .

La libertad vigilada aparece incardinada dentro de la regulación unitaria de la parte general y del sistema de medidas correctoras y de seguridad que se aplicará, de forma general, a algunos sujetos según las normas del Libro I del CP, y en especial, según las normas del Libro II CP, a los delincuentes sexuales y terroristas ${ }^{973}$. La razón que subyace en esta nueva figura es que estos sujetos necesitan una fase intermedia entre el

\footnotetext{
970 Sin duda una concepción más acorde con formulaciones clásicas de la libertad vigilada, como ya en su día manifestó FOUCAULT, M., Surveiller et punir..., cit. p. 25, al señalar que "lo son también por el juego de esas "medidas de seguridad" de que se hace acompañar la pena (interdicción de residencia, libertad vigilada, tutela penal, tratamiento médico obligatorio), y que no están destinadas a sancionar la infracción, sino a controlar al individuo, a neutralizar su estado peligroso, a modificar sus disposiciones delictuosas, y a no cesar hasta obtener tal cambio".
}

971 ACALE SÁNCHEZ, M., “Medición de la respuesta punitiva...”, cit. pp. 82 y 83. Esta autora resalta que los textos penales europeos manifiestan una tendencia a armonizarse, pero se trata de una expansión que infla su contenido con instrumentos que conllevan un mayor contenido de aflictividad y, en definitiva, se incrementa la punitividad.

972 FEIJOO SÁNCHEZ, B., “La libertad vigilada...”, cit. p. 214

973 No obstante, el Informe del Grupo de expertos y expertas en violencia doméstica y de género del CGPJ acerca de los problemas técnicos detectados en la aplicación de la LO 1/2004, de medidas de protección integral contra la violencia de género y en la de la normativa procesal, sustantiva u orgánica relacionada, y sugerencias de reforma legislativa que los abordan, publicado en enero de 2011, dedica sus páginas 13 y 14 a proponer la aplicación de la libertad vigilada a todos los delitos relacionados con la violencia de género, que sean competencia de los Juzgados de Violencia sobre la Mujer y en los que se imponga pena de prisión, proponiendo la redacción de un nuevo apartado del art. $106 \mathrm{CP}$, que quedaría como sigue: " 5 . La medida de libertad vigilada se aplicará siempre y en cualquier caso en los delitos competencia de los Juzgados de Violencia sobre la Mujer en los que se imponga pena de prisión, tanto si se suspende la pena como si no, a fin de que por vía del apartado $2^{\circ}$, párrafo $2^{\circ}$ se definan cuáles son las medidas de entre las comprendidas en el apartado $1^{\circ}$ que se deberán imponer al penado en desarrollo de la imposición de la medida de libertad vigilada". Puede consultarse el texto íntegro del informe en el siguiente enlace: [http://www.poderjudicial.es/copj/es/Temas/Violencia_domestica_y_de_genero/Grupos_de_expertos/Informe_del_Grupo _de_Expertos_y_Expertas_en_Violencia_Domestica_y_de_Genero_del_Consejo_General_del_Poder_Judicial_acerca_de_ los_problemas_tecnicos_detectados_en_la_aplicacion_de_la_Ley_Organica_1_2004]. (Consultado el 14-4-2014). 
cumplimiento de la pena de prisión y el retorno a su libertad plena, ya que, por presentar mal pronóstico, en muy pocas ocasiones van a poder acceder a la libertad condicional, por lo que dicha fase de cumplimiento no puede conformar esa etapa intermedia en estos sujetos, que pasarían, de forma abrupta, del régimen ordinario al de libertad definitiva974. Dicha regulación, no deja sino abierto el debate sobre su necesidad y su eficacia en relación a la prevención especial, y acerca de la determinación de la peligrosidad de los sujetos a los que será aplicable la medida de seguridad. Como indican algunos autores, es de dudosa licitud que la imposición de una medida - que puede alcanzar una duración de hasta diez años- se base en un juicio de probabilidad, ya que la ley nunca podrá establecer si una persona concreta va a reincidir o no si no es a través de las presunciones, de modo que únicamente podrá fijar unas pautas que, con carácter general, orientarán al juez, por lo que "dada la naturaleza del juicio de probabilidad, la tensión con el principio de certeza es clara" ${ }^{975}$.

La reforma opta decididamente por combatir la peligrosidad criminal que persiste tras el cumplimiento de la pena, no mediante medidas de seguridad privativas de libertad, sino a través de medidas que solo son restrictivas de libertad, mediante una “ponderación cautelosa de riesgos y cargas entre los derechos de los delincuentes (que tienen que soportar ciertas restricciones de derechos) y la seguridad de la sociedad o de las víctimas (que tienen que soportar a su vez una vida en libertad que genera inseguridades) en el marco de un Estado democrático de Derecho, con la que se ha pretendido extremar las cargas de los delincuentes que encierran peligrosidad criminal" 976 .

La doctrina manifiesta que esta medida constituye un tertium genus que se caracteriza por ejercer un control sobre una persona capaz y que la ratio iuris gravita sobre

\footnotetext{
974 GARCÍA ALBERO, R., “La nueva medida de seguridad...”, cit. p. 185. Como señala este autor, "el tránsito hacia la libertad sin límites plantea muchos problemas: no ha existido oportunidad real de una intervención reeducadora en el medio real del sujeto, y por lo mismo, tampoco existen instrumentos para una eficaz observación y consecuente control. Bien mirado la libertad vigilada impuesta a imputables vendría a ser, materialmente y demorada en el tiempo, lo que en buena técnica procesal debería haber sido también la regla para delincuentes con mal pronóstico: la libertad condicional previa a la excarcelación. Una libertad condicional que, no nos engañemos, nadie está dispuesto a asumir tratándose de ciertos delincuentes peligrosos. Así las cosas, el riesgo es evidente: hacer gravitar exclusivamente sobre la pena de prisión las demandas de inocuización, pervirtiendo su naturaleza y límites".
}

975 SIERRA LÓPEZ, M.V., La medida de libertad vigilada..., cit. pp. 101 y 102.

976 FEIJOO SÁNCHEZ, B., “La libertad vigilada...”, cit. p. 217. 
los sentimientos de indefensión y ausencia de seguridad jurídica que existe en la sociedad frente a ciertos colectivos que son etiquetados como peligrosos por los medios de comunicación, que "ajenos a cualquier planteamiento científico o criminológico imponen una lógica derivada del sensacionalismo inherente a una sociedad de consumo cada vez menos racionalizada", y con ello se crea un híbrido jurídico que conjuga caracteres de penas y de medidas de seguridad pero sin atender a los límites de cada una de ellas, esto es, sin la certeza y predeterminación de las penas y sin los pronósticos propios de las medidas de seguridad 977 .

El Preámbulo de la LO 5/2010, habla de que, para determinados perfiles criminológicos, los objetivos centrales del sistema de penas y, en concreto, de la pena privativa de libertad, presentan mayor resistencia. Este discurso motivador, parte de la justificación de que el objetivo imperante en nuestro sistema de penas es la rehabilitación y reinserción social del delincuente, y que el pretendido efecto rehabilitador no se alcanza con la pena privativa de libertad en determinados supuestos, toda vez que dicha pena resulta insuficiente o inadecuada para eliminar el elevado riesgo de reincidencia. Refiere el texto, pues, a los delincuentes sexuales y a los terroristas, manifestando que "su actuar se enmarca en una actitud de índole pretendidamente ideológica, que comporta la negación de la condición delictiva misma de su conducta, y por tanto el rechazo radical de la pena como respuesta legítima del Estado de Derecho, y la consiguiente resistencia a sus consecuencias".

Consecuentemente, la inocuización del delincuente - dice el Preámbulo- sería contraria a los principios elementales del Derecho penal que proclama la Constitución. Sobre este particular, la Exposición de Motivos del Proyecto contenía una referencia a que ya el Código prevé respuestas penológicas para determinados tipos de delitos que, por su duración y por su especial régimen de cumplimiento (refiriéndose a cumplimiento íntegro, período de seguridad, y demás especialidades introducidas en la reforma de la

977 GUDÍN RODRÍGUEZ-MAGARIÑOS, F., La nueva medida de seguridad..., cit. pp. 281 a 286. Este autor señala que la desigualdad que provoca la previsión de una medida de seguridad para dos clases de delincuentes viene motivada por "los sentimientos vindicativos de la opinión pública en dos áreas muy delicadas para los sentimientos de la comunidad, dado que se ha visto atormentada por episodios enormemente sangrantes. Mas dicho dolor se ha visto distorsionado y contaminado por ciertas informaciones tendenciosas que han incrementado exagerando los niveles de reincidencia y provocando una sensación de necesidad absoluta, un tanto irreal". 
ejecución penal de 2003)978, arroja resultados muy cercanos a una auténtica condena a perpetuidad. Sin embargo, esta referencia a la prisión perpetua fue eliminada en el texto definitivo del Preámbulo de la LO 5/2010979, al igual que la referencia a los perfiles criminales 980 .

No obstante, sigue diciendo el texto que "agotada la dimensión retributiva de la pena" puesto que no es posible prolongarla más en el tiempo por imperativos del propio marco constitucional, la respuesta es la aplicación de medidas de seguridad, porque - dice el texto- "se hace necesario, por tanto, para tales casos de especial gravedad expresamente previstos, contemplar otras soluciones que, sin cejar en el esfuerzo rehabilitador que debe seguir inspirando el tratamiento penitenciario, permitan conciliar las referidas exigencias constitucionales con otros valores no menos dignos de tutela, como son la seguridad y la libertad del resto de los ciudadanos, potenciales víctimas del delincuente no rehabilitado que el sistema penitenciario devuelve a la sociedad".

Es decir, que si la pena no es capaz de cumplir sus fines a pesar de haberse prolongado lo máximo posible en el tiempo y de haberse cumplido íntegramente, y persiste la peligrosidad criminal en el sujeto, podrá entrar en juego una medida de seguridad que precisamente tiene por objeto el tratamiento de personas peligrosas que han acreditado esa peligrosidad mediante la realización de un hecho delictivo. El Preámbulo refiere a "las potenciales víctimas del delincuente no rehabilitado que el sistema penitenciario devuelve a la sociedad", aspecto que posteriormente se refleja en la regulación del contenido de la libertad vigilada, porque la mayoría de las obligaciones y prohibiciones en que se concreta la medida de seguridad, poco tienen de rehabilitadoras y predomina el carácter asegurativo ${ }^{981}$, que precisamente pretende proteger a esas víctimas pontenciales en lugar de paliar esa falta de rehabilitación del delincuente.

\footnotetext{
978 En profundidad sobre todo ello vid. TAMARIT SUMALLA, J.M. / GARCÍA ALBERO, R., La reforma de la ejecución penal..., cit. pp. 17 y ss.

979 REBOLLO VARGAS, R., La llibertat vigilada..., cit. p. 62. Como indica este autor, "atès que implícitament en el Projecte s'admetia una evidència no massa raonable, com és el fet que a un subjecte que ha complert una condemna de cadena perpètua de facto se l'imposi el compliment d'una mesura de seguretat de llibertat vigilada acordada en el moment de dictar-ne la sentència condemnatòria -sense perjudici que pugui ser substituïda o que s'acordi el cessament- atès que el judici de pronòstic (la seva potencial perillositat) que es preestablia en el moment de dictar-ne sentència es conserva inalterat després del compliment de la pena".

980 ACALE SÁNCHEZ, M., “Medición de la respuesta punitiva...”, cit. p. 158.

981 REBOLLO VARGAS, R., La llibertat vigilada ..., cit. p. 58. Este autor señala que "l'abast de les mesures que configuren la llibertat vigilada no tenen massa de rehabilitadores i sí més de control aflictiu posterior".
} 
Así, dice el texto, mediante una "modificación parcial y una leve reordenación de Título IV del Libro Primero del CP", se introduce una nueva medida denominada libertad vigilada, que se inserta en el régimen general de las medidas de seguridad, y algunas de ellas se refunden en ese concepto común del art. $106 \mathrm{CP}$, como la prohibición u obligación de acudir a determinados lugares o de acercarse a determinadas personas, o de someterse a ciertos tratamientos, etc. En este concreto aspecto, algunos autores enfatizan que no se trata de una leve reordenación, sino de una modificación que rebasa con creces la levedad que el Preámbulo proclama, porque supone una alteración del régimen de medidas de seguridad que se extiende a los imputables ${ }^{982}$.

Ya de entrada, el Preámbulo pretende definir la libertad vigilada como una "medida de seguridad que el Tribunal impone de manera facultativa o preceptiva, según la propia norma señale en cada caso, y cuyo contenido se concreta en una serie de limitaciones, obligaciones, prohibiciones o reglas de conducta, aplicables separada o conjuntamente, dentro de los márgenes de duración específicos que en su caso resulten de la parte especial del Código". Sigue diciendo el Preámbulo que en la fase de ejecución puede ser modificada atendiendo a la evolución del sujeto y "mediante un sencillo trámite" que en la reforma experimenta un reforzamiento de la garantía de contradicción, que se extiende también a las víctimas del delito aunque no sean parte en el proceso.

La novedad sustancial que supone la principal diferencia de esta nueva medida de seguridad en relación a las distintas medidas de corrección y seguridad ya previstas en el $\mathrm{CP}$, es que la libertad vigilada no es únicamente aplicable a inimputables o semiimputables como en el resto de medidas, sino también cuando el pronóstico de peligrosidad deriva de la naturaleza del hecho cometido, por haberlo así previsto el legislador expresamente en los tipos penales a los que es de aplicación ${ }^{983}$. Como indica la doctrina, "la novedad reside en la aplicación de un híbrido, la medida de libertad vigilada, cuya naturaleza jurídica es difícil de asumir ya que no se trata de una pena -su fundamento no reposa en la culpabilidad del autor- ni responde a la naturaleza jurídica de las medidas de seguridad", y conviene recordar que hasta el momento las medidas de seguridad solo podían imponerse a inimputables y semiimputables, previa valoración de

982 REBOLLO VARGAS, R., “De las medidas de seguridad...”, cit. p. 797.

983 ESCRIHUELA CHUMILLA, F.J., Todo Penal. Madrid: La Ley. 2011, pp. 412 a 415. 
su peligrosidad, de forma que la prognosis no era, como sucede en esta nueva formulación, derivada de las características del delito cometido984.

También refiere el Preámbulo a que la aplicación de la libertad vigilada para imputables se justifica "cuando la peligrosidad deriva del específico pronóstico del sujeto imputable en relación con la naturaleza del hecho cometido", de lo que se desprenden dos criterios de valoración de la peligrosidad: uno que se asocia con el pronóstico de peligrosidad (peligrosidad subjetiva); y otro que se asocia con el delito cometido (peligrosidad objetiva), ambos coexisten aunque solo el primer criterio, basado en informes y en una verdadera labor de prognosis, es aceptable desde el punto de vista de la predicción de la peligrosidad, porque el segundo criterio no puede ser más que un indicador incierto de escasa fiabilidad que se basa en hechos acaecidos antes de acabar el tratamiento peniteniacio en cumplimiento de la pena ${ }^{985}$.

Sigue diciendo el Preámbulo que la medida no se establece como alternativa a la pena de prisión, sino que se impone en sentencia junto a la pena de prisión para su ejecución posterior a la excarcelación, y su duración, extinción y su efectiva materialización dependerá del pronóstico de peligrosidad. También habla el Preámbulo del juego de los nuevos arts. 98 y 105 CP, en la concreción del contenido de la medida, de la posible sustitución, modificación, suspensión o cesación, puesto que en dichos aspectos intervendrá el JVP y el Juez o Tribunal sentenciador, que es a quien, según la LECrim, le corresponde la ejecución de la Sentencia dictada en el plenario. El texto analizado justifica la intervención del juez o tribunal sentenciador en la ejecución de la medida en que precisamente quien ha juzgado a esa persona es quien conoce sus circunstancias y quien puede tener un mayor conocimiento del pronóstico que justifique la elección de las medidas particulares en que se concreta el contenido de la libertad vigilada.

En cuanto a la duración de la medida, se mantiene en un máximo de cinco años, que es el límite que se establecía hasta el momento para las medidas de seguridad no

\footnotetext{
984 PORTILlA CONTRERAS, G., "La reforma en los actos preparatorios y favorecimiento de delitos de terrorismo". En QUINTERO OLIVARES, G., (Dir.) La Reforma Penal de 2010: Análisis y Comentarios. Navarra: Thomson Aranzadi. 2010, p. 382.

985 CÁMARA ARROYO, S., “La libertad vigilada...”, cit. pp. 12 y 13. Este autor -con referencia a la más reciente jurisprudencia-, señala que, no obstante, la SAP de Madrid 96/2012, de 8 de marzo, optó por dar preferencia a la gravedad del hecho como criterio de baremación de la peligrosidad a efectos de imponer la libertad vigilada.
} 
privativas de libertad que se refunden bajo el concepto de libertad vigilada. Ahora bien: se añade la excepción de que se puede extender hasta los diez años para los supuestos en que la ley así lo prevea (art. 105.2 CP) y, en concreto, se contempla una previsión de duración de hasta diez años en supuestos de imposición preceptiva de la libertad vigilada (cuando se trate de delitos contra la libertad e indemnidad sexuales o de terrorismo), aunque dicha duración, salvo la posibilidad de imposición facultativa a los delincuentes primarios a la que después referiré, se basa únicamente en la gravedad de la pena privativa de libertad prevista para el delito de que se trate, sin tener en cuenta ningún otro criterio que podría ser indicativo de la existencia de peligrosidad, como la reincidencia, la habitualidad delictiva, o cualquier otra circunstancia que pudiera ser relevante a los efectos de realizar una prognosis de peligrosidad ${ }^{986}$.

El art. único de la Ley 5/2010, de 22 de junio, reguló la libertad vigilada en sus apartados vigésimo segundo a vigésimo octavo. En síntesis, las modificaciones son las siguientes: en el apartado vigésimo segundo se modificó el apartado 3 del art. 96 CP987; el apartado vigésimo tercero modificó el art. 97 CP988; el apartado vigésimo cuarto modificó el art. 98 CP989; el apartado vigésimo quinto modificó, a su vez, el apartado 3 del art. 100

986 SANZ MORÁN, A.J., "La nueva medida de seguridad de libertad vigilada: reflexión político-criminal”. En MUÑOZ CONDE, F. / LORENZO SALGADO, J.M. / FERRÉ OLIVE, J.C. / CORTES BECHIARELLI, E. / NÚÑEZ PAZ, M.A., (Dirs.), Un Derecho penal comprometido. Libro Homenaje al Prof. Dr. Gerardo Landrove Díaz. Valencia: Tirant lo Blanch. 2011, pp. 1019 y 1020.

987 Que queda redactado de la siguiente forma:

“3. Son medidas no privativas de libertad:

$1^{\mathrm{a})}$ La inhabilitación profesional.

$2^{\mathrm{a}}$ ) La expulsión del territorio nacional de extranjeros no residentes legalmente en España.

$3^{\text {a) }}$ La libertad vigilada.

$4^{\text {a) }}$ La custodia familiar. El sometido a esta medida quedará sujeto al cuidado y vigilancia del familiar que se designe y que acepte la custodia, quien la ejercerá en relación con el Juez de Vigilancia Penitenciaria y sin menoscabo de las actividades escolares o laborales del custodiado.

$5^{\text {a) }}$ La privación del derecho a conducir vehículos a motor y ciclomotores.

$\left.6^{a}\right)$ La privación del derecho a la tenencia y porte de armas".

988 Que pasa a tener la siguiente redacción: “Durante la ejecución de la sentencia, el Juez o tribunal sentenciador adoptará, por el procedimiento establecido en el artículo siguiente, alguna de las siguientes decisiones: a) Mantener la ejecución de la medida de seguridad impuesta. b) Decretar el cese de cualquier medida de seguridad impuesta cuando desaparezca la peligrosidad criminal del sujeto. c) Sustituir una medida por otra que estime más adecuada, entre las previstas para el supuesto de que se trate. En el caso de que fuera acordada la sustitución y el sujeto evolucionara desfavorablemente, se dejará sin efecto la sustitución, volviéndose a aplicar la medida sustituida. d) Dejar en suspenso la ejecución de la medida en atención al resultado ya obtenido con su aplicación, por un plazo no superior al que reste hasta el máximo señalado en la sentencia que la impuso. La suspensión quedará condicionada a que el sujeto no delinca durante el plazo fijado, y podrá dejarse sin efecto si nuevamente resultara acreditada cualquiera de las circunstancias previstas en el artículo 95 de este Código".

989 Y reza del siguiente tenor: “1. A los efectos del artículo anterior, cuando se trate de una medida de seguridad privativa de libertad o de una medida de libertad vigilada que deba ejecutarse después del cumplimiento de una pena privativa de libertad, el Juez de Vigilancia Penitenciaria estará obligado a elevar al 
CP990; el apartado vigésimo sexto modificó el art. 103.3 CP; el apartado vigésimo séptimo modificó el art. 105 CP991; y por último, el apartado vigésimo octavo modificó el apartado $106 \mathrm{CP}^{992}$.

menos anualmente, una propuesta de mantenimiento, cese, sustitución o suspensión de la misma. Para formular dicha propuesta el Juez de Vigilancia Penitenciaria deberá valorar los informes emitidos por los facultativos y profesionales que asistan al sometido a medida de seguridad o por las Administraciones Públicas competentes y, en su caso, el resultado de las demás actuaciones que a este fin ordene. 2. Cuando se trate de cualquier otra medida no privativa de libertad, el Juez o Tribunal sentenciador recabará de las Administraciones, facultativos y profesionales a que se refiere el apartado anterior, los oportunos informes acerca de la situación y la evolución del condenado, su grado de rehabilitación y el pronóstico de reincidencia o reiteración delictiva.

3. En todo caso, el Juez o Tribunal sentenciador resolverá motivadamente a la vista de la propuesta o los informes a los que respectivamente se refieren los dos apartados anteriores, oída la propia persona sometida a la medida, así como el Ministerio Fiscal y las demás partes. Se oirá asimismo a las víctimas del delito que no estuvieren personadas cuando así lo hubieren solicitado al inicio o en cualquier momento de la ejecución de la sentencia y permanezcan localizables al efecto".

990 Que queda redactado como sigue: “3. En ambos casos el juez o tribunal deducirá testimonio por el quebrantamiento. A estos efectos, no se considerará quebrantamiento de la medida la negativa del sujeto a someterse a tratamiento médico, pero sí la interrupción injustificada de dicho tratamiento cuando lo haya consentido".

991 En el siguiente sentido: “En los casos previstos en los artículos 101 a 104, cuando imponga la medida privativa de libertad o durante la ejecución de la misma, el Juez o Tribunal podrá imponer razonadamente una o varias medidas que se enumeran a continuación. Deberá asimismo imponer alguna o algunas de dichas medidas en los demás casos expresamente previstos en este Código:

1. Por un tiempo no superior a cinco años:

a) Libertad vigilada.

b) Custodia familiar. El sometido a esta medida quedará sujeto al cuidado y vigilancia del familiar que se designe y que acepte la custodia, quien la ejercerá en relación con el Juez de Vigilancia y sin menoscabo de las actividades escolares o laborales del custodiado.

2. Por un tiempo de hasta diez años:

a) Liberad vigilada, cuando expresamente lo disponga este Código.

b) La privación del derecho a la tenencia y porte de armas.

c) La privación del derecho a conducir vehículos a motor y ciclomotores.

Para decretar la obligación de observar alguna o algunas de las medidas previstas en este artículo, así como para concretar dicha obligación cuando por ley viene obligado a imponerlas, el Juez o Tribunal sentenciador deberá valorar los informes emitidos por los facultativos y profesionales encargados de asistir al sometido a la medida de seguridad.

El Juez de Vigilancia Penitenciaria o los servicios de la Administración correspondientes informarán al juez o tribunal sentenciador.

En los casos previstos en este artículo, el Juez o Tribunal sentenciador dispondrá que los servicios de asistencia social competentes presten la ayuda o atención que precise y legalmente le corresponda al sometido a medidas de seguridad no privativas de libertad".

992 Que pasa a tener la siguiente redacción: “1. La libertad vigilada consistirá en el sometimiento del condenado a control judicial a través del cumplimiento por su parte de alguna o algunas de las siguientes medidas:

a) La obligación de estar siempre localizable mediante aparatos electrónicos que permitan su seguimiento permanente.

b) La obligación de presentarse periódicamente en el lugar que el Juez o Tribunal establezca.

c) La de comunicar inmediatamente, en el plazo máximo y por el medio que el Juez o tribunal señale a tal efecto, cada cambio del lugar de residencia o del lugar o puesto de trabajo.

d) La prohibición de ausentarse del lugar donde resida sin autorización del Juez o Tribunal.

e) La prohibición de aproximarse a la víctima, o a aquellos de sus familiares u otras personas que determine el Juez o tribunal.

f) La prohibición de comunicarse con la víctima, o con aquellos de sus familiares u otras personas que determine el Juez o tribunal.

g) La prohibición de acudir a determinados territorios, lugares o establecimientos.

h) La prohibición de residir en determinados lugares. 
Efectuada esta relación de preceptos que afectan a la libertad vigilada en el articulado del Código, para un estudio sistematizado podemos estructurar su análisis en cuatro grandes bloques: el primero dedicado al concepto de libertad vigilada y su ubicación sistemática en el Código; el segundo dedicado a su contenido y alcance; el tercero dedicado a su ejecución; y el cuarto dedicado al quebrantamiento de la medida de libertad vigilada.

\section{Concepto de libertad vigilada}

El CP no dedica ningún precepto a definirla, sino que, por una parte la enumera dentro del catálogo de las medidas de seguridad no privativas de libertad (art. 96.3. $3^{\mathrm{a}}$ $\mathrm{CP}$ ); por otra regula su duración (art. $105 \mathrm{CP}$ ), y por otra la dota de contenido en el art. 106 CP. Como indican Orts Berenguer y GOnZÁlez Cussac, "lo que se dice en el art. 96 CP con carácter general sobre las medidas no privativas de libertad no coincide plenamente con el desarrollo que de las mismas se hace en el art. $105 \mathrm{CP}$, si bien ahora la introducción de la medida de "libertad vigilada" ha servido justamente para simplificar el catálogo de medidas de seguridad no privativas de libertad, al quedar varias de las anteriores en la

i) La prohibición de desempeñar determinadas actividades que puedan ofrecerle o facilitarle la ocasión para cometer hechos delictivos de similar naturaleza.

j) La obligación de participar en programas formativos, laborales, culturales, de educación sexual u otros similares.

k) La obligación de seguir tratamiento médico externo, o de someterse a control médico periódico.

2. Sin perjuicio de lo dispuesto en el artículo 105, el Juez o Tribunal deberá imponer en la sentencia la medida de libertad vigilada para su cumplimiento posterior a la pena privativa de libertad que así lo disponga de manera expresa este Código.

En estos casos, con anterioridad suficiente a la extinción de la pena privativa de libertad, de modo que la libertad vigilada pueda iniciarse en ese mismo momento, el Juez de Vigilancia Penitenciaria, por el procedimiento previsto en el artículo 98, elevará la oportuna propuesta al Juez o Tribunal sentenciador, que, con arreglo a dicho procedimiento, concretará, sin perjuicio de lo establecido en el artículo 97, el contenido de la medida fijando las obligaciones y prohibiciones enumeradas en el apartado 2 de este artículo que habrá de observar el condenado. / Si éste lo hubiera sido a varias penas privativas de libertad que deba cumplir sucesivamente, lo dispuesto en el apartado anterior se entenderá referido al momento en que concluya el cumplimiento de todas ellas. / Asimismo, el penado a quien se hubiere impuesto por diversos delitos otras tantas medidas de libertad vigilada que, dado el contenido de las obligaciones o prohibiciones establecidas, no pudieran ser ejecutadas simultáneamente, las cumplirá de manera sucesiva, sin perjuicio de que el Juez o Tribunal pueda ejercer las facultades que le atribuye el apartado siguiente.

3. Por el mismo procedimiento del artículo 98, el Juez o Tribunal podrá: a) Modificar en lo sucesivo las obligaciones y prohibiciones impuestas. b) Reducir la duración de la libertad vigilada o incluso poner fin a la misma en vista del pronóstico positivo de reinserción que considere innecesaria o contraproducente la continuación de las obligaciones impuestas. c) Dejar sin efecto la medida cuando la circunstancia descrita en la letra anterior se dé en el momento de concreción de las medidas que se regula en el número 4 del presente artículo.

4. En caso de incumplimiento de una o varias obligaciones, el Juez o Tribunal, a la vista de las circunstancias concurrentes y por el mismo procedimiento indicado en los números anteriores, podrá modificar las obligaciones o prohibiciones impuestas. Si el incumplimiento fuera reiterado o grave, revelador de la voluntad de no someterse a las obligaciones o prohibiciones impuestas, el Juez deducirá, además, testimonio por un presunto delito del artículo 468 de este Código". 
nueva"993. Así, la nueva regulación refunde algunas de las medidas de seguridad previstas con anterioridad que ahora con la reforma desaparecen del catálogo del art. 93.3 $\mathrm{CP}^{994}$ y pasan a estar integradas en el contenido de la libertad vigilada.

Conjugando los citados preceptos podemos extraer las siguientes consideraciones: se trata de una medida de seguridad no pnts esrivativa de libertad, de carácter híbrido dada su finalidad resocializadora y a la vez asegurativa995, que puede ser impuesta por tiempo no superior a cinco años en unos casos y por tiempo de hasta diez años en otros; y consistirá en el sometimiento del condenado al control judicial996 a través del cumplimiento de alguna, algunas o todas las medidas previstas en el art. 106 CP. La libertad vigilada puede entrar en juego como medida principal, como medida sustitutiva de otras medidas o como complementarias de la pena de prisión en casos de delitos sexuales y terrorismo ${ }^{997}$.

RODRÍGUEZ RAMOS afirma que "la libertad vigilada se configura como una medida de seguridad, que a su vez incluye diversas obligaciones activas o pasivas, con una doble naturaleza: como una consecuencia jurídica del delito complementaria o sustitutiva de una pena (medida de seguridad post delictum en sentido estricto), y como una prórroga de la responsabilidad penal derivada de un delito (medida de seguridad post pena y/o medida), en base a la peligrosidad pronosticable del que ya ha cumplido su pena o medida impuesta" 998 .

993 ORTS BERENGUER, E. / GONZÁLEZ CUSSAC, J.L., Compendio..., cit. p. 351.

994 SANZ MORÁN, A.J., “La nueva medida de seguridad...”, cit. p. 1015.

995 SIERRA LÓPEZ, M.V., La medida de libertad vigilada..., cit. p. 102.

996 Cuestión distinta es que el art. $106 \mathrm{CP}$ realmente contenga medidas de vigilancia en sentido estricto, vid. MANZANARES SAMANIEGO, J.L., "La libertad vigilada...", cit. p. 56. Como indica este autor, "no es muy realista pretender controlar judicialmente al condenado sólo a través del cumplimiento de las medidas que a continuación se relacionan. Nada hay aquí de amplio seguimiento del reo como en la LO 5/2000, por ejemplo, y falta la imprescindible figura del delegado especial, parole officer o Bewährungshefer [...]. Basta la lectura de éstas, listadas desde la letra a) a la k), para comprobar que lo del "control judicial a través del cumplimiento" es poco realista, por cuanto su cumplimiento poca relación tiene con una libertad vigilada sin la pieza esencial de un vigilante ad hoc". En el mismo sentido GASCÓN INCHAUSTI, F. / VILLAMARÍN LÓPEZ, M.L., "Otras repercusiones de la LO 5/2010 en el ámbito del Proceso penal". En GASCÓN INSCHAUSTI, F., (Coord.), Repercusiones sobre el Proceso Penal de la Ley Orgánica 5/2010, de Reforma del Código Penal. Navarra: Aranzadi. 2010, pp. 375 y 376, que expresan que se echa en falta la figura del ayudante a prueba.

997 MAPELLI CAFFARENA, B., Las consecuencias..., cit. p. 378.

998 RODRÍGUEZ RAMOS, L., Compendio de Derecho Penal. Parte General. $2^{a}$ Ed. Madrid: Dykinson. 2010, p. 289. 
Por su parte, Cuello Contreras y Mapelli CAFFAREnA, manifiestan que "el empleo de esta medida puede darse en tres escenarios distintos. El primero de ellos como medida no privativa de libertad impuesta con carácter de medida principal. En segundo lugar, como medida sustitutiva de otra medida originaria. Y finalmente, como medida subsiguiente para los imputables condenados por delitos de terrorismo y agresiones sexuales" 999 .

Se hace necesario determinar en este bloque dedicado al concepto de libertad vigilada en qué supuestos procede su aplicación y, dentro de ellos, en qué supuestos puede imponerse hasta cinco años y en qué otros puede llegar hasta los diez. Del contenido de la regulación sistemática de la libertad vigilada podemos extraer que existen dos vertientes: una previsión general, dedicada a sujetos que presentan mermada su imputabilidad, cuya aplicación resulta facultativa, y una previsión especial dedicada a sujetos peligrosos plenamente imputables, de aplicación preceptiva y que no permite el cumplimiento anticipado (sino posterior a la pena privativa de libertad) ni ningún abono a la medida de seguridad del tiempo de privación de libertad ya cumplido ${ }^{1000}$. Ambas previsiones se analizan pormenorizadamente a continuación.

\section{Previsión general. Libertad vigilada para inimputables y semiimputables}

Del tenor literal del precepto (art. $105 \mathrm{CP})^{1001}$ se desprende que la libertad vigilada podrá imponerse en los casos previstos en los arts. 101 a $104 \mathrm{CP}$. En este punto es

\footnotetext{
999 CUELLO CONTRERAS, J. / MAPELLI CAFFARENA, B., Curso de Derecho penal..., cit. p. 360. “Conforme a su nueva formulación se ha concebido más que como una medida con contornos propios, como un registro punitivo bajo el cual se recogen numerosas formas de restringir el ejercicio de derechos bajo el control judicial."

1000 REBOLLO VARGAS, R., La llibertat vigilada..., cit. p. 36.

1001 Art. 105. “En los casos previstos en los artículos 101 a 104, cuando imponga la medida privativa de libertad o durante la ejecución de la misma, el Juez o Tribunal podrá imponer razonadamente una o varias medidas que se enumeran a continuación. Deberá asimismo imponer alguna o algunas de dichas medidas en los demás casos expresamente previstos en este Código.

1. Por un tiempo no superior a cinco años:

a) Libertad vigilada.

b) Custodia familiar. El sometido a esta medida quedará sujeto al cuidado y vigilancia del familiar que se designe y que acepte la custodia, quien la ejercerá en relación con el Juez de Vigilancia y sin menoscabo de las actividades escolares o laborales del custodiado.

2. Por un tiempo de hasta diez años:

a) Libertad vigilada, cuando expresamente lo disponga este Código.

b) La privación del derecho a la tenencia y porte de armas.

c) La privación del derecho a conducir vehículos a motor y ciclomotores.
} 
relevante resaltar, que la libertad vigilada puede imponerse de forma acumulada a una medida de internamiento por tiempo no superior a cinco años ${ }^{1002}$. En ese orden de cosas, lo primero que habrá que analizar es qué supuestos son los previstos en tales preceptos a los que remite el art. $105 \mathrm{CP}$, que no son otros que los previstos con carácter general para la aplicación de las medidas de seguridad ${ }^{1003}$, a saber: 1) art. $101 \mathrm{CP}^{1004}$, sujetos exentos de responsabilidad criminal por aplicación de la eximente del art. $20.1 \mathrm{CP}$, esto es, anomalía o alteración psíquica; 2) art.102 CP1005, sujetos exentos de responsabilidad por aplicación de la eximente del art. 20.2 CP, esto es, intoxicación plena o síndrome de abstinencia, salvo supuestos de actio libera in causa; 3) art. $103 \mathrm{CP} 1006$, sujetos exentos de responsabilidad por eximente del art. $20.3 \mathrm{CP}$, esto es, alteraciones de la percepción, de nacimiento o de la infancia, que impidan al sujeto percibir la conciencia de la realidad; 4) art. $104 \mathrm{CP}^{1007}$, supuestos de eximente incompleta en relación a los arts. 20.1, 2 y 3 CP, es

Para decretar la obligación de observar alguna o algunas de las medidas previstas en este artículo, así como para concretar dicha obligación cuando por ley viene obligado a imponerlas, el Juez o Tribunal sentenciador deberá valorar los informes emitidos por los facultativos y profesionales encargados de asistir al sometido a la medida de seguridad.

El Juez de Vigilancia Penitenciaria o los servicios de la Administración correspondiente informarán al Juez o Tribunal sentenciador.

En los casos previstos en este artículo, el Juez o Tribunal sentenciador dispondrá que los servicios de asistencia social competentes presten la ayuda o atención que precise y legalmente le corresponda al sometido a medidas de seguridad no privativas de libertad".

1002 MUÑOZ CONDE, F. / GARCÍA ARÁN, M., Derecho Penal..., cit. p. 597.

1003 RODRÍGUEZ RAMOS, L., Compendio de Derecho penal. Parte general. Madrid: Dykinson. 2006, pp. 266 a 270.

1004 Art. 101. “1. Al sujeto que sea declarado exento de responsabilidad criminal conforme al número $1^{\circ}$ del art. 20, se le podrá aplicar, si fuere necesaria, la medida de internamiento para tratamiento médico o educación especial en un establecimiento adecuado al tipo de anomalía o alteración psíquica que se aprecie, o cualquier otra de las medidas previstas en el apartado 3 del art. 96 . El internamiento no podrá exceder del tiempo que habría durado la pena privativa de libertad, si hubiera sido declarado responsable el sujeto, y a tal efecto el Juez o Tribunal fijará en la sentencia ese límite máximo. 2. El sometido a esta medida no podrá abandonar el establecimiento sin autorización del Juez o Tribunal sentenciador, de conformidad con lo previsto en el art. 97 de este Código".

1005 Art. 102. “1. A los exentos de responsabilidad penal conforme al número 2. ${ }^{\circ}$ del art. 20 se les aplicará, si fuere necesaria, la medida de internamiento en centro de deshabituación público, o privado debidamente acreditado $\mathrm{u}$ homologado, o cualquiera otra de las medidas previstas en el apartado 3 del art.96. El internamiento no podrá exceder del tiempo que habría durado la pena privativa de libertad, si el sujeto hubiere sido declarado responsable, y a tal efecto el Juez o Tribunal fijará ese límite máximo en la sentencia. 2. El sometido a esta medida no podrá abandonar el establecimiento sin autorización del Juez o Tribunal sentenciador de conformidad con lo previsto en el art. 97 de este Código".

1006 Art. 103. “1. A los que fueren declarados exentos de responsabilidad conforme al número 3. ${ }^{\circ}$ del art. 20, se les podrá aplicar, si fuere necesaria, la medida de internamiento en un centro educativo especial o cualquier otra de las medidas previstas en el apartado tercero del art. 96. El internamiento no podrá exceder del tiempo que habría durado la pena privativa de libertad, si el sujeto hubiera sido declarado responsable y, a tal efecto, el Juez o Tribunal fijará en la sentencia ese límite máximo. 2. ${ }^{\circ}$ El sometido a esta medida no podrá abandonar el establecimiento sin autorización del Juez o Tribunal sentenciador de conformidad con lo previsto en el art. 97 de este Código. 3. En este supuesto, la propuesta a que se refiere el art. 98 de este Código deberá hacerse al terminar cada curso o grado de enseñanza".

1007 Art. 104." 1 . En los supuestos de eximente incompleta en relación con los números $1^{\circ}, 2^{\circ}$ y $3^{\circ}$ del art. 20, el Juez o Tribunal podrá imponer, además de la pena correspondiente, las medidas previstas en los arts. 101, 102 
decir, los supuestos anteriores con la salvedad de que la exención de la responsabilidad no es completa sino incompleta. Por tanto, del tenor literal del precepto se desprende que la libertad vigilada se aplicará a sujetos inimputables o semiimputables, cuando se trate de las causas anteriormente citadas, por lo que, no es aplicable a los sujetos exentos de responsabilidad criminal cuando se trate de los supuestos contemplados en los arts. 20.4 y $20.5 \mathrm{CP}$, esto es: legítima defensa y estado de necesidad.

La libertad vigilada en casos de inimputabilidad, se presenta como una medida de seguridad de aplicación autónoma, que entra en escena sin sujeción necesaria a otra medida de seguridad o a ninguna pena y puede aplicarse con funciones meramente asegurativas ${ }^{1008}$ cuando concurran las eximentes descritas.

A) En la aplicación de la libertad vigilada para inimputables1009, podemos encontrarnos varios supuestos distintos, ya que, según el art. $105 \mathrm{CP}$, la medida puede ser única y principal, en cuyo caso se impone, sin más, tras la sentencia; puede ser una pauta que acompañe a una medida de internamiento, de forma que su cumplimiento sería simultáneo al de aquélla (aunque carecería de efectividad porque la vigilancia que supone el internamiento es mayor que el de la libertad vigilada que lo absorbe, por lo que esta previsión únicamente es atendible en el plano teórico); y como complemento de una medida de internamiento, de forma que su ejecución sería posterior, aunque con el límite de que la suma de las dos no podrán traspasar el límite del tiempo que duraría la pena correspondiente para ese delito en caso de haber sido declarado culpable el sujeto ${ }^{1010}$.

En los supuestos en que se imponga una medida de internamiento, las opciones con las que se cuenta, según los arts. 101, 102 y 103 CP son: la imposición de una medida de internamiento en caso de ser necesaria, o bien las medidas no privativas de libertad del

\footnotetext{
y 103. No obstante, la medida de internamiento sólo será aplicable cuando la pena impuesta sea privativa de libertad y su duración no podrá exceder de la pena prevista por el Código para el delito. Para su aplicación se observará lo dispuesto en el art. 99. 2. Cuando se aplique una medida de internamiento de las previstas en el apartado anterior o en los arts. 101, 102 y 103, el juez o tribunal sentenciador comunicará al ministerio fiscal, con suficiente antelación, la proximidad de su vencimiento, a efectos de lo previsto por la disposición adicional primera de este Código".

1008 CÁMARA ARROYO, S., “La libertad vigilada...", cit. p. 10 a 12.

1009 Desde la entrada en vigor de la LO 5/2010, se han dictado varias resoluciones en las que se impone la libertad vigilada a inimputables, como, por ejemplo, la SAP de Barcelona 581/2012, de 11 de diciembre, la SAP de Valladolid, 98/2013, de 9 de abril, entre otras.

1010 ACALE SÁNCHEZ, M., “Medición de la respuesta punitiva...”, cit. p. 188.
} 
art. 96.3 CP, pero para decretar el internamiento es necesario que el delito cometido lleve aparejada una pena privativa de libertad, en cuyo caso el límite temporal estará marcado por los propios arts. 101 a $103 \mathrm{CP}$, de forma que no podrá exceder del tiempo que habría durado la pena privativa de libertad en caso de haber sido impuesta al sujeto si se hubiese declarado su responsabilidad, en cuyo caso el juez o tribunal fijará en la sentencia ese límite máximo.

Se plantea una contradicción entre la comparación de los arts. 101 a 103 CP con el art. $104 \mathrm{CP}$ en relación a los semiimputables, donde la medida de seguridad se supedita a la pena prevista para el delito de que se trate, que según indica la doctrina, debe ser considerada en abstracto. El art. $105 \mathrm{CP}$ contempla otra posibilidad, consistente en que además de la medida de internamiento se imponga una o varias medidas de seguridad no privativas de libertad del art. $105 \mathrm{CP}$, en cuyo caso la duración no podrá exceder del tiempo que correspondería a la pena privativa de libertad en caso de haber sido impuesta al sujeto responsable, esto es, no podrá exceder del límite máximo del art. $105 \mathrm{CP}$ y, a su vez, del tiempo máximo de la pena en caso de haber sido impuesta, duración que habrá de venir fijada en la sentencia para el cumplimiento del internamiento. También se plantea el problema de la conjugación de dos circunstancias concurrentes: cuando se trata de un sujeto inimputable que además haya cometido algún delito sexual. En estos casos, no es aplicable la presunción de peligrosidad que se prevé para los delincuentes sexuales imputables (exclusivamente) por lo que la peligrosidad en estos supuestos de inimputables deberá ser acreditada en cada caso ${ }^{1011}$.

En los supuestos en que no se imponga ninguna medida de internamiento por no considerarse necesaria y se imponga una medida no privativa de libertad, ésta quedará sujeta al límite de que la duración de la medida de seguridad no podrá exceder del tiempo de duración máximo de la pena prevista para el delito cometido (art. $105 \mathrm{CP}$ ). El otro supuesto es el relativo a cuando el delito cometido no lleve aparejada pena privativa de libertad, sino otra pena de distinta naturaleza, en cuyo caso, la duración de la medida de seguridad deberá ajustarse a las reglas del art. $6.2 \mathrm{CP}$, esto es, que no podrá resultar más grave que la pena que correspondería al delito cometido, ni sobrepasar el límite de lo necesario para prevenir la peligrosidad del autor, por lo que, si se impone la libertad

1011 SIERRA LÓPEZ, M.V., La medida de libertad vigilada..., cit. pp. 139 y 140. 
vigilada en estos casos, la concreción de las obligaciones y prohibiciones que se impongan y su duración serán de difícil concreción, para lo que SIERRA LÓPEZ propone que se tomen como referencia las similitudes entre las distintas obligaciones y prohibiciones que puedan imponerse con las penas que correspondería imponer por el delito cometido, y de ahí extraer el máximo de duración posible para la libertad vigilada1012.

B) Para el caso de los semiimputables, entran en juego las reglas del sistema vicarial $\mathrm{y}$, en ese sentido, nos podemos encontrar con varias situaciones:

1. La primera, cuando al sujeto se le impone una pena y una medida de seguridad, en cuyo caso, la medida de internamiento solo será posible cuando la pena sea privativa de libertad, ex art. 104 CP. En estos casos, se aplicará primero la medida de seguridad y cuando se alce, comenzará a cumplirse la pena, pero el tiempo transcurrido de cumplimiento de la medida de seguridad le será abonado a la pena (art. $99 \mathrm{CP}$ ), que además podrá ser suspendida por el plazo que reste de cumplir o aplicar en su lugar alguna de las medidas de seguridad del art. $96.3 \mathrm{CP}^{1013}$. En este caso, si se impone la libertad vigilada, el límite máximo será el que correspondería a la pena que reste por cumplir.

Dentro de esta primera situación, también puede darse el caso de que se impongan penas privativas de libertad o no privativas de libertad y medidas de seguridad no privativas de libertad. En estos casos, el cumplimiento deberá ser simultáneo si es posible, y en caso de no serlo, el cumplimiento deberá ser sucesivo, en cuyo caso, si la medida de seguridad es de la misma naturaleza que la pena, entrará en juego el límite del art. 6.2 CP, de tal forma que la medida de seguridad no podrá ser más gravosa que la pena impuesta ${ }^{1014}$.

No obstante, algunos autores manifiestan que en este punto el sistema vicarial choca con un inconveniente derivado de la dicción literal del art. $99 \mathrm{CP}$, que refiere a la concurrencia de penas y medidas de seguridad privativas de libertad, que se traduce en que, para el supuesto de que se imponga una medida de internamiento y una pena de

1012 Ibidem, p. 141.

1013 ACALE SÁNCHEZ, M., “Medición de la respuesta...”, cit. p. 188.

1014 SIERRA LÓPEZ, M.V., La medida de libertad vigilada..., cit. p. 142. 
prisión, primero se ejecutará la medida de seguridad y después la pena, pero no es el mismo supuesto de la imposición de pena de multa y libertad vigilada (por ejemplo) donde nada obsta a que se cumpla primero la medida de seguridad o incluso de forma simultánea1015.

El principal problema que nos encontramos es cuando se trate de sujetos semiimputables que además hayan cometido delitos sexuales o de terrorismo, casos en los que habrá que determinar si se aplican las reglas del sistema vicarial o si en estos casos su tratamiento quedaría reconducido a los arts. 192.1 y 579.3 CP considerándolo imputable a los efectos de la aplicación preceptiva de la libertad vigilada por la actividad delictiva de que se trata.

A este interrogante responde SIERRA LÓPEZ diciendo que el criterio que debe seguirse es el de la especialidad, en el sentido de que las reglas del sistema vicarial son ley especial respecto de los arts. 192.1 y $579.3 \mathrm{CP}$, por lo que, en ambos casos, el cumplimiento debería ser simultáneo a ser posible o sucesivo en caso de no serlo1016.

2. La segunda, es cuando al sujeto solamente se le impone una pena atenuada, pero preceptivamente debe serle impuesta también la libertad vigilada, es decir, en supuestos de semiimputables que cometen delitos sexuales o de terrorismo, en los que únicamente se impone una pena atenuada por la imputabilidad reducida.

En estos casos, la aplicación preceptiva de la libertad vigilada viene impuesta por los arts. 192.1 y 579.3 CP respectivamente, y lo que SIERRA LÓPEZ plantea es el "sinsentido" al que nos lleva el legislador de que las reglas de ejecución serían las del art. $98 \mathrm{CP}$ y no las del art. 97 CP genéricas para las medidas de seguridad1017.

\footnotetext{
1015 ACALE SÁNCHEZ, M., “Medición de la respuesta...”, cit. p. 189.

1016 SIERRA LÓPEZ, M.V., La medida de libertad vigilada..., cit. p. 143. Esta autora expresa que “curiosamente también, y dependiendo de que en la sentencia se hubiera impuesto medida de internamiento o no, a los efectos de ejecución pueden regir los arts. 97 ó 98 CP (de cara a una revisión anual). Un sinsentido que se resolverá a favor del art. 98, pues de esta forma queda equiparado a los sujetos imputables ya que conforme a lo establecido en el precepto cumplirían la medida después de ejecutada la pena de prisión, requisito exigido por ley para su aplicación".
}

1017 Ibidem, p. 143. 


\section{Previsión especial. Libertad vigilada para imputables}

El propio art. $105 \mathrm{CP}$, dispone que la libertad vigilada también podrá imponerse "en los demás supuestos en que así lo prevé este Código". En esta remisión es donde se contempla el mayor número de problemas, debido a que hasta su promulgación no había previsión alguna en los delitos de la parte especial del CP que incluyera la imposición de una medida de seguridad y, mucho menos, de la libertad vigilada. En esta modalidad, la libertad vigilada reviste forma de medida de seguridad postpenitenciaria que descansa sobre el presupuesto de la peligrosidad criminal, previamente sintomatizada en el delito cometido de forma culpable, pero su aplicación debe hacerse solo en aquellos supuestos en los que, tras el cumplimiento de la pena de prisión correspondiente, la peligrosidad perdura y es necesario mantener la medida por un tiempo que puede durar hasta cinco o hasta diez años dependiendo de la gravedad del delito o delitos de que se trate1018.

Analizando en el articulado del CP los supuestos a los que refiere son los delitos contra la libertad e indemnidad sexuales, y delitos de terrorismo, a los que seguidamente referiré. No obstante, lo primero que llama la atención es por qué el legislador elige estos delitos y no otros, lo que se traduce en que la reforma abre la puerta a que el catálogo de delitos se amplíe1019, o quizás el verdadero propósito de la misma haya sido aplanar el camino con miras a la imposición de la libertad vigilada a nuevos delitos no previstos ahora $^{1020}$.

En cualquier caso, señala NISTAL BURÓN que cuando se imponga la libertad vigilada con base en la clase de delito cometido se estará actuando a modo de Derecho penal de excepción, aspecto que constituye "una iniciativa jurídicamente arriesgada"1021. De los dos supuestos concretos de aplicación de la libertad vigilada postpenitenciaria a imputables peligrosos, me ocupo a continuación.

\footnotetext{
1018 FEIJOO SÁNCHEZ, B., “La libertad vigilada...”, cit. p. 219.

1019 REBOLLO VARGAS, R., “De las medidas de seguridad...”, cit. p. 805.

1020 REBOLLO VARGAS, R., La llibertat vigilada..., cit. p. 29. Como indica este autor, "1'actual del 2010 (delictes contra la llibertat sexual i terrorisme), no fan més que aplanar el camí per a acumular la pena i mesura de seguretat per als subjectes que es consideren imputables perillosos per a delictes que ara no es preveuen".
}

1021 NISTAL BURÓN, J, “La "libertad vigilada”. La dificultad de su aplicación práctica. (A propósito de la nueva medida de seguridad no privativa de libertad que prevé el Proyecto de Ley Orgánica de reforma del Código Penal de 1995)". En Diario La Ley, núm. 7368, 2010, p. 3. 


\subsection{Libertad vigilada para supuestos de delitos contra la libertad e indemnidad sexuales}

Los delitos contra la libertad e indemnidad sexuales, conforman una materia a la que se le ha dedicado especial atención en las últimas reformas del CP (tanto en la operada mediante la LO 15/2003 como en la de la LO 5/2010), modificando no solo las conductas típicas sino también los marcos penales, con el objetivo de armonizar la regulación con la Decisión Marco 2004/68/JAI, del Consejo, de 22 de diciembre de 2003, relativa a la explotación de los niños y la pornografía infantil1022. En ese sentido, la LO 5/2010, también ha reformado multitud de aspectos, entre ellos el que es objeto de este estudio.

\section{a) Delimitación conceptual}

De la simple lectura del art. 192.1 $\mathrm{CP}^{1023}$ se observa claramente que la libertad vigilada se aplicará, preceptivamente, a los condenados por uno o varios delitos contra la libertad e indemnidad sexuales contenidos en el Título VIII CP, y su duración dependerá en cada caso de la gravedad del delito que se haya cometido. Es decir, que si el delito o delitos por los que el sujeto ha sido condenado, o al menos uno de ellos (cuando sean varios) es grave, la medida de seguridad será de entre cinco y diez años; y si el delito o delitos son menos graves, la medida tendrá una duración de entre uno y cinco años. Se trata de la modalidad más utilizada actualmente por los tribunales desde su entrada en vigor $^{1024}$, y algunos autores afirman que el hecho de que sea preceptiva de una forma tan generalista no termina de ser satisfactorio, puesto que se trata de una tipología de delitos muy heterogénea que varía mucho entre unas figuras y otras, por lo que la previsión es extremadamente abierta y general cuando sería deseable una mayor concreción basada en

\footnotetext{
1022 DOUE de 20 de enero de 2004, L 13/44.

1023 Art. 192.1. “A los condenados a pena de prisión por uno o más delitos comprendidos en este Título se les impondrá además la medida de libertad vigilada que se ejecutará con posterioridad a la pena privativa de libertad. La duración de dicha medida será de cinco a diez años, si alguno de los delitos fuera grave, y de uno a cinco años si se trata de uno o más delitos menos graves. En este último caso, cuando se trate de un solo delito cometido por un delincuente primario, el Tribunal podrá imponer o no la medida de libertad vigilada en atención a la menor peligrosidad del autor".

1024 Vid. SAP de Lleida 124/2012, de 27 de marzo, SAP de Zaragoza 137/2012, de 9 de mayo, SAP de Valencia 611/2011, de 26 de octubre, SAP de Barcelona 216/2012, de 7 de marzo, SAP de Madrid 617/2012, de 27 de abril, SAP de Cáceres 380/2011, de 9 de noviembre, entre otras.
} 
criterios más taxativos atendiendo a las distintas figuras delictivas a las que es aplicable ${ }^{1025}$.

También contiene una previsión específica el precepto (in fine) por la que puede no imponerse la medida de seguridad al sujeto cuando concurran los siguientes requisitos: a) delincuente primario, esto es, que haya delinquido por primera vez o que no cuente con antecedentes penales —condenas previas en sentencias firmes que además deben ser de la misma naturaleza de los que llevan aparejada libertad vigilada como consecuencia de su comisión-1026 incluyendo supuestos en que dichos antecedentes estén cancelados o que pudieran estarlo1027; y b) que el sujeto presente una menor peligrosidad que aconseje la no imposición de la medida. Ahora bien, la cláusula es potestativa para el Juez, puesto que, según esta previsión, aun siendo delincuente primario y aun concurriendo escasa o nula peligrosidad en el autor, puede, según su criterio, imponer o no la libertad vigilada. Obviamente, se trata de una previsión un tanto inconcreta, puesto que se está dejando en manos de los Jueces la aplicación o no, según su criterio, de una medida de seguridad. Es decir, que si concurren esos requisitos, el Juez no es que no deba imponer la medida de seguridad, sino que, simplemente, puede decidir entre imponerla o no, atendiendo a criterios que no aparecen claramente definidos ${ }^{1028}$, pudiendo generar que se produzcan resultados muy distintos en el tratamiento penológico ante supuestos idénticos o muy parecidos.

En estos casos de delincuente primario, la decisión deja de ser obligatoria para ser facultativa, lo que demuestra que la libertad vigilada se impone no en virtud de la peligrosidad criminal, sino de otra clase de peligrosidad "que la supera en sus propios mimbres"1029, dejando de atender al delito cometido y proyectándose hacia la posibilidad de comisión de otros delitos en el futuro, atendiendo a la alarma social que pueda

\footnotetext{
1025 CÁMARA ARROYO, S., “La libertad vigilada...", cit. p. 14.

1026 FEIJOO SÁNCHEZ, B., “La libertad vigilada...”, cit. p. 220.

1027 SIERRA LÓPEZ, M.V., La medida de libertad vigilada..., cit. p. 138.

1028 FEIJOO SÁNCHEZ, B., “La libertad vigilada...”, cit. p. 220. Este autor expresa que la cláusula postestativa en caso de delincuentes primarios implica que no hay obstáculo para que, aun existiendo condenas anteriores no firmes o con antecedentes cancelados, los mismos puedan ser tenidos en cuenta para la peligrosidad, como en casos de los psicópatas.
}

1029 CÁMARA ARROYO, S., “La libertad vigilada...”, cit. p. 14. 
generar ${ }^{1030}$. Se concede una suerte de beneficio de la duda para los delincuentes sexuales primarios, aspecto que fue aplicado en la más reciente jurisprudencia existente en la materia y, en concreto, en la SAP de Barcelona 362/2012, de 29 de marzo, que entendió innecesaria la aplicación de la libertad vigilada en un supuesto de ausencia de antecedenes penales del infractor.

En cualquier caso, se hace necesario delimitar conceptualmente las figuras delictivas a las que podrá ser aplicada la libertad vigilada, que son los delitos comprendidos en el Título VIII del CP, esto es: arts. 185 a 194 CP, "Delitos contra la libertad e indemnidad sexuales". Rúbrica que contempla todas las figuras delictivas descritas en los seis capítulos de los que se compone el título, que son: Capítulo I, “De las agresiones sexuales"; Capítulo II, “De los abusos sexuales"; Capítulo II, Bis “De los abusos y agresiones sexuales a menores de trece años"; Capítulo III, "Del acoso sexual"; Capítulo IV, “De los delitos de exhibicionismo y provocación sexual"; Capítulo V, “De los delitos relativos a la prostitución y a la corrupción de menores"; Capítulo VI, "Disposiciones comunes a los capítulos anteriores" 1031.

1030 QUERALT JIMÉNEZ, J.J., Derecho penal. Parte especial. 6a Ed. Barcelona: Atelier. 2010, p. 261. Este autor explica que "la alarma social que han despertado unos poquísimos casos de predadores sexuales, han motivado la introducción de esta medida de seguridad, de la que cabe que se haga un uso moderado, en la aplicación de los arts. 97 y 98. A la alarma no han sido ajenos organismos públicos, Fiscalía y Administraciones penitenciarias, que han aireado inminentes excarcelaciones, pasando por alto que debidas a que la condena se había ejecutado en su plenitud, casi como una irresponsabilidad de los jueces encargados de la ejecución de las penas y obviando un claro fracaso en los tratamientos aplicados a tales sujetos. Ciertamente, existen los llamados delincuentes de tendencia, que son de difícil reinserción, máxime si no aceptan tratamiento correctivo o paliativo alguno de sus pulsiones, pero si ello es así, la libertad vigilada no hace sino diferir el problema. La solución ha de ser otra: modificar los tratamientos, los medios para llavarlos a cabo y sus contextos".

1031 Sobre estos delitos tras la reforma operada mediante la LO 5/2010, vid. ORTS BERENGUER, E., “Delitos contra la libertad e indemnidad sexuales". En VIVES ANTÓN, T.S. / ORTS BERENGUER, E. / CARBONELL MATEU, J.C. / GONZÁLEZ CUSSAC, J.L. / MARTÍNEZ-BUJÁN PÉREZ C.M., Derecho Penal. Parte Especial. $3^{a}$ Ed. Valencia: Tirant lo Blanch. 2010. Lecciones XI, XII y XIII, pp. 223 a 310; LAMARCA PÉREZ, C., “Delitos contra la libertad e indemnidad sexuales". En LAMARCA PÉREZ, C. (Coord.), Derecho penal. Parte especial. $6^{a}$ Ed. Madrid: Colex. 2011, pp. 161 a 189; CANCIO MELIÁ, M, “Delitos sexuales". En DÍAZ-MAROTO y VILlAREJO, J., (Dir.), Estudios sobre las reformas del Código Penal. Operadas por las LO 5/2010, de 22 de junio, y 3/2011, de 28 de enero. Navarra: Civitas. 2011, pp. 359 a 380; RAMOS TAPIA, M.I., en ZUGALDÍA ESPINAR, J.M. / MARÍN DE ESPINOSA CEBALLOS, E.B. (Dirs.), Derecho penal. Parte especial. Un estudio a través del sistema de casos resueltos. Tomo I. $3^{\text {a }}$ Ed. Valencia: Tirant lo Blanch. 2011, pp. 285 a 348; RIUS DIEGO, F.J., Análisis policial del Código Penal. $3^{\mathrm{a}}$ Ed. Madrid: Tecnos. 2011, pp. 148 a 185; QUERALT JIMÉNEZ, J.J., Derecho penal..., cit. pp. 207 a 262; SÁNCHEZ DAFAUCE, M., "Libertad e indemnidad sexuales: arts. 178 y 180". En ÁlVAREZ GARCÍA, F.J. / GONZÁLEZ CUSSAC, J.L., (Dirs.), Comentarios a la reforma penal de 2010. Valencia: Tirant lo Blanch. 2010, pp. 219 a 223; CUGAT MAURÍ, M., "Delitos contra la libertad e indemnidad sexuales". En ÁlVAREZ GARCÍA, F.J. / GONZÁLEZ CUSSAC, J.L., (Dirs.), Comentarios a la reforma penal de 2010. Valencia: Tirant lo Blanch. 2010, pp. 225 a 246; GARCÍA PÉREZ, J.J., en SÁNCHEZ MELGAR, J. (Coord.), Código penal. Comentarios y jurisprudencia. Tomo I. 3 ${ }^{\text {a }}$ Ed. Madrid: Sepín. 2010, pp. 1243 a 1424; MUÑOZ CONDE, F., Derecho penal. Parte especial. 19a Ed. Valencia: Tirant lo Blanch. 2013, pp. 207 a 252; GUTIÉRREZ ROMERO, F.M., “El tratamiento de los delitos sexuales en la nueva reforma del Código penal: especial 
Sobre este particular, hay un aspecto que llama la atención y es que del listado de delitos contra libertad e indemnidad sexuales, está excluido el delito de trata de seres humanos en su modalidad de explotación sexual, incluida la pornografía ${ }^{1032}$, art. 177 bis.1 b) $\mathrm{CP}$, ya que dichas conductas se encuentra ubicadas en el Título VII Bis, "De la trata de seres humanos", al que no le son aplicables las Disposiciones Comunes a los capítulos del Título VIII (arts. 191 a 194 CP), entre las que se encuentra la previsión especial de aplicación de la libertad vigilada a imputables en supuestos de delitos contra la libertad e indemnidad sexuales. Exclusión que puede deberse a un olvido del legislador o a una carencia en la técnica legislativa motivada por la precipitación experimentada en la aprobación de la reforma, aunque también podría ser que la exclusión haya sido fruto de la voluntad consciente del legislador al entender que estas modalidades delictivas no son cometidas por personas especialmente peligrosas y, por tanto, no hay motivos para incorporar en estas figuras la presunción de peligrosidad postpenitenciaria que justificaría la imposisión de la libertad vigilada, aunque parece que esta exclusión no termina de responder a la orientación político-criminal que precisamente inspira la reforma, pues por el mismo motivo podrían exclusirse muchas otras conductas de índole sexual que sin embargo quedan circunscritas al ámbito de aplicación de la libertad vigilada postpeniteniaria.

La libertad sexual, es "la facultad del ser humano de determinarse autónomamente en el ámbito de la sexualidad; esto es, en el ámbito de la actividad vinculada al impulso

referencia a la libertad vigilada". En Diario La Ley, núm. 7909, 2012, pp. 1 a 4; BOIX REIG, J., en BOIX REIG, J., Derecho penal. Parte especial. Vol. I. Madrid: Iustel. 2010, pp. 315 a 370; AGUADO LÓPEZ, S., en BOIX REIG, J., Derecho penal. Parte especial. Vol. I. Madrid: Iustel. 2010. 371 a 411. Sobre los aspectos generales de estos delitos y su regulación con anterioridad a la reforma, puede verse ORTS BERENGUER, E. / SUÁREZ-MIRA RODRÍGUEZ, C., Los delitos contra la libertad e indemnidad sexuales. Valencia: Tirant lo Blanch. 2001, pp. 14 y ss.

1032 Sobre estos delitos tras la reforma operada mediante la LO 5/2010, vid. TERRADILLOS BASOCO, J.M., “Trata de seres humanos (Art. 177 bis y Disposición Final Segunda)”. En ÁlVAREZ GARCÍA, F.J. / GONZÁLEZ CUSSAC, J.L., (Dirs.), Comentarios a la reforma penal de 2010. Valencia: Tirant lo Blanch. 2010, pp. 207 a 2017; MARAVER GÓMEZ, M., "La trata de seres humanos". En DÍAZ-MAROTO y VILLAREJO, J., (Dir.), Estudios sobre las reformas del Código Penal. Operadas por las LO 5/2010, de 22 de junio, y 3/2011, de 28 de enero. Navarra: Civitas. 2011, pp. 311 a 333; SÁNCHEZ MELGAR, J., en SÁNCHEZ MELGAR, J. (Coord.), Código penal..., cit. Tomo I, pp. 1233 a 1239; FERRÉ OLIVÉ, J.C., “Trabajo sexual, crimen organizado y trata de personas". En MUÑOZ CONDE, F. / LORENZO SALGADO, J.M. / FERRÉ OLIVE, J.C. / CORTES BECHIARELli, E. / NÚÑEZ PAZ, M.A., (Dirs.), Un Derecho penal comprometido. Libro Homenaje al Prof. Dr. Gerardo Landrove Díaz. Valencia: Tirant lo Blanch. 2011, p. 417. Este autor explica que "el legislador se ha hecho eco de todas estas disposiciones, que encuentran su reflejo en el nuevo art. 177 bis que equipara todas las formas de participación en la trata de personas como forma de autoría: captar, trasportar, trasladar, acoger, alojar, etc. agravando la pena "cuando el culpable perteneciera a una organización o asociación de más de dos personas, incluso de carácter transitorio que se dedicase a la realización de tales actividades" [...]". 
venéreo, su excitación y su satisfacción ${ }^{1033^{\prime \prime}}$. Se protege, pues, el aspecto positivo-dinámico de la libertad sexual, esto es, poder llevar a cabo cualquier relación sexual voluntaria, castigando cualquier conducta consistente en obligar a mantenerla sin consentimiento o con algún vicio en el mismo; mientras que el aspecto negativo-estático consistente en impedir que se lleven a cabo conductas sexuales consentidas entre adultos, no quedaría protegido bajo el concepto de libertad sexual, sino que habría que reconducirlos a la esfera de la libertad (amenazas, coacciones, etc.) ${ }^{1034}$.

Indemnidad sexual hace referencia a la necesaria distinción existente en varias figuras ubicadas en el mismo capítulo, en las que el sujeto pasivo es el menor de edad o el incapaz, en los que no puede hablarse de libertad sexual sino del derecho de éstos a no ser invadidos en el terreno sexual, protegiéndoles de cualquier molestia o daño que en este ámbito se les pudiera causar, lo que se traduce en su derecho a un desarrollo adecuado, a una formación digna sin injerencias lesivas o invasivas en sus intereses, y a un correcto proceso de socialización ${ }^{1035}$.

No obstante, efectuadas estas precisiones, el bien jurídico, además, debe concretarse en cada una de las figuras delictivas en que consisten los tipos agrupados bajo la misma rúbrica (contra la libertad e indemnidad sexuales), así por ejemplo, en las agresiones sexuales se protege también la dignidad personal, la intimidad, el riesgo de contagio de enfermedades venéreas o de transmisión sexual y de embarazos no deseados, el bienestar psíquico, etc. ${ }^{1036}$

\section{b) El tratamiento penológico de los delitos contra la libertad e indemnidad sexuales}

Los delitos contra la libertad e indemnidad sexuales son en su mayoría delitos graves y las penas para las agresiones sexuales oscilan entre prisión de uno a cinco años

\footnotetext{
1033 ORTS BERENGUER, E., “Delitos contra la libertad e indemnidad...", cit. p. 223. Este autor señala que "en consecuencia, el contenido de la reiterada libertad sexual estará integrado por la posibilidad de elegir y practicar la opción sexual preferida en cada momento y por la de utilizar y servirse del propio cuerpo en este orden de cosas; de donde derivan las de escoger compañero, con su consentimiento por descontado, y rechazar proposiciones no deseadas y eventuales ataques".

1034 CORCOY BIDASOLO, M. / MIR PUIG, S., Comentarios..., cit. p. 427.

1035 ORTS BERENGUER, E., “Delitos contra la libertad e indemnidad...", cit. p. 224.

1036 Ibidem, p. 227.
} 
para el tipo básico del art. $178 \mathrm{CP}$, prisión de seis a doce años en el subtipo agravado del art. 179 CP, y prisión de 12 a 15 años en los subtipos agravados del art. 180.1 CP, con las especialidades de que algunos de ellos se impondrán en la mitad superior (art. 180.2 CP) cuando concurran dos o más circunstancias previstas en los subtipos agravados del art. 180.1 CP.

Para los abusos sexuales, el tipo básico del art. 181.1 CP prevé prisión de uno a tres años o multa de dieciocho a veinticuatro meses, aplicable a los supuestos del apartado 3 del mismo precepto. Para el subtipo agravado del art. 181.4 CP, la pena es de prisión de cuatro a diez años, con la especialidad del art. 181.5 CP que prevé las penas previstas tanto para el tipo básico en sus tres modalidades como para el subtipo agravado, experimentarán la agravación de colocar la pena en la mitad superior si se dan las circunstancias $3^{\text {a }}$ ó $4^{\text {a }}$ del art. $180 \mathrm{CP}$, que son: cuando la víctima sea especialmente vulnerable por razón de su edad, enfermedad, discapacidad o situación; y cuando concurra prevalencia de relación de superioridad o parentesco con la víctima.

Para los abusos a menores de entre trece y dieciséis años, las penas son, para el tipo básico del art. 182.1 CP, prisión de uno a dos años o multa de doce a veinticuatro meses, y de prisión de dos a seis años para el subtipo agravado del art. 182.2 CP, que a su vez experimenta la agravación que coloca la pena en la mitad superior cuando concurra la circunstancia $3^{\mathrm{a}}$ ó $4^{\mathrm{a}}$ del art. $180.1 \mathrm{CP}$, a las que ya hemos referido.

Cuando se trate de menores de trece años ${ }^{1037}$ las penas son de prisión de dos a seis años para el tipo básico del art. $183.1 \mathrm{CP}$, prisión de cinco a diez años para el subtipo agravado del art. 183.2 CP, y de ocho a doce años o de doce a quince años para los dos supuestos previstos en el art. 183.3 CP. Por su parte, el art. 183.4 CP contiene una agravación específica de los supuestos anteriores que coloca la pena en la mitad superior cuando se den algunas de las circunstancias enumeradas en las letras a) a f); y además, el art. 183.5 CP prevé la pena de inhabilitación absoluta de seis a doce años si las conductas las realiza un funcionario, la autoridad o agente de la misma. Por último, el art. 183 bis $\mathrm{CP}$, contempla un supuesto de abusos por Internet o telefonía o tecnologías de la 
información, para lo que se prevé una pena de uno a tres años o multa de doce a veinticuatro meses.

El acoso sexual está castigado, en su modalidad básica (art. 184.1 CP), con una pena de prisión de tres a cinco meses o multa de seis a diez meses, o de prisión de cinco a siete meses o multa de diez a catorce meses si se trata de la agravación específica del art. 184.3 CP. Se prevé igualmente, prisión cinco a siete meses o multa de diez a catorce meses en el tipo de 184.2 CP, o prisión de seis meses a un año si el supuesto sufre la agravación del art. 184.2 CP. Los delitos de exhibicionismo y provocación sexual, están castigados con pena de prisión de seis meses a un año o multa de doce a veinticuatro meses en los supuestos de los arts. 185 y $186 \mathrm{CP}$.

Por su parte, los delitos relativos a la prostitución y a la corrupción de menores, están castigados con pena de prisión de uno a cinco años y además multa de doce a veinticuatro meses. Nótese que en estos supuestos se imponen ambas sanciones que operan de forma conjunta y no alternativa como los tipos anteriores. El art. 187.2 CP contempla una pena de cuatro a seis años que será impuesta en su mitad superior y además irá acompañada de inhabilitación absoluta por tiempo de seis a doce años, cuando se trate de funcionario, autoridad o agente (art. 187.3 CP). Por su parte el art. 188.1 $\mathrm{CP}$ castiga la conducta tipificada con penas de dos a cuatro años de prisión y multa de doce a veinticuatro meses; y prisión de cuatro a seis años en el subtipo del art. 188.2 CP o de cinco a diez años de prisión en el supuesto del art. 188.3 CP. Penas que podrán, todas ellas, situarse en la mitad superior en los supuestos del art. 188.4 CP.

El art. 189.1 CP tiene asociada una pena de uno a cinco años para supuestos de exhibicionismo con menores, y la mera posesión de material de esa clase está castigada con penas de tres meses a un año o multa de seis meses a dos años (art. 189.2 CP). El art. 189.3 CP contempla un subtipo agravado en el que la pena es de prisión de cinco a nueve años, y el art. 189.4 CP un subtipo atenuado con pena de prisión de seis meses a un año; al igual que el art. $189.5 \mathrm{CP}$ que contempla penas de prisión de tres a seis meses o multa de seis a doce meses. Sobre este particular hemos de resaltar la previsión del art. 189.6 CP que lanza un mandato directo al Ministerio Fiscal para que en estos supuestos promueva las acciones pertinentes encaminadas a la privación de la patria potestad, tutela, guarda o acogimiento familiar a la persona que incurra en inducción a la prostitución de menores 
que tuviere bajo cualquiera de las formas descritas (tetela, guarda o acogimiento). Por último, el art. 189.7 CP contempla las penas de prisión de tres meses a un año o multa de seis meses a dos años para supuestos de pornografía infantil que no utilice directamente a menores, sino que use la voz o imagen alterada.

La reforma de la LO 5/2010 añade, además, un apartado 8 al art. 189 CP por el que, cuando el culpable pertenezca a sociedad $u$ organización dedicada a tales actividades, se impondrán las medidas del art. $129 \mathrm{CP}$ que son consecuencias accesorias. Igualmente mediante la reforma de 2010, se añade un art. 189 bis CP por el que se castigan estas conductas en virtud del nuevo art. 31 bis $\mathrm{CP}$, cuando se cometan por personas jurídicas, en cuyo caso se impondrán las siguientes penas: multa del triple al quíntuple del beneficio obtenido si el delito tiene prevista pena de más de cinco años en abstracto; multa del doble al cuádruple del beneficio obtenido si el delito lleva aparejada pena en abstracto de más de dos años; y multa del doble al triple en los demás casos. En todos los supuestos puede imponerse, además - atendidas las reglas del art. 66 bis $\mathrm{CP}-$, las penas previstas en los apartados b) a g) del art. 33 CP, eso es: disolución, suspensión de actividades, clausura de locales, prohibición de realizar actividades, inhabilitación para obtener subvenciones e intervención judicial ${ }^{1038}$. Finalmente, el art. 190, prevé la posibilidad de aplicar la agravante de reincidencia cuando exista una condena previa por un Tribunal extranjero por alguno de los delitos comprendidos en el Capítulo V, del Título VIII, del Libro II CP (“De los delitos relativos a la prostitución y a la corrupción de menores").

Pues bien, a todos estos supuestos y penas (del Título VIII del Libro II CP), a excepción de las personas jurídicas del art. 189 bis CP, les será impuesta en sentencia la medida de seguridad de libertad vigilada en virtud del art. 192.1 CP, por tiempo de entre cinco y diez años a los condenados por uno o más delitos graves, y de entre uno y cinco años, en caso condena por uno o más delitos menos graves. Lo que conviene destacar es que la libertad vigilada únicamente se impondrá si los delitos se castigan con pena de

\footnotetext{
1038 Sobre estas penas en profundidad vid. MORALES PRATS, F., "La responsabilidad penal de las personas jurídicas, arts. 31 bis, 31.2 supresión, 33.7, 66 bis y 130.2 CP”. En QUINTERO OLIVARES, G., (Dir.), La Reforma Penal de 2010: Análisis y Comentarios. Navarra. Thomson Aranzadi. 2010, pp. 45 a 70; GÓMEZ-JARA DÍEZ, C., "La responsabilidad penal de las personas jurídicas". En Diario La Ley, núm. 7534. Especial Reforma del Código penal, 2010, pp. 7 a 13; y ÚBEDA DE LOS COBOS, J.J., "La responsabilidad penal de las personas jurídicas aprobada por Ley Orgánica 5/2010, de 22 de junio”. En La Ley Penal, núm. 77, 2010, pp. 25 a 40.
} 
prisión, ya que algunos de ellos pueden castigarse con multa, en cuyo caso la libertad vigilada no será aplicable1039.

\subsection{Libertad vigilada para supuestos de delitos de terrorismo}

Esta previsión deriva del apartado centésimo vigésimo noveno del art. único de la LO 5/2010, que modifica el art. 579 CP, de forma que el apartado 3 de dicho precepto pasa a ser ahora el apartado 4, y se introduce un nuevo apartado 3, que dispone que a los condenados a pena grave privativa de libertad por uno o más delitos de entre los comprendidos en el Capítulo VIII, del Título XXII, del Libro II CP (rubricado “De las organizaciones y grupos terroristas y de los delitos de terrorismo"), se les impondrá, además, la medida de libertad vigilada por tiempo de entre cinco y diez años o de entre uno y cinco años si la pena privativa de libertad es menos grave. Pero cuando se trate de un único delito que no sea grave y además estemos ante un delincuente primario, el Tribunal podrá decidir si impone o no la libertad vigilada atendiendo a la menor peligrosidad del autor que deberá apreciarse que concurra.

Nótese una importante diferencia con la previsión del art. 192.1 CP, que reside en que el art. 579.3 CP omite la mención a que la libertad vigilada "se ejecutará con posterioridad a la pena privativa de libertad", omisión que, por otra parte, no puede determinar que se sobreentienda idéntica regulación - ni siquiera de manera implícita- a la del art. 192.1 CP, por cuanto que se estaría incurriendo en una aplicación analógica prohibida1040, que contravendría el principio de legalidad.

\footnotetext{
1039 Vid. DEL CARPIO DELGADO, J., “La medida de libertad vigilada para adultos”. En Revista de Derecho Penal, núm. 36, 2012, pp. 21 a 65.

1040 REBOLLO VARGAS, R., La llibertat vigilada..., cit. p. 70. Este autor explica que “el Codi només disposa el seu compliment amb posterioritat a la pena privativa de llibertat en el cas dels delictes contra la llibertat i la indemnitat sexual, però no en el cas dels delictes de terrorisme previstos en l'art. 579.3; del que no hi ha cap dubte és que en aquest últim precepte es preveu la imposició de la mesura de llibertat vigilada, però res ens diu pel que fa a que el seu compliment sigui o no posterior al compliment de la pena privativa de llibertat, pel que no és aventurat afirmar que la deficient tècnica legislativa utilitzada pel legislador té com resultat la llibertat vigilada com a mesura de seguretat, l'execució de la qual té lloc amb posterioritat al compliment de la condemna privativa de llibertat, només és possible en els casos previstos en l'art. 192, però no en l'art. 579.3, el qual permetria el compliment de la llibertat vigilada de forma simultània a la pena privativa de llibertat, el contrari: la seva execució amb posterioritat en ambdues situacions, suposaria una contravenció flagrant del principi de legalitat penal per una interpretació analògica de la norma penal i, al meu judici, de dubtosa constitucionalitat".
} 
Otra diferencia respecto de la redacción del art. 192.1 CP, es que, a diferencia de dicho precepto que alude a que la imposición y la duración de la libertad vigilada depende de si nos encontramos ante delitos graves o menos graves, el $579.3 \mathrm{CP}$ la redacción alude a penas graves y menos graves - no a delitos-, y como señala SIERRA LÓPEZ, las diferencias no serían perceptibles si atendemos a las penas en abstracto (según los arts. 13 y $33 \mathrm{CP}$ ), pero si atendemos a las penas en concreto la cuestión ya cambia, porque aplicando las reglas de determinación de la pena en casos de concurso y agravantes, podríamos tener que algunos delitos que en abstracto tengan pena menos grave, luego en la concreción la tengan grave, dando lugar a que pueda imponerse la libertad vigilada por tiempo de cinco a diez años. Esta misma autora manifiesta que la diferencia puede deberse a un error técnico del legislador, más que a una voluntad real de conferir un tratamiento diferente, debido a que en el Anteproyecto de reforma del CP de 2008, el criterio era el contrario, de forma que en los delitos de terrorismo su aplicación aparecía como más restringida y en todo caso su aplicación se hacía depender de que el delito fuera grave o menos grave, no de la pena. En cualquier caso, los criterios en la LO $5 / 2010$, son distintos para los delincuentes sexuales y para los terroristas ${ }^{1041}$.

Pero las diferencias entre ambos preceptos son todavía más, si se atiende a que en la redacción del art. 192.1 CP se dice que la medida de libertad vigilada deberá ejecutarse con posterioridad a la pena privativa de libertad, mientras que en el art. $579.3 \mathrm{CP}$ únicamente dice que junto con la pena se impondrá además la libertad vigilada, lo que en opinión de SIERRA LÓPEZ implica que en este segundo caso el cumplimiento puede ser simultáneo y no necesariamente sucesivo, a pesar de que no haya sido esa la voluntad del legislador, aspecto que, sin embargo, no obsta para que dicho cumplimiento pueda hacerse atendiendo al tenor literal del precepto. Consecuentemente, se produce un desajuste entre la previsión del régimen de ejecución de la libertad vigilada contenido en el art. $98 \mathrm{CP}$, que refiere a cuando la libertad vigilada deba ejecutarse después de una pena privativa de libertad, limitando considerablemente esta previsión a los supuestos donde "debe" ejecutarse la medida de seguridad tras la pena, que solo es en los delitos sexuales, ya que, como se ha visto, en los delitos de terrorismo la medida de seguridad puede aplicarse simultáneamente a la pena de prisión, quedando excluida de dicha previsión y reconduciéndose al ámbito del art. $97 \mathrm{CP}$ que, con carácter general, es 
aplicable a la ejecución de las medidas de seguridad para los inimputables y semiimputables ${ }^{1042}$.

De esa forma, la ejecución de la libertad vigilada para terroristas no está sujeta a las especialidades del art. $98 \mathrm{CP}$, entre las que se encuentra la obligación de elevar la propuesta de revisión de la medida al menos anualmente, etc., y de las que me ocuparé más adelante. Sin embargo, CÁMARA ARROYO afirma que esta distinción en la redacción de ambos preceptos no obedece a una diferencia de tratamiento sino a una suerte de "desliz gramatical" del legislador, que se desprende de la falta de competencias del JVP, ya que en el art. 106.2 CP no se establece específicamente si la medida se puede cumplir conjuntamente con la pena privativa de libertad, aspecto que hubiera podido incluirse ${ }^{1043}$.

También se incluye la posibilidad de no imponer la medida cuando se trate de delincuente primario que haya cometido un solo delito que no sea grave y presente menor peligrosidad criminal. A este respecto doy aquí por reproducidas las consideraciones efectuadas sobre la misma previsión contenida en el apartado anterior para delincuentes sexuales, añadiendo que, en este caso, su imposición no se hace depender únicamente del pronóstico, sino también de la gravedad del hecho cometido, que se exige que sea uno solo y además que no sea grave1044. Además, entiendo que la imposición facultativa debería haber sido la regla general y no la excepción ${ }^{1045}$. Como puede observarse, aquí nos encontramos con otra diferencia respecto de la previsión del art. 192 CP para los delincuentes sexuales, puesto que en ese caso se permite no imponer la medida facultativamente atendiendo a la menor peligrosidad cuando se trate de delincuentes primarios que cometan delitos graves o menos graves, mientras que en los casos de terrorismo solo entra en juego esta posibilidad de no imponer la libertad vigilada si se ha

\footnotetext{
1042 Ibidem, p. 138.

1043 CÁMARA ARROYO, S., “La libertad vigilada...”, cit. p. 15.

1044 Ibidem, p. 14.

1045 Así lo indica TAMARIT SUMALLA, J.M., “Delitos relativos a la pornografía infantil y otras medidas relacionadas con la delincuencia sexual (arts. 189 y 192)". En QUINTERO OLIVARES, G., (Dir.) La Reforma Penal de 2010: Análisis y Comentarios. Navarra. Thomson Aranzadi. 2010, p. 178. También expresa este autor que "la redacción de esta última cláusula es reveladora de que el legislador ha partido del prejuicio de presumir incluso "iuris et de iure" en los no primarios, una mayor "peligrosidad criminal", dejando tan sólo en manos del Juez de vigilancia la posibilidad de apreciar que el sujeto, se supone que gracias al tratamiento recibido en prisión, ha dejado de ser peligroso".
} 
comteido un único delito que debe ser menos grave, excluyendo expresamente si se trata de más de un delito menos grave y en todo caso los delitos graves ${ }^{1046}$.

Quizás esta previsión para el delincuente primario, sea consecuencia de las voces doctrinales que proponían una formulación de la libertad vigilada destinada única y exclusivamente a delincuentes habituales y reincidentes ${ }^{1047}$. En ese sentido, SILVA SÁNCHEZ se pronunció en ese sentido: “otras medidas, sin embargo, sí requerirían tal reforma legislativa. Así, por ejemplo, la previsión de algún género de medidas de control de la vida en libertad tras el licenciamiento definitivo del penado. $\mathrm{O}$, también la regulación de medidas de seguridad para sujetos habituales o peligrosos, desde luego no sujetas a un principio absoluto de proporcionalidad con el hecho cometido, que las anula antes de empezar, pero tampoco absolutamente indeterminadas, ni siquiera condicionadas a la -discutible- reversión del pronóstico de peligrosidad"1048. Y del mismo modo TAMARIT SUMALLA, vino a decir que "la libertad vigilada puede desempeñar un rol relevante en la respuesta a determinados supuestos de criminalidad grave y habitual en la que se aprecie un alto riesgo de reincidencia. De todos modos, entiendo que su naturaleza será en estos casos más próxima a una medida de seguridad. La introducción de esta medida resulta en todo caso una solución más adecuada que las demandas efectuadas por aquellos sectores sociales y en ocasiones académicos basadas en la intensificación del internamiento o en respuestas inocuizadoras radicales". Este autor sugirió la fórmula de la previsión de una medida de libertad vigilada siguiendo el modelo de la pena de alejamiento de los arts. 48 y $57 \mathrm{CP}$, para imponerla en sentencia en supuestos tasados en la ley, pero con la especificación de que la duración debería ser mayor que la de la pena privativa de libertad y su cumplimiento podría ser simultáneo a ella, entrando en escena desde la clasificación en tercer grado o en el paso a la libertad condicional, pudiendo extenderse, por encima de la pena ya cumplida, pero con la

\footnotetext{
1046 FEIJOO SÁNCHEZ, B., “La libertad vigilada...”, cit. p. 221.

1047 En ese sentido GUISASOLA LERMA, C., Reincidencia..., cit. p. 159, vino a poner de manifiesto que "la medida de libertad vigilada, si estuviera debidamente articulada en nuestro Código Penal, podría ser un eficaz instrumento de reinserción social, adecuado a las características del sujeto y del penado. [...] Podría pues considerarse la previsión de la medida de libertad vigilada, posterior al cumplimiento de la pena de prisión e, insisto, para el caso de delincuentes reincidentes o habituales y por condenas por delitos graves contra la vida, integridad física y libertad sexual".
}

1048 SILVA SÁNCHEZ, J.M., “El retorno de la inocuización...”, cit. p. 709. 
posibilidad de que el JVP la dejase sin efecto dependiendo de la evolución y del pronóstico del sujeto ${ }^{1049}$.

\section{a) Delimitación conceptual}

La libertad vigilada se aplica, en esta modalidad postpenitenciaria especial, a los delitos contenidos el Capítulo VII, del Título XXII, del Libro II CP “De las organizaciones y grupos terroristas y de los delitos de terrorismo". La Sección $1^{\text {a }}$ lleva por rúbrica “De las organizaciones y grupos terroristas"; y la sección 2a " "De los delitos de terrorismo"1050, que comprende los arts. 571 a $580 \mathrm{CP}$.

El término terrorismo, tiene su origen en el período del terror (Terreur) de la Revolución francesa (1793-1794), y se extiende en el S. XIX referido a la delincuencia política, por lo que se afirma que es un concepto impreciso y ambiguo, que en el lenguaje común se asocia con "sucesión de actos de violencia ejecutados para infundir terror" o "dominación por el terror", asociado normalmente a la forma de actuar de un partido político que impone la violencia como medio esencial para alcanzar sus fines. El concepto jurídico de terrorismo tiene tres planos: la realización de delitos comunes, el fin de

\footnotetext{
1049 TAMARIT SUMALLA, J.M., “La integración jurídica en la Unión Europea...”, cit. p. 84.
}

1050 Sobre todas estas figuras delictivas a partir de la reforma de 2010, vid. VIVES ANTÓN, T.S. / CARBONELL MATEU, J.C., (con la colaboración de MIRA BENAVENT, J.), “Delitos contra el orden público”. En VIVES ANTÓN, T.S. / ORTS BERENGUER, E. / CARBONELL MATEU, J.C. / GONZÁLEZ CUSSAC, J.L. / MARTÍNEZ-BUJÁN PÉREZ C.M., Derecho Penal. Parte Especial. $3^{\mathrm{a}}$ Ed. Valencia: Tirant lo Blanch. 2010, pp. 782 a 796; GARCÍA ALBERO, R., "La reforma de los delitos de terrorismo (arts. 572, 573, 574, 575, 576, 576 bis, 577, 578, 579 CP)”. En QUINTERO OlIVARES, G., (Dir.), La Reforma Penal de 2010: Análisis y Comentarios. Navarra: Thomson Aranzadi. 2010, pp. 369 a 378; LLOBET ANGLI, M., “Tenencia, tráfico y depósito de armas o municiones, organizaciones y grupos criminales y delitos de terrorismo". En SILVA SÁNCHEZ, J.M. (Dir.) / PASTOR MUÑOZ, N., (Coord.), El nuevo Código Penal. Comentarios a la reforma. Madrid: La Ley. 2012, pp. 701 a 724; MUÑOZ CONDE, F., Derecho penal. Parte especial..., cit. pp. 837 a 854; RODRÍGUEZ RAMOS, L. (Dir.) / MARTÍNEZ GUERRA, A., (Coord.), Código Penal. Concordado y comentado con jurisprudencia y leyes penales especiales y complementarias. $4^{\text {a }}$ ed. Madrid: La Ley. 2011, pp. 1733 a 1764; PORTILLA CONTRERAS, G., "La reforma en los actos preparatorios...", cit. pp. 379 a 382; CORCOY BIDASOLO, M. / MIR PUIG, S., Comentarios..., cit. pp. 1119 a 1129; CANCIO MELIÁ, M, “Delitos de organización: criminalidad organizada común y delitos de terrorismo". En DÍAZ-MAROTO y VILLAREJO, J., (Dir.), Estudios sobre las reformas del Código Penal. Operadas por las LO 5/2010, de 22 de junio, y 3/2011, de 28 de enero. Navarra: Civitas. 2011, pp. 565 a 667; CANO PAÑOS, M.A., "Los delitos de terrorismo en el Código Penal español tras la reforma de 2010". En La ley penal, núm. 86, 2011, pp. 17 a 33.; CANCIO MELIÁ, M., “El delito de pertenencia a una organización terrorista en el Código penal español". En LUZÓN PEÑA, D.M., Derecho penal del Estado social y democrático de Derecho. Libro Homenaje a Santiago Mir Puig. Madrid: La Ley. 2010, pp. 897 a 1008; DE URBANO CASTRILLO, E., en SÁNCHEZ MELGAR, J. (Coord.), Código penal. Comentarios y jurisprudencia. Tomo II. $3^{\text {a }}$ Ed. Madrid: Sepín. 2010, pp. 3223 a 3267; LAMARCA PÉREZ, C., "Delitos contra el orden público". En LAMARCA PÉREZ, C. (Coord.), Derecho penal. Parte especial. 6a Ed. Madrid: Colex. 2011, pp. 767 a 779. 
infundir temor en la población, y subvertir el orden constitucional ${ }^{1051}$. Como explica TERRADILLOS BASOCO, el fenómeno terrorista no es coyuntural, sino que se trata de "una forma de criminalidad incardinada en la cotidianeidad y percibida por el poder como un elemento patológicamente estructural al que no conviene hacer frente con instrumentos transitorios"1052; y se caracteriza por la contundencia de los medios y el objetivo político ${ }^{1053}$.

En Derecho español, como afirma MORAL De LA ROSA, “no existe una definición de terrorismo que abarque todas la variedades de terrorismo que han existido a lo largo de la historia, atendiendo a las propias variaciones que ha experimentado". No obstante, para este autor los criterios básicos de definición del terrorismo son la utilización de medios violentos y la finalidad política acompañada del resultado de alarma o intimidación colectiva ${ }^{1054}$. No son pocos los autores que han elaborado un concepto de terrorismo de entre los que destacaremos algunos como CUELlo CALón, que lo define como "la situación creada mediante la ejecución repetida de delitos, de un estado de alarma o de terror en la colectividad o en ciertos grupos sociales para imponer o favorecer la difusión de determinadas doctrinas sociales o políticas"1055. Del mismo modo, GARCíA VALDÉS, define terrorismo como "aquella conducta delictiva que mediante actos de extrema violencia o grave intimidación, y con un fin subversivo, trata de destruir el sistema político democrático empleando, a estos efectos, medios selectivos catastróficos"1056.

1051 GONZÁLEZ CUSSAC, J.L., “El Derecho penal frente al terrorismo”. En GONZÁLEZ CUSSAC, J.L. / GÓMEZ COLOMER, J.L., Terrorismo y Proceso penal acusatorio. Valencia: Tirant lo Blanch. 2006, pp. 70 a 72.

1052 TERRADILlOS BASOCO, J.M., Terrorismo y Derecho. Comentario a las leyes orgánicas 3 y 4/1988, de reforma del Código penal y de la Ley de Enjuiciamiento Criminal. Madrid: Tecnos. 1988, p. 13.

1053 TERRADILlOS BASOCO, J.M., "El Estado de Derecho y el fenómeno del terrorismo". En SERRANO PIEDECASAS, J.R. / DEMETRIO CRESPO, E. (dirs.), Terrorismo y Estado de Derecho. Madrid: Iustel. 2010, p. 274.

1054 MORAL DE LA ROSA, J., Aspectos penales y criminológicos del terrorismo. Madrid: Centro de Estudios Financieros. 2005, p. 160.

1055 CUELLO CALÓN, E., Manual de Derecho Penal. Parte General. Tomo I, Vol. I. $18^{\text {a }}$ Ed. Barcelona: Bosch. 1981, p. 319 .

1056 GARCÍA VALDÉS, C., “La legislación antiterrorista”. En Anuario de Derecho penal y Ciencias Penales, Tomo XXVVII, fascículo II. 1984, p. 295. 
Conviene efectuar una breve referencia a la línea jurisprudencial seguida en nuestro país en relación a estos delitos ${ }^{1057}$, trayendo a colación, por ejemplo, la STS 633/2002, de 21 de mayo de 2002, q ue dispone que "el terrorismo es una forma de delincuencia organizada que se integra por una pluralidad de actividades que se corresponden con los diversos campos o aspectos que se pueden asemejar a una actividad empresarial de naturaleza delictiva. No es la única delincuencia organizada existente, pero sí la que presenta como señal específica de identidad una férrea cohesión ideológica claramente patógena dados los fines que orientan toda su actividad, que primero ilumina el camino de la acción y después da sentido y justificación a la actividad delictiva, aunque también debe recordarse la existencia de diversos tipos de terrorismo que junto con elementos comunes, tienen otros que los diferencian".

HERRERO-TEJEDOR ALGAR destaca el elemento ideológico que caracteriza el fenómeno del terrorismo, al afirmar que "se trata de una delincuencia "por convicción" generada por motivaciones personales rayanas en una especie de religión pagana. Hay que salvar al mundo (o la nación) de los peligros que la acechan, y para lograr ese fin son lícitos todos los medios. Nada importa el sacrificio de vidas humanas (en ocasiones, ni siquiera la propia) en la "cruzada" que los terroristas mantienen. Lejos de provocar el sentimiento de culpabilidad, los crímenes cometidos creen poseer una finalidad justa y libertaria que los justifica ante su autor. Ni éste se considera un delincuente, ni sufre el rechazo de su entorno, sino que suele ocurrir exactamente lo contrario: su "compromiso" provoca el aplauso y la admiración de sus compañeros, que los consideran héroes o incluso "mártires" de la causa si pierden la vida o caen en manos del aparato del Estado, auténtico represor de su lucha por la libertad y por los ideales que inspiran al grupo"1058.

En Derecho internacional, el terrorismo es un fenómeno que merece una respuesta jurídica global, habiendo sido incluso catalogado como crimen contra la humanidad1059, por lo que ha sido objeto de regulación en diversos tratados internacionales, como el

\footnotetext{
1057 Véanse a este respecto, por ejemplo, las Sentencias del Tribunal Supremo STS de 29 de noviembre de 1997; STS de 7 de junio de 2002; STS de 25 de enero de 1993; STS de 12 de marzo de 1992. Las Sentencias del Tribunal Constitucional STC 89/1993; STC 199/1987; STC 69/1989; STC 151/1997; STC 184/1995; 133/1987; y la Sentencia de la Audiencia Nacional de 20 de octubre de 2000 (entre otras).

1058 HERRERO-TEJEDOR ALGAR, F., “Terrorismo y tribunales militares...”, cit. pp. 39 y 40.

1059 SERRANO PIEDECASAS, J.R., "La calificación de los actos contra los derechos humanos en Derecho español". En GARCÍA ARÁN, M. / LÓPEZ GARRIDO, D., (Coords.), "Crimen Internacional y Jurisdicción Universal. El caso Pinochet". Valencia: Tirant Lo Blanch. 2000, pp. 129 a 144.
} 
Convenio de Naciones Unidas para la Represión de la Financiación del Terrorismo, elaborado en Nueva York el 9 de diciembre de 1999; el Convenio Internacional para la Represión de los atentados terroristas cometidos con Bombas, aprobado por la Asamblea General de Naciones Unidas en Nueva York el 15 de diciembre de 1997; el Convenio Europeo para la Represión del Terrorismo, de 27 de enero de 1977; y la Posición Común 2001/931/PESC del Consejo de la Unión Europea, de 27 de diciembre de 2001, sobre aplicación de medidas específicas en materia de lucha contra el terrorismo. Todo ello, se traduce en la Decisión Marco de 13 de junio de 2002, sobre lucha contra el terrorismo, que fue posteriormente sustituida por la Decisión Marco 2008/919/JAI, del Consejo, de 28 de noviembre, que se centra en una triple configuración o, lo que es lo mismo, delimita las figuras delictivas en relación a la finalidad perseguida, esto es, con un concepto teleológico-delimitador. De ese modo, para que podamos hablar de delito de terrorismo, el delito debe cometerse con uno de estos fines: intimidar gravemente a una población; obligar indebidamente a los poderes públicos o a una organización internacional a realizar un acto o a abstenerse de hacerlo; desestabilizar gravemente o destruir las estructuras fundamentales políticas, constitucionales, económicas o sociales de un país u organización internacional ${ }^{1060}$. Precisamente la referida Decisión Marco 2008/919/JAI, fue invocada de forma genérica en el Preámbulo de la LO 5/2010, de reforma del CP, confiriendo así una justificación para la "profunda de reordenación y clarificación del tratamiento penal" del terrorismo. No obstante, mantienen una posición muy crítica con la reforma autores como CANCIO MELIÁ, que señala que la justificación que invoca la Decisión Marco 2008/919/JAI, nada tiene que ver con el contenido del texto que finalmente se aprobó, ya que se desdibuja el concepto de organización terrorista -hasta banalizarlo- al introducir el régimen general de diferenciación entre organizaciones y grupos criminales y erosiona la definición típica de la conducta de pertenencia" y se produce una "extensión insoportable de los confines de la colaboración con una organización terrorista y de los actos preparatorios" ${ }^{1061 .}$

\footnotetext{
1060 Sobre esta triple finalidad vid. MORAL DE LA ROSA, J., Aspectos penales y criminológicos del terrorismo..., cit. p. 165.

1061 CANCIO MELIÁ, M., “Delitos de terrorismo”. En ÁLVAREZ GARCÍA, J. / GONZÁLEZ CUSSAC, J.L., (Dirs.), Comentarios a la reforma penal de 2010. Valencia: Tirant lo Blanch. 2010, p. 531.
} 
En resumen, las notas esenciales del terrorismo que vienen siendo proclamadas tanto por la doctrina como por la intensa actividad legislativa existente en esta materia1062, las podemos resumir en las siguientes: "1) Se trata de actos graves ejecutados por medios especialmente violentos, aptos para producir terror en la población o parte de ella. 2) Comportan, al menos, un peligro para la vida, la integridad física o la salud de las personas, es decir, para los bienes jurídicos más básicos. 3) Tratan de influir ilegalmente en las tomas de decisión sobre asuntos políticos a través de la amenaza de repetición de los actos, y 4) Se hallan dirigidos a subvertir, total o parcialmente, el orden político constituido"1063.

\section{b) El tratamiento penológico de los delitos de terrorismo}

Los delitos de terrorismo son en su totalidad delitos graves que llevan aparejadas penas también graves. En efecto, los tipos que contiene el Capítulo VI, de la Sección Segunda, del Título XXII, del Libro II del CP, añadido por la LO 5/2010 y dedicado a las organizaciones y grupos criminales, contempla las siguientes penas: para el tipo del art. 570 bis $2 \mathrm{CP}$, hay cuatro posibilidades dependiendo de las circunstancias de la conducta concreta, que son: prisión de cuatro a ocho años, prisión de tres a seis años, prisión de dos a cinco años, o prisión de uno a tres años. Todas estas penas, podrán experimentar una agravación que podrá situar la pena en su mitad superior, cuando se trate de los supuestos previstos en los arts. 570 bis 2 y 3 CP.

El art. 570 ter $1 \mathrm{CP}$, en su apartado a) lleva aparejada penas de dos a cuatro años de prisión si se trata de uno o más delitos graves, o de uno a tres años de prisión si se trata de delitos menos graves. En el apartado b) las penas pueden ser de prisión de seis meses a dos años; y en el apartado c) las penas pueden ser de tres meses a un año, pero esta pena podrá ser colocada en su mitad inferior en algunos casos. Todas estas penas podrán ser

1062 En profundidad sobre el concepto de terrorismo vid. CAPITA REMEZAL, M., Análisis de la legislación penal antiterrorista. Madrid: Colex. 2008, pp. 21 a 78; MORAL DE LA ROSA, J., Aspectos penales y criminológicos..., cit. pp. 11 y ss.; GÓMEZ MARTÍN, V., "Notas para un concepto funcional de terrorismo". En SERRANO PIEDECASAS, J.R. / DEMETRIO CRESPO, E.D., (dirs.), Terrorismo y Estado de Derecho. Madrid: Iustel. 2010, pp. 25 a 52. LAMARCA PÉREZ, C., “La regulación del terrorismo en el código penal español”. En PÉREZ ÁLVAREZ, F., (Edit.), Vniversitas Vitae, homenaje a Ruperto Núñez Barbero. Salamanca: Aquílafuente. Ediciones Universidad de Salamanca. 2007, pp. 359 a 371; FERNÁNDEZ REQUENA, J., El delito de terrorismo urbano de baja intensidad. Análisis del artículo 577 CP. Valencia: Tirant lo Blanch. 2009, pp. 15 y ss.

1063 VIVES ANTÓN, T.S. / CARBONELL MATEU, J.C., (con la colaboración de MIRA BENAVENT, J.), "Delitos contra el orden...", cit. p. 778. 
igualmente impuestas en su mitad superior en los supuestos del art. 570 ter. 2 CP, y si concurren dos o más circunstancias de las previstas en dicho precepto, se impondrá la pena superior en grado.

El art. 570 quáter $1 \mathrm{CP}$ aplica la reciente incorporada responsabilidad penal de las personas jurídicas del art. 31 bis CP al que remite, al tiempo que en el art. 570 quáter $2 \mathrm{CP}$ se contempla la pena de inhabilitación especial por un tiempo de entre seis y veinte años por encima de la pena de privación de libertad. En el apartado 3 de art. 570 quáter $\mathrm{CP}$, se contempla la posibilidad de minorar la pena en uno o dos grados cuando el sujeto haya abandonado de forma voluntaria sus actividades delictivas y haya colaborado con las autoridades.

El art. 571.1 CP contempla penas de prisión de ocho a catorce años e inhabilitación especial para empleo o cargo público por tiempo de ocho a quince años; y de prisión de seis a doce años e inhabilitación especial para empleo o cargo público por tiempo de seis a catorce años en el art. 571.2 CP.

El art. 572.1 CP tiene una pena de prisión de quince a veinte años, sin perjuicio de la pena que corresponda si se produjera lesión para la vida, integridad física o salud de las personas; el art. 572.2 CP prevé penas de prisión de veinte a treinta años en su apartado 1), prisión de quince a veinte años en su apartado 2), y prisión de diez a quince años en su apartado 3); supuestos todos ellos que pueden experimentar un incremento que las sitúe en la mitad superior en los casos del art. 573.2 CP.

El art. 573 CP lleva aparejada pena de prisión de seis a diez años, mientras que el art. $574 \mathrm{CP}$ prevé una suerte de agravación genérica para cualquier delito o falta cometido perteneciendo, actuando o colaborando con organizaciones o grupos terroristas, en cuyo caso se impondrá la pena que corresponda en su mitad superior. Si además se cometen delitos contra el patrimonio con la finalidad de allegar fondos a las organizaciones o grupos terroristas o facilitar sus actividades, se impondrá la pena prevista para el delito de que se trate, pero superior en grado (art. $575 \mathrm{CP}$ ).

El art. 576 CP contempla una pena de prisión de cinco a diez años y multa de dieciocho a veinticuatro meses, que podrá, en algunos casos, imponerse en la mitad 
superior; mientras que el art. 576 bis 1 CP lleva aparejadas dos penas: prisión de cinco a diez años y multa de dieciocho a veinticuatro meses, que podrán imponerse inferiores en uno o dos grados en los supuestos del art. 576 bis $2 \mathrm{CP}$. El art. 576 bis $3 \mathrm{CP}$, contempla las penas para supuestos de responsabilidad penal de las personas jurídicas, remitiendo al art. $31 \mathrm{CP}$, que son: apartado a), multa de dos a cinco años si el delito cometido por la persona física tiene prevista una pena de prisión de más de cinco años; apartado b), multa de uno a tres años si el delito cometido por la persona física tiene prevista una pena de más de dos años de privación de libertad no incluida en el anterior inciso, y remitiendo en el segundo párrafo del precepto a las reglas de los arts. 66 bis y 33 letras b) a g) CP.

$\mathrm{El}$ art. 577 CP contempla una agravación genérica que coloca las penas en la mitad superior a la del delito de que se trate, para los casos en que, con la finalidad de subvertir el orden constitucional o de alterar gravemente la paz pública, o la de contribuir a estos fines atemorizando a los habitantes de una población o a los miembros de un colectivo social político o profesional, cometieren homicidios, lesiones, detenciones ilegales secuestros amenazas o coacciones contra las personas, o llevaren a cabo cualesquiera delitos de incendios, estragos, daños o tenencia, fabricación, depósito, tráfico, transporte o suministro de armas, municiones o sustancias o aparatos explosivos, inflamables, incendiarios o asfixiantes, o de sus componentes.

El art. 578 CP que regula en enaltecimiento del terrorismo, lleva aparejada pena de prisión de uno a dos años y alguna o algunas de las prohibiciones previstas en el art. 57 CP. El art. 579.1 CP permite la rebaja de uno o dos grados en los supuestos anteriores para casos de provocación, conspiración y proposición; el segundo párrafo del mismo precepto, castiga con pena de prisión de seis meses a dos años aquellas situaciones que no se hallen comprendidas en el párrafo anterior del mismo artículo o en otro precepto del Código que establezca mayor pena, dirigidas a provocar o favorecer la comisión de cualquiera de los delitos comprendidos en el mismo capítulo. El art. $579.2 \mathrm{CP}$ obliga a imponer a los supuestos anteriores, además, la pena de inhabilitación absoluta por tiempo de seis a veinte años por encima de la pena de prisión impuesta en sentencia; mientras que el art. 579.4 CP prevé la posibilidad de rebajar uno o dos grados en todos los supuestos de la Sección segunda, del Capítulo VII, del Título XXII, del Libro II CP, cuando el sujeto haya abandonado voluntariamente sus actividades delictivas, confiese los hechos 
y colabore activamente para impedir nuevos delitos $\mathrm{u}$ obtener pruebas para la identificación o captura de otros terroristas.

El art. $580 \mathrm{CP}$, contempla la posibilidad de imponer la agravante de reincidencia para cuando existan condenas anteriores por parte de Tribunales extranjeros. Y, por último, el art. 579.3 CP, prevé la aplicación de la libertad vigilada a todos los supuestos anteriores (contemplados en el Capítulo VII, del Título XXII, del Libro II CP), por tiempo de entre cinco y diez años a los condenados a uno más delitos que lleven aparejada pena grave; y de entre uno y cinco años, si el delito al que acompaña fuera menos grave, con la faculta de no imposición a los delincuentes primarios.

Los delitos de terrorismo (junto con los cometidos en el seno de organizaciones criminales que no son objeto del presente estudio) constituyen la excepción a todo el régimen general de ejecución penal introducido en la reforma operada mediante la LO 7/2003, que igualmente ha sido objeto de algunas modifiaciones en la más reciente reforma de 2010 (LO 5/2010). En efecto, el período de seguridad (o la imposibilidad de acceder al tercer grado de tratamiento penitenciario hasta que se haya cumplido la mitad de la pena impuesta siempre que se trate de pena superior a cinco años de prisión que introdujo la LO 7/2003), mediante la LO 5/2010 quedó redactado de forma distinta, al pasar a ser facultativa la posibilidad de que la clasificación del penado en tercer grado no se efectúe hasta haber cumplido la mitad de la pena.

La reforma de 2010 estableció una excepción a la norma general, enumerando una serie de delitos que, cuando la pena impuesta por los mismos sea superior a cinco años, la clasificación en tercer grado no podrá hacerse hasta haber cumplido la mitad de la pena, y son: delitos de terrorismo, cometidos en el seno de organizaciones criminales, abusos y agresiones sexuales a menores y prostitución y pornografía de menores ${ }^{1064}$. Del mismo

1064 Art. 36.2. “Cuando la duración de la pena de prisión impuesta sea superior a cinco años, el Juez o Tribunal podrá ordenar que la clasificación del condenado en el tercer de tratamiento penitenciario no se efectúe hasta el cumplimiento de la mitad de la pena impuesta.

En cualquier caso, cuando la duración de la pena de prisión impuesta sea superior a cinco años y se trate de los delitos enumerados a continuación, la clasificación del condenado en el tercer grado de tratamiento penitenciario no podrá efectuarse hasta el cumplimiento de la mitad de la misma:

a) Delitos referentes a organizaciones y grupos terroristas y delitos de terrorismo del Capítulo VII del Título XXII del Libro II de este Código.

b) Delitos cometidos en el seno de una organización o grupo criminal.

c) Delitos del artículo 183. 
modo, la reforma estableció en el último párrafo del art. $36.2 \mathrm{CP}$, la posibilidad de reversión y la aplicación del régimen general de cumplimiento, previo pronóstico favorable de reinserción y valorando las especiales circunstancias del reo y su evolución en relación al tratamiento reeducador. No obstante, para los delitos anteriormente expuestos, la propia norma establece nuevamente una excepción imposibilitando con ello el retorno al régimen normal de cumplimiento ${ }^{1065}$.

Por otra parte, en la acumulación jurídica, el límite máximo de cumplimiento de penas del art. $76 \mathrm{CP}^{1066}$, supuso con la reforma de 2003 una elevación de los límites máximos de cumplimiento en relación a la barrera infranqueable de treinta años que propugnaba la redacción inicial del CP de 1995. En efecto, el principio quot delicta tot poenae que rige en el cumplimiento de penas en caso de concurso real de delitos, acumulación material o suma aritmética, puede ahora llegar hasta los cuarenta años. El precepto se articula sobre la base de dos tipos de límites, uno absoluto que se traduce en que no se podrá cumplir más del triple de la pena más grave que al penado se le haya impuesto, y otros de carácter relativo, que se traducen en veinte, veinticinco, treinta y

d) Delitos del Capítulo V del Título VIII del Libro II de este Código, cuando la víctima sea menor de trece años.

El Juez de Vigilancia, previo pronóstico individualizado y favorable de reinserción social y valorando, en su caso, las circunstancias personales del reo y la evolución del tratamiento reeducador, podrá acordar razonadamente, oídos el Ministerio Fiscal, Instituciones Penitenciarias y las demás partes, la aplicación del régimen general de cumplimiento, salvo en los supuestos contenidos en el párrafo anterior".

1065 Opción muy criticada por la doctrina a raíz de esta última reforma, y en ese sentido manifiestan algunos autores como BACH FABREGÓ, R. / GIMENO CUBERO, M.A., “Clases y contenido de penas y ejecución de las penas (arts. 33, 36, 46, 50, 52, 53, 56, 58, 66 bis, 83 100, 103 y 106 CP”. En QUINTERO OLIVARES, G., (Dir.) La Reforma Penal de 2010: Análisis y Comentarios. Navarra. Thomson Aranzadi. 2010, p. 86, que lo deseable habría sido que el legislador hubiera suprimido totalmente los períodos de seguridad y retornar al régimen anterior a 2003, por la incompatibilidad o falta de armonización con el sistema de individualización científica que exige que el régimen de cumplimiento de la pena de prisión descanse sobre cierta flexibilidad "que permita en cada momento la adopción de las decisiones de tratamiento más adecuadas a la situación personal del penado, y el cumplimiento del mandato contenido en la legislación penitenciaria de no mantener al penado en un grado inferior cuando la evolución de su tratamiento le haga merecedor de su progresión. Por lo menos debería haberse optado por la posibilidad de retorno al régimen general de cumplimiento por decisión del Juez de Vigilancia Penitenciaria en todos los supuestos [...]".

1066 Art. 76. “1. No obstante lo dispuesto en el artículo anterior, el máximo de cumplimiento efectivo de la condena del culpable no podrá exceder del triple del tiempo por el que se le imponga la más grave de las penas en que haya incurrido, declarando extinguidas las que procedan desde que las ya impuestas cubran dicho máximo, que no podrá exceder de 20 años. Excepcionalmente, este límite máximo será: a) De 25 años, cuando el sujeto haya sido condenado por dos o más delitos y alguno de ellos esté castigado por la ley con pena de prisión de hasta 20 años. b) De 30 años, cuando el sujeto haya sido condenado por dos o más delitos y alguno de ellos esté castigado por la ley con pena de prisión superior a 20 años. c) De 40 años, cuando el sujeto haya sido condenado por dos o más delitos y, al menos, dos de ellos estén castigados por la ley con pena de prisión superior a 20 años. d) De 40 años, cuando el sujeto haya sido condenado por dos o más delitos de terrorismo de la sección segunda del capítulo V del título XXII del libro II del Código y alguno de ellos esté castigado por la ley con pena de prisión superior a 20 años.

2. La limitación se aplicará aunque las penas se hayan impuesto en distintos procesos si los hechos, por su conexión o el momento de su comisión, pudieran haberse enjuiciado en uno sólo". 
cuarenta años. Pues bien, en lo que respecta a los delitos de terrorismo, el límite máximo de cumplimiento se sitúa en los cuarenta años (art. 76.1. d. CP), cuando el condenado lo haya sido por dos o más delitos de terrorismo de la Sección segunda, del Capítulo V, del Título XXII, del libro II CP, y alguno de ellos esté castigado con pena de prisión superior a veinte años.

Especial detenimiento merecen las reglas contenidas en el art. $78 \mathrm{CP}$, puesto que establece tres regímenes de cumplimiento distinto, que responden al espíritu reformista de 2003 basado en la idea de "cumplimiento íntegro de las penas". En efecto, el primero es el contenido en el primer párrafo ${ }^{1067}$ del citado precepto, al que GARCíA ALBERO denomina "régimen de cumplimiento efectivo contingente"1068, que se aplicará a penados por varios delitos concurriendo los siguientes requisitos: que la pena a cumplir sea inferior a la mitad de la total de las impuestas, de entre las cuales ninguna debe ser por delitos con pena de prisión hasta veinte años. En estos casos, se otorga una plena capacidad decisoria al Juez o Tribunal para que los beneficios penitenciarios, los permisos de salida, la clasificación en tercer grado y el cómputo para la libertad condicional, se refiera a la totalidad de las penas impuestas en las sentencias.

El segundo es el régimen previsto en el art. $78 \mathrm{CP}$, segundo párrafo ${ }^{1069}$, que se traduce en que los penados que se hallen limitados en el cumplimiento por las reglas del art. 76 CP (veinticinco, treinta o cuarenta años, vid. supra) se encuentran imperativamente sujetos a la regla - de preceptiva aplicación por el Juez o Tribunal- relativa a que los beneficios penitenciarios, los permisos de salida, la clasificación en tercer grado y el cómputo para la libertad condicional, se refiera a la totalidad de las penas impuestas en las sentencias, mientras que en la regla del párrafo primero, como se ha visto, la aplicación resulta facultativa. El párrafo tercero del art. $78 \mathrm{CP}^{1070}$ establece una fórmula para el

\footnotetext{
1067 Artículo 78.1. “Si a consecuencia de las limitaciones establecidas en el apartado 1 del artículo 76 la pena a cumplir resultase inferior a la mitad de la suma total de las impuestas, el juez o tribunal sentenciador podrá acordar que los beneficios penitenciarios, los permisos de salida, la clasificación en tercer grado y el cómputo de tiempo para la libertad condicional se refieran a la totalidad de las penas impuestas en las sentencias".

1068 TAMARIT SUMALLA, J.M. / GARCÍA ALBERO, R., La reforma ..., op. cit. p. 77.

1069 Art. 78.2. “Dicho acuerdo será preceptivo en los supuestos previstos en los párrafos a, b, c y d del apartado 1 del artículo 76 de este Código, siempre que la pena a cumplir resulte inferior a la mitad de la suma total de las impuestas".

1070 Art. 78. 3. “En estos casos, el juez de vigilancia, previo pronóstico individualizado y favorable de reinserción social y valorando, en su caso, las circunstancias personales del reo y la evolución del tratamiento reeducador, podrá acordar razonadamente, oídos el Ministerio Fiscal, Instituciones Penitenciarias y las demás
} 
regreso al sistema de cómputo normal, siempre basada en criterios de previo pronóstico individualizado y favorable de reinserción social1071.

Y una vez más, encontramos lo que supone la regla excepcional que implica el establecimiento de plazos distintos para delitos de terrorismo y cometidos en el seno de organizaciones criminales, o dicho de otra forma: establecimiento de un régimen de cumplimiento íntegro de penas para los referidos delitos, previsto en el tercer párrafo del art. $78 \mathrm{CP}$ in fine. Consiste en condicionar la vuelta al régimen normal de cumplimiento a que el penado haya cumplido cuatro quintas partes del límite de la pena para el acceso al tercer grado1072; y las siete octavas partes cuando pretenda la libertad condicional, partiendo de que los períodos a los que hace referencia el precepto son siempre los que ya se encuentran limitados $e x$ art. 76 CP. Esta norma hay que ponerla en relación directa con el art. 36.2 CP, ya que, frente a ella, la norma que ahora analizamos constituye lex specialis en el sentido de que la clasificación al tercer grado no podrá llevarse a efecto hasta que el penado haya cumplido la mitad de la pena impuesta ${ }^{1073}$.

partes, la aplicación del régimen general de cumplimiento. Si se tratase de delitos de terrorismo de la sección segunda del capítulo V del título XXII del libro II del Código o cometidos en el seno de organizaciones criminales, y atendiendo a la suma total de las penas impuestas, la anterior posibilidad sólo será aplicable: a) Al tercer grado penitenciario, cuando quede por cumplir una quinta parte del límite máximo de cumplimiento de la condena. b) A la libertad condicional, cuando quede por cumplir una octava parte del límite máximo de cumplimiento de la condena".

1071 Reflexiona acertadamente GARCÍA ALBERO al manifestar que "se trata de valorar si en el momento en que el penado ha cumplido la mitad del tiempo ex art. 76 -pero no la mitad de la suma de las penas impuestas-, un favorable pronóstico de reinserción a los solos efectos de su progresión en grado -que no de libertad condicional-, permite acordar el regreso al sistema normal y, por ello mismo, la progresión". TAMARIT SUMALLA, J.M. / GARCÍA ALBERO, R., La reforma..., cit. p. 81.

1072 Sobre esta norma advierte GONZÁLEZ CUSSAC, J.L., “El sistema de penas español: balance crítico y propuesta alternativa”. En ARROYO ZAPATERO, L. / CRESPO BARQUERO, P. / GONZÁLEZ CUSSAC, J.L. / QUINTERO OLIVARES, G. / ORTS BERENGUER, E., "La reforma del Código Penal tras 10 años de vigencia". Navarra: Thomson Aranzadi. 2006, pp. 57 y 58, que la misma deviene inútil, al manifestar que "en los últimos años no se conocen casos de calificación al tercer grado de terroristas, pues desgraciadamente se trata de "delincuentes por convicción" que al no renunciar al uso de la violencia, deviene imposible considerarlos resocializados y en consecuencia emitir pronóstico favorable de reinserción. Por otra parte, al exceptuarse con carácter absoluto y general esta posibilidad, se cierra absurdamente el Estado esta fructífera vía de lucha antiterrorista, que tan excelentes resultados ha cosechado en otros países y en el nuestro propio hasta fechas no muy lejanas. En efecto, la utilización de los llamados "arrepentidos" ha sido una eficaz herramienta para obtener información y para socavar la firmeza de otros terroristas, que comprobaban tras largos años de cárcel como otros antiguos compañeros rehacían sus vidas".

1073 No obstante, centrándonos en la regla del art. 78.3 CP, hemos de poner de manifiesto que el legislador nada dice acerca de los plazos de cumplimiento para el acceso a permisos penitenciarios, centrándose en la exigencia de cumplimiento de cuatro quintas partes para el acceso al tercer grado, y de siete octavas para la libertad condicional. A este respecto, como afirma GARCÍA ALBERO, "nada obsta a que pudiera acordarse el retorno a la normalidad, a los solos efectos de permisos ordinarios de salida, en cuanto existiese respecto del penado un pronóstico favorable de reinserción, por mucho que no hubiese cumplido la cuarta parte de la suma total de las penas impuestas, sino sólo la cuarta parte de límite máximo de cumplimiento". Vid. TAMARIT SUMALLA, J.M. / GARCÍA ALBERO, R., La reforma..., cit. p. 87. 
Igual sucede con las normas relativas a la libertad condicional ${ }^{1074}$ contemplando un régimen especial para delitos de terrorismo y cometidos en el seno de organizaciones criminales. En general, los requisitos se encuentran en el art. $90 \mathrm{CP}$ y son: encontrarse en el tercer grado de tratamiento penitenciario, haber extinguido las tres cuartas partes de la condena, haber observado buena conducta, y que exista un pronóstico individualizado y favorable de reinserción social. Por lo que respecta a los delitos de terrorismo y de criminalidad organizada los requisitos están dotados de un mayor contenido restrictivo, que se concreta, sobre todo, en que el pronóstico favorable de reinserción solo se entenderá que concurre cuando existan signos inequívocos de abandono de la actividad terrorista y exista una real y efectiva colaboración con las autoridades para la represión de tales delitos. Además, expresa el citado art. $90 \mathrm{CP}$ que este requisito se entiende cumplido mediante una declaración expresa de repudio de sus actividades delictivas y de abandono de la violencia y una petición expresa de perdón a las víctimas de su delito, y se exige además que existan informes técnicos que acrediten que el preso está realmente desvinculado de la organización terrorista y del entorno y actividades de asociaciones y colectivos ilegales que la rodean y su colaboración con las autoridades.

Además, se impide de forma absoluta que a los delincuentes terroristas, se les puedan aplicar los únicos beneficios penitenciarios que prevé el $\mathrm{CP}$, consistentes en el adelantamiento excepcional de la libertad condicional, contemplados en el art. $91 \mathrm{CP}^{1075}$. El primero de los beneficios es el que de alguna forma sustituye la antigua redención de penas por el trabajo (que a día de hoy continúa desplegando efectos por imperativos del principio de irretroactividad), y se traduce en que se podrá adelantar el acceso a la libertad condicional siempre y cuando el penado haya cumplido dos terceras partes de su condena, y haya desarrollado continuadamente actividades laborales, culturales $\mathrm{u}$ ocupacionales (art. 90.1 CP). Se podrá adelantar, pues, hasta un máximo de noventa días por cada año transcurrido de cumplimiento efectivo de condena, y siempre que el penado haya desarrollado continuadamente las referidas actividades con un requisito añadido basado en la necesidad de que acredite la participación efectiva y favorable en programas de reparación a las víctimas o programas de tratamiento o desintoxicación. El segundo de los beneficios penitenciarios es el relativo a enfermos incurables y septuagenarios,

\footnotetext{
1074 Sobre la libertad condicional véase la obra de CERVELLÓ DONDERIS, V., Derecho Penitenciario. Valencia: Tirant lo Blanch. 2006, pp. 249 a 272.

1075 Exclusión que, como advierte la doctrina, supone una “discriminación injustificada”. Ibidem, p. 254.
} 
previsto en el art. $92 \mathrm{CP}$, en estos supuestos el legislador no hace expresa exclusión para delincuentes terroristas, por lo que tendrían acceso al adelantamiento de la libertad condicional, siempre que concurran los requisitos tasados en la ley penal.

Además, existen reglas especiales que afectan a la revocación de la libertad condicional para delitos de terrorismo, previstas en el art. $93 \mathrm{CP}^{1076}$. En efecto, el incumplimiento de las normas de conducta que acompañan a la libertad condicional, o incluso si el penado vuelvo a delinquir, implica, como norma general, el reingreso en prisión para cumplir el período que le resta, computándose el tiempo que ha pasado en libertad condicional. Pues bien, para los delitos de terrorismo, el incumplimiento supone el reingreso en prisión y la pérdida del tiempo pasado en libertad condicional, con lo cual al penado le restará por cumplir la pena completa sin que pueda computarse el tiempo cumplido en libertad condicional1077. Para tal fin, el JVP puede solicitar informes que permitan acreditar que subsisten las condiciones que sirvieron de base para conceder la libertad condicional, y tiene la facultad de revocarla si se han incumplido dichas condiciones.

Efectuadas estas consideraciones, se hace necesario ilustrar, a título de ejemplo, un supuesto concreto de cumplimiento de penas para un condenado por delitos de terrorismo: supongamos que un reo está condenado a cien años de prisión por la comisión de varios delitos de los de esta clase. El primer límite con el que nos encontramos es el del art. $76 \mathrm{CP}$, esto es, cuarenta años, que será el tope máximo de cumplimiento. Ahora bien, para los permisos se exige una cuarta parte de la totalidad de la condena sin excepción, con lo cual hasta cumplidos veinticinco años no podrá acceder a ningún permiso penitenciario. Para el tercer grado, como se ha visto, tiene que haber cumplido cuatro quintas partes de la condena, esto es, treinta y dos años; y para la libertad condicional el

\footnotetext{
1076 Art 93.1. "En las penas de prisión inferiores a diez años, los jueces o tribunales impondrán, atendiendo a la gravedad del delito, como penas accesorias, alguna o algunas de las siguientes: 1) Suspensión de empleo o cargo público. 2) Inhabilitación especial para el derecho de sufragio pasivo durante el tiempo de la condena. 3) Inhabilitación especial para empleo o cargo público, profesión, oficio, industria, comercio, ejercicio de la patria potestad, tutela, curatela, guarda o acogimiento o cualquier otro derecho, la privación de la patria potestad, si estos derechos hubieran tenido relación directa con el delito cometido, debiendo determinarse expresamente en la sentencia esta vinculación, sin perjuicio de la aplicación de lo previsto en el artículo 579 de este Código. 2. Lo previsto en este artículo se entiende sin perjuicio de la aplicación de lo dispuesto en otros preceptos de este Código respecto de la imposición de estas penas".
}

1077 ORTS BERENGUER, E. / GONZÁLEZ CUSSAC, J.L., Compendio..., cit. p. 482. 
condenado debe haber cumplido siete octavas partes de la misma, es decir: treinta y cinco años. La libertad definitiva la obtendrá cuando haya cumplido cuarenta años.

Como novedad en la reforma de 2003, se introdujo, además, la condición de la reparación del daño para el acceso al tercer grado y a la libertad condicional ${ }^{1078}$. La reforma operada mediante LO 15/2003 introdujo por primera vez contenidos que inciden en la reparación del daño, pero en fases posteriores a la sentencia. Aspecto que, como indica TAMARIT SUMALLA, "responde a la evolución de las tendencias favorables a la justicia reparadora, que tiene entre sus manifestaciones el impulso de la mediación, otras formas de participación de la víctima y de la comunidad en las distintas fases del sistema penal, además del favorecimiento de la reparación del daño"1079.

La Exposición de Motivos de la LO 7/2003, justifica la introducción de la reparación del daño en articular el impedimento de que ciertos condenados por delitos económicos de gran importancia, puedan ver mejorada su situación penitenciaria sin haber devuelto el dinero ${ }^{1080}$, y todo ello a la luz de la incomodidad que se ha hecho ver en la opinión pública ante ciertos casos de personas famosas ${ }^{1081}$. El art. 72.5 de la LOGP requiere para la progresión al tercer grado que el penado haya satisfecho las responsabilidades civiles que deriven del delito, para lo que se considerará la conducta del penado en orden a restituir lo sustraído y se valorará su capacidad real, presente y

\footnotetext{
1078 Ello responde a la voluntas legislatoris encaminada hacia una política criminal de carácter reparador en la ejecución penal, y ello pasa principalmente por la reforma del art. 72 de la LOGP, en sus apartados 5 y 6; y el art. $91.2 \mathrm{CP}$, lo que se complementa con un nuevo apartado en el art. 989 LECrim que atribuye a Jueces y Tribunales la facultad de averiguación patrimonial del penado para hacer frente a la responsabilidad civil mientras la misma no se haya extinguido, pudiendo oficiar a la Agencia Tributaria a efectos de averiguación de créditos y devoluciones que pudiera tener con la misma o con la Tesorería General de la Seguridad Social, así como rentas existentes y demás patrimonio. Vid. TAMARIT SUMALLA, J.M. / GARCÍA ALBERO, R., La reforma..., cit. pp. 114 a 127.

1079 Ibidem. cit. p. 115.

1080 Así, dice la Exposición de Motivos de la LO 7/2003 que “esta exigencia se justifica plenamente en aquellos delitos que han permitido al culpable obtener un importante enriquecimiento ilícito y no se satisfacen las responsabilidades pecuniarias fijadas en sentencia a causa de haber ocultado su patrimonio".

1081 La LOGP en el segundo párrafo del art. 33-1 d) pone de manifiesto el carácter embargable de las remuneraciones obtenidas por los internos en las mismas condiciones y requisitos establecidos para el sueldo del trabajador libre, lo cual implica que no podrá ser objeto de embargo la cantidad equivalente al salario mínimo interprofesional (IPREM). Vid. GONZÁLEZ CUSSAC, J.L., "El sistema de penas español: balance crítico y propuesta alternativa". En ARROYO ZAPATERO, L. / CRESPO BARQUERO, P. / GONZÁLEZ CUSSAC, J.L. / QUINTERO OLIVARES, G. / ORTS BERENGUER, E., "La reforma del Código Penal tras 10 años de vigencia". Navarra: Thomson Aranzadi. 2006, pp. 57 y 58. No obstante, como indica TAMARIT, "el problema es actualmente más bien de carácter práctico, dado que el trabajo penitenciario no permite normalmente aportar ingresos suficientes para atender los legítimos intereses de los perjudicados". Vid. TAMARIT SUMALLA, J.M. / GARCÍA ALBERO, R., La reforma..., cit. p. 117.
} 
futura. Para delitos de terrorismo (o cometidos en el seno de organizaciones criminales), dispone el art. 75.6 LOGP que para el acceso al tercer grado (y posteriormente, en su caso, a la libertad condicional) además del requisito de haber satisfecho la responsabilidad civil, se requiere que el penado muestre signos inequívocos de haber abandonado los fines y medios terroristas y que haya colaborado activamente con las autoridades para impedir la producción de nuevos delitos o para la identificación y captura de los responsables de otros delitos de la misma clase. A todo esto, como ya se ha dicho, hay que añadir la medida de seguridad de libertad vigilada introducida a través de la LO 5/2010.

\section{LIBERTAD VIGILADA. CONTENIDO Y ALCANCE}

La libertad vigilada es aplicable, por un lado a supuestos de inimputabilidad y semiimputabilidad (previsión general), y por otro a imputables: terroristas y delincuentes sexuales (previsión especial), y su contenido se concreta en el cumplimiento de una serie de obligaciones y prohibiciones previstas en un catálogo contenido en el propio CP. En efecto, el art $106 \mathrm{CP}$ dice que la libertad vigilada "consistirá en el sometimiento del condenado a control judicial a través del cumplimiento por su parte de alguna o algunas de las siguientes medidas:" y efectúa una relación. Por otra parte, muchas de estas medidas que relaciona el precepto, aparecen también como deberes en el contexto de la suspensión de la pena privativa de libertad del art. $83 \mathrm{CP}$, o en el de la sustitución de la pena del art. $88 \mathrm{CP}$ y, como indica SANZ MORÁN, "también podrá venir acompañada de la imposición de las reglas de conducta del art. $83 \mathrm{CP}$, o de las medidas previstas en el art. 96.3 CP -entre las que se encuentra la "libertad vigilada" $\left(\mathrm{n}^{\mathrm{o}} 3^{\circ}\right)$-, al que remite expresamente el art. $90.2 \mathrm{CP}^{\prime \prime 1082}$. No obstante, algunos autores manifiestan que la estructura de las obligaciones y prohibiciones - medidas dentro de medidas- no es la más adecuada ${ }^{1083}$.

Las medidas en que se concreta el contenido de la libertad vigilada son una serie de obligaciones y prohibiciones que seguidamente serán analizadas, aunque conviene hacer referencia a que todas ellas, exceptuando la obligación de estar siempre localizable mediante aparatos electrónicos, ya estaban previstas anteriormente como medidas de seguridad no privativas de libertad o como penas privativas de derechos, de forma que, el

1082 SANZ MORÁN, A.J., “La nueva medida de seguridad...”, cit. pp. 1015 y 1016.

1083 CÁMARA ARROYO, S., “La libertad vigilada...”, cit. p. 15. 
contenido de esta nueva medida de seguridad introducida en 2010, no añade mucho a lo que ya estaba previsto en el articulado de nuestro texto punitivo1084. Es más, en cuanto a la previsión para delincuentes sexuales, las obligaciones y prohibiciones en que se concreta la medida de seguridad, estaban también previstas como consecuencias accesorias, por lo que parece difícil que de su cumplimiento se pueda esperar algún efecto añadido1085. Por ese motivo, la libertad vigilada aglutina en una sola medida lo que antes eran varias sanciones penales autónomas y además añade otras nuevas, proyectando una posibilidad de imposición conjunta de un elenco muy variado de obligaciones y prohibiciones, bajo el prisma y justificación de una única medida ${ }^{1086}$.

Por otra parte, conviene tener presente que el Preámbulo de la LO 5/2010 proclama que la finalidad de la libertad vigilada es doble: la protección de las víctimas por una parte y la reinserción y rehabilitación por otra, por lo que, cada una de las obligaciones y prohibiciones en que concreta e individualiza la libertad vigilada, puede estar ordenada a finalidades distintas dentro de esas citadas posibilidades. Del análisis del catálogo de medidas que dotan de contenido a la libertad vigilada me ocupo a continuación.

a) La obligación de estar siempre localizable mediante aparatos electrónicos que permitan su seguimiento permanente.

La medida responde a una creciente tendencia al uso de nuevas tecnologías en el tratamiento del delincuente peligroso ${ }^{1087}$ y a la irrupción de la era telemática en materia penitenciaria, por lo que un sector de la doctrina afirma que "esta reforma no es más que la punta del iceberg de una serie de cambios que la ciencia y la tecnología va a introducir

\footnotetext{
1084 Estaban ya vigentes en la anterior regulación la prohibición de residir en un determinado lugar, la prohibición de comunicar o aproximarse a la víctima o sus familiares y demás personas que se designase, la obligación de participar en programas formativos, culturales, profesionales, de educación sexual o similares, la prohibición de acudir a determinados lugares o territorios, espectáculos deportivos o establecimientos de bebidas alcohólicas o de juego, o la obligación de someterse a tratamiento médico externo en centros médicos o de carácter socio-sanitario.

1085 Cfr. SIERRA LÓPEZ, M.V., La medida de libertad vigilada..., cit. p. 115.

1086 MAPELLI CAFFARENA, B., Las consecuencias..., cit. p. 378. Este autor expresa que "se ha concebido más que como una medida con contornos propios, como un registro punitivo bajo el cual se recogen numerosas formas de restringir el ejercicio de derechos bajo el control judicial".

1087 Vid. NELLYS, M., Electronic Monitoring and Community Supervision: Origins, Uses, Effects and Prospects. I Jornada de Criminologia "Control penal i prevenció del delicte en la societat de la informació". Barcelona: CEJFE-UOC. 2011, pp. 1 a 12.
} 
en nuestro sistema legal"1088. Esta posibilidad de control telemático no es nueva, ya que se contempla también para el control de sujetos que acceden al tercer grado de tratamiento penitenciario, según dispone el art. 86.4 RP1089, aunque sí supone una novedad entre las demás obligaciones que contiene la libertad vigilada que, como ya se ha dicho, antes ya existían de forma autónoma, por eso la libertad vigilada encuentra la inspiración de su nombre en esta obligación de estar siempre localizable, que además, es la más controvertida, tal y como expone SIERRA LÓPEZ, por cuanto que resulta dudoso que el sujeto deba soportar que después de haber cumplido su pena de prisión, tenga que estar siempre localizable con la consecuente lesión al derecho fundamental a la intimidad. El legislador le otorga el mismo rango que a las demás obligaciones y prohibiciones del art. 106 CP, cuando es la más incisiva y la que más problemas comporta1090.

La libertad vigilada para su efectivo control, necesitaría un entramado de recursos humanos de elevadísimo coste económico difícilmente asumible en estos tiempos de políticas de recortes y austeridades ${ }^{1091}$, por lo que la vigilancia electrónica gravita sobre la libertad vigilada como un factor esencial para su efectividad, puesto que de lo contrario estaríamos ante una mera condición de libertad con las que ya cuenta nuestro ordenamiento $\mathrm{y}$, en consecuencia, nada nuevo añadiría la libertad vigilada al sistema, pues no sería más que una simple derivación normativa de la libertad bajo palabra o condicional ${ }^{1092}$. Los medios telemáticos de control además requieren un soporte humano

1088 GUDÍN RODRÍGUEZ-MAGARIÑOS, F., La nueva medida de seguridad..., cit. pp. 18 y 19. Este autor opina que "la reforma puede ser reputada como un inicio o un esbozo legal de futuras reformas penales de mayor calado, las cuales debe ser enmarcadas dentro de un contexto del irrefrenable desembarco de las nuevas tecnologías en el orbe penal".

1089 Art. 86. "Salidas del Establecimiento. 4. En general, el tiempo mínimo de permanencia en el Centro será de ocho horas diarias, debiendo pernoctarse en el Establecimiento, salvo cuando, de modo voluntario, el interno acepte el control de su presencia fuera del Centro mediante dispositivos telemáticos adecuados proporcionados por la Administración Penitenciaria u otros mecanismos de control suficiente, en cuyo caso sólo tendrán que permanecer en el Establecimiento durante el tiempo fijado en su programa de tratamiento para la realización de actividades de tratamiento, entrevistas y controles presenciales".

1090 SIERRA LÓPEZ, M.V., La medida de libertad vigilada..., cit. pp. 123 y 124.

1091 Como expresa VIVES ANTÓN, en relación a la previsión sobre medios electrónicos que contenía el Anteproyecto de 14 de noviembre de 2008, "no vamos a ser capaces, o por lo menos es muy dudoso que vayamos a serlo, de establecer un sistema de vigilancia efectivo que no tenemos ni siquiera en materia de control de la condena condicional. Establecer un sistema efectivo requiere unos medios y un tiempo de los que, hoy por hoy, no se dispone y un esfuerzo que no se va a poder llevar a cabo. No estamos, pues, ante una solución sino ante un desafortunado brindis al sol". Vid. VIVES ANTÓN, T.S., Reflexiones jurídico-políticas a propósito..., cit. p. 5 .

1092 GUDÍN RODRÍGUEZ-MAGARIÑOS, F., La nueva medida de seguridad..., cit. p. 26. Según este autor, “la medida de libertad vigilada no será viable si no va acompañada por medidas tecnológicas que le confieran rigurosidad, de otro modo sería una especie de libertad bajo palabra (parole) y carecería de cualquier sentido o novedad". 
altamente cualificado a efectos no solo técnico en el sentido del propio medio, sino también a los efectos de propiciar la reinserción ${ }^{1093}$, por lo que podríamos en principio dudar de la posibilidad real de dotar al sistema de esos medios ${ }^{1094}$. En cualquier caso, se trata de medios que debe proporcionar la administración penitenciaria y partimos de su elevado coste material y humano, pero sin embargo, como afirma SIERRA LÓPEZ, según estudios realizados en Reino Unido, el coste del control de un penado mediante medios electrónicos es bastante menor a lo que cuesta mantenerlo en prisión ${ }^{1095}$, por lo que la imposibilidad real de su implementación por motivos económicos no parece que sea un impedimento real sino al contrario.

Algunos autores ponen de manifiesto que la obligación de estar siempre localizable mediante aparatos electrónicos convierte la libertad vigilada en una suerte de cárcel electrónica ${ }^{1096}$ que incide directamente en la esfera de la libertad mediante técnicas de coacción mental1097, y que se caracteriza porque el establecimiento penitenciario y sus medios de control no cesan del todo, sino que se "difuminan en el espacio", desnaturalizando la verdadera y plena libertad que se convierte en una auténtica "prisión espacial difusa"1098. Es una medida que se configura como la más importante de las que componen la libertad vigilada, por lo que deberá usarse solo en los casos que revista la mayor importancia, dado que carece de limitaciones concretas en su regulación ${ }^{1099}$. No obstante, sobre esta obligación de estar localizable mediante aparatos electrónicos, podemos extraer varias cuestiones fundamentales:

\footnotetext{
1093 Ibidem, p. 26.

1094 CÁMARA ARROYO, S., “La libertad vigilada...”, cit. p. 15.

1095 SIERRA LÓPEZ, M.V., La medida de libertad vigilada..., cit. p. 125. comportarán una tortura mental".

1098 Ibidem, p. 26.

1099 MAPELLI CAFFARENA, B., Las consecuencias..., cit. p. 378.
}

1096 GUDÍN RODRÍGUEZ-MAGARIÑOS, F., La nueva medida de seguridad..., cit. pp. 58 y 59. Este autor explica que "la cárcel electrónica se basa en una sensación de libertad ofusca de la realidad del control. El vigilado pasa a una primera fase de euforia, donde comprueba que aparentemente se halla libre, que puede desplazarse, disfrutar de su hogar y su entorno, estar con sus amigos y familiares. Mas, posteriormente, cuando advierte la intensidad del control al que se halla sometido, tras el súbito sentimiento de embriaguez sobreviene una fase de decaimiento, es entonces cuando comprueba la dureza de las medidas y constata que su libertad en cierta medida es sólo un espejismo y que su comportamiento realmente se halla condicionado. Así resulta significativo que en los países que se aplica la vigilancia electrónica como un paso previo general para la excarcelación, un $24 \%$ de los internos se hayan negado a someterse a la misma".

1097 Ibidem, p. 57. Como indica este autor, "paralelamente los excesos penitenciarios (cadena perpetua, sometimiento intemporal a celda cerrada) derivarán a un tortura física, los excesos de la cárcel electrónica 
$\left.1^{a}\right)$ La inconcreción de la norma en cuanto la utilización de los pretendidos medios electrónicos nos obliga a plantearnos qué medios son los que pueden ser utilizados1100; teniendo en cuenta que el desarrollo reglamentario operado mediante RD 840/2011 no ha incluido concreción alguna al respecto, y parece que el CP está remitiendo a un ulterior desarrollo reglamentario para regular la implantación y utilización de los mencionados medios electrónicos, cuya ocasión dejó pasar el citado RD sin haber concretado cuáles son los medios que se van a utilizar, omitiendo también incluir al agente de vigilancia que podría ser de mucha utilidad en la ejecución de esta medida, tanto en el aspecto material como en el psicológico'1101.

El seguimiento puede hacerse por diferentes medios como los sistemas de vigilancia electrónica estáticos, de control móvil, etc. ${ }^{1102}$, pero con los que actualmente se cuenta en España, según la Secretaría General de Instituciones Penitenciarias, son los siguientes: a) El sistema de monitorización mediante pulseras por red telefónica, bien vía red conmutada (fija), bien vía móvil, a través de las denominadas unidades celulares. b) Los sistemas de verificación de voz, tanto a través de los teléfonos fijos ubicados en los lugares de control, bien a través de dispositivos que transmiten la información usando líneas celulares. c) Los sistemas de seguimiento continuo de internos mediante tecnologías GPS, que permiten conocer la ubicación geográfica del sujeto en todo momento, y establecer zonas de estancia obligatoria o acceso no permitido (zonas de inclusión en las que el vigilado deba permanecer o de exclusión a las que no pueda acceder o aproximarse) ${ }^{1103}$. d) Las unidades de seguimiento móviles para el control de internos con

1100 CÁMARA ARROYO, S., “La libertad vigilada...”, cit. p. 16. Este autor refiere a que no se regulan ni los medios ni la frecuencia del control, ni la remisión de informes al JVP sobre el seguimiento, y que la Instrucción 13/2006, sobre el régimen abierto penitenciario restringido con control telemático, ya advirtió de que "la aplicación de las previsiones del art. 86.4 precisa un permanente seguimiento de los casos y debe ser periódicamente revisada".

1101 SIERRA LÓPEZ, M.V., La medida de libertad vigilada..., cit. p. 126.

1102 MAPELLI CAFFARENA, B., Las consecuencias..., cit. pp. 378 y 379. Este autor afirma que los aparatos que informan sobre parámetros distintos al de la finalidad de la medida que es la localización, como pueden ser los aparatos tecnológicos que ofrecen datos sobre la presión sanguínea, sudoración o ritmo cardíaco, entre otros, no tendrían cobertura legal en el términos en que está redactado el precepto, por lo que no se podrían utilizar.

1103 TORRES ROSELL, N., “Libertad vigilada y seguimiento..." ; cit. pp. 4 y 5. Esta autora señala que “a diferencia de los sistemas estáticos, que pretenden primordialmente comprobar la presencia del individuo respecto de un determinado lugar -generalmente su propio domicilio-, los sistemas de seguimiento continuado, conocidos también como sistemas de tracking o de segunda generación, por la evolución tecnológica de la que resultan, permiten la ubicación del individuo monitorizado allí donde este se encuentre. Para ello se ha venido empleando el sistema GPS (Global Positioning System) que, mediante un cálculo matemático efectuado sobre la base de las señales que el dispositivo recibe de alguno de los satélites que 
pulseras telemáticas en lugares distintos al habitual (por ejemplo, su lugar de trabajo). e) Los sistemas combinados de localización mediante pulseras telemáticas, con control del consumo de alcohol a distancia1104.

TORRES ROSELL señala que los componentes necesarios para el seguimiento del delincuente son de varios tipos, pero la unidad que generalmente se usa es la que incluye un receptor GPS con un brazalete que se acopla al tobillo de la persona y que no admite manipulaciones que alteren su configuración, que además va dotado de una batería y un mecanismo de recarga. Hay otras opciones como la que permite adicionar un teléfono móvil para posibilitar que el centro de control pueda contactar en todo momento con el sujeto, por vía de llamada o por emisión de mensajes de aviso, como alertas de sonido, de luz o vibración, para cuando se aproxima a áreas excluidas o incluso a la víctima1105.

Por tanto, como indica SIERRA LÓPEZ, contamos con medios de control estáticos, que permiten registrar la presencia o ausencia de un individuo en un lugar concreto; y también que permiten registrar la proximidad del sujeto a un lugar o a una persona, mediante la técnica bilateral. Además están los medios de control de seguimiento continuado de los movimientos del sujeto, pero de momento no se conoce cuál de los medios se va a utilizar porque todavía no hay un protocolo de actuación específico, tal y como se hizo para la implantación y seguimiento por medios telemáticos en materia de violencia de género por Resolución de 17 de julio de 2009 de la Secretaría de Estado de

orbitan sobre la tierra, permite determinar la latitud, longitud y altitud en la que un sujeto o un objeto se halla, y plasmar entonces esta información en un mapa, permitiendo la localización de la persona o del objeto a tiempo real y con unos escasos metros de diferencia. Si bien los países europeos han venido empleando también el sistema GPS, el desarrollo del sistema Galileo mediante el que la Unión Europea pretende cierta independencia estratégica respecto de los Estados Unidos ha empezado a materializarse, con el lanzamiento en octubre de 2011 de los primeros satélites. El sistema Galileo está llamado a formar una constelación de 30 satélites, y cuando en 2014 empiece a funcionar podría reemplazar al sistema GPS actualmente vigente".

1104 En la propia información oficial que al respecto proporciona el Ministerio del Interior, vid. [http://www.institucionpenitenciaria.es/web/portal/cumplimientoMedioAbierto/controlTelematico.html], (consultado el 12/06/2014), en todos estos sistemas de vigilancia se permite establecer previamente las restricciones de movimientos que se consideren convenientes en cada caso para favorecer la integración social y la seguridad ciudadana. Además, el Ministerio invoca como ventajas del control telemático que "este tipo de medidas de vigilancia evitan el ingreso en prisión, tanto de los internos en régimen ordinario como en régimen abierto y de infractores no peligrosos que no hayan cometido delitos graves. Facilitan también que se cumpla la condena en el entorno familiar y social, evitando la desestructuración familiar. Permite, además, que el penado continúe su vida laboral y pueda atender así a la indemnización de la víctima. La persona sometida a control telemático no sufre los efectos desocializadores del internamiento en prisión". En cuanto a las pulseras de control telemático, dice el Ministerio que "no suponen ningún coste para el usuario y son respetuosos con la privacidad de su entorno. Se pueden introducir en el agua y sumergir hasta 5 metros de profundidad. Una persona con marcapasos puede llevar también una pulsera de control telemático. Se puede viajar en avión con pulsera telemática. El único inconveniente que puede presentarse es con el detector de metales de los aeropuertos".

1105 Vid. TORRES ROSELL, N., “Libertad vigilada y seguimiento...”, cit. pp. 5 a 7. 
Seguridad. Además, sigue diciendo esta autora, que será necesario un plan de ejecución estableciendo horarios determinados y zonas de exclusión en los que deba encontrarse el sometido a la medida de acuerdo con dichos horarios, al igual que se precisará de un fichero de datos de carácter personal, debido a la incidencia de esta medida en los derechos fundamentales del vigilado como la intimidad, tal y como se hizo en materia de violencia de género mediante la Orden IGD/1702/2010, de 15 de junio ${ }^{1106}$.

La doctrina afirma que la finalidad de esta medida es preventiva, que pretende disuadir al sujeto para que no cometa más delitos, y en ese sentido el control telemático tiene la ventaja de confrontar al sujeto con su situación. Todo ello conlleva -según algunos autores- a que necesariamente se deba desligar el carácter asegurativo o de control de esta medida del carácter aflictivo del que debe carecer y centrarlo en el preventivo, esto es, no puede estar dotado de un carácter punitivo que se añada a la finalidad preventiva aseguradora o rehabilitadora que proclama la LO 5/2010 para la libertad vigilada, por lo que esta autora mantiene que su aplicación debería quedar vinculada a los principios de subsidiariedad y de proporcionalidad. Por último, expresa esta misma autora que su aplicación quedaría excluida en sujetos inimputables, porque su aplicación requiere conocimiento y reconocimiento de la trascendencia de la obligación y de las consecuencias que acarrea la misma, por lo que, en esta clase de sujetos, difícilmente se podrá dar ese reconocimiento, impidiendo su aplicación, que quedaría circunscrita únicamente a los imputables a los que puede ser aplicable tras la pena de prisión ${ }^{1107}$.

$2^{\mathrm{a}}$ ) La segunda cuestión es la referente a qué actividades concretas se van a vigilar, ya que son susceptibles de ser vigiladas por medios electrónicos multitud de actividades como las conversaciones telefónicas o las comunicaciones por cualquier medio online, así como cualesquiera otras actividades que puedan ser vigiladas. La localización mediante aparatos electrónicos únicamente aparece en la letra a) del art. $106.1 \mathrm{CP}$, por lo que no es, en principio, aplicable a las demás letras del precepto, esto es, a la prohibición de residir, aproximarse, etc. - art. 106.1 letras d) a g) $\mathrm{CP}-$, a pesar de que para las penas privativas

1106 SIERRA LÓPEZ, M.V., La medida de libertad vigilada..., cit. p. 127.

1107 Ibidem, p. 128. 
de derechos de idéntico contenido, el art. 48.4 CP lo prevé expresamente1108, al igual que está previsto para el caso de la pena de localización permanente según el art. 37.4 CP1109, precisamente introducido por la LO 5/20101110.

En cualquier caso, la elección de las obligaciones y prohibiciones en que se va a individualizar la medida de seguridad, es una facultad discrecional del juez, pudiendo optar entre todas las que hay por las que mejor crea que se adaptan al sujeto que va ser vigilado. En ese sentido, el art. $106 \mathrm{CP}$ recoge otras medidas de control con las que la obligación de estar localizable mediante aparatos electrónicos se solapa, que serían las de las letras d) a i) del art. $106 \mathrm{CP}$ (esto es, la prohibición de ausentarse del lugar donde resida o de un determinado territorio sin autorización del Juez o Tribunal; la prohibición de aproximarse a la víctima, o a aquellos de sus familiares $u$ otras personas que determine el Juez o Tribunal; la prohibición de comunicarse con la víctima, o con aquellos de sus familiares $\mathrm{u}$ otras personas que determine el Juez o Tribunal; la prohibición de acudir a determinados territorios, lugares o establecimientos; la prohibición de residir en determinados lugares; la prohibición de desempeñar determinadas actividades que puedan ofrecerle o facilitarle la ocasión para cometer hechos delictivos de similar naturaleza). Las únicas obligaciones que no se solaparían serían la de las letras b) y c) que requieren un comportamiento activo (que son la obligación de presentarse periódicamente en el lugar que el Juez o Tribunal establezca y la de comunicar inmediatamente, en el plazo máximo y por el medio que el Juez o Tribunal señale a tal efecto, cada cambio del lugar de residencia o del lugar o puesto de trabajo), y las de las letras j) y k) que son de eminente finalidad resocializadora (que son la obligación de participar en programas formativos, laborales, culturales, de educación sexual u otros similares, y la obligación de seguir tratamiento médico externo, o de someterse a un control médico periódico).

Todo ello nos debe conducir a plantearnos que si se impone la regla de la letra a) del art. $106 \mathrm{CP}$, no deberían imponerse las demás (a excepción de las letras b), c), j) y k), que serían compatibles), porque se estaría imponiendo varias veces las mismas

\footnotetext{
1108 Art. 48.4. “El juez o tribunal podrá acordar que el control de estas medidas se realice a través de aquellos medios electrónicos que lo permitan".

1109 Art. 37.4. "Para garantizar el cumplimiento efectivo, el Juez o Tribunal podrá acordar la utilización de medios mecánicos o electrónicos que permitan la localización del reo".

1110 SANZ MORÁN, A.J., “La nueva medida de seguridad...”, cit. p. 1016.
} 
obligaciones de control permanente, y la consecuencia que puede tener en el sujeto es que puede desembocar en que el incumplimiento de una de ellas, suponga el incumplimiento de varias, lo que tendría incidencia en el delito de quebrantamiento de condena ${ }^{1111 .}$ Entonces, el siguiente paso en la argumentación sería, si la imposición de la letra a) del art 106 CP no puede consistir en las restantes obligaciones del precepto, debemos plantearnos qué es lo que se pretende controlar realmente con esta previsión ambigua de estar siempre localizable mediante aparatos electrónicos, aspecto sobre el que SIERRA LÓPEZ afirma que estar siempre localizable plantea reparos por posible vulneración del derecho a la intimidad, y que tendríamos dos opciones interpretativas al respecto: la primera entendería esa obligación como consistente en saber qué hace el vigilado en todo momento, esto es, seguimiento permanente. Y la segunda, sería que la obligación consiste en controlar los movimientos del vigilado de forma que, por esta primera obligación, podríamos introducir obligaciones no incluidas en el art. $106 \mathrm{CP}$, como las del art. $48.2 \mathrm{CP}$, que contempla la prohibición de aproximarse a la víctima o a sus familiares, etc., y además prevé la prohibición de acercarse a su domicilio, a sus lugares de trabajo y a cualquier otro frecuentado por ellos, aspectos estos últimos que no aparecen expresamente en el $106 \mathrm{CP}$ y que podrían ser objeto de control a través de la letra a) del mismo precepto, en la medida en que el control mediante medios electrónicos permitiría saber si se aproxima a estos lugares e impedirlo. Y sigue diciendo esta autora que, "en todo caso, sí parece que con la obligación de estar siempre localizable no solo puede buscarse "vigilar permanentemente" sino también corregir conductas, esto es, "reeducar" en el sentido más literal del término, en tanto en cuanto pueden controlar comportamientos mediante un régimen de vida de bajo riesgo" ${ }^{\prime 112}$.

Conviene precisar si esta obligación de estar siempre localizable mediante aparatos electrónicos es una medida instrumental o autónoma. En el primer caso sería una medida destinada a dar cobertura al cumplimiento efectivo de las restantes obligaciones y prohibiciones que se adopten; y en el segundo caso, la obligación de estar localizable sería la única finalidad en sí misma. Sobre este particular, afirma TORRES ROSELL que su finalidad es esencialmente instrumental, pero se permite su aplicación de forma autónoma según autoriza el art. $106 \mathrm{CP}$ sin que sea condición necesaria para su imposición que acompañe a ninguna otra obligación o prohibición de las demás posibles.

1111 SIERRA LÓPEZ, M.V., La medida de libertad vigilada..., cit. p. 125.

1112 Ibidem, p. 126. 
Según esta autora, "es precisamente en este contexto en el que se acusa la parquedad de la ley penal. Ni el concreto contenido ni el régimen de cumplimiento de esta medida han sido abordados en el texto legal, quedando pues indeterminadas las implicaciones para el penado de su sumisión al seguimiento continuado, así como la forma en que éste deba hacerse efectivo. Puesto que la concreta ubicación del penado va a ser suministrada por los propios dispositivos telemáticos, resulta importante desentrañar cuáles son las obligaciones que afectan al penado"1113.

Además, es relevante destacar que la obligación de estar siempre localizable mediante aparatos electrónicos contiene dos vertientes: una activa, que consiste en la obligación de que al sujeto le sean facilitados los medios electrónicos y que le sean instalados para permitir el control efectivo, así como la obligación de mantenimiento en correcto estado de funcionamiento de los mismos para que su uso y efectividad no se vea interrumpida durante el tiempo de sometimiento a la medida. Y la segunda vertiente es la pasiva, que se materializa en la obligación que incumbe al vigilado de consentir la instalación de los dispositivos con la consecuente intromisión en su esfera de intimidad y libertad. El sujeto no se puede negar, ya que no es necesario su consentimiento en modo alguno (aunque sí se exige el consentimiento para el sometimiento a tratamientos médicos), por lo que su negativa a utilizar los medios de control, daría lugar al quebrantamiento de condena. No obstante, dicho quebrantamiento no se producirá si es la administración encargada de colocar y de mantener los dispositivos en funcionamiento quien incumple su obligación en la vertiente activa, que no concierne al vigilado1114.

TORRES ROSELL señala que en el supuesto de que se imponga la libertad condicional con sujeción a seguimiento mediante aparatos electrónicos si así se acuerda en la concreción de las reglas de conducta que el penado deberá observar durante el período de libertad condicional, según autoriza el art. $90.2 \mathrm{CP}$, cuando además se imponga a continuación la libertad vigilada y se acuerde esta obligación de estar siempre localizable mediante aparatos electrónicos, supondrá un incremento notable del tiempo en que el sujeto esté sometido a esta clase de control. No obstante, esta misma autora indica que esta situación no será muy habitual en la praxis, debido a que la libertad condicional no es precisamente una institución de la que pueda hacerse un uso generalizado en esta clase de

1113 TORRES ROSELL, N., “Libertad vigilada y seguimiento...”, cit. pp. 12 a 14.

1114 Ibidem, p. 14. 
delincuentes a quienes está prevista la imposición de la libertad vigilada postpenitenciaria, pero no es imposible que se conceda -sobre todo en delincuentes sexuales o en terroristas arrepentidos- y en todo caso las obligaciones y prohibiciones en que se concrete la libertad vigilada, no deberán ser más gravosas que las aplicadas para la libertad condicional1115.

Finalmente, conviene hacer referencia a algunos de los inconvenientes que esta obligación plantea y que han sido señalados por la doctrina científica1116:

1. Las limitaciones tecnológicas y ambientales pueden provocar que los dispositivos fallen, como cuando se pasa por un túnel, se entra en un ascensor, edificio alto, etc., situaciones equiparables a la pérdida de cobertura en los dispositivos de telefonía móvil. Esto puede provocar multitud de alarmas infundadas que se producen por error generando una reacción del personal al servicio del seguimiento que se vuelva innecesaria, y además se trata de alarmas que no implican una voluntad del sujeto de incumplir, pudiéndose generar situaciones de incumplimiento con consecuencias jurídicas importantes cuando ese aspecto no podría acreditarse con seguridad. No obstante, esta misma autora indica que con el tiempo este inconveniente se irá solventando a través de la evolución de la tecnología.

Otra causa que produce falsas alarmas son los errores técnicos o tecnológicos del propio dispositivo, que en ocasiones puede averiarse o desprogramarse. Sin embargo, GUDín RODRÍGUEZ señala que las críticas basadas en deficiencias técnicas son coyunturales y se basan en fallos técnicos aislados, pero no hay que olvidar que los sistemas electrónicos de control "pueden ser infinitamente más duros e implacables que el más psicopatoide y estricto de los vigilantes humanos, más toda perfección técnica comporta una mayor reducción de los derechos fundamentales"1117.

2. Ante la gran cantidad de situaciones de alarma resulta necesario destinar un elevado número de recursos humanos para solventar las situaciones de riesgo que luego resultan ser falsas por esos motivos antes aducidos, con la consecuencia de que esos

1115 Ibidem. Pág. 11.

1116 Ibidem. Págs. 35 a 39.

1117 GUDÍN RODRÍGUEZ-MAGARIÑOS, F., La nueva medida de seguridad..., cit. p. 288. 
recursos no pueden destinarse a otros menesteres, porque se está atendiendo a alarmas erróneas. El efecto que se produce, además, es que ante tanta falsa alarma de incumplimiento por parte del vigilado, los agentes encargados del control y seguimiento se vuelven insensibles, recordándonos a la fábula del pastor que gasta la broma de dar el aviso de que viene el lobo, y cuando un día de verdad se acerca el lobo nadie hace caso del aviso y se come las ovejas de toda la aldea.

3. Una de las causas que más alarmas puede provocar cuando el sujeto intenta manipular el dispositivo, alterar su funcionamiento, inhibir su frecuencia, o simplemente despojarse de él. Los meros intentos ya pueden resultar conducentes a que salte la alarma generando la intervención de los agentes de seguimiento, dejando abierta la posibilidad que por estas intenciones que no se terminan de consumar pero que se producen realmente y hacen saltar la alarma, nos encontremos ante verdaderos incumplimientos con los efectos jurídicos que comporta incumplir cualquiera de las obligaciones y prohibiciones que puedan imponerse (modificación de las reglas de conducta o deducción de testimonio por quebrantamiento de condena, según los casos de reiteración o gravedad). No obstante, señala TORRES ROSELL que si el penado se deshace del dispositivo, se genera el inconveniente de que su detención va a ser mucho más difícil que si el seguimiento se hiciera por agentes y no por dispositivos electrónicos, porque se desconoce su paradero.

4. Se puede optar por varios sistemas de control mediante este tipo de aparatos: el activo, que consiste en un seguimiento permanente y continuo debido a que la señal es constante y permite en todo momento su identificación; el pasivo, que solo emite datos una o dos veces al día; y el híbrido que combina ambas formas con cierta intermitencia a intervalos temporales ${ }^{1118}$. El sistema activo es obviamente más costoso, por lo que suele optarse por el pasivo que ofrece menor control efectivo que si lo llevan a cabo los agentes $y$, en consecuencia, el riesgo de reincidencia o de futura actividad delictiva que se pretende neutralizar, es mayor con los dispositivos electrónicos.

5. Otro inconveniente señalado por esta misma autora, es que sentirse controlado las veinticuatro horas todos los días, puede impedir el desarrollo de habilidades

1118 TORRES ROSELL, N., “Libertad vigilada y seguimiento...”, cit. p. 6. 
necesarias para llevar una vida en libertad de forma responsable, con lo cual, puede verse obstaculizada la reinserción.

6. También se objeta a la utilización de estos dispositivos electrónicos, que producen un efecto similar a la marca, estigmatizando al delincuente que puede verse imposibilitado para emprender una reinserción total, debido a que, por ejemplo, puede resultar un fuerte obstáculo para empezar relaciones afectivas de pareja, o para encontrar un trabajo con el que mantenerse mientras está en libertad, teniendo en cuenta que la manutención que se le proporciona en prisión cuando sale en libertad debe procurárselo el propio sujeto, que puede verse imposibilitado a encontrar trabajo porque está marcado con el dispositivo de control, impidiendo que pueda mantenerse y, por tanto, imposibilitando la reinserción. Esta imposibilidad de encontrar trabajo también puede derivar de las propias limitaciones tecnológicas y de las falsas alarmas a las que antes refería, debido a que, en determinados lugares el dispositivo puede presentar un fallo como si estuviese desconectado, saltando la alarma y dando lugar a la intervención de los agentes, estigmatizando al vigilado de forma considerable y consiguiendo que finalmente no pueda permanecer en ningún puesto de trabajo, o bien, tendría muy limitadas las opciones para trabajar, que quedarían reducidas a lugares donde exista seguridad de que las condiciones circundantes no van a influir en el dispositivo anulándolo o provocando alarmas erróneas.

7. La vinculación con el dispositivo puede generar mayor riesgo de fuga, sobre todo si la previsión del tiempo por el que va a estar controlado es muy largo, pudiendo generar en el sujeto la sensación de que no tiene nada que perder si intenta fugarse o desprenderse del GPS.

8. Incrementa el volumen de trabajo de supervisión del personal encargado, porque, según afirma TORRES ROSELL, muchos estudios revelan que, aunque esta medida de control se suele introducir con la finalidad de ahorrar costes a la administración penitenciaria, en realidad supone una mayor inversión de tiempo debido al gran número de delincuentes al que se les puede aplicar esta medida, de forma que el personal encargado debe previamente instalar los dispositivos e informar a los penados de su funcionamiento y de las reacciones que deben tener ante fallos o incidencias. Posteriormente deben responder a los avisos de alarma que se produzcan, deben hacer el 
seguimiento, reparar los errores técnicos, dedicarse a la contratación con las empresas proveedoras de dispositivos, etc. Sin olvidar que las víctimas de un nuevo delito, puede luego reclamar a la administración por no haber dado solución inmediata al aviso de alarma que se produjo y no haber evitado el delito.

9. Por último, en cuanto a los aspectos de eficiencia económica, esta misma autora indica que hay que atender a la valoración global y que sería imprudente introducir esta clase de medidas en la legislación sin tener en cuenta los recursos necesarios para su puesta en funcionamiento y mantenimiento en condiciones de efectividad. Los costes se suelen calcular en la proporción de que por cada interno en prisión, pueden ser sometidos a vigilancia electrónica seis individuos, pero si no se reduce la población carcelaria, la medida no resulta eficiente, esto es, la eficiencia resulta de reducir el tiempo en prisión o evitar la encarcelación de muchos penados aplicándoles los dispositivos electrónicos, pero se produce el efecto contrario cuando además de la prisión, no se reduce la encarcelación, no se sustituye un tramo de la pena por la libertad con sujeción a vigilancia electrónica, sino que se ambas sanciones se suman, produciendo una multiplicación de costes en términos globales ${ }^{1119}$.

10. La utilización de medios electrónicos se basa en que los sujetos peligrosos, ante el inevitable retorno a la sociedad, deben ser sometidos a medios de localización esperando que la presión que ejercen sobre su intimidad y libertad les contenga sus impulsos delictivos, pero lo cierto es que, según esta autora, no existen datos que evidencien que el buen comportamiento de estos sujetos se deba a los dispositivos y no al tratamiento recibido en prisión en aplicación de la pena, pero sí puede afirmarse que los dispositivos influyen de forma negativa en el proceso de reinserción porque interfieren, como ya se ha dicho, en multitud de aspectos, al tiempo que se fuerza a los funcionarios a que atiendan los avisos y demás cuestiones relacionadas con el seguimiento de la medida, y se vean obligados a abandonar las funciones asistenciales que resultan necesarias ${ }^{1120}$.

Por todo ello, esta misma autora sugiere tener en cuenta ciertas cautelas a la hora de implementar estos medios electrónicos de seguimiento en la libertad vigilada, comenzando por el necesario desarrollo reglamentario del art. $106 \mathrm{CP}$, delimitando y

\footnotetext{
1119 Ibidem. Págs. 35 a 39.

1120 Ibidem, p. 41.
} 
concretando el contenido y alcance de esta obligación. Habría que determinar también si la utilización de esta medida es instrumental o autónoma, teniendo en cuenta que en la mayoría de países se ha optado por que sea instrumental; y por último, habría que tener presentes las especialidades de cada tipología de delincuentes sexuales e investigar previamente a cuáles de ellos les es adecuada esta medida de control, evitando un uso generalizado ${ }^{1121}$. También se acusa la orientación puramente asegurativa y de control de esta medida, que se aleja sensiblemente de la vertiente rehabilitadora, por lo que sería necesario potenciar la finalidad resocializadora a través de un factor complementario que necesariamente tendrá que ser de asistencia humana ${ }^{1122}$.

b) La obligación de presentarse periódicamente en el lugar que el Juez o Tribunal establezca.

Es una obligación de presentación periódica que no aparecía anteriormente en el catálogo de medidas de seguridad no privativas de libertad, aunque sí estaba previsto algo similar como concreción de la medida cautelar de libertad provisional, en el art. 530 LECrim $^{1123}$. Se trata de una obligación a la que solo habrá que acudir en caso de riesgo de huida, y deberá concretarse por el juez en cuanto a la periodicidad y teniendo en cuenta las circunstancias del vigilado como el horario laboral, etc. ${ }^{1124}$

La presentación será, normalmente, en la sede de Tribunal o en el Juzgado de Paz del municipio de residencia del penado en caso de no coincidir éste con el del partido judicial donde se esté conociendo la ejecutoria, que se llevará a efecto a través de auxilio judicial. Pero no necesariamente, puesto que, tratándose de una medida de seguridad, su seguimiento y control a efectos del contenido de la propia medida, podría encomendarse a instituciones penitenciarias especiales (art. 7.c) de la LOGP) y a los centros penitenciarios destinados a formas especiales de ejecución previstos en el Título VII del Reglamento Penitenciario, aprobado por RD 190/1996, de 9 de febrero; o incluso a servicios sociales. Algunos autores señalan que se advierte la necesidad de introducir un

\footnotetext{
1121 Ibidem, pp. 42 y 43.

1122 CÁMARA ARROYO, S., “La libertad vigilada...”, cit. p. 16.

1123 ACALE SÁNCHEZ, M., “Medición de la respuesta punitiva...”, cit. p. 194.

1124 SIERRA LÓPEZ, M.V., La medida de libertad vigilada..., cit. p. 128.
} 
elemento más pedagógico en esta medida, para lo que aducen que habría sido conveniente acudir al ordenamiento penal de menores ${ }^{1125}$.

Es una obligación que se solapa con la de la letra a) del art. $106 \mathrm{CP}$, consistente en estar siempre localizable, por lo que su imposición deberá hacerse con racionalidad, porque la obligación de estar siempre localizable ya puede conllevar el contenido de esta obligación ${ }^{1126}$.

c) La obligación de comunicar inmediatamente, en el plazo máximo y por el medio que el Juez o Tribunal señale a tal efecto, cada cambio del lugar de residencia o del lugar o puesto de trabajo.

Es también una novedad introducida en la reforma de la LO 5/2010, que está basada en las "notification orders" del Derecho anglosajón1127, y no supone una prohibición de cambiar de domicilio o de trabajo, sino una mera medida de control que conlleva la obligación de informar al juzgado de cada cambio que se produzca, de forma que bastará con comunicarlo sin que sea necesario solicitar autorización para hacerlo1128. Su finalidad puede ser meramente psicológica, que genera la sensación en el penado de que sus movimientos laborales y residenciales siguen estando controlados por la administración de justicia, creando una sensación de ausencia de libertad plena en sus decisiones que tan solo sería en realidad aparente, porque el vigilado puede cambiar de residencia o de domicilio todas las veces que quiera o que su situación lo exija. Como afirma SIERRA LÓPEZ, esta medida podría tener sentido en delincuentes sexuales, por el riesgo que puede haber por la proximidad de ciertos barrios, colegios o lugares de mayor riesgo ${ }^{1129}$. Otros autores señalan que habría sido perfectamente posible incluir esta medida dentro de la de estar siempre localizable sin necesidad de regularla de forma autónoma1130.

\footnotetext{
1125 CÁMARA ARROYO, S., “La libertad vigilada...”, cit. p. 16.

1126 SIERRA LÓPEZ, M.V., La medida de libertad vigilada..., cit. p. 129.

1127 GARCÍA ALBERO, R., en QUINTERO OLIVARES, G., Comentarios..., cit. Tomo I, p. 689.

1128 ACALE SÁNCHEZ, M., “Medición de la respuesta punitiva...”, cit. p. 194.

1129 SIERRA LÓPEZ, M.V., La medida de libertad vigilada..., cit. p. 129

1130 CÁMARA ARROYO, S., “La libertad vigilada...”, cit. p. 16.
} 
Conviene mencionar que la referencia al plazo máximo que debe fijar el Juez es tan indeterminada que puede ser el mismo día en que se produzca el cambio de domicilio o de lugar de trabajo, o incluso uno, dos o tres semanas más tarde, dependiendo del plazo que se fije por el órgano jurisdiccional. Más correcta habría sido la fórmula que previese un plazo máximo fijo en que el penado deberá comunicar el cambio de domicilio o de trabajo (v.g. 48 horas, tres días, etc.), facilitando con ello su aplicación por parte de los Tribunales y la ejecución de la medida en condiciones de igualdad, restando margen de maniobra al arbitrio judicial y sirviendo con ello a las exigencias del principio de taxatividad.

También conviene hacer referencia en este punto al medio por el que el penado debe comunicar el cambio de domicilio, que deberá ser el que el Tribunal señale al efecto. En ese orden de cosas, en principio, atendiendo a las razones lógicas del funcionamiento de nuestro sistema judicial, ese medio consistirá en remitir un simple escrito al juzgado poniendo en su conocimiento dicho cambio, con expresión del nuevo lugar de radicación o de trabajo, pero podría ser perfectamente admisible que, en caso de no poder presentar ese escrito o estar rebasando el plazo máximo indicado, el penado se ponga en contacto telefónico con el juzgado para que el funcionario que lleva la ejecutoria haga constar la circunstancia en el expediente $y$, de no ser suficiente tal extremo, puede incluso ponerse al habla el Secretario Judicial y llevar a cabo una diligencia de comunicación telefónica que quede incorporada a los autos de su ejecutoria. Incluso puede ser el abogado quien realice la gestión, el procurador, o cualquier persona que acredite la representación (poder notarial, autorización firmada para comunicar tal extremo al juzgado, etc.). Obviamente, también será admisible la mera comparecencia del penado en el juzgado a efectos de comunicar el cambio de domicilio. Sin duda la mejor fórmula habría sido que la comunicación podrá hacerse por cualquier medio válido admitido en Derecho.

Es una obligación que cuyo contenido se solapa con el de la letra a) del art. $106 \mathrm{CP}$, consistente en estar siempre localizable, por lo que su imposición deberá hacerse con racionalidad, porque la obligación de estar siempre localizable ya puede conllevar el contenido de esta obligación ${ }^{1131}$.

1131 SIERRA LÓPEZ, M.V., La medida de libertad vigilada..., cit. p. 129. 
d) La prohibición de ausentarse del lugar donde resida o de un determinado territorio sin autorización del Juez o Tribunal.

Deberá solicitarse autorización al juez para ausentarse de su lugar de residencia, entendiendo por ausentarse cualquier viaje que implique una salida de su término municipal, o de su territorio que parece que se refiere a territorio nacional, autonómico o provincial1132. La autorización se requiere para efectuar viajes vacacionales, laborales, por estudios, o de cualquier otra índole, como pudiera ser la visita a familiares, salidas para presenciar eventos deportivos, atenciones hospitalarias que requieran desplazamientos, etc. Normalmente, si los desplazamientos están justificados documentalmente, el Juez no tiene por qué denegarlos, puesto que la prohibición no es absoluta, sino que solo implica que deberá mediar autorización judicial, por lo que, solicitada la autorización, en principio debería concederse.

Se trata de una mera medida de control judicial de los movimientos geográficos del penado, y no de una prohibición de la libertad deambulatoria que le impida desplazarse. La prohibición únicamente estriba en el hecho de desplazarse sin haber solicitado la autorización judicial. Ahora bien, el supuesto problemático que puede plantear esta previsión es determinar si, solicitada por escrito la autorización al JVP y, por motivos de exceso de trabajo del Juzgado, llega la fecha en que el sujeto tiene que desplazarse (v.g. porque es la fecha del evento deportivo, o porque es la fecha de sus vacaciones, etc.) y el escrito no ha sido ni siquiera proveído (como tantas veces sucede en la praxis diaria judicial). En estos casos, se plantea el interrogante de si podemos entender que el sujeto ha incumplido la medida o si basta la mera solicitud para que se entienda concedida la autorización o, al menos para haber cumplido el requisito de no desplazarse sin autorización. En mi opinión la mera solicitud ya le autorizaría a desplazarse, siempre que el silencio judicial se haya producido por causas no imputables al propio sujeto solicitante.

Es una prohibición que se solapa con la de la letra a) del art. $106 \mathrm{CP}$, consistente en estar siempre localizable y, al igual que en las obligaciones de las letra b) y c) del mismo precepto, su imposición deberá hacerse con racionalidad, porque la obligación de estar siempre localizable ya puede conllevar el contenido de esta prohibición, teniendo en

1132 ACALE SÁNCHEZ, M., “Medición de la respuesta punitiva...”, cit. p. 195. 
cuenta que estas medidas se imponen por el riesgo de nuevos delitos, por la peligrosidad y como medidas de control, no con base en los delitos ya cometidos ${ }^{1133}$.

e) La prohibición de aproximarse a la víctima, o a aquellos de sus familiares $u$ otras personas que determine el Juez o Tribunal.

Se trata de una prohibición que tiene por finalidad la protección a la víctima para evitar el acercamiento del vigilado a ella, a sus familiares o a las personas que el órgano jurisdiccional determine. Es una prohibición que coincide, en esencia, con la pena privativa de derechos del art. 48.2 CP, aunque en esta última el legislador confirió una redacción más amplia al prever que la prohibición se extiende a cualquier lugar donde dichas personas se encuentren, así como acercarse a su domicilio, a sus lugares de trabajo y a cualquier otro que sea frecuentado por ellos, y también especifica el precepto que queda en suspenso el régimen de visitas, comunicación y estancia que, respecto de los hijos, se hubiese acordado en sentencia civil, suspensión que se extenderá hasta el total cumplimiento de la pena. En la libertad vigilada la prohibición es más escueta, queda en manos del Juez determinar su alcance ${ }^{1134}$, pero, en principio, su contenido aparece limitado por la aproximación física, por lo que nada impide el contacto telefónico, correo ordinario o electrónico, etc. ${ }^{1135}$

Algunos autores, sin embargo, se han mostrado críticos con esta medida (y con la del apartado siguiente, que es la prohibición de comunicarse) porque entienden que se aparta de la esencia preventivo-especial de las medidas de seguridad, por lo que no está justificada su inclusión como prohibición concreta dentro de la libertad vigilada1136.

f) La prohibición de comunicarse con la víctima, o con aquellos de sus familiares u otras personas que determine el Juez o Tribunal.

Al igual que la prohibición de la letra e) del art. 106 CP acabada de analizar, su finalidad es de protección a la víctima y a su entorno, y también coincide con la pena privativa de derechos prevista en el art. $48.3 \mathrm{CP}$, aunque ésta última es también más

\footnotetext{
1133 SIERRA LÓPEZ, M.V., La medida de libertad vigilada..., cit. p. 129.

1134 Ibidem, p. 130.

1135 ACALE SÁNCHEZ, M., “Medición de la respuesta punitiva...”, cit. p. 196.

1136 CÁMARA ARROYO, S., “La libertad vigilada...”, cit. p. 16.
} 
amplia en su redacción ${ }^{1137}$, al contener además la concreción de que la prohibición de comunicarse "impide al penado establecer con ellas, por cualquier medio de comunicación o medio informático o telemático, contacto escrito, verbal o visual", de forma que se deja al criterio discrecional del Juez la concreción de las personas con las que no se podrá comunicar, no los medios que aparecen detallados ${ }^{1138}$. Sin embargo en la prohibición de la libertad vigilada dichas concreciones no aparecen y solo se contiene la prohibición genérica de comunicarse, quedando por tanto a discrecionalidad del Juez determinar el alcance de dicha prohibición, que en principio no tiene por qué incluir el contacto visual si no se concreta en la resolución. En cualquier caso, a falta de indicación concreta, entendemos que la prohibición de comunicación comprende todos los medios posibles para ello, incluyendo los medios informáticos, telemáticos, verbales o escritos.

\section{g) La prohibición de acudir a determinados territorios, lugares o establecimientos}

Se trata de una prohibición que implica que el vigilado no podrá acudir físicamente a determinados, territorios, lugares o establecimientos. En principio se plantea un problema de delimitación conceptual acerca de los vocablos que utiliza el código, ya que por territorios debe entenderse zonas geográficas dentro de las demarcaciones autonómicas, provinciales o locales comprendidas en el territorio nacional1139; lugares que deben entenderse como sitios específicos como emplazamientos concretos donde hay ubicado algo o alguien; y establecimientos son lugares cerrados que pueden ser al aire libre pero delimitados igualmente, como discotecas, recintos deportivos, pubs, piscinas públicas, etc. ${ }^{1140}$ La fundamentación descansa sobre la omnicomprensión de que se trata de lugares que pueden propiciar la comisión de nuevos delitos, como las escuelas, parques infantiles, lugares de dispensa de bebidas alcohólicas, sex shops, reuniones políticas, mítines, manifestaciones, etc. ${ }^{1141}$ Antes de la reforma, esta prohibición estaba

\footnotetext{
1137 SIERRA LÓPEZ, M.V., La medida de libertad vigilada..., cit. p. 130.

1138 ACALE SÁNCHEZ, M., “Medición de la respuesta punitiva...”, cit. pp. 196 y 197.

1139 CÁMARA ARROYO, S., “La libertad vigilada...”, cit. p. 16. Este autor, sin embargo, afirma que la palabra "territorios" resulta redundante y absurda, porque significa igualmente lugares concretos, y propone interpretarlo en su vertiente jurídica como "circuito o término que comprende una jurisdicción, un cometido oficial u otra función análoga".

1140 ACALE SÁNCHEZ, M., “Medición de la respuesta punitiva...”, cit. p. 197.

1141 GARCÍA ALBERO, R., en QUINTERO OLIVARES, G., Comentarios..., cit. Tomo I, p. 690. Este autor afirma que la apertura a la definición de los lugares o establecimientos pretende permitir la máxima flexibilidad para adaptar la prohibición a cada caso concreto teniendo en cuenta tanto las potenciales víctimas a las que se trata de proteger, como los estímulos que los lugares en cuestión puedan desencadenar un nuevo delito en el sujeto, como los parques infantiles para los pederastas.
} 
prevista en el art. 96.3.5 $\mathrm{CP}$, aunque con un contenido un poco más explícito al concretar que la prohibición era de acudir a determinados lugares o territorios, espectáculos deportivos o culturales y establecimientos de bebidas alcohólicas.

Como indica SIERRA LÓPEZ, en ocasiones la prohibición tendrá sentido si se trata del lugar en el que se cometió el delito pasado, debido a la sensibilidad en la víctima o en el entorno, ya que puede que la mera presencia del sujeto en ese lugar suponga un riesgo añadido o coloque en situación de malestar o de incomodidad por temor fundado en la víctima o en el entorno, incluido el vecindario. Pero, comoquiera que la previsión es excesivamente amplia y el requisito del peligro real no se contiene expresamente, no es verdaderamente necesario que concurra, y puede ser acordada sin atender al mismo y sin necesidad de constatarlo. En cualquier caso, esta misma autora señala que será necesaria la intervención de los servicios policiales para la comprobación del cumplimiento y deberán actuar de forma coordinada con los servicios de gestión del cumplimiento de penas y medidas alternativas ${ }^{1142}$. Otros autores afirman que más que controlar la libertad del sometido a la medida, se pretende proteger a otros de su presencia, por lo que quizás hubiese sido mejor regularla como medida autónoma y no dentro de otra más grande como la libertad vigilada de contenido tan amplio y versátil1143.

Esta prohibición coincide también con la prevista en el art. $48.1 \mathrm{CP}$ —conforme a la redacción que le dio también la LO 5/2010-, junto con la prohibición de residir en determinados lugares (que se analiza a continuación), aunque la previsión del art. 48.1 CP es también más amplia que la de la libertad vigilada, por cuanto que el contenido de la pena es, literalmente, la siguiente: "la privación del derecho a residir en determinados lugares o acudir a ellos impide al penado residir o acudir al lugar en que haya cometido el delito o falta, o a aquel en que resida la víctima o su familia, si fueren distintos".

\section{h) La prohibición de residir en determinados lugares}

Dando por reproducidas las consideraciones acerca de la coincidencia del contenido con el art. $48.1 \mathrm{CP}$ a la que acabamos de hacer referencia, esta medida es otra de las prohibiciones en las que se plasma claramente la finalidad de protección de la víctima

\footnotetext{
1142 SIERRA LÓPEZ, M.V., La medida de libertad vigilada..., cit. p. 131.

1143 ACALE SÁNCHEZ, M., “Medición de la respuesta punitiva...”, cit. p. 197.
} 
y de su entorno, prohibiendo que el vigilado resida en determinados lugares, extrayendo al delincuente de su ambiente criminógeno, lo que denota su eminente carácter asegurativo o profiláctico que además pretende rehabilitar al sujeto, ya que la prohibición podría acordarse, por ejemplo, en casos en que el sujeto resida en barrios marginales con gran presencia de actividad delictiva. No obstante, esta prohibición entraña el peligro de que si la persona carece de otro lugar donde residir, podría conducirle a la indigencia, lo que iría en contra de la dignidad de la persona, por lo que deberá acordarse siempre que suponga una protección efectiva para la víctima, y en los demás casos, solo cuando la imposición de la prohibición no vaya a tener efectos excesivamente destructivos en el vigilado.

La doctrina señala que se impondrá normalmente junto con la prohibición de aproximarse a la víctima y de acudir a determinados lugares. No obstante, SIERRA LÓPEZ se pregunta qué debemos entender por "lugares", que podrían ser, por ejemplo, calles, barriadas o municipios ${ }^{1144}$.

Como ya se ha dicho, las prohibiciones de las letras e), f) g) y h) del art. $106 \mathrm{CP}$, coinciden plenamente con las penas privativas de derechos del art. 39 f), g) y h) CP, en relación al art. 48.1, 2 y $3 \mathrm{CP}$, con las únicas diferencias en el contenido a las que ya hemos hecho referencia y con la salvedad de que, para la libertad vigilada, no son penas sino medidas concretas incardinadas, a su vez, dentro de la libertad vigilada que es una medida de seguridad. Por otro lado, estas prohibiciones coinciden también, en buena parte, con el contenido de la denominada "orden de protección" en el ámbito de la violencia de género, pues su contenido coincide plenamente con el contenido de la misma, a saber: e) La prohibición de aproximarse a la víctima, o a aquellos de sus familiares u otras personas que determine el Juez o Tribunal; f) La prohibición de comunicarse con las personas previstas en la letra anterior; g) La prohibición de acudir a determinados territorios, lugares o establecimientos; h) La prohibición de residir en determinados lugares.

Esta previsión del Código, viene a trasponer la tendencia legislativa a la híperprotección de las víctimas a la que refiere la denominada orden de protección, que

1144 SIERRA LÓPEZ, M.V., La medida de libertad vigilada..., cit. pp. 131 y 132. 
fue introducida mediante la Ley 27/2003, de 31 de julio, de protección a las víctimas de violencia doméstica, y posteriormente fue modificada por la LO 15/2003, de 25 de noviembre ${ }^{1145}$. El alejamiento, por tanto, incorporado por la LO 14/1999, de 9 de junio, mediante la redacción del art. 544 bis de la LECrim, abarca diferentes figuras que son: la prohibición de aproximarse a determinados lugares, la prohibición de acercamiento, tanto a determinados lugares como a determinadas personas; y la prohibición de comunicarse con ellas, coincidiendo - una vez más- con el contenido de las obligaciones concretas de la libertad vigilada en de los apartados letras e), f), g) y h) del art. $106 \mathrm{CP}$, cuyo fundamento, pues, no puede ser otro que la protección a las víctimas, lo cual tiene lógica atendiendo a una determinada política criminal encaminada a la represión de los delitos cometidos contra las mujeres y, en ese orden de cosas, los delitos contra la libertad e indemnidad sexuales quedan plenamente incardinados en dicho ámbito, pues las víctimas suelen ser, aunque no siempre, mujeres. El problema es que lo que realmente se está articulando con la libertad vigilada es una medida de seguridad y no una medida cautelar ni una pena restrictiva de derechos, lo cual implica que el fundamento de la misma estriba en la peligrosidad criminal y en la protección a las víctimas, por lo que se trata de inocuizar a esa clase de delincuentes no mediante una pena (que ya se habrá cumplido) sino mediante un medida de seguridad (sui generis) que se aplicará con posterioridad.

De todo ello podemos extraer que con la entrada en vigor de la libertad vigilada tenemos el siguiente marco punitivo para el delincuente sexual que además lo sea en el ámbito de la violencia de género: orden de protección en fase sumarial; penas privativas de derechos que se imponen junto a la de prisión1146; y cumplida la pena privativa de

\footnotetext{
1145 Se trata de una resolución motivada, que viene regulada en el art. 544 ter de la LECrim, y por definición legal es un estatuto de protección que comprende medidas cautelares de protección de orden penal y, en su caso, civil, así como otras medidas de asistencia y protección social establecidas en el ordenamiento, respecto de la víctima. Se trata de un derecho de la víctima y de su familia a recuperar la sensación de seguridad frente a posibles amenazas o represalias posteriores del agresor. Vid. SOTORRA CAMPODARVE, M. C., "Protección en el ámbito penal”. En RIVAS VALLEJO, M.P. / BARRIOS BAUDOR G.L., (Dir.), Violencia de Género. Perspectiva Multidisciplinar y Práctica Forense. Navarra: Thomson Aranzadi. 2007, p. 401. La orden de protección, confiere a la víctima un estatuto integral de protección y dentro del mismo hay medidas de naturaleza penal, civil, social y asistencial. Por ese motivo, el Juez debe escoger las medidas que se adapten mejor al caso concreto, con las exigencias propias derivadas del art. 68 LOVG, esto es, desde el prisma de los principios de proporcionalidad y necesidad, con intervención del Ministerio Fiscal, y con respeto a los principios de contradicción, audiencia y defensa. Vid. HERRERO-TEJEDOR ALGAR, F., "La orden de protección”. En GÓMEZ COLOMER, J.L., (coord.), Tutela procesal frente a hechos de violencia de género. Col lecció “Estudis jurídics" núm. 13. Castellón: Universitat Jaume I. 2007, pp. 363 a 379.

1146 MANZANARES SAMANIEGO, J.L., “La libertad vigilada...”, cit. p. 57. Este autor indica que "a la vista de los dispuesto en el art. 67, con su remisión al art. 48, y en el nuevo apartado 1 del art. 192, dichas penas y esta medida de seguridad pueden imponerse conjuntamente por razón de unos mismo hechos constitutivos de delitos contra la libertad e indemnidad sexuales. En la previsión del art. 57.2 “se acordará en todo caso, la
} 
libertad, libertad vigilada. Cada una de ellas se aplica en una fase del procedimiento, pero el contenido puede ser idéntico, con la única diferencia de la denominación legal y frente a las que no cabe ningún tipo de abono (ni del tiempo cumplido como medida cautelar a la pena o a la medida de seguridad, ni del tiempo cumplido de la pena a la libertad vigilada).

Además, resulta relevante la cuestión de que la protección a las víctimas se extiende a sus familiares y otras personas que determine el Tribunal, situación que, como advierte REBOLLO VARGAS, “desequilibra la igualdad entre partes procesales, además al adoptar alguna puede comportar materialmente la desocialización del sujeto", todo ello con el problema añadido de que las medidas de protección a la víctima son de difícil control, ya que al no contar con agentes especializados para tal fin, el control debe llevarse a cabo por el JVP, que deberá servirse de las Fuerzas y Cuerpos de Seguridad del Estado ${ }^{1147}$.

No obstante, sin necesidad de adentrarse en el terreno de la violencia de género, se observa una clara afección al principio de ne bis in idem 1148 , ya que el art. 39 f), g) y h) CP, coinciden con el art. 106.1 g), i) y h), con la única diferencia de que el art. 106.1.g), contiene una prohibición de acudir a determinados lugares y el art. 106.1 h) prohíbe residir en determinados lugares, de forma que, se desdoblan las prohibiciones de residir y acudir. Todo ello, relacionado con el art. 57.2 CP, que faculta al Tribunal para imponer una o varias prohibiciones contempladas en el art. $48 \mathrm{CP}^{1149}$ por la comisión de cualquiera de los

aplicación de la pena prevista en el apartado 2 del artículo $48^{\prime \prime}$, que es prohibición de aproximarse a la víctima si se diese el caso del art. 192. Es sólo un ejemplo, porque cabe añadir otros sin abandonar el art. 57. La reforma del CP conforme a la LO 5/2010 ignora estos problemas".

1147 REBOLLO VARGAS, R., La llibertat vigilada..., cit. p. 65. Señala este autor que se trata de "mesures, com es pot observar, de difícil control, on la intervenció del JVP és primordial i qui davant l'absència d'agents o de personal específic destinat a feines de control, necessitarà la col laboració de les Forces i Cossos de Seguretat."

1148 Sobre este principio puede consultarse, GORRIZ ROYO, E., “El principio "ne bis in ídem” y la regla de preferencia del orden jurisdiccional penal a la luz de la STC 177/1999". En Revista de la Asociación de Ciencias Penales, Vol. 3. 2000; PÉREZ MANZANO, M., La prohibición de incurrir en "bis in ídem". Valencia: Tirant lo Blanch. 2002; TORRES FERNÁNDEZ, M.E., “De nuevo sobre el principio non bis in ídem en la jurisprudencia constitucional”. En Revista La Ley, núm. 5824. Madrid. 2003.

1149 Art. 48.1. "La privación del derecho a residir en determinados lugares o acudir a ellos impide al penado residir o acudir al lugar en que haya cometido el delito o falta, o a aquel en que resida la víctima o su familia, si fueren distintos. 2. La prohibición de aproximarse a la víctima, o a aquellos de sus familiares $u$ otras personas que determine el juez o tribunal, impide al penado acercarse a ellos, en cualquier lugar donde se encuentren, así como acercarse a su domicilio, a sus lugares de trabajo y a cualquier otro que sea frecuentado por ellos, quedando en suspenso, respecto de los hijos, el régimen de visitas, comunicación y estancia que, en su caso, se hubiere reconocido en sentencia civil hasta el total cumplimiento de esta pena. 3 . La prohibición de comunicarse con la víctima, o con aquellos de sus familiares u otras personas que determine el juez o tribunal, 
delitos previstos en el propio precepto, se advierte que dichas penas accesorias pueden ser impuestas en delitos contra la libertad e indemnidad sexuales porque están entre los relacionados en dicho precepto ${ }^{1150}$. Con lo cual tenemos que ante delitos contra la libertad e indemnidad sexuales, pueden imponerse las penas accesorias del art. $48 \mathrm{CP}$ que se cumplirán de forma simultánea a la pena, y que podrán prolongarse por tiempo de hasta diez años si se trata de delitos graves y de hasta cinco años si se trata de delitos menos graves, por encima de la pena privativa de libertad1151. A lo que habría que añadir que, de forma preceptiva y posteriormente a la pena privativa de libertad, deberá comenzar a cumplirse la medida de seguridad de libertad vigilada que ya vendrá impuesta desde la sentencia, con una clara incisión en el principio de ne bis in idem, en cuya virtud no podrían imponerse las penas del art. $57 \mathrm{CP}$ en relación al $48 \mathrm{CP}$, y también las del $106 \mathrm{CP}$ (libertad vigilada).

La solución parece ser que algunos de los contenidos ya previstos en las penas accesorias, no podrán ser impuestas como concreción de la libertad vigilada, pero sí las demás ${ }^{1152}$. REBOLLO VARGAS afirma que la libertad vigilada es preceptiva y algunas penas accesorias son facultativas ("podrán imponer"), por lo que habría que imponer la libertad vigilada decayendo con ello la posibilidad de imposición facultativa de las penas accesorias del art. 57 CP en relación al art. 48 CP1153. Por su parte SANZ MORÁN, sugiere

impide al penado establecer con ellas, por cualquier medio de comunicación o medio informático o telemático, contacto escrito, verbal o visual. 4. El juez o tribunal podrá acordar que el control de estas medidas se realice a través de aquellos medios electrónicos que lo permitan".

1150 MANZANARES SAMANIEGO, J.L., "La libertad vigilada...”, cit. p. 57. Este autor expresa que "más graves son, sin embargo, las dificultades que surgen cuando la libertad vigilada concurre con determinadas penas privativas de derechos, principales o accesorias. Los arts. 39, 48 y $57 \mathrm{CP}$ revelan hasta qué punto se difuminan los contornos entre la libertad vigilada -o mejor, las medias posteriores que pueden concretarla- $\mathrm{y}$ aquellas penas.

1151 Art. 57. 1. “Los jueces o tribunales, en los delitos de homicidio, aborto, lesiones, contra la libertad, de torturas y contra la integridad moral, la libertad e indemnidad sexuales, la intimidad, el derecho a la propia imagen y la inviolabilidad del domicilio, el honor, el patrimonio y el orden socioeconómico, atendiendo a la gravedad de los hechos o al peligro que el delincuente represente, podrán acordar en sus sentencias la imposición de una o varias de las prohibiciones contempladas en el artículo 48, por un tiempo que no excederá de diez años si el delito fuera grave o de cinco si fuera menos grave. / No obstante lo anterior, si el condenado lo fuera a pena de prisión y el juez o tribunal acordara la imposición de una o varias de dichas prohibiciones, lo hará por un tiempo superior entre uno y 10 años al de la duración de la pena de prisión impuesta en la sentencia, si el delito fuera grave, y entre uno y cinco años, si fuera menos grave. En este supuesto, la pena de prisión y las prohibiciones antes citadas se cumplirán necesariamente por el condenado de forma simultánea".

1152 GARCÍA ALBERO, R., en QUINTERO OLIVARES, G., Comentarios..., cit. Tomo I, p. 690.

1153 REBOLLO VARGAS, R., La llibertat vigilada..., cit. p. 66. Este autor explica que "en tot cas, atenent a la prohibició de bis in idem, no podrien imposar-se ambdues a la mateixa persona ja que el seu fonament és el mateix; no obstant això, no s'ha previst en el text cap mecanisme per a resoldre aquest conflicte o per a fixar els criteris pels quals hauria d'optar el Jutge o Tribunal. Tot i així, atès que el règim d'imposició de les penes 
que hubiera sido mejor prescindir de las penas privativas de derechos remitiendo su posible aplicación a los criterios del derecho de medidas ${ }^{1154}$. FEIJOO SÁNCHEZ señala que en caso de que se haya impuesto una pena accesoria del art. $57 \mathrm{CP}$ orientada a la protección de la víctima, será tarea del Juez valorar si es necesario complementar la pena con los contenidos de la libertad vigilada atendiendo a la peligrosidad, de modo que, solo será necesario imponer la medida cuando sea necesario otorgar mayor protección a las víctimas si la peligrosidad se mantiene más allá del cumplimiento de esa pena accesoria que tiene la misma finalidad 1155 .

Dando un paso más, el solapamiento y la afección al principio de ne bis in idem se aprecia tanto en los delitos contra la libertad sexual como en los de violencia doméstica, ya que tanto el art. 57.1 CP en aquéllos como el art. 57.2 CP en éstos, dispone que esta clase de delitos llevará consigo la pena de alejamiento, que se cumplirá de forma simultánea a la privativa de libertad pero con la especialidad de que podrá exceder unos años más. Si además se impone la libertad vigilada, la confluencia de la pena y la medida obligará a que no se puedan imponer esta obligaciones y prohibiciones, pero sí las restantes, lo que, de facto, implica que el penado podrá estar cumpliendo una multiplicidad de obligaciones y prohibiciones contenidas, todas ellas, en la libertad vigilada, pero con la salvedad de que algunas de ellas lo serán en concepto de pena. Solo queda proscrita la coincidencia de obligaciones entre pena y medida, las que no sean idénticas pueden concurrir.

Pero lo que llama la atención es el agravio comparativo que supone el régimen de quebrantamiento, ya que si se incumple la pena de alejamiento, se incurre en un nuevo delito de quebrantamiento de condena, mientras que si se incumplen las obligaciones y prohibiciones de la libertad vigilada, solo se incurre en el delito si el incumplimiento es reiterado o grave, pudiendo suceder que simplemente se sustituyan unas medidas por otras. Es más, puede que dichas prohibiciones de no aproximarse o comunicar, se

accessòries és potestatiu, recordem que l'art. 57 es refereix a "podran", mentre que la previsió per a les mesures de seguretat de llibertat vigilada és d'índole preceptiva, "Haurà així d'imposar..." (art. 105.1), sembla que aquest concurs aparent de normes penals es resoldria a favor de la imposició de la llibertat vigilada, la qual cosa impediria la imposició simultània de la pena accessòria."

1154 SANZ MORÁN, A.J., "La nueva medida de seguridad...”, cit. p. 1016. Como señala este autor, "de ahí que, una vez admitida la imposición de medidas a sujetos plenamente responsables, debería haber valorado el legislador la posibilidad de prescindir de las mencionadas penas privativas de derechos, remitiendo su posible aplicación a los criterios específicos del derecho de medidas".

1155 FEIJOO SÁNCHEZ, B., “La libertad vigilada...", cit. p. 224. 
acuerden como contenido de la libertad condicional, y su incumplimiento de lugar la revocación de la misma, no a un nuevo delito ${ }^{1156}$. El agravio comparativo es evidente.

Por último, interesa resaltar el aspecto que comenta CÁMARA ARROYO, cuando afirma que se ha dejado pasar la oportunidad de implementar la utilización de las Unidades Dependientes (UD) que son unidades arquitectónicamente separadas del centro penitenciario y revisten forma de viviendas ordinarias en entornos comunitarios que no tienen signos de distinción externa sobre su cometido, de forma que, en principio, la apariencia es de viviendas normales y solo quien está ligado de alguna forma a la administración penitenciaria tiene conocimiento de su uso postpenitenciario. Este autor, con referencia de la Circular de Instituciones Penitenciarias 117/1995, de 26 de junio, indica que sus servicios son de carácter formativo, laboral, tratamental, gestionado por asociaciones y organismos ajenos a la administración penitenciaria, aunque dependen administrativamente de algún centro penitenciario, y que por tanto, son lugares idóneos para el cumplimiento de estas obligaciones a las que refiere el art. $106.1 \mathrm{CP}$, que además favorecen un ambiente de control y vigilancia con menos restricciones que los centros penitenciarios y sus normas de funcionamiento favorecen la convivencia y comunicación, porque contienen derechos y obligaciones de los ocupantes de la unidades dependientes ${ }^{1157}$.

i) La prohibición de desempeñar determinadas actividades que puedan ofrecerle o facilitarle la ocasión para cometer hechos delictivos de similar naturaleza.

Se trata también de una prohibición eminentemente asegurativa o profiláctica y a este respecto el legislador está pensando en actividades relacionadas con el delito cometido $^{1158}$ y que puedan desencadenar en el sujeto deseos o ansias de volver a delinquir, aunque algunos autores señalan que ante la ausencia de mayores detalles, podría entenderse que se trata de un concepto más amplio que incluye actividades

\footnotetext{
1156 ACALE SÁNCHEZ, M., “Medición de la respuesta punitiva...”, cit. p. 200.

1157 CÁMARA ARROYO, S., “La libertad vigilada...”, cit. p. 17.

1158 SIERRA LÓPEZ, M.V., La medida de libertad vigilada..., cit. p. 132.
} 
económicas, laborales o incluso lúdicas ${ }^{1159}$. Se trata de una medida nueva que hasta la LO 5/2010 no figuraba entre el catálogo de medidas de seguridad existentes ${ }^{1160}$.

Habida cuenta de que la libertad vigilada es una medida de seguridad y el delito previo puede haber sido cometido por patologías o por hábitos derivados de determinadas actividades realizadas anteriormente como la asistencia a rituales satánicos, asociaciones de carácter sectario o que promueven la violencia (por ejemplo, Latin King, Skin Head, etc.), o el exceso de consumo de cine violento o sexual, así como el exceso de lecturas que pueden generar estados de obsesión que promueven la xenofobia, el racismo, el nazismo, etc. En concreto, podemos citar algunos ejemplos para ilustrar brevemente en qué pueden consistir las prohibiciones concretas, como puede ser en el caso de delincuentes que hayan delinquido con ocasión de haberse visto patológicamente involucrados en un juego de rol (el ejemplo más significativo es el juego interactivo de rol por Internet que termina condicionando las actuaciones del sujeto, que se vuelve violento o que delinque como parte del rol que adquiere en el juego); o impedirle al sujeto que se ponga en contacto con juegos de videoconsola de contenido violento que puedan desencadenarle actitudes hostiles; prohibirle el visionado de pornografía, o de material que incluya contenido sexual, acudir al estadio de fútbol donde se irrita notablemente y termina agrediendo al público concurrente, etc.

j) La obligación de participar en programas formativos, laborales, culturales, de educación sexual u otros similares.

Esta medida está claramente orientada a la adquisición de hábitos saludables, al aprendizaje de valores y a la desaparición de vicios que impidan al sujeto llevar una vida normal alejada de la necesidad de delinquir. Es por tanto, una obligación de contenido rehabilitador. En principio se observa que el código usa el vocablo "participar" y no "someterse" lo que indica que está presente la nota de voluntariedad, pero, por otra parte, la medida es coercitiva y, por tanto, si se impone es obligatoria. Este aspecto viene a producir una suerte de disfunción respecto del tratamiento penitenciario, por cuanto que no termina de entenderse que si durante la pena de prisión el sujeto no se ha sometido a

\footnotetext{
1159 CÁMARA ARROYO, S., “La libertad vigilada...”, cit. p. 17.

1160 ACALE SÁNCHEZ, M., “Medición de la respuesta punitiva...”, cit. p. 195.
} 
tratamientos de reinserción dentro de los programas voluntarios, lo vaya a hacer después con la medida pero de forma coactiva en una fase postpenitenciaria1161.

Sobre los programas formativos o laborales se tratará de que el sujeto aprenda uno o varios oficios o actividades que posteriormente podrá desempeñar en el mundo laboral o incluso deportivo, aunque la doctrina se plantea hasta qué punto puede imponerse una obligación consistente en la adquisición de valores culturales o laborales sin el consentimiento del sujeto, por lo que la obligación quedaría un tanto desdibujada si no se cuenta con dicho consentimiento, por lo que SIERRA LÓPEZ señala que el éxito dependerá de la propia motivación del sujeto, y que en todo caso habrá que tenerse en cuenta las opiniones del sujeto y sus propias carencias y características personales, que pueden ser verdaderos condicionantes cuando no impedimentos para la efectividad de esta obligación ${ }^{1162}$.

El problema viene de la mano de los "programas sexuales", puesto que la terapia en este aspecto resulta de muy difícil efectividad o, cuanto menos, de imposible aplicación. Finalmente se incluye una cláusula abierta que refiere a "otros similares", por lo que, será necesario un desarrollo reglamentario que indique a qué otros programas similares puede someterse al sujeto en el seno de esta medida, y comparto la opinión de RUBIO LARA, cuando propone que, para los imputables peligrosos, podría tener cabida en esta cláusula la terapia social, que actualmente no se contempla en el código ${ }^{1163}$.

Se trata de una medida que ya aparecía entre las previstas en el código con anterioridad a la reforma de $2010 \multimap$ con algunas modificaciones que carecen de excesiva relevancia-1164, y también se aprecia coincidencia con instituciones de contenido similar en el ámbito de la pena de trabajos a favor de la comunidad ${ }^{1165}$. Lo que interesa resaltar es que, en la modalidad de libertad vigilada postpenitenciaria para imputables peligrosos, se trata de una medida que no parece tener mucho sentido en su aplicación al ámbito de los

1161 CÁMARA ARROYO, S., “La libertad vigilada...”, cit. p. 17.

1162 SIERRA LÓPEZ, M.V., La medida de libertad vigilada..., cit. p. 132.

1163 RUBIO LARA, P.A., “Las medidas de seguridad...”, cit. p. 112.

1164 ACALE SÁNCHEZ, M., “Medición de la respuesta punitiva...”, cit. p. 195.

1165 CERVERA SALVADOR, S., "La pena de trabajos en beneficio de la comunidad". En Revista de Estudios Penitenciarios, núm. 255. Madrid: Ministerio del Interior. Secretaría General Técnica. 2011, pp. 94 y ss. 
terroristas, sino que parece que va dirigida a los delincuentes sexuales ${ }^{1166}$, aunque la regulación no hace referencia alguna a este extremo.

k) La obligación de seguir tratamiento médico externo, o de someterse a un control médico periódico.

Su adopción deberá estar siempre justificada en la medida en que el sujeto necesite el sometimiento a dicho tratamiento o al control periódico. No obstante, merece que hagamos mención a un aspecto que plantea problemas de interpretación, y es el sometimiento obligatorio a tratamiento médico a un sujeto imputable, que contraviene lo dispuesto en la Ley 41/2002, de 14 de noviembre, básica reguladora de la autonomía del paciente ${ }^{1167}$, por cuanto que el consentimiento del paciente es un requisito indispensable para el sometimiento a cualquier clase de tratamiento1168/1169. En ese sentido hay autores que ponen de manifiesto la irrelevancia de que el sujeto deba prestar el consentimiento, por razones de interpretación sistemática de ambas normas, por lo que, si el penado no presta su consentimiento, bastará con sustituir la medida por otra1170. A mi juicio, ésta es la interpretación correcta por varias razones: la primera, porque el propio art. $100.3 \mathrm{CP}$, prevé que la negativa a someterse a tratamiento médico o a continuarlo no se considerará

1166 FEIJOO SÁNCHEZ, B., “La libertad vigilada...", cit. p. 231.

1167 LUACES GUTIÉRREZ, A.I., "Cuestiones controvertidas en torno al procedimiento para decidir sobre la medida de libertad vigilada". En NEIRA PENA, A. (Coord.) / PÉREZ-CRUZ MARTÍN, A.J. (Dir. Congr.) / FERREIRO BAAMONDE, X. (Dir. Congr.), Los retos del Poder Judicial ante la sociedad globalizada: Actas del IV Congreso Gallego de Derecho Procesal (I Internacional), A Coruña, 2 y 3 de junio de 2011. 2012, pp. 552 y 553, nota al pie 33.

1168 ACALE SÁNCHEZ, M., “Libertad Vigilada”. En ÁLVAREZ GARCÍA, F.J. / GONZÁLEZ CUSSAC, J.L. (Dirs.), Comentarios a la reforma penal de 2010. Valencia: Tirant lo Blanch. 2010, p. 156.

1169 La cuestión que surge es determinar a qué norma hay que atender, ya que, en principio, podría pensarse que sería suficiente con acudir a la teoría de KELSEN sobre la jerarquía normativa (vid. KELSEN, H., Teoría pura del Derecho. 1934. $3^{\text {a }}$ Ed. Buenos Aires. Editorial Universitaria de Buenos Aires. 1970, pp. 135 a 161. Para este autor "una ciencia normativa no puede admitir contradicción entre dos normas que pertenecen a un mismo sistema. Ahora bien, el derecho mismo resuelve el conflicto posible entre dos normas válidas situadas en estratos diferentes, de manera que ninguna contradicción lógica afecta la unidad del orden jurídico en su estructura jerárquica"), puesto que la medida de seguridad emana de una ley orgánica (CP) y el requisito del consentimiento previo deriva de una ley ordinaria (Ley 41/2002), primando el contenido de la primera por tratarse de una norma de mayor rango. Por otra parte, la medida de seguridad se impone en sentencia y se concreta posteriormente mediante auto, por tanto, impuesta la medida y acordado su cumplimiento, se deberá llevar a efecto con o sin consentimiento del penado, en virtud de las leyes adjetivas de aplicación (LECrim y LOPJ). Sin embargo, esta solución no es posible desde el punto de vista sistemático según la actual regulación.

1170 GARCÍA ALBERO, R., “La nueva medida de seguridad...”, cit. p. 187. Este autor expresa que "puesto que de medidas de seguridad se trata, el consentimiento del penado resulta irrelevante, lo que obligará a interpretar la medida consistente en el sometimiento a tratamiento médico, tratándose de imputables, de modo cohoneste con la Ley 41/2002, de 14 de noviembre básica reguladora de la autonomía del paciente, que en su artículo 2 exige el previo consentimiento del paciente o usuario en toda actuación en el ámbito de la sanidad". 
quebrantamiento de la medida1171; y la segunda, porque carecería de sentido que fuera necesario el consentimiento del penado para la imposición de la pena de trabajos en beneficio de la comunidad y no lo fuera para la imposición de la medida de sometimiento a tratamiento médico dentro de la libertad vigilada. Sin olvidar que tal vez esta previsión sea el resultado del intenso y polémico debate parlamentario que tuvo lugar con ocasión de los Proyectos y Anteproyectos de reforma del CP de 2007 y 2008, acerca de la posibilidad de someter a los delincuentes sexuales a una serie de terapias de reducción hormonal reversible, más conocida como castración química1172, con el consiguiente surgimiento de multitud de dudas acerca de su constitucionalidad ${ }^{1173}$.

SIERRA LÓPEZ señala que esta obligación —de carácter claramente terapéutico-, en cuanto se aplicación sea para sujetos imputables, está pensada precisamente para delincuentes sexuales o para aquéllos que presenten alguna anomalía, como los pederastas, toxicómanos, etc., en quienes el tratamiento puede reducir las tasas de reincidencia. No obstante, en relación a la castración química, es un tratamiento que deja secuelas pero es reversible y si el sujeto deja la medicación, el tratamiento deja de ser efectivo. Esta autora manifiesta que será necesario el consentimiento del sometido a la medida, aunque por sí solo es muy difícil que tenga efectividad, ya que ciertos perfiles criminógenos necesitan, además, de un acompañamiento a través de programas psicológicos o sociales ${ }^{1174}$. Por todo ello, considero que la obligación de someterse a tratamiento médico únicamente podrá cumplirse si el penado consiente. En caso contrario, bastará con sustituir la medida por otra1175.

\footnotetext{
1171 GUTIÉRREZ ROMERO, F.M., “El tratamiento de los delitos sexuales...”, cit. p. 4.

1172 GARCÍA ALBERO, R., en QUINTERO OLIVARES, G., Comentarios..., cit. Tomo I, p. 690.

1173 Vid. GARCÍA ALBERO, R., “La nueva medida de seguridad...”, cit. p. 189; ROBLES PLANAS, R., "“Sexual predators...", cit. pp. 8 a 12; ALONSO RIMO, A., "Medidas de seguridad...", cit. p. 129; y GARCÍA ALBERO, R., en QUINTERO OLIVARES, G., Comentarios..., cit. Tomo I, p. 689. Este autor explica que las dudas de constitucionalidad surgen de una simple lectura formal del precepto y que, en todo caso, quedarían excluidos los tratamientos forzosos que impliquen injerencias personales o injestas de medicamentos sin consentimiento, pero mayores dudas plantea la posibilidad de que se proporcionara un tratamiento de terapia de psicología de la conducta, que podrían entrar en el concepto de tratamiento médico externo.
}

1174 SIERRA LÓPEZ, M.V., La medida de libertad vigilada..., cit. pp. 133 y 134.

1175 GARCÍA ALBERO, R., “La nueva medida de seguridad...”, cit. p. 189. Como expresa este autor, "con base en lo dispuesto en la Ley 41/2002, se impone la interpretación señalada de hacer implícitamente exigible el consentimiento, lo que viene a confirmar explícitamente la regulación específica del quebrantamiento de esta medida (art. 100.3)". 
Quizás habría sido más razonable regular la obligación de someterse a tratamiento médico como una medida de seguridad genérica o autónoma dentro del catálogo del art. $96 \mathrm{CP}$, en lugar de como una obligación incardinada dentro de la libertad vigilada, no solo porque la negativa del penado a someterse está regulado de forma autónoma en el art. 100.3 CP como un supuesto específico de incumplimiento que no será considerado quebrantamiento, sino porque su carácter autónomo se revela de los arts. 100.3 y $106.4 \mathrm{CP}$, que no son coincidentes, ya que en el 106.4 CP el incumplimiento de las obligaciones de la libertad vigilada implica la posibilidad de sustitución de la medida por otra de entre las previstas en el propio art. $106 \mathrm{CP}$ (libertad vigilada), y en el art. 100.3 CP el incumplimiento del tratamiento médico conduce a que se sustituya la medida por otra de las aplicables al supuesto de que se trate, esto es, de las contenidas en el catálogo del art. $96 \mathrm{CP}$, no de las obligaciones y prohibiciones de la libertad vigilada1176.

Otra opción posible habría sido la de exigir el previo consentimiento del sujeto ${ }^{1177}$ como requisito para el inicio del cumplimiento, de forma que una vez otorgado ese consentimiento, el tratamiento podría comenzar a cumplirse deviniendo ya a partir de ese momento 1178 .

$\mathrm{Al}$ igual que sucede con la letra j) del art. 106.1 CP, en la modalidad de libertad vigilada postpenitenciaria para imputables peligrosos, se trata de una medida que no parece tener mucho sentido en su aplicación al ámbito de los terroristas, sino que parece que va dirigida exclusivamente a los delincuentes sexuales, por lo que será de difícil imposición en casos de terrorismo ${ }^{1179}$.

En definitiva, sobre el contenido de las obligaciones y prohibiciones analizadas, podemos afirmar, por una parte, que la medida consistente en el sometimiento a tratamiento médico no encuentra acomodo ni entre las obligaciones ${ }^{1180}$ (por ser necesario el consentimiento) ni entre las prohibiciones (por no ser una actividad prohibitiva sino que requiere participación activa del penado), por lo que debemos clasificarla aparte; y

\footnotetext{
1176 SANZ MORÁN, A.J., “La nueva medida de seguridad...”, cit. p. 1025.

1177 GARCÍA ALBERO, R., en QUINTERO OLIVARES, G., Comentarios..., cit. Tomo I, p. 691.

1178 CÁMARA ARROYO, S., “La libertad vigilada...”, cit. p. 17.

1179 FEIJOO SÁNCHEZ, B., “La libertad vigilada...”, cit. p. 231.

1180 ACALE SÁNCHEZ, M., “Medición de la respuesta punitiva...”, cit. p. 203.
} 
por otro lado, de las medidas analizadas se desprende que se debería profundizar más en el contenido rehabilitador1181, puesto que el legislador apunta hacia ella en el Preámbulo de la LO 5/2010, pero del contenido de la reforma no parece que sea esa la orientación que se le ha conferido, por lo que se generan ciertas dudas acerca de que haya sido esa realmente la voluntas legislatoris.

\section{EJECUCIÓN}

El órgano competente para ejecutar la medida es el mismo Juez o Tribunal que tuvo conocimiento del plenario y dictó Sentencia, conjuntamente con el JVP1182, a diferencia de la - para algunos autores menos acertada- previsión del Anteproyecto de 2008 que encomendaba esa tarea al JVP en exclusiva1183. La libertad vigilada se impone siempre en sentencia, aspecto que si bien no plantea mayores problemas en su vertiente de medida de seguridad para los inimputables y semiimputables, en relación a su aplicación en las dos categorías de imputables peligrosos a las que va destinada, sí se advierten algunos inconvenientes, como el relativo a que en esta modalidad, desde la sentencia en la que se impone hasta el momento de comenzar a cumplirla, pueden mediar años o décadas, con la consecuente dificultad para aventurarse a si la peligrosidad

1181 REBOLLO VARGAS, R., La llibertat vigilada..., cit. p. 64.

1182 No obstante, ninguna referencia existe en el texto acerca de las posibilidades de actuación que pueda tener el Juez o Tribunal que tenga encomendado el conocimiento de la ejecutoria según las normas de reparto de asuntos, puesto que, una vez la sentencia adquiere firmeza, la ejecutoria se puede repartir nuevamente y su conocimiento puede no estar encomendado al Tribunal sentenciador. Conviene precisar, que el art. 794 de la LECrim dispone que ejecutará el mismo Juez o Tribunal encargado de dictar Sentencia, pero en algunas comunidades autónomas como la Comunidad Valenciana, se creó un servicio común de ejecutorias penales estructurado en secciones y equipos, que cuentan con una organización jerarquizada y especializada para descargar a los Magistrados de los procesos de ejecución en vista del colapso de causas pendientes de ejecutar que tanta polémica estaban creando a la luz de los acontecimientos acaecidos en los últimos años como por ejemplo el "caso Mari Luz". En multitud de partidos judiciales -como el de Barcelona, Madrid o Valencia-se reparten las ejecutorias entre órganos distintos a los que sentencian, habiéndose creado la especialidad de Juzgados de lo penal de ejecución. Por ese motivo, si la justificación es que el Juez de sentencia ya tiene conocimiento de la circunstancias del sujeto y puede tomar las decisiones -conjuntamente con el JVP-sobre la libertad vigilada, en estos casos de reparto de ejecutorias a juzgados distintos, ese conocimiento de las circunstancias del sujeto va a ser escaso. Por otra parte, esta forma de reparto de las ejecutorias, empero, no resulta del todo armónico con lo dispuesto en la LECrim ni con el principio de legalidad de ejecución en relación con el principio del Juez natural. Sobre el principio de Juez legal predeterminado por la ley vid. LÓPEZ BARJA DE QUIROGA, J., Tratado de Derecho Procesal Penal. Tomo I. $5^{\mathrm{a}}$ Ed. Navarra: Thomson Aranzadi. 2012, pp. 187 a 190; MONTERO AROCA, J., “La Jurisdicción”. En MONTERO AROCA, J. / GÓMEZ COLOMER, J.L. / MONTÓN REDONDO, A. / BARONA VILAR, S., Derecho Jurisdiccional I. Parte General. 21 $1^{\text {a }}$ Ed. Valencia: Tirant lo Blanch. 2013, pp. 87 a 92; RIFA SOLER, J.M. / VALLS GOMBAU, J.F. / RICHARD GONZÁLEZ, M., El proceso penal práctivo..., cit. pp. 121 a 137; MONTERO AROCA, J., Proceso Penal y Libertad. Ensayo polémico sobre el nuevo proceso penal. Navarra: Thomson Civitas. 2008, pp. 36 y 37; GIMENO SENDRA, V., Manual de Derecho procesal penal. $3^{\mathrm{a}}$ Ed. Madrid: UNED, Colex. 2013, pp. 45 a 50; RAMOS MÉNDEZ, F., Enjuiciamiento Criminal. Nueva lectura constitucional. Barcelona: Atelier. 2010, pp. 87 a 116.

1183 GASCÓN INCHAUSTI, F. / VILLAMARÍN LÓPEZ, M.L., “Otras repercusiones...”, cit. p. 372. 
subsistirá llegado ese momento, por eso algunos autores indican que sería más congruente con el sistema penitenciario y con la individualizacón científica, que el juicio de peligrosidad se reservase íntegramente al momento de terminación del cumplimiento de la pena, ya que la libertad vigilada es ahora una fase postpenitenciaria1184.

La concreción de las obligaciones y prohibiciones se debe hacerse antes de terminar la pena de prisión (art. $106.2 \mathrm{CP}$, vid. infra), y la elección deberá hacerse basándose en criterios de prognosis de peligrosidad. En el caso de terroristas, se hace especialmente necesario verificar esa peligrosidad, que solo concurrirá en caso de que el sujeto siga vinculado a la organización terrorista, de lo contrario, estaríamos utilizando como criterio sus ideas, sus convicciones personales, su ideología que carecería de fundamento para presumir la peligrosidad con base en el delito cometido, que resulta insuficiente a estos efectos. Por tanto, en caso de desvinculación con la organización terrorista, la libertad vigilada no parece tener mucho sentido ${ }^{1185}$. Los preceptos que refieren a la ejecución de libertad vigilada se analizan a continuación:

$\mathbf{1}^{\mathbf{0}}$. El art. $97 \mathrm{CP}$ enumera las distintas decisiones que el Juez o Tribunal sentenciador deberá tomar durante la ejecución de la medida, a saber: el mantenimiento de la medida, art. 97.1.a) $\mathrm{CP}$, decretar su cese por desaparición de la peligrosidad criminal, art. 97.1.b) CP, sustituir una por otra, art. 97.1.c) $\mathrm{CP}$, o suspender su ejecución por un plazo no superior al que le reste por cumplir, que será siempre el tiempo máximo de cumplimiento fijado en la sentencia, art. 97.1.c) CP. Ahora bien, respecto de esta última posibilidad, la suspensión podrá dejarse sin efecto si concurren nuevamente las circunstancias del art. $95 \mathrm{CP}$, esto es: que realice un hecho que constituya delito y que se revele en el sujeto un pronóstico de comisión de nuevos delitos en el futuro.

$2^{\circ}$. El art. $98 \mathrm{CP}$ regula el procedimiento ${ }^{1186}$ que debe seguirse para la adopción de las decisiones a las que alude el art. $97 \mathrm{CP}$ que acabamos de citar, y en concreto, a través del apartado 1 del art. 98 CP se lanza un mandato directo al JVP para que, al menos anualmente, eleve al Juez o Tribunal sentenciador una propuesta de mantenimiento, cese,

\footnotetext{
1184 CÁMARA ARROYO, S., “La libertad vigilada...”, cit. p. 14.

1185 FEIJOO SÁNCHEZ, B., “La libertad vigilada...”, cit. p. 232. Este autor indica que esa decisión personal de seguir vinculado con la organización terrorista es lo que supone un coste que justifica la libertad vigilada en un Estado de Derecho, con la que deberá acarrear el sujeto.

1186 ROCA POVEDA, M., “La libertad vigilada...”, cit. pp. 41 y 42.
} 
sustitución o suspensión de la medida. Es decir, que la propuesta deberá hacerse al menos anualmente, aunque nada impide que dichas propuestas, a instancia de cualquiera de las partes, puedan elevarse en un plazo de seis meses, o de tres, desde el inicio del cumplimiento de la medida, siempre que las circunstancias aconsejen la adopción de la decisión. Por tanto, de esta previsión se extrae una doble vertiente: por un lado la obligación del JVP de elevar propuesta anual1187; y por otro, la facultad del mismo de elevar dicha propuesta tan pronto como crea conveniente (sin esperar a que se cumpla el requisito de anualidad) a efectos de que por el órgano judicial sentenciador se adopte alguna de las decisiones previstas en el art. $97 \mathrm{CP}$. De todo ello se desprende que quien toma la decisión es el órgano sentenciador, aspecto que, según señala SIERRA LÓPEZ, resulta inoperante debido a que todo el peso de seguimiento y elaboración de informes recae sobre el JVP, y lo coherente sería que fuera éste quien decidiera con base en ese seguimiento y no el órgano sentenciador1188.

En cuanto al contenido de la propuesta, el propio art. $98 \mathrm{CP}$ dispone que el JVP deberá valorar, por un lado los informes emitidos por facultativos y profesionales encargados del seguimiento de la ejecución de la medida o por las Administraciones Públicas competentes'1189; y por otro, el resultado de las demás actuaciones que, con el fin de la elaboración de la propuesta, pueda ordenar el JVP. Es decir, que la previsión es tan amplia como difusa, puesto que se está ordenando al JVP que valore los informes de los facultativos y profesionales que puedan tener conocimiento directo en relación a la medida impuesta o por las Administraciones Públicas ${ }^{1190 .}$

1187 GUTIÉRREZ ROMERO, F.M., “El tratamiento de los delitos sexuales...”, cit. p. 4.

1188 SIERRA LÓPEZ, M.V., La medida de libertad vigilada..., cit. p. 147.

1189 SANZ MORÁN, A.J., “La nueva medida de seguridad...”, cit. p. 1026. Este autor manifiesta que "resultan absolutamente insuficientes, a este respecto, las previsiones contenidas en los arts. 98 y $105 \mathrm{CP}$. El primero de ellos se refiere genéricamente a "los informes emitidos por facultativos y profesionales encargados del seguimiento de la ejecución de la medida o por las Administraciones Públicas competentes". Y en términos igualmente inconcretos, establece el párrafo final del art. $105 \mathrm{CP}$, que "el Juez o Tribunal sentenciador dispondrá que los servicios de asistencia social competentes presten la ayuda o atención que precise y legalmente le corresponda al sometido a medidas de seguridad no privativas de libertad".

1190 ROCA POVEDA, M., “La libertad vigilada...", cit. p. 48. Este autor indica que "se trata de una ambigüedad escasamente inteligible, que elude señalar a un responsable direto del seguimiento y control que se salvará por decisión del propio Juez de Vigilancia Penitenciaria". 
Pero la cuestión que surge es la relativa a la concreción de a qué Administraciones Públicas competentes se está refiriendo el legislador1191, habida cuenta de que la reforma ha dejado pasar la oportunidad para crear una figura como el agente de vigilancia que se contempla en el sistema anglosajón (probation service) ${ }^{1192}$. No obstante, la reforma dejó la puerta abierta a un desarrollo por vía reglamentaria para concretar la atribución de competencias en materia de seguimiento y control de las medidas, reglamentación que ha venido con el RD 840/2011, de 17 de junio, por el que se establecen las circunstancias de ejecución de las penas de trabajo en beneficio de la comunidad y de localización permanente en centro penitenciario, de determinadas medidas de seguridad, así como de la suspensión de la ejecución de las penas privativas de libertad y sustitución de penas (que deroga el RD 515/2005, de 6 de mayo), que dedica la Sección II —que consta de un único artículo- a la libertad vigilada posterior al cumplimiento de la pena privativa de libertad y, en concreto, el art. 23 dispone que es competencia de la Administración Penitenciaria elevar el un informe técnico al JVP antes de que concluya el cumplimiento de la pena, y que deberá ser elaborado por la Junta de Tratamiento del centro en el que se encuentre o del que esté adscrito si se encuentra en libertad condicional ${ }^{1193}$.

Realmente el desarrollo reglamentario no termina de ser todo lo completo que debería (un único artículo excesivamente breve), y por ese motivo, en el Capítulo VI dedicado a las Disposiciones Comunes, el art. 27 dispone la creación por parte de la Administración Penitenciaria de una comisión técnica de apoyo y seguimiento -con naturaleza de grupo de trabajo-, que estaría formada por personal penitenciario y podrá también estar formada por los representantes de las distintas entidades que colaboren en la ejecución de las penas y medidas de seguridad ${ }^{1194}$. En principio, de dicha previsión

\footnotetext{
1191 En el Anteproyecto de 23 de julio de 2009, no venía referencia alguna a estas Administraciones Públicas, sino sólo a facultativos y profesionales encargados del seguimiento de la medida, por lo que esta inclusión supone una nueva previsión basada en la atribución de competencias a las Administraciones Públicas que aún no han sido reguladas.

1192 LUACES GUTIÉRREZ, A.I., “Cuestiones controvertidas...”, cit. pp. 554 y 555, y notas al pie 40 y 41.

1193 Art. 23. "Competencia de la Administración Penitenciaria. En los supuestos en que se haya impuesto al penado la medida de libertad vigilada de cumplimiento posterior a una pena privativa de libertad, la Administración Penitenciaria, antes de finalizar el cumplimiento de la pena privativa de libertad y a solicitud del Juez de Vigilancia Penitenciaria, elevará a éste un informe técnico sobre la evolución del penado, a los efectos previstos en el artículo 106, párrafo 2, del Código Penal. El referido informe será elaborado por la Junta de Tratamiento, u órgano autonómico equivalente, del Centro Penitenciario en el que el penado se encuentre cumpliendo condena, o del que esté adscrito si se encuentra en libertad condicional".
}

1194 Art. 27. "Comisión técnica de apoyo y seguimiento. 1. La Administración penitenciaria podrá crear una comisión técnica de apoyo y seguimiento, conformada por el personal penitenciario que se determine, para que realice funciones de mera información y apoyo técnico a los órganos competentes de la Administración 
podría deducirse que cabe la creación de una figura como el agente de vigilancia, comisión de vigilancia o análogo, dada la versatilidad y la amplitud de la previsión de la norma reglamentaria. Figura que, por otra parte, sería conveniente y necesaria para la efectividad de la libertad vigilada tal y como ahora se formula1195. Sin embargo, la doctrina manifiesta que del contenido de esta normas (RD 840/2011) se desprende que debe ser la Administración Penitenciaria la que organice, defina y prepare las modalidades a las que debe sujetarse el cumplimiento de las medidas de seguridad no privativas de libertad y que se pueden articular mecanismos de coordinación con otras Administraciones locales o autonómicas para que suscriban convenios de colaboración que les permitan cooperar con la Administración Penitenciaria para la ejecución de la libertad vigilada1196.

Y continuando con la amplitud de la previsión del precepto a la que antes aludía, se observa que el propio art. 98.1 CP prevé, además de la valoración de los informes referidos, la posibilidad de que el JVP ordene distintas actuaciones tendentes a ilustrarle, en la forma que crea conveniente, para llevar a cabo la propuesta anual a la que viene obligado por el propio art. $98 \mathrm{CP}$. Con lo cual, el JVP puede ordenar que se elaboren informes, dictámenes, exámenes médicos o de cualquier tipo, periciales, pruebas analíticas, y cualesquiera otras actuaciones que crea convenientes, que le permitan formar su convicción acerca de la propuesta que debe elevar.

El siguiente paso, una vez elaborado el informe, es la decisión que debe tomar el Juez o Tribunal sentenciador, a la vista de la propuesta del JVP. A este respecto, prevé el

penitenciaria, en aquellas tareas de implementación del sistema de ejecución de las penas desarrolladas en este Real Decreto. Dicha comisión tendrá la naturaleza jurídica propia de un grupo de trabajo, de conformidad con lo previsto en el apartado tercero del artículo 40 de la Ley 6/1997, de 14 de abril, de Organización y Funcionamiento de la Administración General del Estado. 2. De la comisión técnica de apoyo y seguimiento a la que se refiere el apartado anterior podrán formar parte, asimismo, los representantes de las entidades públicas o privadas que colaboren en la ejecución de las distintas penas y medidas de seguridad".

1195 GUDÍN RODRÍGUEZ-MAGARIÑOS, F., La nueva medida de seguridad..., cit. p. 186. Este autor señala que "la introducción de la figura del agente de la libertad vigilada, en estos casos, sería muy eficaz, habida cuenta de que efectuaría un seguimiento y control con carácter previo a que pueda reincidir o siga acosando a la víctima que es lo que, en muchas ocasiones, les lleva a ellas a no denunciar, ya que desconfían de que si lo hacen él no se les vuelva a acercar y sea eficaz la llamada policial cuando esto ocurra".

1196 MAGRO SERVET, V., “Competencia de la administración penitenciaria para la ejecución de las medidas de seguridad no privativas de libertad, y penas y medidas alternativas a la prisión (Desarrollo de lo dispuesto en el Real Decreto 840/2011, de 17 de junio). En La Ley Penal, núm. 106, 2014, p. 139. Concluye este autor (pág. 142) diciendo que, por lo dispuesto en el art. 23 del citado RD 840/2011, “el cumplimiento de las medidas no privativas de libertad del art. $96.2 \mathrm{CP}$, que en concreto se refiere a la libertad vigilada, es competencia de la Administración penitenciaria". 
art. 98.3 CP que el Juez o Tribunal deberá resolver motivadamente, y para ello tendrá en cuenta, la propuesta del JVP, lo que puedan manifestar las partes (todas, incluido el propio sometido a la medida, el Ministerio Público, y las demás partes personadas si las hubiere) y a las víctimas de delito que no estuvieran personadas ${ }^{1197}$. Respecto de esta última cuestión merece que nos detengamos brevemente para efectuar unas reflexiones, puesto que la previsión contempla la posibilidad de que las víctimas que no sean parte del proceso sean oídas a efectos de la decisión sobre la medida impuesta. Para ello se exigen varios requisitos: 1) que las víctimas hayan solicitado que se les oiga a efectos de la toma de decisiones que afecten al mantenimiento, cese, sustitución o suspensión de la medida de seguridad; 2) que dicha solicitud se haya efectuado al inicio de la ejecución de la sentencia o en cualquier momento posterior; y 3) que las víctimas permanezcan localizables a efectos de darles trámite de audiencia al efecto.

A este respecto, tratándose de una medida de seguridad, cuyo fundamento es el hecho delictivo cometido y la peligrosidad criminal del sujeto, la víctima no puede saber mucho del grado de peligrosidad que el sujeto presenta tras el sometimiento a la medida, por lo que ningún dato relevante puede aportar a estos efectos, salvo la puesta en conocimiento del Juez de su temor a volverse a encontrar con el agresor, por lo que, siendo realistas, únicamente se pretende dar entrada a las víctimas en el proceso de ejecución para contentar la presión mediática y social pero eso no significa que puedan aportar algún dato útil al respecto, más allá de manifestar su situación personal que podría únicamente tenerse en cuenta para la prohibiciones de aproximarse y comunicarse con ella o con su entorno.

$3^{\circ}$. El Art. 106.2 CP es el precepto estrella en materia de ejecución de la libertad vigilada, pues contempla el supuesto de imposición de la medida para su cumplimiento posterior a la pena privativa de libertad. Los supuestos de cumplimiento sucesivo de la libertad vigilada son únicamente los previstos especialmente en el Código (delitos contra la libertad e indemnidad sexuales y delitos de terrorismo) donde el Juez o Tribunal en la sentencia deberá imponer, además de la pena privativa de libertad que corresponda al delito de que se trate, la libertad vigilada por tiempo de entre uno y cinco años o de entre cinco y diez años, según disponen los propios arts. 192.1 y 579.3 CP.

1197 GASCÓN INCHAUSTI, F. / VILLAMARÍN LÓPEZ, M.L., “Otras repercusiones...”, cit. p. 374. 
El art. 106.2 CP contempla tres supuestos distintos: el primero es la norma general, (106.2.2 ${ }^{\circ}$ párrafo CP) donde el JVP elevará la propuesta al Juez o Tribunal sentenciador (por el mismo procedimiento del art. $98 \mathrm{CP}$ ) para que éste decida sobre el contenido de la medida según lo previsto en el art. 97.2 CP. El propio precepto indica que la propuesta deberá elevarse dos meses antes de la extinción de la pena privativa de libertad ${ }^{1198}$, de modo que la medida pueda empezar a cumplirse en el momento de la extinción, lo que excluye que la libertad vigilada pueda cumplirse de forma simultánea a la pena1199, esto es, cuando el penado haya alcanzado el tercer grado de tratamiento penitenciario o cuando acceda a la libertad condicional ${ }^{1200}$. El problema que plantea la decisión que con esa antelación debe tomarse, en la relativa a la coincidencia que puede existir entre las penas accesorias del art. 57.1 $\mathrm{CP}^{1201}$ que pueden haberle sido impuestas al penado, y las obligaciones en que se concreta la libertad vigilada, de forma que el Juez deberá optar por imponer las que no coincidan, para evitar incurrir en vulneración del principio de ne bis in idem $^{1202}$. En efecto, el art. 57.1 CP permite imponer en casos de delitos sexuales -entre otros- las penas accesorias del art. $48 \mathrm{CP}$ por tiempo superior a la pena privativa de libertad de entre uno y diez años si son delitos graves, o de entre uno y cinco años si son delitos menos graves, por lo que, las penas privativas de derechos del art. $48 \mathrm{CP}^{1203}$, en

\footnotetext{
1198 Ibidem, p. 374.

1199 Téngase en cuenta lo anteriormente dicho sobre la posibilidad de cumplimiento simultáneo de la pena y la libertad vigilada en casos de terrorismo, según se desprende de las diferencias en la redacción del art. 192.1 y $579.3 \mathrm{CP}$, siendo que éste último precepto no especifica que la libertad vigilada que necesariamente se impondrá en esta clase de delitos deba ejecutarse con posterioridad a la pena privativa de libertad, tal y como se señala para los casos abarcados por el art. 192.1 CP.
}

1200 SIERRA LÓPEZ, M.V., La medida de libertad vigilada..., cit. p. 146.

1201 Art. 57.1. "Los jueces o tribunales, en los delitos de homicidio, aborto, lesiones, contra la libertad, de torturas y contra la integridad moral, la libertad e indemnidad sexuales, la intimidad, el derecho a la propia imagen y la inviolabilidad del domicilio, el honor, el patrimonio y el orden socioeconómico, atendiendo a la gravedad de los hechos o al peligro que el delincuente represente, podrán acordar en sus sentencias la imposición de una o varias de las prohibiciones contempladas en el artículo 48, por un tiempo que no excederá de diez años si el delito fuera grave o de cinco si fuera menos grave.

No obstante lo anterior, si el condenado lo fuera a pena de prisión y el juez o tribunal acordara la imposición de una o varias de dichas prohibiciones, lo hará por un tiempo superior entre uno y 10 años al de la duración de la pena de prisión impuesta en la sentencia, si el delito fuera grave, y entre uno y cinco años, si fuera menos grave. En este supuesto, la pena de prisión y las prohibiciones antes citadas se cumplirán necesariamente por el condenado de forma simultánea".

1202 SIERRA LÓPEZ, M.V., La medida de libertad vigilada..., cit. pp. 106 y 107.

1203 Que son: “1. La privación del derecho a residir en determinados lugares o acudir a ellos impide al penado residir o acudir al lugar en que haya cometido el delito o falta, o a aquel en que resida la víctima o su familia, si fueren distintos. 2. La prohibición de aproximarse a la víctima, o a aquellos de sus familiares u otras personas que determine el juez o tribunal, impide al penado acercarse a ellos, en cualquier lugar donde se encuentren, así como acercarse a su domicilio, a sus lugares de trabajo y a cualquier otro que sea frecuentado por ellos, quedando en suspenso, respecto de los hijos, el régimen de visitas, comunicación y estancia que, en 
caso de haber sido impuestas en la sentencia, impedirán que se impongan las mismas medidas como concreción de la libertad vigilada, lo que posibilitará que se puedan imponer cualesquiera de las restantes que quedan disponibles en el listado del art. 106 CP. En cualquier caso, lo que nos interesa resaltar es que la libertad vigilada solo se activa en contenido concreto si el pronóstico penitenciario evidencia que la peligrosidad cuya persistencia se presumió en el momento de dictar la sentencia, persiste tras la pena ${ }^{1204}$.

El segundo supuesto es el de multiplicidad de penas privativas de libertad que el sujeto deba cumplir de forma sucesiva (art. 106.2.3 ${ }^{\circ}$ párrafo $\mathrm{CP}$ ). En estos casos el cumplimiento simultáneo al que referíamos en el apartado anterior únicamente podrá dar comienzo cuando el penado haya cumplido todas las penas sucesivamente ${ }^{1205}$, en cuyo caso, hasta que no se encuentre cercano el momento en que la última de las penas vaya a extinguirse, no podrá elevarse por el JVP la propuesta a efectos de que el Juez o Tribunal decida sobre la libertad vigilada, puesto que este último no podrá decidir que comience a cumplirse (ni tampoco concretar su contenido) hasta que el sujeto no se encuentre cumpliendo la última de las penas de cumplimiento sucesivo. En este supuesto, el legislador parece no haber tenido presente que las diversas penas privativas de libertad que se cumplen de forma sucesiva, conforman una regla básica de la ejecución penitenciaria: la unidad de ejecución ${ }^{1206}$, por lo que no parece que la norma añada nada a la realidad de las ejecuciones penales. Aparte, la doctrina viene poniendo de manifiesto que tras el cumplimiento sucesivo de varias penas privativas de libertad como paso previo para el inicio del cumplimiento de la libertad vigilada, el juicio de prognosis de peligrosidad que se hizo en su día puede que esté muy alejado de la efectiva peligrosidad que concurra en el momento de ejecutar la medida1207.

su caso, se hubiere reconocido en sentencia civil hasta el total cumplimiento de esta pena. 3. La prohibición de comunicarse con la víctima, o con aquellos de sus familiares u otras personas que determine el juez o tribunal, impide al penado establecer con ellas, por cualquier medio de comunicación o medio informático o telemático, contacto escrito, verbal o visual".

1204 GARCÍA ALBERO, R., en QUINTERO OLIVARES, G., Comentarios..., cit. Tomo I, p. 692.

1205 ROCA POVEDA, M., “La libertad vigilada...”, cit. p. 41.

1206 SANZ MORÁN, A.J., “La nueva medida de seguridad...”, cit. p. 1022.

1207 GASCÓN INCHAUSTI, F. / VILLAMARÍN LÓPEZ, M.L., “Otras repercusiones...”, cit. p. 373. Estos autores explican que, aunque es cierto que en estos casos existe la posibilidad de apartarse de la decisión inicial sobre la libertad vigilada cuando llegue el momento de ejecutarla, reduciéndola o dejándola sin efecto, hubiera sido preferible una previsión que permitiera desvincularse por completo de la decisión llegado ese momento o postergar la decisión sobre la adopción de algunas medidas a ese momento. 
El tercer supuesto es el de multiplicidad de medidas de libertad vigilada impuestas en sentencia (art. 106.2.4 $4^{\circ}$ párrafo CP). En estos casos el cumplimiento de las distintas medidas de libertad vigilada será sucesivo, siempre que el contenido de las obligaciones concretas de las mismas no se pueda cumplir simultáneamente ${ }^{1208}$. Es decir, que se puede cumplir de forma simultánea si las obligaciones en una y otra medida son distintas, en cuyo caso las puede cumplir todas al mismo tiempo. Y en caso de que sean idénticas, las deberá cumplir de forma sucesiva. Regla que, al igual que en el supuesto anterior, traslada al ámbito de la ejecución de las medidas de seguridad, las normas aplicables al concurso de delitos, lo que es bastante discutible ${ }^{1209}$.

Sobre el cumplimiento simultáneo, manifiesta SIERRA LÓPEZ que surge la duda de si esa forma de cumplimiento puede encontrar excepciones basándose en la conveniencia resocializadora, ya que son pocas las reglas que persiguen esa finalidad, por lo que invoca el ejemplo de si debería imponerse primero el tratamiento médico y después el programa de educación sexual, donde el criterio para las modificaciones y reducciones es el pronóstico favorable, por lo que concluye diciendo que no habría inconveniente para ello siempre que se respeten los límites máximos contenidos en los arts. 105, 192.1 y 579.3 $\mathrm{CP}^{1210}$.

$4^{\mathbf{0}}$. La última de las cuestiones que contempla la reforma para la ejecución de la medida es la prevista en el art. 106.3 CP, relativa a la modificación, reducción, finalización y medida sin efecto.

1) La modificación de las medidas es una facultad del Juez con carácter general, que pasa por el ya comentado procedimiento del art. $98 \mathrm{CP}$, y se traduce en una facultad del Juez o Tribunal de cambiar el contenido en que se concreta la medida,1211 bien sustituyendo unas medidas por otras, suprimiendo algunas o incluso imponiendo otras sobre las ya acordadas ${ }^{1212}$.

\footnotetext{
1208 ACALE SÁNCHEZ, M., “Medición de la respuesta punitiva...”, cit. p. 193.

1209 SANZ MORÁN, A.J., “La nueva medida de seguridad...”, cit. p. 1022.

1210 SIERRA LÓPEZ, M.V., La medida de libertad vigilada..., cit. p. 135.

1211 GASCÓN INCHAUSTI, F. / VILLAMARÍN LÓPEZ, M.L., “Otras repercusiones...”, cit. p. 375.

1212 GUTIÉRREZ ROMERO, F.M., “El tratamiento de los delitos sexuales...”, cit. p. 4.
} 
2) La reducción de la duración o la finalización de la medida, es una facultad del Juez o Tribunal que necesariamente deberá estar basada en la existencia de pronóstico positivo de reinserción que implique que la medida pueda ser contraproducente o innecesaria1213.

3) El Juez o Tribunal también tiene la facultad de dejar sin efecto la medida cuando el pronóstico positivo de reinserción que implique que la medida pueda ser contraproducente o innecesaria, concurra en el momento en que (dice el texto) "se dé en el momento de concreción de las medidas que se regula en el número 4 del presente artículo". Lo primero que habría que preguntarse es si lo previsto en el apartado b) del art. $106.3 \mathrm{CP}$, "poner fin" a la medida es lo mismo o algo distinto a "dejar sin efecto" la medida, que se regula en este otro apartado (art. 106.3.c) CP). Parece que el legislador está pensando en cosas distintas, pero realmente "poner fin" y "dejar sin efecto" viene a ser lo mismo a efectos prácticos, por lo que no tiene mucho sentido la distinción, máxime la regulación distinta para uno y otro caso, puesto que para el segundo de los supuestos se exigen más requisitos que para el primero. No obstante, el supuesto que regula el art. $106.3 \mathrm{~d}) \mathrm{CP}$, - dejar sin efecto la medida- viene a referirse a dejar en suspenso la medida, para aquellos casos en los que se aconseje suspender la ejecución en atención al resultado ya obtenido y por el lapso de tiempo que le reste por cumplir de la propia medida, con la única condición de que no delinca ${ }^{1214}$. Se trata, pues, de un supuesto que regula una suerte de "remisión condicional" de la medida de seguridad"1215.

Y si damos un paso más en el articulado, se observa que el apartado 4 del art. 106 $\mathrm{CP}$ es el referido a supuestos de incumplimiento por parte del sujeto de una o varias obligaciones, en cuyo caso, a la vista de las circunstancias concurrentes y, por el mismo procedimiento indicado anteriormente, el Juez o Tribunal podrá modificar las obligaciones impuestas. Esta previsión se traduce en lo siguiente: en los casos en que el sujeto incumpla una o varias medidas en las que se concreta la libertad vigilada, el Juez o Tribunal tiene la facultad de dejar la libertad vigilada sin efecto, siempre que el pronóstico

\footnotetext{
1213 En cuanto al término "contraproducente" que usa el legislador, debe entenderse que la medida produce lo contrario del efecto deseado, por ende, si el efecto deseado es la eliminación de la peligrosidad criminal y la reinserción, corrección o reeducación, la medida será contraproducente cuando genere mayor peligrosidad en el sujeto. A pesar de ello, no alcanzamos a imaginar en qué supuestos puede plantearse tal paradoja.

1214 RUBIO LARA, P.A., “Las medidas de seguridad...”, cit. p. 96.

1215 JORGE BARREIRO, A., en RODRÍGUEZ MOURULlO, G. (Dir.) / JORGE BARREIRO, A. (Coord.), Comentarios..., cit. p. 309.
} 
positivo de reinserción que implique que la medida pueda ser contraproducente o innecesaria se advierta en el momento en que vayan a ser modificadas las concreciones de las medidas porque el sujeto está incumpliéndolas.

En cualquier caso, el articulado del CP no excluye de forma expresa que el sometido a la medida de seguridad pueda dirigirse al Juez o Tribunal en cualquier momento de la ejecución de la libertad vigilada y, ante hechos nuevos o circunstancias sobrevenidas, pueda solicitar la modificación, reducción, suspensión, etc., sin necesidad de aguardar a la propuesta anual, aunque el Juez o Tribunal también puede fijar periodos inferiores al año para la elaboración de dichas propuestas del JVP, según se desprende del tenor literal del art. 98.1 CP (que dice, “al menos anualmente")1216.

\section{EL QUEBRANTAMIENTO DE LA LIBERTAD VIGILADA}

Como acabamos de ver, el art. $106.4 \mathrm{CP}^{1217}$ dispone que el incumplimiento por parte del sujeto de una o varias obligaciones en que se concreta la medida, a la vista de las circunstancias concurrentes y por el mismo procedimiento indicado anteriormente, el Juez o Tribunal podrá modificar las obligaciones o prohibiciones impuestas. En principio lo que llama la atención es que el precepto solo refiere al incumplimiento de las obligaciones, no de las prohibiciones, lo que, en principio parece querer excluirlas, pero entiende la doctrina que no se trata más que de un lapsus del legislador que, en realidad, quiso referir a las reglas de conducta en su conjunto, porque seguidamente en el precepto sí que refiere a las obligaciones y prohibiciones impuestas cuando habla de que el incumplimiento debe ser revelador de la voluntad de no someterse a las mismas ${ }^{1218}$.

Ahora bien, se prevé un supuesto específico en el que se deducirá testimonio por presunto delito de quebrantamiento de condena del art. $468 \mathrm{CP}^{1219}$, siempre que concurran

\footnotetext{
1216 FEIJOO SÁNCHEZ, B., “La libertad vigilada...”, cit. p. 226.

1217 Art. 106.4. "En caso de incumplimiento de una o varias obligaciones el Juez o Tribunal, a la vista de las circunstancias concurrentes y por el mismo procedimiento indicado en los números anteriores, podrá modificar las obligaciones o prohibiciones impuestas. Si el incumplimiento fuera reiterado o grave, revelador de la voluntad de no someterse a las obligaciones o prohibiciones impuestas, el Juez deducirá, además, testimonio por un presunto delito del art. 468 de este Código".

1218 FEIJOO SÁNCHEZ, B., “La libertad vigilada...”, cit. pp. 226 y 227.

1219 En general sobre el quebrantamiento de condena, vid. CORCOY BIDASOLO, M., (Dir.) / BOLEA BARDÓN, C. / CARDENAL MONTRAVERA, S. / GALLEGO SOLER, J.I. / GÓMEZ MARTÍN, V. /
} 
dos requisitos: $1^{\circ}$ ) que el incumplimiento sea reiterado o grave; $2^{\circ}$ ) que el incumplimiento sea revelador de la voluntad de no someterse a las obligaciones o prohibiciones impuestas ${ }^{1220}$. Sobre este particular, no debe olvidarse que en la regulación anterior a la reforma, únicamente era posible el quebrantamiento de medidas de seguridad privativas de libertad en sujetos semiimputables, quedando excluidas de incurrir en el delito del art. 468 CP los incumplimientos de cualesquiera otras medidas de seguridad y en todo caso lo inimputables ${ }^{1221}$. Ahora el art. $468.2 \mathrm{CP}^{1222}$, no solo se aparta de aquella regulación, sino que va más allá al distanciarse incluso de la previsión de pena de multa para el quebrantamiento de medidas de seguridad que contempla el art. $468.1 \mathrm{CP}$, para disponer la necesaria imposición de pena privativa de libertad de seis meses a un año para cuando se quebrante la libertad vigilada ${ }^{1223}$

En cuanto al primero de los requisitos, basta que el incumplimiento sea reiterado o que sea grave, cualquiera de las dos posibilidades es ya por sí sola suficiente para que el sujeto pueda incurrir en el tipo del art. $468 \mathrm{CP}$. La primera de las cuestiones que suscita el precepto es la determinación de cuándo el incumplimiento es grave y cuándo el incumplimiento es reiterado. Por reiterado bastará con que el sujeto haya incumplido dos veces (reiterar significa repetir), y contando con dos infracciones previas, si la tercera es reveladora de la voluntad del sujeto de no someterse al contenido de la medida, entonces se podrá deducir testimonio por quebrantamiento ${ }^{1224}$. Pero lo que no resulta tan fácil es la

SANTANA VEGA, D. / HORTAL IBARRA, J.C. / FERNÁNDEZ BAUTISTA, S. / CARPIO BRIZ, D. / BESIO HERNÁNDEZ, M. / SALVADORI, I., Derecho penal. Parte especial. Doctrina y jurisprudencia con casos solucionados. Tomo 1. Valencia: Tirant lo Blanch. 2011, pp. 802 a 809; SÁNCHEZ MELGAR, en SÁNCHEZ MELGAR, J. (Coord.), Código penal. Comentarios y jurisprudencia. Tomo II. $3^{\text {a }}$ Ed. Madrid: Sepín. 2010, pp. 3015 a 3026; MESTRE DELGADO, E., "Delitos contra la Administración de Justicia". En LAMARCA PÉREZ, C. (Coord.), Derecho penal. Parte especial. 6a Ed. Madrid: Colex. 2011, pp. 697 a 700; CORCOY BIDASOLO, M. / MIR PUIG, S., Comentarios..., cit. pp. 1006 a 1012; ORTS BERENGUER, E., "Quebrantamiento de condena”. En VIVES ANTÓN, T.S. / ORTS BERENGUER, E. / CARBONELL MATEU, J.C. / GONZÁLEZ CUSSAC, J.L. / MARTÍNEZ-BUJÁN PÉREZ, C., Derecho Penal. Parte Especial. $3^{a}$ Ed. Valencia: Tirant lo Blanch. 2010, DVD, lección XL.

1220 GASCÓN INCHAUSTI, F. / VILLAMARÍN LÓPEZ, M.L., “Otras repercusiones...”, cit. p. 375.

1221 SANZ MORÁN, A.J., “La nueva medida de seguridad...”, cit. p. 1024.

1222 Art. 468. 2. "Se impondrá en todo caso la pena de prisión de seis meses a un año a los que quebrantaren una pena de las contempladas en el artículo 48 de este Código o una medida cauatelar o de seguridad de la misma naturaleza impuesta en procesos criminales en los que el ofendido sea alguna de las personas a las que se refiere el artículo 173.2, así como a aquellos que quebrantaren la medida de libertad vigilada".

1223 ORTS BERENGUER, E., "Quebrantamiento de condena...", cit. DVD. Señala este autor que "aunque seguramente resultaba innecesaria su explícita mención, el legislador de 2010 ha incluido la libertad vigilada entre las medidas cuyo quebrantamiento, con carácter general, da lugar a la aplicación de la pena prevista en el número 2 del art. 468".

1224 FEIJOO SÁNCHEZ, B., “La libertad vigilada...”, cit. p. 227. 
determinación de cuándo el incumplimiento reviste gravedad como para que desemboque en un auténtico proceso nuevo con sustantividad propia que implique que al sujeto se le pueda imponer una nueva pena privativa de libertad. A mi juicio, la cuestión es a la inversa, esto es, lo decisivo será determinar cuándo el incumplimiento de una medida de seguridad no es grave, en qué casos la gravedad es tan alta que implica la comisión de un nuevo delito y en qué otros es tan leve que solo implica la modificación de las medidas ya impuestas ${ }^{1225}$.

Sobre estas cuestiones SIERRA LÓPEZ señala que el legislador ha seguido el criterio del informe del CGPJ al Anteproyecto de reforma del CP de 2008, por el que habrá de considerarse que el incumplimiento es grave cuando se incumplan a la vez varias obligaciones o prohibiciones o reglas de conducta ${ }^{1226}$. TORRES ROSELL añade que además, para considerar la gravedad deberá atenderse a la voluntad del vigilado de seguir incumpliendo ${ }^{1227}$, y FEIJOO SÁNCHEZ indica que la gravedad tiene como referencia la vinculación del incumplimiento con la futura comisión de delitos, incluyendo la participación en organizaciones terroristas ${ }^{1228}$. A mayor abundamiento, indica RUBIO LARA que, cuando exista un solapamiento entre penas no privativas de libertad y una prohibición de las contenidas en la libertad vigilada, el incumplimiento de la pena implica la comisión de un delito de quebrantamiento de condena, mientras que en la libertad vigilada, para que constituya delito la conducta debe ser reiterada y grave ${ }^{1229}$. Este supuesto únicamente podría darse para casos de imposición facultativa del art. $57 \mathrm{CP}$ en relación al art. $48 \mathrm{CP}$ para delitos contra la libertad e indemnidad sexuales, pero, como antes se ha dicho, entiendo que no podrían coincidir ambas figuras por imperativos de la regla ne bis in idem, siendo la imposición de la libertad vigilada preceptiva, desplazaría la imposición de penas accesorias que son de imposición facultativa, sin que por ello sea posible que concurran ambas restricciones en los mismos derechos de forma coetánea.

\footnotetext{
1225 En esta cuestión hay una más que probable afección al principio de proporcionalidad, toda vez que son desproporcionadas entre sí ambas consecuencias derivadas del quebrantamiento; pero es que además, con ello se vulnera el principio de igualdad, pues en un caso se incumplen las medidas y sólo se modifican las existentes (supuesto de incumplimiento que no sea grave), y en otro, se incurre en un nuevo delito (supuesto de incumplimiento grave), y la conducta puede ser idéntica ya que no existe un criterio definido en el Código mediante el que ponderar la supuesta gravedad. Por ello, no queda a salvo la cuestión de si esta previsión es del todo respetuosa con el marco constitucional.
}

1226 SIERRA LÓPEZ, M.V., La medida de libertad vigilada..., cit. p. 152.

1227 TORRES ROSELL, N., “Libertad vigilada y seguimiento...”, cit. p. 12.

1228 FEIJOO SÁNCHEZ, B., “La libertad vigilada...", cit. p. 227.

1229 RUBIO LARA, P.A., “Las medidas de seguridad...”, cit. p. 100. 
Existen además, algunas cuestiones que se plantea la doctrina sobre las que no se ofrece respuesta legal, como el caso de que, en supuestos de condena por delito de quebrantamiento del art. $468 \mathrm{CP}$, cuál sería el procedimiento a seguir para el cumplimiento de la pena por el quebrantamiento y si, consecuentemente, habría alguna modificación en relación a la medida de libertad vigilada, si continuaría cumpliéndola incluso quebrantada o cumpliría primero la pena por el quebrantamiento y posteriormente la libertad vigilada ${ }^{1230}$.

El siguiente interrogante que surge es si una vez se ha deducido testimonio y el sujeto debe ingresar nuevamente en prisión, la libertad vigilada debe quedar interrumpida o en suspenso, o si, por el contrario, continúa cumpliéndose, a lo que SIERRA LÓPEZ manifiesta que, en caso de ser posible deberá seguir cumpliéndose ${ }^{1231}$. Por otra parte, TORRES ROSELL señala que ante el incumplimiento reiterado o grave y revelador de la voluntad de no someterse a las obligaciones impuestas, el Juez podría deducir además testimonio por un presunto delito del art. $468 \mathrm{CP}$, con el consiguiente ingreso en prisión, pero eso no impediría que, tras el cumplimiento de la nueva pena, se retome el cumplimiento de la libertad vigilada tal y como se desprende del art. $106.4 \mathrm{CP}$, que dispone que se modificarán las obligaciones y prohibiciones impuestas y además se deducirá testimonio por quebrantamiento de condena ${ }^{1232}$.

Por su parte, FEIJOO SÁNCHEZ manifiesta que, en estos casos, la libertad vigilada debe quedar en suspenso para dar paso al cumplimiento de la pena derivada del quebrantamiento, pero que no parece tener mucho sentido que, tras la pena por el quebrantamiento, se retomen la libertad vigilada derivada de un delito cometido con anterioridad y que habría que considerar la posibilidad de que la pena por quebrantamiento se sustituyese por penas de distinta naturaleza, ya que, por su extensión, es una pena susceptible de ser sustituida, dando paso así a que pueda seguir

\footnotetext{
1230 REBOLLO VARGAS, R., La llibertat vigilada..., cit. p. 71. Como señala este autor, "situacions que en aquests moments manquen d'una regulació expressa i sobre les quals pengen un bon nombre d'interrogants".

1231 SIERRA LÓPEZ, M.V., La medida de libertad vigilada..., cit. p. 152.

1232 TORRES ROSELL, N., “Libertad vigilada y seguimiento...”, cit. pp.14 y 15.
} 
cumpliéndose la libertad vigilada y al mismo tiempo la pena por quebrantamiento sustitutiva de la privativa de libertad que se le asocia ${ }^{1233}$.

Por otra parte, llama la atención que el legislador no haya previsto la consecuencia que para la libertad vigilada tendría la comisión de un nuevo delito, tal y como sí se contempla en la suspensión de la pena y en la libertad condicional. En la libertad vigilada, un nuevo delito supone la constatación del fracaso de la medida y la no consecución de la pretendida reinserción social o del efecto preventivo-especial de las sanciones penales ejecutadas en ese sujeto, pero entre las posibles complicaciones en la ejecución de la libertad vigilada solo se ha previsto expresamente el incumplimiento de reglas de conducta que pueden desembocar en un nuevo delito, no en la comisión de un nuevo delito autónomo sin incumplir ninguna regla de conducta. La consecuencia es que no termina de quedar claro si, ante la necesidad de ejecutar la nueva pena derivada del nuevo delito, la libertad vigilada debe quedar en suspenso para su cumplimiento posterior o si simplemente se debe dejar sin efecto por imposibilidad de cumplimiento o si, por el contrario, se puede cumplir simultáneamente con la nueva pena.

Entendemos que, para estos supuestos, la solución debe ser la misma que para la nueva pena por quebrantamiento de condena que acabamos de comentar, con el añadido de que, si la nueva pena es de más de cinco años, la libertad vigilada tras el cumplimiento de esa nueva pena podría estar prescrita y ser imposible su reanudación ${ }^{1234}$. Cuando el sujeto comete un nuevo delito durante la ejecución de la libertad vigilada pero no incumple ninguna de las obligaciones y prohibiciones que se le impongan, no podría cesarse la medida porque habría desaparecido la peligrosidad, no podría sustituirse porque hay evolución favorable del sujeto, no podría suspenderse porque no es el supuesto para el que está prevista la suspensión, que queda reducido a cuando existan dudas sobre la desaparición o persistencia de la peligrosidad, y tampoco se podría reducir la duración porque no hay pronóstico favorable de reinserción. En estos casos, lo que la doctrina propone es que, si las obligaciones y prohibiciones impuestas son compatibles con la pena privativa de libertad, cabría la posibilidad del cumplimiento simultáneo ${ }^{1235}$,

\footnotetext{
1233 FEIJOO SÁNCHEZ, B., “La libertad vigilada...”, cit. p. 228.

1234 Ibidem, p. 227.

1235 GARCÍA ALBERO, R., en QUINTERO OLIVARES, G., Comentarios..., cit. Tomo I, p. 693. Este autor explica que "si prescindimos del "nomen iuris", no existe ontológicamente un impedimento al cumplimiento
} 
pero si no lo son, habría que modificarlas para permitir la simultaneidad ${ }^{1236}$, sin olvidar que la privación de libertad solo será exigirá compatibilización en ese sentido cuando haya recaído sentencia condenatoria firme, o cuando se haya acordado la prisión provisional como medida cautelar.

Se advierte que se van a generar, inevitablemente, multitud de nuevos procesos judiciales por quebrantamiento de condena por inadaptación del sujeto a las obligaciones concretas que le sean impuestas como contenido de la medida de seguridad ${ }^{1237}$, incrementando la litigiosidad de nuestro sistema. En efecto, el sujeto que cumple una pena excesivamente larga, normalmente, se producen en él unos efectos destructivamente irreversibles, sobre todo en su personalidad (como la regresión a estadios infantiles, pérdida de sociabilidad, destrucción de la personalidad, etc., aspectos que han sido puestos de manifiesto hasta la saciedad por la doctrina científica) ${ }^{1238}$. Entonces, llegado el momento de ser puesto en libertad, el sujeto se encuentra con que dicha libertad no es plena, sino que es "vigilada", sin que pueda decirse que se ha producido un retorno al estado natural del que partió antes de ser condenado. $\mathrm{Y}$ es en ese momento cuando el sujeto, totalmente inadaptado a la sociedad que se encuentra cuando sale de prisión, se ve incapaz de cumplir las obligaciones que la vigilada libertad le impone. La consecuencia no puede ser otra que la deducción de testimonio por quebrantamiento de condena y, tras el nuevo juicio, el ingreso nuevamente del sujeto en prisión.

Se advierte, sin embargo, que de este efecto de retorno a prisión es consciente el legislador, toda vez que expresamente lo contempla - de lo que se desprende que precisamente ese efecto es el que persigue- ya que el art. 468.2 CP precisamente prevé una pena de prisión de seis meses a un año para supuestos de quebrantamiento de la

simultáneo de muchas medidas concretas de la libertad vigilada con la pena de prisión. En consecuencia no debería interrumpirse la medida por el hecho de que el sujeto ingresase, de nuevo, en prisión. Se trataría de aplicar, "mutatis mutandi", lo que que sí prevé el art. 106.2.IV cuando el penado tenga la obligación de cumplir por diversos delitos "tantas medidas de libertad vigilada". (La cursiva es mía).

1236 SIERRA LÓPEZ, M.V., La medida de libertad vigilada..., cit. p. 154.

1237 Pensemos en el siguiente ejemplo: un reo condenado a cien años de prisión por la comisión de varios delitos de los de terrorismo, encuentra el primer límite en el art. $76 \mathrm{CP}$, esto es, cuarenta años de prisión, que será el tope máximo de cumplimiento. Para el acceso al tercer grado de tratamiento penitenciario tiene que haber cumplido cuatro quintas partes de la condena, esto es, treinta y dos años; y para la libertad condicional el condenado debe haber cumplido siete octavas partes de la misma, es decir: treinta y cinco años. Con lo cual, la libertad definitiva, la obtendrá cuando haya cumplido cuarenta años. Será con el acceso a la libertad condicional (treinta y cinco años) o cuando la pena haya remitido totalmente (cuarenta), cuando entrará en escena la libertad vigilada como medida de seguridad.

1238 MAPELLI CAFFARENA, B. / TERRADILLOS BASOCO J.M., Las consecuencias..., cit. p. 69. 
libertad vigilada, frente a la posibilidad del art. 468.1 CP de imposición de multa para los quebranten cualquier otra medida de seguridad. Este efecto de reingreso en prisión, induce el planteamiento reflexivo de si mediante técnicas de etiquetamiento fraudulento de las medidas de seguridad, se articulan verdaderas penas que nos conducen a una encubierta pero real prisión a perpetuidad ${ }^{1239}$.

Por último, conviene tener presente el supuesto contemplado en el art. $100.3 \mathrm{CP}$ -al que ya hemos referido supra- para el supuesto de incumplimiento de la medida de sometimiento a tratamiento médico, esto es, a su abandono o a su negativa a iniciarlo, que no será considerado quebrantamiento de condena por ir en contra de la autonomía del paciente, por lo que, en estos casos, deberá sustituirse la medida por otra de entre las previstas en el catálogo de obligaciones y prohibiciones para la libertad vigilada ${ }^{1240}$, pero, la norma no concreta cuál de ellas habrá que adoptar, por lo que la decisión será libre para el órgano judicial que, preferentemente, deberá optar por alguna de las medidas en las que prime el carácter terapéutico-correctivo frente al meramente asegurativo. Lo que llama la atención de esta previsión es que se haya incluido el art. $100 \mathrm{CP}$ y no en las disposiciones del quebrantamiento de la medida que se encuentran en el art. $106 \mathrm{CP}^{1241}$.

\section{EL REAL DECRETO 840/2011, DE 17 DE JUNIO}

Aunque ya hemos referido anteriormente al RD 840/2011, de 17 de junio, por el que se establecen las circunstancias de ejecución de las penas de trabajo en beneficio de la comunidad y de localización permanente en centro penitenciario, de determinadas medidas de seguridad, así como de la suspensión de la ejecución de la penas privativas de libertad y sustitución de penas ${ }^{1242}$, se hace necesario analizarlo en profundidad, sobre todo en lo concerniente al aspecto que desde mi punto de vista merece mayor atención, que es

\footnotetext{
1239 GARCÍA ALBERO, R., “La nueva medida de seguridad...”, cit. p. 186. Como señala este autor, “la previsión de esta medida, empero, debería ir acompañada de una moderación de las reglas de cumplimiento íntegro y efectivo de las penas, pues añadida a prisiones materialmente equivalentes o incluso más gravosas que la prisión a perpetuidad presente en muchos Códigos europeos no cumple ya función alguna, pudiéndose revelar -el conjunto de pena y medida- manifiestamente desproporcionado".

1240 SÁNCHEZ MELGAR, J., en SÁNCHEZ MELGAR, J. (Coord.), Código penal..., cit. Tomo I, p. 752.

1241 SANZ MORÁN, A.J., "La nueva medida de seguridad...”, cit. p. 1025. Para este autor, esta ubicación de la consecuencia derivada de la negativa a someterse al tratamiento médico, evidencia el carácter autónomo de esta medida y señala que habría sido mejor regularla de manera autónoma.
}

1242 BOE núm. 145, de 18 de junio de 2011, Sec. I, pp. 62933 a 62941. 
la necesidad de que se instaure un agente de vigilancia para la medida de seguridad, que la citada norma no ha previsto. La Exposición de Motivos del RD 840/2011 vino a decir lo siguiente:

“La Ley Orgánica 5/2010, de 22 de junio, ha incidido de manera tan relevante en el sistema de medidas penales - penas y medidas de seguridad- diseñado por el vigente Código Penal, que por sí misma hace necesario un nuevo marco reglamentario regulador de las circunstancias de ejecución de las penas de trabajos en beneficio de la comunidad y de localización permanente, de determinadas medidas de seguridad, así como de la suspensión y sustitución de la ejecución de las penas privativas de libertad, del mismo modo que la Ley Orgánica 15/2003, de 25 de noviembre, determinó el Real Decreto 515/2005, de 6 de mayo.

$$
[\ldots]
$$

Además la reforma legal ha abordado una importante modificación de la regulación de las medidas de seguridad, que se articula entre otros aspectos, en primer lugar, en que se ha sustituido el catálogo de las medidas de seguridad no privativas de libertad, destacando la introducción de la libertad vigilada, que impone el cumplimiento por el sentenciado de ciertas obligaciones y prohibiciones judicialmente establecidas - a las que se han reconducido las medidas de seguridad suprimidas, juntamente con otras diferentes-, y a ello debe sumarse la previsión dentro de la libertad vigilada de una modalidad postpenitenciaria, cuya aplicación se reserva por la ley a una peligrosidad criminal asociada no ya a supuestos de inimputabilidad o semiimputabilidad, sino a la propia tipología delictiva, bien que limitada a casos muy tasados - delitos de terrorismo y ciertos delitos contra la libertad e indemnidad sexual. Por otra parte la reforma de la Ley Orgánica 5/2010, de 22 de junio, ha suprimido la intervención del Juez de Vigilancia en la dinámica del procedimiento revisor de las medidas de seguridad no privativas de libertad, dando así acogida al criterio establecido por el Tribunal Supremo, que a su vez asumió en este sentido anteriores advertencias doctrinales y de los propios Jueces de Vigilancia; tan solo se ha conservado su presencia en la custodia familiar y en relación con la libertad vigilada postpenitenciaria, atendida en este último caso la inmediata relación del Juez de Vigilancia con las Instituciones Penitenciarias a las que se confió el cumplimiento material de la pena de prisión, tras cuyo término se activa esta modalidad de libertad vigilada.

Entre las demás novedades, cabe destacar las realizadas en la pena de trabajo en beneficio de la comunidad. Así, debe partirse de que la legislación impone que el cumplimiento de todas las penas y medidas de seguridad debe realizarse bajo el control de los Jueces y Tribunales, conforme a lo establecido en el art. 3.2 del vigente Código Penal; pero la existencia de un control judicial de ejecución presupone la existencia de una ejecución administrativa que pueda llegar a ser controlada, y en este sentido el mecanismo elegido por el Real Decreto 515/2005 era el de un control judicial a priori, basado en una propuesta de la Administración que en el caso del trabajo 
en beneficio de la comunidad el Juez de Vigilancia debía previamente aprobar, lo que en la práctica implicaba dificultades de notificación de las resoluciones judiciales a reos que no se encuentran a inmediata disposición del Juzgado correspondiente. En el nuevo modelo diseñado por el presente real decreto, ordenada la ejecución por el órgano jurisdiccional competente, articulada a través de la oportuna orden o mandamiento judicial de ejecución $-\mathrm{o}$ de control y seguimiento-, la Administración Penitenciaria procederá a su materialización, definiendo un plan administrativo que se concretará previa citación para audiencia del sentenciado, que tiene así la oportunidad de expresar sus prioridades individuales y sociales -familiares, educativas, laborales-; una vez notificado al sentenciado el plan, éste tiene ejecutividad, y el sentenciado deberá proceder a su cumplimiento escrupuloso, sin perjuicio de las facultades revisoras de la Autoridad Judicial a la que se confíe el control judicial de legalidad de la ejecución administrativa de la medida penal de que se trate, articuladas a través de la puesta en conocimiento del plan, sin perjuicio de que el sentenciado pueda oponerse al mismo".

En cuanto al contenido del RD el art. 2 se dedica a las definiciones, diciendo que a los efectos del propio RD, por libertad vigilada se entenderá la medida de seguridad que consistirá en el sometimiento del condenado a control judicial a través del cumplimiento por su parte de alguna o algunas de las siguientes medidas señaladas en el artículo 106 $\mathrm{CP}$, y seguidamente las enumera todas. Como se observa, la definición no añade nada al contenido del Código.

En el número 4 del mismo precepto, define lo que debe entenderse por "servicios de gestión de penas y medidas alternativas", diciendo que son las "unidades administrativas multidisciplinares dependientes de la Administración penitenciaria que tienen encomendada la tarea de ejecución de las medidas y penas alternativas a la privación de libertad".

Posteriormente, en el Capítulo V, rubricado "Del cumplimiento de medidas de seguridad competencia de la administración penitenciaria", dedica la Sección $2^{\mathrm{a}}$ a la libertad vigilada posterior al cumplimiento de la pena privativa de libertad, a cuyo efecto el art. 23 dispone lo siguiente:

“Competencia de la Administración Penitenciaria.

En los supuestos en que se haya impuesto al penado la medida de libertad vigilada de cumplimiento posterior a una pena privativa de libertad, la Administración Penitenciaria, antes de finalizar el cumplimiento de la pena privativa de libertad y a solicitud del Juez de Vigilancia 
Penitenciaria, elevará a éste un informe técnico sobre la evolución del penado, a los efectos previstos en el artículo 106, párrafo 2, del Código Penal. El referido informe será elaborado por la Junta de Tratamiento, u órgano autonómico equivalente, del Centro Penitenciario en el que el penado se encuentre cumpliendo condena, o del que esté adscrito si se encuentra en libertad condicional".

Como se observa, la norma tampoco añade mucho al contenido del Código penal, más bien lo reproduce, con la única diferencia de que crea un organismo bajo el nombre de "servicio de gestión de penas y medidas alternativas" con muy poco desarrollo en la propia norma. Por otra parte, añade que le corresponde a la Administración penitenciaria elaborar el informe sobre la evolución del penado a quien se le impuso una pena más la libertad vigilada de cumplimiento posterior.

En cualquier caso, la competencia para el cumplimiento de la libertad vigilada, según se desprende de la citada norma, corresponde a la Administración penitenciaria1243 y, como adelantábamos al inicio de este epígrafe, lo relevante es lo que concerniente a que el RD no ha previsto la figura del agente de vigilancia del cumplimiento de la libertad vigilada, por lo que, como pone de manifiesto SIERRA LÓPEZ, la medida de seguridad tendrá escaso control1244. GUDÍN RODRÍGUEZ señala que la libertad vigilada carece de sentido si no hay un factor humano vinculado a su control, que por otra parte debe ser un profesional con formación en el área de la psicología, pedagogía y con conocimientos jurídicos, esto es, personal especializado para atender la complejidad y las necesidades de esta figura. De ese modo, la vigilancia no debe encomendarse a las Fuerzas y Cuerpos de Seguridad del Estado, sino a criminólogos, psicólogos, educadores sociales, trabajadores sociales, técnicos en integración social, etc., que articulen una correcta labor de asistencia que posibilite el efectivo control para los sometidos a vigilancia ${ }^{1245}$. Aspectos que deberían tenerse en cuenta y que, al haberse omitido en el RD 840/2011 que únicamente confiere la competencia a instituciones penitenciarias, provoca que la libertad vigilada presente una importante carencia necesitada de solución.

\footnotetext{
1243 MAGRO SERVET, V., “Competencia de la administración...”, cit. pp. 136 a 142.

1244 SIERRA LÓPEZ, M.V., La medida de libertad vigilada..., cit. p. 106.

1245 GUDÍN RODRÍGUEZ-MAGARIÑOS, F., La nueva medida de seguridad..., cit. pp. 263 y 264.
} 


\section{LIBERTAD VIGILADA Y EXPULSIÓN DE EXTRANJEROS}

Un aspecto relevante es el relativo a la aplicación de la libertad vigilada a los extranjeros residentes ilegalmente en España, en los casos en que se les imponga junto con la pena de prisión, esto es, delitos sexuales o terrorismo. En estos casos, puede ser de aplicación la sustitución de la pena por la medida de expulsión del art. 89 CP que se trata de una medida eminentemente asegurativa y profiláctica para sustituir las penas privativas de libertad inferiores a seis años a los extranjeros no residentes legalmente en España o las penas superiores a seis años una vez hayan cumplido las tres cuartas partes de la condena o alcance el tercer grado ${ }^{1246}$. Tras la reforma de la LO 5/20101247, está prevista con carácter general en el art. $96.3 \mathrm{CP}$ como medida de seguridad no privativa de libertad ${ }^{1248}$ que en su modalidad del art. $89 \mathrm{CP}^{1249}$ sustituye siempre a penas privativas de libertad inferiores a seis años. La sustitución será, por lo general, acordada en la propia sentencia (art. 89.1 CP) o también en un momento posterior (art. 89.1, $2^{\circ}$ párrafo CP). La otra modalidad es la expulsión en supuestos de penas privativas de libertad que el penado ya esté cumpliendo cuando alcance el tercer grado de tratamiento penitenciario y siempre que haya cumplido las tres cuartas partes de la condena - salvo que existan razones que aconsejen la permanencia en el centro penitenciario hasta el cumplimiento íntegro, art. $89.5 \mathrm{CP}$-, siendo esta modalidad de la expulsión una medida de seguridad de cumplimiento posterior.

En estos casos la LO 5/2010 no ha previsto nada en relación a la libertad vigilada, aspecto que podría volverse extremadamente frecuente teniendo en cuenta que, en el caso del terrorismo, en España no ha sido precisamente escasa la presencia de terrorismo islámico, y que tampoco hay razones para no considerar la delincuencia sexual que puedan cometer los migrantes vaya a ser inexistente, por lo que la cuestión sería qué hacer en estos casos. La cuestión es si la sustitución por la expulsión se extiende también a la libertad vigilada, ya que se trata de un supuesto no previsto en el $\mathrm{CP}$, a lo que algunos

\footnotetext{
1246 GUISASOLA LERMA, C., "Reformas penales y tendencias...”, cit. pp. 37 a 54.

1247 GUISASOLA LERMA, C., “Consideraciones político-legales...", cit. pp. 206 a 218.

1248 LANDECHO VELASCO C.M. / MOLINA BLÁZQUEZ, C., Derecho Penal..., cit. p. 613.

1249 GUISASOLA LERMA, C., “La reforma del Código penal...”, cit. pp. 131 a 136.
} 
autores afirman que la expulsión sustituye a ambas sanciones con arreglo a los fundamentos de la sustitución ${ }^{1250}$.

El otro supuesto posible es el de la expulsión gubernativa de la LO 4/2000, sobre derechos y libertades de los extranjeros en España y su integración social1251. Se trata de una expulsión administrativa ${ }^{1252}$ que conlleva la imposibilidad de regresar a España y de ingresar en cualquier país del espacio Schengen ${ }^{1253 / 1254}$ durante un período máximo de cinco años, que en casos en los que se aprecie que el extranjero supone una amenaza grave

1250 ROCA POVEDA, M., “La libertad vigilada...”, cit. p. 43.

1251 Dicha ley fue modificada en parte por la LO 8/2000, de 22 diciembre, y posteriormente en 2003 sufrió dos modificaciones de gran relevancia: a) La LO 11/2003, de 29 de septiembre, de medidas concretas en materia de seguridad ciudadana, violencia doméstica e integración social de los extranjeros, que vino a modificar el cuadro de infracciones y sanciones de la LO 4/2000; b) la LO 14/2003, de 20 de noviembre, de reforma de la LO 4/2000, que vino además seguida de su Reglamento de desarrollo (RD 2393/2004, de 30 de diciembre). Este cambio normativo fue de gran relevancia pero de dudosa constitucionalidad para algunos autores (Vid. RUBIO MARÍN, R., “La inclusión del emigrante: un reto para las democracias”. En Extranjería e Inmigración. Actas de las IX Jornadas de la Asociación de Letrados del Tribunal Constitucional. Madrid: Centro de Estudios Políticos y Constitucionales. 2004, p. 47). Postgeriormente se promulgó la LO 2/2009, de 11 de diciembre, de reforma de la LO 4/2000, con su desarrollo reglamentario aprobado por Real Decreto 557/2011, de 20 abril; y finalmente la LO 10/2011, de 27 de julio, por la que se ampliaron las medidas de protección a las mujeres extranjeras víctimas de violencia de género o de trata de seres humanos que denuncian al maltratador o al explotador, otorgándoles mayorprotección jurídica.

1252 Lo que para algunos autores ha sido calificado de "fraude de etiquetas" por tratarse de una sanción de extrema dureza que por su contenido, gravedad y sentido, así como por las formas que reviste, debería ser considerada como una auténtica sanción penal. BRANDARIZ GARCÍA, J.A. / FERNÁNDEZ BESSA, C., "La construcción de los migrantes como categoría de riesgo: fundamento, funcionalidad y consecuencias para el sistema penal español”. En PALIDDA, S. / BRANDARIZ GARCÍA, J.A., (Dirs.), Criminalización racista de los migrantes en Europa. Granada: Comares. 2010, p. 279, nota al pie 18.

1253 Hay que tener en cuenta que, según el art. 1 de la LO 4/2000, son extranjeros los que carecen de nacionalidad española según los arts. 17 a 26 del Código Civil español, sin perjuicio de lo establecido en los tratados internacionales y con la salvedad de los ciudadanos de la Unión Europea y a quienes sea de aplicación el régimen comunitario y el Acuerdo sobre el Espacio Económico Europeo, que es el denominado espacio Schengen que es un acuerdo que se firmó en 1985 para la supresión gradual de controles de fronteras comunes debido a la -por aquel entonces- falta de desarrollo de una auténtica libertad de circulación de personas en las Comunidades Europeas, adoptado en 1985 por Alemania, Bélgica, Francia, Luxemburgo y países Bajos, complementado por el Convenio de Schengen, de 19 de junio de 1990, para la aplicación del acuerdo de Schenguen, que hoy abarca números Estados: Alemania, Austria, Bélgica, Chipre, Eslovenia, Eslovaquia, España, Estonia, Finlandia, Francia, Grecia, Holanda, Hungría, Islandia, Letonia, Liechtesntein, Lituania, Luxemburgo, Malta, Noruega, Polonia, Portugal, Reino Unido, República Checa, Suecia y Suiza. No obstante, el contenido esencial del sistema Schengen viene a coincidir con el Título IV del Tratado de la Unión Europea (TUE) en materia de circulación de personas, y tras la entrada en vigor del Tratado de Amsterdam de 1999 debido al Protocolo núm. 2 anejo al TUE y al Tratado de la Comunidad Europea (TCE), el acervo de Schenguen es aplicable a todos los estados miembros con excepción de Reino Unido, Irlanda, Noruega e Islandia. Sobre este particular, vid. AZCÁRRAGA MONZONÍS, C., "El régimen de la extranjería en España". En FERNÁNDEZ MASIÁ, E., (Dir.) Nacionalidad y Extranjería. Valencia: Tirant lo Blanch. 2011, p. 79. Están también excluidos de la condición de extranjero los Diplomáticos y representantes y funcionarios de organismos internacionales (art. 2 LO 4/2000).

1254 En realidad se trata de una previsión del art. 245.2 del Real Decreto 557/2011, de 20 de abril, por el que se aprueba el Reglamento de la Ley Orgánica 4/2000, sobre derechos y libertades de los extranjeros en España y su integración social, tras su reforma por Ley Orgánica 2/2009, que extiende la prohibición de entrada a los territorios de los Estados en los existan acuerdos en dicho sentido y en los que España sea parte, que en este momento, es la zona Schengen. 
para el orden público, la seguridad pública, la seguridad nacional o para la salud pública, podrá llegar a los diez años (arts. 58.1 de la LO 4/2000 y 245.2 de Reglamento). En todo caso, la expulsión implica la extinción de cualquier autorización administrativa de residencia y el archivo de cualquier expediente de autorización de residencia o trabajo, así como las renovaciones en su caso. La expulsión implica la salida obligatoria de España1255, y podrá acordarse por infracción de la LO 4/2000, por imposibilidad de obtener cualquier permiso de residencia legal en España -ya que uno de los requisitos es la carencia de antecedentes penales- y por denegación de la misma una vez solicitada. Por ese motivo, tras la pena privativa de libertad, una vez liberado, el penado podrá ser objeto de expulsión gubernativa por imposibilidad de obtener el permiso de residencia o por denegación de la misma si la solicita ${ }^{1256}$. Por otra parte, la expulsión se acordará en todo caso en los supuestos del art. 57.2 de la LO 4/2000, cuando el extranjero haya sido condenado, dentro o fuera del país, por una conducta dolosa que constituya delito en España y que esté castigado en el CP con pena privativa de libertad superior a un año ${ }^{1257}$.

En cuanto a nuestro objeto de estudio, la expulsión administrativa puede producirse cuando se termina de cumplir la pena de prisión, en cuyo caso se plantea igualmente una fricción con la medida de seguridad de libertad vigilada de cumplimiento posterior a la pena, si ésta ha sido impuesta en la sentencia si la condena ha sido por delitos sexuales o terrorismo. La cuestión será determinar cómo se va a conciliar la aplicación de la libertad vigilada con la expulsión gubernativa. Entiendo que cuando la

\footnotetext{
1255 “Art. 28. De las salidas de España. 3. La salida será obligatoria en los siguientes supuestos: a) Expulsión del territorio español por orden judicial, en los casos previstos en el Código Penal. b) Expulsión o devolución acordadas por resolución administrativa en los casos previstos en la presente Ley. c) Denegación administrativa de las solicitudes formuladas por el extranjero para continuar permaneciendo en territorio español, o falta de autorización para encontrarse en España. d) Cumplimiento del plazo en el que un trabajador extranjero se hubiera comprometido a regresar a su país de origen en el marco de un programa de retorno voluntario".

1256 No entramos a considerar los supuestos en que también puede acordarse la expulsión por infracción de la normativa de extranjería, podrá acordarse en los supuestos previstos en los arts. 57.1 de la LO 4/2000, cuando se trate de infracciones muy graves previstas en los apartados a) a f) del art. 53.1 de la LO 4/2000, previa tramitación de oportuno expediente administrativo con observancia de todos los principios antes referidos. En estos casos, la expulsión no es preceptiva, sino facultativa ya que el tenor literal del precepto refiere a que podrá aplicarse en lugar de la multa, atendiendo razones de proporcionalidad, por lo que su imposición no es automática y depende de las circunstancias de cada caso que deberán ser valoradas en el expediente.

1257 La imposibilidad de acceso a permisos de salida -por el elevado riesgo de fuga-, libertad condicional o régimen de semi-libertad, puesto que, por lo general, cuando el sujeto alcanza dicha fase de tratamiento penitenciario, se opta por la expulsión (art. 89.1 CP) o, en su defecto, su puesta en libertad conlleva la imposibilidad de obtener cualquier autorización de residencia administrativa por existencia de antecedentes penales, es uno de los factores que la doctrina aduce como determinantes de la inclusión de los migrantes como categoría de riesgo. Vid. BRANDARIZ GARCÍA, J.A., / FERNÁNDEZ BESSA, C., "La construcción de los migrantes...", cit. pp. 286 a 292.
} 
pena se extinga, deberá empezar a cumplirse la libertad vigilada y si se produce la expulsión gubernativa, la libertad vigilada debe dejarse sin efecto, porque la peligrosidad ya no subsiste al no estar físicamente en el territorio español y tener prohibida la entrada como consecuencia de la expulsión. No obstante, suele suceder que aun contando con la resolución administrativa de expulsión, el extranjero no abandona el país voluntariamente, en cuyo caso, deberá persistir la libertad vigilada, y solo cuando se constate la salida del país o se produzca la expulsión administrativa forzosa, deberá dejarse sin efecto la libertad vigilada.

Dando un paso más, podría darse la situación de que nos encontremos con un sujeto que comienza a cumplir la libertad vigilada y se acuerda la expulsión gubernativa -o se incoa el expediente- $y$ se procede a su custodia en un Centro de Internamiento de Extranjeros (CIE) ${ }^{1258}$, con la consecuente incongruencia derivada de que el sujeto puede estar penalmente en libertad vigilada y administrativamente en internamiento en un CIE, esto es, privado de libertad y en libertad al mismo tiempo. En principio, el internamiento en el CIE es una medida cautelar que se acuerda en los supuestos en que el extranjero se encuentra a la espera de la resolución administrativa de expulsión (que, a su vez, requiere autorización judicial) ${ }^{1259}$, y se trata de una medida de aseguramiento de la efectividad de la expulsión (art. 61 de la LO 4/2000)1260. Dichos internamientos no tendrán en ningún

1258 Vid. RD 162/2014, de 14 de marzo, por el que se aprueba el reglamento de funcionamiento y régimen interior de los centros de internamiento de extranjeros, publicado en BOE núm. 64, de 15 de marzo de 2014, Sec. I, pp. 23236 a 23264. Esta norma, en su Disposición derogatoria única, deroga expresamente el art. 258 del Reglamento de la LO 4/2000, de 11 de enero, aprobado por RD 557/2011, de 20 de abril, y la Orden del Ministerio de la Presidencia de 22 de febrero de 1999, sobre normas de funcionamiento y régimen interior de los centros de internamiento de extranjeros, así como cuantas disposiciones, de igual o inferior rango, se opongan al contenido del nuevo RD 162/2014.

1259 Las medidas cautelares están previstas en el art. 61 de la LO 4/2000, se pueden acordar cuando exista un expediente administrativo por infracciones muy graves, y las más frecuentes son la presentación periódica ante las autoridades competentes, la residencia obligatoria en determinado lugar, y la retirada del pasaporte $o$ documento acreditativo de su nacionalidad, previa entrega al interesado del resguardo acreditativo de tal medida, aunque también pueden acordarse la detención cautelar y el internamiento en un centro de extranjeros.

1260 En efecto, el extranjero puede ser objeto de detención cautelar por la Policía por la presunta comisión de infracciones calificadas como muy graves por la LO 4/2000 (art. 61.1 d), que en ningún caso podrá durar más de 72 horas; transcurrido dicho plazo, podrá acordarse judicialmente la medida cautelar de internamiento (art. 61.1 e) en un centro de internamiento de extranjeros (art. 62 de la LO 4/2000 y 258 del Reglamento) a la espera de la resolución sobre la expulsión -que en muchas ocasiones termina en multa y puesta en libertad de la persona tras la tramitación del oportuno expediente-, y durará el tiempo estrictamente necesario sin que sea posible que se prolongue el internamiento injustificadamente. En todo caso el plazo máximo serán sesenta días -aunque nada impide que judicialmente se acuerde un plazo menor- y en ningún caso podrá acordarse un nuevo internamiento. (Vid. DE LORENZO SEGRELLES, M., "El régimen sancionador en materia de extranjería”. En FERNÁNDEZ MASIÁ, E., (Dir.), Nacionalidad y Extranjería. Valencia: Tirant lo Blanch. 2011, pp. 256 y 257). Si en ese plazo no ha recaído resolución sobre la expulsión, el extranjero será inmediatamente 
caso carácter penitenciario y son meramente de custodia encaminada a garantizar la efectividad de la medida de expulsión que previsiblemente pueda ser acordada.

Por lo que respecta a nuestro estudio, entiendo que el sujeto no puede estar cumpliendo la medida de seguridad de libertad vigilada y, a su vez, estar internado en un CIE para ser expulsado, porque ambas restricciones en la esfera de sus derechos individuales recaen sobre la libertad y si el sujeto ya está vigilado con obligaciones, por ejemplo, de no ausentarse sin autorización o de comunicar el cambio de residencia, etc., no tiene sentido tenerle, a su vez, internado por si se ausenta sin avisar. Es más, podría dar lugar a que, a causa de estar internado, incurra en quebrantamiento de condena por imposibilidad de cumplir las obligaciones impuestas en la libertad vigilada. La incongruencia es evidente, pero no parece que haya previsión específica para ello, por lo que, entiendo, que si se impone la libertad vigilada y se incoa un expediente de expulsión, sería ya suficiente con el mantenimiento de esa medida de seguridad para acordar la expulsión, sin necesidad de internamiento en el CIE. O, al contrario, si se acuerda el internamiento en un CIE para proceder a la expulsión, ya no tiene sentido la medida de seguridad, por lo que habría que dejarla sin efecto.

\section{OTROS ASPECTOS RELEVANTES}

La libertad vigilada postpenitenciaria plantea un problema importante: el incierto juicio de pronóstico sobre la probabilidad de delinquir en el futuro, que se asienta sobre criterios poco fiables, sobre todo teniendo en cuenta que el pronóstico de peligrosidad, en algunos casos, se emite a cuarenta años vista, lo que no deja de ser una "descabellada hipótesis de ficción simbólica antagonista con la seguridad jurídica"1261. Además, no parece que sean muy admisibles las presunciones de peligrosidad basadas únicamente en el hecho cometido, desvinculadas de la habitualidad o contumacia ${ }^{1262}$. La presunción de peligrosidad para imputables, que para algunos autores es iuris tantum ${ }^{1263}$ y para otros

puesto el libertad, y tanto la detención como el internamiento deberá comunicarse inmediatamente al Ministerio de Asuntos Exteriores y a la Embajada, Consulado o Misión Diplomática del país del extranjero presuntamente infractor (art. 62.5 de la LO 4/2000).

1261 REBOLLO VARGAS, R., La llibertat vigilada..., cit. p. 51.

1262 SANZ MORÁN, A.J., “La nueva medida de seguridad...", cit. p. 1027.

1263 SIERRA LÓPEZ, M.V., La medida de libertad vigilada..., cit. p. 114; GARCÍA RIVAS, N., “La libertad vigilada...", cit. p. 26. Este autor indica que del tenor literal del art. 106.3 c) CP que permite dejar la medida sin efecto, "contrarresta la posibilidad de considerar que la imposición de la libertad vigilada posterior a la 
iuris et de iure ${ }^{1264}$, supone la creación de una nueva categoría de medidas de seguridad, basada en el binomio culpabilidad-pasado (como en las penas) y no en el de peligrosidad-futuro (como en el resto de medidas de seguridad) ${ }^{1265}$. La libertad vigilada para imputables, se apresura en exceso en aventurar la peligrosidad postpenitenciaria, que solo podrá saberse si subsiste el mal pronóstico tras el cumplimiento de su condena en prisión ${ }^{1266 .}$

La vigente regulación de la libertad vigilada no constata la peligrosidad sino que la presume ${ }^{1267}$ cuando se trate de imputables que hayan cometido delitos contra la libertad e indemnidad sexuales y de terrorismo ${ }^{1268}$, lo que nos aboca a una concepción propia del Derecho penal de autor ${ }^{1269}$ que se aparta de los principios de igualdad, proporcionalidad, seguridad jurídica y prohibición de exceso, y se apoya en el Derecho penal de la seguridad 1270 . Las tendencias legislativas en materia penal de los últimos tiempos se proponen abocar al Estado de Derecho hacia la total inocuización de determinados delincuentes, en una clara transposición normativa positivizada de la construcción teórica

prisión se basa en una presunción de peligrosidad", sin que dicha peligrosidad la deberá constatar el JVP antes de dar cumplimiento a la libertad vigilada"; FEIJOO SÁNCHEZ, B., "La libertad vigilada...", cit. p. 220, señala que no es una presunción iuris et de iure depeligrosidad, sino un presupuesto para posibilitar que, en un posterior juicio tras el cumplimiento de la pena que deberá realizar el órgano jurisdiccional, volver a entrar a valorar la peligrosidad criminal del sujeto.

1264 REBOLlO VARGAS, R., "De las medidas de seguridad...”, cit. p. 818; GARCÍA ALBERO, R., en QUINTERO OLIVARES, G., Comentarios..., cit. Tomo I, pp. 687 y 692.

1265 MUÑOZ CONDE, F. / GARCÍA ARÁN, M., Derecho Penal..., cit. p. 597. Estos autores indica que "debe basarse en la peligrosidad la expresa el delito cometido y enjuiciado".

1266 REBOLLO VARGAS, R., La llibertat vigilada..., cit. p. 51. Como apunta este autor, "s'estableix pel tribunal, en el moment de dictar Sentència, una presumpció característica d'un Dret penal d'autor, en definitiva, una presumpció iuris et de iure pel que fa a la perillositat futura del subjecte, la qual cosa, com acabo d'esmentar, suposa una fallida del règim general de les mesures de seguretat en Dret penal espanyol i, amb això, la seva aplicació als subjectes imputables que es consideren perillosos en atenció al delicte comès."

1267 MUÑOZ CONDE, F. / GARCÍA ARÁN, M., Derecho Penal..., cit. p. 597. Según estos autores, “si esta clase de libertad vigilada se impusiera después de cumplirse la pena de prisión, se trataría, en realidad, de una medida pre-delictual basada exclusivamente en el pronóstico de nuevos delitos".

1268 GARCÍA ALBERO, R., "La nueva medida de seguridad...", cit. p. 186. Para este autor "la reforma de 2010 limita la medida para imputables a los casos de delitos sexuales y terrorismo, sobre la base de un automatismo estéril, obligando, que no facultando, a imponer en sentencia la medida sin perjuicio de su material implementación y confirmación una vez cumplida la pena de prisión".

1269 GUDÍN RODRÍGUEZ-MAGARIÑOS, F., La nueva medida de seguridad..., cit. p. 285.

1270 GARCÍA RIVAS, N., “La libertad vigilada...”, cit. p. 27. Este autor confiere una evaluación final muy negativa a la novedad legislativa que supone la libertad vigilada, precisamente porque "se apoya en los postulados del Derecho penal de la seguridad, campo abonado a extralimitaciones punitivas. En lugar de acomodarse el legislador a un tratamiento normalizado de la libertad vigilada, confinándola a su función positiva de sustituto penal o de medida asociada al último período de cumplimiento de la pena de prisión (libertad condicional), ha optado por un tratamiento excepcional, sin justificación real". 
formulada por JAKOBS ${ }^{1271}$ del Derecho penal del enemigo ${ }^{1272}$ a pesar de las críticas de la práctica totalidad de la doctrina científica1273.

Si bien en los delitos sexuales se ha dado una respuesta al problema de la delincuencia de tendencia interna irresistible, que se presenta en sujetos que son incapaces de inhibir sus tendencias o instintos sexuales pero que no se les puede considerar inimputables, en el caso del terrorismo, no se puede afirmar que la finalidad sea de tratamiento del delincuente por convicción ya que esta clase de delincuentes que cumplen largas penas de prisión, suelen quedar inservibles para seguir con la lucha armada porque quedan destrozados en el plano personal, por lo que se advierte que en realidad el fundamento de la libertad vigilada postpenitenciaria no es la peligrosidad

1271 JAKOBS, G., “Derecho penal de ciudadano y Derecho penal del enemigo”. En JAKOBS, G., / CANCIO MELIÁ, M., Derecho penal del enemigo. Madrid: Thomson Civitas. 2003, pp. 21 a 56; JAKOBS, G., La pena estatal..., cit. pp. 167 a 182; JAKOBS, “ ¿Derecho penal del enemigo? Un estudio acerca de los presupuestos de la juridicidad”. En CANCIO MELIÁ, M. / GÓMEZ-JARA DÍEZ, C., (Coords.), Derecho penal del enemigo. 2006, pp. 93 a 116; JAKOBS, G., "Coacción y personalidad. Reflexiones sobre una teoría de las medidas de seguridad complementarias a la pena". En InDret. Revista para el análisis del Derecho. 1/2009. Barcelona: 2009, pp. 8 a 14. De hecho el propio JAKOBS publicó un trabajo en 2006 dedicado a los terroristas como enemigos dentro de su propia construcción teórica antes aludida, vid. JAKOBS, G., “¿Terroristas como personas en Derecho?”. En CANCIO MELIÁ, M., / GÓMEZ-JARA DÍEZ, C., (coords.), Derecho penal del enemigo. El discurso penal de la exclusión. Vol. 2. Madrid: Edisofer, 2006, pp. 77 a 92. Algunos autores como OLÁSOLO ALONSO, H. / PÉREZ CEPEDA, A.I., Terrorismo internacional y conflicto armado. Valencia: Tirant lo Blanch. 2008, pp. 29 a 72, hablan de que el Derecho penal del enemigo se presenta como respuesta al fenómeno del terrorismo internacional y como justificación en el plano teórico de las legislaciones penales nacionales antiterroristas. Y MUÑOZ CONDE, F., "De nuevo sobre el "derecho penal del enemigo"“. En PÉREZ ÁLVAREZ, F., (Edit.), Vniversitas Vitae, homenaje a Ruperto Núñez Barbero. Salamanca: Aquilafuente. 2007, pp. 527 y 528, incluye el régimen de ejecución de penas en España para delitos de terrorismo y crimen organizado tras la reforma de 2003, como un ejemplo claro de manifestaciones legislativas de los Estados sociales que, de facto, vienen a coincidir con el derecho penal del enemigo, enumerando además otros ejemplos como la Patriot Act de EE.UU.

1272 GARCÍA RIVAS, N., “La libertad vigilada...”, cit. p. 12. Este autor expresa que "existe un amplio debate doctrinal en torno a un supuesto "nuevo" Derecho penal que ha traspasado las líneas de contención del Estado de Derecho y avanza sin pausa tomando como rehenes a las garantías que se han construido en los últimos siglos para contener la arbitrariedad punitiva: el llamado "Derecho penal del enemigo", al que se adscriben medidas como la libertad vigilada española o la custodia de seguridad alemana". También ACALE SÁNCHEZ, M., "Medición de la respuesta punitiva...", cit. pp. 203 a 209, habla de que existe un objetivo encubridor en la introducción de esta medida de seguridad para los terroristas y delicuentes sexuales, que responde a una suerte de "lucha contra los enemigos del sistema".

1273 GONZÁLEZ CUSSAC, J.L. “El renacimiento del pensamiento totalitario en el seno de Estado de Derecho: la doctrina del derecho penal del enemigo". En Revista La Ley Penal, núm. 19, enero de 2007, pp. 52 a 69; POLAINO NAVARRETE, M., "Entre el Derecho penal simbólico...”, cit. pp. 673 a 612; MUÑOZ CONDE, F., “De nuevo...", cit. pp. 527 y 528; DEMETRIO CRESPO, E., “El “Derecho penal del enemigo". Darf nicht sein! Sobre la ilegitimidad del llamado "Derecho penal de enemigo" y la idea de seguridad". En GARCÍA RIVAS, N. / RODRÍGUEZ YAGÜE, C. / PÉREZ CEPEDA, A.I. / DEMETRIO CRESPO, E. / RIQUERT, F.L. / PALACIOS, L.P. / VERVAELE, J. / ACALE SÁNCHEZ, M. / PORTERO HENARES, M. / QUINTERO OLIVARES, G. / VIGANÒ, F., El derecho penal frente a la inseguridad. Albacete: Bomarzo. 2007, pp. 149 a 166; RAMOS VÁZQUEZ, J.A., "Del otro lado del espejo: reflexiones desordenadas acerca del Derecho penal en la sociedad actual". En FARALDO CABANA, P., (Dir.) / BRANDARIZ GARCIA, J.A., / PUENTE ABA, L.M., (Coords.), Nuevos retos del Derecho penal en la era de la globalización. Valencia: Tirant lo Blanch. 2004, pp. 65 a 122; DEMETRIO CRESPO, E., "Acerca del a contraposición entre libertad y seguridad en el Derecho penal". En PÉREZ ÁlVAREZ, F., (Edit.), Vniversitas Vitae, homenaje a Ruperto Núñez Barbero. Salamanca: Aquílafuente. 2007, pp. 182 a 189. 
individual, sino una manifestación de combate del Estado contra el terrorismo, que se sirve de la libertad vigilada como instrumento inocuizador, siguiendo en la línea iniciada con la reforma de la ejecución penal operada a través de la LO 7/2003 para el cumplimiento íntegro de las penas, y fomentando lo que un sector de la doctrina ha comenzado a llamar "Derecho penitenciario del enemigo", y esta modalidad de libertad vigilada postpenitenciaria es la legitimación judicial de las actuaciones de los servicios de inteligencia, a través de resoluciones que las dotan de validez ${ }^{1274}$.

En ese sentido, como afirma GUDÍN RODRÍGUEZ, hasta ahora se venía manteniendo que la tecnología y sus avances aplicados al Derecho penal estaban encaminados a la resocialización y la excarcelación, pero la libertad vigilada no va dirigida a hacia ese camino sino al opuesto, "a hipertrofiar las potencialidades de control del Estado sobre grupúsculos etiquetados como previamente peligrosos. Es un ejemplo paradigmático del "widening effect the net" orientado a extender la red de control inherente a la incipiente sociedad de la información". De ahí que se afirme que existe cierta hipocresía en la inclusión de esta figura en el texto punitivo, porque esconde una auténtica cadena perpetua $^{1275}$ que traspone una tendencia uniforme de los últimos años que camufla como medidas que pretenden aligerar y excarcelar, cuando lo único que persiguen es controlar a determinados sectores de la población ${ }^{1276}$.

La imposición de la pena privativa de libertad más la libertad vigilada, plantea un problema de compatibilidad entre la suspensión de la pena y el cumplimiento de la medida de seguridad, que se traduce en que, en los delitos graves no es posible la suspensión salvo los supuestos del art. $87 \mathrm{CP}$, pero en los delitos menos graves en los que sí es posible la suspensión de la pena, no termina de resolverse la duda en torno a si puede aplicarse igualmente la libertad vigilada cuando termine el período de suspensión acordado, a lo que la doctrina manifiesta que no sería posible por incompatibilidad entre suspensión de la pena y persistencia de la peligrosidad en la que se fundamenta la

\footnotetext{
1274 FEIJOO SÁNCHEZ, B., “La libertad vigilada...”, cit. pp. 231 y 232. Este autor explica que la experiencia demuestras que una estrategia estatal que consigue debilitar a los grupos terroristas es tener al mayor número de ellos cumpliendo penas de prisión largas, y si bien la LO 7/2003 tuvo esa finalidad político-criminal, en la LO 5/2010 la libertad vigilada para terroristas sigue la misma línea continuista.

1275 GARCÍA RIVAS, N., “La libertad vigilada...”, cit. p. 27. Según expresa este autor, la restricción de la libertad posterior a una pena de prisión que puede llegar a los cuarenta años "constituye un exceso punitivo manifiesto que vulnera los postulados de la proporcionalidad de la intervención penal".

1276 GUDÍN RODRÍGUEZ-MAGARIÑOS, F., La nueva medida de seguridad..., cit. pp. 290 y 291.
} 
medida de seguridad, a lo que hay que añadir que las prohibiciones y obligaciones susceptibles de ser acordadas para el periodo de suspensión de la pena previstas en el art. 83.1 CP, permiten cubrir la finalidad de la libertad vigilada y ello haría innecesaria —cuando no incompatible- su aplicación posterior. Y además, la regla $6^{\mathrm{a}}$ del art. $83 \mathrm{CP}$, permite acudir a otras reglas de conducta, y acordar que el sujeto cumpla "los demás deberes que el Juez o Tribunal estime convenientes para la rehabilitación social del penado, previa conformidad de éste, siempre que no atenten contra su dignidad como persona", por lo que, a través de esta previsión, podrían acordarse, en caso de ser necesario o conveniente para el buen fin de la suspensión de la pena, algunas de las obligaciones y prohibiciones concernientes a la libertad vigilada, lo que excluiría igualmente su ejecución posterior por innecesaria o incompatible ${ }^{1277}$.

El éxito de la libertad vigilada dependerá del esfuerzo económico que se haga para ponerla en funcionamiento ${ }^{1278}$, ya que requiere medios personales y materiales de elevado coste. Comenzando por la ausencia del agente de vigilancia, la mención que hace el CP a los informes en los que el JVP deberá basar sus decisiones sobre la medida, elaborados por facultativos y profesionales que asistan al sometido a la medida o por las administraciones públicas competentes (art. 98.1 CP) se traduce en que necesariamente se necesitará un verdadero esfuerzo económico para poner en marcha tales previsiones por los referidos operadores que intervengan. Y terminando por los medios de electrónicos de control que, obviamente, implican una importante inversión en tecnología de vanguardia que no se sabe muy bien si todas las Comunidades Autónomas serán capaces de asumir con plena capacidad que implique la exitosa realidad de su puesta en funcionamiento.

Es necesario que se introduzca la figura del agente de vigilancia en la ejecución de la libertad vigilada1279, tal y como se ha puesto también de manifiesto en la Recomendación CM/Rec (2010) 1, del Comité de Ministros (adopatada el 20 de enero de 2010 en la reunión 1075 de delegados de Ministros), a los Estados miembros sobre la

\footnotetext{
1277 SIERRA LÓPEZ, M.V., La medida de libertad vigilada..., cit. p. 149.

1278 SANZ MORÁN, A.J., “La nueva medida de seguridad...”, cit. p. 1026.

1279 CÁMARA ARROYO, S., “La libertad vigilada...", cit. pp. 18 y 19. Este autor afirma que "la libertad vigilada post-penitenciaria ha nacido huérfana", por cuanto que se trata de una "libertad vigilada sin vigilante", y que se torna necesario regular una figura similar a las previstas en países anglosajones para suplir la carencia, lo cual podría hacerse por vía reglamentaria o bien a través de un replanteamiento de estatuto jurídico de la libertad vigilada "considerando su aplicación conjunta con la pena de prisión y establecer mayores competencias en el ámbito penitenciario".
} 
Reglas del Consejo de Europa relativas a la probation ${ }^{1280}$. Además, la presunción de peligrosidad debe ser rechazada, y estar únicamente a la constatación efectiva mediantes los correspondientes informes elaborados al efecto. También habría que optar preferentemente por imponer obligaciones y prohibiciones de naturaleza correctiva antes que de naturaleza asegurativa. Y apostar por los tratamientos de reinserción durante la ejecución de la pena (como los del art. 116.4 RP) antes que delegar esa función a la medida de seguridad de cumplimiento posterior ${ }^{1281}$.

Hay autores como CÁMARA ARROYO, que afirman que la libertad vigilada, tal y como ha sido regulada en la LO 5/2010, es una versión moderna de la cláusula de retención que tiene por finalidad asegurar el control del Estado sobre determinada delincuencia, y que su legislación se encuentra desligada del ámbito penitenciario, por lo que propone una mejor regulación tomando en consideración estos aspectos: realizar estudios criminológicos sobre la pertinencia de la medida postpenitenciaria a determinados tipos de delincuentes dentro de las tipologías marcadas por la ley para su aplicación, establecer el juicio de peligrosidad en el momento del inicio de la medida; permitir el cumplimiento conjunto de la pena y la medida; dotar de mayor contenido resocializador a las medidas; aprovechar las Unidades Dependientes (UD); crear un servicio de seguimiento o figura del agente de vigilancia; otorgar mayores competencias al JVP en el control de la libertad vigilada y establecer que los informes de la juntas de tratamiento sean vinculantes para las decisiones sobre la medida que deban tomar el JVP y el Tribunal sentenciador de forma conjunta ${ }^{1282}$.

FEIJOO SÁNCHEZ afirma que la opción de tratar al delincuente peligroso con medidas de seguridad complementarias a la pena es legítima y es un buen criterio, aunque su formulación en la LO 5/2010 ha sido "desastrosa", porque se fijan de forma

\footnotetext{
1280 También insiste ROCA POVEDA, M., “La libertad vigilada...", cit. pp. 48 y 49, en la necesidad del agente de vigilancia e invoca el modelo del agente de probation como ejemplo y la citada Recomendación del Comité de Ministros, y también afirma que "el seguimiento y control de la libertad vigilada tiene, más que una regulación insatisfactoria, una nula regulación. Se hace necesario elaborar su marco reglamentario; no hacerlo, además de suponer una merma del principio de legalidad, puede contribuir sin duda al descrédito de esta medida cuando no a su ineficacia. Se ha puesto de manifiesto que uno de los aspectos más importantes es el agente de ejecucóin encargado de su seguimiento. Teniendo en cuenta el elenco de situaciones que podrían producirse (incluso y naturalmente en un mismo sujeto) se hace necesarui crear la figura del Agente de Libertad Vigilada que gestionaría el mapa de recursos existente en la comunidad informando al Juez o Tribunal".

1281 SIERRA LÓPEZ, M.V., La medida de libertad vigilada..., cit. p. 155 y 156.

1282 CÁMARA ARROYO, S., “La libertad vigilada...”, cit. p. 21.
} 
arbitraria determinados perfiles criminológicos a los que va a ser aplicada respondiendo con ello a "las inseguridades que generan determinados tipos de delincuentes en el imaginario colectivo", lo que provoca que se generalice en relación a la peligrosidad que, por otra parte, debería responder a situaciones específicas que deriven de estudios individualizados, no generalizados. En ese sentido, invoca este autor el ejemplo del psicópata $^{1283}$ que no llega a ser inimputable pero que presenta un alto índice de dificultad inhibitoria de los impulsos violentos, y si comete un homicidio no puede serle impuesta la libertad vigilada, pero si comete un abuso sexual, entonces sí. Por eso señala que no termina de ser satisfactorio el recurso a las tipologías de delitos en general, que presentan perfiles criminológicos muy variados, sino que la libertad vigilada tendría que basarse en criterios de peligrosidad individualizados.

También explica este autor que la solución no termina de ser correcta, porque si bien el recurso a esta clase de figuras es válido y acertado, no lo es que se haya mantenido la opción seguida hasta ahora en el texto punitivo de tratar de forma monista la peligrosidad mediante exasperación de las penas, y además añadir un nuevo modelo dualista para suplir las carencias de las penas en cuanto a la peligrosidad, porque el brutal rigor punitivo del $\mathrm{CP}$ se ve acrecentado con la libertad vigilada, por lo que, entiende este autor, que para un correcto anclaje en el sistema - siguiendo los modelos continentales a los que parece que pretende aproximarse- la libertad vigilada debería ir acompañada de un nuevo diseño de las sanciones penales que impidiera, por ejemplo, no imponer penas mayores de veinte años de prisión por razones de prevención general, ya que por encima de esos topes podría entrar en escena la medida de seguridad si fuese necesario, de modo que la libertad vigilada operaría a modo de "válvula de escape" para que se termine restringiendo la libertad de aquellos individuos de peligrosidad excepcional que requieren medidas concretas tras la pena por la culpabilidad ya cumplida1284.

También valora positivamente este autor la opción de incluir la libertad vigilada para imputables peligrosos, porque sus principales destinatarios son penados que no van a tener acceso a la libertad condicional por ausencia de pronóstico favorable de reinserción y no es del todo sensato permitir que esta clase de sujetos pasen de forma

\footnotetext{
1283 Sobre la libertad vigilada y la psicopatía sexual, vid. NAVARRO FRÍAS, I., "Psicopatía y medidas de seguridad. El caso de los psicópatas sexuales y la libertad vigilada tras la última reforma del Código Penal". En Cuadernos de política criminal, núm. 105, 2011, pp. 117 a 158.

1284 FEIJOO SÁNCHEZ, B., “La libertad vigilada...”, cit. pp. 233 a 238.
} 
abrupta de la privación de libertad a la libertad plena si una suerte de transición a modo de libertad condicional o que haga las veces de ella. Además, considera que la opción que acude simplemente a la exasperación de las penas y a su exacerbación para combatir la peligrosidad, no hace más que servir a las demandas de inocuización y se convierte en prisión más prisión, por lo que parece más correcto optar por prisión más libertad vigilada en términos de proporcionalidad.

Ahora bien, este autor opone algunas objeciones importantes a la formulación conferida en la LO 5/2010, toda vez que el recurso a medidas de seguridad de esta clase debería ir acompañada de una reducción de las penas, esto es, moderar las reglas de cumplimiento íntegro de las penas y no convertir la simbiosis pena-medida de seguridad en una suerte de prisión perpetua que rebase los límites de la proporcionalidad ${ }^{1285}$.

1285 GARCÍA ALBERO, R., en QUINTERO OLIVARES, G., Comentarios..., cit. Tomo I, pp. 686 y 687. 


\section{CAPÍTULO CUARTO. LA LIBERTAD CONDICIONAL}

El presente capítulo se dedica a la libertad condicional y su relación con la libertad vigilada, para delimitar con claridad los supuestos en que una y otra figura confluyen a efectos de determinar con precisión sus respetivos ámbitos de aplicación y los problemas de armonización que se puedan presentar.

\section{ASPECTOS GENERALES DE LA LIBERTAD CONDICIONAL}

La libertad condicional es el último estadio de la ejecución de la pena de prisión en el sistema progresivo, es una institución en la que se plasma de forma absoluta la necesaria reintroducción del penado en la sociedad ${ }^{1286}$ por haber cumplido parte de la condena en prisión y haber presentado síntomas de poder ser reinsertado incluso antes de haberse producido el licenciamiento definitivo ${ }^{1287}$, condicionando el cumplimiento del resto de la pena en libertad a que el penado no delinca y cumpla una serie de condiciones que le sean impuestas. Es una forma de preparación para la libertad definitiva, de modo que el paso de la privación de libertad a la libertad definitiva no se produce de forma abrupta, sino que mediante este instrumento de reinserción social, el penado se prepara para quedar desligado de su relación penitenciaria, concretándose con ello la orientación de las penas hacia la reinserción que proclama el art. 25.2 CE CE $^{1288 / 1289}$ y el art. 1 LOGP1290/1291.

\footnotetext{
1286 DE VICENTE MARTÍNEZ, R., Vademécum de Derecho penal. Valencia: Tirant lo Blanch. 2011, p. 184. Esta autor indica que "la libertad condicional es un concepto de Derecho penal y Penitenciario fundamental para entender el mandato constitucional de la reeducación y reinserción social del reo (art. 25 de la CE). Es una forma de seguir cumpliendo condena, pero en libertad, otorgando el Estado su confianza a quien ya está a punto de terminar su condena y quiere volver a ser parte activa de la misma. En tal sentido la libertad condicional es considerada como una "libertad a prueba", como un instrumento necesario para la consecución de los fines resocializadores de la pena privativa de libertad".

1287 LISZT, F., Tratado de Derecho penal..., cit. Tomo III, pp. 424 y 425. En palabras de este autor: "la verdad penal baja del cielo de la utopía y se relativiza, que es el modo de humanizarse la verdad. Entonces la vida también vida del derecho- llega hasta ella incorporándola al proteísmo de sus formas, que es como comprende la vida. El correccionalismo, predicado dogmática y enfáticamente desde el pobre Sinaí del Krausismo, fracasa en el siglo XIX, ese siglo irónico; pero vuelto al mundo en carne mortal de sensata y relativa enseñanza, de serio y esforzado pronóstico, es aceptado bajo la fórmula de adaptación. La corrección se incorpora como condición de fórmulas extintivas penales, creadoras premiales; unas relativas, otras absolutas. A través del seductor sistema penitenciario, resumen y perfección de otros -el sistema progresivo irlandés-, se piensa en la situación jurídica de los reos que por su buena conducta llegaron al último período. El rigor preceptivo del sistema pide, para estos buenos penados, un modo de libertad en la pena, de relativa y vigilada libertad".
}

1288 Art. 25.2. "Las penas privativas de libertad y las medidas de seguridad estarán orientadas hacia la reeducación y reinserción social y no podrán consistir en trabajos forzados. El condenado a pena de prisión que estuviere cumpliendo la misma gozará de los derechos fundamentales de este Capítulo, a excepción de 
los que se vean expresamente limitados por el contenido del fallo condenatorio, el sentido de la pena y la Ley penitenciaria. En todo caso, tendrá derecho a un trabajo remunerado y a los beneficios correspondientes de la Seguridad Social, así como al acceso a la cultura y al desarrollo integral de su personalidad".

1289 NARANJO DE LA CRUZ, R., “Derechos fundamentales”. En AGUDO ZAMORA, M. / ÁLVAREZOSSORIO MICHEO, F. / GÓMEZ CORONA, E. / MARTÍNEZ RUANO, P. / MORALES ARROYO, J.M. / NARANJO DE LA CRUZ, R. / PÉREZ SOLA, N. / PORRAS NADALES, A. / RASCÓN ORTEGA, J.L. / REVENGA SÁNCHEZ, M. / RODRÍGUEZ, A. / SALAZAR BENÍTEZ, O., Manual de Derecho Constitucional. $2^{\mathrm{a}}$ Ed. Madrid: Tecnos. 2011, p. 497. Expresa este autor que "dispone el art. 25.2 CE que "las penas privativas de libertad y las medidas de seguridad estarán orientadas hacia la reeducación y reinserción social y no podrán consistir en trabajos forzados". Este párrafo no contiene derecho fundamental alguno, sino un mandato dirigido al legislador penitenciario y a la Administración por él creada para orientar la ejecución de las penas privativas de libertad (SSTC 2/1987 y 55/1996). Tampoco supone que la reeducación y la reinserción social sean las únicas finalidades legítimas de las penas privativas de libertad (SSTC 19/1998 y 119/1996). El TC ha llegado a señalar, incluso, que tal finalidad "debe ceder siempre que resulte contrapuesta a las necesidades de carácter preventivo-general o de reafirmación del ordenamiento jurídico". Por otra parte, sobre este punto la reciente STC 40/2012, de 29 de marzo, dictada por el pleno a raíz de la aplicación de la doctrina Parot por la Sala de lo Penal de la Audiencia Nacional a D. Joseba Koldobika Artola Ibarretxe, en su FJ 11 dispone lo siguiente: "el art. 25.2 CE no expresa un derecho fundamental del ciudadano susceptible de ser invocado en amparo, sino más bien un mandato dirigido al legislador para orientar la política penal y penitenciaria con objeto de que configure las sanciones penales para que cumplan estos fines de reinserción establecidos en la Constitución, sin que se deriven derechos subjetivos del mismo (por todas, SSTC 88/1998, de 21 de abril, FJ 3; 204/1999, de 8 de noviembre, FJ 3; 120/2000, de 10 de mayo, FJ 4; y ATC 279/2000, de 29 de noviembre, FJ 4)".

1290 Art. 1. "Las instituciones penitenciarias reguladas en la presente Ley tienen como fin primordial la reeducación y la reinserción social de los sentenciados a penas y medidas penales privativas de libertad, así como la retención y custodia de detenidos, presos y penados. Igualmente tienen a su cargo una labor asistencial y de ayuda para internos y liberados".

1291 GARCÍA ARÁN, M., “De las penas. Arts. 80 a 93”. En CÓRDOBA RODA, J. / GARCÍA ARÁN, M., (Dirs.), Comentarios al Código Penal. Parte General. Madrid: Marcial Pons. 2011, p. 753. Como consecuencia de la obra HOWARD "The state of Prisons in England and Wales" (1777), que puso de manifiesto la multitud de falencias de las prisiones, como el hacinamiento de presos, la ociosidad, la falta de condiciones higiénicas, la mezcla de menores de edad y adultos, hombres y mujeres, delincuentes habituales y primarios, enfermos y sanos, etc. Vid. FERNÁNDEZ GARCÍA, J., "El Derecho penitenciario. Concepto". En BERDUGO GÓMEZ DE LA TORRE, I., (Coord.), Lecciones y materiales para el Estudio del Derecho penal. Tomo VI. Derecho penitenciario. Madrid: Iustel. 2010, p. 43; y del Congreso de Cincinnati (Ohaio) en 1870 en el que se apostó por implementar figuras como la probation o la libertad condicional como figuras complementarias para combatir la delincuencia. Vid. TÉBAR VILCHES, B., El modelo de libertad condicional español. Tesis doctoral. Universidad Autónoma de Barcelona. 2004, p. 11, surgen los sistemas penitenciarios: el sistema Filadélfico o Pensilvánico que nace a finales del siglo XVIII como reacción frente a los problemas de hacinamiento y promiscuidad que presentaban las prisiones americanas, para ello en la penitenciaría de Filadelfia se instauró un sistema consistente en un aislamiento absoluto que se inspiraba en la austeridad de los cuáqueros, grupo religioso que defendía la no violencia. Su característica más importante era el aislamiento total durante todo el día y el silencio absoluto, por eso se le conoce también con el nombre de sistema celular. El preso pasaba día y noche en la celda en absoluta soledad, sin visitas ni actividad alguna, más que la lectura de la Biblia. Contribuyó a la separación de reclusos y a la mejora de la higiene y la salubridad, siendo por el contrario su mayor inconveniente el deterioro psíquico que producía el aislamiento total en los reclusos. Vid. CERVELLÓ DONDERIS, V., Derecho penitenciario. Valencia: Tirant lo Blanch. 2006. [www.tirantonline.com] TOL 1.020.782, p. 6. Esta autora señala que "este sistema se exportó a Europa; en España la cárcel de Madrid construida por orden de Alfonso XII en 1876 inspiró su arquitectura en los principios que propugnaba"; el sistema de Auburn o de la regla del silencio que nace en esta ciudad del Estado de Nueva York a principios del siglo XIX (1823), se mantiene el aislamiento nocturno pero la novedad es que se incorpora el trabajo y la vida en común durante el día; la permanencia de la regla de silencio absoluto exige, para mantenerlo, una disciplina severa a base de duros castigos corporales ${ }^{1291}$, y se caracteriza por la prohibición de contactos exteriores no permitiéndose ninguna visita ni siquiera de sus familiares. El autor de este sistema es LYNDS, que afirmaba que el silencio era la columna vertebral, su incumplimiento era inmediatamente corregido con castigos corporales que se llevaban a cabo mediante azotes con látigo o con el conocido como gato de nueve colas, que era un látigo compuesto por nueve finas correas que producían igual número de heridas en cada latigazo. No obstante, la regla del silencio no supuso la incomunicación total entre los reclusos, porque supieron suplir esa falta de comunicación verbal a través del ingenio, desarrollando multitud de sistemas de comunicación no verbal, como la mínimica, los golpes, espejos, etc. Vid. FERNÁNDEZ GARCÍA, J., “El Derecho penitenciario...” , cit. p. 
La libertad condicional fue introducida por primera vez en Derecho español 1292 mediante la Ley de 24 de julio de 19141293, desde donde se incorporó al CP1294, aunque anteriormente se aplicó en la prisión de San Agustín de Valencia por el Coronel Montesinos ${ }^{1295}$, entre 1835 y 18501296. Posteriormente se reguló en los Códigos penales de 1928, 1932 y 19441297. En el CP de 1973 se contemplaba en los arts. 98 y 99, regulación que debía ser completada con lo dispuesto en los arts. 90 y 256 del Reglamento

46; y finalmente los sistemas progresivos, que surgen en el siglo XIX en Europa para alcanzar la reforma del sujeto a través de la mejora de condiciones en función del buen comportamiento del recluso, donde el cumplimiento se divide en etapas que van desde el aislamiento total hasta la libertad condicional, siendo cada una de ellas una progresión de la anterior en función de la buena conducta que va demostrando el reo y que le proporciona, gradualmente, menor disciplina y mayor libertad. Vid. CERVELLÓ DONDERIS, V., Derecho penitenciario..., cit. TOL 1.020.782, pp. 6 y 7. Este sistema, en esencia, es el que predomina en la práctica penitenciaria europea de los siglos XIX y XX con la pena dividida en las siguientes fases: la primera era un inicial aislamiento celular para la observación y clasificación del penado; la segunda era una etapa en la que, a continuación, se pasaba a la vida en común con instrucción y trabajo; la tercera y tras ello, se pasaba a la preparación previa para la vida en libertad fomentando las salidas al exterior; y finalmente se accedía a la libertad condicional como libertad a prueba. La característica común a los distintos sistemas progresivos es que el interno, al ingresar, está absolutamente aislado y a medida que avanza la condena, su buen comportamiento y su trabajo en prisión, derivan en la concesión de beneficios de manera gradual, de forma que el penado experimenta una evolución hacia la libertad con un régimen más benévolo aunque, cualquier incidente negativo que pudiera tener, implica un retroceso en la progresión pudiendo experimentar regresiones en la evolución de la concesión de beneficios. El incentivo que estos sistemas ofrecen al penado para que, progresivamente, se adapten a sus nuevas formas de vida, es lo que propició su éxito y aceptación. Vid. FERNÁNDEZ GARCÍA, J., "El Derecho penitenciario...", cit. p. 46. Es en este contexto del nacimiento de los sistemas progresivos donde se sitúa el origen de la libertad condicional, concretamente en las colonias penales inglesas en Australia, "ticket of leave system", que se implementó en la isla de Norfolk en 1840, lugar al que Inglaterra, a través del capitán de la marina Maconochie, enviaba a sus reclusos más rebeldes, Vid. FERNÁNDEZ GARCÍA, J., "La libertad condicional y los beneficios penitenciarios”. En BERDUGO GÓMEZ DE LA TORRE, I. (Coord.), Lecciones y materiales para el estudio del Derecho penal. Tomo VI. Derecho penitenciario. Madrid: Iustel. 2010, p. 228, y que consistía en que el penado acumulaba una especie de vales como contraprestación por su trabajo y su buen comportamiento, que ulteriormente podía canjear por una libertad anticipada. Vid. CERVELLÓ DONDERIS, V., Derecho penitenciario..., cit. TOL 1.020.782, p. 7. Esta autora explica que "en Inglaterra lo aplicó Maconochie en 1840 en la colonia penal de la isla de Norfolk dividiendo en tres fases la ejecución: régimen cerrado o periodo de prueba, régimen intermedio de trabajo en comunidad y libertad condicional. La duración de la pena era una suma de trabajo y buena conducta representada por un número de marcas o boletos, así, la cantidad de marcas que el penado tenía que obtener antes de obtener la libertad estaba en proporción a la gravedad del hecho criminal".

1292 No obstante conviene tener presente que el CP de 1822, en su art. 44 regulaba una suerte de rebaja de la cuarta o tercera parte de la condena en casos de arrepentimiento y enmienda del condenado, cuando hubiera cumplido la mitad de la pena, aunque esta libertad anticipada no era revocable, por lo que no era exactamente una libertad condicional. Vid. TÉBAR VILCHES, B., El modelo de libertad condicional español. Tesis..., cit. p. 22.

1293 LANDROVE DÍAZ, G., Las consecuencias..., cit. p. 69

1294 CERVERA SALVADOR, S., “La pena de trabajos...”, cit. p. 45, nota al pie 24.

1295 FERNÁNDEZ GARCÍA, J., “La libertad condicional...”, cit. p. 228.

1296 CERVELLÓ DONDERIS, V., Derecho penitenciario..., cit. TOL 1.020.782, pp. 6. Esta autora manifiesta que “en España lo experimentó desde 1835 a 1850 el Coronel Montesinos en el penal de San Agustín de Valencia, convento abandonado tras la desamortización al que consiguió trasladar a los penados civiles desde las inadecuadas Torres de Cuarte donde se instalaba el presidio militar. Para ello dividió la prisión en cuatro periodos: hierros, trabajo, libertad intermedia y libertad definitiva. Curiosamente hasta 1900 no se implanta de manera general en todo el país y lo hace bajo el nombre de sistema progresivo irlandés".

1297 ROCA AGAPITO, L., El sistema de sanciones..., cit. p. 577. 
Penitenciario ${ }^{1298}$. En dicha regulación, la libertad condicional quedaba limitada a condenas que fueran de más de un año de privación de libertad, requisito que desaparece en la formulación que hizo el CP de 1995, que unificó todas las normas sobre libertad condicional que existían en la legislación anterior, plasmando en su articulado algunos aspectos que ya se introdujeron en la praxis penitenciaria por vía reglamentaria, como el régimen especial para septuagenarios o enfermos incurables, que ya venía contemplado en el art. 60 del Reglamento Penitenciario de 1981; o el adelantamiento por haber realizado actividades laborales, culturales $\mathrm{u}$ ocupacionales, art. 91 del mismo Reglamento ${ }^{1299}$. La entrada en vigor de la LOGP en 1979 supuso una reforma importante en la libertad condicional, toda vez que dispuso la atribución de la potestad para acordarla al JVP1300.

\section{NATURALEZA JURÍDICA}

Se discute si su naturaleza es la de derecho subjetivo del condenado, o si se trata de un beneficio penitenciario ${ }^{1301}$. La primera opción es la mantenida por los sistemas anglosajones, que conciben la libertad condicional como un derecho que el condenado adquiere con su buen comportamiento y que se otorga — sin sujeción a la discrecionalidad

\footnotetext{
1298 LANDECHO VELASCO C.M. / MOLINA BLÁZQUEZ, C., Derecho Penal..., cit. p. 577.

1299 TAMARIT SUMALLA, J.M. / GARCÍA ALBERO, R., La reforma ..., cit. p. 90.
}

1300 Es también relevante destacar que después de la Segunda Guerra Mundial dio comienzo una notable evolución para la transformación de los sistemas penitenciarios que tuvo como hecho más relevante la creación de las Reglas Mínimas para el tratamiento de los reclusos, que fueron redactadas en 1955 en el Primer Congreso de las Naciones Unidas sobre Prevención del Delito y Tratamiento del Delincuente, celebrado en Ginebra, aprobadas por el Consejo de Naciones Unidas por Resolución 663 C I (XXIV), de 31 de julio de 1957. En dichas reglas mínimas se estableció que antes del término de la ejecución de una pena o medida de seguridad, deberán adoptarse todos los medios que sean necesarios para posibilitar que los penados puedan retornar de forma progresiva a la sociedad, y para ello, podrá optarse por un régimen o fase preparatoria para la vida en libertad que podrá encomendarse a instituciones destinadas a tal fin o incluso en el interior del propio centro penitenciario, o a través de figuras como la libertad condicional, bajo la supervisión y vigilancia de asistentes sociales y no de policías. Vid. TAMARIT SUMALLA, J.M. / GARCÍA ALBERO, R. / RODRÍGUEZ PUERTA, M.J. / SAPENA GRAU, F., Curso de Derecho penitenciario. $2^{\mathrm{a}}$ Ed. Valencia: Tirant lo Blanch. 2005, p. 39; NICOLÁS GUARDIOLA J.J., "Recomendaciones internacionales en materia penitenciaria”. En NICOLÁS GUARDIOLA J.J. (Dir.) / GINER ALEGRÍA, C.A. (Coord.), Prevención, predicción y tratamiento. Condenados a penas privativas de libertad. Murcia: DM. 2011, p. 108.

1301 ZAFFARONI, E.R. / ALAGIA, A. / SLOKAR, A., Derecho Penal..., cit. p. 956. Como afirman estos autores, "los dispositivos que tienden a reducir la privación de libertad fueron desde el comienzo desconcertantes para la doctrina, por lo cual no es de extrañar que la naturaleza de la libertad condicional haya sido materia de las más encontradas opiniones. Así, se la ha considerado una rectificación de la pena, una remisión parcial a título de recompensa legal y no de gracia, o bien, una interrupción de la ejecución de la pena, que de modo tentativo reemplaza la pena por un acto de cuidado social, llegando algunos a considerarla una verdadera modificación de la sentencia. También se ha dicho que si la libertad condicional es una modalidad ejecutiva no puede sostenerse el fin expiatorio de la pena". 
de los órganos judiciales encargados de la ejecución- bajo una serie de condiciones especiales. La segunda opción es la mantenida por los sistemas continentales europeos, que conciben la libertad condicional como un beneficio penitenciario ${ }^{1302}$ que puede concederse o denegarse con amplia discrecionalidad y sobre criterios que se asientan en la observación y valoración del interno, su pronóstico de readaptación, etc. Y una tercera opción es la mantenida en países como Alemania, donde la libertad condicional se regula como una suspensión a prueba del resto de la pena, de imposición obligatoria o facultativa según los casos ${ }^{1303}$.

Las formulaciones clásicas de la libertad condicional han venido manteniendo que es una fórmula extintiva penal1304 y la doctrina viene discutiendo si se trata de una forma sustitutiva de las penas privativas de libertad, o si es una forma de cumplimiento de la pena como una fase de la ejecución penal, debido a la confusión que crea la ubicación en el CP (Capítulo III, del Título III, del Libro I), que lleva por rúbrica "De las formas sustitutivas de la ejecución de las penas privativas de libertad y de la libertad condicional", mientras que el art. 72.1 LOGP califica a la libertad condicional como una etapa de la

1302 FERNÁNDEZ GARCÍA, J., "La libertad condicional y los beneficios penitenciarios". En BERDUGO GÓMEZ DE LA TORRE, I. (Coord.), Lecciones y materiales para el estudio del Derecho penal. Tomo VI. Derecho penitenciario. Madrid: Iustel. 2010, pp. 226 a 228. Este autor -con cita de MAPELLI y TERRADILLOSconsidera que la libertad condicional es un beneficio penitenciario por cuanto que supone un acortamiento en sentido material de la pena o una reducción del tiempo de internamiento, al igual que lo serían los permisos de salida y el régimen abierto, aunque especifica que en el $\mathrm{CP}$, beneficios penitenciarios en sentido estricto únicamente son el adelantamiento de la libertad condicional y el indulto particular, lo cual no impide, en sentido amplio, considerar también un beneficio el efecto de reducción efectivo del tiempo de internamiento que implica la libertad condicional. Y directamente relacionado con lo anterior, aduce también si, partiendo de que es un beneficio penitenciario, es un derecho subjetivo o una recompensa, a lo que responde en sentido de que se trata de un derecho subjetivo condicionado al cumplimiento de unos requisitos, ya que su aplicación no es automática por la extinción de una parte de la pena, sin o que se halla supeditado al cumplimiento del resto de los requisitos, sin olvidar que aparece regulado como derecho de contenido penitenciario en el art. 4g) RP, y “también en la VII Reunión del JVP (septiembre de 1993), se estableció que: “la libertad condicional es una forma específica de cumplimiento de la condena de privación de libertad, que se configura como un derecho del interno, condicionado a que concurran los requisitos establecidos por la Ley, de manera que, cuando aquél los reúna, la Junta de Régimen y Administración del establecimiento deberá elevar al JVP el expediente correspondiente".

1303 JESCHECK, H.H., Tratado de Derecho Penal..., cit. pp. 770 y 771.

1304 Así, para LISZT, F., Tratado de Derecho penal..., cit. Tomo III, p. 425, “mediante la generosidad de la ley, se pasa de la libertad en la pena a la libertad sin pena; condicionada, naturalmente su continuidad, por la buena conducta. Es la llamada libertad condicional, esto es, libertad condicionada al cumplimiento de la condición de honradez y deberes político-penales, libertad penal, como debiera ser toda libertad política. Extinción parcial condicional de la pena". Para este autor, la libertad condicional es la fase en la que se pone de manifiesto el éxito de la corrección por el cumplimiento de una parte de la pena, lo que se traduce en el absurdo del mantenimiento de la pena determinada a priori. 
ejecución de la pena privativa de libertad ${ }^{1305}$. La mayoría de la doctrina entiende que se trata de una forma de cumplimiento de la pena ${ }^{1306}$, pero en cualquier caso se trata de una consecuencia lógica del sistema progresivo y es una figura inspirada en la finalidad resocializadora, que permite la excarcelación anticipada en la que el penado se va a ver sometido a una serie de condiciones que necesariamente deberá cumplir, y cuyo incumplimiento conlleva la revocación de la libertad condicional y el retorno a prisión. LANDROVE DíAZ la define como "el último período de los regímenes penitenciarios progresivos, en el que el liberado sigue siendo técnicamente un penado, aunque su vida trascurra en libertad efectiva, solo recortada en algunos sistemas por la vigilancia y sujeción a determinadas restricciones y, en todo caso, sujeta a la condición de buen comportamiento hasta el momento de pronunciarse el licenciamiento definitivo"1307. La finalidad que se persigue al permitir ese cumplimiento en libertad de una porción de la pena, es evitar la desocialización, la destrucción de la persona como ser social y en muchos casos evitar los efectos perversos que pueden producir en el sujeto las penas excesivamente largas y que afectan directamente a su personalidad, produciendo síntomas como la reducción de funciones vitales, desarrollo patológico de la personalidad, regresión a estadios infantiles, etc. ${ }^{1308}$

1305 Art. 72. 1. “Las penas privativas de libertad se ejecutarán según el sistema de individualización científica, separado en grados, el último de los cuales será el de libertad condicional, conforme determina el Código Penal".

1306 Aspecto por el que se inclinan GRACIA MARTIN, L. / ALASTUEY DOBÓN, M.C., “La ejecución de las penas privativas de libertad". En GRACIA MARTIN, L., (Coord.), Tratado de Consecuencias Jurídicas del delito. Valencia: Tirant lo Blanch. 2006, p. 367, puesto que la figura tiene eminente naturaleza jurisdiccional; y GARCÍA ARÁN afirma que el concepto estricto de sustitutivo se limita a las figuras que evitan el ingreso en prisión -que son únicamente la suspensión y la sustitución de la pena- y además, la rúbrica separa las formas sustitutivas de la libertad condicional porque menciona ambas, lo permite considerar a la libertad condicional como una institución distinta a las formas sustitutivas propiamente, aparte de que cuando se acuerda la libertad condicional la pena no se sustituye sino que se sigue cumpliendo de forma distinta, tal y como indica el art. $192 \mathrm{RP}$ “los penados clasificados en tercer grado que reúnan los demás requisitos establecidos al efecto en el Código Penal cumplirán el resto de su condena en situación de libertad condicional, conforme a lo dispuesto en dicho Código", por lo que la libertad condicional no supone un acortamiento de la condena, ya que no se dará por cumplida hasta que se extinga todo el tiempo que aparece fijado en la sentencia. Vid. GARCÍA ARÁN, M., “De las penas...", cit. pp. 751 y 752. Por su parte, ORTS BERENGUER y GONZÁLEZ CUSSAC indican que "se trata de una forma de cumplir la condena, que el Código Penal regula en un lugar erróneo junto a las formas sustitutivas, con las que nada tiene que ver". Vid. ORTS BERENGUER, E. / GONZÁLEZ CUSSAC, J.L., Compendio..., cit. p. 480. En el mismo sentido SÁNCHEZ YLLERA, I., en VIVES ANTÓN, T.S., (Coord.), Comentarios al Código Penal de 1995. Vol. I. Valencia: Tirant lo Blanch. 1996, p. 511.

1307 LANDROVE DÍAZ, G., Las consecuencias..., cit. p. 69. “De ahí, precisamente, la terminología de "condicional" con que se recoge en los sistemas latinos, o "bajo palabra" en los anglosajones".

1308 MAPELLI CAFFARENA, B. / TERRADILLOS BASOCO J.M., Las consecuencias..., cit. p. 69. No obstante, conviene tener presente que desde la STS de 4 de junio de 2010, se reconoce la responsabilidad patrimonial de la administración penitenciaria por los daños que pueda causar un penado cuando sale en libertad condicional, debido a que no existe un deber jurídico del perjudicado de soportar los perjuicios causados por el penado y porque los riesgos objetivamente derivados de la libertad condicional los debe asumir la sociedad y no el particular que resulta perjudicado "porque así lo impone la función de resocialización propia de la 


\section{REGULACIÓN LEGAL}

Actualmente la libertad condicional se encuentra regulada en una pluralidad de textos legales, y ello puede explicarse por la diversidad de aspectos que deben tenerse en cuenta para su aplicación. Así, su regulación en el CP la encontramos en la Sección Tercera, del Título III, del Capítulo III, del libro I, arts. 90 a 93. En cuanto la perspectiva del tratamiento penitenciario, la libertad condicional se encuentra regulada en la LOGP como la última fase de tratamiento en el art. 72.1, y en cuanto a la vertiente administrativa de la libertad condicional, se encuentra en el Capítulo I, del Título VIII, del Reglamento Penitenciario, arts. 192 y siguientes ${ }^{1309 / 1310 .}$

pena que establece la propia Constitución y los compromisos internacionales asumidos por España, de modo que deben ser compartidos en virtud del principio de solidaridad por el conjunto de la sociedad". Vid. DE MARCOS MADRUGA, F., "De la libertad condicional”. En GÓMEZ TOMILLO, M., (Dir.), Comentarios al Código Penal. Valladolid: Lex Nova. 2010, p. 410.

1309 Conviene tener presente que la regulación del CP fue notablemente reformada por LO 7/2003, que modificó los arts. 90, 91 y 93 CP; y la LO 15/2003 (en menor medida) que modificó el art. 92 y la rúbrica de la Sección Tercera, del Título III, del Capítulo III, del libro I CP, que pasó a denominarse: "De las formas sustitutivas de la ejecución de las penas privativas de libertad y de la libertad condicional". Reforma muy profunda que el legislador justificó en la Exposición de Motivos de la LO 7/2003, diciendo que se trata de garantizar la seguridad jurídica del art. 9.3 CE, concretado en el derecho a conocer con certeza cuál es la forma en que se van a aplicar las penas y en qué se va a traducir en la práctica la sanción impuesta. La Exposición de Motivos de la LO 7/2003 vino a decir que: "El ciudadano tiene derecho a saber con certeza jurídica qué es delito o falta y qué no lo es. El mismo derecho tiene a saber cuál es la pena que le corresponde a la acción tipificada en la norma penal como delito o falta. Consecuencia lógica de estos derechos y exigencia necesaria del principio de seguridad jurídica que rige nuestro ordenamiento, es el derecho del ciudadano a conocer con certeza cuál es la forma en la que se van a aplicar las penas, a saber, en definitiva, en qué se va a traducir en la práctica la pena o sanción impuesta. La realidad diaria y la experiencia ponen de manifiesto cómo en el cumplimiento de las penas existen amplios ámbitos de discrecionalidad, ámbitos variables en los que resulta oportuno, según la mejor doctrina, establecer reglas para hacer un pronóstico más certero de la pena a cumplir. Esta Ley Orgánica se dirige a perfeccionar el ordenamiento jurídico con el fin de concretar la forma del cumplimiento de las penas para conseguir que se lleve a cabo de manera íntegra y efectiva y, en consecuencia, dar mayor protagonismo al principio de seguridad jurídica en esta materia, siempre desde el escrupuloso respeto a los principios contenidos en el art. 25 CE". (La cursiva es mía). Se trata, pues, de aspectos que "revelan este uso inverso del principio de seguridad jurídica, convertido en coartada al servicio de una involución penal y penitenciaria hecha a espaldas a la realidad y a las exigencias propias de una política penal democrática". Vid. TAMARIT SUMALLA, J.M., en TAMARIT SUMALLA, J.M. / GARCÍA ALBERO, R., La reforma..., cit. p. 93. Una cuestión relevante sobre la reforma es la relativa a la aplicación retroactiva de la redacción dada por la LO 7/2003 a los arts. 90 y $93.2 \mathrm{CP}$, esto es, a los requisitos para su concesión y para la revocación en casos de terrorismo, al igual que para los arts. 72.5 y 6 LOGP, sobre la clasificación en tercer grado, ya que la Disposición Transitoria Unica de la LO 7/2003 vino a disponer que "será aplicable a las decisiones que se adopten sobre dichas materias desde su entrada en vigor, con independencia del momento de comisión de los hechos delictivos o de la fecha de la resolución en virtud de la cual se esté cumpliendo la pena". Esta previsión estableció una aplicación retroactiva de disposiciones no favorables, con la consecuente colisión frontal con el art. 9.3 CE, que proscribe la retroactividad de disposiciones no favorables o restrictivas de derechos individuales. Vid. GARCÍA ARÁN, M., “De las penas...", cit. p. 758; y concluye el informe diciendo que "por ello no está prohibida constitucionalmente la aplicación de la nueva ley, aunque sea una ley desfavorable, cuando no se trata de retroactividad auténtica, sino sólo de retrospección". Vid. informe CGPJ, pág. 37. Sobre este particular, en relación a lo que el referido informe adujo sobre la posibilidad de aplicación retroactiva de preceptos procesales o de índole procesal cuando no son favorables, hemos de manifestar que la doctrina viene afirmando que la retroactividad de la ley más favorable se extiende también a la ley procesal. Vid. JAKOBS, G., Derecho penal..., cit. p. 115. Este autor manifiesta que 
"el principio de legalidad, y con él la prohibición de retroactividad, debe llegar allí donde sea necesaria la garantía de objetividad. Por eso la prohibición no termina ante el Derecho procesal. [...] El en Derecho procesal cabe aceptar la retroactividad -paralelamente al declive de taxatividad legal desde la Parte Especial a la teoría de la imputación de la Parte General- con más facilidad cuando afecte a los delitos y por eso no pueda aprovecharse (o sólo con dificultad) para practicar manipulaciones. Desde luego, las normas procesales especiales para delitos concretos no se podrán introducir retroactivamente". Si durante la tramitación del proceso hay aspectos en la ley que benefician a quien soporta la carga del proceso, que debe ser titular de los derechos subjetivos que los cambios en el proceso le reportan. Vid. IGLESIAS RÍO, M.A., "Algunas reflexiones sobre retro-irretroactividad de la ley penal. A propósito de las últimas reformas del Código penal". En Revista jurídica de Castilla y León, núm. 6. Mayo de 2005, p. 32. Explica este autor que "sólo el caso de las normas procesales referidas a cuestiones exclusivamente rituarias (v.gr. modificación de plazos para interponer un recurso de apelación) escaparía al principio de irretroactividad. Muy al contrario, las normas relativas a los plazos de acceso al régimen de semilibertad y a la libertad condicional no poseen una naturaleza procesal sino prioritariamente de carácter sustantivo, pues redundan en una ampliación o restricción de la libertad y, además, prevalece su finalidad resocializadora, en conexión con los postulados constitucionales". Interpretación que descansa sobre la idea de seguridad jurídica. Ibidem, $p$. 22. Señala este autor que "de hecho, lo que más seguridad aporta es una aplicación sin fisuras del principio -acuñado por la doctrina alemana decimonónica- tempus regit actum. Incluso, el imperativo que acompaña al valor de la seguridad jurídica, entendida como certeza, impone algún límite a la aplicación de la retroactividad más beneficiosa aun a pesar de la generosa cláusula del art. 2.2 CP. Tal es el caso de las penas de multas ya satisfechas: aun cuando la ley penal posterior contemplara una pena de multa de inferior cuantía, ello no se traduce en la devolución de multas ya ingresadas en el Tesoro Público". De ese modo, se viene afirmando que no podrá aplicarse una regulación procesal nueva a quienes se hallen cumpliendo condena cuando suponga una nueva restricción en sus derechos individuales no previstos en la anterior regulación, como v.g., la incorporación de nuevos requisitos procesales para formalizar la solicitud del acceso a la libertad condicional, la supresión de recursos en materia de ejecución penitenciaria, etc., en cuyo caso debería mantenerse la regulación anterior si era más beneficiosa para el penado por imperativos del principio de irretroactividad. Ibidem, pp. 34 y 35. Y al revés: si los requisitos procesales para la solicitud del acceso a la libertad condicional se suavizan, o se establecen nuevos mecanismos procesales que confieren mayores derechos subjetivos para la defensa de sus intereses en el seno de la ejecución de la pena, quien está cumpliendo condena podrá beneficiarse de la nueva regulación.

1310 Por otra parte, IGLESIAS RÍO señala que la STC 20/2003, de 10 de febrero, “declara que para determinar cuál es la ley penal más favorable han de ser comparados no sólo los marcos penales, sino la totalidad de las previsiones de una y otra ley, haciéndose referencia expresa en este pronunciamiento a los sustitutivos penales y a los beneficios penitenciarios aplicables al caso. Así, las cuestiones que afectan al quantum de la pena o a los derechos adquiridos están sometidos al principio de legalidad y a la no retroactividad más perjudicial. En conclusión, la determinación de la ley más favorable no podrá ser el fruto de una comparación "abstracta" de los tipos y de las amenazas penales, sino que lo decisivo es la ley que, en el "caso concreto", permita imponer la menor condena posible, para lo que habrá de tenerse en cuenta la regulación legal global relevante con respecto al hecho concreto, como pueden ser las modificaciones para la suspensión condicional de la pena, acceso al régimen abierto y de libertad condicional, sustitutivos penales, etc." Vid. IGLESIAS RÍO, M.A., "Algunas reflexiones sobre retro-irretroactividad...", cit. pp. 26 y 27. En ese orden de cosas, la Disposición Transitoria Única de la LO 7/2003 es inconstitucional según una parte de la doctrina por infracción de los arts. 9.3 y 25.1 CE, vid. CEREZO MIR, J., Curso de derecho penal (I)..., cit. p. 220; y al menos de discutible constitucionalidad por otro sector (vid. VIDALES RODRÍGUEZ, C., “La libertad condicional y la retroactividad de las disposiciones que la regulan. Razones para un debate acerca de su posible inconstitucionalidad". En Revista de Derecho Penal, núm. 12. 2004, p. 104; BERDUGO GÓMEZ DE LA TORRE, I. / ARROYO ZAPATERO, L. / FERRÉ OLIVÉ, J.C. / GARCÍA RIVAS, N. / SERRANO PIEDECASAS, J.R., / TERRADILlOS BASOCO, J.M., Curso de Derecho Penal..., cit. p. 58; IGLESIAS RÍO, M.A., “Algunas reflexiones sobre retro-irretroactividad...", cit. p. 31, nota al pie 45), en especial GARCÍA ALBERO, afirma que no es convincente el argumento que considera que las normas de clasificación y libertad condicional son ajenas al Derecho penal material y que pertenecen al Derecho procesal de ejecución extrayéndolas de la cobertura del art. 25.1 de la CE, y a tal efecto manifiesta que "por encima de artificiosas distinciones clasificatorias, no está ni mucho menos claro que el artículo 25.1 proyecte sus efectos exclusivamente al Derecho penal sustantivo supuesto que ambas instituciones no pertenezcan a él-, y que por "disposiciones sancionadoras" (término expresamente manejado en el art. 9.3 CE) haya que excluir a las de naturaleza procesal, cuando, y esto es lo decisivo, conciernen directamente al estatuto de la libertad como derecho fundamental. De lo contrario no se entendería por qué precisan tales materias ser reguladas por Ley Orgánica, lo cual nadie discute, al constituir desarrollo del derecho a la libertad. El informe de la mayoría del Consejo trata así de extrapolar una doctrina forjada fundamentalmente en torno a las situaciones de los funcionarios, para proyectarla a los internos de los centros penitenciarios. [...] Desde tal perspectiva, la disposición transitoria única ha de reputarse 
inconstitucional". vid. GARCÍA ALBERO, R., en TAMARIT SUMALLA, J.M. / GARCÍA ALBERO, R., La reforma..., cit. TOL. 519.285, p. 7 y 8. Este autor manifiesta que "por otro lado, sostener que la "ejecución de la pena" no forma parte del contenido material de la pena misma, contradice el entendimiento mayoritario de la naturaleza del derecho de ejecución penal, y nada por lo demás contracorriente con la filosofía que inspira la ley misma, cuando vincula nada más y nada menos al principio de proporcionalidad y seguridad jurídica, como se verá, el nuevo arsenal de medidas. En efecto, si conforme a la Exposición de motivos de la Ley, se trata de que el ciudadano conozca con suficiente anticipación el cumplimiento "real" de las condenas, si se trata en suma de satisfacer el principio de proporcionalidad entre la gravedad del ilícito cometido y la pena impuesta, entendiendo por ésta no sólo la condena nominal, sino su efectivo cumplimiento, ¿cómo afirmar luego que dichas medidas son sólo de naturaleza procedimental y ajenas al nulla poena sine praevia lege? Definitivamente, los argumentos en pro de la retrospección de la nueva ley no logran convencer, y por lo demás aparecen contradichos por precedentes históricos análogos, como el tratamiento dispensado a la desaparecida redención de penas por el trabajo con el advenimiento del Código Penal de 1995". IGLESIAS RÍO, M.A., "Algunas reflexiones sobre retro-irretroactividad...", cit. p. 35, afirma que toda decisión judicial que afecte al régimen de ejecución penitenciaria, pertenece al ámbito de la individualización judicial de la pena, por lo que los criterios que deben regir para su determinación requieren que justificaciones basadas en criterios penales de naturaleza sustantiva y no adjetiva-procesal, en especial por la afección a la libertad -derecho fundamental- que comporta repercusiones significativas en el tiempo en que el penado va a permanecer privado de libertad. Este autor manifiesta que la prohibición de aplicación retroactiva de las disposiciones no favorables es un elemento del principio de legalidad cuya finalidad es la materialización de la seguridad jurídica, que se traduce en "la calculabilidad de las consecuencias del delito, la previsibilidad de la duración de la condena en el momento de ser dictada la sentencia, así como cualquier otra condición de excarcelación". Por ese motivo es inconstitucional la aplicación retroactiva de una ley que reduce los beneficios penitenciarios o que amplía el cómputo global del cumplimiento total de la condena, aspecto que además supone aplicar una norma a un supuesto concreto que en el momento de producirse los hechos era inexistente. Por su parte, VIDALES RODRÍGUEZ, C., “La libertad condicional...", cit. pp. 105 y 106, afirma que las garantías del principio de legalidad no deben proyectarse sólo sobre los presupuestos de la infracción penal, sino sobre todos los elementos de los que pueda deducirse una condena penal o que puedan desplegar efectos sobre ella; y -con cita de la STC 21/1993, de 18 de enero- afirma que el principio de irretroactividad de la ley penal se identifica con el de legalidad y con una garantía que asiste a cualquier persona que consiste en que no pueda ser "sorprendido a posteriori" con nuevas calificaciones jurídicas de los hechos delictivos o con sanciones penales no prevista o de mayor gravedad que las vigentes en el momento en que se cometió el hecho. La permanencia en prisión por más tiempo del legalmente establecido en el momento de la sentencia es una prolongación de la condena que implica un incremento del castigo inicial. Si la seguridad jurídica es una expectativa razonablemente fundada del ciudadano en saber cómo va aplicarse el Derecho, en este caso opina esta autora- no nos encontramos ante una "esperanza ilusoria del condenando, sino en una expectativa que trae causa en las exigencias legales vigentes al dictar sentencia". Y con cita de la STC 20/2003, de 10 de febrero, por la que el alto tribunal vino a decir -con referencias expresas a los sustitutivos penales y a los beneficios penitenciarios- que en la aplicación de la ley penal más favorable han de ser comparados tanto los marcos penales como todas las demás previsiones de una y otra ley, por lo que con más motivo habrán de ser observados también los aspectos relativos a la libertad condicional. El principio de legalidad es un límite al ejercicio estatal del ius puniendi que se traduce en una garantía del ciudadano frente a la constitucionalmente proscrita arbitrariedad de los poderes públicos, pero que no ha sido esa la lectura del principio que ha llevado a cabo el legislador en la reforma operada mediante la LO 7/2003, por cuanto que "se subvierte el significado del principio de legalidad", ya que Exposición de Motivos de la norma lo concibe como un derecho de los ciudadanos no delincuentes a que las penas se ejecuten, e igual suerte asiste al principio de seguridad jurídica, que arrincona los fines constitucionales de la pena de prisión. Según la opinión de esta autora, llevar a cabo un sacrificio de la legalidad para la conseguir una mayor eficacia contra la criminalidad grave, es un error que la Historia viene demostrando, y que no es aceptable que este tipo de reformas invoquen el principio de legalidad como garantía de la seguridad jurídica, a lo que añade que "mayor burla es inconcebible". Ibidem, pp. 107 y 108. Si la libertad condicional y el tercer grado de tratamiento penitenciario persiguen un fin muy concreto que se traduce en el favorecimiento de la reinserción, no debería valorarse a los efectos de su concesión ningún otro aspecto que no fuese el pronóstico favorable de reinserción, y mucho menos deberían tener cabida a estos efectos "factores ajenos a los requisitos legalmente establecidos en el momento en que se produjo la sentencia”. Ibidem, p. 110. Finalmente, concluye esta autora que según la STC 27/1981, de 20 de julio, la seguridad jurídica es la suma de los principios de certeza, legalidad, jerarquía y publicidad normativa, irretroactividad de lo no favorable e interdicción de la arbitrariedad, todo ello encaminado a la promoción de la justicia e igualdad en libertad; y la LO 7/2003 no contribuye precisamente a la pretendida certeza tal y como hace creer la Exposición de Motivos, por todo ello, "con tanta reforma y contrarreforma el ciudadano puede estar bien seguro [...] de que el delincuente no va a saber cuál es la ley aplicable y las consecuencias 
Y entrando en el análisis de su regulación, lo primero que hay que delimitar es el ámbito de aplicación, que no queda reducido únicamente a la pena de prisión, sino también se extiende a la responsabilidad personal subsidiaria por impago de multas 1311 del art. $35 \mathrm{CP}^{1312}$, pero en relación a la pena de localización permanente del art. $37 \mathrm{CP}$, que también aparece enumerada como pena privativa de libertad en el art. $35 \mathrm{CP}^{1313}$, no le es aplicable la libertad condicional por imposibilidad material de cumplimiento del primer requisito, previsto en el art. 90.1.a), consistente en encontrarse en tercer grado de tratamiento penitenciario ${ }^{1314}$.

legales de su actuar, a no ser que esté dotado de adivinación o que esté asesorado por quien sea capaz de vaticinar lo que el futuro legislativo pueda depararnos". Ibidem, p. 113.

1311 Sobre esta pena vid. BAUCELLS LLADÓS, J., “De las penas”. En CÓRDOBA RODA, J. / GARCÍA ARÁN, M., (Dirs.), Comentarios al Código Penal. Parte General. Madrid: Marcial Pons. 2011, pp. 541 a 554.

1312 CORCOY BIDASOLO, M. / MIR PUIG, S., Comentarios..., cit. p. 173. Estos autores señalan que “la responsabilidad personal subsidiaria es una pena privativa de libertad (art. 35). Por lo tanto, podrá suspenderse se ejecución (arts. 80 a 87), o cumplirse ininterrumpidamente en un establecimiento penitenciario (cfr. art. 88.3), será de aplicación la legislación penitenciaria, podrá refundirse con otras penas privativas de libertad, le será abonable el tiempo de privación de libertad sufrido preventivamente (art. 58), y deberá figurar en el fallo de la sentencia". Sobre este particular, algunos autores se han pronunciado en contra, aduciendo que esta pena no está orientada a la reinserción, sino que su razón de ser radica en el impago de una pena de multa que se sustituye por privación de libertad en prisión, por lo que sería incompatible con la finalidad resocializadora de la libertad condicional. Vid. SERRANO BUTRAGUEÑO, I., en SERRANO BUTRAGUEÑO, I., (Coord.), Código Penal de 1995. Comentarios y jurisprudencia. Granada: Comares. 1998, p. 769. Sin embargo, la mayoría de autores argumentan que es aplicable también a esta pena. Vid. ORTS BERENGUER, E. / GONZÁLEZ CUSSAC, J.L., Compendio..., cit. p. 480; LANDECHO VELASCO C.M. / MOLINA BLÁZQUEZ, C., Derecho Penal..., cit. p. 577, porque aunque el art. 90.1 CP refiere a la pena privativa de libertad en singular, no impide que se aplique a otras penas privativas de libertad (en ese sentido SÁNCHEZ YLLERA aduce que precisamente con la entrada en vigor del CP de 1995, desapareció el límite mínimo de duración de las penas a las que podía ser aplicable la libertad condicional tal y como se entendía esta figura en la legislación derogada (que imponía como requisito la existencia de condena a pena privativa de libertad de más de un año), toda vez que el nuevo texto punitivo reconduce su ámbito de aplicación a cuando el sujeto haya sido condenado a pena privativa de libertad en sentencia firme, evitando así todos los problemas suscitados en torno a si las penas cortas o las sanciones de distinta naturaleza como el arresto sustitutorio, podían ser objeto de aplicación de esta figura. Vid. SÁNCHEZ YLLERA, I., en VIVES ANTÓN, T.S., (Coord.), Comentarios..., cit. p. 512), porque de lo contrario el CP habría hecho mención expresa a que es aplicable a la pena de prisión, excluyendo así las demás. Vid. GARCÍA ARÁN, M., "De las penas...”, cit. p. 754. También se argumenta que no es posible privar del fin resocializador a la responsabilidad personal subsidiaria por impago de multas y que, excluir la libertad condicional en esta pena, podría suponer en algunos casos que las personas condenadas a prisión más multa que se sustituya por responsabilidad personal subsidiaria en caso de impago, a pesar de estar disfrutando de libertad condicional, tendrían que regresar a prisión tras la extinción de aquélla. Vid. TÉBAR VILCHES, B., "El modelo de libertad condicional español”. En Revista Aranzadi de Derecho y Proceso penal, núm. 15. Navarra: Aranzadi. 2006, p. 127.

1313 Sobre la localización permanente vid. TORRES ROSELL, N., “Contenido y fines de la pena de localización permanente". En InDret. Revista para el análisis del Derecho. 1/2011. Barcelona: 2011, pp. 2 a 26.

1314 CERVELLÓ DONDERIS, V., Derecho Penitenciario..., cit. p. 250, ya que la libertad condicional en sí misma aparece vinculada a los grados de ejecución penitenciaria que no son predicables respecto de la localización permanente. Vid. GARCÍA ARÁN, M., “De las penas...”, cit. p. 755. 


\section{a) Requisitos}

Son cuatro los requisitos que necesariamente deben concurrir para el acceso a la libertad condicional1315:

$1^{\circ}$. Que el penado se encuentre en tercer grado de tratamiento penitenciario. Es decir, que previamente debe haber superado el filtro de la clasificación prevista en los arts. $36.2 \mathrm{CP}$ (periodo de seguridad) ${ }^{1316}$ y $72.5^{1317}$ y 61318 de la LOGP, y encontrarse en el denominado

1315 Vid. FERRER GUTIÉRREZ, A., Manual práctico sobre ejecución penal y Derecho penitenciario. Doctrina, jurisprudencia y formularios. Valencia: Tirant lo Blanch. 2011, pp. 337 a 340.

1316 Art. 36.2 “Cuando la duración de la pena de prisión impuesta sea superior a cinco años, el Juez o Tribunal podrá ordenar que la clasificación del condenado en el tercer grado de tratamiento penitenciario no se efectúe hasta el cumplimiento de la mitad de la pena impuesta.

En cualquier caso, cuando la duración de la pena de prisión impuesta sea superior a cinco años y se trate de los delitos enumerados a continuación, la clasificación del condenado en el tercer grado de tratamiento penitenciario no podrá efectuarse hasta el cumplimiento de la mitad de la misma:

a. Delitos referentes a organizaciones y grupos terroristas y delitos de terrorismo del Capítulo VII del Título XXII del Libro II de este Código.

b. Delitos cometidos en el seno de una organización o grupo criminal.

c. Delitos del artículo 183.

d. Delitos del Capítulo V del Título VIII del Libro II de este Código, cuando la víctima sea menor de trece años.

El Juez de Vigilancia, previo pronóstico individualizado y favorable de reinserción social y valorando, en su caso, las circunstancias personales del reo y la evolución del tratamiento reeducador, podrá acordar razonadamente, oídos el Ministerio Fiscal, Instituciones Penitenciarias y las demás partes, la aplicación del régimen general de cumplimiento, salvo en los supuestos contenidos en el párrafo anterior".

1317 Art. 72.5. "La clasificación o progresión al tercer grado de tratamiento requerirá, además de los requisitos previstos por el Código Penal, que el penado haya satisfecho la responsabilidad civil derivada del delito, considerando a tales efectos la conducta efectivamente observada en orden a restituir lo sustraído, reparar el daño e indemnizar los perjuicios materiales y morales; las condiciones personales y patrimoniales del culpable, a efectos de valorar su capacidad real, presente y futura para satisfacer la responsabilidad civil que le correspondiera; las garantías que permitan asegurar la satisfacción futura; la estimación del enriquecimiento que el culpable hubiera obtenido por la comisión del delito y, en su caso, el daño o entorpecimiento producido al servicio público, así como la naturaleza de los daños y perjuicios causados por el delito, el número de perjudicados y su condición.

Singularmente, se aplicará esta norma cuando el interno hubiera sido condenado por la comisión de alguno de los siguientes delitos:

a. Delitos contra el patrimonio y contra el orden socioeconómico que hubieran revestido notoria gravedad y hubieran perjudicado a una generalidad de personas.

b. Delitos contra los derechos de los trabajadores.

c. Delitos contra la Hacienda Pública y contra la Seguridad Social.

d. Delitos contra la Administración pública comprendidos en los capítulos V al IX del título XIX del libro II del Código Penal".

1318 Art. 72.6. “Del mismo modo, la clasificación o progresión al tercer grado de tratamiento penitenciario de personas condenadas por delitos de terrorismo de la sección segunda del capítulo V del título XXII del libro II del Código Penal o cometidos en el seno de organizaciones criminales, requerirá, además de los requisitos previstos por el Código Penal y la satisfacción de la responsabilidad civil con sus rentas y patrimonio presentes y futuros en los términos del apartado anterior, que muestren signos inequívocos de haber abandonado los fines y los medios terroristas, y además hayan colaborado activamente con las autoridades, bien para impedir la producción de otros delitos por parte de la banda armada, organización o grupo terrorista, bien para atenuar los efectos de su delito, bien para la identificación, captura y procesamiento de responsables de delitos terroristas, para obtener pruebas o para impedir la actuación o el desarrollo de las 


\section{régimen abierto1319. La clasificación es "el conjunto de actuaciones de la Administración}

Penitenciaria que concluyen en una resolución que atribuye al penado un grado de

organizaciones o asociaciones a las que haya pertenecido o con las que haya colaborado, lo que podrá acreditarse mediante una declaración expresa de repudio de sus actividades delictivas y de abandono de la violencia y una petición expresa de perdón a las víctimas de su delito, así como por los informes técnicos que acrediten que el preso está realmente desvinculado de la organización terrorista y del entorno y actividades de asociaciones y colectivos ilegales que la rodean y su colaboración con las autoridades".

1319 Con carácter previo, conviene hacer referencia a la clasificación penitenciaria, que es sin duda una de las cuestiones más relevantes del sistema progresivo en el que el penado va accediendo paulatinamente a cuotas de libertad a medida que avanza en su tratamiento y mejora su pronóstico de reinserción, y tras una clasificación inicial del penado, se debe proceder a determinar la fase de tratamiento que le corresponda. Según el art. 59 LOGP: "1. El tratamiento penitenciario consiste en el conjunto de actividades directamente dirigidas a la consecución de la reeducación y reinserción social de los penados. 2. El tratamiento pretende hacer del interno una persona con la intención y la capacidad de vivir respetando la Ley penal, así como de subvenir a sus necesidades. A tal fin, se procurará, en la medida de lo posible, desarrollar en ellos una actitud de respeto a sí mismos y de responsabilidad individual y social con respecto a su familia, al prójimo y a la sociedad en general". El tratamiento es el conjunto de actividades dirigidas a conseguir la reeducación y reinserción social de los penados (art. 59.1 LOGP) y pueden consistir en cualquier ayuda de tipo médico, psiquiátrico, psicológico, pedagógico, laboral o social siendo su límite el respeto a los derechos constitucionales no afectados por la condena (art. 60.2 LOGP), Vid. CERVELLÓ DONDERIS, V., Derecho penitenciario..., cit. TOL. 1.020.789, p. 1. Como indica esta autora, “con lo cual quedarían proscritos aquellos que anulan la personalidad (por ej. el conductismo más agresivo) o los que puedan suponer una agresión física (por ej. la castración)". Con la finalidad de que el interno sea una persona con la intención y capacidad de vivir respetando la ley y subvenir a sus necesidades. Bajo esta concepción del tratamiento subyace la pretensión resocializadora que se dirige a las interrelaciones sociales del interno a través de la formación, la cultura, el deporte y el trabajo e incluso hacia la propia institución con la mejora de sus medios materiales y humanos, lo que se comprueba precisamente los preceptos de la LOGP (art. 110) y del RP cuando enumera sus objetivos, que son: diseñar programas formativos para desarrollar las aptitudes de los internos, para enriquecer sus conocimientos, mejorar su capacidad profesional y compensar sus carencias, con el fin de mejorar la preparación cultural y profesional de los internos; la utilización de técnicas psicosociales para mejorar la capacidad de los internos trabajando sobre los problemas que hubieran podido influir en la conducta delictiva, que se trata de una actuación sobre las carencias concretas que tenga el interno en el plano personal como pueda ser una personalidad agresiva, o intervenciones sociales para el entrenamiento en habilidades sociales; potenciar los contactos del interno con el exterior, lo que para un sector de la doctrina "es donde se recoge verdaderamente la finalidad actual del tratamiento ya que se trata de acercar al recluso al mundo exterior implicando directamente a la sociedad en la acogida y aceptación de éste". Ibidem, p. 2. Esta autora explica que "la importancia del tratamiento en la vida carcelaria depende en gran medida de su relación con el régimen, en este sentido la LOGP se encuentra en un punto medio, ya que aunque regula el tratamiento y el régimen en títulos separados, subordina las funciones regimentales a las exigencias de tratamiento. Esto se debe a la declaración de la reeducación y reinserción social como fines primordiales a través del tratamiento, lo que convierte al régimen en un medio y no un fin en sí mismo (art. 71.1 LOGP) exigiéndose para ello una debida coordinación (art. $73.3 \mathrm{RP}$ ). El cumplimiento de tal propósito se debería reflejar en ejemplos concretos como pueda ser permitir el aplazamiento de un traslado para no interrumpir una actividad de tratamiento o incluso suspender el cumplimiento de una sanción por los mismos motivos, sin embargo, si en tales casos el orden y la seguridad imperan, ni el traslado ni la sanción anterior serían evitables por ser necesarios para el interés preponderante". El tratamiento penitenciario tiene dos características principales: la voluntariedad, en la medida de que ningún interno puede ser obligado a recibir el tratamiento penitenciario pero sí es un derecho del que goza en todo momento. Ibidem, pp. 2 y 3. Sigue diciendo esta autora que "se trata de un derecho y en ningún caso de una obligación. Esto da lugar a que la Ley Penitenciaria declare que "se fomentará que el interno participe en la planificación y ejecución de su tratamiento" (art. 61.1 LOGP) y el Reglamento que "se estimulará la participación" (art. $112 \mathrm{RP}$ ), declarando a continuación en el $\mathrm{n}^{\circ} 3$ del mismo artículo que el interno podrá rechazar libremente o no colaborar en la realización de cualquier técnica de estudio de su personalidad, sin que tenga consecuencias disciplinarias ni regimentales. Quizá en esta afirmación falta una referencia más explícita al rechazo a cualquier método de tratamiento como se hacía en el anterior Reglamento. La única excepción a la voluntariedad es el supuesto de la enseñanza obligatoria de los estudios básicos (art. 122.2 RP) lo que no ha de entenderse como una concesión al empleo de medios coactivos para conseguir dicho propósito, sino a la motivación y el estímulo para la participación del interno. Esto significa que su rechazo no puede provocar la imposición de sanciones, ni la regresión de grado, ni el uso de medios coercitivos, sin embargo el hecho de que su aceptación y colaboración activa sí tenga efectos positivos como el 
tratamiento -clasificación inicial- o bien cambia uno que se le había asignado anteriormente -progresión o regresión-, y que determina el establecimiento penitenciario de destino"1320. Así, la clasificación en grado es la concreción del sistema progresivo, que conduce al penado hacia la libertad plena mediante la atribución de mayor responsabilidad y libertad en cada fase, de forma que juega un papel vital la confianza en el interno ${ }^{1321}$ (art. 65.2 LOGP) ${ }^{1322}$. El tratamiento se divide en tres grados en los que interno puede ser clasificado:

El primer grado corresponde al régimen cerrado ${ }^{1323}$, se caracteriza porque los reclusos están sometidos a un régimen penitenciario más duro que el resto, por ende, excepcional, que se basa en la peligrosidad extrema del interno que puede desprenderse de la gravedad de los delitos cometidos, de la peligrosidad criminal o de la gravedad de las conductas de su vida en convivencia dentro de la prisión que impliquen peligrosidad de convivencia interna; y en su manifiesta inadaptación a otros regímenes internos, que puede desprenderse de la reiteración en la comisión de faltas disciplinarias graves y muy graves,

acceso a los beneficios penitenciarios, da lugar a concluir que no es tan voluntario como la propia legislación expresa"; y la generalización, lo que significa que ningún interno queda excluido de ser admitido en tareas de tratamiento. Está informado por los principios previstos en el art. 62 LOGP, de estudio científico de la personalidad del interno, que implica que se ha de analizar el temperamento, carácter, aptitudes y actitudes o las motivaciones para poder determinar la personalidad del sujeto; diagnóstico de personalidad criminal y juicio pronóstico, que consiste en emitir un informe en el que para calificar la criminalidad del sujeto y los pronósticos de futuro se tengan en cuenta datos de su actividad delictiva y del entorno familiar o social que le rodea. El principio de individualización implica el carácter subjetivo y personal del tratamiento en función de las características personales del interno. El tratamiento es en sí mismo complejo, porque supone utilizar varios métodos coordinados y evitar por tanto su simplificación; será programado, porque deberá ajustarse a un plan general; y por último, será continuo y dinámico, porque la evolución del interno requiere que el tratamiento se vaya revisando durante la condena y se compruebe su evolución a efectos de la clasificación de interno en los grados que correspondan a su pronóstico de reinserción.

1320 ZÚÑIGA RODRÍGUEZ, L., “El tratamiento penitenciario...”, cit. p. 162.

1321 GARCÍA ALBERO, R., en TAMARIT SUMALLA, J.M. / GARCÍA ALBERO, R., La reforma..., cit. TOL 519.286 , p. 5. “La clasificación no consiste en otra cosa que en asignar al penado el régimen de vida más idóneo a las exigencias derivadas de su programa de tratamiento, por definición individualizado al depender de variables personales -Cfr. Art. 63 LOGP y 102.2 RP-".

1322 Art. 65. 2. "La progresión en el tratamiento dependerá de la modificación de aquellos sectores o rasgos de la personalidad directamente relacionados con la actividad delictiva; se manifestará en la conducta global del interno y entrañará un acrecentamiento de la confianza depositada en el mismo y la atribución de responsabilidades, cada vez más importantes, que implicarán una mayor libertad".

1323 El régimen cerrado es el más restrictivo (art. 10 LOGP) y está destinado a los internos que son extremadamente peligrosos o manifiestamente inadaptados. Sus notas características son la excepcionalidad, porque se trata de una situación extrema, la necesidad frente al fracaso de otros regímenes, y la provisionalidad, puesto que el mantenimiento del interno en esa situación es de duración limitada. Se cumple en celdas individuales en módulos de aislamiento y asistido por un equipo técnico especializado que necesariamente contará con un psicólogo, un médico, un educador, un trabajador social y un representante del área de vigilancia. Vid. PÉREZ CEPEDA, A.I. / FERNÁNDEZ GARCÍA, J., "Los establecimientos penitenciarios”. En BERDUGO GÓMEZ DE LA TORRE, I., (Coord.) Lecciones y materiales para el Estudio del Derecho penal. Tomo VI. Derecho penitenciario. Madrid: Iustel. 2010, pp. 105 y 106. 
resistencia a la adaptación a las reglas básicas de convivencia, etc. No obstante, el art. 102.5 RP enumera una serie de factores que deberán tenerse en cuenta para la clasificación en primer grado, que son, la naturaleza de los hechos cometidos en su historial delictivo que denote personalidad agresiva, violenta y antisocial, y en concreto delitos contra la vida, integridad física, libertad sexual o contra la propiedad cometidos con violencia; pertenencia a grupos u organizaciones criminales, bandas armadas o grupos terroristas cuando no muestren signos inequívocos de haberse desvinculado de dichas organizaciones; participación en motines, agresiones físicas, amenazas o coacciones dentro de la prisión; comisión de infracciones graves o muy graves de forma reiterada; introducción o posesión de armas de fuego o drogas tóxicas, estupefacientes y sustancias psicotrópicas en el interior del centro ${ }^{1324}$.

El segundo grado corresponde al régimen ordinario que se aplica también a los penados sin clasificar y a los detenidos y $\operatorname{presos}^{1325}$ y es el que se aplica a la mayor parte de los reclusos porque es la clasificación común de los penados. Se aplican los principios que inspiran la LOGP sin mayores restricciones, esto es: sistema progresivo, tratamiento individualizado, salidas ordinarias y extraordinarias, comunicaciones regulares con familiares y amigos, etc.

El tercer grado corresponde al régimen abierto o de semilibertad ${ }^{1326}$, que se basa en una corriente teórica que pretende dotar al sistema de alternativas a la prisión y en el

1324 ZÚNIIGA RODRÍGUEZ, L., “El tratamiento penitenciario...”, cit. p. 171. Esta autora expresa que “existen dos modalidades de régimen cerrado, siendo uno más restrictivo que otro: a) Régimen cerrado propiamente (art. 91.1 RP) para aquellos penados clasificados en primer grado que demuestren una manifiesta inadaptación a los regímenes internos comunes. Normalmente se trata de internos que han infringido reiteradamente faltas muy graves y graves, demostrando serios problemas de acatamiento a las reglas de un régimen ordinario. b) Departamentos especiales (art. 91.3 RP), para aquellos penados clasificados en primero grado que haya protagonizado o inducido alteraciones regimentales muy graves, que hayan puesto en peligro la vida o la integridad de los funcionarios, autoridades, otros internos o personas ajenas, tanto dentro como fuera del establecimiento penitenciario y en las que se evidencie una peligrosidad extrema".

${ }^{1325}$ En el régimen ordinario rige el criterio de separación interior (hombres y mujeres, etc.) y se considera el trabajo como actividad básica; existe un horario para las actividades obligatorias, que serían todas las relacionadas con el orden y disciplina como los registros, recuentos, etc.; y para las voluntarias, que vendrían a ser todas las relacionadas con el tratamiento como las educativas, culturales, laborales, ocupacionales, deportivas o recreativas. También dispondrán de ocho horas de descanso nocturno, dos horas para asuntos propios y tiempo suficiente para atender actividades culturales y terapéuticas así como a los contactos con el mundo exterior. Vid. PÉREZ CEPEDA, A.I. / FERNÁNDEZ GARCÍA, J., "Los establecimientos penitenciarios...", cit. pp. 99 y 100.

1326 El régimen abierto se aplica a los penados clasificados en tercer grado para que continúen su tratamiento en semilibertad. El art. 80 RP dispone que pueden ser de tres tipos: centros abiertos o de inserción social, que son establecimientos dedicados a internos clasificados en tercer grado; secciones abiertas, que son establecimientos polivalentes que cuentan con una parte dedicada los internos clasificados en tercer grado; y unidades 
ideal resocializador que apuesta decididamente por la autorresponsabilidad en casos de delitos de gravedad media o de delincuentes primarios, y cuando las circunstancias personales del sujeto aconsejan el cumplimiento con condiciones más benignas, debido a que cuentan - por ejemplo- con trabajo reconocido, relaciones familiares estables, y en definitiva presentan un elevado pronóstico favorable de reinserción. Para acceder al tercer grado se exige haber cumplido la cuarta parte de la condena, estar en segundo grado de tratamiento penitenciario, y haber satisfecho la responsabilidad civil derivada del delito $^{1327}$ (art. 72.5 LOGP), aunque excepcionalmente se puede clasificar al interno en tercer grado de forma inicial debido a sus especiales circunstancias. Por lo general, los clasificados en tercer grado suelen ser delincuentes ocasiones o pasionales en los que el delito es un incidente en sus vidas pero que no presentan elevados índices de desintegración social, lo que hace intuir que no recaerán nuevamente en el delito, por lo que el cumplimiento se puede hacer en régimen de semilibertad de forma que únicamente acuden al centro penitenciario a pernoctar, pudiendo durante el día dedicarse a su trabajo y a su familia cuyo mantenimiento se considera importante a pesar de estar cumpliendo la pena privativa de libertad ${ }^{1328}$. Del mismo modo, la práctica totalidad de los penados, pueden acceder al tercer grado si presentan pronóstico favorable de reinserción y sus tratamientos individualizados arrojan resultados positivos, de forma que la semilibertad no solo ayuda a la preparación del interno para su ulterior vida en plena libertad, sino que supone un incentivo para tratar de completar con éxito los programas de reinserción y presentar buena conducta interna y, en definitiva, para presentar pronóstico favorable de reinserción que le posibilitará el acceso a la progresión en grado.

dependientes, que son instalaciones residenciales situadas fuera de los recintos penitenciarios. La organización de estas instituciones descansa sobre la idea de la confianza en el interno, por lo que hay una minimización de las medidas de seguridad y vigilancia que incrementa el sentido de responsabilidad del propio interno que le acercan en lo posible a la vida en libertad para la que se le prepara. Vid. PÉREZ CEPEDA, A.I. / FERNÁNDEZ GARCÍA, J., “Los establecimientos penitenciarios...", cit. pp. 100 a 104.

1327 CERVELLÓ DONDERIS, V., “Responsabilidad civil y tratamiento penitenciario”. En Cuadernos de Derecho judicial, núm. XXII. Derecho penitenciario: incidencia de las nuevas modificaciones. Madrid: Consejo General del Poder Judicial. 2006, p. 102. “Considerando a tales efectos: conducta efectivamente observada en orden a restituir lo sustraído, reparar el daño e indemnizar los perjuicios materiales y morales; las condiciones personales y patrimoniales del culpable a efectos de valorar su capacidad real, presente y futura para satisfacer la responsabilidad civil que correspondiera; garantías que permitan asegurar su satisfacción futura; estimación del enriquecimiento obtenido por la comisión del delito y el daño o entorpecimiento producido al servicio público, así como la naturaleza de los daños y perjuicios causados por el delito, número de perjudicados y su condición".

1328 ZÚÑIGA RODRÍGUEZ, L., “El tratamiento penitenciario...”, cit. p. 172. 
El siguiente estadio sería la libertad condicional (arts. 90 a $93 \mathrm{CP}$ ) que algunos autores denominan cuarto grado1329, para lo que el primer requisito es encontrarse clasificado en tercer grado de tratamiento penitenciario ${ }^{1330}$. La justificación radica en garantizar que el penado no cometerá delitos al ser excarcelado, toda vez que el tercer grado se ha obtenido después de una favorable evolución del penado ${ }^{1331}$. Por otra parte, la necesidad de que el penado se halle sometido a previa clasificación en tercer grado para obtener la libertad condicional excluye a los presos preventivos $\mathrm{y}$, como ya se ha dicho, las

1329 Ibidem, p. 162.

1330 El proceso de clasificación inicial se lleva a cabo valorando la personalidad del interno, su historial delictivo, familiar, social, la duración de las penas y el medio social al que retornará cuando salga en libertad. El estudio se lleva a cabo por un equipo de observación que deberá formular una propuesta razonada de grado, y será el Centro Directivo quien dictará una resolución escrita y motivada en el plazo de dos meses, clasificando al interno en el grado que corresponda, y que será recurrible ante el JVP por el propio interno y por el Ministerio Fiscal. Ibidem, p. 164. Cada seis meses se estudiará por el Equipo Técnico que tenga relación directa con el penado, su situación individual para valorar la clasificación inicial y a partir de ahí podrá la Junta de Tratamiento proponer el cambio de grado al Centro Directivo, que resolverá de forma motivada sobre la propuesta. La progresión en grado (art. 65.2 LOGP) deriva de la evolución del tratamiento penitenciario e implica la modificación positiva de los factores relacionados con la actividad delictiva que se manifiestan en la conducta global del interno, que irá acompañada de la atribución de mayores cuotas de libertad y de confianza, como, por ejemplo, permisos de salida que el interno puede disfrutar en consonancia con el buen fin del tratamiento de reinserción. La regresión en grado (art. 65.3 LOGP, "la regresión de grado procederá cuando se aprecie en el interno, en relación al tratamiento, una evolución desfavorable de su personalidad"), por el contrario, viene dada por la evolución negativa y desfavorable en el pronóstico de reinserción, que se valora de forma global por la conducta del interno, aunque hay casos concretos en que se prevé la regresión en grado: cuando el interno no regresa al centro después de disfrutar de un permiso de salida o de cualquier otra salida autorizada, cuando son detenidos o procesados por la comisión de nuevos delitos -estando en tercer gradoen cuyo caso se clasificará al penado en segundo grado y se podrán suspender cautelarmente las salidas a las que pudiere tener derecho de acuerdo con la evolución de su tratamiento. El procedimiento de resolución de las propuestas y el régimen de recursos es similar al anteriormente citado para la clasificación inicial. Ibidem, pp. 166 y 165.

1331 ORTS BERENGUER, E. / GONZÁLEZ CUSSAC, J.L., Compendio..., cit. p. 481. No obstante, nada impediría que la clasificación en tercer grado y la libertad condicional se llevaran a efecto de forma simultánea. Vid. MAPELLI CAFFARENA, B. / TERRADILLOS BASOCO J.M., Las consecuencias..., cit. p. 147, aunque para que esta situación se produzca tendrán que concurrir los demás requisitos de la libertad condicional por lo que, será difícil que se produzca. Vid. GRACIA MARTIN, L. / ALASTUEY DOBÓN, M.C., "La ejecución de las penas...", cit. p. 368. Por otra parte, los criterios de actuación, conclusiones y acuerdos aprobados por los JVP en sus XVIII reuniones celebradas entre 1981 y 2009, en su texto refundido actualizado a junio de 2009, en su criterio 125 bis, pusieron de manifiesto que cualquier petición de libertad condicional de penados que no estuviesen clasificados en tercer grado en el momento de cursar su solicitud debe ser rechazada a limine litis, salvo enfermos graves o septuagenarios. En ese orden de cosas, SÁNCHEZ YLLERA manifiesta que hay que tener en cuenta si el penado se encontraba en tercer grado y haciendo vida en régimen de semilibertad, o si venía disfrutando de permisos penitenciarios con regularidad y haciendo buen uso de los mismos, de lo que cabría deducir resocialización. Este autor aduce que el uso correcto del tercer grado implicaría ya casi de forma automática la existencia de ese pronóstico favorable, habida cuenta de que la libertad condicional es la continuación de la clasificación en tercer grado y del régimen en semilibertad. Aunque puede darse el caso de que no exista tercer grado previo pero sí un buen uso de los permisos y una evolución favorable en el tratamiento en la prisión, por lo que, si no hay tercer grado previo, habrá que valorar los informes del equipo técnico sobre el uso de los permisos, en los que, según el art. 67 LOGP, deberá expresarse los resultados conseguidos con el tratamiento y un juicio de probabilidad sobre el comportamiento futuro. En tales casos, podrá simultáneamente clasificarse al penado en tercer grado y conceder la libertad condicional. Vid. SÁNCHEZ YLLERA, I., en VIVES ANTÓN, T.S., (Coord.), Comentarios..., cit. pp. 516 y 517. 
penas para las que no cabe clasificación como la localización permanente ${ }^{1332}$. Al margen de lo anterior, conviene hacer referencia a que el art. 36.2 CP contiene una especialidad en materia de clasificación en tercer grado, conocido como periodo de seguridad ${ }^{1333}$, que consiste en que, los condenados a penas superiores a cinco años de prisión, para acceder a la clasificación en tercer grado se les podrá exigir que hayan cumplido la mitad de la pena impuesta1334. La reforma operada mediante LO 7/2003 concebía este periodo de seguridad como un requisito de para poder progresar en grado en estos casos, aspecto que fue muy criticado por la doctrina debido a que la clasificación debe responder a criterios de pronóstico y no en la mayor o menor gravedad de la pena ${ }^{1335}$, pero la LO 5/2010 modificó el art. 36.2 CP de forma que ahora contempla dos modalidades ${ }^{1336}$, una facultativa para el juez, y otra obligatoria para cuando se trate de delitos de terrorismo y cometidos en el seno de organizaciones criminales, delitos del agresiones sexuales a menores del art. 183 $\mathrm{CP}$, y delitos relativos a la prostitución y corrupción de menores del Capítulo VII, del Título XXII, del Libro II CP, cuando la víctima sea menor de trece años ${ }^{1337}$.

1332 CERVELLÓ DONDERIS, V., Derecho Penitenciario. Valencia: Tirant lo Blanch. Tirant monografías núm.194. 2006, p. 250.

1333 DE VICENTE MARTÍNEZ, R., Vademécum..., cit. p. 214.

1334 Vid. BAUTISTA SAMANIEGO, C., "Periodo de seguridad y crimen organizado”. En Cuadernos de Derecho Judicial, núm. XXII. Derecho penitenciario: incidencia de las nuevas modificaciones. Madrid: Consejo General del Poder Judicial. 2006, pp. 145 a 147, y nota al pie 2. Este autor señala que como antecedentes de esta figura la Ordenanza General de Prisiones del Reino de 14 de abril de 1834, que imponía la necesidad de tener cumplida la mitad de la pena para poder abrir la posibilidad de reducción de la pena, el Reglamento de 3 de junio de 1901, que incluía el acceso a un período intermedio cuando se hubiera cumplido la mitad de la pena, y por último cita un antecedente inmediato de 1994, en forma de enmienda que se presentó por el Grupo Popular al Proyecto del actual $\mathrm{CP}$, proponiendo que en el segundo requisito del art. 91 de haber extinguido las tres cuartas partes de la condena para acceder a la libertad condicional, se sustituyera el término "extinguido" por "cumplido".

1335 Vid. BAUCELLS LLADÓS, J., “De las penas...”, cit. Pág. 437. Este autor indica que “además, constituía un botón de muestra relevante del ocaso de las teorías de las reinserción y rehabilitación social ante el imparable auge de criterios retribucionistas, inocuizadores y preventivo-generales positivos".

1336 CORCOY BIDASOLO, M. / MIR PUIG, S., Comentarios..., cit. p. 145. Estos autores ponen de manifiesto que "la reforma del art. 36.2 introducida por la LO 5/2010 ha ampliado los supuestos en los que no rige el "régimen general de cumplimiento" y el "período de seguridad" es imperativo. [...] La reforma pretende destacar que el "régimen general" no comporta necesariamente de un "periodo de seguridad" y, menos aún, con una duración que alcance la mitad de la pena impuesta. Además, hace innecesaria una decisión del JVP para que pueda otorgarse el tercer grado de tratamiento penitenciario antes del cumplimiento de la mitad de la pena impuesta, salvo que el juez o tribunal que impuso la pena hubiera ordenado lo contrario. En definitiva, la reforma amplía los supuestos en los que es imperativo el cumplimiento de un periodo de seguridad, y reduce los supuestos en los que el JVP debe fiscalizar la concesión del tercer grado".

1337 No obstante, un tercer párrafo del mismo precepto dispone que el JVP podrá acordar que se aplique el régimen general de cumplimiento si hay pronóstico favorable de reinserción y teniendo en cuenta las circunstancias personales del sujeto y la evolución del tratamiento reeducador, previa audiencia del Ministerio Fiscal, Instituciones Penitenciarias y las demás partes. Vid. BAUCELLS LLADÓS, J., “De las penas...", cit. pp. 438 a 441. 
$2^{\circ}$. El segundo requisito para acceder a la libertad condicional es exclusivamente temporal y consiste en que se hayan extinguido las tres cuartas partes de la condena impuesta1338.

\section{$3^{\circ}$. El tercer requisito es que se haya observado buena conducta y exista pronóstico} individualizado y favorable de reinserción social del sujeto. Se observa que este tercer requisito se desdobla a su vez en dos más: uno es la buena conducta, y el otro es el pronóstico favorable. Respecto a la buena conducta, debe ser entendida como buena conducta penitenciaria, sin incidencias, y no como un comportamiento excelente o ejemplar ${ }^{1339}$. Conviene mencionar a este respecto que la exigencia de la referida buena conducta, en la regulación anterior al CP de 1995 la referencia era a "intachable conducta", con lo cual ahora parece no exigirse tan brillante trayectoria penitenciaria para entender cumplido el

1338 En relación a este requisito hay que tener en cuenta tres cuestiones: a) la primera es que también sería posible el cómputo en relación a la exigencia de las tres cuartas partes cuando se haya concedido algún beneficio penitenciario como un indulto parcial. Dispone el art. 193.1 ${ }^{\mathrm{a}} \mathrm{RP}$ que "el tiempo de condena que fuera objeto de indulto se rebajará al penado del total de la pena impuesta, a los efectos de aplicar la libertad condicional, procediendo como si se tratase de una nueva pena de inferior duración"; b) la segunda es que en caso de una pluralidad de penas privativas de libertad rige el principio de unidad de ejecución. Vid. GRACIA MARTIN, L. / ALASTUEY DOBÓN, M.C., “La ejecución de las penas...”, cit. p. 368; y ello deriva de la previsión del art. 193.2 RP que se traduce en que a efectos del cumplimiento de las tres cuartas partes de la condena se computa la suma total de las impuestas como si fuera una sola. Cuando se hayan extinguido las tres cuartas partes de la condena considerada como una sola, entonces será el momento de analizar si el penado está en condiciones de acceder a la libertad condicional por la concurrencia de los demás requisitos exigidos. SÁNCHEZ YLLERA viene a poner de manifiesto que existen multitud de variantes en función de la cuantía y duración de las condenas impuestas o de que se acumulen causas con libertad condicional revocada, pero en cualquier caso lo importante es que deben ser consideradas una sola condena a efectos de la libertad condicional, "aunque llegado el cumplimiento del tiempo mínimo exigido no se halle clasificado en tercer grado no cabe proponer el licenciamiento definitivo de esta causa quedando otras vigentes y pendientes de cumplir en su expediente, porque se cerraría así la posibilidad de que la evolución del interno en el tiempo que le queda de cumplimiento le permita acceder a tercer grado y disfrutar de la libertad condicional en el total de las causas". Vid. DE MARCOS MADRUGA, F., “De la libertad condicional...", cit. p. 406; c) la tercera, es la excepción prevista en el art. $78 \mathrm{CP}$, que viene a decir que si a consecuencia de los límites máximos de cumplimiento previstos en el art. $76 \mathrm{CP}$, (esto es, 20, 25, 30 ó 40 años según el supuesto de que se trate), la pena resultante fuera inferior a la mitad de la suma total de las impuestas, el juez podrá acordar que el cómputo de tiempo para la libertad condicional se refiera a la totalidad de las penas impuestas en las sentencias. Vid. FERNÁNDEZ GARCÍA, J., "La libertad condicional...", cit. p. 231. Según este precepto, un condenado a seis penas de prisión de 10 años cada una, (o sea, 60 años) por mor del art. $76.1 \mathrm{CP}$ en principio el reo sólo cumplirá 20 años; ahora bien, como ese tiempo es inferior a la mitad de la suma total de las impuestas, el juez podrá acordar que el cómputo de la extinción de las tres cuartas partes de la pena se realice sobre la suma total (60), con lo cual, la situación es la siguiente: hasta cumplidos 45 años no se alcanza el segundo de los requisitos para acceder a la libertad condicional, y como el límite de cumplimiento ex art. 76.1 CP es 20 años, la consecuencia real es que ese sujeto cumplirá 20 años de prisión sin que tenga derecho a la libertad condicional. Vid. GRACIA MARTIN, L. / ALASTUEY DOBÓN, M.C., "La ejecución de las penas...", cit. p. 369.

1339 DE MARCOS MADRUGA, F., “De la libertad condicional...”, cit. p. 407. Este autor refiere a que debe tratarse de "buena conducta objetiva", que se desprende de la ausencia de sanciones sin cancelar y de la constatación de un perfil positivo en el penado que le permita reintegrarse en la sociedad y para ello deberán tenerse en cuenta diversos factores como las posibilidades de acceso al mercado laboral, medios económicos de vida, apoyo familiar, etc. 
requisito ${ }^{1340}$.

Respecto del pronóstico individualizado y favorable de reinserción social del sujeto, debe ser favorable conforme a lo dispuesto en el art. 67 de la LOGP1341, esto es, emitido en el informe final elaborado por el Equipo Técnico del centro ${ }^{1342}$. No obstante, este requisito solo se entenderá cumplido si por el penado se ha satisfecho la responsabilidad civil derivada del delito ${ }^{1343}$, en los mismos términos que del art. 72.5 y 6 de la LOGP para el tercer grado, norma que reitera los requisitos que se establecen para el mismo, puesto que, según se ha visto en el primero de los requisitos, es materialmente imposible acceder a la libertad condicional si no es desde el tercer grado ${ }^{1344}$. En ese orden de cosas, la exigencia de haber satisfecho la responsabilidad civil que ya se exige a través de los arts. 72.5 y 6 LOGP a los que remite el art. 90.1 c) CP para la clasificación en tercer grado, es también un requisito para la libertad condicional, lo que implica que dicha valoración deba hacerse dos veces y como expresa GARCíA ARÁN “ello puede ser contemplado como una redundancia producto de la deficiente técnica legislativa, lo que conduce a la suficiencia de una sola valoración en la mayoría de los casos", y especifica que la doble valoración solo podrá tener sentido si hay una separación temporal importante entre ambas decisiones y "si habiéndose apreciado el esfuerzo del condenado en el momento de concederse el tercer grado, al llegar la decisión sobre libertad condicional las condiciones personales y económicas del sujeto todavía le permiten actuar

\footnotetext{
1340 FERNÁNDEZ GARCÍA, J., “La libertad condicional...”, cit. pp. 231 y 232.
}

1341 Art. 67. "Concluido el tratamiento o próxima la libertad del interno, se emitirá un informe pronóstico final, en el que se manifestarán los resultados conseguidos por el tratamiento y un juicio de probabilidad sobre el comportamiento futuro del sujeto en libertad, que, en su caso, se tendrá en cuenta en el expediente para la concesión de la libertad condicional".

1342 SÁNCHEZ YLLERA, I., en VIVES ANTÓN, T.S., (Coord.), Comentarios..., cit. p. 517. Este autor afirma que el referido pronóstico "no es un pronóstico de peligrosidad criminal, ni cabe equipararla a tener oferta de trabajo en libertad, ya que dicha circunstancia no está al alcance de todo ciudadano libre. Las garantías de hacer vida honrada en libertad deben conectarse más con la personalidad del individuo y su evolución y comportamiento que con las circunstancias materiales en que se va a desenvolver la vida en libertad, ya que éstas, por su estancia en prisión no suelen variar, y lo único que el penado puede variar es su propio comportamiento mediante la asunción de pautas vitales que le lleven al convencimiento de vivir en libertad sin quebrantar las normas penales".

1343 ORTS BERENGUER, E. / GONZÁLEZ CUSSAC, J.L., Compendio..., cit. p. 481; TAMARIT SUMALLA, J.M., en TAMARIT SUMALLA, J.M., / GARCÍA ALBERO, R., La reforma..., cit. TOL 519.288, pp. 6 y 7. Estos autores expresan que "la exigencia de haber reparado el daño como condición para beneficiarse de la libertad condicional constituye una de las novedades más relevantes introducidas por la reforma. Nos encontramos ante un importante paso adelante en la introducción de contenidos de carácter reparador en la ejecución penal".

1344 Inciden sobre la innecesariedad de esta norma CERVELLÓ DONDERIS, V., Derecho Penitenciario..., cit. p. 252; y LANDECHO VELASCO C.M. / MOLINA BLÁZQUEZ, C., Derecho Penal..., cit. p. 578. 
1345 GARCÍA ARÁN, M., “De las penas...”, cit. pp. 765 y 766. Sin embargo esta autora -con cita de ACALE SÁNCHEZ- aduce que dicha previsión de valorar los esfuerzos por cubrir la responsabilidad civil en el momento de acordar la libertad condicional podría quedar vacía de contenido en función del tiempo transcurrido, porque el CP guarda silencio sobre la naturaleza de la responsabilidad civil, lo que implica una remisión a los plazos fijados en el CC, y en concreto al plazo de un año previsto en el art. 1968.1 CC para la prescripción de la obligaciones civiles.

1346 La reparación del daño en fase posterior a la sentencia fue introducida mediante la LO 7/2003 lo que "responde a la evolución de las tendencias favorables a la justicia reparadora, que tiene entre sus otras manifestaciones el impulso de la mediación, otras formas de participación de la víctima y de la comunidad en las distintas fases del sistema penal, además del favorecimiento de la reparación del daño". Vid. TAMARIT SUMALLA, J.M. / GARCÍA ALBERO, R., La reforma..., cit. p. 115. La doctrina incide en que este requisito de haber satisfecho la responsabilidad civil, que aparece vinculado al pronóstico, nada tiene que ver con él, sino que se basa en la justicia reparativa y en la promoción de la reparación a la víctima. Vid. VIDALES RODRÍGUEZ, C., "La libertad condicional...", cit. pp. 95 y 96. Esta autora refiere a que la proyección de las tendencias de la justicia reparativa a las víctimas en realidad pretenden la sustitución de las formas represivas penales a favor de otras de carácter reparador y no como lo ha previsto el legislador como un mantenimiento de la prisión basado únicamente en el impago de la responsabilidad civil, que elude cualquier consideración de otros factores, lo cual es dudoso que pueda satisfacer a nadie, y además "es profundamente evocador de una siempre repugnante prisión por deudas". Los criterios de actuación, conclusiones y acuerdos aprobados por los JVP en sus XVIII reuniones celebradas entre 1981 y 2009, según el texto refundido actualizado a junio de 2009, en su criterio 128, pusieron de manifiesto en cuanto a la naturaleza de la exigencia del pago de la responsabilidad civil, que "no cabe concluir dogmáticamente que es absolutamente generalizada la exigencia de pago de las responsabilidades civiles. Luego, no se trata de una resurrección de la prisión por deudas, sino de un precepto acorde con los principios de política criminal actual relativa a la víctima del delito". Este criterio -que fue aprobado en 2004- tiene no obstante un voto particular del Ilmo. Sr. Juan Pablo González del Pozo, del JVP núm. 2 de Castilla-La Mancha (Ocaña), en el que expresa que este criterio debería suprimirse porque no arroja claridad en la interpretación del art. 72.5 LOGP, siembra dudas y desfigura el borroso perfil técnico del mismo. Sigue diciendo el voto particular que el criterio introduce "una dosis de ambigüedad innecesaria a la exégesis del ya impreciso precepto". Si se observa la Exposición de Motivos de la LO 7/2003, se aprecia que se pretende combatir a quienes a pesar de tener importantes responsabilidades civiles fijadas en la sentencia, ocultan su patrimonio ilícitamente obtenido imposibilitando su recuperación, y justifica la introducción de la reparación del daño en una pretensión de articular el impedimento de que ciertos condenados por delitos económicos de gran importancia, puedan ver mejorada su situación penitenciaria sin haber devuelto el dinero (la Exposición de Motivos de la LO 7/2003 dice que "esta exigencia se justifica plenamente en aquellos delitos que han permitido al culpable obtener un importante enriquecimiento ilícito y no se satisfacen las responsabilidades pecuniarias fijadas en sentencia a causa de haber ocultado su patrimonio"), y todo ello a la luz de la incomodidad que se ha hecho ver en la opinión pública ante ciertos casos de personas famosas. Sin embargo, se trata de una modificación general que afecta a todos los penados, no sólo a los de gran solvencia proveniente de delitos económicos sino también a los insolventes, de ahí que tal vinculación resulte cuestionada por la doctrina ya que sería perfectamente posible que pudiera concurrir un pronóstico favorable de reinserción en penado insolventes que no hayan satisfecho la responsabilidad civil por imposibilidad material. Vid. GARCÍA ARÁN, M., “De las penas...”, cit. p. 764 . Todo ello conduce a interpretar restrictivamente el requisito, en relación con el contenido del art. 72.5 y 6 LOGP, que impone la obligación de considerar las distintas circunstancias, a saber: la conducta efectivamente observada en orden a restituir lo sustraído, reparar el daño e indemnizar los perjuicios materiales y morales; las condiciones personales y patrimoniales del culpable, a efectos de valorar su capacidad real, presente y futura para satisfacer la responsabilidad civil que le correspondiera; las garantías que permitan asegurar la satisfacción futura; la estimación del enriquecimiento que el culpable hubiera obtenido por la comisión del delito y, en su caso, el daño o entorpecimiento producido al servicio público, así como la naturaleza de los daños y perjuicios causados por el delito, el número de perjudicados y su condición; por lo que la valoración de la capacidad económica que pueda concurrir en el futuro no será posible aplicarla a aquellos que carecen de posibilidades de obtener ingresos o de incrementar su patrimonio durante la condena y tampoco si se observa -como sucede en la mayor parte de reclusos- que no cuentan con expectativas futuras de que, al ser excarcelados, vayan a experimentar un aumento de su capacidad económica. Ibidem, $p$. 765. Resulta relevante resaltar que los criterios de actuación, conclusiones y acuerdos aprobados por los JVP en sus XVIII reuniones celebradas entre 1981 y 2009, en su texto refundido actualizado a junio de 2009, en su criterio 129, contempla la posibilidad de imponer al liberado condicional la obligación de satisfacer determinada cantidad mensual hasta extinguir la responsabilidad civil, como regla de conducta incardinada en el art. 83.1.5 $\mathrm{CP}$, en los casos 
Conviene tener presente que el $2^{\circ}$ párrafo del art. 72.5 LOGP, añade que "singularmente" se aplicará esa norma cuando el penado haya sido condenado por alguno de los delitos que el propio precepto relaciona ${ }^{1347}$. Previsión que lleva a un sector de la doctrina a considerar que dicho requisito de haber satisfecho la responsabilidad civil vinculándola al pronóstico, solo debería ser predicable respecto de esta clase de delitos y no en todos los demás, al entender que la previsión de este catálogo es realmente la ratio legis de la norma ${ }^{1348}$. Para la satisfacción de la responsabilidad civil, la LOGP en el segundo párrafo del art. 33.1 d) pone de manifiesto el carácter embargable de las remuneraciones obtenidas por los internos en las mismas condiciones y requisitos establecidos para el sueldo del trabajador libre, lo cual implica que no podrá ser objeto de embargo la cantidad equivalente el salario mínimo interprofesional (IPREM)1349.

en que los penados se hayan comprometido al pago fraccionado de dicha deuda y lo estén haciendo efectivo a través de los ingresos obtenidos del trabajo llevado a cabo en régimen abierto. También resalta el mencionado criterio 129, que en caso de no haber sido autorizado el pago fraccionado por el órgano sentenciador, puede el JVP acordarlo en el momento de conceder la libertad condicional de forma motivada, atendiendo a la capacidad económica, ingresos, proporcionalidad, etc.

1347 Que son: delitos contra el patrimonio y el orden socioeconómico, que hubieran revestido notoria gravedad y hubieren perjudicado a una pluralidad de personas (sobre estos delitos vid. CORCOY BIDASOLO, M. / MIR PUIG, S., Comentarios..., cit. pp. 518 a 670); delitos contra los derechos de los trabajadores (sobre estos delitos vid. NAVARRO CARDOSO, F., Los delitos contra los derechos de los trabajadores. Valencia: Tirant lo Blanch. 1998; y vid. DE VICENTE MARTÍNEZ, R., Los delitos contra los derechos de los trabajadores. Valencia: Tirant lo Blanch. 2008); delitos contra la Hacienda Pública y contra la Seguridad Social (sobre estos delitos vid. MARTÍNEZBUJÁN PÉREZ, C.M., "Delitos contra la Hacienda Pública y contra la Seguridad Social”. En VIVES ANTÓN, T.S. / ORTS BERENGUER, E. / CARBONELL MATEU, J.C. / GONZÁLEZ CUSSAC, J.L. / MARTÍNEZBUJÁN PÉREZ, C.M., Derecho Penal Parte Especial. Tirant Lo Blanch. 2010, pp. 523 a 540, y vid. también el DVD que incluye esta obra donde se contempla el análisis de varias figuras delictivas de las de esta clase, lección XXIX); delitos contra la Administración Pública comprendidos en los Capítulos V al IX, del título XIX, del Libro II CP (Sobre estos delitos vid. ORTS BERENGUER, E., "Delitos contra la administración pública". En VIVES ANTÓN, T.S. / ORTS BERENGUER, E. / CARBONELL MATEU, J.C. / GONZÁLEZ CUSSAC, J.L. / MARTÍNEZ-BUJÁN PÉREZ, C.M., Derecho Penal Parte Especial. Tirant Lo Blanch. 2010, pp. 697 a 733. y vid. también el DVD que incluye esta obra donde se contempla el análisis de varias figuras delictivas de las de esta clase, lecciones XXXVII y XXXVIII).

1348 Vid. TAMARIT SUMALLA, J.M. / GARCÍA ALBERO, R., La reforma..., cit. p. 123 y ss., opinión con la que no concuerda GARCÍA ARÁN, M., "De las penas...", cit. p. 765, que afirma que "aun compartiendo absolutamente la finalidad restrictiva de tal interpretación y su coincidencia con lo que parece ser la voluntad predominante del legislador, en mi opinión, la estructura del art. 72.5 LOGP indica el enunciado de una regla general -aunque restringible en su aplicación- $\mathrm{y}$, a continuación, una llamada de atención sobre algunos delitos en los que la ejecución penal debe atender -"singularmente" - a la satisfacción de responsabilidades civiles, en una enumeración que no debería considerarse como lista cerrada, porque no se alcanzan razones para no considerar este requisito, por ejemplo, en los delitos urbanísticos". No obstante, esta autora aclara que aun tratándose de una previsión general aplicable a toda clase de delitos, no debe obstaculizar la reinserción social al proyectarse como una especie de confiscación de todos los bienes del penado, que le dejen sin medios económicos en el momento de su liberación, lo que impediría la reinserción.

1349 No obstante, TAMARIT afirma que “el problema es actualmente más bien de carácter práctico, dado que el trabajo penitenciario no permite normalmente aportar ingresos suficientes para atender los legítimos intereses de los perjudicados". TAMARIT SUMALLA, J.M., en TAMARIT SUMALLA, J.M. / GARCÍA ALBERO, R., La reforma..., cit. p. 117. Hay que tener presente que la regulación de la reparación del daño del CP y de la LOPG se complementa con un nuevo apartado en el art. 989 LECrim que que atribuye a jueces y tribunales la facultad de averiguación patrimonial del penado para hacer frente a la responsabilidad civil mientras la misma no se haya extinguido, pudiendo oficiar a la Agencia Tributaria a efectos de averiguación 
Por último, sobre la exigencia de haber satisfecho la responsabilidad civil, considero necesario resaltar algunos aspectos que -entre otros muchos- pone de manifiesto VIDALES RODRÍGUEZ1350: 1) La relación que puede tener este requisito para acordar la libertad condicional y su valoración para acordar la suspensión de la pena. En efecto, el art. $81.3 \mathrm{CP}$ exige para suspender la pena que se haya satisfecho la responsabilidad civil, salvo que el reo sea insolvente, en cuyo caso, oídas las partes, el juez puede acordar la suspensión por lo que, en realidad, la responsabilidad civil no sería un obstáculo en ese sentido; pero por el contrario sí lo es para acordar la libertad condicional, que no puede acordarse si la responsabilidad civil no está satisfecha o no hay previsiones de futuro para satisfacerla. Además, cuando se trata de delincuentes primarios con pena inferior a dos años, la responsabilidad civil se valora dos veces, una para negar la suspensión de la pena y otra para negar la concurrencia de pronóstico favorable de reinserción e impedir la progresión en el tratamiento, lo que podría afectar al principio de ne bis in idem. 2) La medida puede ser innecesaria, porque si el legislador está pensando en quienes no quieren pagar la responsabilidad civil —en lugar de en quienes no pueden- ya hay previstos en el ordenamiento otros mecanismos como el comiso y el alzamiento de bienes específico del art. 258 CP1351.

\section{b) Condiciones}

El cumplimiento por el penado del resto de la pena que le queda cuando accede a la libertad condicional, está sometido a una serie de condiciones para su mantenimiento.

de créditos y devoluciones que pudiera tener con la misma o con la Tesorería General de la Seguridad Social, así como rentas existentes y demás patrimonio. Sobre los aspectos de la ejecución del contenido civil de la sentencia, vid. GÓMEZ COLOMER, J.L., “El proceso de ejecución...”, cit. pp. 473 y 474.

1350 Vid. VIDALES RODRÍGUEZ, C., “La libertad condicional...”, cit. pp. 97 y 98.

1351 Sobre este delito vid. VIVES ANTÓN, T.S. / GONZÁLEZ CUSSAC, J.L., “Delitos contra el patrimonio y el orden socioeconómico (IX): Insolvencias punibles". En VIVES ANTÓN, T.S. / ORTS BERENGUER, E. / CARBONELL MATEU, J.C. / GONZÁLEZ CUSSAC, J.L. / MARTÍNEZ-BUJÁN PÉREZ, C.M., Derecho Penal. Parte Especial. $3^{\text {a }}$ Ed. Valencia: Tirant lo Blanch. 2010. Véase el DVD que contiene esta obra, lección XXVI, donde estos autores explican que "la conducta típica es esencialmente similar al alzamiento, pues requiere realizar actos de disposición patrimonial o generador de deudas que provoquen una insolvencia total o parcial. Precisa igualmente de la concurrencia de un elemento subjetivo: su finalidad ha de ser eludir el cumplimiento de la responsabilidad civil (STS 9 junio 1999). Pero también es un alzamiento específico, precisamente porque la insolvencia se circunscribe únicamente a los efectos de poder satisfacer su responsabilidad civil dimanante del delito. Sólo a ella, pero bastando para la consumación que no pueda hacerse frente a una parte de la misma. Qué ha de entenderse por responsabilidad civil dimanante de delito, remite a lo dispuesto en los artículos 109 y siguientes del Código Penal. [...] El artículo 258 se refiere exclusivamente a la responsabilidad civil derivada de la comisión de un hecho delictivo. Queda, por consiguiente fuera de su ámbito el impago de las penas pecuniarias". 
La primera y principal es que el sujeto no vuelva a delinquir durante el tiempo que le resta de condena1352, lo cual debe entenderse solo para delitos, quedando excluidas las faltas. Y la segunda, tal y como dispone el art. 90.2 CP, que no incumpla las reglas de comportamiento que el JVP puede imponerle al sujeto, previstas en los arts. 83 y $96.3 \mathrm{CP}$, de forma que son reglas de conducta ${ }^{1353} \mathrm{y}$ medidas privativas de derechos ${ }^{1354}$.

Sobre estas obligaciones se discute si se trata de la imposición de medidas de seguridad que encontrarían su justificación para su aplicación en la peligrosidad del sujeto, pero como indican GRACIA MARTín y ALASTUEY DOBÓN, no se imponen medidas de seguridad porque, de ser así, estaríamos tratando al sujeto como criminalmente peligroso y, en consecuencia, "faltaría el requisito del pronóstico favorable y no podría concederse ya el beneficio de la libertad condicional"1355. Se trata de normas de comportamiento que pretenden favorecer la reinserción y fortalecer los resultados obtenidos para acceder a la libertad condicional. Por ese motivo, aunque el art. 96.3 CP las catalogue como medidas de seguridad, en realidad el JVP cuando las impone no está centrando la atención en el mismo aspecto que el tribunal sentenciador cuando acuerda la imposición de medidas de seguridad basadas en la peligrosidad criminal del sujeto apreciada en el juicio por el delito cometido, sino que el JVP tiene las funciones limitadas exclusivamente a los aspectos concernientes a la ejecución de la condena, por lo que su decisión se centra en la adopción de las reglas de conducta encaminadas a la mejor materialización de los objetivos resocializadores que persigue la libertad condicional, así como en la necesidad de adoptar las reglas de conducta que mejor se adapten a las especiales y concretas circunstancias del penado, de forma que "no se frustren los objetivos resocializadores alcanzados durante el previo cumplimiento de la pena"1356.

\footnotetext{
1352 ORTS BERENGUER, E. / GONZÁLEZ CUSSAC, J.L., Compendio..., cit. p. 482.

1353 RODRÍGUEZ ALONSO, A. / RODRÍGUEZ AVILÉS, J.A., Lecciones de Derecho penitenciario. $4^{\text {a }}$ Ed. Granada: Comares. 2011, pp. 289 y 290.

1354 Vid. RÍOS MARTÍN, J.C., “La libertad condicional...”, cit. p. 183. Como indica SÁNCHEZ YLLERA, I., en VIVES ANTÓN, T.S., (Coord.), Comentarios..., cit. p. 517, en ocasiones sucede que el análisis de las circunstancias personales del penado conducen a concluir que se mantienen intactos algunos factores criminógenos en su personalidad que le llevaron, en su día, a cometer el delito, y que su retorno a la vida en libertad de forma plena sin contar con un control específico, pueden derivar en un pronóstico al menos incierto de esa inminente vida en libertad. Por eso, para evitar que la libertad condicional sea denegada, se articula un sistema de imposición de reglas de conducta que regirán durante esa vida en libertad condicional, sin las que, probablemente, tal fase de cumplimiento de la condena sería de difícil acceso.
}

1355 GRACIA MARTIN, L. / ALASTUEY DOBÓN, M.C., “La ejecución de las penas...”, cit. p. 371.

1356 GARCÍA ARÁN, M., “De las penas...”, cit. pp. 772 y 773. 
Por otra parte, algunos autores llaman la atención sobre que, al comparar ambos preceptos -el 83 y el $96.3 \mathrm{CP}$-, se observa que algunas reglas de conducta están previstas doblemente -como la prohibición de aproximarse a la víctima- y que en realidad podrían fijarse otras reglas de conducta no previstas en el catálogo, dada la riqueza de situaciones que pueden producirse en la práctica, por lo que la fijación de estas reglas deberá hacer con base en un criterio de flexibilidad que permita adaptarlas a cada situación fáctica con miras a la consecución de la pretendida reinserción social ${ }^{1357}$.

Pueden imponerse una o varias obligaciones de las previstas en los citados arts. 83 y 96.3 CP, y algunos autores mantienen que no cabe la suspensión, el cese o la sustitución de unas por otras durante la ejecución de la libertad condicional1358, aunque otros afirman que en momentos posteriores a la concesión de la misma se pueden fijar nuevas reglas de conducta si aparecen de forma sobrevenida nuevos factores criminógenos o se observa la necesidad de modificarlas en vista de la evolución de la conducta del sujeto ${ }^{1359}$.

Siguiendo la clasificación que formulan CUELlo CONTRERAS y MAPELLI CAFFARENA, las obligaciones que pueden imponerse son las siguientes ${ }^{1360}$ : 1) Obligaciones restrictivas de la libertad ambulatoria, que sería la prohibición de acudir o residir en determinados lugares, con obligación de declarar el domicilio elegido y de comunicar cada cambio se produzca; la prohibición de visitar establecimientos de bebidas alcohólicas; la prohibición de aproximarse o comunicarse con la víctima o con las personas que el JVP determine; la prohibición de ausentarse sin autorización del JVP del lugar donde resida; la obligación de residir en determinados lugares; la expulsión del territorio nacional de extranjeros no residentes legalmente en España; la obligación de comparecencia periódica ante el juzgado o ante la administración penitenciaria para informar de sus actividades; y la libertad vigilada. Sobre esta última, la doctrina afirma que lo que el JVP puede imponer cuando concede la libertad condicional no es la libertad vigilada en sí misma como medida de seguridad — que se basa en la peligrosidad-, sino solo las obligaciones y prohibiciones concretas propias de la libertad vigilada del art. 106.1

\footnotetext{
1357 DE MARCOS MADRUGA, F., “De la libertad condicional...”, cit. p. 408.

1358 CUELLO CONTRERAS, J. / MAPELLI CAFFARENA, B., Curso de Derecho penal..., cit. p. 293.

1359 RÍOS MARTÍN, J.C., “La libertad condicional...”, cit. p. 185. Este autor cita en apoyo de su argumentación el criterio 131 de la Reunión de JVP de junio de 2005.

1360 CUELLO CONTRERAS, J. / MAPELLI CAFFARENA, B., Curso de Derecho penal..., cit. pp. 292 y 293.
} 
CP1361. 2) Obligaciones inhabilitantes, que serían la privación del derecho a conducir vehículos a motor y ciclomotores; la privación de la licencia o permiso de armas; y la inhabilitación profesional. 3) Obligaciones terapéuticas, que serían la de participar en programas formativos, laborales, culturales u ocupacionales, de educación vial, sexual y otros similares; cumplir otros deberes impuestos por el JVP, con el consentimiento del liberado; la custodia familiar; y la sumisión a tratamiento externo en centros médicos o establecimientos sociosanitarios.

\section{c) Revocación de la libertad condicional}

La revocación de la libertad condicional se produce por incumplimiento de las condiciones, esto es, por el incumplimiento de las reglas de conducta, por la comisión de un nuevo delito o cuando dejen de concurrir los presupuestos que permitieron su concesión ${ }^{1362}$, lo que implica el retorno al régimen de cumplimiento en prisión en el período o grado penitenciario que le corresponda, donde permanecerá el tiempo que le reste de condena computándose el tiempo cumplido en libertad condicional, según dispone el art. 93.1 CP. Hay una excepción para cuando se trate de delitos de terrorismo, en cuyo caso la revocación implica el reingreso en prisión para cumplir el período restante de condena y la pérdida del tiempo pasado en libertad condicional1363, con lo cual al penado le quedará por cumplir la condena completa1364, excepción que para algunos autores es inconstitucional por infracción del principio de ne bis in idem ${ }^{1365}$. En estos casos, el JVP puede solicitar informes que permitan acreditar que subsisten las condiciones que sirvieron de base para conceder la libertad condicional, y tiene la facultad de revocarla si dichas condiciones se han incumplido ${ }^{1366}$.

\footnotetext{
1361 GARCÍA ARÁN, M., “De las penas...”, cit. p. 773.

1362 FERRER GUTIÉRREZ, A., Manual práctico sobre ejecución ..., cit. pp. 347 y 348.

1363 LANDECHO VELASCO C.M. / MOLINA BLÁZQUEZ, C., Derecho Penal..., cit. p. 578.

1364 ORTS BERENGUER, E. / GONZÁLEZ CUSSAC, J.L., Compendio..., cit. p. 482.

1365 GARCÍA ARÁN, M., “De las penas...”, cit. p. 784.
}

1366 Por otra parte, la doctrina viene diciendo que la revocación de la libertad condicional implica la aplicación del régimen ordinario hasta que la junta de tratamiento resuelva una nueva clasificación y, en ese orden de cosas, también podrá serle concedida nuevamente la libertad condicional, ya que el art. $201 \mathrm{RP}$, no excluye expresamente esa posibilidad. Vid. RÍOS MARTÍN, J.C., “La libertad condicional...”, cit. pp. 214 y 215. En art. 201 RP dispone lo siguiente: “causas de revocación. 1. El período de libertad condicional durará todo el tiempo que falte al liberado para cumplir su condena siempre que durante el mismo observe un comportamiento que no dé lugar a la revocación del beneficio y reingreso en Establecimiento penitenciario. 2. Si en dicho período el liberado volviera a delinquir o inobservase las reglas de conducta impuestas, en su caso, por el Juez de Vigilancia, el responsable de los servicios sociales lo comunicará, con remisión de cuantos datos 
1) Por la comisión de un nuevo delito. La expresión "si el reo delinquiere" que usa el art. 93.1 CP, implica que la infracción que puede dar lugar a la revocación solo puede ser la que constituya delito, quedando excluidas las faltas, pero la previsión no contiene especificación alguna sobre si los delitos deben ser dolosos o si también están incluidos los imprudentes. Sobre este aspecto la doctrina afirma que la amplitud de la previsión y el automatismo con el que puede acordarse la revocación implica que deben quedar incluidas las infracciones imprudentes ${ }^{1367}$, pero algunos autores aconsejan que la norma se interprete a favor de la exclusión de la imprudencia por razones de política criminal ${ }^{1368}$. La revocación de la libertad condicional no se debe producir hasta que no recaiga sentencia condenatoria firme del nuevo delito ${ }^{1369}$, criterio que está en consonancia con el respeto al principio de presunción de inocencia ${ }^{1370}$.

2) Por incumplimiento de las reglas de conducta. Esta causa de revocación no exige condena firme, sino únicamente un informe de servicios sociales que comunique al JVP el incumplimiento al JVP para que pueda resolver sobre la revocación (art. 201.2 RP) ${ }^{1371}$, y queda circunscrita al incumplimiento de las reglas que el JVP haya impuesto al penado en virtud del art. $90.2 \mathrm{CP}$, de forma que solo procederá la revocación si incumple dichas reglas, lo que no incluye eventuales actitudes del interno que vayan en contra del programa individualizado de seguimiento que simplemente a efectos de control haya elaborado la junta de tratamiento (art. 200.3 RP).

puedan ser útiles, a éste para la adopción de la resolución que proceda respecto a la revocación de la libertad condicional. 3. En caso de revocación, cuando el interno reingrese en prisión le será de aplicación el régimen ordinario, hasta que por la Junta de Tratamiento se proceda nuevamente a su clasificación".

1367 GARCÍA ARÁN, M., “De las penas...”, cit. p. 782.

1368 RÍOS MARTÍN, J.C., “La libertad condicional...”, cit. pp. 215 y 216.

1369 DE MARCOS MADRUGA, F., “De la libertad condicional...”, cit. p. 415, con cita del Auto del TC de 114/1997, de 21 de abril.

1370 Vid. CERVELLÓ DONDERIS, V., Derecho Penitenciario..., cit. p. 259. Además, ello implica que la mera incoación de diligencias sumariales impide la revocación de la libertad condicional en la medida en que no es posible extraer consecuencia negativa alguna de la nueva causa hasta que sea destruida la presunción de inocencia a través de la sentencia que se dicte sobre el fondo (Vid. SÁNCHEZ YLLERA, I., en VIVES ANTÓN, T.S., (Coord.), Comentarios..., cit. p. 523), de esta afirmación se desprende que la revocación únicamente podrá producirse si la sentencia condenatoria se produce antes de que el periodo de libertad condicional haya expirado, por lo que si la sentencia deviene con posterioridad al mismo (cuando la libertad condicional ha concluido y la pena se ha extinguido) no cabrá la revocación, por lo que la efectividad de la misma dependerá de la celeridad con que la nueva causa se tramite. Vid. RÍOS MARTÍN, J.C., "La libertad condicional...", cit. p. 215. Este autor cita en apoyo de esta afirmación el Auto de JVP de Catilla y León núm. 1, de 18 de noviembre de 1994.

1371 RÍOS MARTÍN, J.C., “La libertad condicional...”, cit. pp. 216. 
No obstante, la doctrina viene poniendo de manifiesto que la equiparación de este incumplimiento a la comisión de delitos a efectos de la revocación puede resultar desproporcionada, y que el excesivo automatismo que proclama la regulación para acordar la revocación puede frustrar los objetivos de reinserción, de tal forma que el JVP deberá valorar las circunstancias del incumplimiento para que el citado automatismo no haga fracasar los objetivos de reinserción, como puede ocurrir en los casos en que el penado incumple su obligación de comparecer ante el tribunal o la administración que corresponda, cuando dicho incumplimiento pueda haber sido ocasional y no revele una voluntad real de sustraerse al contenido de las obligaciones impuestas ${ }^{1372}$.

Otros autores inciden en que habría sido aconsejable que se hubiera previsto en la regulación las posibilidad de extinguir, suspender o sustituir unas medidas por otras tal y como sucede en la suspensión de la pena cuando va acompañada de medidas de seguridad durante el tiempo de suspensión (art. 84.2 CP), y que en todo caso cabría la posibilidad de aplicar analógicamente las disposiciones de las medidas de seguridad en ese sentido, de tal forma que habría que pedir al JVP que no revoque la libertad condicional, sino que sustituya unas medidas por otras en caso de que el incumplimiento pueda no ser fruto de un actitud rupturista del penado y cuando el reingreso en prisión pueda suponer un retroceso en los avances en la reinserción del sujeto ${ }^{1373}$.

\section{d) Suspensión de la libertad condicional}

La suspensión se produce cuando el penado está disfrutando de un periodo de libertad condicional y sobreviene una sentencia condenatoria por hechos cometidos con anterioridad a la concesión de la libertad condicional. En estos casos, la libertad condicional queda cautelarmente en suspenso, de forma que el penado deberá ingresar en prisión, comunicándolo de inmediato al JVP y procediendo la institución penitenciaria a solicitar al tribunal sentenciador que efectúe la nueva liquidación de condena sin demora ${ }^{1374}$. La libertad condicional también debe quedar en suspenso en un supuesto que

\footnotetext{
1372 GARCÍA ARÁN, M., “De las penas...”, cit. p. 783.

1373 RÍOS MARTÍN, J.C., “La libertad condicional...”, cit. Pág 217.

1374 Los efectos de la nueva liquidación pueden ser dos: 1) si la nueva condena sobrepasa las tres cuartas partes o las dos terceras -según los casos- del total, el JVP dictará un auto ampliando la libertad condicional; 2) si,
} 
sucede con frecuencia en la práctica, aunque no está previsto en la regulación legal y es cuando un sujeto se encuentra en libertad condicional y se acuerda una medida cautelar de prisión provisional ${ }^{1375}$ por otra causa, que implica que debe ingresar cautelarmente en prisión. En estos casos, al ser incompatible la situación de libertad condicional con la prisión provisional, aquélla deberá quedar en suspenso hasta que ésta sea levantada1376.

\section{e) Adelantamiento de la libertad condicional}

En la legislación penitenciaria vienen previstos ciertos beneficios que suponen un efectivo acortamiento de la condena ${ }^{1377}$. El primero de los beneficios que como tales se contempla en el art. $202.2 \mathrm{RP} 1378$, al nominar que "constituyen, por tanto, beneficios penitenciarios el adelantamiento de la libertad condicional y el indulto particular". El adelantamiento de la libertad condicional es lo que de alguna forma sustituye la antigua redención de penas por el trabajo ${ }^{1379}$ y se traduce en que, excepcionalmente, el JVP podrá conceder anticipadamente la libertad condicional siempre y cuando el penado se encuentre en tercer grado de tratamiento penitenciario, haya cumplido dos terceras partes de su condena (frente a las tres cuartas partes como ocurre en la libertad condicional ordinaria) y haya desarrollado continuadamente actividades laborales, culturales $u$ ocupacionales (art. 91.1 CP).

Deben concurrir, pues, los requisitos del art. 90 a) y c) CP, y el beneficio consiste en que bastará con el cumplimiento de dos terceras partes de la condena para que se pueda

por el contrario, no alcanzan dichas partes, la libertad condicional quedará en suspenso hasta que se llegue a ellas. En este caso, el penado deberá ser reclasificado, pero en la práctica el penado suele permanecer en tercer grado, no siendo frecuente que pase al régimen ordinario, ya que, como afirma RÍOS MARTíN, J.C., "La libertad condicional...", cit. pp. 217 y 218, en estos casos no existe revocación de la libertad condicional, sino una suspensión a efectos de una posible ampliación, por lo que el penado deberá ingresar en prisión en tercer grado.

1375 Sobre la prisión provisional, vid. BARONA VILAR, S., “El proceso cautelar...”, cit. pp. 504 a 515.

1376 DE MARCOS MADRUGA, F., “De la libertad condicional...”, cit. p. 416.

1377 Como indican TAMARIT SUMALLA, J.M. / GARCÍA ALBERO, R. / RODRÍGUEZ PUERTA, M.J. / SAPENA GRAU, F., Curso de Derecho Penitenciario..., cit. p. 185, “los beneficios penitenciarios son un elemento de vital importancia para el recluso, dado que implican un acortamiento de la condena. Ello induce al interno a cumplir los requisitos que faciliten la consecución de la libertad en un período de tiempo más corto".

1378 Art. 202. “Concepto y clases. 1. A los efectos de este Reglamento, se entenderá por beneficios penitenciarios aquellas medidas que permiten la reducción de la duración de la condena impuesta en sentencia firme o de la del tiempo efectivo de internamiento. 2. Constituyen, por tanto, beneficios penitenciarios el adelantamiento de la libertad condicional y el indulto particular".

1379 GARCÍA ARÁN, M., “De las penas...”, cit. pp. 775 y 776. Sobre la jurisprudencia de los JVP, AP y TS en relación a si es aplicable este beneficio a penados por el CP de 1973, vid. CONDE, M., Derecho penitenciario vivido. Granada: Comares. 2006, pp. 291 a 297. 
acordar la libertad condicional, sin necesidad de aguardar al cumplimiento de tres cuartas partes que se exige para los demás supuestos de concesión de la libertad condicional1380. Por su parte, SÁNCHEZ YLLERA —con cita de la STC 172/89—1381 mantiene que para la

1380 Dicho adelantamiento podrá fundamentarse en cualquiera de las actividades que describe el RP en sus arts. 55 y ss., sobre las áreas de participación en materias educativas, culturales, etc., en sus arts. 132 y ss., sobre el trabajo productivo, y en sus arts. 153 y ss., sobre trabajos ocupacionales no productivos. Sin embargo, el requisito de que las actividades se desempeñen continuadamente dependerá en gran medida de la disponibilidad y de la oferta de actividades en los centros penitenciarios, aspectos que de no estar presentes en cada centro como posibilidades reales y efectivas para los internos, no podrá desembocar en que el requisito no se cumpla aunque haya periodos de inactividad del penado que no puedan ser imputables a él. De esa forma, el condenado cumplirá el requisito si consta fehacientemente su voluntad de realizar dichas actividades y no las desarrolla por ausencia de oferta por parte del centro penitenciario. Vid. GARCÍA ARÁN, M., “De las penas...", cit. p. 765. En ese mismo sentido, afirma RÍOS MARTÍN, J.C., "La libertad condicional. Límites en el concurso real de delitos: especial referencia a la sentencia Parot". En Cuadernos de Derecho Judicial, núm. XXII. Derecho penitenciario: incidencia de las nuevas modificaciones. Madrid: Consejo General del Poder Judicial. 2006, p. 189, que las actividades pueden también interrumpirse por otras causas ajenas al penado como traslados motivados por juicios pendientes en otros partidos judiciales, por sobrepoblación carcelaria en un centro penitenciario determinado, por sanciones encubiertas de la Administración, o por otros motivos, por lo que, en estos supuestos, "necesariamente la valoración de la continuidad tiene que ser tomando los períodos de trabajo y las causas de las interrupciones. En cualquier caso, esta valoración debe tener en cuenta todos estos datos, además, obviamente, de los criterios establecidos en la Instrucción 3/2004 de la DGIP, sobre sistema de evaluación e incentivación de las actividades de los internos".

1381 La STC 172/89, de 19 de octubre de 1989, denegó el amparo a un interno que invocó el derecho al adelantamiento de la libertad condicional cuando el centro no contaba con trabajos para todos los presos, aduciendo en sus $\mathrm{FJ} 3^{\circ}$ y $4^{\circ}$ lo siguiente: “3. En el primer aspecto, existe, ciertamente un específico deber de la Administración Penitenciaria de crear y proporcionar los puestos de trabajo que permitan sus disponibilidades presupuestarias, y un mandato, incluso, al legislador, conforme al artículo 53.3 de la C.E., de que atienda a la necesidad de pleno empleo de la población reclusa, según las posibilidades socioeconómicas y sin perder de vista, precisamente, la indicada finalidad reeducadora y de reinserción social, que por disposición constitucional, tiene la pena. Y, desde el punto de vista subjetivo de quien está cumpliendo pena de prisión, es un derecho de aplicación progresiva, cuya efectividad se encuentra condicionada a los medios de que disponga la Administración en cada momento, no pudiendo pretenderse, conforme a su naturaleza, su total exigencia de forma inmediata (SSTC 82/1986 y 2/1987). En el segundo aspecto, como derecho a la actividad laboral dentro de la organización prestacional existente, sí debe reconocerse una situación jurídica plenamente identificable con un derecho fundamental del interno, con la doble condición de derecho subjetivo y elemento esencial del ordenamiento jurídico (SSTC 25/1981 y 163/1986), exigible frente a la Administración Penitenciaria en las condiciones legalmente establecidas [art. 26.2 e), Capítulo Segundo de la LOGP, art. 182.2 d) y Capítulo Cuarto del Título III del RP], tanto en vía jurisdiccional como, en su caso, en sede constitucional a través del recurso de amparo. De acuerdo con los citados criterios, reiteradamente expuestos por la jurisprudencia de este Tribunal (AATC 256/1988, 1.112/1988, 95/1989 y PTC de 13 de marzo de 1989, RA 1.573/1988), la Administración Penitenciaria debe superar gradualmente las situaciones de carencia o de imposibilidad de proporcionar a todos los internos un trabajo retribuido, arbitrando las medidas necesarias a su alcance, y observando mientras tanto no se consiga el pleno empleo de la población reclusa, el orden de prelación que el art. 201 del Reglamento Penitenciario establece para distribuir los puestos de trabajo disponibles. Pero únicamente tendrá relevancia constitucional el amparo del derecho al trabajo del penado si se pretende un puesto de trabajo existente al que se tenga derecho dentro del orden de prelación establecido, que no puede ser objeto de una aplicación arbitraria o discriminatoria. 4. Teniendo en cuenta la expresada jurisprudencia de este Tribunal, ya consolidada, no cabe apreciar en el presente caso la infracción del art. 25.2 de la C.E. que el actor denuncia. Por el contrario, por una parte, las resoluciones judiciales recurridas parten del explícito y formal reconocimiento del derecho del condenado a un trabajo remunerado y a los beneficios correspondientes de la Seguridad Social, con la protección específica que otorga el art. 53.2 de la C.E. a los comprendidos en la Sección 1. ${ }^{a}$, Capítulo Segundo del Título I del propio Texto constitucional, apuntando, incluso, la diferencia que a este respecto existe con el derecho al trabajo del resto de los ciudadanos proclamado en el art. 35.1 de la C.E., y, por otra, atienden, sin embargo, a los datos fácticos, sobre los que este Tribunal no puede pronunciarse [art. 44.1 b) de la LOTC] y que ni siquiera son cuestionados en vía constitucional, del índice de desempleo en la sociedad, insuficiencia de los talleres existentes en el Centro Penitenciario de Córdoba y la concreta ausencia de puestos de trabajo en aquéllos, "ya que los únicos con los 
adjudicación de puestos de trabajo se deberá atender a los criterios de preferencia contenidos en la LOGP y en el RP, de forma que no cabrá alegar vulneración del derecho fundamental a obtener un trabajo en prisión cuyo desarrollo conllevaría el adelantamiento de la libertad condicional, si el centro no puede proporcionarlo1382. Se exige también que haya informes del Ministerio Público, de Instituciones Penitenciarias y de las partes personadas ${ }^{1383}$, esto es, las acusaciones particulares y la popular ${ }^{1384}$.

Una segunda excepción (art. 91.2 CP) refiere a que, cumplida la mitad de la condena y siempre que concurran también los requisitos del art. 90 a) y c) CP y siempre que no se trate de delitos de terrorismo ${ }^{1385}$ o cometidos en el seno de organizaciones criminales, el JVP podrá adelantar el acceso a la libertad condicional un máximo de noventa días por cada año de condena cumplido ${ }^{1386}$.

Este beneficio lo aprueba el JVP1387 a propuesta de las Juntas de Tratamiento de los centros penitenciarios ${ }^{1388}$, previo informe del Ministerio Público y de las demás partes. En

que contaban estaban cubiertos", así como a la falta de cualificación del penitenciario para ocupar el único que cabía aumentar en el taller de cuero y derivados, para adoptar la única medida razonablemente exigible establecida en el art. 77 de la LOGP, esto es, formular una propuesta a la Dirección General de Instituciones Penitenciarias para que considere la necesidad de otorgar un puesto de trabajo a todos los internos en cumplimiento del mandato constitucional, al que debe dar respuesta la política penitenciaria y presupuestaria del Estado".

1382 SÁNCHEZ YLLERA, I., en VIVES ANTÓN, T.S., (Coord.), Comentarios..., cit. p. 520.

1383 ORTS BERENGUER, E. / GONZÁLEZ CUSSAC, J.L., Compendio..., cit. p. 482.

1384 Sobre la intervención de las acusaciones en la ejecución de la pena, aunque se les deba dar traslado para que puedan alegar lo que estimen conveniente antes de la toma de decisión por parte del JVP, eso no significa que deba conferírseles disponibilidad alguna sobre la decisión que se tome, debido a que las decisiones sobre libertad condicional se basan en cuestiones de pronóstico de reinserción del que las acusaciones poco pueden aportar más allá de su mera voluntad de que la permanencia en prisión se prolongue, por lo que, a pesar de que es preceptivo que emitan informe, el mismo no puede ser vinculante. Vid. GARCÍA ARÁN, M., “De las penas...", cit. p. 775 .

1385 ORTS BERENGUER, E. / GONZÁLEZ CUSSAC, J.L., Compendio..., cit. p. 483.

1386 GARCÍA ARÁN, M., “De las penas...", cit. p. 777. Esta autor explica que "no se trata de conceder la libertad condicional tras el cumplimiento de la mitad de la condena, sino de que llegado ese momento, cabe adelantar el cumplimiento de los dos tercios de la condena ("el plazo previsto en el apartado anterior"), hasta un máximo de tres meses (90 días) por cada año de cumplimiento efectivo transcurrido".

1387 GRACIA MARTIN, L. / ALASTUEY DOBÓN, M.C., “La ejecución de las penas...”, cit. p. 376.

1388 RÍOS MARTÍN, J.C., "La libertad condicional...", cit. pp. 193 a 195. Este autor afirma que podría concederse incluso si ni hay propuesta de la junta de tratamiento, o cuando exista informe negativo del centro, basado en que la STC 163/2002, de 21 de noviembre, que permitió que el JVP proponga el indulto al Ministerio de Justicia a pesar del informe negativo del centro penitenciario, basado en la facultad de control judicial de la actuación administrativa (art. 106.1 CE) y en que corresponde al JVP aprobar las propuestas que formulen los centros sobre beneficios penitenciarios cuando suponga un acortamiento de la condena (art. 76.2 c) LOGP), así como la previsión del art. $206.1 \mathrm{RP}$ sobre que no es competencia exclusiva del centro penitenciario la tramitación del indulto, que lo puede solicitar directamente el penado ante el JVP. Por todo ello, concluye este autor que tratándose la figura del adelantamiento de la libertad condicional de un beneficio 
este supuesto, también se exige que el penado haya desarrollado de forma continuada las actividades indicadas en el art. 91.1 CP -laborales, culturales u ocupacionales- y además acredite la participación efectiva y favorable en programas de reparación a las víctimas o de desintoxicación ${ }^{1389}$, requisito que solo se entenderá cumplido cuando se haya satisfecho la responsabilidad civil, o cuando la misma se esté satisfaciendo de forma fraccionada, aplazada, total o parcialmente, incluso cuando pueda asegurarse el cumplimiento de planes de reparación que puedan pactarse en ese momento ${ }^{1390}$.

Por tanto, serán obligatorias, por una parte las actividades laborales, culturales $\mathrm{u}$ ocupacionales y además, por otra, o bien la reparación o bien el tratamiento desintoxicador ${ }^{1391 / 1392}$.

penitenciario que descansa sobre los mismos presupuesto que el indulto en cuanto a la propuesta del JVP, el órgano jurisdiccional puede aprobar el adelantamiento de la libertad condicional por vía de recurso.

1389 MORILLAS CUEVA, L., "Alternativas a la pena de prisión". En Cuadernos de Derecho Judicial, núm. XXII. Derecho penitenciario: incidencia de las nuevas modificaciones. Madrid: Consejo General del Poder Judicial. 2006, p. 61.

${ }^{1390}$ TAMARIT SUMALLA, J.M. / GARCÍA ALBERO, R. / RODRÍGUEZ PUERTA, M.J. / SAPENA GRAU, F., Curso de Derecho penitenciario..., cit. p. 190

1391 RÍOS MARTÍN, J.C., “La libertad condicional...”, cit. p. 193. Este autor señala que "por otra parte, quien esté sometido a cualquier programa de tratamiento o desintoxicación se entiende que está reparando el daño causado trabajando activamente sobre las causas que motivaron la conducta delictiva. Es suficiente con programas libres de drogas o de mantenimiento con la metadona".

${ }^{1392}$ La doctrina viene afirmando que esta modalidad plantea algunas limitaciones, la primera derivada de la existencia de posibilidades reales de participar en programas de desintoxicación o de reparación a las víctimas, ya que todos los internos no reúnen el perfil: todos son toxicómanos ni todos cometen delitos que necesiten actividades de reparación a la víctimas, piénsese en los delitos en los que no se deriva responsabilidad civil o los cometidos contra bienes jurídicos supraindividuales (vid. GARCÍA ARÁN, M., “De las penas...", cit. pp. 777 y 778); o supuestos en que no existan programas de reparación o incluso cuando la víctima no quiera participar en ellos, lo que supondría en muchos casos que el requisito deviniera de imposible cumplimiento, motivos por los que algún autor afirma que para cumplir el requisito de la reparación bastará haber satisfecho la responsabilidad civil "o bien con una carta sincera de arrepentimiento". Vid. RÍOS MARTÍN, J.C., "La libertad condicional...", cit. p. 193. La segunda limitación es la voluntariedad del sometimiento del interno a esos programas, ya que la oferta de adelantamiento de la libertad condicional puede condicionar esa voluntariedad en la aceptación, conduciendo a los internos a que se sometan a ellos sin que sea esa su voluntad y únicamente porque buscan del incentivo del adelantamiento, lo que puede derivar en que la efectividad de dichos programas disminuya, porque si en un toxicómano falta la voluntad real y efectiva de desintoxicarse, los programas y tratamientos de desintoxicación son ineficaces y pueden ser contraproducentes. Existe un derecho a que las penas privativas de libertad estén orientadas a la reinserción (art. 25.2 CE), pero en ningún caso el sometimiento a los programas puede ser una obligación para los condenados (vid. ZÚÑIGA RODRÍGUEZ, L., "El tratamiento penitenciario...", cit. p. 160), ni tampoco pueden articularse como una opción sin alternativa que implique que la negativa a someterse a ellos genere consecuencias perniciosas para los internos. Por tanto, en cierta medida la voluntariedad de los tratamientos puede quedar alterada (vid. GARCÍA ARÁN, M., "De las penas...", cit. p. 777), porque si bien no se generan perjuicios, se veda el acceso a los beneficios penitenciarios por el hecho de no someterse a los tratamiento, situación que, aunque no es equiparable a un verdadero perjuicio para el penado, en cierto modo se aproxima porque produce una suerte de efecto no beneficioso para el mismo, pudiendo generar que se vea forzado a someterse a los tratamientos de reinserción con la consecuente pérdida de la nota de voluntariedad que preside el sometimiento a los mismos. 


\section{f) Supuestos especiales}

\section{Septuagenarios y enfermos incurables}

Excepcionalmente, se podrá conceder la libertad condicional a septuagenarios y enfermos incurables ${ }^{1393}$ que se encuentren en tercer grado de tratamiento penitenciario ${ }^{1394}$, y en los que concurra buena conducta y pronóstico favorable de reinserción ${ }^{1395}$. En estos supuestos la libertad condicional puede anticiparse sin necesidad de que se hayan cumplido las tres cuartas partes de la condena o las dos terceras en su caso (art. $92 \mathrm{CP})^{1396}$, por lo que la libertad condicional podrá acordarse en cualquier momento de cumplimiento de la pena, siempre y cuando concurran también los demás requisitos del art. $90 \mathrm{CP}^{1397}$. En ese orden de cosas, tampoco sería aplicable a estos supuestos el periodo de seguridad del art. $36.2 \mathrm{CP}$ por la que se puede exigir al penado de que haya cumplido la mitad de la pena cuando sea superior a cinco años para poder tener acceso a la clasificación en tercer grado ${ }^{1398}$, y también en los supuestos en que ese requisito es obligatorio 1399

1393 RÍOS MARTÍN, J.C., “La libertad condicional...", cit. p. 197. Según este autor, "cuando una persona padece una enfermedad grave e incurable, o tiene setenta años o los cumple durante la extinción de la condena, si concurren los demás requisitos establecidos para la libertad condicional, excepto el de tener cumplidas las tres cuartas partes, podrán sr propuestos para libertad condicional (art. 92.2 CP y 196 RP)".

1394 GARCÍA ALBERO, R., en TAMARIT SUMALLA, J.M. / GARCÍA ALBERO, R., La reforma..., cit. TOL 519.286, p. 21. Este autor explica que "como es sabido, estar previamente clasificado en tercer grado constituye uno de los requisitos exigidos por el artículo 90 del CP para obtener la libertad condicional. Tratándose de septuagenarios o de enfermos incurables, el artículo 92 del CP prevé la dispensa del requisito relativo al cumplimiento de las tres cuartas partes, o en su caso, las dos terceras partes de la condena para obtener dicho beneficio. Al no haberse modificado el artículo $92 \mathrm{CP}$ hay que entender que las propuestas y resoluciones de tercer grado efectuadas al amparo del artículo 104.4 del Reglamento no resultan condicionadas por el "período de seguridad". Consecuentemente, la Junta de Tratamiento puede realizar tales propuestas con independencia del tiempo de condena extinguido, correspondiendo su aprobación al JVP".

1395 DE MARCOS MADRUGA, F., “De la libertad condicional...”, cit. pp. 413 y 414.

1396 ROCA AGAPITO, L., El sistema de sanciones..., cit. pp. 513 y 514.

1397 Sobre este especial tratamiento a estas dos clases de penados, advierten COBO DEL ROSAL, M. / VIVES ANTÓN, T.S., Derecho Penal..., cit. p. 856, nota al pie 12, sobre la posible lesión al derecho de igualdad al referir que "la anticipación de la libertad condicional a septuagenarios y enfermos incurables podría resultar incompatible con el artículo 14 de la CE, si bien no lo sostenemos".

1398 CUELLO CONTRERAS, J. / MAPELLI CAFFARENA, B., Curso de Derecho penal..., cit. p. 295, con cita de los Acuerdos de la XIII Reunión de JVP celebrada en Valencia en marzo de 2004, así como el Auto de la AP de Madrid, Sec. $5^{\text {a }}$, de 16 de marzo de 2008.

1399 BAUCELLS LLADÓS, J., “De las penas...”, cit. p. 441. Indica este autor que “son, por tanto, una excepción al periodo de seguridad fundada en razones humanitarias y de dignidad personal. Así lo ha considerado la Dirección General de Instituciones Penitenciarias en sus distintas instrucciones 9/2003, 2/2004 y 2/2005". El fundamento reside en el principio de humanidad de las penas que se desprende de la previsión del art. $15 \mathrm{CE}$ que proscribe las penas inhumanas o degradantes. Vid. NARANJO DE LA CRUZ, R., "Derechos fundamentales...", cit. pp. 467 y 468. Este autor explica que "el TC asume doctrina del TEDH en la materia y 
No obstante, se exige igualmente que exista pronóstico favorable de reinserción social, que deberá quedar vinculado para su apreciación a las especiales circunstancias del sujeto, por lo que no es exactamente igual que el pronóstico favorable que se exige con carácter general para los demás supuestos, ya que en este caso la libertad condicional no es una preparación para la vida en libertad ni tampoco el siguiente paso en la progresividad del tratamiento penitenciario ni una progresión en grado, sino una liberación anticipada por razones humanitarias ${ }^{1400}$. También es aplicable el requisito de la responsabilidad civil, por lo que en esta clase de sujetos, se les exige el esfuerzo por satisfacer la responsabilidad civil si tienen medios económicos ${ }^{1401}$.

exige, para que el trato pueda ser calificado de "degradante" que ocasione al interesado sufrimientos de una especial intensidad o le provoquen -ante los demás o ante sí mismo- una humillación o sensación de envilecimiento que alcance un nivel determinado. En el ámbito carcelario, dicho nivel debe ser distinto y superior al que suele llevar aparejada la imposición de la condena (SSTC 65/1986 y 12/1990)". Y también en el principio de la dignidad humana como fundamento del orden político y de la paz social (art. $10 \mathrm{CE}$ ), vid. PÉREZ TREMPS, P., “Los derechos fundamentales”. En LÓPEZ GUERRA, L. / ESPÍN, E. / GARCÍA MORILLO, J. / PÉREZ TREMPS, P. / SATRÚSTEGUI, M., Derecho Constitucional. Vol. I. El ordenamiento constitucional. Derechos y deberes de los ciudadanos. $8^{\text {a }}$ Ed. Valencia: Tirant lo Blanch. 2010, p. 121. Este autor indica que "este precepto actúa como "pórtico" introductorio de todo el título y en él se recalca el carácter básico del individuo, de su dignidad como tal, y de sus derechos para el orden político; asimismo en el apartado segundo, se establecen determinadas reglas en torno a la interpretación de los derechos fundamentales". Ambos fundamentos se proyectan sobre la renuncia del Estado a mantener el cumplimiento de la pena cuando las especiales características del interno incrementan innecesariamente el contenido aflictivo de la sanción -al margen de que, en esos casos, la pena ya no puede cumplir finalidad resocializadora alguna- (vid. RÍOS MARTÍN, J.C., "La libertad condicional...", cit. p. 199) que podría suponer un abuso del ius puniendi (vid. GARCÍA ARÁN, M., “De las penas...", cit. p. 779). Junto a ello, se plasma el derecho a una muerte digna, atendiendo a lo que sugirió la Organización Mundial de la Salud en Ginebra, en 1987, sobre que debe adelantarse la liberación de los enfermos incurables para que puedan morir dignamente y en libertad. Vid. RÍOS MARTÍN, J.C., "La libertad condicional...", cit. p. 198 y 199. Este autor también incide en que hay una afección al principio de personalidad de las penas reconocido implícitamente en el art. $25 \mathrm{CE}$, en la medida en que terceros inocentes se ven afectados por la prisión del condenado, y cita el Auto de la AP de Madrid, Secc. $5^{\mathrm{a}}$, de 16 de diciembre de 1997, que dispone que "esa afectación es singularmente dura cuando, como en el caso de la madre del interno, la privación de su presencia actual se presenta como prólogo de su definitiva sentencia".

1400 Y como indica GARCÍA ARÁN, M., “De las penas...”, cit. p. 779, “la relación con la idea de reinserción no se inscribe, como en el régimen general, en el sistema de individualización científica y la progresión en grado, sino que depende, en gran parte, de valorar si sigue existiendo la posibilidad física de delinquir". Es decir, que la exigencia del art. 92.2 CP -introducido por la LO 15/2003- sobre que el JVP deberá valorar las circunstancias personales, la dificultad para delinquir y la escasa peligrosidad del sujeto, vid. SÁNCHEZ YLLERA, I., en VIVES ANTÓN, T.S., (Coord.), Comentarios..., cit. p. 521. No es más que una concreción del requisito de que exista pronóstico favorable de reinserción y no una valoración añadida al mismo (vid. GARCÍA ARÁN, M., “De las penas...”, cit. p. 781). Además, a efectos de limitar al mínimo las probabilidades de comisión de nuevos delitos, es posible que el JVP acuerde la imposición de alguna regla de conducta del art. 83 ó $96.3 \mathrm{CP}$, como el sometimiento a tratamiento ambulatorio o la prohibición de acudir a determinados lugares, o incluso el tratamiento de desintoxicación si fuese drogodependiente. Vid. RÍOS MARTíN, J.C., "La libertad condicional...", cit. p. 197. Este autor expresa que "a estos efectos habría que aportar informe de un centro de tratamiento de drogodependientes en el que conste que el penado tiene plaza de ingreso y que se comprometen a realizar su seguimiento; aportar documentos en el que consten los medios de vida que tendrá el penado una vez que salga en libertad (pensiones, subsidios, ayuda familiar); y compromiso de familiares cercanos o asociaciones de apoyo de acompañarle en el proceso".

1401 Pero no podrá estimarse siempre las perspectivas futuras de satisfacción de la responsabilidad civil, que quedarán muy condicionadas al desarrollo de la enfermedad o a la esperanza de vida del anciano. Vid. GARCÍA ARÁN, M., "De las penas...", cit. p. 781; y sigue diciendo esta autora que hay que tener en cuenta 
El supuesto de los penados de setenta años de edad, no plantea ningún problema al ser un límite cronológico, pero el supuesto de los enfermos muy graves con padecimientos incurables, precisará informe médico, salvo que provenga de los servicios médicos penitenciarios o la enfermedad le conste fehacientemente a la administración penitenciaria ${ }^{1402}$. En casos de urgencia (art. 92.3 CP) cuando exista peligro patente de muerte para el interno a causa de la enfermedad o de su avanzada edad, el JVP podrá acordar la progresión en grado y autorizar la libertad condicional sin más trámite que requerir al centro penitenciario el informe de pronóstico final, para valorar la ausencia de peligrosidad y la dificultad para delinquir, aspecto que, como afirma la doctrina, resulta excesivo cuando se trata de peligro de muerte1403. En estos casos, no son exigibles los requisitos de haber satisfecho la responsabilidad civil ni las especialidades aplicables en casos de terrorismo y organizaciones criminales. No obstante, el precepto al final mantiene la necesidad de llevar a cabo el seguimiento y control al que refiere el art. 75 LOGP, que igualmente deberá hacerse en estos supuestos ${ }^{1404}$.

que en casos de terrorismo y delitos cometidos en el seno de organizaciones criminales, además se exige que hayan colaborado con las autoridades.

1402 Sólo en el supuesto del art. $92.3 \mathrm{CP}$, para casos de urgencia, se requiere que el informe esté emitido por el médico forense y por los servicios médicos penitenciarios. La enfermedad muy grave con padecimientos incurables no debe equipararse a la enfermedad terminal, que ya se encuentra prevista en el supuesto de urgencia, al tiempo que la fundamentación humanitaria que rige en casos de enfermedades muy graves impone que se aplique, como ha indicado la STC 48/1996, en casos en que la permanencia en prisión suponga una aumento del contenido aflictivo de la pena que incremente las dolencias y sufrimientos del penado. Vid. GARCÍA ARÁN, M., “De las penas...”, cit. p. 779.

1403 Algunos autores inciden en que la exigencia de que se tenga que conceder previamente el tercer grado podría comportar un retraso nada deseable en caso de la urgencia que proclama el precepto. Vid. ORTS BERENGUER, E. / GONZÁLEZ CUSSAC, J.L., Compendio..., cit. p. 483. Como indica RÍOS MARTÍN, J.C., “La libertad condicional...", cit. p. 199, con cita del Auto de la AP de Madrid, Secc. $5^{\text {a }}$, de 16 de diciembre de 1997, en la práctica algunas libertades condicionales se conceden con la única finalidad de que el penado pueda morir en el centro hospitalario, aunque suele ocurrir que el deceso se produce en el propio centro penitenciario o durante el traslado al hospital. "Para evitar que los trámites de procedimiento se dilaten hasta el punto de causar la muerte, el legislador ha mostrado sensibilidad en la nueva regulación penal para el caso de que la enfermedad fuese patente por acreditarlo con el dictamen del médico forense y los servicios médicos penitenciarios. En estas situaciones el JVP puede aprobar la libertad condicional, acordando previamente y, entendemos, en el mismo auto, la progresión a tercer grado, solicitando el informe de pronóstico final al centro penitenciario para los controles que establece el art. 75 LOGP de seguimiento por los organismos sociales"1403. Es un supuesto en el que se agilizan los trámites, se parte de que la pena ya no cumple el fin resocializador en el penado y es inviable orientar la ejecución de la pena a la reinserción y a la preparación para la vida en libertad si esa libertad puede quedar reducida a unas horas o unos pocos días entre la puesta en libertad y la defunción.

1404 GARCÍA ARÁN, M., “De las penas...”, cit. pp. 781 y 782. El supuesto que más problemas plantea es de los enfermos de VIH, que comenta la doctrina, en el sentido de que en un principio se atendía al estadio de evolución de la enfermedad, de forma que para la excarcelación se exigía la existencia de un grave desarrollo de la patología. Sin embargo, la práctica demostró que resultaba imposible concretar un momento objetivo en que dicha enfermedad evolucionaba de forma que se pudiera afirmar categóricamente que se trataba de un padecimiento incurable en los términos de la norma, por eso, según este autor, lo importante para posibilitar la libertad condicional anticipada en estos casos no es el estadio fatal de la enfermedad -porque no es algo que 


\section{Delitos de terrorismo y crimen organizado}

La LO 7/2003 introdujo un régimen especial para delitos de terrorismo y cometidos en el seno de organizaciones criminales, que en virtud del art. $78.3 \mathrm{CP}$ exige que el penado haya cumplido cuatro quintas partes del límite de la pena para el acceso al tercer grado ${ }^{1405}$; y las siete octavas partes cuando pretenda la libertad condicional. Además, los requisitos del art. $90 \mathrm{CP}$ están dotados de un mayor contenido restrictivo ${ }^{1406}$, que se concreta, sobre todo, en que el pronóstico favorable de reinserción solo se entenderá cuando existan signos inequívocos de abandono de la actividad terrorista y exista una real y efectiva colaboración con las autoridades para la represión de tales delitos. Además, expresa el citado art. 90 CP (con remisión a los arts. 72.5 y 6 de la LOGP) que este requisito se entiende cumplido mediante una declaración expresa de repudio de sus actividades delictivas y de abandono de la violencia y una petición expresa de perdón a las víctimas de su delito, y se exige además que existan informes técnicos que acrediten que el preso está realmente desvinculado de la organización terrorista y del entorno y actividades de asociaciones y colectivos ilegales que la rodean, así como su colaboración

se exija legalmente-, sino las circunstancias del penado para su puesta en libertad, que se traduce en las condiciones en que va a permanecer cuando sea excarcelado, en las expectativas de atención médica, la capacidad económica de subsistir, la posibilidad de subsistencia por sí mismo o con ayuda de terceros, etc. No obstante, sigue diciendo este mismo autor, que puede fijarse un criterio objetivo por la evolución del VIH para conceder la libertad condicional anticipada, cuando el enfermo presente el Síndrome de Inmunodeficiencia Adquirida. Vid. SÁNCHEZ YLLERA, I., en VIVES ANTÓN, T.S., (Coord.), Comentarios..., cit. p. 521 y 522. Este autor expresa que "dicha situación de Síndrome de Inmunodeficiencia Adquirida, correspondería a todos los casos incluidos en la categoría C-1, subgrupo C, Grupo IV de la clasificación del CDC (Center for Desease Control de Estados Unidos), o en el estadio WR6 de la clasificación de Walter Reed; y alguno de los casos englobados en los otros Subgrupos del Grupo IV o en el estadio WR5 de los esquemas clasificatorios anteriores".

1405 Sobre esta norma advierte GONZÁLEZ CUSSAC que la misma deviene inútil porque "en los últimos años no se conocen casos de calificación al tercer grado de terroristas, pues desgraciadamente se trata de "delincuentes por convicción" que al no renunciar al uso de la violencia, deviene imposible considerarlos resocializados y en consecuencia emitir pronóstico favorable de reinserción. Por otra parte, al exceptuarse con carácter absoluto y general esta posibilidad, se cierra absurdamente el Estado esta fructífera vía de lucha antiterrorista, que tan excelentes resultados ha cosechado en otros países y en el nuestro propio hasta fechas no muy lejanas. En efecto, la utilización de los llamados "arrepentidos" ha sido una eficaz herramienta para obtener información y para socavar la firmeza de otros terroristas, que comprobaban tras largos años de cárcel como otros antiguos compañeros rehacían sus vidas”. Vid. GONZÁLEZ CUSSAC, J.L., “El sistema de penas español...", cit. pp. 57 y 58.

1406 Contenido que, como expresa la doctrina, "supone una concesión a la pretensión retribucionista en detrimento de la orientación a la reinserción. Se trata de una expresión de la ideología de la seguridad con el consecuente derecho penal de excepción que extrae casos de la regla general con el riesgo de anulación". Vid. GARCÍA ARÁN, M., “De las penas...”, cit. p. 767. 
con las autoridades ${ }^{1407}$. Plantea VIDALES RODRíGUEZ la pregunta de si los requisitos contenidos en el art. 90.1 CP —colaborar activamente con las autoridades y la declaración expresa de repudio de sus actividades delictivas y de abandono de la violencia y la

1407 Como indica VIDALES RODRÍGUEZ, C., “La libertad condicional...", cit. p. 99. Con cita de CUERDA ARNAU, M.L., Atenuación y remisión de la pena en los delitos de terrorismo. Madrid: Ministerio de Justicia e Interior, Centro de Publicaciones. 1995, esta previsión se basa en una incorrecta e interesada lectura del art. 6 de la Decisión Marco de la UE de 13 de junio de 2002, sobre lucha contra el terrorismo, que faculta a los Estados Miembros a adoptar mecanismos para conseguir el abandono de las actividades terroristas y les faculta para que la cooperación de los terroristas con las autoridades suponga una rebaja de la pena, pero en modo alguno en dicha Decisión Marco se incluye la posibilidad de que estas facultades incidan en el tercer grado o en la libertad condicional ni tampoco que pueda vincularse al pronóstico favorable e individualizado de reinserción que preside la progresión en grado y el acceso a la libertad condicional; sin olvidar que el CP ya cuenta con un mecanismo específico que permite rebajar la pena en casos de abandono de la actividad terrorista, plasmado de forma efectiva en el art. $579 \mathrm{CP}$, que posibilita la rebaja de la pena en uno o dos grados en estos casos, Esta previsión inicialmente estaba contemplada en el art. 579.3 CP, pero desde la reforma operada mediante la LO 5/2000, aparece en el art. 579.4 CP, a cuyo tenor: "En los delitos previstos en esta sección, los jueces y tribunales, razonándolo en sentencia, podrán imponer la pena inferior en uno o dos grados a la señalada por la ley para el delito de que se trate, cuando el sujeto haya abandonado voluntariamente sus actividades delictivas y se presente a las autoridades confesando los hechos en que haya participado, y además colabore activamente con éstas para impedir la producción del delito o coadyuve eficazmente a la obtención de pruebas decisivas para la identificación o captura de otros responsables o para impedir la actuación o el desarrollo de organizaciones o grupos terroristas a los que haya pertenecido o con los que haya colaborado". Vid. CORCOY BIDASOLO, M. / MIR PUIG, S., Comentarios..., cit. pp. 1128 y 1129. Algunos autores denominan esta previsión como "semiexcusa absolutoria". Vid. VIVES ANTÓN, T.S. / CARBONELL MATEU, J.C., (con la colaboración de MIRA BENAVENT, J.,) "Delitos contra el orden público...", cit. p. 796. Estos autores señalan que "la semiexcusa absolutoria tal y como se halla redactada no alcanza a las conductas de pertenencia a organización o grupo terrorista sino sólo a los restantes delitos lo cual resulta, a simple vista, absurdo; y que en el artículo 780 se contiene, además de las especialidades enumeradas las constituida por la reincidencia internacional". Por otra parte, sigue diciendo VIDALES RODRÍGUEZ, C., "La libertad condicional...", cit. p. 100, que el tenor del precepto no especifica cuándo debe darse la colaboración activa del terrorista con las autoridades, dando lugar a dos nuevas cuestiones: 1) la primera es que dicha colaboración puede haberse dado para atenuar la pena antes de la sentencia aplicando así el art. 579 $\mathrm{CP}$, en cuyo caso cabría preguntarse si esa valoración ya debe de aceptarse para acreditar el pronóstico favorable de reinserción, aspecto al que refiere también GARCÍA ARÁN, M., "De las penas...", cit. p. 772, que expresa que para acordar la libertad condicional hay que acreditar las circunstancias a los solos efectos de la formulación del pronóstico de reinserción "y nada impide que en dicho trámite se den por probadas tales circunstancias cuando así conste en la sentencia condenatoria, documento probatorio por excelencia". No obstante, VIDALES incide en que si esto es así, carecería de sentido por ser imposible de justificar, que le fuera aplicable la previsión del art. 36 CP relativa al periodo de seguridad. Si por el contrario, se atenuó la pena en su día y ello no sirve para acreditar que exista pronóstico favorable de reinserción en el momento de acordar la progresión en grado o la libertad condicional convendría plantearse qué utilidad puede tener esta privación de libertad, en la medida en que en la sentencia hay una atenuación que premia al arrepentido y en la fase de ejecución se entiende que no existe pronóstico favorable ni aun contando con dicho precedente en los autos y 2) la segunda cuestión, si el sujeto se negó en su día a la colaboración dando lugar a que no se le aplicase el art. $579 \mathrm{CP}$, la cuestión es si puede acceder al tercer grado o a la libertad condicional si se cumplen los restantes requisitos, a lo que VIDALES responde que la actitud del penado en la fase de ejecución debe ser valorada con independencia de la actitud antes de la condena, habida cuenta de la distinta naturaleza jurídica de ambas figuras con sus respectivos efectos. Pero la cuestión plantea un nuevo interrogante, derivado de que el penado puede que no esté en condiciones de colaborar activamente con las autoridades si ya se desvinculó de la actividad terrorista en el momento anterior a la sentencia, lo que impediría la materialización de esa exigencia legal, o por el contrario, puede que sí que esté en condiciones de colaborar en un momento posterior habiéndose desvinculado previamente, lo que nos conduciría a afirmar que esa desvinculación no fue plena y, por tanto, supondría la negación a posteriori de un aspecto que ya se valoró en su día para atenuar la pena. En cualquier caso, se somete al penado a un "chantaje de difícil aceptación. Vid. VIDALES RODRÍGUEZ, C., "La libertad condicional...", cit. pp. 100 y 101. También plantean algunos autores que el penado puede que no esté en condiciones de colaborar con las autoridades debido a los largos años transcurridos en prisión, aspecto que puede incluso promover acusaciones falsas para obtener la libertad condicional y la inversión de la carga de la prueba para el delatado 
petición expresa de perdón a las víctimas de su delito- son alternativos o concurrentes, esto es, si deben darse todos o si solo uno de ellos independientemente del que sea. Todo apunta a que la dicción literal del precepto impone la concurrencia de todos ellos para progresar en grado, lo cual implica que se tenga que valorar un elemento ético-subjetivo que se traduce en que exista una reconversión ideológica en un ámbito de la delincuencia que lo es por convicción. Es decir, que la concesión del tercer grado y de la libertad condicional dependería de una actitud interna del sujeto que rememora el Derecho penal de autor ${ }^{1408}$.

También advierte la doctrina de la dificultad para desvincular de la actividad delictiva a los penados por crimen organizado1409, y en ese sentido GARCÍA ARÁN manifiesta que la norma debe ser interpretada de forma restrictiva y que no es posible que abarque todo supuesto incluido en la amplísima definición de organizaciones criminales que el CP asumió con posterioridad a esta regulación de la libertad condicional, en especial esas exigencias de colaborar con las autoridades como contenido integrador del pretendido pronóstico de reinserción social, no parece que tengan mucho sentido cuando se trata de pequeñas organizaciones que se dedican a cometer delitos de poca gravedad o faltas reiteradas, que son figuras que "no justifican tan excepcionales medios de intervención"1410.

Continuando con las especialidades que conciernen a la libertad condicional en materia de terrorismo y crimen organizado, la LO 7/2003 introdujo también una fórmula por la que se impide de forma absoluta que a los condenados por delitos de terrorismo o cometidos en el seno de organizaciones criminales, se les puedan aplicar los únicos

\footnotetext{
1408 VIDALES RODRÍGUEZ, C., “La libertad condicional...”, cit. p. 102. Por su parte, GARCÍA ARÁN, M., “De las penas...", cit. p. 769, aduce que la interpretación correcta de esta "redacción farragosa con profusión de conjunciones disyuntivas y copulativas que dificultan su comprensión" sería la siguiente: una primera exigencia que sería concurrente o acumulativa en relación a los requisitos de presentar signos inequívocos de abandono de los fines y medios de la organización terrorista y la colaboración activa con las autoridades en alguna de las formas posibles que aparecen como alternativas, que son: impedir futuros delitos, atenuar los efectos del delito ya cometido, identificar, capturar o procesar a los responsables de delitos de terrorismo y obtener pruebas o impedir la actuación o el desarrollo de la organización a la que hubiera pertenecido o con la que hubiera colaborado. Y en ese orden de cosas, el precepto luego enuncia las formas en que todo ello podrá acreditarse, que será mediante una declaración expresa de repudio a la violencia y de abandono de la actividad, y concurrentemente una petición expresa de perdón a las víctimas. También puede acreditarse a través de informes técnicos que acrediten la desvinculación con la organización y la colaboración con las autoridades, es decir, que esta última posibilidad aparece como alternativa a la anterior, debido a la expresión "así como" que utiliza el precepto.
}

1409 VIDALES RODRÍGUEZ, C., “La libertad condicional...”, cit. p. 102.

1410 GARCÍA ARÁN, M., “De las penas...”, cit. p. 769. 
beneficios consistentes en el adelantamiento excepcional de la libertad condicional del art. $91 \mathrm{CP}$, exclusión que como advierte la doctrina supone una "discriminación injustificada"1411.

Además, existen reglas especiales que afectan a la revocación de la libertad condicional para delitos de terrorismo, previstas en el art. $93 \mathrm{CP}$, que ya han sido analizadas supra, aunque conviene destacar que estas especialidades no se extiende a los delitos cometidos en el seno de organizaciones criminales, sino que únicamente refieren a delitos de terrorismo ${ }^{1412}$.

Un último aspecto que conviene mencionar, es la posibilidad de que se conceda la libertad condicional domiciliaria a condenados por delitos de terrorismo, con independencia de los requisitos exigidos para este tipo de penados, cuando exista peligro de muerte inminente a causa de que el interno haya emprendido una huelga hambre, tal y como a raíz de la STS 149/2007, de 26 de febrero, se resolvió en el caso de Juan Antonio De Juana Chaos en el Auto del JCVP, de 1 de marzo de 20071413.

\section{g) Extranjeros no residentes en España}

El art 197.1 RP, dispone que en caso de internos extranjeros no residentes legalmente en España o de españoles residentes en el extranjero, el JVP podrá acordar que la libertad condicional se cumpla en el país de origen del extranjero o en el país en que el español resida, siempre que exista previa conformidad documentada del interno. También dice el precepto que se podrá solicitar a las autoridades competentes del Estado del país fijado, que se apliquen las medidas de seguimiento y control de la libertad condicional, previstas en la legislación interna de dicho país, siempre y cuando las normas de Derecho Internacional lo permitan ${ }^{1414}$.

\footnotetext{
1411 CERVELLÓ DONDERIS, V., Derecho Penitenciario..., cit. p. 254.
}

1412 “Lo cual puede explicarse por la preocupación predominante del Grupo Político impulsor de Proyecto de reforma por los supuestos de terrorismo". Vid. TAMARIT SUMALLA, J.M. / GARCÍA ALBERO, R. / RODRÍGUEZ PUERTA, M.J. / SAPENA GRAU, F., Curso de Derecho Penitenciario..., cit. p. 356.

1413 GÓMEZ COLOMER, J.L., “El proceso de ejecución”. En MONTERO AROCA, J. / GÓMEZ COLOMER, J.L. / MONTÓN REDONDO, A. / BARONA VILAR, S., Derecho Jurisdiccional III. Proceso Penal. $18^{\mathrm{a}}$ Ed. Valencia: Tirant lo Blanch. 2010, pp. 472 y 473.

1414 DE MARCOS MADRUGA, F., “De la libertad condicional...”, cit. p. 409. Este autor aduce que en el marco de la Unión Europea son de aplicación la Decisión Marco 2008/909/JAI del Consejo, de 27 de noviembre de 
El art. 197.2 RP, contiene una previsión para dar cumplimiento a la medida de expulsión del art. $89 \mathrm{CP}$, por la que, con antelación suficiente, se comunicarán al Ministerio Fiscal las propuestas de libertad condicional de penados extranjeros junto con un breve resumen de su situación penal y penitenciaria, en el que se harán constar expresamente las fechas de cumplimiento de las dos terceras partes y de las tres cuartas partes de su condena o condenas ${ }^{1415 / 1416}$.

2008, relativa a la aplicación del principio de reconocimiento mutuo de sentencias en materia penal por las que se imponen penas u otras medidas privativas de libertad a efectos de su ejecución en la Unión Europea, y la Decisión Marco 2008/947/JAI del Consejo, de 27 de noviembre de 2008, relativa a la aplicación del principio de reconocimiento mutuo de sentencias y resoluciones de libertad vigilada con miras a la vigilancia de las medidas de libertad vigilada y las penas sustitutivas.

1415 Este precepto plantea algunos problemas desde la reforma del CP operada mediante LO 5/2010, ya que, el art. $89 \mathrm{CP}$, que regula la medida de seguridad de expulsión de los extranjeros, en la redacción dada por la LO $11 / 2003$, anterior a la reforma, decía que excepcionalmente podría ejecutarse la pena y no la expulsión si existían razones que justificasen el cumplimiento en un centro penitenciario de España. La nueva redacción del art. 89.5 CP ya no hace referencia a que deba ser en un centro penitenciario, sino que refiere a "cumplimiento en España", de lo que se infiere que puede cumplirse la libertad condicional también en España porque es una forma de cumplimiento de la pena, y cabría la posibilidad de que, si hay razones que justifiquen el cumplimiento de la pena en España, esas razones se extiendan a la libertad condicional. Por ese motivo Vid. GARCÍA ARÁN, M., “De las penas...”, cit. pp. 766 y 767, afirma que la posibilidad reglamentaria de cumplimiento de la libertad condicional en un país extranjero "no encuentra acomodo entre las únicas posibilidades de expulsión o cumplimiento en España que prevé el CP", por lo que opina que la aplicabilidad el art 197.1 RP queda reducida a los españoles que residan en el extranjero. No se regula la posibilidad de los extranjeros residentes legalmente en España que quieran que se cumpla la libertad condicional en sus países de origen, pero la doctrina viene diciendo que no habría ningún obstáculo para que pudiera concederse esa posibilidad. Vid. DE MARCOS MADRUGA, F., “De la libertad condicional...”, cit. p. 409.

1416 Un aspecto relevante es la fricción existente entre la situación de libertad condicional del extranjero y la expulsión gubernativa que pudiera acordarse por aplicación de la LO 4/2000, de 11 de enero, sobre derechos y libertades de los extranjeros en España y su integración social (reformada por la LO 2/2009), ya que la existencia de condenas anteriores, los antecedentes penales y los informes desfavorables de las autoridades competentes en materia de extranjería, conducen necesariamente a la denegación de cualquier expediente de autorización de residencia y trabajo o a su renovación. Vid. ESPINOSA CALABUIG, R., "Permanencia de los extranjeros en España”. En FERNÁNDEZ MASIÁ, E., (Dir.) Nacionalidad y Extranjería. Valencia: Tirant lo Blanch. 2011, p. 182 a 208. lo que a su vez conduce a la expulsión, por lo que podría darse el caso de que el penado se halle en situación de libertad condicional para su cumplimiento en España, pero al mismo tiempo se acuerde la expulsión gubernativa quedando desnaturalizada la figura de la libertad condicional. Sobre este aspecto la doctrina afirma que un extranjero que disfrute de la libertad condicional no podrá ser expulsado administrativamente. lo que a su vez conduce a la expulsión, por lo que podría darse el caso de que el penado se halle en situación de libertad condicional para su cumplimiento en España, pero al mismo tiempo se acuerde la expulsión gubernativa quedando desnaturalizada la figura de la libertad condicional. Sobre este aspecto la doctrina afirma que un extranjero que disfrute de la libertad condicional no podrá ser expulsado administrativamenteid. lo que a su vez conduce a la expulsión, por lo que podría darse el caso de que el penado se halle en situación de libertad condicional para su cumplimiento en España, pero al mismo tiempo se acuerde la expulsión gubernativa quedando desnaturalizada la figura de la libertad condicional. Sobre este aspecto la doctrina afirma que un extranjero que disfrute de la libertad condicional no podrá ser expulsado administrativamente, (vid. DE MARCOS MADRUGA, F., “De la libertad condicional...", cit. p. 409), al menos hasta que se haya cumplido la totalidad de la condena, y la expulsión se llevará a cabo en caso de que no consiga regularizar su situación tras el cumplimiento de la pena. Vid. RÍOS MARTÍN, J.C., "La libertad condicional...", cit. pp. 226 y 227, con cita del Auto de JVP núm. 3 de Madrid, de 6 de octubre de 1996, que señala que el liberado condicional sigue cumpliendo condena. 


\section{h) Procedimiento}

Como ya se ha dicho, la competencia para acordar la libertad condicional recae sobre el JVP1417, en virtud de los arts. 90 y ss. CP y 76.2 b) LOGP. De esa forma, una vez se hayan alcanzado los límites temporales de tres cuartas partes de la condena o dos terceras según los casos, la junta de tratamiento deberá iniciar el expediente de libertad condicional ${ }^{1418}$ con la debida antelación para que la resolución no se demore (art. 194 $R P)^{1419}$, a cuyo efecto deberá hacer la propuesta al JVP para que resuelva sobre su concesión ${ }^{1420}$. En el expediente de libertad condicional deberán constar los documentos que relacionan en art. 195 RP1421. Cuando el expediente haya concluido, la junta de tratamiento lo remitirá al JVP con las certificaciones e informes que sean necesarias para acreditar la concurrencia de los requisitos para acordarla1422, y acompañará una propuesta razonada a favor de la libertad condicional. El JVP remitirá su resolución acordando la libertad condicional al Director centro penitenciario, que dará cuenta a la junta de tratamiento para que expida el certificado de libertad condicional y proceda a la liberación del penado en la fecha prevista. De ese modo, cuando sea liberado condicionalmente, se someterá al control y seguimiento de los servicios sociales que haya dispuesto el JVP en su

1417 GÓMEZ COLOMER, J.L., “El proceso de ejecución...”, cit. p. 473.

1418 DE MARCOS MADRUGA, F., “De la libertad condicional...”, cit. p. 408.

1419 Art. 194. “Iniciación del expediente. La Junta de Tratamiento deberá iniciar la tramitación del correspondiente expediente con la antelación necesaria para que no sufra retraso la concesión de este beneficio".

1420 CUELLO CONTRERAS, J. / MAPELLI CAFFARENA, B., Curso de Derecho penal..., cit. p. 293.

${ }^{1421}$ Que son: a) el testimonio de la sentencia o sentencias recaídas y de la correspondiente liquidación de condena; b) la certificación acreditativa de los beneficios penitenciarios y de la clasificación en tercer grado; c) el informe pronóstico de integración social, emitido por la Junta de Tratamiento de acuerdo con lo establecido en el art. 67 LOGP; d) el resumen de la situación penal y penitenciaria del penado, con indicación de las fechas de prisión continuada y de las de cumplimiento de las dos terceras partes y tres cuartas partes de la condena, así como de la fecha de libertad definitiva; e) la indicación de los permisos de salida disfrutados y sus incidencias, así como las sanciones y sus cancelaciones, para lo cual se podrá aportar copia de los ficheros informáticos penitenciarios; f) el programa individual de libertad condicional y plan de seguimiento; g) el acta de compromiso de acogida por parte de su familia, persona allegada o instituciones sociales extrapenitenciarias; h) la manifestación del interesado sobre la localidad en que piensa fijar su residencia y sobre si acepta la tutela y control de un miembro de los servicios sociales del Centro, que informarán sobre las posibilidades de control del interno. En la fijación de la residencia se habrá de tener en cuenta la prohibición de residir en un lugar determinado o de volver a determinados lugares que, en su caso, hubiera impuesto el tribunal; i) la manifestación del interesado sobre el trabajo o medio de vida de que dispondrá al salir en libertad o, en el supuesto de que no disponga, informe de los servicios sociales sobre la posibilidad de trabajo en el exterior; j) la certificación literal del acta de la junta de tratamiento del establecimiento en la que se recoja el acuerdo de iniciación del expediente a que se refiere el artículo anterior, donde, en su caso, se propondrá al JVP la aplicación de una o varias de las reglas de conducta previstas en el art.105 CP. Vid. GRACIA MARTIN, L. / ALASTUEY DOBÓN, M.C., “La ejecución de las penas...”, cit. p. 374; y RÍOS MARTÍN, J.C., “La libertad condicional...", cit. pp. 220 a 222.

1422 FERNÁNDEZ GARCÍA, J., “La libertad condicional...”, cit. p. 236. 
resolución basándose en el programa individualizado de seguimiento con indicación, en su caso, de las reglas de conducta a seguir, que deberá haber elaborado previamente la junta de tratamiento ${ }^{1423}$.

\section{i) La libertad condicional en el Proyecto de reforma del Código penal, de 20 de septiembre de 2013}

En el Proyecto de reforma del CP, de 20 de septiembre de 2013, la libertad condicional pasa a regularse como una suspensión a prueba del resto de la pena, esto es, como una forma de suspensión de la parte de pena que reste por cumplir. En ese sentido se proyecta una reforma de los arts. 90, 91, 92 y $93 \mathrm{CP}$, con la consecuencia de que, durante la libertad condicional, el penado seguirá cumpliendo condena, pero ese resto de pena que quede por cumplir estará en suspenso. Si el penado incumple las condiciones que se le impongan, ese resto de pena deberá cumplirse íntegramente sin posibilidad de abono del tiempo cumplido en libertad condicional.

La Exposición de Motivos del Proyecto dice que "la libertad condicional pasa a ser regulada como una modalidad de suspensión de la ejecución del resto de la pena. Al contrario de lo que venía sucediendo hasta ahora, el tiempo en libertad condicional no computará como tiempo de cumplimiento de condena, sino que la concesión de la libertad condicional determinará la suspensión de la ejecución del resto de la pena durante un determinado período de tiempo: si, durante ese tiempo, el penado no reincide y cumple las condiciones impuestas, se declarará extinguida la pena pendiente de cumplimiento; por el contrario, si durante ese período de libertad condicional (o de suspensión de la ejecución del resto de la pena) comete un nuevo delito o incumple gravemente las condiciones impuestas, la libertad será revocada y deberá cumplir toda la pena que restaba. Por esta razón, el régimen de la libertad condicional pasa a estar regulado, en gran parte, por remisión a la regulación de la suspensión de la ejecución de la pena".

1423 GRACIA MARTIN, L. / ALASTUEY DOBÓN, M.C., “La ejecución de las penas...”, cit. p. 375. No obstante, el JVP puede denegar la concesión de la libertad condicional, en cuyo caso el penado continuará en tercer grado de tratamiento penitenciario, no siendo posible la regresión al segundo grado por ese motivo, aspecto que, sin embargo, se produce algunas veces y que ha sido puesto de relieve por la doctrina como una práctica contraria a Derecho y, por ende, nula. Vid. RÍOS MARTÍN, J.C., "La libertad condicional...", cit. p. 222, con cita del Auto de JVP de Granada de 9 de junio de 1995. Por último, las decisiones de los JVP sobre libertad condicional son susceptibles de ser recurridas en apelación ante la AP, sin olvidar que cuando la competencia sea de los JCVP, que se da en los casos en que los delitos sean a su vez competencia de la AN, los recursos de apelación contra las decisiones de los JCVP se sustanciarán ante la Sala de lo Penal de la AN. Vid. GARCÍA ARÁN, M., “De las penas...”, cit. p. 756. 
Algunos autores han manifestado que esta transformación de la libertad condicional en una suerte de suspensión del resto de la pena que se viene proyectando, implica la desnaturalización de la figura de la libertad condicional y desnaturaliza también el método de individualización científica dentro de la progresividad del sistema penitenciario español previsto en el art. 72 LOGP, pues mientras que las figuras de las suspensión y sustitución de la pena tienen por finalidad evitar el ingreso en prisión y posibilitar que dicho ingreso no se haga más que en los casos en que sea realmente necesario o imprescindible, la libertad condicional no tiene ese objeto, sino que se trata de una última etapa de cumplimiento de la pena de prisión, solo que ese cumplimiento se hace en libertad. Por eso, la doctrina viene diciendo que ese cambio de naturaleza, tiene como punto de partida un "falso entendimiento" -que comienza con la promulgación de la LO 7/2003-, de que la libertad condicional o incluso el tercer grado de tratamiento penitenciario no es realmente un cumplimiento de la pena. Por ello, esta transformación implica un nuevo endurecimiento de la figura, que sigue el camino iniciado en $2003^{1424}$.

\section{LIBERTAD CONDICIONAL Y LIBERTAD VIGILADA}

De los dos supuestos a los que es aplicable la libertad vigilada, el primero, a sujetos inimputables o semiimputables, la cuestión no plantea problemas porque la libertad vigilada no encuentra ningún punto de fricción con la libertad condicional. En cuanto a los plenamente imputables, el supuesto concreto es el relativo al cumplimiento de la medida de libertad vigilada por el penado que accede a la libertad condicional - cuando se trata de delincuentes sexuales o terroristas-. Lo que interesa resaltar a este respecto, es que la libertad vigilada no es incompatible con la libertad condicional, es decir, que un sujeto (de los de esta categoría) condenado a una pena privativa de libertad y también sometido a libertad vigilada (impuesta en la sentencia), puede gozar igualmente del estadio de la libertad condicional.

El verdadero inconveniente que se observa es el relativo a cómo va a ser posible que tras la libertad condicional, que ya requiere un pronóstico favorable de reinserción, se

1424 RODRÍGUEZ YAGÜE, C. / GUISASOLA LERMA, C. / ACALE SÁNCHEZ, M., “Libertad condicional: Artículos 90, 91, 92 y 93 CP”. En ÁLVAREZ GARCÍA, F.J., (Dir.) / DOPICO GÓMEZ-ALLER, J., (Coord.), Estudio crítico sobre el Anteproyecto de Reforma penal de 2012. Valencia: Tirant lo Blanch. 2013, pp. 384 y 385. 
empiece a cumplir la medida de seguridad de libertad vigilada encaminada precisamente a alcanzar una reinserción social mediante la desaparición de la peligrosidad criminal que, paradójicamente, ya se ha alcanzado, al menos apriorísticamente, para contar con el acceso a la libertad condicional. Es más, si la libertad vigilada puede imponerse durante el tiempo necesario hasta que exista un pronóstico favorable de reinserción y reducirse o extinguirse tan pronto como desaparezca la necesidad de imponerle al penado normas de conducta resocializadoras, lo que cabe plantear es si sería posible dejar sin efecto la medida de seguridad de libertad vigilada contando únicamente con el pronóstico favorable de reinserción exigido para la libertad condicional, esto es, si la libertad condicional podría suponer la necesaria extinción de la medida de seguridad. Parece que lo más acertado sería reducir la aplicación de la libertad vigilada a aquellos supuestos en los que el penado no haya tenido acceso a la libertad condicional ${ }^{1425}$ por inexistencia de pronóstico favorable de reinserción ${ }^{1426}$ y, por tanto, no pudiendo prolongar más tiempo su condena por exigencias del principio de legalidad estaría justificado el cumplimiento de la medida, pero en caso contrario no parece muy adecuado que la libertad vigilada deba empezar a cumplirse.

Autores como FEIJOO SÁNCHEZ han advertido que la libertad condicional será un indicio de la innecesariedad de la libertad vigilada posterior y que, en caso de ejecutarla a pesar de que la evolución del sujeto sea positiva, las obligaciones que se impongan nunca deberán ser más restrictivas que las acordadas en la fase de libertad condicional, porque de lo contrario se produciría una regresión. En cualquier caso, este autor se posiciona en la opinión de que la libertad vigilada no debería ejecutarse en supuestos en que la progresión del penado haya sido adecuada y exista pronóstico favorable de reinserción social, por lo que concluye que la libertad vigilada estaría destinada solamente a los sujetos que no han accedido al tercer grado ni a la libertad condicional ${ }^{1427}$.

Otro planteamiento sería el que previera que para el caso de penados que accedan a la libertad condicional y su condena incluya la medida de seguridad de libertad vigilada, la misma se aplicara durante el mínimo tiempo posible y que se impusiera la obligación al juez de extinguirla si no concurre ninguna circunstancia que justifique su

\footnotetext{
1425 GARCÍA ALBERO, R., en QUINTERO OLIVARES, G., Comentarios..., cit. Tomo I, p. 693.

1426 NISTAL BURÓN, J, “La “libertad vigilada...", cit. p. 6.

1427 FEIJOO SÁNCHEZ, B., “La libertad vigilada...”, cit. p. 222.
} 
prolongación, esto es, si el sujeto sometido a la medida no ha incumplido las obligaciones o prohibiciones que le hayan sido impuestas $y$, en definitiva, si no han variado las circunstancias que motivaron el pronóstico favorable que permitió al sujeto acceder a la libertad condicional. De lo contrario, nos encontraríamos ante la incongruencia de que el penado cumple la pena de prisión en libertad condicional por existir pronóstico de reinserción y, seguidamente, la medida de libertad vigilada por necesitar pautas de conducta para su reinserción, lo cual no parece casar bien con la esencia misma de las medidas de seguridad, y sería más bien un complemento punitivo prolongador de la restricción de la libertad y no una figura que persiga profundizar en labores efectivas de prevención especial, como impone su naturaleza jurídica.

En cualquier caso, lo que no parece tener sentido es que un sujeto que accede a la libertad condicional (y por lo tanto se encuentra en un régimen de libertad), se encuentre prácticamente reinsertado, que su vida ya reviste apariencia de normalidad y que está a punto de alcanzar su licenciamiento definitivo por extinción de la pena de prisión por efectivo cumplimiento de la totalidad de su condena, que sea en ese momento cuando comience a cumplirse una medida de seguridad de libertad vigilada que puede incluso implicar mayor contenido restrictivo en la libertad individual dependiendo de las prohibiciones $u$ obligaciones en que se concrete ${ }^{1428}$. Es decir, la posibilidad de que la medida de seguridad empiece a ejecutarse tras el cumplimiento de la prisión en la fase de libertad condicional, podría resultar incluso más grave que la pena, aspecto que supondría un grave retroceso en la ejecución penal de ese sujeto y que además iría en contra de la esencia misma del sistema progresivo ${ }^{1429}$. Si la libertad vigilada se basa en la peligrosidad y ese sujeto ha estado en libertad condicional por pronóstico favorable de reinserción, no puede afirmarse que concurra la peligrosidad que justifica la libertad vigilada. Si esa peligrosidad ha desaparecido y en su lugar hay pronóstico favorable de reinserción, no parece que exista ningún fundamento con el que permitir que se ejecute la medida de seguridad.

En definitiva, la libertad vigilada para los supuestos de terroristas y delincuentes sexuales, puede suponer un retroceso en la progresión penitenciaria, supondrá un nuevo

\footnotetext{
1428 LEGANÉS GÓMEZ, S., “Clasificación penitenciaria y libertad vigilada”. En La Ley Penal, núm. 96-97, 2012, p. 34 .

1429 CÁMARA ARROYO, S., “La libertad vigilada...”, cit. p. 18.
} 
obstáculo para la reinserción y puede que no sea capaz de servir a sus fines. Por eso, debería sopesarse la posibilidad de ofrecer una previsión que imponga la automática extinción de la libertad vigilada si en el sujeto hay pronóstico favorable de reinserción o, lo que es lo mismo: que la libertad condicional implique la no ejecución de la libertad vigilada por haber desaparecido la peligrosidad del sujeto en cuyo fundamento se construye, de lo contrario, la libertad vigilada se convierte en un complemento punitivo para terroristas y delincuentes sexuales que supone un total abandono del sistema progresivo de ejecución de penas ${ }^{1430}$, por cuanto que su aplicación, una vez cumplida la pena privativa de libertad, retrocede en la reinserción social debido a que el contenido de la libertad vigilada puede llegar incluso a ser más gravoso y con más restricciones en la esfera de la libertad individual del sujeto, que la pena de prisión cuando se cumple en régimen de semilibertad o de libertad condicional ${ }^{1431}$. Por otra parte, la concesión de la libertad condicional puede venir acompañada de la imposición de una serie de reglas de conducta que pueden coincidir con las que corresponderían a la libertad vigilada, produciéndose el efecto de que el sujeto podría pasar a cumplir un régimen más restrictivo estando en libertad que durante el cumplimiento de la pena, por lo que habría que compaginar las exigencias legales en materia de ejecución penitenciaria con el cumplimiento de la libertad vigilada ${ }^{1432}$.

Para una correcta aplicación de la libertad vigilada tras la pena privativa de libertad habría que tener en cuenta que no es posible retroceder en la progresividad, de forma que, cuando se accede al tercer grado o a la libertad condicional, ya no debería ser posible la ejecución posterior de la libertad vigilada, al igual que tampoco debería ejecutarse cuando las penas hayan experimentados agravaciones especiales cuando no se tiene acceso a beneficios penitenciarios, o a regímenes de semilibertad o libertad condicional.

Otros autores como CÁMARA ARROYO manifiestan que, mientras la libertad condicional encuentra su fundamento en la confianza en el sujeto, la libertad vigilada

1430 REBOLLO VARGAS, R., La llibertat vigilada: pena accessòria o mesura de seguretat..., cit. p. 61; SANZ MORÁN, A.J., "La nueva medida de seguridad...", cit. pp. 1021 y 1022.

1431 NISTAL BURÓN, J., “La “libertad vigilada”. La dificultad de su aplicación práctica. (A propósito de la nueva medida de seguridad no privativa de libertad que prevé el Proyecto de Ley Orgánica de reforma del Código Penal de 1995)". En Diario La Ley, núm. 7368, 2010, p. 6.

1432 SIERRA LÓPEZ, M.V., La medida de libertad vigilada..., cit. p. 150. 
parte de la desconfianza en el penado, lo cual supone "un nuevo paradigma en la en la filosofía del sistema de ejecución"; y que la regulación actual se encuentra desligada de la regulación penitenciaria, que lleva a confrontar significativamente la medida de seguridad con las anteriores fases de cumplimiento de la pena, desestabilizando el sistema de cumplimiento progresivo y de individualización científica. Este autor entiende que el legislador considera posible el cumplimiento de la libertad vigilada tras la libertad condicional, con los obstáculos de congruencia que ello implica, que se refuerza con la Instrucción de la Secretaría General de Instituciones Penitenciarias 19/2011, de 16 de noviembre, de cumplimiento de las medidas de seguridad competencia de la Administración penitenciaria, que dispone que en caso de penados que tengan impuesta la libertad vigilada para su cumplimiento posterior a la pena privativa de libertad, con tres meses de antelación a la extinción de la pena, deberá elevar un informe técnico al JVP, "la Junta de Tratamiento penitenciario del centro en el que se encuentre el penado o de aquél al que estuviera adscrito si se hallare en libertad condicional"1433. Por ello, este autor propone que se permita el cumplimiento de la libertad vigilada durante el transcurso de la pena de prisión ${ }^{1434}$.

Por otra parte, la libertad vigilada se puede imponer como contenido de las reglas de conducta para la libertad condicional, aspecto que, como se ha dicho supra, no implica que se imponga realmente una medida de seguridad basada en la peligrosidad, sino que solo se imponen las reglas de conducta en las que se concreta la medida, de forma que solo se traslada a la libertad condicional el contenido de la medida, no la medida en sí. No obstante, lo que en principio podría suponer una suerte de solapamiento sería el hecho de que, como contenido de la libertad condicional, se acuerde la liberta vigilada y se concrete en algunas de sus obligaciones o prohibiciones del catálogo previsto y que, posteriormente al extinguirse la pena, se produzca una continuidad con la libertad vigilada postpenitenciaria —en los casos en que es posible aplicarla- con las mismas

\footnotetext{
1433 Tambiém refiere a este extremo el art. 23 del Real Decreto 840/2011, de 17 de junio, por el que se establecen las circunstancias de ejecución de las penas de trabajo en beneficio de la comunidad y de localización permanente en centro penitenciario, de determinadas medidas de seguridad, así como de la suspensión de la ejecución de las penas privativas de libertad y sustitución de penas, que dispone que dispone que es competencia de la Administración Penitenciaria, en los supuestos en que se haya impuesto al penado la medida de libertad vigilada de cumplimiento posterior a una pena privativa de libertad, antes de finalizar el cumplimiento de la pena privativa de libertad y a solicitud del JVP, elevar a éste un informe técnico sobre la evolución del penado, a los efectos previstos en el art. 106, $2^{\circ}$ párrafo $\mathrm{CP}$, que será elaborado por "la Junta de Tratamiento, u órgano autonómico equivalente, del Centro Penitenciario en el que el penado se encuentre cumpliendo condena, o del que esté adscrito si se encuentra en libertad condicional".
}

1434 CÁMARA ARROYO, S., “La libertad vigilada...”, cit. p. 18. 
obligaciones y prohibiciones pero con la diferencia de que esta vez sí respondería a la fundamentación de una medida de seguridad basada en la peligrosidad, al contrario que sucedía cuando esas mismas obligaciones formaban parte de la libertad condicional. Y dando un paso más, sería posible incluso que se cambiaran esas obligaciones imponiendo otras más graves, retrocediendo en la progresividad. En principio se observa que la continuación con las mismas obligaciones sería contradictorio y podría vulnerar el principio de ne bis in idem, que podría salvarse simplemente con la imposición del resto de obligaciones y prohibiciones que no hubiesen sido impuestas como contenido de la libertad condicional, independientemente de que tengan mayor o menor contenido restrictivo en los derechos del condenado. Pero sin duda, la mejor opción sería la que impidiera la repetición de obligaciones en la libertad vigilada si ya se han usado en la libertad condicional, dando lugar a que se impongan otras de las previstas en el catálogo pero siempre con menor contenido restrictivo que las utilizadas en la libertad condicional, para evitar que se retroceda en la progresividad y para no incurrir en una incongruencia al afirmar que durante la ejecución de la pena se ha usado el contenido de la libertad vigilada como reglas de conducta - con fines distintos a neutralizar la peligrosidad- y que, tras ella, se impongan las mismas reglas precisamente afirmando que sirven al fin de neutralizar la peligrosidad que, por otra parte, si la libertad condicional ha concluido sin ser revocada, difícilmente podrá afirmarse que concurra.

Por todos estos motivos, algunos autores como GARCía RIVAS, hablan de que la evaluación final de la libertad vigilada en cuanto que supone una novedad legislativa, es claramente negativa porque descansa sobre el denominado Derecho penal de la seguridad que se presta a extralimitaciones punitivas, y que "en lugar de acomodarse el legislador a un tratamiento normalizado de la libertad vigilada, confinándola a su función positiva de sustituto penal o de medida asociada al último período de cumplimiento de la pena de prisión (libertad condicional), ha optado por un tratamiento excepcional, sin justificación real"1435. Quizás la opción que invoca este autor de configurar la libertad vigilada como forma sustitutiva de la libertad condicional, permitiendo que la libertad condicional dé paso a la medida de seguridad sin que ello suponga la imposición de la medida tras la pena cumplida en su integridad, habría sido más razonable, aunque dicha opción no consigue salvar el inconveniente del retroceso en la progresividad ni de la justificación de

1435 GARCÍA RIVAS, N., “La libertad vigilada...”, cit. p. 27. 
la imposición de una medida de seguridad basada en la peligrosidad cuando la libertad condicional ya contempla una elevada dosis de ausencia de la misma por la acreditación de la concurrencia de pronóstico favorable de reinserción, por lo que, en cualquier caso, podría imponerse una serie se reglas de conducta de las previstas en el catálogo de la libertad vigilada para dar contenido a la libertad condicional -tal y como ya aparece previsto-, otra opción no resulta de fácil anclaje en el sistema.

También refiere a esta solución GARCÍA ALBERO, al explicar que le parece desacertada la opción elegida por el legislador para que la libertad vigilada se cumpla tras la pena de prisión $y$, desde ese punto de vista, afirma que sería posible regular el cumplimiento simultáneo de la libertad condicional (o incluso del tercer grado) con la libertad vigilada que, posteriormente, se podría prolongar si fuera necesario. Con ello se conseguirían algunos beneficios como el incentivo que esa forma atenuada de cumplimiento podría suponer para el sujeto a la hora de hacer un buen uso de su libertad condicional, ya que el buen fin de la misma puede suponer la no prolongación de la libertad vigilada que también está ya parcialmente cumplida.

Otro aspecto positivo sería la evitación de antinomias, porque el JVP podría dotar de una doble naturaleza a las reglas de conducta, como deberes de los que depende el mantenimiento de la libertad condicional y como deberes propios de la medida de seguridad, tal y como sucede en las medidas de alejamiento, cuya vulneración puede desembocar en la revocación de la libertad condicional y eventualmente la deducción de testimonio por quebrantamiento de condena. Se trataría, pues, de imponer la libertad vigilada en la sentencia, pero su cumplimiento empezaría con la progresión al tercer grado o a la libertad condicional, y si activarían o no los deberes para su concreción dependiendo del pronóstico penitenciario, al igual que se dejaría sin efecto si desaparece la peligrosidad, salvando así las objeciones que comporta la actual formulación que no solo presume la peligrosidad, sino también el fracaso de la pena de prisión. Termina este autor diciendo que, para incorporar esta solución, habría que cambiar el nomen iuris y llamarlo, a modo de la suivi sociojudiciarie francesa, algo así como "medida de vigilancia judicial de conducta u otro control judicial"1436.

1436 GARCÍA ALBERO, R., en QUINTERO OLIVARES, G., Comentarios..., cit. Tomo I, p. 694. 
Cuando se acuerda la libertad vigilada como contenido de la libertad condicional, se produce lo que la doctrina llama "un arsenal de medidas", puesto que concurren las once obligaciones y prohibiciones del art. $106 \mathrm{CP}$ con las otras seis que contiene el art. 83 $\mathrm{CP}$, y se afirma que hay medidas que en su contenido se superponen, por lo que devienen superfluas, lo que implica que solo la regla del art. 83.5 CP puede resultar de naturaleza distinta a las demás. Lo que conviene tener presente es que si se incumplen los contenidos de la libertad condicional, se produce la revocación, pero no se incurre en un nuevo delito como sucede si se incumplen las obligaciones o prohibiciones cuando se está cumpliendo la libertad vigilada ${ }^{1437}$.

En el supuesto de los extranjeros, en relación a la posibilidad del art. 197.1 RP, que dispone que la libertad condicional podrá disfrutarse en el país de origen, no hay regulación específica que disponga si en los supuestos en que está pendiente de cumplirse la libertad vigilada posterior a la pena, será posible acceder a dicha opción o si la misma devendrá de imposible aplicación. Algunos autores entienden que la libertad condicional para su disfrute en el país de origen debe concederse igualmente, articulándola de forma que el Juez o Tribunal fije como reglas de conducta en la libertad condicional el contenido de la libertad vigilada que considere oportuno como habilita el art. $90.2 \mathrm{CP}$, en relación al art. 96.3 CP, y enlazando seguidamente con la libertad vigilada de cumplimiento posterior, notificándole tal aspecto al interno. Se trataría de un supuesto ampliado de control "y la cuestión es su registro administrativo/policial a los efectos de conocer el alcance de la medida si regresa legal o ilegalmente a nuestro país"1438.

Otro aspecto que no aparece regulado es qué hacer con la libertad vigilada cuando se acuerda la libertad condicional en supuestos especiales, como enfermos terminales o septuagenarios. En estos casos, parece lógico que si se adelanta la libertad condicional por razones humanitarias y por inexistencia de peligrosidad que justifique el mantenimiento de la prisión, parece lógico que igual suerte deba correr la libertad vigilada y dejarse sin efecto, si es que finalmente se extingue la pena y debe empezar a cumplirse la libertad vigilada. Aplicarla tras la pena, en caso de que todavía les resten años de vida, no parece que sea muy coherente con la finalidad de la medida y con el régimen especial de libertad condicional que se les aplica.

\footnotetext{
1437 ROCA POVEDA, M., “La libertad vigilada...”, cit. p. 49.

1438 Ibidem, p. 43.
} 


\section{CAPÍTULO QUINTO. LA LIBERTAD VIGILADA EN EL PROYECTO DE REFORMA DEL CÓDIGO PENAL, DE 20 DE SEPTIEMBRE DE 2013}

En los últimos años, (2012 y 2013), desde el Gobierno de España se ha venido impulsando una nueva reforma del texto punitivo, a través de la publicación de varios Anteproyectos ${ }^{1439}$ que culminan con el Proyecto de reforma del CP, de 20 de septiembre de 20131440. Por ese motivo, en este Capítulo se analizan los principales aspectos de la reforma proyectada que afectan a la libertad vigilada y cuya aprobación en el Congreso de los Diputados podría producirse próximamente. Los principales aspectos que introduce el Proyecto son la modificación del sistema de medidas de seguridad y del sistema vicarial, la ampliación de los supuestos de aplicación de la libertad vigilada, la introducción de la prisión permanente revisable ${ }^{1441}$, la reforma del régimen de suspensión y sustitución de las penas y de la libertad condicional ${ }^{1442}$, la modificación de la regulación del comiso ${ }^{1443}$, la introducción de multitud de nuevas figuras y reformas en la parte especial1444, la

\footnotetext{
1439 Anteproyecto de reforma del Código penal de 17 de julio de 2012 y Anteproyecto de Reforma del Código penal de 11 octubre de 2012.

1440 Proyecto 121/000065 de Ley Orgánica por la que se modifica la LO 10/1995, de 23 de noviembre, del CP. BOCG, de octubre de 2013, serie A, núm. 66-1, págs. 1 a 100.

1441 Vid. DEL CARPIO DELGADO, J., “La pena de prisión permanente en el Anteproyecto de 2012 de Reforma del Código Penal". En Diario La Ley, núm. 8004. 2013, pp. 2 a 24; MARTín PALLín, J.A., "Reforma penal y prisión perpetua revisable. La prisión tiene un límite". En Notario del Siglo XXI, núm. 52, 2013, pp. 56 a 58; FERNÁNDEZ GARCÍA, J., “Las penas privativas de libertad en la reforma de Gallardón: Especial referencia a la prisión permanente revisable". En PÉREZ CEPEDA, A.I. (Dir.) / GORJÓN BARRANCO, M.C., El Proyecto de Reforma del Código penal de 2013 a debate. Salamanca: Ratio Legis. 2014, pp. 49 a 88; ACALE SÁNCHEZ, M. / MARÍN DE ESPINOSA y CEBALLOS, E.B. / GONZÁLEZ TASCÓN, M.M., "Sistema de penas". En ÁLVAREZ GARCÍA, F.J., (Dir.) / DOPICO GÓMEZ-ALLER, J., (Coord.), Estudio crítico sobre el Anteproyecto de Reforma penal de 2012. Valencia: Tirant lo Blanch. 2013, pp. 179 a 221.
}

1442 ABEL SOUTO, M. / ACALE SÁNCHEZ, M. / TRAPERO BARREALES, M.A. / GONZÁLEZ TASCÓN, M.M. / TERRADILLOS BASOCO, J.M / BOZA MARTÍNEZ, D. / RODRÍGUEZ YAGÜE, C. / GUISASOLA LERMA, C., "Formas sustitutivas de la ejecución de las penas privativas de libertad y libertad condicional". En ÁLVAREZ GARCÍA, F.J., (Dir.) / DOPICO GÓMEZ-ALLER, J., (Coord.), Estudio crítico sobre el Anteproyecto de Reforma penal de 2012. Valencia: Tirant lo Blanch. 2013, pp. 291 a 394.

${ }^{1443}$ AGUADO CORREA, T., “Comiso: crónica de una reforma anunciada”. En InDret. Revista para el análisis del Derecho. 1/2014. Barcelona: 2014, pp. 3 a 52.

1444 Vid., por ejemplo, SÁNCHEZ BERNAL, J., "Delincuencia de los poderosos y cohecho. Modificaciones previstas en el Proyecto de Ley Orgánica de Reforma del Código Penal del 2013". En PÉREZ CEPEDA, A.I. (Dir.) / GORJÓN BARRANCO, M.C., El Proyecto de Reforma del Código penal de 2013 a debate. Salamanca: Ratio Legis. 2014, pp. 177 a 195; PEÑARANDA RAMOS, E., "El delito de asesinato". En ÁLVAREZ GARCÍA, F.J., (Dir.) / DOPICO GÓMEZ-ALLER, J., (Coord.), Estudio crítico sobre el Anteproyecto de Reforma penal de 2012. Valencia: Tirant lo Blanch. 2013, pp. 485 a 510; GALDEANO SANTAMARÍA, A. / CANCIO MELIÁ, M., "Delitos contra la integridad física". En ÁLVAREZ GARCíA, F.J., (Dir.) / DOPICO GÓMEZ-ALLER, J., (Coord.), Estudio crítico sobre el Anteproyecto de Reforma penal de 2012. Valencia: Tirant lo Blanch. 2013, pp. 511 a 532; ACALE SÁNCHEZ, M. / GÓMEZ LÓPEZ, R. / GALDEANO SANTAMARÍA, A. / PORTERO HENARES, M., “Violencia de género". En ÁLVAREZ GARCíA, F.J., (Dir.) / DOPICO GÓMEZ-ALLER, J., (Coord.), Estudio crítico sobre el Anteproyecto de Reforma penal de 2012. Valencia: Tirant lo Blanch. 2013, pp. 533 a 548; GÓMEZ INIESTA, D. / GÓRRIZ ROYO, E. / MAQUEDA ABREU, M.L. / ACALE SÁNCHEZ, M. / GÓMEZ LÓPEZ, R. / GALDEANO SANTAMARÍA, A. / GUTIÉRREZ CASTAÑEDA, A. / MATALLÍN 
modificación la responsabilidad penal de las personas jurídicas ${ }^{1445}$ y la supresión de las faltas ${ }^{1446}$. Obviamente, no me puedo ocupar aquí de todas las cuestiones relatadas, sino únicamente de lo que afecta al objeto de nuestro estudio que se reduce a la nueva

EVANGELIO, A. / VILLACAMPA ESTIARTE, C., "Delitos contra la libertad". En ÁLVAREZ GARCÍA, F.J., (Dir.) / DOPICO GÓMEZ-ALLER, J., (Coord.), Estudio crítico sobre el Anteproyecto de Reforma penal de 2012. Valencia: Tirant lo Blanch. 2013, pp. 549 a 612; VILLACAMPA ESTIARTE, C., "Víctimas de la trata de seres humanos: su tutela a la luz de las últimas reformas penales sustantivas y procesales proyectadas". En Indret. Revista para el análisis del Derecho. 2/2014. Barcelona: 2014, pp. 2 a 16; ACALE SÁNCHEZ, M. / BOZA MARTÍNEZ, D. / COBOS GÓMEZ DE LINARES, M.A. / GARCÍA SEDANO, T., "Trata de seres humanos". En ÁLVAREZ GARCÍA, F.J., (Dir.) / DOPICO GÓMEZ-ALLER, J., (Coord.), Estudio crítico sobre el Anteproyecto de Reforma penal de 2012. Valencia: Tirant lo Blanch. 2013, pp. 613 a 638; TERRADILLOS BASOCO, J.M., "El delito de inmigración ilegal y la trata de personas". En PÉREZ CEPEDA, A.I. (Dir.) / GORJÓN BARRANCO, M.C., El Proyecto de Reforma del Código penal de 2013 a debate. Salamanca: Ratio Legis. 2014, pp. 133 a 156; RODRÍGUEZ PUERTA, M.J. / CABRERA MARTÍN, M. / RAMOS TAPIA, M.I. / MIRÓ LINARES, F. / MORÓN LERMA, E. / RODRÍGUEZ PUERTA, M.J. / FERNÁNDEZ TERUELO, J.G., "Delitos contra la indemnidad sexual". En ÁlVAREZ GARCÍA, F.J., (Dir.) / DOPICO GÓMEZ-ALLER, J., (Coord.), Estudio crítico sobre el Anteproyecto de Reforma penal de 2012. Valencia: Tirant lo Blanch. 2013, pp. 639 a 706; CARRASCO ANDRINO, M.M. / MOYA FUENTES, M.M. / OTERO GONZÁLEZ, M.P. / MORALES PRATS, F., "Delitos contra la intimidad". En ÁLVAREZ GARCÍA, F.J., (Dir.) / DOPICO GÓMEZ-ALLER, J., (Coord.), Estudio crítico sobre el Anteproyecto de Reforma penal de 2012. Valencia: Tirant lo Blanch. 2013, pp. 707 a 716; DE VICENTE MARTÍNEZ, R. / BAUCELLS LLADÓS, J. / BRAGE CENDÁN, S.B. / ROCA AGAPITO, L. / QUINTERO OLIVARES, G. / SÁNCHEZ DAFAUCE, M. / CASTRO MORENO, A. / GUTIÉRREZ RODRÍGUEZ, M. / NIETO MARTÍN, A. / ANDRÉS DOMÍNGUEZ, A.C., "Delitos contra el patrimonio y contra el orden socioeconómico". En ÁLVAREZ GARCÍA, F.J., (Dir.) / DOPICO GÓMEZ-ALLER, J., (Coord.), Estudio crítico sobre el Anteproyecto de Reforma penal de 2012. Valencia: Tirant lo Blanch. 2013, pp. 717 a 808; IGLESIAS RÍO, M.A. / MANJÓN-CABEZA OLMEDA, A. / GÓMEZ LANZ, J. / TERRADILLOS BASOCO, J.M. / LAURENZO COPELLO, P. /POMARES CINTAS, E. / PÉREZ ALONSO, E. / RODRÍGUEZ MESA, M.J. / GUISASOLA LERMA, C., "Delitos contra la Hacienda Pública y la Seguridad Social”. En ÁLVAREZ GARCÍA, F.J., (Dir.) / DOPICO GÓMEZ-ALLER, J., (Coord.), Estudio crítico sobre el Anteproyecto de Reforma penal de 2012. Valencia: Tirant lo Blanch. 2013, pp. 809 a 892; HAVA GARCÍA, E. / MUÑOZ LORENTE, J., "Delitos relativos a la protección de la flora, la fauna y los animales domésticos". En ÁLVAREZ GARCÍA, F.J., (Dir.) / DOPICO GÓMEZ-ALLER, J., (Coord.), Estudio crítico sobre el Anteproyecto de Reforma penal de 2012. Valencia: Tirant lo Blanch. 2013, pp. 893 a 902; HAVA GARCÍA, E. / VÁZQUEZ PORTOMEÑE, F. / PUENTE ABA, L.M. / ROCA AGAPITO, L. / CUGAT MAURI, M. / SÁNCHEZ TOMÁS J.M. / GARROCHO SALCEDO, A. / PORTILlA CONTRERAS, G., "Delitos contra la seguridad colectiva". En ÁlVAREZ GARCÍA, F.J., (Dir.) / DOPICO GÓMEZ-ALLER, J., (Coord.), Estudio crítico sobre el Anteproyecto de Reforma penal de 2012. Valencia: Tirant lo Blanch. 2013, pp. 903 a 942; FARALDO CABANA, P. / CUENCA GARCÍA, M.J., "Asociaciones ilícitas y organizaciones y grupos criminales". En ÁLVAREZ GARCÍA, F.J., (Dir.) / DOPICO GÓMEZ-ALLER, J., (Coord.), Estudio crítico sobre el Anteproyecto de Reforma penal de 2012. Valencia: Tirant lo Blanch. 2013, pp. 943 a 954; CUERDA ARNAU, M.L. / OLLOQUIEGUI SUCUNZA, I. / DE LA CUESTA AGUADO, P.M. / BAUCELLS LLADÓS, J. / MARTÍNEZ GUERRA, A., "Delitos contra el orden público". En ÁlVAREZ GARCÍA, F.J., (Dir.) / DOPICO GÓMEZ-ALLER, J., (Coord.), Estudio crítico sobre el Anteproyecto de Reforma penal de 2012. Valencia: Tirant lo Blanch. 2013, pp. 955 a 989.

1445 TERRADILlOS BASOCO, J.M., “Responsabilidad penal de las personas jurídicas”. En ÁLVAREZ GARCÍA, F.J., (Dir.) / DOPICO GÓMEZ-ALLER, J., (Coord.), Estudio crítico sobre el Anteproyecto de Reforma penal de 2012. Valencia: Tirant lo Blanch. 2013, pp. 171 a 177; CARRILLO DE TESO, A.E., "Responsabilidad penal de la persona jurídicas: Pasado, presente y futuro". En PÉREZ CEPEDA, A.I. (Dir.) / GORJÓN BARRANCO, M.C., El Proyecto de Reforma del Código penal de 2013 a debate. Salamanca: Ratio Legis. 2014, pp. 109 a 131; DÍAZ GÓMEZ, A., "Novedades del Proyecto de reforma de 2013 del Código Penal sobre la responsabilidad de las personas jurídicas". En Revista Electrónica del Departamento de Derecho de la Universidad de La Rioja (REDUR), núm. 11, 2013, pp. 149 a 168.

1446 Vid. FERNÁNDEZ HERNÁNDEZ, A. / OLLOQUIEGUI SUCUNZA, I. / MARÍN DE ESPINOSA y CEBALLOS, E.B. / GONZÁlEZ TASCÓN, M.M. / GALDEANO SANTAMARÍA, A. / ANDRÉS DOMÍNGUEZ, A.C., "Supresión del Libro III". En ÁLVAREZ GARCÍA, F.J., (Dir.) / DOPICO GÓMEZALLER, J., (Coord.), Estudio crítico sobre el Anteproyecto de Reforma penal de 2012. Valencia: Tirant lo Blanch. 2013, pp. 67 a 162. 
regulación de las medidas de seguridad en cuanto al sistema vicarial y en la nueva formulación de la libertad vigilada.

Pero no quisiera abordar estos aspectos sin antes hacer una breve referencia a lo que manifiesta PÉREZ CEPEDA cuando explica que el Proyecto gravita sobre una suerte de populismo punitivo, sobre una vis expansiva del Derecho penal que además criminaliza el ejercicio de los derechos fundamentales y se dirige decididamente hacia el llamado Derecho penal de la seguridad, que es, pues, el verdadero Derecho penal de la peligrosidad ${ }^{1447}$. Y ACALE SÁNCHEZ advierte de que los puntos esenciales de la reforma proyectada son la normativización del concepto de peligrosidad, la consideración del autor como enemigo social, la inocuización como fin del sistema penal, la confusión de penas y medidas de seguridad y un pensamiento retro de la defensa social frente a los delincuentes ${ }^{1448}$.

\section{LAS MEDIDAS DE SEGURIDAD}

La regulación conjunta de las medidas de seguridad experimenta un cambio muy significativo hacia el modelo dualista rígido de corte clásico que apuesta decididamente por la doble vía, acumulando penas y medidas de seguridad para los sujetos imputables peligrosos que hayan delinquido, con una limitación considerable de sistema vicarial, y la desaparición del límite máximo temporal en la aplicación de las medidas de seguridad. Conviene recordar que en los textos de los anteriores Anteproyectos de reforma del Código penal (el de 17 de julio de 2012 y el de 11 octubre de 2012), se incorporó la medida de seguridad de origen alemán (Sicherungsverwahrung) bajo el nombre de "custodia de seguridad"1449, pero finalmente en el texto del Proyecto de 20 de septiembre de 2013, no aparece tal medida, posiblemente debido a la multitud de críticas recibidas.

1447 PÉREZ CEPEDA, A.I., “Prólogo”. En PÉREZ CEPEDA, A.I. (Dir.) / GORJÓN BARRANCO, M.C., El Proyecto de Reforma del Código penal de 2013 a debate. Salamanca: Ratio Legis. 2014, pp. 15 a 20.

1448 ACALE SÁNCHEZ, M., “Nuevos presupuestos para la imposición de medidas de penas y medidas de seguridad”. En PÉREZ CEPEDA, A.I. (Dir.) / GORJÓN BARRANCO, M.C., El Proyecto de Reforma del Código penal de 2013 a debate. Salamanca: Ratio Legis. 2014, p. 48.

1449 Vid. BORJA JIMÉNEZ, E., “Apuntes de urgencia sobre la legitimidad...", cit. pp. 1 a 16; ACALE SÁNCHEZ, M. / ÁlVAREZ GARCÍA, F.J. / BORJA JIMÉNEZ, E. / DEMETRIO CRESPO, E. / DOPICO GÓMEZ-ALLEZ, J. / EXTEBARRIA ZARRABEITIA, X. / GARCÍA RIVAS, N. / MANSO PORTO, T. / MARAMBIO AVARIA, A. / MUÑOZ CONDE, F. / ORTIZ DE URBINA GIMENO, I. / POZUELO PÉREZ, L. / REBOllO VARGAS, R. / RODRÍGUEZ HORCAJO, D. / MOLINA BLÁZQUEZ, C., "Custodia de seguridad". En ÁLVAREZ GARCÍA, F.J., (Dir.) / DOPICO GÓMEZ-ALLER, J., (Coord.), Estudio crítico sobre el Anteproyecto de Reforma penal de 2012. Valencia: Tirant lo Blanch. 2013, pp. 395 a 414. 
Por otra parte, autores como SANZ MORÁN han manifestado que la reforma proyectada requeriría, además, algunas modificaciones de la LECrim para sustituir la prisión provisional por medidas de seguridad de entre las previstas en el $\mathrm{CP}$, para atender al mejor interés del imputado dada su situación de inimputabilidad, así como también la necesidad de configurar de forma específica el estatus procesal del enfermo mental confiriendo la posibilidad de optar por la finalización anticipada del proceso, así como la necesidad de modificar de forma drástica las previsiones actuales para la inimputabilidad sobrevenida durante la tramitación del proceso penal la causa o durante la ejecución de la pena, para compatibilizar estas previsiones legales con el nuevo régimen sistemático de las medidas de seguridad que se proyecta ${ }^{1450}$.

\section{a) Aspectos generales}

La Exposición de Motivos del Proyecto, en su apartado VII, explica que la reforma de las medidas de seguridad reviste notable profundidad en un doble sentido: por una parte se desarrolla el principio de peligrosidad como fundamento de las medidas de seguridad y, por otra, se apuesta decididamente por el dualismo como forma estructural de coexistencia de penas y medidas de seguridad, aquéllas basadas en la culpabilidad y éstas basadas en la peligrosidad1451. De ese modo, "se abandona definitivamente la idea de que las medidas de seguridad no puedan resultar más graves que las penas aplicables al delito cometido: el límite de la gravedad de la pena viene determinado por la culpabilidad por el hecho; pero el límite de la medida de seguridad, por el contrario, se encuentra en la peligrosidad del autor"1452. También explica la Exposición de Motivos que se fija la obligación de optar por la medida menos gravosa de entre aquéllas que puedan resultar suficientes para prevenir la peligrosidad del autor, y se introducen mayores límites para la adopción y prórroga de las medidas de

1450 SANZ MORÁN, A.J., “Medidas de seguridad”. En ÁLVAREZ GARCÍA, F.J., (Dir.) / DOPICO GÓMEZALLER, J., (Coord.), Estudio crítico sobre el Anteproyecto de Reforma penal de 2012. Valencia: Tirant lo Blanch. 2013, p. 479.

1451 “En la parte general se lleva a cabo una profunda reforma de las medidas de seguridad en un doble sentido: se desarrolla de un modo coherente el principio conforme al cual el fundamento de las medidas de seguridad reside en la peligrosidad del autor; y se culmina la evolución hacia un sistema dualista de consecuencias penales".

1452 Sigue diciendo la Exposición de Motivos que "tal y como ha puesto de manifiesto gran parte de la doctrina desde la entrada en vigor del Código Penal de 1995, y como reflejan las soluciones adoptadas en el Derecho comparado, las medidas de seguridad deben ser proporcionadas, no sólo a la gravedad del hecho delictivo cometido, sino también a la de aquéllos que se prevea que pudiera llegar a cometer y, por tanto, a su peligrosidad". (La "a” que aparece en cursiva la añado yo). 
internamiento. Todo ello irá acompañado de la fijación de una serie de plazos de duración máxima que serán concretados por el órgano jurisdiccional valorando previamente la peligrosidad individual y las necesidades que presente cada sujeto particular, pero cuando se trate de medidas de seguridad de internamiento en centro psiquiátrico y en centro de educación especial, existirá la posibilidad de prorrogar esos plazos de forma sucesiva si ello resulta necesario y proporcionado o cuando sea "imprescindible porque exista una probabilidad elevada de comisión en el futuro de delitos de especial gravedad"1453.

La Exposición de Motivos dice que se supera el sistema monista tradicional que venía rigiendo nuestros textos punitivos desde el de 1848, superando la exigencia de que las medidas de seguridad solo puedan imponerse a inimputables peligrosos, ya que existen ciertos sujetos responsables de haber cometido algún delito que también presentan peligrosidad manifiesta y cuyo tratamiento jurídico-penal justifica la imposición de medidas de seguridad ${ }^{1454}$. También explica la Exposición de Motivos que la reforma operada mediante la LO 5/2010, al introducir la libertad vigilada de cumplimiento sucesivo a la pena de prisión en determinados sujetos imputables peligrosos, fue el primer paso hacia esa evolución que con esta nueva reforma proyectada culmina "hacia la consagración de un sistema dualista, tomando como punto de partida la distinción y separación entre penas y medidas de seguridad", diferenciación que permite que las dos sanciones se impongan de manera conjunta sin rebasar el límite de la prohibición que deriva del principio de ne bis in idem, ofreciendo así una solución a los casos de penas cortas o de duración insuficiente para compensar la peligrosidad del autor que en estos casos aparece como elevada al desprenderse de la gravedad de los delitos cometidos.

En estos supuestos de insuficiencia de la pena para compensar la peligrosidad del autor, "no resulta razonable hacer recaer todos los costes de esa peligrosidad sobre la sociedad; al

\footnotetext{
1453 Sigue diciendo la Exposición de Motivos: “Así, por ejemplo, en el caso de la persona que sufre una grave patología psiquiátrica que le ha llevado a cometer reiterados delitos contra la vida o la libertad sexual, cuando las valoraciones psiquiátricas disponibles confirmen que continúa existiendo una elevada probabilidad de comisión de nuevos delitos de especial gravedad".

1454 La Exposición de Motivos dice: “se supera el sistema monista que históricamente habían asumido nuestros Códigos Penales desde 1848. En todos ellos, se había tratado siempre de un sistema de respuesta única frente al delito o al delincuente, de forma que al delincuente culpable se le imponía una pena, y al sujeto no responsable que comete un delito (inimputable) se le podía imponer una medida de seguridad cuando la comisión del delito había puesto de manifiesto su peligrosidad. Este sistema ha venido siendo objeto de crítica, pues resulta evidente que las medidas de seguridad no tienen como fundamento la no responsabilidad del autor de un delito, sino su peligrosidad, y que existen delincuentes responsables que deben recibir una pena y que además son peligrosos, lo que justifica o puede justificar una posterior medida de seguridad".
} 
contrario, parte de esos costes deben ser trasladados al propio penado, al que se impone, en consecuencia, una medida de seguridad", y con esa finalidad se amplía el contenido y el ámbito de aplicación de la libertad vigilada, cuyo contenido se ajustará a las necesidades de cada caso particular. En este punto ACALE SÁNCHEZ explica que las modificaciones en los presupuestos para la imposición de las medidas de seguridad, "tuercen el sentido del sistema "binario" por el sistema "dualista" y sortean el principio non bis in idem declarando que en dicho sistema pena y medida tiene un fundamento distinto. Así se afirma que "el límite de la gravedad de la pena viene determinado por la culpabilidad por el hecho", mientras que "el límite de la medida de seguridad, por el contrario, se encuentra en la peligrosidad del autor", olvidando que en ambos casos se trata de la comisión de un hecho constitutivo de delito, que es el verdadero fundamento de la imposición de pena y medida. Si el fundamento es el mismo, o cambia el sujeto, o cambia el hecho, o se violará el principio non bis in idem"1455.

La Exposición de Motivos sigue diciendo que las medidas de internamiento psiquiátrico no experimentan cambios significativos en su regulación, pero se realizan algunas mejoras en la regulación del régimen de control y en el de la suspensión de las medidas de seguridad, que irá acompañada de libertad vigilada. También se modifican las condiciones de revocación de la suspensión ya concedida. Otro aspecto que se modifica es la intervención en crisis, que permite el internamiento temporal del sometido a la medida en casos de grave recaída en su trastorno que aconseje el internamiento pero no justifica la revocación de la suspensión de la medida de seguridad. Igualmente explica el texto de la Exposición de Motivos que se incluyen algunas modificaciones en la medida de internamiento en centro de deshabituación, como la previsión de un régimen especial aplicable a los supuestos de imposición conjunta de esta medida con una pena de prisión de más de cinco años.

En cuanto al sistema vicarial, la Exposición de Motivos refiere a que se mantiene solamente en los casos del internamiento en centro psiquiátrico, en centro de educación especial o cuando se impone la medida de internamiento en centro de deshabituación, en este último caso con algunos matices. De tal forma, que penas y medidas de seguridad se impondrán de forma simultánea en los casos de eximente incompleta de los arts. $20.1^{\circ}$,

1455 ACALE SÁNCHEZ, M., “Nuevos presupuestos...”, cit. p. 32. 
$20.2^{\circ}$ y $20.3^{\circ} \mathrm{CP}$. La medida de seguridad se ejecutará en primer lugar y su duración se abonará a la pena subsiguiente pero puede renunciarse a la ejecución de la pena restante cuando resulta innecesaria o se pone en peligro el resultado de la medida.

Entrando en el contenido del articulado del Proyecto, el mismo consta de un art. único, que modifica la LO 10/1995, de 23 de noviembre, del CP, y seguidamente se analizan los apartados que guardan relación directa con la materia objeto de este estudio. El apartado tercero del art. único del Proyecto, modifica el apartado 2 del art. 6 CP, que así: "2. Las medidas de seguridad no podrán exceder el límite de lo necesario para prevenir la peligrosidad del autor". De ese modo, se abandona el criterio de que las medidas de seguridad no pueden rebasar el máximo de pena que correspondería si el sujeto hubiese sido declarado culpable, pues el límite que establece el Proyecto es el tiempo que sea necesario para prevenir la peligrosidad, es decir: duración indeterminada. Al respecto ACALE SÁNCHEZ opina que si se suprime del art. 6.2 CP el límite de la medida de seguridad atendiendo al hecho cometido, "se des-objetiviza la responsabilidad y se pone en manos exclusivamente de la peligrosidad del autor, que por otro lado queda en entre dicho si por tal se entiende la mera probabilidad de reiteración de conductas constitutivas de delito: subjetivización y confusión entre peligrosidad criminal y peligrosidad social son motivos suficientes como para criticar desde los postulados de un Derecho penal garantista el modelo propuesto" 1456 .

El apartado quincuagésimo séptimo del art. único del Proyecto, modifica el art. 95 $\mathrm{CP}$, cuya redacción dispone, en su apartado 1, que "las medidas de seguridad se aplicarán por el Juez o Tribunal, previos los informes que estime convenientes, cuando concurran las siguientes circunstancias: 1) que el sujeto haya cometido un hecho previsto como delito; 2) que del hecho y de las circunstancias personales del sujeto pueda deducirse un pronóstico de comportamiento futuro que revele la probabilidad de comisión de nuevos delitos; 3) que la imposición de una medida de seguridad resulte necesaria para compensar, al menos parcialmente, la peligrosidad del sujeto". El apartado 2, es el que se dedica a la proporcionalidad, aduciendo que "la medida de seguridad que se imponga deberá ser proporcionada a la gravedad del delito cometido y de aquéllos que se prevea que pudiera llegar a cometer, así como a la peligrosidad del sujeto". De ese modo, la proporcionalidad se convierte en un límite para el Juez y no para el legislador, "pero si se

1456 Ibidem, p. 28. 
elimina la proporcionalidad en abstracto, difícilmente podremos encontrarla en el caso concreto" 1457 .

ACALE SÁNCHEZ explica que la reforma debe ser criticada porque las medidas de seguridad no son para compensar la peligrosidad del sujeto, sino a lo sumo para contrarrestarla haciéndola gravitar sobre los déficits que hayan podido propiciar la perpetración del delito por parte del sujeto peligroso, por lo que carecen, además, de contenido punitivo y no es posible utilizarlas como amenaza de un mal, pues no suponen en sí mismas un mal como en las penas. Por eso, incide esta autora en la idea de que el Proyecto confunde la idea de peligrosidad criminal, que hasta ahora era el riesgo de comisión de nuevos delitos, y que el Proyecto transforma hasta hacerlo desaparecer, pues no se alcanza a comprender qué es lo que el legislador entiende por peligrosidad. “ ¿La peligrosidad social derivada no de los hechos, sino de las características del autor? Si la respuesta es afirmativa, esto es un derecho penal de autor que en el ámbito de una construcción teórica de unas 'medidas de seguridad' que 'castigan' al sujeto, debería tenerse en consideración. Sobre todo si no se olvida que la peligrosidad criminal es una circunstancia de carácter subjetivo que no cabe no obstante desvincularse de los hechos cometidos"1458. En el mismo sentido se pronuncia ZUGALDÍA ESPINAR, cuando afirma que “lo que se 'compensa' a través de la pena es la culpabilidad del autor. La peligrosidad del autor se 'previene'1459".

El apartado quincuagésimo noveno del art. único del Proyecto, modifica el art. 97 $\mathrm{CP}$, que dispone, en su apartado 1, que habrá que optar por la medida menos gravosa en caso de que puedan imponerse varias en un mismo caso para la misma finalidad ${ }^{1460}$, pero acto seguido, en su apartado 2, dispone que "si resultan necesarias varias medidas para prevenir de modo suficiente la peligrosidad del sujeto, todas ellas podrán ser impuestas conjuntamente". De modo que, por una parte se emite un mandato al órgano jurisdiccional para que imponga la medida menos grave de entre las posibles, pero por otra parte le habilita para que imponga varias conjuntamente si lo cree necesario para prevenir la

\footnotetext{
1457 Ibidem, p. 29.

1458 Ibidem, pp. 30 y 31.

1459 ZUGALDÍA ESPINAR, J.M., “Medidas de seguridad”. En ÁlVAREZ GARCÍA, F.J., (Dir.) / DOPICO GÓMEZ-ALLER, J., (Coord.), Estudio crítico sobre el Anteproyecto de Reforma penal de 2012. Valencia: Tirant lo Blanch. 2013, p. 481.

1460 Art. 97.1. “Cuando existan varias medidas igualmente adecuadas para prevenir de modo suficiente la peligrosidad del sujeto y solamente una de ellas resulte necesaria, se impondrá la que resulte menos grave".
} 
peligrosidad del sujeto. Lo que no termina de entenderse es cuándo van a ser necesarias varias medidas para alcanzar esa suficiencia en la prevención de la peligrosidad a la que refiere el precepto.

El apartado sexagésimo primero del art. único del Proyecto, modifica el art. $98 \mathrm{CP}$, que ahora dispone que en caso de eximente completa del art. 20.1 $\mathrm{CP}$ (anomalía o alteración psíquica), o en caso de eximente incompleta, el órgano jurisdiccional podrá imponer el internamiento en centro psiquiátrico si tras efectuarse una evaluación exhaustiva del sujeto y de la acción que llevó a cabo, hay base suficiente para concluir que, debido a su trastorno, es posible prever la comisión por aquél de nuevos delitos de gravedad relevante, que el propio precepto aclara que la relevancia en la gravedad se entiendo concurrente cuando se trate de delitos con pena máxima igual o superior a tres años de prisión ${ }^{1461}$. El apartado 2, dispone que el internamiento solo se ejecutará en régimen cerrado si existe un peligro relevante de quebrantamiento de la medida o de comisión de nuevos delitos. En otro caso, procederá un régimen abierto ${ }^{1462}$.

El apartado 3 del mismo artículo, dispone que el internamiento no podrá tener una duración superior a cinco años salvo que se acuerde la prórroga, en los casos en que haya trascurrido ese plazo de cinco años y no concurran las condiciones exigibles para suspender la medida de seguridad, y se advierta que el internamiento sigue siendo necesario para evitar que el sujeto cometa nuevos delitos a causa de su alteración psíquica. En esos casos, el órgano jurisdiccional, a solicitud del Ministerio Fiscal y contando con la previa propuesta de la Junta de Tratamiento y tras un procedimiento contradictorio con intervención del sujeto sometido a la medida -asistido de abogado- y del Ministerio Público, podrá acordar la prolongación del internamiento por períodos sucesivos de un máximo de cinco años cada periodo ${ }^{1463}$. El precepto contiene otra

\footnotetext{
1461 Art. 98.1. “El Juez o Tribunal podrá acordar el internamiento en un centro psiquiátrico del sujeto que haya sido declarado exento de responsabilidad criminal conforme al número $1^{\circ}$ del artículo 20 , o al que le haya sido apreciado esa eximente con carácter incompleto, si tras efectuarse una evaluación exhaustiva del mismo y de la acción que llevó a cabo, exista base suficiente para concluir que, debido a su trastorno, es posible prever la comisión por aquél de nuevos delitos de gravedad relevante.

A estos efectos, se consideran delitos de gravedad relevante aquéllos para los que esté prevista la imposición de una pena máxima igual o superior a tres años de prisión".

1462 Art. 98.2. “El internamiento se ejecutará en régimen cerrado cuando exista un peligro relevante de quebrantamiento de la medida o de comisión de nuevos delitos".

1463 Art. 98.3. “El internamiento en centro psiquiátrico no podrá tener una duración superior a cinco años, salvo que se acordare su prórroga.
} 
previsión in fine por la que se permite que, una vez extinguida la medida por haber cumplido el plazo máximo inicial o el de cualquiera de sus prórrogas, se pueda imponer la libertad vigilada -por tiempo no concretado en este precepto-, salvo que su aplicación no resulte necesaria, entiéndase que haya desaparecido totalmente la peligrosidad por curación definitiva o situaciones similares que impliquen que el internamiento no debe prorrogarse y que tampoco es procedente la libertad vigilada. Obviamente, la ausencia de criterios objetivos y claros sobre los que guiarse para optar entre las distintas posibilidades, se aprecia con nitidez. Interesa resaltar que, con esta previsión proyectada, un sujeto puede ser condenado a una medida de internamiento hasta su muerte, porque si bien la prisión permanente revisable es una pena indeterminada con plazos de revisión, en las medidas de seguridad hay plazos determinados pero, a su vez, son prorrogables de forma indeterminada sin necesidad de internamiento civil ni de incapacitación, produciéndose una transgresión del principio de igualdad, pues a igualdad de hechos cometidos, el tratamiento penológico es muy distinto ${ }^{1464}$. También se muestra contrario a esta posibilidad de internamiento ilimitado ZULGADÍA ESPINAR, que señala que sería conveniente incluir una regla que disponga que el internamiento no pueda exceder del máximo de duración de la pena que correspondería por el delito cometido y por el que el sujeto se halle internado, de modo que se establezca una debida proporcionalidad que abarque, además de la peligrosidad del sujeto, la gravedad del delito de que se trate ${ }^{1465}$.

El apartado sexagésimo segundo, modifica el art. $99 \mathrm{CP}$, que dispone que en caso de eximente completa del art. $20.3^{\circ} \mathrm{CP}$ (alteraciones en la percepción desde el nacimiento o la infancia), así en caso de que dicha eximente sea incompleta, se acordará el internamiento en un centro educativo especial, si tras efectuarse una evaluación exhaustiva del sujeto y de la acción que cometió, se aprecia que hay base suficiente para prever la comisión de nuevos delitos graves a causa de sus alteraciones. En estos casos hay una remisión al párrafo $2^{\circ}$ del apartado 1 del art. $98 \mathrm{CP}$ (para la concreción de qué se

\footnotetext{
$\mathrm{Si}$, transcurrido dicho plazo, no concurren las condiciones adecuadas para acordar la suspensión de la medida y, por el contrario, el internamiento continúa siendo necesario para evitar que el sujeto que sufre la anomalía o alteración psíquica cometa nuevos delitos a causa del mismo, el Juez o Tribunal, a petición del Ministerio Fiscal, previa propuesta de la Junta de Tratamiento, podrá acordar tras un procedimiento contradictorio en el que intervendrán el Ministerio Fiscal y el sometido a la medida, asistido por su abogado, la prolongación de la misma por períodos sucesivos de una duración máxima, cada uno de ellos, de cinco años.

En otro caso, extinguida la medida de internamiento impuesta, se impondrá al sujeto una medida de libertad vigilada, salvo que la misma no resultara necesaria".
}

1464 ACALE SÁNCHEZ, M., “Nuevos presupuestos...”, cit. p. 35.

1465 ZUGALDÍA ESPINAR, J.M., “Medidas de seguridad...”, cit. p. 482. 
entiende por delitos graves, que son los que lleven aparejada pena máxima de tres años de prisión) y a los apartados 2 y 3 del mismo art. $98 \mathrm{CP}$, que hacen referencia a las prórrogas y a la posibilidad de imposición de libertad vigilada en caso de extinción de la medida de internamiento o de cualquiera de sus prórrogas ${ }^{1466 .}$

El apartado sexagésimo tercero del art. único del Proyecto, modifica el art. $100 \mathrm{CP}$, que queda redactado de forma similar a los dos preceptos anteriores, de modo que el internamiento en un centro de deshabituación se acordará cuando el sujeto haya delinquido a causa de su grave adicción al alcohol o a las drogas y el internamiento pueda servir para evitar la comisión de nuevos delitos ${ }^{1467}$.

El apartado sexagésimo cuarto del art. único del Proyecto, modifica el art. $101 \mathrm{CP}$, que regula las situaciones de concurrencia de pena de prisión y alguna de las medidas de seguridad de internamiento de los arts. 98 a 100 CP. En estos casos, la medida de seguridad se ejecutará antes que la pena, y el tiempo de cumplimiento de la medida se abonará a la pena hasta el límite de las tres cuartas partes de la duración total de la pena de prisión. Es decir, que el tiempo de cumplimiento de la medida de seguridad no siempre va a ser abonable a la pena, sino solo un tramo de la misma que encuentra el límite en las tres cuartas partes de la pena, quedando a salvo una cuarta parte que se deberá ejecutar. No obstante, una vez alzada la medida, esa parte restante de pena de

1466 “1. El Juez o Tribunal podrá acordar el internamiento en un centro educativo especial del sujeto que haya sido declarado exento de responsabilidad criminal conforme al número $3 .^{\circ}$ del artículo 20 , o al que le haya sido apreciado esa eximente con carácter incompleto, si tras efectuarse una evaluación exhaustiva del mismo y de la acción que llevó a cabo, exista base suficiente para concluir que, debido a su trastorno, es posible prever la comisión por aquél de nuevos delitos de gravedad relevante.

2. En estos casos será de aplicación lo dispuesto en el párrafo segundo del apartado 1 y en los apartados 2 y 3 del artículo anterior".

1467 Art. 100. “1. El Juez o Tribunal podrá acordar el internamiento en un centro de deshabituación del sujeto que haya cometido un delito a causa de su grave adicción al alcohol, a las drogas tóxicas, estupefacientes, sustancias psicotrópicas u otras que produzcan efectos análogos, y se prevea que se pueda evitar así que cometa nuevos delitos.

Esta medida solamente se impondrá cuando existan indicios que permitan fundar la expectativa razonable de que el sujeto superará su adicción mediante el tratamiento o, al menos, de que durante un período de tiempo relevante no recaerá en el consumo de aquellas sustancias y no cometerá nuevos delitos motivados por el mismo.

Si el sujeto no hubiera sido declarado exento de responsabilidad criminal conforme al número $3^{\circ}$ del artículo 20, y tampoco le hubiera sido apreciada esa eximente con carácter incompleto, esta medida solamente podrá ser impuesta con su consentimiento.

2. El tratamiento se llevará a cabo en un establecimiento especializado o, si resulta necesario, en un hospital psiquiátrico. En cualquier caso, su régimen y contenido se ajustará a las circunstancias concretas del sujeto y a su evolución

3. El internamiento en centro de deshabituación no podrá, por regla general, tener una duración superior a dos años. Este período comenzará a computarse desde el inicio del internamiento y podrá prorrogarse hasta el límite constituido por la duración de la pena de prisión que hubiera sido impuesta o un máximo de cinco años, cuando no se hubiera impuesto ninguna pena". 
prisión, podrá ser suspendida por el órgano jurisdiccional si se estima que su ejecución puede poner en peligro los efectos conseguidos con la medida de seguridad ya cumplida. En realidad se trata de una posibilidad de cumplimiento de esa parte de la pena en libertad condicional -que en el Proyecto se regula como una suspensión a prueba del resto de la pena- porque además se impone el requisito de que la suspensión debe resultar procedente conforme a una valoración que se ajuste a lo que dispone el art. 90.1, $2^{\circ}$ párrafo $\mathrm{CP}$, con el añadido de que serán de aplicación apartados 4,5 y 6 del art. $90 \mathrm{CP}$, que regulan la libertad condicional ${ }^{1468}$.

El apartado 2 del mismo artículo dispone que en casos de imposición de una pena de prisión de más de cinco años y una medida de internamiento del art. $100 \mathrm{CP}$, el órgano jurisdiccional podrá acordar que se cumpla en primer lugar una parte de la pena y seguidamente la medida de seguridad. Para estos casos, el propio artículo fija una regla que implica que la parte de la pena que deba ser cumplida primero, deberá fijarse de forma que, cuando se sume a la medida de seguridad, en total se hayan extinguido dos terceras partes de la pena total impuesta. Del mismo modo que en el apartado anterior, hay una previsión por la que, cuando se haya alzado la medida de seguridad, el órgano podrá suspender la ejecución del resto de la pena concediendo la libertad condicional, remitiendo al párrafo $2^{\circ}$ del apartado anterior del mismo art. $101 \mathrm{CP}^{1469}$.

Sobre todos estos preceptos que invierten los términos del sistema vicarial tal y como venía configurado desde la promulgación del CP en 1995, se advierte que el régimen proyectado confiere prioridad a la medida de seguridad y determina que al Juez le corresponde decidir - atendiendo a las circunstancias del caso- si ejecuta la pena o si la sustituye por otra, computando previamente el tiempo pasado en la medida de

\footnotetext{
1468 Art. 101.1. “Cuando se impongan al tiempo una pena de prisión y una medida de internamiento de las reguladas en los artículos 98, 99 ó 100 del Código Penal, la medida de seguridad se ejecutará antes que la pena. El tiempo de cumplimiento de aquélla se abonará como tiempo de cumplimiento de la pena hasta el límite de las tres cuartas partes de la duración de la misma.

En estos casos, una vez alzada la medida, el Juez o Tribunal podrá suspender la ejecución del resto de la pena, si con ella se pusieran en peligro los efectos conseguidos a través de la ejecución de la medida, y resultara procedente conforme a una valoración ajustada a lo dispuesto en el párrafo segundo del artículo 90.1 del Código Penal. En este caso será de aplicación lo dispuesto en los apartados 4, 5 y 6 del artículo 90".

1469 Art. 101.2. “Si se hubieran impuesto al tiempo una pena de más de cinco años de prisión y una medida de internamiento del artículo 100 del Código Penal, el Juez o Tribunal podrán acordar que se cumpla en primer lugar una parte de la pena, y seguidamente la medida de seguridad. En este caso, la parte de la pena que debe ser cumplida en primer lugar se fijará de modo tal que, sumado el tiempo de duración de la medida de seguridad, se hayan extinguido dos terceras partes de la pena total impuesta. Una vez alzada la medida, el Juez o Tribunal, podrá acordar la suspensión de la ejecución del resto de la pena y la concesión de la libertad condicional conforme a lo dispuesto en el párrafo segundo del apartado anterior".
} 
internamiento - en cualquiera de sus modalidades- hasta el límite de las tres cuartas partes de la duración de la pena impuesta; y se si trata de la medida de internamiento en un centro de deshabituación, el Juez puede invertir el orden y dar prioridad a la pena en la prelación de ejecución de ambas sanciones ${ }^{1470}$.

El apartado 3 del art. $101 \mathrm{CP}$, dispone que cuando concurran una pena de prisión y una medida de seguridad de libertad vigilada, la pena se ejecutará antes que la medida de seguridad, de forma que siempre se da prioridad a la pena, aspecto que para algunos autores resulta "sorprendente" debido a que esta prioridad se hace extensiva a todos los supuestos en que puede aplicarse, incluyendo los casos de semiimputabilidad, aplicándoles primero la pena y luego la libertad vigilada equiparando su régimen al de los imputables peligrosos del listado de delitos a los que la libertad vigilada se aplica. Por eso, la doctrina incide en que la única finalidad que se persigue es "el castigo del sujeto, desconociendo su dignidad personal"1471.

El apartado 4 del art. $101 \mathrm{CP}$, dispone que en el caso de que, desde el momento en que adquiera firmeza la imposición de una medida de seguridad privativa de libertad de internamiento de los arts. 98 o $99 \mathrm{CP}$, si han transcurrido más de dos años sin que la misma haya sido ejecutada, se deberá verificar por el órgano jurisdiccional si persisten los condicionantes que hicieron necesaria la imposición de la medida de seguridad. Si no persisten, la medida debe ser revisada y no ejecutarse, porque la finalidad de la norma es que si en ese tiempo el sujeto ha mejorado en sus trastornos y no resulta ya peligroso, no es procedente la ejecución de la medida de seguridad.

\section{b) Mantenimiento, cese y suspensión de las medidas de seguridad}

El apartado sexagésimo quinto del art. único del Proyecto, modifica el art. $102 \mathrm{CP}$, que confiere una facultad al JVP para que pueda comprobar, en cualquier momento de la ejecución de las medidas de seguridad, si las circunstancias que justificaron su imposición perduran. A tal efecto podrá acordar el mantenimiento, el cese o la suspensión de la ejecución de la medida que irá acompañada de libertad vigilada por tiempo máximo de

\footnotetext{
1470 ACALE SÁNCHEZ, M., “Nuevos presupuestos...”, cit. p. 40.

1471 Ibidem, p. 40.
} 
cinco años ${ }^{1472}$. El mantenimiento no ofrece dudas de interpretación, pero sí las hay en relación al cese y la suspensión. El cese de la medida se acordará si la finalidad ha sido conseguida y su ejecución ya no resulta necesaria, de lo que, en principio no termina de comprenderse si son dos requisitos distintos o uno solo, porque el primero refiere a cuando haya desaparecido la peligrosidad que, a su vez, por lógica, necesariamente implica que la ejecución no es necesaria, por lo que esa segunda concreción no añadiría nada al primer requisito de haber alcanzado su finalidad y entiendo que el requisito para acordar el cese es la desaparición de la peligrosidad y nada más.

En cuanto a la suspensión de la medida, el texto no contiene ningún requisito adicional más allá de la mera apreciación subjetiva del juzgador, pero en cualquier caso entendemos que, para decretarla, igualmente debe haber desaparecido la peligrosidad o, de lo contrario, no se encuentra justificación alguna para que la medida pueda quedar en suspenso. En el supuesto de suspensión se impondrá la libertad vigilada por un plazo no superior a cinco años, aspecto en sí mismo contradictorio porque el fundamento que debe servir de base para decretar la suspensión es igualmente la desaparición de la peligrosidad, y no parece lógico imponer en su lugar otra medida de seguridad que encuentra su fundamento precisamente en esa peligrosidad cuya desaparición sirve de base para acordar la suspensión. Igual sucede en casos en que se acuerde el cese de la medida cuando su finalidad haya sido conseguida y su ejecución ya no resulte necesaria (desaparición de la peligrosidad), supuesto para el que también se prevé la imposición de la libertad vigilada.

La intención del legislador es articular una especie de probation del sistema anglosajón o suspensión a prueba, sin reparar en que simplemente se sustituye una medida por otra que está basada en lo mismo. El texto asume sin reparos que cuando hay razones para que la medida de seguridad privativa de libertad no se siga cumpliendo y se cesa o se suspende, persisten, por el contrario, razones suficientes para imponer en su lugar la libertad vigilada; pero no parece tener mucho sentido que si existen razones para suspenderla o cesarla, siga habiéndolas para imponer en su lugar la libertad vigilada,

\footnotetext{
1472 Art. 102.1. “El Juez de Vigilancia Penitenciaria podrá, en cualquier momento durante la ejecución de la medida, verificar si se mantienen las circunstancias que hicieron necesaria su imposición y adoptar alguna de las siguientes resoluciones: a) Mantener la ejecución de la medida de seguridad impuesta. b) Decretar el cese de la medida, cuando su finalidad haya sido conseguida y su ejecución ya no resulte necesaria. c) Suspender la ejecución de la medida. En este caso, se impondrá al sujeto una medida de libertad vigilada con una duración máxima de cinco años".
} 
porque ambas figuras se basan en la existencia de peligrosidad, y sin peligrosidad no puede haber medida. No hay que perder de vista, no obstante, que la otra gran diferencia entre el cese y la suspensión es que el cese es definitivo y la suspensión podrá revocarse si el sujeto comete un nuevo delito, si incumple gravemente las obligaciones y condiciones impuestas en la libertad vigilada, si incumple reiteradamente su deber de comparecer y de facilitar información al funcionario encargado del seguimiento del cumplimiento de la medida, o cuando se aprecien circunstancias que habrían llevado a denegar la suspensión si se hubiesen conocido en el momento de acordarla (arts. 103. 1 y 2 CP). En cualquier caso, para mantener esas diferencias, si el legislador realmente pretende articular una suerte de suspensión a prueba para las medidas de seguridad, habría que definir claramente -como en la libertad condicional-qué requisitos se necesitan para acordar la suspensión en detrimento del cese que resulta más benigno para el sometido a la medida.

Se impone también una obligación al JVP de revisar la medida a efectos de acordar la continuación, el cese o la suspensión, con una periodicidad máxima semestral, en el caso del internamiento en centro de deshabituación; y un año, en el caso del internamiento en centro psiquiátrico o de educación especial (art. 102.2)1473, aunque el art. 102.3 CP confiere al tribunal la facultad de fijar en su resolución un nuevo plazo de revisión inferior a los marcados en el apartado 2, o podrán determinar un plazo, dentro del plazo máximo fijado en el apartado 2, durante el cual -haya o no desaparecido la peligrosidad- no se podrá instar ninguna petición de revisión ${ }^{1474}$.

El apartado sexagésimo sexto del art. único del Proyecto, modifica el art. 103 CP, que regula la revocación de la suspensión de las medidas de seguridad que el JVP podrá acordar cuando resulte necesario para asegurar los fines de la medida si el sometido a ella comete un nuevo delito, incumple gravemente las obligaciones y condiciones que hubieran sido impuestas en la libertad vigilada, o incumple reiteradamente su deber de comparecer y de facilitar información al funcionario encargado del seguimiento del

\footnotetext{
1473 Art. 102.2. “El Juez de Vigilancia Penitenciaria deberá resolver conforme al apartado anterior con una periodicidad máxima semestral, en el caso del internamiento en centro de deshabituación; y un año, en el caso del internamiento en centro psiquiátrico o de educación especial".

1474 Art. 102.3. “El Juez de Vigilancia Penitenciaria podrá fijar, en su resolución, un plazo de revisión inferior; o podrán determinar un plazo, dentro del plazo máximo fijado en el apartado anterior, dentro del cual no se dará curso a las peticiones de revisión presentadas por la persona sujeta a la medida".
} 
cumplimiento de la medida ${ }^{1475}$. El apartado 2 del propio art. 103 CP añade un supuesto de revocación de la suspensión para cuando se pongan de manifiesto circunstancias que habrían llevado a denegar la suspensión de la medida de haber sido conocidas en el momento en que ésta fue acordada, o cuando se ponga de manifiesto un cambio de las circunstancias que hubieran dado lugar a la suspensión que no permita mantener ya el pronóstico de ausencia de peligrosidad en que se fundaba la decisión adoptada. La revocación, no obstante, deberá hacerse por un procedimiento que deberá ser instado por el Ministerio Fiscal y en el que habrá que dar audiencia al sometido a la medida, previo análisis de los informes y comprobaciones pertinentes para tomar la decisión de revocación; pero contempla también un supuesto concreto en el que la suspensión se podrá revocar cuando, por razones de urgencia, el Ministerio Fiscal lo solicite, aunque posteriormente deberá realizarse todo el procedimiento antes referido y ratificar o reformar la revocación de la suspensión ${ }^{1476}$. Sobre este particular, conviene tener presente que el Proyecto, en su disposición adicional cuarta, contiene también una regla -a mi juicio redundante- que refuerza estos aspectos ${ }^{1477}$.

El apartado 3 del art. $103 \mathrm{CP}$, dispone que la duración del internamiento en su conjunto no podrá exceder del límite legal de duración máxima de la medida de seguridad, sin perjuicio de que el mismo pudiera haber experimentado algunas prórrogas

\footnotetext{
1475 Art. 103. 1. “El Juez de Vigilancia Penitenciaria podrá revocar la suspensión de la ejecución de la medida privativa de libertad cuando ello resulte necesario para asegurar los fines de la medida a la vista de la concurrencia de alguna de las siguientes circunstancias: a) El sometido a la medida cometa un nuevo delito. b) Incumpla gravemente las obligaciones y condiciones que hubieran sido impuestas en la libertad vigilada. c) Incumpla reiteradamente su deber de comparecer y facilitar información al funcionario encargado del seguimiento del cumplimiento de la medida".
}

1476 Art. 102. 2. “También podrá acordarse la revocación de la suspensión cuando se pongan de manifiesto circunstancias que habrían llevado a denegar la suspensión de la medida de haber sido conocidas en el momento en que ésta fue acordada, o cuando se ponga de manifiesto un cambio de las circunstancias que hubieran dado lugar a la suspensión que no permita mantener ya el pronóstico de falta de peligrosidad en que se fundaba la decisión adoptada.

El Juez de Vigilancia Penitenciaria acordará la revocación de la suspensión a petición del Ministerio Fiscal, previa audiencia al sujeto a la medida, realizadas las comprobaciones y recabados los informes que resulten necesarios.

En todo caso, cuando existan razones de urgencia podrá ordenar, a petición del Ministerio Fiscal, la revocación inmediata de la suspensión. En estos casos, ratificará o reformará su decisión después de haber procedido conforme a lo dispuesto en el párrafo anterior.

1477 La Disposición adicional cuarta reza así: "Las resoluciones judiciales relativas a la suspensión de la ejecución de la pena, salvo que hubiera sido acordada en sentencia, su modificación o revocación; sustitución de la pena, salvo que hubiera sido acordada en sentencia; concesión de libertad condicional; aplicación, ejecución, revocación o sustitución de las medidas de seguridad; y sustitución de las penas privativas de libertad se adoptarán previa audiencia del sujeto afectado y del Ministerio Fiscal. No obstante lo dispuesto en el apartado anterior, el Juez o Tribunal podrá resolver de forma inmediata, cuando existan razones de urgencia que así lo justifiquen. En este caso, el Juez o Tribunal dará posteriormente audiencia al Ministerio Fiscal y al afectado, y resolverá seguidamente ratificando, modificando o dejando sin efecto la resolución adoptada". 
según lo previsto en el art. $98.3 \mathrm{CP}$ al que ya hemos referido'1478. Y, por último, el apartado 4 del art. $103 \mathrm{CP}$, dispone que si la medida de libertad vigilada que se haya impuesto al acordar la suspensión de la medida de seguridad privativa de libertad, se ejecuta sin haber acordado la revocación de la suspensión, la medida de internamiento quedará extinguida. Es decir, que la suspensión y el posterior cumplimiento de la libertad vigilada lo que propicia es que la medida quede en suspenso, pero en ese momento empieza a cumplirse otra medida de seguridad que, si concluye sin ser revocada, implica la extinción de la otra medida que quedó en suspenso. Pero en el caso de que la libertad vigilada fuera revocada, el efecto sería que la medida de seguridad que quedó suspendida retomaría su cómputo de cumplimiento en el momento en que quedó en suspenso, pudiendo, desde ahí, terminar el período inicial de cinco años por el que fue acordada o prorrogarse por iguales periodos.

La única circunstancia que impediría que se retomara el cumplimiento de esa medida de seguridad suspendida, sería el buen fin de la libertad vigilada, pues su fracaso podrá conducir a un nuevo internamiento que podría extenderse sine die gracias a las eventuales prórrogas que podrían acordarse.

El apartado sexagésimo séptimo del art. único del Proyecto, introduce un nuevo art. 103 bis $\mathrm{CP}$, por el que se regula el supuesto del empeoramiento grave de la salud mental del sometido a la libertad vigilada cuando haya sido impuesta para acordar la suspensión de la medida de internamiento, en cuyo caso se podrá acordar el internamiento por un plazo máximo de tres meses prorrogables por otros tres meses más, sin necesidad de revocar la suspensión. Pero si la salud mental no mejora en ese plazo, la consecuencia será que deberá revocarse la suspensión y volver al régimen normal de cumplimiento de la medida de seguridad de internamiento que se mantenía suspendida 1479 .

1478 Art. 102. 3. “La duración del internamiento en su conjunto no podrá exceder del límite legal de duración máxima de la medida, sin perjuicio de que el mismo pudiera haber sido prorrogado conforme al artículo 98.3".

1479 Art. 103 bis. 1. "Si durante el cumplimiento de una medida de libertad vigilada que hubiera sido impuesta al suspenderse la ejecución de una medida de internamiento en centro psiquiátrico se pusiera de manifiesto un empeoramiento grave en la salud mental de la persona sujeta a la medida, el Juez o Tribunal podrán acordar, con la finalidad de evitar una revocación de la medida, su internamiento en un centro psiquiátrico por un plazo máximo de tres meses que podrá ser prorrogado por tres meses más.

2. En este caso, la duración del internamiento en su conjunto tampoco podrá exceder del límite legal de duración máxima de la medida, sin perjuicio de que el mismo pudiera haber sido conforme al artículo 98.3". 


\section{LA LIBERTAD VIGILADA}

\section{a) Aspectos generales}

La Exposición de Motivos del Proyecto explica que la libertad vigilada experimenta algunas modificaciones "para mejorar la regulación y favorecer su aplicación en la práctica", se amplían los supuestos en los que es aplicable para su cumplimiento tras la pena de prisión, que aparecerán de forma tasada en la parte especial del CP; además se exigirá que el sujeto haya sido condenado a pena superior a un año y "que se constate la peligrosidad de comisión de delitos futuros que es presupuesto general de todas las medidas de seguridad". El otro supuesto en el que se permite la imposición de libertad vigilada es tras el cumplimiento de una medida de seguridad privativa de libertad o como sustitutivo de la misma, tal y como ya hemos señalado supra.

El apartado sexagésimo noveno del art. único del Proyecto, modifica el art. $104 \mathrm{CP}$, que regula los supuestos en que cabe imponer la libertad vigilada y sus requisitos. El apartado 1 del art. 104 CP exige al Juez o Tribunal que para acordar la libertad vigilada previamente esté prevista su imposición como consecuencia jurídica en ese delito concreto, esto es, deberá venir prevista en la parte especial1480. Además debe haber una condena a una pena de más de un año de prisión; y deben de cumplirse los requisitos de los números 2 y 3 del art. $95.1 \mathrm{CP}$, que son: que del hecho y de las circunstancias personales pueda deducirse un pronóstico de comportamiento futuro que revele la probabilidad de comisión de nuevos delitos y que la imposición de la medida resulte necesaria para compensar la peligrosidad del sujeto al menos en parte ${ }^{1481}$.

El apartado 2 del art. $104 \mathrm{CP}$, contiene dos supuestos más en los que se podrá acordar la libertad vigilada, que son: en casos de absolución por alguna de las eximentes de los números $1^{\circ}, 2^{\circ}$ ó $3^{\circ}$ del art. $20 \mathrm{CP}$, o haya sido apreciada la atenuante $1^{\mathrm{a}}$ del art. 21 $\mathrm{CP}$ con relación a alguna de ellas, y se cumplan los demás requisitos del art. 95.1 CP. El

\footnotetext{
1480 Sobre este aspecto, algunos autores afirman que debería suprimirse este requisito y posibilitar su aplicación generalizada en casos de reincidentes que cometen, por ejemplo, hurtos. Vid. ZUGALDÍA ESPINAR, J.M., “Medidas de seguridad...”, cit. pp. 483 y 484.

1481 Art. 104.1. “El Juez o Tribunal podrá imponer una medida de libertad vigilada cuando se cumplan los siguientes requisitos: a) La imposición de la medida de libertad vigilada esté prevista en la Ley penal para el delito cometido. b) Se haya impuesto al sujeto una pena de más de un año de prisión. c) Se cumplan los requisitos de los números 2 y 3 del artículo 95.1 del Código Penal".
} 
segundo supuesto es cuando se haya acordado el cese de una medida de seguridad privativa de libertad 1482 .

El apartado 3 del art. $104 \mathrm{CP}$ regula los supuestos en que el JVP deberá imponer la libertad vigilada, a saber: cuando haya acordado suspender la ejecución de una medida de seguridad privativa de libertad; y cuando se cumpla el plazo máximo de duración de la medida de seguridad privativa de libertad que se hubiera impuesto o se decrete su cese y resulte necesario para compensar el riesgo de comisión de nuevos delitos. Para ello, el JVP deberá valorar los informes y comprobaciones que estime necesarios y se exige la audiencia tanto del penado como del Ministerio Fiscal con carácter previo a resolver sobre la imposición de la medida ${ }^{1483}$.

\section{b) Contenido de la libertad vigilada}

El apartado septuagésimo del art. único del Proyecto, introduce un nuevo art. 104 bis $\mathrm{CP}$, cuyo apartado 1 dispone que el Juez o Tribunal podrá imponer al sujeto sometido a la medida de libertad vigilada, el cumplimiento de alguna, algunas o todas las obligaciones y condiciones que se enumeran en el propio precepto, durante todo el tiempo que dure la medida o durante un período concreto. En principio, las principales novedades son que ahora se utiliza el término condiciones en lugar de prohibiciones que utilizó la LO 5/2010, quizás debido a las dificultades existentes para encuadrar en la órbita de las obligaciones y prohibiciones algunas de las medidas del catálogo, como el caso de la obligación de someterse a tratamiento médico. En cualquier caso, esta denominación de "condiciones" parece ser más acertada, sobre todo teniendo en cuenta que en muchas ocasiones la libertad vigilada se usa a modo de suspensión condicional de la medida de seguridad privativa de libertad, siendo que las condiciones son las medidas concretas de la libertad vigilada que se impone en su lugar. Por otra parte, el contenido de

\footnotetext{
1482 Art. 104.2. “Asimismo, podrá imponer una medida de libertad vigilada en los siguientes casos: $1^{\circ}$. Cuando el sujeto haya sido absuelto por haber sido apreciada la concurrencia de alguna de las eximentes de los

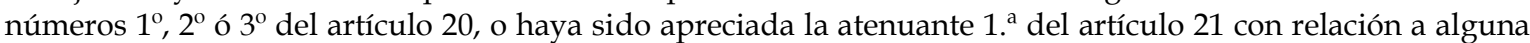
de las anteriores, y se cumplan los demás requisitos del artículo 95.1 del mismo. $2^{\circ}$. Cuando se haya acordado el cese de una medida de seguridad privativa de libertad".

1483 Art. 104.3. “El Juez de Vigilancia Penitenciaria impondrá el cumplimiento de una medida de libertad vigilada en los siguientes casos: a) Cuando haya acordado suspender la ejecución de una medida de seguridad privativa de libertad. b) Cuando se cumpla el plazo máximo de duración de la medida de seguridad privativa de libertad que se hubiera impuesto o se decrete su cese, y resulte necesario para compensar el riesgo de comisión de nuevos delitos.

El Juez de Vigilancia Penitenciaria resolverá previos los informes y comprobaciones que estime necesarios y después de haber oído al penado y al Ministerio Fiscal".
} 
dichas obligaciones y condiciones se diseña ahora con mayor contenido controlador, lo que para algunos autores conforma una medida de contenido policial que no debe confundirse con el fundamento y la justificación de las medidas de seguridad ${ }^{1484}$.

La otra novedad es que se permite que el Juez o Tribunal acuerde que cada una de las obligaciones o condiciones que se impongan tenga una duración determinada, esto es, se pueden imponer algunas por plazo igual al de la duración de la medida y otras por un plazo determinado, atendiendo a criterios de necesidad de las medidas que se pretendan adoptar en relación a la personalidad del sujeto y a la naturaleza del delito cometido. Son diecisiete las obligaciones y condiciones que pueden imponerse y ya no aparecen ordenadas en letras sino en números ordinales. Son las siguientes:

$1^{a}$. Prohibición de aproximarse a la víctima o a otros miembros de su familia que se determine por el Juez o Tribunal, a sus domicilios, a sus lugares de trabajo o a otros lugares habitualmente frecuentados por ellos. La imposición de esta prohibición será siempre comunicada a las personas con relación a las cuales sea acordada.

Se amplía notablemente el contenido de esta prohibición, que ahora, además de aproximarse a la víctima o a aquellos de sus familiares $\mathrm{u}$ otras personas que determine el Juez o Tribunal, se añade que la prohibición se extiende a sus domicilios o a sus lugares de trabajo o a otros lugares a los que dichas personas suelan concurrir. Además se impone una obligación al órgano jurisdiccional de que, cuando se imponga esta regla de conducta, se comunique a las personas sobre las que se proyecta la prohibición.

$2^{a}$. Prohibición de establecer contacto con personas determinadas o con miembros de un grupo determinado, cuando se trate de individuos de los que pueda sospecharse que pueden facilitarle la ocasión para cometer nuevos delitos o incitarle a hacerlo. También se le podrá prohibir establecer relación, ofrecer empleo, facilitar formación o albergar a cualquiera de las personas mencionadas.

No se encuentra ahora en el articulado la prohibición de comunicarse con la víctima, sino que se prohíbe establecer contacto -que entendemos será por cualquier medio, aunque el precepto no lo concreta- con personas determinadas o con miembros de grupos determinados siempre que sean personas de quienes se tenga una mera

1484 ACALE SÁNCHEZ, M., “Nuevos presupuestos...”, cit. p. 42. 
sospecha, de que pueden incitar al sujeto a volver a delinquir o facilitarle la ocasión para ello ${ }^{1485}$. Baste decir que la sospecha deberá estar fundada en materiales fácticos para tener entidad suficiente como para justificar la imposición de la prohibición, no siendo posible que se adopten criterios abstractos o meras afirmaciones carentes de sustento. El legislador es consciente de que si exige la certeza en lugar de la sospecha, esta medida nunca llegará a imponerse, por lo que opta por flexibilizar el criterio permitiendo su imposición basándose en un cálculo de probabilidades de tratarse de persona sospechosa de incitar al delito o facilitarle la ocasión, que no aparecen ni siquiera delimitados a efectos de tomar referencias de partida para establecer con claridad una sospecha que sea bastante ${ }^{1486}$.

Además se añade que será posible la prohibición de establecer relación, ofrecer empleo, facilitar formación o albergar a cualquiera de las personas mencionadas. En primer lugar, se observa que no termina de ser coherente esta segunda prohibición, ya que no se entiende de qué modo se puede establecer relación sin contacto, al igual que el resto de prohibiciones. Por lo que la primera prohibición de establecer contacto ya impediría, por sí sola, el resto de prohibiciones. Por ese motivo, entiendo que la previsión solo tiene sentido si las prohibiciones de establecer relación, ofrecer empleo, etc., se acuerdan sin necesidad de imponer también la prohibición de contacto, esto es, se trataría de prohibiciones autónomas, que permitirían el contacto pero no ir más allá de él.

En cualquier caso, la prohibición de establecer relación, lejos de ofrecer alguna pista sobre qué clase de relación se pretende prohibir, no deja sino abierto un elenco de posibilidades que implica que la relación podrá ser de cualquier tipo: laboral, profesional, sentimental, de amistad, enemistad o incluso las relaciones amor-odio que tantos quebraderos de cabeza han venido generando en la praxis diaria de la protección penal y procesal en materia de violencia de género, sobre todo en la adopción de medidas

1485 ACALE SÁNCHEZ, M. “Medidas de seguridad”. En ÁLVAREZ GARCÍA, F.J., (Dir.) / DOPICO GÓMEZALLER, J., (Coord.), Estudio crítico sobre el Anteproyecto de Reforma penal de 2012. Valencia: Tirant lo Blanch. 2013, p. 440. Esta autor explica que "la finalidad de las medidas de seguridad no es la de prohibirle al autor determinados comportamientos, tuitivamente, controlar que no vuelve a cometer delito. Se trata de una medida de contenido puramente policial que no puede confundirse con la esencia de las medidas de seguridad. Siendo así que, además, se olvida el legislador de prohibirle el contacto con la víctima dejándola desprotegida, que es una de las finalidades que se persigue con esta medida de libertad vigilada".

1486 ACALE SÁNCHEZ, M., “Nuevos presupuestos...”, cit. p. 42. Esta autora señala que de esta previsión se desprende la una "filosofía de desconfianza absoluta hacia penado", ya que se trata de "meras sospechas abiertamente reconocidas". 
cautelares y en la ejecución de penas de alejamiento. Por otra parte, en la medida en que desaparece del elenco de prohibiciones la prohibición de desempeñar determinadas actividades que puedan ofrecerle o facilitarle la ocasión para cometer hechos delictivos de similar naturaleza, la prohibición de establecer relación, ofrecer empleo, facilitar formación o albergar a cualquiera de las personas mencionadas, parece no ser más que la versión ampliada de la misma, concretando en qué consisten esas actividades que antes se enunciaban de forma más genérica. Desaparece también la prohibición de acudir a determinados territorios, lugares o establecimientos, que ahora no tiene previsión específica en el articulado.

3a. Mantener su lugar de residencia en un lugar determinado con prohibición de abandonarlo sin autorización de los servicios de gestión de penas y medidas alternativas.

Se añade una nueva regla de conducta que consiste en mantener el lugar de residencia con prohibición de abandonarlo sin autorización de los servicios de gestión de penas y medidas alternativas. No parece que el mantenimiento sea una obligación absoluta, sino que el sujeto puede cambiar de residencia si solicita autorización a los servicios de gestión competentes. Sobre qué debe entenderse por los servicios de gestión de penas y medidas alternativas, el art. 2, apartado 4 del RD 804/2011, por el que se establecen las circunstancias de ejecución de las penas de trabajo en beneficio de la comunidad y de localización permanente en centro penitenciario, de determinadas medidas de seguridad, así como de la suspensión de la ejecución de la penas privativas de libertad y sustitución de penas, los define diciendo que son las "unidades administrativas multidisciplinares dependientes de la Administración penitenciaria que tienen encomendado la tarea de ejecución de las medidas y penas alternativas a la privación de libertad". Estos organismos adquieren especial protagonismo en la regulación proyectada de la libertad vigilada, ya que aparecen en varios preceptos, como se verá a continuación.

$4^{a}$. Prohibición de residir en un lugar determinado o de acudir al mismo, cuando en ellos pueda encontrar la ocasión o motivo para cometer nuevos delitos.

Se modifica la prohibición de residir en determinados lugares y ahora se especifica que lo que se prohíbe es residir en un lugar determinado pero también acudir a él, siempre que dicho lugar sea propicio para que el sujeto pueda encontrar ocasión o motivo para delinquir nuevamente. Se trata de precisar que esta prohibición no puede ser a título 
de castigo cuando el lugar al que se prohíbe ir o residir no guarda relación con la naturaleza de los delitos que se pretenden prevenir, por lo que no sería válida una prohibición genérica de no ir al río, o a la playa, o no poder ir a cines o teatros, a modo de castigo como quien castiga a un menor en el ámbito doméstico. Las prohibiciones tienen que estar justificadas desde el punto de vista de la relación que guarden con los delitos que se pretende que el sujeto no cometa.

$5^{a}$. Informar sin demora a los servicios de gestión de penas y medidas alternativas de sus cambios de residencia y de sus datos de localización.

Se modifica la obligación de comunicar inmediatamente, en el plazo máximo y por el medio que el Juez o Tribunal señale a tal efecto, cada cambio del lugar de residencia o del lugar o puesto de trabajo, por un deber de informar, sin demora, a los servicios de gestión de penas y medidas alternativas cada cambio de residencia y los datos para su localización. Desaparece la necesidad de que el Juez o Tribunal señale un medio por el que poner en conocimiento dichos cambios y también el plazo, que ahora se debe realizar sin demora, esto es, tan pronto como se produzca el cambio de residencia o de los datos de localización, que puede ser, por ejemplo, el cambio de número de teléfono.

$6^{a}$. Comparecer personalmente con la periodicidad que se determine ante los servicios de gestión de penas y medidas alternativas o el servicio de la administración que se determine, para informar de sus actividades y justificarlas.

Sustituye a la anterior obligación de presentarse periódicamente en el lugar que el Juez o Tribunal establezca, que pasa a ser una comparecencia personal ante los servicios de gestión de penas y medidas alternativas o, en su caso, ante el servicio de la administración que se determine, con la única finalidad de informar de sus actividades y justificarlas, entendiendo que deberá ofrecerse información de haber llevado a cabo las reglas de conducta impuestas en la libertad vigilada. Se trata de una condición al servicio del control y seguimiento de la medida de seguridad.

$7^{a}$. Participar en programas formativos, laborales, culturales, de educación vial, sexual, de defensa del medio ambiente, de protección de los animales, de igualdad de trato y no discriminación, y otros similares. 
La obligación de participar en programas formativos, laborales, culturales, de educación sexual u otros similares, queda ampliada con esta nueva redacción que incluye programas de educación vial, de defensa del medio ambiente, de protección de los animales, de igualdad de trato y no discriminación, y finalmente añade una cláusula abierta en la que caben otros programas similares.

8a. Participar en programas de deshabituación al consumo de drogas tóxicas o sustancias estupefacientes o programas de tratamiento de adicciones sociales patológicas.

Es una novedad entre los contenidos de la libertad vigilada, que no venía prevista en modo alguno en la redacción de la LO 5/2010, y consiste en participar en programas de deshabituación en el consumo de drogas o de tratamiento para las adicciones sociales, que pueden ser adicciones al juego, al trabajo, al sexo, a las comidas, a las redes sociales, a las compras, a la televisión, etc., pero entiendo que las adicciones sociales que pretendan ser objeto de tratamiento en los programas, deberán guardar relación con los delitos que se pretende evitar que cometa en el futuro, porque si un sujeto es adicto a las rebajas y al trabajo pero no su delito no tuvo nada que ver con ellas, no será procedente tratarle por esas adicciones, menos aún como obligación concreta de la libertad vigilada.

\section{$9^{a}$. Privación del derecho a conducir vehículos de motor o ciclomotores.}

Se trata de una medida de seguridad que ahora queda refundida bajo el concepto de libertad vigilada, que en la LO 5/2010 no se incluyó y mantenía su carácter autónomo. En la formulación proyectada se puede imponer, junto con otras reglas de conducta, como contenido específico de la libertad vigilada, siempre que la medida sea idónea para neutralizar la peligrosidad criminal del sujeto que justifica su imposición. Por otra parte, desaparece como medida de seguridad autónoma, puesto que el aparatado quincuagésimo octavo del art. único del Proyecto, modifica el catálogo del art. $96 \mathrm{CP}$, siendo que solo se contemplan como medidas de seguridad no privativas de libertad la prohibición de ejercicio de actividad profesional, la expulsión del territorio nacional de extranjeros y la libertad vigilada.

Sobre la medida de seguridad de privación del derecho a conducir, se ha dicho por la doctrina que está reservada a los inimputables, porque para el resto de personas que delinquen está prevista la pena privativa de derechos con la que, de otra forma se 
solaparía ${ }^{1487}$. Ahora con la reforma, puede imponerse a todos, sin que se proponga solución alguna para solucionar el solapamiento y respetar la prohibición de ne bis in idem.

$10^{a}$. Privación del derecho al porte o tenencia de armas.

Al igual que la prohibición anterior, se trata de una medida de seguridad que ahora queda refundida bajo el concepto de libertad vigilada, que en la LO 5/2010 no se incluyó y mantenía su carácter autónomo. En la formulación proyectada se puede imponer, junto con otras reglas de conducta, como contenido específico de la libertad vigilada, siempre que la medida sea idónea para neutralizar la peligrosidad criminal del sujeto que justifica su imposición. Sobre esta medida de seguridad, a pesar de su contenido profiláctico, la doctrina venía afirmando que carece de efectos rehabilitadores y que su aplicación queda reducida a los inimputables que tenían permiso de armas y se han servido del mismo para delinquir, porque para los semiimputables y para los imputables, ya está la pena privativa de derechos y la medida no sería procedente aplicarla ${ }^{1488}$. Con la reforma proyectada, se advierte que puede imponerse en todos los casos, sin que quede claro cómo resolver el solapamiento con la pena sin incurrir en infracción del principio de ne bis in ídem.

11. Prohibición de consumir alcohol, drogas tóxicas, sustancias estupefacientes o psicotrópicas, cuando existan razones que permitan suponer que aquél pueda incrementar el riesgo de comisión de nuevos delitos. En estos casos, se impondrá también el deber de someterse al control de consumo de esas sustancias con la periodicidad que se determine o cuando se considere oportuno por los servicios de gestión de penas y medidas alternativas.

Se trata de una novedad en el contenido de la libertad vigilada, y es donde el legislador parece estar dotado de una ingenuidad manifiesta, al pretender que mediante la imposición de una regla de conducta dentro de una medida de seguridad, se va a conseguir eliminar algo tan fuerte como la adicción que causan ciertas sustancias tóxicas, etílicas o psicotrópicas. Quizás sea cierto que el consumo de dichas sustancias puede incrementar el riesgo de comisión de nuevos delitos, pero prohibir el consumo -cuando el mismo es más o menos frecuente- es sinónimo de fracaso en el tratamiento, ya que las adicciones solo se combaten a través de tratamientos médicos o psicológicos en los que el

1487 LEAL MEDINA, J., “Un estudio de las actuales medidas...”, cit. p. 417.

1488 Ibidem. Pag. 416. 
principal exponente es la voluntariedad del paciente y su deseo de someterse y de abandonar el consumo. Las prohibiciones de consumo de sustancias cuando se imponen por la fuerza, suelen acarrear resultados contraproducentes y además no es frecuente que arrojen resultados positivos para el pretendido fin de la desaparición del hábito.

Por otra parte, el sometimiento del vigilado a las medidas de control de consumo que periódicamente puedan llevarse a cabo por parte de los servicios de gestión de penas y medidas alternativas, puede que no hagan más que provocar continuos incumplimientos y evidenciar que la peligrosidad criminal no desaparece sino que subsiste a pesar de las condiciones pretendidamente beneficiosas para su adicción, permitiendo las sucesivas prórrogas de la libertad vigilada.

\section{$12^{a}$. Inscribirse en las oficinas de empleo.}

Es también una novedad en el texto proyectado que no se incluía en las reglas de conducta de la libertad vigilada en su redacción dada por la LO 5/2010, y consiste en la obligación de inscribirse en las oficinas de empleo. Lo que no termina de resolver la redacción es si el vigilado cumple con su obligación al inscribe en dichas oficinas como demandante de empleo, o si existe un deber de mantener la inscripción, esto es, estar inscrito y de alta mientras no se tenga trabajo. Ello implica que hay que hacer las renovaciones periódicas del documento de alta y renovación de la demanda de empleo (DARDE), pero no termina de quedar claro qué sucede si el sujeto no renueva la inscripción, no acude a las citas para entrevistas de trabajo o cursos de formación que se ofrezcan para desempleados y, en definitiva, incumple las demás consecuencias derivadas del alta en la oficina del Instituto Nacional de Empleo. En principio tendríamos dos interpretaciones, si no renueva - o no acude cuando es citado-incumple la obligación con los efectos que correspondan en el incumplimiento de la libertad vigilada; la segunda interpretación es que sería suficiente con volver a imponer nuevamente esa medida a solicitud del Ministerio Fiscal cuando el servicio de gestión de penas y de medidas alternativas, dé cuenta de la baja en el Instituto Nacional de Empleo por no renovar la inscripción el día fijado al efecto, a que se inscriba sin mayores efectos para la ejecución de la libertad vigilada en su conjunto. De ese modo la obligación sería de inscribirse, pudiendo ser acordada nuevamente si se causa baja, pues el incumplimiento solo se haría si el sujeto no se inscribe. Esta segunda parece la interpretación más correcta. 
Por otra parte, no se impone la obligación de aceptar el trabajo que hipotéticamente podría proporcionarle su condición de demandante de empleo, lo que plantearía el problema de que al igual que en las penas de trabajos a favor de la comunidad, sería necesario el consentimiento del sometido a la medida, por lo que este aspecto sería de difícil viabilidad aun estando previsto en la norma -que no está-, y su regulación como derecho al trabajo remunerado tendría que guardar las mismas especialidades y condicionantes que envuelven el trabajo en los centros penitenciarios de los condenados a penas de prisión.

En cualquier caso, lo que no podemos olvidar es que esta obligación evoca en nuestra memoria la regulación que contenía el CP 1848 de la pena correccional de "sujecion á la vigilancia de la autoridad" (art. 24), pues entre sus contenidos, se presentaba como obligación más importante, la de tener un oficio1489, (art. $42 \mathrm{CP}$ ) bajo esta nominación: "3a. Adoptar oficio, arte, industria ó profesión, si no tuviere medios propios y conocidos de subsistencia". Hay que tener presente que se trataba de una pena que adquiría especial importancia cuando se cometía el delito de vagancia y además concurría reincidencia, puesto que se trataba de una sanción penal destinada a neutralizar los estados de peligrosidad social derivados de los sujetos vagos y mendigos. Su regulación se reprodujo en el CP de 1850 pero desaparecio con el CP de 18701490. Conviene tener presente estos antedecentes porque quizás el legislador no está siendo consciente de que puede estar involucionando el Derecho hacia figuras que tuvieron su auge en el S. XIX y a mediados del S. XX, pero que desaparecen con la derogación de las leyes de vagancia y peligrosidad social. La obligación de inscribirse en las oficinas de empleo, puede que no sea más que la versión moderna de esta clase de sanciones, que suponen una proyección involucionista hacia la neutralización de la peligrosidad social más que hacia la efectiva eliminación de la peligrosidad criminal.

13a. Someterse a tratamiento ambulatorio. En este caso se determinarán las fechas o la periodicidad con que el sometido a la medida debe presentarse ante un médico, psiquiatra o psicólogo.

\footnotetext{
1489 GARCÍA RIVAS, N., “La libertad vigilada...”, cit. p. 5.

1490 MANZANARES SAMANIEGO, J.L., “La libertad vigilada...”, cit. pp. 2 y 3.
} 
Frente a la tan polémica obligación de seguir tratamiento médico externo, o de someterse a un control médico periódico que introdujo la LO 5/2010, se proyecta ahora una nueva redacción que consiste en someterse a tratamiento ambulatorio, determinando las fechas o la periodicidad con que el vigilado deberá presentarse ante un médico, psiquiatra o psicólogo. Más allá de los cambios en la redacción y de la especificación de que debe tratarse de un médico, psiquiatra o psicólogo, no se proporciona solución alguna al tema de la voluntariedad del tratamiento para los imputables ni se impone como requisito que el vigilado deba prestar el consentimiento previamente, aspecto que se ha dejado pasar nuevamente dando lugar a que persistan las dudas de interpretación sobre cuál será la consecuencia del incumplimiento o el abandono del tratamiento. En cualquier caso, queda también incluido en esta nueva redacción de esta medida, el supuesto de los tratamiento antiandrógenos inhibidores de la libido (castración química) para los delincuentes sexuales, que tanto dieron que hablar tras la introducción de la libertad vigilada para delincuentes sexuales en la LO 5/2010, que se posibilitaba gracias a la obligación -que no era tal- de someterse a tratamiento médico y cuyo incumplimiento, negativa o abandono, no daba lugar al quebrantamiento de condena sino a que se sustituyera una medida por otra.

$14^{a}$. Someterse a custodia familiar o residencial. En este caso, el sujeto a la medida será puesto bajo el cuidado y vigilancia de una persona o institución que a tal fin se designe y que acepte el encargo de custodia. El ejercicio de la custodia comprenderá la obligación de informar al servicio competente de la administración penitenciaria sobre la situación del custodiado, con una periodicidad al menos mensual. La información será inmediata de sustraerse a la vigilancia o control.

Es también una novedad que no aparecía en la redacción conferida mediante la LO 5/2010 como medida dentro de la libertad vigilada, y que ahora se presenta bajo la forma de custodia familiar o residencial y consiste en permanecer bajo el cuidado y vigilancia de una persona o institución que será designada al efecto y que aceptará el cargo de custodia. No obstante, esta clase de custodia venía prevista como medida de seguridad no privativa de libertad ${ }^{1491}$, pero con esta nueva redacción se amplía el ámbito de personas que pueden

\footnotetext{
1491 Esta clase de custodia familiar tiene un antecedente en el RD de 3 de julio de 1931, art. 27 d), que disponía que el alta de los enfermos psiquiátricos podía concederse si alguno de sus familiares lo solicitase y se hiciesen cargo de los mismos, (vid. LEAL MEDINA, J., “Un estudio de las actuales medidas...”, cit. p. 413). Por otra parte, en la redacción inicial de del Código penal de 1995, esta medida estaba dentro del art. 105 CP y su
} 
estar sometidos a la misma, extendiéndose así a los imputables. De momento no se ofrecen más pistas de qué instituciones residenciales puede tratarse, pero en cualquier caso deberán ser aptas para mantener custodiado al sujeto sometido a la medida. La custodia impone la obligación de informar al menos mensualmente al servicio competente de la administración penitenciaria sobre la situación del custodiado, salvo que el vigilado intente sustraerse a la custodia, en cuyo caso existe un deber de información inmediata por parte del encargado de la misma.

Sobre esta medida, la doctrina ya vino poniendo de manifiesto que tiene las ventajas de ser especialmente útil para evitar el internamiento sin menoscabar su control, y que permitía imponerse conjuntamente con el tratamiento ambulatorio ${ }^{1492}$. Pero algunos autores se han mostrado escépticos con la eficacia de esta medida para el control de la peligrosidad1493, y también se han venido señalando sus inconvenientes ${ }^{1494}$, que resultan de los eventuales incumplimientos del control en el caso de los familiares, bien por imposibilidad o bien por abandono, habida cuenta de que puede resultar una carga difícil de mantener $\mathrm{y}$, sobre todo, de controlar sin incidentes que pueden ser más o menos frecuentes. También se ha dicho que se necesita una definición más clara de la custodia, así como el procedimiento por el que debe llevarse a cabo la función, aspectos que no han sido tampoco emprendidos en el Proyecto quedando la norma con la misma insuficiencia que antes se advertía. Por último, se objeta a esta clase de custodia que se trata de una figura que está íntimamente relacionada con instituciones civiles, aspecto que deja en entredicho su carácter penal y, por la serie de materias ajenas al mismo a las que conviene remitirse para su efectivo cumplimiento, es posible que las funciones que debe cumplir la medida no puedan conseguirse, deviniendo poco útil e ineficaz ${ }^{1495}$. Al preverse ahora que

aplicación como medida de seguridad venía propiciada por la remisión a ese precepto que hacía el art. 96.2 CP, SÁNCHEZ YLLERA, I., en VIVES ANTÓN, T.S., (Coord.), Comentarios al Código Penal de 1995. Vol. I. Valencia: Tirant lo Blanch. 1996, p. 568, vino a decir que parecía que se trataba de una medida pensada para jóvenes o para semiimputables, pero mediante esta reforma su proyección parece dirigirse hacia la generalización de su uso.

1492 CORCOY BIDASOLO, M. / MIR PUIG, S., Comentarios..., cit. p. 243. Estos autores explican que la SAP de Madrid 366/1998, de 17 de junio, impuso esta custodia en el caso de una persona que tras un intento de suicidio quedó con una grave discapacidad que le impedía caminar.

1493 SANZ MORÁN, A.J., Las medidas de corrección y de seguridad..., cit. p. 232.

1494 Vid. LEAL MEDINA, J., “La custodia familiar. Pasado, presente y futuro de una medida de seguridad insuficientemente regulada y de difícil encaje en el Derecho penal”. En Revista La Ley, núm. 2, 2006, pp. 1400 a 1408.

1495 LEAL MEDINA, J., “Un estudio de las actuales medidas...”, cit. p. 413. 
la custodia puede llevarse a cabo a través de instituciones, parece que se pretende mitigar estos efectos.

15 a Llevar consigo y mantener en adecuado estado de conservación los dispositivos electrónicos que hubieran sido dispuestos para controlar los horarios en que acude a su lugar de residencia o, cuando resulte necesario, a los lugares en que se encuentra en determinados momentos o el cumplimiento de alguna de las medidas a que se refieren las reglas $1^{a}$ a $4^{a}$. Esta regla solamente podrá ser impuesta cuando el sujeto hubiera sido condenado por alguno de los delitos del artículo 57.

Se modifica notablemente la obligación de estar siempre localizable mediante aparatos electrónicos que permitan su seguimiento permanente que contenía la LO 5/2010, y en la redacción proyectada la regla de conducta consiste en llevar consigo y mantener en adecuado estado de conservación los dispositivos electrónicos que le hayan sido aplicados para controlar los horarios en que acude a su lugar de residencia o a los lugares en que se encuentra en determinados momentos o el cumplimiento de alguna de las medidas a que se refieren las reglas $1^{\mathrm{a}}$ a $4^{\mathrm{a}}$, que son la prohibición de aproximarse a la víctima o a otros miembros de su familia que se determine por el Juez o Tribunal, a sus domicilios, a sus lugares de trabajo o a otros lugares habitualmente frecuentados por ellos, la prohibición de establecer contacto con personas determinadas o con miembros de un grupo determinado, o la prohibición de establecer relación, ofrecer empleo, facilitar formación o albergar a cualquiera de las personas mencionadas; la obligación de mantener su lugar de residencia en un lugar determinado con prohibición de abandonarlo sin autorización; y la prohibición de residir en un lugar determinado o de acudir al mismo.

Parece que se pretende que el vigilado sea el encargado de que el dispositivo no se rompa o no deje de funcionar, pudiendo considerarse incumplimiento de la medida si ese aparato se avería o se deteriora, trasladando al vigilado la carga que supone el mantenimiento del correcto funcionamiento para garantizar el seguimiento. Puede convertirse en una nueva forma de generar incumplimientos y prórrogas de la libertad vigilada porque el sujeto tiene una doble obligación: llevar el dispositivo consigo y garantizar que funcione. 
Por otra parte, no conviene perder de vista que la inutilización o perturbación de los dispositivos electrónicos, no llevarlos consigo u omitir las medidas exigibles para que dichos aparatos funcionen correctamente, podrá constituir el delito de quebrantamiento de condena castigado con penas de multa de seis a doce meses, según la previsión del apartado ducentésimo decimoquinto del art. único del Proyecto, que añade un apartado 3 al art. $468 \mathrm{CP}$, tipifica estas conductas como modalidad específica de quebrantamiento ${ }^{1496}$, sin olvidar que en los dispositivos que consisten en pulseras electrónicas, se detecta cualquier intento de sabotaje porque disponen de un sistema especial de cierre que informa de su manipulación ${ }^{1497}$.

El precepto añade un requisito in fine para su imposición, que consiste en que esta regla solo podrá imponerse en casos de condena por alguno de los delitos del art. $57 \mathrm{CP}$, que son los delitos de homicidio, aborto, lesiones, contra la libertad, de torturas y contra la integridad moral, trata de seres humanos, contra la libertad e indemnidad sexuales, la intimidad, el derecho a la propia imagen y la inviolabilidad del domicilio, el honor, el patrimonio y el orden socioeconómico. No termina de comprenderse la elección de esta clase de delitos para esta medida, pero lo relevante es que hay que tener en cuenta que muchos de estos delitos no tienen prevista la libertad vigilada expresamente (como los delitos contra la intimidad, el derecho a la propia imagen y la inviolabilidad del domicilio, el honor) por lo que no les será aplicable aunque aparezcan en el art. 57 CP.

16 ${ }^{a}$. Prohibición de conducir vehículos de motor que no dispongan de dispositivos tecnológicos que condicionen su encendido o funcionamiento a la comprobación previa de las condiciones físicas del conductor, cuando el sujeto haya sido condenado por un delito contra la seguridad vial y la medida resulte necesaria para prevenir la posible comisión de nuevos delitos.

Es también una novedad en el Proyecto, que implica que cuando el sujeto haya sido condenado por algún delito contra la seguridad vial, no podrá conducir si el vehículo no está equipado con unos dispositivos de encendido y funcionamiento que impidan su circulación cuando el conductor no se encuentra en condiciones físicas. Es decir, que no se prohíbe conducir vehículos a motor - para eso ya hay una regla de conducta específica-

\footnotetext{
1496 Art. 468.3 CP. “Los que inutilicen o perturben el funcionamiento normal de los dispositivos técnicos que hubieran sido dispuestos para controlar el cumplimiento de penas, medidas de seguridad o medidas cautelares, no los lleven consigo u omitan las medidas exigibles para mantener su correcto estado de funcionamiento, serán castigados con una de multa de seis a doce meses".

1497 VEGA ALOCÉN, M., El tercer grado con control telemático. Granada: Comares. 2010, p. 70.
} 
por lo que ésta solo se podrá aplicar si no se ha impuesto la otra, de lo contrario la prohibición absoluta abarca también los vehículos dotados de estos dispositivos.

Por tanto, el sujeto puede conducir pero solo esta clase de vehículos. El problema que se plantea es, si realmente lo que se pretende es forzar a los conductores que han sido condenados por delitos contra la seguridad del tráfico a que adapten sus vehículos a este sistema, porque lo cierto es que actualmente en España este tipo de vehículos no abundan y, debido a la recesión económica sufrida en los últimos años, no se avanza precisamente a la modernización de los medios tradicionales de transporte. En cualquier caso, el legislador evidencia un optimismo que quizás esté fuera de lugar y de tiempo.

17a. Cumplir los demás deberes que el Juez o Tribunal estime convenientes para la rehabilitación social del penado, previa conformidad de éste, siempre que no atenten contra su dignidad como persona.

Se trata de una cláusula abierta en la que puede entrar todo, con el único límite de que esos deberes no pueden atentar contra la dignidad de la persona y articulando el necesario consentimiento del propio sometido a la medida para terminar consiguiendo un efecto que recuerda a la analogía y que, en Derecho penal, no conviene usarse en exceso para no rebasar el límite de la legalidad que viene impuesta por tal principio. En cualquier caso, hará falta determinar cuáles son esos demás deberes que, sin estar incluidos en el amplio elenco de obligaciones y condiciones, puedan ser de aplicación. Quizás el motivo sea que, habiendo tantos delitos a los que ahora se aplica la libertad vigilada posterior a la pena de prisión, es difícil elaborar un elenco de condiciones que, en forma de medida de seguridad, podrían ser eficaces para el buen fin de la misma y la consecución de la pretendida desaparición de la peligrosidad, por eso se permite la creación judicial de reglas de conducta que el precepto llama "deberes".

El apartado 2 del art. 104 bis CP, incluye una cláusula abierta adicional, que reza así: "El Juez o Tribunal podrán también imponer, durante todo el tiempo de duración de la medida o durante un período de tiempo determinado, el cumplimiento de otras obligaciones y condiciones, especialmente aquéllas que se refieren a la formación, trabajo, ocio, o desarrollo de su actividad habitual". Como se observa, es posible imponer otras obligaciones y condiciones, en especial - pero no en exclusiva - las que afecten a la formación, trabajo, ocio o desarrollo de su actividad habitual, y podrán ser impuestas conjuntamente con las otras obligaciones 
y condiciones previstas en el catálogo, por tiempo determinado o por un período concreto. Las mismas consideraciones efectuadas al art. 104 bis, $1,17^{\mathrm{a}} \mathrm{CP}$, son trasladables a este precepto.

El apartado 3 del art. 104 bis CP, contiene una regla genérica por la que no se podrán imponer deberes y obligaciones si resultan excesivos y desproporcionados con las circunstancias del caso. Lo que no se deja ver ni por aproximación son los criterios para medir la proporcionalidad o los eventuales excesos, que quedan en manos de los criterios subjetivos del juzgador que en cada caso se barajen, al margen de que ambas expresiones parecen redundantes, pues no se aprecia distinción alguna entre reglas de conducta excesivas y desproporcionadas ${ }^{1498}$.

El apartado 4 del art. 104 bis $\mathrm{CP}^{1499}$, prevé una regla para el caso de que un sujeto esté cumpliendo una medida de seguridad de libertad vigilada y se le imponga otra libertad vigilada más. En estos casos, la regla que se incorpora es que se podrán incluir también en la segunda las obligaciones y prohibiciones que ya se hubieran impuesto en la primera, de forma que el cumplimiento de las mismas se computará a ambas. El cumplimiento es, pues, simultáneo independientemente de las obligaciones y condiciones que se impongan.

El apartado 5 del art. 104 bis CP, dispone que le corresponde al JVP concretar el contenido de la libertad vigilada en los casos en que deba cumplirse tras la pena de prisión, debiendo, al menos dos meses antes de la extinción de la pena, resolver dichas concreciones con base en los informes y comprobaciones que considere pertinentes, exigiéndose además la audiencia al penado y al Ministerio Fiscal. También le corresponderá determinar el contenido de la libertad vigilada en los supuestos del art. 104.2. $2^{\circ}$ y 104.3 CP, que son: cuando se haya acordado el cese de una medida de seguridad privativa de libertad, cuando haya acordado suspender la ejecución de una medida de seguridad privativa de libertad y cuando se cumpla el plazo máximo de duración de la

\footnotetext{
1498 ACALE SÁNCHEZ, M. "Medidas de seguridad...", cit. p. 444. Esta autora indica que "semejante limitación carece de sentido doblemente. Por un lado, como se ha propuesto en este estudio, es necesario que se incluya en el Título preliminar una cláusula de proporcionalidad en abstracto en aplicación a las medidas de seguridad. Pero además, los deberes y obligaciones que se adopten deberán tener en consideración la peligrosidad criminal del autor, no las circunstancias del caso que parecen apuntar más a una proporcionalidad típica en el ámbito de las penas".

1499 Art. 104 bis. 4. "Cuando la medida de libertad vigilada fuera impuesta a un sujeto que ya estuviera sometido a otra medida de la misma naturaleza, el Juez o Tribunal podrán incluir también la imposición de las obligaciones y condiciones que ya se hubieran adoptado en el marco de aquella libertad vigilada previa".
} 
medida de seguridad privativa de libertad que se hubiera impuesto o se decrete su cese, y resulte necesario para compensar el riesgo de comisión de nuevos delitos ${ }^{1500}$.

\section{c) Duración de la libertad vigilada}

El apartado septuagésimo primero del art. único del Proyecto, introduce un nuevo art. 104 ter CP, que en su apartado 1 dispone que la duración de la libertad vigilada será de un mínimo de tres años ${ }^{1501}$ y de un máximo de cinco, pero el apartado 2 especifica que el plazo máximo podrá ser prorrogado por plazos sucesivos de cinco años cada uno como máximo, pero nada impide que las prórrogas sean por tiempos menores incluso de los tres años que marca el apartado 1 que hace referencia solo al período mínimo inicial. Esas prórrogas solo podrán acordarse cuando se hayan producido incumplimientos relevantes de las obligaciones y condiciones impuestas, y además que de dichos incumplimientos puedan derivarse indicios que evidencien un riesgo relevante de comisión futura de nuevos delitos. Pero se añaden más requisitos que deben concurrir, pues solo cabe la prórroga si se trata de delitos sexuales, por remisión expresa al art. $192.1 \mathrm{CP}$, o si se trata de una libertad vigilada que se ha impuesto al acordar la suspensión de la ejecución de una medida de seguridad privativa de libertad, por remisión expresa al art. 102.1 c) ${ }^{1502}$. Aun así, la doctrina viene diciendo que en tanto en cuanto la libertad vigilada también supone una importante intromisión en las libertades individuales, las prórrogas de cinco años son excesivas y, en cualquier caso, no es posible mantener a un sujeto cumpliendo

1500 Art. 104 bis. 5. “Corresponderá en todo caso al Juez de Vigilancia Penitenciaria determinar el contenido de la libertad vigilada: a) Cuando la medida de libertad vigilada deba cumplirse después de una pena de prisión. En este caso, al menos dos meses antes de la extinción de la pena de prisión, el Juez de Vigilancia Penitenciaria resolverá previos los informes y comprobaciones que estime necesarios y después de haber oído al penado y al Ministerio Fiscal. b) En los supuestos del número $2^{\circ}$ del apartado 2 y del apartado 3 del artículo 104".

1501 EXTEBARRIA ZARRABEITIA, X., “Medidas de seguridad y su ejecución”. En ÁLVAREZ GARCÍA, F.J., (Dir.) / DOPICO GÓMEZ-ALLER, J., (Coord.), Estudio crítico sobre el Anteproyecto de Reforma penal de 2012. Valencia: Tirant lo Blanch. 2013. Este autor señala que la medida de seguridad no puede tener una duración mínima, sino que, por su propia esencia y fundamento, debe cesar si desaparece la peligrosidad, con independencia del tiempo mínimo que se haya cumplido.

1502 Art. 104 ter. 1. “La libertad vigilada tendrá una duración mínima de tres años y una duración máxima de cinco.

2. El plazo máximo de duración podrá ser prorrogado por plazos sucesivos de una duración máxima de cinco años cada uno de ellos, cuando se hubieran producido anteriormente incumplimientos relevantes de las obligaciones y condiciones impuestas conforme al artículo 104 bis de los que puedan derivarse indicios que evidencien un riesgo relevante de comisión futura de nuevos delitos, y además: a) La medida de libertad vigilada hubiera sido impuesta en los supuestos del artículo 192.1, o, b) de conformidad con lo dispuesto en la letra c) del artículo 102.1.

3. La libertad vigilada comienza en la fecha en que se extinga la pena impuesta o cuando se acuerde su suspensión, en el caso del artículo 104.1; con la firmeza de la sentencia, en el caso de la letra a) del artículo 104.2; o con la resolución en que se acuerda la suspensión de otra medida de seguridad privativa de libertad, en los demás casos. No se computará como plazo de cumplimiento aquél en el que el sujeto a la medida se hubiera mantenido en situación de rebeldía". 
una libertad vigilada durante toda su vida ${ }^{1503}$. Además, se trata de una previsión que permite la duración ilimitada de la libertad vigilada, contraria a la Recomendación del Consejo de Ministros del Consejo de Europa de 2014 relativa a los delincuentes peligrosos ${ }^{1504}$ (que solo incluye a los condenados por un delito sexual o con violencia contra las personas que debe ser muy grave, con alta probabilidad de cometer nuevas infracciones sexuales o con violencia también muy graves), Recomendación que también maneja un régimen más estricto que el que contiene el Proyecto en relación a la duración indeterminada de las medidas aplicables en la comunidad ${ }^{1505}$, por lo que esta posibilidad de prolongación ilimitada debería suprimirse de la regulación proyectada, de forma que la libertad vigilada se imponga atendiendo a criterios de proporcionalidad que incluyan tanto la peligrosidad individual como la gravedad del delito cometido ${ }^{1506}$.

El apartado 3 del art. 104 ter CP, dispone que la libertad vigilada se empieza a cumplir en la fecha en que se extingue la pena impuesta o cuando se acuerda la suspensión de la medida de seguridad privativa de libertad de que se trate en el caso del art. 104.1 CP, con la firmeza de la sentencia en el caso del art. 104.2 a) CP (sic). Entendemos que se trata de una errata de legislador, pues el art. 104.2 no tiene letra a), sino ordinales $1^{\circ}$ y $2^{\circ}$, por lo que entendemos que será el art. $104.2 .1^{\circ} \mathrm{CP}$, que dispone que la libertad vigilada será de aplicación cuando el sujeto haya sido absuelto por apreciarse la eximente del art. $20.1^{\circ}, 2^{\circ}$ ó $3^{\circ}$, o la atenuante del art. $21,1^{\circ} \mathrm{CP}$ en relación al art. 95.1 $\mathrm{CP}$. Sigue diciendo el precepto en estudio que en los demás casos comenzará a cumplirse la libertad vigilada con la resolución que acuerde la suspensión de otra medida de seguridad privativa de libertad. Finalmente, el precepto añade una regla que dispone que no se computará como plazo cumplido de la libertad vigilada el tiempo en que el vigilado se hubiera mantenido en rebeldía ${ }^{1507}$.

\footnotetext{
1503 EXTEBARRIA ZARRABEITIA, X., “Medidas de seguridad y su ejecución...”, cit. p. 466.

1504 Recomendación $\mathrm{CM} / \operatorname{Rec}$ (2014) del Comité de Ministros a los Estados miembros relativa a los delincuentes peligrosos, (adoptada por el Comité de Ministros el 19 de febrero de 2014 en la $1192^{a}$ sesión de los Delegados de Ministros). El texto íntegro en: [https://bioderecho.wordpress.com/recomendacion/].

1505 MARTÍNEZ GARAY, L., “La libertad vigilada...”, cit. p. 35.

1506 ZUGALDÍA ESPINAR, J.M., “Medidas de seguridad...”, cit. p. 484.

1507 Art. 104 ter. 3. "La libertad vigilada comienza en la fecha en que se extinga la pena impuesta o cuando se acuerde su suspensión, en el caso del artículo 104.1; con la firmeza de la sentencia, en el caso de la letra a) del artículo 104.2; o con la resolución en que se acuerda la suspensión de otra medida de seguridad privativa de libertad, en los demás casos. No se computará como plazo de cumplimiento aquél en el que el sujeto a la medida se hubiera mantenido en situación de rebeldía".
} 
El apartado septuagésimo segundo del art. único del Proyecto, modifica el art. 105 $\mathrm{CP}$, que en su apartado 1 dispone que el JVP, en cualquier momento de la ejecución de la libertad vigilada, bien de oficio o a instancia de los servicios de gestión de penas y medidas alternativas o del propio vigilado, podrá verificar si las circunstancias que hicieron necesaria su imposición persisten y, en consecuencia, podrá decidir acerca del mantenimiento o el cese de la libertad vigilada. El mantenimiento podrá ir acompañado de alteraciones o modificaciones del contenido de la medida, en concreto sobre las obligaciones y condiciones impuestas si resulta necesario o conveniente para facilitar el cumplimiento de los fines de la misma. El cese se podrá acordar cuando su finalidad haya sido conseguida y su ejecución ya no resulte necesaria ${ }^{1508}$.

El apartado 2 del art. $105 \mathrm{CP}$ dispone que el JVP deberá resolver conforme a lo dispuesto en el art. 105.1 CP a efectos de acordar el mantenimiento o el cese de la libertad vigilada, con una periodicidad máxima anual, en los casos de las medidas de los números $14^{\mathrm{a}}$ y $15^{\mathrm{a}}$ del art. 104 bis $1 \mathrm{CP}$, esto es, el sometimiento a custodia familiar o residencial y la obligación de llevar consigo y mantener en adecuado estado de conservación los dispositivos electrónicos que le hubieren sido proporcionados ${ }^{1509}$.

El apartado 3 del art. $105 \mathrm{CP}$, fija un límite para el caso de que la resolución del JVP sobre el mantenimiento o el cese de la libertad vigilada, haya tenido su origen en la solicitud del sometido a la medida, en cuyo caso, el JVP podrá fijar un plazo -que no podrá ser superior a un año-, en el que no se volverá a dar curso a ninguna petición similar instada por el vigilado1510, pero nada impide que las solicitudes las formule el Ministerio Público o el servicio de gestión de penas y medidas alternativas, en su caso.

\footnotetext{
1508 Art. 105.1. “El Juez de Vigilancia Penitenciaria podrá, en cualquier momento durante la ejecución de la medida de libertad vigilada, de oficio o instancia de los servicios de gestión de penas y medidas alternativas o de la persona sujeta a la medida, verificar si se mantienen las circunstancias que hicieron necesaria su imposición y adoptar alguna de las siguientes resoluciones: a) Mantener la ejecución de la medida de seguridad impuesta, alterando o modificando las obligaciones y condiciones impuestas cuando resulte necesario o conveniente para facilitar el cumplimiento de los fines de la medida. b) Decretar el cese de la medida, cuando su finalidad haya sido conseguida y su ejecución ya no resulte necesaria".

1509 Art. 105.2. “El Juez de Vigilancia Penitenciaria deberá resolver conforme al apartado anterior con una periodicidad máxima anual sobre el mantenimiento de las medidas a que se refieren los números $14^{\mathrm{a}}$ ó $15^{\mathrm{a}}$ del apartado 1 del artículo 104 bis".

1510 Art. 105.3. “Cuando el Juez de Vigilancia Penitenciaria hubiera resuelto conforme al apartado 1 de este artículo a instancias de la persona sujeta a la medida, podrá fijar un plazo dentro del cual no se dará curso a las peticiones de revisión presentadas por la persona sujeta a la medida. Este plazo no podrá ser superior a un año".
} 
El apartado septuagésimo tercero del art. único del Proyecto, modifica el art. 106 $\mathrm{CP}$, cuyo contenido ahora versa sobre la terminación de la libertad vigilada y sus prórrogas. En efecto, el apartado 1 del art. $106 \mathrm{CP}$ dispone que la libertad vigilada se termina cuando se cumple el plazo máximo de duración, establecido en el art. 104 ter 1 $\mathrm{CP}$, esto es, al término del plazo que se haya fijado judicialmente para su cumplimiento, que será de un mínimo de tres años y de un máximo de cinco. No obstante, acto seguido el precepto contiene la excepción a la regla general, que consiste en que dicho plazo de cumplimiento no pondrá fin a la libertad vigilada si se acordara la prórroga conforme al art. 104 ter $2 \mathrm{CP}^{1511}$. A esta posibilidad de prórroga de la libertad vigilada, la doctrina afirma que se trata de una medida de seguridad que no debería poder prorrogarse atendiendo a fórmulas temporales que, por ser innecesarias, postergan la dignidad del penado 1512 .

El apartado 2 del art. $106 \mathrm{CP}$ dispone que en los casos en que se esté cumpliendo una medida de seguridad de libertad vigilada y se acuerde la ejecución de una pena de prisión o una medida de seguridad privativa de libertad, la libertad vigilada se suspenderá mientras se cumpla o bien la pena de prisión o bien la medida de seguridad privativa de libertad, reanudándose el cumplimiento de la libertad vigilada cuando dichas sanciones se extingan ${ }^{1513}$. No obstante, algunos autores afirman que la dignidad del penado obliga a que se dé prioridad a la medida de seguridad, por lo que sería preferible introducir una facultad de decisión judicial acerca de si se mantiene o se cambia la medida ${ }^{1514}$.

El apartado 3 del art. $106 \mathrm{CP}$, regula el supuesto de que, estando en ejecución una medida de seguridad de libertad vigilada, recaiga una nueva medida de seguridad de la misma naturaleza (otra libertad vigilada), en cuyo caso el Juez o Tribunal ordenará el cumplimiento de una sola medida de libertad vigilada y su contenido se adaptará a las obligaciones y condiciones que se hubieren acordado en cada una de ellas. Además,

1511 Art. 106.1. “La libertad vigilada termina cuando se cumple el plazo máximo de duración establecido en el número 1 del artículo 104 ter, salvo que hubiera sido acordada su prórroga conforme a lo dispuesto en el número 2 del mismo precepto".

1512 ACALE SÁNCHEZ, M. “Medidas de seguridad...”, cit. p. 446.

1513 Art. 106.2. “Cuando durante la ejecución de una medida de libertad vigilada fuera acordada la ejecución de una pena de prisión o de una medida de seguridad privativa de libertad, la ejecución de la libertad vigilada se mantendrá en suspenso durante el tiempo de cumplimiento de aquéllas, y se reanudará una vez que queden extinguidas".

1514 ACALE SÁNCHEZ, M. “Medidas de seguridad...”, cit. p. 448. 
deberá establecerse un plazo máximo de duración de la nueva medida de libertad vigilada refundida, que no podrá exceder el límite de la suma de duración de las medidas impuestas. Conviene precisar que este límite temporal se halla previamente limitado por el plazo general de cinco años de duración máxima de la libertad vigilada, por lo que, si se impuso una libertad vigilada por tiempo de tres años y otra por cuatro años, la nueva libertad vigilada que el órgano jurisdiccional ordene cumplir, fijará un nuevo plazo que no podrá ser superior a cinco años, siendo incorrecto fijar un plazo de siete años como resultado de la suma aritmética. Por otra parte, nada impide que el nuevo plazo que se fije sea inferior, ya que la norma no exige nada al respecto. Satisfaría las exigencias del precepto la fijación de un plazo de cuatro años, atendiendo a la duración más grave de las impuestas. En cualquier caso, la norma es tan incongruente como inoperante, porque la suma de las dos libertades vigiladas no puede ser nunca inferior a seis años, ya que el mínimo son tres años, y si se imponen dos, el mínimo entre ambas será de seis, por lo que, la nueva libertad vigilada que se fije refundiendo las dos, no podrá exceder nunca del máximo de la suma de ambas pero no porque lo diga el precepto, sino porque su límite son cinco años. Cuestión distinta es si el legislador está tratando de extraer del límite de cinco años este supuesto de refundición de medidas de seguridad, pero del tenor literal del precepto no podemos alcanzar tal conclusión ${ }^{1515}$. Por otra parte, aparece también la excepción a los plazos de duración máxima, pues acto seguido el precepto indica que será de aplicación el art. 104 ter 2 CP, que implica que la nueva libertad vigilada podrá prorrogarse por iguales plazos de cinco años.

El apartado 4 del art. $106 \mathrm{CP}$ regula el supuesto de cuando haya sido acordada la suspensión de la pena de prisión o el penado acceda a la libertad condicional y tenga pendiente de cumplimiento una medida de seguridad de libertad vigilada. La redacción del precepto no es precisamente muy esclarecedora ${ }^{1516}$, pero de su tenor se desprende que,

\footnotetext{
1515 Art. 106.3. “Cuando durante la ejecución de una medida de libertad vigilada fuera acordada la ejecución de otra medida de seguridad de la misma naturaleza, el Juez o Tribunal de ejecución ordenará el cumplimiento de una sola medida de libertad vigilada cuyo contenido será ajustado conforme a lo dispuesto para cada una de las medidas que se hubieran impuesto, y establecerá un plazo máximo de duración que no podrá exceder del límite de la suma de la duración de las medidas impuestas, ni ser superior a siete años. En estos casos, resulta igualmente aplicable lo dispuesto en el apartado 2 del artículo 104 ter".

1516 Art. 106.4. “Cuando se acordara la suspensión de la ejecución de una pena de prisión o se concediere al penado la libertad condicional y estuviese pendiente de ser cumplida una medida de libertad vigilada, su contenido se determinará conforme a lo dispuesto en el artículo 104 bis, y se incluirán en su caso en la misma las obligaciones y condiciones de que se hubiera hecho depender la suspensión o la libertad condicional. En este caso, el plazo de duración de la libertad vigilada no podrá ser inferior al tiempo fijado para la suspensión conforme al artículo 81 .
} 
en estos casos, la libertad vigilada empezará a cumplirse cuando se haya acordado la suspensión de la pena de prisión o la libertad condicional, de forma que las condiciones suspensivas en ambos casos pasan por cumplir las obligaciones y condiciones que conforme a las reglas del art. 104 bis CP se acuerden. El precepto indica que esas obligaciones y condiciones que se impongan en la libertad vigilada, deberán ajustarse a las reglas de conducta que se hubieren acordado -en caso de no tener pendiente una libertad vigilada posterior- para suspender la pena, o para acordar la libertad condicional, por lo que, atendiendo a que las obligaciones y condiciones previstas en los números $1^{\mathrm{a}}$ a $4^{\mathrm{a}}$ y $5^{\mathrm{a}}$ a $8^{\mathrm{a}}$ del art. 104 bis $\mathrm{CP}$ coinciden con las reglas de conducta que pueden ser impuestas para la suspensión de la pena privativa de libertad, entendemos que el precepto está indicando que solamente podrán imponerse esas y no las demás.

El propio art. 106.4 CP contiene una regla especial de duración de la libertad vigilada para estos casos, de modo que no podrá ser inferior al tiempo fijado para la suspensión de la pena según el art. $81 \mathrm{CP}$ al que remite, que según la nueva redacción que le confiere el apartado Cuadragésimo quinto del art. único del Proyecto, será de dos a cinco años si la pena que se suspende es no superior a dos años, y de tres meses a un año si se trata de penas leves, o de entre tres y cinco años si la suspensión se acuerda en virtud del art. 80.5 CP, que regula la posibilidad de acordar la suspensión de cualquier pena sin sujeción a los restantes requisitos para la misma, en casos de enfermedad muy grave con padecimientos incurables, salvo que en el momento de la comisión del delito tuviera ya otra pena suspendida por el mismo motivo ${ }^{1517}$.

Además, el mismo art. 106.4 CP contiene al final una regla por la que se concreta que el incumplimiento grave de la libertad vigilada determinará la revocación de la suspensión o de la libertad condicional si el incumplimiento se ha producido dentro del

En estos casos, el incumplimiento grave de la libertad vigilada determinará la revocación de la suspensión de la ejecución de la pena o de la libertad condicional cuando se hubiera producido dentro del tiempo de la suspensión".

1517 Art. 106.4. “Cuando se acordara la suspensión de la ejecución de una pena de prisión o se concediere al penado la libertad condicional y estuviese pendiente de ser cumplida una medida de libertad vigilada, su contenido se determinará conforme a lo dispuesto en el artículo 104 bis, y se incluirán en su caso en la misma las obligaciones y condiciones de que se hubiera hecho depender la suspensión o la libertad condicional. En este caso, el plazo de duración de la libertad vigilada no podrá ser inferior al tiempo fijado para la suspensión conforme al artículo 81.

En estos casos, el incumplimiento grave de la libertad vigilada determinará la revocación de la suspensión de la ejecución de la pena o de la libertad condicional cuando se hubiera producido dentro del tiempo de la suspensión". 
tiempo de suspensión. En principio se observa que no hay referencias al incumplimiento reiterado, sino solo al grave, aunque esta gravedad es difícil de determinar, pues faltará por dilucidar cuándo el incumplimiento no es grave y se mantiene la suspensión de la pena o la libertad condicional, y cuándo reviste especial gravedad que implique la revocación.

El otro efecto que el incumplimiento puede producir, es que, además de cumplirse la pena suspendida o el tramo que reste de libertad condicional, el penado tendrá pendiente además la libertad vigilada posterior a la pena, ya que no hay previsión alguna que diga que la misma se extingue o que el tiempo cumplido de la medida de seguridad mientras la pena estaba suspendida, se deba abonar a la medida de seguridad postpenitenciaria.

\section{e) Delitos a los que se aplica}

El Proyecto amplía considerablemente los delitos a los que esta libertad vigilada de cumplimiento posterior a la pena de prisión es aplicable, pero interesa destacar que en la mayoría de casos la imposición de la libertad vigilada es facultativa y no preceptiva, incluso en los delitos sexuales. No obstante, en la parte referente a la libertad vigilada en relación a los delitos de terrorismo, la reforma no experimenta modificaciones, por lo que se queda como único supuesto en que la imposición facultativa solo es para los delincuentes primarios.

El apartado nonagésimo noveno del art. único del Proyecto introduce un nuevo art. 140 bis CP por el que a los condenados por uno o más delitos comprendidos en el Título I, del Libro II CP, que lleva por rúbrica "del homicidio y sus formas", se les podrá imponer, de forma facultativa, además de las penas que correspondan una medida de libertad vigilada, siempre que concurran el resto de requisitos del art. 104.1 CP en relación al art. 95.1 CP.

El apartado centésimo quinto del art. único del Proyecto introduce un nuevo art. 156 ter $\mathrm{CP}$, por el que a los condenados por uno o más delitos comprendidos en el Título III, del Libro II CP, que lleva por rúbrica "de las lesiones", se les podrá imponer, de forma facultativa, una medida de libertad vigilada, siempre que se den el resto de requisitos del art. 104.1 CP en relación al art. 95.1 CP. 
El apartado centésimo séptimo del art. único del Proyecto, introduce un nuevo art. 168 bis $\mathrm{CP}$, que dispone que a los condenados por la comisión de uno o más delitos comprendidos en el Capítulo I, del Título IV, del Libro II CP, que lleva por rúbrica "de las detenciones ilegales", se les podrá imponer además una medida de libertad vigilada, siempre que se den el resto de requisitos del art. 104.1 CP en relación al art. 95.1 CP.

El apartado centésimo undécimo del art. único del Proyecto, introduce un nuevo art. 172 ter $\mathrm{CP}$, que crea un nueva figura delictiva de acoso, y en el apartado 5 del precepto se señala que, en estos casos, podrá imponerse la libertad vigilada, entendiendo que, al igual que en las previsiones acabadas de ver, deberán concurrir el resto de requisitos para ello.

El apartado centésimo duodécimo del art. único del Proyecto modifica el apartado 2 del art. $173 \mathrm{CP}$, confiriendo algunas modificaciones en la regulación de la violencia habitual en el ámbito familiar, supuestos para los que se prevé la imposición facultativa de la libertad vigilada cuando concurran los demás requisitos exigibles.

El apartado centésimo decimosexto del art. único del Proyecto, introduce un nuevo apartado 12 en el art. 177 bis CP, que permite la imposición facultativa de la libertad vigilada en los supuestos del art. 177 bis $\mathrm{CP}$, dedicado a la trata de seres humanos. Por su parte, el art. centésimo vigésimo séptimo del art. único del Proyecto, modifica el apartado 1 del art. 192 CP, que dispone que a los condenados por delitos comprendidos en el Título VIII, del Libro II CP, que lleva por rúbrica "delitos contra la libertad e indemnidad sexuales", se les podrá imponer además una medida de libertad vigilada. Como se observa, la imposición ya no es obligatoria sino facultativa, siempre que concurran los demás requisitos exigidos en el Código.

El apartado centésimo trigésimo noveno del art. único del Proyecto, introduce un nuevo art. 236 bis $\mathrm{CP}$, por el que se permite la imposición de una medida de libertad vigilada a los condenados por uno o más delitos de los contenidos en el Capítulo Primero, del Título XIII, del Libro II CP, rubricado "de los hurtos". Y en apartado centésimo cuadragésimo cuarto del art. único del Proyecto, introduce un nuevo art. 242 bis CP, por el que se permite la imposición de la libertad vigilada en casos de delitos del Capítulo segundo del mismo Título, que lleva por rúbrica "de los robos". 
El apartado centésimo cuadragésimo quinto del art único del Proyecto, modifica el art. $243 \mathrm{CP}$, que tipifica la extorsión, y en su aparatado 2 dispone que en estos casos se podrá, además, imponer una medida de libertad vigilada. Igual suerte asiste al art. $244 \mathrm{CP}$ que regula el robo y hurto de uso de vehículos, al que se añade un apartado 5 por el que se posibilita la imposición de la libertad vigilada en estos delitos.

El apartado centésimo quincuagésimo primero del art. único del Proyecto, modifica el art. 251 bis, que pasa a numerarse como art. 251 ter, y se introduce un nuevo art. 251 bis, que permite la imposición facultativa de la libertad vigilada a los condenados por uno o más delitos de los comprendidos en la Sección 1, del Capítulo VI, del Título XIII, del Libro II CP, rubricada "de las estafas". El Proyecto sin embargo presenta una errata en este punto, pues dice que se introduce un nuevo art. 252 bis, cuando en realidad lo que se introduce en un nuevo art. 251 bis, ya que el antiguo pasa a ser el 251 ter CP. El art. $252 \mathrm{CP}$ que regula la apropiación indebida no guarda relación con los anteriores preceptos, por lo que creo que no se trata más que de un error de redacción.

El apartado centésimo octogésimo quinto del art. único del Proyecto, introduce un nuevo art. 304 bis $\mathrm{CP}$, por el que se permite que a los condenados por haber cometido uno o más delitos de los previstos en el Capítulo XIV, del Título XIII, del Libro II CP, cuya rúbrica es "de la receptación y el blanqueo de capitales", se les podrá imponer además una medida de libertad vigilada, siempre que se den el resto de requisitos exigidos en el Código.

El apartado centésimo octogésimo noveno del art. único del Proyecto, modifica el art. 318 bis CP, relativo a los delitos contra los derechos de los ciudadanos extranjeros, y añade un apartado 7 por el que se posibilita que, además de las penas que correspondan, pueda imponerse la libertad vigilada en todos los supuestos comprendidos en el art. 318 bis $\mathrm{CP}$, entendiendo que deberán concurrir el resto de requisitos exigidos en el Código.

El aparado centésimo nonagésimo séptimo del art. único del Proyecto, introduce un nuevo Capítulo VI en el Título XVII, del Libro II CP que consta de un nuevo art. 385 quáter, que bajo la rúbrica de "disposición común" consiste en que a los condenados por los delitos comprendidos en todo el Título XVII, rubricado "de los delitos contra la seguridad colectiva", se les podrá imponer, además de las penas que correspondan, la libertad vigilada si concurren los demás requisitos para ello. 
Por último, el apartado ducentésimo trigésimo séptimo del art. único del Proyecto, introduce un nuevo Capítulo VIII en el Título XXII, del Libro II CP, que consta de un nuevo art. 580 bis CP, bajo la rúbrica "disposición común", que consiste en que a los condenados por la comisión de uno o más delitos de los previstos en el Título XXII, que es el dedicado a los "delitos contra el orden público", se podrá imponer, además de la pena que corresponda, una medida de seguridad de libertad vigilada, si concurren los demás requisitos para ello.

\section{LOS INFORMES CONSULTIVOS}

En este apartado se analizan los informes consultivos del CGPJ, del Consejo Fiscal y el dictamen del Consejo de Estado. Antes de entrar en el análisis de cada uno de ellos, conviene precisar que las consultas que se realizaron al CGPJ, al Consejo Fiscal y al Consejo de Estado, versaron sobre el anterior Anteproyecto, el de 11 octubre de 2012, donde dichos organismos manifestaron diversas críticas al conjunto de la reforma proyectada, incidiendo especialmente en la inclusión de la custodia de seguridad postpenitenciaria que seguía el modelo alemán. Lo curioso es que el Proyecto que finalmente se ha publicado para someterlo a debate parlamentario, ya no contiene esa medida de seguridad y muchos otros aspectos han sido modificados, por lo que, el Proyecto presentado es distinto del sometido a consulta y muchas de las supresiones o modificaciones son producto de haber atendido, al menos en parte, a las indicaciones o críticas sobre las regulaciones proyectadas.

\section{a) El informe del Consejo General del Poder Judicial, de 16 de enero de 2013}

El informe se muestra muy crítico con la formulación conjunta de las medidas de seguridad, diciendo que se trata de "una regulación de la materia poco satisfactoria y demasiado inconcreta e indeterminada, abre la puerta a la instauración de medidas indeterminadas por tiempo indeterminado, pese a una apariencia formal de determinación"1518. También denuncia el informe la ausencia de un procedimiento de revisión de las medidas de seguridad y la inexistencia de un derecho de ejecución de las mismas ${ }^{1519}$. Critica

\footnotetext{
1518 Vid. Informe CGPJ, pág. 112.

1519 Vid. Informe CGPJ, págs. 112 y 113. Dice el informe que "la regla de proporcionalidad que contiene el hoy vigente art. $6.2 \mathrm{CP}$ atiende al hecho cometido y establece que las medidas no pueden ser más gravosas ni tener
} 
abiertamente la imprecisión de la regulación que aparece excesivamente abierta y que atenta de ese modo contra el principio de legalidad. Además señala la que previsión del art. 95.1 CP, en su apartado 3 que exige como presupuesto legitimador de las medidas de seguridad que su imposición resulte necesaria para compensar, aunque sea en parte, la peligrosidad del sujeto, expresión que contraviene el principio de subsidiariedad porque la medida de seguridad solo debe imponerse cuando sea absolutamente necesaria, no como compensación total o parcial de algo ${ }^{1520}$. También critica el informe que a los efectos de cuál es la medida de seguridad concreta que quepa imponer, desaparece "el límite de la no onerosidad respecto de la pena que en abstracto se pudiera imponer al hecho", debido a que el 95.2 proyectado dispone que la medida de seguridad deberá ser proporcional a la gravedad del delito y a la de los que se prevea que puede cometer, y también se atenderá a la peligrosidad del sujeto ${ }^{1521}$.

A mayor abundamiento, el informe formula una observación de enorme relevancia en lo referente al sistema vicarial, al que da por finiquitado con esta nueva regulación, quedando solo a salvo las medidas de internamiento en centro psiquiátrico, centro de educación especial o de deshabituación, que sí mantienen un tratamiento vicarial con matices, ya que la vicarialidad es parcial, puesto que el nuevo art. 102.1 CP contiene un inciso final que pone un límite temporal de abono de la medida de seguridad a la pena,

más duración que la pena abstracta por el hecho cometido. Estos límites tienen especial repercusión en las medidas de internamiento, tanto respecto al presupuesto exigido para su adopción, teniendo que ser un hecho típico antijurídico castigado con pena privativa de libertad; como con su duración temporal, que puede ser mayor que el de la pena aplicable al hecho cometido. Ciertamente este artículo suscitó muchas críticas doctrinales, que reclamaban que la proporcionalidad en las medidas se vinculara a la peligrosidad del sujeto y a la gravedad de los delitos que se estima pudiera cometer en el futuro, al ser más respetuoso con el concepto, fundamento y fines de las medidas de seguridad. Es verdad también que el Tribunal Constitucional en Sentencia del Pleno 24/1993, de 21 de enero de 1993, se pronunció a favor de la constitucionalidad de medidas de seguridad de duración indeterminada, pero -añadía- siempre que existan controles sucesivos que permitan valorar su necesidad actual. Y es en este punto donde el anteproyecto hace una regulación imprecisa, inconcreta y vaga, a la vez que suprime el procedimiento para la revisión de la regulación actual, no estableciendo uno alternativo, en el que se dé audiencia al sujeto a la medida y a su letrado, con plenas garantías de audiencia y contradicción. A lo que se añade la falta de previsión de la necesidad de informes periódicos sobre la peligrosidad y la evolución del sometido a la medida, como sí existen en el Derecho Francés. Esta indeterminación del sistema de control y revisión de la medida de seguridad de duración indeterminada y que se presenta, a priori, como indefinida por la vía de las prórrogas ilimitadas que se establecen, ofrece un resultado poco satisfactorio y adecuado a las garantías de inherentes a todo Estado de Derecho y a los principios de seguridad y de legalidad, con la garantía de determinación de la sanción penal que el mismo implica".

1520 Vid. Informe CGPJ, pág. 120.

1521 Vid. Informe CGPJ, pág. 121. 
que se fija en las tres cuartas partes de duración de la misma, quedando una cuarta parte que necesariamente se tendrá que cumplir, a no ser que se suspenda su ejecución1522.

En relación a la libertad vigilada tras la pena de prisión, el informe señala que se van a generar multitud de problemas en la aplicación conjunta de libertad vigilada y suspensión de la pena de prisión o libertad condicional, porque la regla del art. 106.4 CP carece de la claridad necesaria para ello, pues el criterio que aparece al final del precepto que dispone que en estos casos el plazo de duración de la libertad vigilada no será inferior al tiempo fijado para la suspensión de la pena ex art. $81 \mathrm{CP}$, en principio parece que implica una suerte de cumplimiento simultáneo de la suspensión de pena suspendida o en libertad condicional y libertad vigilada, pero no terminan de quedar despejadas todas las dudas de interpretación ${ }^{1523}$. Sobre la ampliación del elenco de delitos a los que pretende aplicarse la libertad vigilada postpenitenciaria, el informe parte de la inexplicabilidad del criterio seguido por el legislador para su elección y que llama la atención que delitos más graves como la tortura, hayan quedado fuera del catálogo ${ }^{1524}$.

No obstante, hay una cuestión que el informe acoge favorablemente, y es la supresión de la imposición obligatoria de la libertad vigilada para determinados delitos como aparecía en la LO 5/2010 - que solo permitía la imposición facultativa en caso de delincuentes primarios-, de modo que en la regulación proyectada, se utiliza en la parte especial la fórmula "se podrá imponer", aunque el art. 104.1 y 2 CP utiliza la expresión “impondrán", pero para que la libertad vigilada pueda ser impuesta a una persona imputable condenada por delitos que contemplen como consecuencia jurídica expresa la libertad vigilada, además deberá haberse impuesto una pena superior a un año de prisión, contar con pronóstico de peligrosidad y que además se valore la medida como necesaria. El único caso de imposición preceptiva es cuando se suspenda una medida de seguridad privativa de libertad ${ }^{1525}$.

\footnotetext{
1522 Vid. Informe CGPJ, pág. 121.

1523 Vid. Informe CGPJ, pág. 122.

1524 Vid. Informe CGPJ, pág. 136.

1525 Vid. Informe CGPJ, págs. 136 y 137. “De manera que pese a estarse ante un delito que tenga prevista la libertad vigilada, el Juez o Tribunal podrá no imponerla si entiende que el sujeto no es peligroso o que la libertad vigilada no se presenta como necesaria para compensar tal peligrosidad. Lo mismo, cuando se trate de una libertad vigilada impuesta a un inimputable absuelto por alguna de las eximentes del art. $20.1^{\circ}, 2^{\circ}$ y $3^{\circ}$ $\mathrm{CP}$, o cuando se imponga a consecuencia del cumplimiento del plazo máximo de duración de otra medida de seguridad privativa de libertad impuesta. Únicamente en el caso de suspensión de una medida de seguridad privativa de libertad, la libertad vigilada resulta de imperativa imposición".
} 
Por otra parte, el informe se muestra especialmente crítico con la supresión de la definición legal de libertad vigilada, que califica como "censurable al atentar contra el principio de legalidad y de seguridad de las sanciones penales, cuyo concepto y contornos han de estar debidamente determinados en la Ley penal". Del mismo modo critica el informe que la regulación proyectada no contiene referencia alguna a si la libertad vigilada se impone en sentencia y se deja la concreción del contenido para la fase de ejecución, aspecto que, al no aparecer concretado, podría dar lugar a problemas de interpretación e imponerse ex novo tras la pena de prisión ${ }^{1526}$.

Por lo que se refiere a la ampliación del contenido de la libertad vigilada, el informe se muestra escéptico con algunas de las obligaciones y condiciones proyectadas, como la inscripción en las oficinas de empleo, cuyo efecto rehabilitador se presenta como de dudosa virtualidad, sobre todo porque la regla se limita a exigir la inscripción, sin llegar a extenderse hacia la eventual realización de cursos de formación o la aceptación de un trabajo si se le presenta, y advierte que, en estos casos, sería necesario el consentimiento del sometido a la medida1527.

Sobre la prohibición de consumo de alcohol o drogas y la obligación de someterse a controles de consumo de esas sustancias, el informe señala que se trata de un medida que implica "una grave injerencia en la libre determinación del sometido a la misma; considerando que sin su previo consentimiento no puede serle impuesta, pues en todo caso sería ineficaz". También indica el informe que para el tratamiento de deshabituación o tratamiento médico, será necesario el consentimiento que exige la interpretación sistemática de la norma con la Ley 41/2002 de autonomía del paciente. Especialmente crítico se muestra el informe con la eliminación de la previsión expresa que realizó la LO 5/2010, en relación a que el incumplimiento del tratamiento médico o su abandono, no será considerado quebrantamiento de condena, situación que puede plantear problemas que desembocarían en que las personas se sometan a tratamientos médicos con el consentimiento viciado solo por temor a las consecuencias del incumplimiento o de su negativa a someterse, que podrían desembocar en un nuevo delito de quebrantamiento, aspecto que, según el informe, "supone una intrusión inaceptable en los derechos personales del

\footnotetext{
1526 Vid. Informe CGPJ, págs. 137 y 138.

1527 Vid. Informe CGPJ, pág. 138.
} 
penado, viniendo a suponer de facto la imposición de un tratamiento médico, psicológico, psiquiátrico o de deshabituación forzoso, contrario a la Constitución"1528.

El informe también se muestra crítico con la previsión del quebrantamiento de condena para el supuesto de la obligación de llevar consigo y mantener en funcionamiento los dispositivos electrónicos, por cuanto que, por una parte se produce un quebrantamiento con posibilidad de imposición de nuevas sanciones, y por otra parte se propicia que la libertad vigilada puede prorrogarse, lo cual supone, a juicio de CGPJ, una doble punición de la misma conducta. Y, por último, en cuanto al plazo de duración de la libertad vigilada, el informe critica que se hayan eliminado los límites de de 5 a 10 años para penas graves y de 1 a 5 años para las menos graves, por cuanto que el plazo que introduce el Proyecto es de un mínimo de 3 y un máximo de 5 años, pero no es un límite absoluto, sino que permite prórrogas sucesivas por iguales periodos sin límite alguno, lo que fácticamente "podría llevar a una libertad vigilada de por vida, lo que resulta inaceptable en cuanto se opone al mandato del art. 25 CE"1529.

No obstante, los vocales del CGPJ Antonio Dorado Picón y Concepción Espejel Jorquera, formularon un voto particular al informe del Pleno del CGPJ, al que se adhirieron los vocales Fernando de Rosa Torner y Claro José Fernández-Carnicero, en el que expresaron su discrepancia con el informe manifestado diciendo que no concurre ningún obstáculo de constitucionalidad en la pretendida reforma de las medidas de seguridad y que el informe incurre en el defecto de elevar a la categoría de reparo técnico jurídico lo que solo son reservas doctrinales de quienes lo suscriben, ya que dichas objeciones olvidan la distinta naturaleza de las penas y las medidas, por lo que la previsión no vulnera el principio de ne bis in idem. También afirma que las referencias al Derecho comparado son parciales, que contienen una lectura interesada de las resoluciones del TC alemán y que solo se cita la sentencia del TEDH que refiere únicamente a ciertos aspectos - no a todos- de la regulación alemana, cuando la custodia de seguridad está vigente en muchos más países, por lo que ninguna de las objeciones puestas de manifiesto por el TEDH concurren en la regulación proyectada, de lo que se desprende -dice el voto- un "carácter voluntarista y parcial del informe". Además, se indica en el voto particular que no se comparte la afirmación del informe del Pleno en relación

\footnotetext{
1528 Vid. Informe CGPJ, pág. 139.

1529 Vid. Informe CGPJ, pág. 140.
} 
que se establece un sistema de medidas de seguridad de duración indeterminada y no previsible, que carece de mecanismos de control ciertos y claros, porque el art. $103 \mathrm{CP}$ contempla un sistema de revisión periódica de las medidas de seguridad, con periodicidades máximas fijadas normativamente, y la posibilidad de que el órgano jurisdiccional fije un plazo de revisión inferior y, excepcionalmente, podrá fijarse dentro de los límites máximos, un período de tiempo dentro del cual no se dé curso a las peticiones.

También formuló un voto particular la vocal del CGPJ Gemma Gallego, diciendo que el sentido del informe del Pleno responde a una indebida utilización de ciertos aforismos y términos jurídicos, ya que la pena se basa en la culpabilidad y la medida en la peligrosidad, por lo que los límites de la medida son ajenos a la duración de la pena. Además refiere a que el Pleno proporciona información sesgada en las referencias al TEDH, y destaca la improcedencia de la cita de la STC 21/1987, que no prohíbe que por un mismo hecho pueda imponerse pena y medida de seguridad ${ }^{1530}$. No obstante, concuerda con el pleno en que hay aspectos necesitados de mejora técnica, claridad y precisión que permitan su correcta aplicación por los órganos jurisdiccionales.

\section{b) El informe del Consejo Fiscal, de 20 de diciembre de 2012}

El informe contiene varias observaciones al sistema de medidas de seguridad proyectado, comenzando por la modificación del art. $6.2 \mathrm{CP}$, que elimina el límite máximo de cumplimiento de la medida de seguridad, que ya no guarda relación con la pena que correspondería si el sujeto fuera declarado culpable. Incide en que no se menciona en el Proyecto la prohibición de no aplicar medidas de seguridad cuando el delito no esté castigado con pena privativa de libertad ${ }^{1531}$, por lo que los principios de onerosidad y duración de las medidas de seguridad quedan desterrados del Proyecto ${ }^{1532}$.

\footnotetext{
1530 El voto particular incide en que en el informe han primado las valoraciones subjetivas sobre la emisión de un análisis imparcial de los aspectos concretos de la custodia de seguridad, lo que ha impedido enfatizar en su contenido restándole eficacia técnica.

1531 Vid. Informe del Consejo Fiscal, pág. 89. “Tal prohibición se suprime en el Anteproyecto, posibilitando así la imposición de una medida de seguridad privativa de libertad aunque el sujeto no fuera condenado a una pena de tal naturaleza. Debe estimarse ello congruente con los principios que inspiran la proyectada reforma. En efecto, como se ha apuntado, el supuesto de hecho de la medida de seguridad es la peligrosidad criminal y se orienta al futuro, por lo que ni la duración ni la clase de pena impuesta pueden condicionar el que la medida no pueda alcanzar su fin. No obstante, este principio queda matizado [...] al imponer al Juez o Tribunal la aplicación, dentro del abanico de medidas adecuadas, la menos grave".
}

1532 Vid. Informe del Consejo Fiscal, págs. 9 y 10. 
Concretamente respecto a la duración de las medidas de seguridad, el informe aduce que cuando se imponen límites temporales a las mismas, se está confundiendo los fundamentos de ambas sanciones penales, y que dichas limitaciones puede suponer obstáculos importantes para el buen fin de los tratamientos rehabilitadores que ofrecen las medidas de seguridad, en especial en los supuestos de criminales contumaces. Justifica, pues, que puedan imponerse medidas de seguridad tras la pena cuya duración sea exclusivamente proporcionada a la peligrosidad criminal sin sujeción al hecho ni a la pena que se le asocia1533. No obstante, incide en que la peligrosidad no puede presumirse, sino que ha de estar probada1534.

Sobre la redacción proyectada del art. $95 \mathrm{CP}$, el informe indica que no varían los presupuestos de postdelictualidad y peligrosidad como fundamentos de las medidas de seguridad, pero sí efectúa una observación en relación al apartado 3 del art. 95 CP, que "formula un desiderátum, en cuanto a que la medida de seguridad debe ser necesaria para contrarrestar siquiera de una manera parcial la peligrosidad del sujeto". Sobre este aspecto explica el informe que será esencial el papel del órgano jurisdiccional en punto a la valoración de la clase y duración de la medida que quepa imponer, teniendo en cuenta que el Proyecto también señala que deberá imponerse la medida que resulte menos grave o incluso imponerse varias cuando sea necesario para prevenir la peligrosidad. Sigue diciendo el informe que el principio de proporcionalidad de la medida que se enlaza con la gravedad del delito cometido y de los que se espere que pueda cometer en el futuro, plantea cierta confusión porque si la medida se orienta hacia la prevención especial para la evitación de nuevos delitos, carece de sentido que el delito ya cometido se configure como un condicionante para la aplicación de la medida.

En opinión del Consejo Fiscal, la medida de seguridad deberá ser proporcionada a la gravedad de las infracciones penales que se prevea que puede cometer en el futuro, no de las ya cometidas, cohonestando así el fundamento de la imposición de las medidas que se traduce en la existencia de peligrosidad ${ }^{1535}$. No obstante, considera el informe que la fórmula por la que opta el legislador sobre que la medida de seguridad será

\footnotetext{
1533 Vid. Informe del Consejo Fiscal, pág. 10. “Las SSTC n 112/1998, de 8 de junio y 24/1993, de 21 de enero, refiriéndose a la regulación anterior al Código Penal de 1995, vienen a avalar la constitucionalidad de la duración de las medidas de seguridad conforme a la peligrosidad del sujeto".

1534 Vid. Informe del Consejo Fiscal, pág. 11.

1535 Vid. Informe del Consejo Fiscal, pág. 88.
} 
proporcionada a la gravedad del delito cometido y de los que espere que pueda cometer, y a la peligrosidad, es correcta, con las matizaciones señaladas ${ }^{1536}$. Por lo demás, se muestra conforme el Consejo Fiscal con la consolidación de sistema dualista, iniciado con la LO 5/2010 y que ahora se consolida1537.

En cuanto a la libertad vigilada, el informe destaca positivamente que haya desaparecido la imposición obligatoria para dar paso a su imposición facultativa en los casos en que esté prevista legalmente para su ejecución postpenitenciaria ${ }^{1538}$. No obstante critica algunos de los nuevos contenidos de la libertad vigilada como la cláusula abierta que permite la imposición de otras obligaciones y condiciones distintas de las relacionadas en el catálogo, previsión que considera "extremadamente vaga" y de difícil armonización con el principio de legalidad ${ }^{1539}$. También considera improcedente la regla consistente en la inscripción en las oficinas de empleo, y la regla relativa a los aparatos electrónicos, que queda circunscrita a los delitos del art. 57, el informe critica el reducido abanico de aplicación de esta medida, porque podría ampliarse a otros delitos cometidos con violencia o intimidación ${ }^{1540}$.

El informe asume que la libertad vigilada, a pesar de sus plazos de duración, puede prorrogarse de forma indefinida. Al respecto manifiesta que la STC 112/1988, de 8 de junio, referida a la medida de internamiento y concluye que el establecimiento de unos plazos rigurosos en las medidas de seguridad pueden ser un obstáculo para el éxito del tratamiento. "De ahí que la fijación de un plazo principal y un sistema de prórrogas como el que se prevé resulte acertado"1541. Además, invoca el Derecho comparado para justificar la validez de este criterio, como el caso del seguimiento socio-judicial de Francia, el caso de Italia y el de Alemania1542. También refiere el informe a que las referencias que contiene el texto a los incumplimientos, que en el Anteproyecto eran "relevantes" y en el Proyecto son "graves", debería ser sustituida por incumplimientos "reiterados"1543. Y también señala

\footnotetext{
1536 Vid. Informe del Consejo Fiscal, pág. 90.

1537 Vid. Informe del Consejo Fiscal, págs. 94 y 95.

1538 Vid. Informe del Consejo Fiscal, pág. 104.

1539 Vid. Informe del Consejo Fiscal, pág. 105.

1540 Vid. Informe del Consejo Fiscal, pág. 106.

1541 Vid. Informe del Consejo Fiscal, págs. 106 y 107.

1542 Vid. Informe del Consejo Fiscal, págs. 108 y 109.

1543 Vid. Informe del Consejo Fiscal, págs. 110.
} 
que en el art. $106 \mathrm{CP}$ deberían delimitarse los contornos del delito de quebrantamiento del art. $468 \mathrm{CP}$ y exigirse que el incumplimiento sea incumplimiento reiterado, grave y revelador del propósito de no someterse a la libertad vigilada para que exista el delito de quebrantamiento de la medida. Por último, el informe indica que se tendría que concretar qué Juez o Tribunal debe refundir las medidas de libertad vigilada cuando se hayan impuesto varias para cumplir una sola, ya que no se determina este extremo. En cualquier caso el Consejo Fiscal considera que debe ser último Tribunal sentenciador ${ }^{1544}$.

\section{c) El dictamen del Consejo de Estado, de 27 de junio de 2013}

Explica el dictamen ${ }^{1545}$ que en relación a las dudas constitucionales que puede plantear el sistema de medidas de seguridad proyectado, sobre todo en lo referente a la duración total resultante de la acumulación de penas largas de prisión con libertad vigilada posterior, al respecto, el Consejo se limita a invocar lo que ya dijo en su dictamen de 29 de octubre de 2009, y con cita del fundamento jurídico 23 de la STC 136/1999, dice: “el Tribunal Constitucional ha señalado que el juicio de proporcionalidad en materia penal, respecto a la cantidad y calidad de la pena en relación con el tipo de comportamiento incriminado, debe partir de "la potestad exclusiva del legislador para configurar los bienes penalmente protegidos, los comportamientos penalmente reprensibles, el tipo y la cuantía de las sanciones penales, y la proporción entre las conductas que pretende evitar y las penas con las que intenta conseguirlo". En el ejercicio de dicha potestad el legislador goza, dentro de los límites establecidos en la Constitución, de un amplio margen de libertad que deriva de su posición constitucional y, en última instancia, de su específica legitimidad democrática, por lo que "la relación de proporción que deba guardar un comportamiento penalmente típico con la sanción que se le asigna será el fruto de un complejo juicio de oportunidad", y para el que "ha de atender no solo al fin esencial y directo de protección al que responde la norma, sino también a otros fines legítimos que pueda perseguir con la pena".

El dictamen contiene también algunas observaciones de contenido técnico programático y aconseja adaptar la estructura a las mismas para dotarlo de coherencia, la gran mayoría han sido observadas y en el Proyecto de 2013 ya no aparecen, evidenciando

\footnotetext{
1544 Vid. Informe del Consejo Fiscal, págs. 111.

1545 El texto completo en: [https://wwww.boe.es/buscar/doc.php?id=CE-D-2013-358]. (Consultado el 26-4-2014).
} 
que se ha atendido a las recomendaciones, al menos a las de forma ${ }^{1546}$. Sobre la ampliación de los supuestos a los que es aplicable la libertad vigilada, el dictamen dice que la LO 5/2010 desbordó los presupuestos que limitaban la aplicación de las medidas de seguridad inimputables y semiimputables, y en el ámbito de los delitos de terrorismo y contra la libertad e indemnidad sexuales tuvo su "campo de pruebas", siendo que ahora se extiende la aplicación, aspecto al que el Consejo "no tiene, en línea de principio, nada que objetar". Por otra parte cuestiona los criterios por los que se han elegido esos delitos y no otros, resaltando que la memoria que se acompaña al proyecto no justifica suficientemente la elección. En este punto el dictamen trae a colación las palabras literales del informe del CGPJ (analizado supra), sobre que otros crímenes como la tortura no se contemplen y sí algunos de maltrato en el ámbito familiar.

El Consejo de Estado valora de forma positiva la desaparición de la imposición preceptiva de la libertad vigilada postpenitenciaria, aduciendo que la decisión es acorde con la peligrosidad como fundamento de las medidas y no la gravedad del delito cometido, pero no se muestra favorable con que se mantenga un régimen excepcional con los terroristas donde se mantiene la imposición preceptiva de la libertad vigilada salvo que se trate de primarios, añadiendo que se echa en falta una explicación detallada de los motivos de tal distinción.

En cuanto al contenido de la medida de libertad vigilada, el Consejo se muestra sorprendido por la desaparición de la definición de la medida, lo cual dificulta un mayor respeto por el principio de legalidad y dificulta su comprensión. Pero se pronuncia a favor de varios aspectos como la decisión de la concreción de las medidas que deberá hacerse al menos dos meses antes de la extinción de la pena de prisión, etc., porque permite individualizar las obligaciones y prohibiciones en atención a las circunstancias concurrentes en el sujeto en el momento de empezar a cumplir la libertad vigilada, que no tienen por qué ser las mismas que se advirtieron en el momento de la sentencia.

\footnotetext{
1546 Dice el dictamen: “el Anteproyecto, que introduce modificaciones en todos estos artículos y crea tres artículos nuevos (103 bis, 104 bis y 104 ter), rompe con la referida estructura del Título IV, pues las reglas sobre aplicación de las medidas privativas de libertad (internamiento en centro psiquiátrico, educativo especial y de deshabituación) quedan en los artículos 98, 99 y 100, integrados en el Capítulo I, cuando deberían estar en el Capítulo II, y la regulación de la mayor parte de la libertad vigilada (apartados 103 bis, 104, 104 bis y 104 ter) se encontraría en principio en la Sección $1^{a}$ del Capítulo II, pese a tratarse de una medida no privativa de libertad. Resulta indispensable, en consecuencia, realizar en el Anteproyecto las correspondientes adaptaciones de la estructura del Título IV, para que este refleje adecuadamente el contenido de cada una de sus divisiones".
} 


\section{CONCLUSIONES}

1. Del análisis efectuado en el presente estudio, se desprende que la libertad vigilada sigue siendo una figura discutible, por lo que, para poder aplicarla, su interpretación deberá ser lo más restrictiva posible. Partiendo de que no aparece definición en el CP, dificultando su aplicación desde la legalidad misma, merece valoración positiva que se haya optado por la formulación de la libertad vigilada como medida de seguridad, frente a los distintos intentos de regularla como pena accesoria, privativa de derechos, etc. La libertad vigilada como una medida más de seguridad aplicable con carácter general a supuestos de peligrosidad en el sujeto que venga determinada por la comisión de un previo delito y por la concurrencia de una o varias causas de inimputabilidad o semiimputabilidad es perfectamente válida, legítima y además se advierte un gran porcentaje de éxito en su aplicación práctica, por lo que este aspecto merece, a mi juicio, una valoración positiva sobre el conjunto de su regulación en la reforma del $\mathrm{CP}$, y más por el hecho de que bajo la libertad vigilada se refunden en una sola muchas otras medidas de seguridad que desaparecen así del catálogo del Código.

2. En la libertad vigilada postpenitenciaria plantea un problema importante el incierto juicio de pronóstico sobre la probabilidad de delinquir en el futuro, que se asienta sobre criterios poco fiables, sobre todo teniendo en cuenta que el pronóstico de peligrosidad. La presunción iuris tantum de peligrosidad, no es del todo armónica con un ámbito, el penal, en el que no puede tener cabida las presunciones más allá de la de inocencia. Esta presunción provoca que la libertad vigilada gravite sobre el binomio culpabilidad-pasado (como en las penas) y no en el de peligrosidad-futuro (como en el resto de medidas de seguridad).

3. La libertad vigilada para imputables se apresura en exceso en aventurar la peligrosidad postpenitenciaria, que solo podrá saberse si subsiste el mal pronóstico tras el cumplimiento de la pena en prisión.

4. La presunción de peligrosidad para imputables que cometen delitos contra la libertad e indemnidad sexuales y de terrorismo, es una manifestación del Derecho penal de autor (del enemigo) que se aleja de los principios de igualdad, proporcionalidad, seguridad jurídica y prohibición de exceso, y se apoya en el Derecho penal de la seguridad. 
5. La imposición de la pena privativa de libertad más la libertad vigilada, plantea un problema de compatibilidad entre la suspensión de la pena y el cumplimiento de la medida de seguridad, que se traduce en que, en los delitos graves no es posible la suspensión salvo los supuestos del art. $87 \mathrm{CP}$, pero en los delitos menos graves en los que sí es posible la suspensión de la pena, no termina de resolverse la duda en torno a si puede aplicarse igualmente la libertad vigilada cuando termine el período de suspensión acordado, teniendo en cuenta que podría existir una incompatibilidad entre suspensión de la pena y persistencia de la peligrosidad en la que se fundamenta la medida de seguridad.

6. El éxito de la libertad vigilada dependerá del esfuerzo económico que se haga para ponerla en funcionamiento, dotando de medios personales y materiales apropiados a los contenidos de la medida de seguridad, que, obviamente, son de elevado coste.

7. Se necesita la figura del agente de vigilancia en la ejecución de la libertad vigilada, tal y como se ha puesto también de manifiesto en la Recomendación CM/Rec (2010) 1 del Comité de Ministros (adopatada el 20 de enero de 2010 en la reunión 1075 de delegados de Ministros), a los Estados miembros sobre la Reglas del Consejo de Europa relativas a la probation.

8. En relación al contenido de las obligaciones y prohibiciones que quepa adoptar para la concreción de la medida de seguridad, se hace necesario un criterio unificado que implique optar preferentemente por imponer obligaciones y prohibiciones de naturaleza correctiva antes que de naturaleza asegurativa. Además, se hace necesario reforzar los tratamientos de reinserción durante la ejecución de la pena y no renunciar a ellos defiriéndolos a la ejecución de la libertad vigilada posterior.

9. Se hace necesario dotar al sistema de libertad vigilada postpenitenciaria, de criterios sólidos basados en estudios criminológicos para individualizar la medida atendiendo a la enorme variedad de delitos a los que se aplica, reforzando su contenido para la desaparición de la peligrosidad mediante la concreción de obligaciones y prohibiciones que sean apropiadas. Las distintas tipologías delictivas requieren que se adapte la libertad vigilada a su realidad criminológica. 
10. Con la libertad condicional, la libertad vigilada para imputables no es incompatible con la libertad condicional, es decir, que un sujeto (de los de esta categoría) condenado a una pena privativa de libertad y también sometido a libertad vigilada (impuesta en la sentencia), puede gozar igualmente del estadio de la libertad condicional. Pero el inconveniente del acceso a la libertad condicional por contar con pronóstico favorable de reinserción, colisiona con la existencia de peligrosidad criminal que justifica la libertad vigilada. Además, si se accede a la libertad condicional y posteriormente se ejecuta la libertad vigilada, puede incurrirse en un efecto contrario a la progresividad del sistema penitenciario, con resultados perjudiciales para la reinserción. Las soluciones que se proponen son las siguientes:

a) Debe dejarse sin efecto la medida de seguridad de libertad vigilada contando únicamente con el pronóstico favorable de reinserción exigido para la libertad condicional, esto es, la necesaria extinción de la medida de seguridad si previamente hay acceso a la libertad condicional.

b) Reducir la aplicación de la libertad vigilada a aquellos supuestos en los que el penado no haya tenido acceso a la libertad condicional por inexistencia de pronóstico favorable de reinserción y, por tanto, no pudiendo prolongar más tiempo su condena por exigencias del principio de legalidad estaría justificado el cumplimiento de la medida para neutralizar la peligrosidad persistente.

c) Configurar la libertad vigilada como forma sustitutiva de la libertad condicional, permitiendo que dé paso a la medida de seguridad sin que ello suponga la imposición de la medida tras la pena cumplida en su integridad. Sería posible regular el cumplimiento simultáneo de la libertad condicional (o incluso del tercer grado) con la libertad vigilada que, posteriormente, se podría prolongar si fuera necesario. Se trataría de imponer la libertad vigilada en la sentencia, pero su cumplimiento empezaría con la progresión al tercer grado o a la libertad condicional, y se activarían o no los deberes para su concreción dependiendo del pronóstico penitenciario, al igual que se dejaría sin efecto si desaparece la peligrosidad, salvando así las objeciones que comporta la actual formulación que no solo presume la peligrosidad, sino también el fracaso de la pena de prisión. 
11. En el supuesto de los extranjeros, en relación a la posibilidad de que la libertad condicional pueda disfrutarse en el país de origen, en los supuestos en que está pendiente de cumplirse la libertad vigilada posterior a la pena, debe concederse igualmente la posibilidad de cumplir la libertad condicional y la libertad vigilada en el país de origen, aunque faltaría una previsión al respecto.

12. La libertad vigilada cuando se acuerda la libertad condicional en supuestos especiales, como enfermos terminales o septuagenarios, deberá dejarse sin efecto, si es que finalmente se extingue la pena y debe empezar a cumplirse la libertad vigilada. Aplicarla tras la pena, en caso de que todavía les resten años de vida, es incoherente con la finalidad de la medida y con el régimen especial de libertad condicional que se les aplica.

13. Sobre el Proyecto de reforma del CP, de 23 de abril de 2013, las conclusiones son las siguientes:

a) El dualismo que propugna el Proyecto permite la extensión de las medidas de seguridad sin límite alguno, por lo que considero mejor el sistema actual que el proyectado, para evitar los excesos en la restricción en la esfera de las libertades y para que la proporcionalidad pueda medirse en parámetros divisables y no excesivamente abstractos como la proyectada proporción a la peligrosidad, magnitud difícilmente cuantificable.

b) Si bien la prisión permanente revisable es una pena indeterminada con plazos de revisión, en las medidas de seguridad se produce el efecto inverso: son medidas con plazos determinados pero, a su vez, son prorrogables de forma indeterminada hasta la muerte del sometido a las mismas sin necesidad de internamiento civil ni de incapacitación.

c) El elenco de delitos a los que se pretende aplicar es muy amplio y no termina de estar justificada la elección de esos delitos y no otros. Además, dentro de ellos, las tipologías de los delitos son muy amplias y no hay concreción sobre a cuáles debe aplicarse, sin tener en cuenta que no todos ellos son idóneos para la libertad vigilada 
como medida para la desaparición de la peligrosidad, ni tampoco todos los contenidos de la medida pueden ser apropiados.

d) Se elimina también la audiencia a la víctima para las decisiones sobre la medida, aspecto que evidencia que nada puede aportar para tomar las decisiones en que la libertad vigilada se funda, que no son otras que la peligrosidad criminal, aspecto totalmente ajeno a la víctima.

e) Se trata de una medida de seguridad cuyas obligaciones y condiciones están dotadas de escaso contenido rehabilitador, por lo que prima su carácter de medida de control, vigilancia e inocuización, que parece servir más a fines de prevención especial negativa y de prevención general negativa.

f) Deberían coexistir los nuevos métodos de determinación de la peligrosidad con estudios de las tipologías delictivas y ceñir el margen de aplicación a los que realmente requieran la libertad vigilada postpenitenciaria.

g) Sigue sin estar justificado el automatismo con el que se aplica en los delitos de terrorismo y más aún cuando ahora se conforma - una vez más- como un régimen excepcional -cuyo mantenimiento tampoco queda justificado-, porque es el único supuesto de imposición preceptiva en su modalidad postpenitenciaria.

h) En definitiva, la reforma proyectada empeora sensiblemente la regulación conferida mediante la LO 5/2010, por lo que sería conveniente que la reforma mantuviera la regulación de la libertad vigilada con las observaciones realizadas en esta tesis. 
La libertad vigilada necesita una reforma para solucionar todos los problemas de interpretación y de aplicación que se han venido poniendo de manifiesto en este trabajo, porque:

a) Se necesita evitar el retroceso en la progresividad que se puede producir tras el tratamiento de reinserción recibido en cumplimiento de la pena de prisión.

b) Se necesita que la medida de seguridad sirva más a criterios de prevención especial positiva enfocada a la reinserción, que a criterios de prevención especial negativa que se centran en la inocuización. Tampoco deben prevalecer funciones de prevención general positiva o negativa, ya que la peligrosidad criminal que justifica su imposición requiere exclusivamente que se fije la atención en el sujeto peligroso para la desaparición de su peligrosidad criminal en aras de la reinserción social, no en su absoluta inocuización, ni en el efecto que la sanción pueda tener en la generalidad de personas o en el fortalecimiento - o en la confirmación-de la vigencia de la norma.

c) Se necesita que la libertad vigilada se imponga atendiendo a criterios individualizados y constatables de medición y determinación del pronóstico de peligrosidad, alejándose del juego de las presunciones. 
BIBLIOGRAFÍA

ABEL SOUTO, M. / ACALE SÁNCHEZ, M. / TRAPERO BARREALES, M.A. / GONZÁlEZ TASCÓN, M.M. / TERRADILLOS BASOCO, J.M / BOZA MARTÍNEZ, D. / RODRÍGUEZ YAGÜE, C. / GUISASOLA LERMA, C., “Formas sustitutivas de la ejecución de las penas privativas de libertad y libertad condicional”. En ÁLVAREZ GARCÍA, F.J., (Dir.) / DOPICO GÓMEZ-ALLER, J., (Coord.), Estudio crítico sobre el Anteproyecto de Reforma penal de 2012. Valencia: Tirant lo Blanch. 2013.

ACALE SÁNCHEZ, M., “Prisión permanente revisable: Arts. 36 (3 y 4), 70.4, 76.1, 78 bis, 92, 136 y concordantes en la Parte Especial”. En ÁLVAREZ GARCÍA, F.J., (Dir.) / DOPICO GÓMEZ-ALLER, J., (Coord.), Estudio crítico sobre el Anteproyecto de Reforma penal de 2012. Valencia: Tirant lo Blanch. 2013.

ACALE SÁNCHEZ, M., “Nuevos presupuestos para la imposición de medidas de penas y medidas de seguridad". En PÉREZ CEPEDA, A.I. (Dir.) / GORJÓN BARRANCO, M.C., El Proyecto de Reforma del Código penal de 2013 a debate. Salamanca: Ratio Legis. 2014.

ACALE SÁNCHEZ, M. “Medidas de seguridad”. En ÁlVAREZ GARCÍA, F.J., (Dir.) / DOPICO GÓMEZ-ALLER, J., (Coord.), Estudio crítico sobre el Anteproyecto de Reforma penal de 2012. Valencia: Tirant lo Blanch. 2013.

ACALE SÁNCHEZ, M. / MARÍN DE ESPINOSA y CEBALLOS, E.B. / GONZÁLEZ TASCÓN, M.M., "Sistema de penas". En ÁlVAREZ GARCÍA, F.J., (Dir.) / DOPICO GÓMEZ-ALLER, J., (Coord.), Estudio crítico sobre el Anteproyecto de Reforma penal de 2012. Valencia: Tirant lo Blanch. 2013.

ACALE SÁNCHEZ, M. / GÓMEZ LÓPEZ, R. / GALDEANO SANTAMARÍA, A. / PORTERO HENARES, M., “Violencia de género". En ÁlVAREZ GARCÍA, F.J., (Dir.) / DOPICO GÓMEZ-ALLER, J., (Coord.), Estudio crítico sobre el Anteproyecto de Reforma penal de 2012. Valencia: Tirant lo Blanch. 2013.

ACALE SÁNCHEZ, M. / BOZA MARTÍNEZ, D. / COBOS GÓMEZ DE LINARES, M.A. / GARCÍA SEDANO, T., “Trata de seres humanos”. En ÁlVAREZ GARCÍA, F.J., (Dir.) / DOPICO GÓMEZ-ALLER, J., (Coord.), Estudio crítico sobre el Anteproyecto de Reforma penal de 2012. Valencia: Tirant lo Blanch. 2013. 
ACALE SÁNCHEZ, M. / ÁLVAREZ GARCÍA, F.J. / BORJA JIMÉNEZ, E. / DEMETRIO CRESPO, E. / DOPICO GÓMEZ-ALLEZ, J. / EXTEBARRIA ZARRABEITIA, X. / GARCÍA RIVAS, N. / MANSO PORTO, T. / MARAMBIO AVARIA, A. / MUÑOZ CONDE, F. / ORTIZ DE URBINA GIMENO, I. / POZUELO PÉREZ, L. / REBOLLO VARGAS, R. / RODRÍGUEZ HORCAJO, D. / MOLINA BLÁZQUEZ, C., “Custodia de seguridad”. En ÁlVAREZ GARCÍA, F.J., (Dir.) / DOPICO GÓMEZ-ALLER, J., (Coord.), Estudio crítico sobre el Anteproyecto de Reforma penal de 2012. Valencia: Tirant lo Blanch. 2013.

ACALE SÁNCHEZ, M., “Libertad Vigilada”. En ÁLVAREZ GARCÍA, F.J. / GONZÁLEZ CUSSAC, J.L., (Dirs.), Comentarios a la reforma penal de 2010. Valencia: Tirant lo Blanch. 2010.

ACALE SÁNCHEZ, M., “Medición de la respuesta punitiva y Estado de Derecho. Especial referencia al tratamiento penológico del delincuente imputable peligroso". En Revista Aranzadi de Derecho y Proceso Penal, núm. 24. 2010.

ACALE SÁNCHEZ, M. “Medidas de seguridad”. En ÁLVAREZ GARCÍA, F.J., (Dir.) / DOPICO GÓMEZ-ALLER, J., (Coord.), Estudio crítico sobre el Anteproyecto de Reforma penal de 2012. Valencia: Tirant lo Blanch. 2013.

ACALE SÁNCHEZ, M., “Nuevos presupuestos para la imposición de penas y medidas de seguridad”. En PÉREZ CEPEDA, I. (Dir.) / GORJÓN BARRANCO, M.C., (Coord.), El proyecto de reforma del Código Penal de 2013 a debate. Salamanca: Ratio Legis. 2014.

AGUADO LÓPEZ, S., La multirreincidencia y la conversión de faltas en delito: Problemas constitucionales y alternativas político-criminales. Madrid: Iustel. 2008.

AGUADO LÓPEZ, S., en BOIX REIG, J., Derecho penal. Parte especial. Vol. I. Madrid: Iustel. 2010.

AGUADO LÓPEZ, S., “Tratamiento penal del delincuente reincidente peligroso: ¿con medidas de seguridad o en la ejecución de la pena?". En La Ley Penal, núm. 102, 2013.

AGUADO CORREA, T., “Comiso: crónica de una reforma anunciada”. En InDret. Revista para el análisis del Derecho. 1/2014. Barcelona: 2014.

AHARONI, E. / VINCENT, G.M. / HARENSKI, C.L. / CALHOUN, V.D. / SINNOTT-ARMSTRONG, W. / GAZZANIGA, M.S. / KIEHL, K.A., “Neuroprediction of future rearrest”. En PNAS vol. 110, núm. 15, abril 2013.

ALCÁCER GUIRAO, R., Los fines del Derecho penal. Liberalismo y comunitarismo en la justificación de la pena. Buenos Aires: Ad-hoc. 2001. 
ALCÁCER GUIRAO, R., Los fines del Derecho penal. Liberalismo y comunitarismo en la justificación de la pena. Buenos Aires: Ad-hoc. 2001.

ALONSO RIMO, A., “Medidas de seguridad y proporcionalidad con el hecho cometido (a propósito de la peligrosa expansión del Derecho penal de la peligrosidad)". En Estudios Penales y Criminológicos. Vol. XXIX. 2009.

ARMAZA ARMAZA, E.J., El tratamiento penal del delincuente imputable peligroso. Tesis doctoral. Universidad del País Vasco. 2011.

ASENCIO MELLADO, J.M., en ASENCIO MELLADO, J.M. (Coord.), Ley de Enjuiciamiento Civil comentada y con jurisprudencia. Madrid: La Ley. 2013.

ANDRÉS DOMÍNGUEZ, A.C., “Falta de daños”. En ÁLVAREZ GARCÍA, F.J., (Dir.) / DOPICO GÓMEZ-ALLER, J., (Coord.), Estudio crítico sobre el Anteproyecto de Reforma penal de 2012. Valencia: Tirant lo Blanch. 2013.

ANDRÉS PUEYO, A., “El control i el tractament dels delinqüents d'alt risc: la "gestió dels casos"“. I Jornada de Criminologia "Control penal i prevenció del delicte en la societat de la informació". Barcelona: Centre d'Estudis Jurídics i Formació Especialitzada Universitat Oberta de Catalunya. 2011.

ANTÓN ONECA, J., Los antecedentes del nuevo Código penal. Madrid, 1929.

ANTÓN ONECA, J., La prevención general y la prevención especial en la teoría de la pena. Discurso leído en la apertura del curso académico de 1944 a 1945. Universidad de Salamanca, imprenta Cervantes. 1944.

ANTÓN ONECA, J., Derecho penal. $2^{a}$ Ed., anotada y corregida por José Julián Hernández Guijarro y Luis Beneytez Merino. Madrid: Akal. 1986.

ANTOLISEI, F., Manuale di Diritto penale. Parte generale. Sedicesima edizione. Milano: Dott. A. Giuffrè Editore. 2003.

ARÁNGUEZ SÁNCHEZ, C. / ALARCÓN NAVÍO, E., El Código Penal francés. Traducido y anotado. $2^{\text {a }}$ Ed. Granada. Comares. 2003.

ARISTÓTELES, Política. En ARISTÓTELES, Obras filosóficas. Barcelona: Océano. 2000.

ARROM LOSCOS, R., El Proceso Penal con Implicación de Menores. (Ley Orgánica 5/2000 sobre Responsabilidad Penal de los Menores). Assaigs Jurídics 8. Palma de Mallorca: Universitat de les Illes Balears. 2002.

AYO FERNÁNDEZ, M., “Las garantías del menor infractor. (Ley orgánica 5/2000, de 12 de enero, sobre Responsabilidad Penal de los Menores y sus modificaciones posteriores)". En Revista de Derecho y Proceso Penal. Monografía núm. 12. Navarra: Thomson Aranzadi. 2004. 
AZCÁRRAGA MONZONÍS, C., “El régimen de la extranjería en España”. En FERNÁNDEZ MASIÁ, E., (Dir.) Nacionalidad y Extranjería. Valencia: Tirant lo Blanch. 2011.

BACH FABREGÓ, R. / GIMENO CUBERO, M.A., “Clases y contenido de penas y ejecución de las penas (arts. 33, 36, 46, 50, 52, 53, 56, 58, 66 bis, 83 100, 103 y 106 CP)”. En QUINTERO OliVARES, G., (Dir.), La Reforma Penal de 2010: Análisis y Comentarios. Navarra. Thomson Aranzadi. 2010.

BANACLOCHE PALAO, J. “Los procesos especiales”. En BANACLOCHE PALAO, J. / CUBILLO LÓPEZ, I.J., Aspectos fundamentales de Derecho procesal civil. Madrid: La Ley. 2012.

BARATTA, A., “Viejas y nuevas tendencias del Derecho penal”. En BUSTOS RAMÍREZ, J., Prevención y teoría de la pena. Santiago de Chile: Editorial Jurídica ConoSur Ltda. 1995.

BARONA VILAR, S., "El proceso cautelar". En MONTERO AROCA, J. / GÓMEZ COLOMER, J.L. / MONTÓN REDONDO, A. / BARONA VILAR, S., Derecho

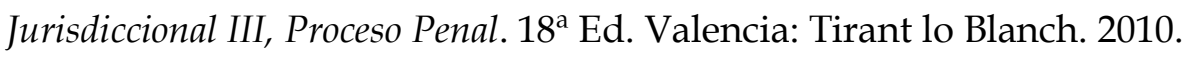

BAUCELlS LlADÓS, J., “De las penas. Arts. 32 a 60”. En CÓRDOBA RODA, J. / GARCÍA ARÁN, M., (Dirs.), Comentarios al Código Penal. Parte General. Madrid: Marcial Pons. 2011.

BAUTISTA SAMANIEGO, C., "Periodo de seguridad y crimen organizado". En Cuadernos de Derecho Judicial, núm. XXII. Derecho penitenciario: incidencia de las nuevas modificaciones. Madrid: Consejo General del Poder Judicial. 2006.

BECCARIA, C., Dei delitti et delle pene, 1764. Edición traducida por Francisco Tomás y Valiente, De los delitos y las penas. Ediciones Libertador. Buenos Aires 2005.

BELZUNEGUI, B., “La libertad vigilada en la última reforma de Código penal español”. En Derecho penal online, [http://www.derechopenalonline.-com/derecho.php?id=16,691,0,0,1,0.]

BELLAVISTA, La libertà vigilata. Palermo: Circolo giuridico. 1934.

BENEYTEZ MERINO, L., en CONDE-PUMPIDO FERREIRO, C., (Dir.), Código penal comentado. Tomo I. Barcelona: Bosch. 2004.

BENTHAM, J., Panopticon. 1791. Traducción de E. Mira, El panòptic. Barcelona: Edicions 62.1985 .

BERDUGO GÓMEZ DE LA TORRE, I. / ARROYO ZAPATERO, L. / GARCÍA RIVAS, N. / FERRÉ OLIVÉ, J.C. / SERRANO PIEDECASAS, J.R., Lecciones de Derecho penal. 
Parte general. $2^{\text {a }}$ Ed. Barcelona: Praxis. 1999.

BERDUGO GÓMEZ DE LA TORRE, I. / ARROYO ZAPATERO, L. / FERRÉ OLIVÉ, J.C. / GARCÍA RIVAS, N. / SERRANO PIEDECASAS, J.R., / TERRADILLOS BASOCO, J., Curso de Derecho Penal. Parte General. Barcelona: Ediciones Experiencia. 2004.

BERTILLON, A., “La identificación antropométrica”. En Revista Mexicana de Criminología, núm. 1, 1976.

BLANCO LOZANO, C., Tratado de Derecho penal español. Tomo I. El sistema de la parte general. Vol. 1. Fundamentos del Derecho penal español. Las consecuencias jurídico-penales. Barcelona: Bosch. 2004.

BOIX REIG, J., en BOIX REIG, J., Derecho penal. Parte especial. Vol. I. Madrid: Iustel. 2010.

BOLDOVA PASAMAR, M.A., "Penas privativas de derechos". En GRACIA MARTIN, L., (Coord.), Tratado de Consecuencias Jurídicas del delito. Valencia: Tirant lo Blanch. 2005.

BOLDOVA PASAMAR, M.A., “Consideraciones político—criminales sobre la introducción de la libertad vigilada". En ReCrim. Revista del Instituto Universitario de investigación en Criminología y Ciencias Penales de la UV. 2009.

BORJA JIMÉNEZ, E., “Custodia de seguridad, peligrosidad postcondena y libertad en un Estado democrático de la era de la globalización: una cuestión de límites". En Revista General de Derecho penal, núm. 18, 2012.

BORJA JIMÉNEZ, E., “Apuntes de urgencia sobre la legitimidad y los límites de la custodia de seguridad en el Anteproyecto de Reforma del Código Penal de 2012". En Revista General de Derecho Penal, núm. 19, 2013.

BOULOC, B., Droit pénal général. 20a Ed. Paris: Dalloz. 2007.

BRANDARIZ GARCÍA, J.A. / FERNÁNDEZ BESSA, C., "La construcción de los migrantes como categoría de riesgo: fundamento, funcionalidad y consecuencias para el sistema penal español". En PALIDDA, S. / BRANDARIZ GARCÍA, J.A., (Dirs.), Criminalización racista de los migrantes en Europa. Granada: Comares. 2010.

BUENO ARÚS, F., “Menor de edad: imputabilidad o inimputabilidad sui generis. Influencia en este punto de la Ley Orgánica Reguladora de la Responsabilidad penal del menor". En Estudios de Derecho judicial, núm. 110. Actual doctrina de la imputabilidad. Madrid: Consejo General del Poder Judicial. 2007.

BURNS / RUSSELL SWERDLOW, “Right Orbitofrontal Tumor with Pedophilia Symptom and Constructional Apraxia Sign". En Archiv Neurology, núm. 60, 2003. 
CADENA SERRANO, F.A., "Las medidas previstas en la LORRPM". En SAMANES ARA, C., (Coord.), La responsabilidad penal de los menores. Zaragoza: El justicia de Aragón. 2003.

CALDERÓN CEREZO, A. / CHOCLÁN MONTALVO, J.A., Código penal comentado. Barcelona: Deusto. 2005.

CÁMARA ARROYO, S., “La libertad vigilada en adultos: naturaleza jurídica, modos de aplicación y cuestiones penitenciarias". En La Ley Penal, núm. 96-97, 2012.

CANCIO MELIÁ, M., “El delito de pertenencia a una organización terrorista en el Código penal español". En LUZÓN PEÑA, D.M., Derecho penal del Estado social y democrático de Derecho. Libro Homenaje a Santiago Mir Puig. Madrid: La Ley. 2010.

CANCIO MELIÁ, M., “Delitos sexuales”. En DÍAZ-MAROTO y VILLAREJO, J., (Dir.), Estudios sobre las reformas del Código Penal. Operadas por las LO 5/2010, de 22 de junio, y 3/2011, de 28 de enero. Navarra: Civitas. 2011.

CANCIO MELIÁ, M., “Delitos de organización: criminalidad organizada común y delitos de terrorismo". En DÍAZ-MAROTO y VILLAREJO, J., (Dir.), Estudios sobre las reformas del Código Penal. Operadas por las LO 5/2010, de 22 de junio, y 3/2011, de 28 de enero). Navarra: Civitas. 2011.

CANCIO MELIÁ, M., "Psicopatía y Derecho penal: algunas consideraciones introductorias". En FERNÁNDEZ TERUELO, J.G. / GONZÁLEZ TASCÓN, M.M. / VILLA SIEIRO, S.V., (Coords.), Estudios penales en homenaje al profesor Rodrigo Fabio Suárez Montes. Oviedo: Constitutio Criminalis Carolina, D.L. 2013.

CANO PAÑOS, M.A., "El marco jurídico y criminológico de la custodia de seguridad (Sicherungsverwahrung) en el Derecho penal alemán". En Cuadernos de Doctrina y Jurisprudencia Penal, núm. 20-21, 2006.

CANO PAÑOS, M.A., “Los delitos de terrorismo en el Código Penal español tras la reforma de 2010". En La ley penal, núm. 86, 2011.

CAPITA REMEZAL, M., Análisis de la legislación penal antiterrorista. Madrid: Colex. 2008.

CARBONELL MATEU, J.C., Derecho penal. Concepto y principios constitucionales. $2^{\mathrm{a}}$ Ed. Valencia: Tirant lo Blanch. 1996.

CARBONELL MATEU, J.C., "Reflexiones sobre el abuso del Derecho Penal y la banalización de la legalidad". En ARROYO ZAPATERO, L.A. / BERDUGO GÓMEZ DE LA TORRE, I., (Dirs.), Homenaje al Dr. Marino Barbero Santos, in memoriam. Vol. I. Ediciones Universidad Castilla-La Mancha. Cuenca. 2001.

CARBONELL MATEU, J.C. / GONZÁLEZ CUSSAC, J.L., con la colaboración de 
GUARDIOLA GARCÍA, J., “Lesiones”. En VIVES ANTÓN, T.S. / ORTS BERENGUER, E. / CARBONELL MATEU, J.C. / GONZÁLEZ CUSSAC, J.L. / MARTÍNEZ-BUJÁN PÉREZ, C., Derecho Penal. Parte Especial. $3^{\mathrm{a}}$ Ed. Valencia: Tirant lo Blanch. 2010.

CARDENAL MONTRAVETA, S., "La reincidencia en el Derecho penal de menores. En LUZÓN PEÑA, D.M., Derecho penal del Estado social y democrático de Derecho. Libro Homenaje a Santiago Mir Puig. Madrid: La Ley. 2010.

CARMONA SALGADO, C., “Causas de inimputabilidad: alteración de la percepción”. En Estudios de Derecho judicial, núm. 110. Actual doctrina de la imputabilidad. Madrid: Consejo General del Poder Judicial. 2007.

CARRARA, F., Programa de Derecho Criminal. Parte General. Dictado en la Universidad de Pisa. Vol. II. Traducido de la $11^{a}$ edición italiana por Sebastián Soler. Buenos Aires: Depalma. 1944.

CARRASCO ANDRINO, M.M. / MOYA FUENTES, M.M. / OTERO GONZÁLEZ, M.P. / MORALES PRATS, F., “Delitos contra la intimidad”. En ÁLVAREZ GARCÍA, F.J., (Dir.) / DOPICO GÓMEZ-ALLER, J., (Coord.), Estudio crítico sobre el Anteproyecto de Reforma penal de 2012. Valencia: Tirant lo Blanch. 2013.

CARRILLO DE TESO, A.E., “Responsabilidad penal de la persona jurídicas: Pasado, presente y futuro". En PÉREZ CEPEDA, A.I. (Dir.) / GORJÓN BARRANCO, M.C., El Proyecto de Reforma del Código penal de 2013 a debate. Salamanca: Ratio Legis. 2014.

CASANAS LEVI, J.F., Manual de Derecho penal. Parte General. 6a Ed. Asunción: La Ley Paraguaya. 2012.

CASTELLÓ NICÁS, N., “Causas de inimputabilidad: drogadicción”. En Estudios de Derecho judicial, núm. 110. Actual doctrina de la imputabilidad. Madrid: Consejo General del Poder Judicial. 2007.

CENTURIÓN ORTIZ, R.F., Derecho penal. Parte General. Asunción: La Ley Paraguaya. 2010.

CEREZO MIR, J., “Alteraciones en la percepción”. En QUINTERO OLIVARES, G. / MORALES PRATS, F. (Coords.), El nuevo Derecho penal español. Estudios penales en memoria del Profesor José Manuel Valle Muñiz. Navarra: Aranzadi. 2001.

CEREZO MIR, J., Curso de derecho penal Español. Parte General. I Introducción. 6 a Ed. Madrid: Tecnos. 2004.

CEREZO MIR, J., Curso de derecho penal Español. Parte General. III Teoría del delito/2. $6^{\mathrm{a}}$ Ed. Madrid: Tecnos. 2004. 
CERVELLÓ DONDERIS, V., Derecho Penitenciario. Valencia: Tirant lo Blanch. 2006.

CERVELLÓ DONDERIS, V., La medida de internamiento en el Derecho penal del menor. Valencia: Tirant lo Blanch. 2009.

CERVELLÓ DONDERIS, V., "Responsabilidad civil y tratamiento penitenciario". En Cuadernos de Derecho judicial, núm. XXII. Derecho penitenciario: incidencia de las nuevas modificaciones. Madrid: Consejo General del Poder Judicial. 2006.

CERVELLÓ DONDERIS, V., "Sistema de sanciones en el Derecho penal de menores". En CERVELLÓ DONDERIS, V. / COLÁS TURÉGANO, A., La responsabilidad penal del menor de edad. Madrid: Tecnos. 2002.

CERVELLÓ DONDERIS, V., “Las medidas en el Derecho penal de menores". En GONZÁLEZ CUSSAC, J.L. / CUERDA ARNAU, M.L., (Coords.), Estudios sobre la responsabilidad penal del menor. Col lecció "Estudis jurídics" núm. 9. Castellón: Universitat Jaume I. 2006.

CERVERA SALVADOR, S., "La pena de trabajos en beneficio de la comunidad". En Revista de Estudios Penitenciarios, núm. 255. Madrid: Ministerio del Interior. Secretaría General Técnica. 2011.

CEZÓN GONZÁLEZ, C., La nueva Ley Orgánica reguladora de la responsabilidad penal de los menores. Barcelona: Bosch. 2001.

CHIMENO CANO, M., Incapacitación, tutela e internamiento del enfermo mental. Navarra: Thomson Aranzadi. 2003.

CHOCLÁN MONTALVO, J.A., Individualización de la pena. Función de la culpabilidad y la prevención en la determinación de la sanción. Madrid: Colex. 1997.

CHOCLÁN MONTALVO, J.A., “La medida de seguridad”. En CALDERÓN CEREZO, A. / CHOClÁn MONTAlVO, J.A., Derecho penal. Tomo I. Parte general. $2^{\mathrm{a}}$ Ed. Barcelona: Bosch. 2001.

CID MOLINÉ, J., “La medida de seguridad de libertad vigilada (art. 106 CP y concordantes)". En SILVA SÁNCHEZ, J.M., (Dir.) / PASTOR MUÑOZ, N., (Coord.), El nuevo Código penal: comentarios a la reforma. Las Rozas: La Ley. 2012.

COBO DEL ROSAL, M. / QUINTANAR DÍEZ, M., Instituciones de Derecho penal español. Parte general. Madrid: CESEJ. 2004.

COBO DEL ROSAL, M., “El sistema de penas y el arbitrio judicial en el Código Penal de 1948". Madrid: Real Academia de Jurisprudencia y Legislación. 1970. En COBO DEL ROSAL, M., Quisicosas del Derecho penal. Madrid: CESEJ. 2005.

COBO DEL ROSAL, M. / VIVES ANTÓN, T.S., Derecho Penal, Parte General. $5^{\mathrm{a}}$ Ed. 
Valencia: Tirant lo Blanch. 1999.

COLÁS TURÉGANO, A., “Aspectos penales característicos de la delincuencia juvenil”. En GONZÁLEZ CUSSAC, J.L. / CUERDA ARNAU, M.L., (Coords.), Estudios sobre la responsabilidad penal del menor. Col lecció "Estudis jurídics" núm. 9. Castellón: Universitat Jaume I. 2006.

CONDE, M., Derecho penitenciario vivido. Granada: Comares. 2006

CONTRERAS, D. / CATENA, A. / CÁNDIDO, A. / PERALES, J.C. / MALDONADO, A., "Funciones de la corteza prefrontal ventromedial en la toma de decisiones emocionales". En International Journal of clinical and health Psychology, vol. 8, núm. 1, 2008.

CÓRDOBA RODA, J., “De la infracción penal”. En CÓRDOBA RODA, J. / GARCÍA ARÁN, M., (Dirs.), Comentarios al Código Penal. Parte General. Madrid: Marcial Pons. 2011.

CORCOY BIDASOlO, M. / MIR PUIG, S., Comentarios al Código Penal: Reforma 5/2010. Valencia. Tirant lo Blanch. 2011.

CORCOY BIDASOLO, M., (Dir.) / BOLEA BARDÓN, C. / CARDENAL MONTRAVERA, S. / GALLEGO SOLER, J.I. / GÓMEZ MARTíN, V. / SANTANA VEGA, D. / HORTAL IBARRA, J.C. / FERNÁNDEZ BAUTISTA, S. / CARPIO BRIZ, D. / BESIO HERNÁNDEZ, M. / SALVADORI, I., Derecho penal. Parte especial. Doctrina y jurisprudencia con casos solucionados. Tomo 1. Valencia: Tirant lo Blanch. 2011.

COUTO DE BRITO, A., "Sistemas penales comparados. Las medidas de seguridad. Brasil". En Revista Penal, núm. 23, 2008.

CUELLO CALÓN, E., El nuevo Código penal español. Tomo I. Barcelona, 1929.

CUELLO CALÓN, E., Derecho Penal. Tomo I. Parte General. Vol. I. Barcelona: Bosch. 1960.

CUEllo CAlÓN, E., Manual de Derecho Penal. Parte General. Tomo I, Vol. I. $18^{\text {a }}$ Ed. Barcelona: Bosch, 1981.

CUELLO CALÓN, E., La moderna penología. Barcelona: Bosch. 1973.

CUELLO CONTRERAS, J., El nuevo Derecho penal de menores. Madrid: Civitas. 2000.

CUELlO CONTRERAS, J., El Derecho penal español. Parte general. Notas introductorias. Teoría del delito. Madrid: Dykinson. 2002.

CUELLO CONTRERAS, J. / MAPELLI CAFFARENA, B., Curso de Derecho penal. Parte General. Madrid: Tecnos. 2011.

CUERDA ARNAU, M.L., Atenuación y remisión de la pena en los delitos de terrorismo. Madrid: Ministerio de Justicia e Interior, Centro de Publicaciones. 1995. 
CUERDA ARNAU, M.L., “Aproximación al principio de proporcionalidad en Derecho Penal". En Estudios en Memoria del profesor Dr. D. José Ramón Casabó Ruiz. Vol. I, Universidad de Valencia. Instituto de Criminología. 1997.

CUERDA ARNAU, M.L. / OLLOQUIEGUI SUCUNZA, I. / DE LA CUESTA AGUADO, P.M. / BAUCELLS LLADÓS, J. / MARTÍNEZ GUERRA, A., “Delitos contra el orden público". En ÁLVAREZ GARCÍA, F.J., (Dir.) / DOPICO GÓMEZ-ALLER, J., (Coord.), Estudio crítico sobre el Anteproyecto de Reforma penal de 2012. Valencia: Tirant lo Blanch. 2013.

CUGAT MAURI, M, “La desaprovechada reforma de la expulsión de extranjeros, art. 89 CP". En QUINTERO OlIVARES, G., (Dir.), La Reforma Penal de 2010: Análisis y Comentarios. Navarra: Thomson Aranzadi. 2010.

CUGAT MAURÍ, M., “Delitos contra la libertad e indemnidad sexuales”. En ÁLVAREZ GARCÍA, F.J. / GONZÁLEZ CUSSAC, J.L., (Dirs.), Comentarios a la reforma penal de 2010. Valencia: Tirant lo Blanch. 2010.

CURIA, L.R., CÉSPEDES, L. / NICOLETTI, J., (Edit.), Vade Mecum. 14ª Ed. São Paulo: Saraiva. 2012.

DE LACERDA DA COSTA PINTO, F., “Sistemas penales comparados. Las medidas de seguridad. Portugal”. En Revista Penal, núm. 23, 2008.

DE LA MATA BARRANCO, N.J., El principio de proporcionalidad penal. Valencia: Tirant lo Blanch. 2007.

DE LA ROSA CORTINA, J.M., “Las medidas y sus reglas de aplicación”. En DE URBANO CASTRILLO, E. / DE LA ROSA CORTINA, J.M., La responsabilidad penal de los menores. Adaptada a la LO 8/2006, de 4 de diciembre. Navarra: Thomson Aranzadi. 2007.

DE LA ROSA CORTINA, J.M., en SÁNCHEZ MELGAR, Julián (coord.), Ley de Enjuiciamiento Criminal. Comentarios y jurisprudencia. Tomo II. Madrid: Sepín. 2010.

DE LEÓN VELASCO, H.A. / DE MATA VELA, J.F., Derecho penal guatemalteco. $12^{\mathrm{a}}$ Ed. Guatemala: Editorial Lerena. 2000.

DE LLERA SUÁREZ-BÁRCENA, E., “Imputabilidad y fines de la pena. La relación de los efectos psicológicos previstos en el art. 20 y en el art. 60 CP”. En Estudios de Derecho judicial, núm. 110. Actual doctrina de la imputabilidad. Madrid: Consejo General del Poder Judicial. 2007.

DE LORENZO SEGRELLES, M., "El régimen sancionador en materia de extranjería”. En FERNÁNDEZ MASIÁ, E., (Dir.) Nacionalidad y Extranjería. Valencia: Tirant lo 
Blanch. 2011.

DE MARCOS MADRUGA, F., “De la libertad condicional”. En GÓMEZ TOMILLO, M., (Dir.), Comentarios al Código Penal. Valladolid: Lex Nova. 2010.

DE MARCOS MADRUGA, F., en GÓMEZ TOMILlO, M., (Dir.), Comentarios al Código penal. $2^{\text {a }}$ Ed. Valladollid: Lex Nova. 2011.

DE URBANO CASTRILLO, E., “Medidas cautelares”. En DE URBANO CASTRILLO, E. /

DE LA ROSA CORTINA, J.M., La responsabilidad penal de los menores. Adaptada a la LO 8/2006, de 4 de diciembre. Navarra: Thomson Aranzadi. 2007.

DE URBANO CASTRILlO, E., en SÁNCHEZ MELGAR, J. (Coord.), Código penal. Comentarios y jurisprudencia. Tomo II. $3^{\text {a }}$ Ed. Madrid: Sepín. 2010.

DE VICENTE MARTÍNEZ, R., El principio de legalidad penal. Valencia: Tirant Lo Blanch. 2004.

DE VICENTE MARTÍNEZ, R., Vademécum de Derecho penal. Valencia: Tirant lo Blanch. 2011.

DE VICENTE MARTíNEZ, R. / BAUCELLS LLADÓS, J. / BRAGE CENDÁN, S.B. / ROCA AGAPITO, L. / QUINTERO OLIVARES, G. / SÁNCHEZ DAFAUCE, M. / CASTRO MORENO, A. / GUTIÉRREZ RODRÍGUEZ, M. / NIETO MARTÍN, A. / ANDRÉS DOMÍNGUEZ, A.C., "Delitos contra el patrimonio y contra el orden socioeconómico". En ÁLVAREZ GARCÍA, F.J., (Dir.) / DOPICO GÓMEZ-ALLER, J., (Coord.), Estudio crítico sobre el Anteproyecto de Reforma penal de 2012. Valencia: Tirant lo Blanch. 2013.

DEL CARPIO DELGADO, J., “La medida de libertad vigilada para adultos”. En Revista de Derecho Penal, núm. 36, 2012.

DEL CARPIO DELGADO, J., “La pena de prisión permanente en el Anteproyecto de 2012 de Reforma del Código Penal”. En Diario La Ley, núm. 8004. 2013.

DEMETRIO CRESPO, E., "El "Derecho penal del enemigo". Darf nicht sein! Sobre la ilegitimidad del llamado "Derecho penal de enemigo" y la idea de seguridad". En GARCÍA RIVAS, N. / RODRÍGUEZ YAGÜE, C. / PÉREZ CEPEDA, A.I. / DEMETRIO CRESPO, E. / RIQUERT, F.L. / PALACIOS, L.P. / VERVAELE, J. / ACALE SÁNCHEZ, M. / PORTERO HENARES, M. / QUINTERO OLIVARES, G. / VIGANÒ, F., El derecho penal frente a la inseguridad. Albacete: Bomarzo. 2007.

DEMETRIO CRESPO, E., “Acerca del a contraposición entre libertad y seguridad en el Derecho penal". En PÉREZ ÁLVAREZ, F., (Edit.), Vniversitas Vitae, homenaje a Ruperto Núñez Barbero. Salamanca: Aquílafuente. 2007. 
DEMETRIO CRESPO, E., “Libertad de voluntad, investigación sobre el cerebro y responsabilidad penal. Aproximación a los fundamentos del moderno debate sobre Neurociencias y Derecho penal". En InDret. Revista para el análisis del Derecho. 2/2011. Barcelona: 2011.

DEMETRIO CRESPO, E., (Dir.) / MAROTO CALATAYUD, M., (Coord.), Neurociencias y Derecho penal. Nuevas perspectivas en el ámbito de la culpabilidad y tratamiento jurídico-penal de la peligrosidad. Madrid: Edisofer. 2013.

DÍAZ GÓMEZ, A., “Novedades del Proyecto de Reforma de 2013 del Código Penal sobre la responsabilidad de las personas jurídicas". En Revista Electrónica del Departamento de Derecho de la Universidad de La Rioja (REDUR), núm. 11, 2013.

DÍAZ MARTÍNEZ, M., La Instrucción en el Proceso Penal de Menores. Madrid: Colex. 2003.

DÍAZ MARTÍNEZ, M. / LUACES GUTIÉRREZ, A.I., “El proceso Penal de Menores (I)”, En VÁZQUEZ GONZÁLEZ, C. / SERRANO TÁRRAGA, M.D., (Edits.), Derecho Penal Juvenil. Madrid: Dykinson. 2005.

DÍEZ RIPOLLÉS, J.L., “Aspectos generales de la imputabilidad”. En Estudios de Derecho judicial, núm. 110. Actual doctrina de la imputabilidad. Madrid: Consejo General del Poder Judicial. 2007.

DIEGO DÍAZ SANTOS, M.R. / MATELLANES RODRÍGUEZ, N.P. / FABIÁN CAPARRÓS, E.A., (Comps.), Anteproyecto de Ley Orgánica de 14 de noviembre de 2008, de Reforma del Código Penal. Acompañado de los informes del Consejo General del Poder Judicial y del Consejo Fiscal. XXI Congreso Universitario de Alumnos de Derecho Penal. Universidad de Salamanca: Ratio legis. 2009.

DOLZ LAGO, M.J., Comentarios a la legislación penal de Menores. Valencia: Tirant lo Blanch. 2007.

DREYER, E., Droit pénal général. Paris: Flammarion. 2006.

EIRANOVA ENCINAS, E., (Coord.), Código Penal alemán StGB. Código Procesal Penal alemán StPO. Madrid: Marcial Pons. 2000.

ESCRIHUELA CHUMILLA, F.J., Todo Penal. Madrid: La Ley. 2011.

ESPINOSA CALABUiG, R., "Permanencia de los extranjeros en España". En FERNÁNDEZ MASIÁ, E., (Dir.) Nacionalidad y Extranjería. Valencia: Tirant lo Blanch. 2011.

ETXEBARRÍA ZARRABEITIA, X., "Las medidas de seguridad como instrumentos de reinserción". En Revista Sepín práctica penal. Nº 60. 2010. 
EXTEBARRIA ZARRABEITIA, X., “Medidas de seguridad y su ejecución”. En ÁLVAREZ GARCÍA, F.J., (Dir.) / DOPICO GÓMEZ-ALLER, J., (Coord.), Estudio crítico sobre el Anteproyecto de Reforma penal de 2012. Valencia: Tirant lo Blanch. 2013.

EXNER, F., Die theorie der Scherungsmittel. Berlin: 1914.

FARALDO CABANA, P. / CUENCA GARCÍA, M.J., “Asociaciones ilícitas y organizaciones y grupos criminales". En ÁLVAREZ GARCÍA, F.J., (Dir.) / DOPICO GÓMEZ-ALLER, J., (Coord.), Estudio crítico sobre el Anteproyecto de Reforma penal de 2012. Valencia: Tirant lo Blanch. 2013.

FERNÁNDEZ GARCÍA, J., “Las penas privativas de libertad en la reforma de Gallardón: Especial referencia a la prisión permanente revisable". En PÉREZ CEPEDA, A.I. (Dir.) / GORJÓN BARRANCO, M.C., El Proyecto de Reforma del Código penal de 2013 a debate. Salamanca: Ratio Legis. 2014.

FERNÁNDEZ HERNÁNDEZ, A. / OLLOQUIEGUI SUCUNZA, I. / MARÍN DE ESPINOSA y CEBALLOS, E.B. / GONZÁLEZ TASCÓN, M.M. / GALDEANO SANTAMARÍA, A. / ANDRÉS DOMÍNGUEZ, A.C., “Supresión del Libro III”. En ÁLVAREZ GARCÍA, F.J., (Dir.) / DOPICO GÓMEZ-ALLER, J., (Coord.), Estudio crítico sobre el Anteproyecto de Reforma penal de 2012. Valencia: Tirant lo Blanch. 2013. FEIJOO SÁNCHEZ, B., “Derecho Penal y Neurociencias. ¿Una relación tormentosa?”. En InDret. Revista para el análisis del Derecho. 2/2011. Barcelona: 2011.

FEIJOO SÁNCHEZ, B., "Culpabilidad jurídico-penal y Neurociencias”. En DEMETRIO CRESPO, E., (Dir.) / MAROTO CALATAYUD, M., (Coord.), Neurociencias y Derecho penal. Nuevas perspectivas en el ámbito de la culpabilidad y tratamiento jurídico-penal de la peligrosidad. Madrid: Edisofer. 2013.

FEIJOO SÁNCHEZ, B., "La libertad vigilada en el Derecho penal de adultos". En DÍAZ-MAROTO y VILLAREJO, J. (Dir.), Estudios sobre las reformas del Código Penal: (operadas por las LO 5/2010, de 22 de junio, y 3/2011, de 28 de enero). Navarra: Civitas. 2011.

FERNÁNDEZ ARÉVALOS, E., “Medidas de Vigilancia, de Mejoramiento y de Seguridad en el Nuevo Código Penal". En Nuevo Código Penal. Opiniones y comentarios. Asunción: Colegio de Abogados del Paraguay. 1999.

FERNÁNDEZ GARCÍA, J., "La actual reforma del Código Penal ¿acierto o confusión?”. En DIEGO DÍAZ-SANTOS, M.R. / FABIÁN CAPARRÓS, E.A. (Coords.) El sistema penal frente a los retos de la nueva sociedad. Madrid: Colex. 2003.

FERNÁNDEZ GARCÍA, J., “La libertad condicional y los beneficios penitenciarios”. En 
BERDUGO GÓMEZ DE LA TORRE, I. (Coord.), Lecciones y materiales para el estudio del Derecho penal. Tomo VI. Derecho penitenciario. Madrid: Iustel. 2010.

FERNÁNDEZ GARCÍA, J., “El Derecho penitenciario. Concepto”. En BERDUGO GÓMEZ

DE LA TORRE, I., (Coord.), Lecciones y materiales para el Estudio del Derecho penal. Tomo VI. Derecho penitenciario. Madrid: Iustel. 2010.

FERRÉ OLIVÉ, J.C., “Trabajo sexual, crimen organizado y trata de personas”. En MUÑOZ CONDE, F. / LORENZO SALGADO, J.M. / FERRÉ OLIVE, J.C. / CORTES BECHIARELLI, E. / NÚÑEZ PAZ, M.A., (Dirs.), Un Derecho penal comprometido. Libro Homenaje al Prof. Dr. Gerardo Landrove Díaz. Valencia: Tirant lo Blanch. 2011.

FERREIRO BAAMONTE, X.X., en PÉREZ-CRUZ MARTÍN, A.J. / FERREIRO BAAMONTE, X.X. / PIÑOL RODRÍGUEZ, J.R. / SEOANE SPIEGELBERG, J.L., Derecho Procesal penal. $2^{\mathrm{a}}$ Ed. Navarra: Civitas. 2010.

FERRER GUTIÉRREZ, A., Manual práctico sobre ejecución penal y Derecho penitenciario.

Doctrina, jurisprudencia y formularios. Valencia: Tirant lo Blanch. 2011.

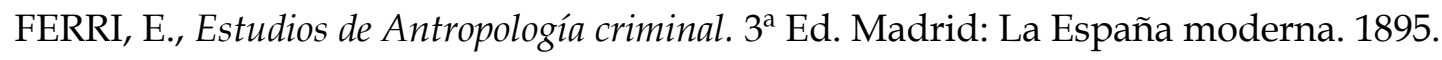

FERRI, E., Sociología criminal. Tomo II. Madrid: Centro editorial del Góngora. 1907.

FERNÁNDEZ PALMA, R., “Acoso laboral e inmobiliario (arts. 172.1, párrafo tercero y 173.1, párrafos segundo y tercero CP)". En QUINTERO OLIVARES (Dir.) La Reforma Penal de 2010: Análisis y Comentarios. Navarra. Thomson Aranzadi. 2010.

FERNÁNDEZ REQUENA, J., El delito de terrorismo urbano de baja intensidad. Análisis del artículo 577 CP. Valencia: Tirant lo Blanch. 2009.

FEUERBACH, P.J.A., Lehrbuch des gemeinen in Deutchsland gültigen. Peinlichen Retchs. Giefsen. 14 ${ }^{\mathrm{a}}$ Ed. München. 1847.

FIGUEIREDO DIAS, J., Direito penal português. Parte General II. As consequências juridicas do crime. $2^{\text {a }}$ Reimpressão. Coimbra: Coimbra Editora. 2009.

FIANDACA, G., / MUSCO, E., Diritto penale. Parte generale. Quinta Edizione. Bologna: Zanichelli Editore. 2007.

FOUCAULT, M., Maladie mentale et personnalité. París.1954. Traducción de E. Kelstelboim, Enfermedad mental y personalidad. 2a Ed. Buenos Aires: Paidos. 1979.

FOUCAULT, M., Surveiller et punir. París. 1975. Traducción de A. Garzón del Camino. $18^{\text {a }}$ Ed. Madrid: Siglo XXI de España editores S.A. 1990.

FRISCH, W., “Las medidas de corrección y seguridad en el sistema de consecuencias jurídicas del Derecho penal. Clasificación en las teorías de la pena, configuración material y exigencias en el Estado de Derecho". En InDret. Revista para el análisis del 
Derecho. 3/2007. Barcelona: 2007.

GALAIN PALERMO, P., "Sistemas penales comparados. Las medidas de seguridad. Uruguay". En Revista Penal, núm. 23, 2008.

GALDEANO SANTAMARÍA, A. / CANCIO MELIÁ, M., “Delitos contra la integridad física". En ÁlVAREZ GARCÍA, F.J., (Dir.) / DOPICO GÓMEZ-ALLER, J., (Coord.), Estudio crítico sobre el Anteproyecto de Reforma penal de 2012. Valencia: Tirant lo Blanch. 2013.

GARBERÍ LLOBREGAT, J. (Dir.) / TORRES FERNÁNDEZ DE SEVILLA, J.M. / CASERO LINARES, L., Los procesos civiles. Comentarios a la Ley de Enjuiciamiento Civil, con formularios y jurisprudencia. Vol. 4. 2a Ed. Barcelona: Bosch. 2010.

GARBERÍ LLOBREGAT, J. Derecho procesal civil. Procesos declarativos y proceso de ejecución. $2^{\mathrm{a}}$ Ed. Barcelona: Bosch. 2012.

GARCÍA ALBERO, R., “Acumulación jurídica de penas y cumplimiento íntegro: La reforma de los artículos 76 y 78 CP”. En TAMARIT SUMALLA, J.M. / GARCÍA ALBERO, R., La reforma de la ejecución penal. Valencia: Tirant lo Blanch. 2004. [www.tirantonline.com]. TOL519.287.

GARCÍA ALBERO, R., “Ejecución de penas en el proyecto de reforma. Estudio de un problema concreto: ¿qué hacer con los reos habituales o reincidentes en los que subsiste la peligrosidad criminal tras el licenciamiento definitivo?" En ÁLVAREZ GARCÍA. F., (Dir.), La adecuación del Derecho penal español al ordenamiento de la Unión Europea. La politica criminal europea. Valencia: Tirant Lo Blanch. 2009.

GARCÍA ALBERO, R., “La nueva medida de seguridad de libertad vigilada”. En Revista Aranzadi doctrinal, núm. 6. Octubre 2010.

GARCÍA ALBERO, R., “La reforma de los delitos de terrorismo (arts. 572, 573, 574, 575, 576, 576 bis, 577, 578, 579 CP)". En QUINTERO OLIVARES, G., (Dir.), La Reforma Penal de 2010: Análisis y Comentarios. Navarra: Thomson Aranzadi. 2010.

GARCÍA ALBERO, R., en QUINTERO OLIVARES, G., Comentarios al Código penal. Tomo I. Navarra: Aranzadi. 2011.

GARCÍA ARAN, M., Fundamentos y Aplicación de Penas y Medidas de Seguridad en el Código Penal de 1995. Navarra: Aranzadi. 1997.

GARCÍA ARÁN, M., “De las penas. Arts. 80 a 93”. En CÓRDOBA RODA, J. / GARCÍA ARÁN, M., (Dirs.), Comentarios al Código Penal. Parte General. Madrid: Marcial Pons. 2011.

GARCÍA Y GARCÍA-SOTUGA, F.J., en CORDÓN MORENO, F. / ARMENTA DEU, T. / 
MUERZA ESPARZA, J.J. / TAPIA FERNÁNDEZ, I., (Coords.), Comentarios a la Ley de Enjuiciamiento Civil. Vol. II. Navarra: Aranzadi. 2001

GARCÍA PÉREZ, O., (Dir.) / DÍEZ RIPOLLÉS, J.L. / PÉREZ JIMÉNEZ, F. / GARCÍA RUIZ, S., La delincuencia juvenil ante los Juzgados de Menores. Valencia: Tirant lo Blanch. 2008.

GARCÍA PÉREZ, J.J., en SÁNCHEZ MELGAR, J. (Coord.), Código penal. Comentarios y

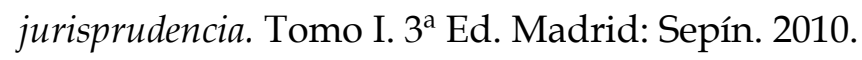

GARCÍA RIVAS, N., “La libertad vigilada y el Derecho penal de la peligrosidad”. En Revista General de Derecho Penal, núm.16. 2011.

GARCÍA VALDÉS, C., "La legislación antiterrorista". En Anuario de Derecho penal y Ciencias Penales, Tomo XXVVII, fascículo II. 1984.

GARCÍA-PABLOS DE MOLINA, A., "Funciones y fines de las instituciones penitenciarias". En COBO DEL ROSAL, M. / BAJO FERNÁNDEZ, M., (Dirs.), Comentarios a la legislación penal. Ley Orgánica General Penitenciaria. Tomo VI. Vol. 2. Madrid, 1986.

GARCÍA-PABLOS DE MOLINA, A., Derecho penal. Introducción. $2^{\mathrm{a}}$ Ed. Madrid: Universidad Complutense. 2000.

GARCÍA-PABLOS DE MOLINA, A., Criminología. Una introducción a sus fundamentos teóricos. $6^{\text {a }}$ Ed. Valencia: Tirant lo Blanch. 2007.

GASCÓN INCHAUSTI, F. / VILLAMARÍN LÓPEZ, M.L., “Otras repercusiones de la LO 5/2010 en el ámbito del Proceso penal”. En GASCÓN INSCHAUSTI, F., (Coord.), Repercusiones sobre el Proceso Penal de la Ley Orgánica 5/2010, de Reforma del Código Penal. Navarra: Aranzadi. 2010.

GIMENO SENDRA, V., Manual de Derecho procesal penal. $3^{\mathrm{a}}$ Ed. Madrid: UNED, Colex. 2013.

GÓMEZ, E., Tratado de Derecho Penal. Tomo I. Doctrina y principios fundamentales. Buenos Aires: Compañía Argentina de Editores. 1939.

GÓMEZ COLOMER, J.L., (coord.), Tutela procesal frente a hechos de violencia de género. Col lecció Estudis Jurídics No 13. Castelló: Universitat Jaume I. 2007.

GÓMEZ COLOMER, J.L., “El proceso de ejecución”. En MONTERO AROCA, J. / GÓMEZ COLOMER, J.L. / MONTÓN REDONDO, A. / BARONA VILAR, S., Derecho Jurisdiccional III. Proceso Penal. 18 ${ }^{\mathrm{a}}$ Ed. Valencia: Tirant lo Blanch. 2010.

GÓMEZ COLOMER, J.L., “El proceso de ejecución”. En MONTERO AROCA, J. / GÓMEZ COLOMER, J.L. / MONTÓN REDONDO, A. / BARONA VILAR, S., 
Derecho Jurisdiccional III. Proceso Penal. 21 ${ }^{\text {a }}$ Ed. Valencia: Tirant lo Blanch. 2013.

GÓMEZ COLOMER, J.L., "Procesos civiles no dispositivos”. En MONTERO AROCA, J. /

GÓMEZ COLOMER, J.L. / BARONA VILAR, S. / CALDERÓN CUADRADO,

M.P., Derecho jurisdiccional II. Proceso Civil. 21ª Ed. Valencia: Tirant lo Blanch. 2013.

GÓMEZ INIESTA, D. / GÓRRIZ ROYO, E. / MAQUEDA ABREU, M.L. / ACALE

SÁNCHEZ, M. / GÓMEZ LÓPEZ, R. / GALDEANO SANTAMARÍA, A. /

GUTIÉRREZ CASTAÑEDA, A. / MATALLÍN EVANGELIO, A. / VILLACAMPA

ESTIARTE, C., “Delitos contra la libertad”. En ÁLVAREZ GARCÍA, F.J., (Dir.) /

DOPICO GÓMEZ-ALLER, J., (Coord.), Estudio crítico sobre el Anteproyecto de Reforma penal de 2012. Valencia: Tirant lo Blanch. 2013.

GÓMEZ-JARA DÍEZ, C., "La responsabilidad penal de las personas jurídicas”. En Diario

La Ley, núm. 7534. Especial Reforma del Código Penal, 2010.

GÓMEZ MARTÍN, V., El Derecho penal de autor. Valencia: Tirant lo Blanch. 2007.

GÓMEZ MARTÍN, V., “Notas para un concepto funcional de terrorismo”. En SERRANO

PIEDECASAS, J.R. / DEMETRIO CRESPO, E.D., (dirs.), Terrorismo y Estado de Derecho. Madrid: Iustel. 2010.

GONZÁLEZ CUSSAC, J.L., Teoría general de las circunstancias modificativas de la responsabilidad criminal. Valencia: Universidad de Valencia. 1988.

GONZÁLEZ CUSSAC, J.L., “El sistema de penas español: balance crítico y propuesta alternativa". En ARROYO ZAPATERO, L. / CRESPO BARQUERO, P. / GONZÁLEZ CUSSAC, J.L. / QUINTERO OLIVARES, G. / ORTS BERENGUER, E., La reforma del Código Penal tras 10 años de vigencia. Navarra: Thomson Aranzadi. 2006.

GONZÁLEZ CUSSAC, J.L., “La Contrarreforma Penal de 2003: nueva y vieja política criminal”. En Revista Xurídica Galega, núm. 38. 2003.

GONZÁLEZ CUSSAC, J.L., "El Derecho penal frente al terrorismo. Cuestiones y perspectivas". En GONZÁLEZ CUSSAC, J.L. / GÓMEZ COLOMER, J.L., (Coords.) Terrorismo y Proceso penal acusatorio. Valencia: Tirant lo Blanch. 2006.

GONZÁLEZ CUSSAC, J.L., El derecho penal frente al terrorismo. Cuestiones y perspectivas. Lección inaugural del curso 2005/2006. Castellón. Universitat Jaume I. 2005.

GONZÁLEZ CUSSAC, J.L., "El renacimiento del pensamiento totalitario en el seno de Estado de Derecho: la doctrina del derecho penal del enemigo". En Revista Penal. La Ley, núm. 19, enero de 2007.

GONZÁLEZ POVEDA, P., en XIOL RÍOS, J.A., (Coord.) Enjuiciamiento civil. Comentarios y 
jurisprudencia. Tomo III. Madrid: Sepín. 2008.

GONZÁleZ ROURA, O., Derecho Penal. Parte General. Tomo II. 2a Ed. Buenos Aires: Valerio Abeledo Editor. 1925.

GONZÁLEZ TASCÓN, M.M., “Prisión perpetua: Arts. 36 (3 y 4), 70, 76 y 78 bis CP”. En ÁLVAREZ GARCÍA, F.J., (Dir.) / DOPICO GÓMEZ-ALLER, J., (Coord.), Estudio crítico sobre el Anteproyecto de Reforma penal de 2012. Valencia: Tirant lo Blanch. 2013. GORRIZ ROYO, E., "El principio "ne bis in idem" y la regla de preferencia del orden jurisdiccional penal a la luz de la STC 177/1999". En Revista de la Asociación de Ciencias Penales, Vol. 3. 2000.

GRACIA MARTÍN, L., El horizonte del finalismo y el "derecho penal del enemigo". Valencia: Tirant lo Blanch. 2005.

GRACIA MARTÍN, L., "Sobre la legitimidad de medidas de seguridad contra delincuentes imputables peligrosos en el Estado de Derecho". En GARCÍA VALDÉS, C. / CUERDA RIEZU, A. / MARTÍNEZ ESCAMILLA, M. / ALCÁCER GUIRAO, R., / VALLE MARISCAL DE GANTE, M., Estudios penales en homenaje a Enrique Gimbernat. Vol I. Madrid: Edisofer. 2008.

GRACIA MARTÍN, L., “El sistema de penas”. En GRACIA MARTíN, L. (Coord.) / BOLDOVA PASAMAR, A. / ALASTUEY DOBÓN, C., Tratado de consecuencias jurídicas del delito. Valencia: Tirant lo Blanch. 2006.

GRACIA MARTÍN, L., "Las medidas de seguridad y reinserción social". En GRACIA MARTÍN, L. (Coord.) / BOLDOVA PASAMAR, A. / ALASTUEY DOBÓN, C., Tratado de consecuencias jurídicas del delito. Valencia: Tirant lo Blanch. 2006.

GRACIA MARTIN, L. / ALASTUEY DOBÓN, M.C., "La ejecución de las penas privativas de libertad". En GRACIA MARTIN, L., (Coord.), Tratado de Consecuencias Jurídicas del delito. Valencia: Tirant lo Blanch. 2006.

GROTIUS, H., De iure belli ac pacis. Liber II, caput XX. Paris: 1926.

GRUPO DE ESTUDIOS DE POLÍTICA CRIMINAL, Una propuesta alternativa al sistema de penas y su ejecución, y a las medidas cautelares personales. Málaga: GEPC. 2005.

GIMENO SENDRA, V., Derecho Procesal Penal. $2^{\text {a }}$ Ed. Madrid: Colex. 2007.

GUDÍN RODRÍGUEZ MAGARIÑOS, F., La nueva medida de seguridad postdelictual de libertad vigilada. Especial referencia a los sistemas de control telemáticos. Valencia: Tirant lo Blanch. 2011.

GUISASOLA LERMA, C., "La delincuencia de menores en la provincia de Valencia: análisis de las estadísticas oficiales”. En GONZÁLEZ CUSSAC, J.L. / CUERDA 
ARNAU, M.L., (Coords.), Estudios sobre la responsabilidad penal del menor. Col lecció “Estudis jurídics" núm. 9. Castellón: Universitat Jaume I. 2006.

GUISASOLA LERMA, C., Reincidencia y delincuencia habitual. Valencia: Tirant lo Blanch. 2008.

GUISASOLA LERMA, C., "Reformas penales y tendencias político-criminales en materia de inmigración". En La Ley Penal, núm. 67, 2010.

GUISASOLA LERMA, C., “Consideraciones político-legales para una reformulación de la expulsión legal de condenados extranjeros sin residencia legal. (Art. 89 del CP)". En Estudios penales y criminológicos, núm. 30, 2010.

GUISASOLA LERMA, C., "La reforma del Código penal en materia de expulsión judicial de extranjeros como medida sustitutiva de penas privativas de libertad (art. 89)". En ÁlVAREZ GARCÍA, F.J. / GONZÁLEZ CUSSAC, J.L., (Dirs.), Comentarios a la reforma penal de 2010. Valencia: Tirant lo Blanch. 2010.

GUTIÉRREZ ROMERO, F.M., “El tratamiento de los delitos sexuales en la nueva reforma del Código penal: especial referencia a la libertad vigilada". En Diario La Ley, núm. 7909, 2012.

HASSEMER, W., Einführung in die Grundlagen des Strafrechts. 2a Ed. München: C.H. Beck. 1990.

HASSEMER, W., “Neurociencias y culpabilidad en Derecho penal”. En InDret. Revista para el análisis del Derecho. 2/2011. Barcelona: 2011.

HAVA GARCÍA, E. / RÍOS CORBACHO, J.M., “Las medidas aplicables a menores en la ley 5/2000". En RUIZ RODRÍGUEZ, L.R. / NAVARRO GUZMÁN, J.I. (Coords.), Menores. Responsabilidad pena y atención psicosocial. Valencia: Tirnat lo Blanch. 2004.

HAVA GARCÍA, E. / MUÑOZ LORENTE, J., “Delitos relativos a la protección de la flora, la fauna y los animales domésticos". En ÁLVAREZ GARCÍA, F.J., (Dir.) / DOPICO GÓMEZ-ALLER, J., (Coord.), Estudio crítico sobre el Anteproyecto de Reforma penal de 2012. Valencia: Tirant lo Blanch. 2013.

HAVA GARCÍA, E. / VÁZQUEZ PORTOMEÑE, F. / PUENTE ABA, L.M. / ROCA AGAPITO, L. / CUGAT MAURI, M. / SÁNCHEZ TOMÁS J.M. / GARROCHO SALCEDO, A. / PORTILLA CONTRERAS, G., "Delitos contra la seguridad colectiva". En ÁlVAREZ GARCÍA, F.J., (Dir.) / DOPICO GÓMEZ-ALLER, J., (Coord.), Estudio crítico sobre el Anteproyecto de Reforma penal de 2012. Valencia: Tirant lo Blanch. 2013.

HEGEL, W.F., Fundamentos de la Filosofía del Derecho. 1820. Traducción de C. Díaz. Madrid: 
Libertarias/Prodhufi. 1993.

HERNÁNDEZ BASUALTO, H., "Sistemas penales comparados. Las medidas de seguridad. Alemania". En Revista Penal, núm. 23, 2008.

HERRERO-TEJEDOR ALGAR, F., “Terrorismo y tribunales militares”. En GONZÁLEZ CUSSAC, J.L. (Dir.) / FERNÁNDEZ HERNÁNDEZ, A., Fuerzas armadas y seguridad pública. Consideraciones en torno al terrorismo y la inmigración. Castellón. Universitat Jaume I. Col lecció “Estudis jurídics”, núm. 14. 2007.

HERRERO-TEJEDOR ALGAR, F., “La orden de protección”. En GÓMEZ COLOMER, J.L., (coord.), Tutela procesal frente a hechos de violencia de género. Col lecció “Estudis Jurídics" núm. 13. Castellón: Universitat Jaume I. 2007.

HENDLER, E.S., Derecho Penal y Procesal de los Estados Unidos. Buenos Aires: Ad-Hoc. 1996.

HIGUERA GUIMERÁ, J.F., Derecho penal juvenil. Barcelona: Bosch. 2003.

IGLESIAS RÍO, M.A., “La eximente de “anomalía o alteración psíquica”. (Art. 20.1 CP). Una problemática abierta hacia el futuro científico". En Anuario de Derecho Penal y Ciencias Penales. Tomo 56, núm. 1. 2003.

IGLESIAS RÍO, M.A., “Algunas reflexiones sobre retro-irretroactividad de la ley penal. A propósito de las últimas reformas del Código penal". En Revista jurídica de Castilla y León, núm. 6. Mayo de 2005.

IGLESIAS RÍO, M.A. / MANJÓN-CABEZA OLMEDA, A. / GÓMEZ LANZ, J. / TERRADILLOS BASOCO, J.M. / LAURENZO COPELLO, P. /POMARES CINTAS, E. / PÉREZ ALONSO, E. / RODRÍGUEZ MESA, M.J. / GUISASOLA LERMA, C., “Delitos contra la Hacienda Pública y la Seguridad Social”. En ÁLVAREZ GARCÍA, F.J., (Dir.) / DOPICO GÓMEZ-ALLER, J., (Coord.), Estudio crítico sobre el Anteproyecto de Reforma penal de 2012. Valencia: Tirant lo Blanch. 2013.

JAKOBS, G., Derecho penal. Parte General. Fundamentos y teoría de la imputación. $2^{\mathrm{a}}$ Ed. Traducida por J. Cuello Contreras y J.L. Serrano González de Murillo. Madrid: Marcial Pons. 1997.

JAKOBS, G. Sociedad, norma y persona en una teoría del Derecho penal funcional. Traducción de M. Cancio Meliá y B. Feijóo Sánchez. Madrid: Civitas. 1996.

JAKOBS, G., Sobre la teoría de la pena. Traducción de Manuel Cancio Meliá. Cuadernos de conferencias y artículos, núm. 16. Bogotá: Universidad Externado de Colombia. Centro de Investigaciones de Derecho Penal y Filosofía del Derecho. 1998.

JAKOBS, G. / CANCIO MELIÁ, M., Derecho penal del enemigo. $2^{\mathrm{a}}$ Ed. Madrid: Thomson 
Civitas. 2006.

JAKOBS, G., La Pena Estatal. Significado y Finalidad. Traducción de M. Cancio Meliá y B. Feijóo Sánchez. Navarra: Thomson Civitas. 2006.

JAKOBS, G., El Derecho penal como disciplina científica. Traducción de A. Van Weezel. Navarra: Civitas. 2008.

JAKOBS, G., “Coacción y personalidad. Reflexiones sobre una teoría de las medidas de seguridad complementarias a la pena". En InDret. Revista para el análisis del Derecho. 1/2009. Barcelona: 2009.

LARGUIER, J., Droit pénal général. 19ª Ed. Paris. Dalloz. 2003.

JESCHECK, H.H., Tratado de Derecho Penal. Parte General. $4^{\mathrm{a}}$ Ed. Traducida por J.L. Manzanares Samaniego, Granada: Comares.1993.

JIMÉNEZ BARBERO, M.A., “La ejecución de la pena”. En Revista de Ciencias Penales, Vol. 1 $\mathrm{N}^{\mathrm{o}} 1,1998$.

JIMÉNEZ DE ASÚA, L., Al servicio del Derecho penal. Madrid, 1930.

JIMÉNEZ DE ASÚA, L., Principios de Derecho penal. La ley y el delito. $3^{\text {a }}$ Ed. 1958. Buenos Aires: Abeledo-Perrot. Reimpresión de 1997.

JIMÉNEZ VILLAREJO, J., en CONDE-PUMPIDO FERREIRO, C., (Dir.), Código penal. Doctrina y jurisprudencia. Tomo I. Madrid: Trivium. 1997.

JORGE BARREIRO, A., Las medidas de seguridad en el Derecho español. Madrid: Civitas. 1976.

JORGE BARREIRO, A., en RODRÍGUEZ MOURULLO, G. (Dir.) / JORGE BARREIRO, A. (Coord.), Comentarios al Código Penal. Madrid: Civitas. 1997.

JORGE BARREIRO, A., en COBO DEL ROSAL, M., (Dir.), Comentarios al Código penal. Tomo IV. Madrid: Edersa. 1999.

JORGE BARREIRO, A., “Reflexiones sobre la compatibilidad de las medidas de seguridad en el CP de 1995 con las exigencias del Estado de derecho". En Homenaje al Prof. Rodríguez Mourullo. Madrid: Civitas. 2005.

JORGE BARREIRO, A., "Reflexiones sobre la problemática actual y el futuro de las medidas de seguridad criminales: su regulación en el Derecho penal español y en el Derecho comparado". En LUZÓN PEÑA, D.M., (Dir.), Derecho penal del Estado social y democrático de Derecho. Libro homenaje a Santiago Mir Puig. Madrid: La Ley. 2010.

JORGE BARREIRO, A., en LASCURAÍN SÁNCHEZ, J.A., Introducción al Derecho penal. Navarra: Civitas. 2011.

KANT, I., La metafísica de las costumbres. 1797. Traducción y notas de Adela Cortina Orts y 
Jesús Conill Sancho. Barcelona: Atalaya. 1993.

KAUFMANN, A., “Die Aufgabe des Strafrechs”, Stafrechtsdogmatik zwischen Sein und Wert. Gesammelte Aufsätze und Vorträge. Köln: Carl Heymanns Verlag KG. 1982.

KELSEN, H., Teoría pura del Derecho. 1934. $3^{\text {a }}$ Ed. Buenos Aires. Editorial Universitaria de Buenos Aires. 1970.

KERTSCHMER, E., Constitución y carácter. Traducción de J. Solé Segarra de la edición alemana, (Körperbau und Charakter, Berlin: Springer. 1921), Barcelona: Labor. 1947.

LANDECHO VELASCO, C.M., en COBO DEL ROSAL, M., (Dir.), Comentarios al Código penal. Tomo IV. Madrid: Edersa. 1999.

LANDECHO VELASCO C.M., / MOLINA BLÁZQUEZ, C., Derecho Penal Español. Parte General. Madrid: Tecnos. 2010.

LAMARCA PÉREZ, C., “La regulación del terrorismo en el código penal español”. En PÉREZ ÁlVAREZ, F., (Edit.), Vniversitas Vitae, homenaje a Ruperto Núñez Barbero. Salamanca: Aquílafuente. Ediciones Universidad de Salamanca. 2007.

LAMARCA PÉREZ, C., “Delitos contra la libertad e indemnidad sexuales”. En LAMARCA PÉREZ, C. (Coord.), Derecho penal. Parte especial. $6^{a}$ Ed. Madrid: Colex. 2011.

LAMARCA PÉREZ, C., “Delitos contra el orden público”. En LAMARCA PÉREZ, C. (Coord.), Derecho penal. Parte especial. $6^{\text {a }}$ Ed. Madrid: Colex. 2011.

LANDROVE DÍAZ, G., Las consecuencias jurídicas del delito. $6^{\mathrm{a}}$ Ed. Madrid: Tecnos 2005.

LASCURAÍN SÁNCHEZ, J.A., “Por un Derecho Penal solo penal: Derecho Penal, Derecho de medidas y Derecho Administrativo sancionador". En Homenaje al Prof. Rodríguez Mourullo. Madrid: Civitas. 2005.

LAYLLE CONTRERAS, L.B., "Análisis jurídico de la aplicación de medidas de seguridad en el Hospital Nacional de salud mental de Guatemala". Tesis. Guatemala: Universidad de San Carlos de Guatemala. 2007.

LEAL MEDINA, J., La historia de las medidas de seguridad. De las instituciones preventivas más remotas a los criterios científicos penales modernos. Navarra: Thomson Aranzadi. 2006.

LEAL MEDINA, J., “Un estudio de las actuales medidas de seguridad y los interrogantes que plantean en la moderna dogmática del Derecho penal". En Revista Aranzadi de Derecho y Proceso Penal, núm. 20. Navarra: Thomson Aranzadi. 2008.

LEAL MEDINA, J., “La custodia familiar. Pasado, presente y futuro de una medida de seguridad insuficientemente regulada y de difícil encaje en el Derecho penal". En 
Revista La Ley, núm. 2, 2006.

LEGANÉS GÓMEZ, S., “La expulsión de los penados extranjeros”. En La Ley Penal, núm. 91, 2012.

LEGANÉS GÓMEZ, S., “Clasificación penitenciaria y libertad vigilada”. En La Ley Penal, núm. 96-97, 2012.

LEROY, J., Droit pénal général. $3^{\text {a }}$ Ed. Paris: L.G.D.J. Lextenso Editions. 2010.

LISZT, F., Tratado de Derecho Penal, $4^{\mathrm{a}}$ Ed. 1926. Traducido de la 20 a Edición Alemana por Luis Jiménez de Asúa. Tomo II. Madrid: Reus. 1999.

LISZT, F., Tratado de Derecho Penal, $4^{\mathrm{a}}$ Ed. 1926. Traducido de la 20a Edición Alemana por Luis Jiménez de Asúa. Tomo III. Madrid: Reus. 1999.

LISZT, F., Der Zweekgedanke im Strafrecht. 1882. Traducción de C. Pérez del Valle, La idea del fin en Derecho penal. Granada: Comares. 1995.

LLOBET ANGLI, M., “Tenencia, tráfico y depósito de armas o municiones, organizaciones y grupos criminales y delitos de terrorismo". En SILVA SÁNCHEZ, J.M. (Dir.) / PASTOR MUÑOZ, N., (Coord.), El nuevo Código Penal. Comentarios a la reforma. Madrid: La Ley. 2012.

LLORCA ORTEGA, J., Manual de determinación de la pena. $6^{\mathrm{a}}$ Ed. Valencia: Tirant lo Blanch. 2005.

LOMBROSO, C., Los criminales. Barcelona: Centro editorial Presa. 1876.

LOMBROSO, C., L'uomo delinquente.Torino: Fratelli Boca Editori. 1889.

LOMBROSO, C. / FERRERO, G., La donna delinquente, la prostitutita en la donna normale. Torino: Frateli Bocca Editore. 1903.

LÓPEZ BARJA DE QUIROGA, J., Tratado de Derecho Procesal Penal. Tomo I. $5^{\text {a }}$ Ed. Navarra: Thomson Aranzadi. 2012.

LÓPEZ CABRAL, M.O., Código Penal paraguayo. $2^{\mathrm{a}}$ Ed. Asunción: Intercontinental. 2009.

LÓPEZ LÓPEZ, A.M., La Ley Penal del Menor y el Reglamento para su aplicación. Comentarios, concordancias y jurisprudencia. Comares, 2007.

LÓPEZ LÓPEZ, A. / DE URBANO CASTRILLO, E., en SÁNCHEZ MELGAR, Julián (coord.), Ley de Enjuiciamiento Criminal. Comentarios y jurisprudencia. Tomo II. Madrid: Sepín. 2010.

LORCA NAVARRETE, A.M. (Dir.) / GUILARTE GUTIÉRREZ, V. (Coord.), Comentarios a la nueva Ley de Enjuiciamiento Civil. Tomo IV. Valladolid: Lex Nova. 2000.

LOZANO BLANCO, J., en TORIBIOS FUENTES, F. (Dir.), Comentarios a la Ley de Enjuiciamiento Civil. Valladolid: Lex Nova. 2012. 
LUACES GUTIÉRREZ, A.I., “Cuestiones controvertidas en torno al procedimiento para decidir sobre la medida de libertad vigilada". En NEIRA PENA, A. (Coord.) / PÉREZ-CRUZ MARTÍN, A.J. (Dir. Congr.) / FERREIRO BAAMONDE, X. (Dir. Congr.), Los retos del Poder Judicial ante la sociedad globalizada: Actas del IV Congreso Gallego de Derecho Procesal (I Internacional), A Coruña, 2 y 3 de junio de 2011. 2012.

LUZÓN CUESTA, J.M, Compendio de Derecho Penal. Parte General. 18 ${ }^{\mathrm{a}}$ Ed. Madrid: Dykinson. 2010.

LLORCA GARCÍA, P., “La ejecución de las medidas”. En GÓMEZ RIVERO, M., C., Comentarios a la Ley Penal del Menor (Conforme a las reformas introducidas por la LO 8/2006). Madrid: Iustel. 2007.

MAGRO SERVET, V., “Competencia de la administración penitenciaria para la ejecución de las medidas de seguridad no privativas de libertad, y penas y medidas alternativas a la prisión (Desarrollo de lo dispuesto en el Real Decreto 840/2011, de 17 de junio). En La Ley Penal, núm. 106, 2014.

MAGRO SERVET V. / SOLAZ SOLAZ, E., Manual Práctico sobre Ejecución Penal. Las medidas alternativas a la prisión: suspensión, sustitución y expulsión. $2^{\text {a }}$ Ed. Madrid: La Ley. 2010. Pág. 225.

MAGGIORE, G., Derecho penal. Vol. II. El delito. La pena. Medidas de seguridad y sanciones civiles. Traducción de la $5^{\mathrm{a}}$ Ed. italiana por José J. Ortega Torres. Bogotá: Temis. 1954.

MANIGOT, M.A., Código Penal de la Nación Argentina. Anotado y comentado. Buenos Aires: Abeledo-Perrot. 1969.

MANTOVANI, F., “El Derecho penal del enemigo, el Derecho penal del amigo, el enemigo del Derecho Penal, y el amigo del Derecho penal". En GARCÍA VALDÉS, C. / CUERDA RIEZU, A. / MARTÍNEZ ESCAMILLA, M. / ALCÁCER GUIRAO, R. / VALLE MARISCAL DE GANTE, M., (Coords.), Estudios penales en homenaje a Enrique Gimbernat. Madrid: Edisofer. 2008.

MANZANARES SAMANIEGO, J.L., “La libertad vigilada”. En Diario La Ley, núm. 7534. Especial Reforma del Código Penal, 2010.

MAPELLI CAFFARENA, B., Las consecuencias jurídicas del delito. $5^{\mathrm{a}}$ Ed. Navarra: Civitas. 2011.

MAPELLI CAFFARENA, B. / TERRADILLOS BASOCO J.M., Las consecuencias jurídicas del delito, $3^{\text {a }}$ Ed. Madrid: Civitas. 1996.

MAPELLI CAFFARENA, B. / GONZÁLEZ CANO, M.I. / AGUADO CORREA, T., 
Comentarios a la Ley Orgánica 5/2000 Reguladora de la Responsabilidad Penal de los Menores. Sevilla: Junta de Andalucía. Consejería de Justicia y Administración Pública. Instituto Andaluz de Administración Pública. 2002.

MARAVER GÓMEZ, M., “La trata de seres humanos”. En En DÍAZ-MAROTO y VILlAREJO, J., (Dir.), Estudios sobre las reformas del Código Penal. Operadas por las LO 5/2010, de 22 de junio, y 3/2011, de 28 de enero. Navarra: Civitas. 2011.

MARTÍN HERNÁNDEZ, M.A., “ ¿Cabe la sustitución de la pena de privación de libertad por una medida de seguridad en el caso de concurrencia de la atenuante de grave drogadicción?" En GUZMÁN DÁLBORA, J.L. / SERRANO MAÍlLO, A., (Coords.), Derecho penal y Criminología como fundamento de la política criminal. Estudios en homenaje al Profesor Alfonso Serrano Gómez. Madrid: Dykinson. 2006.

MARTÍN PALLÍN, J.A., “Reforma penal y prisión perpetua revisable. La prisión tiene un límite". En Notario del Siglo XXI, núm. 52, 2013.

MARTÍN SÁNCHEZ, A., “Las medidas en la Ley Orgánica 5/20010, de 12 de enero de responsabilidad penal de los menores". En ORNOSA FERNÁNDEZ, M.R. (Dir.), La responsabilidad penal de los menores: aspectos sustantivos y procesales. Cuadernos de Derecho Judicial. Madrid: CGPJ. 2001.

MARTÍNEZ GARAY, L., “La incertidumbre de los pronósticos de seguridad: consecuencias para la dogmática de las medidas de seguridad". En InDret. Revista para el análisis del Derecho. 2/2014. Barcelona. 2014.

MARTÍNEZ GARAY, L., "Minority Report: pre-crimen y pre-castigo. Prevención y predicción". En VIVES ANTÓN, T.S. / CARBONELL MATEU, J.C. / GONZÁLEZ CUSSAC, J.L. / ALONSO RIMO, A. / ROIG TORRES, M., (Dirs.), Crímenes y castigos. Miradas al Derecho penal a través del arte y la cultura. Valencia: Tirant lo Blanch. 2014.

MARTÍNEZ GONZÁLEZ, I., “De las medidas”. En GÓMEZ RIVERO, M.C., Comentarios a la Ley Penal del Menor (Conforme a las reformas introducidas por la LO 8/2006). Madrid: Iustel. 2007.

MARTÍNEZ SERRANO, A., "Principios sustantivos y procesales básicos de la responsabilidad penal de los menores establecidos en la LO 5/2000". En ORNOSA FERNÁNDEZ, M.R. (Dir.), La responsabilidad penal de los menores: aspectos sustantivos y procesales. Cuadernos de Derecho Judicial. Madrid: CGPJ. 2001.

MARTÍNEZ-BUJÁN PÉREZ, C.M., “Delitos contra la Hacienda Pública y contra la Seguridad Social". En VIVES ANTÓN, T.S., ORTS BERENGUER, E., CARBONELL 
MATEU, J.C., GONZÁLEZ CUSSAC, J.L., MARTÍNEZ-BUJÁN PÉREZ, C.M., Derecho Penal Parte Especial. Tirant Lo Blanch, 2010.

MEDINA SCHULZ, G., "Sistemas penales comparados. Principales reformas en la legislación penal y procesal (2003-2006). Alemania". En Revista penal, núm. 18. 2006.

MERKEL, G., "Incompatible Contrasts? - Preventive Detention in Germany and the European Convention on Human Rights". En German Law Journal, Vol. 11, núm. $09,2010$.

MESTRE DELGADO, E., "Delitos contra la Administración de Justicia”. En LAMARCA PÉREZ, C. (Coord.), Derecho penal. Parte especial. 6ª Ed. Madrid: Colex. 2011.

MEZGER, E., Modernas orientaciones de la dogmática jurídico-penal. Traducción de Francisco Muñoz Conde. Valencia: Tirant lo Blanch. 2000.

MEZGER, E., Tratado de Derecho penal. Traducción de la $2^{\mathrm{a}}$ Ed. Alemana (1933) y notas de Derecho español por J.A. Rodríguez Muñoz. Madrid: Revista de Derecho privado. 1935. Tomo II.

MILTON PERALTA, J., “Prevención general positiva como respeto por el orden jurídico. A su vez, una distinción analítica entre distintos conceptos de "prevención general positiva"." En InDret. Revista para el análisis del Derecho. 2/2008. Barcelona: 2008.

MIR PUIG, S., Derecho penal. Parte general. $8^{\text {a }}$ Ed. Barcelona: Reppertor. 2008.

MOLFESSIS, N. (Dir.) / DESPORTES, F. / LE GUNEHEC, F., Droit pénal général. 9a Ed. Paris: Economica. 2002.

MONGE FERNÁNDEZ, A., La circunstancia agravante de reincidencia desde los fundamentos y fines de la pena. Barcelona: Bosch. 2009.

MONGE FERNÁNDEZ, A., De los abusos sexuales a menores de trece años. Análisis de los arts. 183 y 183 bis CP, conforme a la LO 5/2010. Barcelona: Bosch. 2011.

MONTERO AROCA, J., Principios del proceso penal. Una explicación basada en la razón. Valencia: Tirant lo Blanch. 1997.

MONTERO AROCA, J., Proceso Penal y Libertad. Ensayo polémico sobre el nuevo proceso penal. Navarra. Thomson Civitas. 2008.

MONTERO AROCA, J., “La Jurisdicción”. En MONTERO AROCA, J. / GÓMEZ COLOMER, J.L. / MONTÓN REDONDO, A. / BARONA VILAR, S., Derecho Jurisdiccional I. Parte General. 21 a Ed. Valencia: Tirant lo Blanch. 2013.

MONTERO HERNÁNDEZ, T., La justicia juvenil en España. Comentarios y reflexiones. Madrid: La Ley. 2009. 
MONTÓN REDONDO, A., “Los actos de investigación”. En MONTERO AROCA, J. / GÓMEZ COLOMER, J.L. / MONTÓN REDONDO, A. / BARONA VILAR, S., Derecho Jurisdiccional III. Proceso Penal. 21ª Ed. Valencia: Tirant lo Blanch. 2013.

MORA ALARCÓN, J.A., Derecho penal y procesal de menores. Valencia: Tirant lo Blanch. 2002.

MORA RODAS, N.A., Código Penal paraguayo comentado. $4^{a}$ Ed. Asunción: Intercontinental. 2009.

MORAL DE LA ROSA, J., Aspectos penales y criminológicos del terrorismo. Madrid: Centro de Estudios Financieros. 2005.

MORALES PRATS, F., La alteración en la percepción (art. $8.2 \mathrm{CP}$ ): contenido y límites, en Jornadas sobre psiquiatría forense. Madrid: Centro de Estudios Judiciales. 1990.

MORALES PRATS, F., “La responsabilidad penal de las personas jurídicas, arts. 31 bis, 31.2 supresión, 33.7, 66 bis y 130.2 CP". En QUINTERO OLIVARES, G., (Dir.), La Reforma Penal de 2010: Análisis y Comentarios. Navarra. Thomson Aranzadi. 2010.

MORENILLA RODRÍGUEZ, J.M., "Peligrosidad social y la tipología del sujeto peligroso".

En Documentación Jurídica núm. 20. Madrid: Ministerio de Justicia, Secretaría General Técnica. 1978.

MORENO CATENA, V. (Dir.) / COQUILLAT VICENTE, A. / DE DIEGO DÍEZ, A. / JUANES PECES, A. / DE LLERA SUÁREZ BÁRCENA, E., El Proceso penal. Doctrina, jurisprudencia y formularios. Vol. V. Valencia: Tirant lo Blanch. 2000.

MORILLAS CUEVA, L., "Alternativas a la pena de prisión”. En Cuadernos de Derecho Judicial, núm. XXII. Derecho penitenciario: incidencia de las nuevas modificaciones. Madrid: Consejo General del Poder Judicial. 2006.

MUÑOZ CONDE, F. / GARCÍA ARÁN, M., Derecho Penal. Parte General. $8^{\mathrm{a}}$ Ed. Valencia: Tirant lo Blanch. 2010.

MUÑOZ CONDE, F., Derecho penal. Parte especial. 19a Ed. Valencia: Tirant lo Blanch. 2013. MUÑOZ CONDE. F. / GARCÍA ARÁN, M., Derecho penal. Parte especial. 18ª Ed. Valencia: Tirant lo Blanch. 2010.

MUÑOZ CONDE, F., “De nuevo sobre el "Derecho penal del enemigo"“. En PÉREZ ÁlVAREZ, F., (Edit.), Vniversitas Vitae, homenaje a Ruperto Núñez Barbero. Salamanca: Aquílafuente. 2007.

MUÑOZ CONDE, F., “Las reformas de la Parte Especial del Código Penal español de 2003, de la tolerancia cero al derecho penal del enemigo". En Revista de Derecho penal, núm. 2. Buenos Aires. 2005. 
NARANJO DE LA CRUZ, R., “Derechos fundamentales”. En AGUDO ZAMORA, M. / ÁlVAREZ-OSSORIO MICHEO, F. / GÓMEZ CORONA, E. / MARTÍNEZ RUANO, P. / MORALES ARROYO, J.M. / NARANJO DE LA CRUZ, R. / PÉREZ SOLA, N. / PORRAS NADALES, A. / RASCÓN ORTEGA, J.L. / REVENGA SÁNCHEZ, M. / RODRÍGUEZ, A. / SALAZAR BENÍTEZ, O., Manual de Derecho Constitucional. $2^{\text {a }}$ Ed. Madrid: Tecnos. 2011.

NARVÁEZ MORA, M., “El impacto de la neurociencia sobre el derecho: el caso de la responsabilidad subjetiva". En Revista Telemática de Filosofía del Derecho, núm. 15. 2012.

NAUCKE, W., "Prevención general y derechos fundamentales de la persona". En NAUCKE, W. / HASSEMER, W. / LÜDERSSEN, K., Principales problemas de la prevención general. Traducción de Traducción de Gustavo Eduardo Aboso y Tea Löw, Buenos Aires-Montevideo: Bdef. 2004.

NAVARRO FRÍAS, I., “Psicopatía y medidas de seguridad. El caso de los psicópatas sexuales y la libertad vigilada tras la última reforma del Código Penal". En Cuadernos de política criminal, núm. 105, 2011.

NELLYS, M., Electronic Monitoring and Community Supervision: Origins, Uses, Effects and Prospects. I Jornada de Criminologia "Control penal i prevenció del delicte en la societat de la informació". Barcelona: CEJFE-UOC. 2011.

NICOLÁS GUARDIOLA J.J. “Recomendaciones internacionales en materia penitenciaria”. En NICOLÁS GUARDIOLA J.J. (Dir.) / GINER ALEGRÍA, C.A. (Coord.), Prevención, predicción y tratamiento. Condenados a penas privativas de libertad. Murcia: DM. 2011.

NIÑO, L.F., “Sistemas penales comparados. Las medidas de seguridad”. Argentina. En Revista Penal, núm. 23, 2008.

NISTAL BURÓN, J., “La "libertad vigilada". La dificultad de su aplicación práctica. (A propósito de la nueva medida de seguridad no privativa de libertad que prevé el Proyecto de Ley Orgánica de reforma del Código Penal de 1995)”. En Diario La Ley, núm. 7368, 2010.

NOVAKOVSKY, F., “Freiheit, Schuld, vergeltung”, Festschrift für Thodor Rittler, 1957.

Novisima Recopilación de las Leyes de España. Mandada formar por el Señor Carlos IV. Dividida en XII libros en que se reforma la Recopilación publicada por el Señor Don Felipe II en el año de 1567, reimpresa últimamente en el de 1775. Y se incorporan las pragmáticas, cédulas, decretos, órdenes y resoluciones Reales, y otras providencias no 
recopiladas, y expedidas hasta el de 1804. Madrid: 1805.

OBREGÓN GARCÍA, A., La eximente del art. 20.2, inciso $1^{\circ} \mathrm{CP}$ : estado de intoxicación plena por consumo de alcohol u otras drogas. En Estudios de Derecho judicial, núm. 110. Actual doctrina de la imputabilidad. Madrid: Consejo General del Poder Judicial. 2007.

OlÁSOlO ALONSO, H. / PÉREZ CEPEDA, A.I., Terrorismo internacional y conflicto armado. Valencia: Tirant lo Blanch. 2008.

ORNOSA FERNÁNDEZ, M.R., Derecho Penal de Menores. Comentarios a la Ley Orgánica 5/200, de 12 de enero, reguladora de la responsabilidad penal de los menores y a su Reglamento aprobado por Real Decreto 1774/2004, de 30 de julio. $3^{\mathrm{a}}$ Ed. Barcelona: Bosch. 2005.

ORTELLS RAMOS, M. / CUCARELLA GALIANA, L.A., en GIMENO SENDRA, V. (Dir.), Proceso civil práctivo. Tomo X. $4^{\text {a }}$ Ed. Madrid: La Ley. 2010.

ORTS BERENGUER, E., "Delitos contra la libertad e indemnidad sexuales". En VIVES ANTÓN, T.S. / ORTS BERENGUER, E. / CARBONELL MATEU, J.C. / GONZÁLEZ CUSSAC, J.L. / MARTÍNEZ-BUJÁN PÉREZ, C., Derecho Penal. Parte Especial. $3^{\text {a }}$ Ed. Valencia: Tirant lo Blanch, 2010.

ORTS BERENGUER, E., “Delitos contra la administración pública”. En VIVES ANTÓN, T.S., ORTS BERENGUER, E., CARBONELL MATEU, J.C., GONZÁLEZ CUSSAC, J.L., MARTÍNEZ-BUJÁN PÉREZ, C.M., Derecho Penal Parte Especial. Tirant Lo Blanch. 2010.

ORTS BERENGUER, E., "Delitos contra la Administración de Justicia". En VIVES ANTÓN, T.S. / ORTS BERENGUER, E. / CARBONELL MATEU, J.C. / GONZÁLEZ CUSSAC, J.L. / MARTÍNEZ-BUJÁN PÉREZ, C., Derecho Penal. Parte Especial. $3^{\text {a }}$ Ed. Valencia: Tirant lo Blanch. 2010. Lección XL-10. DVD.

ORTS BERENGUER, E., “Quebrantamiento de condena”. En VIVES ANTÓN, T.S. / ORTS BERENGUER, E. / CARBONELL MATEU, J.C. / GONZÁlEZ CUSSAC, J.L. / MARTÍNEZ-BUJÁN PÉREZ, C., Derecho Penal. Parte Especial. $3^{\mathrm{a}}$ Ed. Valencia: Tirant lo Blanch. 2010

ORTS BERENGUER, E. / SUÁREZ-MIRA RODRÍGUEZ, C., Los delitos contra la libertad e indemnidad sexuales. Valencia: Tirant lo Blanch. 2001.

ORTS BERENGUER, E. / GONZÁLEZ CUSSAC, J.L., Compendio de Derecho Penal. Parte General. $3^{\text {a }}$ Ed. Valencia: Tirant lo Blanch. 2011.

PACHECO, F., El Código Penal comentado y concordado de 1848. Tema I, Introducción. $5^{\mathrm{a}}$ Ed. 
Madrid. 1853.

PAGLIARDO, A., Principi de Dirito penale. Parte generale. Quarta edizione. Milano: Dott. A. Giuffrè Editore. 1993.

PARDO, M.S., / PATERSON, D., "Fundamentos filosóficos del Derecho y la neurociencia". En InDret. Revista para el análisis del Derecho. 2/2011. Barcelona: 2011.

PEÑARANDA RAMOS, E., “El delito de asesinato”. En ÁLVAREZ GARCÍA, F.J., (Dir.) / DOPICO GÓMEZ-ALLER, J., (Coord.), Estudio crítico sobre el Anteproyecto de Reforma penal de 2012. Valencia: Tirant lo Blanch. 2013.

PÉREZ CEPEDA, A.I. / FERNÁNDEZ GARCÍA, J., “Los establecimientos penitenciarios” En BERDUGO GÓMEZ DE LA TORRE, I., (Coord.) Lecciones y materiales para el Estudio del Derecho penal. Tomo VI. Derecho penitenciario. Madrid: Iustel. 2010.

PÉREZ CEPEDA, A.I., "Prólogo". En PÉREZ CEPEDA, A.I. (Dir.) / GORJÓN BARRANCO, M.C., El Proyecto de Reforma del Código penal de 2013 a debate. Salamanca: Ratio Legis. 2014.

PÉREZ MANZANO, M., La prohibición de incurrir en "bis in ídem". Valencia: Tirant lo Blanch. 2002.

PÉREZ MANZANO, M., “Fundamento y fines de Derecho penal. Una revisión a la luz de las aportaciones de la Neurociencia". En InDret. Revista para el análisis del Derecho. 2/2011. Barcelona: 2011.

PÉREZ RAMÍREZ, M. / MARTÍNEZ GARCÍA, M. / REDONDO ILLESCAS, S., "Evaluación y predicción del riesgo de reincidencia en agresores sexuales". En Documentos de Trabajo. Investigación: Delitos sexuales y reincidencia. Barcelona: Centre d’Estudis Jurídics i Formació Especialitzada. 2009.

PÉREZ TREMPS, P., “Los derechos fundamentales”. En LÓPEZ GUERRA, L. / ESPÍN, E. / GARCÍA MORILLO, J. / PÉREZ TREMPS, P. / SATRÚSTEGUI, M., Derecho Constitucional. Vol. I. El ordenamiento constitucional. Derechos y deberes de los

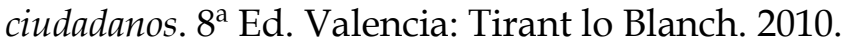

PÉREZ Y LÓPEZ, A.J., Teatro de la legislación universal de España é Indias. Por orden cronológico de sus cuerpos y decisiones no recopiladas; y alfabético de sus títulos y principales materias. Madrid: Imprenta de Don Antonio Espinosa. 1797. Tomo XVI.

PIGHI, G., "Sistemas penales comparados. Las medidas de seguridad. Italia”. En Revista Penal, núm. 23, 2008.

PLATÓN, “Gorgias”. En PLATÓN, Obras completas. Traducción de Patricio de Azcárate. 
Tomo 5. Madrid: Medina y Navarro. 1871.

PLATÓN, “Las leyes. Libro noveno”. PLATÓN, Obras completas. Traducción de Patricio de Azcárate. Tomo 10. Madrid: Medina y Navarro. 1872.

POLAINO NAVARRETE, M., Derecho penal. Parte general. Tomo I. Fundamentos científicos del Derecho penal. 6a Ed. Barcelona: Bosch. 2008.

POLAINO NAVARRETE, M., “Entre el Derecho penal simbólico y el Derecho penal del enemigo: la represión punitiva de la llamada "violencia de género"“. En DÍAZ-MAROTO VILLAREJO (Coord.), Derecho y Justicia penal en el S XXI. Liber amicorum, Homenaje al profesor Antonio González-Cuellar García. Madrid: Colex. 2006.

POLO RODRÍGUEZ, J.J. / HUÉLAMO BUENDÍA, A.J., La nueva Ley Penal del Menor. $3^{\mathrm{a}}$ Ed. Madrid: Colex 2007.

PORTILLA CONTRERAS, G., “La reforma en los actos preparatorios y favorecimiento de delitos de terrorismo". En QUINTERO OLIVARES, G., (Dir.) La Reforma Penal de 2010: Análisis y Comentarios. Navarra: Thomson Aranzadi. 2010.

PORTILLA CONTRERAS, G., “La exclusión de la inmigración ilegal del espacio físico y moral: un nuevo Narrenschiff Europeo". En ÁLVAREZ GARCÍA, F.J. (Dir.), La adecuación del Derecho penal español al ordenamiento de la Unión Europea. La política criminal europea. Valencia: Tirant lo Blanch. 2009.

PRADEL, J., Droit Pénal général. 16ª Ed. Paris: Éditions Cujas. 2006.

PRIETO SANCHÍS, L., Garantismo y Derecho penal. Madrid: Iustel. 2011.

PUERTA LUIS, L.R., Causas de inimputabilidad: anomalías y alteraciones psíquicas. Trastorno mental transitorio. En Estudios de Derecho judicial, núm. 110. Actual doctrina de la imputabilidad. Madrid: Consejo General del Poder Judicial. 2007.

QUERALT JIMÉNEZ, J.J., Derecho penal. Parte especial. 6a Ed. Barcelona: Atelier. 2010.

QUINTERO OLIVARES, G. (DIR.) / MORALES PRATS, F., (Coord.) / TAMARIT SUMAllA, J.M. / GARCÍA ALBERO, R., Comentarios al Código Penal. $6^{\mathrm{a}}$ Ed. Pamplona: Thomson Aranzadi, 2008.

QUINTANO RIPOLLÉS, A., Curso de Derecho Penal. Tomo I. Madrid: Editorial Revista de Derecho Privado. 1963.

RAMOS, J.P., Curso de Derecho penal. Tomo I. Fundamentos y teorías generales. Buenos Aires: Ariel. 1927.

RAMOS MÉNDEZ, F., Enjuiciamiento Criminal. Nueva lectura constitucional. Barcelona: Atelier. 2010. 
RAMOS TAPIA, M.I., en ZUGALDÍA ESPINAR, J.M. / MARÍN DE ESPINOSA CEBALlOS, E.B. (Dirs.), Derecho penal. Parte especial. Un estudio a través del sistema de casos resueltos. Tomo I. $3^{\text {a }}$ Ed. Valencia: Tirant lo Blanch. 2011.

RAMOS VÁZQUEZ, J.A., "Del otro lado del espejo: reflexiones desordenadas acerca del Derecho penal en la sociedad actual". En FARALDO CABANA, P., (Dir.) / BRANDARIZ GARCIA, J.A., / PUENTE ABA, L.M., (Coords.), Nuevos retos del Derecho penal en la era de la globalización. Valencia: Tirant lo Blanch. 2004.

RAMOS VÁZQUEZ, J.A., Ciencia, libertad y Derecho penal. (Aporías del determinismo y defensa de la libertad de acción como base del sistema penal). Valencia: Tirant lo Blanch. 2013.

REBOLLO VARGAS, R., La llibertat vigilada: pena accessòria o mesura de seguretat contra els condemnats per delictes sexuals $i$ delictes de terrorisme. Barcelona: Centre d'Estudis Jurídics i Formació Especialitzada. 2010.

REBOLLO VARGAS, R., “De las medidas de seguridad”. En CÓRDOBA RODA, J. / GARCíA ARÁN, M., (Dirs.), Comentarios al Código Penal. Parte General. Madrid: Marcial Pons. 2011.

REQUEJO RODRÍGUEZ, P., “Peligrosidad criminal y Constitución”. En Indret. Revista para el Análisis del Derecho, 3/2008. Barcelona: 2008.

RIFA SOLER, J.M. / VALLS GOMBAU, J.F. / RICHARD GONZÁLEZ, M., El proceso penal práctivo. $6^{\text {a }}$ Ed. Madrid: La Ley. 2009.

RÍOS MARTÍN, J.C., “La libertad condicional. Límites en el concurso real de delitos: especial referencia a la sentencia Parot". En Cuadernos de Derecho Judicial, núm. XXII. Derecho penitenciario: incidencia de las nuevas modificaciones. Madrid: Consejo General del Poder Judicial. 2006.

RIUS DIEGO, F.J., Análisis policial del Código Penal. 3ª Ed. Madrid: Tecnos. 2011.

ROBLES PLANAS, R., "Sexual Predators. Estrategias del Derecho Penal de la peligrosidad". En InDret. Revista para el análisis del Derecho. 4/2007. Barcelona, 2007.

ROCA AGAPITO, L., El sistema de sanciones penales en el derecho penal español. Barcelona: Bosch Penal, 2007.

ROCA POVEDA, M., “La libertad vigilada. Notas desde una visión penitenciaria”. En La Ley Penal, núm. 96-97, 2012.

RODRÍGUEZ ALONSO, A. / RODRÍGUEZ AVILÉS, J.A., Lecciones de Derecho penitenciario. $4^{\text {a }}$ Ed. Granada: Comares. 2011. 
RODRÍGUEZ DEVESA, J.M. / SERRANO GÓMEZ, A., Derecho penal español. Parte general. 18a Ed. Madrid: Dykinson. 1995.

RODRÍGUEZ LÓPEZ, P., Ley orgánica de Responsabilidad Penal de los Menores. Especial análisis de la reparación del daño. Madrid: Dijusa. 2005.

RODRÍGUEZ MOURULLO, G., Derecho Penal. Parte General. Madrid: Civitas. 1978.

RODRÍGUEZ PUERTA, M.J. / CABRERA MARTÍN, M. / RAMOS TAPIA, M.I. / MIRÓ LINARES, F. / MORÓN LERMA, E. / RODRÍGUEZ PUERTA, M.J. / FERNÁNDEZ TERUELO, J.G., “Delitos contra la indemnidad sexual”. En ÁLVAREZ GARCÍA, F.J., (Dir.) / DOPICO GÓMEZ-ALLER, J., (Coord.), Estudio crítico sobre el Anteproyecto de Reforma penal de 2012. Valencia: Tirant lo Blanch. 2013.

RODRÍGUEZ YAGÜE, C. / GUISASOLA LERMA, C. / ACALE SÁNCHEZ, M., “Libertad condicional: Artículos 90, 91, 92 y 93 CP”. En ÁLVAREZ GARCÍA, F.J., (Dir.) / DOPICO GÓMEZ-ALLER, J., (Coord.), Estudio crítico sobre el Anteproyecto de Reforma penal de 2012. Valencia: Tirant lo Blanch. 2013.

RODRÍGUEZ RAMOS, L., Compendio de Derecho penal. Parte general. Madrid: Dykinson. 2006 .

RODRÍGUEZ RAMOS, L., Compendio de Derecho Penal. Parte General. 2a Ed. Madrid: Dykinson. 2010.

RODRÍGUEZ RAMOS, L. (Dir.) / MARTÍNEZ GUERRA, A., (Coord.), Código Penal. Concordado y comentado con jurisprudencia y leyes penales especiales y complementarias. $4^{\text {a }}$ ed. Madrid: La Ley. 2011.

ROLAND RIZ, Lineamenti di Dirito penal. Parte generale. Padova: CEDAM. 2000.

ROTH, G., “Delincuentes violentos: ¿seres malvados o enfermos mentales?" En DEMETRIO CRESPO, E., (Dir.) / MAROTO CALATAYUD, M., (Coord.), Neurociencias y Derecho penal. Nuevas perspectivas en el ámbito de la culpabilidad y tratamiento jurídico-penal de la peligrosidad. Madrid: Edisofer. 2013.

ROXIN, C., "Fin y justificación de la pena y de las medidas de seguridad". En ROXIN, C. / BELOFF, M. / MAGARIÑOS, M. / ZIFFER, P.S. / BERTONI, E.A. / RÍOS, R.T., Determinación judicial de la pena. Buenos Aires: Editores del Puerto. 1993.

ROXIN, C., Fundamentos. La estructura de la teoría del delito. Traducción de la $2^{\mathrm{a}}$ Ed. alemana por D.M., Luzón Peña, M. Díaz y García-Conlledo, y J., De Vicente Remesal, Madrid: Civitas. 1997.

RUBIA, F.J., “Neurociencia y libertad”. En DEMETRIO CRESPO, E., (Dir.) / MAROTO CALATAYUD, M., (Coord.), Neurociencias y Derecho penal. Nuevas perspectivas en el 
ámbito de la culpabilidad y tratamiento jurídico-penal de la peligrosidad. Madrid: Edisofer. 2013.

RUBIO LARA, P.A., “Las Medidas de Seguridad tras la Reforma de la LO 5/2010 de 22 de junio del Código Penal: Perspectivas Doctrinales y Jurisprudenciales. Problemas y Soluciones". En Revista de Derecho Penal y Procesal, núm. 25. Navarra: Aranzadi. 2011.

RUBIO MARÍN, R., “La inclusión del emigrante: un reto para las democracias". En Extranjería e Inmigración. Actas de las IX Jornadas de la Asociación de Letrados del Tribunal Constitucional. Madrid: Centro de Estudios Políticos y Constitucionales. 2004.

SAINZ CANTERO, J.A., Lecciones de Derecho penal. Parte general. $3^{\mathrm{a}}$ Ed. Barcelona: Bosch. 1990.

SÁNCHEZ DAFAUCE, M., "Libertad e indemnidad sexuales: arts. 178 y 180". En ÁLVAREZ GARCÍA, F.J. / GONZÁLEZ CUSSAC, J.L., (Dirs.), Comentarios a la reforma penal de 2010. Valencia: Tirant lo Blanch. 2010.

SÁNCHEZ MELGAR, J., en SÁNCHEZ MELGAR, J. (Coord.), Código penal. Comentarios y jurisprudencia. Tomo I. $3^{\text {a }}$ Ed. Madrid: Sepín. 2010.

SÁNCHEZ MELGAR, en SÁNCHEZ MELGAR, J. (Coord.), Código penal. Comentarios y jurisprudencia. Tomo II. $3^{\text {a }}$ Ed. Madrid: Sepín. 2010.

SÁNCHEZ YLLERA, I., en VIVES ANTÓN, T.S., (Coord.), Comentarios al Código Penal de 1995. Vol. I. Valencia: Tirant lo Blanch. 1996.

SANCHO GARGALLO, I., en FERNÁNDEZ-BALLESTEROS, M.A. / RIFÁ SOLER, J.M. / VALLS GOMBAU, J.F., (Coords.), Comentarios a la Nueva Ley de Enjuiciamiento Civil. Tomo III. Barcelona: Atelier. 2000.

SANZ MORÁN, A.J., Las medidas de corrección y de seguridad en el Derecho Penal. Valladolid: Lex Nova. 2003.

SANZ MORÁN, A.J., "De nuevo sobre el tratamiento del delincuente habitual peligroso". En BUENO ARÚS, F. / HELMUT KURY / RODRÍGUEZ RAMOS, L. / ZAFFARONI, E.R., (Dirs.), Derecho penal y Criminología como fundamento de la política criminal. Estudios en homenaje al profesor Alfonso Serrano Gómez. Madrid: Dykinson. 2006.

SANZ MORÁN, A.J., “Las teorías penales hoy”. En DÍAZ Y GARCÍA CONLLEDO, M. / GARCÍA AMADO, J.A., (Edits.), Estudios de filosofía del Derecho penal. Bogotá: Universidad Externado de Colombia. 2006. 
SANZ MORÁN, A.J., "Sobre la justificación de las medidas de corrección y de seguridad”. En Homenaje al profesor Dr. Gonzalo Rodríguez Mourullo. Navarra: Thomson Civitas. 2005.

SANZ MORÁN, A.J., “La nueva medida de seguridad de libertad vigilada: reflexión político-criminal". En MUÑOZ CONDE, F. / LORENZO SALGADO, J.M. / FERRÉ OLIVE, J.C. / CORTES BECHIARELLI, E. / NÚÑEZ PAZ, M.A., (Dirs.), Un Derecho penal comprometido. Libro Homenaje al Prof. Dr. Gerardo Landrove Díaz. Valencia: Tirant lo Blanch. 2011.

SANZ MORÁN, A.J., "Las teorías penales hoy”. En DÍAZ Y GARCÍA CONLLEDO, M. / GARCÍA AMADO, J.A., (Edit.) Estudios de filosofía del Derecho penal. Bogotá: Universidad Externado de Colombia. 2006.

SANZ MORÁN, A.J., “Libertad vigilada y quebrantamiento de condena. Arts. 106 y 468 CP". En ALVAREZ GARCÍA, F.J. / GONZÁlEZ CUSSAC, J.L., (Dirs.), Consideraciones a propósito del Proyecto de Ley de 2009 de modificación del Código Penal. (Conclusiones del seminario interuniversitario sobre la reforma del Código Penal celebrado en la Universidad Carlos III de Madrid). Valencia: Tirant lo Blanch. 2010.

SANZ MORÁN, A.J., “La libertad vigilada (arts. 106 y 468)”. En ALVAREZ GARCÍA, F.J.

/ GONZÁlEZ CUSSAC, J.L., (Dirs.) Comentarios a la reforma penal de 2010. Valencia: Tirant lo Blanch. 2010. SÁNCHEZ BERNAL, J., “Delincuencia de los poderosos y cohecho. Modificaciones previstas en el Proyecto de Ley Orgánica de Reforma del Código Penal del 2013". En PÉREZ CEPEDA, A.I. (Dir.) / GORJÓN BARRANCO, M.C., El Proyecto de Reforma del Código penal de 2013 a debate. Salamanca: Ratio Legis. 2014.

SANZ MORÁN, A.J., “Medidas de seguridad”. En ÁlVAREZ GARCÍA, F.J., (Dir.) / DOPICO GÓMEZ-ALLER, J., (Coord.), Estudio crítico sobre el Anteproyecto de Reforma penal de 2012. Valencia: Tirant lo Blanch. 2013.

SEOANE SPIEGELBERG, J.L., en PÉREZ-CRUZ MARTÍN, A.J. / FERREIRO BAAMONTE, X.X. / PIÑOL RODRÍGUEZ, J.R. / SEOANE SPIEGELBERG, J.L., Derecho Procesal penal. $2^{\mathrm{a}}$ Ed. Navarra: Civitas. 2010.

SERRANO BUTRAGUEÑO, I., en SERRANO BUTRAGUEÑO, I., (Coord.), Código Penal de 1995. Comentarios y jurisprudencia. Granada: Comares. 1998.

SERRANO PIEDECASAS, J.R., “La calificación de los actos contra los derechos humanos en Derecho español”. En GARCÍA ARÁN, M. / LÓPEZ GARRIDO, D., (Coords.), Crimen Internacional y Jurisdicción Universal. El caso Pinochet. Valencia: Tirant Lo 
Blanch. 2000.

SERRANO TÁRRAGA, M.D., "Medidas susceptibles de imposición a los menores”. En VÁZQUEZ GONZÁLEZ, C. / SERRANO TÁRRAGA, M.D., (Editores), Derecho Penal Juvenil. Madrid: Dykinson. 2005.

SCHÖNE, W., Contribuciones al orden jurídico-penal paraguayo. Asunción: Intercontinental. 2000.

SIERRA LÓPEZ, M.V., Las medidas de seguridad en el nuevo Código Penal. Tirant monografías 62. Valencia: Tirant lo Blanch. 1997.

SIERRA LÓPEZ, M.V., La medida de libertad vigilada. Tirant monografías 843. Valencia: Tirant lo Blanch. 2013.

SILVA SÁNCHEZ, J.M., Tiempos de Derecho penal. Madrid: Edisofer. 2009.

SILVA SÁNCHEZ, J.M., "La reforma del Código Penal: una aproximación desde el contexto". En Diario La Ley, núm. 7464, 2010.

SILVA SÁNCHEZ, J.M., "El retorno de la inocuización. El caso de las reacciones jurídico-penales frente a los delincuentes sexuales violentos". En ARROYO ZAPATERO, L. / BERDUGO GÓMEZ DE LA TORRE, I., (Dirs.), Homenaje al Dr. Marino Barbero Santos in memoriam. Vol. I. Castilla-La Mancha: Ediciones Universidad de Castilla-La Mancha, Salamanca: Ediciones Universidad de Salamanca. 2001.

SILVA SÁNCHEZ, El nuevo Código Penal: cinco cuestiones fundamentales. Barcelona: Bosch. 1997.

SILVA SÁNCHEZ, J.M., "Consideraciones sobre las medidas de seguridad para inimputables y semiimputables". En Homenaje al Prof. Rodríguez Mourullo. Madrid: Civitas. 2005.

SOTORRA CAMPODARVE, M. C., "Protección en el ámbito penal”. En RIVAS VALLEJO, M P. / BARRIOS BAUDOR G. L., (Dir.), Violencia de Género. Perspectiva Multidisciplinar y Práctica Forense. Navarra: Thomson Aranzadi. 2007.

STOOS, C., Strafe und sicherden Massanahmen, ZStrR, 1905.

STOOS, C., Zur natur der sicherden Massanahmen, ZStrR, 1930.

STRATENWERTH, G., Derecho Penal. Parte General I. El hecho punible. Traducción de M. Cancio Meliá y M.A. Sancinetti. Navarra: Thomson Civitas. 2005.

SYLVESTRE MARTÍNEZ, M., Librería de jueces, utilísima y universal. Madrid: Imprenta de Blas Román. 1772. Tomo octavo.

SYMINGTON, G., “Neurolaw: de la defensa judicial hacia un Derecho Penal del 
enemigo". En Revista de la Universidad de Estudios de Bogotá. núm. 9. Colombia, 2012.

TAMARIT SUMALLA, J.M., “Culpabilidad, maldad e imputabilidad: aportaciones de la dogmática penal a la cultura jurídica europea". En Revista de Derecho penal y Criminología, 2a Época, núm. 17, 2006.

TAMARIT SUMALLA, J.M., “Sanciones penales, Derecho comparado y política criminal europea". En TAMARIT SUMALLA, J.M., (Coord.), Revista Aranzadi de Derecho y proceso penal, núm. 21. Las sanciones penales en Europa. Navarra: Aranzadi. 2009.

TAMARIT SUMALLA, J.M., “La integración jurídica en la Unión Europea y la reforma de 2006. Las penas y la reforma”. En ÁLVAREZ GARCÍA, F.J. (Dir.), La adecuación del Derecho penal español al ordenamiento de la Unión Europea. La política criminal europea. Valencia: Tirant lo Blanch. 2009.

TAMARIT SUMALLA, J.M. / GARCÍA ALBERO, R., La reforma de la ejecución penal. Valencia: Tirant lo Blanch. 2004.

TAMARIT SUMALLA, J.M., “Delitos relativos a la pornografía infantil y otras medidas relacionadas con la delincuencia sexual (arts. 189 y 192)". En QUINTERO OLIVARES, G., (Dir.), La Reforma Penal de 2010: Análisis y Comentarios. Navarra. Thomson Aranzadi. 2010.

TAMARIT SUMALLA, J.M. / GARCÍA ALBERO, R. / RODRÍGUEZ PUERTA, M.J. / SAPENA GRAU, F., Curso de Derecho Penitenciario. $2^{\mathrm{a}}$ Ed. Valencia: Tirant lo Blanch. 2005.

TÉBAR VILCHES, B., El modelo de libertad condicional español. Tesis doctoral. Universidad Autónoma de Barcelona. 2004.

TÉBAR VILCHES, B., "El modelo de libertad condicional español”. En Revista Aranzadi de Derecho y Proceso penal, núm. 15. Navarra: Aranzadi. 2006.

TERRADILlOS BASOCO, J.M, Peligrosidad social y Estado de Derecho. Madrid: Akal. 1981.

TERRADILLOS BASOCO, J.M., Terrorismo y Derecho. Comentario a las leyes orgánicas 3 y 4/1988, de reforma del Código penal y de la Ley de Enjuiciamiento Criminal. Madrid: Tecnos. 1988

TERRADILLOS BASOCO, J.M., “Trata de seres humanos (Art. 177 bis y Disposición Final Segunda)". En ÁlVAREZ GARCÍA, F.J. / GONZÁLEZ CUSSAC, J.L., (Dirs.), Comentarios a la reforma penal de 2010. Valencia: Tirant lo Blanch. 2010.

TERRADILLOS BASOCO, J.M., “El Estado de Derecho y el fenómeno del terrorismo”. En SERRANO PIEDECASAS, J.R. / DEMETRIO CRESPO, E. (dirs.), Terrorismo y 
Estado de Derecho. Madrid: Iustel. 2010.

TERRADILLOS BASOCO, J.M., "Responsabilidad penal de las personas jurídicas”. En ÁLVAREZ GARCÍA, F.J., (Dir.) / DOPICO GÓMEZ-ALLER, J., (Coord.), Estudio crítico sobre el Anteproyecto de Reforma penal de 2012. Valencia: Tirant lo Blanch. 2013.

TERRADILLOS BASOCO, J.M., “El delito de inmigración ilegal y la trata de personas”. En PÉREZ CEPEDA, A.I. (Dir.) / GORJÓN BARRANCO, M.C., El Proyecto de Reforma del Código penal de 2013 a debate. Salamanca: Ratio Legis. 2014.

TORRES FERNÁNDEZ, M.E., “De nuevo sobre el principio non bis in ídem en la jurisprudencia constitucional". En Revista La Ley, núm. 5824. Madrid. 2003.

TORRES ROSELL, N., “El delito de hurto”. En QUINTERO OLIVARES, G., (Dir.), La Reforma Penal de 2010: Análisis y Comentarios. Navarra. Thomson Aranzadi. 2010.

TORRES ROSELL, N., "Contenido y fines de la pena de localización permanente". En InDret. Revista para el análisis del Derecho. 1/2011. Barcelona: 2011.

TORRES ROSELL, N., “Libertad vigilada y seguimiento continuado de penados. Contenido e implicaciones político criminales". En Revista Electrónica de Ciencia Penal y Criminología (en línea). núm. 14, 2012.

ÚBEDA DE LOS COBOS, J.J., “La responsabilidad penal de las personas jurídicas aprobada por Ley Orgánica 5/2010, de 22 de junio". En La Ley Penal, núm. 77, 2010.

ULLENBRUCH, T., "Nachträgliche Schierungsverwahrung - ein legislativer "Spuk" im judikativen "fegefeuer"?" En NStZ, 2007.

URRUELA MORA, A., “Los principios informadores del derecho de medidas en el Código Penal de 1995". En Revista de Derecho Penal y Criminología de la UNED, núm. 8. Madrid. 2001.

URRUELA MORA, A., "Culpabilidad y herencia genética”. En Bioética y Derecho. Studia iuridica 20. CGPJ - CEJFE. 2004.

URRUELA MORA, A., Las medidas de seguridad y reinserción social en la actualidad. Especial consideración de las consecuencias jurídico-penales aplicables a sujetos afectos de anomalía o alteración psíquica. Granada: Comares. 2009.

VARGAS CABRERA, B., en CONDE-PUMPIDO FERREIRO, C., Ley de la responsabilidad penal de los menores. Doctrina con jurisprudencia y normativa complementaria. Madrid: Trivium. 2001.

VÁZQUEZ IRUZUBIETA, C., Comentario a la Ley de Enjuiciamiento Civil. $2^{\mathrm{a}}$ Ed. Madrid: Economist \& Jurist. 2012. 
VEGA ALOCÉN, M., El tercer grado con control telemático. Granada: Comares. 2010.

VIDALES RODRÍGUEZ, C., "La libertad condicional y la retroactividad de las disposiciones que la regulan. Razones para un debate acerca de su posible inconstitucionalidad". En Revista de Derecho Penal, núm. 12. 2004.

VILLACAMPA ESTIARTE, C., "Víctimas de la trata de seres humanos: su tutela a la luz de las últimas reformas penales sustantivas y procesales proyectadas". En Indret. Revista para el análisis del Derecho. 2/2014. Barcelona: 2014.

VIVES ANTÓN, T.S., Fundamentos del Sistema Penal. Acción Significativa y Derechos Constitucionales. $2^{\text {a }}$ Ed. Valencia: Tirant lo Blanch. 2011.

VIVES ANTÓN, T.S., Reflexiones jurídico-políticas a propósito de un Anteproyecto de Código Penal ¿Estado democrático o Estado autoritario? Valencia: www.tirantonline.com. TOL1.405.952. 2008.

VIVES ANTÓN, T.S., “Constitución y medidas de seguridad”. En la libertad como pretexto. Valencia: Tirant lo Blanch. 1995. Edición original el Poder Judicial, núm. 3, 1986.

VIVES ANTÓN, T.S., "Métodos de determinación de la Peligrosidad". En la libertad como pretexto. Valencia: Tirant lo Blanch. 1995. Pág. 18. Edición original en Peligrosidad social y medidas de seguridad, Colección de Estudios del Instituto de Criminología y Departamento de Derecho Penal de la Universidad de Valencia. 1974.

VIVES ANTÓN, T.S. / CARBONELL MATEU, J.C., (con la colaboración de MIRA BENAVENT, J.,) “Delitos contra el orden público". En VIVES ANTÓN, T.S. / ORTS BERENGUER, E. / CARBONELL MATEU, J.C. / GONZÁLEZ CUSSAC, J.L. / MARTÍnEZ-BUjÁN PÉREZ, C., Derecho Penal. Parte Especial. $3^{\mathrm{a}}$ Ed. Valencia: Tirant lo Blanch. 2010.

VIVES ANTÓN, T.S. / GONZÁLEZ CUSSAC, J.L., “Delitos contra el patrimonio y el orden socioeconómico (IX): Insolvencias punibles". En VIVES ANTÓN, T.S. / ORTS BERENGUER, E. / CARBONELL MATEU, J.C. / GONZÁLEZ CUSSAC, J.L. / MARTínEZ-BUjÁN PÉREZ, C., Derecho Penal. Parte Especial. $3^{\mathrm{a}}$ Ed. Valencia: Tirant lo Blanch. 2010.

VIVES ANTÓN, T.S., "Neurociencia y determinismo reduccionista: una aproximación crítica". En DEMETRIO CRESPO, E., (Dir.) / MAROTO CALATAYUD, M., (Coord.), Neurociencias y Derecho penal. Nuevas perspectivas en el ámbito de la culpabilidad y tratamiento jurídico-penal de la peligrosidad. Madrid: Edisofer. 2013.

WELZEL, H., Derecho penal. Parte General. Traducción de Carlos Fontán Balestra, Buenos Aires: Depalma. 1956. 
WELZEL, H., El nuevo Sistema de Derecho penal. Una introducción a la doctrinal de la acción finalista. Reimpresión de la $1^{\text {a }}$ Ed. en Castellano. Traducida por Cerezo Mir. Montevideo: Bdef Montevideo-Buenos Aires. 2001.

WORRAlL, A. / HOY, C., Punishment in the Community. 2a Ed. Cullompton. 2005.

ZACHARIAS, S., "La medida de custodia de seguridad a posteriori. ¿Pena o medida de seguridad?". En DÍAZ CORTÉS, L.M., (Coord.), Delito, pena, politica criminal y tecnologías de la información y la comunicación en las modernas ciencias penales. Memorias del II Congreso Internacional de Jóvenes Investigadores en Ciencias penales. Salamanca: Aquilafuente. 2012.

ZAFFARONI, E.R., “Teoría de las Consecuencias Jurídicas del Hecho Punible”. En Nuevo Código Penal. Opiniones y comentarios. Asunción: Colegio de Abogados del Paraguay. 1999.

ZAFFARONI, E.R. / AlAGIA, A. / SLOKAR, A., Derecho Penal. Parte General. $2^{\mathrm{a}}$ Ed. Buenos Aires: Adiar. 2002.

ZUGALDÍA ESPINAR, J.M., Fundamentos de Derecho penal. $3^{\mathrm{a}}$ Ed. Valencia: Tirant lo Blanch. 1993.

ZUGALDÍA ESPINAR, J.M., “Medidas de seguridad complementarias y acumulativas para autores peligrosos tras el cumplimiento de la pena". En Revista de Derecho penal y Criminología. núm. 1, 2009.

ZUGALDÍA ESPINAR, J.M., “Medidas de seguridad”. En ÁLVAREZ GARCÍA, F.J., (Dir.) / DOPICO GÓMEZ-ALLER, J., (Coord.), Estudio crítico sobre el Anteproyecto de Reforma penal de 2012. Valencia: Tirant lo Blanch. 2013.

ZÚÑIGA RODRÍGUEZ, L., “El tratamiento penitenciario”. En BERDUGO GÓMEZ DE LA TORRE, I. (Coord.), Lecciones y materiales para el estudio del Derecho penal. Tomo VI. Derecho penitenciario. Madrid: Iustel. 2010. 